\title{
Mineral Deposit Models
}

\section{U.S. GEOLOGICAL SURVEY BULLETIN 1693}

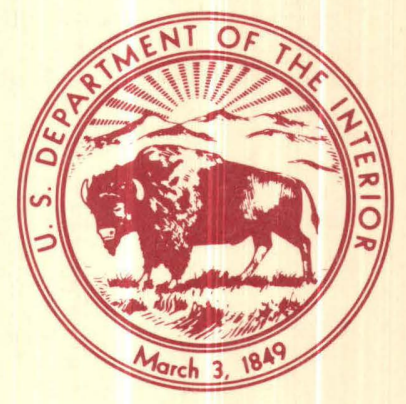




\section{AVAILABILITY OF BOOKS AND MAPS OF THE U.S. GEOLOGICAL SURVEY}

Instructions on ordering publications of the U.S. Geological Survey, along with the last offerings, are given in the current-year issues of the monthly catalog "New Publications of the U.S. Gcological Survey." Prices of available U.S. Geological Survey publications released prior to the current year are listed in the most recent annual "Price and Availability List." Publications that are listed in various U.S. Geological Survey catalogs (see back inside cover) but not listed in the most recent annual "Price and Availability List" are no longer available.

Prices of reports released to the open files are given in the listing "U.S. Geological Survey Open-File Reports," updated monthly, which is for sale in microfiche from U.S. Geological Survey Book and Open-File Report Sales, Box 25425, Denver, CO 80225.

Order U.S. Geological Survey publications by mail or over the counter from the offices given below.

\section{BY MAIL}

\section{Books}

Professional Papers, Bulletins, Water-Supply Papers, Techniques of Water-Resources Investigations, Circulars, publications of general interest (such as leaflets, pamphlets, booklets), single copies of periodicals (Earthquakes \& Volcanocs, Preliminary Determination of Epicenters), and some misccllaneous reports, including some of the foregoing series that have gone out of print at the Superintendent of Documents, are obtainable by mail from

\section{U.S. Geological Survey, Book and Open-File Report Sales Box 25425 \\ Denver, CO 80225}

Subscriptions to periodicals (Earthquakes \& Volcanoes and Preliminary Determination of Epicenters) can be obtained ONLY from

\section{Superintendent of Documents \\ U.S. Government Printing Office \\ Washington, DC 20402}

(Check or money order must be payable to Supcrintendent of Documents.)

\section{Maps}

For maps, address mail orders to

$$
\begin{gathered}
\text { U.S. Geological Survey, Map Sales } \\
\text { Box } 25286 \\
\text { Denver, CO } 80225
\end{gathered}
$$

Residents of Alaska may order maps from

$$
\begin{aligned}
& \text { U.S. Geological Survey, Map Sales } \\
& 101 \text { Twelfth Ave. - Box } 12 \\
& \text { Fairbanks, AK } 99701
\end{aligned}
$$

\section{OVER THE COUNTER Books}

Books of the U.S. Geological Survey are available over the counter at the following U.S. Gcological Survey offices, all of which are authorized agents of the Supcrintendent of Documents.

- ANCHORAGE, Alaska--4230 University Dr., Rm. 101

- ANCHORAGE, Alaska--605 West 4th Ave., Rm G-84

- DENVER, Colorado--Federal Bldg., Rm. 169, 1961 Stout St.

- LAKEWOOD, Colorado-- Federal Center, Bldg. 810

- MENLO PARK, California--Bldg. 3, Rm. 3128,345 Middleficld Rd.

- RESTON, Virginia--National Center, Rm. 1C402, 12201 Sunrise Valley Dr.

- SALT LAKE CITY, Utah--Federal Bldg., Rm. 8105, 125 South State St.

- SAN FRANCISCO, California--Customhouse, Rm. 504, 555 Battery St.

- SPOKANE, Washington--U.S. Courthouse, Rm. 678, West 920 Riverside Ave.

- WASHINGTON, D.C.--U.S. Department of the Interior Bldg., Rm. 2650, 1849 C St., NW.

\section{Maps}

Maps may be purchased over the counter at the U.S. Geological Survey offices where books are sold (all addresses in above list) and at the following Geological Survey offices:

- ROLlA, Missouri--1400 Independence Rd.

- FAIRBANKS, Alaska--New Federal Buildıng, 101 Twelfth Ave. 


\section{Mineral Deposit Models}

DENNIS P. COX and DONALD A. SINGER, Editors 


\section{U.S. DEPARTMENT OF THE INTERIOR MANUEL LUJAN, JR., Secretary}

U.S. GEOLOGICAL SURVEY

Dallas L. Peck, Director

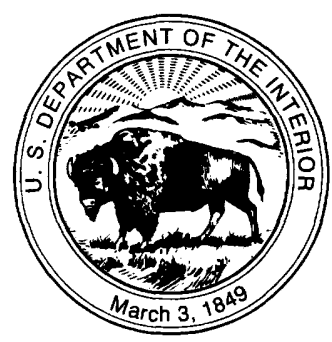

Any use of trade, product, or firm names

in this publication is for descriptive purposes only

and does not imply endorsement by the U.S. Government

First printing 1986

Second printing 1987

Third printing 1992

For sale by

Book and Open-File Report Sales

U.S. Geological Survey

Federal Center, Box 25425

Denver, CO 80225

Library of Congress Cataloging-in-Publication Data

Mineral deposit models

(U.S. Geological Survey Bulletin 1693)

Bibliography

1. Ore Deposits. 2. Mines and mineral resources. I. Cox, Dennis P.

II. Singer, Donald A. III. Series.

QE75.B9 No. 1693

[TN263] 


\section{PREFACE}

By Paul B. Barton

Conceptual models that describe the essential characteristics of groups of similar deposits have a long and useful role in geology. The first models were undoubtedly empirical attempts to extend previous experiences into future success. An example might be the seeking of additional gold nuggets in a stream in which one nugget had already been found, and the extension of that model to include other streams as well. Emphasis within the U.S. Geological Survey on the synthesis of mineral deposit models (as contrasted with a long line of descriptive and genetic studies of specific ore deposits) began with the collation by R. L. Erickson (1982) of 48 models. The 85 descriptive deposit models and 60 grade-tonnage models presented here are the culmination of a process that began in 1983 as part of the USGS-INGEOMINAS Cooperative Mineral Resource Assessment of Colombia (Hodges and others, 1984). Effective cooperation on this project required that U.S. and Colombian geologists agree on a classification of mineral deposits, and effective resource assessment of such a broad region required that grade-tonnage models be created for a large number of mineral deposit types. A concise one-page format for descriptive models was drawn up by Dennis Cox, Donald Singer, and Byron Berger, and Singer devised a graphical way of presenting grade and tonnage data. Sixty-five descriptive models (Cox, $1983 \mathrm{a}$ and b) and 37 grade-tonnage models (Singer and Mosier, 1983a and b) were applied to the Colombian project. Because interest in these models ranged far beyond the Colombian activity, it was decided to enlarge the number of models and to include other aspects of mineral deposit modeling. Our colleagues in the Geological Survey of Canada have preceded this effort by publishing a superb compilation of models of deposits important in Canada (Eckstrand, 1984). Not surprisingly, our models converge quite well, and in several cases we have drawn freely from the Canadian publication.

It is a well-known axiom in industry that any excuse for drilling may find ore; that is, successful exploration can be carried out even though it is founded upon an erroneous model. Examples include successful exploration based on supposed (but now proven erroneous) structural controls for volcanogenic massive sulfide deposits in eastern Canada and for carbonate-hosted zinc in east Tennessee. As the older ideas have been replaced, additional ore has been found with today's presumably more valid models.

Although models have been with us for centuries, until recently they have been almost universally incomplete when descriptive and unreasonably speculative when genetic. What is new today is that, although we must admit that all are incomplete in some degree, models can be put to rigorous tests that screen out many of our heretofore sacred dogmas of mineral formation. Examples are legion, but to cite a few: (1) fluid-inclusion studies have shown conclusively that the classic Mississippi Valley-type ores cannot have originated from either syngenetic processes or unmodified surface waters; (2) epithermal base- and precious-metal ores have been proved (by stable-isotope studies) to have formed through the action of meteoric waters constituting fossil geothermal systems; and (3) field and laboratory investigations clearly show that volcanogenic massive sulfides are the products of syngenetic, submarine, exhalative processes, not epigenetic replacement of sedimentary or volcanic rocks. Economic geology has evolved quietly from an "occult art" to a respectable science as the speculative models have been put to definitive tests.

Several fundamental problems that may have no immediate answers revolve around these questions: Is there a proper number of models? Must each deposit fit into one, and only one, pigeon-hole? Who decides (and when?) that a model is correct and reasonably complete? Is a model ever truly complete? How complete need a model be to be useful?

In preparing this compilation we had to decide whether to discuss only those deposits for which the data were nearly complete and the interpretations concordant, or whether to extend coverage to include many deposits of uncertain affiliation, whose characteristics were still subjects for major debate. This compilation errs on the side of scientific optimism; it includes as many deposit types as possible, even at the risk of lumping or splitting types incorrectly. Nevertheless, quite a few types of deposits have not been incorporated.

The organization of the models constitutes a classification of deposits. The arrangement used emphasizes easy access to the models by focusing on host-rock lithology and tectonic setting, the features most apparent to the geologist preparing a map. The system is nearly parallel to a genetic arrangement for syngenetic ores, but it diverges strongly for the epigenetic where it creates some strange juxtapositions of deposit types. Possible ambiguities are accommodated, at least in part, by using multiple entries in the master list in table 1.

In considering ways to make the model compilation as useful as possible, we have become concerned about ways to enhance the ability of the relatively inexperienced geoscientist to find the model(s) applicable to his or her observations. Therefore, we have included extensive tables of attributes in which the appropriate models are identified.

Our most important immediate goal is to provide assistance to those persons engaged in mineral resource assessment or exploration. An important 
secondary goal is to upgrade the quality of our model compilation by encouraging (or provoking?) input from those whose experience has not yet been captured in the existing models. Another target is to identify specific research needs whose study is particularly pertinent to the advance of the science. We have chosen to err on the side of redundancy at the expense of neatness, believing that our collective understanding is still too incomplete to rule out some alternative interpretations. Thus we almost certainly have set up as separate models some types that will ultimately be blended into one, and there surely are groupings established here that will subsequently be divided. We also recognize that significant gaps in coverage still exist. Even at this stage the model compilation is still experimental in several aspects and continues to evolve. The product in hand can be useful today. We anticipate future editions, versions, and revisions, and we encourage suggestions for future improvements. 


\section{CONTENTS}

Preface, by Paul B. Barton III

Introduction, by Dennis P. Cox, Paul B. Barton, and Donald A. Singer 1

Deposit models

Deposits related to mafic and ultramafic intrusions in stable environments
1
$\begin{array}{lll}2 a & \text { Descriptive model of Stillwater Ni-Cu, by Norman J Page } 11 \\ 2 b & \text { Descriptive model of Merensky Reef PGE, by Norman J Page } 14 \\ 3 & \text { Descriptive model of Bushveld Fe-Ti-V, by Norman J Page } 15\end{array}$

Deposits related to mafic-ultramafic rocks in unstable areas

$5 a$ Descriptive model of Duluth $\mathrm{Cu}-\mathrm{Ni}-\mathrm{PGE}$, by Norman J Page $\mathbf{1 6}$

5b Descriptive model of Noril'sk Cu-Ni-PGE, by Norman J Page 17

6a Descriptive model of komatiitic $\mathrm{Ni}-\mathrm{Cu}$, by Norman $J$ Page 18 Grade and tonnage model of komatiitic Ni-Cu, by Donald A. Singer, Norman J Page, and W. David Menzie $\mathbf{1 8}$

$6 \mathrm{~b}$ Descriptive model of dunitic Ni-Cu, by Norman J Page 24 Grade and tonnage model of dunitic Ni-Cu, by Donald A. Singer and Norman J Page 24

7a Descriptive model of synorogenic-synvolcanic $\mathrm{Ni}-\mathrm{Cu}$, by Norman J Page 28 Grade and tonnage model of synorogenic-synvolcanic Ni-Cu, by Donald A. Singer, Norman J Page, and W. David Menzie 28

7b Descriptive model of anorthosite Ti, by Eric R. Force 32

8 Descriptive model of podiform chromite, by John P. Albers 34 Grade and tonnage model of minor podiform chromite, by Donald A. Singer and Norman J Page 34

8b Grade and tonnage model of major podiform chromite, by Donald A. Singer, Norman $J$ Page, and Bruce R. Lipin 38

8c Descriptive model of Limassol Forest Co-Ni, by Norman J Page 45

8d Descriptive model of serpentine-hosted asbestos, by Norman J Page 46 Grade and tonnage model of serpentine-hosted asbestos, by Greta J. Orris 46

9 Descriptive model of Alaskan PGE, by Norman J Page and Floyd Gray 49

Deposits related to alkaline intrusions

10 Descriptive model of carbonatite deposits, by Donald A. Singer 51 Grade and tonnage model of carbonatite deposits, by Donald A. Singer 52

12 Descriptive model of diamond pipes, by Dennis P. Cox 54

Deposits related to felsic phanerocrystalline intrusive rocks

14a Descriptive model of $W$ skarn deposits, by Dennis P. Cox 55

Grade and tonnage model of W skarn deposits, by W. David Menzie and Gail M. Jones 55

14b Descriptive model of Sn skarn deposits, by Bruce L. Reed and Dennis P. Cox 58 Grade and tonnage model of Sn skarn deposits, by W. David Menzie and Bruce L. Reed 58 Descriptive model of replacement $\mathrm{Sn}$, by Bruce L. Reed 61 
Grade and tonnage model of replacement Sn, by W. David Menzie and Bruce L. Reed 62 Descriptive model of Wveins, by Dennis P. Cox and William C. Bagby 64 Grade and tonnage model of W veins, by Gail M. Jones and W. David Menzie 65

15b Descriptive model of Sn veins, by Bruce L. Reed 67 Grade and tonnage model of Sn veins, by W. David Menzie and Bruce L. Reed 67 Descriptive model of Sn greisen deposits, by Bruce L. Reed 70 Grade and tonnage model of Sn greisen deposits, by W. David Menzie and Bruce L. Reed

Deposits related to felsic porphyroaphanitic intrusions

16 Descriptive model of Climax Mo deposits, by Stephen D. Ludington 73 Grade and tonnage model of Climax Mo deposits, by Donald A. Singer, Ted G. Theodore, and Dan L. Mosier 73

17 Descriptive model of porphyry $\mathrm{Cu}$, by Dennis P. Cox 76 Grade and tonnage model of porphyry $\mathrm{Cu}$, by Donald A. Singer, Dan L. Mosier, and Dennis P. Cox 77

18a Descriptive model of porphyry Cu, skarn-related deposits, by Dennis P. Cox 82 Grade and tonnage model of porphyry $\mathrm{Cu}$, skarn-related deposits, by Donald A. Singer 82

18b Descriptive model of Cu skarn deposits, by Dennis P. Cox and Ted G. Theodore 86 Grade and tonnage model of $\mathrm{Cu}$ skarn deposits, by Gail M. Jones and W. David Menzie 86 Descriptive model of $\mathrm{Zn}-\mathrm{Pb}$ skarn deposits, by Dennis P. Cox 90 Grade and tonnage model of $\mathrm{Zn}-\mathrm{Pb}$ skarn deposits, by Dan L. Mosier 90 Descriptive model of Fe skarn deposits, by Dennis P. Cox 94 Grade and tonnage model of Fe skarn deposits, by Dan L. Mosier and W. David Menzie 94 Descriptive model of carbonate-hosted asbestos, by Chester T. Wrucke Jr. and Andrew F. Shride 98

19a Descriptive model of polymetallic replacement deposits, by Hal T. Morris 99 Grade and tonnage model polymetallic replacement deposits, by Dan L. Mosier, Hal T. Morris, and Donald A. Singer 101

19b Descriptive model of replacement Mn, by Dan L. Mosier 105 Grade and tonnage model of replacement Mn, by Dan L. Mosier 105

20a Descriptive model of porphyry $\mathrm{Sn}$, by Bruce L. Reed 108

20b Descriptive model of Sn-polymetallic veins, by Yukio Togashi 109

20c Descriptive model of porphyry Cu-Au, by Dennis P. Cox 110

Grade and tonnage model of porphyry $\mathrm{Cu}-\mathrm{Au}$, by Donald A. Singer and Dennis P. Cox 110

21a Descriptive model of porphyry Cu-Mo, by Dennis P. Cox 115

Grade and tonnage model of porphyry $\mathrm{Cu}-\mathrm{Mo}$, by Donald A. Singer, Dennis P. Cox, and Dan L. Mosier 116

21b Descriptive model of porphyry Mo, low-F, by Ted G. Theodore 120 Grade and tonnage model porphyry Mo, low-F, by W. David Menzie and Ted G. Theodore 120

22a Descriptive model of volcanic-hosted Cu-As-Sb, by Dennis P. Cox 123

22b Descriptive model of Au-Ag-Te veins, by Dennis P. Cox and William C. Bagby 124

22c Descriptive model of polymetallic veins, by Dennis P. Cox 125

Grade and tonnage model polymetallic veins, by James D. Bliss and Dennis P. Cox 125 
Deposits related to subaerial mafic extrusive rocks

23 Descriptive model of basaltic $\mathrm{Cu}$, by Dennis P. Cox 130

Deposits related to marine mafic extrusive rocks

$24 a$ Descriptive model of Cyprus massive sulfide, by Donald A. Singer 131 Grade and tonnage model of Cyprus massive sulfide, by Donald A. Singer and Dan L. Mosier 131

24b Descriptive model of Besshi massive sulfide, by Dennis P. Cox 136 Grade and tonnage model of Besshi massive sulfide, by Donald A. Singer 136

24c Descriptive model of volcanogenic Mn, by Randolph A. Koski 139 Grade and tonnage model of volcanogenic Mn, by Dan L. Mosier 139

24d Descriptive model of Blackbird Co-Cu, by Robert L. Earhart 142

Deposits related to subaerial felsic to mafic extrusive rocks

25a Descriptive model of hot-spring $\mathrm{Au}-\mathrm{Ag}$, by Byron $\mathrm{R}$. Berger 143

25b Descriptive model of Creede epithermal veins, by Dan L. Mosier, Takeo Sato, Norman J Page, Donald A. Singer, and Byron R. Berger 145

Grade and tonnage model of Creede epithermal veins, by Dan L. Mosier, Takeo Sato, and Donald A. Singer 146

25c Descriptive model of Comstock epithermal veins, by Dan L. Mosier, Donald A. Singer, and Byron R. Berger 150

Grade and tonnage model of Comstock epithermal veins, by Dan L. Mosier, Takeo Sato, and Donald A. Singer 151

25d Descriptive model of Sado epithermal veins, by Dan L. Mosier, Byron R. Berger, and Donald A. Singer 154

Grade and tonnage model of Sado epithermal veins, by Dan L. Mosier and Takeo Sato

25e Descriptive model of epithermal quartz-alunite Au, by Byron R. Berger 158 Grade and tonnage model of epithermal quartz-alunite $\mathrm{Au}$, by Dan L. Mosier and W. David Menzie 159

$25 \mathrm{f}$ Descriptive model of volcanogenic U, by William C. Bagby 162 Grade and tonnage model of volcanogenic U, by Dan L. Mosier 162

25g Descriptive model of epithermal Mn, by Dan L. Mosier 165 Grade and tonnage model of epithermal Mn, by Dan L. Mosier 166

25h Descriptive model of rhyolite-hosted Sn, by Bruce L. Reed, Wendell Duffield, Stephen D. Ludington, Charles H. Maxwell, and Donald H. Richter 168 Grade and tonnage model rhyolite-hosted Sn, by Donald A. Singer and Dan L. Mosier

25i Descriptive model of volcanic-hosted magnetite, by Dennis P. Cox 172 Grade and tonnage model volcanic-hosted magnetite, by Dan L. Mosier 172

26a Descriptive model of carbonate-hosted Au-Ag, by Byron R. Berger 175 Grade and tonnage model carbonate-hosted $\mathrm{Au}-\mathrm{Ag}$, by William C. Bagby, W. David Menzie, Dan L. Mosier, and Donald A. Singer 175

$27 \mathrm{a}$ Descriptive model of hot-spring $\mathrm{Hg}$, by James J. Rytuba 178 Grade and tonnage model of hot-spring $\mathrm{Hg}$ by James J. Rytuba 178 
Grade and tonnage model of silica-carbonate $\mathrm{Hg}$, by James $\mathrm{J}$. Rytuba and Simon M. Cargill 181

27d Descriptive model of simple Sb deposits, by James D. Bliss and Greta J. Orris 183 Grade and tonnage model of simple Sb deposits, by James D. Bliss and Greta J. Orris 184

27e Grade and tonnage model of disseminated Sb deposits by James D. Bliss and Greta J. Orris 187

Deposits related to marine felsic to mafic extrusive rocks

28a Descriptive model of kuroko massive sulfide, by Donald A. Singer 189 Grade and tonnage model kuroko massive sulfide, by Donald A. Singer and Dan L. Mosier 190 28b Descriptive model of Algoma Fe, by William F. Cannon 198

Deposits in clastic sedimentary rocks

29a Descriptive model of quartz pebble conglomerate Au-U, by Dennis P. Cox 199

$29 b$ Descriptive model of Olympic Dam Cu-U-Au, by Dennis P. Cox 200

30a Descriptive model of sandstone-hosted $\mathrm{Pb}-\mathrm{Zn}$, by Joseph A. Briskey 201 Grade and tonnage model of sandstone-hosted $\mathrm{Pb}-\mathrm{Zn}$, by Dan L. Mosier 202

30b Descriptive model of sediment-hosted $\mathrm{Cu}$, by Dennis P. Cox 205 Grade and tonnage model of sediment-hosted $\mathrm{Cu}$, by Dan L. Mosier, Donald A. Singer, and Dennis P. Cox 206

30c Descriptive model of sandstone U, by Christine E. Turner-Peterson and Carroll A. Hodges 209

31a Descriptive model of sedimentary exhalative $\mathrm{Zn}-\mathrm{Pb}$, by Joseph $\mathrm{A}$. Briskey 211 Grade and tonnage model of sedimentary exhalative $\mathrm{Zn}-\mathrm{Pb}$, by $\mathrm{W}$. David Menzie and Dan L. Mosier 212

31b Descriptive model of bedded barite, by Greta J. Orris 216 Grade and tonnage model of bedded barite, by Greta J. Orris 216

31c Descriptive model of emerald veins, by Dennis P. Cox 219

Deposits in carbonate rocks

32a Descriptive model of southeast Missouri Pb-Zn, by Joseph A. Briskey 220

32b Descriptive model of Appalachian Zn, by Joseph A. Briskey 222 Grade and tonnage model of southeast Missouri $\mathrm{Pb}-\mathrm{Zn}$ and Appalachian $\mathrm{Zn}$ deposits, by Dan L. Mosier and Joseph A. Briskey 224

32c Descriptive model of Kipushi $\mathrm{Cu}-\mathrm{Pb}-\mathrm{Zn}$, by Dennis P. Cox and Lawrence R. Bernstein 227

Chemical-sedimentary deposits

$34 \mathrm{a}$ Descriptive model of Superior Fe, by William F. Cannon 228 Grade and tonnage model of Superior Fe and Algoma Fe deposits, by Dan L. Mosier and Donald A. Singer 228

34b Descriptive model of sedimentary Mn, by William F. Cannon and Eric R. Force 231 Grade and tonnage model of sedimentary Mn, by Dan L. Mosier 231

34c Descriptive model of upwelling type phosphate deposits, by Dan L. Mosier 234 
Grade and tonnage model of upwelling type phosphate deposits, by Dan L. Mosier 234

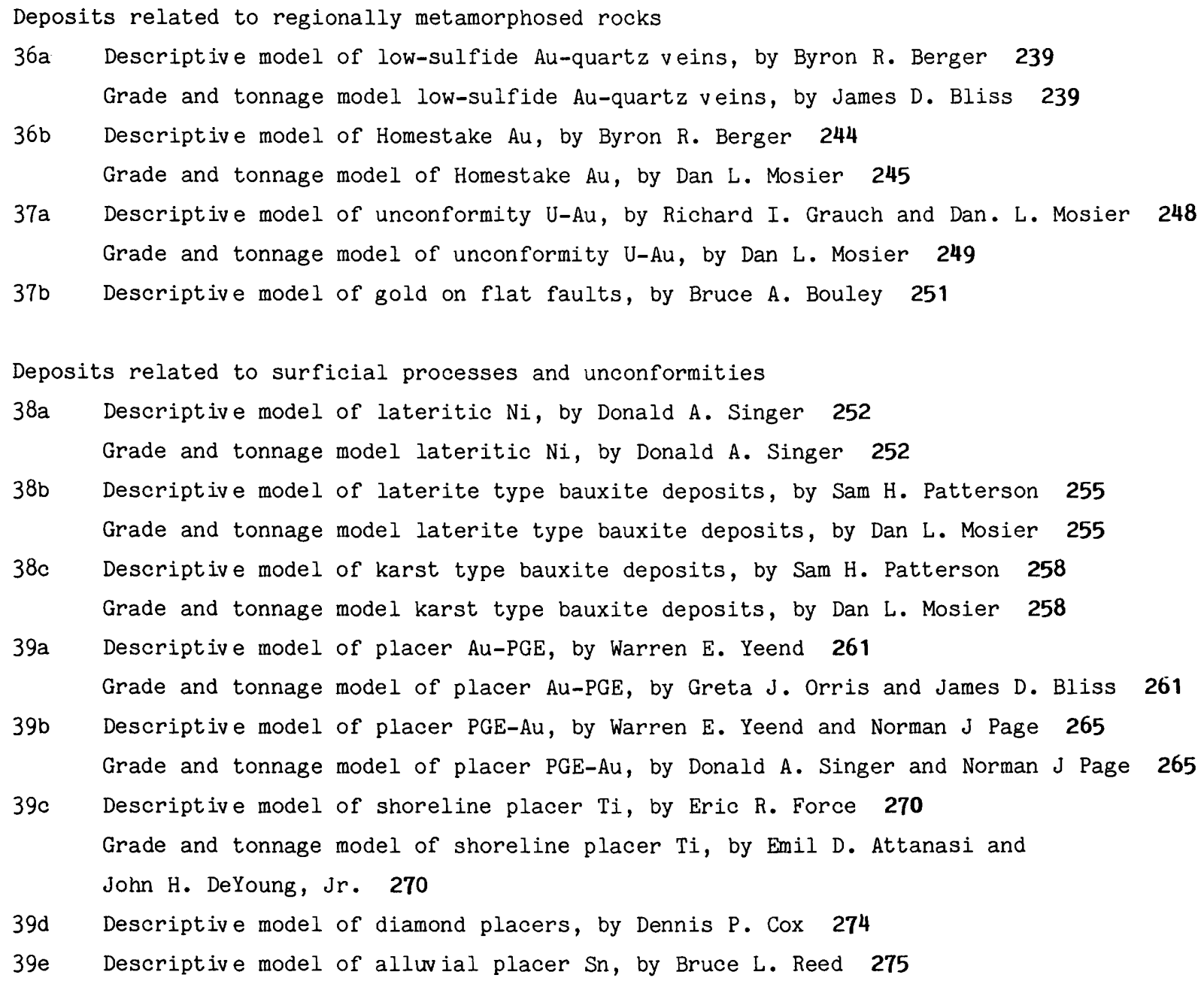


1. Tree diagram showing relationship of broad lithologic-tectonic environments to deposit models 2

2. Flow sheet showing the evolution of model types 9

3. Schematic growth patterns for the understanding of some typical genetic model 10

4. Comparison of the relative levels of understanding of some important model types 10

5. Diagram of a typical mafic-ultramafic stratiform complex 12

6. Cartoon cross-section of a typical komatiitic volcanic sedimentary sequence 19

7. Tonnages of komatilitic Ni-Cu deposits 20

8. Nickel and gold grades of komatiltic $\mathrm{Ni}-\mathrm{Cu}$ deposits 21

9. PGE grades of komatiitic $\mathrm{Ni}-\mathrm{Cu}$ deposits 22

10. Base metal grades among komatiitic Ni-Cu deposits 23

11. Tonnages of dunitic $\mathrm{Ni}-\mathrm{Cu}$ deposits 26

12. Nickel grades of dunitic $\mathrm{Ni}-\mathrm{Cu}$ deposits 26

13. PGE grades of dunitic $\mathrm{Ni}-\mathrm{Cu}$ deposits 27

14. By-product grades of dunitic $\mathrm{Ni}-\mathrm{Cu}$ deposits 27

15. Tonnages of synorogenic-synvolcanic Ni-Cu deposits 29

16. Nickel grades of synorogenic-synvolcanic Ni-Cu deposits 30

17. Copper grades of synorogenic-synvolcanic Ni-Cu deposits 30

18. By-product grades of synorogenic-synvolcanic Ni-Cu deposits 31

19. Cartoon cross-section of anorthosite ferrodiorite intrusions 33

20. Cartoon cross-section of podiform chromite deposits 40

21. Tonnages of podiform chromite deposi a typical mafic-ultramafic stratiform complex 41

22. Chromite grades of podiform chromite deposits from California and Oregon, U.S.A. 41

23. PGE grades of podiform chromite deposits from California and Oregon, U.S.A. 42

24. Tonnages of major podiform chromite deposits 43

25. Chromite grades of major podiform chromite deposits 43

26. PGE grades of major podiform chromite deposits; A, rhodium; B, iridium; C, ruthenium; D, palladium; E, platinum 44

27. Tonnage of serpentine-hosted asbestos deposits 48

28. Asbestos grade of serpentine-hosted asbestos deposits 48

29. Generalized geologic map of a zoned ultramafic complex 50

30. Tonnages of carbonatite deposits 52

31. Grades of carbonatite deposits 53

32. Tonnages of $\mathrm{W}$ skarn deposits 57

33. Tungsten grades of $W$ skarn deposits 57

34. Cartoon cross section showing relationship between $\mathrm{Sn}$ skarn, replacement $\mathrm{Sn}$ and $\mathrm{Sn}$ vein deposits to granite intrusions 59

35. Tonnages of $\mathrm{Sn}$ skarn deposits 60

36. Tin grades of $\mathrm{Sn}$ skarn deposits 60

37. Tonnages of replacement Sn deposits 63

38. Tin grades of replacement $\mathrm{Sn}$ deposits 63

39. Maps and sections of $W$-vein deposits illustrating mineral and alteration zoning 65

40. Tonnages of $W$ vein deposits 66

41. Tungsten grades of $W$ vein deposits 66

42. Tonnages of $S n$ vein deposits 69

43. Tin grades of $\mathrm{Sn}$ vein deposits 69

44. Cartoon cross section of a Sn greisen 71

45. Tonnages of $\mathrm{Sn}$ greisen deposits $\mathbf{7 2}$

46. Tin grades of $\mathrm{Sn}$ greisen deposits 72

47. Cartoon cross section of a Climax Mo deposit 74

48. Tonnages of Climax Mo deposits 75

49. Molybdenum grades of Climax Mo deposits 75

50. Cartoon cross section of illustrating a generalized model for porphyry Cu deposits 79

51. Tonnages of porphyry $\mathrm{Cu}$ deposits $\mathbf{8 0}$

52. Copper grades of porphyry $\mathrm{Cu}$ deposits 80

53. By-product grades of porphyry $\mathrm{Cu}$ deposits $\mathbf{8 1}$

54. Tonnages of porphyry Cu-skarn-related deposits 84

55. Copper grades of porphyry Cu-skarn-related deposits 84

56. By-product grades of porphyry Cu-skarn-related deposits 85

57. Cartoon cross section of a Cu skarn deposit 87

58. Tonnages of $\mathrm{Cu}$ skarn deposits $\mathbf{8 8}$

59. Copper grades of $\mathrm{Cu}$ skarn deposits $\mathbf{8 8}$

60 . Precious metal grades of $\mathrm{Cu}$ skarn deposits 89

61. Tonnages of $\mathrm{Zn}-\mathrm{Pb}$ skarn deposits 91

62. Zinc grades of $\mathrm{Zn}-\mathrm{Pb}$ skarn deposits 92 
63. Lead grades of $\mathrm{Zn}-\mathrm{Pb}$ skarn deposits 92

64. Silver grades of $\mathrm{Zn}-\mathrm{Pb}$ skarn deposits 93

65. Metal grades of $\mathrm{Zn}-\mathrm{Pb}$ skarn deposits 93

66. Tonnages of $\mathrm{Fe}$ skarn deposits 97

67. Iron grades of $\mathrm{Fe}$ skarn deposits 97

68. Generalized map showing metal- and mineral-zoning in a polymetallic replacement deposits 100

69. Tonnages of polymetallic replacement deposits 102

70. Lead grades of polymetallic replacement deposits 102

71. Zinc grades of polymetallic replacement deposits 103

72. Copper grades of polymetallic replacement deposits 103

73. Silver grades of polymetallic replacement deposits 104

74. Gold grades of polymetallic replacement deposits 104

75. Tonnages of replacement Mn deposits 106

76. Manganese and copper grades of replacement Mn deposits

77. Cartoon cross section of a porphyry $\mathrm{Cu}-\mathrm{Au}$ deposit 111

78. Tonnages of porphyry $\mathrm{Cu}-\mathrm{Au}$ deposits 112

79. Copper grades of porphyry $\mathrm{Cu}-\mathrm{Au}$ deposits 112

80. Gold grades of porphyry $\mathrm{Cu}-\mathrm{Au}$ deposits 113

81. By-product grades of porphyry Cu-Au deposits 114

82. Cartoon cross section of a porphyry Cu-Mo deposit 116

83. Tonnages of porphyry $\mathrm{Cu}-\mathrm{Mo}$ deposits 117

84. Copper grades of porphyry Cu-Mo deposits 117

85. Molybdenum grades of porphyry Cu-Mo deposits 118

86. Gold grades of porphyry Cu-Mo deposits 118

87. Silver grades of porphyry Cu-Mo deposits 119

88. Tonnages of porphyry Mo-low F deposits 122

89 Molybdenum grades of porphyry Mo-low F deposits 122

90. Tonnages of polymetallic vein deposits 127

91. Silver grades of polymetallic vein deposits 127

92. Gold grades of polymetallic vein deposits 128

93. Lead grades of polymetallic vein deposits 128

94. Zinc and copper grades of polymetallic vein deposits 129

95. Generalized stratigraphic column through the Troodos ophiolite showing Cyprus massive sulfides and other deposit types and their associated rock types 133

96. Cross section through the Kalav os district Cyprus showing relationship of massive sulfide deposits to faults and spreading axis 133

97. Tonnages of Cyprus massive sulfide deposits 134

98. Copper grades of Cyprus massive sulfide deposits 134

99. By-product grades of Cyprus massive sulfide deposits 135

100. Tonnages of Besshi massive sulfide deposits 137

101. Copper grades of Besshi massive sulfide deposits 138

102. By-product grades of Besshi massive sulfide deposits 138

103. Tonnages of volcanogenic Mn deposits 141

104. Metal grades of volcanogenic Mn deposits 141

105. Cartoon cross-section of a hot-spring Au-Ag deposit 144

106. Cartoon cross section of a typical Creede type epithermal vein deposit 146

107. Tonnages of Creede epithermal vein deposits 147

108. Copper grades of Creede epithermal vein deposit,s 147

109. Lead grades of Creede epithermal vein deposits 148

110. Zinc grades of Creede epithermal vein deposits 148

111. Silver grades of Creede epithermal vein deposits 149

112. Gold grades of Creede epithermal vein deposits 149

113. Tonnages of Comstock epithermal vein deposits 152

114. Gold grades of Comstock epithermal vein deposits 152

115. Silver grades of Comstock epithermal vein deposits 153

116. By-product grades of Comstock epithermal vein deposits 153

117. Tonnages of Sado epithermal vein deposits 156

118. Gold grades of Sado epithermal vein deposits 156

119. By-product of Sado epithermal vein deposits 157

120. Tonnages of epithermal quartz-alunite vein deposits 160

121. Gold grades of epithermal quartz-alunite vein deposits $\mathbf{1 6 0}$

122. Silver grades of epithermal quartz-alunite vein deposits 161

123. Copper grades of epithermal quartz-alunite vein deposits 161

124. Tonnages of volcanogenic U deposits 164

125. Uranium grade of volcanogenic U deposits 164

126. Tonnages of epithermal Mn deposits 167 
127. Manganese grade of epithermal Mn deposits 167

128. Cartoon cross section of a rhyolite-hosted Sn deposit 170

129. Tonnages of rhyolite-hosted Sn deposits 171

130. Tin grades of rhyolite-hosted Sn deposits 171

131. Tonnages of volcanic-hosted magnetite deposits 173

132. Iron grades of volcanic-hosted magnetite deposits 174

133. Phosphorus grades of volcanic-hosted magnetite deposits 174

134. Tonnages of carbonate-hosted $\mathrm{Au}-\mathrm{Ag}$ deposits 177

135. Precious metal grades of carbonate-hosted Au-Ag deposits 177

136. Tonnages of hot-spring Hg deposits 179

137. Mercury grades of hot-spring $\mathrm{Hg}$ deposits 179

138. Tonnages of silica-carbonate $\mathrm{Hg}$ deposits 182

139. Mercury grades of silica-carbonate $\mathrm{Hg}$ deposits 182

140. Tonnages of simple Sb deposits 185

141. Antimony grades of simple Sb deposits 185

142. Precious metal grades of simple Sb deposits 186

143. Tonnages of disseminated simple Sb deposits 188

144. Antimony grades of disseminated simple $\mathrm{Sb}$ deposits 188

145. Cartoon cross section of a kuroko massive sulfide deposit 194

146. Tonnages of kuroko massive sulfide deposits 195

147. Copper grades of kuroko massive sulfide deposits 195

148. Lead-zine grades of kuroko massive sulfide deposits 196

149. Precious metal grades of kuroko massive sulfide deposits

150. Tonnages of sandstone-hosted $\mathrm{Pb}-\mathrm{Zn}$ deposits 203

151. Lead grades of sandstone-hosted $\mathrm{Pb}-\mathrm{Zn}$ deposits 203

152. Zinc grades sandstone-hosted $\mathrm{Pb}-\mathrm{Zn}$ deposits 204

153. Silver grades sandstone-hosted $\mathrm{Pb}-\mathrm{Zn}$ deposits 204

154. Tonnages of sediment-hosted $\mathrm{Cu}$ deposits 207

155. Copper grades of sediment-hosted $\mathrm{Cu}$ deposits 207

156. By-product grades of sediment-hosted $\mathrm{Cu}$ deposits 208

157. Cartoon sections showing diagenetic and roll-front mineralization in sandstone U deposits 210

158. Cartoon cross section showing mineral zoning in sedimentary exhalative $\mathrm{Zn-Pb}$ deposits 213

159. Tonnages of sedimentary exhalative $\mathrm{Zn}-\mathrm{Pb}$ deposits 213

160. Zinc grades of sedimentary exhalative $\mathrm{Zn}-\mathrm{Pb}$ deposits 214

161. Lead grades of sedimentary exhalative $\mathrm{Zn}-\mathrm{Pb}$ deposits 214

162. Silver grades of sedimentary exhalative $\mathrm{Zn}-\mathrm{Pb}$ deposits 215

163. Copper grades of sedimentary exhalative $\mathrm{Zn}-\mathrm{Pb}$ deposits 215

164. Tonnages of bedded barite deposits 218

165. Barite grades of bedded barite deposits 218

166. Cartoon cross section of a southeast Missouri $\mathrm{Pb}-\mathrm{Zn}$ deposit 221

167. Cartooncross section illustrating a typical Appalachian Zn deposit 223

168. Tonnages of southeast Missouri $\mathrm{Pb}-\mathrm{Zn}$ and Appalachian $\mathrm{Zn}$ deposits 225

169. Zinc grades of southeast Missouri $\mathrm{Pb}-\mathrm{Zn}$ and Appalachian $\mathrm{Zn}$ deposits 225

170. Lead grades of southeast Missouri $\mathrm{Pb}-\mathrm{Zn}$ and Appalachian $\mathrm{Zn}$ deposits 226

171. Silver grades of southeast Missouri Pb-Zn and Appalachian Zn deposits 226

172. Tonnages of Algoma Fe and Superior Fe deposits 229

173. Iron grades of Algoma $\mathrm{Fe}$ and Superior Fe deposits 230

174. Phosphorus grades of Algoma Fe and Superior Fe deposits 230

175. Cartoon cross section showing relation of sedimentary facies to sedimentary Mn deposits 232

176. Tonnages of sedimentary $\mathrm{Mn}$ deposits 233

177. Metal grades of sedimentary Mn deposits 233

178. Tonnages of upwelling type phosphate deposits 236

179. $\mathrm{P}_{2} \mathrm{O}_{5}$ grades of upwelling type phosphate deposits 236

180. Tonnages of warm-current type phosphate deposits 238

181. $\mathrm{P}_{2} \mathrm{O}_{5}$ grades of warm-current type phosphate deposits 238

182. Tonnages of low-sulfide Au-quartz vein deposits 242

183. Precious metal grades of low-sulfide Au quartz vein deposits 243

184. Tonnages of Homestake Au deposits 246

185. Gold grades of Homestake Au deposits 247

186. Silver grades of Homestake $\mathrm{Au}$ deposits 247

187. Tonnages of unconformity U-Au deposits 250

188. Uranium grades of unconformity U-Au deposits 250

189. Tonnages of lateritic Ni deposits 254

190. Metal grades of lateritic Ni deposits 254

191. Tonnages of laterite type bauxite deposits 257

192. Alumina grades of laterite type bauxite deposits 257 
193. Tonnages of karst type bauxite deposits 260

194. Alumina grades of karst type bauxite deposits 260

195. Cartoon cross section showing three stages of heavy mineral concentrations typical of placer AuPGE deposits 263

196. Tonnages of placer Au-PGE deposit 263

197. Precious metal grades of placer Au-PGE deposits 264

198. Tonnages of placer PGE-Au deposits 267

199. Precious metal grades of placer PGE-Au deposits 268

200. Other PGE grades of placer PGE-Au deposits 269

201. Tonnages of shoreline placer Ti deposits 271

202. $\mathrm{ZrO}_{2}$ grades from zircon in shoreline placer Ti deposits 272

203. TiO2 grades from ilmenite in shoreline placer Ti deposits 272

204. $\mathrm{TiO}_{2}$ grades from rutile in shoreline placer Ti deposits 273

205. Other metal grades of shoreline placer Ti deposits 273

206. Matrix diagram showing deposit models and their geochemical signature 304

\section{TABLES}

1. Classification of deposit models by lithologic-tectonic environment 3

2. Comparison of application of the five model subtypes by various users $\mathbf{1 0}$

3. Types of hydrothermal alteration characteristic of porphyry copper and other deposit models 
r

$r$

S 


\section{Mineral Deposit Models}

\author{
Dennis P. Cox and Donald A. Singer, Editors
}

\section{INTRODUCTION}

By Dennis P. Cox, Paul B. Barton, and Donald A. Singer

The U.S. Geological Survey has a long and distinguished history' in assessing the mineral resources of the public domain, and that role remains active today in programs designed to assess the mineral resources of the lands administered by the U.S. Bureau of Land Management and Forest Service, the Alaska Mineral Resource Assessment Program, and the Conterminous United States Mineral Assessment Program. The Survey has thus an immediate and constantly recurring need to upgrade and maintain the capability of its staff to identify and assess areas favorable for mineral deposits. One major step toward fulfilling this need is the assembly of a comprehensive group of mineral deposit models that enable any geologist to compare his or her observations with the collective knowledge and experience of a much wider group of geoscientists.

This report deals exclusively with nonfuel minerals (including uranium), for these show a commonality of geologic expressions that differ markedly from those of the areally much larger (and economically even more important) coal, oil, and gas deposits.

\section{CITATION AND ACKNOWLEDGMENTS}

This report has been assembled through the generous efforts of many persons. The authors of the individual models and many of the other sections are indicated. We all would appreciate it if the individual authors could be cited whenever practical rather than simply refering to the whole compilation.

Among the editors, Dennis Cox had the lead in soliciting the model authors and in assembling the brief models; Donald Singer played a similar role for all of the grade and tonnage models; and Paul Barton provided the attribute cross-indexes and carefully reviewed the overall package. The editors greatly appreciate the encouragement and suggestions from (in alphabetical order) Larry Bernstein, John H. DeYoung, Jr., Bob Earhart, Ralph Erickson, Fred Fisher, Bill Greenwood, Carroll Ann Hodges, Kate Johnson, Steve Ludington, Dick McCammon, Hal Morris, Rob Robinson, Don White, and many others. The editors were greatly helped by suggestions from geologists outside the USGS, particularly D. F. Sangster, R. V. Kirkham, and J. M. Franklin of the Geological Survey of Canada, and by Ryoichi Kouda, Takeo Sato, and
Yukio Togashi of the Geological Survey of Japan. Among the many geologists from private industry who provided helpful information and suggestions were $R$. G. Blair, A. E. Soregaroli, E. I. Bloomstein, and G. E. McKelvey.

\section{SOME FUNDAMENTAL DEFINITIONS}

A "mineral occurrence" is a concentration of a mineral (usually, but not necessarily, considered in terms of some commodity, such as copper, barite or gold) that is considered valuable by someone somewhere, or that is of scientific or technical interest. In rare instances (such as titanium in a rutile-bearing black sand), the commodity might not even be concentrated above its average crustal abundance.

A "mineral deposit" is a mineral occurrence of sufficient size and grade that it might, under the most favorable of circumstances, be considered to have economic potential.

An "ore deposit" is a mineral deposit that has been tested and is known to be of sufficient size, grade, and accessibility to be producible to yield a profit. (In these days of controlled economies and integrated industries, the "profit" decision may be based on considerations that extend far beyond the mine itself, in some instances relating to the overall health of a national economy.)

On one hand, the field observations usually begin with "mineral occurrences" (or with clues to their existence) and progress with further study to "mineral deposits" and only rarely to "ore deposits," but we must present information that helps us deal with all classes of "mineral occurrences," not just "ore deposits." On the other hand, in terms of accessible information our sample is strongly biased toward "ore deposits," for it is only in them that sufficient exposure is available to develop a real knowledge of the overall character of the mineralization process. Some mineral occurrences are, therefore, unrecognized mineral deposits, while others are simply mineralized localities where ore-forming processes were so weak or incomplete that a deposit was not formed. Thus we summarize the state of knowledge regarding ore deposit models, and we call them "mineral deposit models" with the hope that what we have learned about large and high-grade metal concentrations will help us sort out all mineral occurrences to identify their true character and, we hope, to recognize which have potential to constitute ore deposits. 
The attributes or properties of a mineral occurrence are, of course, those features exhibited by the occurrence. When applied to a model, these terms refer to those features possessed by the class of deposits represented by the model. It is useful to consider attributes on at least two scales: the first deals with local features that may be observed directly in the field (mineralogy, zonal patterns, local chemical haloes, and so on); the second is those features concerning the regional geologic setting and which must be interpreted from the local studies or may be inferred from global tectonic considerations (for instance, that the rock sequence under study represents a deep-water, back-arc rift environment, or that the area is underlain by anomalously radioactive high-silica rhyolite and granite). Two of the most prominent attributes, the commodities/geochemical patterns and the mineralogy, are cross-indexed to model types in Appendixes $\mathrm{C}$ and $\mathrm{D}$, respectively.

To the greatest extent possible, models were constructed so as to be independent of site-specific attributes and therefore contain only those features which are transferable from one deposit to another. This goal is difficult to attain, because we do not always know which features are site specific.

The term "model" in an earth-science context elicits a wide variety of mental images, ranging from the physical duplication of the form of a subject, as in a scale model of the workings of a mine, to a unifying concept that explains or describes a complex phenomenon. In this context we shall apply only the latter usage. Therefore, let us propose a working definition of "model" in the context of mineral deposits, the overriding purpose being to communicate information that helps mankind find and evaluate mineral deposits. A mineral deposit model is the systematically arranged information describing the essential attributes (properties) of a class of mineral deposits. The model may be empirical (descriptive), in which instance the various attributes are recognized as essential even though their relationships are unknown; or it may be theoretical (genetic), in which instance the attributes are interrelated through some fundamental concept.

One factor favoring the genetic model over the simply descriptive is the sheer volume of descriptive information needed to represent the many features of complex deposits. If all such information were to be included, the number of models would escalate until it approached the total number of individual deposits considered. Thus we should no longer have models, but simply descriptions of individual deposits. Therefore, the compilers must use whatever sophisticated or rudimentary genetic concepts are at their disposal to distinguish the critical from the incidental attributes. It is commonly necessary to carry some possibly superficial attributes in order not to preclude some permissible but not necessarily favored, multiple working concepts.

The following example illustrates the problem. One of the commonly accepted attributes of the model for the carbonate-hosted lead-zinc deposits of the Mississippi Valley type is the presence of secondary dolomite. But do we know that this is essential? Suppose a deposit were found in limestone; would we reject its assignment to the Mississippi Valley class?
Or could it be correct that the critical property is permeability and that the formation of dolomite either (1) enhances permeability (and thereby makes the ground more favorable), or (2) reflects pre-existing permeability that is exploited by both the dolomite and the ore? Perhaps the dolomite merely records a particular range of $\mathrm{Ca} / \mathrm{Mg}$ ratio in the fluid which in turn is characteristic of the basinal brines that constitute the ore fluid. In any event, the dolomite is a powerful ore guide and belongs somewhere in the "final model."

\section{CLASSIFICATION OF MODELS USED IN THIS COMPILATION}

For the purpose at hand the classification scheme has two requirements: (1) it must be open so that new types of deposits can be added in the future, and (2) the user must be able to find easily the appropriate models to apply to the rock and tectonic environments being investigated.

Figure 1 maps out the four logic trees that constitute a broad lithotectonic classification; this system is similar to one developed by Page and others (1982c). The classification of deposits by the environment of formation of their host rocks is continued on a finer scale in table 1. This classification scheme is relatively straightforward for deposits formed essentially contemporaneously with their host rock. However, for epigenetic deposits a conflict arises between the lithotectonic environment of the formation of the host and the lithotectonic environment of the mineralization process. Therefore, for epigenetic deposits we have selected the most important aspect of the lithotectonic alternatives and classified the deposit accordingly. This procedure

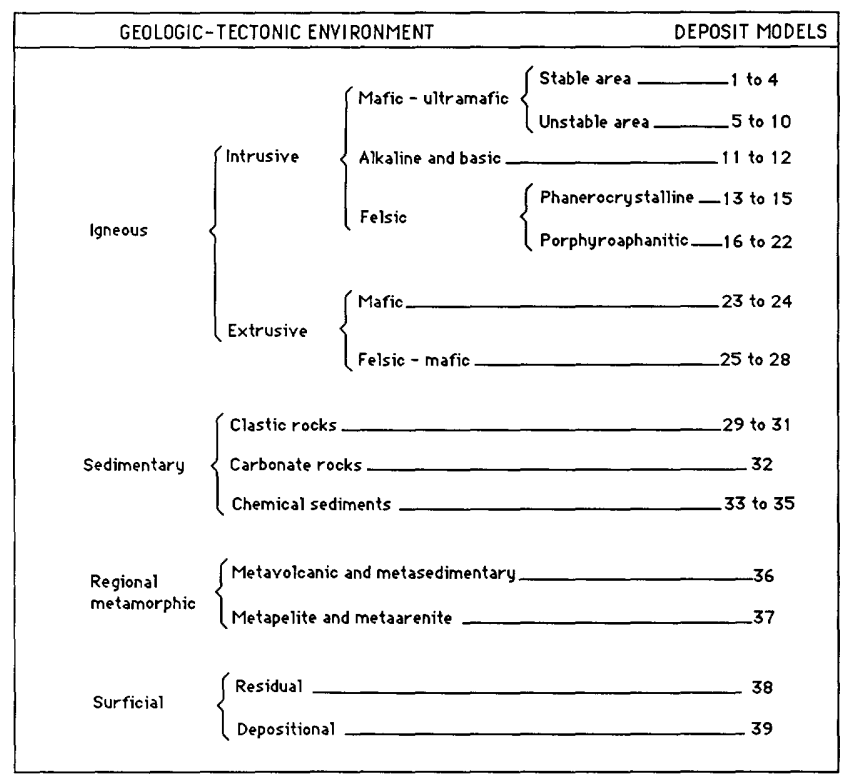

Figure 1. Tree diagram showing relationship of broad geologic-tectonic environments to models. These deposit models are classified on a finer scale in table 1 . 
Table 1. Classification of deposit models by lithologic-tectonic environment

[*indicates that model is not included in this bulletin]

Deposit environment

Mafic and ultramafic intrusions

A. Tectonically stable area; stratiform complexes

Stratiform deposits

Basal zone

Stillwater $\mathrm{Ni}-\mathrm{Cu}$

Intermediate zone

Bushveld chromitite -

Merensky Reef PGE -

Upper zone

Bushveld Fe-Ti-V

Pipe-like deposits

$\mathrm{Cu}-\mathrm{Ni}$ pipes

PGE pipes -

B. Tectonically unstable area

Intrusions same age as volcanic rocks

Rift environment

Duluth Cu-Ni-PGE -

Noril'sk Cu-Ni-PGE -_-

Greenstone belt in which lowermost rocks of

sequence contain ultramafic rocks

Komatiitic $\mathrm{Ni}-\mathrm{Cu}$

Dunitic Ni-Cu -

Intrusions emplaced during orogenesis

Synorogenic in volcanic terrane

Synorogenic-synvolcanic $\mathrm{Ni}-\mathrm{Cu}-1-0 .-1 \mathrm{a}$

Synorogenic intrusions in non-volcanic terrane

Anorthosite-Ti -

Ophiolites

Podiform chromite -

Major podiform chromite

(Lateritic Ni) -

(Placer Au-PGE) -

Serpentine

Limassol Forest Co-Ni

Serpentine-hosted asbestos -

(Silica-carbonate $\mathrm{Hg}$ ) -

(Low-sulfide Au-quartz vein) -

Cross-cutting intrusions (concentrically zoned)

Alaskan PGE -

(Placer PGE-Au)

C. Alkaline intrusions in stable areas

Carbonatite -.-

Alkaline complexes -

Diamond pipes -

Felsic irtrusions

D. Mainly phanerocrystalline textures

Pegmatitic

Be-Li pegmatites -

$\mathrm{Sn}-\mathrm{Nb}-\mathrm{Ta}$ pegmatites $-(-13 \mathrm{~b}$ *

Granitic intrusions

Wallrocks are calcareous

W skarn -

Sn skarn -

Replacement Sn - Sn 
Table 1. Classification of deposit models by lithologic-tectonic environment --Continued

Deposit environment

Model No.

D. Mainly phanerocrystalline textures--Continued Granitic intrusions--Continued

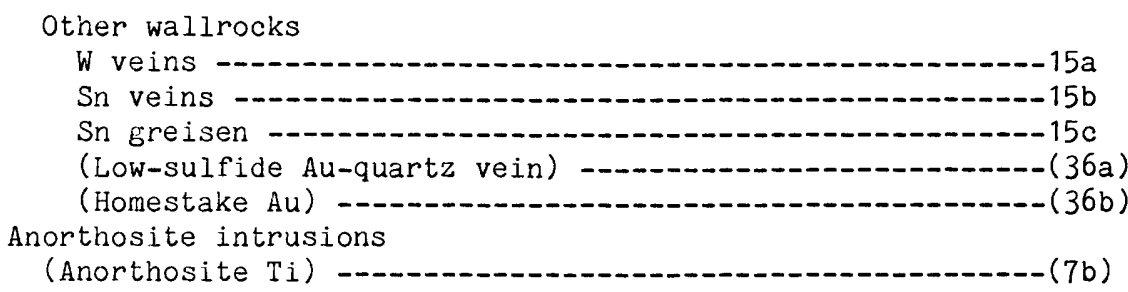

E. Porphyroaphanitic intrusions present

High-silica granites and rhyolites

Climax Mo -

(Fluorspar deposits) -

Other felsic and mafic rocks including alkalic

Porphyry $\mathrm{Cu}$

Wallrocks are calcareous

Deposits near contact

Porphyry $\mathrm{Cu}$, skarn-related -

Cu skarn -

$\mathrm{Zn}-\mathrm{Pb}$ skarn

Fe skarn -_-

Carbonate-hosted asbestos -

Deposits far from contact

Polymetallic replacement

Replacement Mn -

(Carbonate-hosted $\mathrm{Au}$ ) -

Wall rocks are coeval volcanic rocks

In granitic rocks in felsic volcanics

Porphyry Sn -

Sn-polymetallic veins --

In calcalkalic or alkalic rocks

Porphyry $\mathrm{Cu}-\mathrm{Au}$

(Epithermal Mn) -

Wallrocks are older igneous and sedimentary rocks

Deposits within intrusions

Porphyry Cu-Mo -

Porphyry Mo, low-F -

Porphyry $W$ -

Deposits within wallrocks

Volcanic hosted $\mathrm{Cu}-\mathrm{As}-\mathrm{Sb}$

$\mathrm{Au}-\mathrm{Ag}-\mathrm{Te}$ veins -

Polymetallic veins -...-

(Epithermal quartz-alunite $\mathrm{Au}$ ) -

(Low-sulfide Au-quartz vein)

Extrusive rocks

F. Mafic extrusive rocks

Continental or rifted craton

Basaltic $\mathrm{Cu}$

(Sediment-hosted $\mathrm{Cu}$ )

Marine, including ophiolite-related

Cyprus massive sulfide -

Besshi massive sulfide -

Volcanogenic Mn -

Blackbird Co-Cu -

(Komatiitic $\mathrm{Ni}-\mathrm{Cu}$ ) 
Table 1. Classification of deposit models by lithologic-tectonic environment --Continued

\begin{tabular}{ll}
\hline Deposit environment & Model No.
\end{tabular}

G. Felsic-mafic extrusive rocks

Subaerial

Deposits mainly within volcanic rocks

Hot-spring Au-Ag -

Creede epithermal vein

Comstock epithermal vein

Sado epithermal vein

Epithermal quartz-alunite $\mathrm{Au}$

Volcanogenic U - -

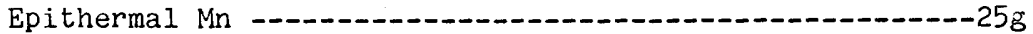

Rhyolite-hosted Sn -

Volcanic-hosted magnetite -

(Sn polymetallic veins)

Deposits in older calcareous rocks

Carbonate-hosted Au-Ag -

Fluorspar deposits

Deposits in older clastic sedimentary rocks

Hot-spring $\mathrm{Hg}$

Almaden $\mathrm{Hg}$ -

Silica-carbonate $\mathrm{Hg}$

Simple Sb -

Marine

Kuroko massive sulfide -

Algoma $\mathrm{Fe}$

(Volcanogenic $M n$ ) -

(Volcanogenic U) -

(Low-sulfide Au-quartz vein) -

(Homestake $\mathrm{Au}$ ) -

(Volcanogenic U) -

Sedimentary rocks

H. Clastic sedimentary rocks

Conglomerate and sedimentary breccia

Quartz pebble conglomerate Au-U -

Olympic Dam Cu-U-Au -

(Sandstone U) -

(Basaltic $\mathrm{Cu}$ ) -

Sandstone

Sandstone-hosted $\mathrm{Pb}-\mathrm{Zn}$

Sediment-hosted $\mathrm{Cu}$

Sandstone U -.-

(Basaltic $\mathrm{Cu}$ ) -

(Kipushi Cu-Pb-Zn) -

(Unconformity U-Au)

Shale-siltstone

Sedimentary exhalative $\mathrm{Zn}-\mathrm{Pb}$

Bedded barite -

Emerald veins -_-

(Basaltic Cu) -

(Carbonate-hosted $\mathrm{Au}-\mathrm{Ag}$ ) -

(Sediment-hosted $\mathrm{Cu}$ )

I. Carbonate rocks

No associated igneous rocks

Southeast Missouri Pb-Zn -

Appalachian Zn -

Kipushi $\mathrm{Cu}-\mathrm{Pb}-\mathrm{Zn}$

(Replacement $\mathrm{Sn}$ ) 
Table 1. Classification of deposit models by lithologic-tectonic environment -- Continued

Deposit environment $\quad$ Model No.

I. Carbonate rocks--Continued

No associated igneous rocks--Continued

(Sedimentary exhalative $\mathrm{Zn}-\mathrm{Pb}$ )

(Karst bauxite) -

Igneous heat sources present

(Polymetallic replacement)

(Replacement Mn) -

(Carbonate-hosted Au-Ag) -

(Fluorspar deposits)

J. Chemical sediments

Oceanic

Mn nodules -

Mn crusts -

Shelf

Superior Fe -

Sedimentary Mn -

Phosphate, upwelling type -

Phosphate, warm-current type

Restricted basin

Marine evaporite

Playa evaporite -

(Sedimentary exhalative $\mathrm{Zn}-\mathrm{Pb}$ )

(Sedimentary Mn) -

Regionally metamorphosed rocks

K. Derived mainly from eugeosynclinal rocks

Low-sulfide Au-quartz vein

Homestake Au -

(Serpentine-hosted asbestos) -

(Gold on flat faults)

L. Derived mainly from pelitic and other sedimentary rocks

Unconformity U-Au -.

Gold on flat faults

Surficial and unconformity-related

M. Residual

Lateritic Ni -

Bauxite, laterite type -

Bauxite, karst type -

(Unconformity U-Au) -

N. Depositional

Placer Au-PGE -

Placer PGE-Au -

Shoreline placer Ti -

Diamond placers --_-_-

Stream placer Sn -

(Quartz pebble conglomerate Au-U) -

inevitably introduces a substantial bias on the part of the classifier, thus we have followed a system of including, parenthetically, alternative classifications less favored by the compiler at the appropriate alternative points in the classification scheme.

\section{MODEL NAMES}

Each model has been assigned a name that is derived either from the special characteristics of the classes or from a type locality. The latter strategy 
was employed to avoid excessively long descriptive names. The use of type names derived from specific deposits does produce confusion in some readers, however, who may feel, for example, that a deposit that does not look "exactly" like Comstock cannot be represented by a "Comstock epithermal vein" model. This confusion may be minimized by realizing that most models are blends of attributes from a large number of deposits and that the names are only conveniences, not constrictions. The contributors to this report and the literature in general are not without disagreements regarding nomenclature (as well as genetic aspects and some facets of the groupings made here), but provision for alternative names is made in the model format under the heading of approximate synonyms.

\section{DESCRIPTIVE MODELS}

Because every mineral deposit, like every fingerprint, is different from every other in some finite way, models have to progress beyond the purely descriptive in order to represent more than single deposits. Deposits sharing a relatively wide variety and large number of attributes come to be characterized as a "type," and a model representing that type can evolve. As noted above, generally accepted genetic interpretations play a significant role in establishing model classes. Here we shall emphasize the more descriptive aspects of the deposits because our goal is to provide a basis for interpreting geologic observations rather than to provide interpretations in search of examples. The attributes listed are intended to be guides for resource assessment and for exploration, both in the planning stage and in the interpretation of findings.

The descriptive models have two parts. The first, the "Geological Environment," describes the environments in which the deposits are found; the second gives the identifying characteristics of the deposits. The headings "Rock Types" and "Textures" cover the favorable host rocks of deposits as well as source rocks believed to be responsible for hydrothermal fluids which may have introduced epigenetic deposits. "Age" refers to the age of the event responsible for the formation of the deposit. "Tectonic Setting" is concerned with major features or provinces (perhaps those that might be portrayed only at 1:1,000,000 or smaller scale), not ore control by structures that are local and often site-specific. "Associated Deposits" are listed as deposits whose presence might indicate suitable conditions for additional deposits of the type portrayed by the model.

The second part of the model, the "Deposit Description," provides the identifying characteristics of the deposits themselves, particularly emphasizing aspects by which the deposits might be recognized through their geochemical and geophysical anomalies. In most cases the descriptions also contain data useful in project planning for mineral assessment or exploration; this aspect is especially important where limited financial and manpower resources must be allocated to the more significant tasks.

\section{GRADE-TONNAGE MODELS}

Estimated pre-mining tonnages and grades from over 3,900 well-explored, well-characterized deposits were used to construct 60 grade-tonnage models. Where several different estimates were available for a deposit, the estimated tonnages associated with the lowest cutoff grades were used. Grades not available (always for by-products) were treated as zero. Except for a few instances, the data base is so large as to preclude specific references. Several published compilations of data were particularly useful sources for multiple deposit types (Canada Department of Energy, Mines and Resources, 1980; DeYoung and others, 1984; Krauss and others, 1984; Laughlin, 1984; Menzie and Mosier, 1985; Mosier and others, 1983; Mosier and others, in press; Singer and others, 1980; Yamada and others, 1980). The U.S. Geological Survey has a great deal of data available in the Mineral Resources Data System.

The grade-tonnage models are presented in graphical format to make it easy to compare deposit types and to display the data. All plots show either grade or tonnage on the horizontal axis, while the vertical axis is always the cumulative proportion of deposits. Plots of the same commodity or tonnages are presented on the same scale; a logarithmic scale is used for tonnage and most grades. Each dot represents an individual deposit (or, rarely, a district), cumulated in ascending grade or tonnage. Where a large number of deposits is plotted, individual digits represent the number of deposits. Smoothed curves are plotted through arrays of points, and intercepts for the $90 \mathrm{th}$, 50 th, and 10 th percentiles are constructed. For tonnages and most grades, the smoothed curves represent percentiles of a lognormal distribution that has the same mean and standard deviation as the observed data; exceptions are plots where only a small percentage of deposits had reported grades and grade plots that are presented on an arithmetic scale, such as iron or manganese, for which the smoothed curve was fit by eye. Summary statistics by deposit type are provided in Appendix B. The number of deposits in each type is indicated at the upper right of each diagram. The deposits used to construct each model are listed with the model and cross-indexed to model types in Appendix E. Correlations among grades and between tonnage and each grade are indicated only when significant at the 1 percent level.

There are important limitations inherent in the data base used for all grade-tonnage models. Estimates of cutoff grades within individual deposit types can vary because of regional, national, or operator differences. All too commonly there is no mention of the actual cutoff grades or mining widths that are incorporated into published reserve figures; nevertheless, the grade-tonnage figures given do represent material that the company or the government believed might someday be economic to mine. Stratiform deposits of large areal extent, such as phosphate or sedimentary manganese, are special problems because of differences in opinion and practice regarding how closely drilled they must be to "prove" ore tonnages and regarding the thicknesses and depths of what may be considered for eventual mining. Effects of another source of variation, mining 
methods, are recognized in some of the placer models; typically, however, mining methods are fairly consistent within a deposit type. In a few instances, irregular cumulative frequency plots reflect mixing of economic and scientific data sources, such as in the plot of gold in porphyry copper deposits. In spite of the current difficulty of quantifying variation of grades and tonnages with respect to changes in cutoff grades or mining methods, the models presented here are believed to account for the main source of variation in grades and tonnages of mineral deposits-variation due to differences among types of deposits.

The question of whether one counts deposits within a cluster of related deposits as individuals or as a total will probably never be resolved to everyone's satisfaction. Some geostatisticians would separate each ore body (and then argue about whether two operations on the same body should be counted separately), whereas some economic geologists would lump everything from a single district (and then argue about district boundaries). For the most part the entities summarized are individual deposits, but in some instances such data are mixed with data representing entire districts. Because of these inconsistencies, some care is necessary in comparing grade-tonnage models between deposit types or in comparing this summary with those prepared using alternative methods.

Care is also warranted in interpreting the grade distributions for which data are missing; this concerns principally by-product grades. In some instances, such as the platinum-group element (PGE) contents in podiform chromite and the cobalt content of laterites, the fragmentary information given probably represents the entire class. In other instances, such as the lead content of Cyprus massive sulfide deposits, the missing grades probably represent values below the lowest reported grades. The grades derived from studies of trace elements in ores more probably represent the former situation rather than the latter.

Deposits strongly suspected to be small or very low grade are seldom sampled well enough to be characterized in terms of grade and tonnage, thus the sample of many deposit classes is truncated by economics. Nonetheless, probably 40 percent of the deposits used in these models are, in fact, noneconomic today; and a perusal of the figures will discover examples of both small deposits and lowgrade deposits.

Potential metal supply is dominated by the very few largest tonnage deposits, as shown by Singer and DeYoung (1980), who also pointed out that inverse correlations between grade and tonnage are surprisingly rare. Thus the fact that a deposit is large does not necessarily mean that it will prove to be of low grade. This means that most low-grade deposits are not likely to have huge resources and also that the omission of a few low-grade or small tonnage deposits will not seriously degrade the predictions of potential national supplies for most commodities. In contrast, the missing low-grade and small deposits suggest that the grade-tonnage models represent a biased sample of the large number of low-grade or small-tonnage occurrences and prospects found by exploration. This fact must be considered in cases where the number of undiscovered deposits is estimated. In order for the estimated number of deposits to be consistent with a grade-tonnage model, approximately half of the deposits estimated should have greater than the model's median tonnage or grade. Thus the probability that an untested prospect represents a significant deposit can too easily be overestimated.

\section{OTHER TYPES OF MODELS AND THEIR INTERRELATIONSHIPS}

The bulk of this report deals with descriptive mineral deposit models and their grade-tonnage counterparts, but there are other useful aspects which we wish to discuss even though we have not yet had the opportunity to develop or exploit them. They are the genetic, occurrence probability, and quantitative process models.

Many authors prefer to keep a clear distinction between descriptive and genetic models, apparently feeling that the descriptive models somehow represent "pure truth" whereas the genetic constitute a less objective philosophical position (or at least make the investigator "skate on thin ice"). It is altogether desirable to avoid confusing interpretation with fact; but it is well to remember, for example, that each time a field geoscientist extrapolates geology across a covered area he or she adds an element of "interpretation" to a "factual" map, and that this interpretation is not necessarily any more "real" (or "unreal") than, for example, an isotope geologist's conclusion that a given oxygen and hydrogen isotopic signature extracted from fluid inclusions points to a meteoric origin for the fluid. The point is that the whole of our professional knowledge rests on a broad continuum of interpretations; many of them are so commonly accepted that they are no longer questioned, but many others still evoke challenges. Thus we suggest that a combination descriptivegenetic model is not inconsistent with professional practice. The model begins as a description, but various aspects of the model become genetic as they acquire satisfactory genetic explanations. Eventually much of the model becomes genetic, as has happened, for example, with the Cyprus-type massive sulfide deposits or the sandstone uranium deposits of the Colorado Plateau.

As the attributes of a model become understood in a genetic sense, the descriptive model evolves to a genetic model:

1. Genetic models are compilations of the properties of a group of related deposits in which the reasons for certain attributes being favorable are identified. Descriptive models evolve into genetic models, and as such they become far more flexible and powerful.

We have presented the three model subtypes above as if they constituted a linear logical sequence leading toward the "final" model, but in fact there must be an iterative relationship among descriptive, genetic, and grade/tonnage models. The consequence of examining any of these three may be a reassessment of the groupings of deposits chosen to be represented by a model type and the redesignation of the attributes diagnostic for that type.

With a dominantly genetic model in hand, two 
more model types can be generated:

2. Occurrence probability models are models that predict the probability of a deposit (of a size and grade indicated by the appropriate grade-tonnage models) occurring within a given area. As with the descriptive and genetic models, probability models that are tied to lithic or structural geologic entities (that is, they are genetic) are far more focused; in fact, it is probably impossible to generate a useful probability model before the establishment of a genetic model. Accurate probability models are very difficult to construct because although the technical community has very complete data on mineral producers (mines), the data on non-producing mineral deposits (prospects and mineral shows) are much less well documented, a point also covered in the discussion of grade-tonnage models. Even more importantly, data on barren areas are sparse. We must extrapolate from a very fragmentary base toward a completely unseen target.

There is much to learn before the probability model can be made a dependable tool; yet the successful targeting of exploration programs by industry demonstrates that, at least on a qualitative basis, areas with better-than-average probabilities can be identified. It is worth noting, also, that mineral fuels are much more predictable and now can have realistic probability-of-occurrence values attached to specific volumes of sediments provided that the initial character and postdepositional histories of the sediments are well known. It is a distant but not unreasonable dream to anticipate that some day we shall approach that level of certainty for some types of nonfuel mineral deposits.

3. Quantitative process models are models that describe quantitatively some process related to mineral deposit formation; they are offshoots of the genetic model. Examples would be models of heat or fluid flow around a cooling pluton; rates of crystal growth as functions of supersaturation, impurities, and temperature; or sequences and amounts of minerals deposited from evaporating seawater.

All five of these model subtypes can be parts of the "final" model, and recycling of the model back to the original groupings stage helps refine the selection process. Figure 2 shows the flow of information that results in the generation of the models we have discussed.

Table 2 compares the five model subtypes with five distinct types of uses for the information. Note that persons engaged in research guidance and especially exploration and development have broadranging needs, whereas those dealing with the availability of minerals or of land-use allocation have less use for genetic or quantitative process models. Overall there is a need for a comprehensive array of mineral deposit models to meet these individual objectives.

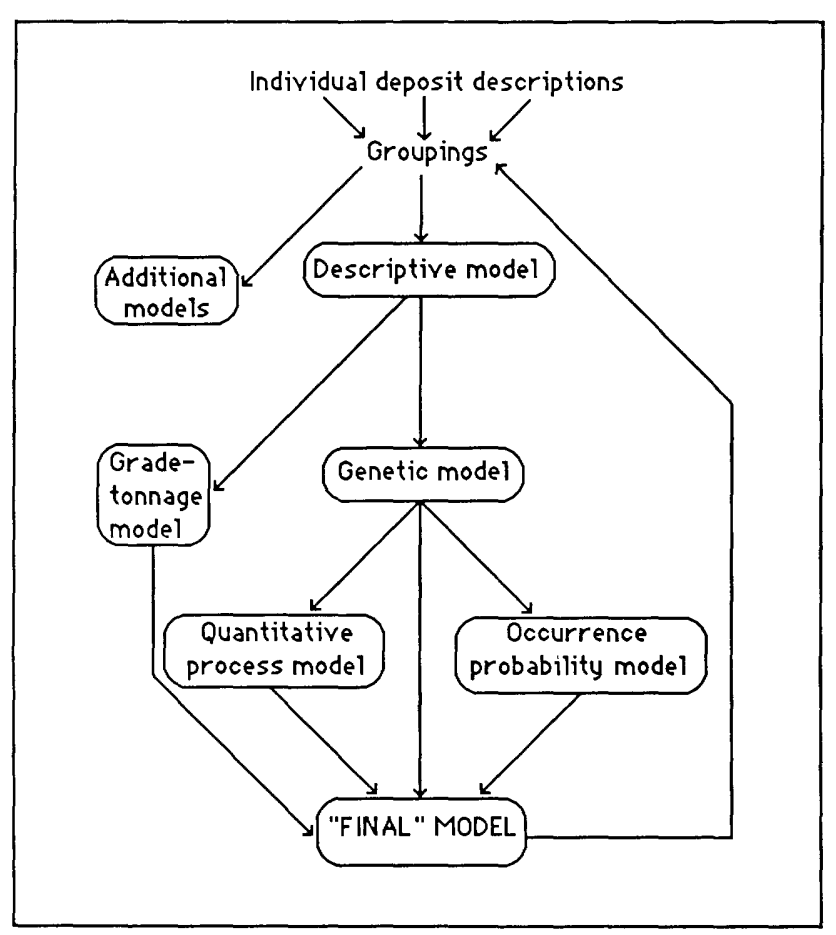

Figure 2. Flow sheet showing evolution of model types. Individual model subtypes are discussed in text. It is essential that such a structure represents the repetitive cycling of information leading to continual refinement of groupings of deposits that represent each model type.

\section{MATURITY OF DESCRIPTIVE-GENETIC MODELS}

The rate at which we gain understanding and the current levels of genetic knowledge vary considerably from one deposit type to another, as figures 3 and 4 show. Such types as placers and evaporites are well known genetically and the problems in their exploration and utilization concern local site-specific geologic issues rather than mineral genesis or the degree of maturation of the model. In contrast, others such as the Coeur d'Alene $\mathrm{Ag}-\mathrm{Pb}-\mathrm{Zn}$ veins, or the massive $\mathrm{Zn}-\mathrm{Mn}-\mathrm{Fe}$ oxide/silicate bodies at Franklin and Sterling Hill, or the $\mathrm{Cu}-\mathrm{U}-\mathrm{Au}$ at Olympic Dam, or the $\mathrm{Cu}-\mathrm{Zn}-\mathrm{Pb}-\mathrm{Ge}$ ores of Kipushi and the Tsumeb pipe remain genetic enigmas despite, in the instances of the first two, extensive research spanning many years. Still others, such as the diamond-bearing kimberlite pipes, are geologically well understood regarding their origin yet very poorly understood in terms of the reasons for their existing at any particular site. Our rate of acquisition of information is very irregular, as the schematic diagram in figure 3 shows. The several scarps between plateaus in the knowledge curve for the marine phosphate model might mark, successively, the recognition that the phosphate was a chemical precipitate, that it occurred on continental shelves where upwelling of deep marine waters occurred, and that the upwelling regions were related to wind and current patterns that were tied to the global configuration of the continents and ocean basins. A 
Table 2. Comparison of application of the five model subtypes by various users

[Level of use: Major, $\mathbf{x}$; minor, $x$; minimal, $x$ ]

\begin{tabular}{|c|c|c|c|c|c|}
\hline \multirow[b]{2}{*}{ Uses } & \multicolumn{5}{|c|}{ Subtypes of models } \\
\hline & $\begin{array}{l}0 \\
0 \\
0 \\
0 \\
0 \\
0 \\
+ \\
0 \\
0 \\
0 \\
0 \\
0 \\
0\end{array}$ & 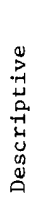 & 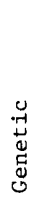 & 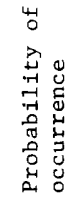 & 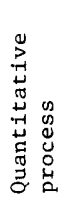 \\
\hline Exploration/development & $\mathbf{X}$ & $\mathbf{x}$ & $\mathbf{x}$ & $\mathrm{X}$ & $\mathrm{X}$ \\
\hline Supply potential & $\mathbf{x}$ & $x$ & $\mathrm{x}$ & $\mathbf{x}$ & $\mathrm{x}$ \\
\hline Land use & $\mathbf{x}$ & $x$ & $\mathrm{x}$ & $\mathbf{x}$ & $\mathbf{x}$ \\
\hline Education & $\mathrm{x}$ & $\mathrm{X}$ & $\mathbf{X}$ & $\mathrm{x}$ & $\mathbf{X}$ \\
\hline Research guidance & $\mathrm{x}$ & $\mathrm{x}$ & $\mathbf{x}$ & $\mathrm{X}$ & $\mathbf{x}$ \\
\hline
\end{tabular}

second example from the Mississippi Valley-type ores might involve scarps marking the recognition (from fluid-inclusion evidence) that the ores were deposited from warm (about $100^{\circ} \mathrm{C}$ ) highly saline solutions that could represent neither simple surface nor marine waters. A second scarp might be associated with the recognition that the deposits were integral parts of a regional hydrologic regime whose distribution and character was susceptible to interpretation.

Figures 3 and 4 bring out another point: some aspects of any model always remain to be determined, thus we never acquire a "complete" model. Indeed, the approach to "complete" understanding is asymptotic, and a lot of additional effort to clear up the "last" uncertainty in a nearly perfect model is probably unwarranted. But, as the examples in figure 3 show, new ideas and new technologies can provide the impetus for new spurts in knowledge for heretofore incomplete models.

Note that the horizontal axis in figure 3 is simply "years of effort" devoted to fundamental geologic investigation. The scale certainly needs to be exponential in order to fit the intensively studied and sparsely studied deposit types, but this figure is strictly schematic, there being no source of documentation for either coordinate. The figure also indicates that different deposit types may require different amounts of effort to achieve a similar level of genetic understanding.

Figure 4 shows a hypothetical growth curve along which different types of deposits have been schematically arrayed. Because some deposits (such as volcanogenic massive sulfides) are so much more difficult to understand than others (gold placers), the horizontal axis has been "normalized" by plotting a ratio of effort done to effort needed thereby permitting a smooth, although admittedly subjective

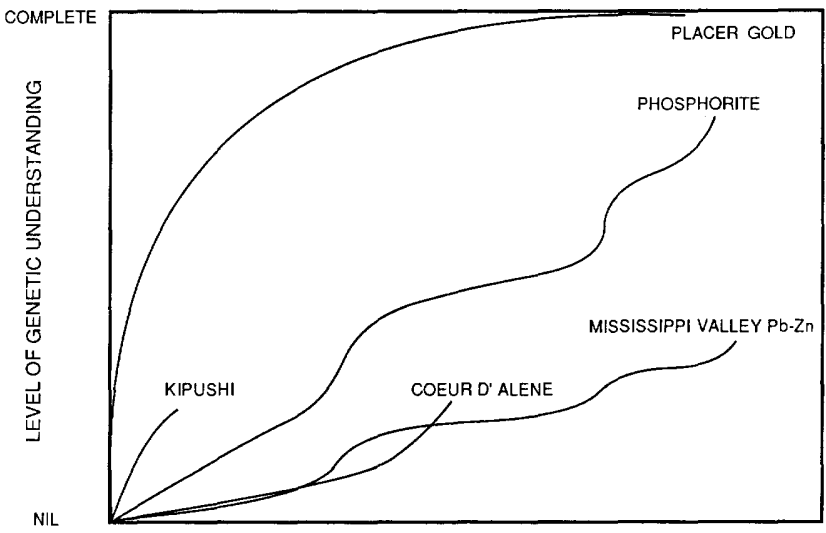

PERSON-YEARS OF EFFORT (Schematic log scale)

Figure 3. Schematic growth patterns for understanding of some typical genetic models. Individual curves discussed in text.

and schematic, curve to be illustrated. As with figure 3 , there is no documentation to support this diagram, although the general concept meets with agreement among most contributors to this volume.

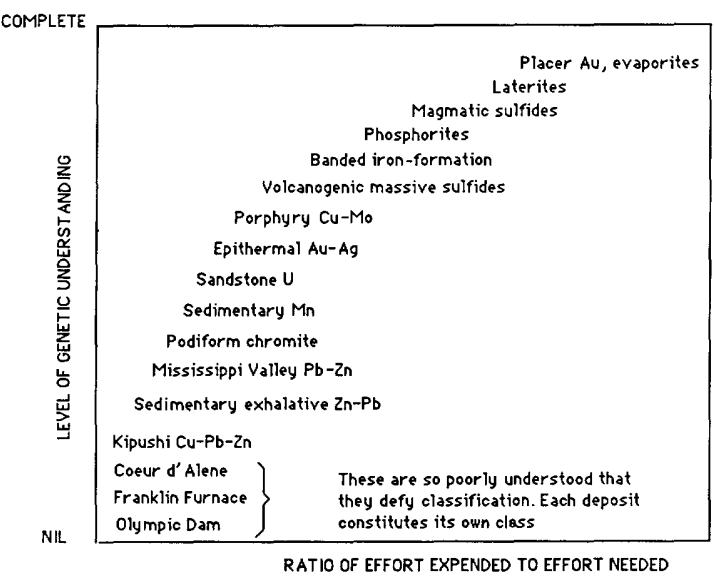

Figure 4. Comparison of relative levels of understanding of some important model types. Vertical coordinate same as for figure 3; but because difficulty of acquiring the genetic information differs so widely among model types, the horizontal coordinate is "normalized" as noted in text. 


\section{DESCRIPTIVE MODEL OF STILLWATER Ni-Cu}

By Norman J Page

APPROXIMATE SYNONYM Stratiform mafic-ultramafic Ni-Cu.

DESCRIPTION $\mathrm{Ni}$, Cu sulfides at base of large repetitively layered mafic-ultramafic intrusion. (see fig. 5).

GENERAL REFERENCES Geological Society of South Africa, Special Publication 1 (1969); Economic Geology, v. 77, no. 6 (1982) and v. 71, no. 7 (1976).

GEOLOGICAL ENVIRONMENT

Rock Types Layered intrusion contains norite, gabbro-norite, dunite, harzburgite, peridotite, pyroxenite, troctolite, anorthosite, and gabbro.

Textures Cumulate textures; layers with gradational proportions of euhedral crystals; locally with poikilitic matrix.

Age Range Generally Precambrian, but may be as young as Tertiary.

Depositional Environment Intruded into granitic gneiss or volcanic-sedimentary terrane.

Tectonic Setting(s) Cratonal, mostly in Precambrian shield areas.

Associated Deposit Types Bushveld Cr, Merensky Reef PGE, Bushveld Fe-Ti-U. PGE placers.

DEPOSIT DESCRIPTION

Mineralogy Pyrrhotite + chalcopyrite + pentlandite + cobalt sulfides, by-product platinum group metals (PGE).

Texture/Structure Locally massive; interstitial to silicates; disseminated.

Alteration None related to ore.

Ore Controls Basins in basal. contact of intrusion with rapidly varying lithologies. Sulfides may intrude fractures in footwal]. country rock. Ingress of sulfur through fractures in footwall may be important ore control.

Weathering Gossan.

Geochemical Signature $\mathrm{Cu}, \mathrm{Ni}, \mathrm{PGE}$, Co. High $\mathrm{Mg}$; low $\mathrm{Na}, \mathrm{K}$, and $\mathrm{P}$.

EXAMPLES

Stillwater Complex, USMT (Page, 1977) 


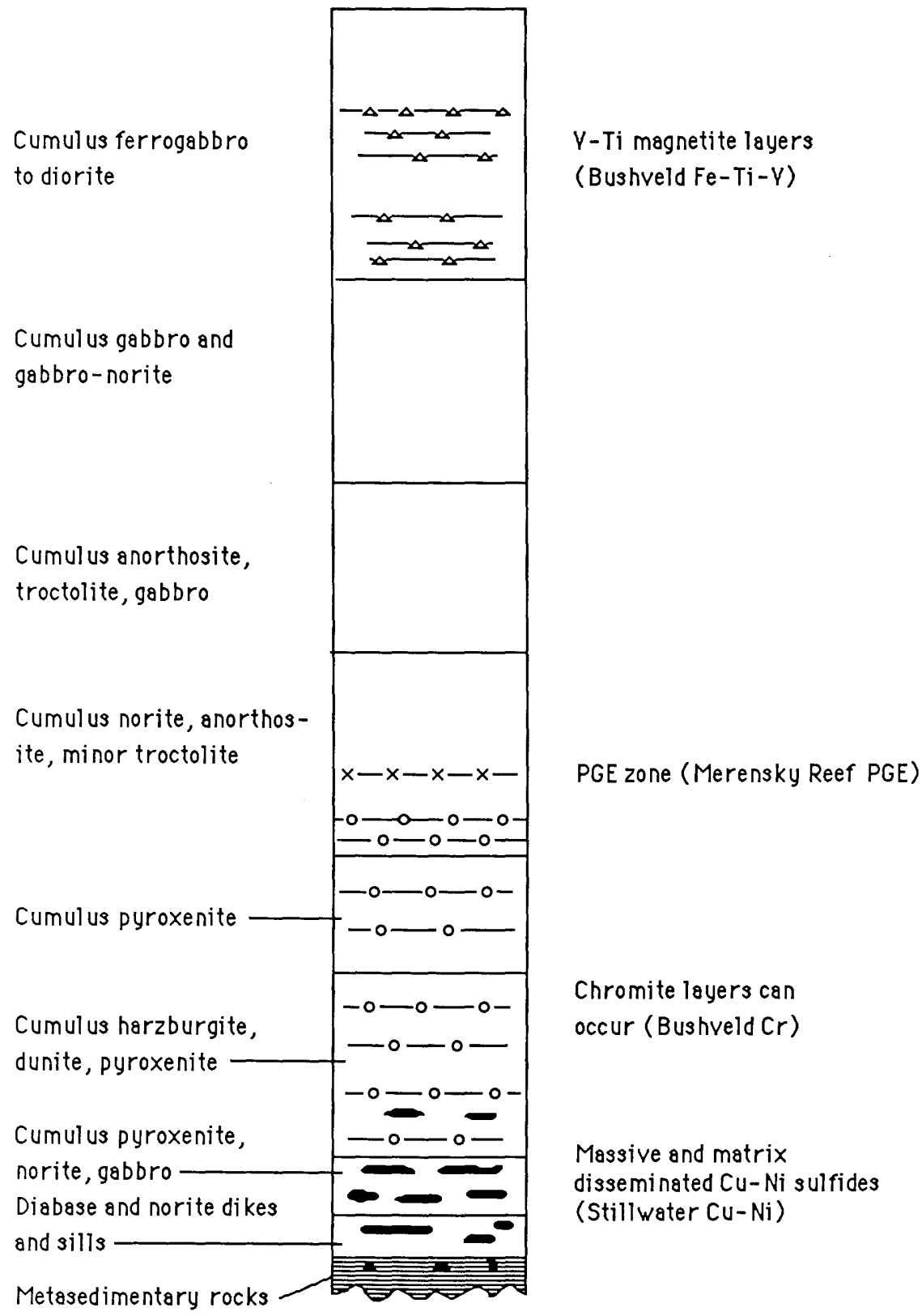

Figure 5. Diagram of typical mafic-ultramafic stratiform complex, 500 to $1,500 \mathrm{~m}$ thick, showing stratigraphic relations of rock units and mineral deposits. Deposit models shown in parentheses. 


\section{DESCRIPTIVE MODEL OF BUSHVELD $\mathrm{Cr}$}

By Norman J Page

SYNONYM Stratiform mafic-ultramafic $\mathrm{Cr}$.

DESCRIPTION Layered chromitite in lower intermediate zone of large repetitively layered maficultramafic intrusions (see fig. 5).

GEOLOGICAL ENVIRONMENT

Rock Types Intrusion may contain norite, gabbro-norite, dunite, harzburgite, peridotite, pyroxenite, troctolite, anorthosite, and gabbro.

Textures Cumulate textures; layers with gradational proportions of euhedral crystals; locally with poikilitic matrix.

Age Range Generally Precambrian, but may be as young as Tertiary.

Depositional Environment Intruded into granitic gneiss or into volcanic-sedimentary terrane.

Tectonic Setting(s) Cratonal, mostly in Precambrian shield areas.

Associated Deposit Types Stillwater-Ni-Cu, Merensky Reef PGE, and Bushveld Fe-Ti-V deposits. PGE placers.

\section{DEPOSIT DESCRIPTION}

Mineralogy Chromite \pm ilmenite \pm magnetite \pm pyrrhotite \pm pentlandite \pm chalcopyrite \pm PGE minerals (dominantly laurite, cooperite, and braggite).

Texture/Structure Massive to disseminated layers, cumulus texture.

Alteration None related to ore.

Ore Controls May be in dunite, orthopyroxenite, or anorthosite. Thickness of chromite increases in basinal depressions in layering.

Weathering Abundant blocks of chromitite in soil and alluvium.

Geochemical Signature Cr, PGE. High Mg; low Na, K, P.

EXAMPLES

Bushveld Complex, SAFR

Stillwater Complex, USMT

Great Dyke, ZIMB
(Cameron and Desborough, 1969)

(Jackson, 1969)

(Bichan, 1969) 
Model 2b

\title{
DESCRIPTIVE MODEL OF MERENSKY REEF PGE
}

\author{
By Norman J Page
}

SYNONYM Stratiform mafic-ultramafic PGE.

DESCRIPTION Disseminated PGE-rich sulfides in olivine-rich rocks in anorthosite-gabbro zone of large layered intrusions (see fig. 5).

GEOLOGICAL ENVIRONMENT

Rock Types Norite, gabbro-norite, dunite, harzburgite, peridotite, pyroxenite, troctolite, anorthosite, and gabbro.

Textures Cumulate textures; layers with gradational proportions of euhedral crystals; locally with poikilitic matrix.

Age Range Generally Precambrian, but may be as young as Tertiary.

Depositional Environment Intruded into granitic gneiss or into volcanic-sedimentary terrane.

Tectonic Setting(s) Cratonal, mostly in Precambrian shield areas.

Associated Deposit Types Stillwater $\mathrm{Ni}-\mathrm{Cu}$, Bushveld $\mathrm{Cr}$, and Bushveld Fe-Ti-V. PGE placers. DEPOSIT DESCRIPTION

Mineralogy Pyrrhotite + chalcopyrite + pentlandite \pm chromite \pm graphite. PGE minerals are braggite, cooperite, kotulskite, vysotskite, sperrylite, moncheite, and alloys of platinum-group metals.

Texture/Structure Clots of massive sulfide and disseminated grains.

Alteration None related to ore.

Ore Controls In layers near first reappearance of olivine as a cumulate phase after thick accumulation of plagioclase pyroxene rocks. May be related to introduction of new magma. Locally associated with pipes of Fe-rich olivine.

Weathering Difficult to see ore zone on weathered surface, exploration requires extensive sampling and chemical analysis.

Geochemical Signature PGE, $\mathrm{Cu}, \mathrm{Ni}, \mathrm{Cr}, \mathrm{Ti} . \mathrm{High} \mathrm{Mg}$; low Na, K, P.

EXAMPLES

Bushveld Complex, SAFR

Stillwater Complex, USMT
(Vermaak and Hendriks, 1976)

(Todd and others, 1982) 


\section{DESCRIPTIVE MODEL OF BUSHVELD Fe-Ti-V}

By Norman J Page

SYNONYM Stratiform mafic-ultramafic Fe-Ti-V.

DESCRIPTION Layers of Ti-V-rich magnetite in upper parts of large repetitively layered maficultramafic intrusions (see fig. 5).

GEOLOGICAL ENVIRONMENT

Rock Types Norite, gabbro-norite, dunite, harzburgite, peridotite, pyroxenite, troctolite, anorthosite, and gabbro.

Textures Cumulate textures; layers with gradational proportions of euhedral crystals; locally with poikilitic matrix.

Age Range Generally Precambrian, but may be as young as Tertiary.

Depositional Environment Intruded into granitic gneiss or into volcanic-sedimentary terrane.

Tectonic Setting(s) Cratonal, mostly in Precambrian shield areas.

Associated Deposit Types Bushveld $\mathrm{Cr}$, Stillwater Ni-Cu, and Merensky Reef PGE. PGE placers.

DEPOSIT DESCRIPTION

Mineralogy Vanadium-bearing magnetite \pm ilmenite \pm traces of sulfides.

Texture/Structure Massive magnetite-ilmenite, cumulus textures.

Ore Controls Layers near top of intrusion. Layers may be cut by pipes and veins rich in ilmenite.

Weathering Blocks of magnetite in soil and alluvium.

Geochemical Signature Fe, Ti, V.

\section{EXAMPLES}

Bushveld Complex, SAFR (Williams, 1969; Molyneux, 1969) 
Model $5 \mathrm{a}$

\title{
DESCRIPTIVE MODEL OF DULUTH CU-Ni-PGE
}

\author{
By Norman J Page
}

DESCRIPTION Sporadically distributed massive to disseminated sulfides associated with basal portion of large layered intrusions in rift environments.

GENERAL REFERENCE Weiblen and Morey (1980).

\section{GEOLOGICAL ENVIRONMENT}

Rock Types Peridotite, harzburgite, pyroxenite, norite, augite, troctolite, anorthosite.

Associated with pyritic shale, anhydrite, or recognizable source of sulfur to contaminate magma.

Textures Cumulus textures, locally diabasic or ophitic textures.

Age Range Precambrian to Tertiary(?).

Depositional Environment Intruded during rifting into metasedimentary (slate, argillite, graywacke) and metavolcanic rocks.

Tectonic Setting(s) Rift environment.

\section{DEPOSIT DESCRIPTION}

Mineralogy Pyrrhotite + pentlandite + chalcopyrite + cubanite \pm PGE minerals \pm graphite.

Texture/Structure Disseminated, matrix, and massive sulfides.

Alteration Locally sulfides may show evidence of hydrothermal remobilization.

Ore Controls Zone of active syn-intrusion faulting forming basins, in basal part of intrusion; source of external sulfur; source of silicic material to contaminate magma.

Geochemical Signature $\mathrm{Ni} / \mathrm{Cu}$ approximately $1 / 3, \mathrm{Cu}, \mathrm{Ni}$; PGE, Co, Ti; sulfur isotopes show nonmagmatic sulfur.

EXAMPLES

Duluth Complex, USMN

(Dunka Road deposits)
(Weiblen and Morey, 1980;

Bonnichsen, 1972; Ripley, 1981) 


\section{DESCRIPTIVE MODEL OF NORIL'SK Cu-Ni-PGE}

By Norman J Page

DESCRIPTION Massive to disseminated sulfides in small shallow mafic to ultramafic intrusives with an external source of sulfur.

\section{GEOLOGICAL ENVIRONMENT}

Rock Types Flood basalts, picritic intrusive rocks, picritic gabbro, norite, olivine gabbro, dolerite, intrusive and volcanic breccias. Associated with evaporites or some external source of sulfur.

Textures Ophitic, subophitic, gabbroic, cumulate.

Age Range Paleozoic.

Depositional Environment Magma has intruded through evaporites or pyritic shale, and formed sills in flood basalts during active faulting.

Tectonic Setting(s) Rift environment.

DEPOSIT DESCRIPTION

Mineralogy Pyrrhotite + pentlandite + chalcopyrite + cubanite + millerite + vallerite + pyrite + bornite + gersdorffite + sperrylite + PGE alloys + polarite + PGE tellurides, arsenides, and antimonides.

Texture/Structure Lenses, layers of massive, matrix, and disseminated sulfide.

Alteration None related to ore.

Ore Controls External source of sulfur; sulfides form persistent basal layers to intrusion and dike-like bodies into country rock; and form in fault-bounded depressions.

Geochemical Signature $\mathrm{Ni} / \mathrm{Cu}=1.5$ to $0.5, \mathrm{Co} / \mathrm{Ni}=1 / 16 ; \mathrm{Pt} /(\mathrm{Pd} / \mathrm{Ni})=1 / 500$

EXAMPLES

Noril'sk, USSR (Krauss and Schmidt, 1979) 
Model $6 \mathrm{a}$

\section{DESCRIPTIVE MODEL OF KOMATIITIC Ni-Cu}

By Norman J Page

DESCRIPTION Lenticular, irregular elongate to tabular, pipelike Ni-Cu sulfides associated with komatitic volcanic extrusive rocks (see fig. 6).

GENERAL REFERENCE Arndt and Nisbet (1982).

GEOLOGICAL ENVIRONMENT

Rock Types Dunite, pyroxenite, peridotite, basalt, komatiites, komatiitic basalts. Rocks contain more than 15 percent and may approach 40 percent MgO.

Textures Bladed olivine or pyroxene with skeletal appearance in random or parallel orientations; spinifex textures, fracture or joint patterns that resemble pillows.

Age Range Archean or Proterozoic generally, but some may be Cretaceous or Tertiary.

Depositional Environment Mafic to felsic rock sequences with numerous volcanic events.

Tectonic Setting(s) Greenstone belts.

Associated Deposit Types Dunitic Ni.

DEPOSIT DESCRIPTION

Mineralogy Pyrite + pyrrhotite + chalcopyrite + pentlandite, by-product PGE.

Texture/Structure Sulfide contents vary from base to top of deposit. Base contains massive sulfide grading into net-textured or matrix sulfide into disseminated sulfide.

Alteration None related to ore.

Ore Controls In lowermost flows more than $10 \mathrm{~m}$ thick; in zones of increased spinifex development; and near feeder areas for the flows. Orebodies show evidence of active faulting at the time the flows were deposited and have thickening and thinning of flows along strike. Ore occurs in irregularities at bottom of flows. Unit contains greater than 1,000 ppm sulfur or is associated with sulfide-bearing chert and argillite. Shale or iron carbonate sequences occur below flows.

Weathering Develop gossans, laterites.

Geochemical Signature High $\mathrm{Mg}, \mathrm{Ni}, \mathrm{Cu}, \mathrm{Mg}$, PGE. Gossans contain 15 to $30 \mathrm{ppb} \mathrm{Pd}$ and 5 to $10 \mathrm{ppb}$ Ir over known $\mathrm{Ni}-\mathrm{Cu}$ deposits where $\mathrm{Cu}$ and $\mathrm{Ni}$ are leached out of the gossan.

\section{EXAMPLES}

Kambalda, AUWA

Damba, ZIMB

Langmuir, CNON
(Gresham and Loftus-Hills, 1981)

(Williams, 1979)

(Green and Naldrett, 1981)

\section{GRADE AND TONNAGE MODEL OF KOMATIITIC Ni-Cu}

By Donald A. Singer, Norman J Page, and W. David Menzie

COMMENTS Nickel grade is correlated with tonnage $(r=-0.47)$ and with copper grade $(r=0.59, n=21)$. Au, Ir, Pt, and Pd grades are based on reported analyses of samples from the deposits. See figs. 7-10. 
DEPOSITS

Name

Carnilya E.

Carnilya Hill

Damba

Epoch

E. Scotia

Hitura

Hunters Road

Kambalda

Kotalahti

Langmuir 1

Langmuir 2

Marbridge

McWatters

Miriam

Mt. Edwards

Mt. Windarra

Country
AUWA
AUWA
ZIMB
ZIMB
AUWA
FNLD
ZIMB
AUWA
FNLD
CNON
CNON
CNQU
CNON
AUWA
AUWA
AUWA

Name

Country

Munda

AUWA

Nepean

AUWA

Perseverance ZIMB

Rankin Inlet CNNT

Redross AUWA

Scotia AUWA

Selukwe ZIMB

Shangani ZIMB

Sothman Twp. CNON

Spargoville AUWA

S. Windarra AUWA

Textmont CNON

Trojan ZIMB

Wannaway AUWA

Wigie 3 AUWA

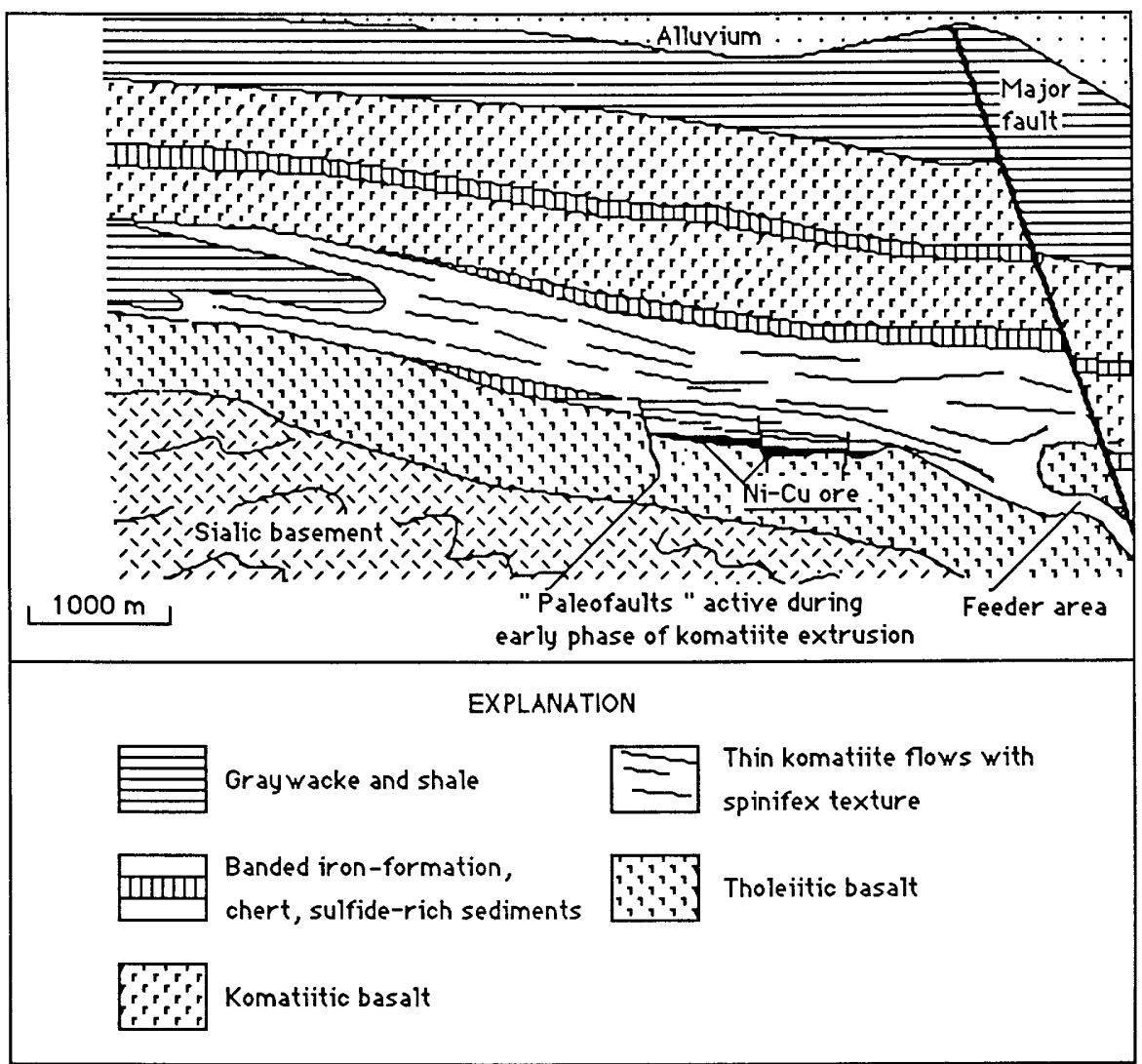

Figure 6. Cartoon cross section of typical komatiitic vol canic sedimentary sequence showing ore controls of komatiitic Ni-Cu deposits. Modified from Marston and others (1981). 
Model 6a--Con.

KOMATIITE NICKEL-COPPER

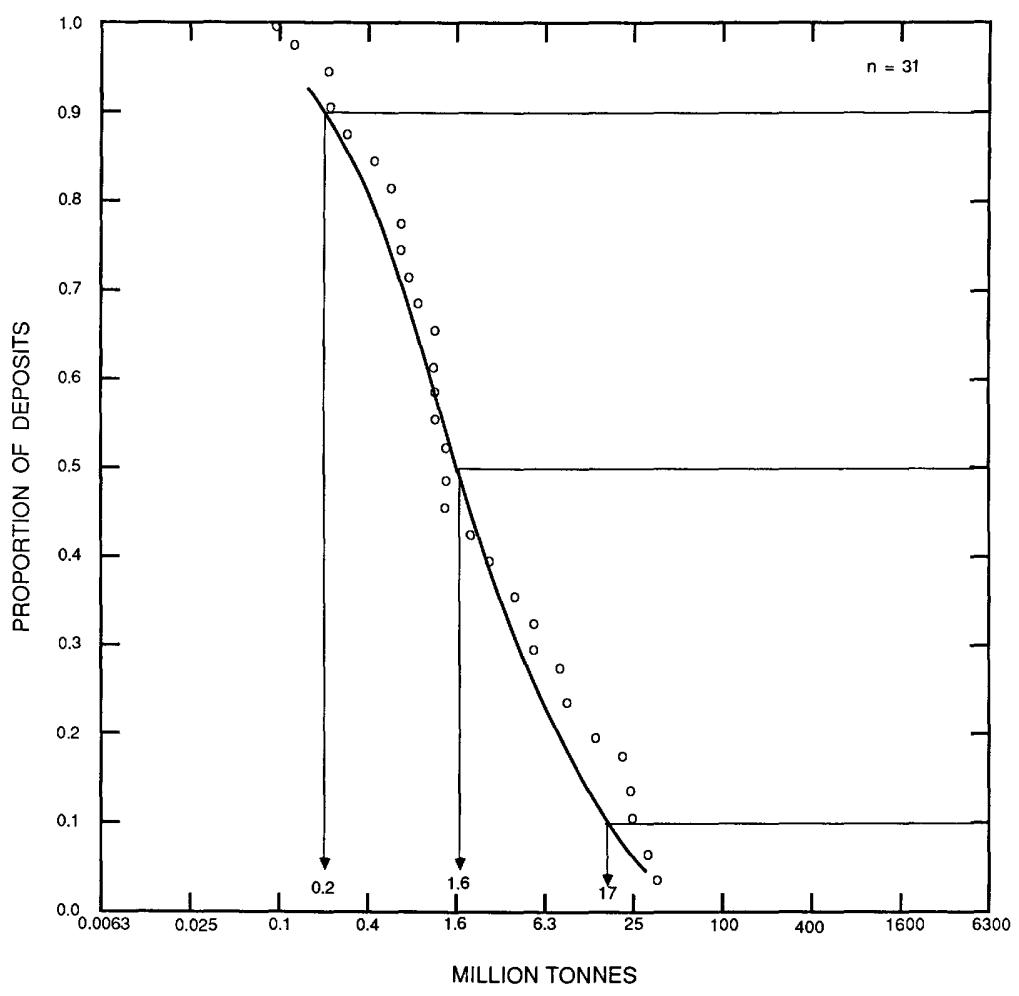

Figure 7. Tonnages of komatiitic Ni-Cu deposits. 
Model 6a--Con.

KOMATIITE NICKEL--COPPER
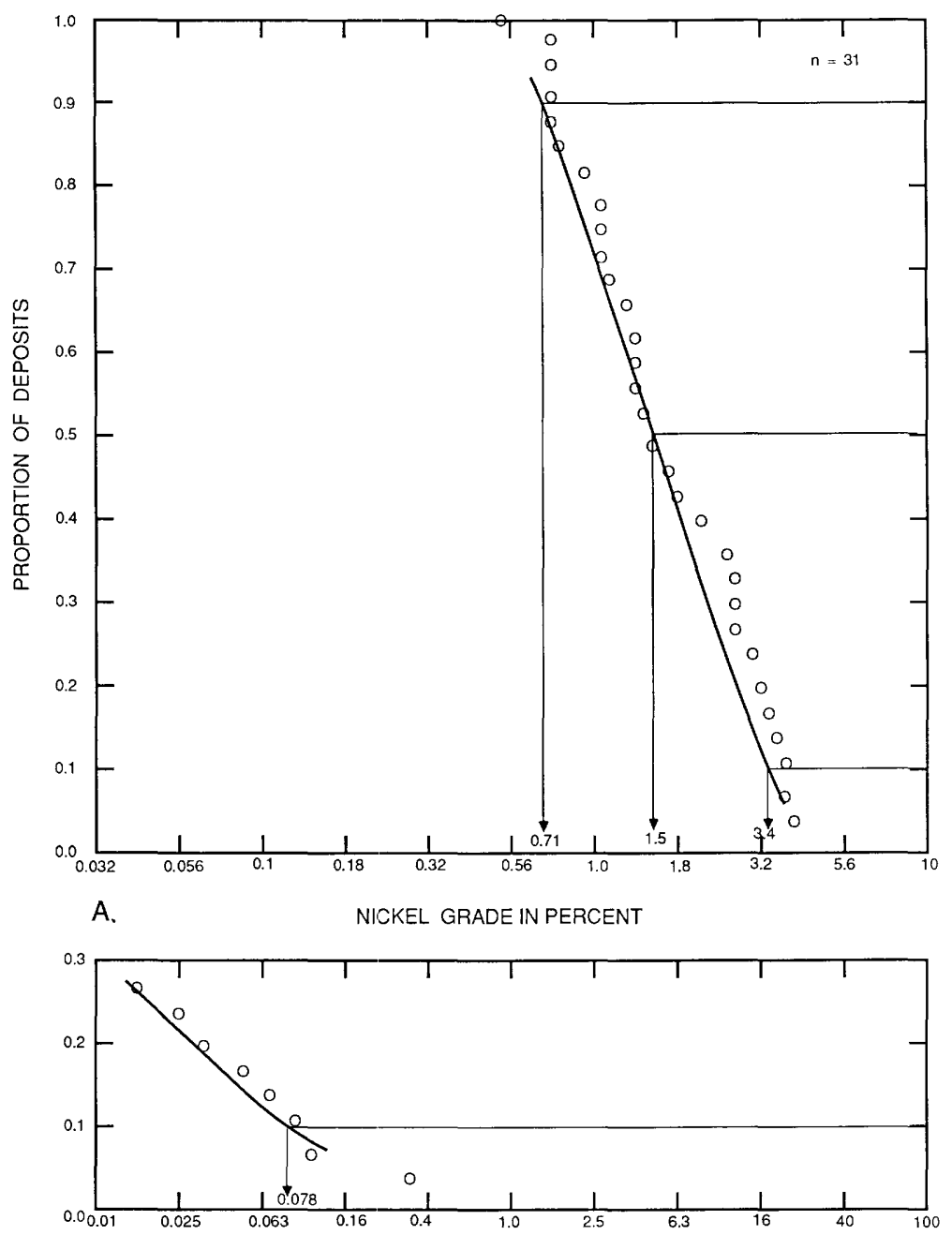

B。

GOLD GRADE IN GRAMS PER TONNE

Figure 8. Nickel and gold grades of komatiitic Ni-Cu deposits. A, Nickel. B, Gold. 
Model 6a--Con.

KOMATIITIC NICKEL--COPPER
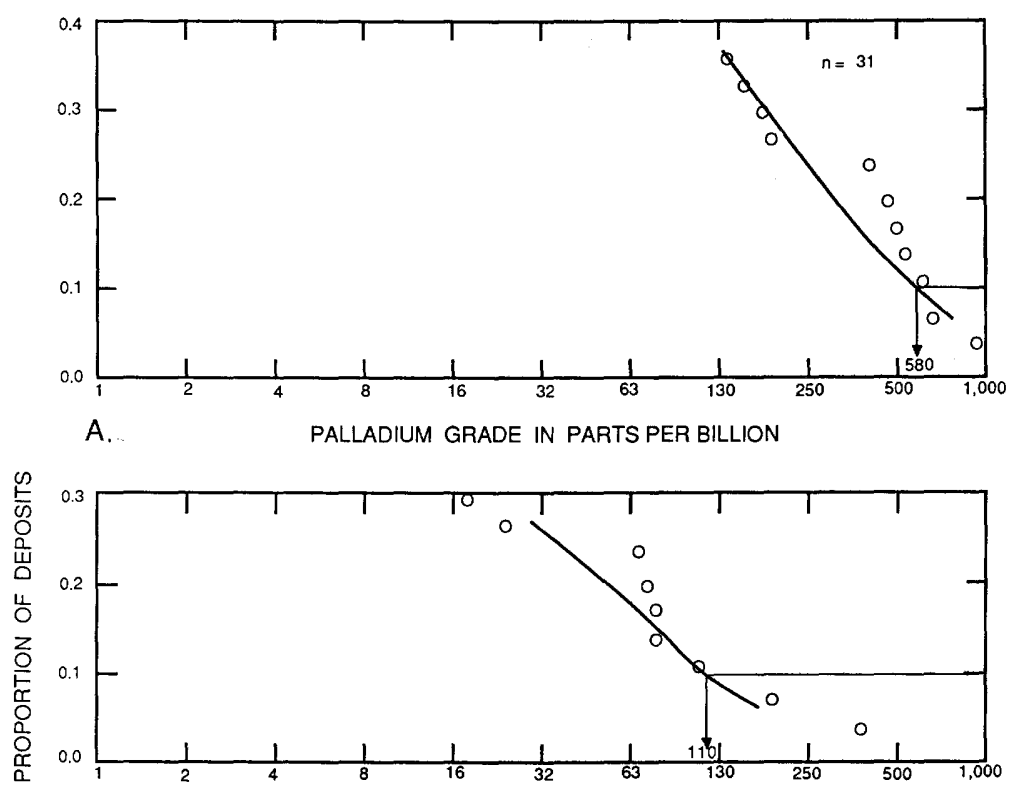

B.

IRIDIUM GRADE IN PARTS PER BILLION

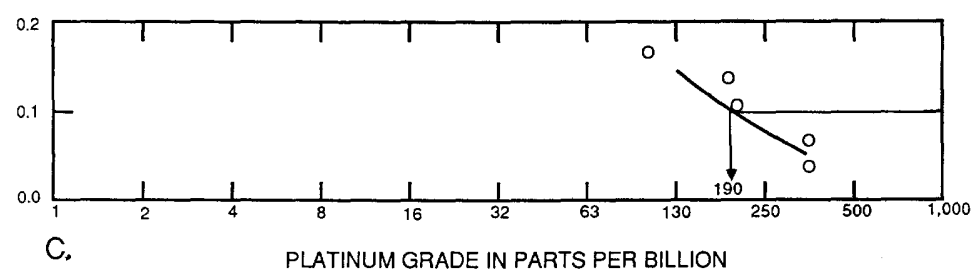

Figure 9. PGE grades of komatiitic Ni-Cu deposits. A, Palladium. $\underline{B}$, Iridium. $\underline{\mathrm{C}}, \mathrm{Pl}$ atinum. 

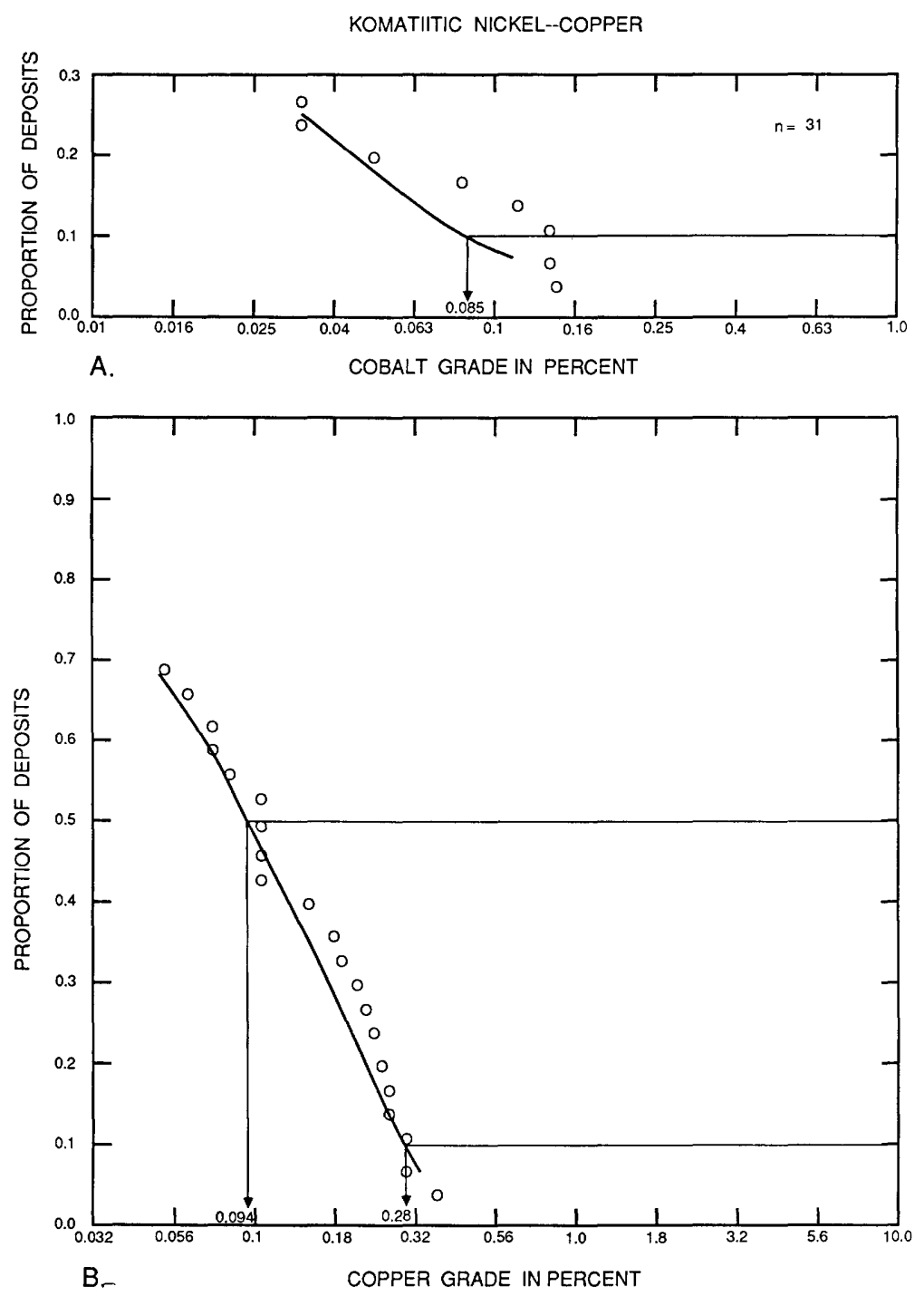

Figure 10. Base-metal grades among komatiitic $\mathrm{Ni}-\mathrm{Cu}$ deposits. A, Cobal t. B, Copper. 
Model 6b

DESCRIPTIVE MODEL OF DUNITIC Ni-Cu

By Norman J Page

DESCRIPTION Disseminated sulfide mineralization in intrusive dunites.

GENERAL REFERENCE Marston and others (1981); Ross and Travis (1981).

GEOLOGICAL ENVIRONMENT

Rock Types Dunite, olivine peridotite in subconcordant lenses 500-1,000 m 10ng, 50-100 m thick.

Textures Dunite; coarse-grained $(2-20 \mathrm{~mm})$ subequant olivine (Fo $87_{-95}$ ) interlocked to give polygonal to mosaic texture; olivine peridotite; ovate olivine with intercumulus pyroxene, sulfide and oxide minerals.

Age Range Precambrian.

Depositional Environment Intruded into contacts between clastic sedimentary and felsic volcanic rocks and mafic to ultramafic volcanic rocks.

Tectonic Setting(s) Greenstone belts.

Associated Deposit Types Komatiitic Ni, synorogenic-synvolcanic-Ni talc-carbonate Ni-Au, layered sedimentary $\mathrm{Ni}$.

DEPOSIT DESCRIPTION

Mineralogy High grade (1-9 percent Ni): pyrrhotite + pentlandite + magnetite + pyrite + chalcopyrite + chromite. Low grade $(0.4-1$ percent $\mathrm{Ni})$ : the same minerals \pm millerite \pm heazlewoodite \pm godlevskite \pm polydymite \pm vaesite \pm awaruite \pm bravoite \pm cobaltite \pm nickeliferous linnaeite \pm cubanite $\pm \mathrm{Fe}-\mathrm{Ni}$ arsenides.

Texture/Structure Lenticular shoots of massive, matrix, and breccia ores are fine to medium grained, also occurs as interstitial films. Olivine is commonly rounded when sulfide is present.

Alteration Prograde and retrograde serpentinization after deposition; usually metamorphosed.

Ore Controls Dunitic lenses close to major strike-slip faults and at high stratigraphic position in volcanic pile; most Ni-rich ores concentrated at one margin, perhaps at base of intrusion.

Weathering Lateritic zones may be enriched in PGE.

Geochemical Signature $\mathrm{Ni}, \mathrm{Cu}, \mathrm{PGE}, \mathrm{Cr}$, Co, $\mathrm{Mg}$. $\mathrm{Ni} / \mathrm{Cu}=19-70+, \mathrm{Ni} / \mathrm{Co}=30-70$. Massive sulfide ores 6-9 percent $\mathrm{Ni}$, disseminated ores up to 3 percent $\mathrm{Ni}$.

\section{EXAMPLES}

Agnew (Perseverance), AUWA (Martin and Allchurch, 1975)

Mt. Keith, AUWA

(Burt and Sheppy, 1975)

GRADE AND TONNAGE MODEL OF DUNITIC Ni-Cu

By Donald A. Singer and Norman J Page

COMMENTS Nickel grade is correlated with tonnage $(r=-0.54)$ and copper grade $(r=0.84, n=12)$. Ir, $P d, A u$, and Co grades are based on reported analyses of samples from the deposits. See fig. 11-14. 


\section{DEPOSITS}

Name

Agnew (Perserverance)

Amax

Birch Tree

Black Swan

Bowden Lake

Bucko

Discovery

Dumont

Forrestania Group

Geol. Reser. No. 34

Hambone

\section{Country}

AUWA

CNMN

CNMN

AUWA

CNMN

CNMN

CNMN

CNQU

AUWA

CNMN

CNMN
Name

Honeymoon Well

Manibridge

Moak

Mt. Keith

Mystery Lake

Pipe

Six Mile

Soab N.

Soab S.

Thompson

Weebo Bore
Country

AUWA

CNMN

CNMN

AUWA

CNMN

CNMN

AUWA

CNMN

CNMN

CNMN

AUWA 
Model 6b--Con.

Figure 11. Tonnages of dunitic $\mathrm{Ni}-\mathrm{Cu}$ deposits.
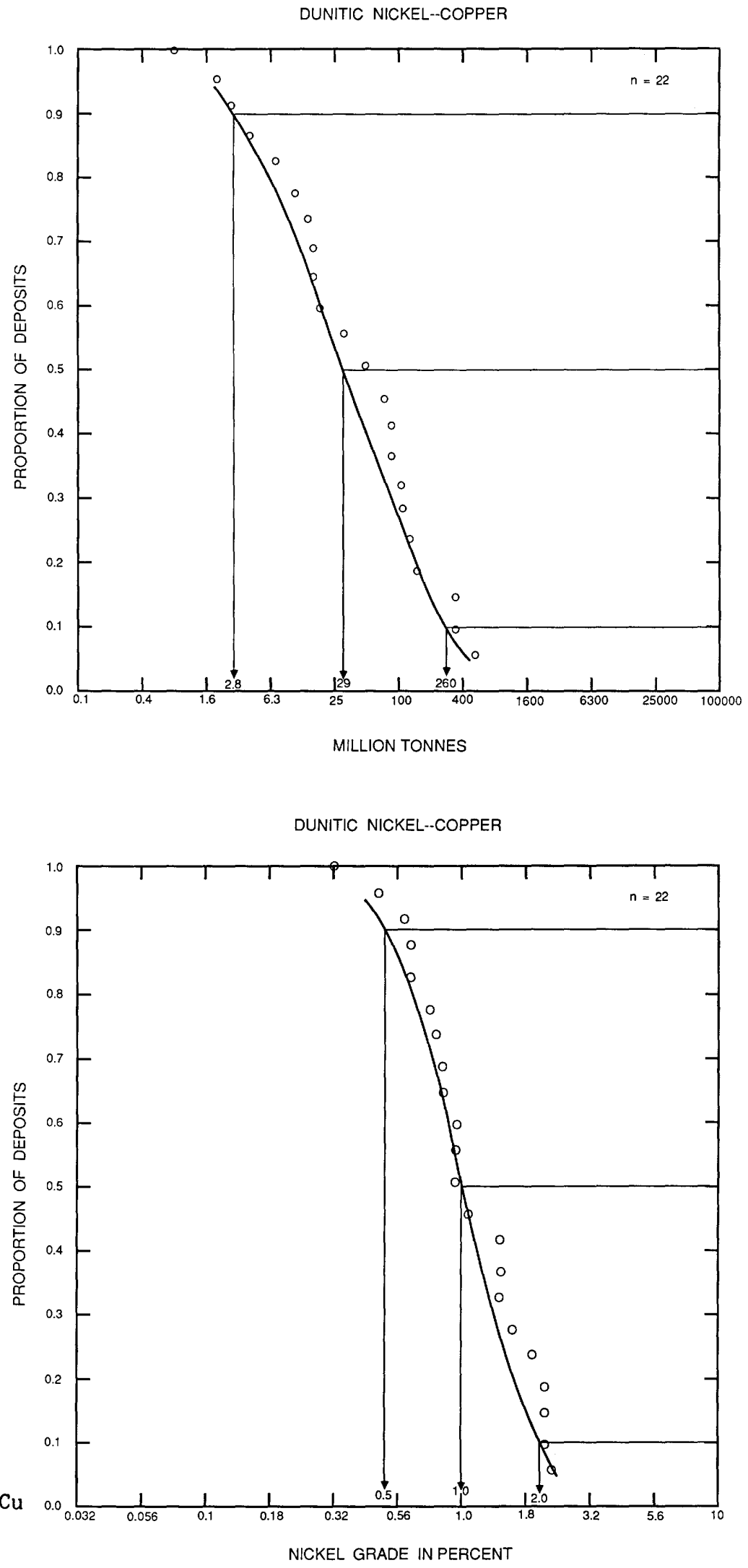

Figure 12. Nickel grades of dunitic Ni-Cu deposits.

KEL GRADE INPERCENT 
DUNITIC NICKEL--COPPER
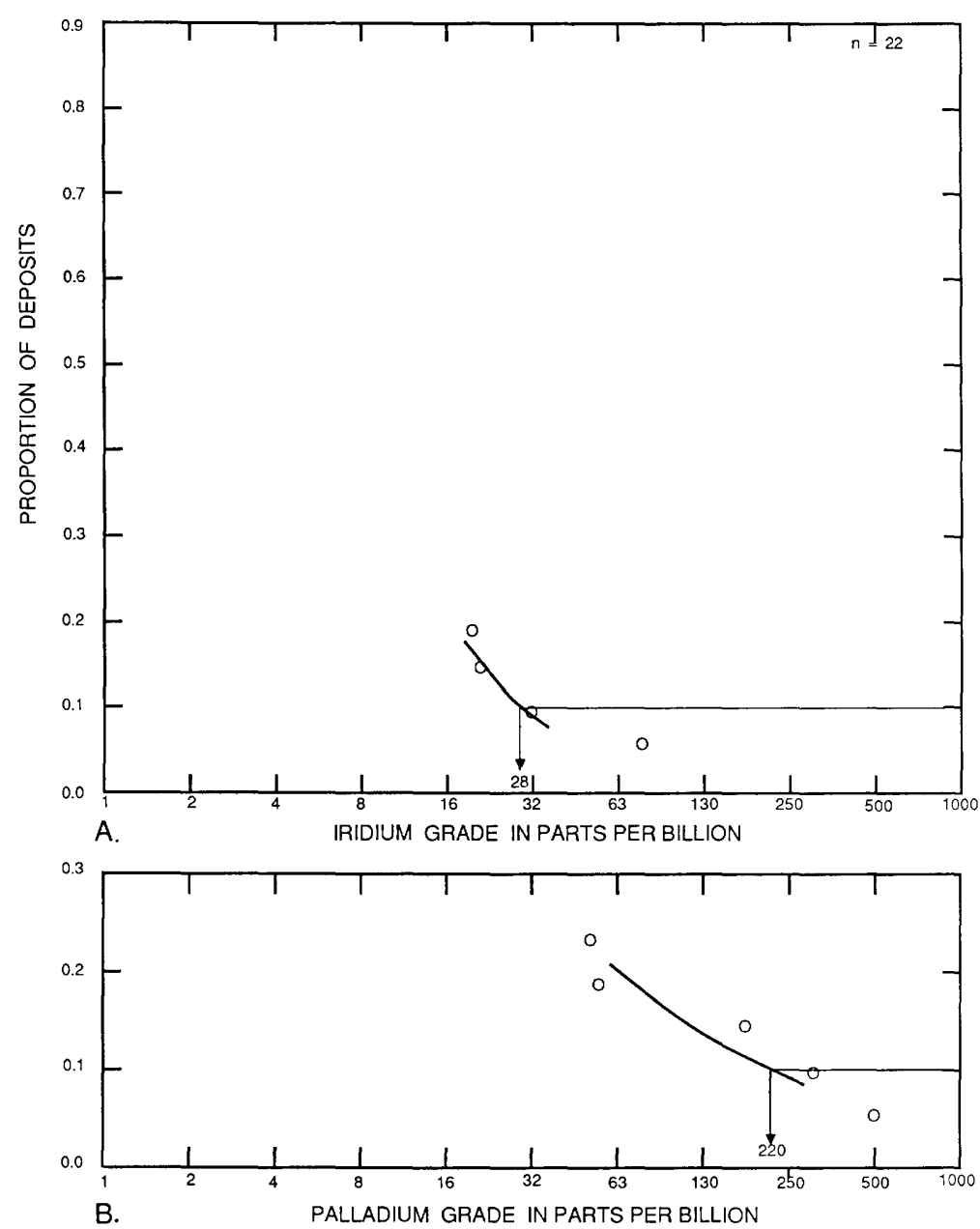

DUNITIC NICKEL--COPPER

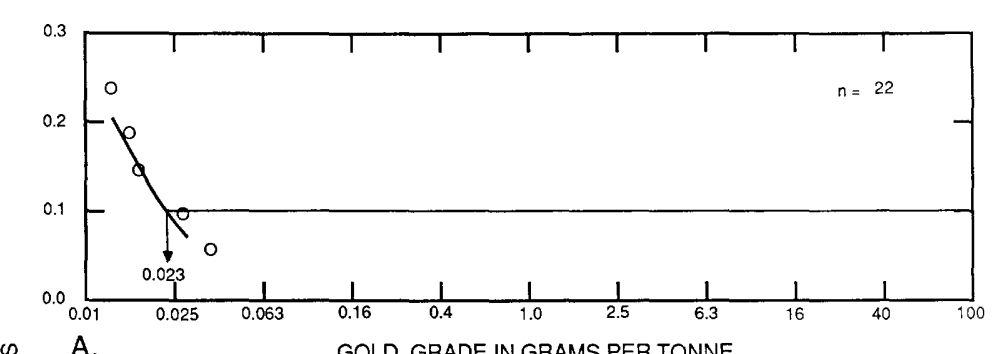

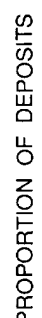

0.1

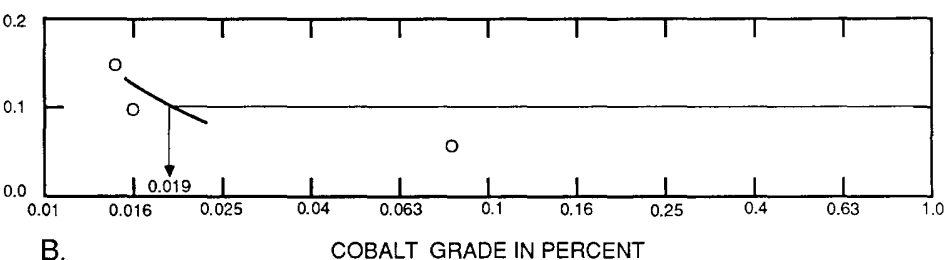

B. COBALT GRADE IN PERCENT

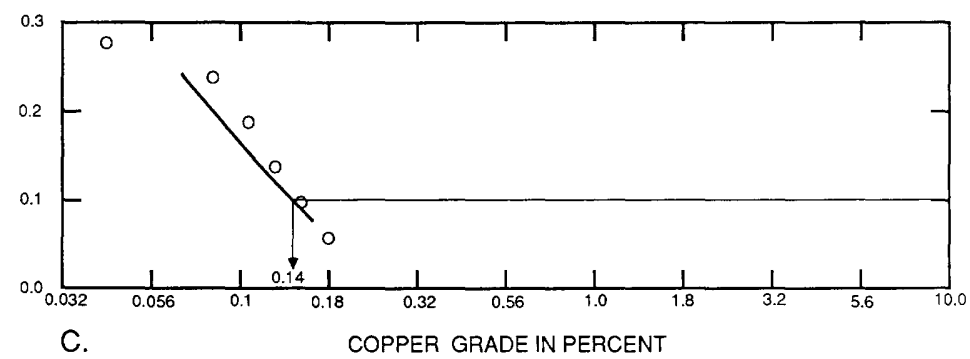

Model 6b--Con.

Figure 13. PGE grades of dunitic $\mathrm{Ni}-\mathrm{Cu}$ deposits. $\underline{A}$, Iridium. $\underline{B}$, Palladium.
Figure 14. By-product grades of dunitic Ni-Cu deposits. A, Gold. B, Cobalt. $\underline{C}$, Copper. 
Model $7 \mathrm{a}$

\section{DESCRIPTIVE MODEL OF SYNOROGENIC-SYNVOLCANIC Ni-Cu}

By Norman J Page

APPROXIMATE SYNONYMS Gabbroid class (Ross and Travis, 1981), gabbroid associated (Marston and others, 1981).

DESCRIPTION Massive lenses, matrix and disseminated sulfide in small to medium sized gabbroic intrusions in greenstone belts.

\section{GEOLOGICAL ENVIRONMENT}

Rock Types Norite, gabbro-norite, pyroxenite, peridotite, troctolite, and anorthosite forming layered or composite igneous complexes.

Textures Phase and cryptic layering sometimes present, rocks usually cumulates.

Age Range Archean to Tertiary, predominantly Archean and Proterozoic.

Depositional Environment Intruded synvolcanically or during orogenic development of a metamorphic terrane containing volcanic and sedimentary rocks.

Tectonic Setting(s) Metamorphic belts, greenstone belts, mobile belts.

Associated Deposit Types Komatiitic $\mathrm{Ni}-\mathrm{Cu}$, dunitic $\mathrm{Ni}-\mathrm{Cu}$, talc-carbonate $\mathrm{Ni-Au}$ (no model available).

DEPOSIT DESCRIPTION

Mineralogy Pyrrhotite + pentlandite + chalcopyrite \pm pyrite \pm Ti-magnetite \pm Cr-magnetite \pm graphite--by-product Co and PGE.

Texture/Structure Predominantly disseminated sulfides; commonly highly deformed and metamorphosed so primary textures and mineralogy have been altered. Deformation about the same age as the deposit.

Ore Control Sulfides commonly are in the more ultramafic parts of the complex and near the basal contacts of the intrusion.

Weathering Lateritic.

Geochemical Signature $\mathrm{Ni}, \mathrm{Cu}$, Co, PGE.

EXAMPLES

Sally Malay, AUWA (Thornett, 1981)

Rana, NRWY

(Boyd and Mathiesen, 1979)

Moxie pluton, USMA

(Thompson and Naldrett, 1984)

GRADE AND TONNAGE MODEL OF SYNOROGENIC-SYNVOLCANIC Ni-Cu

By Donald A. Singer, Norman J Page, and W. David Menzie

COMMENTS Pd, Pt, Au, and Co grades are based on reported analyses of samples from the deposits. See figs. 15-18.

DEPOSITS

Name

Country Name

Country

Bamble

Carr Boyd

NRWY

Empress

AUWA

Flaat

ZIMB

NRWY

Funter Bay
Gap
Giant Mascot
Hosanger

USAK

USPA

CNBC

NRWY 
Model 7a--Con.

Kenbridge

Kylmakoski

Lainijaur

Lappuat tnet

Laukunkawges

Lorraine

Lynn Lake

Madziwa

Makola

Mjodvattnet

Montcalm

Mt. Sholl

$\begin{array}{lll}\text { CNON } & \text { Phoenix } & \text { BOTS } \\ \text { FNLD } & \text { Pikwe } & \text { BOTS } \\ \text { SWDN } & \text { Renzy } & \text { CNQU } \\ \text { SWDN } & \text { Risliden } & \text { SWDN } \\ \text { FNLD } & \text { Selebi } & \text { BOTS } \\ \text { CNQU } & \text { Selebi N. } & \text { BOTS } \\ \text { CNMN } & \text { Selkirk } & \text { BOTS } \\ \text { ZIMB } & \text { Tekwane } & \text { BOTS } \\ \text { FNLD } & \text { Thierry } & \text { CNON } \\ \text { SWDN } & \text { Vakkerlien } & \text { NRWY } \\ \text { CNON } & \text { Vammala } & \text { FNLD } \\ \text { AUWA } & \text { Yakobi Island } & \text { USAK }\end{array}$

SYNOROGENIC--SYNVOLCANIC NICKEL--COPPER

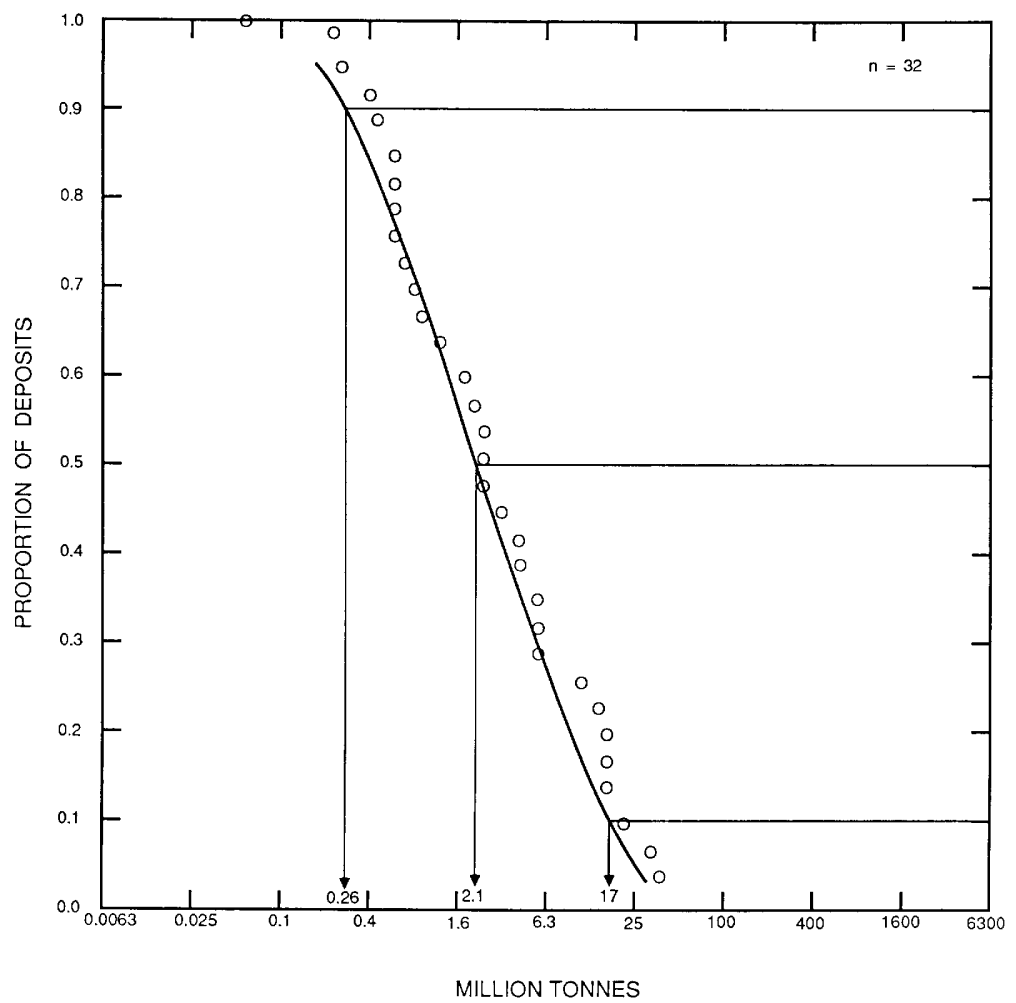

Figure 15. Tonnages of synorogenic-synvol canic Ni-Cu deposits. 
Model 7a--Con.

SYNOROGENIC--SYNVOLCANIC NICKEL--COPPER

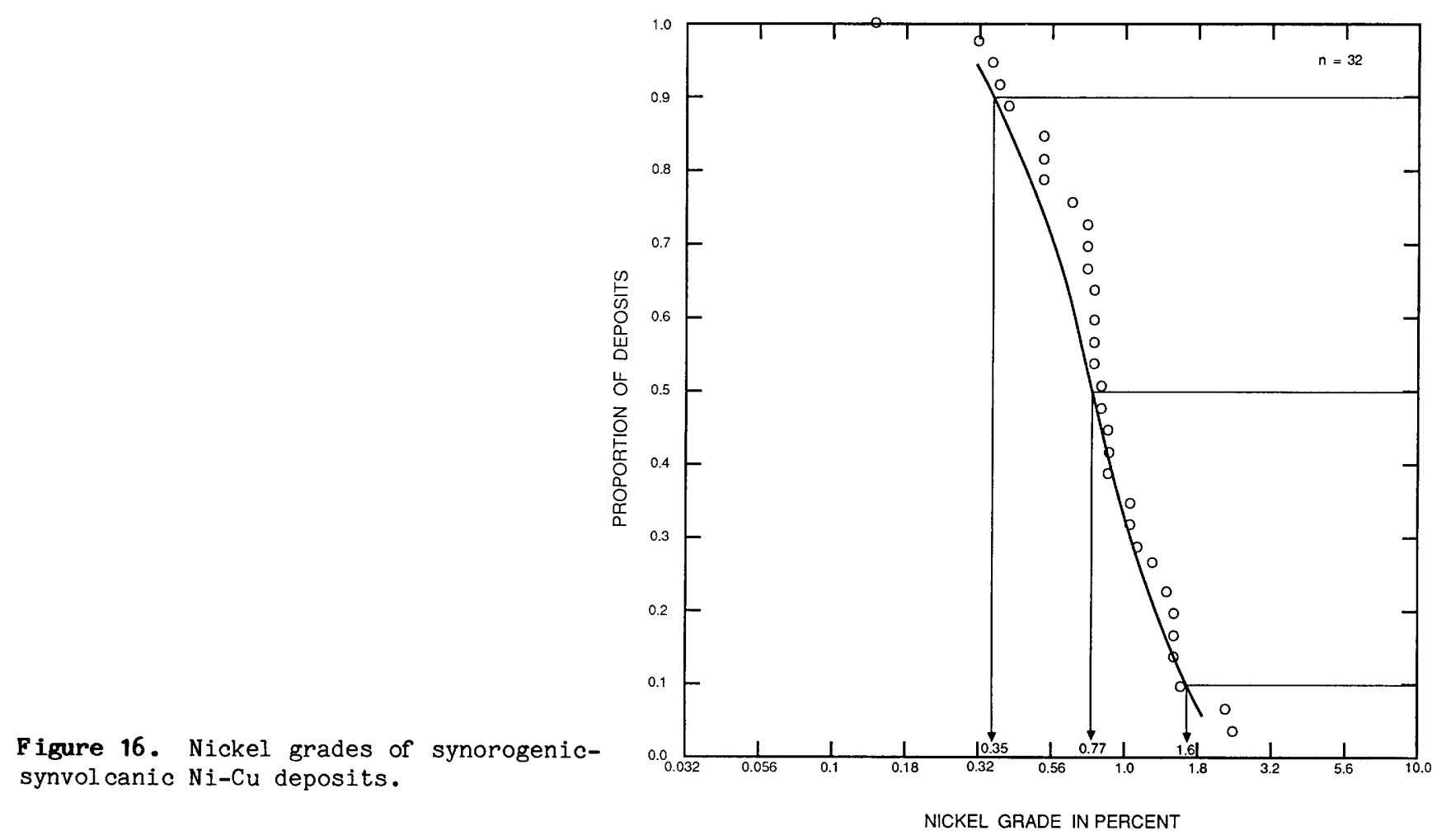

SYNOROGENIC--SYNVOLCANIC NICKEL--COPPER

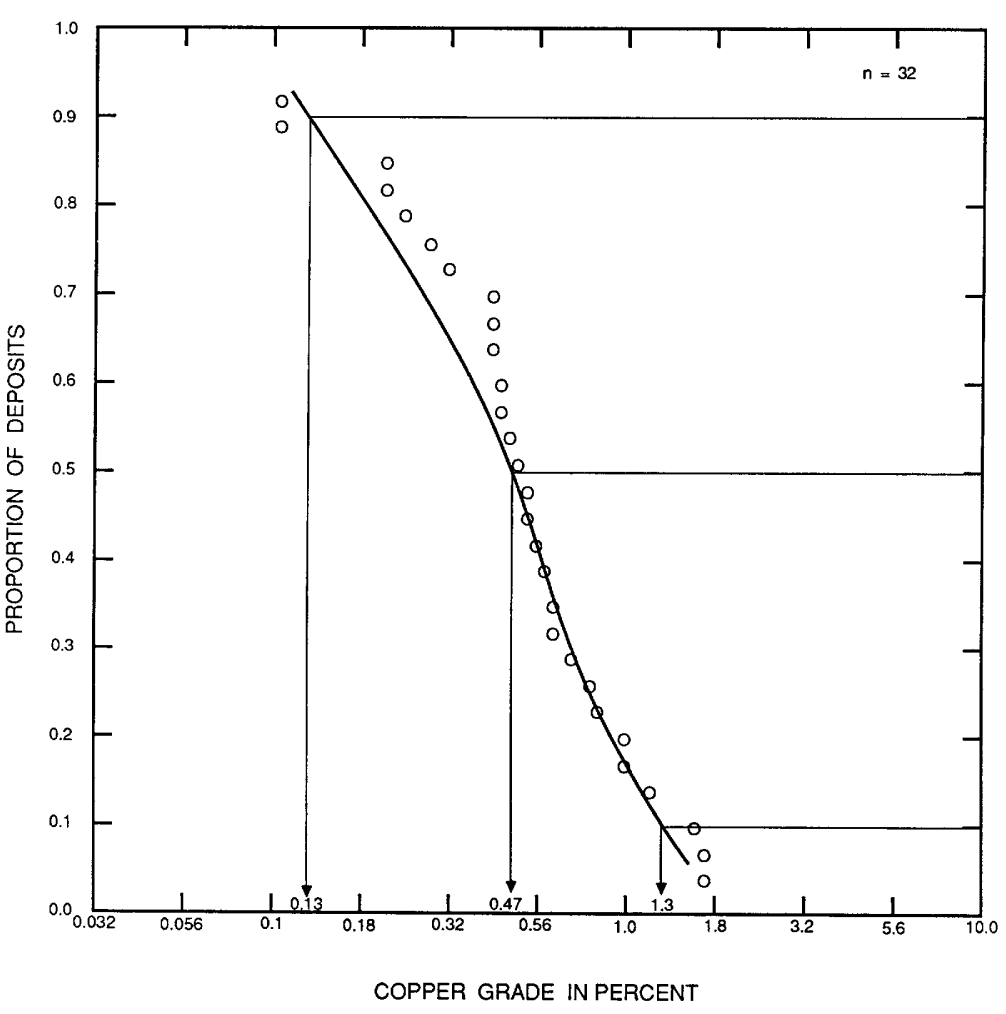

Figure 17. Copper grades of synorogenicsynvol canic $\mathrm{Ni}-\mathrm{Cu}$ deposits. 
SYNOROGENIC--SYNVOLCANIC NICKEL--COPPER

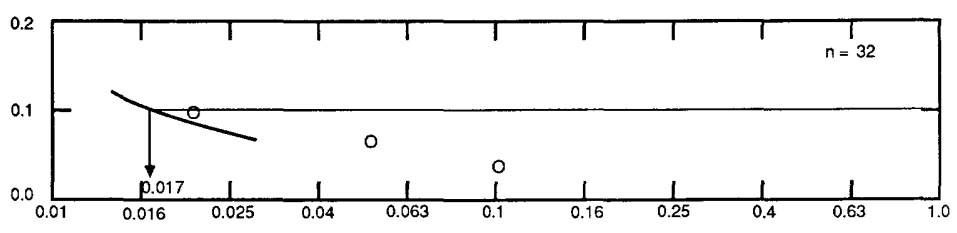

A. COBALT GRADE IN PERCENT

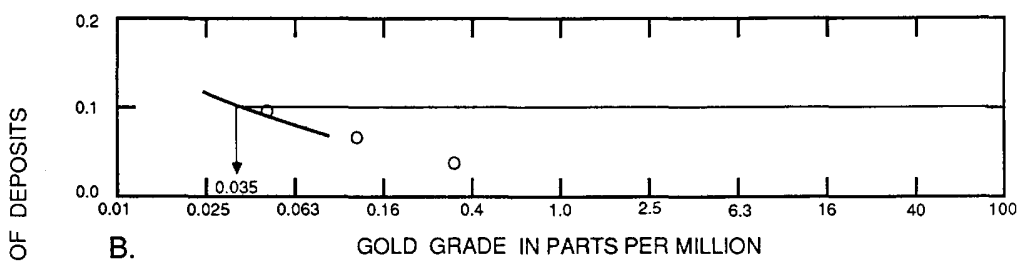

B.

GOLD GRADE IN PARTS PER MILLION

0
0
0
0
0
0
0
0
0

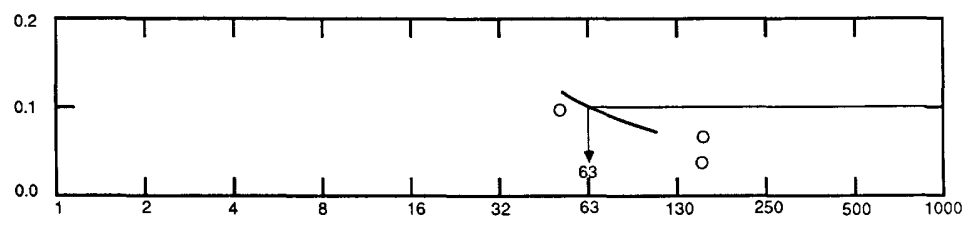

c.

PALLADIUM GRADE IN PARTS PER BILLION

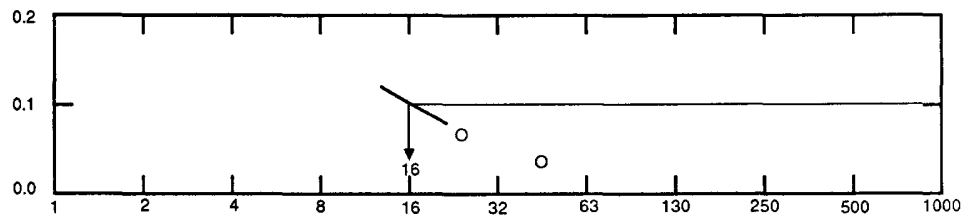

D.

PLATINUM GRADE IN PARTS PER BILLION

Figure 18. By-product grades of synorogenic-synvol canic $\mathrm{Ni}-\mathrm{Cu}$ deposits. A, Cobalt. B, Gold. , Palladium. ㅁ, Platinum. 
Model $7 \mathrm{~b}$

\section{DESCRIPTIVE MODEL OF ANORTHOSITE Ti}

By Eric R. Force

DESCRIPTION Ilmenite (and rutile) deposits in granulite metamorphic terranes intruded by anorthosite-ferrodiorite-clan plutons. Two subsets ( 1 and 2) distinguished below (see fig. 19). GEOLOGICAL ENVIRONMENT

Rock Types (1) Andesine anorthosite massifs in granulite-facies country rocks (associated mineralization includes rutile if andesine is antiperthitic).

(2) Ferrodiorite-type intrusive rocks (gabbro, charnockite, jutunite) generally younger than anorthosite, with associated ilmenite \pm apatite mineralization.

Textures Granulation in anorthosite, quartz platy and blue where present.

Age Range Most, and perhaps all, between 900 and $1,500 \mathrm{m.y}$. in age.

Depositional Environment Lower crust, intrusion under hot, dry conditions.

Tectonic Setting(s) Not well known.

Associated Deposit Types None known.

DEPOSIT DESCRIPTION

Mineralogy: (1) Ilmenite \pm rutile

(2) Ilmenite \pm apatite

Deposit value is much greater if intergrown magnetite and ulvospinel are absent.

Texture/Structure (1) Disseminations to veinlets along anorthosite margins, hosted by both impure anorthosite and adjacent country rock.

(2) Both concordant layers within or at base of ferrodiorite-clan sheets, and veinlike massive bodies in underlying structural units (especially anorthosite).

Alteration None related to ore.

Ore Controls (1) High-temperature metasomatism between Ti-Fe oxides-rich country rock, and anorthosite, coupled with unknown processes in anorthosite magma. Especially concentrated in swarms of anorthosite sills.

(2) Immiscible $\mathrm{Ti}, \mathrm{P}$ liquid in ferrodioritic magma, forming both cumulate-like bodies and fracture fillings.

Weathering Residual enrichment may occur in weathering zone.

Geochemical and Geophysical Signature (2) High Ti, P, and Zr. Magnetic anomalies.

EXAMPLES

(1) Roseland, USVA

Pluma Hidalgo, MXCO

(2) Roseland, USVA

Sanford Lake, USNY

Laramie Range, USWY
(Herz and Force, 1984)

(Paulson, 1964)

(Herz and Force, 1984)

(Gross, S. 0., 1968)

(Eberle and Atkinson, 1983) 


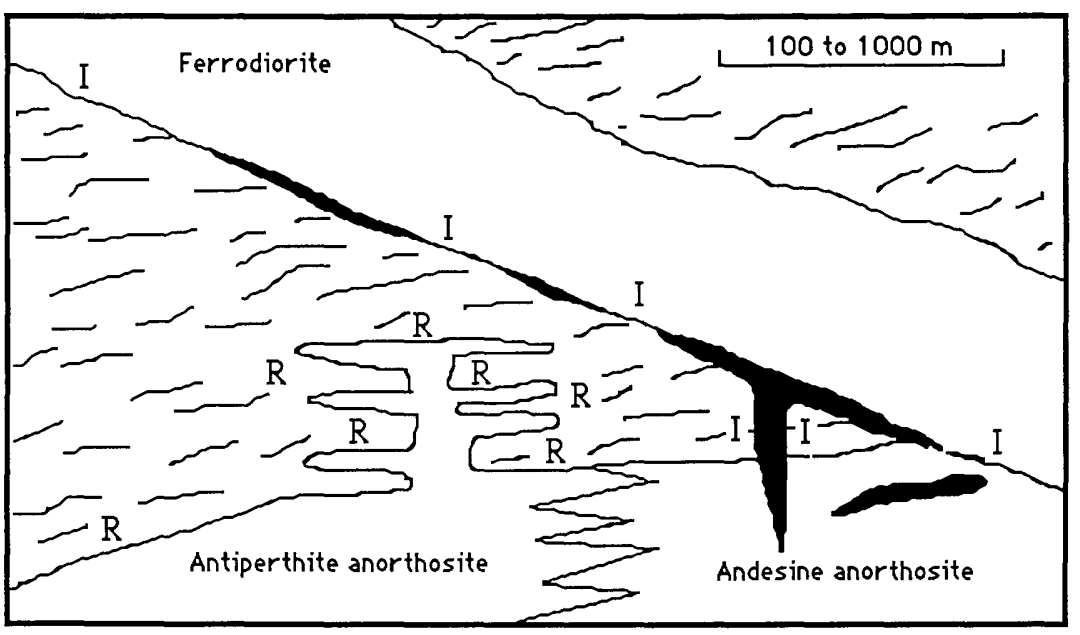

EXPLANATION

Massive ilmenite-apatite

7 Granuite-facies country rock

$R$, Disseminated rutile

I, Disseminated ilmenite

Figure 19. Cartoon cross section of a typical anorthosite ferrodiorite intrusion showing relation between different forms of $\mathrm{Ti}$ concentrations. 
Model $8 \mathrm{a}$

\title{
DESCRIPTIVE MODEL OF PODIFORM CHROMITE
}

\author{
By John P. Albers
}

APPROXIMATE SYNONYM Alpine type chromite (Thayer, 1964).

DESCRIPTION Podlike masses of chromitite in ultramafic parts of ophiolite complexes (see fig. 20).

GENERAL REFERENCE Dickey (1975).

GEOLOGICAL ENVIRONMENT

Rock Types Highly deformed dunite and harzburgite of ophiolite complexes; commonly serpentinized.

Textures Nodular, orbicular, gneissic, cumulate, pull-apart; most relict textures are modified or destroyed by flowage at magmatic temperatures.

Age Range Phanerozoic.

Depositional Environment Lower part of oceanic lithosphere.

Tectonic Setting(s) Magmatic cumulates in elongate magma pockets along spreading plate boundaries. Subsequently exposed in accreted terranes as part of ophiolite assemblage.

Associated Deposit Types Limassol Forest Co-Ni-S-As.

DEPOSIT DESCRIPTION

Mineralogy Chromite \pm ferrichromite \pm magnetite \pm Ru-Os-Ir alloys \pm laurite.

Texture/Structure Massive coarse-grained to finely disseminated.

Alteration None related to ore.

Ore Controls Restricted to dunite bodies in tectonized harzburgite or lower portions of ultramafic cumulate (see fig. 99).

Weathering Highly resistant to weathering and oxidation.

Geochemical Signature None recognized.

EXAMPLES

High Plateau, Del Norte Cty, USCA (Wells and others, 1946)

Coto Mine, Luzon, PLPN (LeBlanc and Violette, 1983)

GRADE AND TONNAGE MODEL OF MINOR PODIFORM CHROMITE

By Donald A. Singer and Norman J Page

DATA REFERENCES Singer and others (1980); Calkins and others (1978); Carlson and others (1985).

COMMENTS All deposits in this grade-tonnage compilation are from California and Oregon. The two largest tonnage deposits are actually districts rather than individual deposits. The majority of the grades represent shipping grades. Grades less than 35 percent typically represent in-place "ore". The mixture of shipping grades and in-place grades may explain the significant negative correlation $(r=-0.25)$ between grade and tonnage. $\mathrm{Rh}, \mathrm{Ir}, \mathrm{Ru}, \mathrm{Pd}$, and Pt grades are based on reported analyses of samples from the deposits. Unreported PGE grades are probably similar to those presented here. Rhodium is correlated with chromite $(r=0.35$, $\mathrm{n}=69)$, platinum $(\mathrm{r}=0.69, \mathrm{n}=31)$, iridium $(\mathrm{r}=0.47, \mathrm{n}=35)$, ruthenium $(r=0.56, \mathrm{n}=28)$. Ruthenium is correlated with palladium $(r=0.72, n=21)$ and iridium $(r=0.59, n=29)$. See figs. 21-23. 
Model 8a--Con.

DEPOSITS

Name

Ace of Spades

Adobe Canyon Gp.

Ajax

Alice Mine

Allan (Johnson)

Alta Hill

Althouse

Alyce and Blue Jay

American Asbestos

Anti Axis

Apex (Del Norte Co.)

Apex (El Dorado Co.)

Applegate

Associated Chromite

Babcock

Baby foot

Beat

Big Bear

Big Bend

Big Chief

Big Dipper (Robr) USCA

Big Four

Big Pine Claim

Big Yank No. 1

Binder No. 1

Black Bart (Great Western)

Black Bart Claim (Avery)

Black Bart Group

Black Bear

Black Beauty

Black Boy

Black Chrome

Black Diamond

Black Diamond (Grey Eagle

Gp.)

Country

USCA

USCA

USOR

USCA

USCA

USCA

USOR

USCA

USCA

USCA

USCA

USCA

USOR

USOR

USOR

USOR

USCA

USOR

USCA

USOR

USOR

USCA

USOR

USCA

USCA

USCA

USCA

USCA

USOR

USOR

USCA

USOR

USCA

Black Hawk

USOR

USOR

USCA

USOR

USOR

USCA

USCA

USCA

USCA

USCA

USCA

USCA

USCA

USOR

USCA

USOR

USOR

USCA

USOR

USCA

USCA

USCA

USCA

USOR

USCA
Name

Castro Mine

Cattle Springs

Cavyell Horse C

Country

USCA

USCA

USOR

Cavyell Horse Mountain USOR

Cedar Creek USOR

Celebration USOR

Challange area USCA

Chambers USOR

Chicago USCA

Christian Place USCA

Chrome Camp USCA

Chrome Gulch USCA

Chrome Hill USCA

Chrome King (Josephine Co.) USOR

Chrome King (Jackson Co.) USOR

Chrome No. 3 USOR

Chrome Ridge USOR

Clara $\mathrm{H}$ USCA

Clary and Langford USCA

Cleopatra USOR

Clover Leaf USCA

Codd Prospect USCA

Coggins USCA

Collard Mine USOR

Commander USCA

Coon Mt. Nos. 1-3 USCA

Copper Creek (Low Divide) USCA

Courtwright USCA

Courtwright (Daggett) USCA

Cow Creek Gp. USCA

Crouch USOR

Crown USOR

Cyclone Gap USCA

Cynthia USOR

Daisy (Aldelabron) USCA

Dark Star USOR

Darrington USCA

Deep Gorge Chrome USOR

Delare Prospect USOR

Detert USCA

Diamond USCA

Dickerson USCA

Dickey and Drisbach USCA

Dirty Face USOR

Doe Flat USCA

Don Pedro USCA

Dorriss USCA

Dozier USCA

Dry Creek USOR

Earl Smith USCA

Early Sunrise USOR

Edeline USCA

Eden USCA

Eggling and Williams USCA

E1 Primero USCA

Elder Claim USCA

Elder Creek USCA

Elder Creek Gp. USCA

Elk Creek Claim USCA

Elkhorn Chromite USOR 
Model 8a--Con.

\begin{tabular}{|c|c|c|c|}
\hline Ellingwood & USCA & Jim Bus & USOR \\
\hline Ellis & USCA & Johns & USOR \\
\hline Esterly Chrome & USOR & Josephine & USCA \\
\hline Esther and Phyllis & USCA & Josephine No. 4 & USOR \\
\hline Fairview & USCA & Judy (Hicks) & USCA \\
\hline Fiddler's Green & USCA & Julian & USCA \\
\hline Fields and Stoker & USCA & Kangaroo Court Mine & USCA \\
\hline Finan & USCA & Kingsley & USOR \\
\hline Forest Queen & USCA & Kleinsorge Gp. & USCA \\
\hline Foster & USOR & Kremmel and Froelich & USCA \\
\hline Four Point & USOR & Lacey & USCA \\
\hline Fourth of July & USCA & Lambert & USCA \\
\hline French Hill & USCA & Langley Chrome & USOR \\
\hline Friday & USOR & Lassic Peak & USCA \\
\hline Gallagher & USOR & Last Buck & USOR \\
\hline Gardner Mine & USOR & Last Chance (Coos) & USOR \\
\hline Gas Canyon & USCA & Last Chance (Josephine) & USOR \\
\hline Geach & USCA & Laton & USCA \\
\hline Gibsonville & USCA & Letty & USCA \\
\hline Gill (Gill Ranch) & USCA & Liberty & USCA \\
\hline Gillan & USCA & Liberty Bond Claim & USCA \\
\hline Gillis Prospect & USCA & Linda Marie & USOR \\
\hline Glory Ho & USOR & Little Boy & USOR \\
\hline Golconda Fraction & USCA & Little Castle Creek & USCA \\
\hline Gold Bug Claim & USCA & Little Hope & USCA \\
\hline Goncolda & USOR & Little Rock Mine & USCA \\
\hline Gray Boy & USOR & Little Siberia & USOR \\
\hline Gray Buck Gp. & USOR & Lone Gravel & USCA \\
\hline Green (Americus) & USCA & Long Ledge Gp. & USCA \\
\hline Green Mine & USCA & Lost Lee & USOR \\
\hline Green Ridge & USCA & Lotty & USCA \\
\hline Green's Capco Leases & USCA & Lucky Boy & USCA \\
\hline Griffin Chromite & USOR & Lucky Friday & USOR \\
\hline Gunn Claims & USCA & Lucky Girl & USCA \\
\hline Half Chrome & USCA & Lucky Hunch & USOR \\
\hline Hanscum & USOR & Lucky L. \& R. & USOR \\
\hline Happy Go Lucky & USCA & Lucky Nine Gp. & USOR \\
\hline Harp and Sons Ranch & USCA & Lucky Star & USOR \\
\hline Hawks Rest View & USOR & Lucky Strike (Lake Co.) & USCA \\
\hline Hayden and Hilt & USCA & Lucky Strike (S.L.O. Co.) & USCA \\
\hline Helemar & USCA & Lucky Strike (Curry Co.) & USOR \\
\hline Hendricks No. 2 & USCA & Lucky Strike & USOR \\
\hline High Dome & USCA & Mackay & USCA \\
\hline High Plateau & USCA & Madeira & USCA \\
\hline Hill-Top Chrome & USCA & Madrid & USCA \\
\hline Hodge Ranch & USCA & Manchester & USCA \\
\hline Hoff & USCA & Maralls Capro Leases & USCA \\
\hline Holbrook and McGuire & USCA & Marks \& Tompson & USOR \\
\hline Holseman (and others) & USCA & Mary Jane & USCA \\
\hline Holston (Vaughn) & USCA & Mary Walker & USOR \\
\hline Horseshoe & USCA & Maxwell & USCA \\
\hline Horseshoe Chrome & USOR & May flower & USCA \\
\hline Houser \& Burges & USOR & McCaleb's Sourdough & USOR \\
\hline Hudson (Fuller Claims) & USCA & McCarty & USCA \\
\hline I-Wonder & USCA & McCormick & USCA \\
\hline Illinois River & USOR & McGuffy Creek Gp. & USCA \\
\hline Independence & USOR & McMurty & USCA \\
\hline Irene Chromite & USOR & Meeker (Sonoma Chrome) & USCA \\
\hline Iron King & USOR & Merrifield & USCA \\
\hline Iron Mountain & USOR & Mighty Joe & USOR \\
\hline Jack Forth & USCA & Milton & USCA \\
\hline Jack Sprat Gp. & USCA & Mockingbird & USOR \\
\hline Jackson & USOR & Moffett Creek Gp. & USCA \\
\hline
\end{tabular}




\begin{tabular}{|c|c|}
\hline Mohawk Claim & USOR \\
\hline Moore & USCA \\
\hline Moscatelli & USCA \\
\hline Moscatelli No. 2 & USCA \\
\hline Mountain View & USCA \\
\hline Mountain View Gp. & USCA \\
\hline MuNaly & USCA \\
\hline Mulcahy Prospect & USCA \\
\hline Mule Creek & USCA \\
\hline Mum and Alice June Claim & USCA \\
\hline Murphy & USCA \\
\hline Muzzleloader (Stevens & \\
\hline No. 1) & USCA \\
\hline New Hope & USCA \\
\hline New Hope Claim & USOR \\
\hline Newman & USCA \\
\hline Nichelini Mine & USCA \\
\hline Nickel Mountain & USOR \\
\hline Nickel Ridge & USOR \\
\hline No. 5 & USCA \\
\hline Noble Electric Co. & USCA \\
\hline Norcross & USCA \\
\hline North End, West End, & \\
\hline Spotted Fawn & USCA \\
\hline North Fork Chrome & USCA \\
\hline North Star & USOR \\
\hline North Star (Red Mtn) & USCA \\
\hline Norway & USOR \\
\hline Oak Ridge & USCA \\
\hline Olive B. & USOR \\
\hline Olsen & USCA \\
\hline Onion Springs & USOR \\
\hline Oregon Chrome & USOR \\
\hline Oxford & USCA \\
\hline P. U. P. (Zenith) & USCA \\
\hline Paradise No. 1 & USOR \\
\hline Paradise No. 2 & USOR \\
\hline Park's Ranch & USCA \\
\hline Parker & USCA \\
\hline Parkeson & USCA \\
\hline Pearsoll Peak & USOR \\
\hline Peewan & USCA \\
\hline Peg Leg (Lambert) & USCA \\
\hline Pennington Butte & USOR \\
\hline Perconi Ranch & USCA \\
\hline Pillikin & USCA \\
\hline Pine Mountain Claim & USCA \\
\hline Pines & USOR \\
\hline Pleasant No. $1 \& 2$ & USOR \\
\hline Poco Tiempo Quartz & USCA \\
\hline Pony Shoe & USCA \\
\hline Poodle Dog & USCA \\
\hline Porter Property & USCA \\
\hline Powers & USOR \\
\hline Prater & USOR \\
\hline Pyramid & USCA \\
\hline Queen of May & USOR \\
\hline Quigg & USCA \\
\hline Rainbow & USOR \\
\hline Rainy Day & USOR \\
\hline Rancherie & USOR \\
\hline Randall & USCA \\
\hline Rattlesnake Mountain & USCA \\
\hline
\end{tabular}

Ray (Tip Top) USOR

Ray Spring USOR

Red Ledge USCA

Red Mountain USOR

Red Slide Gp. USCA

Redskin USCA

Richards USCA

Richey, U.S. \& S.J. USCA

Robt. E. USOR

Rock Creek USOR

Rock Wren Mine USCA

Rose Claim USCA

Rosie Claim USOR

Round Bottom USCA

Roupe USCA

Sad Sack USOR

Saddle Chrome USOR

Saint USCA

Sally Ann USOR

Salt Rock USOR

Saturday Anne "USOR

Schmid USOR

Seiad Creek (Mt. View) USCA

September Morn USCA

Sexton Mountain USOR

Shade Chromite USOR

Shafer Lease USCA

Shamrock USCA

Shelly USCA

Sheppard Mine USCA

Shotgun Creek USCA

Silver Lease USOR

Simmons USCA

Simon USCA

Sims USCA

Six-Mile USOR

Skyline Mine USCA

Skyline No. 1 USCA

Skyline No. 2 USCA

Smith Geitsfield USOR

Snakehead (Jumbo) USCA

Snowy Ridge USCA

Snowy Ridge USOR

Snyder USCA

Sour Dough USOR

Sousa Ranch USCA

Southern Pacific Property USCA

Spot USCA

Spring Hill USCA

St. Patrick (Camp 8) USCA

Stafford USCA

Stark Bee USCA

State School USCA

Stevens-Miller USOR

Stewart USCA

Stone \& Haskins USOR

Store Gulch USOR

Stray Dog USOR

Sullivan and Kahl USCA

Sunnyslope USCA

Sunrise USCA

Sunset (Fresno Co.) USCA

Sunset (Placer Co.) USCA 
Model 8a--Con.

\begin{tabular}{|c|c|c|c|}
\hline Sunshine & USCA & Unknown Name & USOR \\
\hline Sutro Mine & USCA & Valen Prospect & USOR \\
\hline Suzy Bell (Lucky Strike) & USCA & Valenti & USCA \\
\hline Swayne & USCA & Victory No. 3 & USCA \\
\hline Sweetwater & USCA & Violet & USOR \\
\hline Tangle Blue Divide & USCA & Vogelgesang & USCA \\
\hline Tennessee Chrome & USOR & Wait & USCA \\
\hline Tennessee Pass & USOR & Waite & USCA \\
\hline Thompson Gp. & USOR & Walker & USCA \\
\hline Tomkin & USCA & War Bond & USCA \\
\hline Toujours Gai & USCA & War Eagle-Miller & USCA \\
\hline Trinidad & USCA & Ward & USOR \\
\hline Twin Cedars & USOR & Ward and Lyons & USCA \\
\hline Twin Valley & USOR & Washout & USCA \\
\hline Unnamed & USCA & Welch Prospect & USCA \\
\hline Uncle Sam & USOR & West Chrome & USCA \\
\hline Unknown Name & USOR & Western Magnesite & USCA \\
\hline Unknown Name & USOR & White Bear & USCA \\
\hline Unknown Name & USOR & White Cedar & USCA \\
\hline Unknown Name & USOR & White Feather & USCA \\
\hline Unknown Name & USOR & White Pine Mine & USCA \\
\hline Unknown Name & USOR & Wild Cat Claim & USOR \\
\hline Unknown Name & USOR & Wilder (Fish Creek) & USCA \\
\hline Unknown Name & USOR & Windy Point & USOR \\
\hline Unknown Name & USOR & Wolf Creek & USCA \\
\hline Unknown Name & USOR & Wolf Creek area & USCA \\
\hline Unknown Name & USOR & Wonder & USOR \\
\hline Unknown Name & USOR & Wonder Gp. & USOR \\
\hline Unknown Name & USOR & Yellow Pine & USCA \\
\hline Unknown Name & USOR & Young & USOR \\
\hline Unknown Name & USOR & Young's Mine & USOR \\
\hline Unknown Name & USOR & Zerfirg Ranch & USCA \\
\hline Unknown Name & USOR & & \\
\hline
\end{tabular}

GRADE AND TONNAGE MODEL OF MAJOR PODIFORM CHROMITE

By Donald A. Singer, Norman J Page, and Bruce R. Lipin

DATA REFERENCES Page and others (1979), Page and others (1982b), Page and others (1984).

COMMENTS This model, number $8 \mathrm{~b}$, is provided as an alternative to the podiform chromite model, number $8 \mathrm{a}$, based on California and Oregon deposits because of the significant difference in tonnage of the two groups. The two groups are geologically similar and share the same descriptive model. $\mathrm{Rh}$, Ir, Ru, Pd, and Pt grades are based on reported analyses of samples from the deposits. Platinum grade is correlated with chromite grade $(r=0.76, n=12)$ and iridium grade ( $r=0.71$, $n$ = 8). Rhodium is correlated with iridium grade $(r=0.88, n=7)$. See figs. $24-26$.

\section{DEPOSITS}

Name

$\begin{array}{ll}\text { Abdasht } & \text { IRAN } \\ \text { Akarca } & \text { TRKY } \\ \text { Akcabuk } & \text { TRKY } \\ \text { Akkoya } & \text { TRKY } \\ \text { Alice Louise } & \text { NCAL } \\ \text { Alpha } & \text { NCAL } \\ \text { Altindag } & \text { TRKY } \\ \text { Amores } & \text { CUBA } \\ \text { Andizlik } & \text { TRKY } \\ \text { Anna Madeleine } & \text { NCAL } \\ \text { Asagi Zorkum } & \text { TRKY } \\ \text { Aventura } & \text { CUBA } \\ \text { Avsar } & \text { TRKY }\end{array}$

$\underline{\text { Name }}$

Bagin

Bagirsakdire

Balcicakiri

Batikef

Bati-N. Yarma

Bati-Taban

Bati-W. Yarma

Bellacoscia

Bellevue

Bereket

Bezkere-Bulurlii

Bicir-Cakir

Bicir-Gul
Country

TRKY

TRKY

TRKY

TRKY

TRKY

TRKY

TRKY

NCAL

NCAL

TRKY

TRKY

TRKY

TRKY 
Model 8b--Con.

\begin{tabular}{|c|c|c|c|}
\hline Bonsecours & NCAL & Karatas-Kumocak & TRKY \\
\hline Bozkonus & TRKY & Kartalkoyu & TRKY \\
\hline Bozotluk-No. 551 & TRKY & Kavakcali & TRKY \\
\hline Bugugan & TRKY & Kavakdere & TRKY \\
\hline Buyiik Gurleyen & TRKY & Kazadere-Kandil & TRKY \\
\hline Buyiik Karamanli & TRKY & Kefdag-East & TRKY \\
\hline Caledonia & CUBA & Kemikli Inbasi & TRKY \\
\hline Camaguey & CUBA & Kilic-Kafasi 1 & TRKY \\
\hline Catak & TRKY & Kilic-Kafasi 2 & TRKY \\
\hline Catak-Koraalan & TRKY & Kiranocak & TRKY \\
\hline Catolsinir I & TRKY & Koca & TRKY \\
\hline Catolsinir II & TRKY & Komek & TRKY \\
\hline Cenger & TRKY & Koycegiz-Curukcu & TRKY \\
\hline Cenger-Adatepe & TRKY & Koycegiz-Kurardi & TRKY \\
\hline Cenger-Demirk & TRKY & Koycegiz-Orta & TRKY \\
\hline Cenger-Domuza & TRKY & Kuldoden & TRKY \\
\hline Cezni & TRKY & Kundikan-Keluskdere & TRKY \\
\hline Chagrin & NCAL & Kundikan-Kelusktepe & TRKY \\
\hline Child Harold & NCAL & Kurudere & TRKY \\
\hline Consolation & NCAL & Kuyuluk Isletmesi & TRKY \\
\hline Cosan & TRKY & Kuzkavak & TRKY \\
\hline Coto & PLPN & La Caridid & CUBA \\
\hline Cromita & CUBA & Lagonoy & PLPN \\
\hline Dagardi & TRKY & La Victoria & CUBA \\
\hline Dagkuplu & TRKY & Lolita & CUBA \\
\hline Danacik & TRKY & Marais Kiki & NCAL \\
\hline Dcev 7 & NCAL & Meululter & TRKY \\
\hline Delta & CUBA & Middle Ore Body & PLPN \\
\hline Demirli & TRKY & Mirandag Koru & TRKY \\
\hline Dinagat & PLPN & Mirandag Mevki & TRKY \\
\hline Dogu Ezan & TRKY & Morrachini & NCAL \\
\hline Dogu Kef & TRKY & Musa Danisman & TRKY \\
\hline Domuzburnu II & TRKY & Narciso & CUBA \\
\hline Dovis & IRAN & $\mathrm{Ni} \mathrm{Te}$ Ocutes & CUBA \\
\hline East Ore Body & PLPN & Ochanocagi & TRKY \\
\hline El Cid & CUBA & Ofelia & CUBA \\
\hline Eldirek & TRKY & Orta Ezan & TRKY \\
\hline Ermenis & TRKY & Otmanlar-Harpuzlu & TRKY \\
\hline Fanrouche & NCAL & Otmanlar-Mesebuku & TRKY \\
\hline Findikli & TRKY & Panamana-An & PLPN \\
\hline Findikli 非301 & TRKY & P. B. & NCAL \\
\hline Findikli 非306-非307 & TRKY & Pergini & TRKY \\
\hline Findik1i $\$ 326$ & TRKY & Potosi & CUBA \\
\hline General Gallieni & NCAL & Ruff Claim No. 32 & PLPN \\
\hline Gerdag & TRKY & Saka & TRKY \\
\hline Golalan & TRKY & Salur & TRKY \\
\hline Gorunur & TRKY & Sarialan & TRKY \\
\hline Govniikbelen & TRKY & Sarikaya & TRKY \\
\hline Gr2h & NCAL & Saysin & TRKY \\
\hline Guillermina & CUBA & Sekioren & TRKY \\
\hline Gunlet-Uckopur & TRKY & Shahin & IRAN \\
\hline Gunliik Basi & TRKY & Sicankale & TRKY \\
\hline Herpit Yayla & TRKY & Sirac & TRKY \\
\hline Ikisulu-Gercek & TRKY & Sofulu & TRKY \\
\hline Jose & CUBA & Sogham & IRAN \\
\hline Kagit Octu & TRKY & Sta. Cruz & PLPN \\
\hline Kandira & TRKY & Stephane & NCAL \\
\hline Kapin & TRKY & Suluiyeh & IRAN \\
\hline Karaculha & TRKY & Sulu & TRKY \\
\hline Karageban & TRKY & Suluk & TRKY \\
\hline Karani & TRKY & Sutpinar & TRKY \\
\hline Karaninar & TRKY & Suzanne & NCAL \\
\hline Karasivri & TRKY & Tekneli & TRKY \\
\hline
\end{tabular}


Model 8b--Con.

$\begin{array}{llll}\text { Tepebasi } & \text { TRKY } & \text { West Ore Body } & \text { PLPN } \\ \text { Terlik } & \text { TRKY } & \text { Yanikara } & \text { TRKY } \\ \text { Tiebaghi } & \text { NCAL } & \text { Yaprakli } & \text { TRKY } \\ \text { Tilkim-Karanlik } & \text { TRKY } & \text { Yayca Boyna } & \text { TRKY } \\ \text { Togobomar } & \text { PLPN } & \text { Yilmaz Ocagi } & \text { TRKY } \\ \text { Tosin } & \text { TRKY } & \text { Yukari Zorkum } & \text { TRKY } \\ \text { Toparlar-Alacik } & \text { TRKY } & \text { Yunus Yayla } & \text { TRKY } \\ \text { Tuzlakaya } & \text { TRKY } & \text { Yurtlak } & \text { TRKY } \\ \text { Uckopru } & \text { TRKY } & \text { Zambales Ch } & \text { PLPN } \\ \text { Vieille Montagne } 1 & \text { NCAL } & \text { Zimparalik } & \text { TRKY } \\ \text { Vieille Montagne 2 } & \text { NCAL } & & \end{array}$

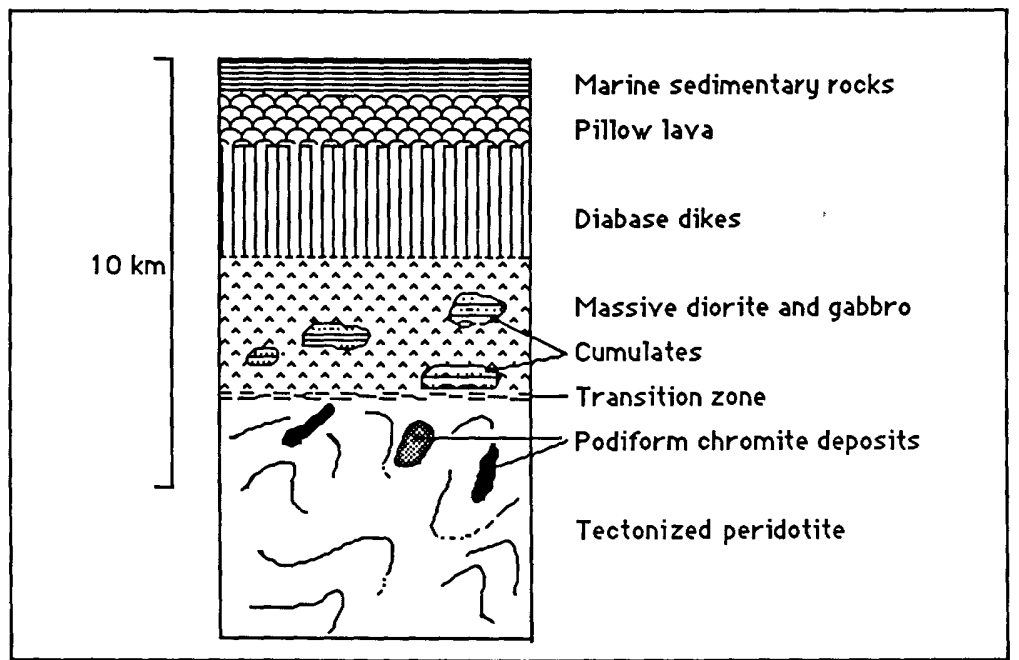

Figure 20. Cartoon cross section of a typical ophiolite sequence showing locations of podif orm chromite deposits. From Dickey (1975). 


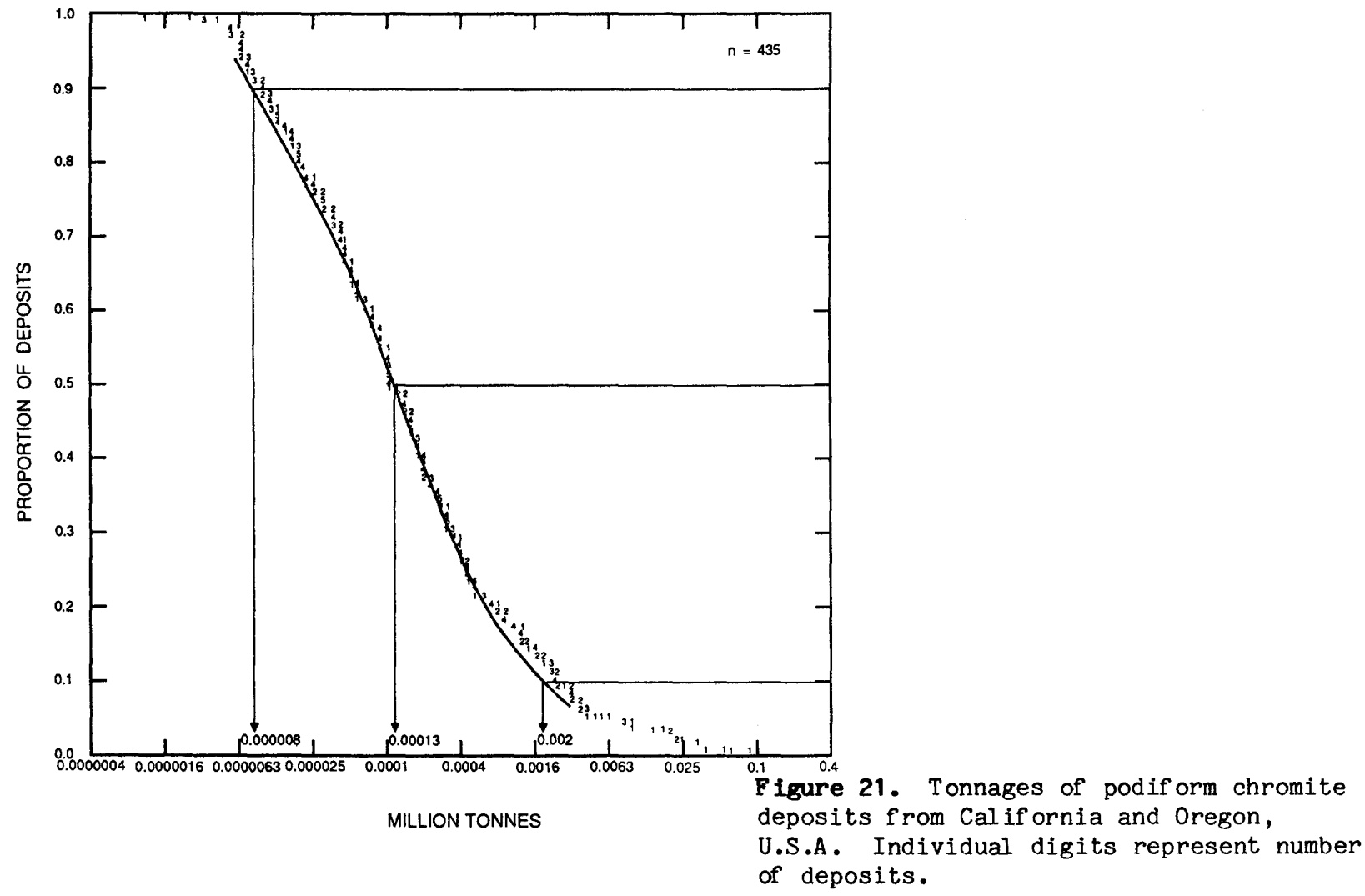

PODIFORM CHROMITE

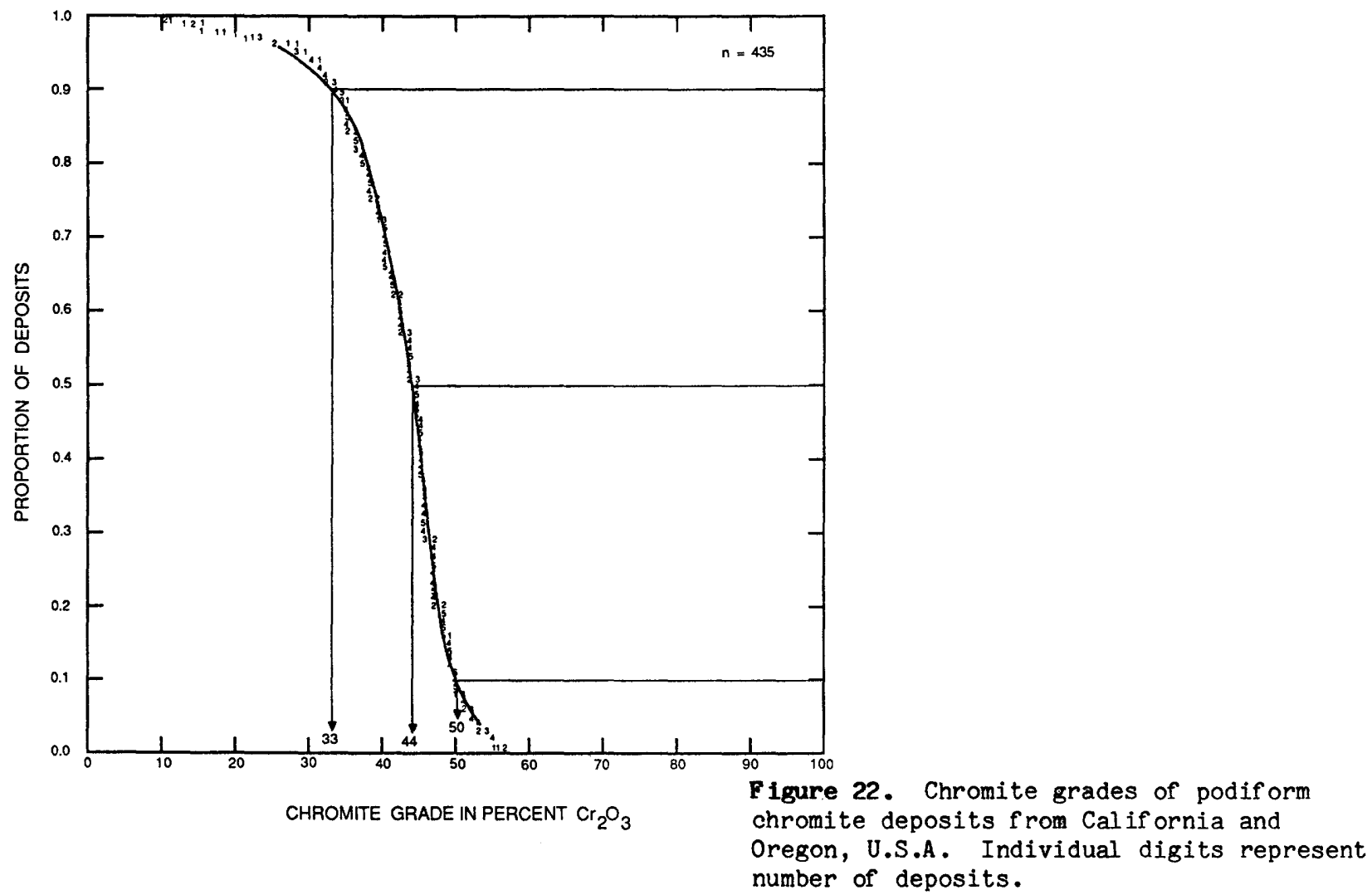


Model 8a--Con.
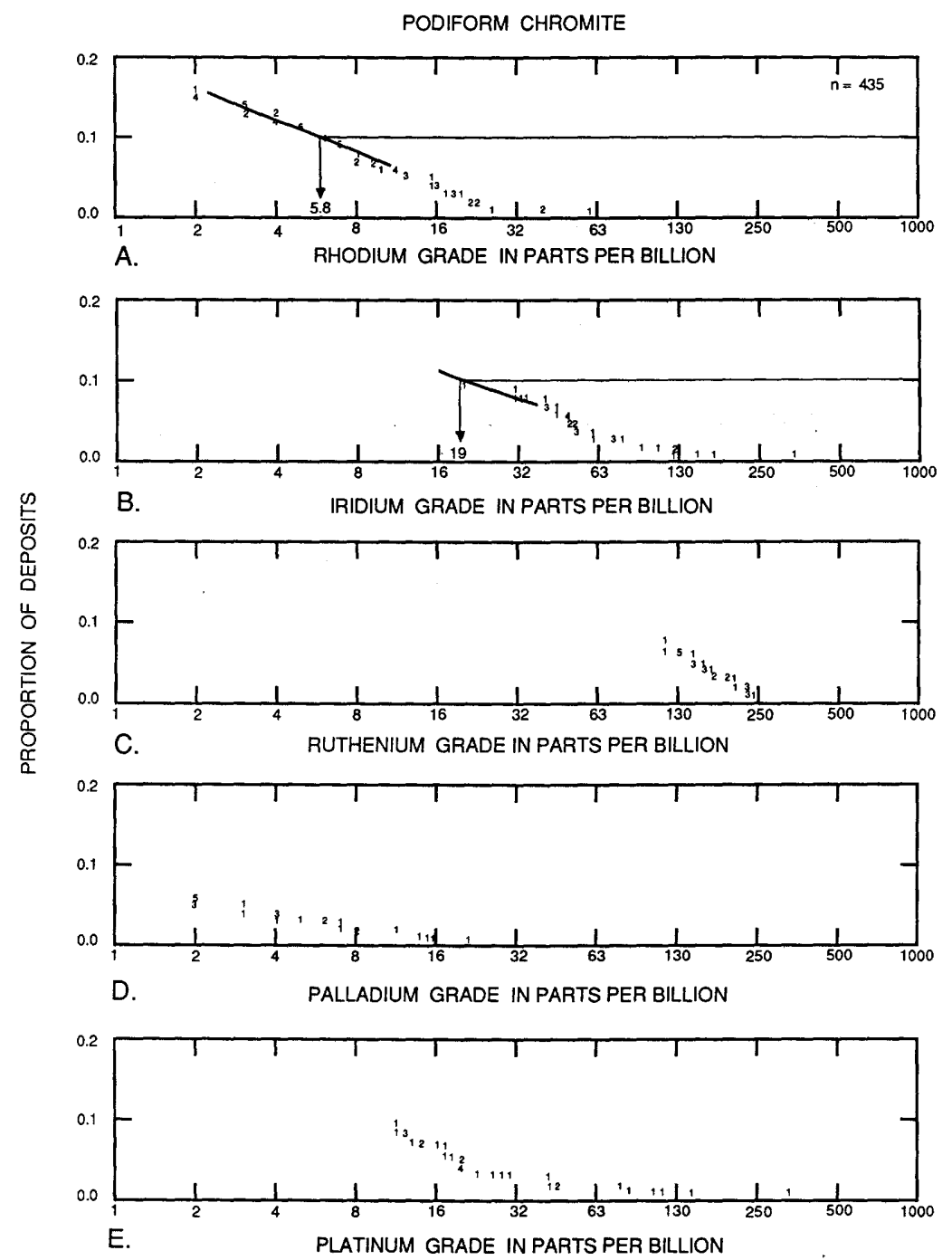

Figure 23. PGE grades of podif orm chromite deposits from Cal if ornia

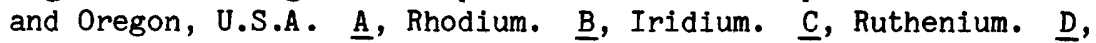
Palladium. E, Platinum. Individual digits represent number of deposits. 
MAJOR PODIFORM CHROMITE

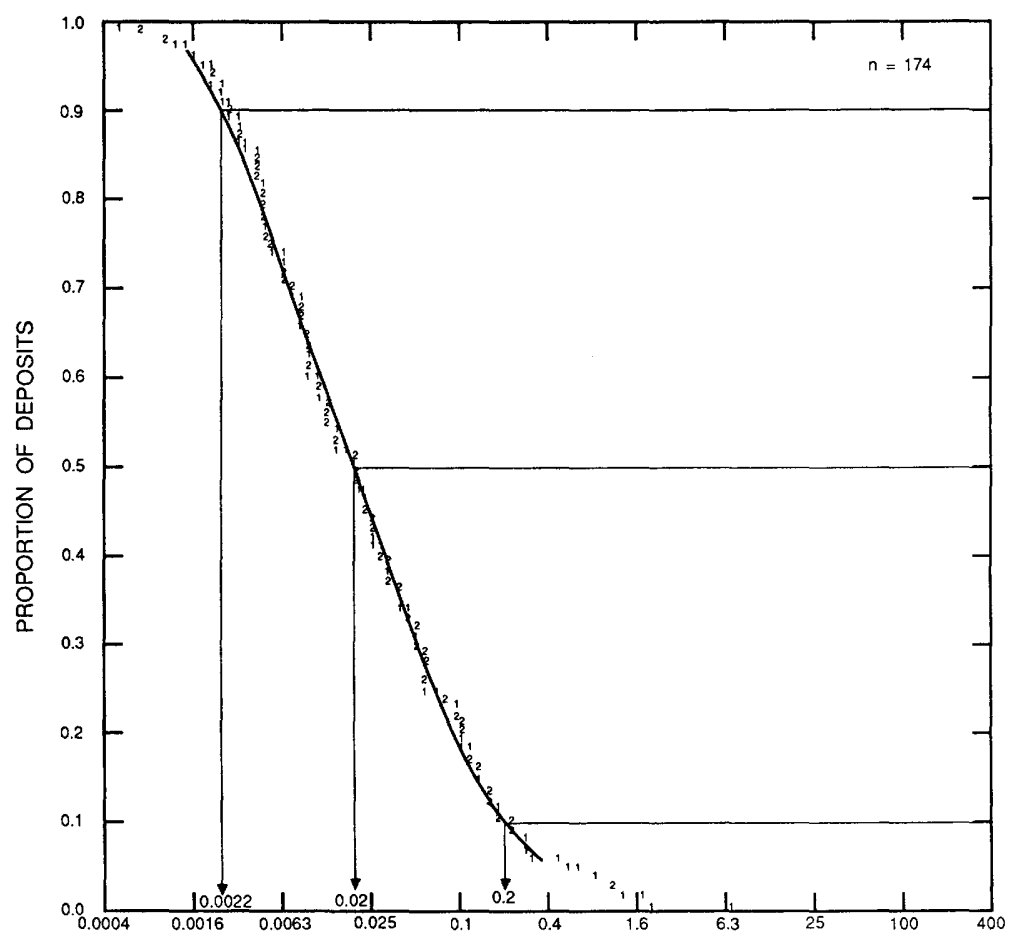

Figure 24. Tonnages of major podiform chromite deposits. Individual digits represent number of deposits.

MAJOR PODIFORM CHROMITE

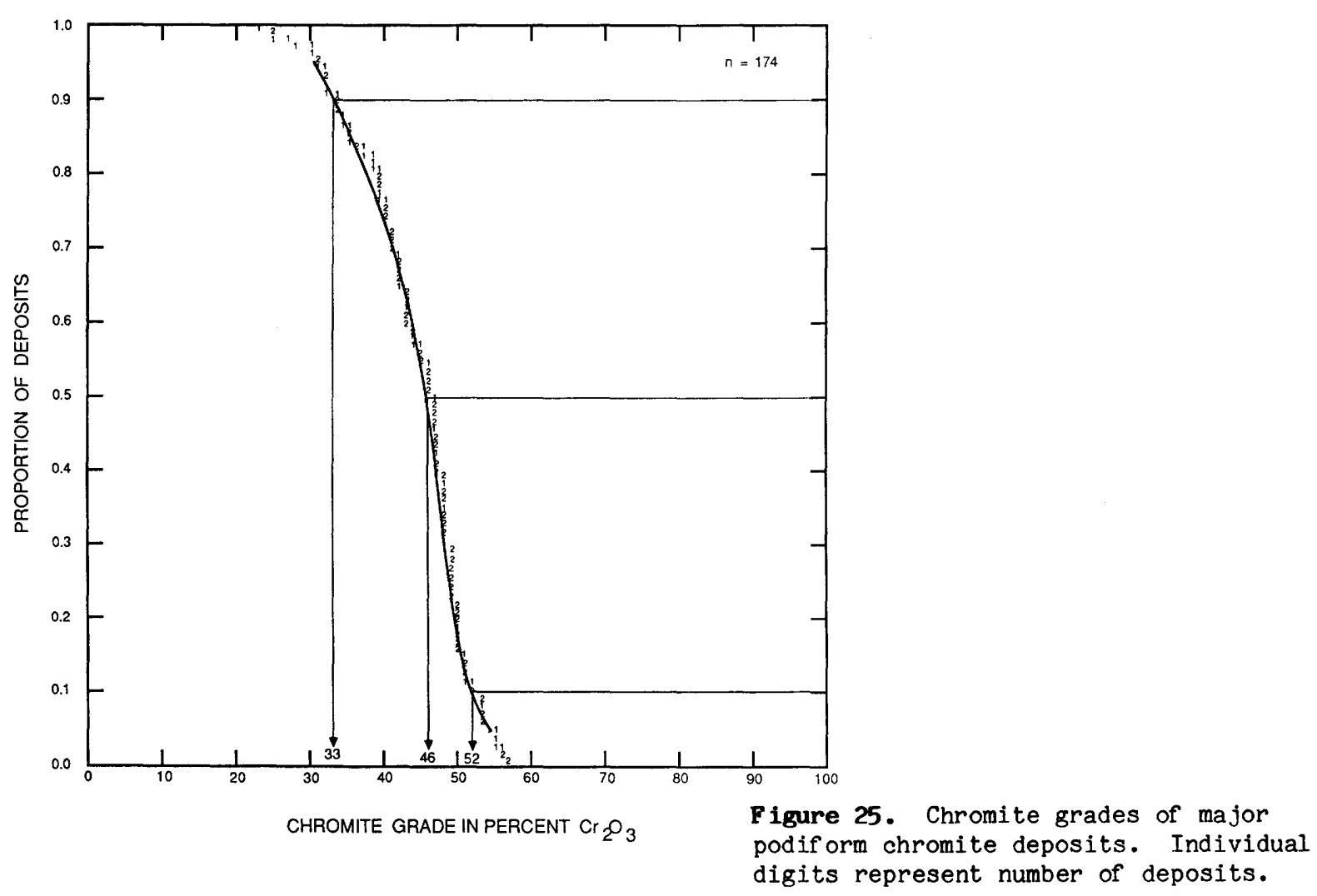


MAJOR PODIFORM CHROMITE
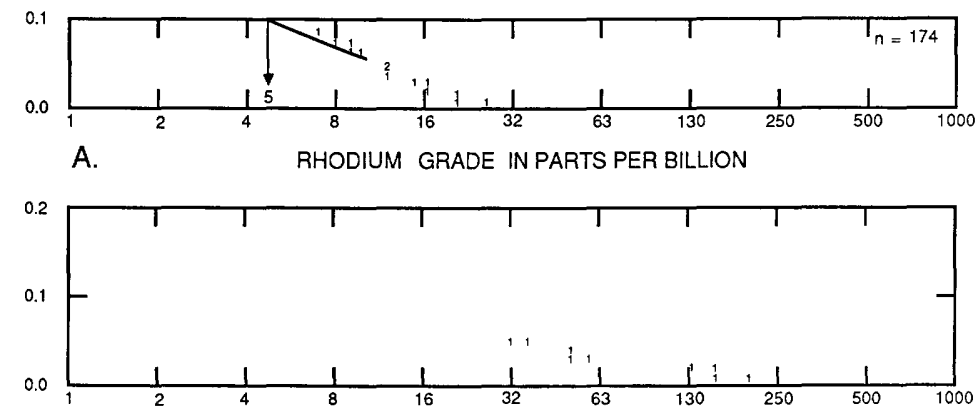

B.

IRIDIUM GRADE IN PARTS PER BILLION
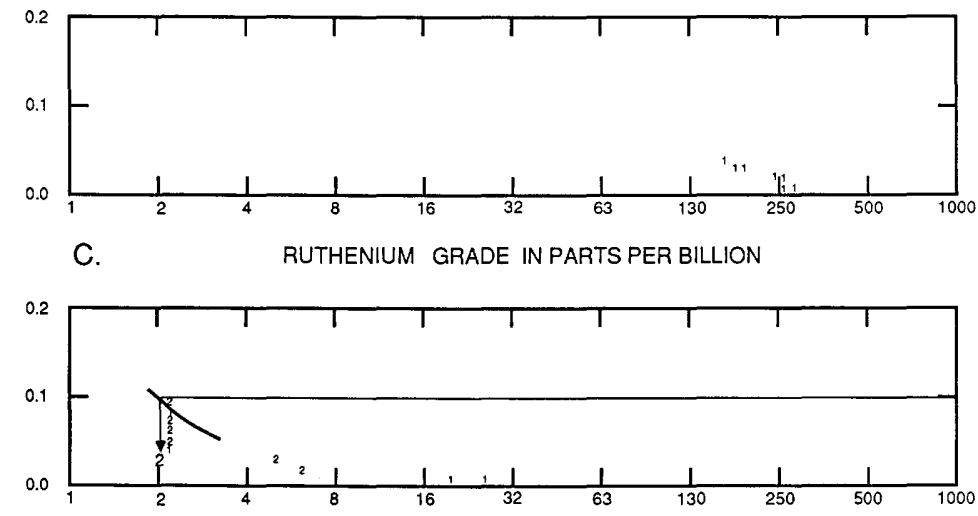

D.

PALLADIUM GRADE IN PARTS PER BILLION

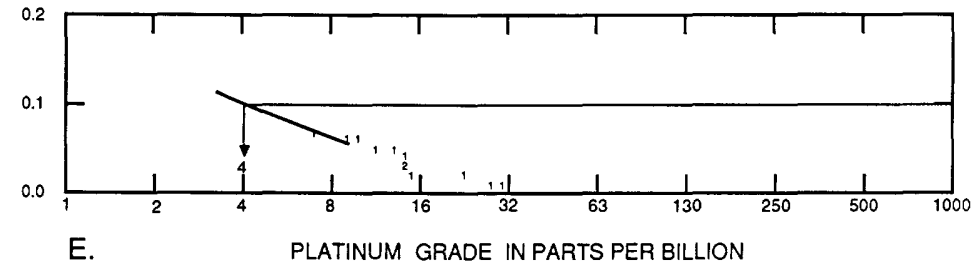

Figure 26. PGE grades of major podiform chromite deposits. A, Rhodium. B, Iridium. C, Ruthenium. D, Palladium. E, Platinum. Individual digits represent number of deposits. 


\section{DESCRIPTIVE MODEL OF LIMASSOL. FOREST CO-Ni}

\section{By Norman J Page}

DESCRIPTION Irregular veins, pods and lenses associated with serpentinized peridotite and dunite or nearby country rocks.

GEOLOGICAL ENVIRONMENT

Rock Types Highly serpentinized dunite, harzburgite, pyroxenite; quartz-carbonate rocks.

Textures Sheared.

Age Range Paleozoic and Mesozoic.

Depositional Environment Faults, fractures associated with serpentinized ultramafic rocks of an ophiolite.

Tectonic Setting(s) Unstable, accreted terranes, near plate boundaries.

Associated Deposit Types Podiform chromite, Ni-laterite, Co-Ni-Cu ophiolite sulfide.

DEPOSIT DESCRIPTION

Mineralogy: Pyrrhotite + pyrite \pm pentlandite \pm chalcopyrite \pm vallerite \pm loellingite \pm niccolite \pm maucherite \pm skutterudite \pm gersdorffite \pm cobaltite \pm magnetite \pm chromite \pm mackinawite \pm pararammelsbergite.

Texture/Structure Irregular vein and fracture fillings.

Alteration Serpentinization and quartz-carbonate.

Ore Controls Serpentinized ultramafic rock, possible external source of arsenic (see fig. 99).

Geochemical Signature As, Co, $\mathrm{Ni}$

EXAMPLES

Bou Azzer, MRCO

Limmasol Forest, CYPS
(LeBlanc, 1981; LeBlanc and Bilaud, 1982)

(Panayiotou, 1980) 
Model $8 d$

DESCRIPTIVE MODEL. OF SERPENTINE-HOSTED ASBESTOS

By Norman J Page

APPROXIMATE SYNONYM Quebec Type (Shride, 1973).

DESCRIPTION Chrysotile asbestos developed in stockworks in serpentinized ultramafic rocks.

GEOLOGICAL ENVIRONMENT

Rock Types Serpentinites, dunite, harzburgite, pyroxenite.

Textures Highly fractured and veined, serpentinized ultramafic rocks.

Age Range Paleozoic to Tertiary.

Depositional Environment Usually part of an ophiolite sequence. Later deformation and igneous intrusion may be important.

Tectonic Setting(s) Unstable accreted oceanic terranes.

Associated Deposit Types Podiform chromite.

DEPOSIT DESCRIPTION

Mineralogy Chrysotile asbestos \pm magnetite \pm brucite \pm talc \pm tremolite-actinolite.

Texture/Structure Stockworks of veins in serpentinized ultramafic rocks.

Alteration None associated with ore, but silica-carbonate, talc may be developed.

Ore Controls Two periods of serpentinization, an earlier pervasive one and a later period near the end of intense deformation accompanied by hydrothermal activity perhaps as a function of intrusion of acidic, igneous rocks highly dependent upon major faulting, and fracture development.

Geochemical signature None.

EXAMPLES:

Thetford-Black Lake, CNQU (Riordon, 1957)

GRADE AND TONNAGE MODEL OF SERPENTINE-HOSTED ASBESTOS

By Greta J. Orris

COMMENTS Long and short fibers are combined. Some literature did not specify if reported production was tons of fiber or tons of ore. In these cases, production was assumed to be tons of ore which may have led to underestimation of some deposit tonnages. See Figs. $27,28$. 
Model 8d--Con.

DEPOSITS

Name

Abitibi

Advocate

Asbestos Hill

Asbestos Island

Belvidere

Black Lake

British Canadian

Caley

Carey/East Broughton

Cana Brava

Cassiar Mine

Clinton Creek

Continental

Courvan Mine

Cranbourne

Daffodil

Eagle

Gilmont

Golden Age

Havelock Mine

Jefferson Lake

Jeffrey Lake

Kinlock

Kolubara-Azbest

Kudu Asbestos Mine
Country Name

CNQU

CNNF

CNQU

CNQU

USVT

CNQU

CNQU

CNYT

CNQU

BRZL

CNBC

CNYT

CNQU

CNQU

CNQU

CNON

USAK

CNQU

CNQU

SWAZ

USCA

CNQU

SAFR

YUGO

ZIMB

Lili

Rex
Lafayette

Lake Asbestos

Las Brisas

McAdam

Midlothian

Moladezhnoye

Munro

National

Nicolet Asbestos

Normandie/Penhale

Pontbriand

Qala-el-Nahl?

Reeves

Roberge Lake

St. Adrien Mtn.

St. Cyr

Santiago Papalo

Shihmien

Steele Brook

Thetford Group

Windsor

Woodsreef Mine

Zindani

\section{Country}

CNQU

CNQU

CLBA

CNQU

CNQU

CNON

URRS

CNON

CNQU

CNQU

CNQU

CNQU

SUDN

CNON

CNYT

CNQU

CNQU

CNQU

MXCO

CINA

CNQU

CNQU

CNQU

AUNS

GREC 
Model 8d--Con.

SERPENTINE--HOSTED ASBESTOS

Figure 27. Tonnages of serpentine-hosted asbestos deposits.

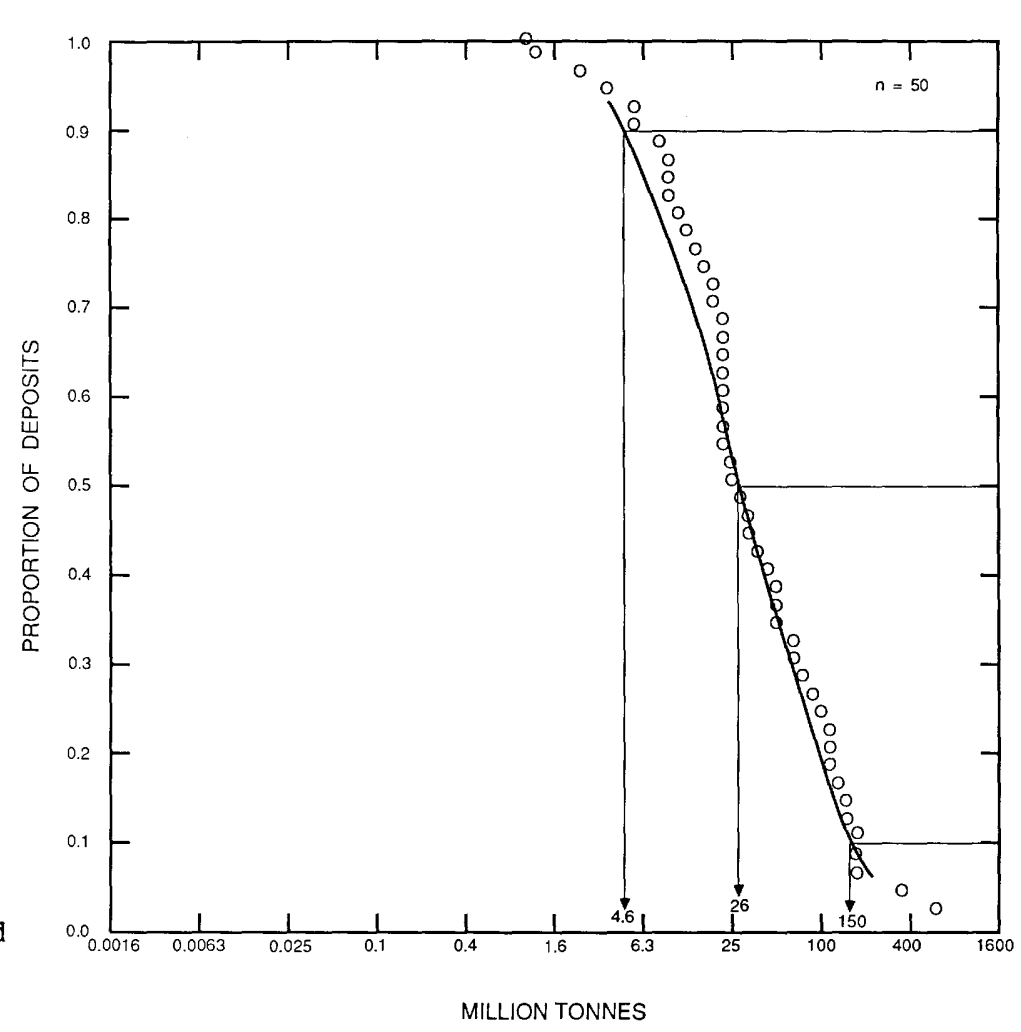

SERPENTINE--HOSTED ASBESTOS

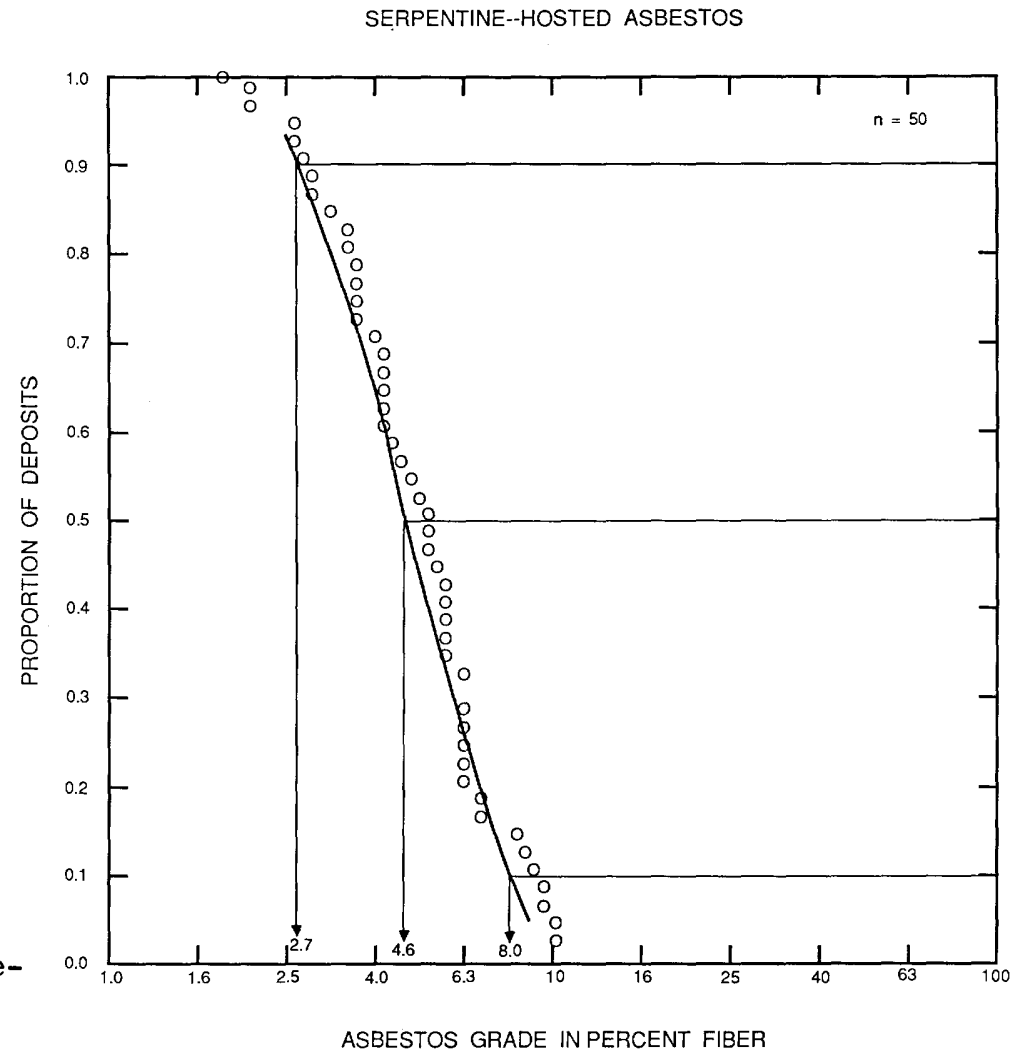

Figure 28. Asbestos grades of serpentinehosted asbestos deposits. 
DESCRIPTIVE MODEL OF ALASKAN PGE

By Norman $J$ Page and Floyd Gray

APPROXIMATE SYNONYMS Zoned ultramafic Cr-Pt; Kachkanar-type (Cabri and Naldrett, 1984 ).

DESCRIPTION Crosscutting ultramafic to felsic intrusive rocks with approximately concentric zoning of rock types containing chromite, platinum, and Ti-V-magnetite (see fig. 29).

GEOLOGICAL ENVIRONMENT

Rock Types Dunite, wehrlite, harzburgite, pyroxenite, magnetite-hornblende pyroxenite, twopyroxene gabbros, hornblende gabbro, hornblende clinopyroxenite, hornblende-magnetite clinopyroxenite, olivine gabbro, norite. Post-orogenic tonalite and diorite are commonly spatially related. Orthopyroxene-bearing rocks absent in Klamath Mountains.

Textures Cumulus textures, poikilitic, mush flow textures, lineated fabrics, layered.

Age Range Precambrian to late Mesozoic, most Paleozoic and Mesozoic.

Depositional Environment Deposits occur in layered ultramafic and mafic rocks that intrude into granodiorite, island arc or ophiolite terranes. Evidence indicates shallow levels of emplacement.

Tectonic Setting(s) Unstable tectonic areas.

Associated Deposit Types PGE placer deposits.

DEPOSIT DESCRIPTION

Mineralogy Assemblage 1: chromite + Pt-Fe alloys + Os-Ir alloys + platinum-iridium \pm pentlandite \pm pyrrhotite \pm native gold \pm PGE arsenides. Assemblage 2: Ti-V magnetite $\pm \mathrm{Pt}-\mathrm{Fe}$ alloys \pm Os-Ir alloys \pm cooperite \pm bornite \pm chalcopyrite.

Texture/Structure Assemblage 1: clots, pods, schlieren, wisps of chromite in dunite, clinopyroxenite, harzburgite. Assemblage 2: magnetite segregations, layers in wehrlite, pyroxenite, gabbro (see fig. 29).

Alteration None: post-mineralization serpentinization.

Ore Controls Appear to be restricted to specific rock types by magmatic processes.

Weathering Mechanical weathering produces placers; chemical weathering could produce laterites. Geochemical Signature $\mathrm{Cr}$, PGE, Ti, V, $\mathrm{Cu}, \mathrm{Ni}, \mathrm{S}$, As. Assemblage 2 ores in Klamath Mountains are low in $\mathrm{Cr}$ and $\mathrm{Ni}$.

\section{EXAMPLES}

Urals, USSR

Duke Island, USAK

Guseva-Gora, USSR

Tin Cup Peak, USOR
(Duparc and Tikonovitch, 1920)

(Irvine, 1974)

(Razin, 1976)

(Page and others, 1982a) 
Model 9--Con.

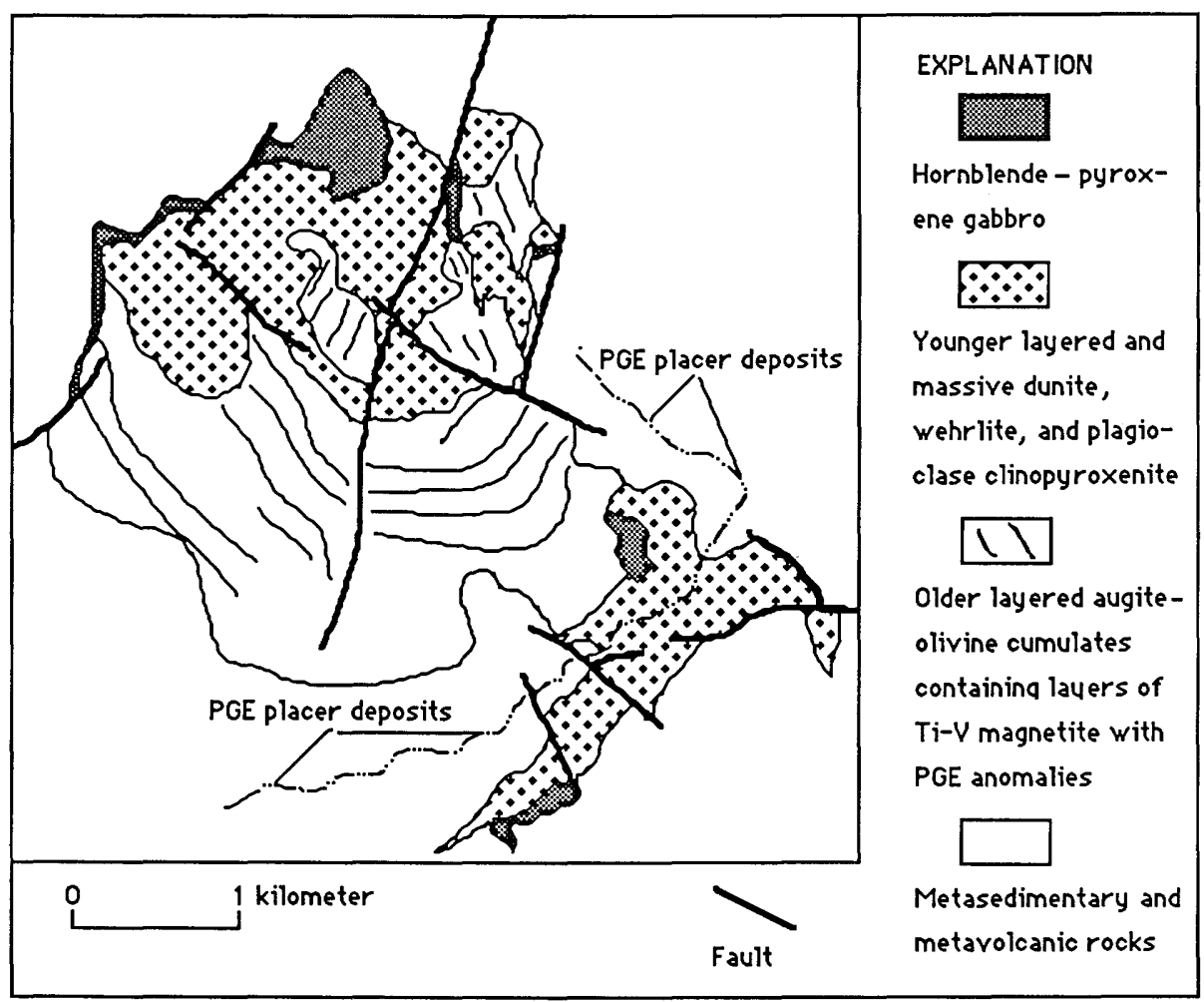

Figure 29. Generalized geologic map of zoned ul tramafic complex at Lower Coon Mountain, Calif. (from Gray and Page, 1985). V-rich magnetite layers and anomal ous PGE concentrations typical of Alaskan Cr-Pt deposits are associated with plutons of this type. 


\title{
DESCRIPTIVE MODEL OF CARBONATITE DEPOSITS
}

\author{
By Donald A. Singer
}

APPROXIMATE SYNONYM Apatite-magnetite and rare earths in carbonatites.

DESCRIPTION Apatite-magnetite and rare-earth deposits and combinations of these in zoned complexes consisting of central plug of carbonatite or syenite breccia surrounded by ring dikes and cone sheets of alternating rock types.

GENERAL REFERENCE Tuttle and Gittins (1966).

\section{GEOLOGICAL ENVIRONMENT}

Rock Types Apatite-magnetite deposits tend to be in sovite (calcitic carbonatite); RE types tend to occur in ankerite carbonatite; most deposits have both. In general pyroxenite, nepheline and feldspathic pyroxenite, carbonatite, fenite, ijolite, dunite, picrite-porphyrites, gneiss and alkalic fenitized gneiss, and locally alkaline volcanics rocks.

Textures Hypidiomorphic-granular, poikiloblastic. Breccias abundant. Carbonatites show intrusive relations. Wallrocks fenitized.

Age Range Almost all known carbonatite complexes are intrusive into Precambrian shields, however, the carbonatites themselves may be much younger.

Depositional Environment Multiple stages of igneous, deuteric and metasomatic crystallization in carbonatite magma.

Tectonic Setting(s) Continental shields. Spatially related to fault lineaments such as East African rift system. Locally related to alkaline volcanism.

Associated Deposit Types None.

DEPOSIT DESCRIPTION

Mineralogy Apatite-magnetite-type: apatite, magnetite, pyrochlore \pm columbite \pm perovskite \pm niocalite. RE-type: barite, strontianite \pm siderite \pm rhodochrosite \pm ankerite \pm bastnaesite \pm chlorites \pm parisite \pm monagite \pm breunnerite. General: calcite, dolomite, fluorite, pyrrhotite, ilmenite, molybdenite, chalcopyrite, pyrite, sphalerite, pyroxene, biotite, phlogopite, amphibole, spinel, \pm galena, \pm hematite, \pm quartz, \pm forsterite, \pm serpentine, $\pm z i r c o n ~ \pm$ sphene, \pm anatase, \pm rutile, \pm brookite, \pm fersmite.

Texture/Structure Disseminated and banded.

Alteration Fenitization (widespread alkali metasomatism of quartzo-feldspathic rock; mostly alkalic feldspar with some aegerine and subordinate alkali-hornblende and accessory sphene and apatite) near contact of carbonatite intrusion. Locally, chloritization.

Ore Controls Commonly restricted to carbonatite dikes, sills, breccias, sheets, veins, and large masses, but may occur in other rocks associated with the complex rocks.

Weathering May result in goethite-rich soil enriched in $\mathrm{P}, \mathrm{Nb}$, and $\mathrm{RE}$.

Geochemical Signature Radiometric anomalies, magnetic anomalies, high gravity anomalies, Th, U, $\mathrm{Ti}, \mathrm{Zn}, \mathrm{Nb}, \mathrm{Y}, \mathrm{Ce}, \mathrm{Mo}, \mathrm{Cu}, \mathrm{V}, \mathrm{P}, \mathrm{Mn}, \mathrm{S}, \mathrm{La}, \mathrm{Sm}, \mathrm{Pb}, \mathrm{Zr}, \mathrm{Ba}$, Eu. High values of Be, B, Li, Sn, Ta, $\mathrm{Hf}$, and $\mathrm{W}$ are rare.

\section{EXAMPLES}

Oka, CNQU

Iron Hill, USCO

St. Honore, CNQU

Gem Park, USCO

Mountain Pass, USCA
(Gold and others, 1966)

(Temple and Grogan, 1965)

(Dawson, 1974)

(Parker and Sharp, 1970)

(Olson and others, 1954) 
Model 10--Con.

GRADE AND TONNAGE MODEL OF CARBONATITE DEPOSITS

By Donald A. Singer

COMMENTS Locally these carbonatite complexes may contain economically interesting grades of uranium, thorium, titanium, iron, copper, vermiculite, zirconium or phosphorus; frequently, these other commodities are in different zones than the niobium-rich parts of the complex. See figs. 30 , 31.

\section{DEPOSITS}

\section{Name}

Araxa

Bingo

Dominion Gulf

Catalao

Iron $\mathrm{Hill}$

James Bay

Lueshe

Mbeya

Martison Lake

Manitou Island
Country

BRZL

ZIRE

CNON

BRZL

USCO

CNON

ZIRE

TNZN

CNON

CNON
Name

Mountain Pass

Mrima Hill

Nemogos (Lackner Lake)

Oka CNQU

Salitre

Serra Negra

Søve

Sukulu

St. Honore (Soquem)

Tapira
Country

USCA

KNYA

CNON

BRZL

BRZL

NRWY

UGND

CNQU

BRZL

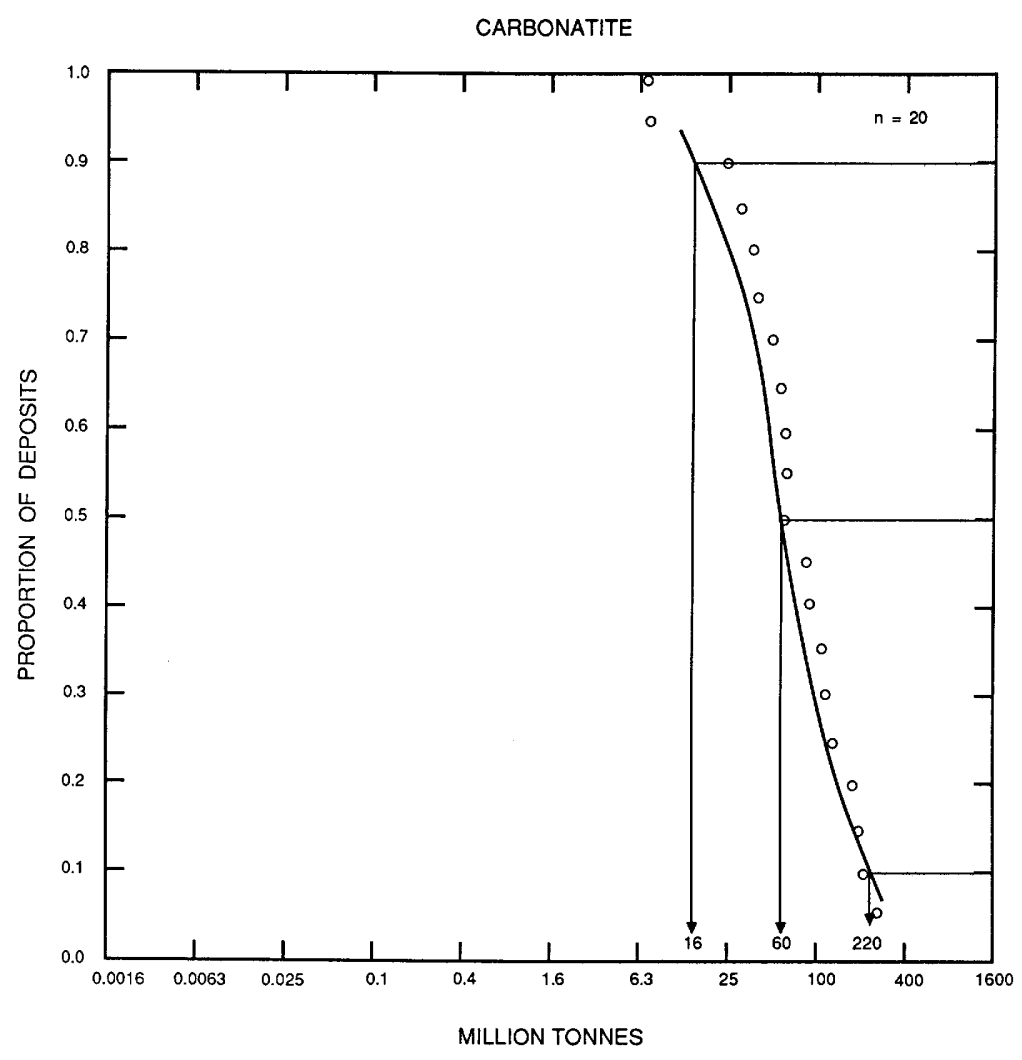

Figure 30. Tonnages of carbonatite deposits. 
Model 10--Con.
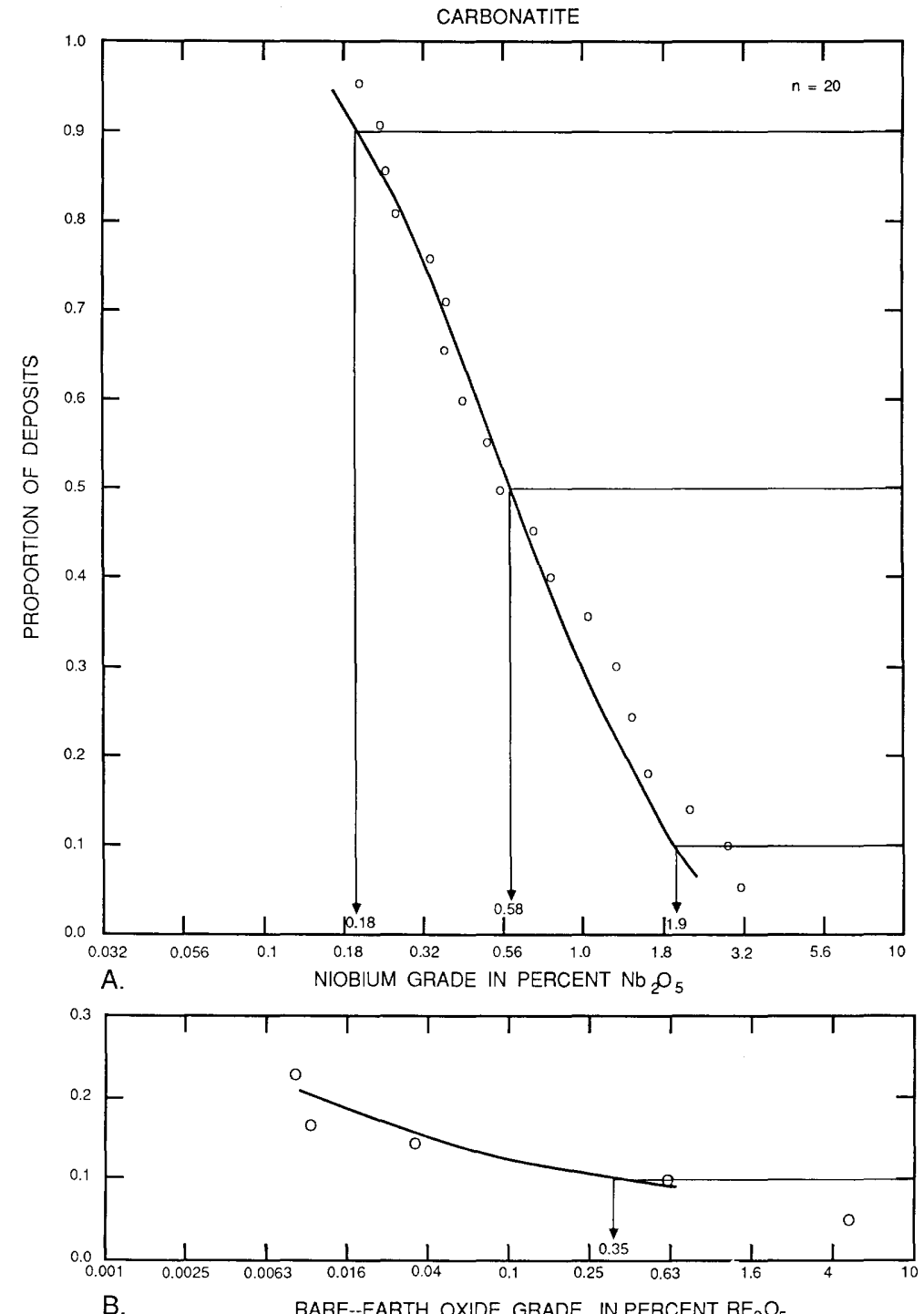

B. RARE-EARTH OXIDE GRADE IN PERCENT $\mathrm{RE}_{2} \mathrm{O}_{5}$

Figure 31. Grades of carbonatite deposits. A, Niobium. B, Rareearth oxides. 
Model 12

\section{DESCRIPTIVE MODEL OF DIAMOND PIPES}

By Dennis P. Cox

DESCRIPTION Diamonds in kimberlite diatremes and other alkaline mafic rocks.

GENERAL REFERENCE Orlov (1973), Dawson (1980), Gold (1984).

GEOLOGICAL ENVIRONMENT

Rock Types Kimberlite diatremes. Olivine lamproite (K-rich Mg-lamprophyre) and leucite lamproite.

Textures Pipes: porphyritic igneous texture. Breccias with inclusions of many rocks from mantle, basement and overlying sequences. Lapilli tuff locally fills upper levels of diatreme.

Age Range Most productive pipes are $80-100,250$, and 1,000-1,100 m.y. in age.

Depositional Environment Pipes intruded from mantle source under high pressure but with rapid quenching.

Tectonic Setting(s) Most pipes intrude cratonal areas, stable since Early Proterozoic. Some intrude folded cover rocks that overlie deformed cratonal margins. Pipes are not correlated with orogenic events but occur in areas of epeirogenic warping or doming and along major basement fracture zones. Some pipes occur at intersections of regional zones of weakness visible in LANDSAT or SLAR.

Associated Deposit Types Diamond placers.

\section{DEPOSIT DESCRIPTION}

Mineralogy Diamond, bort or carbonado (polycrystalline generally dark colored), ballas (spherulitic polycrystalline), and amorphous carbonado.

Texture/Structure Diamonds are sparsely disseminated as phenocrysts or xenocrysts in breccia. Mined kimberlites yield from 0.1 to $0.6 \mathrm{ppm}$ diamond.

Alteration Serpentinization resulting in "blue clay" zones. Silicification and carbonate alteration of country rock near pipe; rarely, alkalic metasomatism forming $\mathrm{K}-\mathrm{feldspar}$ and $\mathrm{Na-}$ amphiboles.

Ore Controls Diamond distribution is irregular and restricted to kimberlite or lamproite pipes and upward-flaring crater zones. Productive pipes are rare and, at present, can only be identified by their diamond content.

Weathering Pipes weather rapidly to form topographic depressions.

Geochemical Signature $\mathrm{Cr}, \mathrm{Ti}, \mathrm{Mn}, \mathrm{Ni}, \mathrm{Co}, \mathrm{PGE}, \mathrm{Ba}$. Anomalous $\mathrm{Ni}$, Nb, and heavy minerals pyrope, garnet, phlogopite, and $\mathrm{Mg}$-ilmenite indicate nearby pipes. Lamproite pipes lack ilmenite.

\section{EXAMPLES}

African deposits

Western Australia deposits

Wyoming-Colorado
(Sutherland, 1982)

(Atkinson and others 1984)

(Lincoln, 1983) 
DESCRIPTIVE MODEL OF W SKARN DEPOSITS

By Dennis P. Cox

DESCRIPTION Scheelite in calc-silicate contact metasomatic rocks.

GENERAL REFERENCE Einaudi and Burt (1982), Einaudi and others (1981).

GEOLOGICAL ENVIRONMENT

Rock Types Tonalite, granodiorite, quartz monzonite; limestone.

Textures Granitic, granoblastic.

Age Range Mainly Mesozoic, but may be any age.

Depositional Environment Contacts and roof pendants of batholith and

thermal aureoles of apical zones of stocks that intrude carbonate rocks.

Tectonic Setting(s) Orogenic belts. Syn-late orogenic.

Associated Deposit Types Sn-W skarns, Zn skarns.

DEPOSIT DESCRIPTION

Mineralogy Scheelite \pm molybdenite \pm pyrrhotite \pm sphalerite \pm chalcopyrite \pm bornite \pm arsenopyrite \pm pyrite \pm magnetite \pm traces of wolframite, fluorite, cassiterite, and native bismuth.

Alteration Diopside-hedenbergite + grossular-andradite. Late stage spessartine + almandine. Outer barren wollastonite zone. Inner zone of massive quartz may be present.

Ore Controls Carbonate rocks in thermal aureoles of intrusions.

Geochemical Signature W, Mo, $\mathrm{Zn}, \mathrm{Cu}, \mathrm{Sn}, \mathrm{Bi}, \mathrm{Be}, \mathrm{As}$.

EXAMPLES

$\begin{array}{ll}\text { Pine creek, USCA } & \text { (Newberry, 1982) } \\ \text { MacTung, CNBC } & \text { (Dick and Hodgson, 1982) } \\ \text { Strawberry, USCA } & \text { (Nokleberg, 1981) }\end{array}$

GRADE AND TONNAGE MODEL OF W SKARN DEPOSITS

By W. David Menzie and Gail M. Jones

COMMENTS All mines associated with the contact zone of a particular intrusive with a favorable host rock were combined to form a single deposit. In the absence of detailed geologic information, mines within $10 \mathrm{~km}$ of each other were combined. See figs. 32,33 .

DEPOSITS

Name

Bailey

Brejui

$\mathrm{Cab}$

Calvert (Red Button)

Cantung

Dublin Gulch (GSZ)

Emerald-Dodger

Iron Mountain

King Island
Country

CNYT

BRZL

CNYT

USMT

CNNT

CNYT

CNBC

USNM

AUTS
Name

Lost Creek

Lucky Mike

Mactung

Maykhura

Milford area

Nevada-Massachusetts

Nevada-Scheelite

Osgood Range

Pine Creek
Country

USMT

CNBC

CNNT

URTD

USUT

USNV

USNV

USNV

USCA 
Model 14a--Con.

$\begin{array}{ll}\text { Quixaba } & \text { BRZL } \\ \text { Ray Gulch } & \text { CNYT } \\ \text { Sang Dong } & \text { SKOR } \\ \text { Stormy Group } & \text { CNYT } \\ \text { Tem Piute district } & \text { USNV }\end{array}$

Tyrny-Auz URRS

Uludag TRKY

Victory CNBC

Yellow Pine district USID

Ysxjoberg SWDN 

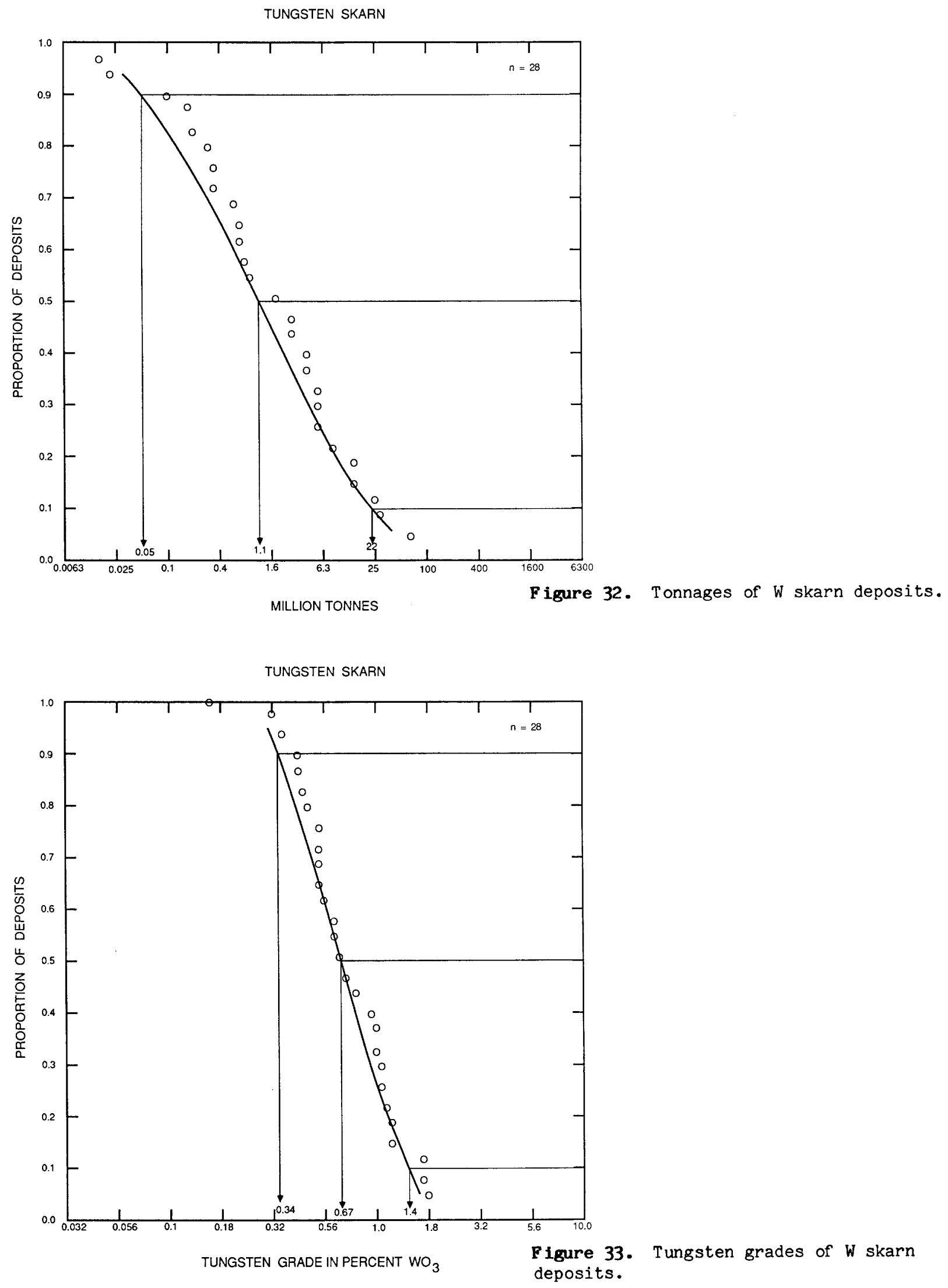
Model 14b

\section{DESCRIPTIVE MODEL OF Sn SKARN DEPOSITS}

By Bruce L. Reed and Dennis P. Cox

DESCRIPTION Tin, tungsten, beryllium minerals in skarns, veins, stockworks and greisens near granite-limestone contacts (see fig. 34 ).

GENERAL REFERENCE Einaudi and Burt (1982), Einaudi and others (1981), Scherba (1970). GEOLOGICAL ENVIRONMENT

Rock Types Leucocratic biotite and(or) muscovite granite, specialized phase or end members common, felsic dikes, carbonate rocks.

Textures Plutonic textures most common (granitic, seriate, fine-grained granitic). Also porphyritic-aphanitic; skarn is granoblastic to hornfelsic, banded skarn common.

Age Range Mainly Mesozoic, but may be any age.

Depositional Environment Epizonal(?) intrusive complexes in carbonate terrane.

Tectonic Setting(s) Granite emplacement generally late (post orogenic).

Associated Deposit Types W skarn, Sn greisen, and quartz-cassiterite-sulfide veins; at increasing distances from intrusive-carbonate contact $\mathrm{Sn}$ replacement and fissure lodes may develop (as at Renison Bell).

DEPOSIT DESCRIPTION

Mineralogy Cassiterite \pm minor scheelite \pm sphalerite + chalcopyrite \pm pyrrhotite \pm magnetite \pm pyrite \pm arsenopyrite \pm fluorite in skarn. Much Sn may be in silicate minerals and be metallurgically unavailable.

Texture/Structure Granoblastic skarn, wrigglite [chaotic laminar pattern of alternating light (fluorite) and dark (magnetite) lamellae], stockworks, breccia.

Alteration Greisenization (quartz-muscovite-topaz \pm tourmaline, fluorite, cassiterite, sulfides) near granite margins and in cusps. Topaz tourmaline greisens. Idocrase + Mn-grossular-andradite \pm $\mathrm{Sn}$-andradite \pm malayaite in skarn. Late-stage amphibole + mica + chlorite and mica + tourmaline + fluorite.

Ore Controls Mineralized skarns may or may not develop at intrusive contact with carbonate rocks; major skarn development up to $300 \mathrm{~m}$ from intrusion controlled by intrusion-related fractures; cross-cutting veins and felsic dikes.

Weathering Erosion of lodes may lead to deposition of tin placer deposits.

Geochemical Signature Sn, W, F, Be, Zn, Pb, Cu, Ag, Li, Rb, Cs, Re, B. Specialized granites characteristically have $\mathrm{SiO}_{2}>73$ percent, $\mathrm{K}_{2} \mathrm{O}>4$ percent and are depleted in $\mathrm{CaO}$, $\mathrm{TiO}{ }_{2}$, $\mathrm{MgO}$, and total $\mathrm{Fe}$. They are enriched in $\mathrm{Sn}, \mathrm{F}, \mathrm{Rb}, \mathrm{Li}, \mathrm{Be}, \mathrm{W}, \mathrm{Mo}, \mathrm{Pb}, \mathrm{B}, \mathrm{Nb}, \mathrm{Cs}, \mathrm{U}, \mathrm{Th}, \mathrm{Hf}$, Ta, and most REE. They are depleted in $\mathrm{Ni}, \mathrm{Cu}, \mathrm{Cr}, \mathrm{Co}, \mathrm{V}, \mathrm{Sc}, \mathrm{Sr}, \mathrm{La}$, and $\mathrm{Ba}$.

EXAMPLES

Lost River, USAK (Dobson, 1982)

Moina, AUTS (Kwak and Askins, 1981)

(Scherba, 1970)

GRADE AND TONNAGE MODEL OF Sn SKARN DEPOSITS

By $W$. David Menzie and Bruce L. Reed

COMMENTS Normally a grade-tonnage model would not be built with so few deposits. However, this model is presented because tin skarn deposits are significantly different than replacement deposits 
in grades, tonnages, and other characteristics. Because of the small number of deposits plotted, the cumulative plot of discrete data points differes from the continuous lognormal curve. If the deposits had been plotted in descending order, the points would fall on the other side of the curve. Potential by-products from these deposits include tungsten, fluorite, beryllium, zinc, and gold. See figs. 35,36 .

\section{DEPOSITS}

$\underline{\text { Name }}$

Gilliam

Lost River

Moina

Pinnacles
Country

AUQL

USAK

AUTS

AUQL

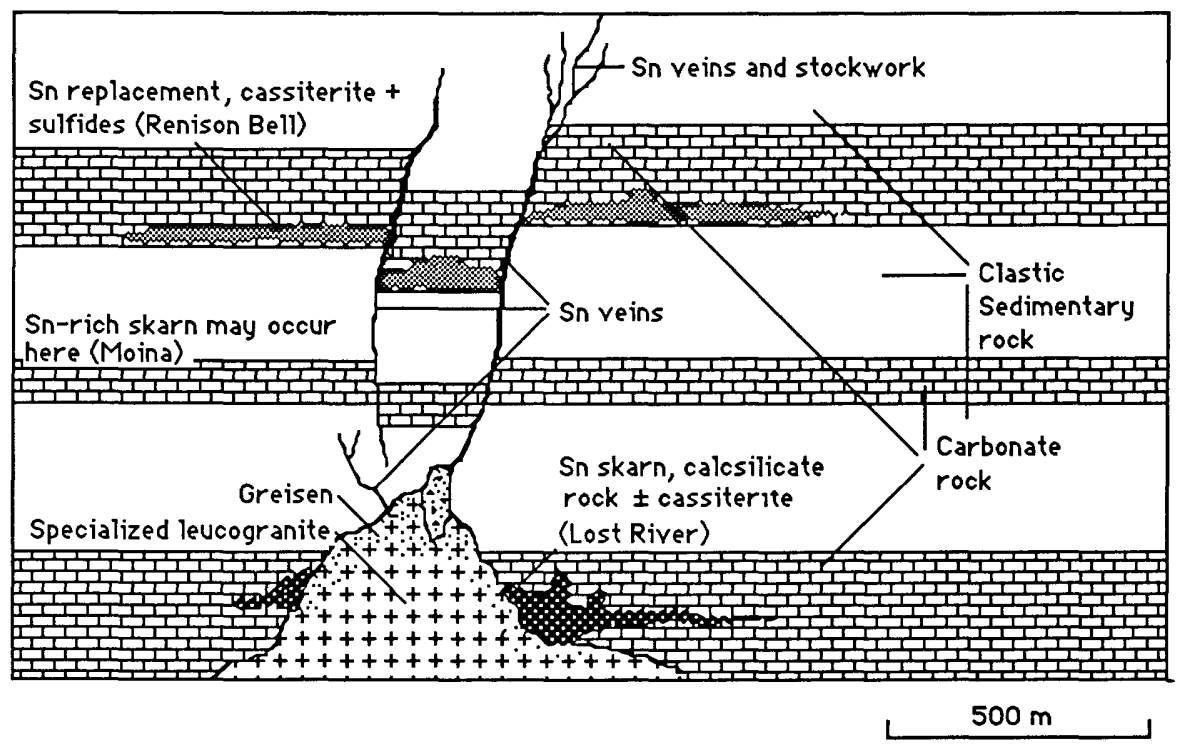

Figure 34. Cartoon cross section showing relation between Sn skarn, replacement $\mathrm{Sn}$ and $\mathrm{Sn}$ vein deposits, and granite intrusions. 
Model 14b--Con.

TIN SKARN

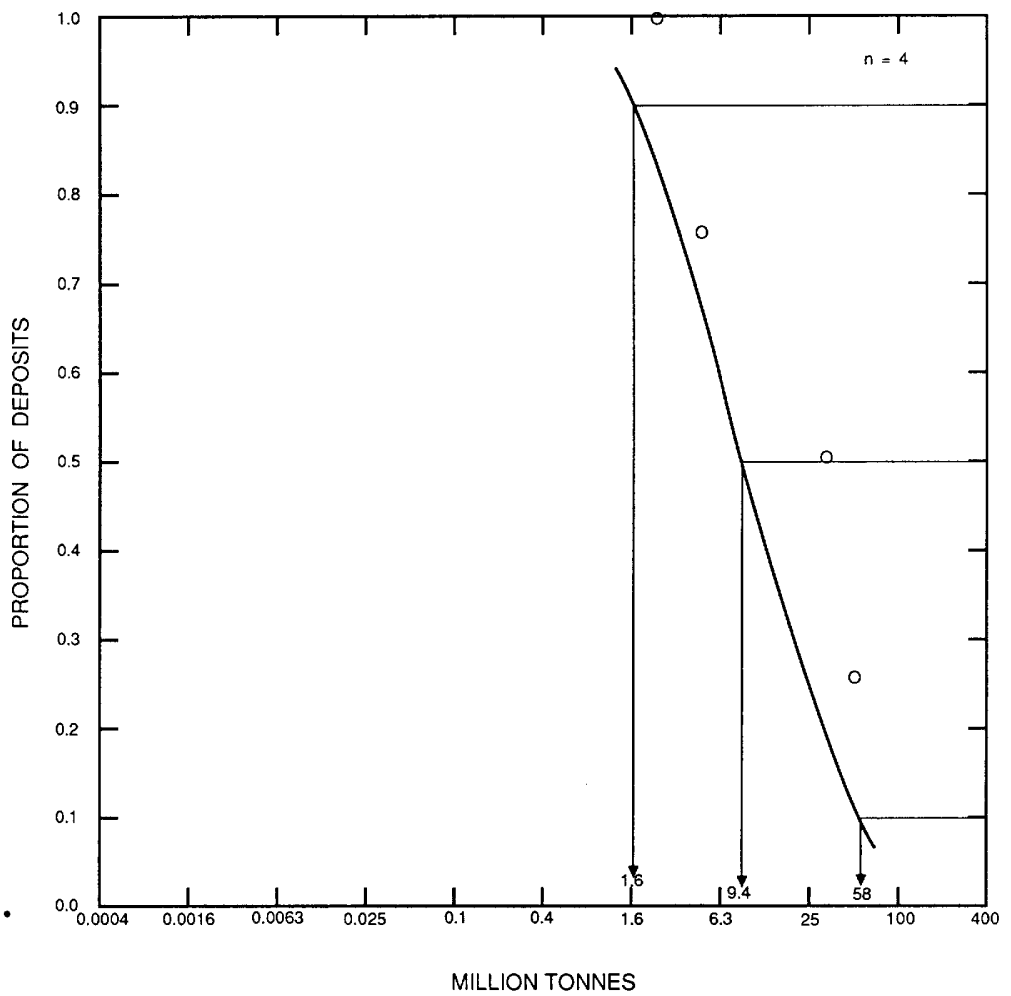

TIN SKARN

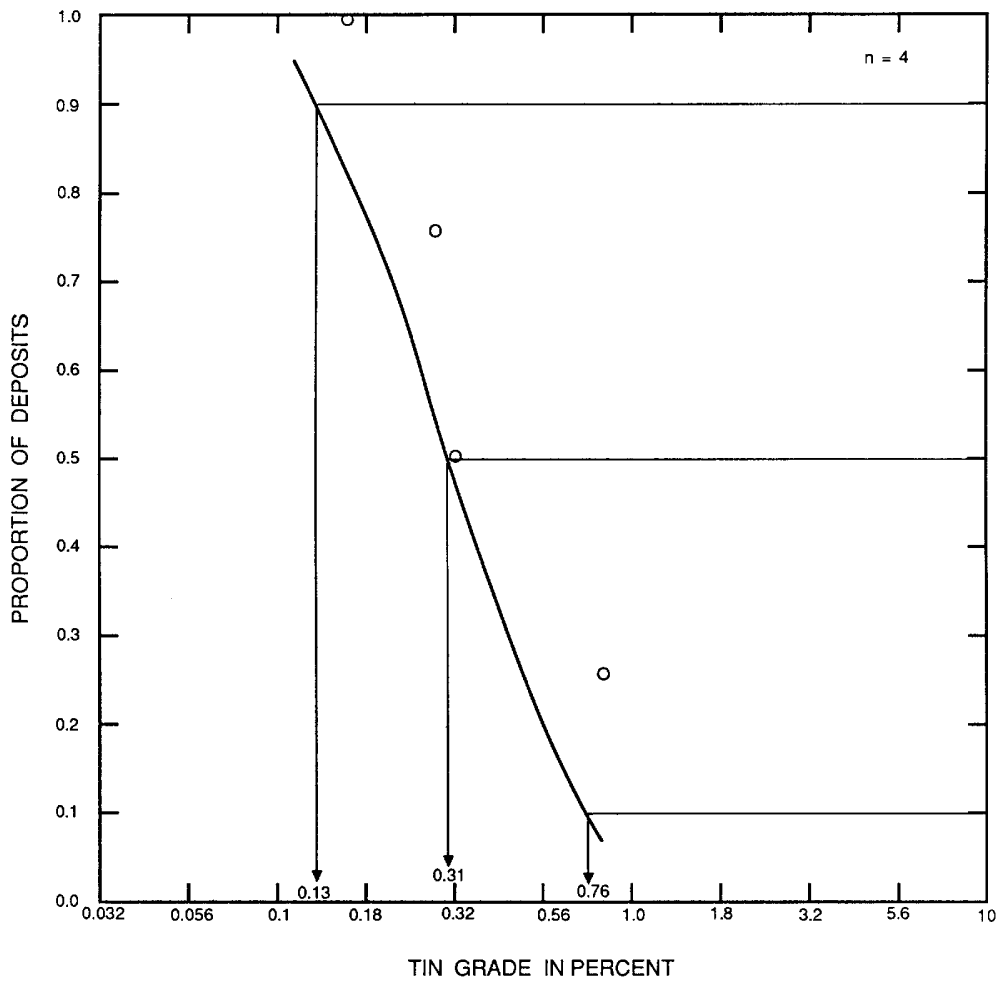

igure 36. Tin grades of $\mathrm{Sn}$ skarn

TIN GRADE IN PERCENT 


\section{DESCRIPTIVE MODEL OF REPLACEMENT Sn}

By Bruce L. Reed

APPROXIMATE SYNONYM EXhalative Sn (P1imer, 1980; Hutchinson, 1979).

DESCRIPTION Stratabound cassiterite-sulfide (chiefly pyrrhotite) replacement of carbonate rocks and associated fissure lodes related to underlying granitoid complexes (see fig. 34 ).

GENERAL REFERENCE Patterson and others (1981).

\section{GEOLOGICAL ENVIRONMENT}

Rock Types Carbonate rocks (limestone or dolomite); granite, monzogranite, quartz porphyry dikes generally present; quartz-tourmaline rock; chert, pelitic and iron-rich sediments, and volcanic rocks may be present.

Textures Plutonic (equigranular, seriate, porphyritic).

Age Range Paleozoic and Mesozoic most common; other ages possible.

Depositional Environment Epizonal granitic complexes in terranes containing carbonate rocks. Note: the epigenetic replacement classification for these deposits has been questioned and an alternative exhalative synsedimentary origin followed by postdepositional metamorphic reworking hypothesis proposed (Hutchinson, 1979, 1982; PIimer, 1980; Lehmann and Schneider, 1981 ).

Tectonic Setting(s) Late orogenic to postorogenic passive emplacement of high-level granitoids in foldbelts containing carbonate rocks; alternatively, tin and associated metals were derived from submarine exhalative processes with subsequent reequilibration of sulfide and silicate minerals.

Associated Deposit Types Greisen-style mineralization, quartz-tourmaline-cassiterite veins, Sn-WMo stockworks, $\mathrm{Sn-W}$ skarn deposits close to intrusions.

DEPOSIT DESCRIPTION

Mineralogy Pyrrhotite + arsenopyrite + cassiterite + chalcopyrite (may be major) + ilmenite + fluorite; minor: pyrite, sphalerite, galena, stannite, tetrahdedrite, magnetite; late veins: sphalerite + galena + chalcopyrite + pyrite + fluorite.

Texture/Structure Vein stockwork ores, and massive ores with laminations following bedding in host rock, locally cut by stockwork veins, pyrrhotite may be recrystallized.

Alteration Greisenization ( $t$ cassiterite) near granite margins; sideritic alteration of dolomite near sulfide bodies; tourmalization of clastic sediments; proximity to intrusions may produce contact aureoles in host rocks.

Ore Controls Replacement of favorable carbonate units; fault-controlled fissure lodes common. Isolated replacement orebodies may lie above granitoid cupolas; faults provide channels for mineralizing fluids.

Geochemical Signature $\mathrm{Sn}, \mathrm{As}, \mathrm{Cu}, \mathrm{B}, \mathrm{W}, \mathrm{F}, \mathrm{Li}, \mathrm{Pb}, \mathrm{Zn}, \mathrm{Rb}$.

\section{EXAMPLES}

Renison Bell, AUTS

Cleveland, AUTS

Mt. Bischoff, AUTS

Changpo-Tongkeng, CINA
(Patterson and others, 1981)

(Collins, 1981)

(Groves and others, 1972)

(Liang and others, 1984) 
Model 14c--Con.

\section{GRADE AND TONNAGE MODEL OF REPLACEMENT Sn}

By W. David Menzie and Bruce L. Reed

COMMENTS This model is built with deposits from Tasmania. Deposits of this type also occur in the Dachang and Geijui ore fields of the Peoples Republic of China. Potential by-products from this type of deposit include zinc, lead, and copper. See figs. 37,38 .

DEPOSITS

Name

Cleveland

Mount Bischoff

Queen Hill

Razorback

Renison Bell

St. Dizier
Country

AUTS

AUTS

AUTS

AUTS

AUTS

AUTS 
Model $14 \mathrm{c}--$ Con.

TIN REPLACEMENT

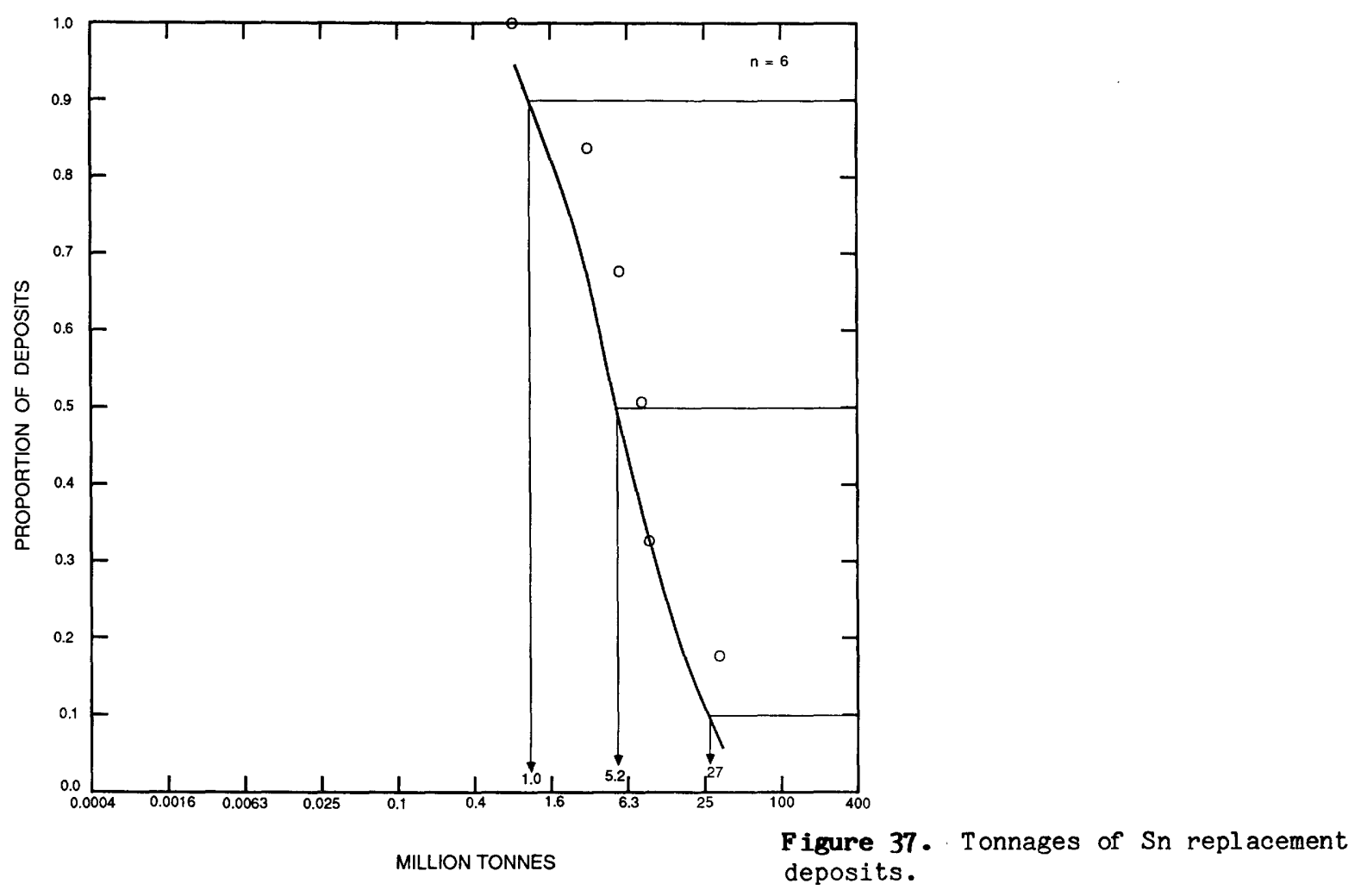

TIN REPLACEMENT

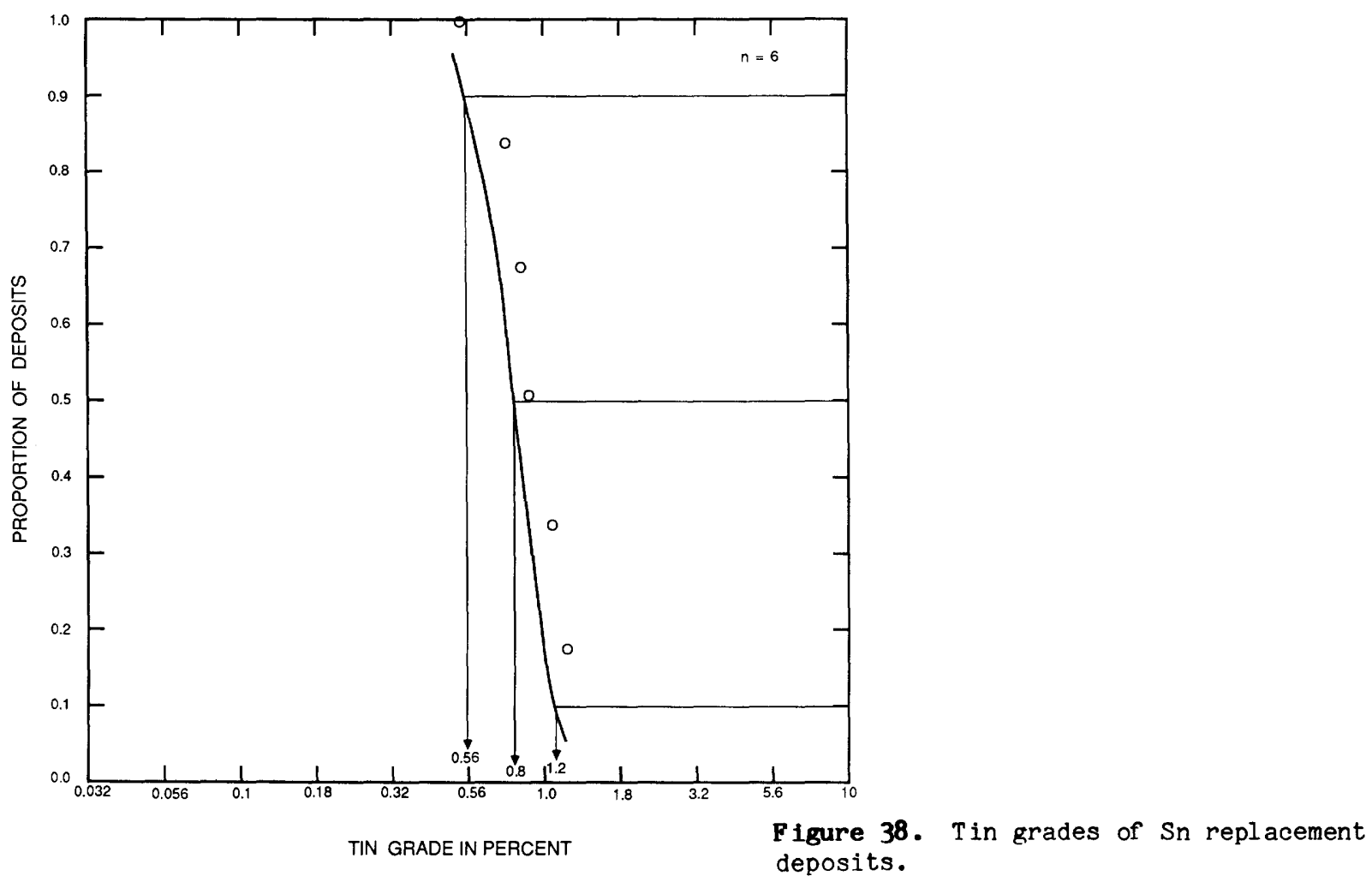


Model 15a

DESCRIPTIVE MODEL OF W VEINS

By Dennis P. Cox and William C. Bagby

APPROXIMATE SYNONYM Quartz-wolframite veins (Kelly and Rye, 1979).

DESCRIPTION Wolframite, molybdenite, and minor base-metal sulfides in quartz veins (see fig. 39). GEOLOGICAL ENVIRONMENT

Rock Types Monzogranite to granite stocks intruding sandstone, shale, and metamorphic equivalents.

Textures Phanerocrystalline igneous rocks, minor pegmatitic bodies, and porphyroaphanitic dikes.

Age Range Paleozoic to late Tertiary.

Depositional Environment Tensional fractures in epizonal granitic plutons and their wallrocks.

Tectonic Setting(s) Belts of granitic plutons derived from remelting of continental crust. Country rocks are metamorphosed to greenschist facies.

Associated Deposit Types Sn-W veins, pegmatites.

\section{DEPOSIT DESCRIPTION}

Mineralogy Wolframite, molybdenite, bismuthinite, pyrite, pyrrhotite, arsenopyrite, bornite, chalcopyrite, scheelite, cassiterite, beryl, fluorite; also at Pasto Bueno, tetrahedrite-

tennantite, sphalerite, galena, and minor enargite.

Texture/Structure Massive quartz veins with minor vugs, parallel walls, local breccia.

Alteration Deepest zones, pervasive albitization; higher pervasive to vein-selvage pink K-feldspar replacement with minor disseminated REE minerals; upper zones, vein selvages of dark-gray muscovite or zinnwaldite (greisen). Chloritization. Widespread tourmaline alteration at Isla de Pinos.

Ore Controls Swarms of parallel veins cutting granitic rocks or sedimentary rocks near igneous contacts.

Weathering Wolframite persists in soils and stream sediments. Stolzite and tungstite may be weathering products.

Geochemical Signature W, Mo, Sn, Bi, As, Cu, Pb, Zn, Be, F.

\section{EXAMPLES}

Pasto Bueno, PERU

Xihuashan, CINA

Isla de Pinos, CUBA

Hamme District, USNC

Round Mountain, USNV

Chicote Grande, BLVA
(Landis and Rye, 1974)

(Hsu, 1943; Giuliani, 1985; and

personal visit)

(Page and McAllister, 1944)

(Foose and others, 1980)

(Shawe and others, 1984)

(Personal visit) 


\section{GRADE AND TONNAGE MODEL OF $W$ VEINS}

By Gail M. Jones and W. David Menzie

COMMENTS Data are for vein systems rather than for individual veins or mines. Some data are based on past production only. Xihuashan is the sole deposit from the Peoples Republic of China. See figs. 40,41 .

\section{DEPOSITS}

Name

Country

GRBR

Carrock Fell

Chicote Grande

Grey River

Hamme District

Isla de Pinos

Josefina

Kami

Los Condores
BLVA

CNNF

USNC

CUBA

AGTN

BLVA

AGTN
Name

Montredon

Needle Hill

Oakleigh Creek

Panasqueria

Pasto Bueno

San Martin

Storeys Creek

Xihuashan
Country

FRNC

HONG

AUTS

PORT

PERU

AGTN

AUTS

CINA

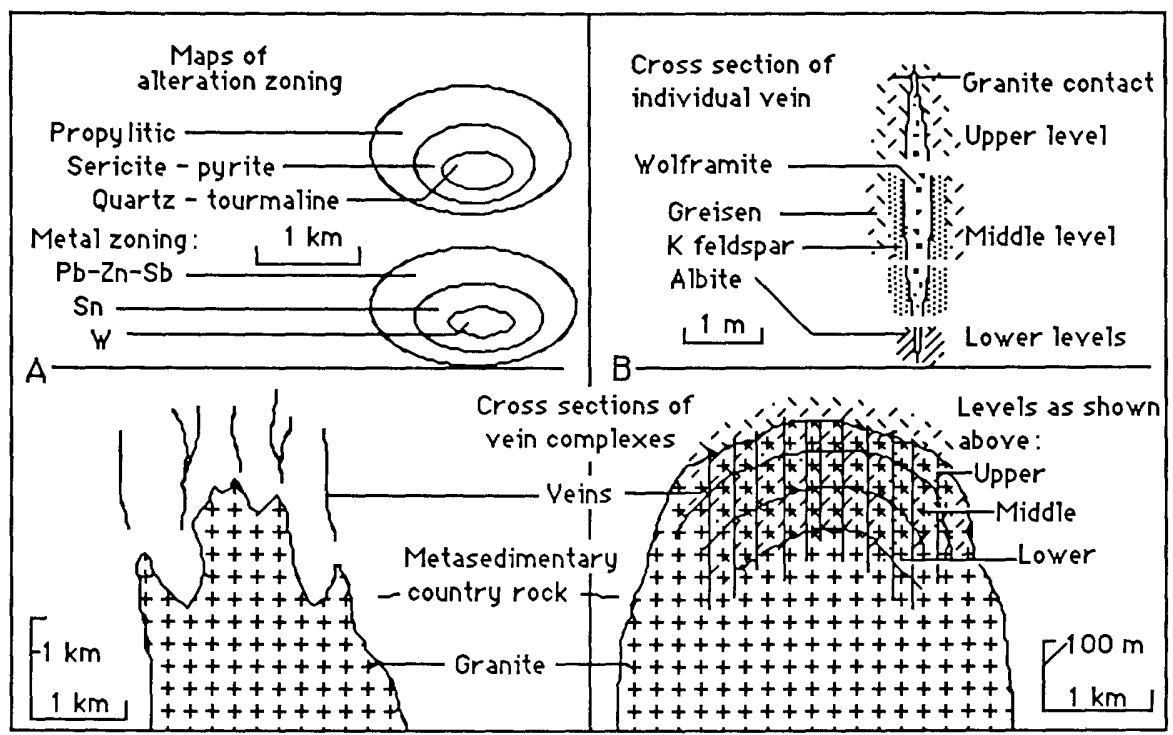

Figure 39. Maps and sections of $W$ vein deposits illustrating mineral and alteration zoning. A, Chicote Grande deposit, Bolivia. B, Xihuashan, China. 
Model 15a--Con.

Figure 40. Tonnages of $W$ vein deposits.
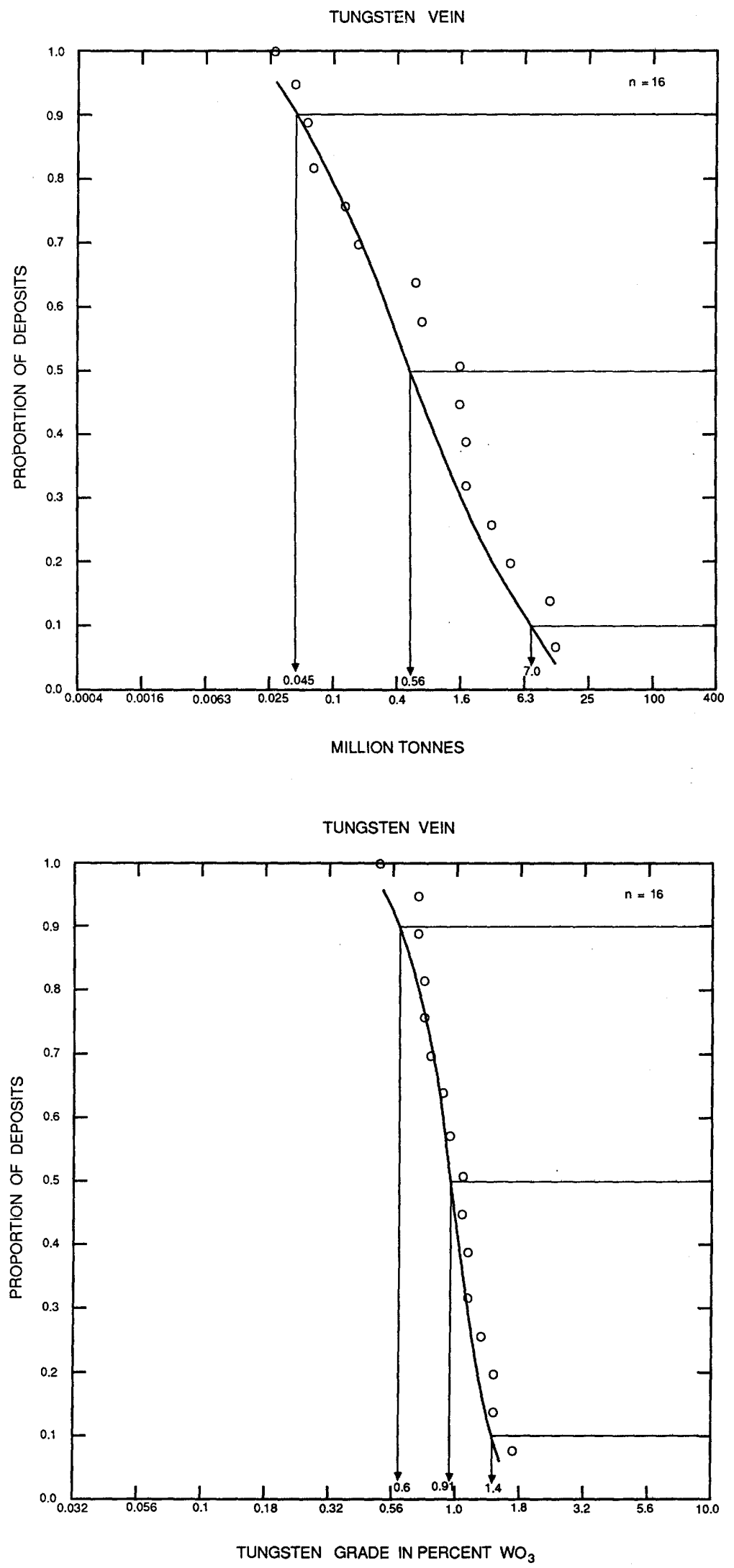

Figure 41. Tungsten grades of $W$ vein deposits. 


\section{DESCRIPTIVE MODEL OF Sn VEINS}

By Bruce L. Reed

APPROXIMATE SYNONYM Cornish type lodes.

DESCRIPTION Simple to complex quartz-cassiterite \pm wolframite and base-metal sulfide fissure fillings or replacement lodes in ore near felsic plutonic rocks (see fig. 34 ).

GENERAL REFERENCE Hosking (1974), Taylor (1979).

GEOLOGICAL ENVIRONMENT

Rock Types Close spatial relation to multiphase granitoids; specialized biotite and(or) muscovite leucogranite common; pelitic sediments generally present.

Textures Common plutonic textures.

Age Range Paleozoic and Mesozoic most common; may be any age.

Depositional Environment Mesozonal to hypabyssal plutons; extrusive rocks generally absent; dikes and dike swarms common.

Tectonic Setting(s) Foldbelts and accreted margins with late orogenic to postorogenic granitoids which may, in part, be anatectic; regional fractures common.

Associated Deposit Types Sn greisen, Sn skarn, and replacement Sn deposits.

DEPOSIT DESCRIPTION

Mineralogy Extremely varied; cassiterite \pm wolframite, arsenopyrite, molybdenite, hematite, scheelite, beryl, galena, chalcopyrite, sphalerite, stannite, bismuthinite; although variations and overlaps are ubiquitous, many deposits show an inner zone of cassiterite \pm wolframite fringed with $\mathrm{Pb}, \mathrm{Zn}, \mathrm{Cu}$, and $\mathrm{Ag}$ sulfide minerals.

Texture/Structure Variable; brecciated bands, filled fissures, replacement, open cavities.

Alteration Sericitization (greisen development) \pm tourmalization common adjacent to veins and granite contacts; silicification, chloritization, hematization. An idealized zonal relation might consist of quartz-tourmaline-topaz, quartz-tourmaline-sericite, quartz-sericite-chlorite, quartzchlorite, chlorite.

Ore Controls Economic concentrations of tin tend to occur within or above the apices of granitic cusps and ridges; localized controls include variations in vein structure, lithologic and structural changes, vein intersections, dikes, and cross-faults.

Weathering Cassiterite in stream gravels, placer tin deposits.

Geochemical Signature Sn, As, W, B are good pathfinder elements; elements characteristic of specialized granites (F, Rb, Be, Nb, Cs, U, Mo, REE, see model 14b).

EXAMPLES
Cornwall, GRBR
(Hosking, 1969)

Herberton, AUQL

(Blake, 1972)

GRADE AND TONNAGE MODEL OF Sn VEINS

By W. David Menzie and Bruce L. Reed

COMMENTS The grade-tonnage model for this deposit type is built with data from 43 deposits, or in some cases, districts. The imprecise definition of what constitutes a deposit has arisen here because many lodes were mined by a number of operators during the second half of the nineteenth century. Data for most deposits and districts consist of past production, although for some 
Model 15b--Con.

deposits, especially those still operating, reserves are included. of the 43 deposits in the model, 27 are from Australia. These include most of the small tonnage deposits. This is thought to be an artifact of data reporting. For example, if data were available for many of the small deposits in Cornwall, the deposits would undoubtedly fall within the low tonnage part of the curve. See figs. $42,43$.

\section{DEPOSITS}

Name

Aberfoyle

Adventure Creek

Bakerville

Basset

Bloodwood Creek

Brownsville

Carn Brea-Tincroft

Carocoles

Conrad Lodes

Coolgarra Dist.

Dargo Range Dist.

Dulcoath

Emu Creek

Emu Dist.

Geevor

Gleneindale Dist.

Grenville

Gundie

Gurrumba Dist.

Hales Siding

Herberton

Irvine Bank

Country
AUTS
AUQL
AUQL
GRBR
AUQL
AUQL
GRBR
BLVA
AUNW
AUQL
AUQL
GRBR
AUQL
AUQL
GRBR
AUQL
GRBR
AUNW
AUQL
AUQL
AUQL
AUQL

Name

Kelapa Kampit

Killifreth

Krupka

Levant

Maranboy

Mawchi

Mount Nolan Dist.

Mount Paynter

Mount Wellington

Mowbray Creek

Nount Wells

Nymbool Dist.

Ottery Lode

Pahang

Royal George

Silver Valley

South Crofty

Stannary Hills

Watsonville

Wheal Jane

Wheal Kitty-Penhalls
Country

INDO

GRBR

CZCL

GRBR

AUNT

BRMA

AUQL

AUNS

GRBR

AUQL

AUNS

AUQL

AUNS

MLYS

AUTS

AUQL

GRBR

AUQL

AUQL

GRBR

GRGB 
Model 15b--Con.

TIN VEIN
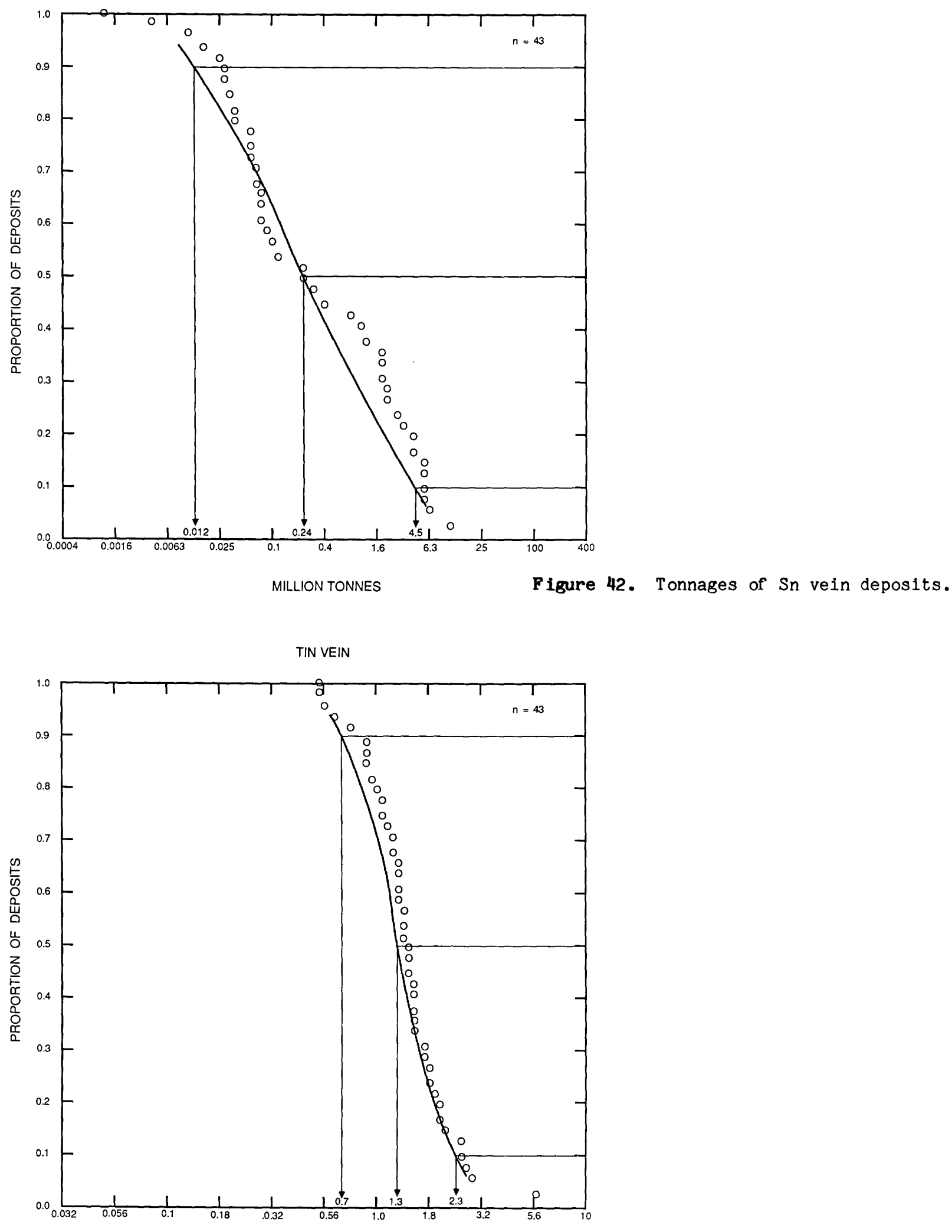

TIN GRADE IN PERCENT

Figure 43. Tin grades of $S n$ vein deposits. 
Model 15c

\section{DESCRIPTIVE MODEL OF Sn GREISEN DEPOSITS}

By Bruce L. Reed

DESCRIPTION Disseminated cassiterite, and cassiterite-bearing veinlets, stockworks, lenses, pipes, and breccia in greisenized granite (see fig. 44).

GENERAL REFERENCE Scherba (1970), Taylor (1979), Reed (1982), Tischendorf (1977).

GEOLOGICAL ENVIRONMENT

Rock Types Specialized biotite and(or) muscovite leucogranite (S-type); distinctive accessory minerals include topaz, fluorite, tourmaline, and beryl. Tin greisens are generally post-magmatic and associated with late fractionated melt.

Textures Common plutonic rock textures, miarolitic cavities may be common; generally nonfoliated; equigranular textures may be more evolved (Hudson and Arth, 1983); aplitic and porphyritic textures common.

Age Range May be any age; tin mineralization temporally related to later stages of granitoid emplacement.

Depositional Environment Mesozonal plutonic to deep volcanic environment.

Tectonic Setting(s) Foldbelts of thick sediments \pm volcanic rocks deposited on stable cratonic shield; accreted margins; granitoids generally postdate major folding.

Associated Deposit Types Quartz-cassiterite sulfide lodes, quartz-cassiterite \pm molybdenite stockworks, late complex tin-silver-sulfide veins.

\section{DEPOSIT DESCRIPTION}

Mineralogy General zonal development of cassiterite + molybdenite, cassiterite + molybdenite + arsenopyrite + beryl, wolframite + beryl + arsenopyrite + bismuthinite, Cu-Pb-Zn sulfide minerals + sulphostannates, quartz veins \pm fluorite, calcite, pyrite.

Texture/Structure Exceedingly varied, the most common being disseminated cassiterite in massive greisen, and quartz veinlets and stockworks (in cupolas or in overlying wallrocks); less common are pipes, lenses, and tectonic breccia.

Alteration Incipient greisen (granite): muscovite \pm chlorite, tourmaline, and fluorite. Greisenized granite: quartz-muscovite-topaz-fluorite, \pm tourmaline (original texture of granites retained). Massive greisen: quartz-muscovite-topaz \pm fluorite \pm tourmaline (typically no original texture preserved). Tourmaline can be ubiquitous as disseminations, concentrated or diffuse clots, or late fracture fillings. Greisen may form in any wallrock environment, typical assemblages developed in aluminosilicates.

Ore Controls Greisen lodes located in or near cupolas and ridges developed on the roof or along margins of granitoids; faults and fractures may be important ore controls.

Weathering Granite may be "reddened" close to greisen veins. Although massive greisen may not be economic as lodes, rich placer deposits form by weathering and erosion.

Geochemical Signature Cassiterite, topaz, and tourmaline in streams that drain exposed tin-rich greisens. Specialized granites may have high contents of SiO ( $>73$ percent) and $\mathrm{K}_{2} \mathrm{O}$ ( $>4$ percent), and are depleted in $\mathrm{CaO}, \mathrm{TiO}_{2}, \overline{\mathrm{MgO}}$, and total $\mathrm{FeO}$. They are enriched in $\mathrm{Sn}, \mathrm{F}, \mathrm{Rb}, \mathrm{Li}, \mathrm{Be}, \mathrm{W}, \mathrm{Mo}$, $\mathrm{Pb}, \mathrm{B}, \mathrm{Nb}, \mathrm{Cs}, \mathrm{U}, \mathrm{Th}, \mathrm{Hf}, \mathrm{Ta}$, and most REE, and impoverished in $\mathrm{Ni}, \mathrm{Cu}, \mathrm{Cr}, \mathrm{Co}, \mathrm{V}, \mathrm{Sc}, \mathrm{Sr}, \mathrm{La}, \mathrm{and}$ $\mathrm{Ba}$.

\section{EXAMPLES}

Lost River, USAK

Anchor Mine, AUTS

Erzgebirge, CZCL
(Dobson, 1982; Sainsbury, 1964)

(Groves and Taylor, 1973)

(Janecka and Stemprok, 1967) 


\section{GRADE AND TONNAGE MODEL OF Sn GREISEN DEPOSITS}

By W. David Menzie and Bruce L. Reed

COMMENTS See figs. $45,46$.

DEPOSITS

Name

Altenberg

Country

Name

Country

Anchor

Archer

GRME

Coal Creek

USAK

AUTS

AUTS

Cinovec

CZCL

E. Kempville

CNNS

Hub

CZCL

Potosi

BRZL

Cista

CZCL

Prebuz

CZCL

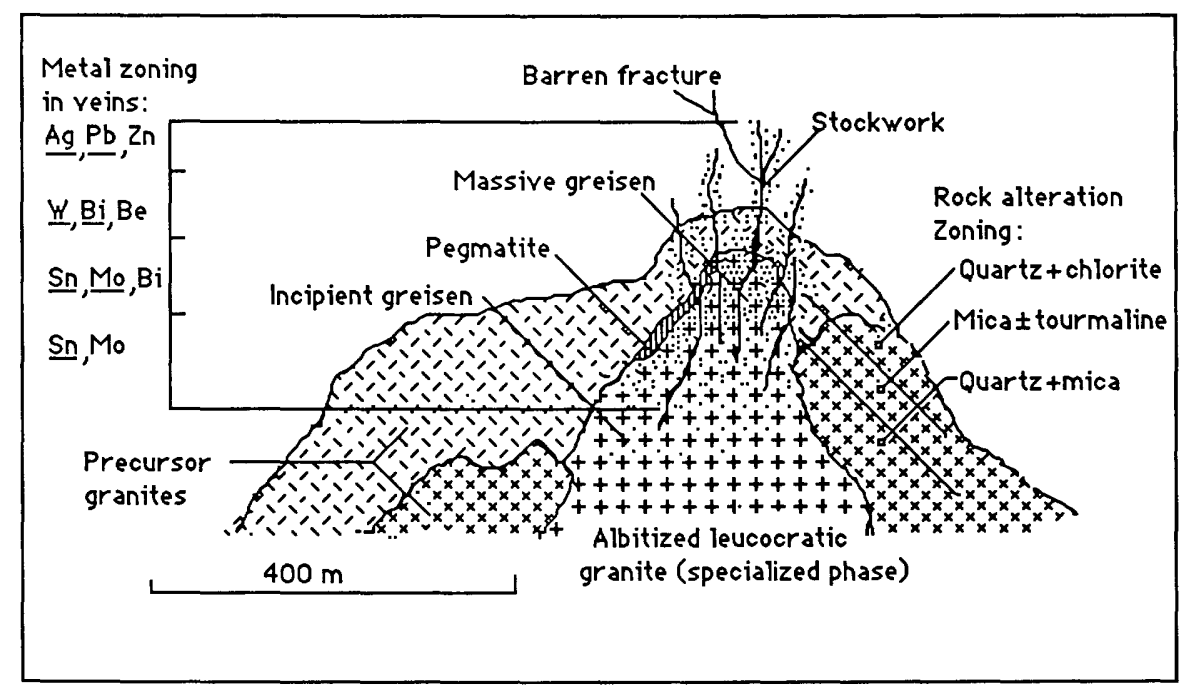

Figure 44. Cartoon cross section of a Sn greisen. 
Model 15c--Con.

Figure 45. Tonnages of Sn greisen deposits.
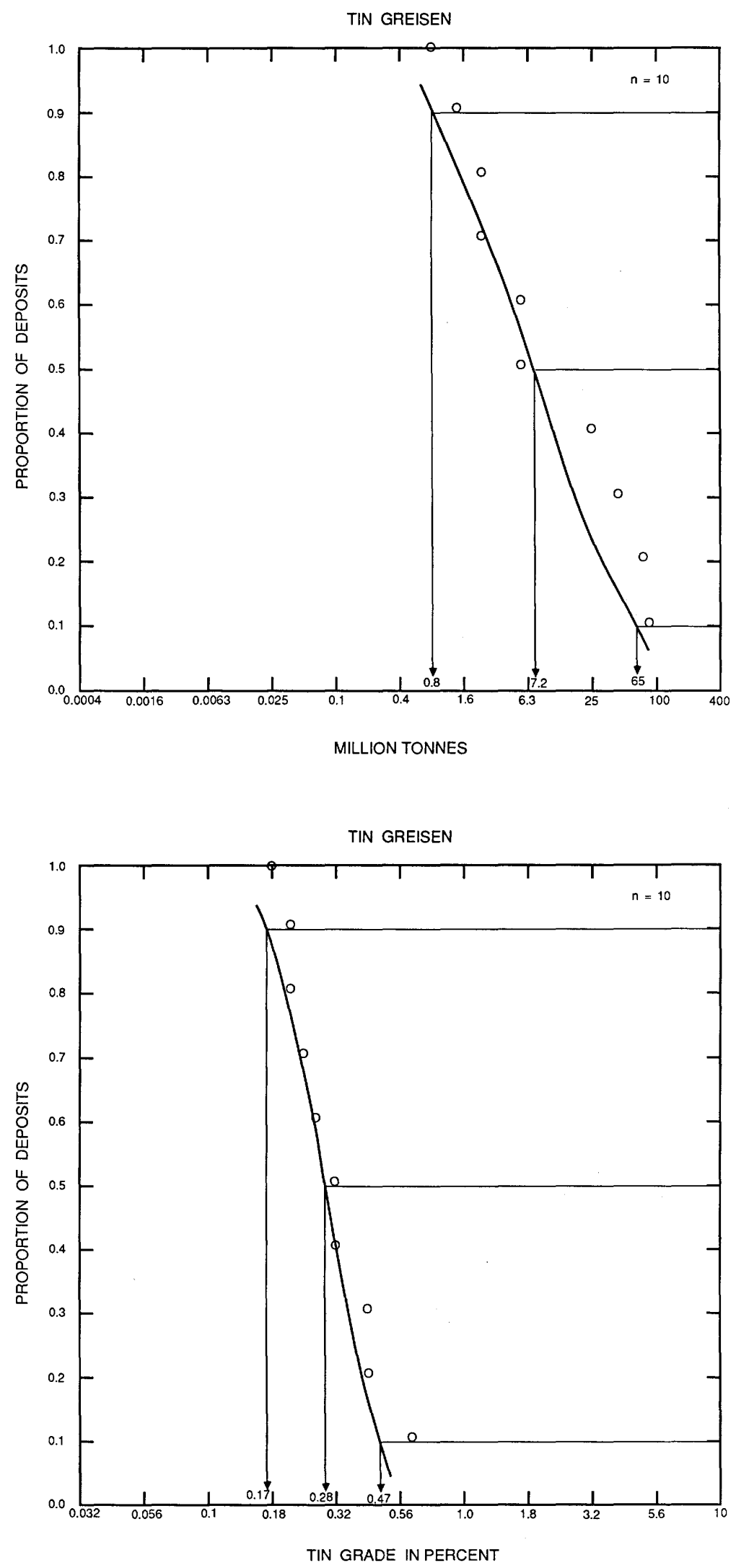

Figure 46. Tin grades of $\mathrm{Sn}$ greisen deposits. 
DESCRIPTIVE MODEL OF CLIMAX MO DEPOSITS

By Stephen D. Ludington

APPROXIMATE SYNONYM Granite molybdenite (Mutschler and others, 1981).

DESCRIPTION Stockwork of quartz and molybdenite associated with fluorite in

granite porphyry (see fig. 47).

GENERAL REFERENCE White and others (1981).

GEOLOGICAL ENVIRONMENT

Rock Types Granite-rhyolite with $>75$ percent $\mathrm{SiO}_{2}$. $\mathrm{Rb}, \mathrm{Y}, \mathrm{Nb}$ are high, $\mathrm{Ba}, \mathrm{Sr}, \mathrm{Zr}$ low. Stocks with radial dikes; small breccias common.

Textures Porphyry with fine- to medium-grained aplitic groundmass.

Age Range Examples are mainly mid-Tertiary.

Depositional Environment Multistage hypabyssal intrusions.

Tectonic Setting(s) Mainly extensional zones in cratons. May be related to subduction, but found far from continental margins in areas of thick crust, and late in the cycles.

Associated Deposit Types Ag-base-metal veins, fluorspar deposits. On the basis of similar geochemistry of associated rhyolite magmas, rhyolite-hosted Sn deposits may be a surface expression. Porphyry tungsten deposits, as at Mount Pleasant, Canada, may be W-rich Climax systems.

\section{DEPOSIT DESCRIPTION}

Mineralogy: Molybdenite + quartz \pm fluorite \pm K-feldspar \pm pyrite \pm wolframite \pm cassiterite \pm topaz.

Texture/Structure Predominantly in veinlets and fractures; minor disseminations.

Alteration Intense quartz and quartz + K-feldspar veining in ore zone. Upper phyllic and propylitic zones. Halo of rhodochrosite, rhodonite, spessartine garnet. Minor greisen veins below ore body.

Ore Controls Stockwork ore zone draped over small, $<1 \mathrm{~km}^{2}$ stocks. Multiple phases of intrusion and mineralization are highly favorable.

Weathering Yellow ferrimolybdite stains.

Geochemical Signature Mo, $\mathrm{Sn}, \mathrm{W}$ and $\mathrm{Rb}$ anomalies close above ore zones. $\mathrm{Pb}, \mathrm{Zn}, \mathrm{F}$, and $\mathrm{U}$ anomalies in wall rocks up to a few kilometers distant. $\mathrm{Cu}$ anomaly external to Mount Emmons deposit. In panned concentrates, $\mathrm{Sn}, \mathrm{W}, \mathrm{Mo}$, and $\mathrm{F}$ may be important.

EXAMPLES

Redwell Basin, Winfield, Middle Mtn.

Climax, Henderson,

and Mt. Emmons, USCO (White and others, 1981)

Pine Grove, USUT (Abbott and Williams, 1981)

Mount Hope, USNV (Westra, 1982b)

Big Ben, USMT (Witkind, 1973)

GRADE AND TONNAGE MODEL OF CLIMAX Mo DEPOSITS

By Donald A. Singer, Ted G. Theodore, and Dan L. Mosier

COMMENTS See figs. $48,49$. 
Model 16--Con.

DEPOSITS

Name

Country

Name

Country

Big Ben

Climax

USMT

USCO

USCO

GRLD

Malmbjerg

USCO

Mount Hope

USNV

Pine Grove

USUT

Questa-Goat Hill USNM

Mount Emmons

USCO

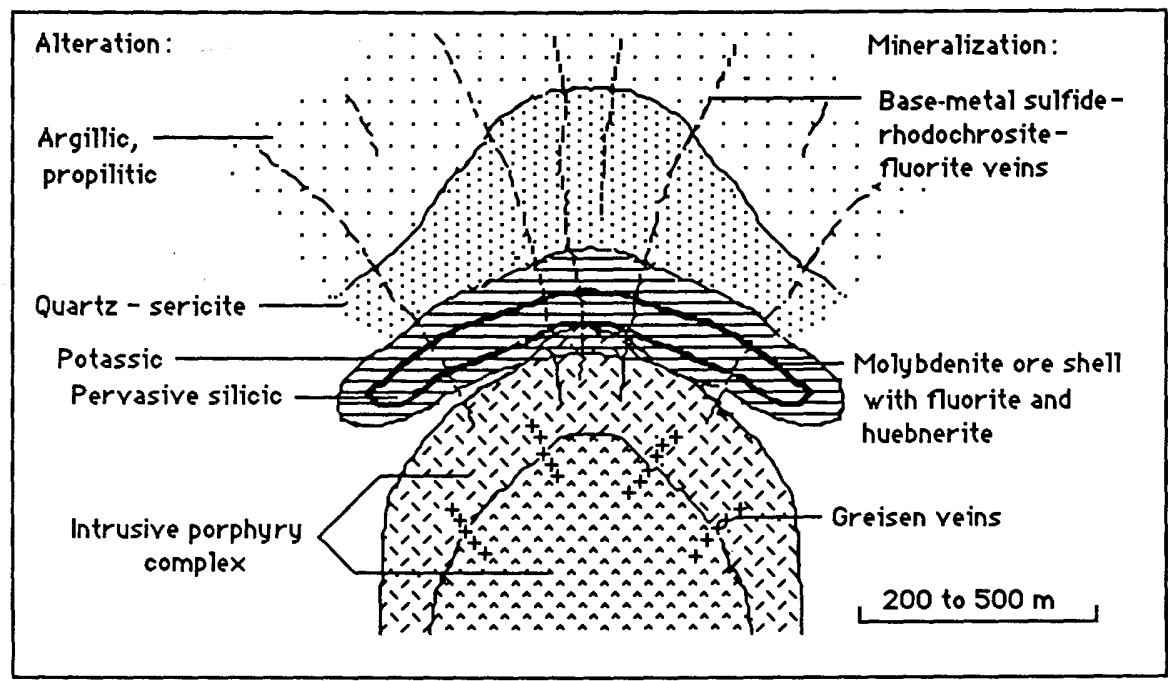

Figure 47. Cartoon cross section of $\mathrm{Cl}$ imax Mo deposit showing relationship of ore and alteration zoning to porphyry intrusions from Mutschler and others (1981). Cartoon represents a region about $1 \mathrm{~km}$ wide. 
Model 16--Con.

MOLYBDENUM PORPHYRY--CLIMAX
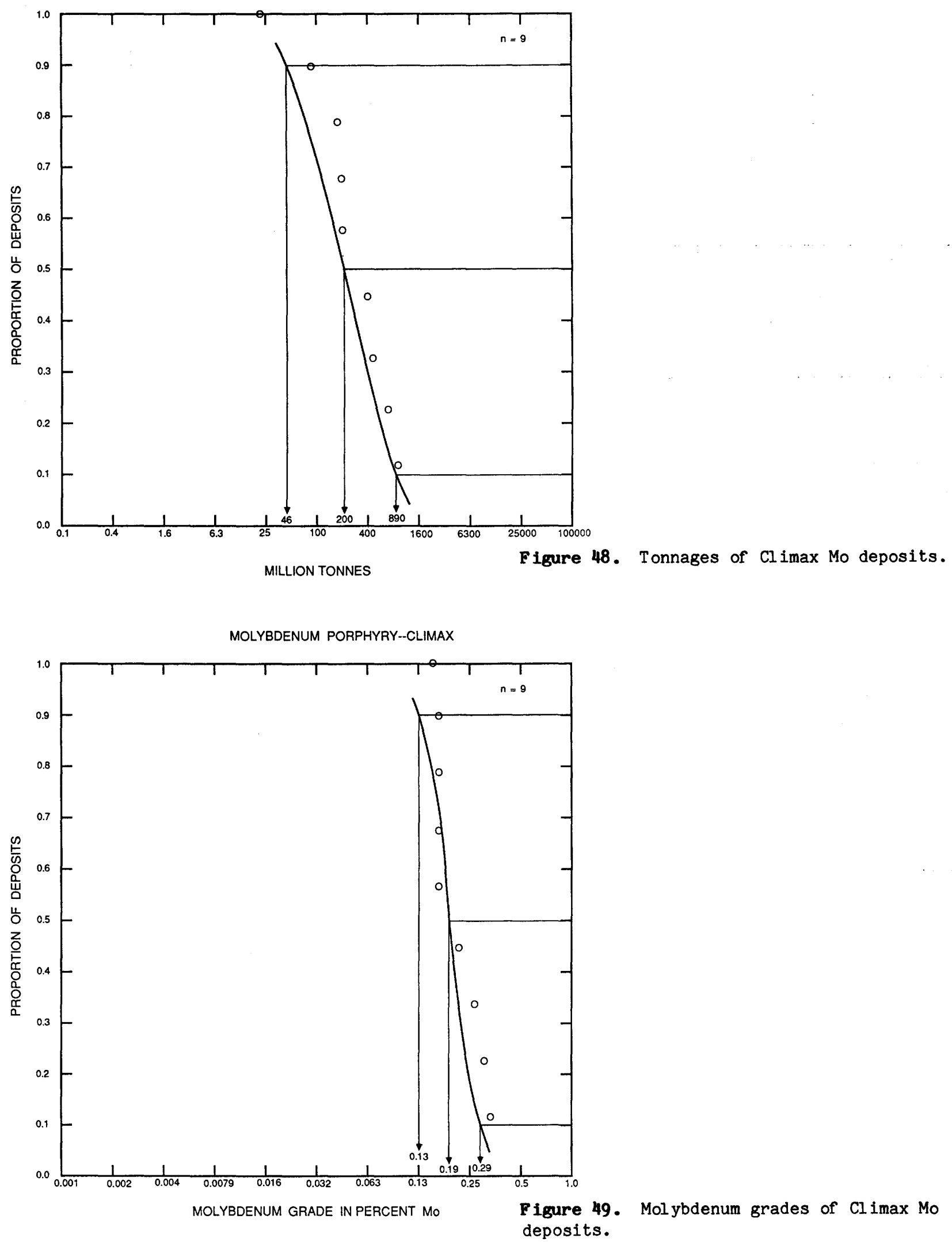
Model 17

\section{DESCRIPTIVE MODEL OF PORPHYRY CU}

By Dennis P. Cox

DESCRIPTION This generalized model includes various subtypes all of which contain chalcopyrite in stockwork veinlets in hydrothermally altered porphry and adjacent country rock (see fig. 50).

GENERAL REFERENCE Titley (1982).

GEOLOGICAL ENVIRONMENT

Rock Types Tonalite to monzogranite or syenitic porphyry intruding granitic, volcanic, calcareous sedimentary, and other rocks.

Textures Porphyry has closely spaced phenocrysts and microaplitic quartz-feldspar groundmass.

Age Range Mainly Mesozoic and Cenozoic, but may be any age.

Depositional Environment High-level intrusive rocks contemporaneous with abundant dikes, breccia pipes, faults. Also cupolas of batholiths.

Tectonic Setting(s) Rift zones contemporaneous with Andean or island-arc volcanism along convergent plate boundaries. Uplift and erosion to expose subvolcanic rocks.

Associated Deposit Types Base-metal skarn, epithermal veins, polymetallic replacement, volcanic hosted massive replacement. See also: Porphyry Cu-skarn related, porphyry Cu-Mo, and porphyry CuAu.

\section{DEPOSIT DESCRIPTION}

Mineralogy: Chalcopyrite + pyrite \pm molybdenite; chalcopyrite + magnetite \pm bornite \pm Au; assemblages may be superposed. Quartz + K-feldspar + biotite \pm anhydrite; quartz + sericite + clay minerals. Late veins of enargite, tetrahedrite, galena, sphalèrite, and barite in some deposits.

Texture/Structure Stockwork veinlets and disseminated sulfide grains.

Alteration From bottom, innermost zones outward: sodic-calcic, potassic, phyllic, and argillic to propylitic. High-alumina alteration in upper part of some deposits. See table 3 . Propylitic or phyllic alteration may overprint early potassic assemblage.

Ore Controls Stockwork veins in porphyry, along porphyry contact, and in favorable country rocks such as carbonate rocks, mafic igneous rocks, and older granitic plutons.

Weathering Green and blue $\mathrm{Cu}$ carbonates and silicates in weathered outcrops, or where leaching is intense, barren outcrops remain after $\mathrm{Cu}$ is leached, transported downward, and deposited as secondary sulfides at water table or paleowater table. Fractures in leached outcrops are coated with hematitic limonite having bright red streak. Deposits of secondary sulfides contain chalcocite and other $\mathrm{Cu}_{2} \mathrm{~S}$ minerals replacing pyrite and chalcopyrite. Residual soils overlying deposits may contain anomalous amounts of rutile.

Geochemical Signature: $\mathrm{Cu}+\mathrm{Mo}+\mathrm{Au}+\mathrm{Ag}+\mathrm{W}+\mathrm{B}+\mathrm{Sr}$ center, $\mathrm{Pb}, \mathrm{Zn}, \mathrm{Au}, \mathrm{As}, \mathrm{Sb}, \mathrm{Se}, \mathrm{Te}, \mathrm{Mn}, \mathrm{Co}$,

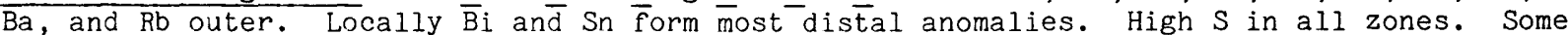
deposits have weak $U$ anomalies.

\section{EXAMPLES}

Bingham, USUT

San Manuel, USAZ

El Salvador, CILE
(Lanier and others, 1978)

(Lowell and Guilbert, 1970)

(Gustafson and Hunt, 1975) 


\title{
GRADE AND TONNAGE MODEL OF PORPHYRY Cu
}

By Donald A. Singer, Dan L. Mosier, and Dennis P. Cox

\begin{abstract}
COMMENTS All porphyry copper deposits with available grades and tonnages were included in these plots in order to provide a model for cases where it is not possible to use the gold-rich or molybdenum-rich models. Parts of the porphyry copper deposits which could be considered skarn were included in these data. Gold grade is correlated with tonnage $(r=-0.49, n=81)$ and with molybdenum grade $(r=-0.45, n=55)$. See figs. 51-53.
\end{abstract}

\section{DEPOSITS}

\begin{tabular}{|c|c|c|c|}
\hline Name & Country & Name & Country \\
\hline Afton & CNBC & Copper Cities & USAZ \\
\hline Ajax & CNBC & Copper Creek & USAZ \\
\hline Ajo & USAZ & Copper Flat & USNM \\
\hline $\mathrm{Am}$ & CNBC & Copper Mountain & CNBC \\
\hline Amacan & PLPN & Cordon & PLPN \\
\hline Andacolla & CILE & Cuajone & PERU \\
\hline Ann & CNBC & Cubuagan & PLPN \\
\hline Ann Mason & USNV & Dexing & CINA \\
\hline Arie & PPNG & Dizon & PLPN \\
\hline Atlas Carmen & PLPN & Dorothy & CNBC \\
\hline Atlas Frank & PLPN & Dos Pobres & USAZ \\
\hline Atlas Lutopan & PLPN & Eagle & $\mathrm{CNBC}$ \\
\hline Axe & CNBC & El Abra & CILE \\
\hline Aya Aya & PLPN & El Arco & $\mathrm{MXCO}$ \\
\hline Bagdad & USAZ & El Pachon & AGTN \\
\hline Basay & PLPN & El Salvador & CILE \\
\hline Bear & USNV & El Soldado & CILE \\
\hline Bell Copper & $\mathrm{CNBC}$ & E1 Teniente & CILE \\
\hline Berg & CNBC & Elatsite & BULG \\
\hline Bethlehem & CNBC & Ely & USNV \\
\hline Big Onion & $\mathrm{CNBC}$ & Escondida & CILE \\
\hline Bingham & USUT & Esperanza & CILE \\
\hline Bisbee & USAZ & Exotica & CILE \\
\hline Bluebird & USAZ & Fish Lake & $\mathrm{CNBC}$ \\
\hline Bond Creek & USAK & Florence & USAZ \\
\hline Boneng Lobo & PLPN & Frieda River & PPNG \\
\hline Bozshchaku & URRS & Galaxy & CNBC \\
\hline Brenda & $\mathrm{CNBC}$ & Galore Creek & $\mathrm{CNBC}$ \\
\hline Brenmac & USWA & Gambier Island & $\mathrm{CNBC}$ \\
\hline Butilad & PLPN & Gaspe & $\mathrm{CNQU}$ \\
\hline Butte & USMT & Gibraltar & $\mathrm{CNBC}$ \\
\hline Campanamah & AGTN & Glacier Peak & USWA \\
\hline Cananea & $\mathrm{MXCO}$ & Granisle & CNBC \\
\hline Canariaco & PERU & Hale-Mayabo & PLPN \\
\hline Cariboo Bell & $\mathrm{CNBC}$ & Heddleston & USMT \\
\hline Carpenter & USAZ & Helvetia & USAZ \\
\hline Cash & CNYT & Highmont & $\mathrm{CNBC}$ \\
\hline Casino & CNYT & Hinobaan & PLPN \\
\hline Castle Dome & USAZ & Huckleberry & CNBC \\
\hline Catface & CNBC & Ingerbelle & CNBC \\
\hline Catheart & USMN & Inguaran & $\mathrm{MXCO}$ \\
\hline Cerro Blanco & CILE & Ino-Capaya & PLPN \\
\hline Cerro Colorado & CILE & Inspiration & USAZ \\
\hline Cerro Colorado & PANA & Iron Mask & CNBC \\
\hline Cerro Verde & PERU & Island Copper & $\mathrm{CNBC}$ \\
\hline Chaucha & ECDR & Ithaca Peak & USAZ \\
\hline Chuquicamata & CILE & June & $\mathrm{CNBC}$ \\
\hline Coalstoun & AUQL & Kadzharan & URAM \\
\hline Copper Basin & USAZ & Kalamaton & PLPN \\
\hline
\end{tabular}


Model 17--Con.

\begin{tabular}{|c|c|}
\hline Kalamazoo-San Manuel & USAZ \\
\hline Kalmakyr & URUZ \\
\hline Kennon & PLPN \\
\hline King-King & PLPN \\
\hline Kirwin & USWY \\
\hline Kounrad & URKZ \\
\hline Krain & $\mathrm{CNBC}$ \\
\hline Kwanika & CNBC \\
\hline La Alumbrera & AGTN \\
\hline La Caridad & MXCO \\
\hline La Florida & $\mathrm{MXCO}$ \\
\hline La Verde & $\mathrm{MXCO}$ \\
\hline Lakeshore & USAZ \\
\hline Lights Creek & USCA \\
\hline Lornex & CNBC \\
\hline Lorraine & CNBC \\
\hline Los Bronces & CILE \\
\hline Los Pelambres & CILE \\
\hline Los Pilares & $\mathrm{MXCO}$ \\
\hline Lumbay & PLPN \\
\hline Luna-Bash & PLPN \\
\hline MacArthur & USNV \\
\hline Maggie & CNBC \\
\hline Majdanpek & YUGO \\
\hline Mamut & MDGS \\
\hline Mantos Blancos & CILE \\
\hline Mapula & PLPN \\
\hline Marcopper & PLPN \\
\hline Margaret & USWA \\
\hline Marian & PLPN \\
\hline Mazama & USWA \\
\hline Metcalf & USAZ \\
\hline Michiquillay & PERU \\
\hline Middle Fork & USWA \\
\hline Mineral Butte & USAZ \\
\hline Misty & CNBC \\
\hline Mocha & CILE \\
\hline Mocoa & CLBA \\
\hline Moniwa & BRMA \\
\hline Morenci & USAZ \\
\hline Morococha & PERU \\
\hline Morrison & CNBC \\
\hline Mountain Mines & PLPN \\
\hline Mount Canninda & AUQL \\
\hline Namosi East & FIJI \\
\hline Namosi West & FIJI \\
\hline North Fork & USWA \\
\hline Ok & CNBC \\
\hline Ok Tedi & PPNG \\
\hline Orange Hill & USAK \\
\hline Pampa Norte & CILE \\
\hline Panguna & PPNG \\
\hline Paramillos & AGTN \\
\hline Parks & AUNS \\
\hline Pashpap & PERU \\
\hline
\end{tabular}

$\begin{array}{ll}\text { Petaquilla } & \text { PANA } \\ \text { Philippine } & \text { PLPN } \\ \text { Pima-Mission } & \text { USAZ } \\ \text { Plurhinaler } & \text { THLD } \\ \text { Poison Mountain } & \text { CNBC } \\ \text { Potrerillos } & \text { CILE } \\ \text { Primer } & \text { CNBC } \\ \text { Quebrada Blanca } & \text { CILE } \\ \text { Quelleveco } & \text { PERU }\end{array}$

Ray USAZ

Recsk HUNG

Red Chris CNBC

Red Mountain USAZ

Rio Blanco CILE

Rio Vivi PTRC

Sacaton (E-W) USAZ

Safford (KCC) USAZ

Saindak East PKTN

Saindak North PKTN

Saindak South PKTN

Samar PLPN

San Antonio PLPN

San Fabian $\quad$ PLPN

San Juan USAZ

San Xavier USAZ

Sanchez USAZ

Santa Rita USNM

Santo Nino PLPN

Santo Tomas MXCO

Santo Tomas PLPN

Sar Cheshmeh IRAN

Schaft Creek CNBC

Sierra Gorda CILE

Silver Bell USAZ

Sipalay PLPN

Star Mt.-Fubilan PPNG

Star Mt.-Futik PPNG

Star Mt.-Nong River PPNG

Star Mt.-Olgal PPNG

Sugarloaf Hill CNBC

Tagpura PLPN

Tanama PTRC

Tawi-Tawi PLPN

Taysan PLPN

Toledo PLPN

Toquepala PERU

Trojan CNBC

Twin Buttes USAZ

Tyrone USNM

Valley Copper CNBC

Vekol USAZ

Washington MXCO

Yandera PPNG

Yeoval AUNS

Yerington USNV 


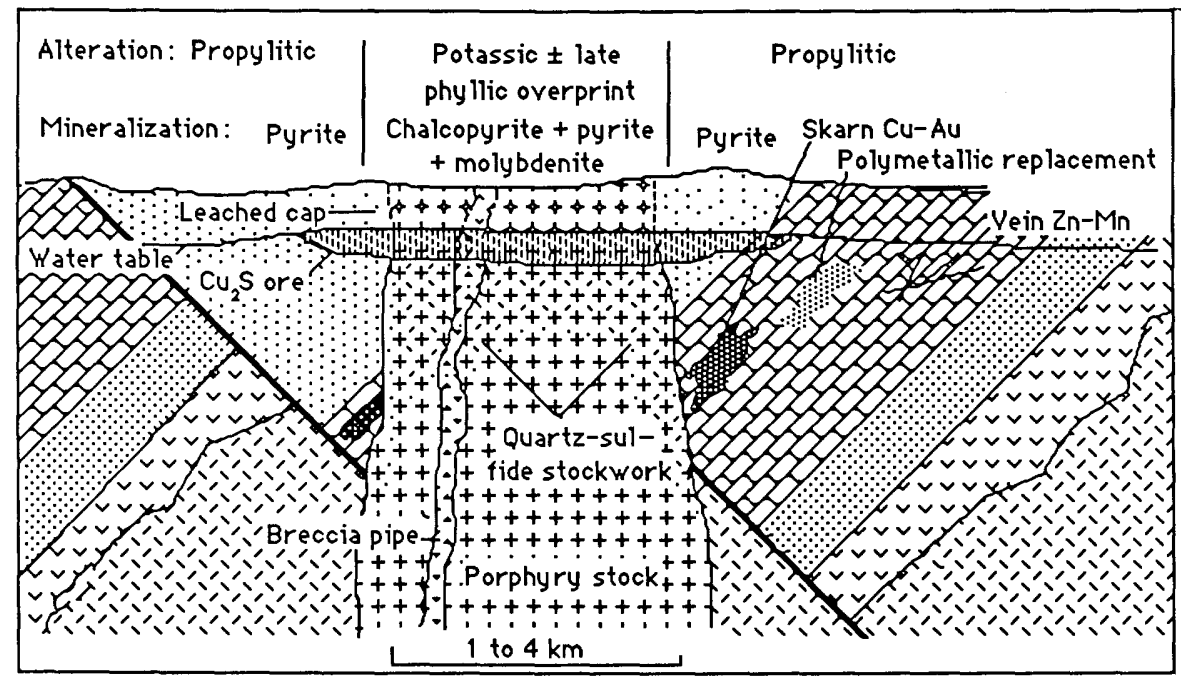

Figure 50. Cartoon cross section illustrating generalized model for porphyry $\mathrm{Cu}$ deposits showing relation of ore minerals, alteration zoning, supergene enrichment and associated skarn, replacement, and vein deposits.

Table 3. Types of hydrothermal alteration characteristic of porphyry copper and other deposit models

\begin{tabular}{|c|c|c|}
\hline $\begin{array}{l}\text { Type of alteration } \\
\text { and synonyms }\end{array}$ & Original mineral & Appearance \\
\hline $\begin{array}{l}\text { Potassic } \\
\text { alteration } \\
\text { (K-silicate) }\end{array}$ & $\begin{array}{ll}\text { plagioclase--.-- } & \text { K-feldspar } \\
\text { hornblende--.-- } & \text { fine-grained } \\
& \text { biotite }+ \\
& \text { rutile }+ \text { pyrite } \\
& \text { or magnetite. } \\
& \text { Anhydrite }\end{array}$ & $\begin{array}{l}\text { Rocks look fresh } \\
\text { but may have pinkish } \\
\text { K-feldspar veinlets. } \\
\text { and black biotite } \\
\text { veinlets and clusters } \\
\text { of fine biotite after } \\
\text { mafic phenocrysts. }\end{array}$ \\
\hline $\begin{array}{l}\text { Sodic-calcic } \\
\text { alteration } \\
\text { (albitic) }\end{array}$ & $\begin{array}{c}\text { K-feldspar------ oligoclase or } \\
\text { albite } \\
\text { biotite--1-0-- actinolite } \\
\text { sphene }\end{array}$ & $\begin{array}{l}\text { Rocks are hard and } \\
\text { dull white. Biotite } \\
\text { is absent. Veinlets of } \\
\text { actinolite, epidote, and } \\
\text { hematite have hard, } \\
\text { white alteration haloes. }\end{array}$ \\
\hline $\begin{array}{l}\text { Phyllic } \\
\text { alteration } \\
\text { (quartz-sericite) }\end{array}$ & 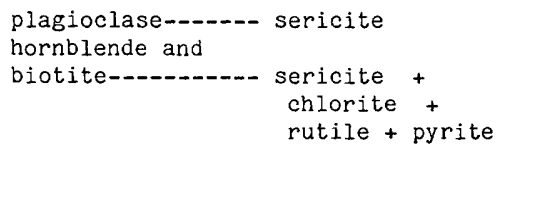 & $\begin{array}{l}\text { Rocks are soft and } \\
\text { dull to lustrous white. } \\
\text { Pyrite veinlets have } \\
\text { distinct, soft translucent } \\
\text { gray, sericite haloes. } \\
\text { Tourmaline rosettes may be } \\
\text { present. }\end{array}$ \\
\hline $\begin{array}{l}\text { Propylitic } \\
\text { alteration }\end{array}$ & 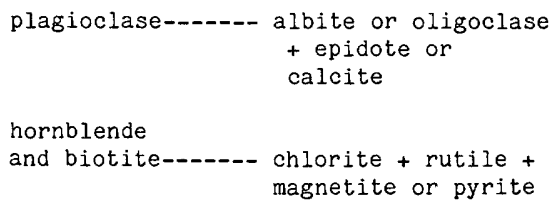 & $\begin{array}{l}\text { Rocks are hard and dull } \\
\text { greenish gray. Veinlets } \\
\text { of pyrite or chlorite and } \\
\text { epidote lack prominent } \\
\text { alteration haloes. }\end{array}$ \\
\hline $\begin{array}{l}\text { Argillic } \\
\text { alteration }\end{array}$ & $\begin{array}{c}\text { plagioclase------ clay }+ \text { sericite } \\
\text { mafic minerals---- clay }+ \text { sericite } \\
+ \text { chlorite }+ \\
\text { pyrite }\end{array}$ & $\begin{array}{l}\text { Rocks are soft and white. } \\
\text { Tongue will stick to clay- } \\
\text { altered minerals. }\end{array}$ \\
\hline $\begin{array}{l}\text { High alumina } \\
\text { (alsic, advanced } \\
\text { argillic) }\end{array}$ & $\begin{array}{l}\text { All original and earlier hydrothermal } \\
\text { minerals converted to pyrophyllite, } \\
\text { alunite, andalusite, corundum, and } \\
\text { diaspore with variable amounts of clay } \\
\text { and sericite. }\end{array}$ & $\begin{array}{l}\text { Rocks are light colored } \\
\text { and moderately soft. }\end{array}$ \\
\hline
\end{tabular}


Model 17--Con.

Figure 51. Tonnages of porphyry $\mathrm{Cu}$ deposits. Individual digits represent number of deposits.
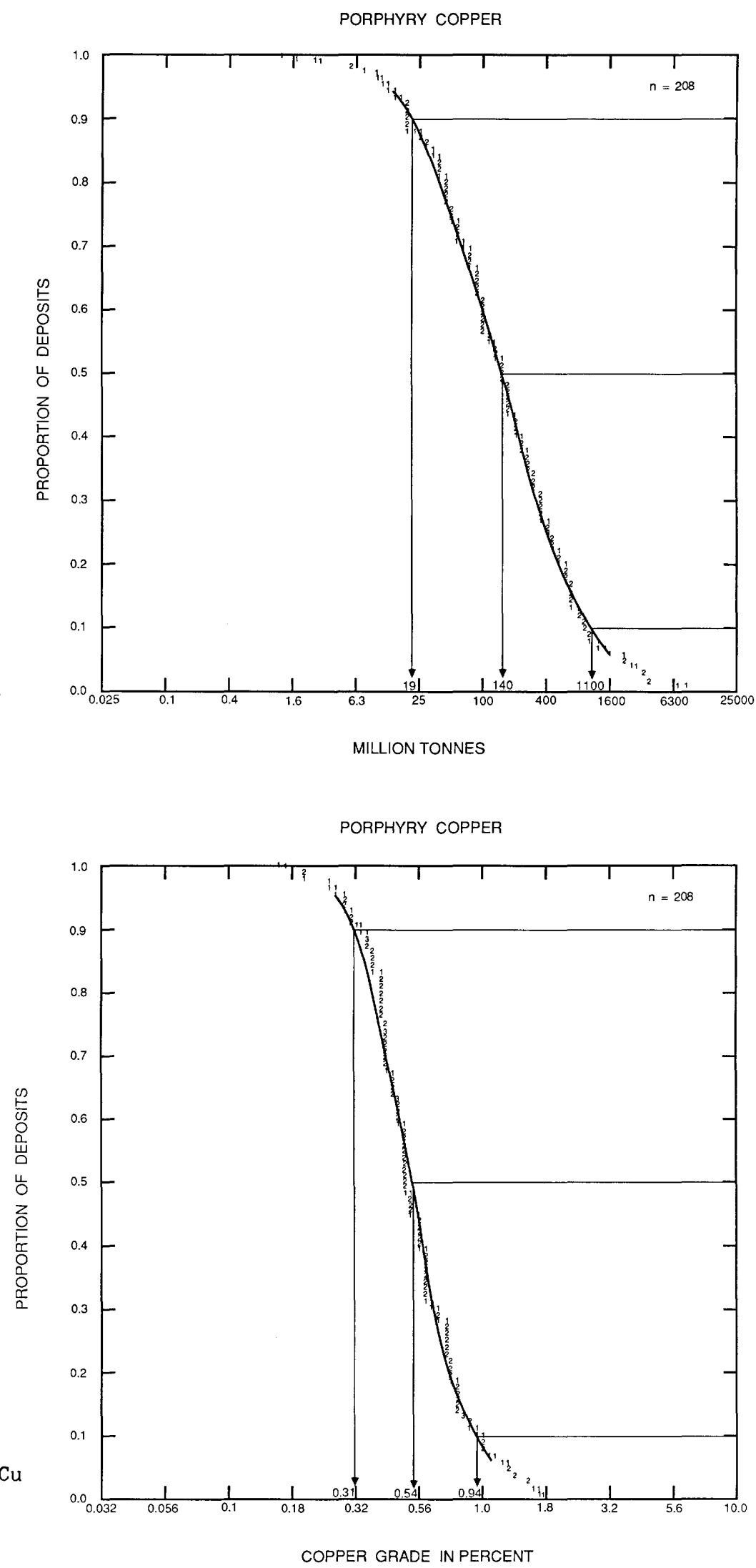
Model 17--Con.

PORPHYRY COPPER

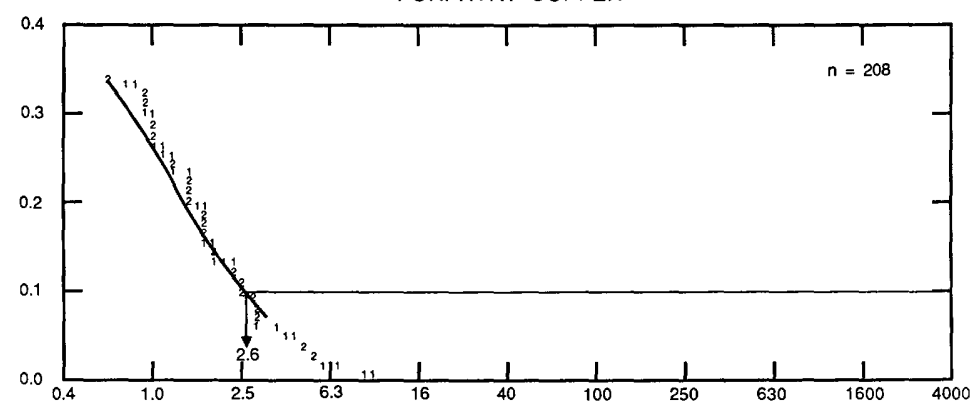

A.

SILVER GRADE IN GRAMS PER TONNE

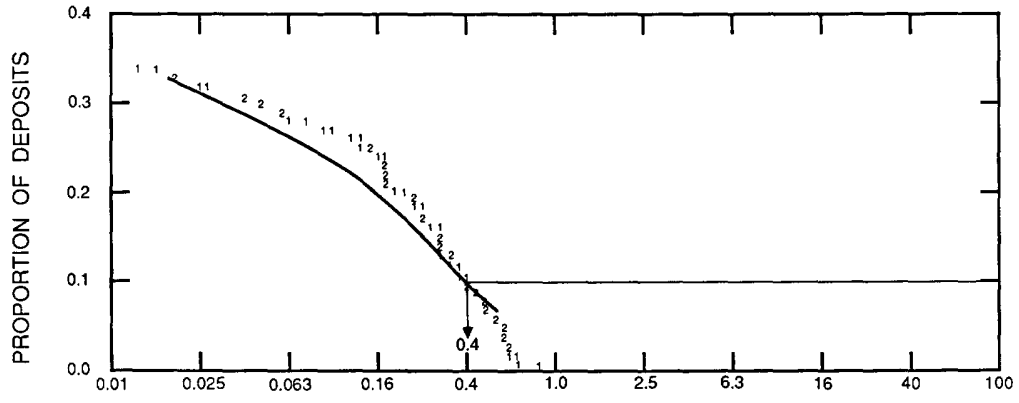

B.

GOLD GRADE IN GRAMS PER TONNE

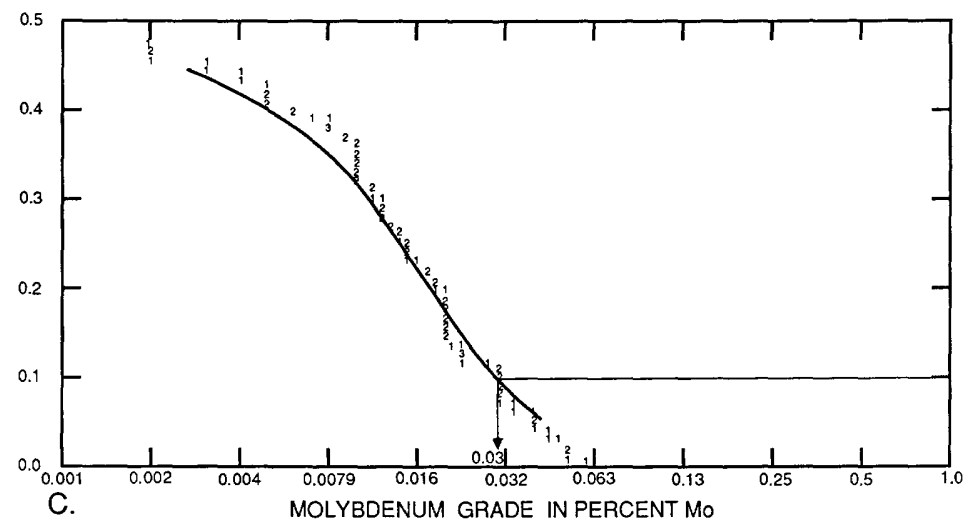

Figure 53. By-product grades of porphyry $\mathrm{Cu}$ deposits. A, Silver. $\underline{B}$, Gold. $\underline{C}$, Molybdenum. Individual digits represent number of deposits. 
Model 18a

\section{DESCRIPTIVE MODEL OF PORPHYRY CU, SKARN-RELATED DEPOSITS}

By Dennis P. Cox

DESCRIPTION Chalcopyrite in stockwork veinlets in hydrothermally altered intrusives and in skarn with extensive retrograde alteration (see fig. 50).

GENERAL REFERENCE Einaudi and others (1981), p. 341-354.

GEOLOGICAL ENVIRONMENT

Rock Types Tonalite to monzogranite intruding carbonate rocks or calcareous clastic rocks.

Textures Porphyry has microaplitic groundmass.

Age Range Mainly Mesozoic and Tertiary, but may be any age.

Depositional Environment Epizonal intrusion of granitic stocks into carbonate rocks. Intense fracturing.

Tectonic Setting(s) Andean-type volcanism and intrusion superimposed on older continental shelf carbonate terrane.

Associated Deposit Types Skarn copper, replacement $\mathrm{Pb}-\mathrm{Zn}-\mathrm{Ag}$.

DEPOSIT DESCRIPTION

Mineralogy Chalcopyrite + pyrite + magnetite in inner garnet pyroxene zone; bornite + chalcopyrite + sphalerite + tennantite in outer wollastonite zone. Scheelite and traces of molybdenite and galena may be present. Hematite or pyrrhotite may be predominant.

Texture/Structure Fine granular calc-silicates and quartz sulfide veinlets.

Alteration Potassic alteration in pluton is associated with andradite and diopside in calcareous rocks. Farther from contact are zones of wollastonite or tremolite with minor garnet, idocrase, and clinopyroxene. These grade outward to marble. Phyllic alteration in pluton is associated with retrograde actinolite, chlorite, and clay in skarn.

Ore Controls Intense stockwork veining in igneous and skarn rocks contains most of the copper minerals. Cu commonly accompanies retrograde alteration.

Weathering Cu carbonates, silicates, Fe-rich gossan.

Geochemical Signature $\mathrm{Cu}, \mathrm{Mo}, \mathrm{Pb}, \mathrm{Zn}, \mathrm{Au}, \mathrm{Ag}, \mathrm{W}, \mathrm{Bi}, \mathrm{Sn}, \mathrm{As}, \mathrm{Sb}$.

\section{EXAMPLES}

$\begin{array}{ll}\text { Ruth, (Ely), USNV } & \text { (Westra, 1982a) } \\ \text { Gaspe, CNQU } & \text { (Allcock, 1982) } \\ \text { Christmas, USAZ } & \text { (Koski and Cook, 1982) } \\ \text { Silver Bell, USAZ } & \text { (Graybeal, 1982) }\end{array}$

GRADE AND TONNAGE MODEL OF PORPHYRY $\mathrm{Cu}$, SKARN-RELATED DEPOSITS

By Donald A. Singer

DATA REFERENCES Einaudi and others (1981), Einaudi (1981).

COMMENTS Skarn copper deposits associated with porphyry copper deposits are included in this model. Tonnages and grades attributable to skarn were estimated for some deposits from estimated proportions of skarn provided by Einaudi and others (1981) and Einaudi (1981). See figs. 54-56. 
Model 18a--Con.

DEPOSITS

Name

Cananea (Capote)

Carr Fork

Christmas

Continental

Copper Basin (Battle Mt. D.) USNV

Copper Canyon

Craigmont

Ely

Gaspe (Needle Mountain)
Country

MXCO

USUT

USAZ

USNM

USNV

CNBC

USNV

CNQU
Name

Gold Coast

Lakeshore

Lyon

Pima-Mission

Potrerillos

Recsk

Santa Rita

Silver Bell

Twin Buttes
Country

PPNG

USAZ

USNV

USAZ

CILE

HUNG

USNM

USAZ

USAZ 
Model 18a--Con.

PORPHYRY COPPER-SKARN--RELATED

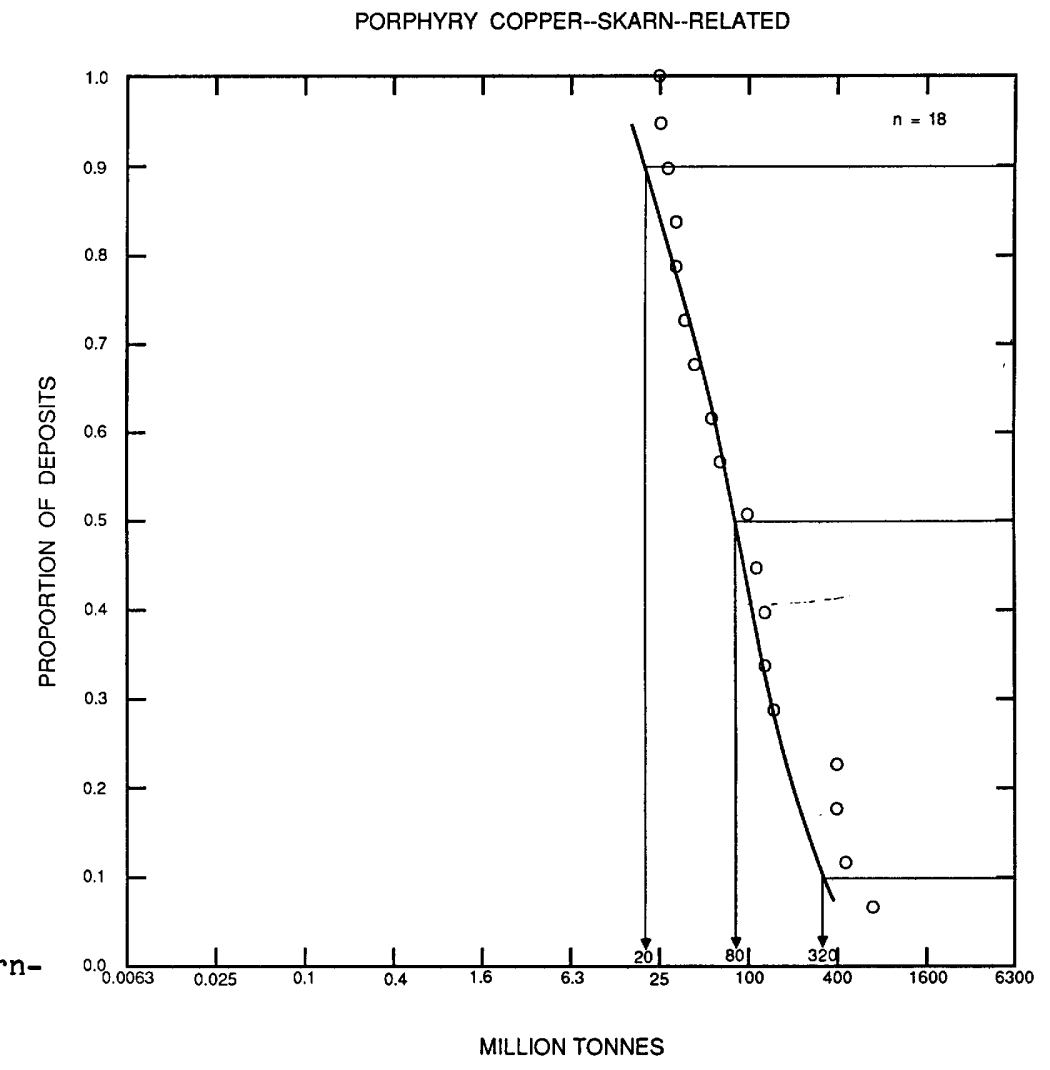

PORPHYRY COPPER--SKARN--RELATED

Figure 54. Tonnages of porphyry Cu-skarnrelated deposits.

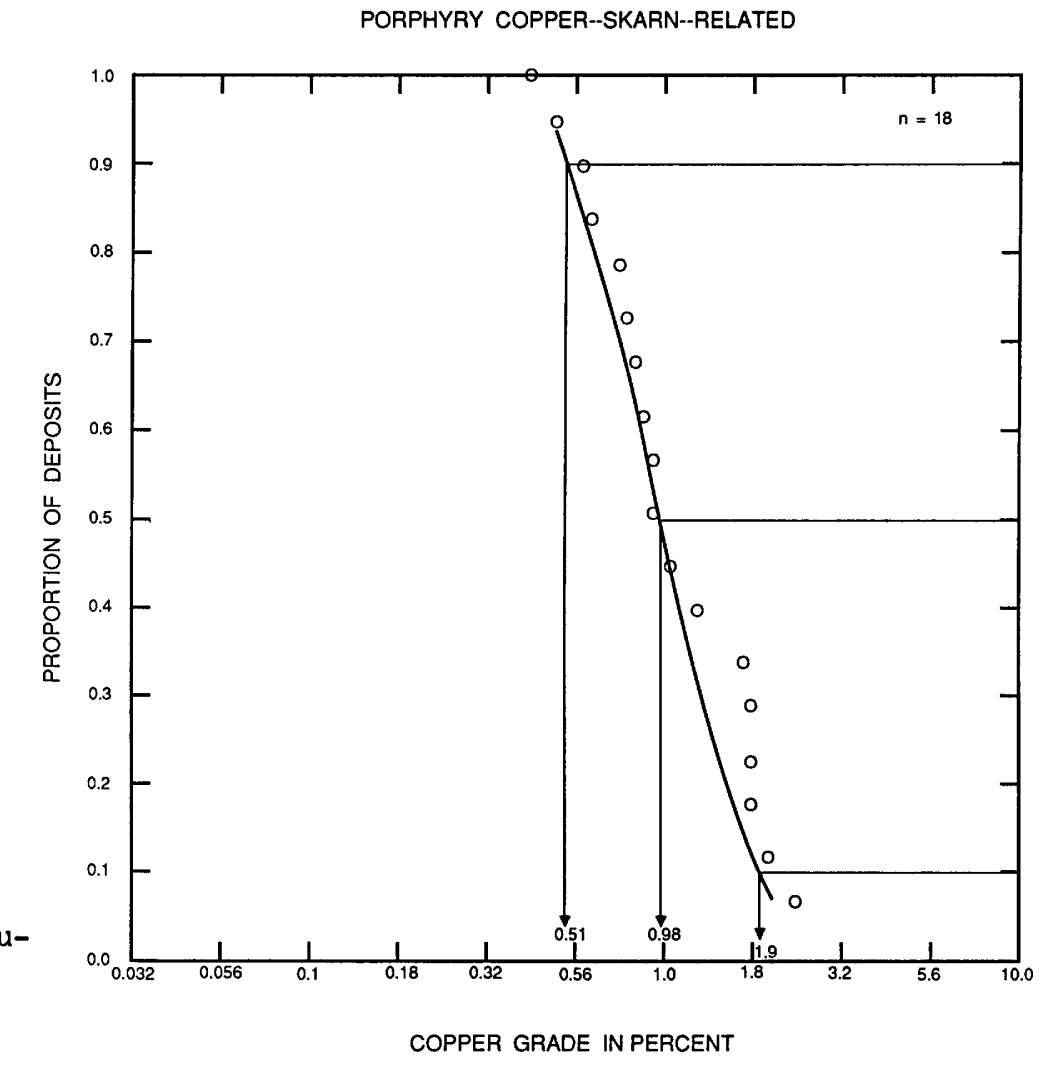

Figure 55. Copper grades of porphyry $\mathrm{Cu}-$ skarn-related deposits. 
PORPHYRY COPPER-SKARN--RELATED
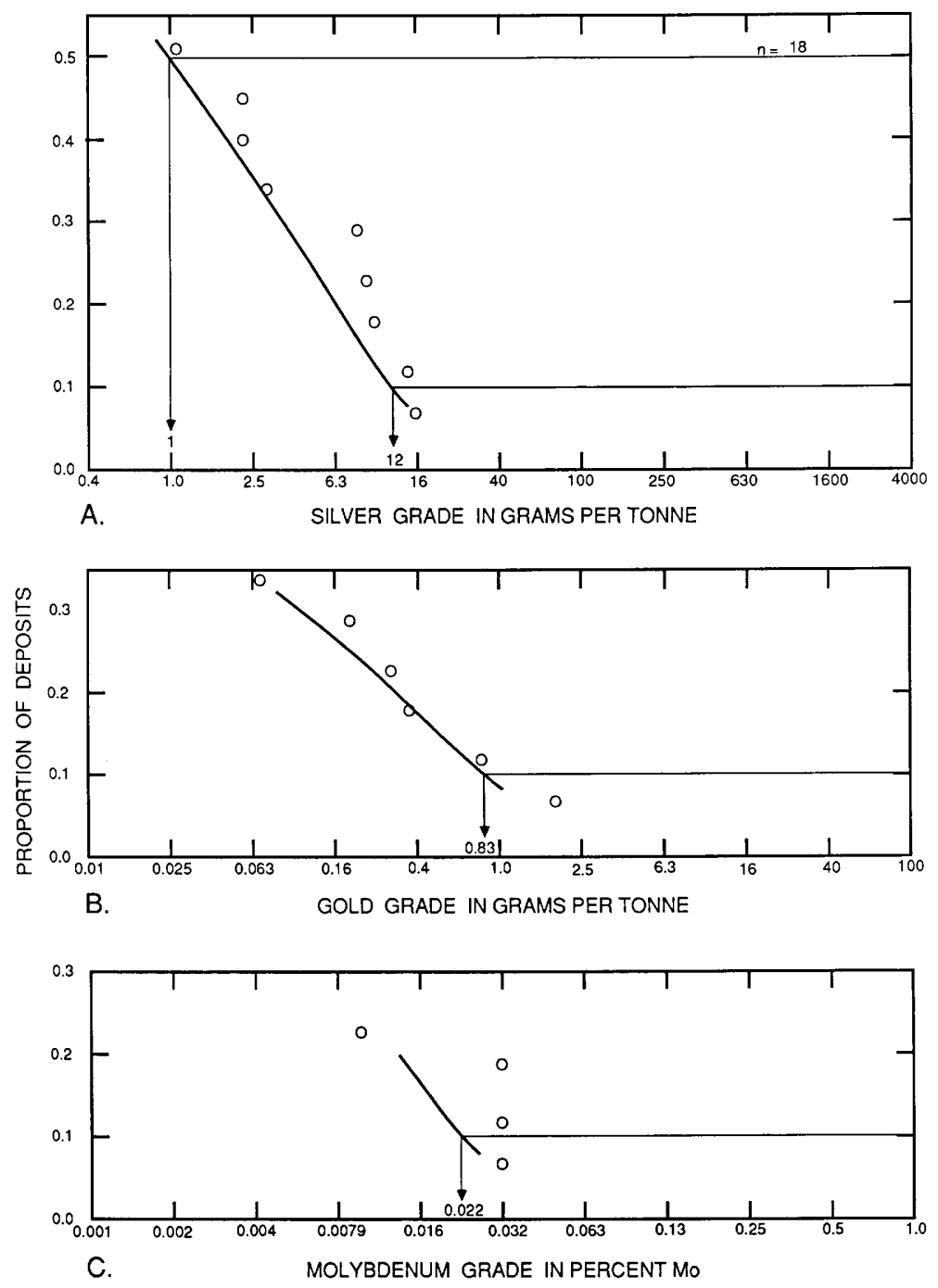

Figure 56. By-product grades of porphyry Cu-skarn-related deposits. A, Silver. $\underline{B}$, Gold. $\underline{C}$, Mol ybdenum. 
Model 18b

\section{DESCRIPTIVE MODEL OF CU SKARN DEPOSITS}

By Dennis P. Cox and Ted G. Theodore

DESCRIPTION Chalcopyrite in calc-silicate contact metasomatic rocks (see fig. 57).

GENERAL REFERENCES Einaudi and Burt (1982), Einaudi and others (1981).

GEOLOGICAL ENVIRONMENT

Rock Types Tonalite to monzogranite intruding carbonate rocks or calcareous clastic

rocks.

Textures Granitic texture, porphyry, granoblastic to hornfelsic in sedimentary rocks.

Age Range Mainly Mesozoic, but may be any age.

Depositional Environment Miogeosynclinal sequences intruded by felsic plutons.

Tectonic Setting(s) Continental margin late orogenic magmatism.

Associated Deposit Types Porphyry Cu, zinc skarn, polymetallic replacement, Fe skarn.

DEPOSIT DESCRIPTION

Mineralogy Chalcopyrite + pyrite \pm hematite \pm magnetite \pm bornite \pm pyrrhotite. Also molybdenite, bismuthinite, sphalerite, galena, cosalite, arsenopyrite, enargite, tennantite, loellingite, cobaltite, and tetrahedrite may be present. $\mathrm{Au}$ and $\mathrm{Ag}$ may be important products.

Texture/Structure Coarse granoblastic with interstitial sulfides. Bladed pyroxenes are common.

Alteration Diopside + andradite center; wollastonite + tremolite outer zone; marble peripheral zone. Igneous rocks may be altered to epidote + pyroxēne + garnet (endoskarn). Retrograde alteration to actinolite, chlorite, and clays may be present.

Ore Controls Irregular or tabular ore bodies in carbonate rocks and calcareous rocks near igneous contacts or in xenoliths in igneous stocks. Breccia pipe, cutting skarn at Victoria, is host for ore. Associated igneous rocks are commonly barren.

Weathering $\mathrm{Cu}$ carbonates, silicates, Fe-rich gossan. Calc-silicate minerals in stream pebbles are a good guide to covered deposits.

Geochemical Signature Rock analyses may show $\mathrm{Cu}-\mathrm{Au}-\mathrm{Ag}-\mathrm{rich}$ inner zones grading outward to Au-Ag zones with high $\mathrm{Au}: \mathrm{Ag}$ ratio and outer $\mathrm{Pb}-\mathrm{Zn}-\mathrm{Ag}$ zone. Co-As-Sb-Bi may form anomalies in some skarn deposits. Magnetic anomalies.

\section{EXAMPLES}

Mason Valley, USNV (Harris and Einaudi, 1982)

Victoria, USNV

Copper Canyon, USNV

Carr Fork, USUT

(Atkinson and others, 1982)

(Blake and others, 1979)

(Atkinson and Einaudi, 1978)

GRADE AND TONNAGE MODEL OF Cu SKARN DEPOSITS

By Gail M. Jones and W. David Menzie

COMMENTS Data used in this model were restricted to copper skarns associated with barren stocks as recommended by Einaudi and others (1981). Some of the data are from districts. See figs. 58-60 
Name

Agordo-Brosso Arctic Chief

B. C.

Benson Lake

Best Chance

Black Cub

Blue Grouse

Bluestone

Caledonia

Cassius

Casting

Cerro de Cobre

Chalcobamba

Coast Copper

Cobriza

Concepcion Del Oro

Copper Queen

Cornell

Cowley Creek

Douglas Hill

Gem

Hiragane

Hope

Iide

Indian Chief

Kamaishi

Kedbeg Copper

Keewenaw

Kodiak Cub

Lily (Ikeno)

Little Chief

Lucky Four

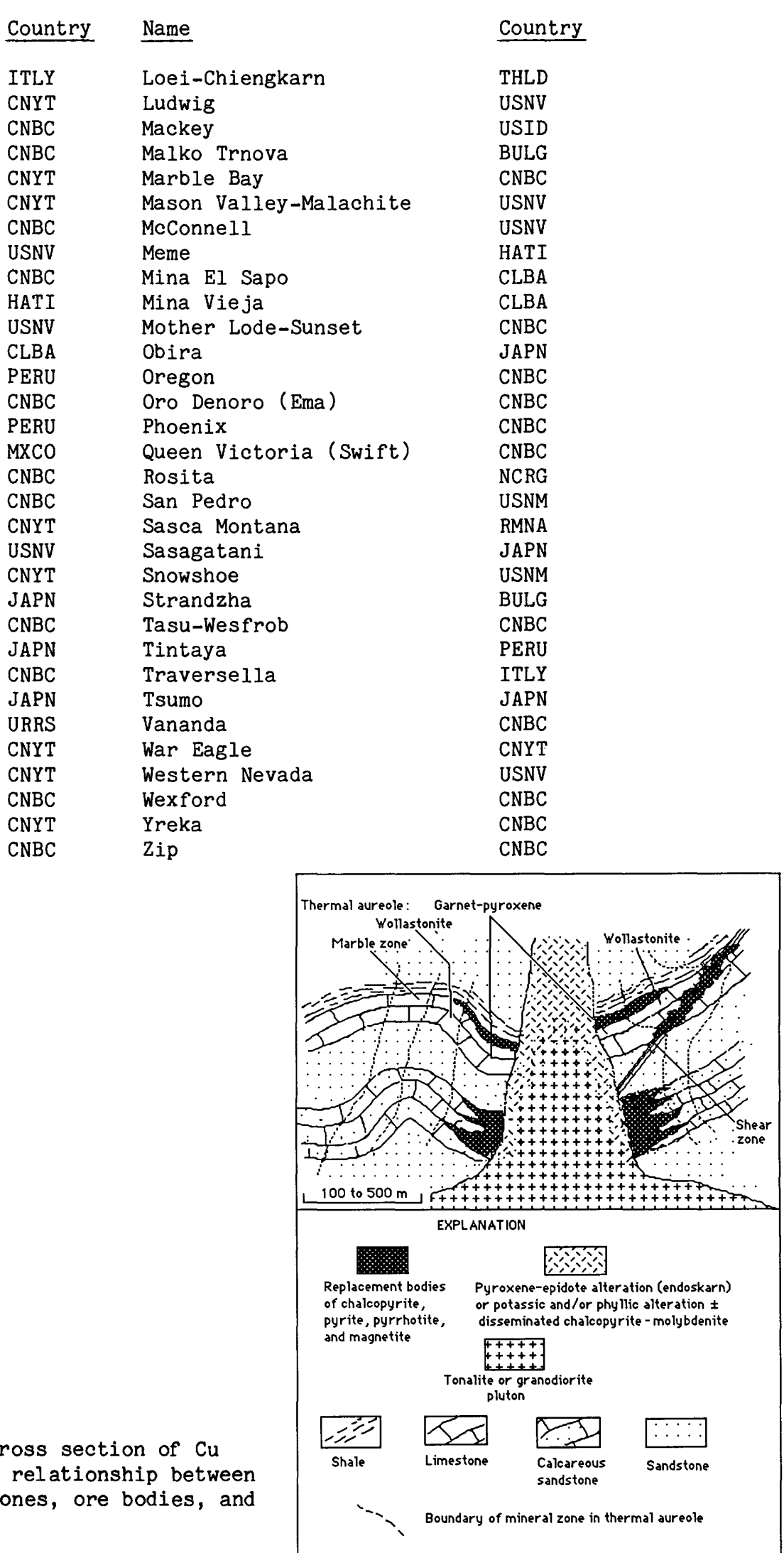

Figure 57. Cartoon cross section of $\mathrm{Cu}$ skarn deposit showing relationship between contact metamorphic zones, ore bodies, and igneous intrusion.

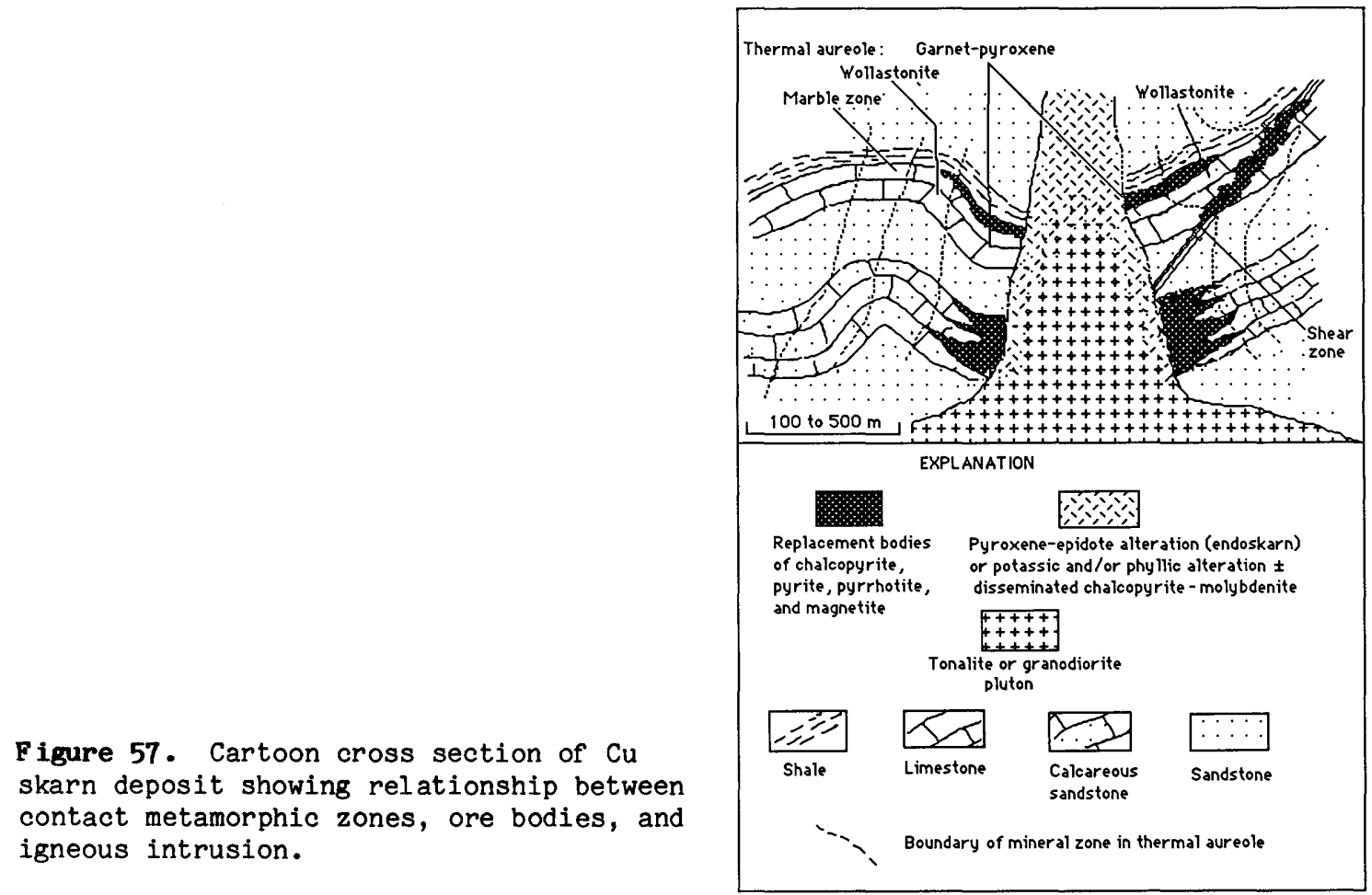


Model 18b--Con.
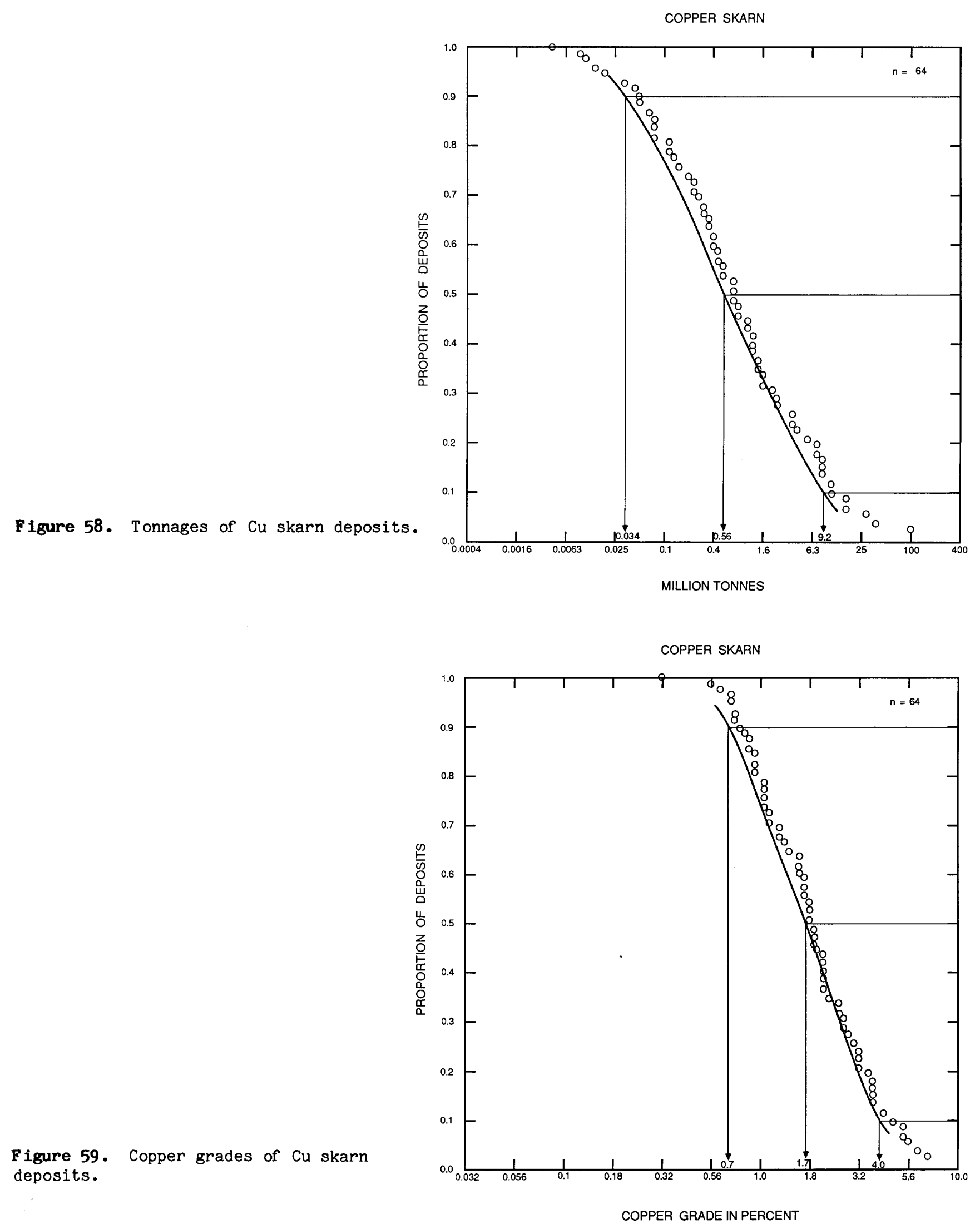


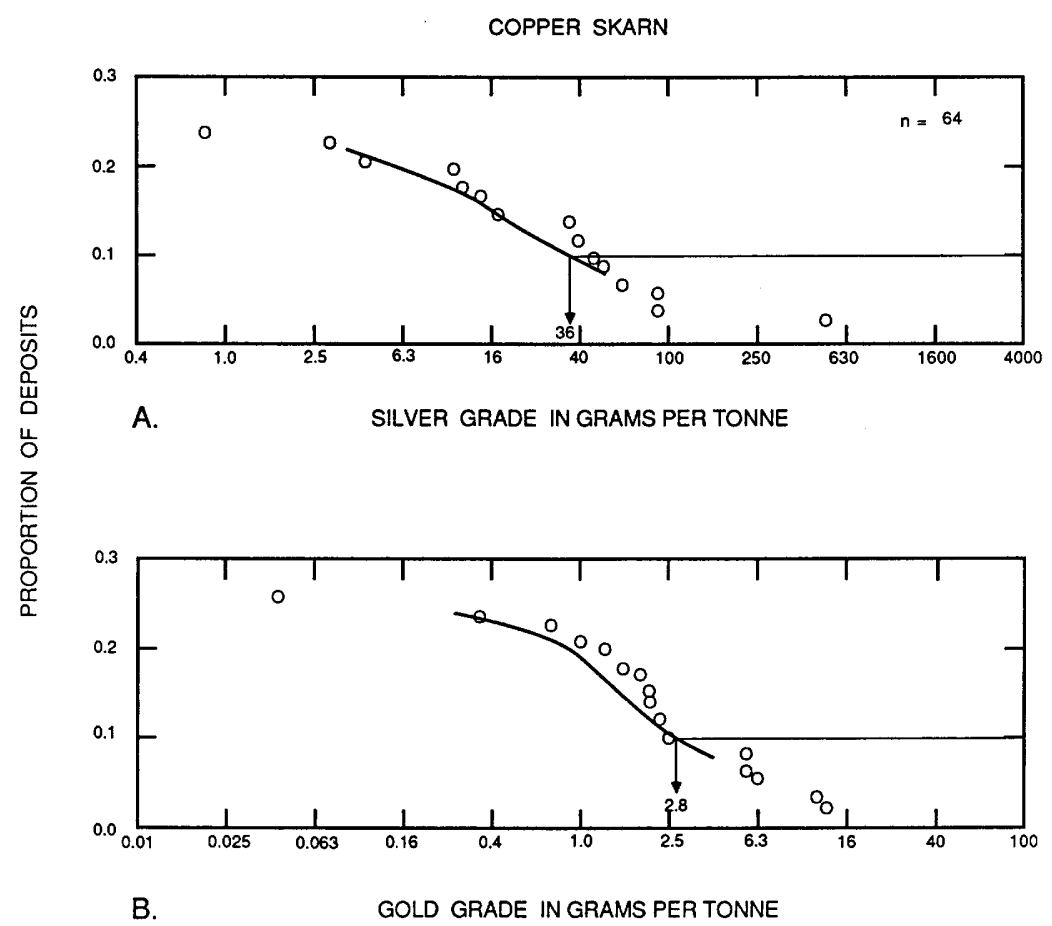

Figure 60. Precious-metal grades of $\mathrm{Cu}$ skarn deposits. A, Silver. $\underline{B}$, Gold. 
Model $18 \mathrm{c}$

\section{DESCRIPTIVE MODEL OF Zn-Pb SRAFA DEPOSITS}

By Dennis P. Cox

DESCRIPTION Sphalerite and galena in calc-silicate rocks.

GENERAL REFERENCES Einaudi and Burt (1982); Einaudi and others (1981).

GEOLOGICAL ENVIRONMENT

Rock Types Granodiorite to granite, diorite to syenite. Carbonate rocks, calcareous clastic rocks.

Textures Granitic to porphyritic; granoblastic to hornfelsic.

Age Range Mainly Mesozoic, but may be any age.

Depositional Environment Miogeoclinal sequences intruded by generally small bodies of igneous rock.

Tectonic Setting(s) Continental margin, late-orogenic magmatism.

Associated Deposit Types Copper skarn.

DEPOSIT DESCRIPTION

Mineralogy Sphalerite + galena \pm pyrrhotite \pm pyrite \pm magnetite \pm chalcopyrite \pm bornite \pm arsenopyrite \pm scheelite \pm bismuthinite \pm stannite \pm fluorite. Gold and silver do not form minerals.

Texture/Structure Granoblastic, sulfides massive to interstitial.

Alteration Mn-hedenbergite \pm andradite \pm grossular \pm spessartine \pm bustamite \pm rhodonite. Late stage Mn-actinolite \pm ilvaite \pm chlorite \pm dannemorite \pm rhodochrosite.

Ore Controls Carbonate rocks especially at shale-limestone contacts. Deposit may be hundreds of meters from intrusive.

Weathering Gossan with strong Mn oxide stains.

Geochemical Signature $\mathrm{Zn}, \mathrm{Pb}, \mathrm{Mn}, \mathrm{Cu}, \mathrm{Co}, \mathrm{Au}, \mathrm{Ag}, \mathrm{As}, \mathrm{W}, \mathrm{Sn}, \mathrm{F}$, possibly Be. Magnetic anomalies.

EXAMPLES

Ban Ban, AUQU (Ashley, 1980)
Hanover-Fierro district, USNM (Hernon and Jones, 1968)

GRADE MND TONNAGE MODEL OF Zn-PD SKAF DEPOSITS

By Dan L. Mosier

COMMENTS Zinc grade is correlated with lead grade $(r=0.66, n=30)$ and with copper ( $r=0.61, n$ $=17)$. See figs. $61-65$.

DEPOSITS

Name

Country

Name

Country

Aguilar

Ammeberg

Aravaipa

Black Hawk

Dolores

AGTN

SWDN

USAZ

USNM

MXCO
E1 Mochito

Ealun

Garpenberg Norra

Garpenberg Odal

Groundhog
HNDR

SWDN

SWDN

SWDN

USNM 
Kalvbacken

Kennecott

Langban

McDame Belle

Meat Cove

Mount Hundere

Nyseter

Parroquio-Magistral

Rajabasa

Ryllshyttan

Sala

Saxberget
SWDN

USNM

SWDN

CNBC

CNNS

CNYT

NRWY

MXCO

INDS

SWDN

SWDN

SWDN
Shuikoushan

\section{Stollberg}

Svardsio

Tetyukhe

Tienpaoshan

Uchucchacua

Ulchin

Washington Camp

Yanchiachangtze

Yeonhwa I

Yeonhwa II

Zip
CINA

SWDN

SWDN

URRS

CINA

PERU

SKOR

USAZ

CINA

SKOR

SKOR

CNBC

ZINC--LEAD SKARN

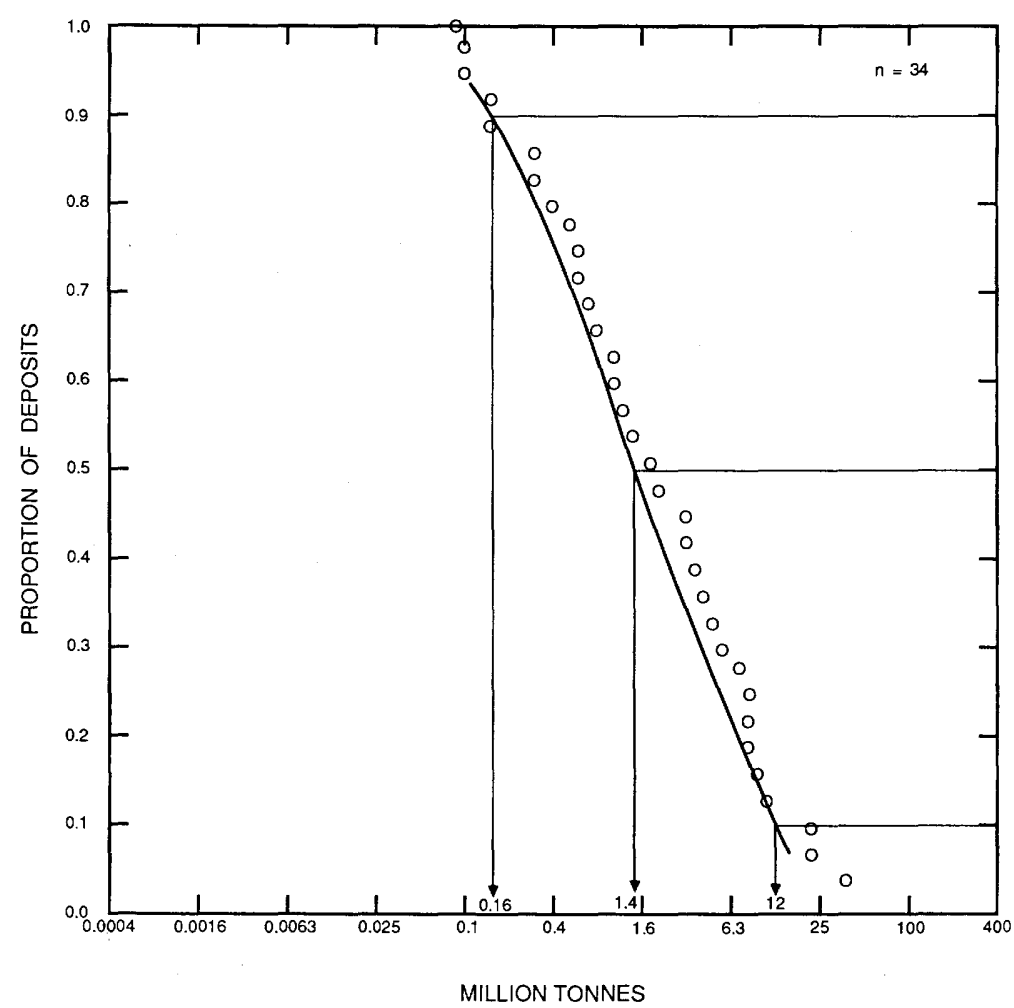

Figure 61. Tonnages of $\mathrm{Zn}-\mathrm{Pb}$ skarn deposits. 
Model 18c--Con.

Figure 62. Zinc grades of $\mathrm{Zn}-\mathrm{Pb}$ skarn deposits.
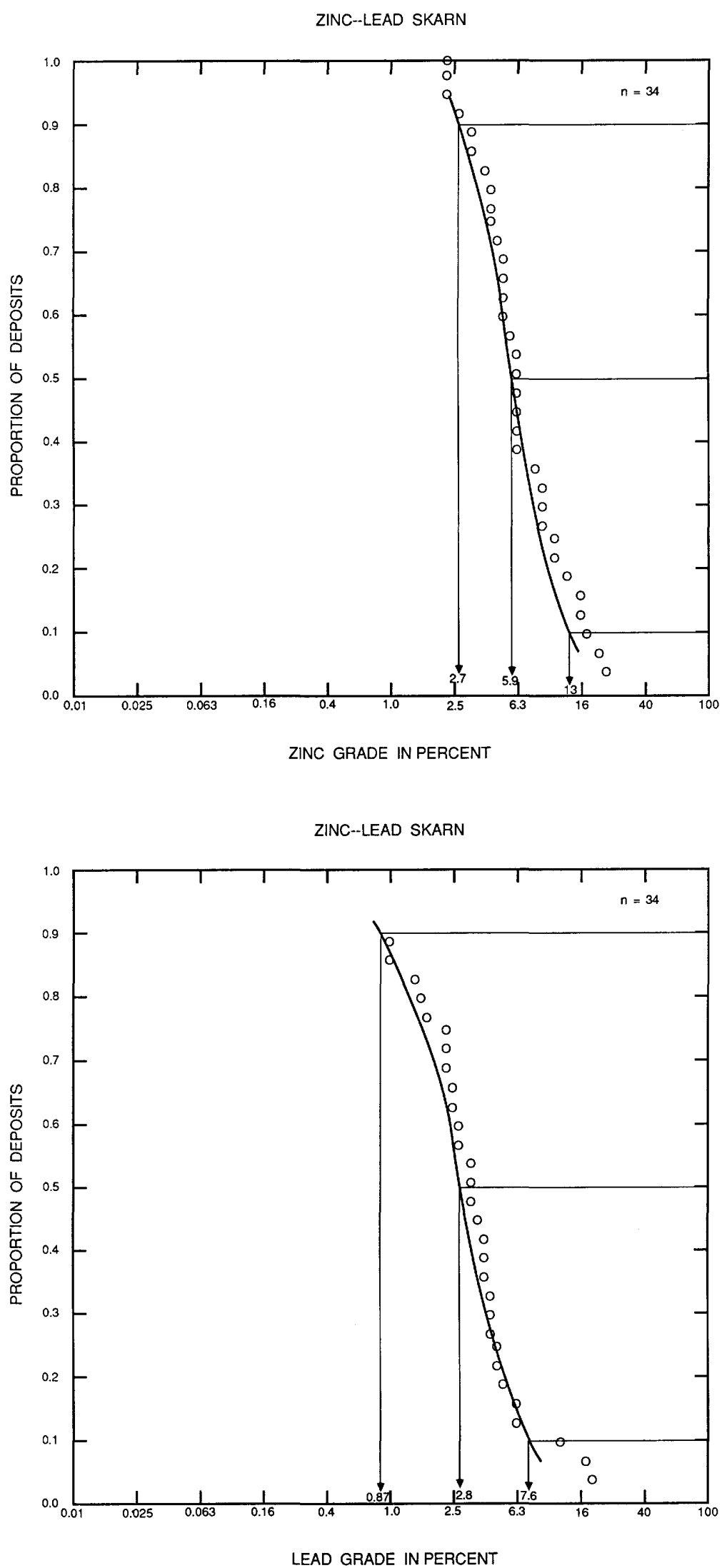

Figure 63. Lead grades of $\mathrm{Zn}-\mathrm{Pb}$ skarn deposits.

LEAD GRADE IN PERCENT 
ZINC--LEAD SKARN

Model 18c--Con.

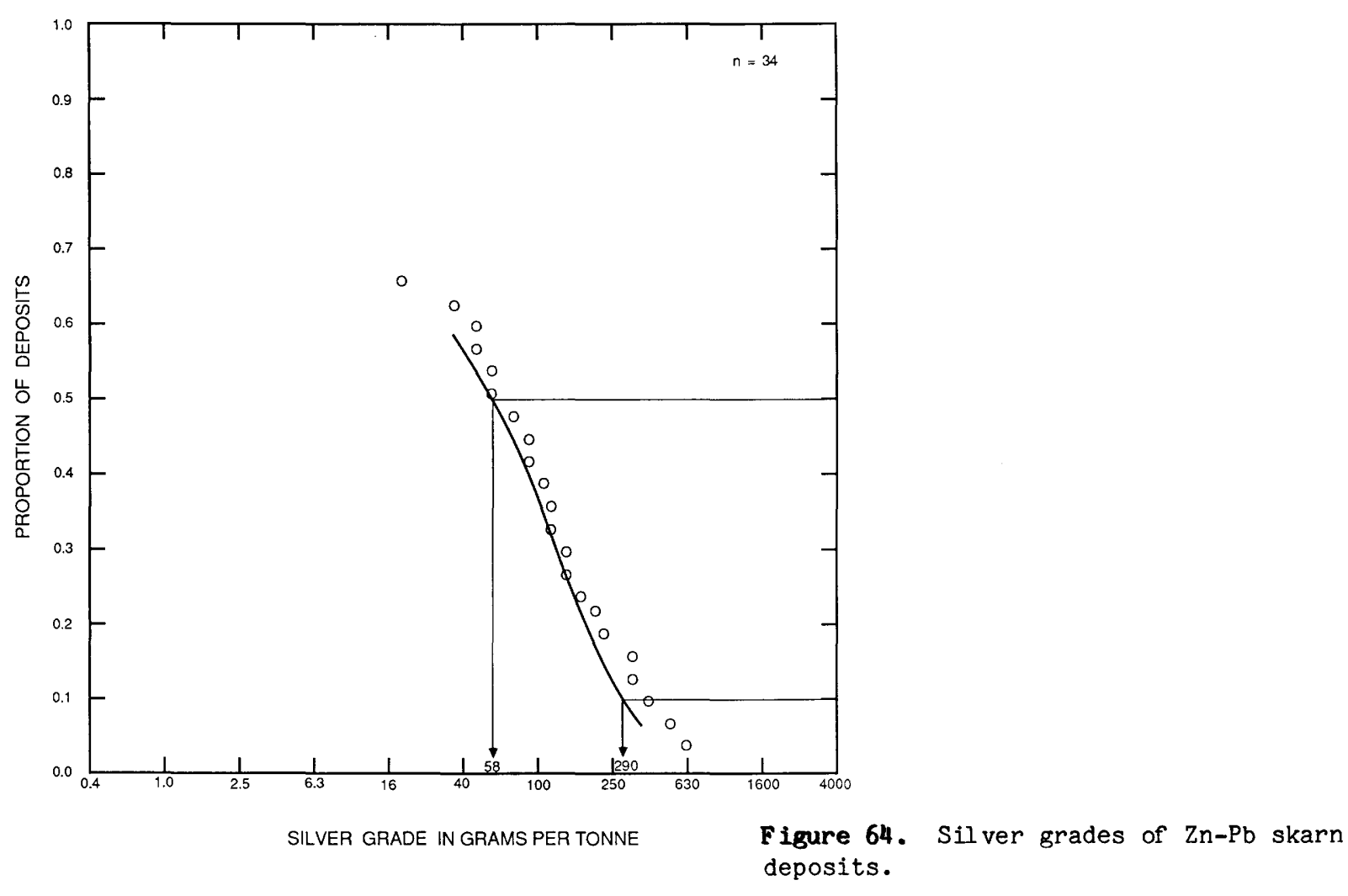

")
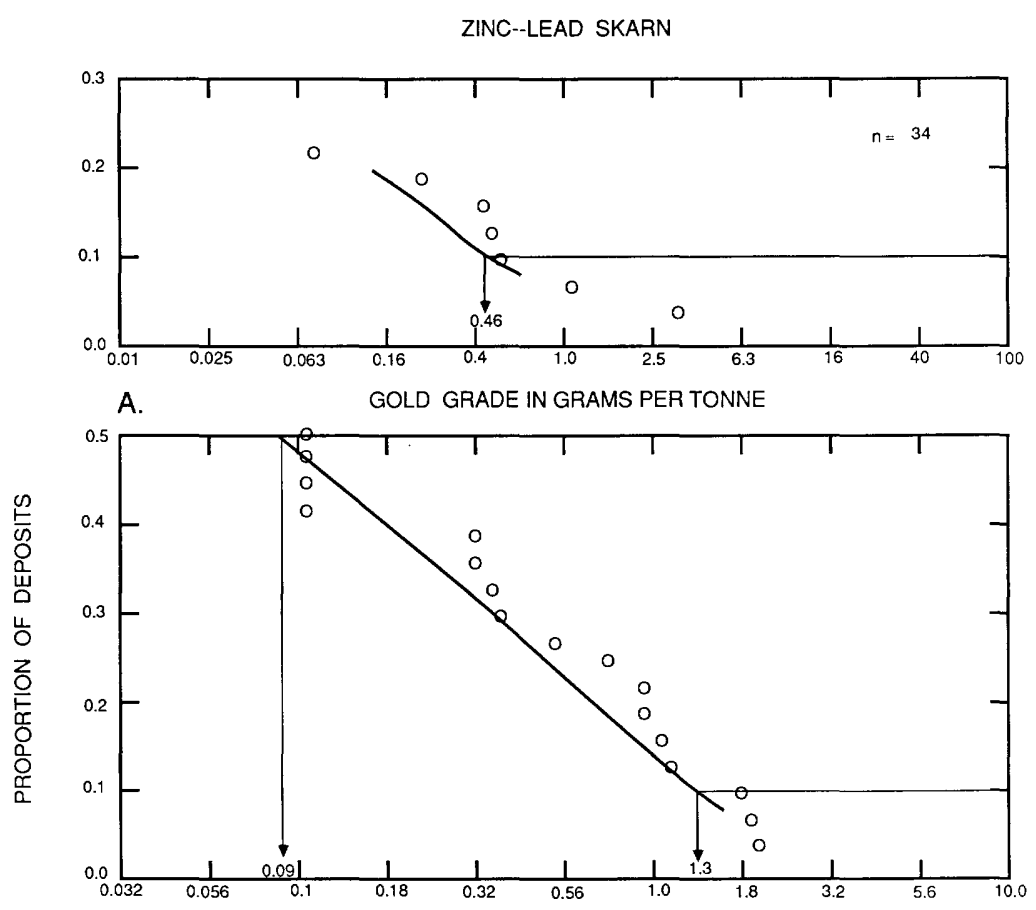

B. COPPER GRADE IN PERCENT

Figure 65. Metal grades of $\mathrm{Zn}-\mathrm{Pb}$ skarn deposits. A, Gold. B, Copper. 


\section{DESCRIPTIVE MODEL OF Fe SKARN DEPOSITS}

By Dennis P. Cox

DESCRIPTION Magnetite in calc-silicate contact metasomatic rocks.

GENERAL REFERENCES Einaudi and Burt (1982), Einaudi and others (1981).

GEOLOGICAL ENVIRONMENT

Rock Types Gabbro, diorite, diabase, syenite, tonalite, granodiorite, granite, and coeval volcanic rocks. Limestone and calcareous sedimentary rocks.

Textures Granitic texture in intrusive rocks; granoblastic to hornfelsic textures in sedimentary rocks.

Age Range Mainly Mesozoic and Tertiary, but may be any age.

Depositional Environment Contacts of intrusion and carbonate rocks or calcareous clastic rocks.

Tectonic Setting(s) Miogeosynclinal sequences intruded by felsic to mafic plutons. Oceanic island arc, Andean volcanic arc, and rifted continental margin.

\section{DEPOSIT DESCRIPTION}

Mineralogy Magnetite \pm chalcopyrite \pm Co-pyrite \pm pyrite \pm pyrrhotite. Rarely cassiterite in Fe skarns in Sn-granite terranes.

Texture/Structure Granoblastic with interstitial ore minerals.

Alteration Diopside-hedenbergite + grossular-andradite + epidote. Late stage amphibole \pm chlorite \pm ilvaite.

Ore Controls Carbonate rocks, calcareous rocks, igneous contacts and fracture zones near

contacts. Fe skarn ores can also form in gabbroic host rocks near felsic plutons.

Weathering Magnetite generally crops out or forms abundant float.

Geochemical and Geophysical Signature $\mathrm{Fe}, \mathrm{Cu}, \mathrm{Co}, \mathrm{Au}$, possibly Sn. Strong magnetic anomaly.

EXAMPLES

$\begin{array}{ll}\text { Shinyama, JAPN } & \text { (Uchida and Iiyama, 1982) } \\ \text { Cornwall, USPA } & \text { (Lapham, 1968) } \\ \text { Iron Springs, USUT } & \text { (Mackin, 1968) }\end{array}$

GRADE AND TONNAGE MODEL OF Fe SKARN DEPOSITS

By Dan L. Mosier and W. David Menzie

COMMENTS Some of the data represent districts. See figs. 66-67.

DEPOSITS

$\underline{\text { Name }}$

Adaevka central

Adaevka north

Adaevka south

Agalteca

Ain Mokra

Ain Oudrer

Akatani
Name

Alagada

Aleshinka

Argonaut

Asvan

Auerbach

Ayazmant

Baghain
Country

PORT

URRS

CNBC

TRKY

URUR

TRKY

IRAN 


\begin{tabular}{|c|c|}
\hline Baisoara & RMNA \\
\hline Beck & USCA \\
\hline Beni Douala & ALGR \\
\hline Benkala & URRS \\
\hline Bessemer & CNON \\
\hline Bizmisen-Akusagi & TRKY \\
\hline Blairton & CNON \\
\hline Bolsherechensk & URRS \\
\hline Bulacan & PLPN \\
\hline Brynor & CNBC \\
\hline Calabogie & CNON \\
\hline Camiglia & ITLY \\
\hline Capacmarca & PERU \\
\hline Capitan & USNM \\
\hline Carmen & CILE \\
\hline Cave Canyon & USCA \\
\hline Cehegin & SPAN \\
\hline Chichibu & JAPN \\
\hline Childs Mine & CNON \\
\hline Colquemarca & PERU \\
\hline Copper Flat & USNM \\
\hline Cuchillo-Negro & USNM \\
\hline Daiquiri & CUBA \\
\hline Dammer Nissar & PKTN \\
\hline Dannemora & SWDN \\
\hline Dayton & USNV \\
\hline Divrigi & TRKY \\
\hline Dungun & MDGS \\
\hline Dzama & URRS \\
\hline Eagle Mountain & USCA \\
\hline El Pedroso & SPAN \\
\hline El Sol y La Luna & $\mathrm{MXCO}$ \\
\hline El Volcan-Piedra Iman & $\mathrm{MXCO}$ \\
\hline Eltay & URRS \\
\hline Estyunin & URRS \\
\hline Fierro-Hannover & USNM \\
\hline Gallinas & USNM \\
\hline Giresun & TRKY \\
\hline Gora Magnitnaya & URRS \\
\hline Gora Vysokaya & URRS \\
\hline Hatillo & DMRP \\
\hline Hierro Indio & AGTN \\
\hline Huacravilca & PERU \\
\hline Hualpai & $\mathrm{CNBC}$ \\
\hline Huancabamba & PERU \\
\hline Hull & CNQU \\
\hline Imanccasa & PERU \\
\hline Ino & JAPN \\
\hline Iron Duke & CNBC \\
\hline Iron Hat & USCA \\
\hline Iron Mike & CNBC \\
\hline Iron Mountain (Colfax Co.) & USNM \\
\hline Iron Mountain (Sierra Co.) & USNM \\
\hline Iron Springs & USUT \\
\hline Jedway & CNBC \\
\hline Jerez de los Caballeros & SPAN \\
\hline Jib & CNBC \\
\hline Jicarilla & USNM \\
\hline Jones Camp & USNM \\
\hline Juncos & $\mathrm{CNBC}$ \\
\hline Kachar & URRS \\
\hline Kalkan & TRKY \\
\hline Kambaikhin central & URRS \\
\hline
\end{tabular}

Kambaikhin east URRS

Kambaikhin north URRS

Karamadazi TRKY

Kaunisvaara-Masugnsbyn SWDN

Kesikkopru TRKY

Kozyrevka URRS

Kroumovo URRS

Kruglogorsk URRS

Kurzhunkul URRS

La Carmen MXCO

La Laguna DMRP

La Paloma MXCO

La Piedra Iman MXCO

Las Animas Cerro Prieto MXCO

Las Truchas MXCO

Larap-Calambayungan PLPN

Lava Bed USCA

Lebyazhka URRS

Livitaca-Velille PERU

Lomonosov URRS

Maanshan HONG

Mac CNBC

Marbella SPAN

Marmoraton CNON

Martinovo BULG

Maslovo URRS

Mati PLPN

Mogpog PLPN

Monte Carmelo NCRG

Munesada JAPN

Nimpkish CNBC

Novo Maslovo URRS

Novo Peschansk URRS

Ocna de Fier RMNA

Old Dad Mountains USCA

Orogrande USNM

Osokino-Aleksandrovsk URRS

Pambuhan Sur PLPN

Pampachiri PERU

Paracale PLPN

Pena Colorada MXCO

Perda Niedda ITLY

Persberg SWDN

Peschansk URRS

Picila MXCO

Piddig PLPN

Plagia GREC

Pokrovsk URRS

Rankin CNON

Recibimiento MXCO

Rondoni PERU

Rose CNBC

Rudna Glava YUGO

Sabana Grande DMRP

Samli TRKY

San Carlos MXCO

San Juan de Chacna PERU

San Leone ITLY

Sankyo JAPN

Santa Lucia PERU

Santa Rita USNM

Sarbay URRS

Senor de Huarquisa PERU 
Model 18d--Con.

$\begin{array}{ll}\text { Severnoe I } & \text { URRS } \\ \text { Severnoe II } & \text { URRS } \\ \text { Severnoe III } & \text { URRS } \\ \text { Shagyrkul } & \text { URRS } \\ \text { Shasta-California } & \text { USCA } \\ \text { Shinyama } & \text { JAPN } \\ \text { Silver Lakes } & \text { USCA } \\ \text { Sorka } & \text { URRS } \\ \text { Sosva } & \text { URRS } \\ \text { South Sarbay } & \text { URRS } \\ \text { Takanokura } & \text { JAPN } \\ \text { Tapairihua } & \text { PERU } \\ \text { Techa } & \text { URRS } \\ \text { Tecolote } & \text { USNM }\end{array}$

Tepustete MXCO

Texada CNBC

Tovarnica YUGO

Tsaitsukou CINA

Val Di Peio ITLY

Valuev URRS

Vorontsovka URRS

Vulcan USCA

Vyhne CZCL

Wagasennin JAPN

Yellow Jacket USNM

Zanitza MXCO

Zarikan IRAN

Zebalios CNBC 

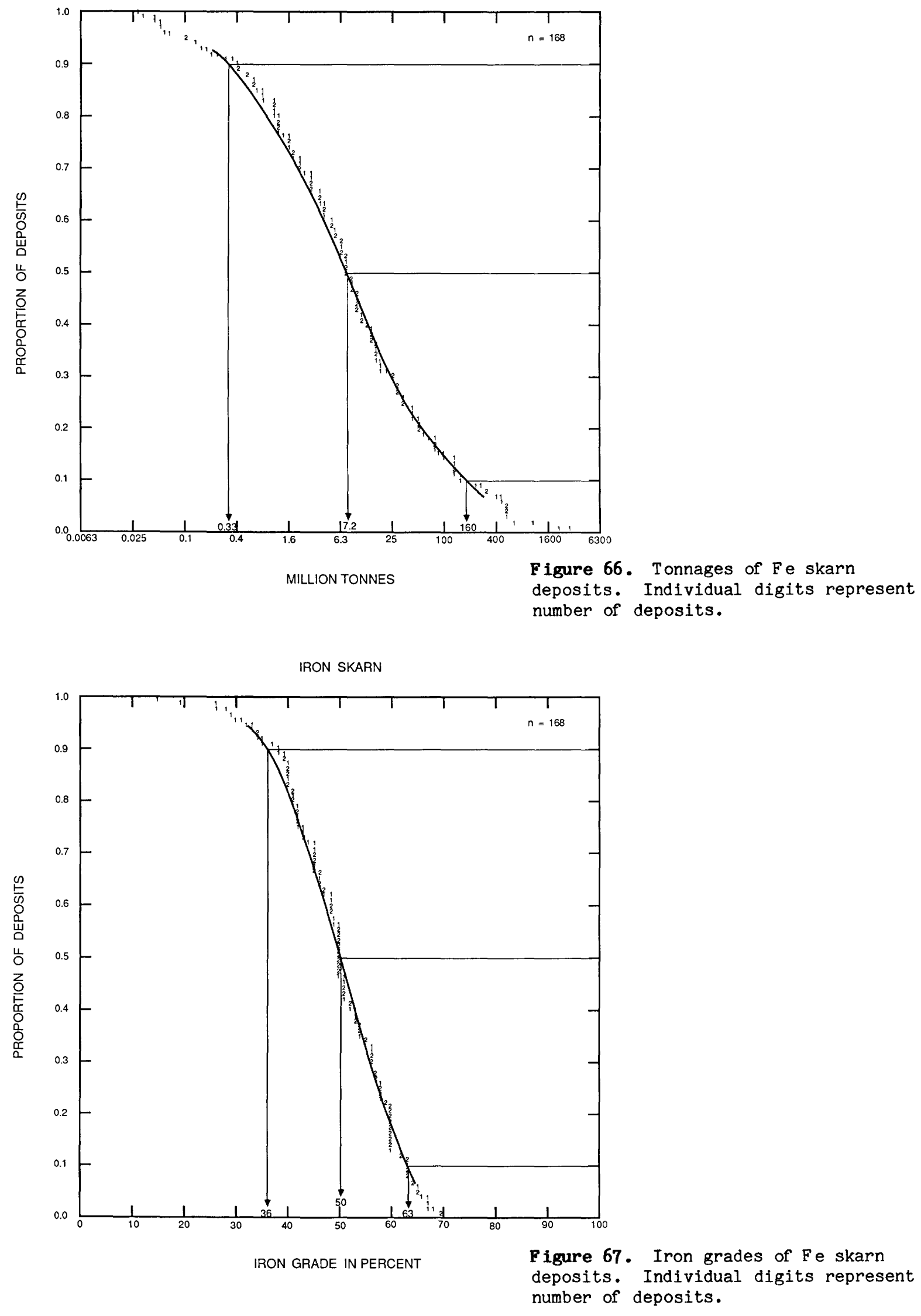
Model $18 \mathrm{e}$

\section{DESCRIPTIVE MODEL OP CARBONATE-HOSTED ASBESTOS}

By Chester T. Wrucke and Andrew F. Shride

APPROXIMATE SYNONYM Arizona type (Shride, 1973).

DESCRIPTION Long-staple chrysotile asbestos in veins developed in tabular layers of serpentine that replaced silicated limestone adjacent to diabase sheets, sills, and dikes.

GENERAL REFERENCE Shride (1969).

GEOLOGIC ENVIRONMENT

Rock Types Serpentine, diabase, silicated limestone, cherty dolomite.

Textures Original bedding details of cherty dolomite preserved in fine-grained metamorphic

limestone that includes nodular silicate masses partly to wholly replaced by serpentine.

Age Range Middle Proterozoic in Arizona, but may be of any age.

Depositional Environment Contact metamorphic aureole associated with injection of diabase magma into cherty dolomite.

Tectonic Setting Probably rifted or partly rifted continental terrane, as suggested by regionally voluminous alkalic olivine tholeiite diabase in nearshore marine and terrestrial strata.

Associated Deposit Types Contact-metamorphic magnetite. Talc deposits exist widely in similar physical settings.

\section{DEPOSIT DESCRIPTION}

Mineralogy Chrysotile asbestos, dense serpentine, magnetite, and calcite.

Texture/Structure Sharp-walled gash fracture and ribbon veins of cross-fiber chrysotile and calcite with occasional veins of dense chrysotile in massive serpentine. Veins mostly less than $0.3 \mathrm{~cm}$ wide but commonly $2-8$ and rarely up to $25 \mathrm{~cm}$.

Alteration Tremolite, diopside, and talc formed during prograde metamorphism were largely replaced by massive serpentine during retrograde metamorphism. Vein minerals were emplaced during late hydrothermal stage.

Ore Controls Favorable stratigraphic zones proximate (within $10 \mathrm{~m}$ ) to diabase. Open folds formed on emplacement of the diabase were favorable sites for small-scale bedding and thrust faults which were repeatedly opened during metamorphism and mineralization.

\section{EXAMPLES}

Gila County, USAZ, Cuddappah district, INDA

southwestern USMT, Barberton-Caroline District, SAFR

Hopeh Province, CINA, near Kanye, BOTS (Sinclair, 1955) 


\section{DESCRIPTIVE MODEL OF POLYMETALLIC REPLACEMENT DEPOSITS}

By Hal T. Morris

APPROXIMATE SYNONYM Manto deposits, many authors.

DESCRIPTION Hydrothermal, epigenetic, $\mathrm{Ag}, \mathrm{Pb}, \mathrm{Zn}, \mathrm{Cu}$ minerals in massive lenses, pipes and veins in limestone, dolomite, or other soluble rock near igneous intrusions (see fig. 68).

GENERAL REFERENCE Jensen and Bateman (1981), p. 134-146.

GEOLOGICAL ENVIRONMENT

Rock Types Sedimentary rocks, chiefly limestone, dolomite, and

shale, commonly overlain by volcanic rocks and intruded by porphyritic, calc-alkaline plutons.

Textures The textures of the replaced sedimentary rocks are not important; associated plutons typically are porphyritic.

Age Range Not important, but many are late Mesozoic to early Cenozoic.

Depositional Environment Carbonate host rocks that commonly occur in broad sedimentary basins, such as epicratonic miogeosynclines. Replacement by solutions emanating from volcanic centers and epizonal plutons. Calderas may be favorable.

Tectonic Setting(s) Most deposits occur in mobile belts that have undergone moderate deformation and have been intruded by small plutons.

Associated Deposit Types Base metal skarns, and porphyry copper deposits.

DEPOSIT DESCRIPTION

Mineralogy Zonal sequence outward: enargite + sphalerite + argentite + tetrahedrite + digenite \pm chalcopyrite, rare bismuthinite; galena + sphalerite + argentite \pm tetrahedrite \pm proustite \pm pyrargyrite, rare jamesonite, jordanite, bournonite, stephanite, and polybasite; outermost sphalerite + rhodochrosite (see fig. 68). Widespread quartz, pyrite, marcasite, barite. Locally, rare gold, sylvanite, and calaverite.

Texture/Structure Ranges from massive to highly vuggy and porous.

Alteration Limestone wallrocks are dolomitized and silicified (to form jasperoid); shale and igneous rocks are chloritized and commonly are argillized; where syngenetic iron oxide minerals are present, rocks are pyritized. Jasperoid near ore is coarser grained and contains traces of barite and pyrite.

Ore Controls Tabular, podlike and pipelike ore bodies are localized by faults or vertical beds; ribbonlike or blanketlike ore bodies are localized by bedding-plane faults, by susceptible beds, or by preexisting solution channels, caverns, or cave rubble.

Weathering Commonly oxidized to ochreous masses containing cerrusite, anglesite, hemimorphite, and cerargyrite.

Geochemical Signature On a district-wide basis ore deposits commonly are zoned outward from a copper-rich central area through a wide lead-silver zone, to a zinc- and manganese-rich fringe. Locally $\mathrm{Au}, \mathrm{As}, \mathrm{Sb}$, and $\mathrm{Bi}$. Jasperoid related to ore can often be recognized by high $\mathrm{Ba}$ and trace $\mathrm{Ag}$ content.

Examples

East Tintic district, USUT (Morris and Lovering, 1979)

Eureka district, USNV

Manto deposit, MXCO

(Nolan, 1962)

(Prescott, 1926) 
Model 19a--Con.

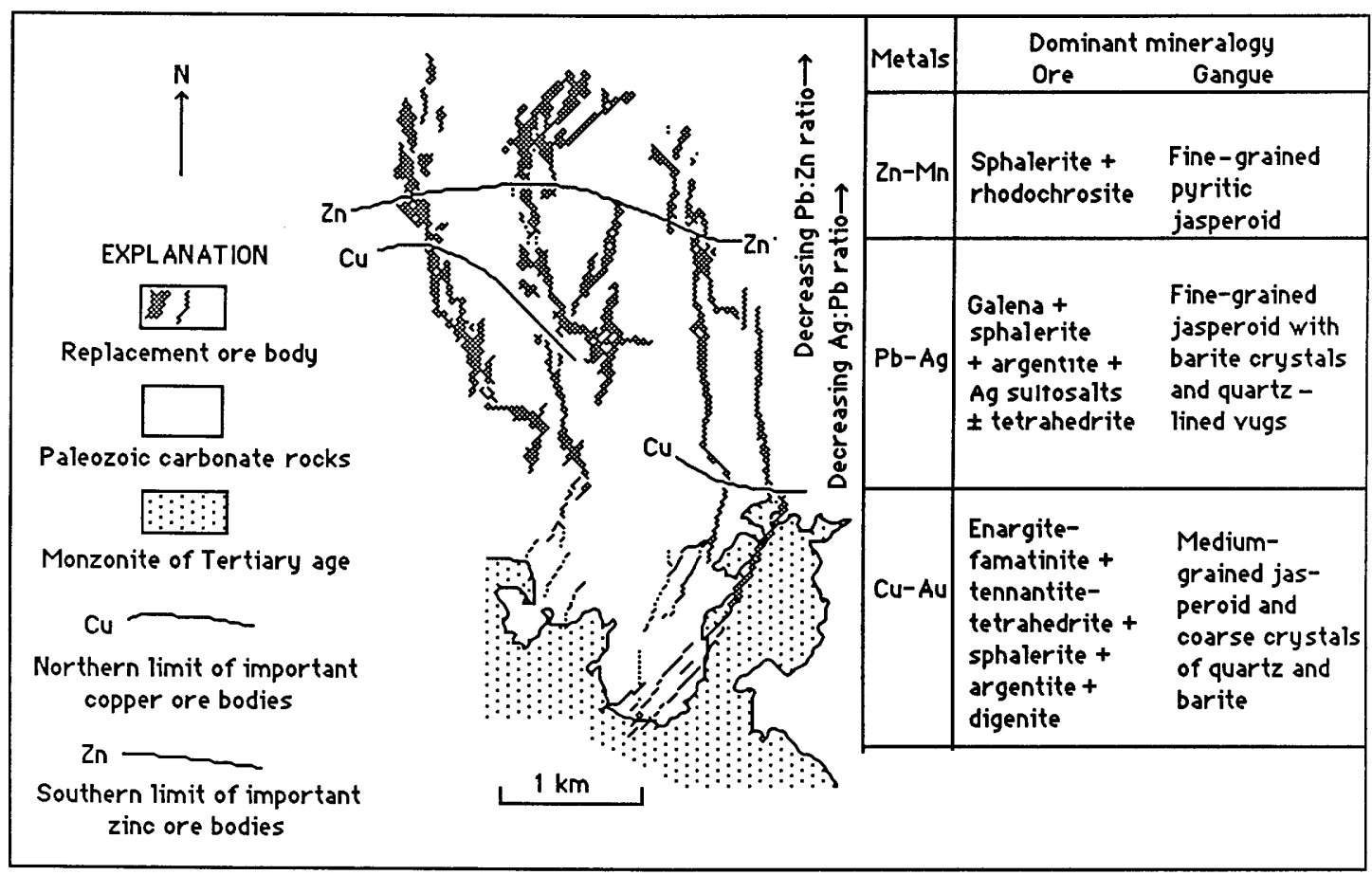

Figure 68. Generalized map showing metal and mineral zoning in polymetallic replacement deposits in the Main Tintic district, Utah. Modified from Morris (1968). 
Model 19a--Con.

\title{
GRAdE AND TONNAGE MODEL OF POLYMETALLIC REPLACEMENT DEPOSITS
}

\author{
By Dan L. Mosier, Hal T. Morris, and Donald A. Singer
}

COMMENTS Carbonate-hosted replacement and transitional vein and other replacement deposits are included. Only districts with combined production and reserves of at least 100,000 tonnes are used. Tonnages for many districts, particularly in the U.S. are biased because only production data were available. The break in slope in the zinc grade plot at about 1 percent may be related to early difficulties of processing zinc oxides, and the consequent underreporting of zinc grades where estimates were based on production. Lead grade is correlated with $\operatorname{silver}(r=0.55, n=$ 45). See figs. 69-74.

\section{DEPOSITS}

\begin{tabular}{llll} 
Name & Country & Name & Country \\
\cline { 2 - 3 } American Fork & USUT & Nakatatsu & JAPN \\
Atacocha & PERU & Mitate & JAPN \\
Bell & USNV & Naica & CNQU \\
Big Cottonwood-L.C. & USUT & New Calumet & GREC \\
Blue Bell & CNBC & Olympias Chalkidiki & USUT \\
Bolkardag & TRKY & Ophir & USUT \\
Bristol (Jack Rabbit) & USNV & Park City & MXCO \\
Cerro Gordo & USCA & Plomosas & USUT \\
Chalchihuites & MXCO & Rush Valley & USUT \\
Charcas & MXCO & San Francisco & MXCO \\
Cortez & USNV & Santa Eulalia & PERU \\
Darwin & USCA & Santander & YUGO \\
Drina & YUGO & Saua-Toranica & CILE \\
East Tintic & USUT & Silva-Aysen & MXCO \\
El Porvenir (Milpo) & PERU & Sombrerete & USNV \\
Eureka & USNV & Spruce Mountain & USUT \\
Hunnan & CINA & Star & YUGO \\
La Encantada & Sumadisa & USCA \\
La Reforma & MXCO & Tecopa & USUT \\
Lampazos & MXCO & Tintic & USAZ \\
Laurium & MXCO & Tombstone & YUGO \\
Liaoning & GREC & Trepca-Kopaonik & MXCO \\
Lone Mountain & VINA & White Pine & USNV \\
Magdalena & USNV & Yellow Pine & USNV \\
Maria Christina & Zimapan & MXCO \\
Mazapil & USNM & &
\end{tabular}


Model 19a--Con.

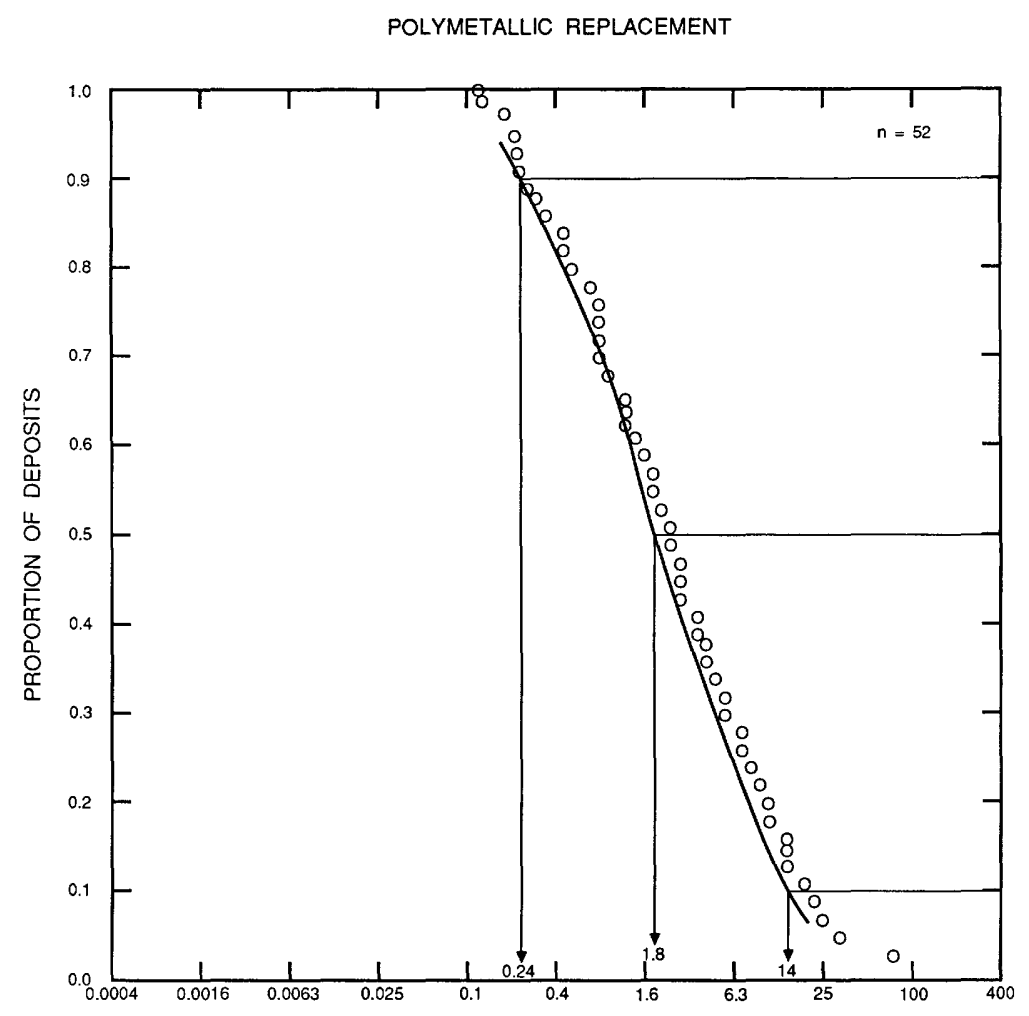

Figure 69. Tonnages of polymetallic replacement deposits.

MILLION TONNES

POLYMETALLIC REPLACEMENT

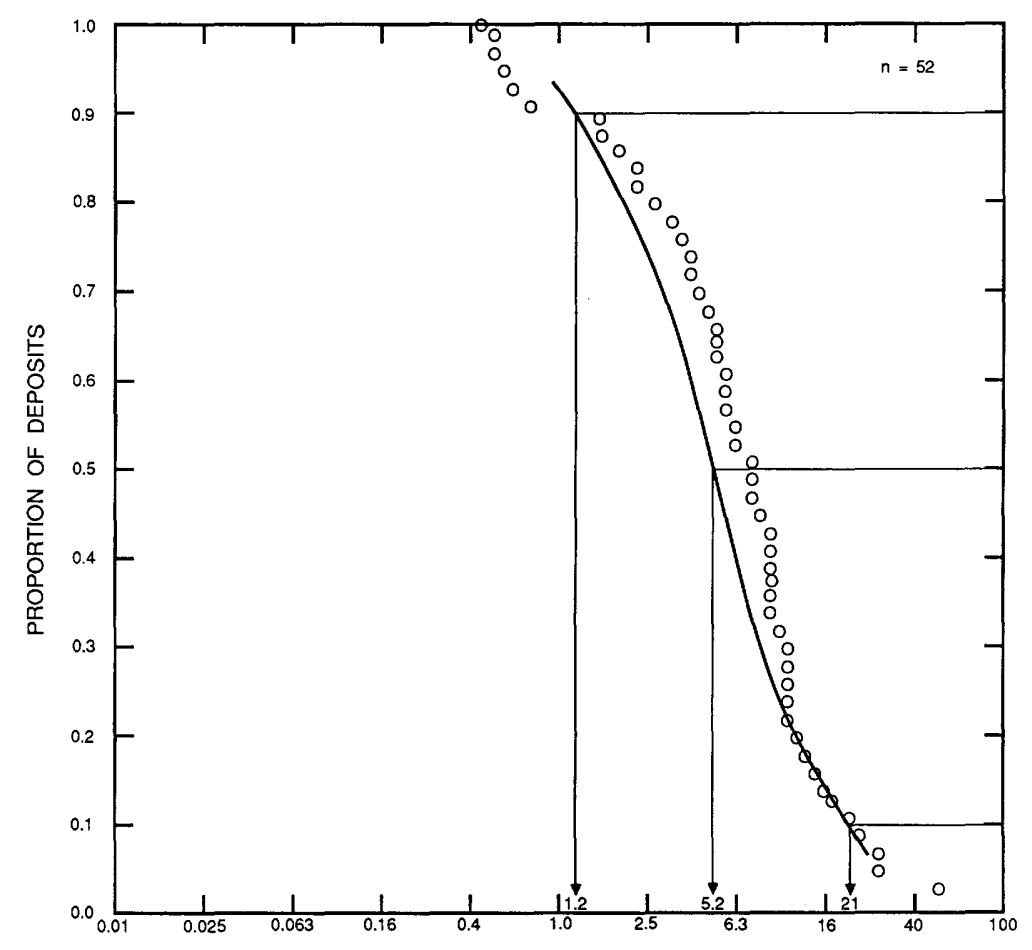

Figure 70. Lead grades of polymetall ic replacement deposits. LEAD GRADE IN PERCENT 
POLYMETALLIC REPLACEMENT

Model 19a--Con.

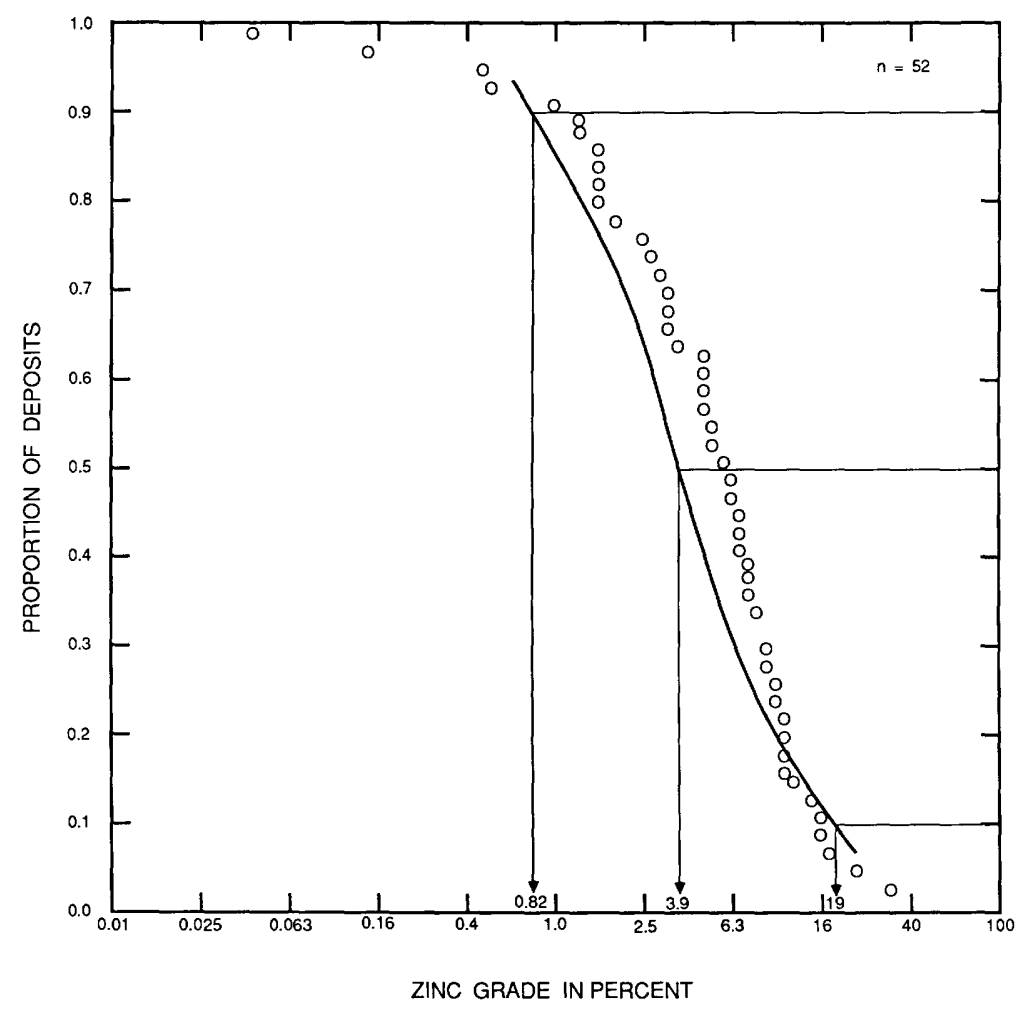

Figure 71. Zinc grades of polymetall ic replacement deposits.

POLYMETALLIC REPLACEMENT

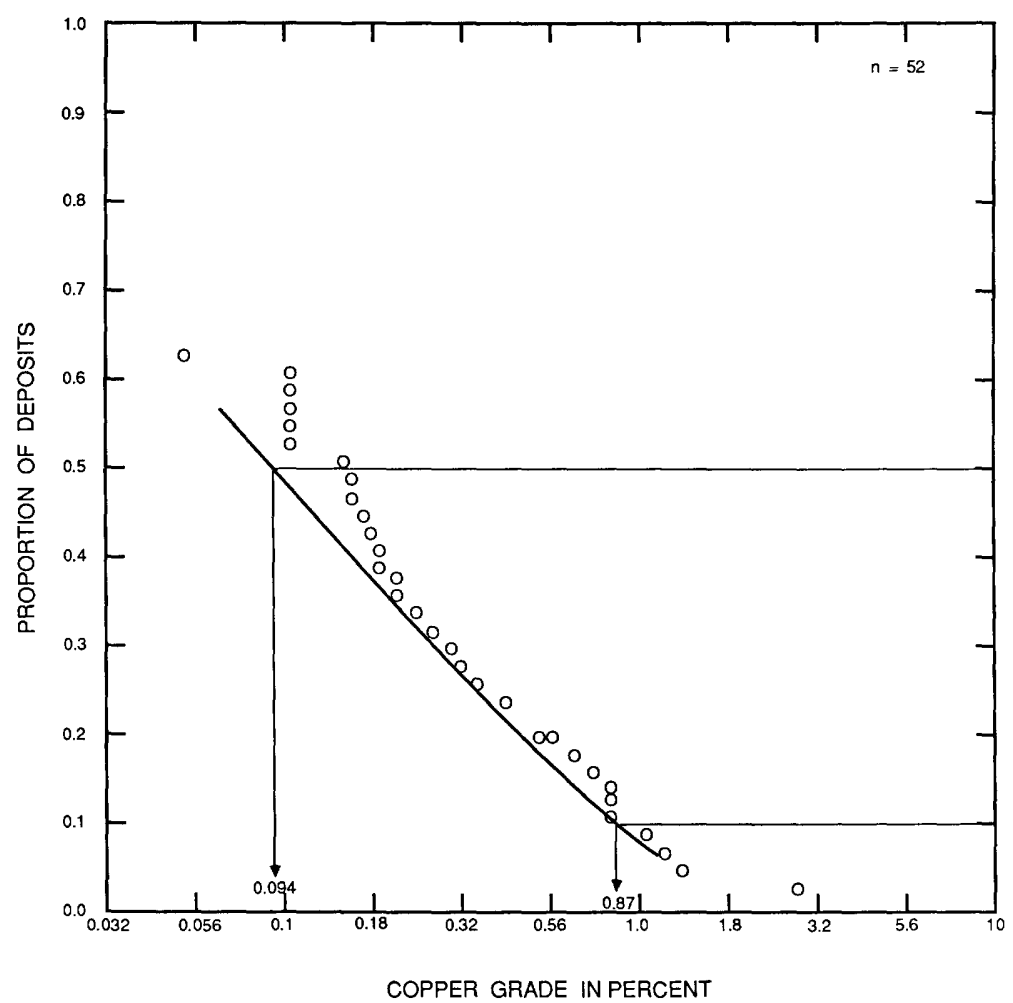

Figure 72. Copper grades of polymetallic replacement deposits. 
Model 19a--Con.

POLYMETALLIC REPLACEMENT

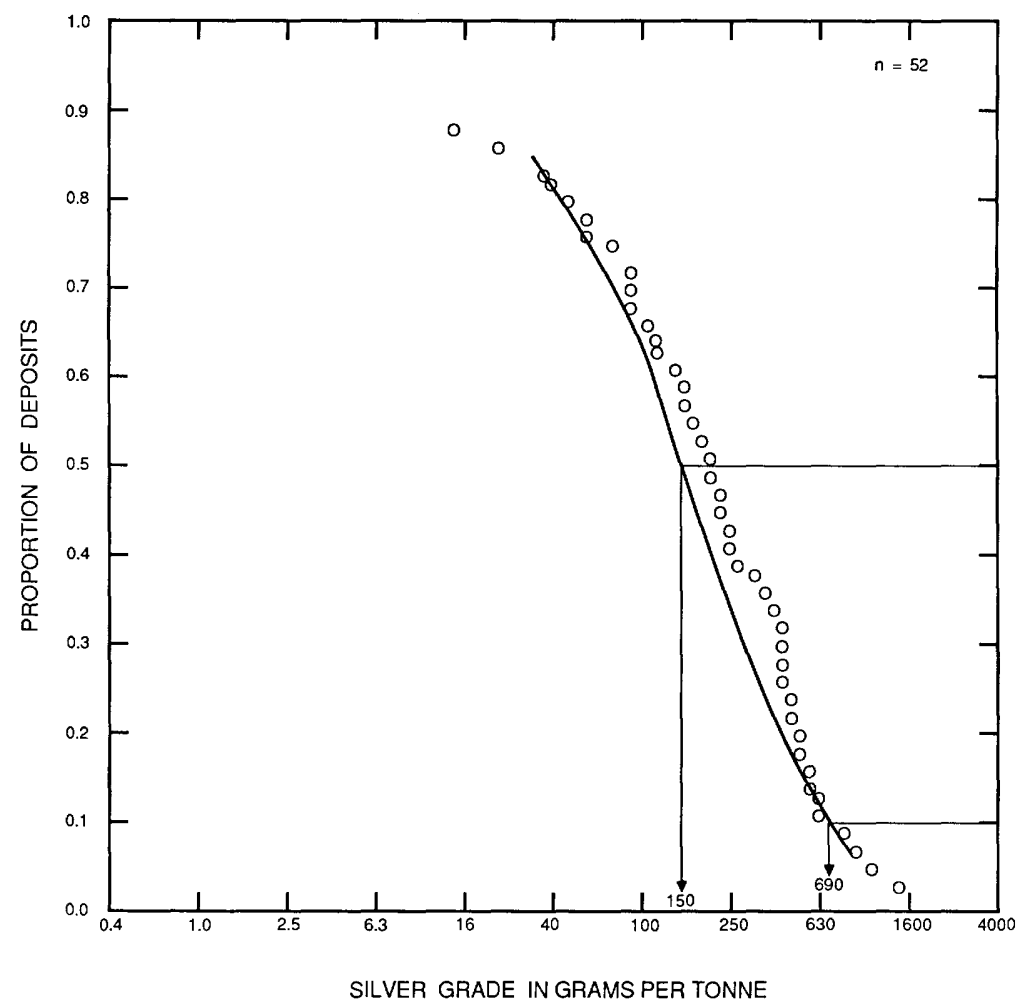

Figure 73. Sil ver grades of polymetallic replacement deposits.

POLYMETALLIC REPLACEMENT

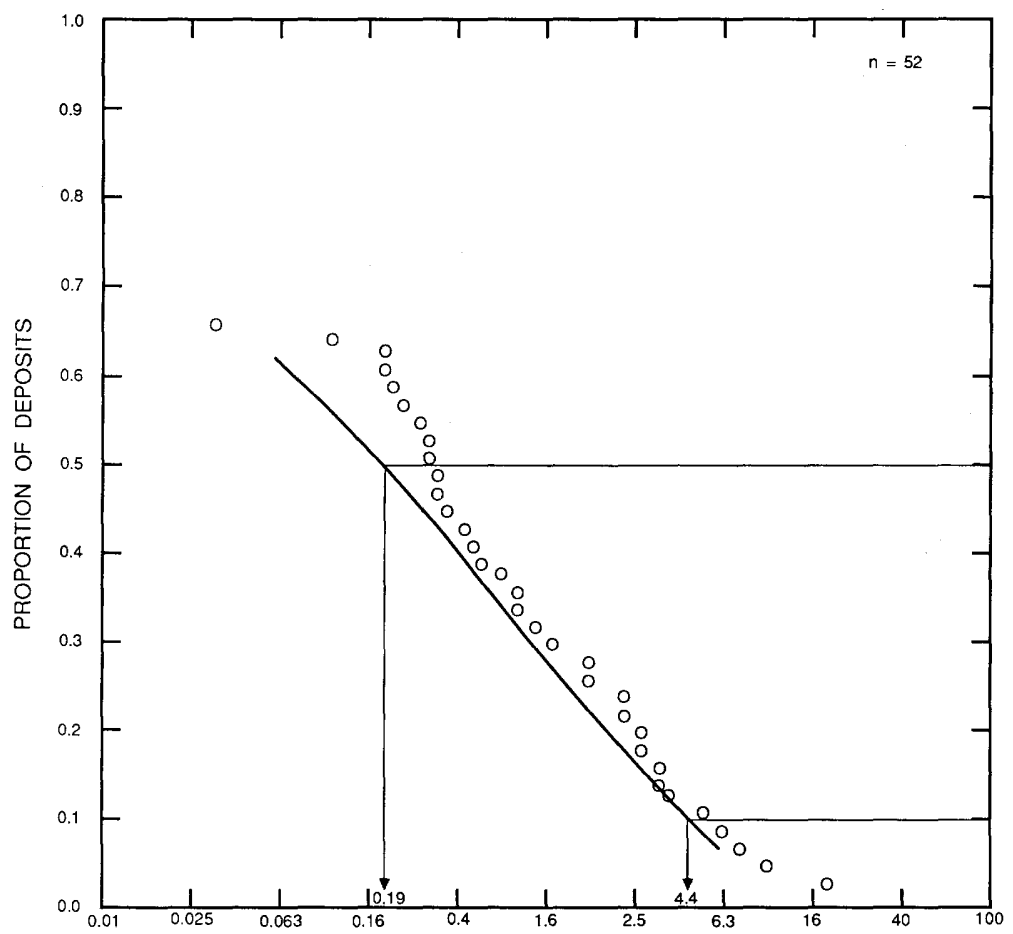

Figure 74. Gold grades of polymetallic replacement deposits. GOLD GRADE IN GRAMS PER TONNE 


\section{DESCRIPTIVE MODEL OF REPLACEMENT Mn}

By Dan L. Mosier

DESCRIPTION Manganese oxide minerals occur in epigenetic veins or cavity fillings in limestone, dolomite, or marble, which may be associated with intrusive complexes.

GEOLOGICAL ENVIRONMENT

Rock Types Limestone, dolomite, marble, and associated sedimentary rocks; granite and granodiorite plutons.

Age Range Mainly Paleozoic to Tertiary, but may be any age.

Depositional Environment Miogeosynclinal sequences intruded by small plutons.

Tectonic Setting(s) Orogenic belts, late orogenic magmatism.

Associated Deposit Types Polymetallic vein, polymetallic replacement, skarn Cu, skarn $\mathrm{Zn}$, porphyry copper.

DEPOSIT DESCRIPTION

Mineralogy Rhodochrosite \pm rhodonite + calcite + quartz \pm barite \pm fluorite \pm jasper \pm manganocalcite \pm pyrite \pm chalcopyrite \pm galena \pm sphalerite.

Texture/Structure Tabular veins, irregular open space fillings, lenticular pods, pipes, chimneys.

Ore Controls Fracture permeability in carbonate rocks. May be near intrusive contact.

Weathering Mn oxide minerals: psilomelane, pyrolusite, and wad form in the weathered zone and make up the richest parts of most deposits. Limonite and kaolinite.

Geochemical Signature $\mathrm{Mn}, \mathrm{Fe}, \mathrm{P}, \mathrm{Cu}, \mathrm{Ag}, \mathrm{Au}, \mathrm{Pb}, \mathrm{Zn}$.

EXAMPLES

Lake Valley, USNM (Farnham, 1961)

Philipsburg, USMT (Prinz, 1963)

Lammereck, ASTR

(Lechner and Plochinger, 1956)

GRADE AND TONNAGE MODEL OF REPLACEMENT Mn

By Dan L. Mosier

COMMENTS Copper grades are only available for some of the low tonnage deposits. See figs. 75-76. DEPOSITS

\begin{tabular}{llll} 
Name & Country & Name & Country \\
\cline { 2 - 4 } Atlas & USAZ & Golden Gate & USAZ \\
Bear Mountain & USNM & Hendricks-Twilight & USAZ \\
Birchfield & USNM & Kahal de Brezina & ALGR \\
Blinman & AUSA & Kingston & USNM \\
Brachy & FRNC & Lake Valley & USNM \\
Chloride Flat & USNM & Lammereck & ASTR \\
Crown King & USAZ & Las Ambollas & FRNC \\
Cynthia & GREC & Las Cabesses & FRNC \\
Danville-Hanchette & USAZ & Lone Mountain & USNM \\
Detroit & USUT & Los Volcanes & MXCO \\
Dinamita & MXCO & Mammoth & USAZ \\
Djebel El Aziza & TUNS & Mercedes & CUBA \\
Essex and Steptoe & USNV & Philipsburg & USMT
\end{tabular}


Model 19b--Con.

Poludnig-Hermagor

Oregon

Saligny

San Carlos

Sattelberges

Summit-No. 4
ASTR

USAZ

F RNC

MXCO

ASTR

USAZ
Thuburnic

TUNS

Ulukoy

Veitsch

Vorderen Strubberges

Waterloo

ASTR

ASTR

USAZ

REPLACEMENT MANGANESE

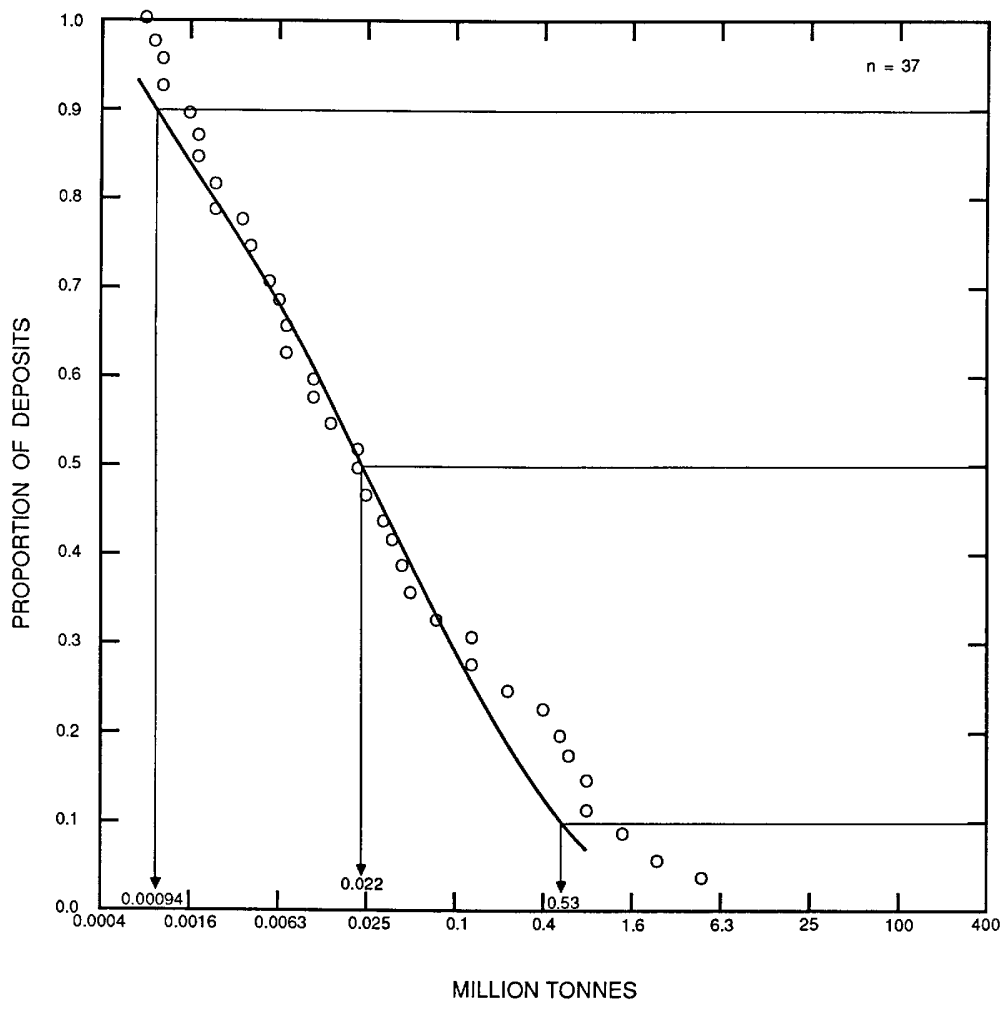

Figure 75. Tonnages of replacement Mn deposits. 
Model 19b--Con.

REPLACEMENT MANGANESE
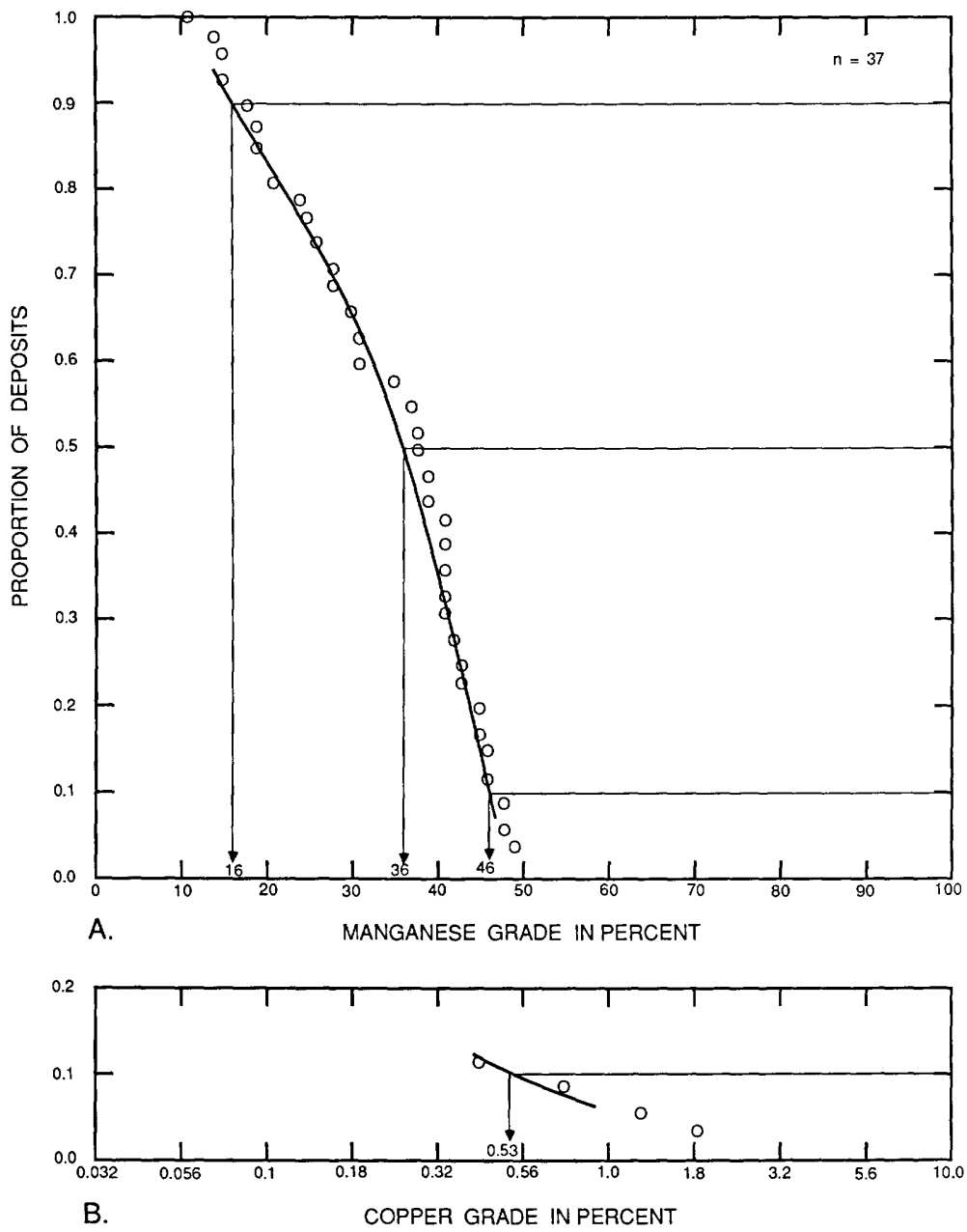

Figure 76. Manganese and copper grades of replacement Mn deposits. 


\section{DESCRIPTIVE MODEL OF PORPHYRY Sn}

By Bruce L. Reed

APPROXIMATE SYNONYM SUbvolcanic tin (Grant and others, 1977).

DESCRIPTION Subvolcanic intrusive complexes containing disseminated, veinlet- and brecciacontrolled fine-grained cassiterite in quartz porphyry and adjacent rocks.

GENERAL REFERENCE Grant and others (1980).

\section{GEOLOGICAL ENVIRONMENT}

Rock Types Intermediate to acid quartz porphyry stocks (quartz-latite, dacite, rhyodacite) and cogenetic calc-alkaline pyroclastics and lavas (quartz-latite to rhyodacite).

Textures Intrusions most closely associated with mineralization are strongly altered and brecciated quartz porphyry.

Age Range May be any age. Classic Bolivian porphyry tin deposits are Miocene. Subvolcanic W-MoSn deposits at Mount Pleasant, New Brunswick, are late Carboniferous.

Depositional Environment Subvolcanic stocks emplaced 1 to $3 \mathrm{~km}$ beneath or within vents of terrestrial strato-volcanoes.

Tectonic Setting(s) Paleozoic foldbelt cut by subduction-generated high-level stocks and cogenetic volcanic rocks.

Associated Deposit Types $S n$ veins and $S n$ polymetallic veins.

DEPOSIT DESCRIPTION

Mineralogy Cassiterite and quartz accompanied by sulfide minerals (chiefly pyrite) but including pyrrhotite, stannite, chalcopyrite, sphalerite, and arsenopyrite; late veins commonly carry complex sulfostannates and Ag minerals.

Texture/Structure Disseminations, veinlets, and fractures in igneous breccia and adjacent wallrock; stocks commonly funnel-shaped and $1-2 \mathrm{~km}^{2}$.

Alteration Pervasive alteration and porphyry tin mineralization predates tin-silver veins; concentric zoning grades from a central quartz-tourmaline core (minor disseminated cassiterite), outward to sericite-tourmaline, sericite (closely related to disseminated cassiterite), and propylitic alteration; argillic alteration present in upper parts of some systems.

Ore Controls Porphyry mineralization is breccia controlled and centered on stocks emplaced in the inner, deeper regions of volcanoes; close relation between disseminated cassiterite and sericitic alteration; late fracture-controlled quartz-cassiterite and quartz-cassiterite-sulfide veins occur within or near the margins of intrusive centers.

Weathering Surface iron staining variable (pyrite); supergene enrichment unlikely; cassiterite may be concentrated in nearby placer deposits.

Geochemical Signature: $\mathrm{Sn}+\mathrm{B}$ center; $\mathrm{Sn}, \mathrm{Ag}, \mathrm{Pb}, \mathrm{Zn}, \mathrm{As}, \mathrm{Sb}, \mathrm{Cu}, \mathrm{Ba}$ in outer zone.

EXAMPLES

Chorolque, BLVA (Grant and others, 1980)
Catavi (Salvadora stock,
Llallagua), BLVA (Sillitoe and others, 1975) 


\section{DESCRIPTIVE MODEL OF Sn-POLYMETALLIC VEINS}

by Yukio Togashi (Geological Survey of Japan)

APPROXIMATE SYNONYMS Polymetallic xenothermal (Imai and others, 1978), Bolivian subvolcanic multistage.

DESCRIPTION Multistage Cu-Zn-Sn-Ag-bearing veins associated with felsic ignimbrites and subvolcanic intrusions.

GENERAL REFERENCES Nakamura and Hunahashi (1970), Grant and others (1977).

GEOLOGICAL ENVIRONMENT

Rock Types Rhyolitic tuff, welded tuff and tuff breccia. Rhyolitic to basaltic dikes. Sandstone, slate, chert, and basic tuff.

Textures Welded and airfall tuff. Porphyritic-aphanitic intrusives.

Age Range Late Cretaceous to Miocene in Japan, Miocene in Bolivia, but may be any age.

Depositional Environment Fissures in and around felsic ignimbrite.

Tectonic Setting(s) Continental margin. Syn-late orogenic.

Associated Deposit Types Polymetallic replacement, epithermal Ag veins, porphyry Sn. DEPOSIT DESCRIPTION

Mineralogy Cassiterite, chalcopyrite, sphalerite, pyrrhotite, pyrite, galena, scheelite, wolframite, arsenopyrite, native bismuth, bismuthinite, argentite, native gold, magnetite, molybdenite, and complex sulfosalt minerals including teallite, frankeite, cylindrite, and stannite.

Texture/Structure Multistage composite veins with $\mathrm{Sn}, \mathrm{Cu}, \mathrm{Zn}$, and $\mathrm{Ag}$ minerals occurring in the same vein.

Alteration Minor quartz-chlorite-sericite alteration close to veins. Tourmaline, fluorite, or siderite may be present.

Ore Controls Veins, breccia veins, and breccia pipes. Metal zoning sequence is $\mathrm{Sn}+\mathrm{W}$ to $\mathrm{Cu}+\mathrm{Sn}$, $\mathrm{Cu}+\mathrm{Zn}, \mathrm{Pb}+\mathrm{Zn}, \mathrm{Pb}+\mathrm{Ag}, \mathrm{Au}+\mathrm{Ag}$ from center to periphery, or from depths to shallow levels. Zones are commonly superimposed or "telescoped" to produce complex veins.

Weathering Limonitization. Cassiterite in soils and gossans.

Geochemical Signature $\mathrm{Cu}, \mathrm{Zn}, \mathrm{Sn}, \mathrm{Pb}, \mathrm{W}, \mathrm{Au}, \mathrm{Ag}, \mathrm{Bi}, \mathrm{As}$.

\section{EXAMPLES}

Ashio, Akenobe, Ikuno, Kishu, JAPN

Potosi, BLVA

(Nakamura, 1970)

(Turneaure, 1971) 
Model 20c

\section{DESCRIPTIVE MODEL OF PORPHYRY Cu-Au}

By Dennis P. Cox

DESCRIPTION Stockwork veinlets of chalcopyrite, bornite, and magnetite in porphyritic intrusions and coeval volcanic rocks. Ratio of Au ( $\mathrm{ppm}$ ) to Mo (percent) is greater than 30 (see fig. 77). GENERAL REFERENCES Sillitoe (1979), Cox and Singer (in press).

\section{GEOLOGICAL ENVIRONMENT}

Rock Types Tonalite to monzogranite; dacite, andesite flows and tuffs coeval with intrusive rocks. Also syenite, monzonite, and coeval high-K, low-Ti volcanic rocks (shoshonites).

Textures Intrusive rocks are porphyritic with fine- to medium-grained aplitic groundmass.

Age Range Cretaceous to Quaternary.

Depositional Environment In porphyry intruding coeval volcanic rocks. Both involved and in largescale breccia. Porphyry bodies may be dikes. Evidence for volcanic center; 1-2 km depth of emplacement.

Tectonic Setting(s) Island-arc volcanic setting, especially waning stage of volcanic cycle. Also continental margin rift-related volcanism.

Associated Deposit Types Porphyry Cu-Mo; gold placers.

\section{DEPOSIT DESCRIPTION}

Mineralogy Chalcopyrite \pm bornite; traces of native gold, electrum, sylvanite, and hessite. Quartz + K-feldspar + biotite + magnetite \pm chlorite \pm actinolite \pm anhydrite. Pyrite + sericite \pm clay minerals \pm calcite may occur in late-s̄tage veinlēts.

Texture/Structure Veinlets and disseminations.

Alteration Quartz \pm magnetite \pm biotite (chlorite) \pm K-feldspar \pm actinolite, \pm anhydrite in interior of system. Outer propylitic zone. Late quartz + pyrite + white mica \pm clay may overprint early feldspar-stable alteration.

Ore Controls Veinlets and fractures of quartz, sulfides, K-feldspar magnetite, biotite, or chlorite are closely spaced. Ore zone has a bell shape centered on the volcanic-intrusive center. Highest grade ore is commonly at the level at which the stock divides into branches.

Weathering Surface iron staining may be weak or absent if pyrite content is low in protore. Copper silicates and carbonates. Residual soils contain anomalous amounts of rutile.

Geochemical Signature Central $\mathrm{Cu}$, $\mathrm{Au}$, $\mathrm{Ag}$; peripheral Mo. Peripheral $\mathrm{Pb}$, $\mathrm{Zn}$, Mn anomalies may be present if late sericite pyrite alteration is strong. Au (ppm):Mo (percent) 30 in ore zone. Au enriched in residual soil over ore body. System may have magnetic high over intrusion surrounded by magnetic low over pyrite halo.

EXAMPLES

$\begin{array}{ll}\text { Dos Pobres, USAZ } & \text { (Langton and Williams, 1982) } \\ \text { Copper Mountain, CNBC } & \text { (Fahrni and others, 1976) } \\ \text { Tanama, PTRC } & \text { (Cox, 1985) }\end{array}$

\section{GRADE AND TONNAGE MODEL OF PORPHYRY Cu-Au}

By Donald A. Singer and Dennis P. Cox

COMMENTS See figs. 78-81. 
Model 20c--Con.

DEPOSITS

\begin{tabular}{llll} 
Name & Country & Name & Country \\
\cline { 2 - 3 } Afton & CNBC & Mamut & MDGS \\
Amacan & PLPN & Mapula & PLPN \\
Atlas Lutopan & PLPN & Marcopper & PLPN \\
Basay & PLPN & Marian & PLPN \\
Bell Copper & CNBC & Mountain Mines & PPNG \\
Boneng Lobo & PLPN & Ok Tedi & PPNG \\
Cariboo Bell & CNBC & Panguana & CNBC \\
Copper Mountain & CNBC & Red Chris & PTRC \\
Cubuagan & PLPN & Rio Vivi & PKTN \\
Dizon & PLPN & Saindak South & PLPN \\
Dos Pobres & USAZ & San Antonio & PLPN \\
Fish Lake & CNBC & San Fabian & PLPN \\
Frieda River & PPNG & Santo Nino & PLPN \\
Galore Creek & CNBC & Santo Tomas & PPNG \\
Hinobaan & PLPN & Star Mt.-Fubilan & PPNG \\
Ingerbelle & CNBC & Star Mt.-Futik & PTRC \\
Kennon & PLPN & Tanama & PLPN \\
La Alumbrera & AGTN & Tawi-Tawi & PLPN \\
Lorraine & CNBC & Taysan & PLPN \\
Lumbay & PLPN & Toledo &
\end{tabular}

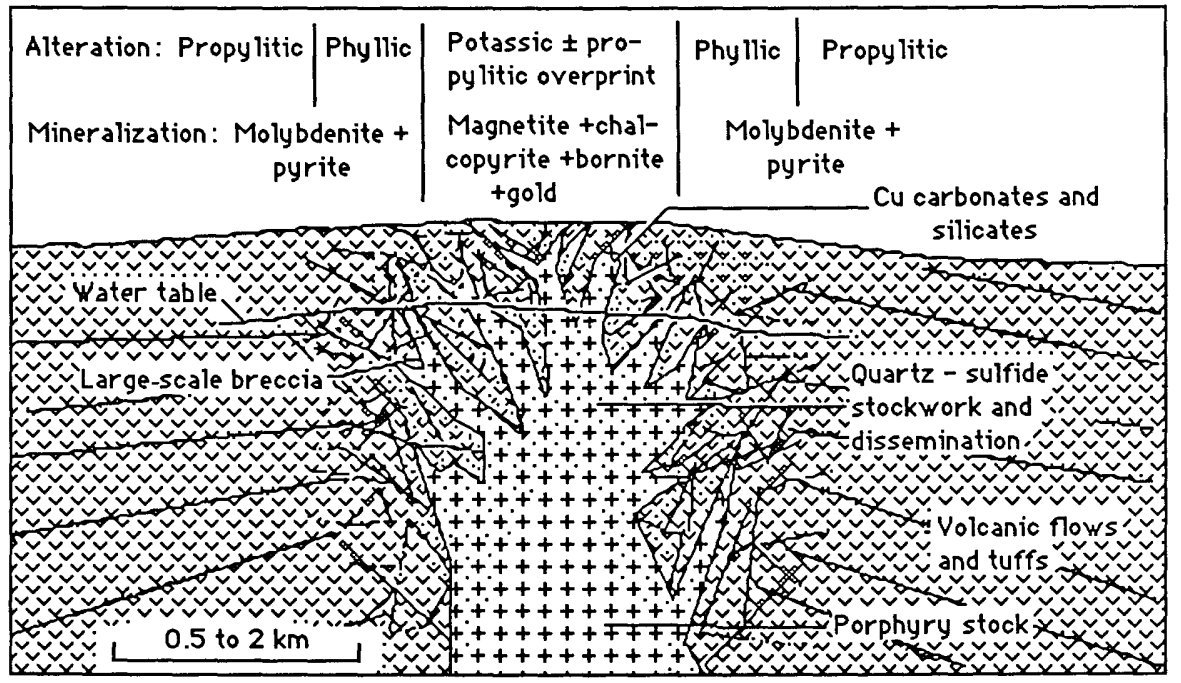

Figure 77. Cartoon cross section of porphyry $\mathrm{Cu}-\mathrm{Au}$ deposit. Modified from Langton and Williams (1982). 
Model 20c--Con.

Figure 78. Tonnages of porphyry $\mathrm{Cu}-\mathrm{Au}$ deposits.
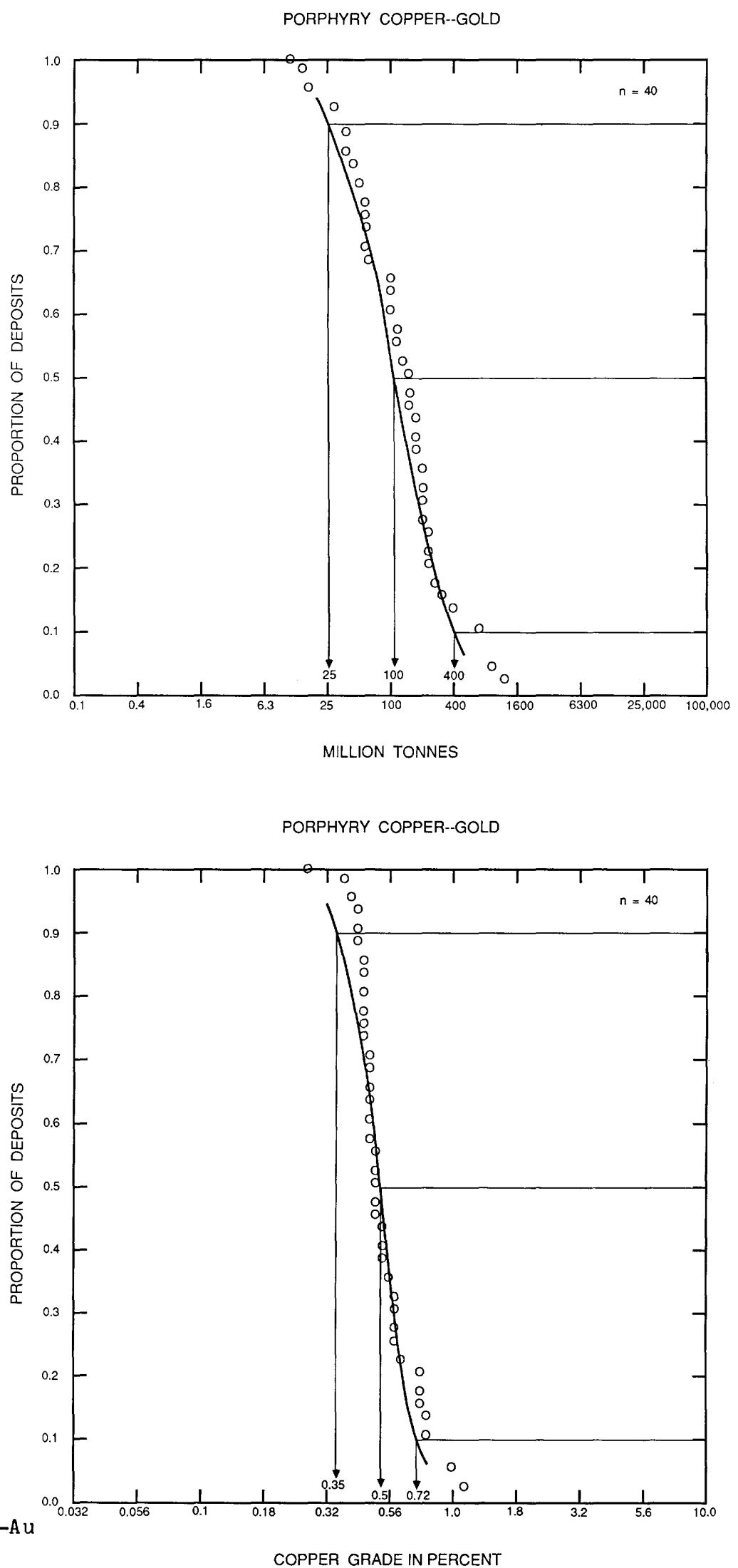

Figure 79. Copper grades of porphyry $\mathrm{Cu}-\mathrm{Au}$ deposits. 


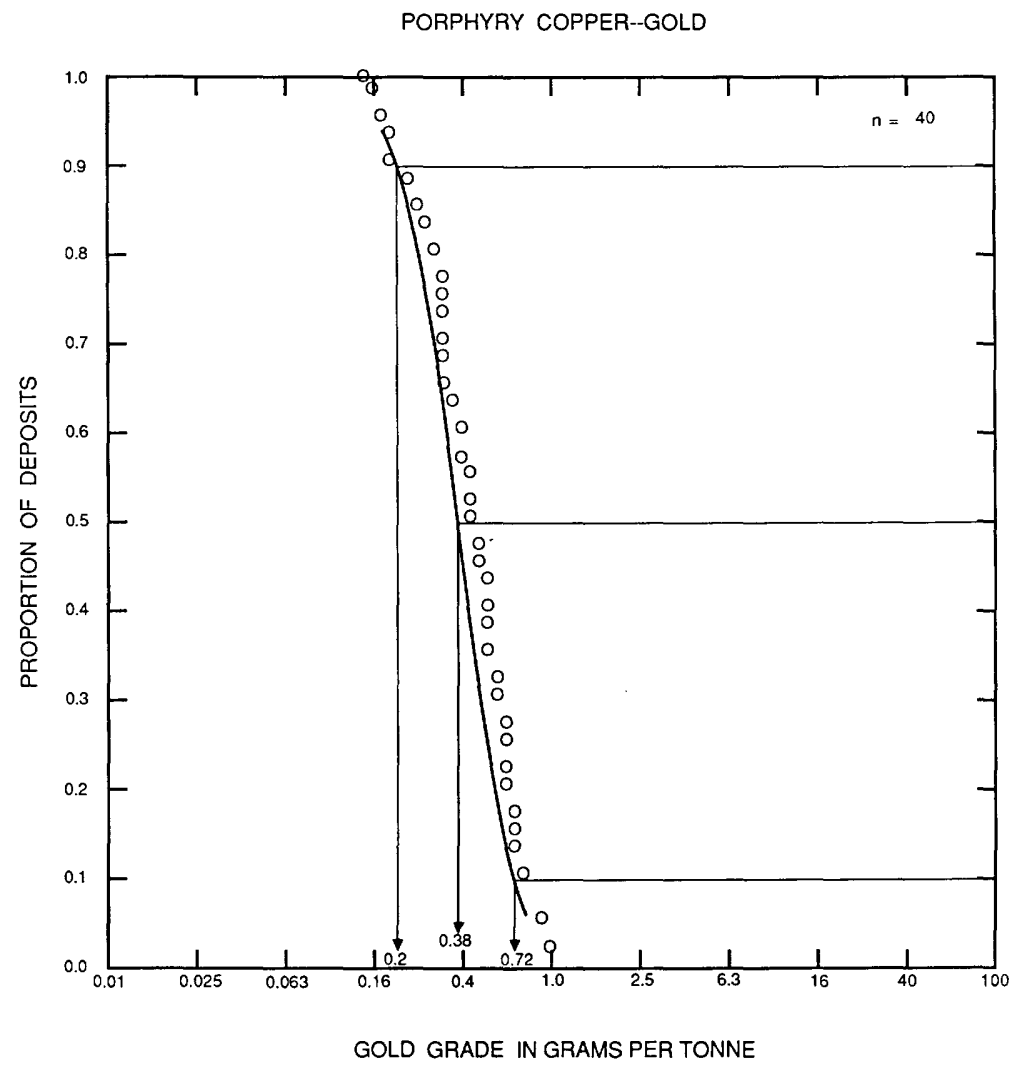

Figure 80. Gold grades of porphyry $\mathrm{Cu}-\mathrm{Au}$ deposits. 
Model 20c--Con.

PORPHYRY COPPER--GOLD

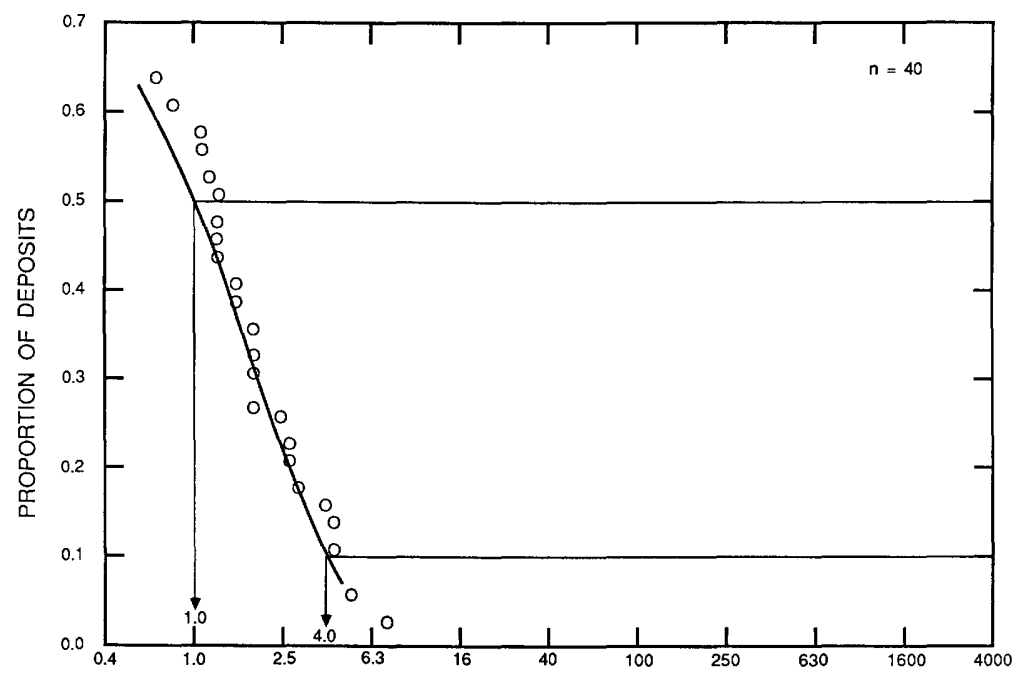

A.

SILVER GRADE IN GRAMS PER TONNE

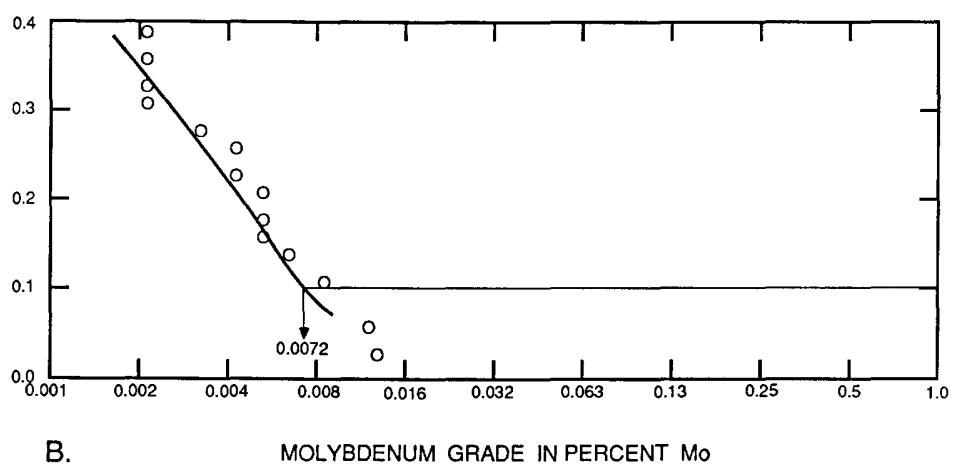

Figure 81. By-product grades of porphyry

$\mathrm{Cu}-\mathrm{Au}$ deposits. A, Silver. $\underline{\mathrm{B}}$, Mol ybdenum. 


\section{DESCRIPTIVE MODEL OF PORPHYRY CU-Mo}

By Dennis P. Cox

DESCRIPTION Stockwork veinlets of quartz, chalcopyrite, and molybdenite in or near a porphyritic intrusion. Ratio of $\mathrm{Au}$ (in $\mathrm{ppm}$ ) to Mo (in percent) less than 3 (See fig. 82).

GENERAL REFERENCE Titley (1982).

GEOLOGICAL ENVIRONMENT

Rock Types Tonalite to monzogranite stocks and breccia pipes intrusive into batholithic, volcanic, or sedimentary rocks.

Textures Intrusions contemporaneous with ore commonly are porphyries with fine- to medium-grained aplitic groundmass. Porphyry texture may be restricted to small dikes in some deposits (Brenda).

Age Range Mainly Mesozoic to Tertiary, but can be any age.

Depositional Environment High-level intrusive porphyry contemporaneous with abundant dikes, faults, and breccia pipes. Cupolas of batholiths.

Tectonic Setting(s) Numerous faults in subduction-related volcanic plutonic arcs. Mainly along continental margins but also in oceanic convergent plate boundaries.

Associated Deposit Types $\mathrm{Cu}, \mathrm{Zn}$, or Fe skarns may be rich in gold, gold + base-metal sulfosalts in veins, gold placers. Volcanic-hosted massive replacement and polymetallic replacement.

\section{DEPOSIT DESCRIPTION}

Mineralogy Chalcopyrite + pyrite + molybdenite. Peripheral vein or replacement deposits with chalcopyrite + sphalerite + galena \pm gold. Outermost zone may have veins of $\mathrm{Cu}-\mathrm{Ag}-\mathrm{Sb}-\mathrm{sulfides}$, barite, and gold.

Texture/Structure Veinlets and disseminations or massive replacement of favorable country rocks.

Alteration Quartz + K-feldspar + biotite (chlorite) \pm anhydrite (potassic alteration) grading outward to propylitic. Late white mica + clay (phyllic) alteration may form capping or outer zone or may affect the entire deposit. High-alumina alteration assemblages may be present in upper levels of the system (see table 3 ).

Ore Controls Ore grade is, in general, positively correlated with spacing of veinlets and mineralized fractures. Country rocks favorable for mineralization are calcareous sediments; diabase, tonalite, or diorite.

Weathering Intense leaching of surface; wide areas of iron oxide stain. Fractures coated with hematitic limonite. Supergene copper as chalcocite may form blanket below leached zone. Residual soils may contain anomalous amounts of rutile.

Geochemical Signature $\mathrm{Cu}+\mathrm{Mo}+\mathrm{Ag} \pm \mathrm{W} \pm \mathrm{B} \pm \mathrm{Sr}$ center; $\mathrm{Pb}, \mathrm{Zn}, \mathrm{Au}, \mathrm{As}, \mathrm{Sb}, \mathrm{Se}, \mathrm{Te}, \mathrm{Mn}, \mathrm{Co}, \mathrm{Ba}$, and $\mathrm{Rb}$ in outer zone. Locally $\mathrm{Bi}$ and $\mathrm{Sn}$ form distal anomalies. High $\mathrm{S}$ in all zones. Ratio of $\mathrm{Au}$ $(\mathrm{ppm})$ : Mo (percent) $\leq 3$. Magnetic low.

EXAMPLES

Brenda, CNBC

Sierrita Esperanza, USAZ
(Soregaroli and Whitford, 1976)

(West and Aiken, 1982) 
Model 21a--Con.

GRADE AND TONNAGE MODEL OF PORPHYRY Cu-Mo

By Donald A. Singer, Dennis P. Cox, and Dan L. Mosier

COMMENTS These deposits are a subset of porphyry Cu-Mo deposits for which a $\mathrm{Cu}$, Mo and $\mathrm{Au}$ grade were available. See figs. 83-87.

\section{DEPOSITS}

Name

Berg

Bethlehem

Brenda

Gambier Island

Gaspe

Gibraltar

Highmont

Huckleberry

\begin{tabular}{|c|c|c|}
\hline Country & Name & Country \\
\hline CNBC & Inspiration & USNM \\
\hline $\mathrm{CNBC}$ & Lornex & CNBC \\
\hline $\mathrm{CNBC}$ & Morenci & USAZ \\
\hline $\mathrm{CNBC}$ & Ray & USAZ \\
\hline CNQU & Sierrita-Esperanza & USAZ \\
\hline $\mathrm{CNBC}$ & Tyrone & USNM \\
\hline $\mathrm{CNBC}$ & Twin Buttes & USAZ \\
\hline $\mathrm{CNBC}$ & Valley Copper & CNBC \\
\hline
\end{tabular}

Figure 82. Cartoon cross section of porphyry Cu-Mo deposit showing relationship between mineral- and alteration-zoning and igneous intrusion. 
Model 21a--Con.

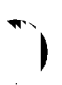

PORPHYRY COPPER--MOLYBDENUM

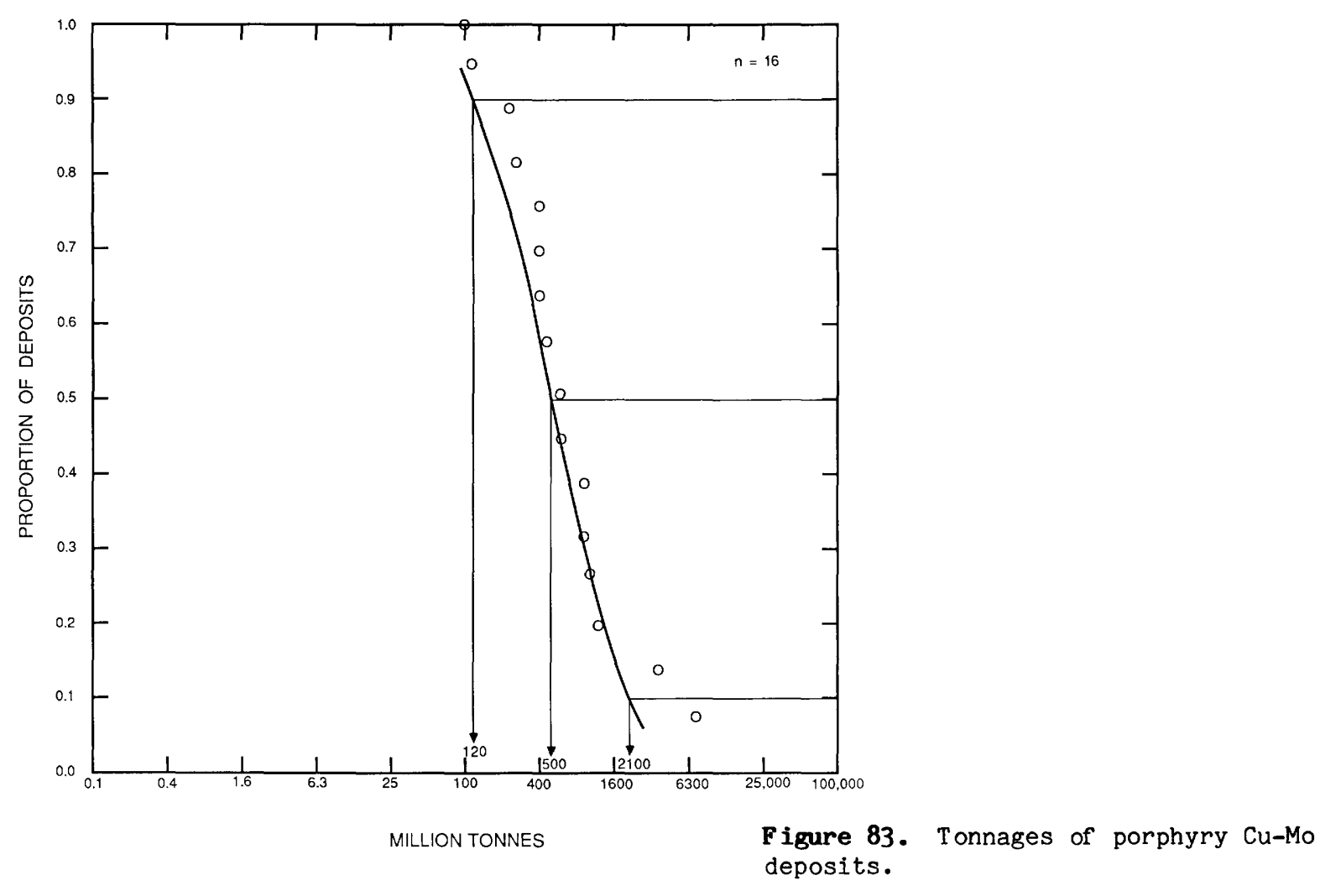

PORPHYRY COPPER--MOLYBDENUM

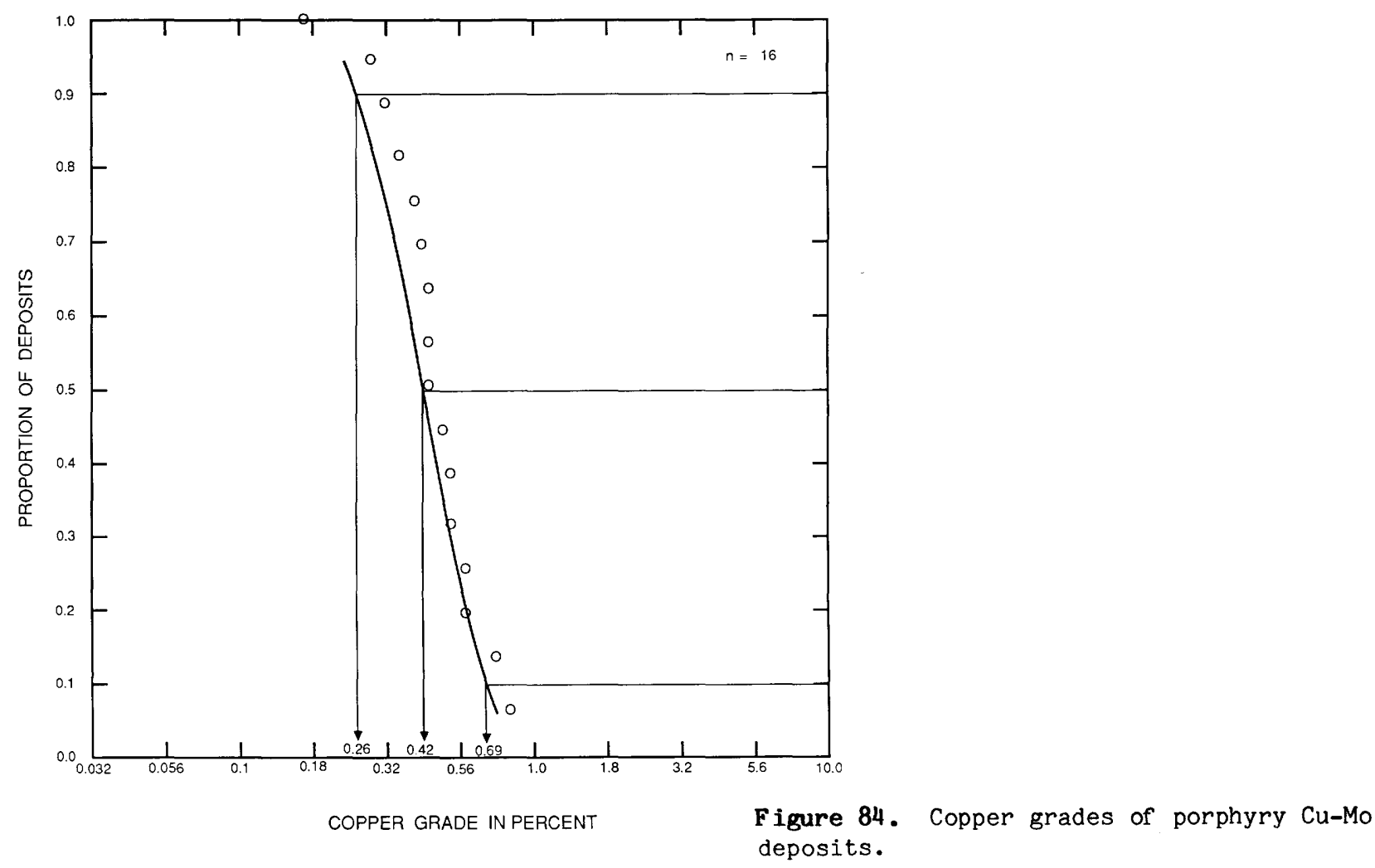


Model 21a--Con.

PORPHYRY COPPER--MOLYBDENUM

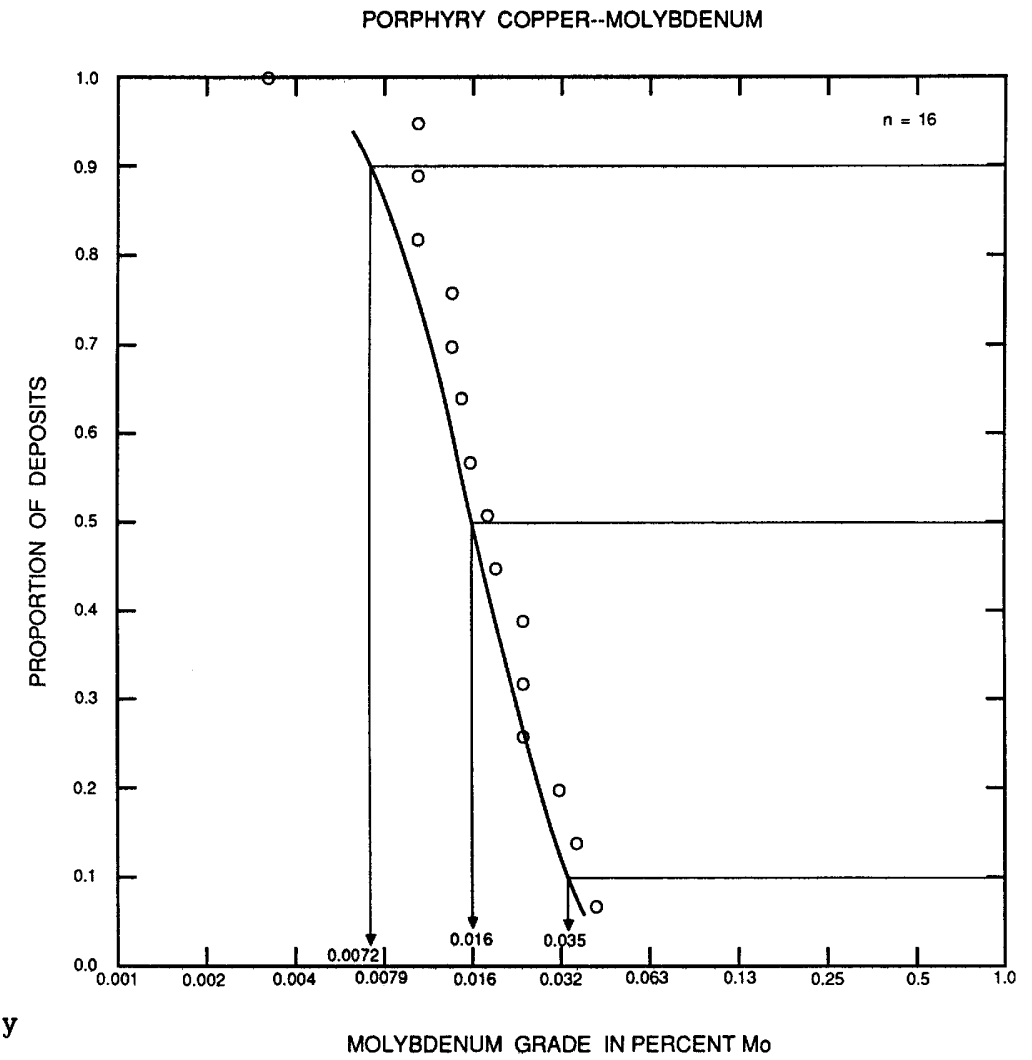

F igure 85. Mol ybdenum grades of porphyry Cu-Mo deposits.

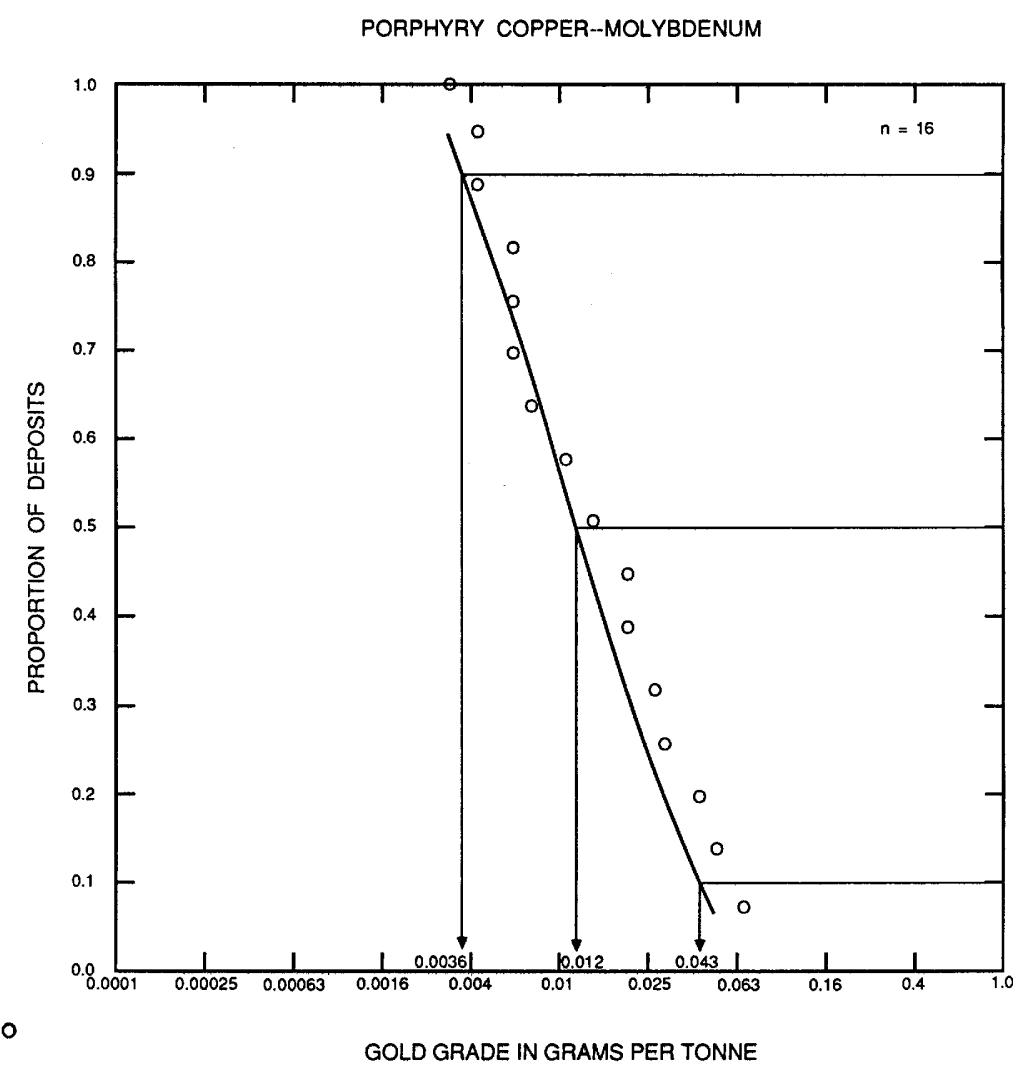

Figure 86. Gold grades of porphyry Cu-Mo deposits. 


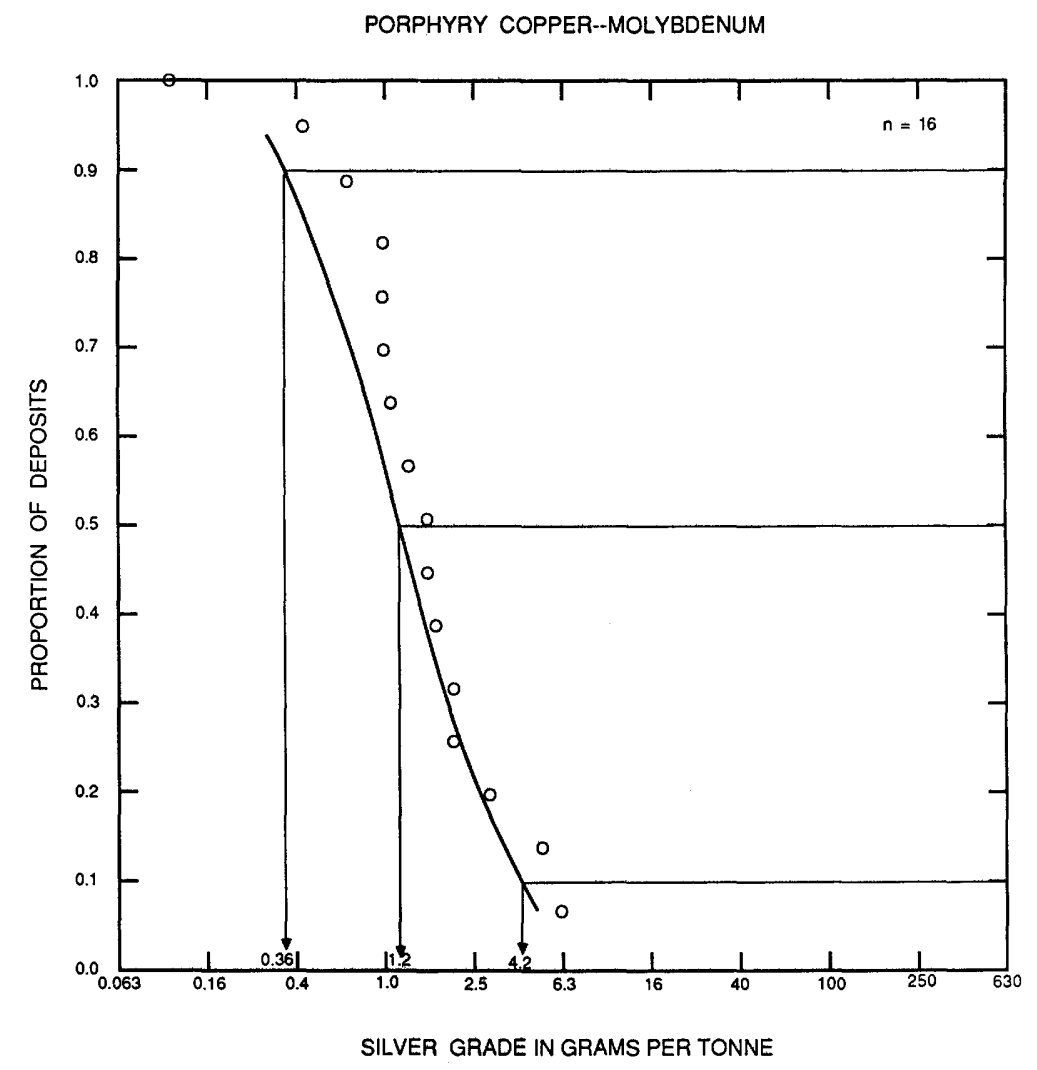

Figure 87. Silver grades of porphyry Cu-Mo deposits. 
Model 21b

\section{DESCRIPTIVE MODEL OF PORPHYRY MO, LOW-F}

By Ted G. Theodore

APPROXIMATE SYNONYM Calc-alkaline Mo stockwork (Westra and Keith, 1981).

DESCRIPTION Stockwork of quartz-molybdenite veinlets in felsic porphyry and in its nearby country rock.

GENERAL REFERENCE Westra and Keith (1981).

GEOLOGICAL ENVIRONMENT

Rock Types Tonalite, granodiorite, and monzogranite.

Textures Porphyry, fine aplitic groundmass.

Age Range Mesozoic and Tertiary.

Depositional Environment Orogenic belt with calcalkaline intrusive rocks.

Tectonic Setting(s) Numerous faults.

Associated Deposit Types Porphyry Cu-Mo, Cu skarn, volcanic hosted Cu-As-Sb.

DEPOSIT DESCRIPTION

Mineralogy Molybdenite + pyrite \pm scheelite \pm chalcopyrite \pm argentian tetrahedrite. Quartz + Kfeldspar + biotite \pm calcite \pm white mica and clays.

Texture/Structure Disseminated and in veinlets and fractures.

Alteration Potassic outward to propylitic. Phyllic and argillic overprint (see table 3 ).

Ore Controls Stockwork in felsic porphyry and in surrounding country rock.

Weathering Yellow ferrimolybdite after molybdenite. Secondary copper enrichment may form copper ores in some deposits.

Geochemical Signature Zoning outward and upward from Mo $+\mathrm{Cu} \pm \mathrm{W}$ to $\mathrm{Cu}+\mathrm{Au}$ to $\mathrm{Zn}+\mathrm{Pb},+\mathrm{Au},+$ $\mathrm{Ag}$. $\mathrm{F}$ may be present but in amounts less than 1,000 ppm.

EXAMPLES

Buckingham, USNV (Blake and others, 1979)

USSR deposits (Pavlova and Rundquist, 1980)

\section{GRADE AND TONNAGE MODEL OF PORPHYRY Mo, LOH-F}

By W. David Menzie and Ted G. Theodore

COMMENTS See figs. $88,89$.

DATA REFERENCE Theodore and Menzie (1983).

DEPOSITS

Name

Anduramba

Adanac (Ruby Creek)

Ajax (Dak River)

B. C. Moly

Bell Molybdenum
Country Name

AUQL

CNBC

CNBC

CNBC

CNBC
Boss Mountain

Boswell River

Buckingham

Cannivan Gulch

Carmi
Country

CNBC

CNYT

USNV

USMT

CNBC 
Model 21b--Con.

$\begin{array}{ll}\text { Creston } & \text { MXCO } \\ \text { Endako } & \text { CNBC } \\ \text { Gem } & \text { CNBC } \\ \text { Glacier Gulch } & \text { CNBC } \\ \text { Hall } & \text { USNV } \\ \text { Haskin Mountain } & \text { CNBC } \\ \text { Karen } & \text { CNBC } \\ \text { Lucky Ship } & \text { CNBC } \\ \text { Machkatica } & \text { YUGO } \\ \text { Mount Thomlinson } & \text { CNBC } \\ \text { Mount Tolman } & \text { USWA } \\ \text { Pine Nut } & \text { USNV }\end{array}$

Pitman (JB) CNBC

Quartz Hill USAK

Red Bird CNBC

Red Mountain CNYT

Serb Creek CNBC

Setting Net Lake CNON

Storie CNBC

Sunshine Creek CNBC

Thompson Creek USID

Trout Lake CNBC

UV Industries USNV 
Model 21b--Con.

Figure 88. Tonnages of porphyry Mo-l ow F deposits.
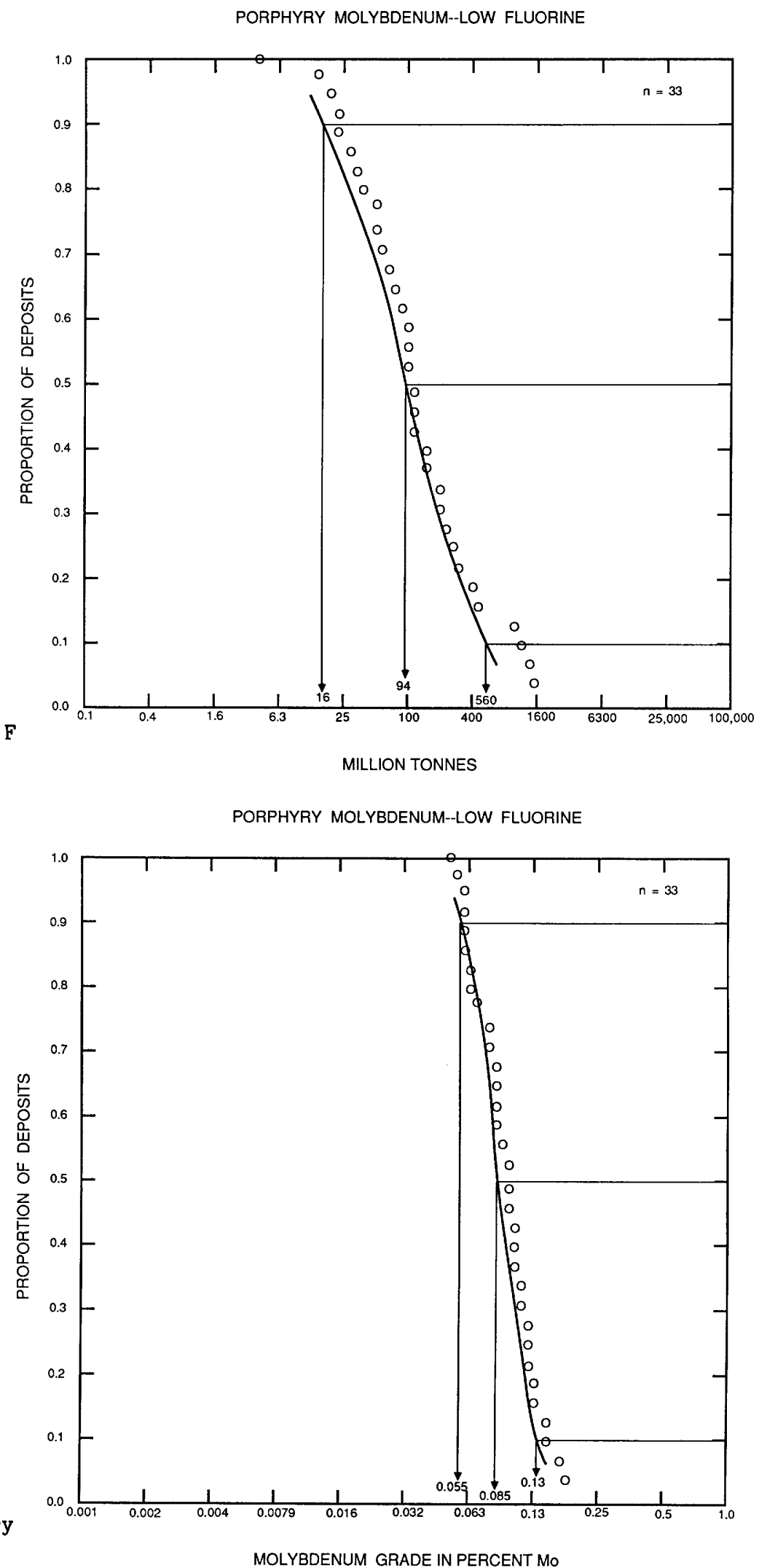

Figure 89. Mol ybdenum grades of porphyry Mo-low F deposits.

MOLYBDENUM GRADE IN PERCENT Mo 


\section{DESCRIPTIVE MODEL OF VOLCANIC-HOSTED Cu-As-Sb}

By Dennis P. Cox

APPROXIMATE SYNONYM Enargite massive sulfide (Sillitoe, 1983)

DESCRIPTION Stratabound to pipelike massive copper sulfosalt deposits in volcanic flows, breccias, and tuffs near porphyry systems.

GENERAL REFERENCES Sillitoe (1983), Ashley (1982).

GEOLOGICAL ENVIRONMENT

Rock Types Andesite, dacite, flows, breccias, and tuffs.

Textures Fine grained, porphyritic, brecciated.

Age Range Mainly Tertiary.

Depositional Environment Volcanic terrane, uppermost levels of intrusive systems.

Tectonic Setting(s) Continental margins and island arcs.

Associated Deposit Types Porphyry Cu-Mo, porphyry Mo low-F.

DEPOSIT DESCRIPTION

Mineralogy All contain pyrite. In addition, enargite + luzonite + tennantite (Lepanto), enargite + covellite + chalcocite + bornite + chalcopyrite (Bor), enargite + luzonite + tetrahedrite (Resck), tetrahedrite + sphalerite + chalcopyrite + arsenopyrite (Sam Goosly). Most contain a few parts per million Au; Sam Goosly is Ag-rich.

Texture/Structure Massive ore, breccia filling, replacement of clasts by sulfides.

Alteration Chalcedony plus high-alumina assemblages containing alunite, pyrophyllite, diaspore, dickite, andalusite. Dumortierite, tourmaline, barite, and scorzalite may be present.

Ore Controls Tuff-breccias or breccia pipes are the channelways for ore solutions originating from younger porphyry copper systems. Known deposits are separated from typical porphyry type mineralization by 500 to $700 \mathrm{~m}$.

Geochemical Signature $\mathrm{As}, \mathrm{Sb}, \mathrm{Cu}, \mathrm{Zn}, \mathrm{Ag}, \mathrm{Au}, \pm$ minor $\mathrm{Sn}$ (Lepanto), and $\mathrm{W}$ (Sam Goosly). EXAMPLES

Lepanto, PLPN

Recsk, HUNG; Bor, YUGO

Sam Goosly (Equity Silver), CNBC
(Gonzales, 1956)

(Sillitoe, 1983)

(Cyr and others, 1984) 
Model 22b

\section{DESCRIPTIVE MODEL OF Au-Ag-Te VEINS}

By Dennis P. Cox and William C. Bagby

DESCRIPTION Gold telluride minerals and fluorite in veins and breccia bodies related to hypabyssal or extrusive alkalic rocks.

\section{GEOLOGICAL ENVIRONMENT}

Rock Types Syenite, monzonite, or diorite; phonolite, monchiquite, and vogesite. Silicaundersaturated low-Ti basalts (shoshonites).

Textures Porphyro-aphanitic. Volcanic breccias and lapilli tuff.

Age Range Mainly Cretaceous and Tertiary, but could be any age.

Depositional Environment Volcanic centers, caldera rims, and caldera-fill breccias.

Tectonic Setting(s) Disrupted Precambrian craton with thin Phanerozoic cover. Also late shoshonitic stage of volcanism in island arcs.

Associated Deposit Types Polymetallic veins, polymetallic replacement deposits.

\section{DEPOSIT DESCRIPTION}

Mineralogy Calaverite, sylvanite, hessite, coloradoite, fine-grained pyrite, galena, sphalerite, tetrahedrite, and stibnite in veins of smokey quartz, calcite, purple fluorite, barite, celestite, roscoelite (V-mica), and adularia. Fluorite absent in Fiji deposit.

Texture/Structure Veins mainly carbonates and quartz. Ore minerals in clusters and locally in vug linings. Breccia-filling textures in some deposits.

Alteration Propylitic, dominated by carbonates (particularly dolomite) and pyrite. Sericite introduced in wallrocks. Silicification is rare.

Ore Controls Rich breccia ores in central zone of caldera. Veins on steep radial fractures and on faults gently inclined toward caldera. Veins may follow porphyry dikes. Replacement ore bodies may form where veins cut limestone, organic-rich argillaceous limestone being especially favorable.

Weathering Tellurides easily destroyed by weathering. Resulting "flour" gold may not be retained in placer deposits. Some tellurium redeposited as green oxides (emmonsite). Supergene enrichment, depositing native Au, occurs in some deposits.

Geochemical Signature $\mathrm{Au}, \mathrm{Ag}, \mathrm{Te}, \mathrm{Cu}, \mathrm{Pb}, \mathrm{Zn}, \mathrm{Sb}, \mathrm{Hg}, \mathrm{F}, \mathrm{Ba}, \mathrm{PGE}$.

EXAMPLES

Cripple Creek, USCO

Gold Hill, USCO

LaPlata district, USCO

Zortman-Landusky (Little Rockies district), USMT

North Mocassin-Warm Springs district), USMT

Emperor mine, Tavua, FIJI
(Loughlin and Koschman, 1935;

Lindgren and Ransome, 1906)

(Kelly and Goddard, 1969)

(Eckel, 1949)

(Corry, 1933)

(Blixt, 1933)

(Colley, 1976) 


\title{
DESCRIPTIVE MODEL OF POLYMETALLIC VEINS
}

\author{
By Dennis P. Cox
}

APPROXIMATE SYNONYM Felsic intrusion-associated Ag-Pb-Zn veins (Sangster, 1984 ).

DESCRIPTION Quartz-carbonate veins with $\mathrm{Au}$ and $\mathrm{Ag}$ associated with base metal sulfides related to hypabyssal intrusions in sedimentary and metamorphic terranes.

GEOLOGICAL ENVIRONMENT

Rock Types Calcalkaline to alkaline, diorite to granodiorite, monzonite to monzogranite in small intrusions and dike swarms in sedimentary and metamorphic rocks. Subvolcanic intrusions, necks, dikes, plugs of andesite to rhyolite composition.

Textures Fine- to medium-grained equigranular, and porphyroaphanitic.

Age Range Most are Mesozoic and Cenozoic, but may be any age.

Depositional Environment Near-surface fractures and breccias within thermal aureol of clusters of small intrusions. In some cases peripheral to porphyry systems.

Tectonic Setting(s) Continental margin and island arc volcanic-plutonic belts. Especially zones of local domal uplift.

Associated Deposit Types Porphyry Cu-Mo, porphyry Mo low-F, polymetallic replacement. Placer Au. DEPOSIT DESCRIPTION

Mineralogy Native $\mathrm{Au}$ and electrum with pyrite + sphalerite \pm chalcopyrite \pm galena \pm arsenopyrite \pm tetrahedrite-tennantite $\pm \mathrm{Ag}$ sulfosalts \pm argentite \pm hematite in veins of quartz + chlorite + calcite \pm dolomite \pm ankerite \pm siderite \pm rhodochrosite \pm barite \pm fluorite \pm chalcedony \pm adularia.

Texture/Structure Complex, multiphase veins with comb structure, crustification, and colloform textures. Textures may vary from vuggy to compact within mineralized system.

Alteration Generally wide propylitic zones and narrow sericitic and argillic zones. Silicification of carbonate rocks to form jasperoid.

Ore Controls Areas of high permeability: intrusive contacts, fault intersections, and breccia veins and pipes. Replacement ore bodies may form where structures intersect carbonate rocks.

Weathering Minor gossans and Mn-oxide stains. $\mathrm{Zn}$ and $\mathrm{Pb}$ carbonates and Pb sulfate. Abundant quartz chips in soil. Placer gold concentrations in soils and stream sediments. Supergene enrichment produces high-grade native and horn silver ores in veins where calcite is not abundant.

Geochemical Signature $\mathrm{Zn}, \mathrm{Cu}, \mathrm{Pb}, \mathrm{As}, \mathrm{Au}, \mathrm{Ag}, \mathrm{Mn}, \mathrm{Ba}$. Anomalies zoned from Cu-Au outward to $\mathrm{Zn}-$ $\mathrm{Pb}-\mathrm{Ag}$ to $\mathrm{Mn}$ at periphery.

\section{EXAMPLES}

St. Anthony (Mammoth), USAZ

Wallapai District, USAZ Marysville District, USMT

Misima I., PPNG

Slocan District, CNBC
(Creasey, 1950)

(Thomas, 1949)

(Knopf, 1913)

(Williamson and Rogerson, 1983)

(Cairnes, 1934)

\section{GRADE AND TONNAGE MODEL OF POLYMETALLIC VEINS}

\author{
By James D. Bliss and Dennis P. Cox
}

COMMENTS The data used to generate grade and tonnage models for polymetallic veins reflect considerable complexity in the geology and economic conditions under which deposits are produced or evaluated. This model represents a first attempt to resolve these complexities. Four important 
factors may affect the adequacy of this model.

1. Zinc grades are subject to considerable uncertainty because smelters have in the past penalized producers for ore containing zinc which in turn caused mine operators to avoid zincbearing ore in their mining and milling. Zinc grades are likely underestimated. Irregular behavior in the zinc-grade model may be due to these factors.

2. Polymetallic veins of two types appear to exist--a base-metal polymetallic vein worked primarily for a base metal or metals and silver and a gold-silver polymetallic vein with copper, lead, and zinc production likely in less than half the deposits. Grade and tonnage models are presented for the base-metal polymetallic veins. Grade and tonnge models are not presented for the gold-silver polymetallic veins because preliminary data are inadequate. In our data, districts in which both types occur generally have six times as many base-metal polymetallic veins as goldsilver polymetallic veins.

3. The Slocan Mining District, British Columbia, Canada, contributed nearly 60 percent of the deposit data for the base-metal polymetallic veins, and this may bias the models in ways not identified.

4. Deposits are defined as all workings within $1 \mathrm{~km}$ of each other and having a minimum of 100 tonnes of ore. A few deposits are for districts with workings of unknown spacing. See figs. $90-$ 94.

\begin{tabular}{|c|c|c|c|}
\hline Name & Country & Name & Count \\
\hline Albert Lea Group & USAZ & Mammoth-St. Anthony & USAZ \\
\hline Altoona-Elkhor-Mercury & $\mathrm{CNBC}$ & Marietta & USMT \\
\hline Amazon & USMT & Mineral Park & USAZ \\
\hline Antoine & $\mathrm{CNBC}$ & Minniehaha & $\mathrm{CNBC}$ \\
\hline Arlington & CNBC & Molly Gibson & CNBC \\
\hline Badger & USAZ & Monitor & $\mathrm{CNBC}$ \\
\hline Baltic and Revenue & USCO & Montezuma & CNBC \\
\hline Baltimore & USMT & Mountain Chief and vicinity & CNBC \\
\hline $\mathrm{Be} 11$ & $\mathrm{CNBC}$ & Mountain Con & CNBC \\
\hline Bell and California & USCO & Noonday & CNBC \\
\hline Bell Boy-Niles-Towsley & USMT & North Cerbat (Golconda) & USAZ \\
\hline Big Four & USMT & Northern Bell-Jackson & CNBC \\
\hline Bosum & $\mathrm{CNBC}$ & Payne Group & $\mathrm{CNBC}$ \\
\hline Bullion & USCO & Pennsylvania & USCO \\
\hline C.O.D. & USAZ & Queen Bess and vicinity & $\mathrm{CNBC}$ \\
\hline California-Hartney-Marion & CNBC & Rambler-Cariboo & $\mathrm{CNBC}$ \\
\hline Carnation-Jennie Lind & $\mathrm{CNBC}$ & Rio & CNBC \\
\hline Central Cerbat District & USAZ & Robert Emmet & USMT \\
\hline Champion-New London & USAZ & Santiago-Commonwealth- & \\
\hline Chlorite District & USAZ & Centennial & USCO \\
\hline Comstock & CNBC & Scraton-Pontiac-Sunset & $\mathrm{CNBC}$ \\
\hline Cork-Province & CNBC & Silversmith-Richmond- & \\
\hline Dardanelles & $\mathrm{CNBC}$ & Ruth-Hope & $\mathrm{CNBC}$ \\
\hline Defiance & USAZ & Slocan-Sovereign & $\mathrm{CNBC}$ \\
\hline Eva May & USMT & Soho & CNBC \\
\hline Fisher Maiden Group & $\mathrm{CNBC}$ & Standard and vicinity & CNBC \\
\hline Flint-Martin & $\mathrm{CNBC}$ & Stockton & USAZ \\
\hline Galena Farm and vicinity & $\mathrm{CNBC}$ & Sunshine-Corinth & CNBC \\
\hline Gray Eagle & USMT & Surprise-Noble Five and & \\
\hline Idaho-Alamo Group & $\mathrm{CNBC}$ & vicinity & $\mathrm{CNBC}$ \\
\hline Idaho-Alamo-Silver Bell & CNBC & Treasure Hill & USAZ \\
\hline Ivanhoe-Canadian & CNBC & Tybo & USNV \\
\hline Keno Hill-Galena Hill & CNYT & Union & USNV \\
\hline King Solomon & USMT & Utica & $\mathrm{CNBC}$ \\
\hline Leadsmith & CNBC & Vancouver Group & CNBC \\
\hline Legal Tender & USMT & Von Roi-Hewitt-A.U. & CNBC \\
\hline Little Nell & USMT & Wellington & CNBC \\
\hline Liverpool & USMT & Wintrop & CNBC \\
\hline Majestic-Sapphire & $\mathrm{CNBC}$ & Wonderful-Elkhorn & CNBC \\
\hline
\end{tabular}


POLYMETALLIC VEIN

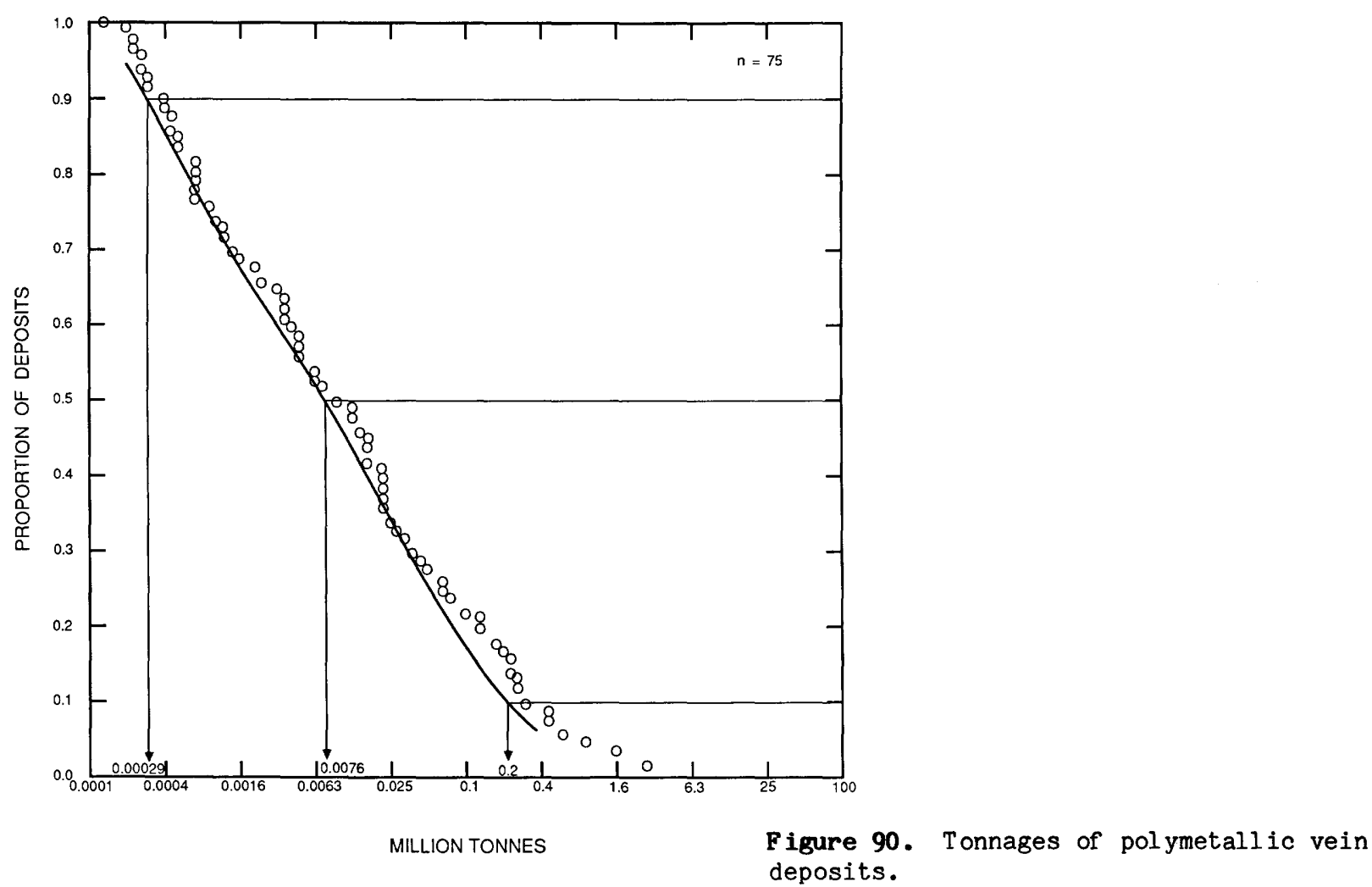

POLYMETALLIC VEIN

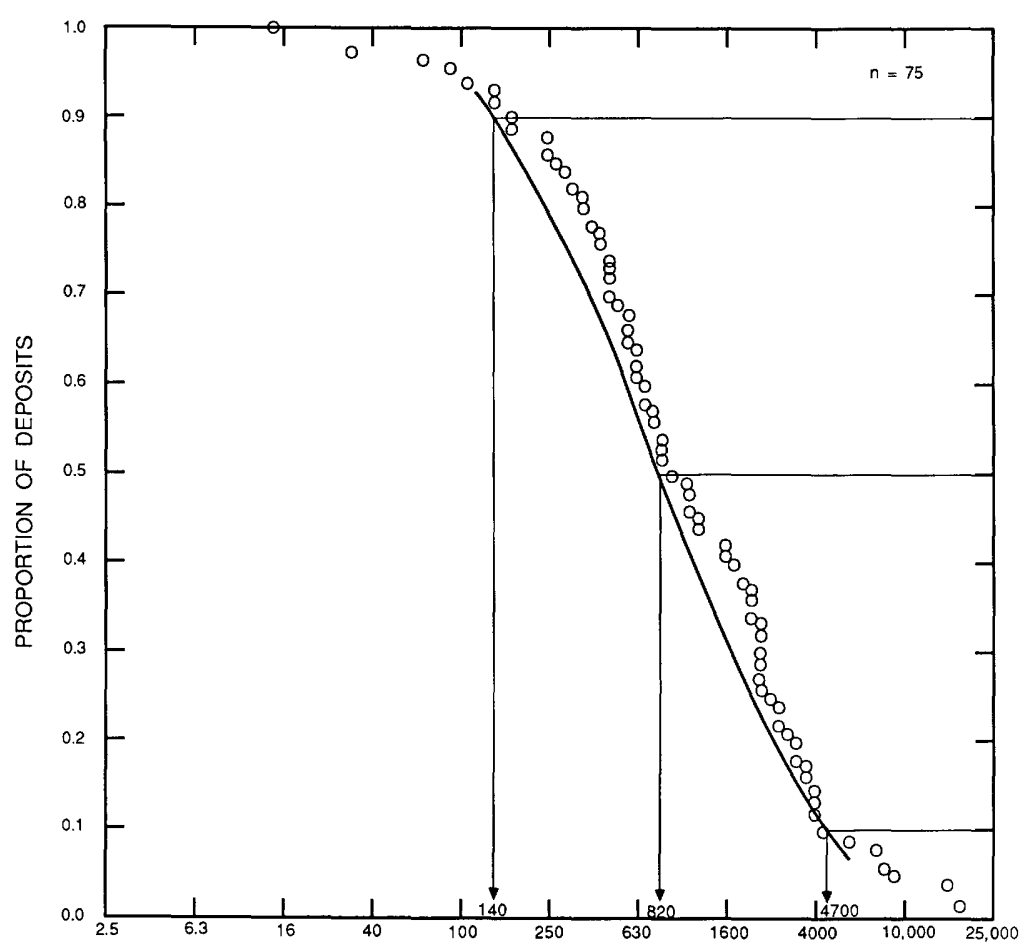

SILVER GRADE IN GRAMS PER TONNE

Figure 91. Silver grades of polymetallic vein deposits. 
Model 22c--Con.

Figure 92. Gold grades of polymetallic vein deposits.
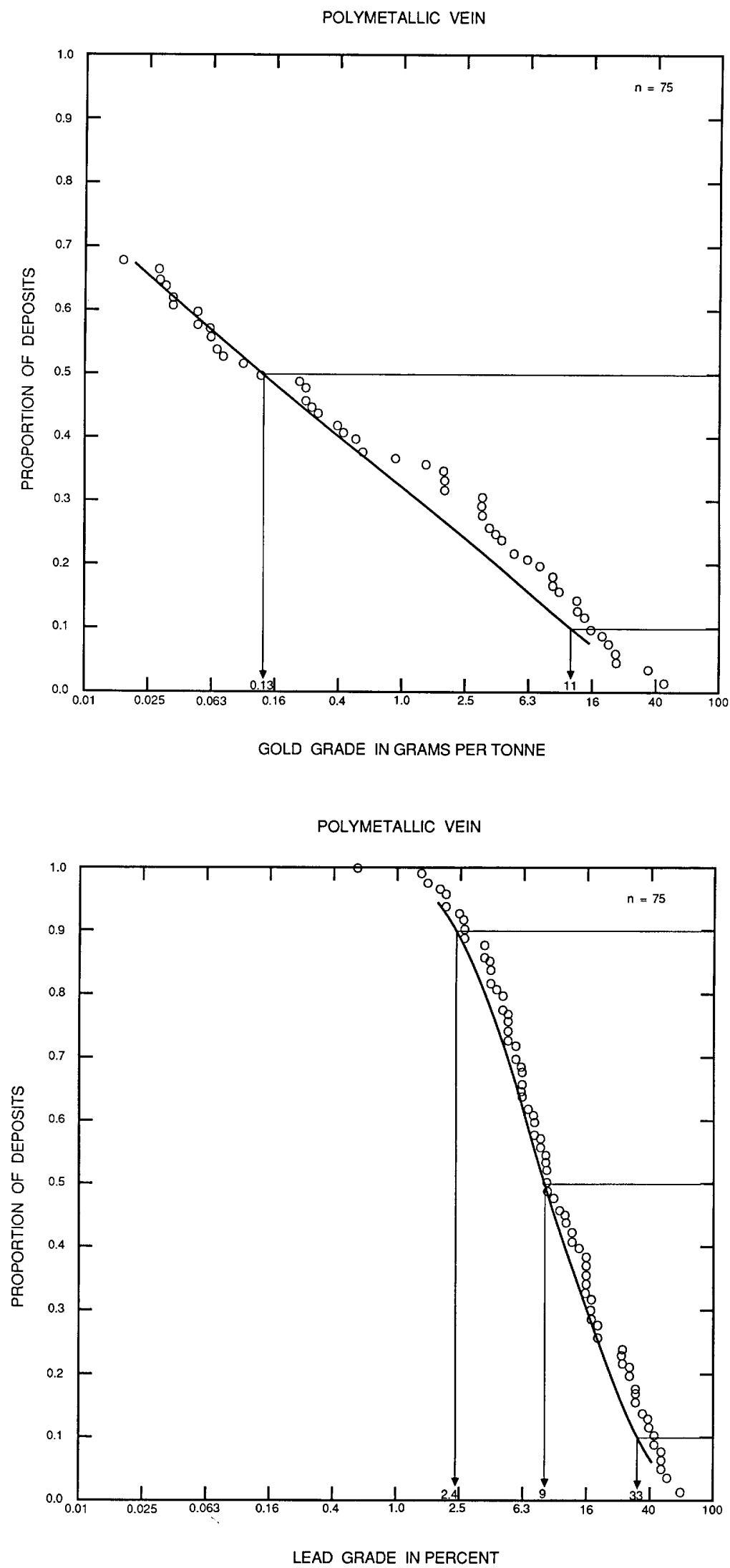

Figure 93. Lead grades of polymetallic vein deposits. 
Model 22c--Con.
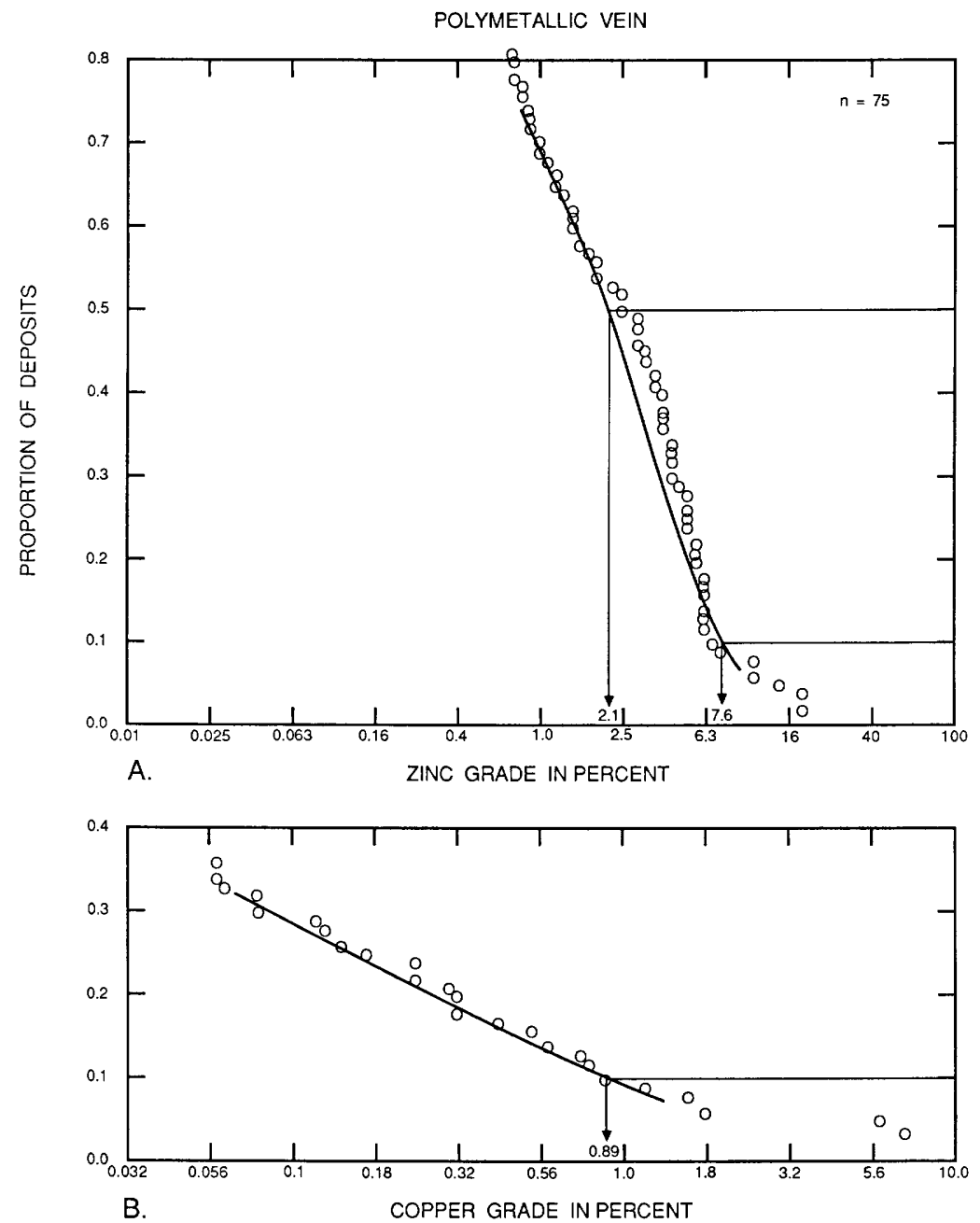

Figure 94. Zinc and copper grades of pol ymetall ic vein deposits. A, Zinc. B, Copper. 
DESCRIPTIVE MODEL OF BASALTIC Cu

By Dennis P. Cox

APPROXIMATE SYNONYM Volcanic redbed Cu (Kirkham, 1984).

DESCRIPTION A diverse group including disseminated native copper and copper sulfides in the upper parts of thick sequences of subaerial basalt, and copper sulfides in overlying sedimentary beds.

GENERAL REFERENCE Kirkham (1984).

\section{GEOLOGICAL ENVIRONMENT}

Rock Types Subaerial to shallow marine basalt flows, breccias and tuffs, red-bed sandstone, tuffaceous sandstone, conglomerate. Younger tidal facies limestone and black shale.

Textures Amygdules, flow-top breccias in lava. Laminated algal carbonate rocks. Sediments with high original porosity.

Age Range Proterozoic, Triassic and Jurassic, and Tertiary deposits known.

Depositional Environment Copper-rich (100-200 ppm) basalt interlayered with red clastic beds and overlain by mixed shallow marine and continental deposits formed near paleo-equator.

Tectonic Setting(s) Intracontinental rift, continental margin rift. Regional low-grade metamorphism may mobilize copper in some districts. Deposits are characteristic of the Triassic part of Wrangellia terrane in Alaska.

Associated Deposit Types Sediment-hosted copper. Volcanogenic Mn at Boleo, Mexico.

\section{DEPOSIT DESCRIPTION}

Mineralogy Native copper, native silver in flows and coarse clastic beds. Chalcocite and other $\mathrm{Cu}_{2} \mathrm{~S}$ minerals and locally bornite and chalcopyrite are concentrated in overlying shale and carbonate rocks. Fine-grained pyrite is common but not abundant with copper sulfide minerals.

Texture/Structure Flow-top breccia and amygdule fillings in basalt. Fine grains in matrix and along shaley parting in clastics. Massive replacement of carbonates at Kennicott. Finely varved chalcopyrite sediment at Denali.

Alteration Calcite-zeolite + epidote + K-feldspar. Red coloration due to fine hematite.

Ore Controls Flow-top breccias, amygdules, fractures in basalt; organic shale, limestone in overlying sequence. Limestone is tidal, algal, with stromatolite fossils. Synsedimentary faulting may be important.

Weathering Widely dispersed copper nuggets in streams draining basalts.

Geochemical Signature $\mathrm{Cu}-\mathrm{Ag}-\mathrm{Zn}-\mathrm{Cd}$. Co at Boleo, Mexico. Cu:Zn ratio is very high. Au anomalously low.

EXAMPLES

Keweenaw, USMI

Calumet, USMI

Kennicott, USAK

Denali, USAK

Boleo, MXCO

Buena Esperanza, CILE

Redstone, CNNT

Sustut, CNBC
(White, 1968)

(Ensign and others, 1968)

(Bateman and McLaughlin, 1920)

(Seraphim, 1975)

(Wilson, 1955)

(Ruiz, 1965)

(Ruelle, 1982)

(Harper, 1977) 


\title{
DESCRIPTIVE MODEL OF CYPRUS MASSIVE SULFIDE
}

\author{
By Donald A. Singer
}

APPROXIMATE SYNONYM Cupreous pyrite.

DESCRIPTION Massive pyrite, chalcopyrite, and sphalerite in pillow basalts (see figs. 95, 96).

GENERAL REFERENCE Franklin, and others (1981).

GEOLOGICAL ENVIRONMENT

Rock Types Ophiolite assemblage: tectonized dunite and harzburgite, gabbro, sheeted diabase dikes, pillow basalts, and fine-grained metasedimentary rocks such as chert and phyllite (fig. 95 ).

Textures Diabase dikes, pillow basalts, and in some cases brecciated basalt.

Age Range Archean(?) to Tertiary--majority are Ordovician or Cretaceous.

Depositional Environment Submarine hot spring along axial grabens in oceanic or back-arc spreading ridges. Hot springs related to submarine volcanoes producing seamounts (fig. 96).

Tectonic Setting(s) Ophiolites. May be adjacent to steep normal faults.

Associated Deposit Types $M n$ and Fe-rich cherts regionally.

\section{DEPOSIT DESCRIPTION}

Mineralogy Massive: pyrite + chalcopyrite + sphalerite + marcasite + pyrrhotite. Stringer

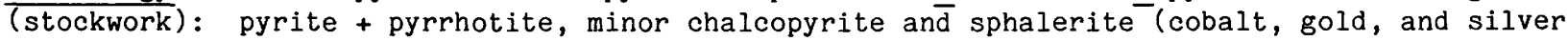
present in minor amounts).

Texture/Structure Massive sulfides ( $>60$ percent sulfides) with underlying sulfide stockwork or stringer zone. Sulfides brecciated and recemented. Rarely preserved fossil worm tubes.

Alteration Stringer zone--feldspar destruction, abundant quartz and chalcedony, abundant chlorite, some illite and calcite. Some deposits overlain by ochre (Mn-poor, Fe-rich bedded sediment containing goethite, maghemite, and quartz).

Ore Controls Pillow basalt or mafic volcanic breccia, diabase dikes below; ores rarely localized in sediments above pillows. May be local faulting.

Weathering Massive limonite gossans. Gold in stream sediments.

Geochemical Signature General loss of $\mathrm{Ca}$ and $\mathrm{Na}$ and introduction and redistribution of $\mathrm{Mn}$ and $\mathrm{Fe}$ in the stringer zone.

EXAMPLES

Cyprus deposits, CYPS (Constantinou and Govett, 1973)

Oxec, GUAT

York Harbour, CNNF

(Petersen and Zantop, 1980)

Turner-Albright, USOR

(Duke and Hutchinson, 1974)

(Koski and Derkey, 1981)

GRADE AND TONNAGE MODEL OF CYPRUS MASSIVE SULFIDE

By Donald A. Singer and Dan L. Mosier

DATA REFERENCE Mosier and others (1983).

COMMENTS Massive sulfide deposits from Mosier and others (1983) which had only mafic or ultramafic rocks immediately above through $500 \mathrm{~m}$ below, and had either pillow basalt or diabase dikes in the sequence were included in these plots. See figs. 97-99. 
Model 24a--Con.

DEPOSITS

Name

Aarja
Agrokipia
Ambelikou
Ana Yatak-Ergani
Apliki
Arinteiro
Bama
Barlo
Bayda
Betts Cove
Big Mike
Bonanza
Bongbongan
Carawison
Carmel
Colchester
Fornas
Hand Camp
Huntingdon
Kapedhes
Kokkinoyia
Kokkinopezoula
Kure (Asikoy)
Kure (Bakibaba)
Kynousa

Aarja

Ana Yatak-Ergani

Apliki

Arinteiro

Betts Cove

Big Mike

Bonanza

Bongbongan

Colchester

Fornas

Hand Camp

Kokkinopezoula

Kure (Bakibaba)

\begin{tabular}{l} 
Country \\
\hline OMAN \\
CYPS \\
CYPS \\
TRKY \\
CYPS \\
SPAN \\
SPAN \\
PLPN \\
OMAN \\
CNNF \\
USNV \\
CNBC \\
PLPN \\
PLPN \\
PLPN \\
CNNF \\
SPAN \\
CNNF \\
CNQU \\
CYPS \\
CYPS \\
CYPS \\
TRKY \\
TRKY \\
CYPS
\end{tabular}

Name

Country

Lasail

OMAN

Limni

Little Bay

Lokken

Lorraine

Mathiati North

Mavrovouni

Mousoulos-Kalavasos

Ny Sulitjelma

Oxec

Peravasa

Platies

Rendall-Jackson

Rua Cove

Sha

CYPS

CNNF

NRWY

PLPN

CYPS

CYPS

CYPS

NRWY

GUAT

CYPS

CYPS

CNNF

USAK

CYPS

TRKY

NRWY

CYPS

NRWY

CNNF

CYPS

USOR

CNNF

CNNF 


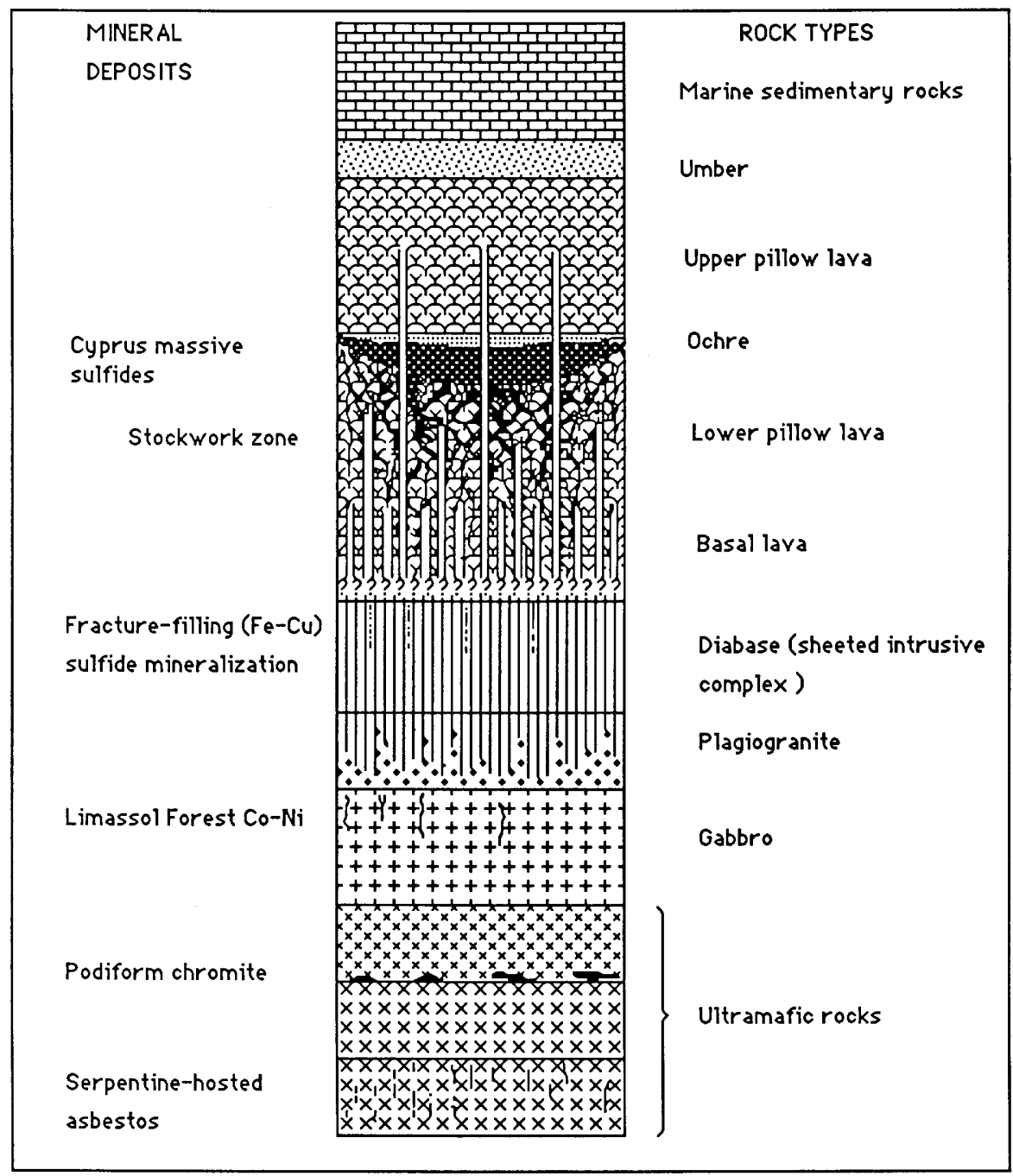

Figure 95. Generalized stratigraphic column through the Troodos ophiolite showing Cyprus massive sulfides and other deposit types and their asssociated rock types. Modified from Constantinou(1980).

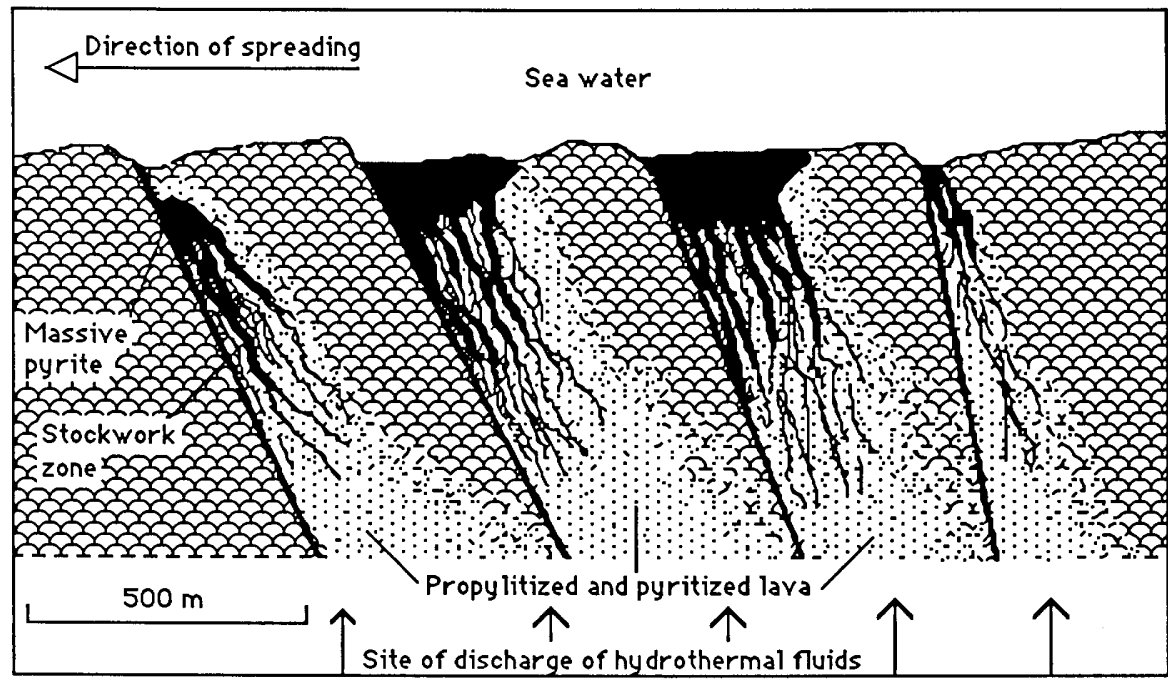

Figure 96. Cross section through the Kalavos district, Cyprus, showing relationship of massive sulfide deposits to faults and alteration zones. Section is drawn normal to the spreading axis and represents a time period prior to deposition of a thick sequence of pillow lavas and sedimentary rocks. Modified from Adamides (1980). 
Model 24a--Con.

Figure 97. Tonnages of Cyprus massive sulfide deposits.

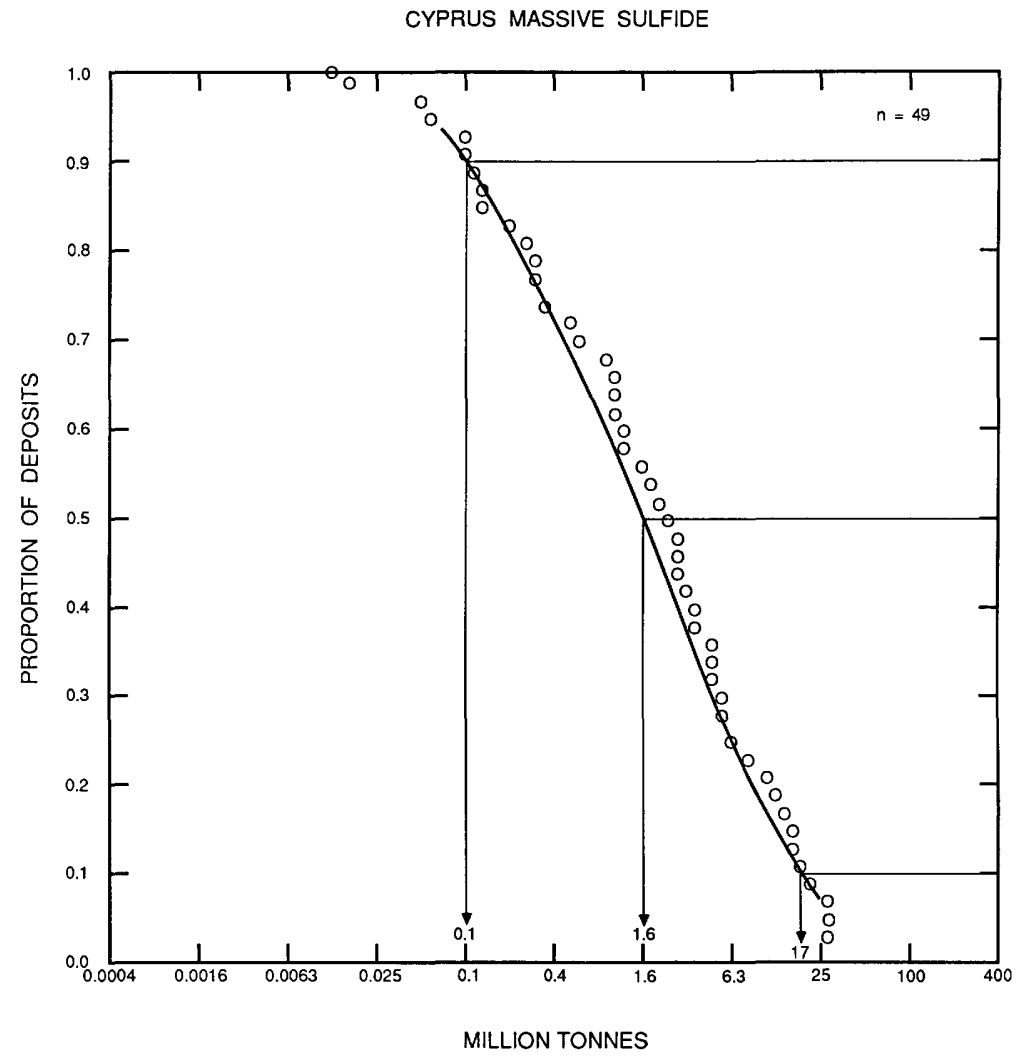

CYPRUS MASSIVE SULFIDE

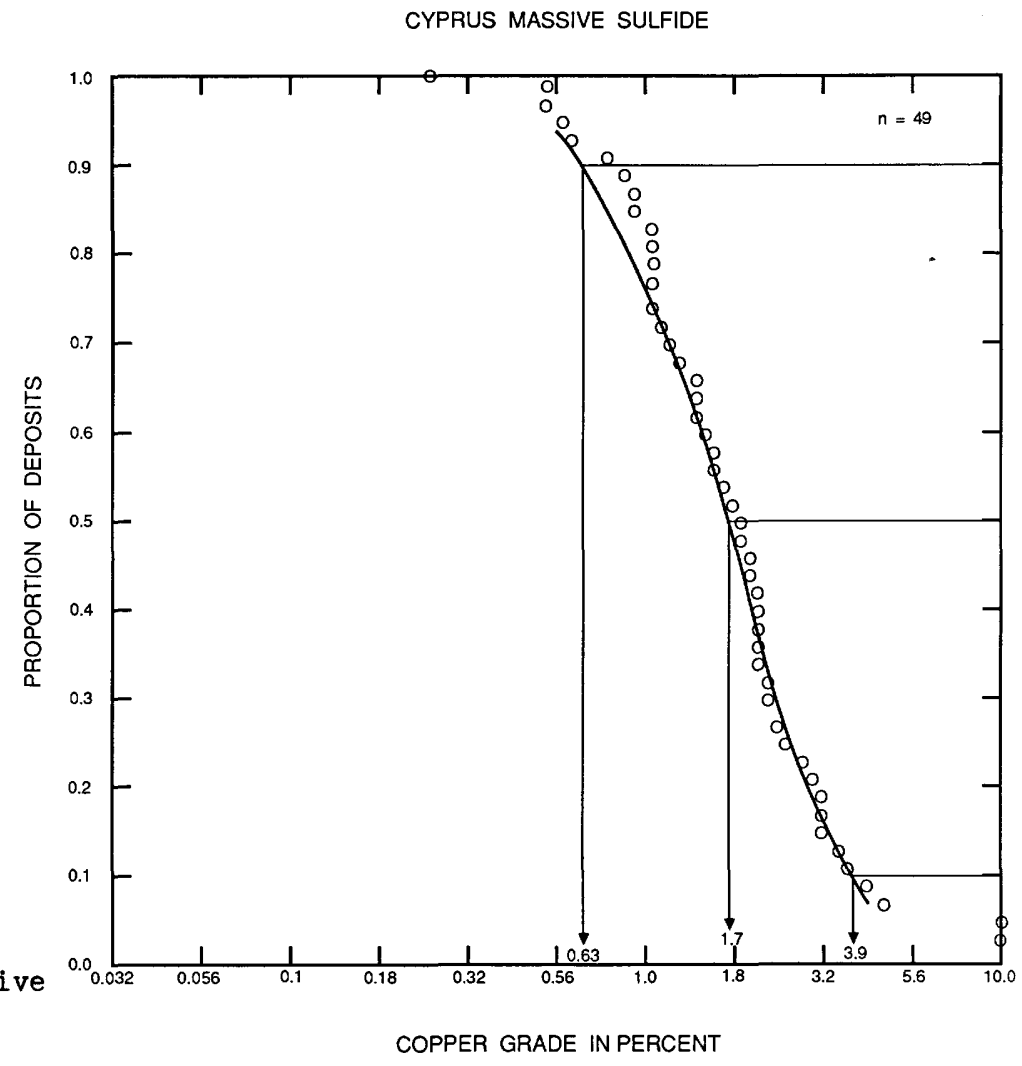

Figure 98. Copper grades of Cyprus massive sulfide deposits. 

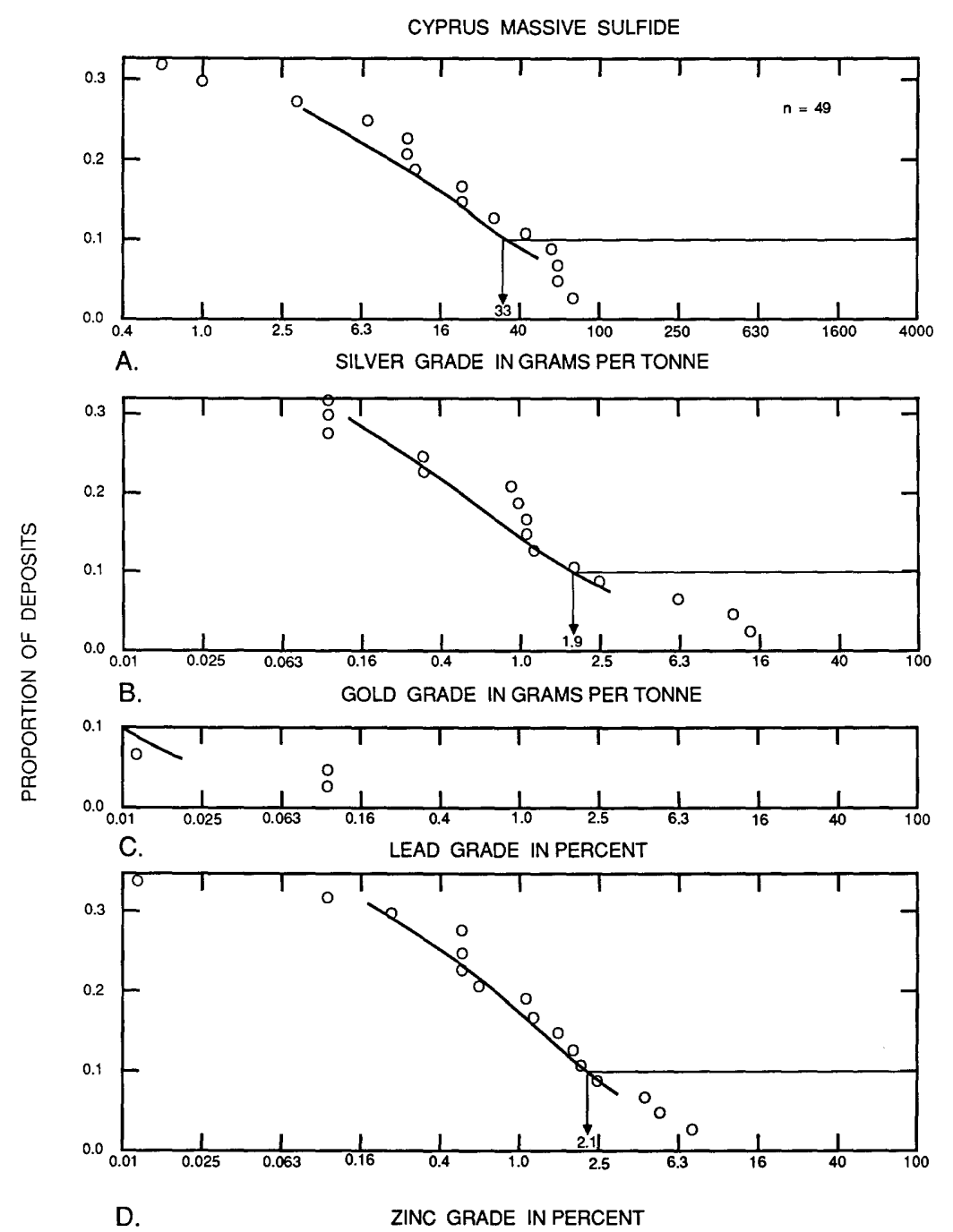

Figure 99. By-product grades of Cyprus massive sulfide deposits. $\underline{A}$, Silver. $\underline{B}$, Gold. $\underline{\text { C, Lead. }}$, Zinc. 
Model 24b

\section{DESCRIPTIVE MODEL OF BESSHI MASSIVE SULFIDE}

By Dennis P. Cox

APPROXIMATE SYNONYM Besshi type, Kieslager.

DESCRIPTION Thin, sheetlike bodies of massive to well-laminated pyrite, pyrrhotite, and chalcopyrite within thinly laminated clastic sediments and mafic tuffs.

GENERAL REFERENCES Klau and Large (1980), Fox (1984).

\section{GEOLOGICAL ENVIRONMENT}

Rock Types Clastic terrigenous sedimentary rocks and tholeiitic to andesitic tuff and breccia. Locally, black shale, oxide-facies iron formation, and red chert.

Textures Thinly laminated clastic rocks. All known examples are in strongly deformed metamorphic terrane. Rocks are quartzose and mafic schist.

Age Range Mainly Paleozoic and Mesozoic.

Depositional Environment Uncertain. Possibly deposition by submarine hot springs related to basaltic volcanism. Ores may be localized within permeable sediments and fractured volcanic rocks in anoxic marine basins.

Tectonic Setting(s) Uncertain. Possibly rifted basin in island arc or back arc. Possibly spreading ridge underlying terrigenous sediment at continental slope.

Associated Deposit Types None known.

\section{DEPOSIT DESCRIPTION}

Mineralogy Pyrite + pyrrhotite + chalcopyrite + sphalerite \pm magnetite \pm valleriite \pm galena \pm bornite \pm tetrahedrite \pm cobaltite \pm cubanite \pm stannite \pm molybdenite. Quartz, carbonate, albite, white mica, chlorite, amphibole, and tourmaline.

Texture/Structure Fine-grained, massive to thinly laminated ore with colloform and framboidal pyrite. Breccia or stringer ore. Cross-cutting veins contain chalcopyrite, pyrite, calcite or galena, sphalerite, calcite.

Alteration Difficult to recognize because of metamorphism. Chloritization of adjacent rocks is noted in some deposits.

Ore Controls Uncertain. Deposits are thin, but laterally extensive and tend to cluster in en echelon pattern.

Weathering Gossan.

Geochemical Signature $\mathrm{Cu}, \mathrm{Zn}$, Co, $\mathrm{Ag}, \mathrm{Ni}, \mathrm{Cr}, \mathrm{Co} / \mathrm{Ni}>1.0$, Au up to $4 \mathrm{ppm}$, Ag up to $60 \mathrm{ppm}$.

EXAMPLES

Besshi, JAPN

Motoyasu, JAPN

Kieslager, ASTR

Raul, PERU
(Kanehira and Tatsumi, 1970)

(Yui, 1983)

(Derkman and Klemm, 1977)

(Ripley and Ohmoto, 1977)

\section{GRADE AND TONNAGE MODEL OF BESSHI MASSIVE SULFIDE}

By Donald A. Singer

DATA REFERENCE Yamada and others (1980).

COMMENTS Only deposits from Japan containing more than 10,000 tonnes are included. See figs. 100102 . 


Name
Akinokawa (Onishi)
Asakawa
Besshi
Choja
Chushiro
Ehime
Higashiyame
Hirabaya
Hirota
Hitachi
Imade \& Ouchi
Imori
Iyo
Izushi
Kamegamori
Kanayama
Kotsu
Kune
Machimi
Makimine, Hibira
Minawa
Miyawa

\begin{tabular}{lll} 
Country & Name & Country \\
\cline { 2 - 3 } JAPN & Motoyasu & JAPN \\
JAPN & Nakayama & JAPN \\
JAPN & Nanogawa & JAPN \\
JAPN & Naruyasu & JAPN \\
JAPN & Nii & JAPN \\
JAPN & Nishinokawa & JAPN \\
JAPN & Noji & JAPN \\
JAPN & Nonowaki & JAPN \\
JAPN & Okuki & JAPN \\
JAPN & Omine & JAPN \\
JAPN & Ryuo & JAPN \\
JAPN & Sazare & JAPN \\
JAPN & Shiiba, Takaragi & JAPN \\
JAPN & Shimokawa & JAPN \\
JAPN & Shimokawa (Kouchi) & JAPN \\
JAPN & Shinga & JAPN \\
JAPN & Shirataki & JAPN \\
JAPN & Takaura & JAPN \\
JAPN & Terano & JAPN \\
JAPN & Yanahara & JAPN \\
JAPN & Yoshimoto & JAPN \\
JAPN & Yuryo & JAPN \\
& &
\end{tabular}

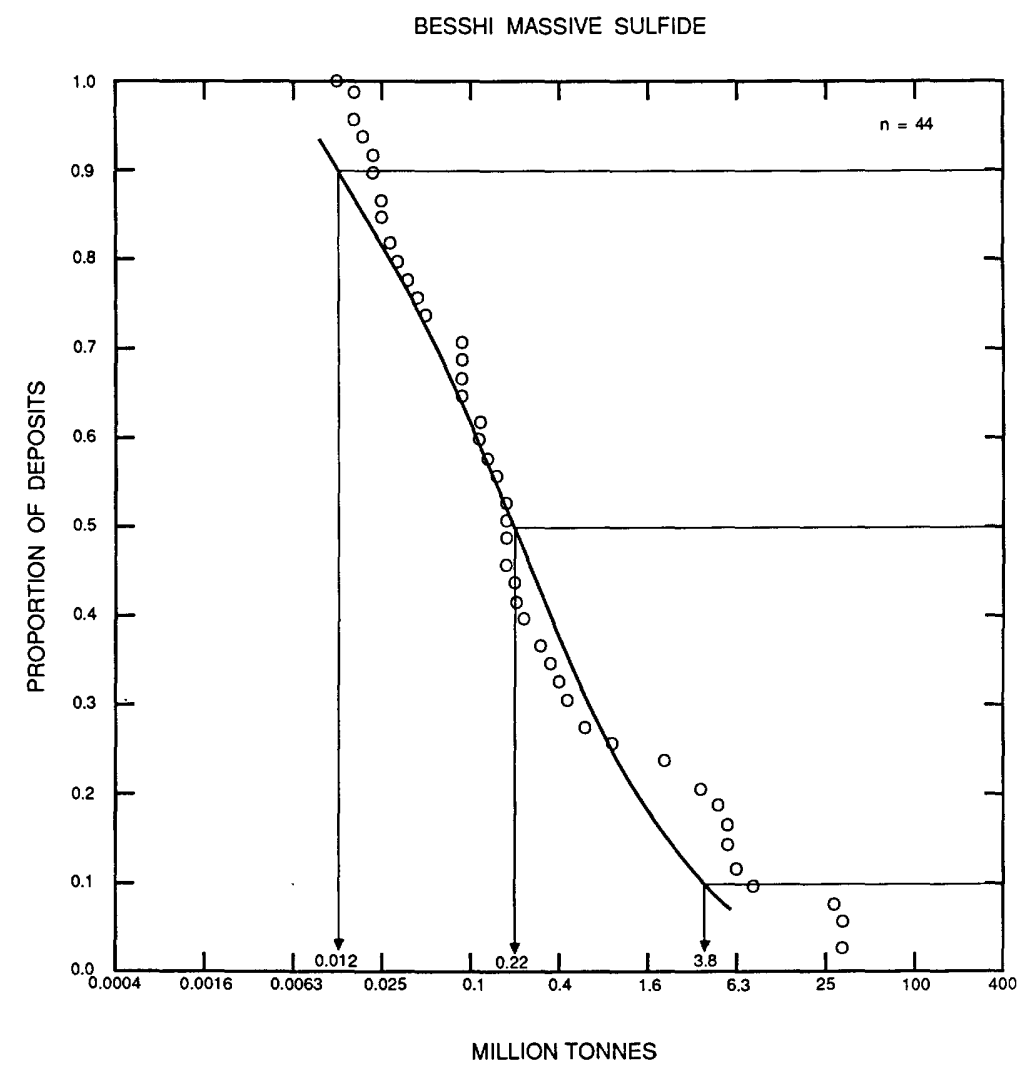

Figure 100. Tonnages of Besshi massive sulfide deposits. 
Model 24b--Con.

Figure 101. Copper grades of Besshi massive sulfide deposits.
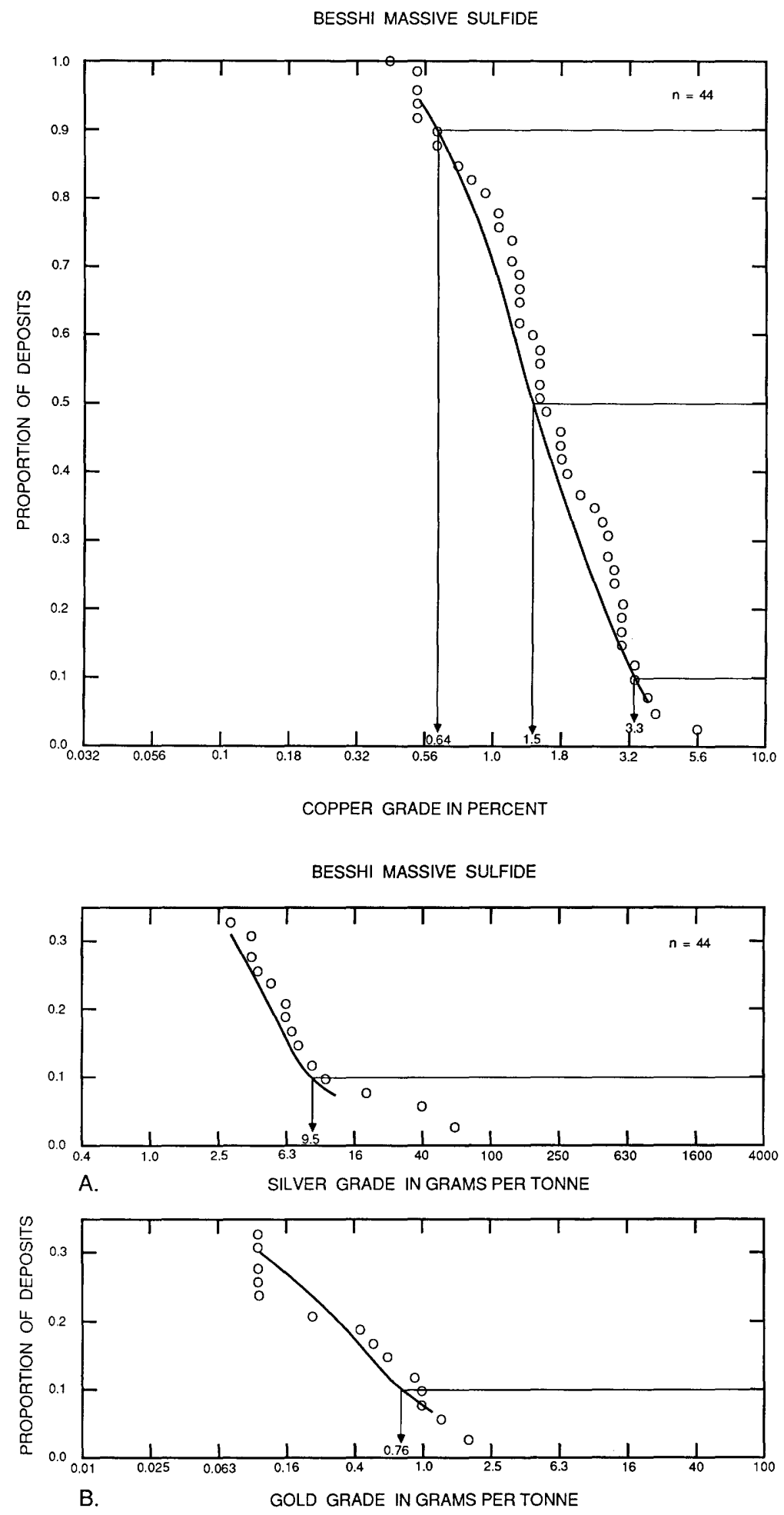

Figure 102. By-product grades of Besshi massive sulfide deposits. A, Silver. $B$, Gold. $\underline{C}$, Zinc.

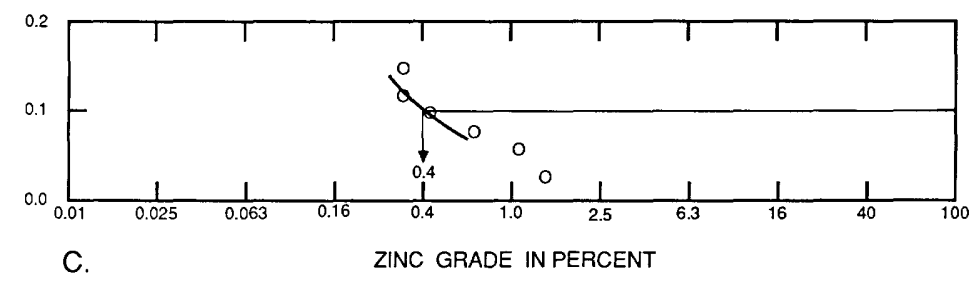




\title{
DESCRIPTIVE MODEL OF VOLCANOGENIC Mn
}

\author{
By Randolph A. Koski
}

APPROXIMATE SYNONYM Volcanogenic-sedimentary (Roy, 1981)

DESCRIPTION Lenses and stratiform bodies of manganese oxide, carbonate, and silicate in volcanicsedimentary sequences. Genesis related to volcanic (volcanogenic) processes.

GENERAL REFERENCE ROy (1981).

\section{GEOLOGICAL ENVIRONMENT}

Rock Types Chert, shale, graywacke, tuff, basalt; chert, jasper, basalt (ophiolite); basalt, andesite, rhyolite (island-arc); basalt, limestone; conglomerate, sandstone, tuff, gypsum.

Age Range Cambrian to Pliocene.

Depositional Environment Sea-floor hot spring, generally deep water; some shallow water marine; some may be enclosed basin.

Tectonic Setting(s) Oceanic ridge, marginal basin, island arc, young rifted basin; all can be considered eugeosynclinal.

Associated Deposit Types Kuroko massive sulfide deposits.

DEPOSIT DESCRIPTION

Mineralogy Rhodochrosite, Mn-calcite, braunite, hausmannite, bementite, neotocite, alleghenyite, spessartine, rhodonite, Mn-opal, manganite, pyrolusite, coronadite, cryptomelane, hollandite, todorokite, amorphous $\mathrm{MnO}_{2}$.

Texture/Structure Fine-grained massive crystalline aggregates, botryoidal, colloform in bedded and lensoid masses.

Alteration Spilitic or greenschist-facies alteration of associated mafic lavas, silicification, hematitization.

Ore Controls Sufficient structure and porosity to permit subsea-floor hydrothermal circulation and sea-floor venting; redox boundary at seafloor-seawater interface around hot spring; supergene enrichment to upgrade Mn content.

Weathering Strong development of secondary Mn oxides (todorokite, birnessite, pyrolusite, amorphous $\mathrm{MnO}_{2}$ ) at the surface and along fractures.

Geochemical Signature Although $\mathrm{Mn}$ is only moderately mobile and relatively abundant in most rocks, Mn minerals may incorporate many other trace elements such as $\mathrm{Zn}, \mathrm{Pb}, \mathrm{Cu}$, and $\mathrm{Ba}$.

Examples

Olympic Peninsula, USWA

Franciscan type, USCA, USOR
(Park, 1942, 1946; Sorem and Gunn, 1967)

(Taliaferro and Hudson, 1943; Crerar and others, 1982; Snyder 1978; Kuypers and Denyer, 1979)

GRADE AND TONNAGE MODEL OF VOLCANOGENIC Mn

By Dan L. Mosier

COMMENTS Tonnage is correlated with manganese grade $(r=-0.32)$ and with phosphorus $\left.\frac{\text { grade }(r}{r}=-0.94, n=8\right)$. See figs. $103-104$. 
Model 24c--Con.

DEPOSITS

Name

Abuhemsin (Abiulya)
Abundancia
Akcakilise Topkirazlar
Akoluuk
Akseki Gokceovacik
Antonio
Augusto Luis and others
Avispa
Black Diablo
Blue Jay
Boston Group

Briseida Group and others

Buckeye

Bueycito

Buritirama

Cadiz

Castillode Palanco

Cavdarli-Komurluk

Cayirli Koy

Charco Redondo-Casualidad

Crescent

Cubenas

Cubuklu Koyu

Cummings

Curiol-Playa Real-Pavones

Danisment

Dassoumble

Djebel Guettara

Durnovskoe

El Cuervo

Esperancita

Estrella-Sopresa

Fabian

Faucogney

Foster Mountain

Glib en Nam

Gloria-Elvira-Polaris

Gocek Koyu

Gran Piedra

Guanaba Group

Gunbasi (Akcakese)

Hyatt No. 1

Idikel

Jo7

Jutinicu

Komurluk Koyunun

\section{Country}

TRKY

TRKY

TRKY

TRKY

TRKY

CUBA

CUBA

CUBA

USNV

USCA

CUBA

CUBA

USCA

CUBA

BRZL

CUBA

SPAN

TRKY

TRKY

CUBA

USWA

CUBA

TRKY

USCA

CORI

TRKY

IVCO

ALGR

URRS

SPAN

CUBA

CUBA

USCA

FRNC

USCA

MRCO

CUBA

TRKY

CUBA

CUBA

TRKY

PANA

MRCO

NCAL

CUBA

TRKY
Name

Korucular

La Calanesa

Ladd

Lagnokaha

Lasbela

La Unica

Laverton-Mt. Lucky

Liberty

Lucia (Generosa)

Lucifer

Magda lena

Manacas Group

Manuel

Montenegro-Adriana

Mrima

Pirki

Piskala

Ponupo

Ponupo de Manacal

Pozo Prieto

Progreso

Quarzazate

Quinto

Raymond

Rhiw

Sabanilla

Santa Rosa

Sapalskoe

Sereno

Sigua

Soloviejo

South Thomas

Taratana

Taritipan

Thatcher Creek

Thomas

Tiere

Tiouine

Tokoro

Topkirozlar

Toscana (Cerchiara)

Tutunculer

Valle de Maganeso

Welch

Woody Woody

Yeya
Country

TRKY

SPAN

USCA

UVOL

PKTN

CUBA

AUWA

USCA

CUBA

MXCO

CUBA

CUBA

CUBA

CUBA

KNYA

TRKY

TRKY

CUBA

CUBA

CUBA

CUBA

MRCO

CUBA

NCAL

GRBR

CUBA

CUBA

URRS

BRZL

CUBA

SPAN

USCA

CUBA

INDS

USCA

USCA

UVOL

MRCO

JAPN

TRKY

ITLY

TRKY

CUBA

USCA

AUWA

CUBA 
VOLCANOGENIC MANGANESE

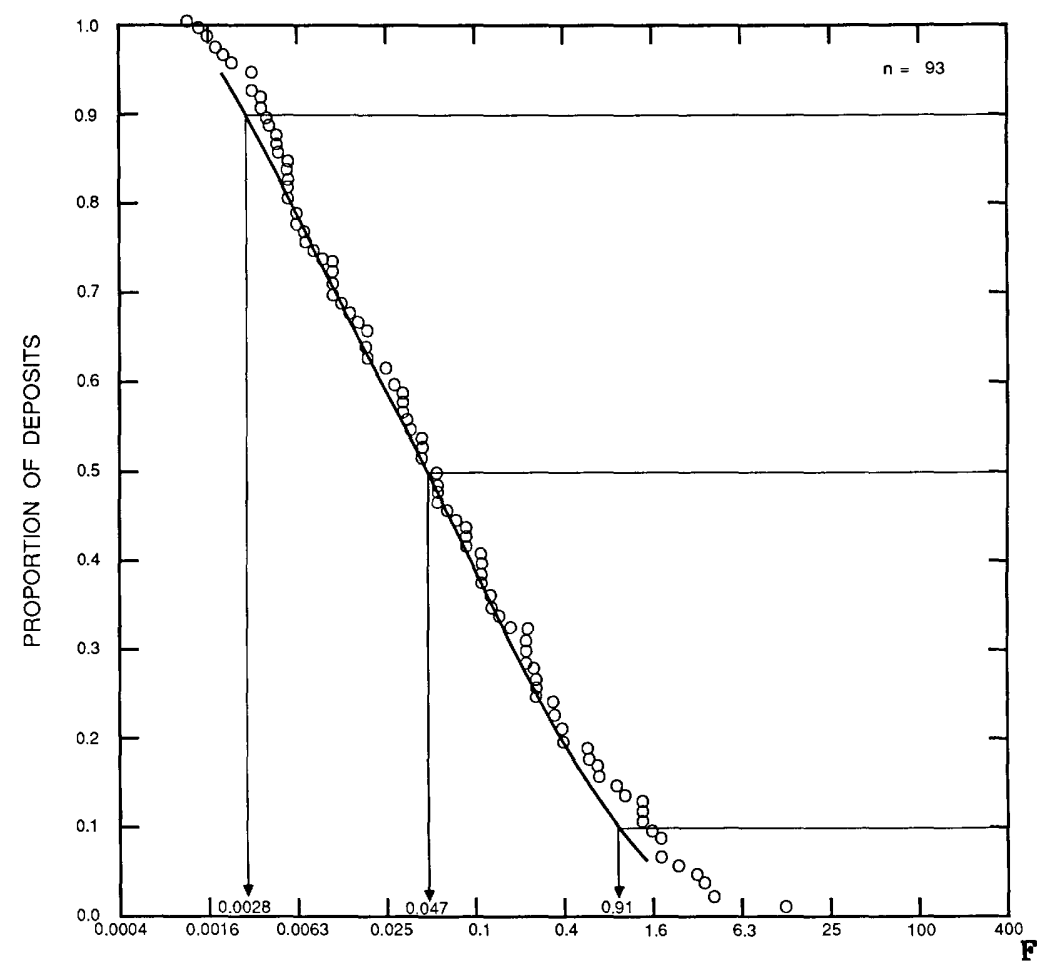

Model 24c--Con.

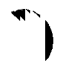

MILLION TONNES

Figure 103. Tonnages of vol canogenic $\mathrm{Mn}$ deposits.
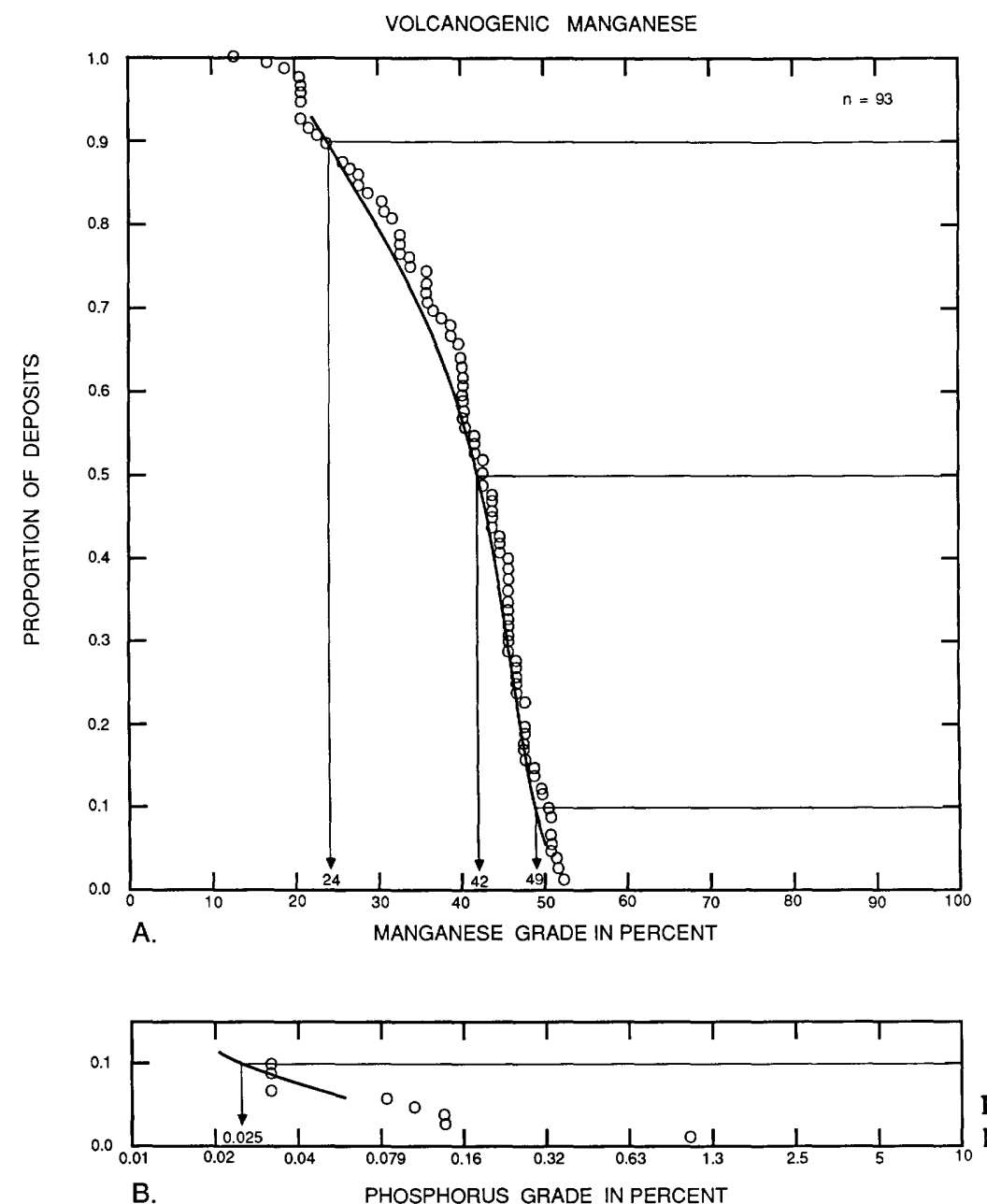

Figure 104. Metal grades of vol canogenic Mn deposits. A, Manganese. B, Phosphorus. B. PHOSPHORUS GRADE IN PERCENT 
Model 24d

\section{DESCRIPTIVE MODEL OF BLACKBIRD CO-Cu}

By Robert L. Earhart

DESCRIPTION Massive and disseminated pyrite, pyrrhotite, arsenopyrite, cobaltite, chalcopyrite, and magnetite in stratabound lenses, stringers, and in quartz-tourmaline breccia pipes.

GENERAL REFERENCES Bennett (1977), Hughes (1983).

\section{GEOLOGICAL ENVIRONMENT}

Rock Types Fine-grained metasedimentary rocks (argillite, siltite, and quartzite), mafic metatuff, and magnetite-pyrite iron formation. Metasedimentary rocks may have large volcanic rock component.

Textures Fine-grained, thin-bedded turbidite sequences, graded beds, mafic dikes.

Age Range The Blackbird example is Proterozoic, but deposits could be of any age.

Depositional Environment Marine turbidite deposition with basaltic pyroclastic activity and submarine hot springs.

Tectonic Setting(s) Failed rift along continental margin.

Similar or Associated Deposit Types Besshi-type massive sulfide (?).

DEPOSIT DESCRIPTION

Mineralogy Cobaltite, chalcopyrite, pyrite, pyrrhotite, arsenopyrite, and magnetite. Gold and silver are locally present in tourmaline breccia pipes. Breccias contain pyrite-arsenopyritepyrrhotite and minor chalcopyrite-cobaltite.

Texture/Structure Fine to fairly coarse sulfides and sulfarsenides in lenses and stringers, locally with cataclastic texture along shear zones. Pyrite locally has colloform structure.

Alteration Silicification and intense chloritization.

Ore Controls Ore commonly occupies disrupted beds, regional distribution of ore closely follows distribution of mafic tuff and (or) iron-formation. Lenses may form at several stratigraphic horizons separated by barren metasedimentary rocks. Relationship between stratabound and breccia pipe mineralization is not understood.

Weathering Forms prominent gossans where sulfide and sulfarsenide-rich rocks crop out.

Geochemical Signature Enriched in Fe, As, B, Co, $\mathrm{Cu}, \mathrm{Au}, \mathrm{Ag}, \mathrm{Mn}$. May be depleted in $\mathrm{Ca}$, $\mathrm{Na}$. Rare-earth and trace-element distribution poorly known.

EXAMPLES Blackbird, USID (Bennett, 1977) 


\section{DESCRIPTIVE MODEL OF HOT-SPRING AU-Ag}

By Byron R. Berger

DESCRIPTION Fine-grained silica and quartz in silicified breccia with gold, pyrite, and Sb and As sulfides (see fig. 105).

GENERAL REFERENCE Berger (1985).

GEOLOGICAL ENVIRONMENT

Rock Types Rhyolite.

Textures Porphyritic, brecciated.

Age Range Mainly Tertiary and Quaternary.

Depositional Environment Subaerial rhyolitic volcanic centers, rhyolite domes, and shallow parts of related geothermal systems.

Tectonic Setting(s) Through-going fracture systems related to volcanism above subduction zones, rifted continental margins. Leaky transform faults.

Associated Deposit Types Epithermal quartz veins, hot-spring Hg, placer Au.

\section{DEPOSIT DESCRIPTION}

Mineralogy Native gold + pyrite + stibnite + realgar; or arsenopyrite \pm sphalerite \pm chalcopyrite \pm fluorite; or native gold + Ag-selenide or tellurides + pyrite.

Texture/Structure Crustified banded veins, stockworks, breccias (cemented with silica or uncemented). Sulfides may be very fine grained and disseminated in silicified rock.

Alteration Top of bottom of system: chalcedonic sinter, massive silicification, stockworks and veins of quartz + adularia and breccia cemented with quartz, quartz + chlorite. Veins generally chalcedonic, some opal. Some deposits have alunite and pyrophyllite. Ammonium feldspar (buddingtonite) may be present.

Ore Controls Through-going fracture systems, brecciated cores of intrusive domes; cemented breccias important carrier of ore.

Weathering Bleached country rock, yellow limonites with jarosite and fine-grained alunite, hematite, goethite.

Geochemical Signature $\mathrm{Au}+\mathrm{As}+\mathrm{Sb}+\mathrm{Hg}+\mathrm{Tl}$ higher in system, increasing $\mathrm{Ag}$ with depth, decreasing $\mathrm{As}+\mathrm{Sb}+\mathrm{Tl}+\mathrm{Hg}$ with depth. Locally, $\mathrm{NH}_{4}$, W.

\section{EXAMPLES}

McLaughlin, USCA

Round Mountain, USNV

Delamar, USID
(Averitt, 1945 and Becker, 1888)

(Tingley and Berger, 1985)

(Lindgren, 1900) 
Model 25a--Con.

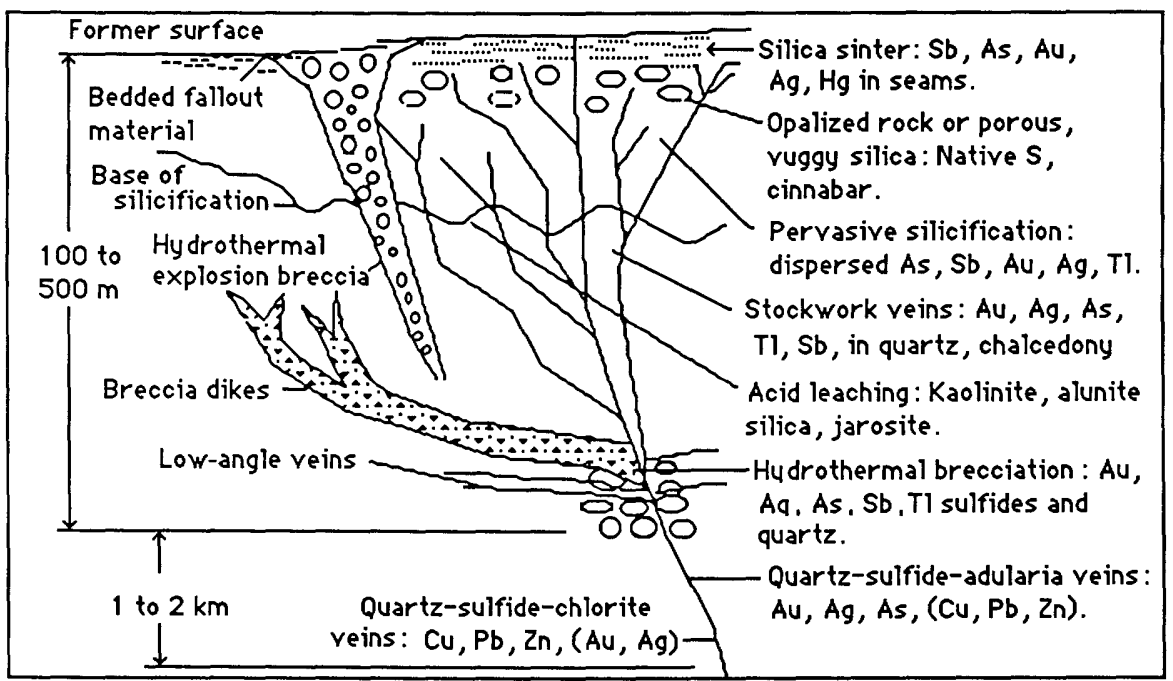

Figure 105. Cartoon cross section of hotspring Au-Ag deposit. 


\section{DESCRIPTIVE MODEL OF CREEDE EPITHERMAL VEINS}

By Dan L. Mosier, Takeo Sato, Norman J Page, Donald A. Singer, and Byron R. Berger

APPROXIMATE SYNONYM Epithermal gold (quartz-adularia) alkali-chloride-type, polymetallic veins (see fig. 106).

DESCRIPTION Galena, sphalerite, chalcopyrite, sulfosalts, + tellurides + gold in quartz-carbonate veins hosted by felsic to intermediate volcanics. Older miogeosynclinal evaporites or rocks with trapped seawater are associated with these deposits.

GENERAL REFERENCES Buchanan (1980), Boyle (1979).

\section{GEOLOGICAL ENVIRONMENT}

Rock Types Host rocks are andesite, dacite, quartz latite, rhyodacite, rhyolite, and associated sedimentary rocks. Mineralization related to calc-alkaline or bimodal volcanism.

Textures Porphyritic.

Age Range Mainly Tertiary (most are 29-4 m.y.).

Depositional Environment Bimodal and calc-alkaline volcanism. Deposits related to sources of saline fluids in prevolcanic basement such as evaporites or rocks with entrapped seawater.

Tectonic Setting(s) Through-going fractures systems; major normal faults, fractures related to doming, ring fracture zones, joints associated with calderas. Underlying or nearby older rocks of continental shelf with evaporite basins, or island arcs that are rapidly uplifted.

Associated Deposit Types Placer gold, epithermal quartz alunite Au, polymetallic replacement. DEPOSIT DESCRIPTION

Mineralogy Galena + sphalerite + chalcopyrite + copper sulfosalts + silver sulfosalts \pm gold \pm tellurides \pm bornite \pm arsenopyrite. Gangue minerals are quartz + chlorite \pm calcite + pyrite + rhodochrosite + barite \pm fluorite \pm siderite \pm ankerite \pm sericite \pm adularia \pm kaolinite. Specularite and alunite may be present.

Texture/Structure Banded veins, open space filling, lamellar quartz, stockworks, colloform textures.

Alteration Top to bottom: quartz \pm kaolinite + montmorillonite \pm zeolites \pm barite \pm calcite; quartz + illite; quartz + adularia \pm illite; quartz + chlorite; presence of adularia is variable.

Ore Controls Through-going or anastomosing fracture systems. High-grade shoots where vein changes strike or dip and at intersections of veins. Hanging-wall fractures are particularly favorable.

Weathering Bleached country rock, goethite, jarosite, alunite--supergene processes often important factor in increasing grade of deposit.

Geochemical Signature Higher in system $\mathrm{Au}+\mathrm{As}+\mathrm{Sb}+\mathrm{Hg} ; \mathrm{Au}+\mathrm{Ag}+\mathrm{Pb}+\mathrm{Zn}+\mathrm{Cu} ; \mathrm{Ag}+\mathrm{Pb}+\mathrm{Zn}, \mathrm{Cu}$ $+\mathrm{Pb}+\mathrm{Zn}$. Base metals generally higher grade in deposits with silver. $W+B i$ may be present.

EXAMPLES

Creede, USCO

Pachuca, MXCO

Toyoha, JAPN
(Steven and Eaton, 1975;

Barton and others, 1977)

(Geyne and others, 1963)

(Yajima and Onta, 1979) 
Model 25b--Con.

GRADE AND TONNAGE MODEL OF CREEDE EPITHERMAL VEINS

By Dan L. Mosier, Takeo Sato, and Donald A. Singer

COMMENTS Gold grade is correlated with zinc grade $(r=-0.52, n=22)$. See figs. $107-112$. DEPOSITS

\begin{tabular}{llll} 
Name & Country & Name & Country \\
\cline { 2 - 3 } Animas & & & Nogal \\
Bonanza & USCO & USNM \\
Casapalca & USCO & Ogane & JAPN \\
Chavin & PERU & Jphir & USCO \\
Coco Mina & PERU & Pachuca-Real del Monte & MXCO \\
Colqui & NCGA & Red Mountain & USCO \\
Creede & PERU & Rio Pallanga & PERU \\
El Tigre & USCO & Sai & JAPN \\
Eureka & MXCO & Sneffels & USCO \\
Hosokura & USCO & Telluride & USCO \\
Kata & JAPN & Toyoha & JAPN \\
Lake City & PERU & Uruachic & MXCO \\
Los Mantiales & USCO & Yatani & JAPN
\end{tabular}

Madrigal

PERU

Figure 106. Cartoon cross section of typical Creedetype epithermal vein deposit.

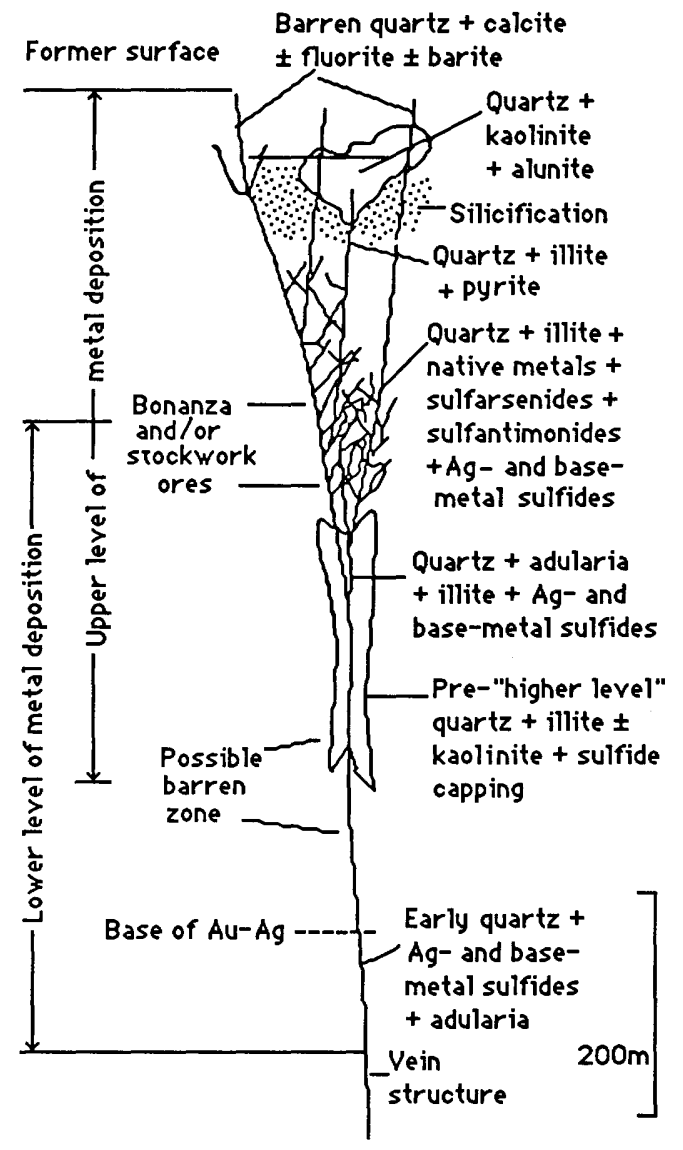


CREEDE EPITHERMAL VEIN

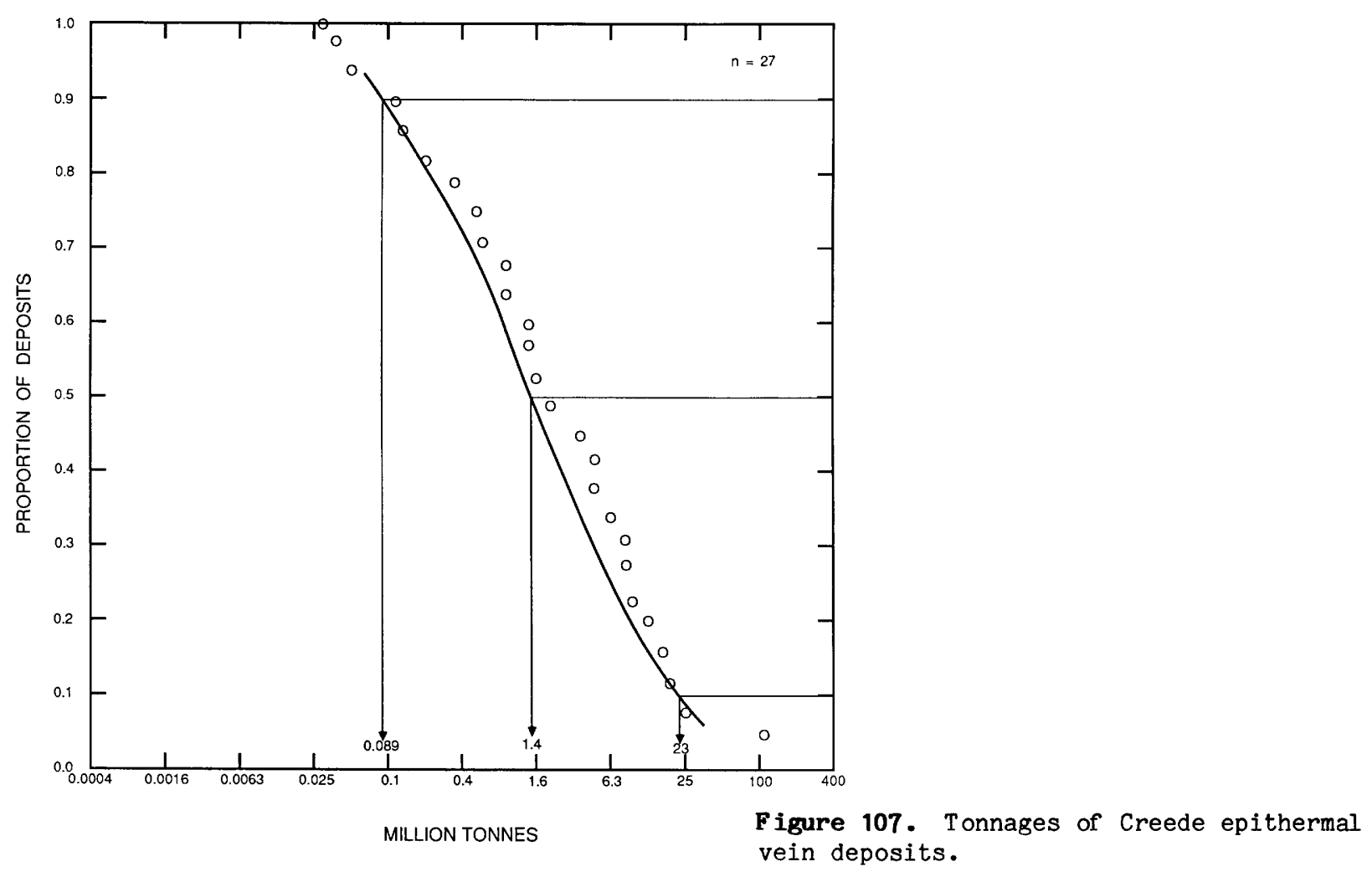

CREEDE EPITHERMAL VEIN

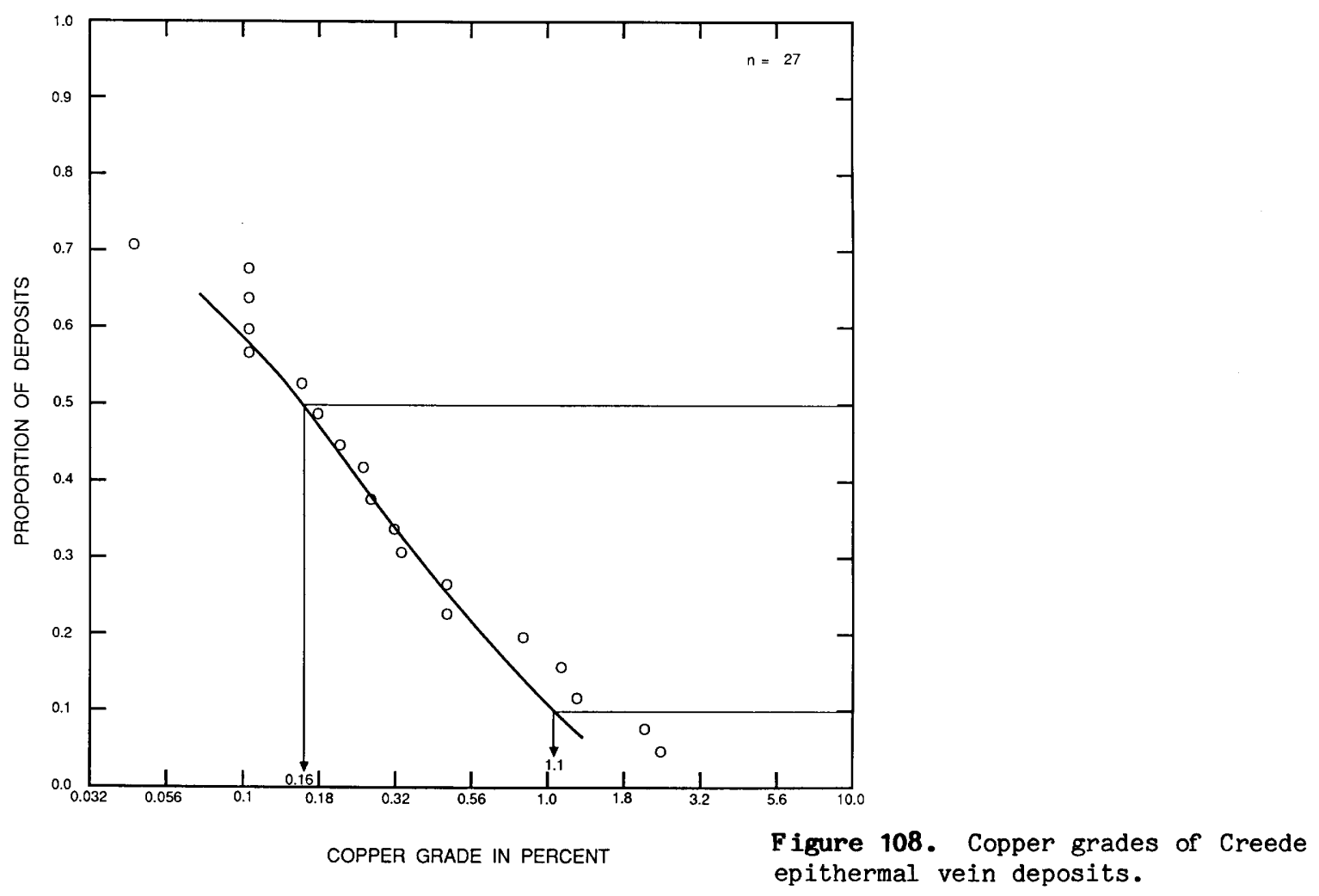


Model 25b--Con.

CREEDE EPITHERMAL VEIN

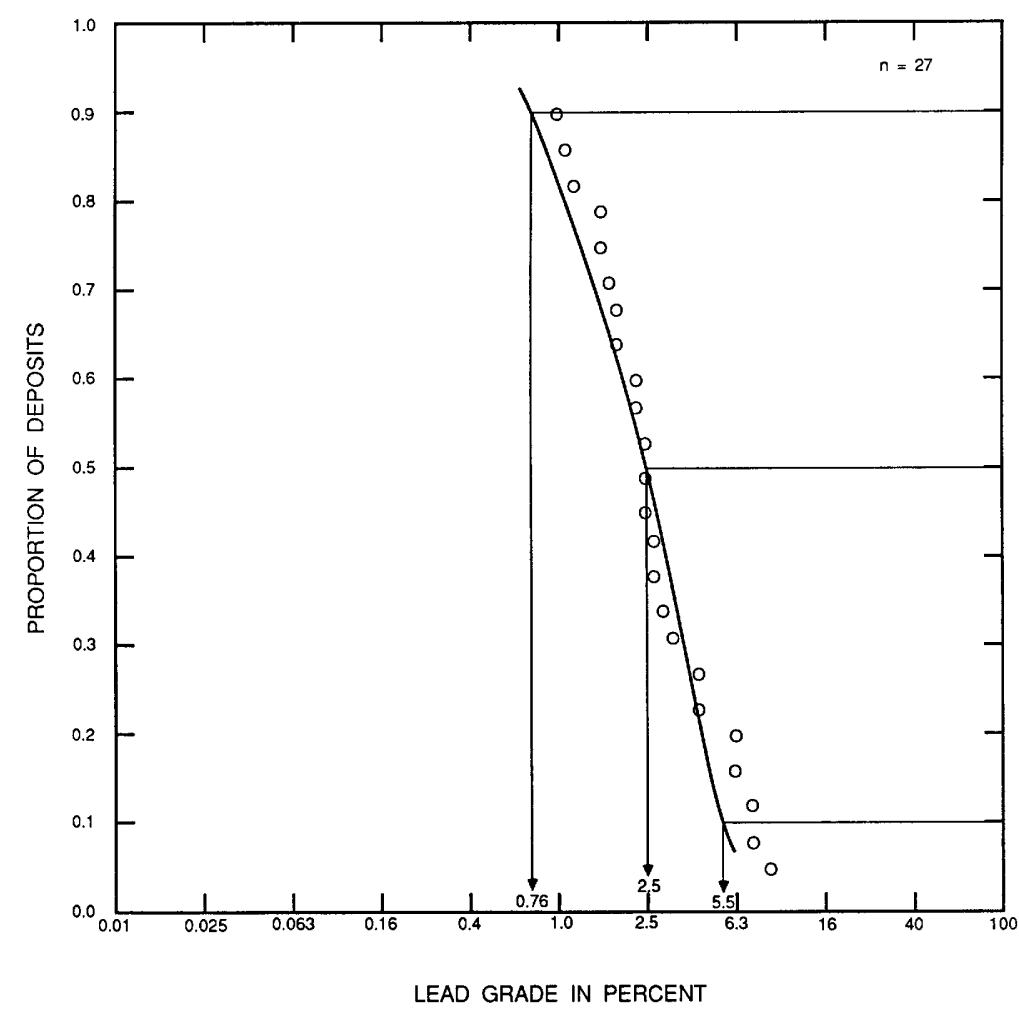

Figure 109. Lead grades of Creede epithermal vein deposits.

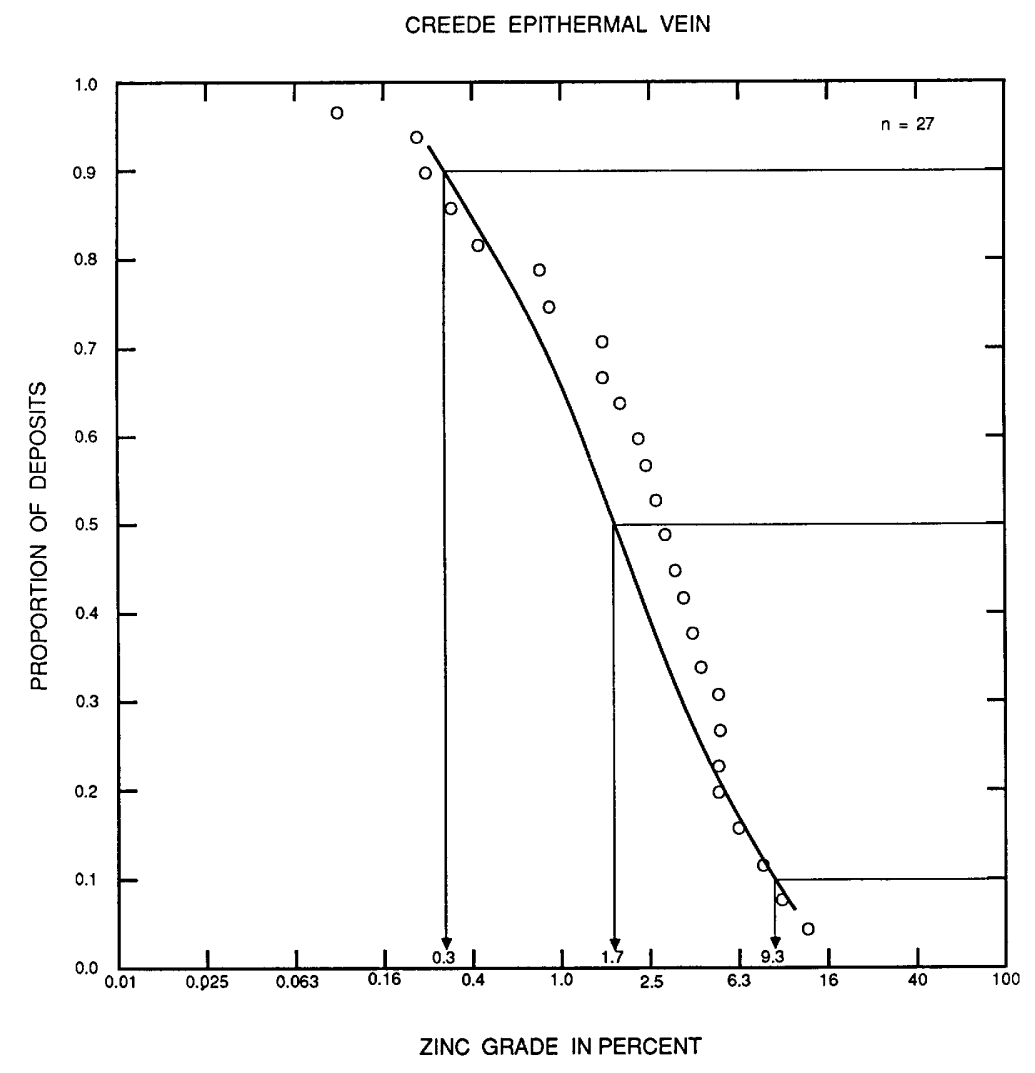

Figure 110. Zinc grades of Creede epithermal vein deposits. 
CREEDE EPITHERMAL VEIN

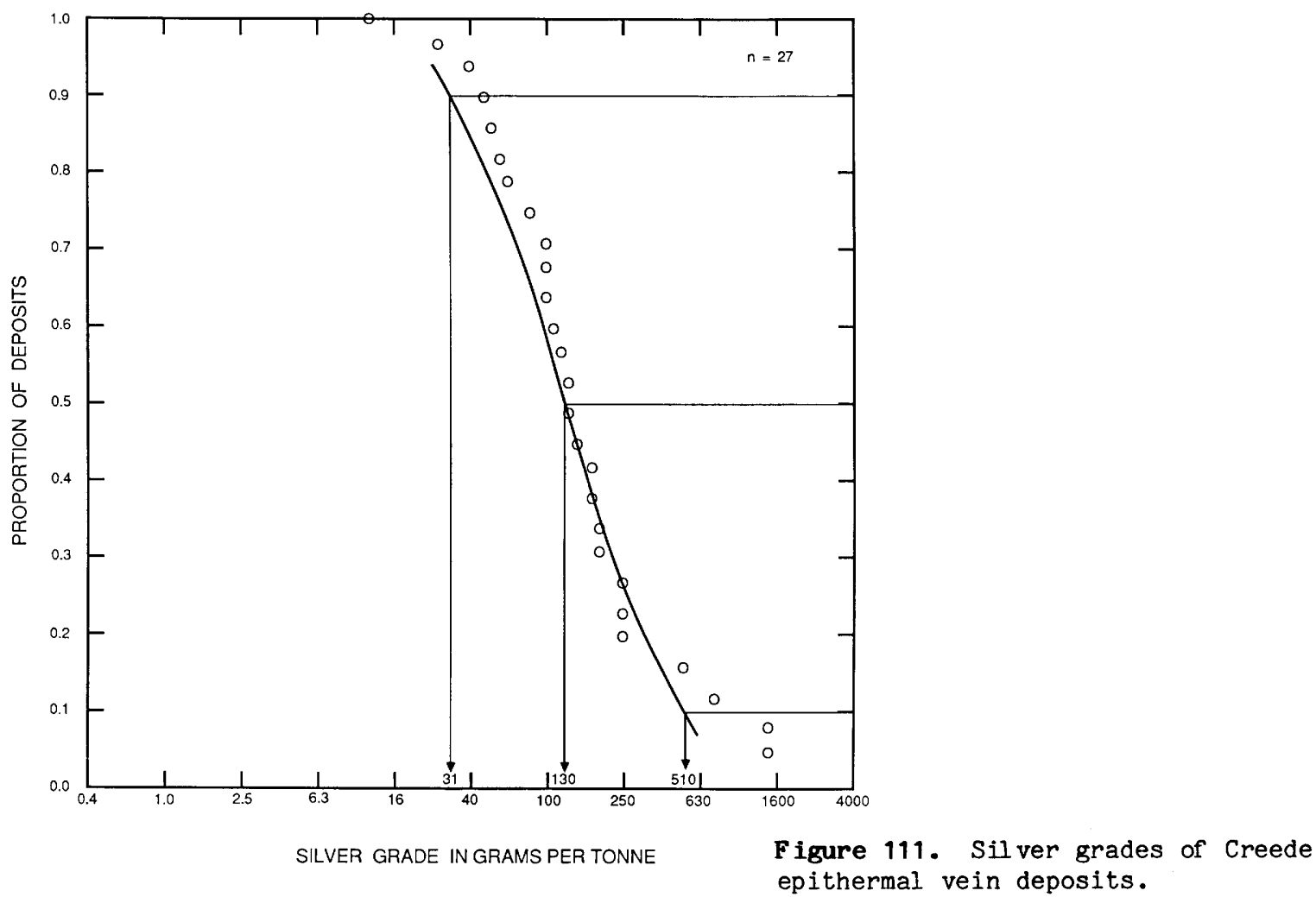

CREEDE EPITHERMAL VEIN

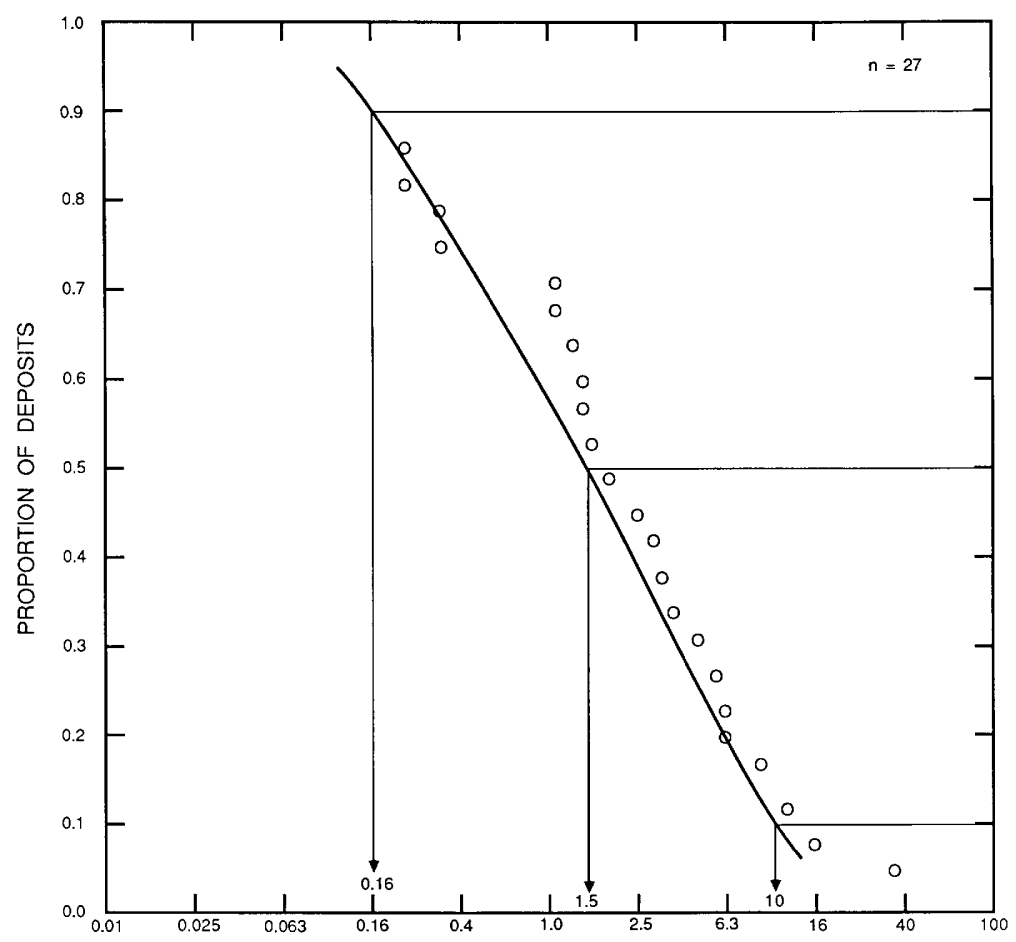

GOLD GRADE IN GRAMS PER TONNE 
Model 25c

DESCRIPTIVE MODEL OF COMSTOCK EPITHERMAL VEINS

\author{
By Dan L. Mosier, Donald A. Singer, and Byron R. Berger
}

APPROXIMATE SYNONYM Epithermal gold (quartz-adularia) alkali-chloride type.

DESCRIPTION Gold, electrum, silver sulfosalts, and argentite in vuggy quartz-adularia veins hosted by felsic to intermediate volcanic rocks that overlie predominantly clastic sedimentary rocks, and their metamorphic equivalents (see fig. 106).

GENERAL REFERENCES Buchanan (1980), Boyle (1979).

GEOLOGICAL ENVIRONMENT

Rock Types Host rocks are andesite, dacite, quartz latite, rhyodacite, rhyolite; and associated sedimentary rocks. Mineralization related to calc-alkaline or bimodal volcanism.

Textures Porphyritic.

Age Range Mainly Tertiary (most are 40-3.7 m.y.).

Depositional Environment Calc-alkaline and bimodal volcanism and associated intrusive activity over basement rocks composed of clastic sedimentary rocks and their metamorphic equivalents.

Volcanic-related geothermal systems lack access to saline fluids from basement sources.

Tectonic Setting(s) Through-going fracture systems, major normal faults, fractures related to doming, ring fracture zones, joints.

Associated Deposit Types Placer gold and epithermal quartz-alunite Au.

DEPOSIT DESCRIPTION

Mineralogy Argentite + gold or electrum \pm silver sulfosalts \pm naumannite. Galena, sphalerite, chalcopyrite, tellurides, hematite, and arsenopyrite are moderate to sparse. Gangue minerals are quartz + pyrite \pm adularia \pm calcite \pm sericite \pm chlorite. Barite, fluorite, rhodochrosite, kaolinite, and montmorillonite are moderate to sparse. Ore minerals constitute only a few percent of vein.

Texture/Structure Banded veins, open space filling, lamellar quartz, stockwork.

Alteration From top to bottom of system: quartz + kaolinite + montmorillonite \pm zeolite \pm barite \pm calcite; quartz + illite; quartz + adularia \pm illite; quartz + chlorite; presence of adularia is variable.

Ore Controls Through-going anastomosing fracture systems, centers of intrusive activity. Hanging wall more favorable.

Weathering Bleached country rock, limonite, jarosite, goethite, alunite, hematite, argillization with kaolinite.

Geochemical Signature Higher in system $\mathrm{Au}+\mathrm{As}+\mathrm{Sb}+\mathrm{Hg}$ or $\mathrm{Au}+\mathrm{As}+\mathrm{Cu} ; \mathrm{Au}+\mathrm{Ag}+\mathrm{Pb}+\mathrm{Cu} ; \mathrm{also}$ Te and $W$.

EXAMPLES

Comstock, USNV

Guanajuato, MXCO
(Becker, 1882)

(Buchanan, 1980;

Wandke and Martinez, 1928) 
Model 25c--Con.

GRADE AND TONNAGE MODEL OF COMSTOCK EPITHERMAL VEINS

By Dan L. Mosier, Donald A. Singer, and Byron R. Berger

COMMENTS See figs. 113-116.

DEPOSITS

Name

Aurora

Bodie

Bovard

Calico

Calistoga

Comstock

Divide

Dolores

El Rincon

Fairview

Fuke

Gold Mountain

Guanacevi

Guana juato

Hostotipaquilla

Katherine

Kushikino-Arakawa

Mochikoshi

Mogollon

Nawa ji

Oatman
Country Name

Ohguchi

Ohito

Olinghouse

Orient

Patterson

Republic

Rosario

Sand Springs

Searchlight

Seikoshi

Seven Trough

Sheep Tank

Silver City

Taio

Tayoltita

Toi

Tonopah

Tuscarora

Weaver

Yugashima
Country

JAPN

JAPN

USNV

USWA

USCA

USWA

HNDR

USNV

USNV

JAPN

USNV

USAZ

USNV

JAPN

MXCO

JAPN

USNV

USAZ

USAZ

JAPN 
Model 25c--Con.

Figure 113. Tonnages of Comstock epithermal vein deposits.
Figure 114. Gold grades of Comstock epithermal vein deposits.

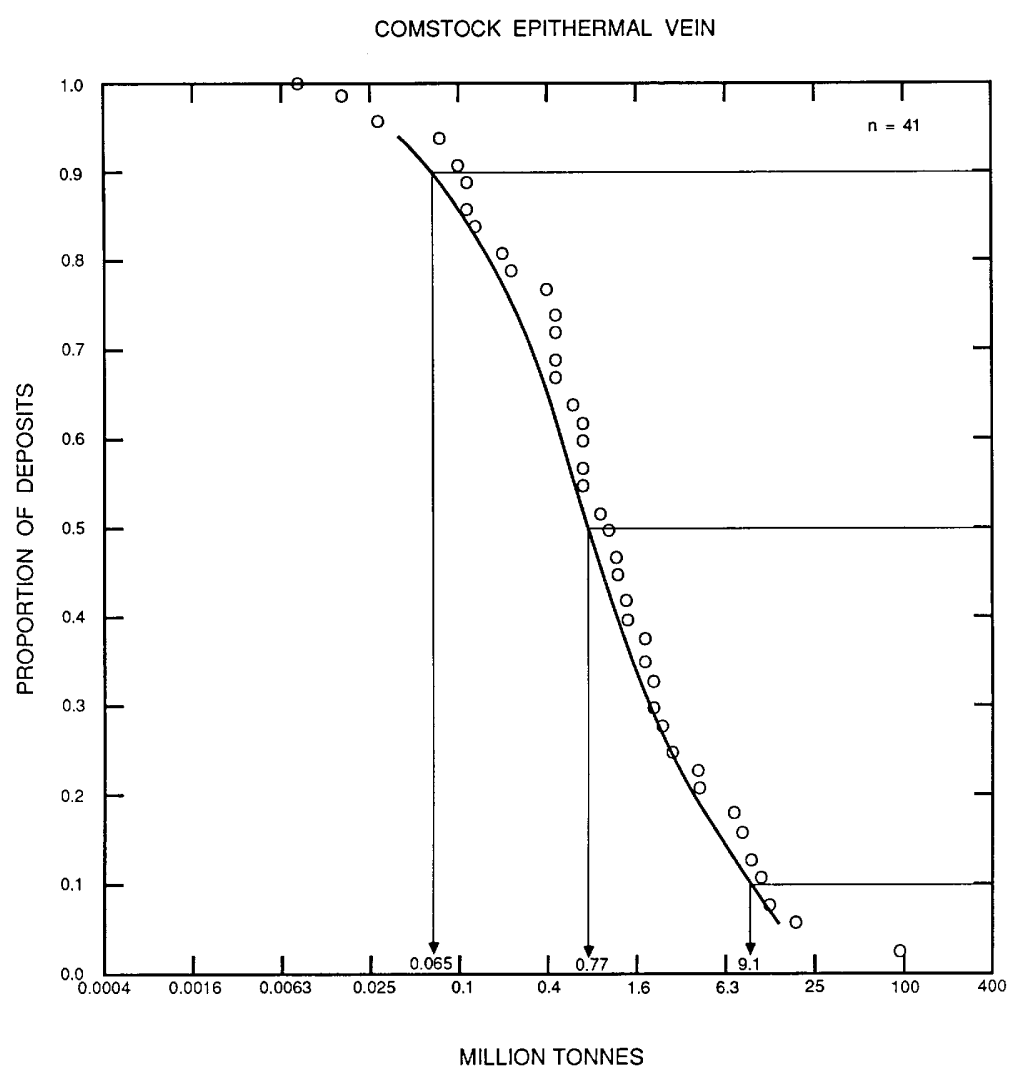

COMSTOCK EPITHERMAL VEIN

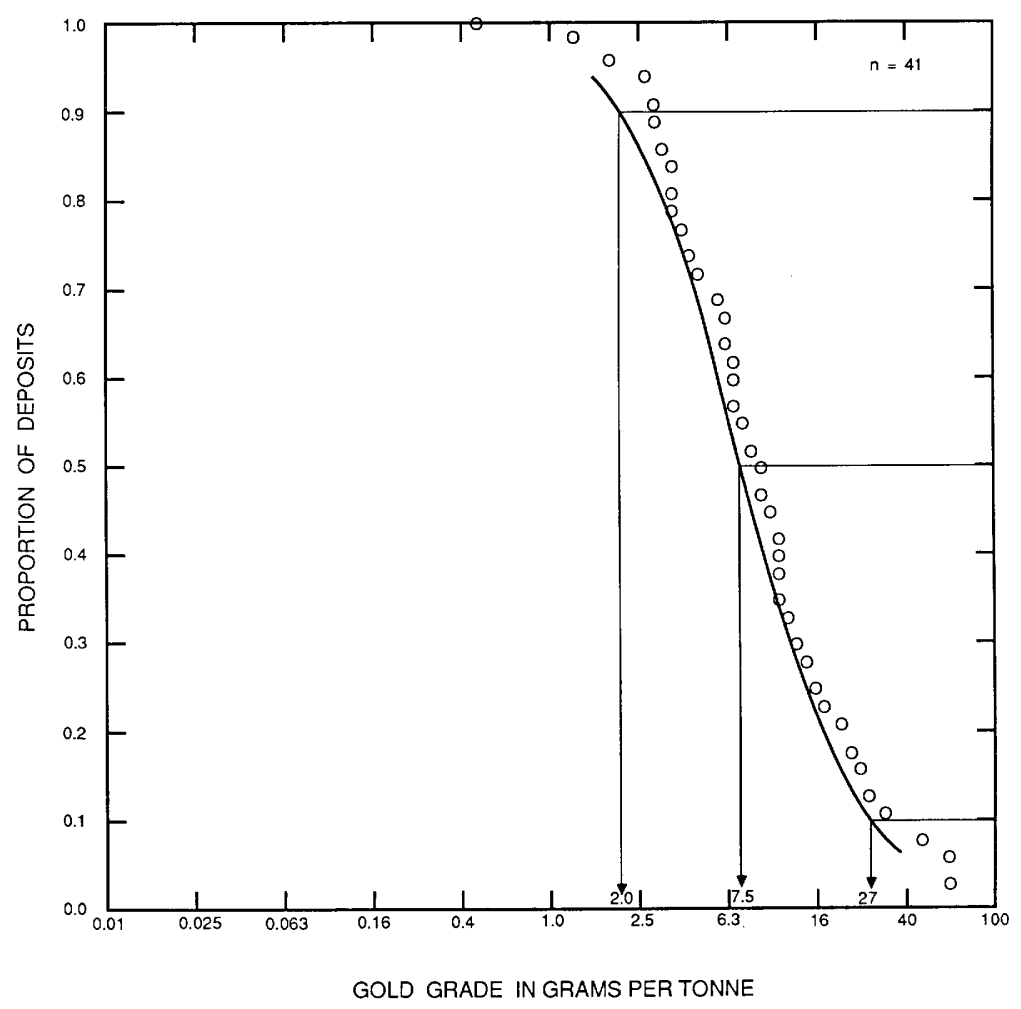


COMSTOCK EPITHERMAL VEIN

Model 25c--Con.

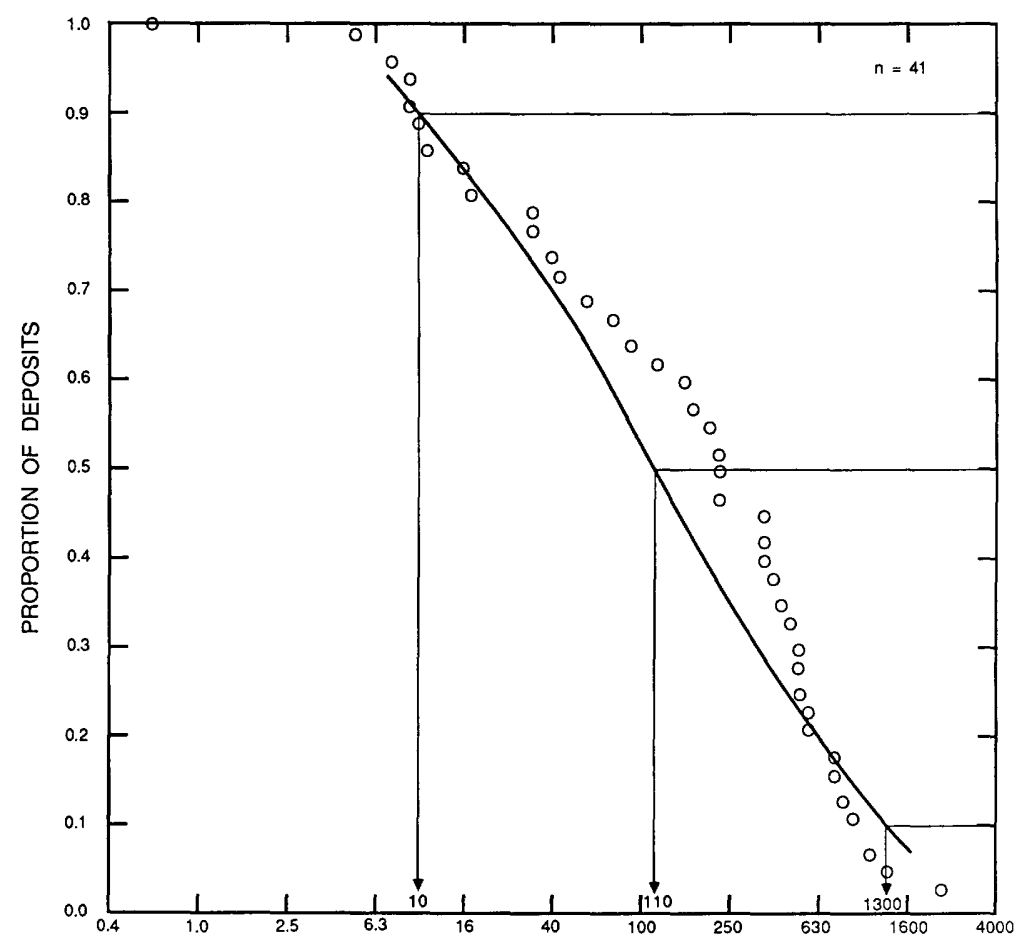

SILVER GRADE IN GRAMS PER TONNE

Figure 115. Silver grades of Comstock epithermal vein deposits.

COMSTOCK EPITHERMAL VEIN

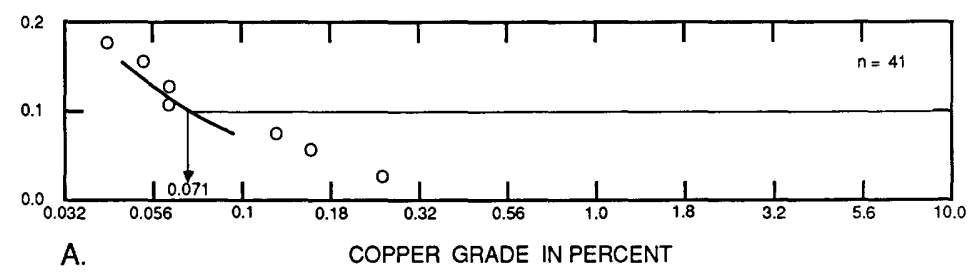

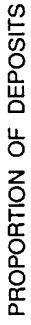

A.

COPPER GRADE IN PERCENT

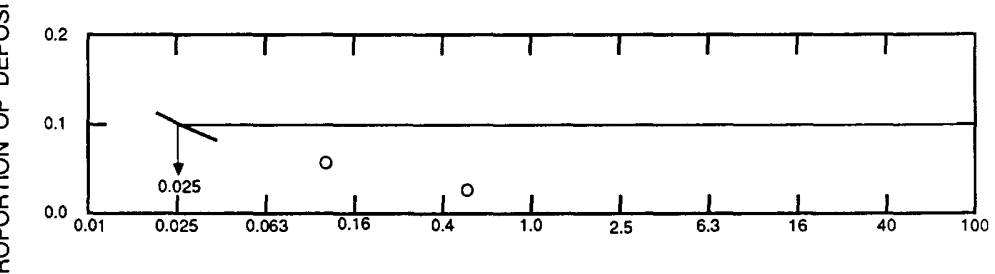

B.

ZINC GRADE IN PERCENT

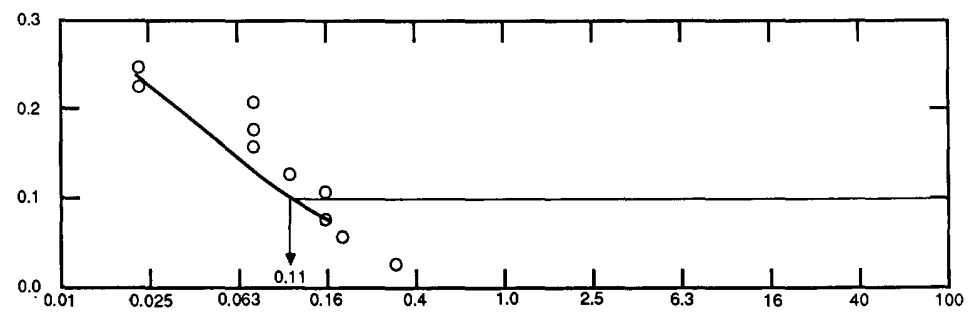

c.

LEAD GRADE IN PERCENT

Figure 116. By-product grades of Comstock epithermal vein deposits. $\mathrm{A}$, Copper. $\underline{B}$, Zinc. $\underline{C}$, Lead. 
Model 25d

\section{DESCRIPTIVE MODEL OF SADO EPITHERMAL VEINS}

By Dan L. Mosier, Bruce R. Berger, and Donald A. Singer

DESCRIPTION Gold, chalcopyrite, sulfosalts, and argentite in vuggy veins hosted by felsic to intermediate volcanic rocks that overlie older volcanic sequences or igneous intrusions (see fig. 106).

GENERAL REFERENCE Boyle (1979).

\section{GEOLOGICAL ENVIRONMENT}

Rock Types Host rocks are andesite, dacite, quartz latite, rhyodacite, rhyolite, and associated sedimentary rocks. Mineralization related to calc-alkaline or bimodal volcanism.

Textures Porphyritic.

Age Range Mainly Tertiary (most are 38-5 m.y.).

Depositional Environment Calc-alkaline and bimodal volcanism and associated intrusive activity over basement rocks composed of thick, older volcanic sequences or igneous intrusives (batholiths). Volcanic-related geothermal systems lack access to saline fluids from basement sources.

Tectonic Setting(s) Through-going fracture systems, major normal faults, fractures related to doming, ring fracture zones, joints.

Associated Deposit Types Placer gold and quartz-alunite Au.

\section{DEPOSIT DESCRIPTION}

Mineralogy Gold \pm argentite + electrum + chalcopyrite. Sulfosalts and tellurides are moderate, galena and sphalerite are sparse. Gangue minerals are quartz \pm pyrite \pm adularia \pm calcite. Chalcedony, adularia, kaolinite, rhodochrosite, chlorite, sericite, and barite are moderate to sparse.

Texture/Structure Banded veins, open space filling, lamellar quartz, stockwork, breccia pipes.

Alteration Silicification zoned by quartz + kaolinite + montmorillonite \pm alunite; may have pervasive propylitic alteration of chlorite + calcite.

Ore Controls Through-going fracture systems; major normal faults, fractures related to doming, ring fractures, joints.

Weathering Bleached country rock, limonite, hematite, goethite, jarosite, alunite; argillization with kaolinite.

Geochemical Signature: $\mathrm{Au}+\mathrm{Ag} ; \mathrm{Au}+\mathrm{Ag}+\mathrm{Cu}$.

EXAMPLES

Takeno, JAPN (Soeda and Watanabe, 1981) 
Model 25d--Con.

\section{GRADE AND TONNAGE MODEL OF SADO EPITHERMAL VEINS}

By Dan L. Mosier and Takeo Sato

COMMENTS The two lowest gold grades were not plotted because it is suspected that their reported grades are in error. See figs. 117-119.

DEPOSITS

$\underline{\text { Name }}$

Bajo

Benten

Bruner

Chitose

Guadalupe and Calvo

Hayden Hill

High Grade

Innai

Kawasaki

Koyama
Country

JAPN

JAPN

USNV

JAPN

MXCO

USCA

USCA

JAPN

JAPN

JAPN
Name

Country

La Libertad
Mamuro
Mizobe
Nagamatsu
Sado
Sanei
Takahata
Takatama
Takeno
Winters

MXCO

JAPN

JAPN

JAPN

JAPN

JAPN

JAPN

JAPN

JAPN

USCA 
Model 25d--Con.

SADO EPITHERMAL VEIN

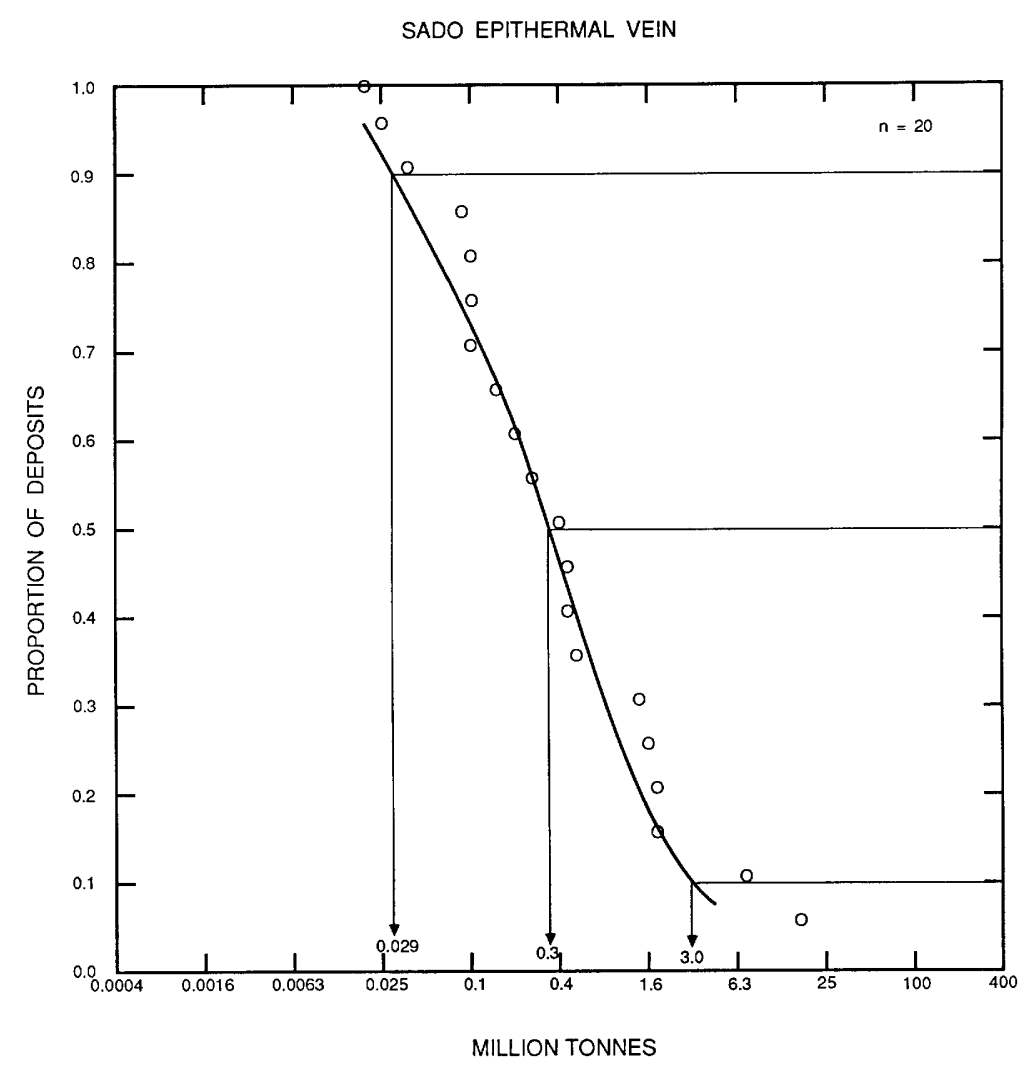

Figure 117. Tonnages of Sado epithermal vein deposits.

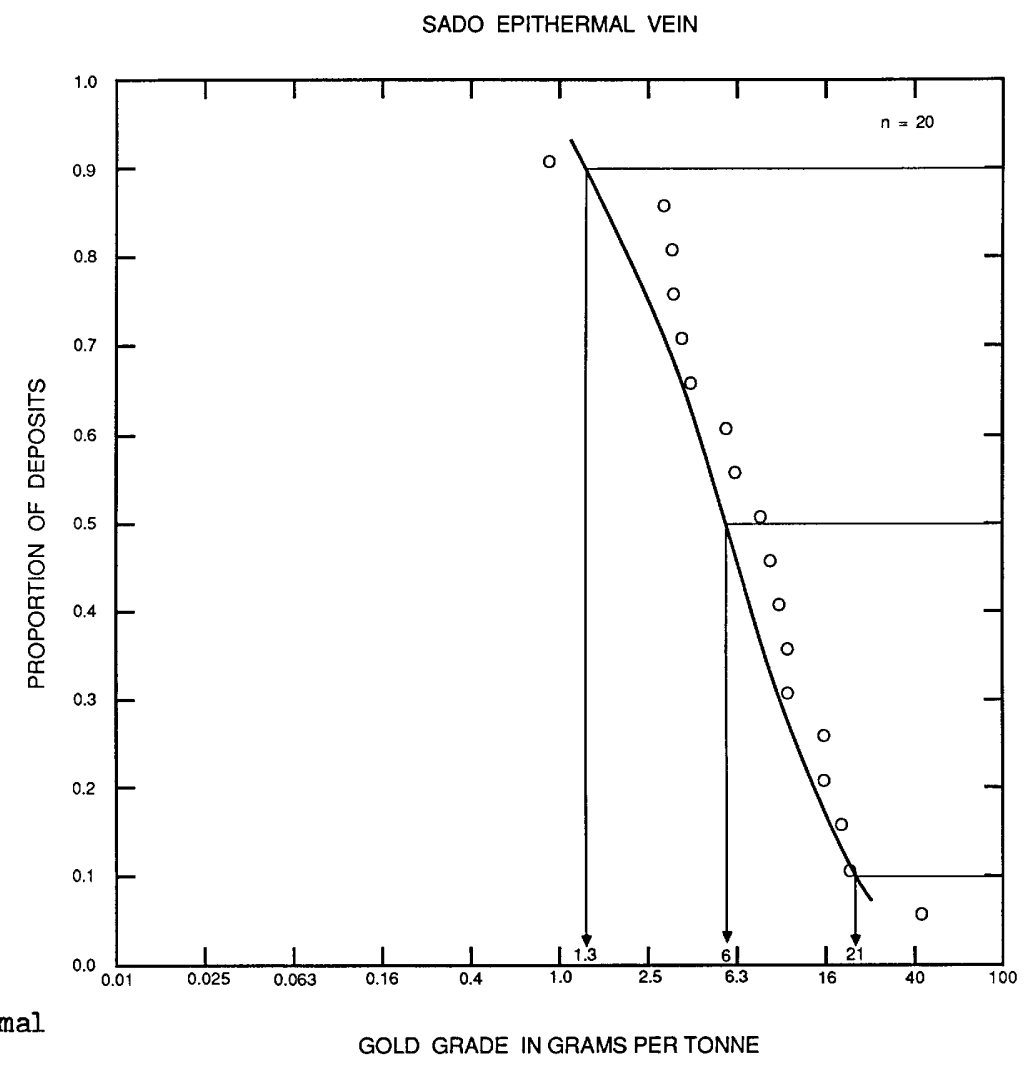

Figure 118. Gold grades of Sado epithermal vein deposits. 

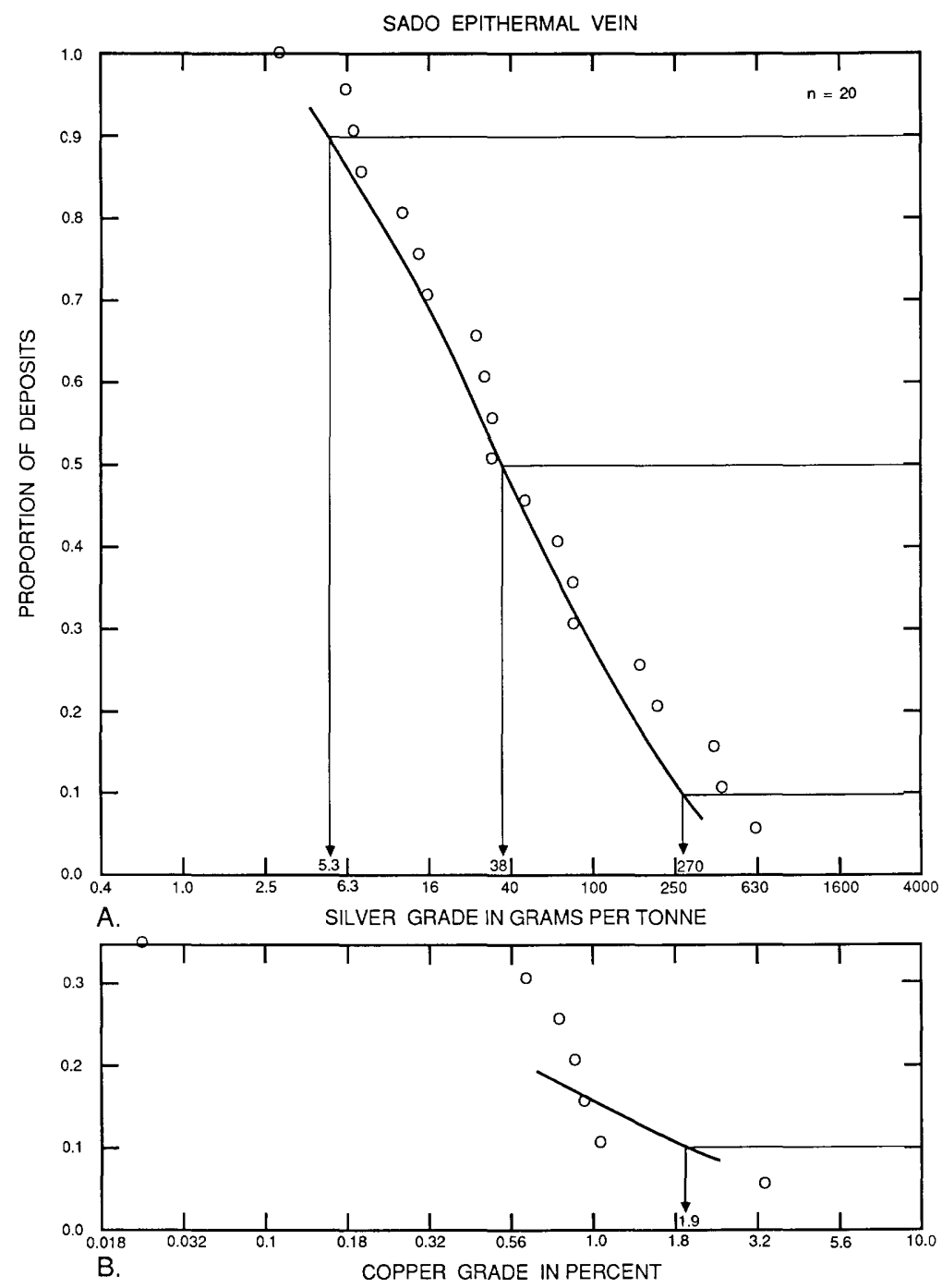

Figure 119. By-product grades of Sado epithermal vein deposits. A, Silver. B, Copper. 


\title{
DESCRIPTIVE MODEL OF EPITHERMAL QUARTZ-ALUNITE AU
}

\author{
By Byron R. Berger \\ APPROXIMATE SYNONYM Acid-sulfate, or enargite gold (Ashley, 1982). \\ DESCRIPTION Gold, pyrite, and enargite in vuggy veins and breccias in zones of high-alumina \\ alteration related to felsic volcanism. \\ GENERAL REFERENCE Ashley (1982).
}

GEOLOGICAL ENVIRONMENT

Rock Types Volcanic: dacite, quartz latite, rhyodacite, rhyolite. Hypabyssal intrusions or domes.

Textures Porphyritic.

Age Range Generally Tertiary, but can be any age.

Depositional Environment Within the volcanic edifice, ring fracture zones of calderas, or areas of igneous activity with sedimentary evaporites in basement.

Tectonic Setting(s) Through-going fracture systems: keystone graben structures, ring fracture zones, normal faults, fractures related to doming, joint sets.

Associated Deposit Types Porphyry copper, polymetallic replacement, volcanic hosted Cu-As-Sb. Pyrophyllite, hydrothermal clay, and alunite deposits.

\section{DEPOSIT DESCRIPTION}

Mineralogy Native gold + enargite + pyrite + silver-bearing sulfosalts \pm chalcopyrite \pm bornite \pm precious-metal tellurides \pm galena \pm sphalerite \pm huebnerite. May have hypogene oxidation phase with chalcocite + covellite \pm luzonite with late-stage native sulfur.

Texture/Structure Veins, breccia pipes, pods, dikes; replacement veins often porous, and vuggy, with comb structure, and crustified banding.

Alteration Highest temperature assemblage: quartz + alunite + pyrophyllite may be early stage with pervasive alteration of host rock and veins of these minerals; this zone may contain corundum, diaspore, andalusite, or zunyite. Zoned around quartz-alunite is quartz + alunite + kaolinite + montmorillonite; pervasive propylitic alteration (chlorite + calcite) depends on extent of early alunitization. Ammonium-bearing clays may be present.

Ore Controls Through-going fractures, centers of intrusive activity. Upper and peripheral parts of porphyry copper systems.

Weathering Abundant yellow limonite, jarosite, goethite, white argillization with kaolinite, finegrained white alunite veins, hematite.

Geochemical Signature Higher in system: $\mathrm{Au}+\mathrm{As}+\mathrm{Cu}$; increasing base metals at depth. Also $\mathrm{Te}$ and (at El Indio) W.

EXAMPLES

Goldfield, USNV

Kasuga mine, JAPN

El Indio, CILE

Summitville, USCO

Iwato, JAPN
(Ransome, 1909)

(Taneda and Mukaiyama, 1970)

(Walthier and others, 1982)

(Perkins and Nieman, 1983)

(Saito and Sato, 1978) 


\section{GRADE AND TONNAGE MODEL OF EPITHERMAL QUARTZ-ALUNITE Au}

By Dan L. Mosier and W. David Menzie

COMMENTS See figs. 120-123.

DEPOSITS

Name

Country

Chinkuashih

TIWN

El Indio

Goldfield

CILE

USNV

JAPN

JAPN

Kasuga

Masonic

Mohave

USCA

USCA

Stedman

USCA 
Model 25e--Con.

EPITHERMAL QUARTZ--ALUNITE VEIN

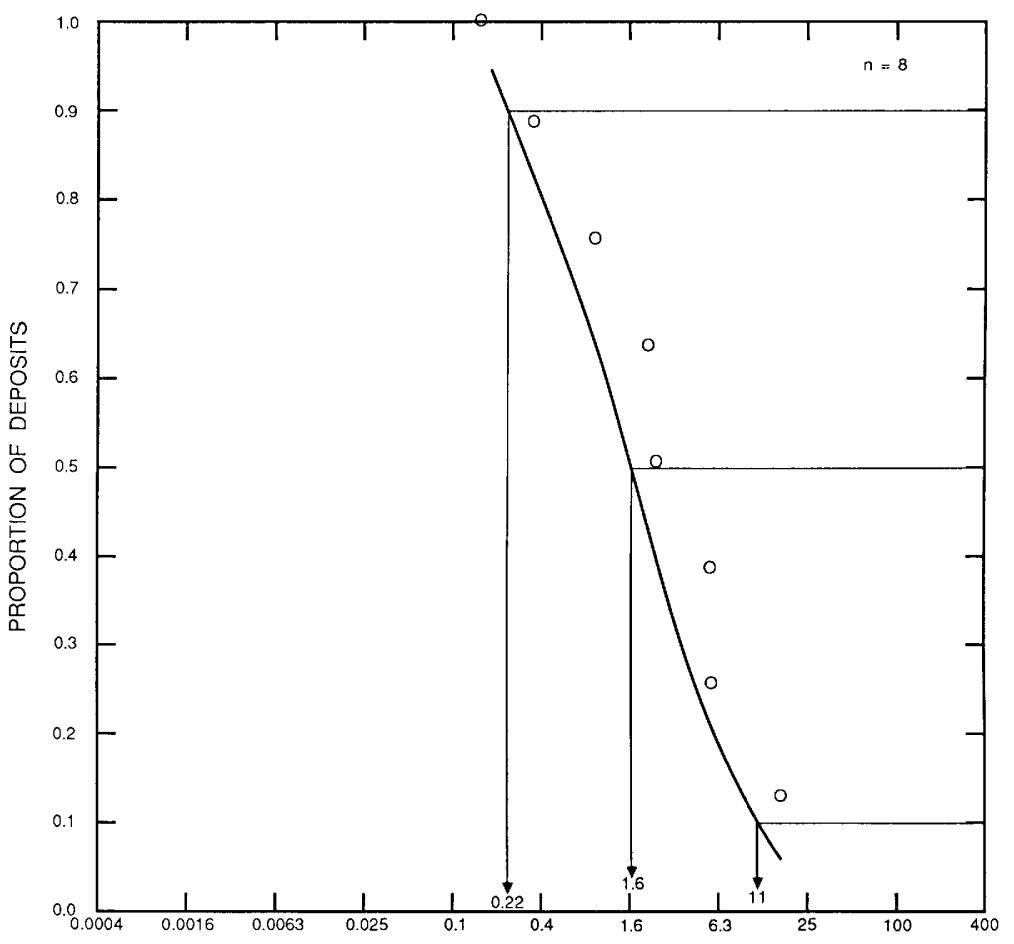

Figure 120. Tonnages of epithermal quartzalunite vein deposits.

MILLION TONNES

EPITHERMAL QUARTZ--ALUNITE VEIN

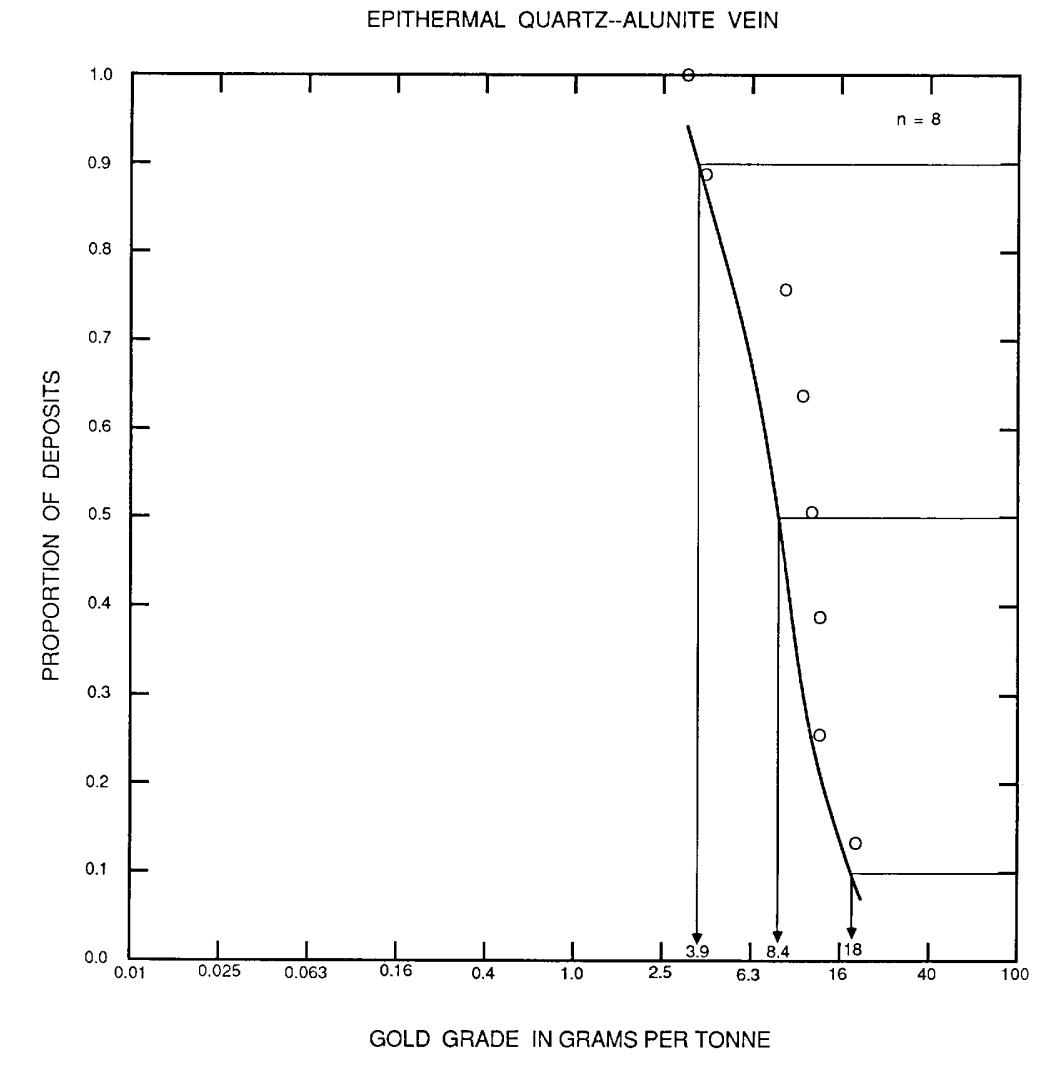

Figure 121. Gold grades of epithermal quartz-alunite vein deposits. 
EPITHERMAL QUARTZ--ALUNITE VEIN

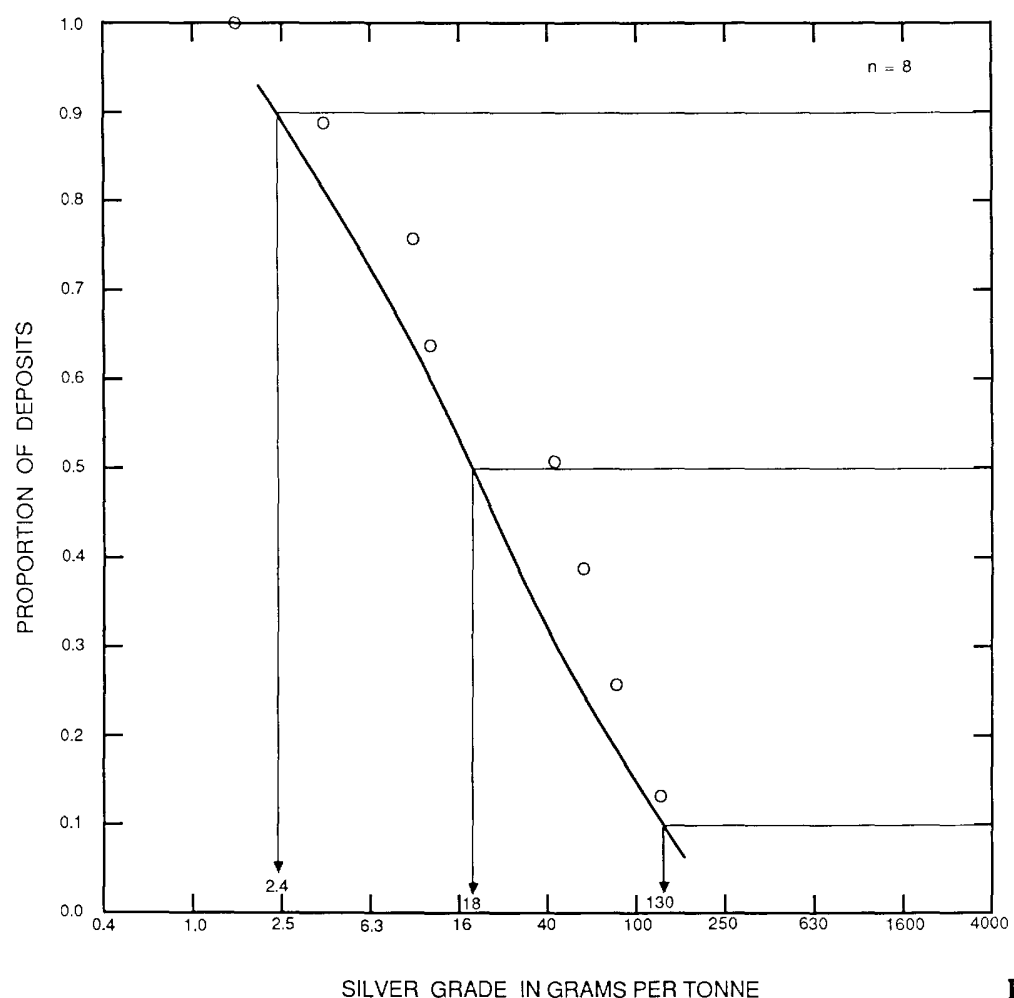

Figure 122. Sil ver grades of epithermal quartz-alunite vein deposits.

EPITHERMAL QUARTZ--ALUNITE VEIN

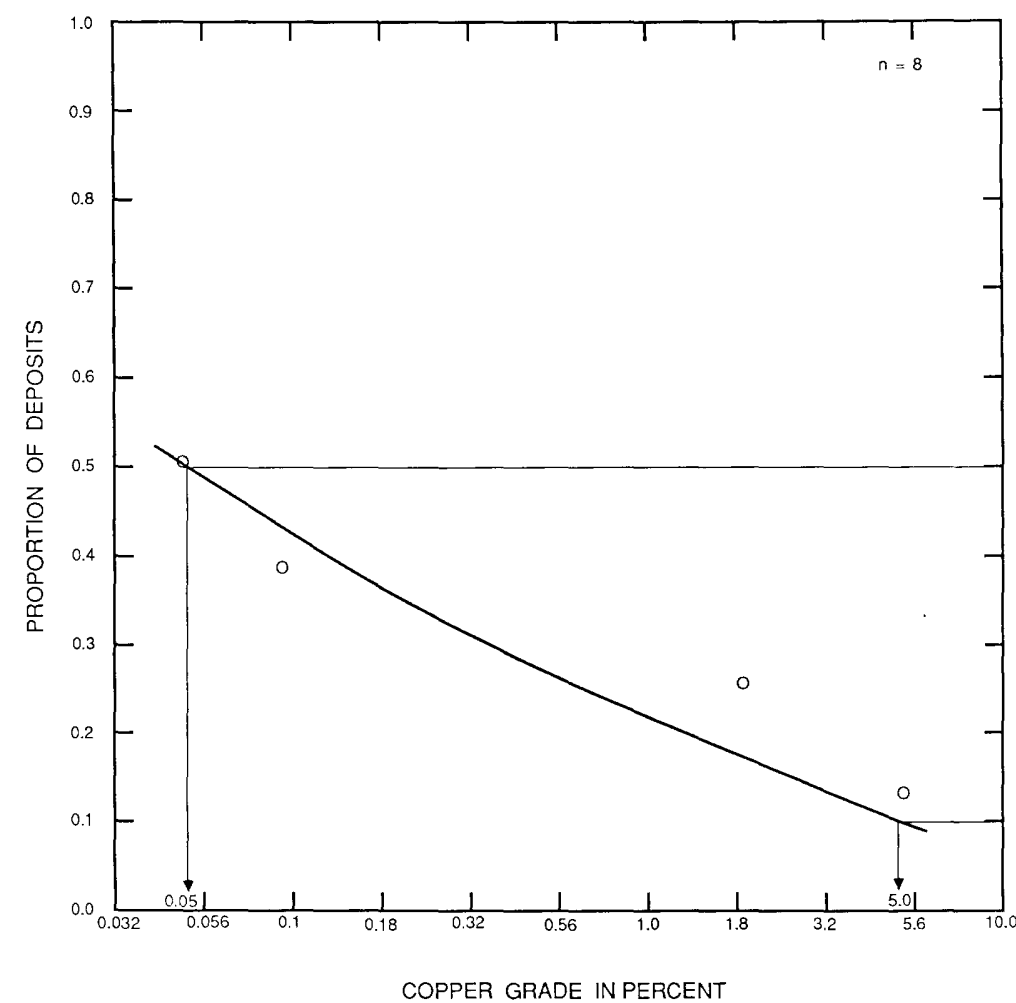

Figure 123. Copper grades of epithermal quartz-al unite vein deposits. 
Model $25 f$

DESCRIPTIVE MODEL OF VOLCANOGENIC U

By William C. Bagby

DESCRIPTION Uranium mineralization in epithermal veins composed of quartz, fluorite, and iron, arsenic, and molybdenum sulfides.

GENERAL REFERENCE Nash (1981).

GEOLOGICAL ENVIRONMENT

Rock Types High-silica alkali rhyolite and potash trachytes. Peralkaline and peraluminous rhyolite host ore.

Textures Porphyritic to aphyric vesicular flows and shallow intrusive rocks.

Age Range Precambrian to Tertiary.

Depositional Environment Subaerial to subaqueous volcanic complexes. Near-surface environment, association with shallow intrusive rocks is important.

Tectonic Setting(s) Continental rifts and associated calderas.

Associated Deposit Types Roll-front uranium in volcaniclastic sediments. Fluorite deposits. DEPOSIT DESCRIPTION

Mineralogy Coffinite, uraninite, brannerite are most common uranium minerals. other minerals include pyrite, realgar/orpiment, leucoxene, molybdenite, fluorite, quartz, adularia, and barite. Gold is present in some deposits. Deposits associated with alkaline complexes may contain bastnaesite.

Texture/Structure Open-space filling in breccias. Uraninite commonly encapsulated in silica.

Alteration Kaolinite, montmorillonite, and alunite are common. Silicification, accompanied by adularia, affects wallrocks spatially most closely associated with ore.

Ore Controls Through-going fractures and breccias formed along the margins of shallow

intrusives. Vugs in surface flows are of minor importance.

Weathering Near-surface oxidation produces jordisite and a variety of secondary uranium minerals. Supergene uranium enrichment is generally not important.

Geochemical Signature $\mathrm{Li}$ and $\mathrm{Hg}$ are zoned away from the ore. High anomalous $\mathrm{As}$, Sb, F, Mo $\pm \mathrm{W}$ occur near and with the ore. Mo is deep, $\mathrm{Hg}$ is shallow. REE may be highly anomalous. Anomalously radioactive.

EXAMPLES

Marysvale, USUT

Aurora prospect, USOR

Rexspar, CNBC
(Kerr and others, 1957)

(Roper and Wallace, 1981)

(Joubin and James, 1956)

\section{GRADE AND TONNAGE MODEL OF VOLCANOGENIC U}

By Dan L. Mosier

COMMENTS Only deposits with reported sizes greater than 1,000 tonnes are included. See figs. 124 , 125 . 
Model $25 \mathrm{f}--$ Con.

DEPOSITS

$\underline{\text { Name }}$

Aurora

Ben Lomond

Bretz

Buckhorn

Coteje

El Mezquite

El Nopal (Nopal I)

Henry district

La Bajada

Laguna colorado

Laguna del Cuervo
Country

USOR

AUQL

USOR

USNV

BLVA

MXCO

MXCO

USUT

USNM

AGTN

$\mathrm{MXCO}$
Name

Los Puertos

Lucky Lass

Macusani

Moonlight

Nopal III

Novazza

Osamu Utsumi

Petersen Mtn.

Rexspar

White King
Country

MXCO

USOR

PERU

USNV

MXCO

ITLY

BRZL

USCA

CNBC

USOR 
Model 25f--Con.

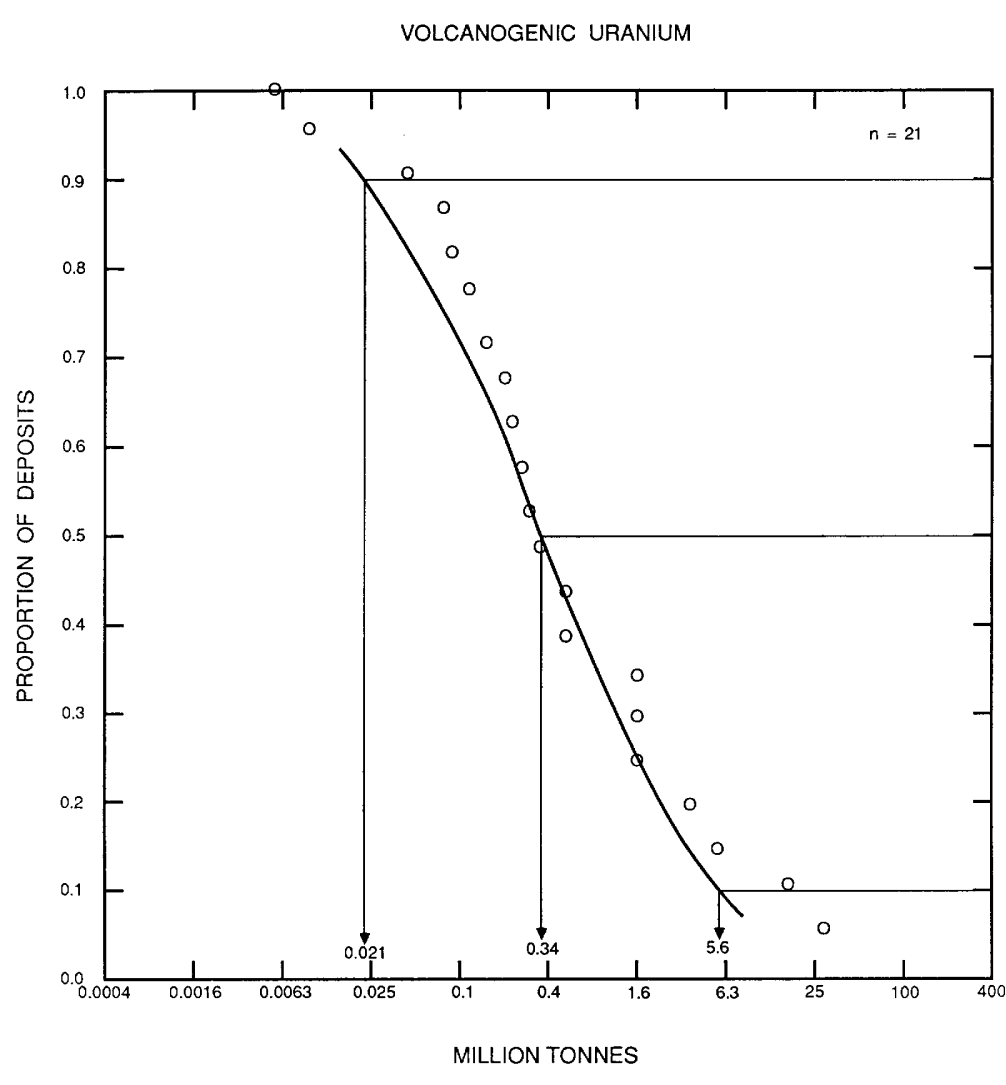

Figure 124. Tonnages of vol canogenic U deposits.

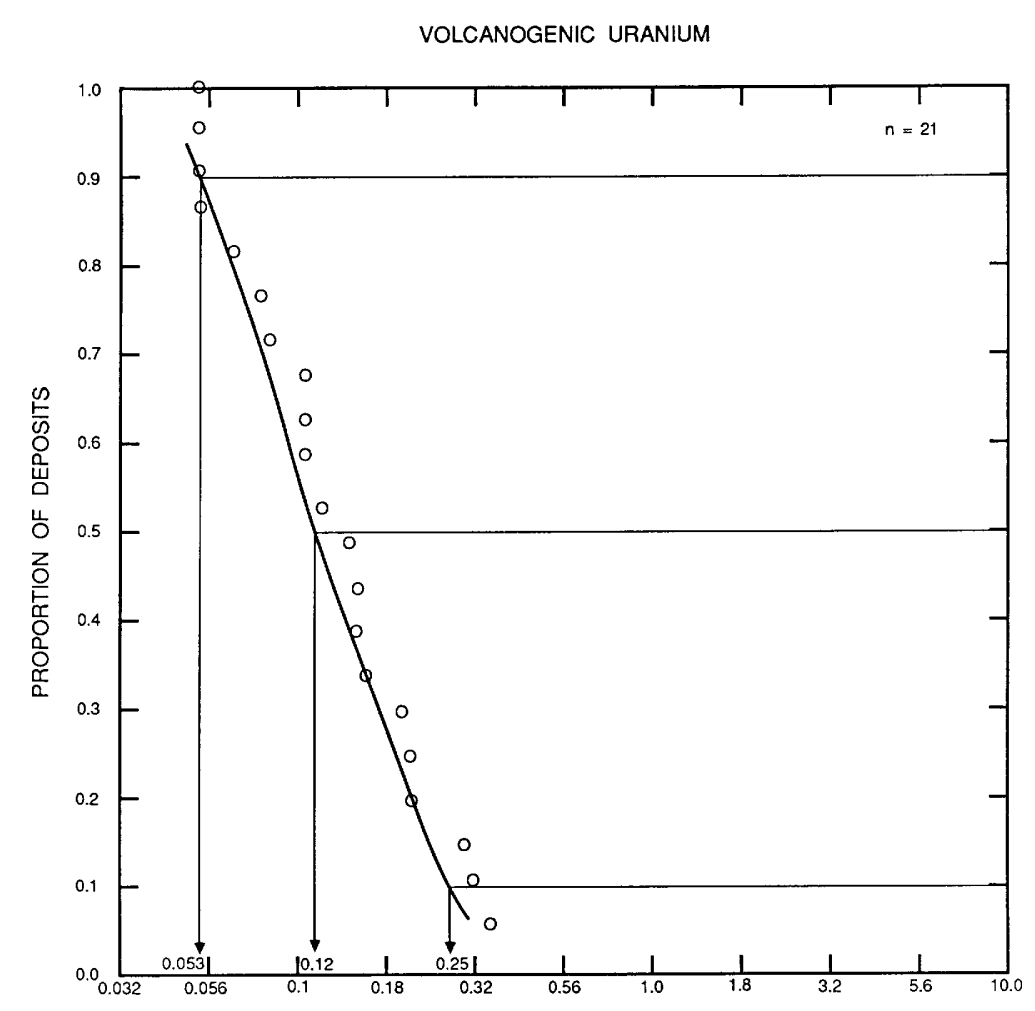

Figure 125. Uranium grades of vol canogenic $\mathrm{U}$ deposits.

URANIUM GRADE IN PERCENT $\mathrm{U}_{3} \mathrm{O}_{8}$ 
Model $25 \mathrm{~g}$

\section{DESCRIPTIVE MODEL OF EPITHERMAL Mn}

By Dan L. Mosier

DESCRIPTION Manganese mineralization in epithermal veins filling faults and fractures in subaerial volcanic rocks.

\section{GEOLOGICAL ENVIRONMENT}

Rock Types Flows, tuffs, breccias, and agglomerates of rhyolitic, dacitic, andesitic or basaltic composition.

Age Range Tertiary.

Depositional Environment Volcanic centers.

Tectonic Setting(s) Through-going fracture systems.

Associated Deposit Types Epithermal gold-silver.

DEPOSIT DESCRIPTION

Mineralogy Rhodochrosite, manganocalcite, calcite, quartz, chalcedony, barite, zeolites.

Texture/Structure Veins, bunches, stringers, nodular masses, disseminations.

Alteration Kaolinitization.

Ore Controls Through-going faults and fractures; brecciated volcanic rocks.

Weathering oxidization zone contains abundant manganese oxides, psilomelane, pyrolusite, braunite, wad, manganite, cryptomelane, hollandite, coronadite, and Fe oxides.

Geochemical Signature $\mathrm{Mn}, \mathrm{Fe}, \mathrm{P}(\mathrm{Pb}, \mathrm{Ag}, \mathrm{Au}, \mathrm{Cu})$. At Talamantes $\mathrm{W}$ is important.

\section{EXAMPLES}

Talamantes, MXCO

Gloryana, USNM

Sardegna, ITLY
(Rocha and Wilson, 1948)

(Farnham, 1961)

(Burckhardt and Falini, 1956) 
Model 25g--Con.

GRADE AND TONNAGE MODEL OF EPITHERMAL Mn

By Dan L. Mosier

COMMENTS See figs. 126-127.

$\underline{\text { DEPOSITS }}$

$\underline{\text { Name }}$

Abra Negra
Armour Group
Atenguillo
Black Crow-San Juan
California Group
Casa de Janos
Casas Grandes
Ciudad Obregon
Cliff Roy
Estacion Llanos
Gloryana
Griffith
Hatton
J.M. Meadows Group
JVB Claim
Karangnunggal
Karatas
Kliripan
Lajas
La Leona
La Noria
Las Varas-La Vaca
Los Borregos
Los Volcanes
M and M Group
Manganese Chief
Manganese Development
Matamoros
Mezcala
Montosa

\begin{tabular}{l} 
Country \\
\hline MXCO \\
USAZ \\
MXCO \\
USNM \\
USAZ \\
MXCO \\
MXCO \\
MXCO \\
USNM \\
MXCO \\
USNM \\
USNM \\
USAZ \\
USAZ \\
USNM \\
INDS \\
TRKY \\
INDS \\
MXCO \\
MXCO \\
MXCO \\
MXCO \\
MXCO \\
MXCO \\
USNM \\
USNM \\
USAZ \\
MXCO \\
MXCO \\
MXCO
\end{tabular}

$\underline{\text { Name }}$

Murguia

Nacozari

Niggerhead

Oviachic $1 \& 2$

Phillips Lease

Pito Real

Red Hill-Red Hill Ext.

St. Pietro

San Bernardo

San Miguel El Alto

Santa Ana

Sardegna

Satevo

Selimiye

Shag Rock

Sierra de El Alto

Sierra de Enmedio

Sierra Los Organos

Soto

Talamantes

Terrenates

Thurston \& Hardy

Topock

Turfullar

U.S. Group

Viterbo-Roma

West Niggerhead

Yahualica

Zacate-Cerro Chino
Country

MXCO

MXCO

USNM

MXCO

USNM

MXCO

USNM

ITLY

MXCO

$\mathrm{MXCO}$

MXCO

ITLY

MXCO

TRKY

CNBC

MXCO

MXCO

MXCO

MXCO

MXCO

MXCO

USAZ

USAZ

TRKY

USAZ

ITLY

USNM

MXCO

$\mathrm{MXCO}$ 
EPITHERMAL MANGANESE
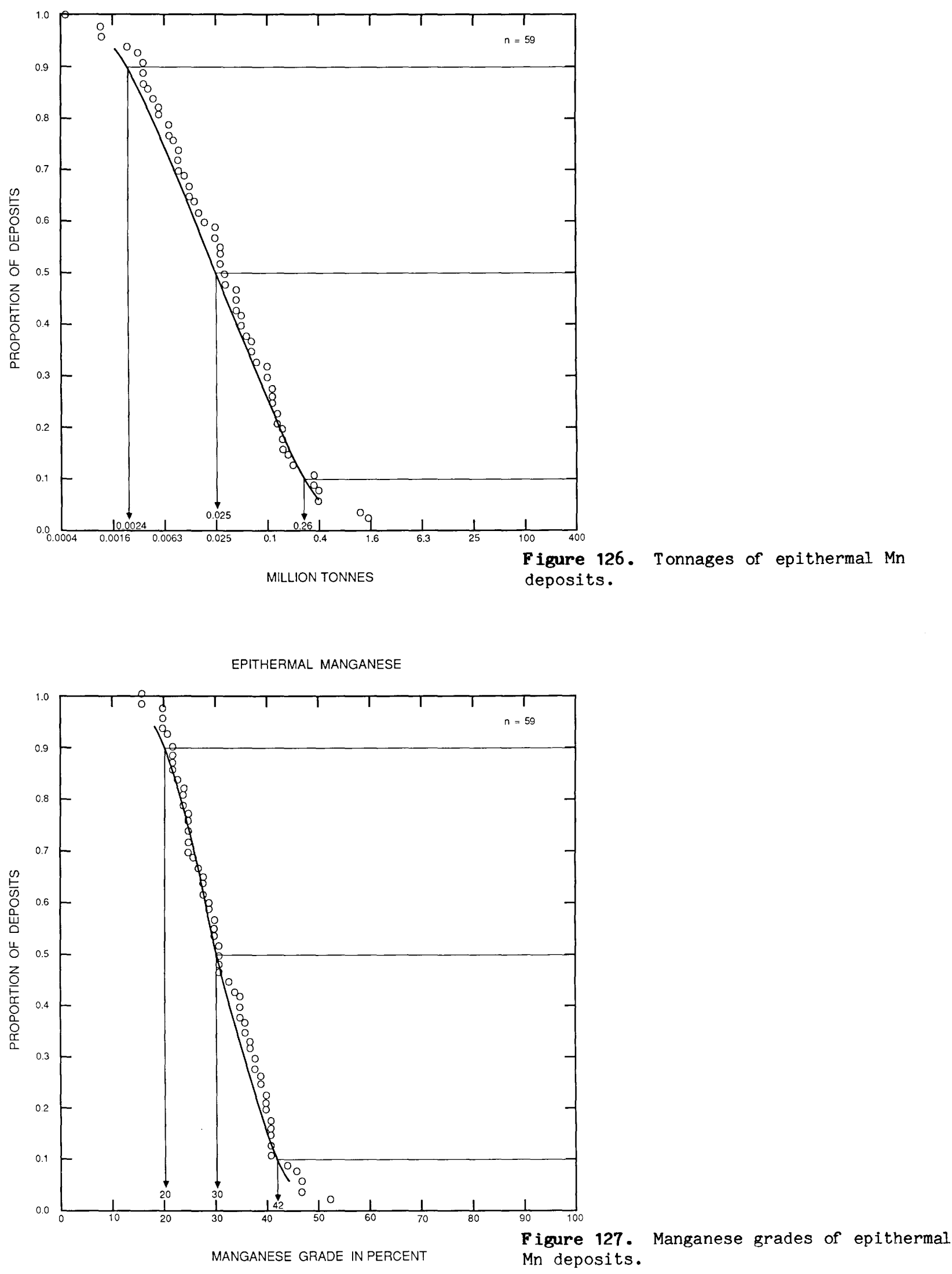
Model $25 \mathrm{~h}$

\section{DESCRIPTIVE MODEL OF RHYOLITE-HOSTED Sn}

By Bruce L. Reed, Wendell Duffield, Stephen D. Ludington, Charles H. Maxwell, and Donald H. Richter

\section{APPROXIMATE SYNONYM Mexican-type.}

DESCRIPTION Cassiterite and wood tin in discontinuous veinlets in rhyolite flow-dome complexes and derivative placers (see fig. 128).

GENERAL REFERENCES Lee-Moreno (1980), Huspeni and others (1984).

\section{GEOLOGICAL ENVIRONMENT}

Rock Types Alkali-feldspar rhyolite with $\mathrm{SiO}_{2}>75$ percent; includes topaz rhyolites of Burt and others (1982) and Christiansen and others (1983). Distinctive accessory minerals may include topaz, fluorite, bixbyite, pseudobrookite, and beryl. Petrochemical signature similar to Climax Mo.

Textures Crystal-poor (5 percent) to crystal-rich (50 percent) rhyolite with quartz and sanidine phenocrysts; rare fayalite, biotite, or hornblende may be present.

Age Range Tertiary; chiefly Oligocene and Miocene.

Depositional Environment Rhyolite flow-dome complexes and related pyroclastic and epiclastic rocks.

Tectonic Setting(s) Silicic volcanic fields, generally in areas of thick continental crust.

Associated Deposit Types None are known, but based on geochemical similarity of associated magmas, these may be a surface expression of Climax Mo.

\section{DEPOSIT DESCRIPTION}

Mineralogy Cassiterite (including wood tin) plus hematite (characteristically specularite) \pm cristobalite, fluorite, tridymite, opal, chalcedony, beudantite, mimetite, adularia, durangite, and zeolite minerals.

Texture/Structure Most commonly as 0.1 - to $10-\mathrm{cm}-$ wide discontinuous veins and veinlets whose other dimensions seldom exceed $75 \mathrm{~m}$. These veins and veinlets may be clustered in zones of somewhat greater dimension. Cassiterite also occurs as disseminations in the matrix of rhyolite flows or fault breccias. These two types of deposits are part of a continuum.

Alteration May be absent; tin may or may not occur in large areas of vapor-phase alteration (tridymite, sanidine, hematite, \pm pseudobrookite); alteration directly associated with mineralization may include cristobalite, fluorite, smectite, kaolinite, and other clay minerals.

Ore Controls Deposits are generally in the fractured and brecciated outer parts of flow-dome complexes where permeability is high.

Weathering Weathering is generally minor, but a translucent red-orange clay mineral (smectite) is present in most deposits.

Geochemical Signature Dispersion of associated elements ( $\mathrm{Sn}, \mathrm{Fe}, \mathrm{Be}, \mathrm{Li}, \mathrm{F}, \mathrm{As}, \mathrm{Sb}, \mathrm{Pb}, \mathrm{Zn}, \mathrm{Bi}$, $\overline{\mathrm{REE}}$ ) in rock is minimal. Best exploration guide is presence of high concentrations of $t i n$ ( $>1,000$ $\mathrm{ppm}$ ) in pan concentrate samples. Cassiterite in stream sediments is usually restricted to within $2-3 \mathrm{~km}$ of tin deposits.

Examples

Black Range, USNM

Mexico deposits
(Fries, 1940; Lufkin, 1972)

(Foshag and Fries, 1942; Smith and others, 1950; Ypma and Simons, 1969; Pan, 1974;

Lee-Moreno, 1980) 
Model 25h--Con.

\section{GRADE AND TONNAGE MODEL OF RHYOLITE-HOSTED Sn}

By Donald A. Singer and Dan L. Mosier

COMMENTS See figs. 129-130.

DATA REFERENCES Bracho (1960, 1961).

COMMENTS Grade and tonnage estimates were based on reserves. Tonnage is significantly correlated with tin grades $(r=0.36)$.

\section{DEPOSITS}

$\underline{\text { Name }}$

Arguilillas

Amigos

Arrieros 非2

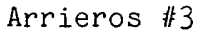

Arrieros \# 4

Arroyo Durango

Castrita

Catas de las Vacas

Catas el Durango

Cerro Blanco

Cerro Grande

Cerro Prieto, La Quemada, La

Colocion

Chavarria

Cordon Estaneros

Don Teodoro

El Abra

El Atascadero

El Baluarte

El Barroso

El Borrego \#1

E1 Borrego \#2

El Calabrote

El Capulin

El Coloradillo

El Corral

El Cristal

El Dorado

E1 Duraznillo

El Durazno (E1 Aguila)

El Durazno (Juan Aldama)

El Encino

El Gotera

El Huacal

El Indio, El

Plieto, Tadeo, San Antonio

El Ladrillo

El Mamey

El Naranjo, Buena

Suerte

El Noladero

El Nopal (Juan Aldama)

El Nopal (La Ochoa)

El Penasco

El Perdido
Country

$\mathrm{MXCO}$

$\mathrm{MXCO}$

MXCO

MXCO

MXCO

MXCO

MXCO

MXCO

MXCO

MXCO

$\mathrm{MXCO}$

$\mathrm{MXCO}$

MXCO

MXCO

MXCO

$\mathrm{MXCO}$

$\mathrm{MXCO}$

MXCO

MXCO

$\mathrm{MXCO}$

$\mathrm{MXCO}$

$\mathrm{MXCO}$

MXCO

$\mathrm{MXCO}$

$\mathrm{MXCO}$

$\mathrm{MXCO}$

$\mathrm{MXCO}$

$\mathrm{MXCO}$

MXCO

MXCO

$\mathrm{MXCO}$

$\mathrm{MXCO}$

$\mathrm{MXCO}$

MXCO

$\mathrm{MXCO}$

$\mathrm{MXCO}$

MXCO

MXCO

$\mathrm{MXCO}$

$\mathrm{MXCO}$

$\mathrm{MXCO}$

$\mathrm{MXCO}$
Name

El Picacho

El Pleito

El Polvillo

El Profesor

El Romadizo

El Santo Nino

E1 Socavon 非 4

E1 Socavon 非

E1 Socavon 非

El Socavon \#7

El Socavon 非8

El Tarango

El Venado

El Zanzon

Galvan

Gavilancillos

Grupos 1 \& 2-Vendo $W$

Grupos 3 \& 4

Guadalupe

Hierbaniz

La Chapeteada

La Chililla

La Chinche

La Chorrera

La Cinta Corrida

La Cocona

La Desparramada

La Escondida

La Esperanza (El Aguila)

La Esperanza (La Ochoa)

La Esperanza (Los Angeles)

La Estrella

La Guera

La Hormiga

La Huacalona

La Leona

La Loba

La Liendre

La Mula

La Polvosa

La Puntilla

Las Aguilas

Las Amarillas

Las Calaveras

Las Flores

Las Fundiciones

Las Marias

Las Pegazones
Country

MXCO

$\mathrm{MXCO}$

$\mathrm{MXCO}$

MXCO

MXCO

MXCO

MXCO

MXCO

MXCO

MXCO

MXCO

MXCO

MXCO

MXCO

MXCO

MXCO

MXCO

MXCO

MXCO

MXCO

MXCO

MXCO

MXCO

MXCO

MXCO

MXCO

MXCO

$\mathrm{MXCO}$

MXCO

MXCO

MXCO

MXCO

MXCO

$\mathrm{MXCO}$

MXCO

MXCO

MXCO

MXCO

$\mathrm{MXCO}$

MXCO

MXCO

MXCO

MXCO

MXCO

MXCO

$\mathrm{MXCO}$

$\mathrm{MXCO}$

$\mathrm{MXCO}$ 
Model 25h--Con.

$\begin{array}{ll}\text { Las Perlitas } & \text { MXCO } \\ \text { Las Tablas } & \text { MXCO } \\ \text { La Triste } & \text { MXCO } \\ \text { La Venadita } & \text { MXCO } \\ \text { La Vibora } & \text { MXCO } \\ \text { La Victoria } & \text { MXCO } \\ \text { La Vieja-El Agua } & \text { MXCO } \\ \text { Leoncitos } & \text { MXCO } \\ \text { Loreto } & \text { MXCO } \\ \text { Los Angeles } & \text { MXCO } \\ \text { Los Arrieros } & \text { MXCO } \\ \text { Los Caballos } & \text { MXCO } \\ \text { Los Campamentos \#1 } & \text { MXCO } \\ \text { Los Campamentos \#2 } & \text { MXCO } \\ \text { Los Campamentos \#3 } & \text { MXCO } \\ \text { Los Cuatillos } & \text { MXCO } \\ \text { Los Garcia } & \text { MXCO } \\ \text { Los Lobos } & \text { MXCO } \\ \text { Los Pinacates } & \text { MXCO } \\ \text { Manga de Lopez } & \text { MXCO } \\ \text { Manzanillas } & \end{array}$

Mina del Aire $\quad M X C O$

Mina Dura MXCO

Palo Colorado MXCO

Panchillo MXCO

Plan de Tecolotes MXCO

Potrero del Molino MXCO

San Francisco MXCO

San Humberto MXCO

San Juanera MXCO

San Rafael MXCO

San Ruperto MXCO

Santa Efigenia MXCO

Santa Gertrudis MXCO

Santa Leonor MXCO

Santa Lucia MXCO

Socorro-Guadalupe MXCO

Sombreretillo MXCO

Soto MXCO

Tecolotes MXCO

Tolano MXCO

Veta Blanca MXCO

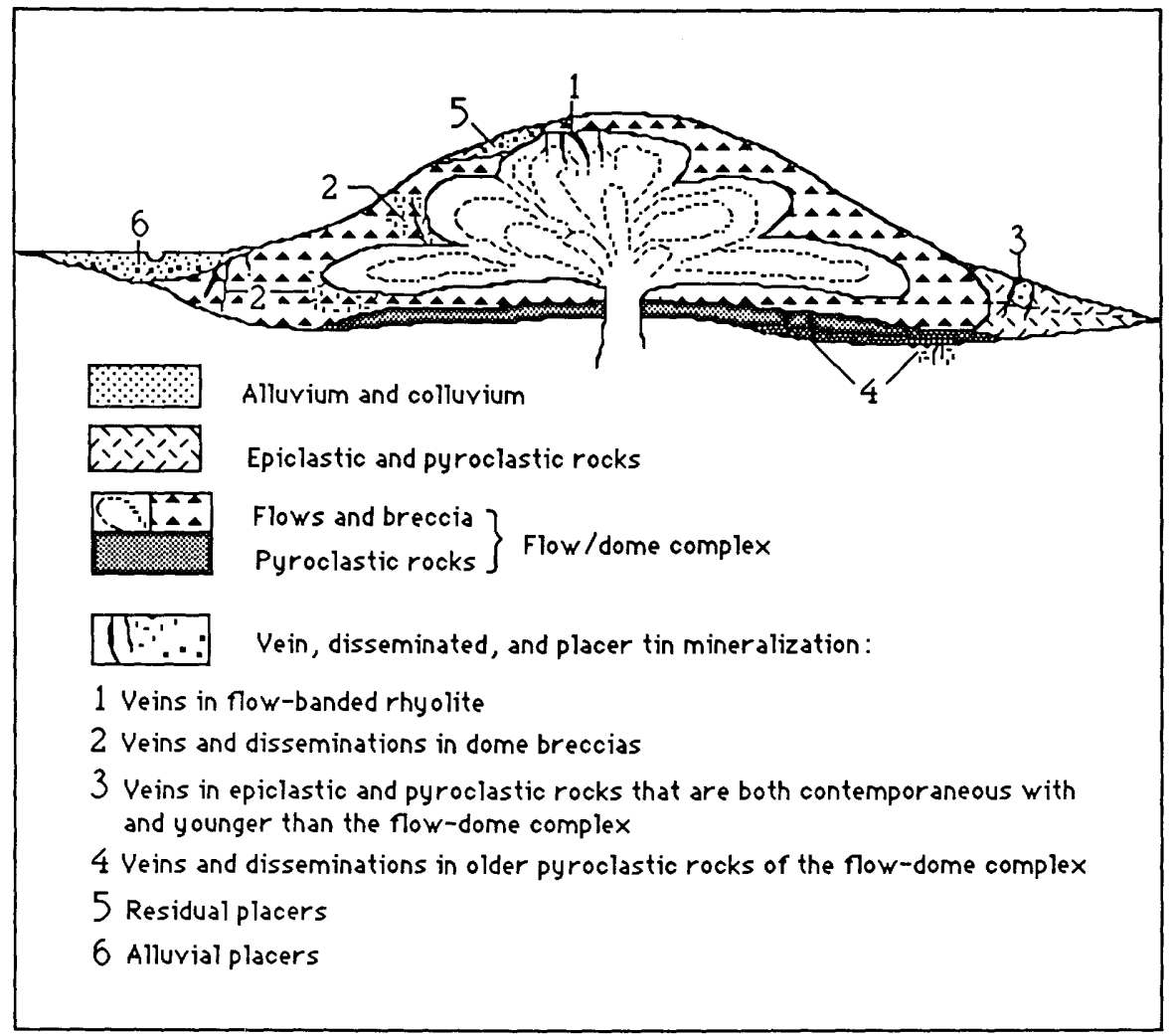

Figure 128. Cartoon cross section of rhyolite-hosted $\mathrm{Sn}$ deposit showing relationship of cassiterite concentrations to rhyolite dome. 
RHYOLITE--HOSTED TIN

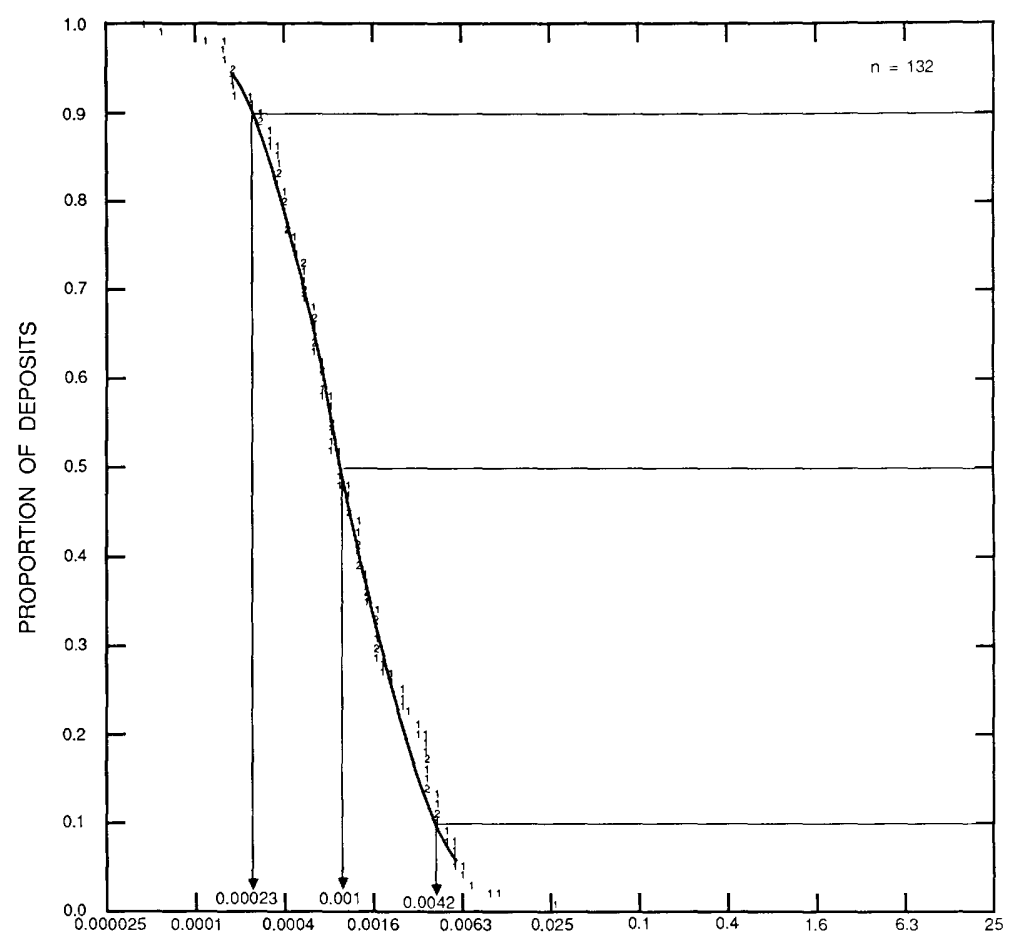

MILLION TONNES

Figure 129. Tonnages of rhyolite-hosted $\mathrm{Sn}$ deposits. Individual digits represent number of deposits.

RHYOLITE--HOSTED TIN

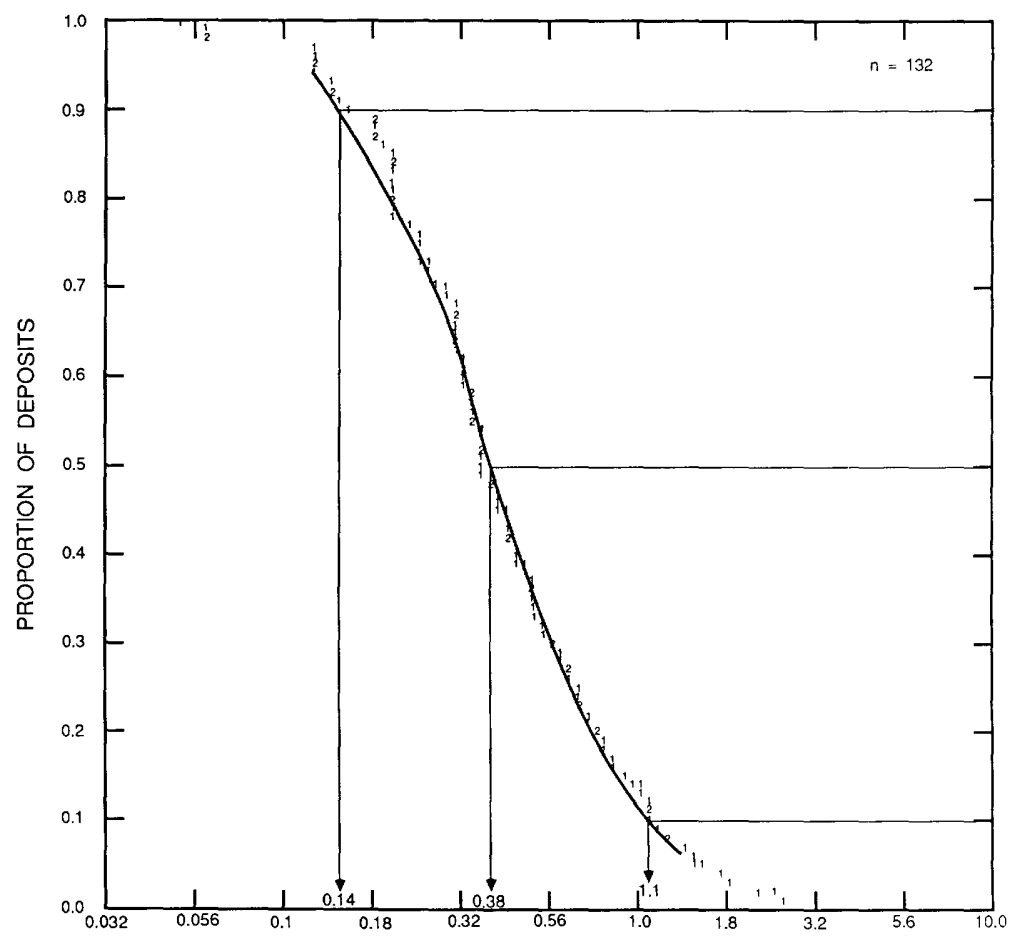

TIN GRADE IN PERCENT

Figure 130. Tin grades of rhyolite-hosted Sn deposits. Individual digits represent number of deposits. 


\title{
DESCRIPTIVE MODEL OF VOLCANIC-HOSTED MAGNETITE
}

\author{
By Dennis P. Cox
}

APPROXIMATE SYNONYM Porphyrite iron, Kiruna iron.

DESCRIPTION Massive concordant and discordant magnetite ore bodies in intermediate to alkalic volcanic rocks with actinolite or diopside alteration.

GEOLOGICAL ENVIRONMENT

Rock Types Andesitic to trachytic flows and subvolcanic intrusions, also at Kiruna, quartz porphyry, syenite porphyry, monzonite, and diorite.

Textures Porphyroaphanitic to fine- to medium-grained equigranular. Flows may be amygdaloidal. Age Range Mesozoic to Holocene in circum-Pacific area. In Sweden and Missouri, 1,300-1,500 m.y. Depositional Environment Continental volcanic rocks and clastic sediments intruded by subvolcanic intermediate plutons.

Tectonic Setting(s) Continental margin, subduction-related volcanic terrane. Especially with high-K volcanic rocks, possibly related to waning stages of volcanism.

Associated Deposit Types Sedimentary Fe in associated clastic rocks, apatite-magnetite deposits, hematite in quartz-sericite alteration, possible disseminated $\mathrm{Au}$.

\section{DEPOSIT DESCRIPTION}

Mineralogy Magnetite + apatite. Rarely pyrite, chalcopyrite, chalcocite, and covellite. Ti is in sphene.

Texture/Structure Fine, granoblastic, skarn type textures.

Alteration Actinolite or diopside, andradite, biotite, quartz, albite, andesine, K-feldspar, sodic scapolite, epidote; carbonates, and locally, tourmaline, sphene, chlorite, barite, fluorite, kaolin, or sericite.

Ore Controls Magnetite in massive replacement, breccia filling and stockwork veins. Orebodies may be stratabound, concordant to intrusive contacts or in cross-cutting veins. Possibly related to cupolas of deeper plutons.

Geochemical and Geophysical Signature Fe, P, V, and minor Ba, F, Bi, Cu, Co; strong magnetic anomalies.

EXAMPLES

Kirunavaara, Sweden

El Romeral, Chile

Middle-Lower Yangtze Valley, CINA

\author{
(Frietsch 1982, 1978) \\ (Bookstrom, 1977) \\ (Research Group of \\ Porphyrite Iron Ore, 1977)
}

GRADE AND TONNAGE MODEL OF VOLCANIC-HOSTED MAGNETITE

By Dan L. Mosier

COMMENTS Only deposits with abundant apatite are included. See figs. 131-133.

DEPOSITS

$\underline{\text { Name }}$

Country

Name

Country

Arnold Hill

USNY

Benson

USNY

Cerro de Mercado

Chador-Malu

MXCO

IRAN 
Model 25i--Con.

Chahehgaz
Choghart
Ekstromberg
El Algarrobo
El Dorado
El Encino
EL Romeral
Grangesberg
Gruvberget
Guadalupe \& Solis
Hercules
Idkerberget
Infiernillo
Joinville
Kiirunavaara
La Grulla
La Perla-La Negra
Leveaniemi

$\begin{array}{lll}\text { IRAN } & \text { Los Vasitos } & \text { MXCO } \\ \text { IRAN } & \text { Luossauara } & \text { SWDN } \\ \text { SWDN } & \text { Malmberget } & \text { SWDN } \\ \text { CILE } & \text { Minarets } & \text { USCA } \\ \text { CILE } & \text { Mineville-Port Henry } & \text { USNY } \\ \text { MXCO } & \text { Modarelli } & \text { USNV } \\ \text { CILE } & \text { Nakerivaara } & \text { SWDN } \\ \text { SWDN } & \text { Northern Anomaly } & \text { IRAN } \\ \text { SWDN } & \text { Painirova } & \text { SWDN } \\ \text { MXCO } & \text { Pea Ridge } & \text { USMO } \\ \text { MXCO } & \text { Ringwood } & \text { USNJ } \\ \text { SWDN } & \text { Saghand } & \text { IRAN } \\ \text { CILE } & \text { Savage River } & \text { AUTS } \\ \text { BRZL } & \text { Se Chakhum } & \text { IRAN } \\ \text { SWDN } & \text { Sterling Lake } & \text { USNY } \\ \text { MXCO } & \text { Tjarrojakka } & \text { SWDN } \\ \text { MXCO } & \text { Unnamed } & \text { MXCO }\end{array}$

VOLCANIC-HOSTED MAGNETITE

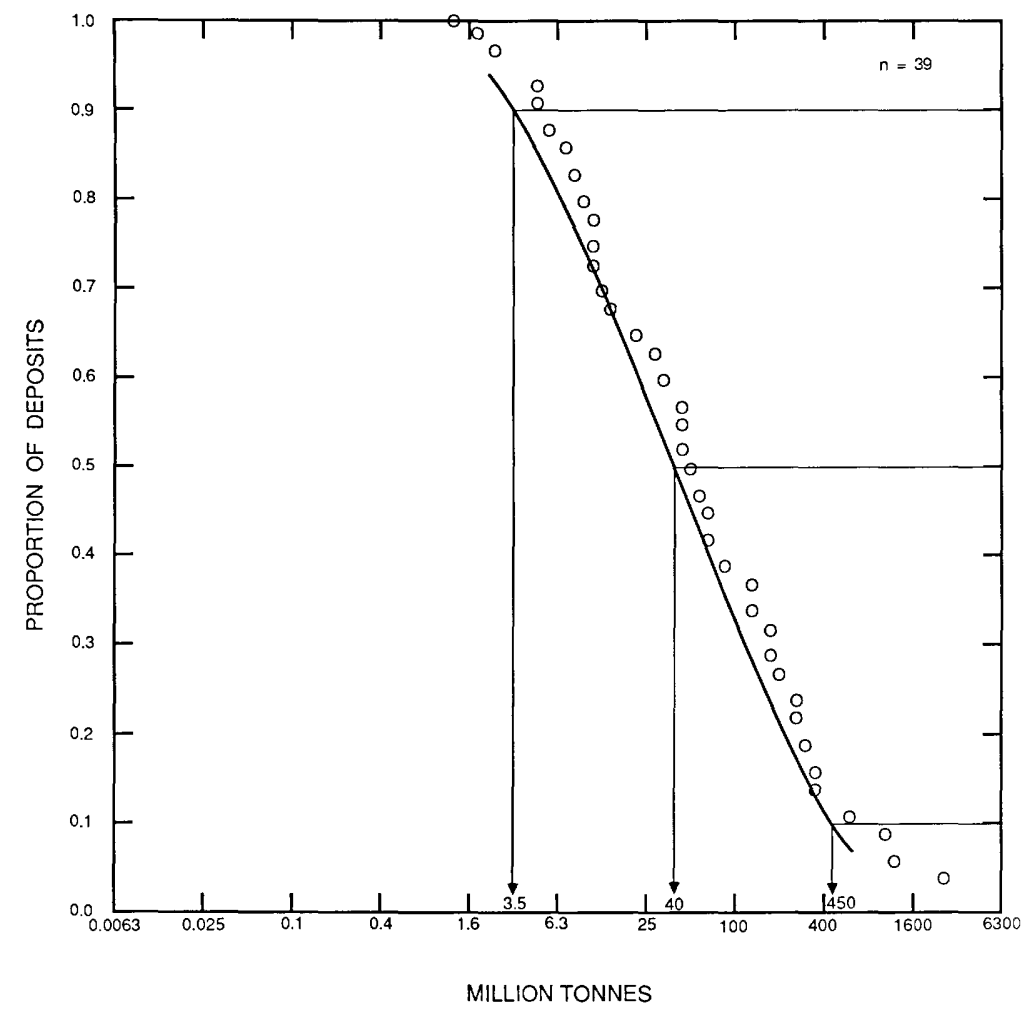

Figure 131. Tonnages of volcanic-hosted magnetite deposits. 
Model 25i--Con.

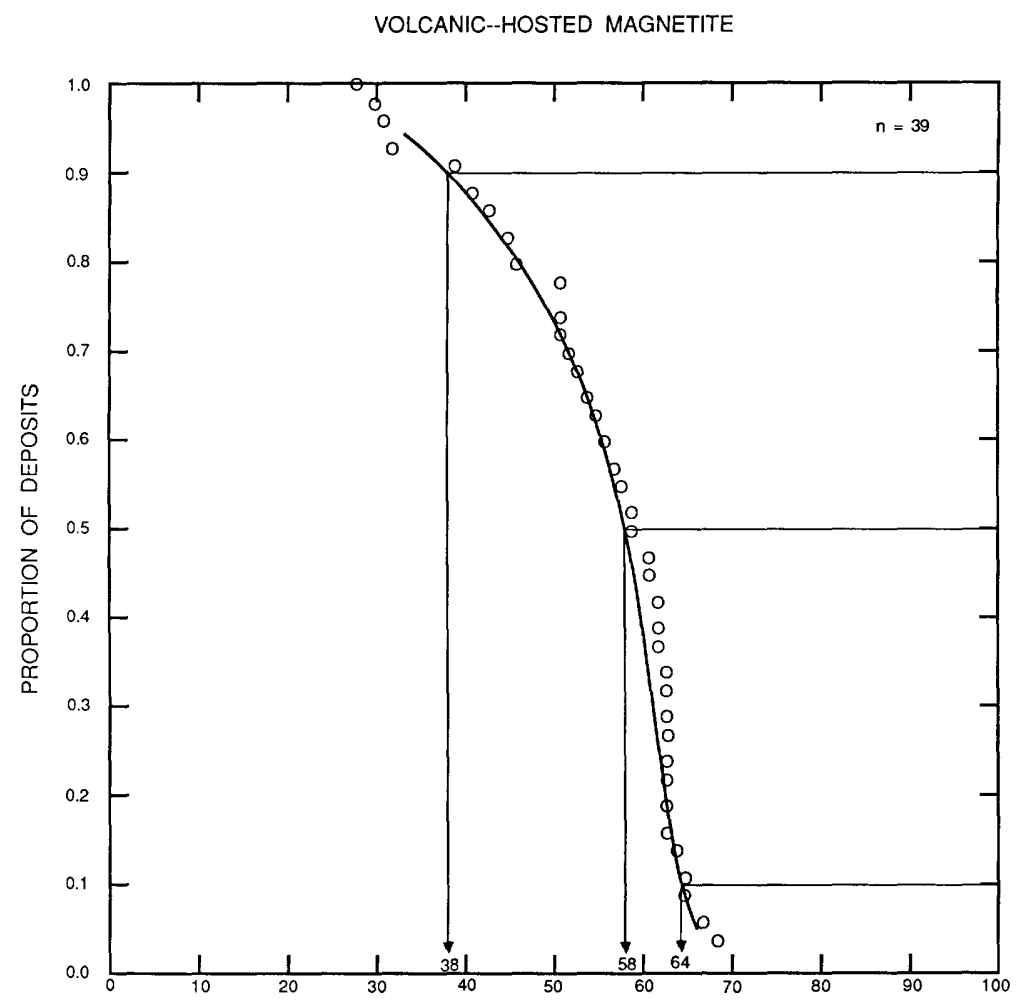

Figure 132. Iron grades of volcanic-hosted magnetite deposits.

IRON GRADE IN PERCENT

VOLCANIC--HOSTED MAGNETITE

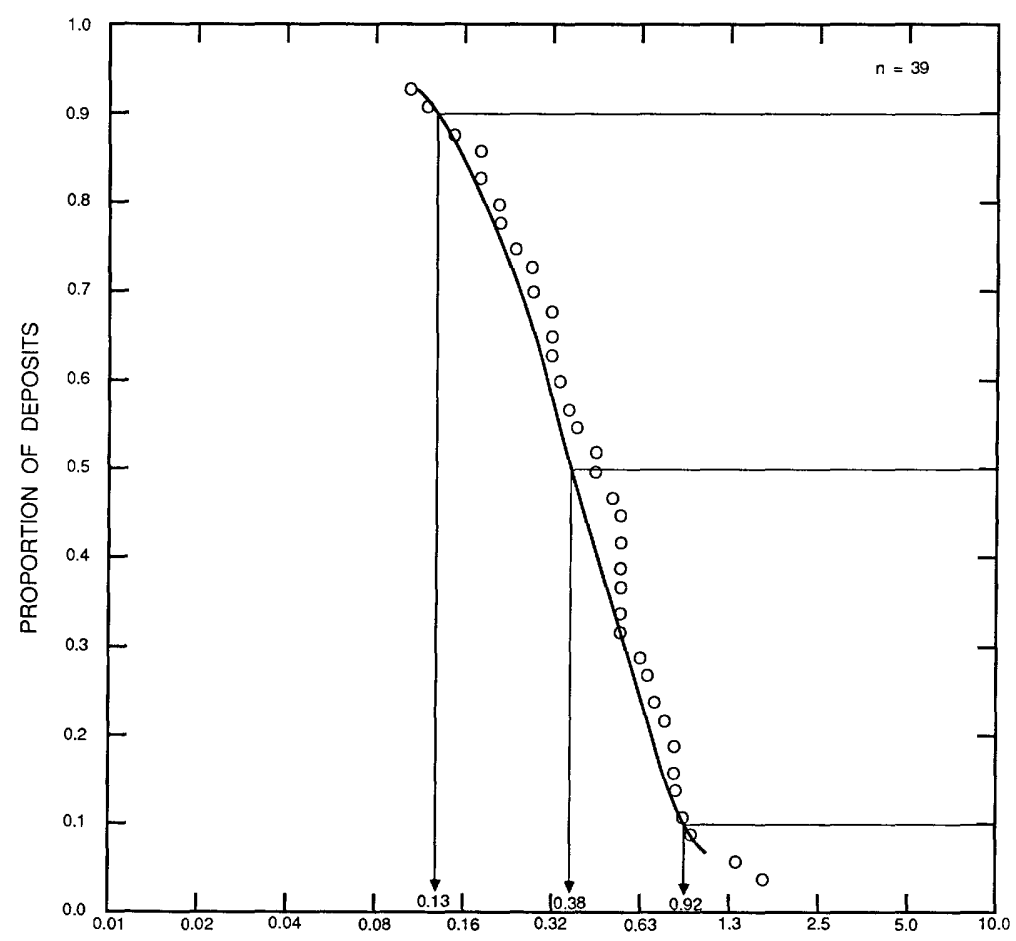

Figure 133. Phosphorus grades of volcanichosted magnetite deposits.

PHOSPHORUS GRADE IN PERCENT 


\section{DESCRIPTIVE MODEL OF CARBONATE-HOSTED Au-Ag}

By Byron R. Berger

APPROXIMATE SYNONYM Carlin-type or invisible gold.

DESCRIPTION Very fine grained gold and sulfides disseminated in carbonaceous calcareous rocks and associated jasperoids.

GENERAL REFERENCE Tooker (1985).

GEOLOGICAL ENVIRONMENT

Rock Types Host rocks: thin-bedded silty or argillaceous carbonaceous limestone or dolomite, commonly with carbonaceous shale. Intrusive rocks: felsic dikes.

Textures Dikes are generally porphyritic.

Age Range Mainly Tertiary, but can be any age.

Depositional Environment Best host rocks formed as carbonate turbidites in somewhat anoxic environments. Deposits formed where these are intruded by igneous rocks under nonmarine conditions.

Tectonic Setting(s) High-angle normal fault zones related to continental margin rifting.

Associated Deposit Types W-Mo skarn, porphyry Mo, placer Au, stibnite-barite veins.

DEPOSIT DESCRIPTION

Mineralogy Native gold (very fine grained) + pyrite + realgar + orpiment \pm arsenopyrite \pm cinnabar \pm fluorite \pm barite \pm stibnite. Quartz, calcite, carbonaceous matter.

Texture/Structure Silica replacement of carbonate. Generally less than 1 percent fine-grained sulfides.

Alteration Unoxidized ore: jasperoid + quartz + illite + kaolinite + calcite. Abundant amorphous carbon locally appears to be introduced. Hypogene oxidized ore: kaolinite + montmorillonite + illite + jarosite + alunite. Ammonium clays may be present.

Ore Controls Selective replacement of carbonaceous carbonate rocks adjacent to and along highangle faults, or regional thrust faults or bedding.

Weathering Light-red, gray, and (or) tan oxides, light-brown to reddish-brown iron-oxide-stained jasperoid.

Geochemical Signature: $\mathrm{Au}+\mathrm{As}+\mathrm{Hg}+\mathrm{W} \pm \mathrm{Mo} ; \mathrm{As}+\mathrm{Hg}+\mathrm{Sb}+\mathrm{Tl} \pm \mathrm{F}$ (this stage superimposed on preceding); $\mathrm{NH}_{3}$ important in some deposits.

\section{EXAMPLES}

Carlin, USNV (Radtke and others, 1980)

Getche11, USNV

(Joralemon, 1951)

Mercur, USUT

(Gilluly, 1932)

\section{GRADE AND TONNAGE MODEL OF CARBONATE-HOSTED Au-Ag}

By William C. Bagby, W. David Menzie, Dan L. Mosier, and Donald A. Singer

COMMENTS See figs. 134-135 
Model 26a--Con.

DEPOSITS

Name

Alligator Ridge
Atlanta
Blue Star
Carlin
Cortez
Dee
Emigrant Springs \#1
Emigrant Springs \#2
Florida Canyon
Getchell
Giltedge
Gold Bar
Gold Acres
Gold Quarry
Horse Canyon

\begin{tabular}{l} 
Country \\
\hline \\
USNV \\
USNV \\
USNV \\
USNV \\
USNV \\
USNV \\
USNV \\
USNV \\
USNV \\
USNV \\
USMT \\
USNV \\
USNV \\
USNV \\
USNV
\end{tabular}

Name

Jerritt Canyon

Maggie Creek

Mercur

Northumberland

Pinson

Preble

Rain

Relief Canyon

Roberts Mtns. Dist.

Santa Fe

Standard

Toiyabe

Tolman

Tonkin Springs

Windfall
Country

USNV

USNV

USUT

USNV

USNV

USNV

USNV

USNV

USNV

USNV

USNV

USNV

USID

USNV

USNV 
CARBONATE--HOSTED GOLD--SILVER

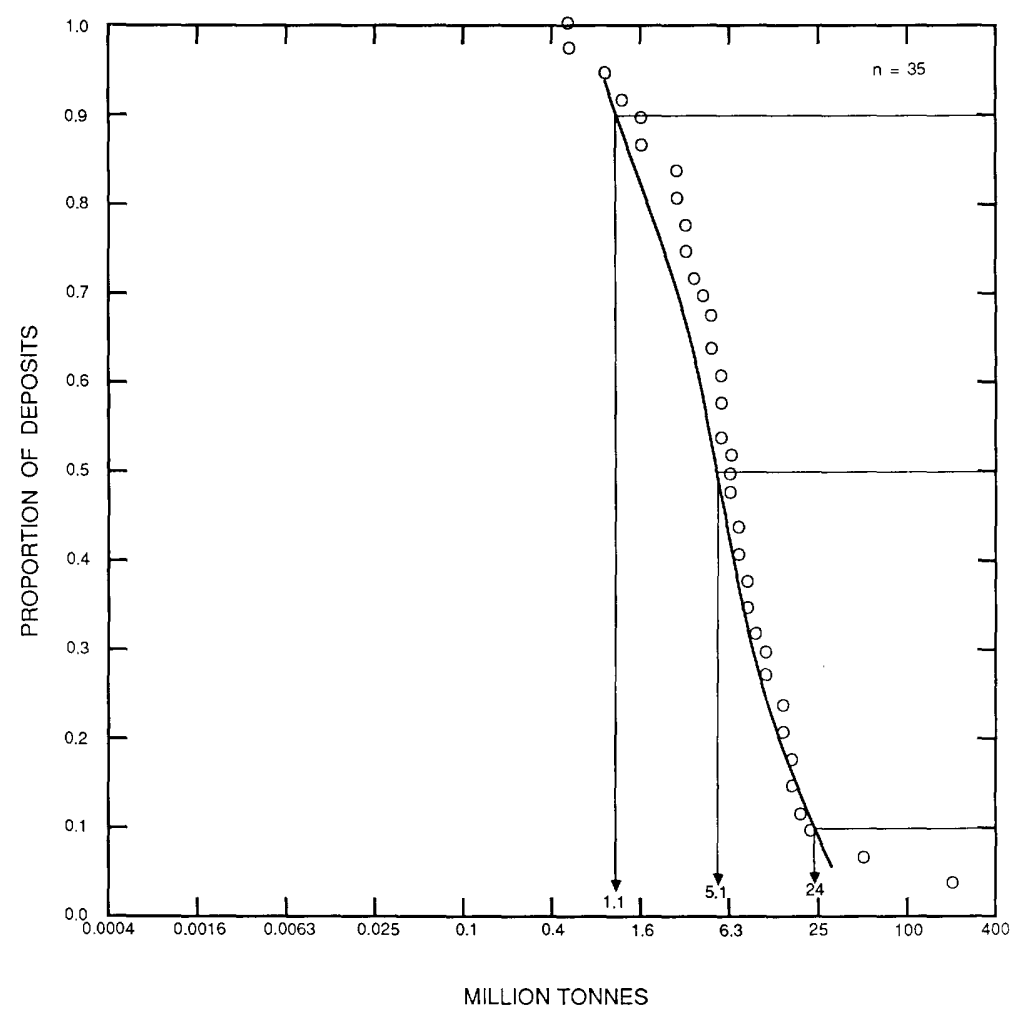

CARBONATE-HOSTED GOLD-SILVER
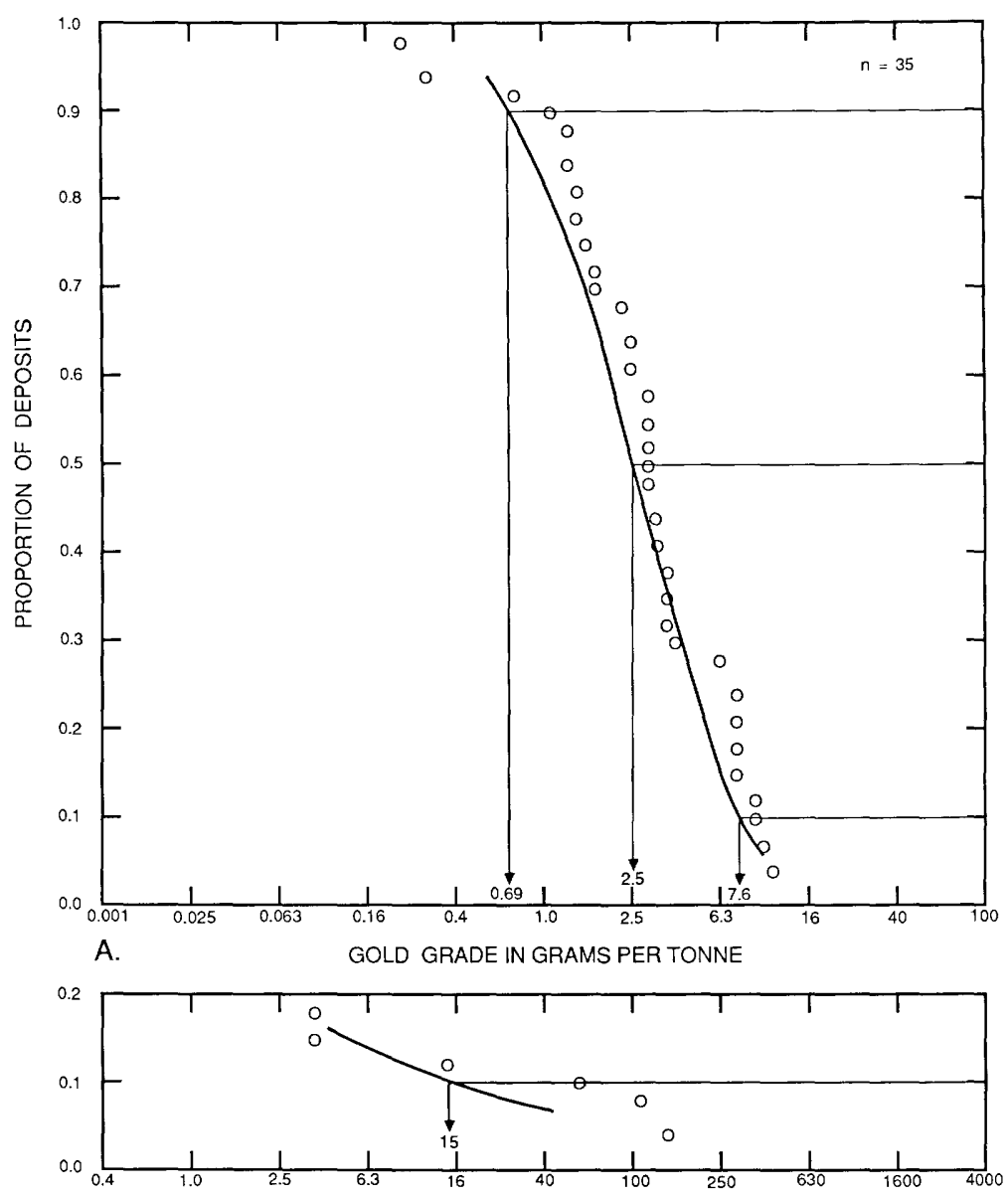

B.

SILVER GRADE IN GRAMS PER TONNE
Model 26a--Con.

F igure 134. Tonnages of carbonate-hosted $\mathrm{Au}-\mathrm{Ag}$ deposits.
Figure 135. Precious-metal grades of carbonate-hosted $\mathrm{Au}-\mathrm{Ag}$ deposits. $\mathrm{A}$, Gold. B, Silver. 
Model 27a

\title{
DESCRIPTIVE MODEL OF HOT-SPRING Hg
}

\author{
By James J. Rytuba
}

APPROXIMATE SYNONYM Sulphur Bank type of White (1981) or sulfurous type of Bailey and Phoenix $(1944)$.

DESCRIPTION Cinnabar and pyrite disseminated in siliceous sinter superjacent to graywacke, shale, andesite, and basalt flows and diabase dikes.

GEOLOGICAL ENVIRONMENT

Rock Types Siliceous sinter, andesite-basalt flows, diabase dikes, andesitic tuffs, and tuff breccia.

Age Range Tertiary.

Depositional Environment Near paleo ground-water table in areas of fossil hot-spring system.

Tectonic Setting(s) Continental margin rifting associated with small volume mafic to intermediate volcanism.

Associated Deposit Types Hot-spring Au.

DEPOSIT DESCRIPTION

Mineralogy Cinnabar + native $\mathrm{Hg}+$ minor marcasite.

Texture/Structure Disseminated and coatings on fractures in hot-spring sinter.

Alteration Above paleo ground-water table, kaolinite-alunite-Fe oxides, native sulfur; below paleo ground-water table, pyrite, zeolites, potassium feldspar, chlorite, and quartz. Opal deposited at the paleo water table.

Ore Controls Paleo ground-water table within hot-spring systems developed along high-angle faults. Geochemical Signature $\mathrm{Hg}+\mathrm{As}+\mathrm{Sb} \pm \mathrm{Au}$.

EXAMPLES

Sulfur bank, USCA (White and Roberson, 1962)

GRADE AND TONNAGE MODEL OF HOT-SPRING Hg

By James J. Rytuba

COMMENTS See figs. $136,137$.

DEPOSITS

\begin{tabular}{llll} 
Name & Country & Name & Country \\
\cline { 2 - 4 } B and B & USNV & Idaho Almaden & USID \\
Baldwin & USNV & Mahattan & USCA \\
Bretz & USOR & McDermitt & USNV \\
Butte & USNV & Nevada Sulphur co. & USNV \\
Coleman & USNV & Opalite & USOR \\
Cordero & USNV & Rim Rock and Homestake & USNV \\
F and L Mine & USNV & Silver Cloud & USNV \\
Glass Butte & USOR & Steamboat Springs & USNV \\
Goldbanks & USNV & Sulphur Bank & USCA \\
Governor & USNV & Walibu & USCA
\end{tabular}


HOT--SPRING MERCURY

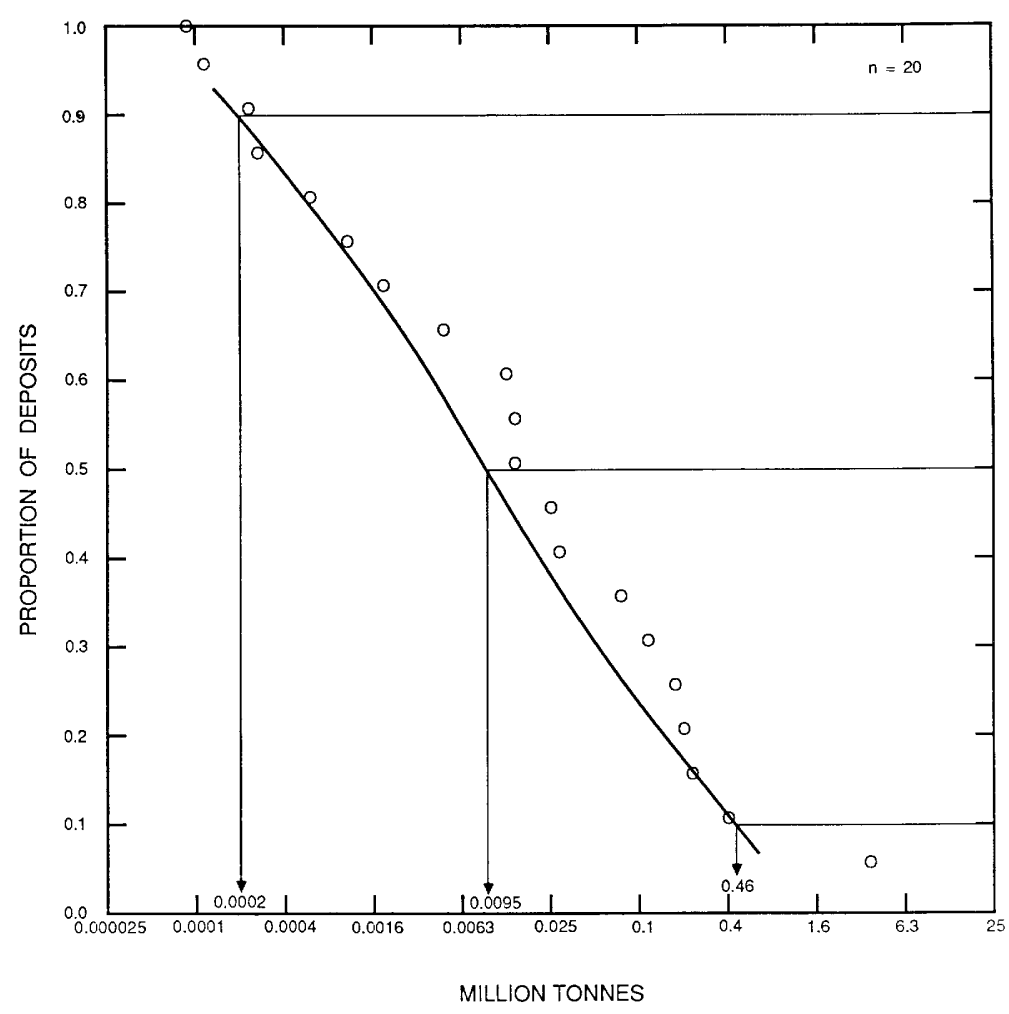

Figure 136. Tonnages of hot-spring $\mathrm{Hg}$ deposits.

HOT--SPRING MERCURY

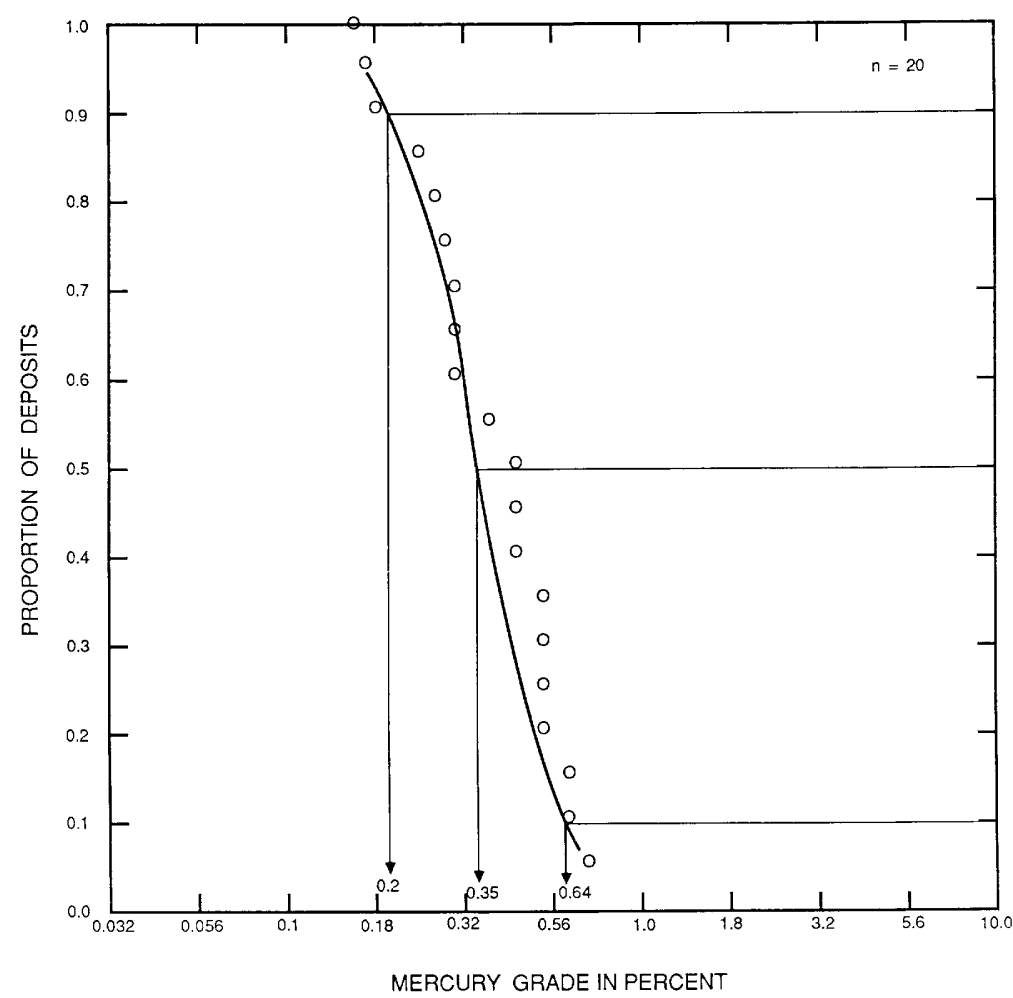

Figure 137. Mercury grades of hot-spring. $\mathrm{Hg}$ deposits. 
Model 27b

\section{DESCRIPTIVE MODEL OF ALMADEN Hg}

By James J. Rytuba

APPROXIMATE SYNONYM Almaden type.

DESCRIPTION Stratabound disseminated cinnabar and native mercury in volcaniclastic sedimentary rocks.

GENERAL REFERENCE Saupe (1973).

GEOLOGICAL ENVIRONMENT

Rock Types Unmetamorphosed shale, graywacke, calcareous graywacke, andesitic lava and tuff, andesite dikes. Volcanic vent breccia.

Age Range Almaden is Silurian, but deposits may be any age.

Depositional Environment Permeable sedimentary rocks, andesite dikes possibly near volcanic center.

Tectonic Setting(s) Volcanic centers along major deep-seated fault zone. Absence of regional metamorphism or plutonism following mineralization.

Associated Deposit Types Stibnite veins.

DEPOSIT DESCRIPTION

Mineralogy Cinnabar \pm native mercury + pyrite + calcite + quartz.

Texture/Structure Disseminated.

Ore Controls Mineralized zone follows major fault, highest grade ore in calcareous graywacke. Geochemical Signature $\mathrm{Hg}$, As, Sb.

EXAMPLES

Almaden, SPAN

Santa Barbara, PERU

Nueva Esperanza, CLBA

(Saupe, 1973)

(Berry and Singewald, 1922)

(Lozano and others, 1977) 


\section{DESCRIPTIVE MODEL OF SILICA-CARBONATE Hg}

By James J. Rytuba

APPROXIMATE SYNONYM New Almaden type.

DESCRIPTION Cinnabar at contact of serpentine and siltstone-graywacke above subduction-related thrust.

GENERAL REFERENCE Bailey (1964).

GEOLOGICAL ENVIRONMENT

Rock Types Serpentine, siltstone-graywacke.

Age Range Tertiary.

Depositional Environment Serpentinized intrusive rocks (sills and dikes) into siltstone, and graywacke and siltstone, fractures in altered serpentine.

Tectonic Setting(s) Deposits occur in accreted terrane above subduction-related thrust fault. Associated Deposit Types Stibnite veins.

DEPOSIT DESCRIPTION

Mineralogy Cinnabar, native Hg, other minor sulfides: pyrite, stibnite, chalcopyrite, sphalerite, galena, and bornite.

Texture/Structure Replacement and minor veins.

Alteration Replacement of serpentine by quartz and dolomite and minor hydrocarbons to form

"silica-carbonate" rock.

Ore Controls Contact of serpentine with siltstone especially where contact forms antiform. Ore primarily in silica-carbonate rock.

Geochemical Signature Unknown, probably $\mathrm{Hg}+\mathrm{Sb}+\mathrm{Cu}+\mathrm{Zn}$.

EXAMPLES

New Almaden, USCA (Bailey, 1964)

\section{GRADE AND TONNAGE MODEL OF SILICA-CARBONATE Hg}

By James J. Rytuba and Simon M. Cargill

COMMENTS (See figs. 138, 139)

DEPOSITS

$\underline{\text { Name }}$

Abbott

Aetna

Bella Oak

Chicago

Contact

Corona

Culver Bear

Dewey's

Esperanza

Great Eastern-Mt. Jackson

Harrison

\begin{tabular}{l} 
Country \\
\hline USCA \\
USCA \\
USCA \\
USCA \\
USCA \\
USCA \\
USCA \\
USCA \\
USCA \\
USCA \\
USCA
\end{tabular}

$\underline{\text { Name }}$

Helen

Keystone

Knoxville

La Joya

La Libertad

Lion Den

Mirabel

Mt. Diablo

New Almaden

Patriquin

Polar Star

Country

USCA

USCA

USCA

USCA

USCA

USCA

USCA

USCA

USCA

USCA

USCA 
Model 27c--Con.

Red Elephant

Red Rick

Reed
USCA

USCA

USCA
Socrates

Twin Peaks

Wall Street
USCA

USCA

USCA

SILICA-CARBONATE MERCURY

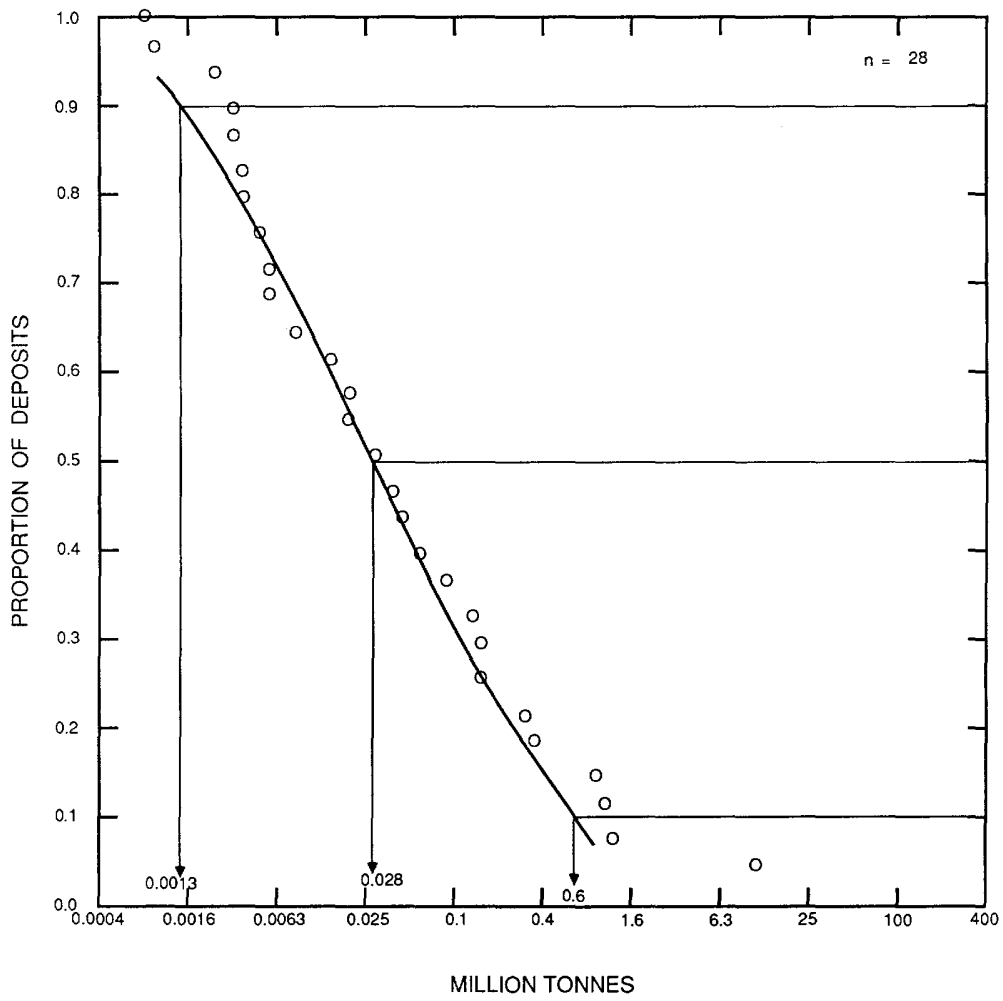

SILICA-CARBONATE MERCURY

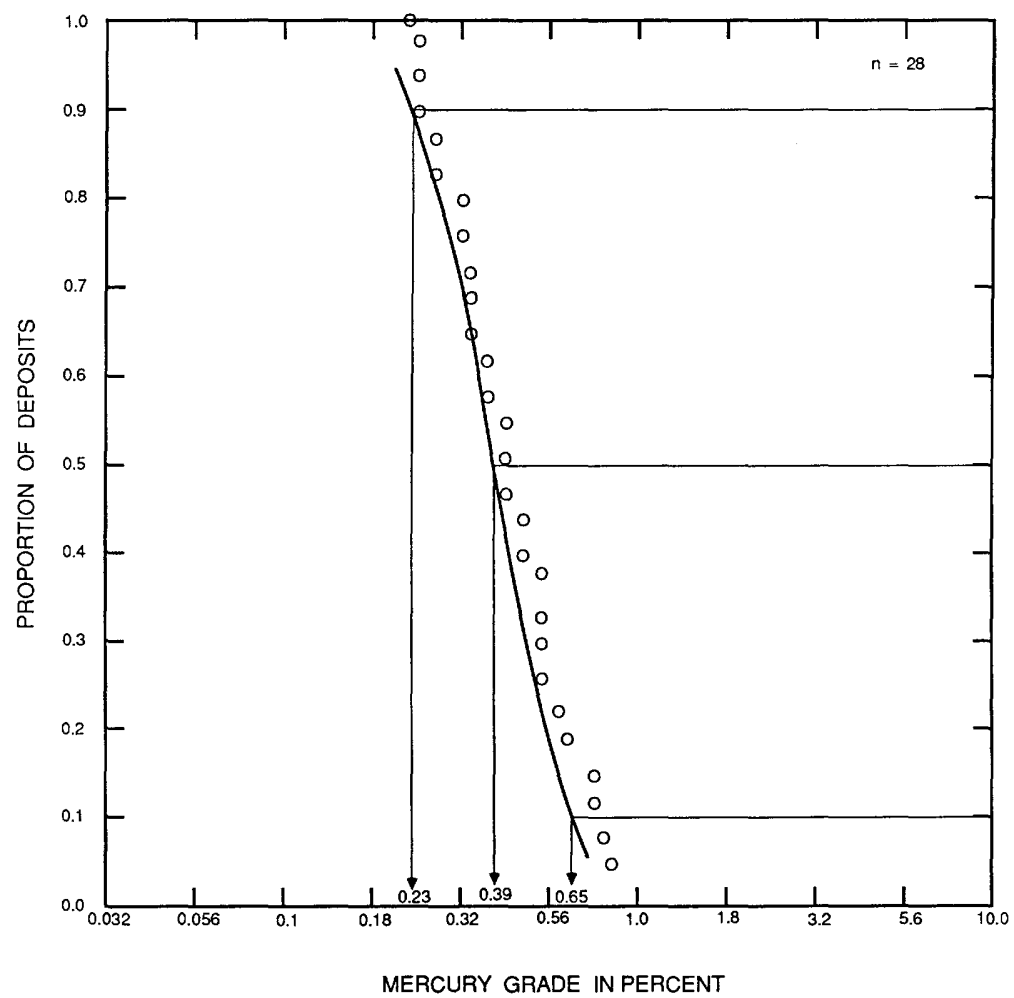

Figure 139. Mercury grades of silicacarbonate $\mathrm{Hg}$ deposits.
Figure 138. Tonnages of silica-carbonate Hg deposits. 


\section{DESCRIPTIVE MODEL OF SIMPLE Sb DEPOSITS}

By James D. Bliss and Greta J. Orris

APPROXIMATE SYNONYM Deposits of quartz-stibnite ore (Smirnov and others, 1983).

DESCRIPTION Stibnite veins, pods, and disseminations in or adjacent to brecciated or sheared fault zones.

GENERAL REFERENCES White (1962), Miller (1973).

\section{GEOLOGICAL ENVIRONMENT}

Rock Types One or more of the following lithologies is found associated with over half of the deposits: limestone, shale (commonly calcareous), sandstone, and quartzite. Deposits are also found with a wide variety of other lithologies including slate, rhyolitic flows and tuffs, argillite, granodiorite, granite, phyllite, siltstone, quartz mica and chloritic schists, gneiss, quartz porphyry, chert, diabase, conglomerate, andesite, gabbro, diorite, and basalt.

Textures Not diagnostic.

Age Range Known deposits are Paleozoic to Tertiary.

Depositional Environment Faults and shear zones.

Tectonic Setting(s) Any orogenic area.

Associated Deposit Types Stibnite-bearing veins, pods, and disseminations containing base metal sulfides \pm cinnabar \pm silver \pm gold \pm scheelite that are mined primarily for lead, gold, silver, zinc, or tungsten; low-sulfide Au-quätz veins; epithermal gold and gold-silver deposits; hotsprings gold; carbonate-hosted gold; tin-tungsten veins; hot-springs and disseminated mercury, gold-silver placers; infrequently with polymetallic veins and tungsten skarns.

\section{DEPOSIT DESCRIPTION}

Mineralogy Stibnite + quartz \pm pyrite \pm calcite; minor other sulfides frequently less than 1 percent of deposit and included \pm arsenopyrite \pm sphalerite \pm tetrahedrite \pm chalcopyrite \pm scheelite \pm free gold; minor minerals only occasionally found include native antimony, marcasite, calaverite, berthierite, argentite, pyrargyrite, chalcocite, wolframite, richardite, galena, jamesonite; at least a third (and possibly more) of the deposits contain gold or silver. Uncommon gangue minerals include chalcedony, opal (usually identified to be $\beta$-cristobalite by $X-r a y)$, siderite, fluorite, barite, and graphite.

Texture/Structure Vein deposits contain stibnite in pods, lenses, kidney forms, pockets (locally); may be massive or occur as streaks, grains, and bladed aggregates in sheared or brecciated zones with quartz and calcite. Disseminated deposits contain streaks or grains of stibnite in host rock with or without stibnite vein deposits.

Alteration Silicification, sericitization, and argillization; minor chloritization; serpentinization when deposit in mafic, ultramafic rocks.

Ore Controls Fissures and shear zones with breccia usually associated with faults; some replacement in surrounding lithologies; infrequent open-space filling in porous sediments and replacement in limestone. Deposition occurs at shallow to intermediate depth.

Weathering Yellow to reddish kermesite and white cerrantite or stibiconite (Sb oxides) may be useful in exploration; residual soils directly above deposits are enriched in antimony.

Geochemical Signature $\mathrm{Sb} \pm \mathrm{Fe} \pm \mathrm{As} \pm \mathrm{Au} \pm \mathrm{Ag} ; \mathrm{Hg} \pm \mathrm{W} \pm \mathrm{Pb} \pm \mathrm{Zn}$ may be useful in specific cases.

\section{EXAMPLES}

Amphoe Phra Saeng, THLD

Caracota, BLVA
(Gardner, 1967)

(U.S. Geological Survey Mineral Resources Data System) 
Model 27d--Con.

Coimadai Antimony Mine, AUVT (Fisher, 1952)

Last Chance, USNV

(Lawrence, 1963)

Lake George, CNNB

(Scratch and others, 1984)

\title{
GRADE AND TONNAGE MODEL OF SIMPLE Sb DEPOSITS
}

\author{
By James D. Bliss and Greta J. Orris
}

COMMENTS Grade and tonnage have been modeled separately for vein-dominated and disseminated simple antimony deposits. The vein-dominated deposits' grades and tonnages in this model reflect handsorting of the ore. A grade-tonnage model for deposits containing disseminated antimony, number 27 , follows this model. At least 15 percent of the simple antimony veins are accompanied by disseminated antimony mineralization. See figs. 140-142.

\section{DEPOSITS}

$\underline{\text { Name }}$

Amphoe Phra Saeong

Antimonial

Antimony Canyon

Antimony King I

Antimony King II

Antimony Lode

Antimony Mines

Antimony Ridge

Apex Antimony

Black Warrior

Bloody Canyon

Blue Dick

Blue Jay

Blue Nose

Blue Ribbon

Bradley

Bray-Beulah

Burns Basin

Cervantite

Choates

Cia Minera Norcro

Coasano

Coeur d'Alene

Coimadai

Conyarigi

Costerfield

Cottonwood

Darwin

Desert

Doi Pha Khan

Donatelli

Drumm

Dry Canyon

Eaton

Elalmis

Electric

Enterprise

Four-of-July

Fujinokawa

Green Antimony

Grey Eagle

\begin{tabular}{c} 
COUNTrY \\
\hline THLD \\
USNV \\
USUT \\
USNV \\
USNV \\
USNV \\
USMT \\
USID \\
USNV \\
USNV \\
USNV \\
USNV \\
USOR \\
USNV \\
USNV \\
USNV \\
USNV \\
USNV \\
USNV \\
USNV \\
HNDR \\
USAK \\
USID \\
AUVT \\
TRKY \\
AUVT \\
USNV \\
USNV \\
USCA \\
THLD \\
USNV \\
USNV \\
USNV \\
USNV \\
TRKY \\
USNV \\
USNV \\
USID \\
JAPN \\
USNV \\
USOR
\end{tabular}

Name

Gribble

Happy Return

Hard Luck

Hermada

Hollywood

Hoyt

Huai Nai Khao THLD

I.H.X.

Ichinokawa

Idaho

Jay Bird

Jerritt Canyon

Johnson-Heizer

Last Chance

Lithia

Lof thouse

Lowry

Lucky Knock

Merrimac

Milton Canyon USNV

Mizpah USNV

Mugi JAPN

Neardie AUQL

Nevada King USNV

Nieves MXCO

Ore Drag USNV

Page USNV

Panther USNV

Prunty USNV

Scrafford USAK

Snowdrift USNV

St. George AUQL

Stewart May USAR

Stibnite USAK

Sutherland USNV

Thompson Falls USMT

Upper Bellingen AUNS

Volcanic Peak USNV

W.P. USNV

Wall Canyon USNV 
Model 27d--Con.

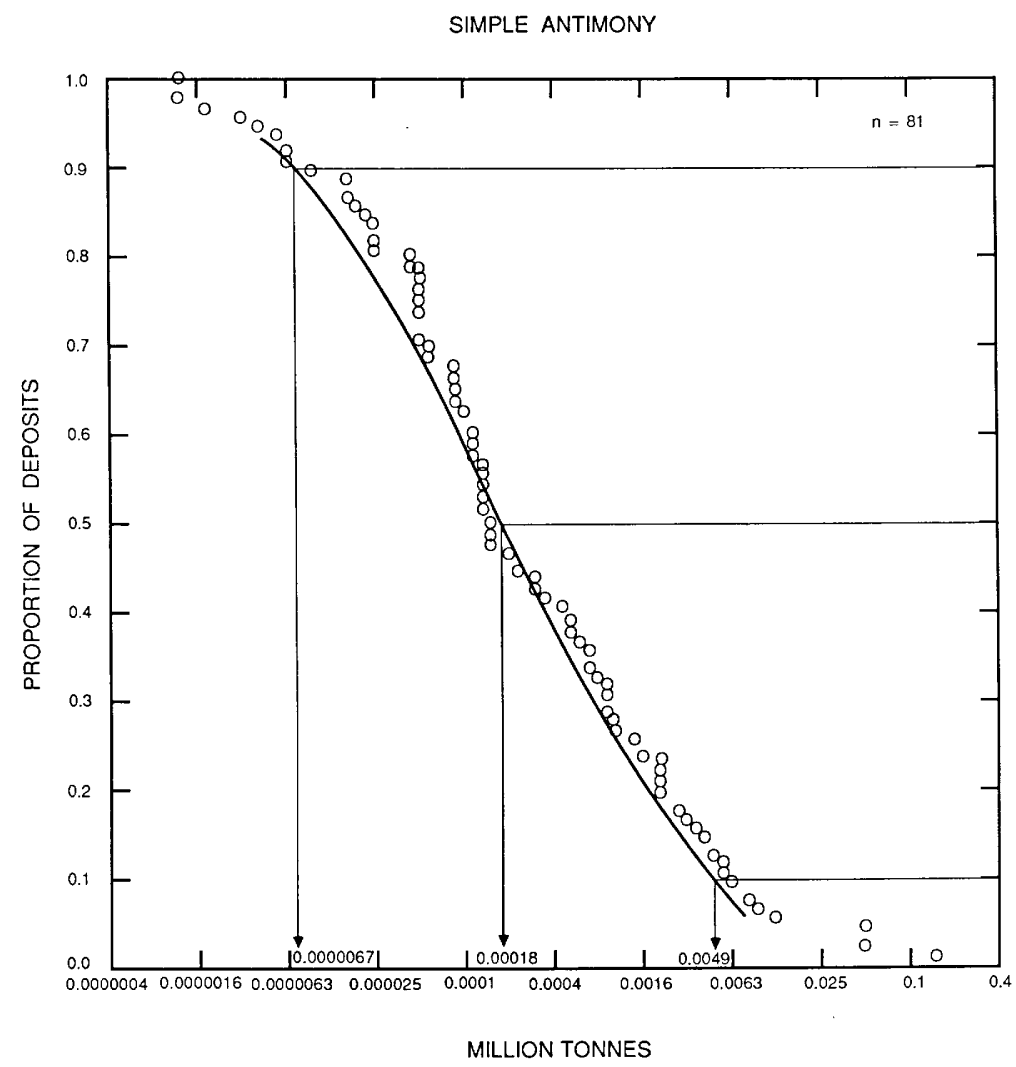

Figure 140. Tonnages of simple Sb deposits.

SIMPLE ANTIMONY

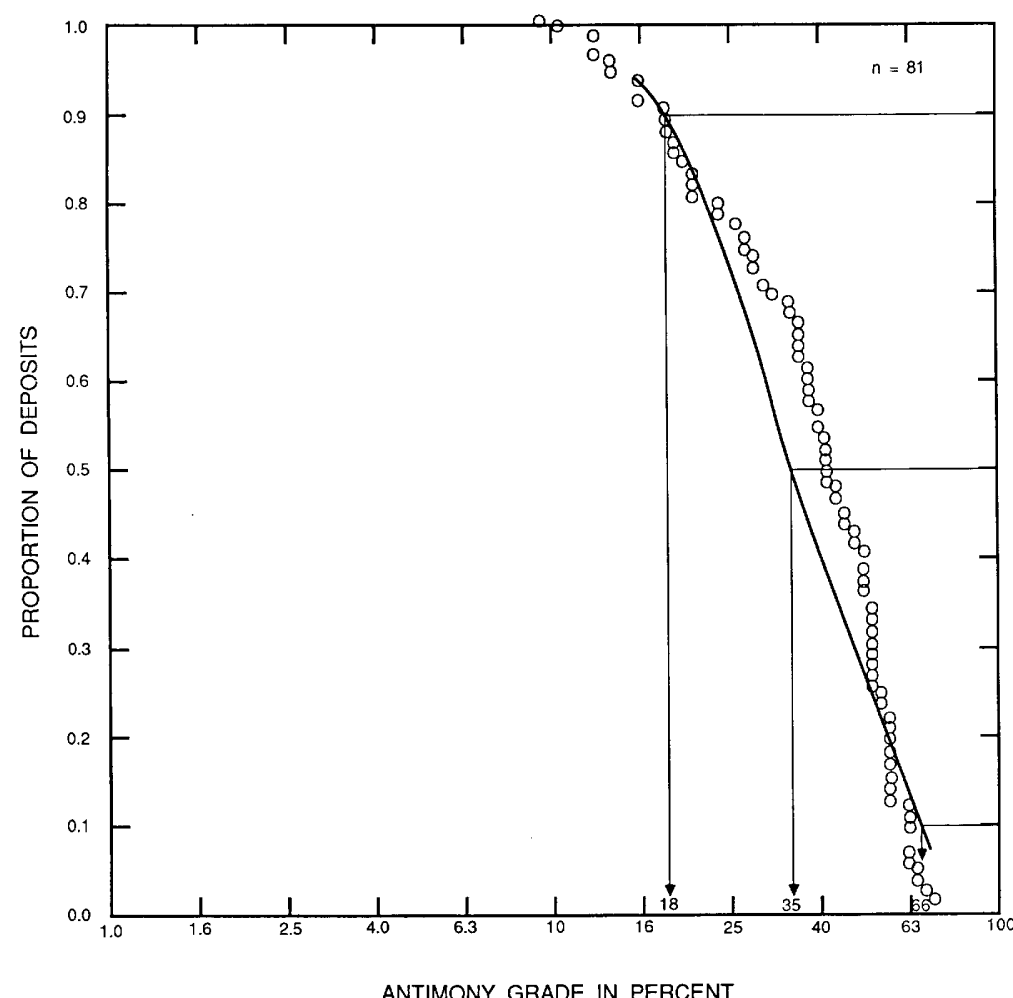

Figure 141. Antimony grades of simple $\mathrm{Sb}$ deposits. 
Model 27d--Con.
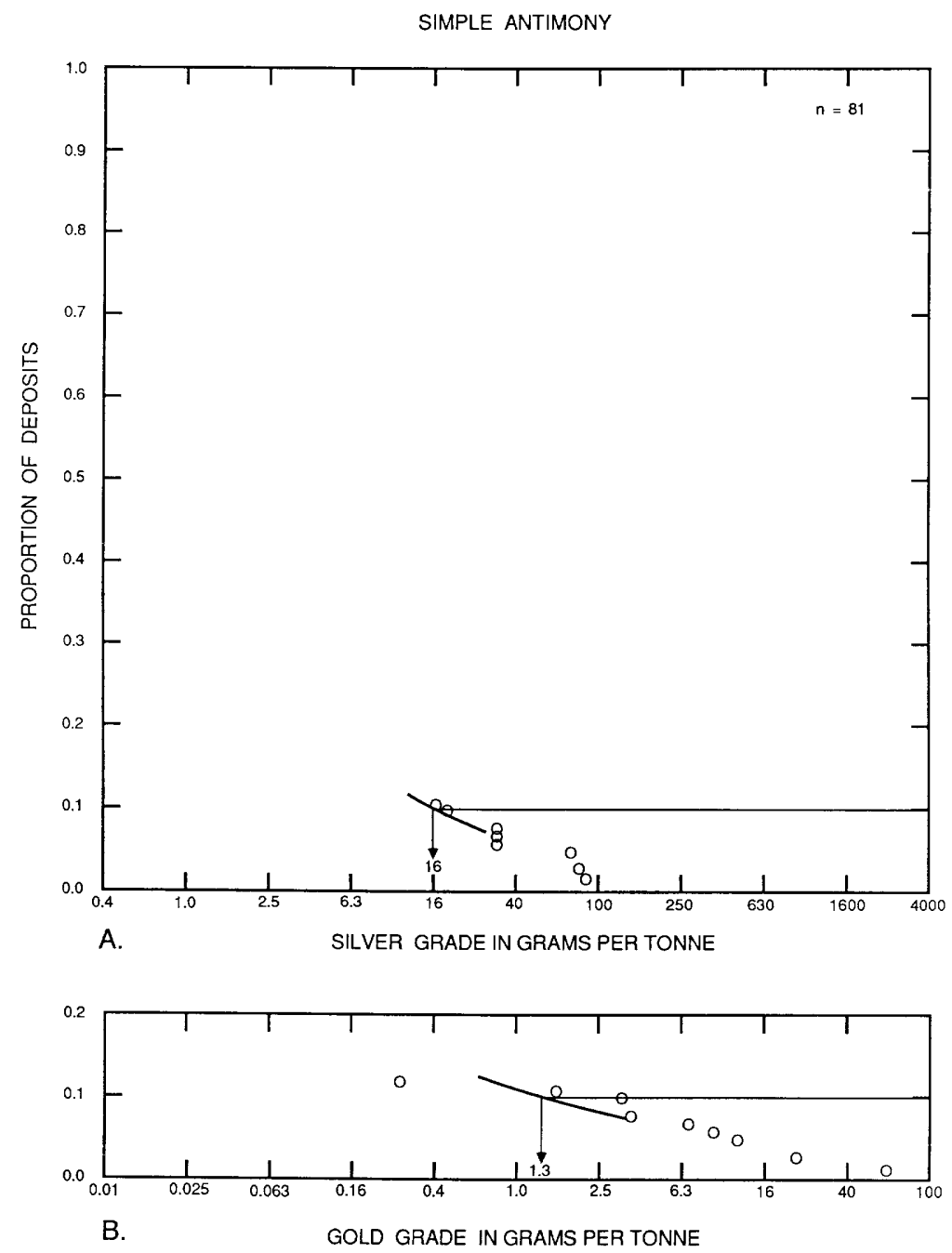

Figure 142. Precious-metal grades of simple Sb deposits. A, Silver. B, Gold. 
GRADE AND TONNAGE MODEL OF DISSEMINATED Sb DEPOSITS

By James D. Bliss and Greta J. Orris

COMMENTS Disseminated simple antimony deposits, model $27 \mathrm{e}$, is presented as an alternative to model 27d because of major differences in grade between the two groups. The two groups are similar geologically and share the same descriptive model. See figs. 143, 144.

DEPOSITS

Name

Buyuk Yenice
Camlica Koyee
Caracota
Dagardi
Demirkapi
Derekoy
Dudas
Emirli
Eskdale
Espiritu Santo
Goynuk
Kucuk Yenice

Buyuk Yenice

Caracota

Dagardi

Demirkapi

Derekoy

Emirli

Eskdale

Goynuk

Kucuk Yenice

\begin{tabular}{l} 
Country \\
\hline TRKY \\
TRKY \\
BLVA \\
TRKY \\
USNV \\
TRKY \\
USNV \\
TRKY \\
AUQL \\
BLVA \\
TRKY \\
TRKY
\end{tabular}

$\underline{\text { Name }}$

La Cruz

Lake George

Madeni

Mitchell River

Montezuma

Orendere

Quien-Sabe

San Emigdio

Tasdibi

West Gore

Wildrose Canyon

Country

MXCO

CNNB

TRKY

AUQL

USNV

TRKY

USCA

USCA

TRKY

CNNS

USCA 
Model 27e--Con.

Figure 143. Tonnages of disseminated simple Sb deposits.
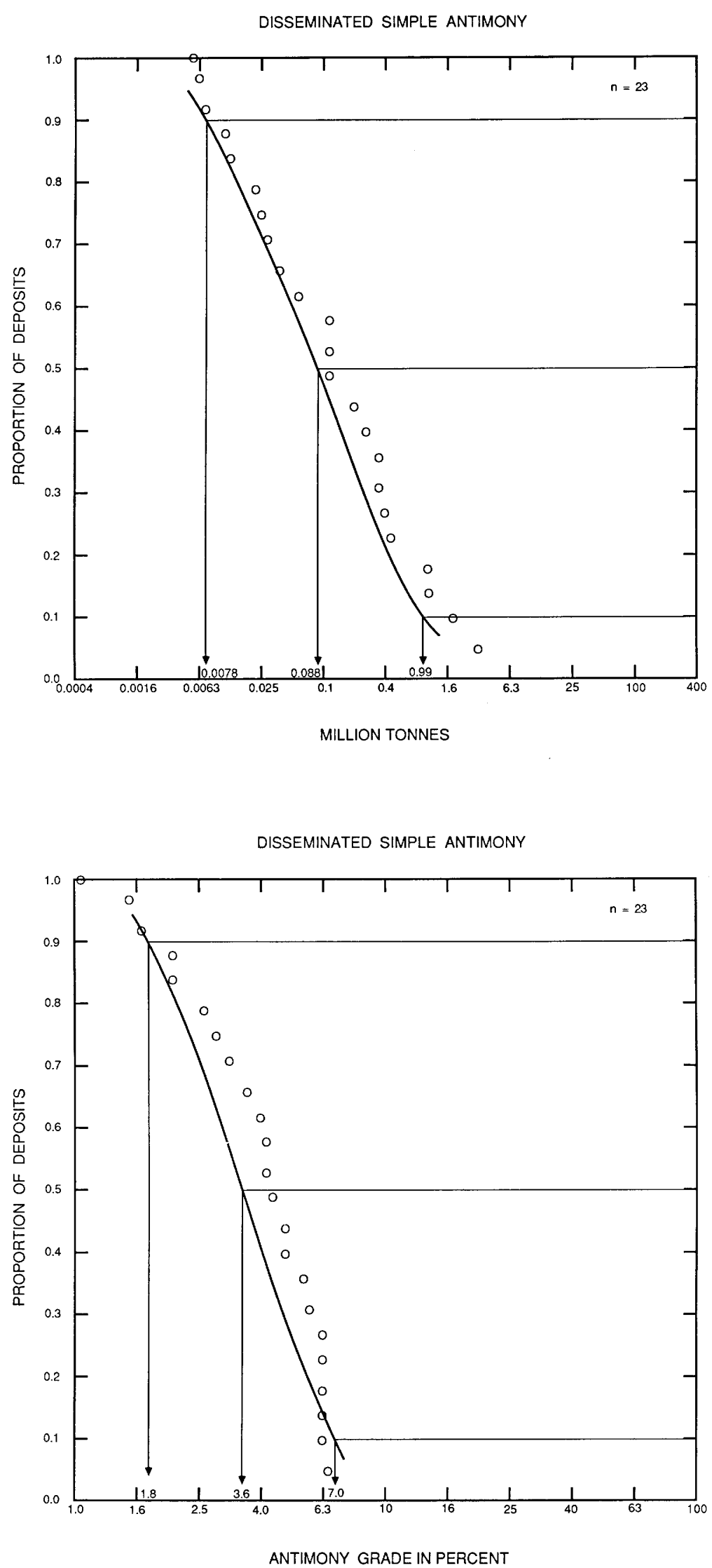

Figure 144. Antimony grades of disseminated simple Sb deposits. 


\title{
DESCRIPTIVE MODEL OF KUROKO MASSIVE SULFIDE
}

\author{
By Donald A. Singer
}

APPROXIMATE SYNONYM Noranda type, volcanogenic massive sulfide, felsic to intermediate volcanic type.

DESCRIPTION Copper- and zinc-bearing massive sulfide deposits in marine volcanic rocks of intermediate to felsic composition (see fig. 145).

GENERAL REFERENCES Ishihara (1974), Franklin and others (1981), Hutchinson and others (1982), Ohmoto and Skinner (1983).

GEOLOGICAL ENVIRONMENT

Rock Types Marine rhyolite, dacite, and subordinate basalt and associated sediments, principally organic-rich mudstone or shale. Pyritic, siliceous shale. Some basalt.

Textures Flows, tuffs, pyroclastics, breccias, bedded sediment, and in some cases felsic domes. Age Range Archean through Cenozoic.

Depositional Environment Hot springs related to marine volcanism, probably with anoxic marine conditions. Lead-rich deposits associated with abundant fine-grained volcanogenic sediments.

Tectonic Setting(s) Island arc. Local extensional tectonic activity, faults, or fractures. Archean greenstone belt.

Associated Deposit Types Epithermal quartz-adularia veins in Japan are regionally associated but younger than kuroko deposits. Volcanogenic $\mathrm{Mn}$, Algoma $\mathrm{Fe}$.

\section{DEPOSIT DESCRIPTION}

Mineralogy Upper stratiform massive zone (black ore)--pyrite + sphalerite + chalcopyrite \pm pyrrhotite \pm galena \pm barite \pm tetrahedrite - tennantite \pm bornite; lower stratiform massive zone (yellow ore)--pyrite + chalcopyrite \pm sphalerite \pm pyrrhotite \pm magnetite; stringer (stockwork) zone--pyrite + chalcopyrite (gold and silver). Gahnite in metamorphosed deposits. Gypsum/anhydrite present in some deposits.

Texture/Structure Massive ( $>60$ percent sulfides); in some cases, an underlying zone of ore stockwork, stringers or disseminated sulfides or sulfide-matrix breccia. Also slumped and redeposited ore with graded bedding.

Alteration Adjacent to and blanketing massive sulfide in some deposits--

zeolites, montmorillonite (and chlorite?); stringer (stockwork) zone--silica, chlorite, and sericite; below stringer--chlorite and albite. Cordierite and anthophyllite in footwall of metamorphosed deposits, graphitic schist in hanging wall.

Ore Controls Toward the more felsic top of volcanic or volcanic-sedimentary sequence. Near center of felsic volcanism. May be locally brecciated or have felsic dome nearby. Pyritic siliceous rock (exhalite) may mark horizon at which deposits occur. Proximity to deposits may be indicated by sulfide clasts in volcanic breccias. Some deposits may be gravity-transported and deposited in paleo depressions in the seafloor. In Japan, best deposits have mudstone in hanging wall.

Weathering Yellow, red, and brown gossans. Gahnite in stream sediments near some deposits.

Geochemical Signature Gossan may be high in $\mathrm{Pb}$ and typically Au is present. Adjacent to depositenriched in $\mathrm{Mg}$ and $\mathrm{Zn}$, depleted in $\mathrm{Na}$. Within deposits--Cu, $\mathrm{Zn}, \mathrm{Pb}, \mathrm{Ba}, \mathrm{As}, \mathrm{Ag}, \mathrm{Au}, \mathrm{Se}, \mathrm{Sn}, \mathrm{Bi}$, $\mathrm{Fe}$. 


\title{
EXAMPLES
}

Kidd Creek, CNON

Mt. Lyell, AUTS

Brittania, CNBC

Buchans, CNNF
(Walker and others, 1975)

(Corbett, 1981)

(Payne and others, 1980)

(Swanson and others, 1981)

\section{GRADE AND TONNAGE MODEL OF KUROKO MASSIVE SULFIDE}

\author{
By Donald A. Singer and Dan L. Mosier
}

DATA REFERENCE Mosier and others (1983).

COMMENTS Includes all deposits listed by Mosier and others (1983) that are associated with felsic or intermediate volcanic rocks. Tonnage is correlated with copper grade $(r=-0.17)$ and with gold grade $(r=-0.19, n=238)$. Zinc grade is correlated with lead grade $(r=0.55, n=184)$ and with silver grade $(r=0.52, n=249)$. Lead grade is correlated with silver $(r=0.55, n=153)$ and with gold grade $(r=0.34, n=124)$. Gold and silver grades are correlated $(r=0.39, n=227)$. See figs. 146-149.

\section{DEPOSITS}

Name

\begin{tabular}{|c|c|}
\hline Abeshiro (Sakura) & JAPN \\
\hline Adak-Lindskold & SWDN \\
\hline Afterthought & USCA \\
\hline Aijala & FNLD \\
\hline Akarsen & TRKY \\
\hline Akkoy & TRKY \\
\hline Akulla Vastra & SWDN \\
\hline Albert & CNQU \\
\hline Aldermac & CNQU \\
\hline Allard River & CNQU \\
\hline Almagrera-Lapilla & SPAN \\
\hline Amulet A & CNQU \\
\hline Amulet $F$ & CNQU \\
\hline Anayatak-Cakmakkaya & TRKY \\
\hline Anderson Lake & CNMN \\
\hline Angelo & AUWA \\
\hline Anne & NRWY \\
\hline Antler & USAZ \\
\hline Arctic & USAK \\
\hline Armstrong (A) & CNNB \\
\hline As Safra & SAAR \\
\hline Asen-east & SWDN \\
\hline Asen-west & SWDN \\
\hline Ash Shizm & SAAR \\
\hline Austin Brook & CNNB \\
\hline Avoca & IRLD \\
\hline Aznacollar & SPAN \\
\hline Bagacay & PLPN \\
\hline Bailadores & VNZL \\
\hline Balaklala & USCA \\
\hline Bald Mountain & USME \\
\hline Bandgan & PKTN \\
\hline Barrett & USME \\
\hline Barrington Lake & CNMN \\
\hline Barvallee-Mogador & CNQU \\
\hline Baskoy & TRKY \\
\hline Bathurst-Norsemines & CNNT \\
\hline Bawdin & BRMA \\
\hline Beatson & USAK \\
\hline Bedford Hill & CNQU \\
\hline
\end{tabular}

Name

Bell Allard
Bell Channel
Bidjovagge (A)
Bid jovagge (B)
Bid jovagge (C)
Bid jovagge (D)
Big Bend
Big Hill

Binghampton

Birch Lake

Bjorkasen

Bjurfors

Bjurliden

Bjurtrask

Blue Ledge

Blue Moon

Bodennec

Boliden

Bossmo

Britannia

Bruce

Brunswick No. 12

Brunswich No. 6

Buchans (LS-Roth.)

Buchans (McLean)

Buchans (OB-Orient.)

Bully Hill-Rising St.

Bursi

Campanario

Canadian Jamieson

Canoe Landing

Captain

Captains Flat

Caribou

Carpio

Castillo Buitron

Castro Verde

CC

Centennial

Chestatee

\section{Country}

CNQU

CNQU

NRWY

NRWY

NRWY

NRWY

USCA

USME

USAZ

CNSK

NRWY

SWDN

SWDN

SWDN

USCA

USCA

FRNC

SWDN

NRWY

CNBC

USAZ

CNNB

CNNB

CNNF

CNNF

CNNF

USCA

NRWY

SPAN

CNON

CNNB

CNNB

AUNS

CNNB

SPAN

SPAN

PORT

CNBC

CNMN

USGA 
Model 28a--Con.

\begin{tabular}{|c|c|}
\hline Chester & CNNB \\
\hline Chisel Lake & CNMN \\
\hline Clinton & $\mathrm{CNQU}$ \\
\hline Conception & SPAN \\
\hline Conigo & CNQU \\
\hline Copper Crown & $\mathrm{CNBC}$ \\
\hline Copper George & AUWA \\
\hline Copper Hill & USCA \\
\hline Corbet & $\mathrm{CNQU}$ \\
\hline Coronation & CNSK \\
\hline Crandon & USWI \\
\hline Cronin & $\mathrm{CNBC}$ \\
\hline Cueva de la Mora & SPAN \\
\hline Cupra D'Estrie & CNQU \\
\hline Cuprus & $\mathrm{CNMN}$ \\
\hline Davis & USMA \\
\hline Deer Isle & USME \\
\hline Delbridge & CNQU \\
\hline Despina & CNQU \\
\hline Detour & CNQU \\
\hline Devils Elbow & CNNB \\
\hline Dickstone & CNMN \\
\hline Don Jon & CNMN \\
\hline Double Ed & CNBC \\
\hline Dumagami & CNQU \\
\hline Dumont Bourlamque & CNQU \\
\hline Dunraine & CNQU \\
\hline Duthie & CNBC \\
\hline Dyce Siding & CNMN \\
\hline Early Bird & USCA \\
\hline East Sullivan & CNQU \\
\hline Ego & CNON \\
\hline Embury Lake & CNMN \\
\hline Emerson & USME \\
\hline Empire Le Tac & CNQU \\
\hline Errington & CNON \\
\hline Estacao & CNON \\
\hline Eulaminna & AUWA \\
\hline Eustis & CNQU \\
\hline F Group & CNON \\
\hline Farewell Lake & CNMN \\
\hline Filon Sur-Esperanza & SPAN \\
\hline Fjeldgruve & NRWY \\
\hline FL \& DH & CNMN \\
\hline Flambeau & USWI \\
\hline Flexar & CNSK \\
\hline Flin Flon & CNMN \\
\hline Fonnfjell & NRWY \\
\hline Fox & CNMN \\
\hline Freddie Wells & AUNS \\
\hline Fretais & PORT \\
\hline Frotet Lake & CNQU \\
\hline Fukazawa & JAPN \\
\hline Furuhaugen & NRWY \\
\hline Furutobe-Ainai & JAPN \\
\hline Gamle Folldal & NRWY \\
\hline Garon Lake & CNQU \\
\hline Gaviao & PORT \\
\hline Gelvenakko & SWDN \\
\hline George Copper & CNBC \\
\hline Ghost Lake & CNMN \\
\hline Giken-Charlotta & NRWY \\
\hline Girilambone & AUNS \\
\hline
\end{tabular}

\begin{tabular}{|c|c|}
\hline Gjersvik & NRWY \\
\hline Golden Grove & AUWA \\
\hline Goodenough & CNMN \\
\hline Gray Eagle & USCA \\
\hline Green Coast & CNON \\
\hline Greens Creek & USAK \\
\hline Gullbridge & CNNF \\
\hline Hacan & TRKY \\
\hline Half Mile Lake (SG) & CNMN \\
\hline Halliwell & CNQU \\
\hline Hanaoka (Doy.-Tsut.) & JAPN \\
\hline Hanaoka (Mats.-Sha.) & JAPN \\
\hline Hanawa (Aket.-Osak.) & JAPN \\
\hline Hanson Lake & CNSK \\
\hline Harkoy & TRKY \\
\hline Heath Steele $(A-C-D)$ & CNNB \\
\hline Heath Steele (B) & CNNB \\
\hline Heath Steele $(E-F)$ & CNNB \\
\hline Hercules & AUTN \\
\hline Herrerias & SPAN \\
\hline Hersjo & NRWY \\
\hline High Lake & CNNT \\
\hline Hixbar & PLPN \\
\hline Hoidal & NRWY \\
\hline Hood River & CNNT \\
\hline Horne-Quemont & CNQU \\
\hline Hunter & CNQU \\
\hline $\mathrm{HW}$ & CNBC \\
\hline Hyers Island & CNMN \\
\hline Iron Dyke & USOR \\
\hline Iron King & USAZ \\
\hline Iron Mountain & USCA \\
\hline Irsahan & TRKY \\
\hline Iso-Magusi-New Insco & CNQU \\
\hline Israil & TRKY \\
\hline Iwami east & JAPN \\
\hline Iwami west & JAPN \\
\hline Izok Lake & CNNT \\
\hline Jabal Sayid & SAAR \\
\hline Jakobsbakken & NRWY \\
\hline Jameland & CNON \\
\hline Jerome & USAZ \\
\hline Joanne & CNMN \\
\hline Joliet & CNQU \\
\hline Josselin & CNQU \\
\hline Joutel & CNQU \\
\hline Kalkanli & TRKY \\
\hline Kam Kotia & CNON \\
\hline Kamitkita (Kominosawa) & JAPN \\
\hline Kankberg & SWDN \\
\hline Kedtrask & SWDN \\
\hline Kelly-Desmond & CNQU \\
\hline Key Anacon & CNNB \\
\hline Keystone & USCA \\
\hline Ketstone-Union & USCA \\
\hline Khans Creek & AUNS \\
\hline Khnaiguiyah & SAAR \\
\hline Kidd Creek & CNON \\
\hline Killingdal & NRWY \\
\hline Kimheden & SWDN \\
\hline Kittelgruvan & SWDN \\
\hline Kizilkaya & TRKY \\
\hline Koff Zone & CNMN \\
\hline
\end{tabular}


Model 28a--Con.

Koprubasi TRKY

Kosaka (Motoyama) JAPN

Kosaka (Uch.-Uwa.) JAPN

Kostere TRKY

Kristineberg SWDN

Kunitomi (3-4-6) JAPN

Kunitomi (7-8) JAPN

Kunitomi (1-5-1N-Fud.) JAPN

Kurosawa JAPN

Kutcho Creek CNBC

Kutlular TRKY

Kuvarshan TRKY

La Joya SPAN

La Torrera SPAN

La Zarza SPAN

Lagunazo SPAN

Lahanos SPAN

Lake Dufault CNQU

Lancha SPAN

Langdal SWDN

Langsele SWDN

Lenora-Twin $\mathrm{J} \quad$ CNBC

Levi SWDN

Lingwick CNQU

Lomero Poyatos SPAN

Lost Lake CNMN

Lousal PORT

Louvem CNQU

Lyndhurst $\quad$ CNQU

Lynx CNQU

Lyon Lake CNON

MacBride Lake CNMN

Madenkoy TRKY

Malaiba PLPN

Mamie CNBC

Mammoth USCA

Mandy CNMN

Mankayan PLPN

Marcos PLPN

Mattabi CNON

Mattagami Lake CNQU

McMaster CNNB

Metsamonttu FNLD

Mic Mac CNQU

Milan USNH

Millenbach CNQU

Mobrun CNQU

Mofjell NRWY

Moinho PORT

Mokoman Lake CNSK

Moleon Lake CNQU

Monpas CNQU

Mons Cupri AUWA

Mordey CNON

Mos NRWY

Moskogaissa NRWY

Moulton Hill CNQU

Mount Bulga AUNS

Mount Chalmers AUQL

Mount Lyell AUTS

Mount Morgan AUQL

Mount Mulcahy AUWA

Murgul
Murray Brook CNNB

Myra Falls-Lynx CNBC

Nasliden SWDN

Nepisiguit CNNB

New Bay Pond CNNF

New Hosco CNQU

Newton USCA

Nine Mile Brook CNNB

Nordre Gjetryggen NRWY

Norita $\quad \mathrm{CNQU}$

Normetal CNQU

North Boundary CNNB

North Keystone USCA

North Star CNMN

Northair $\quad$ CNBC

Nuqrah SAAR

Old Waite CNQU

Orange Point USAK

Orchan CNQU

Orijarvi FNLD

Osbourne Lake CNMN

Oshio JAPN

Ostra Hogkulla SWDN

Pabineau River CNNB

Paronen FNLD

Parys Mountain GRBR

Pater CNON

Paymogo SPAN

Pecos USNM

Pelican USWI

Penn USCA

Penobscot USME

Perrunal SPAN

Phelps Dodge CNQU

Pilleys Island CNNF

Pine Bay CNMN

Piray PLPN

Point Leamington CNNF

Poirier CNQU

Port Aux Moines FRCN

Pot Lake CNMN

Price CNBC

Pyhasalmi FNLD

Que River AUTS

Radiore E CNQU

Rail Lake CNMN

Rakkejaur SWDN

Rambler-Ming CNNF

Ramsey CNSK

Ravliden SWDN

Ravlidmyran SWDN

Rosebery-Read AUTS

Red Wing CNBC

Reed Lake CNMN

Renstrom SWDN

Rieppe NRWY

Rio Tinto SPAN

Rocky Turn CNNB

Rod CNMN

Rodhammeren NRWY

Rodkleiv NRWY

Romanera SPAN

Romerito SPAN 
Model 28a--Con.

\begin{tabular}{|c|c|}
\hline Rostvangen & NRWY \\
\hline Rud t jebacken & SWDN \\
\hline Ruttan & CNMN \\
\hline Sabetjok & NRWY \\
\hline Sagmo & NRWY \\
\hline Sain Bel & FRNC \\
\hline San Antonio & SPAN \\
\hline San Domingos & PORT \\
\hline San Guillermo-Sierra & SPAN \\
\hline San Mateo & PLPN \\
\hline San Pedro & SPAN \\
\hline San Platon & SPAN \\
\hline San Telmo & SPAN \\
\hline Santa Rosa & SPAN \\
\hline Schist Lake & CNMN \\
\hline Selco-Scott & $\mathrm{CNQU}$ \\
\hline Shasta King & USCA \\
\hline Shunsby & CNON \\
\hline Sierrecilla & SPAN \\
\hline Silver Queen & CNBC \\
\hline Skaide & NRWY \\
\hline Solbec & CNQU \\
\hline Sotiel & SPAN \\
\hline Sourdough Bay & CNMN \\
\hline South Dufault & CNQU \\
\hline South Rusty Hill & $\mathrm{CNQU}$ \\
\hline Spenceville & USCA \\
\hline Spruce Point & CNMN \\
\hline Stall Lake & CNMN \\
\hline Steken jokk & SWDN \\
\hline Stirling & CNNS \\
\hline Stowell & USCA \\
\hline Stralak & CNON \\
\hline Stratmat & CNNB \\
\hline Sturgeon Lake & CNON \\
\hline Suffield & CNQU \\
\hline Sulat & PLPN \\
\hline Sun & CNMN \\
\hline Sunshine & CNBC \\
\hline Susu Lake & CNNT \\
\hline Sutro & USCA \\
\hline Tache Lake & CNQU \\
\hline Taisho (Nishimata) & JAPN \\
\hline Takijug Lake & CNNT \\
\hline Taknar I & IRAN \\
\hline Taknar II & IRAN \\
\hline Tapley & USME \\
\hline Tashiro & JAPI \\
\hline & \\
\hline
\end{tabular}

Teahan CNNB

Tedi CNBC

Terra Nova CNNF

Teutonic Bore AUWA

Texas CNNB

Third Portage CNNB

Tjokkola SWDN

Tomogonops CNNB

Trininty CNQU

Trout Bay CNON

Tsuchihata (Hatabira) JAPN

Tsuchihata (Honniozaw.) JAPN

Tsuchihata (Shiratsuc.) JAPN

Tsuchihata (Uenono-Ok.) JAPN

Tsuchihata (Washinosu) JAPN

Tulk's Pond CNNF

Tulsequah CNBC

Tunca TRKY

Tverrf jellet NRWY

Uchi CNON

Udden SWDN

Undu FIJI

Vaddas NRWY

Vamp CNMN

Vauze CNQU

Vermillion CNON

Vigsnes NRWY

Viscaria SWDN

Waden Bay CNSK

Waite East CNQU

Wallaroo AUWA

Wedge CNNB

Weedon CNQU

Weiss TRKY

Westarm CNMN

Whim Creek AUWA

White Lake CNMN

Whundo AUWA

Wildeat PLPN

Willecho CNON

Wim CNMN

Windy $\quad$ CNBC

Woodlawn AUQL

Yava CNNT

Yoichi JAPN

Yokota (Motoyama-Hama.) JAPN

Yoshino (Hisaka) JAPN

Yoshino (Main) JAPN

$Z$ CNMN 
Model 28a--Con.

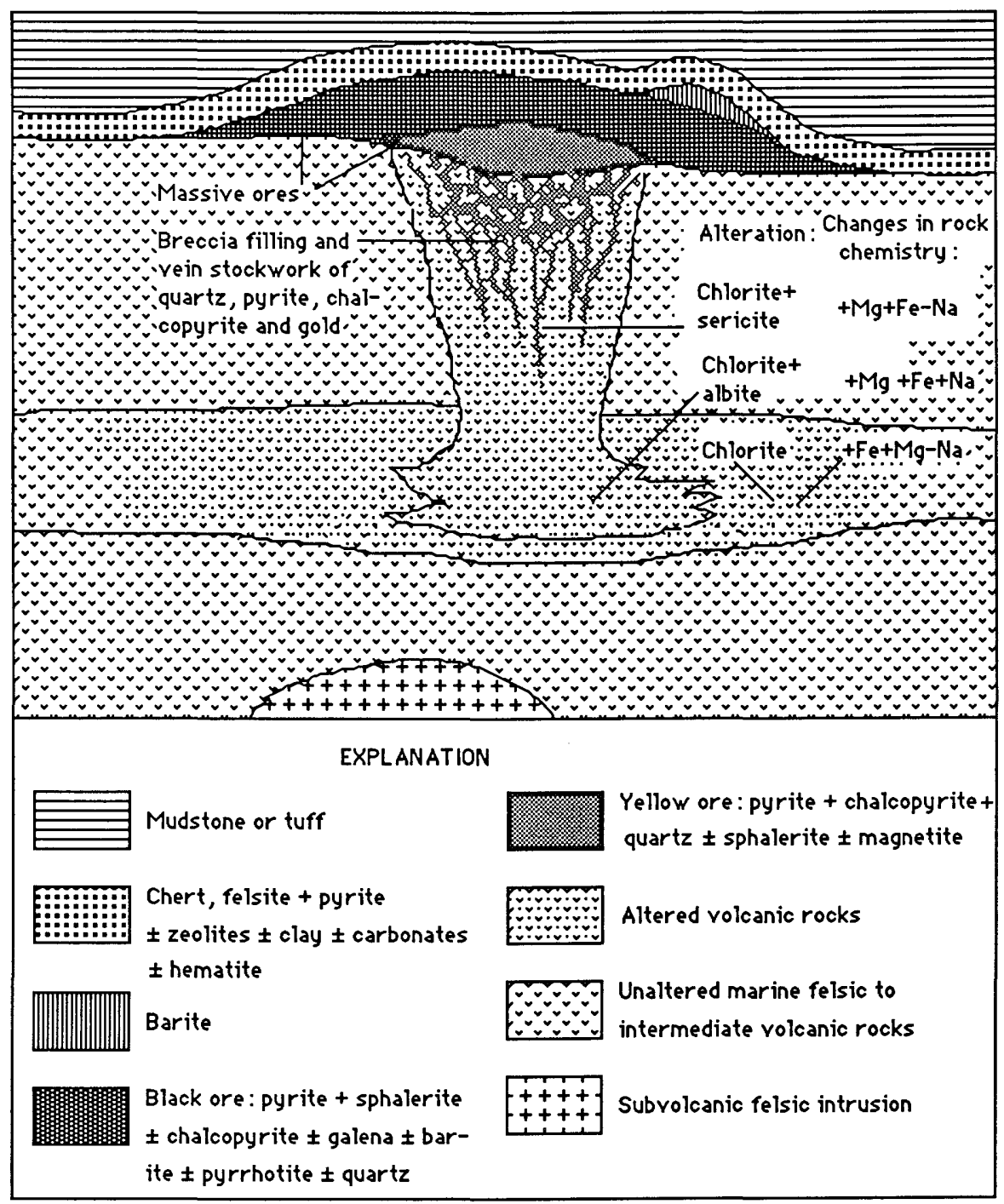

Figure 145. Cartoon cross section of kuroko massive sulfide deposit. Modified from $\mathrm{F}$ rankl in and others (1981). 
KUROKO MASSIVE SULFIDE

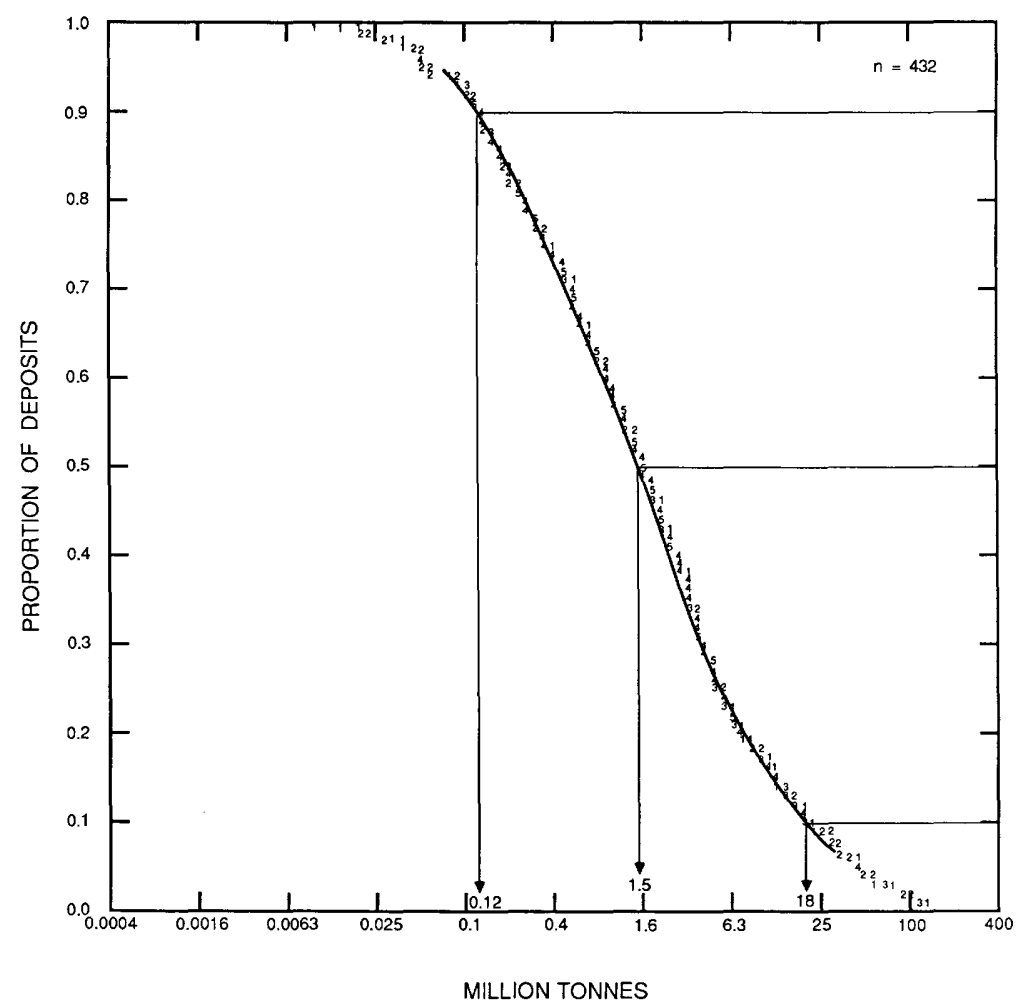

KUROKO MASSIVE SULFIDE

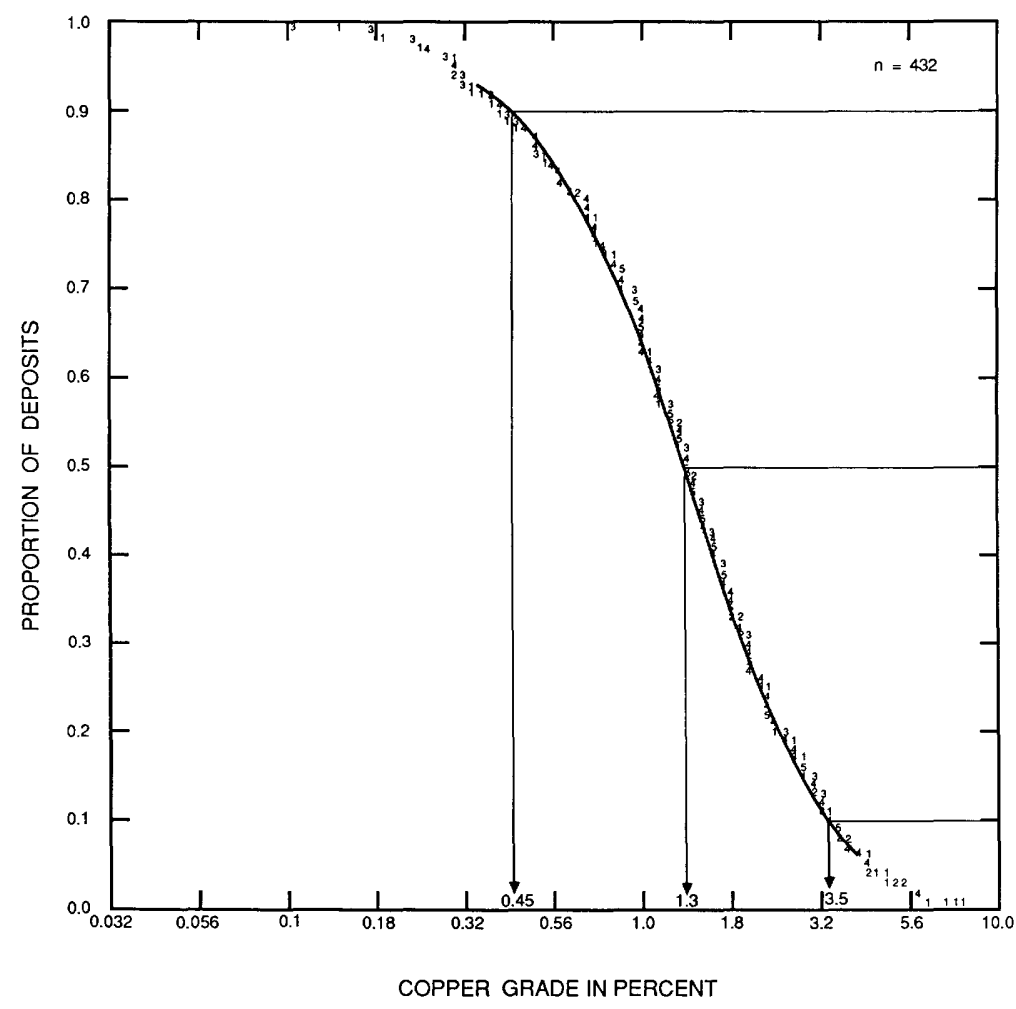

Figure 146. Tonnages of kuroko massive sulfide deposits. Individual digits represent number of deposits.
Figure 147. Copper grades of kuroko massive sulfide deposits. Individual digits represent number of deposits. 
Model 28a--Con.

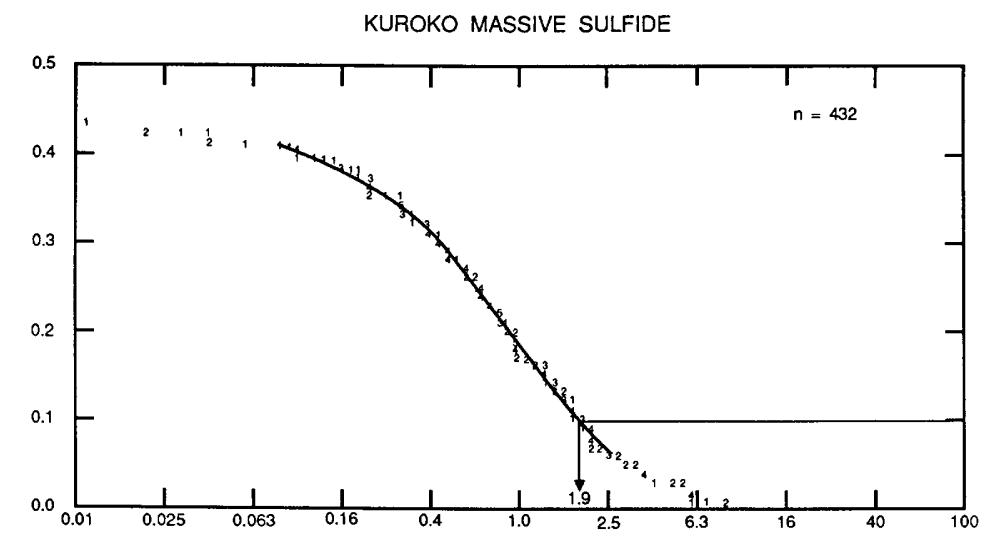

A.

LEAD GRADE IN PERCENT

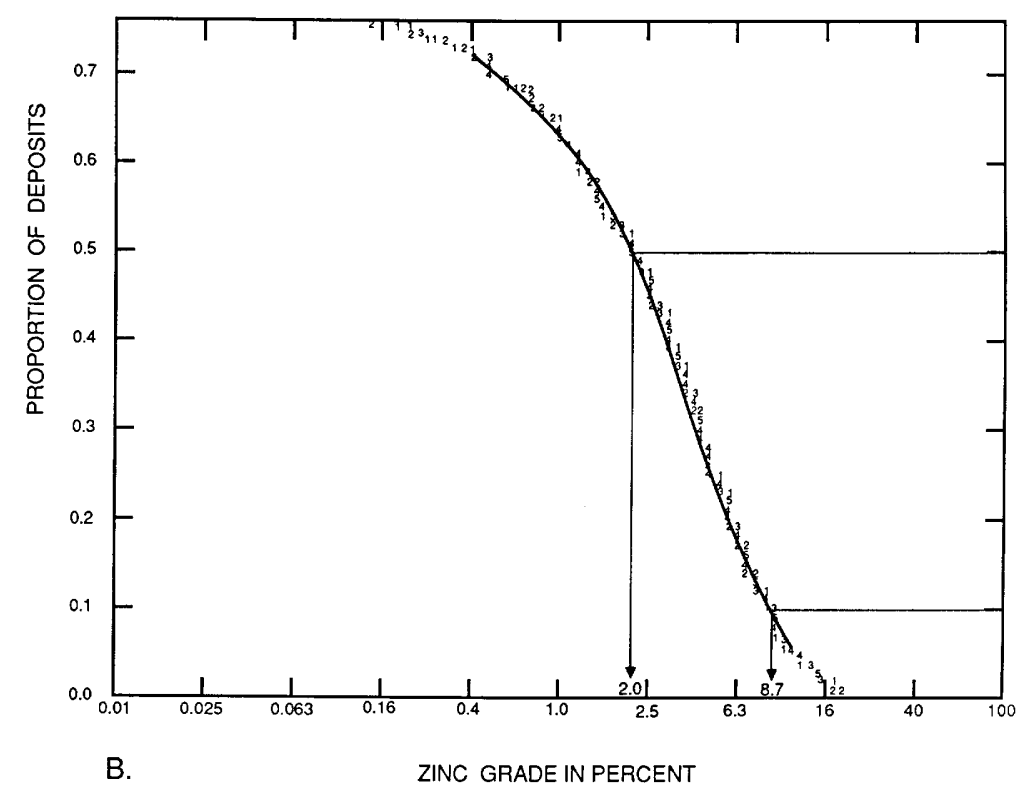

Figure 148. Lead-zinc grades of kuroko massive sulfide deposits.

$\underline{A}$, Lead. $\underline{B}$, Zinc. Individual digits represent number of deposits. 

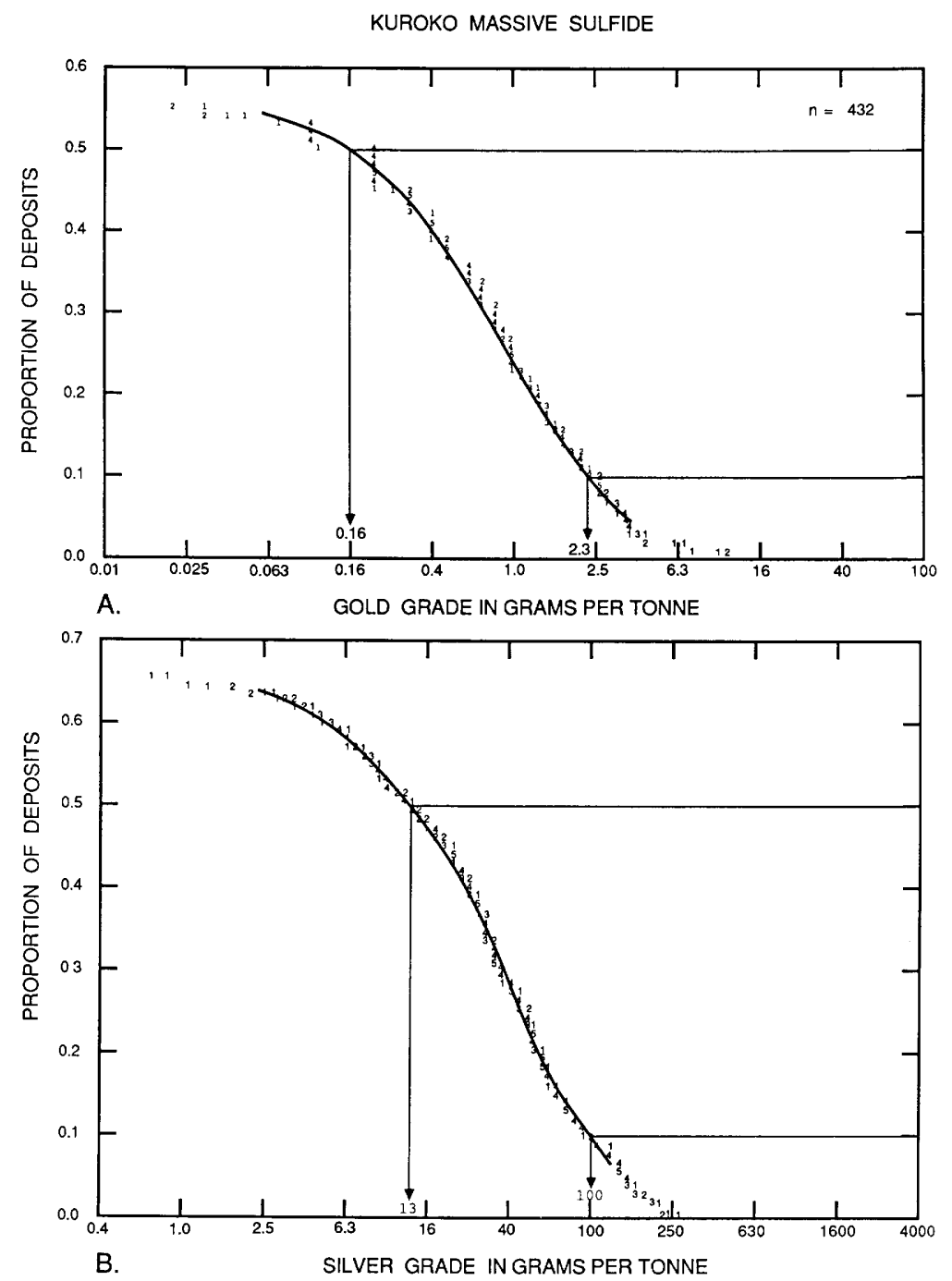

Figure 149. Precious-metal grades of kuroko massive sulfide deposits. A, Gold. B, Silver. Individual digits represent number of deposits. 
Model 28b

\section{DESCRIPTIVE MODEL OF ALGOMA Fe}

By William F. Cannon

APPROXIMATE SYNONYM Volcanogenic iron-formation.

DESCRIPTION Beds of banded iron-rich rock typically in volcanic-sedimentary sequences formed in tectonically active oceanic regions. (The grade-tonnage model for Algoma Fe is included under Superior $\mathrm{Fe}$ ).

GENERAL REFERENCE Goodwin (1973).

GEOLOGICAL ENVIRONMENT

Rock Types Mafic to felsic submarine volcanic rocks and deep-water clastic and volcaniclastic sediments.

Textures Pillowed greenstones, intermediate to felsic tuffs and agglomerates, poorly sorted clastic sediments.

Age Range Mostly Archean.

Depositional Environment Volcano-sedimentary basins (greenstone belts of Precambrian shields) generally with rapid turbidite sedimentation and thick volcanic accumulations.

Tectonic Setting(s) Tectonically active submarine volcanic belts, most commonly preserved in Precambrian shields.

Associated Deposit Types Kuroko massive sulfides and Homestake Au deposits.

DEPOSIT DESCRIPTION

Mineralogy Magnetite, hematite, siderite. Interlayered fine-grained quartz.

Texture/Structure Banded on centimeter scale with chert beds interlayered with Fe-rich beds.

Alteration No syngenetic alteration, but commonly metamorphosed to varying degrees and weathered.

Ore Controls Local controls within general volcano-sedimentary setting are not well established. Sub-basin with low sediment and volcanic input is probably key factor.

Weathering Conversion of iron minerals to Fe-hydroxides; leaching of silica. Intense weathering can form high-grade supergene ores.

Geophysical Signature Magnetic anomalies.

Examples

Vermillion iron-formation, USMN James (1983) 


\section{DESCRIPTIVE MODEL OF QUARTZ PEBBLE CONGLOMERATE AU-U}

By Dennis P. Cox

DESCRIPTION Placer Au, U, and PGE in ancient conglomerate.

GENERAL REFERENCES Pretorius (1981), Minter (1982).

GEOLOGICAL ENVIRONMENT

Rock Types Oligomictic mature conglomerate beds in thick sequence of less mature conglomerate and sandstone deposited on Archean granite-greenstone. Basal volcanic rocks locally. Thick sedimentary sequences underlying Superior type iron-formation.

Textures Well-rounded, well-packed pebbles of vein quartz, chert and pyrite. Bimodal clast-size distribution with well-sorted pebbles and well-sorted matrix. Matrix is quartz, mica, chlorite, pyrite, and fuchsite. Granite clasts are absent.

Age Range Major deposits are Archean to Early Proterozoic (3,100-2,200 m.y.), Tarkwa is 1,900 m.y.

Depositional Environment Very thick onlapping sedimentary deposits in elongate epicontinental basins or half-grabens. Middle and basal reaches of alluvial fans deposited on steeper side of basins. Reducing atmosphere believed to be necessary to preserve detrital pyrite and uraninite.

Tectonic Setting(s) Slow subsidence of Archean craton. Later moderate uplift and erosion to remove Phanerozoic strata and retain Early Proterozoic rocks.

Associated Deposit Types Recent gold placer deposits. Low-sulfide gold quartz veins and Homestake $\mathrm{Au}$ in basement rocks. Superior $\mathrm{Fe}$ in overlying sequences.

\section{DEPOSIT DESCRIPTION}

Mineralogy Quartz, gold, pyrite, uraninite, brannerite, zircon, chromite, monazite, leucoxene, osmium-iridium alloys, isoferro platinum and sperrylite. By-product Ag. Middle Proterozoic (Tarkwa) and Phanerozoic occurrences have only traces of pyrite and no uraninite.

Texture/Structure Pyrite may occur as rounded grains, and concentrically layered concretions. Gold is in small angular grains, 0.005 to $0.1 \mathrm{~mm}$ in diameter.

Ore Controls Braided stream channels in broad unconformity surfaces in alluvial fans. Troughcross bedding, current- or wave-winnowed bedding surfaces. Gold concentrated at base of mature conglomerate beds deposited on an erosion surface. Carbonaceous layers resembling algal mats deposited at low-energy base of fan contain $U$ and fine Au.

Weathering Residual gold in weathering zone.

Geochemical Signature Au, U, PGE; anomalous radioactivity.

\section{EXAMPLES}

Witwatersrand, SAFR

Elliot Lake, CNON

Jacobina, BRZL

Tarkwa, GHNA
(Pretorius, 1981; Feather, 1976)

(Roscoe, 1969)

(Gross, W., 1968; Cox, 1967)

(Sestini, 1973) 


\section{DESCRIPTIVE MODEL OF OLYMPIC DAM CU-U-Au}

By Dennis P. Cox

DESCRIPTION Hematite, bornite, and other minerals in sedimentary breccia filling grabens in granitic basement.

GENERAL REFERENCE Roberts and Hudson (1983).

GEOLOGICAL ENVIRONMENT

Rock Types Proterozoic alkali granite with red K-feldspar, brecciated and forming clasts in matrix-rich breccia. Felsic volcanic breccia and tuff. Hematite iron-formation.

Textures Granophyric intergrowth in granite. Breccias grade from clast-supported in interior of basin to matrix-supported in central iron-rich part.

Age Range The only example is $1,500 \mathrm{~m} . \mathrm{y}$. old.

Depositional Environment Proterozoic granite basement broken by a deep, narrow graben filled by rapidly deposited breccia, iron-formation, and minor felsic volcanic rocks.

Tectonic Setting(s) Narrow graben transcurrent to broad arch. Local gravity high caused by dense iron-formation. Trace of graben can be detected in post-ore cover rocks as photo lineaments.

Associated Deposit Types Sediment-hosted copper deposits, iron-formation.

\section{DEPOSIT DESCRIPTION}

Mineralogy Stratabound hematite + bornite + chalcopyrite; transgressive hematite + chalcocite + bornite with fluorite, barite, and minor carrollite, cobaltite, native silver, coffinite, brannerite, bastnaesite, and florencite.

Texture/Structure ore minerals in breccia matrix and in veins. Pisolitic siderite-fluoritechlorite in stratabound ore.

Alteration Hematite-chlorite and sericite-quartz, also carbonates, fluorite, barite, rutile, and rare anhydrite, tourmaline, and magnetite. Intense chlorite alteration of granite below ore bodies. K-feldspar replaced by chlorite.

Ore Controls Stratiform ore in matrix polymictic-breccia containing clasts of granite, pisolitic rock, hematite, and sulfides. Transgressive ore in fractures parallel to long axis of graben.

Weathering Type example not exposed.

Geochemical and Geophysical Signature $\mathrm{Cu}+\mathrm{U}+\mathrm{Co}+\mathrm{Au}+\mathrm{Ag}+\mathrm{Iight} \mathrm{REE}+\mathrm{F}+\mathrm{Ba}$. Dispersion pattern not known. Cu associated with hematite. Co associated with lower pyrite-rich zone. U-REE associated with $\mathrm{Cu}$ but $\mathrm{Cu}$ not always with $\mathrm{U}-\mathrm{REE}$. Au highest in late chalcocite ore. $\mathrm{Pb}$, $\mathrm{Zn}$ very low.

Radioactivity would be detectable if exposed or shallow. Magnetic high of unknown origin.

EXAMPLES

Olympic Dam, AUSA (Roberts and Hudson, 1983) 


\title{
DESCRIPTIVE MODEL OF SANDSTONE-HOSTED Pb-Zn
}

\author{
By Joseph A. Briskey
}

DESCRIPTION Stratabound to stratiform galena and sphalerite in multiple, thin, sheetlike ore bodies in arenaceous sedimentary rocks.

GENERAL REFERENCES Bjørlykke and Sangster (1981), Briskey (1982).

GEOLOGICAL ENVIRONMENT

Rock Types Continental, terrigenous, and marine quartzitic and arkosic sandstone, conglomerate, grit, and siltstone. Local evaporates.

Textures Bedding, crossbedding, paleochannels, liquification structures, and intraformational slump breccias. Quartz and subordinate calcite cement.

Age Range Proterozoic to Cretaceous host rocks.

Depositional Environment Host rocks deposited in combined continental and marine environments including piedmont, fluvial, lagoonal-lacustrine, lagoonal-deltaic, lagoonal-beach, and tidal channel-sand bar environments. Commonly succeeded by marine transgressions.

Tectonic Setting(s) Deep weathering and regional peneplanation during stable tectonic conditions, accompanied by marine platform or piedmont sedimentation associated with at least some orogenic uplift. Sialic basement, mainly "granites" or granitic gneisses.

Associated Deposit Types Sediment-hosted Cu.

\section{DEPOSIT DESCRIPTION}

Mineralogy Fine- to medium-crystalline galena with sporadic smaller amounts of sphalerite, pyrite, barite, and fluorite. Minor chalcopyrite, marcasite, pyrrhotite, tetrahedrite-tennantite, chalcocite, freibergite, bournonite, jamesonite, bornite, linnaeite, bravoite, and millerite. Quartz and calcite are usual gangue minerals, and organic debris occurs in some deposits.

Texture/Structure Clots of galena 0.5 to several centimeters in diameter; disseminations $0.1-1 \mathrm{~mm}$ in diameter; locally massive. Ore and gangue minerals are intergranular. Galena bands locally highlight crossbedding, and other sedimentary structures in sandstone. Laisvall has crosscutting curvilinear features resembling roll fronts.

Alteration "Sericite" (white mica?) reported in some deposits; but may only be recrystallized sedimentary illite.

Ore Controls Intergranular porosity. Ore may be massive where localized by porous sedimentary structures (above), impermeable barriers, faults, joints, and fractures. Within or immediately above paleochannels, or less commonly, paleoridges.

Weathering Surface oxidation of galena to cerussite, minor anglesite and pyromorphite, chalcopyrite to malachite, azurite, covellite, and chalcocite and (or) sphalerite to smithsonite, hemimorphite, hydrozincite, and goslarite.

Geochemical Signature: Anomalous amounts of $\mathrm{Pb}$ and $\mathrm{Zn}$ in host rocks and derivative soils; Ba, $\mathrm{F}$, and $\mathrm{Ag}$ are enriched in lowermost parts of some deposits. Zinc tends to increase upward in the deposits. Sialic basement may contain anomalous lead concentrations. Background in sandstone: $\mathrm{Pb}$ $=7 \mathrm{ppm} ; \mathrm{Zn}=16 \mathrm{ppm}$.

\section{EXAMPLES}

Laisvall, SWDN

Vassbo and Guttusjo, SWDN

Largentiere, FRNC

Zeida-Bou Mia, MRCO

Bou-Sellam, MRCO
(Rickard and others, 1979)

(Christofferson and others, 1979)

(Samama, 1976; Michaud, 1980)

(Schmitt and Thiry, 1977)

(Caia, 1976) 
Model 30a--Con.

Yava (Salmon R.), CNNS

George Lake, CNSK

Mechernich-Maubach, GRMY
(Hornbrook, 1967; Scott, 1980a, b)

(Karup-Møller and Brummer, 1970;

Sangster and Kirkham, 1974)

(Bjørlykke and Sangster, 1981)

GRADE AND TONNAGE MODEL OF SANDSTONE-HOSTED Pb-Zn

By Dan L. Mosier

COMMENTS Silver grades tend to be reported for the larger deposits only. See figs. 150-153

DEPOSITS

\begin{tabular}{llll} 
Name & Country & Name & Country \\
\cline { 2 - 3 } Belokany-Laura & & & GRMY \\
Bou Mia & URRS & Mechernich & GRMY \\
Boylen & MRCO & Oberpfalz & NRWY \\
George Lake & CNQU & Osen & SWDN \\
Guttusjon & CNSK & Sagliden & NRWY \\
Laisvall & SWDN & Shertingdal & CNNS \\
Largentiere & SWDN & Smithfield & ITLY \\
Lovstrand & FRNC & Tregioivo & SWDN \\
Maiva & SWDN & Vassbo & CNNS \\
Maubach & SWDN & Yava (Silvermine) & MRCO
\end{tabular}


SANDSTONE--HOSTED LEAD--ZINC

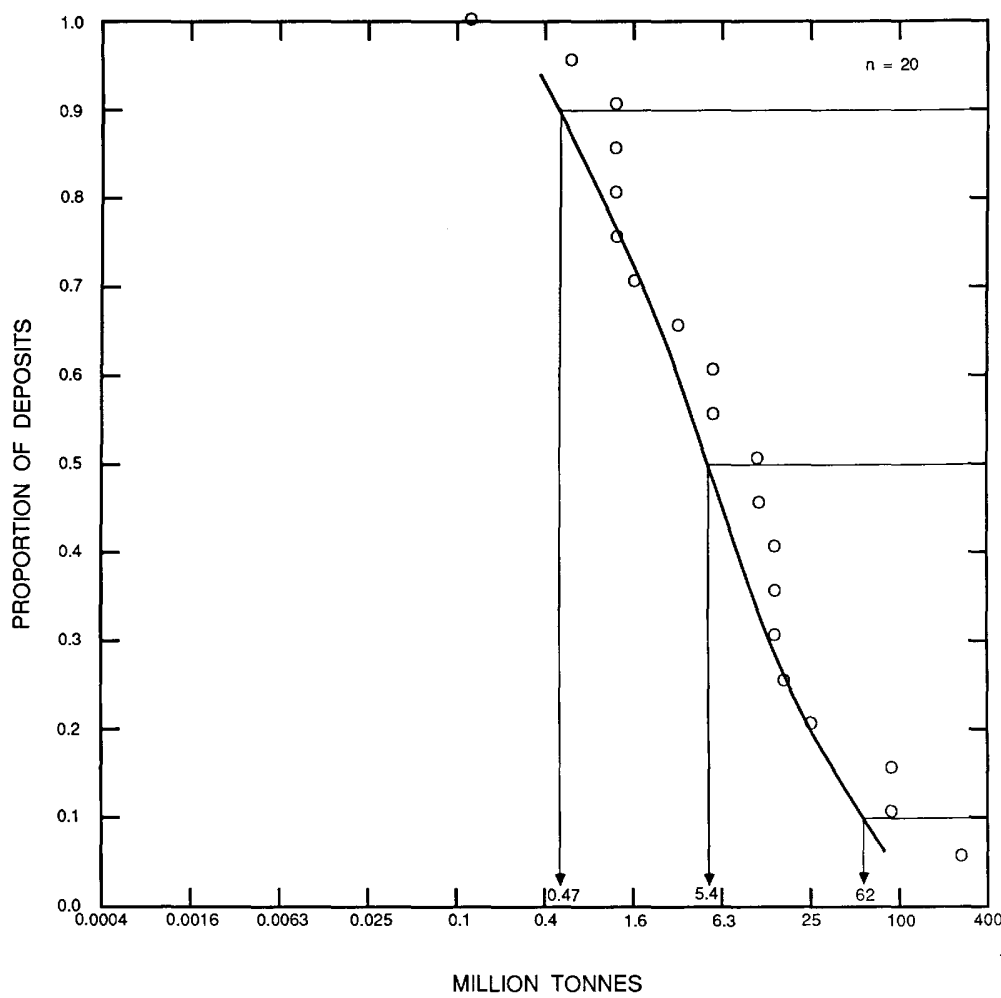

Figure 150. Tonnages of sandstone-hosted $\mathrm{Pb}-\mathrm{Zn}$ deposits.

SANDSTONE--HOSTED LEAD--ZINC

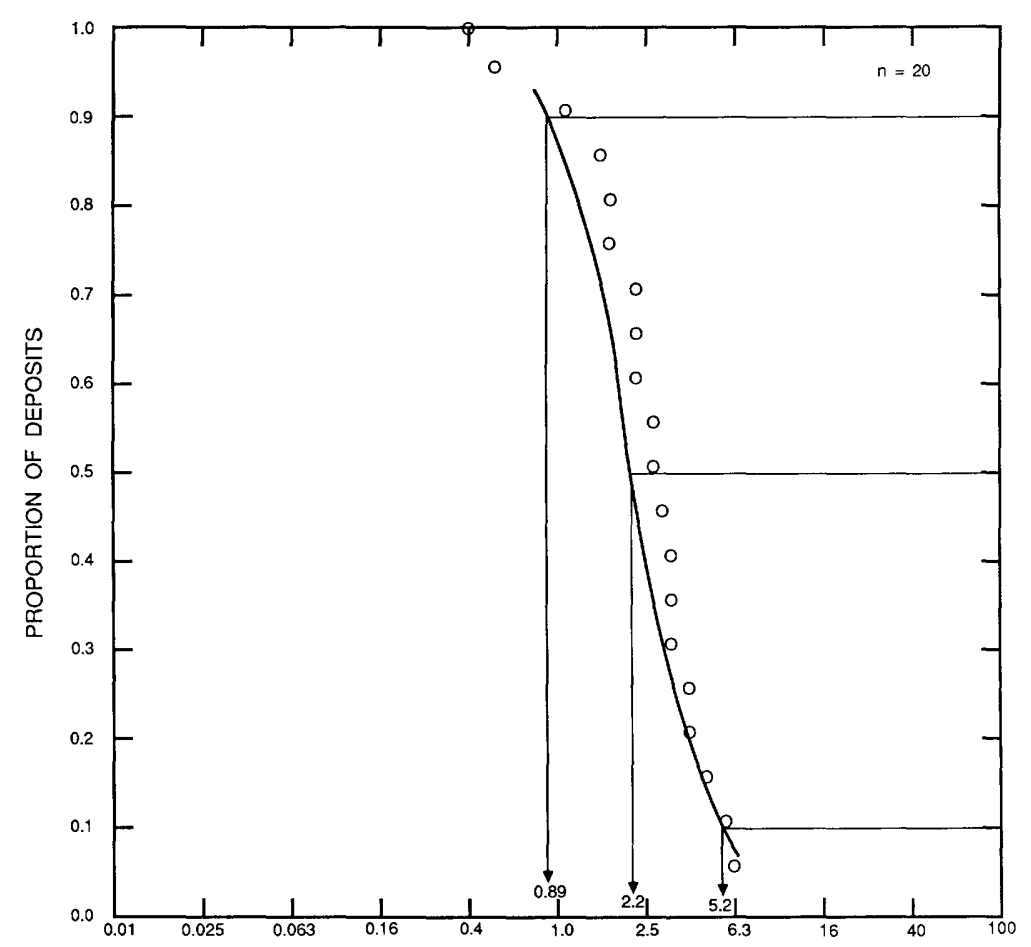

LEAD GRADE IN PERCENT

Figure 151. Lead grades of sandstonehosted $\mathrm{Pb}-\mathrm{Zn}$ deposits. 
Model 30a--Con.

Figure 152. Zinc grades of sandstonehosted $\mathrm{Pb}-\mathrm{Zn}$ deposits.
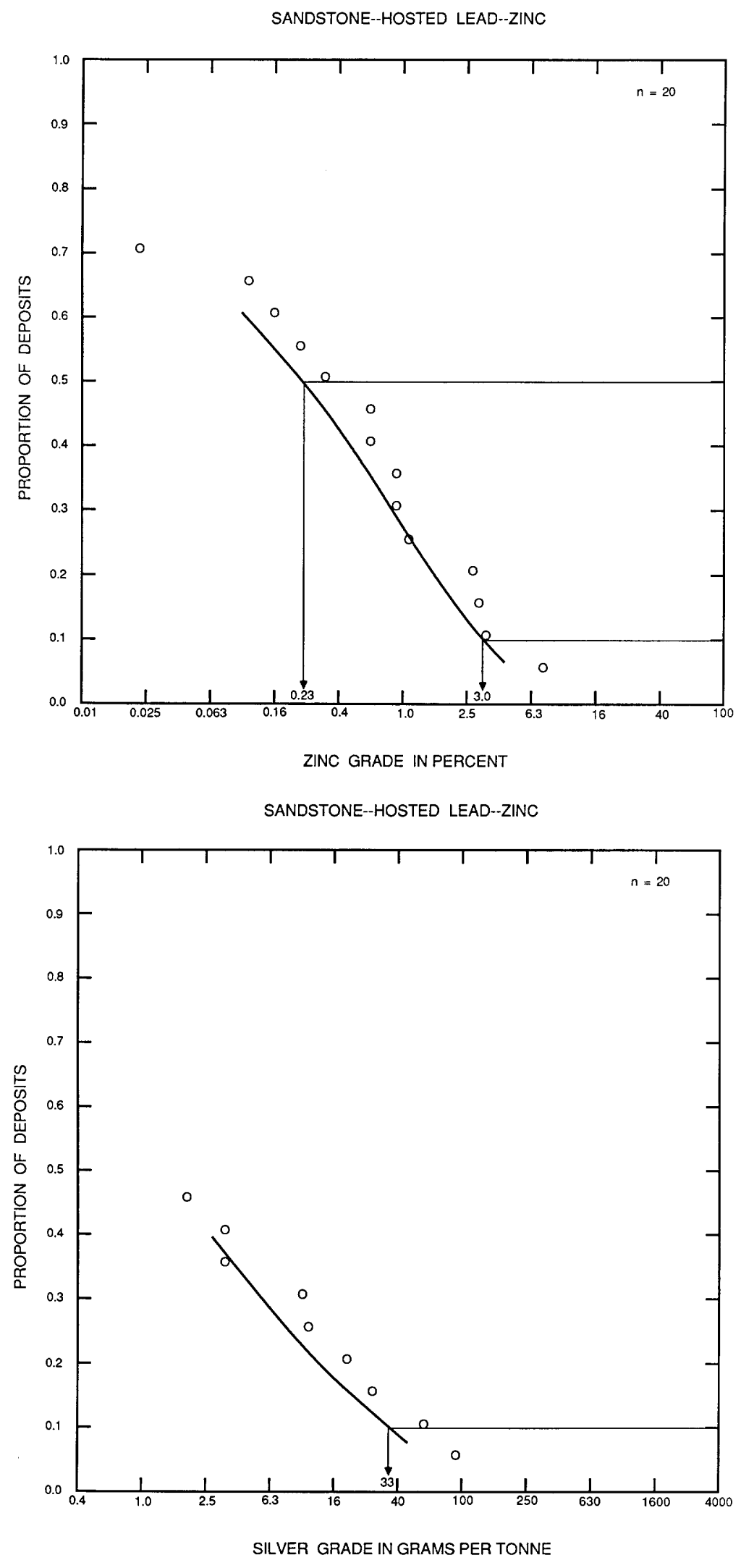

Figure 153. Sil ver grades of sandstonehosted $\mathrm{Pb}-\mathrm{Zn}$ deposits. 


\section{DESCRIPTIVE MODEL OF SEDIMENT-HOSTED Cu}

By Dennis P. Cox

APPROXIMATE SYNONYM Sandstone $\mathrm{Cu}$, includes Cu-shale (Lindsey, 1982).

DESCRIPTION Stratabound, disseminated copper sulfides in reduced beds of red-bed sequences.

GENERAL REFERENCES Tourtelot and Vine (1976), Gustafson and Williams (1981).

\section{GEOLOGICAL ENVIRONMENT}

Rock Types Red-bed sequence containing green or gray shale, siltstone, and sandstone. Thinly laminated carbonate and evaporite beds. Local channel conglomerate. Some deposits in thinly laminated silty dolomite.

Textures Algal mat structures, mudcracks, crossbedding and scour-and-fill structures. Fossil wood in channels.

Age Range Middle Proterozoic and Permian and early Mesozoic. Other Phanerozoic ages possible. Depositional Environment Epicontinental shallow-marine basin near paleo-equator. Sabkhas. High evaporation rate. Sediments highly permeable.

Tectonic Setting(s) Intracontinental rift or aulacogen--failed arm of triple junction of plate spreading. Passive continental margin. Major growth faults.

Associated Deposit Types Halite, sylvite, gypsum, anhydrite. Sandstone uranium, basalt copper, and Kipushi Cu-Pb-Zn.

\section{DEPOSIT DESCRIPTION}

Mineralogy Chalcocite and other $\mathrm{Cu}_{2} \mathrm{~S}$ minerals + pyrite \pm bornite \pm native silver. Cu $\mathrm{Cu}_{2}$ replacement of early fine-grained pyrite is common. Deposits may be zoned with centers of chalcocite \pm bornite, rims of chalcopyrite, and peripheral galena + sphalerite. Some deposits contain carrollite and Co-pyrite and Ge minerals.

Texture/Structure Fine disseminated, stratabound, locally stratiform. Framboidal or colloform pyrite. Cu minerals replace pyrite and cluster around carbonaceous clots or fragments.

Alteration Green, white, or gray (reduced) color in red beds. Regionally metamorphosed red beds may have purple color.

Ore Controls Reducing low-pH environment such as fossil wood, algal mat. Abundant biogenic sulfur. Pyritic sediments. Petroleum in paleoaquifers. High permeability of footwall sediments is critical. Boundaries between oxidized and reduced sediments.

Weathering Surface exposures may be completely leached. Secondary chalcocite enrichment down dip is common.

Geochemical Signature $\mathrm{Cu}, \mathrm{Ag}, \mathrm{Pb}, \mathrm{Zn}$ (Mo, V, U) (Co, Ge). Au is low. Weak radioactivity in some deposits.

\section{EXAMPLES}

Kupferschiefer, GRMY

White Pine, USMI

Western Montana (Belt), USMT (Harrison 1972, 1982)

Kamoto, ZIRE

(Wedepoh1, 1971)

(Brown, 1971)

(Bartholome and others, 1976) 
Model 30b--Con.

GRADE AND TONNAGE MODEL OF SEDIMENT-HOSTED Cu

By Dan L. Mosier, Donald A. Singer, and Dennis P. Cox

COMMENTS Tonnages are probably underestimated for deposits in Zambia and Zaire due to poor reporting. The extent to which mineralization exists between mines in Zambia and Zaire is not considered. Estimates for the deposits in Russia probably represent districts. See figs. $154-156$

DEPOSITS

Name

Alaska

Baluba

Big Horn (Yarrow Ck)

Burra

Bwana Mkubwa

Cattle Grid

Chacarilla

Chambiashi

Chibuluma

Chibuluma West

Chingola-Nchanga

Chongwe

Corocoro

Creta

Crowell Area

Dikulume-Mashamba

Dzhezhkazgan (Magakyan)

Gwai River

Kalengwa

Kalushi (Kalulushi)

Kamoto

Kanmantoo

Kansanshi

Kapunda

Kilembe

Konkola (Bancroft)

Lena

Lubin (LegnicaGlogow)

Lumwana

Mammoth (Gunpowder)

Mangula (Miriam)
Country

ZIMB

ZMBA

CNAL

AUSA

ZMBA

AUSA

BLVA

ZMBA

ZMBA

ZMBA

ZMBA

ZMBA

BLVA

USOK

USTX

ZIRE

URRS

ZIMB

ZMBA

ZMBA

ZIRE

AUSA

ZMBA

AUSA

UGND

ZMBA

URRS

PLND

ZMBA

AUQL

ZIMB
Name

Mangum

Mansfeld

Matchless

Matchless West

Mokambo

Mt. Gunson

Mt. Oxide

Mufulira

Musoshi

Musonoi

Nacimiento

Norah

Oamite

Pintada-Stauber

Presque Isle

Roan Antelope

(Luanshya)

Rokana (Nkana)

Ruwe (Mutoshi)

Shackleton

Silverside

Snowstorm

Spar Lake (Troy)

Tenke-Fungurume

Tshinsenda

Udokan

(Kinsenda)

White Pine
Country

USOK

GRMY

NAMB

NAMB

ZMBA

AUSA

AUQL

ZMBA

ZIRE

ZIRE

USNM

ZIMB

NAMB

USNM

USMI

ZMBA

ZMBA

ZIRE

ZIMB

ZIMB

USMT

USMT

ZIRE

ZIRE

URRS

USMI 


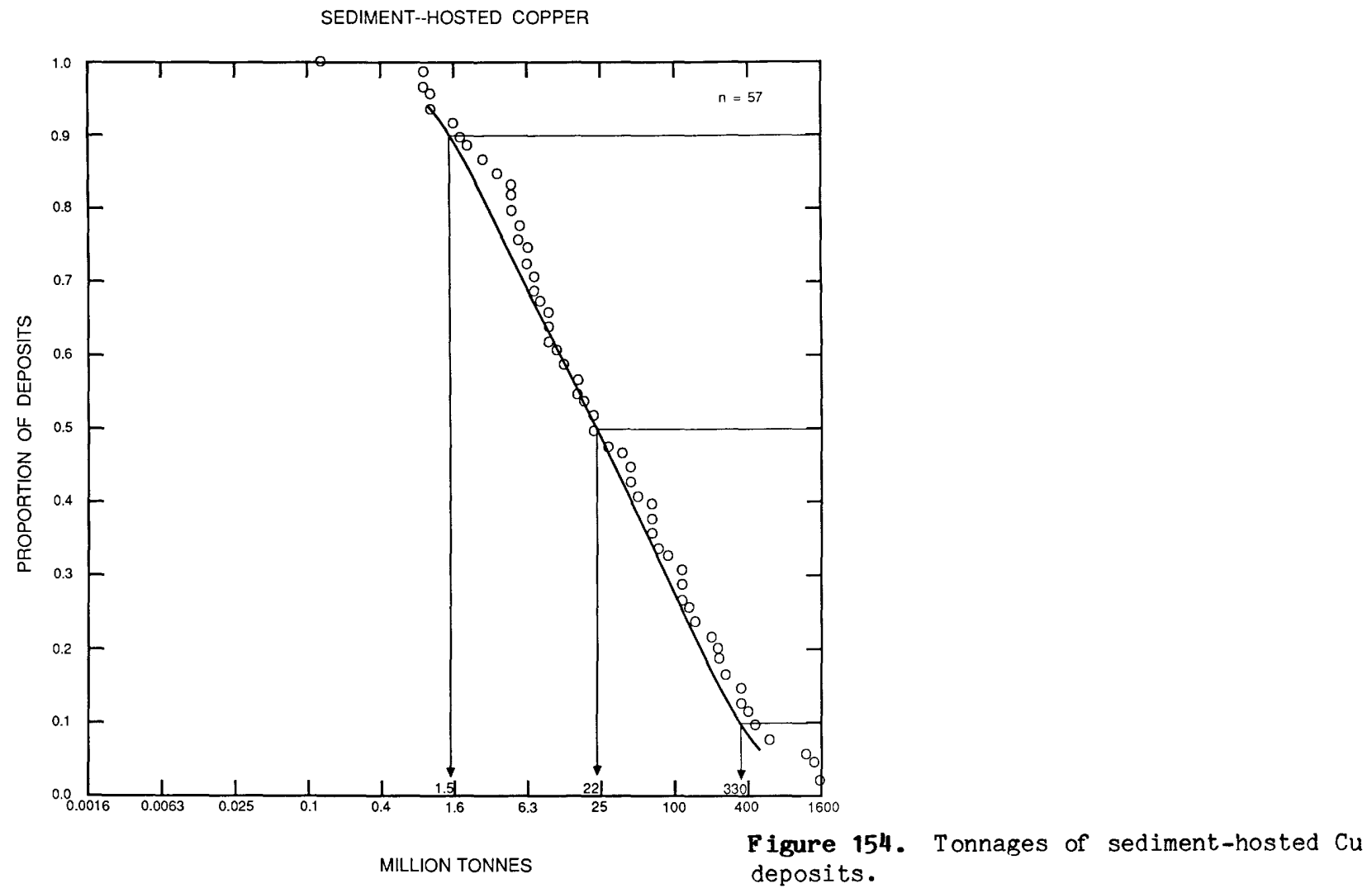

SEDIMENT--HOSTED COPPER

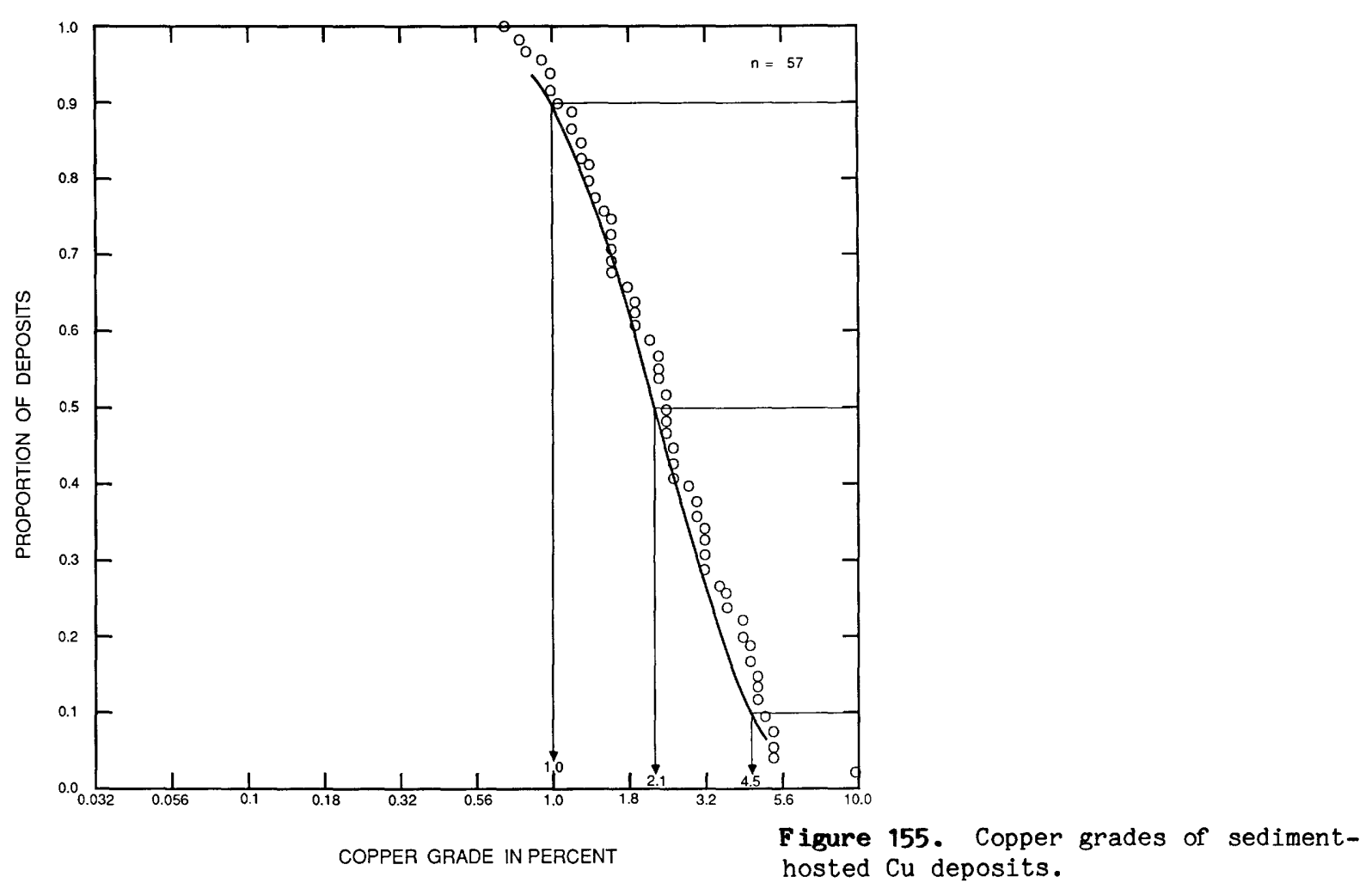


Model 30b--Con.

SEDIMENT--HOSTED COPPER

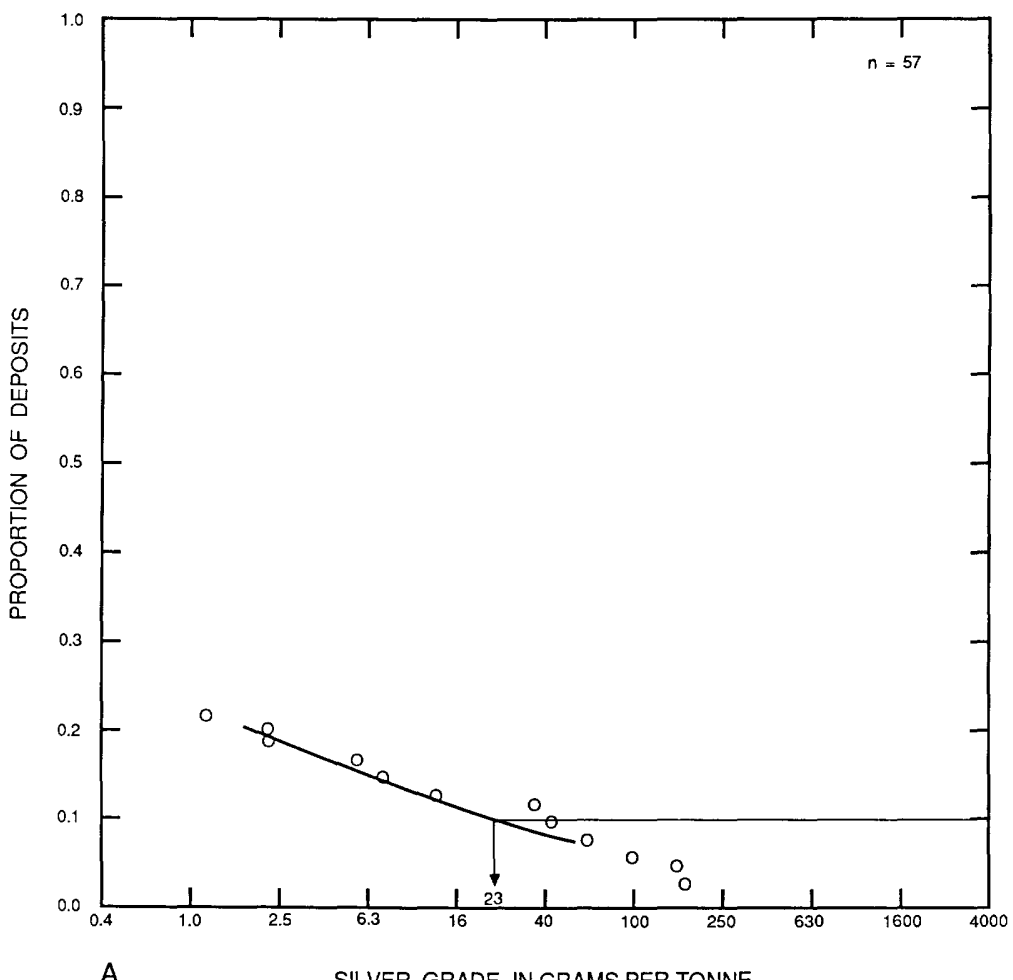

A.

SILVER GRADE IN GRAMS PER TONNE

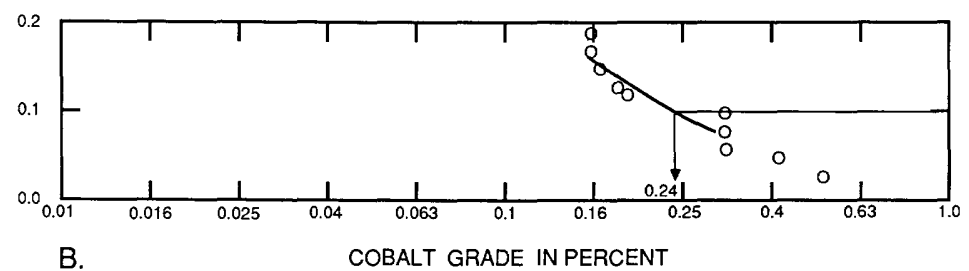

Figure 156. By-product grades of sediment-hosted $\mathrm{Cu}$ deposits. A, silver. $\underline{B}$, Cobalt. 


\section{DESCRIPTIVE MODEL OF SANDSTONE U}

By Christine E. Turner-Peterson and Carroll A. Hodges

APPROXIMATE SYNONYMS Tabular U ore, roll front $U$.

DESCRIPTION Microcrystalline uranium oxides and silicates deposited during diagenesis in localized reduced environments within fine- to medium-grained sandstone beds; some uranium oxides also deposited during redistribution by ground water at interface between oxidized and reduced ground (see fig. 157).

GENERAL REFERENCE Turner-Peterson and Fishman (1986), Granger and Warren (1969).

GEOLOGICAL ENVIRONMENT

Rock Types Host rocks are feldspathic or tuffaceous sandstone. Pyroclastic material is felsic in composition. Mudstone or shale commonly above and/or below sandstones hosting diagenetic ores (see fig. 157 A).

Textures Permeable--medium to coarse grained; highly permeable at time of mineralization, subsequently restricted by cementation and alteration.

Age Range Most deposits are Devonian and younger. Secondary roll-front deposits mainly Tertiary.

Depositional Environment Continental-basin margins, fluvial channels, braided stream deposits, stable coastal plain. Contemporaneous felsic volcanism or eroding felsic plutons are sources of U. In tabular ore, source rocks for ore-related fluids are commonly in overlying or underlying mud-flat facies sediments.

Tectonic Setting(s) Stable platform or foreland-interior basin, shelf margin; adjacent major uplifts provide favorable topographic conditions.

Associated Deposit Types Sediment-hosted $V$ may be intimately associated with U. Sediment-hosted $\mathrm{Cu}$ may be in similar host rocks and may contain $\mathrm{U}$.

\section{DEPOSIT DESCRIPTION}

Mineralogy Uraninite, coffinite, pyrite in organic-rich horizons. Chlorite common.

Texture/Structure Stratabound deposits. Tabular U--intimately admixed with pore-filling humin in tabular lenses suspended within reduced sandstone ( $\mathrm{fig}$. 157A). Replacement of wood and other carbonaceous material. Roll front U--in crescentic lens that cuts across bedding, at interface between oxidized and reduced ground (fig. 157B).

Alteration Tabular--Humic acid mineralizing fluids leach iron from detrital magnetite-ilmenite leaving relict $\mathrm{TiO}_{2}$ minerals in diagenetic ores. Roll front--Oxidized iron minerals in rock updip, reduced iron minerals in rock downdip from redox interface.

Ore Controls Permeability. Tabular--Humin or carbonaceous material the main concentrator of U. Roll front--S species, "sour" gas, FeS 2 . Bedding sequences with low dips; felsic plutons or felsic tuffaceous sediments adjacent to or above host rock are favorable source for U. Regional redox interface marks locus of ore deposition.

Weathering oxidation of primary uraninite or coffinite to a variety of minerals, notably yellow carnotite as bloom in V-rich ores.

Geochemical and Geophysical Signature U, V, Mo, Se, locally Cu, Ag. Anomalous radioactivity from daughter products of U. Low magnetic susceptibility in and near tabular ores.

EXAMPLES

Colorado Plateau

Grants, USNM

Texas Gulf Coast

USWY
(Fischer, 1974)

(Turner-Peterson and Fishman, 1986)

(Reynolds and Goldhaber, 1983)

(Granger and Warren, 1969) 
Model 30c--Con.

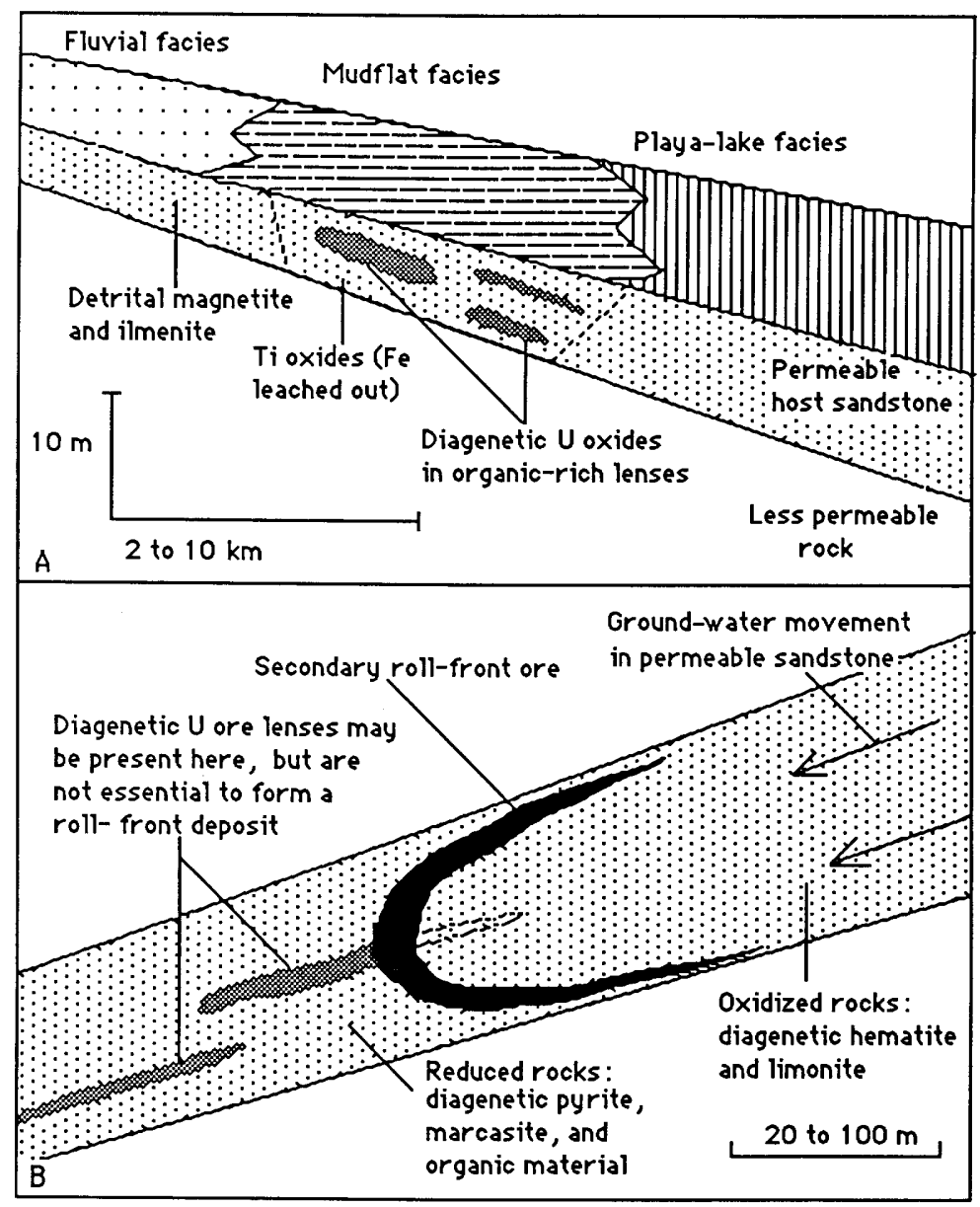

Figure 157. Cartoon sections showing: A, Diagenetic mineralization (from Turner-Peterson and Fishman, 1986); $B$, roll-front mineralization in sandstone $U$ deposits (from Nash and others, 1981). 


\title{
DESCRIPTIVE MODEL OF SEDIMENTARY EXHALATIVE Zn-Pb
}

\author{
By Joseph A. Briskey
}

APPROXIMATE SYNONYMS Shale-hosted $\mathrm{Zn}-\mathrm{Pb}$; sediment-hosted massive sulfide $\mathrm{Zn}-\mathrm{Pb}$.

DESCRIPTION Stratiform basinal accumulations of sulfide and sulfate minerals interbedded with euxinic marine sediments form sheet- or lens-like tabular ore bodies up to a few tens of meters thick, and may be distributed through a stratigraphic interval over 1,000 $\mathrm{m}$ (see fig. 158).

GENERAL REFERENCES Large (1980, 1981, 1983).

\section{GEOLOGICAL ENVIRONMENT}

Rock Types Euxinic marine sedimentary rocks including: black (dark) shale, siltstone, sandstone, chert, dolostone, micritic limestone, and turbidites. Local evaporitic sections in contemporaneous shelf facies. Volcanic rocks, commonly of bimodal composition, are present locally in the sedimentary basin. Tuffites are the most common. Slump breccias, fan conglomerates, and similar deposits, as well as facies and thickness changes, are commonly associated with synsedimentary faults.

Textures Contrasting sedimentary thicknesses and facies changes across hinge zones. Slump breccias and conglomerates near synsedimentary faults.

Age Range Known deposits are Middle Proterozoic (1,700-1,400 m.y.); Cambrian to Carboniferous $(530-300 \mathrm{~m} \cdot \mathrm{y}$.$) .$

Depositional Environment Marine epicratonic embayments and intracratonic basins, with smaller Iocal restricted basins (second- and third-order basins).

Tectonic Setting(s) Epicratonic embayments and intracratonic basins are associated with hinge zones controlled by synsedimentary faults, typically forming half-grabens. Within these grabens (first-order basins), penecontemporaneous vertical tectonism forms smaller basins (second-order basins) and associated rises. Smaller third-order basins (tens of kilometers) within the secondorder basins $\left(10^{2}-10^{5} \mathrm{~km}\right)$ are the morphological traps from the stratiform sulfides.

Associated Deposit Types Bedded barite deposits.

\section{DEPOSIT DESCRIPTION}

Mineralogy Pyrite, pyrrhotite, sphalerite, galena, sporadic barite and chalcopyrite, and minor to trace amounts of marcasite, arsenopyrite, bismuthinite, molybdenite, enargite, millerite, freibergite, cobaltite, cassiterite, valleriite, and melnikovite.

Texture/Structure Finely crystalline and disseminated, monomineralic sulfide laminae are typical. Metamorphosed examples are coarsely crystalline and massive.

Alteration Stockwork and disseminated sulfide and alteration (silicification, tourmalization, carbonate depletion, albitization, chloritization, dolomitization) minerals possibly representing the feeder zone of these deposits commonly present beneath or adjacent to the stratiform deposits. Some deposits have no reported alteration. Celsian, Ba-muscovite, and ammonium clay minerals may be present.

Ore Controls Within larger fault-controlled basins, small local basins form the morphological traps that contain the stratiform sulfide and sulfate minerals. The faults are synsedimentary and serve as feeders for the stratiform deposits. Euxinic facies.

Weathering Surface oxidation may form large gossans containing abundant carbonates, sulfates, and silicates of lead, zinc, and copper.

Geochemical Signature Metal zoning includes lateral Cu-Pb-Zn-Ba sequence extending outward from feeder zone; or a vertical $\mathrm{Cu}-\mathrm{Zn}-\mathrm{Pb}-\mathrm{Ba}$ sequence extending upward. $\mathrm{NH}_{3}$ anomalies may be present. Exhalative chert interbedded with stratiform sulfide and sulfate minerals; peripheral hematite- 
Model 31a--Con.

chert formations. Local (within $2 \mathrm{~km}$ ) $\mathrm{Zn}, \mathrm{Pb}$, and $\mathrm{Mn}$ haloes. Highest expected background in black shales: $\mathrm{Pb}=500 \mathrm{ppm} ; \mathrm{Zn}=1,300 \mathrm{ppm} ; \mathrm{Cu}=750 \mathrm{ppm} ; \mathrm{Ba}=1,300 \mathrm{ppm} ;$ in carbonates: $\mathrm{Pb}=9 \mathrm{ppm} ; \mathrm{Zn}$ $=20 ; \mathrm{Cu}=4 \mathrm{pmm} ; \mathrm{Ba}=10$.

EXAMPLES

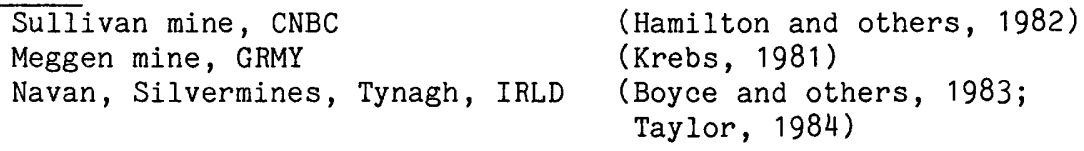

GRADE AND TONNAGE MODEL OF SEDIMENTARY EXHALATIVE Zn-Pb

By W. David Menzie and Dan L. Mosier

COMMENTS Deposits in this model include most commonly identified deposits of this type. Nevertheless, examination of the distribution of silver grade suggests the presence of two subtypes. Lead grades are significantly correlated with silver grades $(r=0.77, n=39)$. See figs. $159-163$.

\section{DEPOSITS}

\begin{tabular}{|c|c|c|c|}
\hline Name & Country & Name & Country \\
\hline Balmat & USNY & McArthur & AUNT \\
\hline Baroi & INDA & Meggen & GRMY \\
\hline Big Syncline & SAFR & Mineral King & $\mathrm{CNBC}$ \\
\hline Black Mtn. & SAFR & Mount Isa & AUQL \\
\hline Broken Hill & SAFR & Navan & IRLD \\
\hline Broken Hill & AUNT & Rajpura-Daiba & INDA \\
\hline Cirque & $\mathrm{CNBC}$ & Rammelsberg & GRMY \\
\hline Dugald River & AUQL & Rampura-Agucha & INDA \\
\hline Duncan Lake & CNBC & Red Dog & USAK \\
\hline Dy & CNYT & Reeves MacDonald & CNBC \\
\hline Faro & CNYT & Rosh Pinah & NAMB \\
\hline $\mathrm{Fx}$ & CNBC & Silvermines & IRLD \\
\hline Grum & CNYT & Squirrel Hills & AUQL \\
\hline $\mathrm{HB}$ & CNBC & Sullivan & CNBC \\
\hline Hilton & AUQL & Swim Lake & CNYT \\
\hline Homestake & CNBC & Tom & CNYT \\
\hline Howards Pass & CNYT & Tynagh & IRLD \\
\hline Jersey Emerald & CNBC & Vangorda & CNYT \\
\hline King Fissure & CNBC & Woodcutters & AUNT \\
\hline Lady Loretta & AUQL & Wigwam & CNBC \\
\hline MacMillan & CNYT & Zawar & INDA \\
\hline Matt Berry & CNYT & Zawarmala & INDA \\
\hline
\end{tabular}




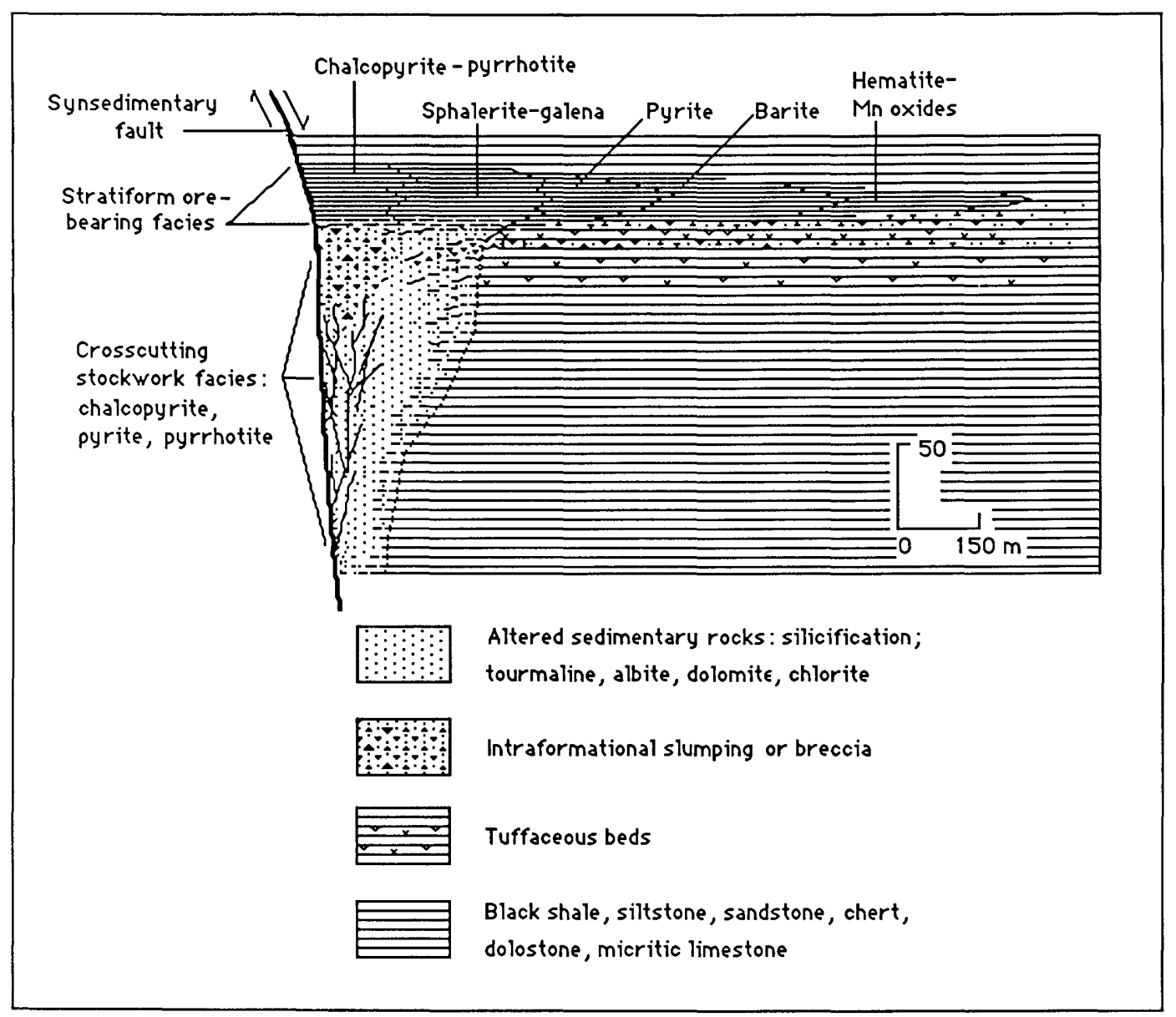

Model 31a--Con.

Figure 158. Cartoon cross section showing mineral zoning in sedimentary exhal ative

SEDIMENTARY EXHALATIVE ZINC--LEAD $\mathrm{Zn}-\mathrm{Pb}$ deposits (modified from Large, 1980).

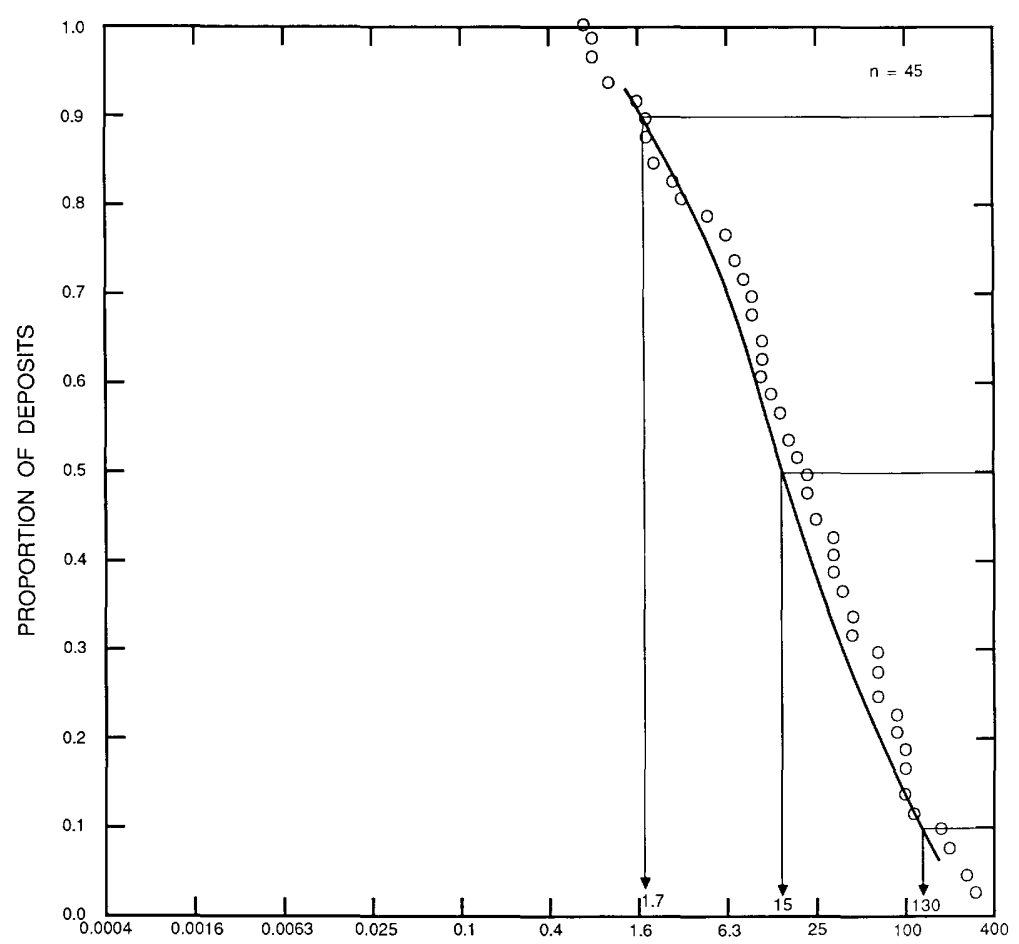

MILLION TONNES

Figure 159. Tonnages of sedimentary exhal ative $\mathrm{Zn}-\mathrm{Pb}$ deposits. 
Model 31a--Con.

Figure 160. Zinc grades of sedimentary exhal ative $\mathrm{Zn}-\mathrm{Pb}$ deposits.
Figure 161. Lead grades of sedimentary exhalative $\mathrm{Zn}-\mathrm{Pb}$ deposits.
SEDIMENTARY EXHALATIVE ZINC--LEAD

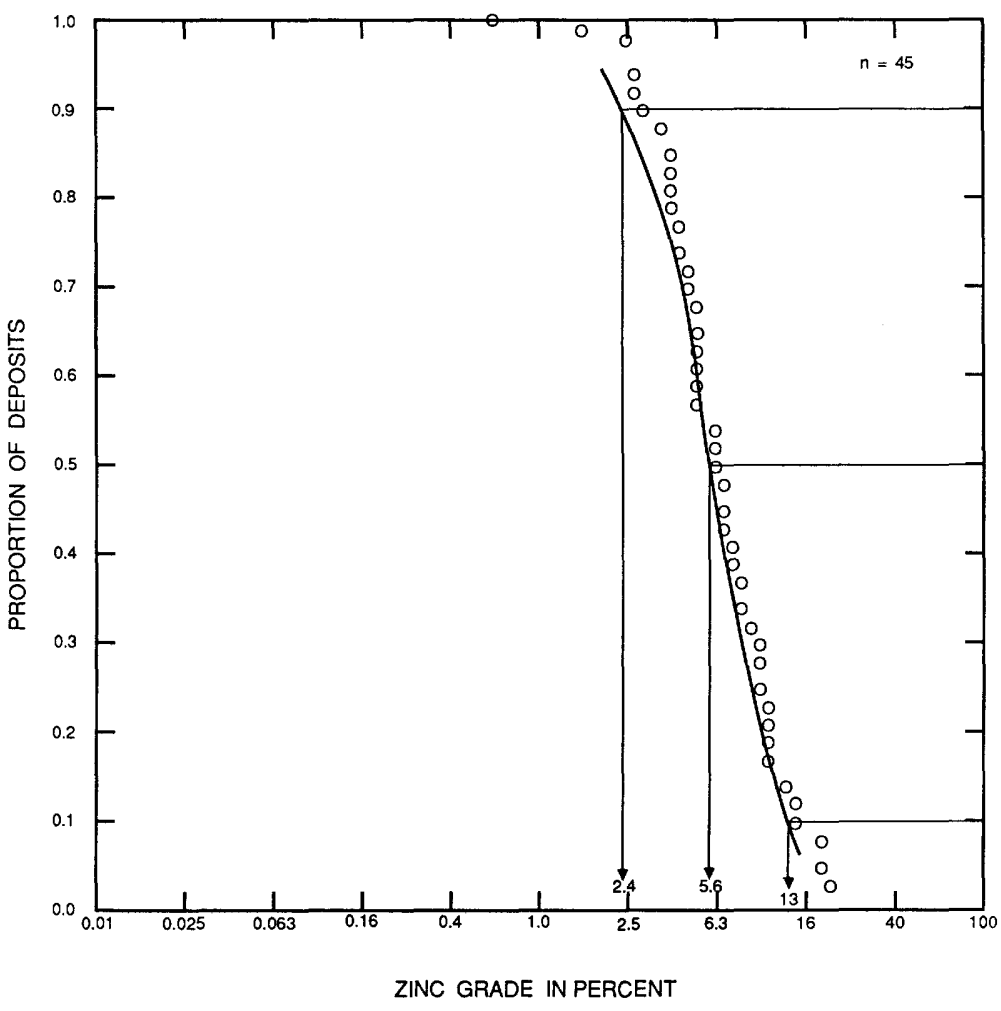

SEDIMENTARY EXHALATIVE ZINC--LEAD

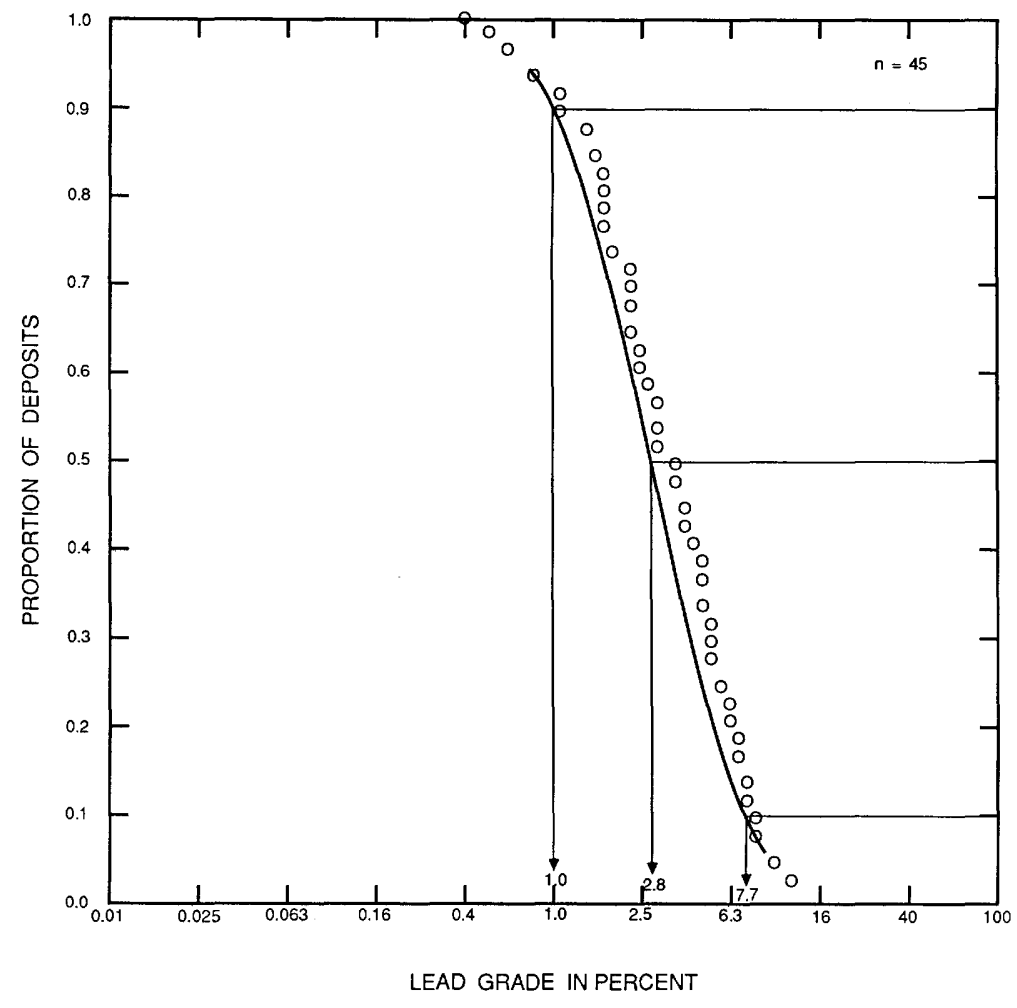


SEDIMENTARY EXHALATIVE ZINC--LEAD

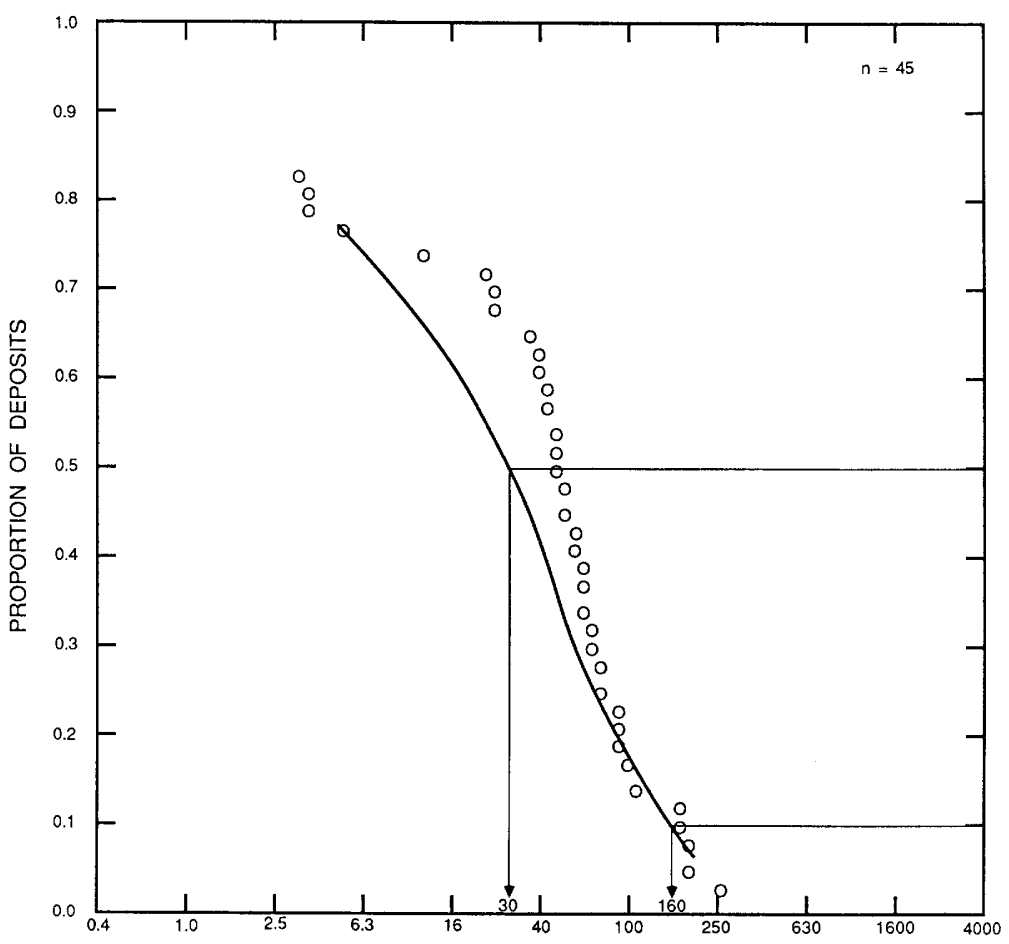

SILVER GRADE IN GRAMS PER TONNE

Figure 162. Silver grades of sedimentary exhal ative $\mathrm{Zn}-\mathrm{Pb}$ deposits.

SEDIMENTARY EXHALATIVE ZINC--LEAD

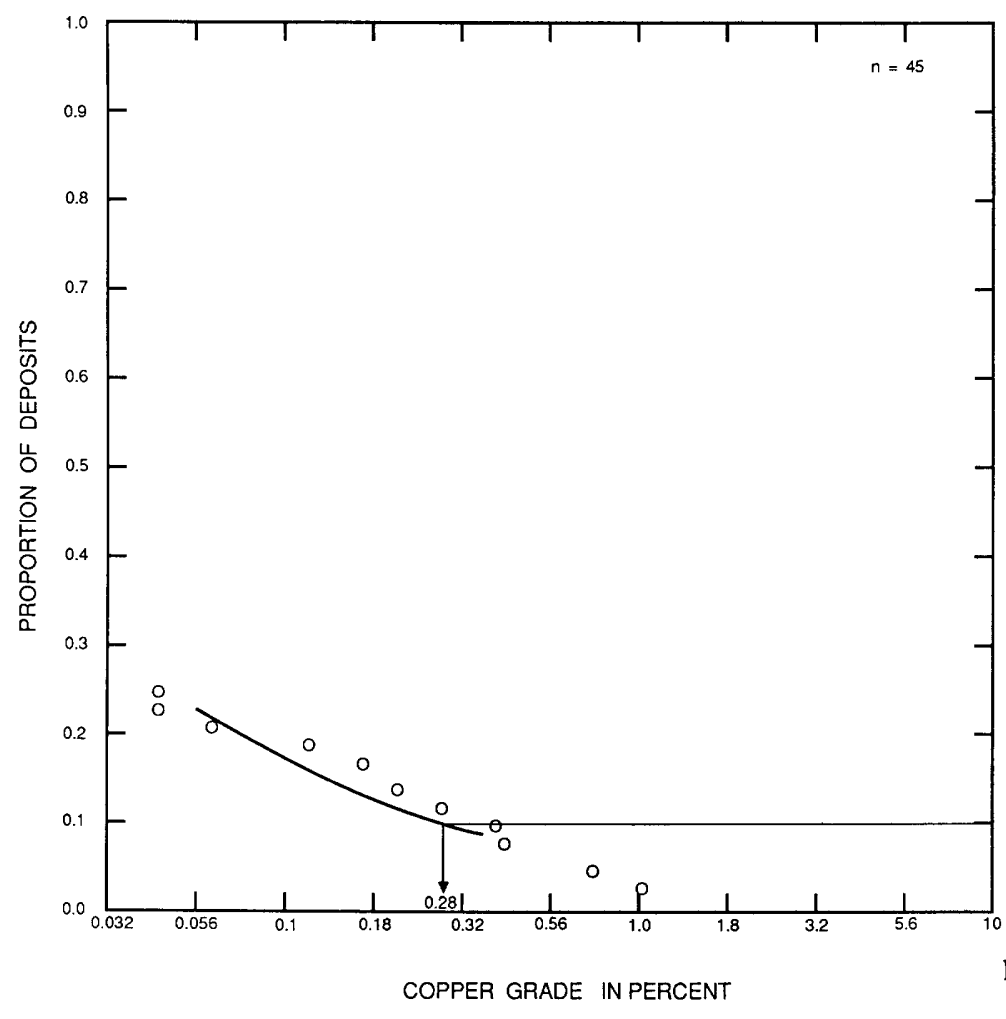

Figure 163. Copper grades of sedimentary exhalative $\mathrm{Zn}-\mathrm{Pb}$ deposits. 
Model 31b

\section{DESCRIPTIVE MODEL OF BEDDED BARITE}

By Greta J. Orris

APPROXIMATE SYNONYM Stratiform barite.

DESCRIPTION Stratiform deposits of barite interbedded with dark-colored cherty and calcareous sedimentary rocks.

GEOLOGICAL ENVIRONMENT

Rock Types Generally dark-colored chert, shale, mudstone, limestone or dolostone. . Also with quartzite, argillite, and greenstone.

Age Range Proterozoic and Paleozoic.

Depositional Environment Epicratonic marine basins or embayments (often with smaller local restricted basins).

Tectonic Setting(s) Some deposits associated with hinge zones controlled by synsedimentary faults. Associated Deposit Types Sedimentary exhalative $\mathrm{Zn-Pb}$ (see fig. 158).

DEPOSIT DESCRIPTION

Mineralogy Barite \pm minor witherite \pm minor pyrite, galena, or sphalerite. Barite typically contains several percent organic matter plus some $\mathrm{H}_{2} \mathrm{~S}$ in fluid inclusions.

Texture/Structure Stratiform, commonly lensoid to poddy; ore laminated to massive with associated layers of barite nodules or rosettes; barite may exhibit primary sedimentary features. Small country rock inclusions may show partial replacement by barite.

Alteration Secondary barite veining; weak to moderate sericitization has been reported in or near some deposits in Nevada.

Ore Controls Deposits are localized in second- and third-order basins.

Weathering Indistinct, generally resembling limestone or dolostone; occasionally weathered-out rosettes or nodules.

Geochemical Signature $\mathrm{Ba}$; where peripheral to sediment-hosted $\mathrm{Zn}-\mathrm{Pb}$, may have lateral ( $\mathrm{Cu}$ )-Pb-Zn$\mathrm{Ba}$ zoning or regional manganese haloes. High organic $\mathrm{C}$ content.

\section{EXAMPLES}

$\begin{array}{ll}\text { Meggen, GRMY } & \text { (Krebs, 1981) } \\ \text { Magnet Cove, USAR } & \text { (Scull, 1958) } \\ \text { Northumberland, USNV } & \text { (Shawe and others, 1969) }\end{array}$

GRADE AND TONNAGE MODEL OF BEDDED BARITE

By Greta J. Orris

COMMENTS See figs. 164-165.

DEPOSITS

Name

Ballynoe

Barite Mtn.

Barite (Mouse)

Barite Valley

Baw Hin Khao

\section{Country}

IRLD

CNYT

CNYT

SAFR

THLD
Name

Brookfield

Castle Island

Cathy (Walt)

Cirque Barite

Greystone
Country

CNNS

USAK

CNYT

CNBC

USNV 
Model 31b--Con.

$\begin{array}{llll}\text { Gurranda } & \text { AUNS } & \text { Mountain Springs } & \text { USNV } \\ \text { Kempfield } & \text { AUNS } & \text { Nimiuktuk } & \text { USAK } \\ \text { Khuzdar } & \text { PKTN } & \text { Rammelsberg Barite } & \text { GRMY } \\ \text { Magnet Cove } & \text { USAR } & \text { Snake Mountain } & \text { USNV } \\ \text { Mangampetta N. } & \text { INDA } & \text { Tea } & \text { CNYT } \\ \text { Mangampetta S. } & \text { INDA } & \text { Uribe } & \text { USWA } \\ \text { Meggen Barite } & \text { GRMY } & \text { Weedaroo } & \text { AUSA } \\ \text { Mel Barite } & \text { CNYT } & & \end{array}$


Model 31b--Con.

BEDDED BARITE

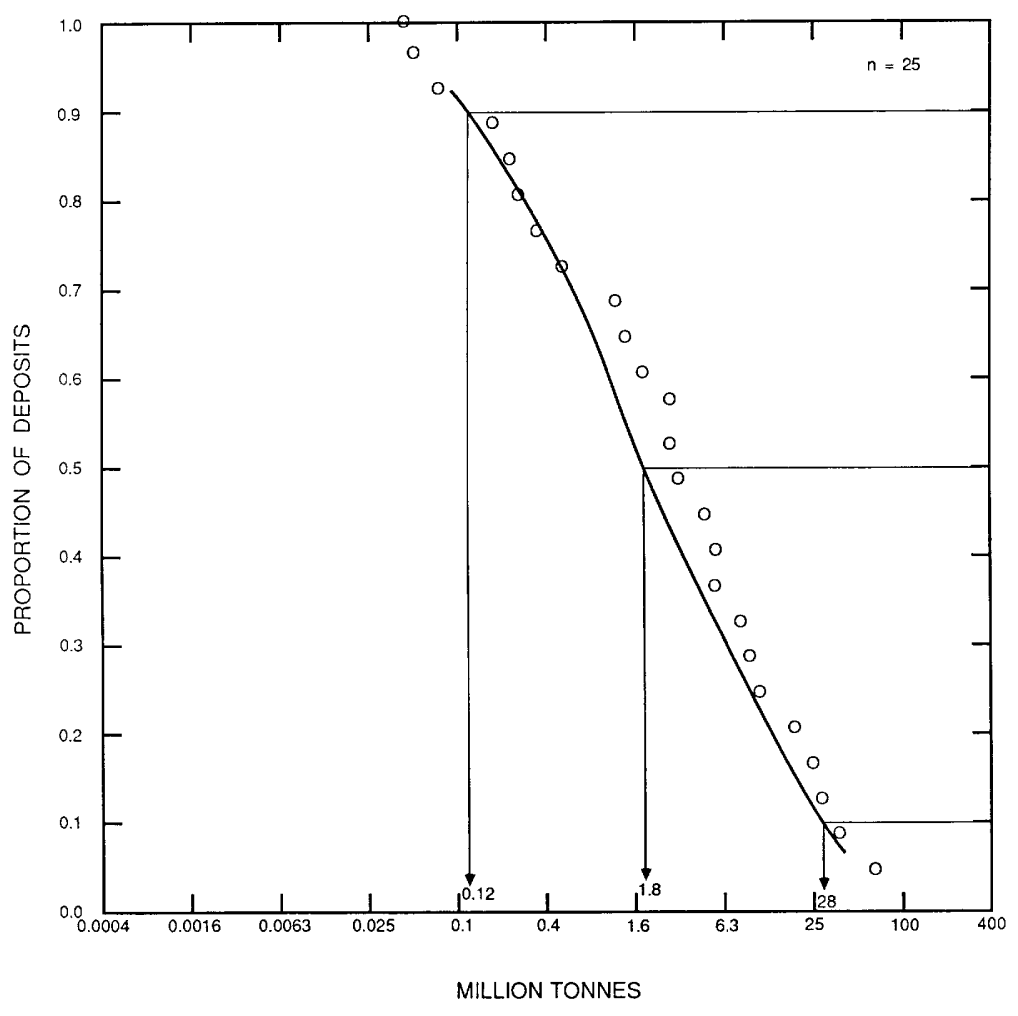

Figure 164. Tonnages of bedded barite deposits.

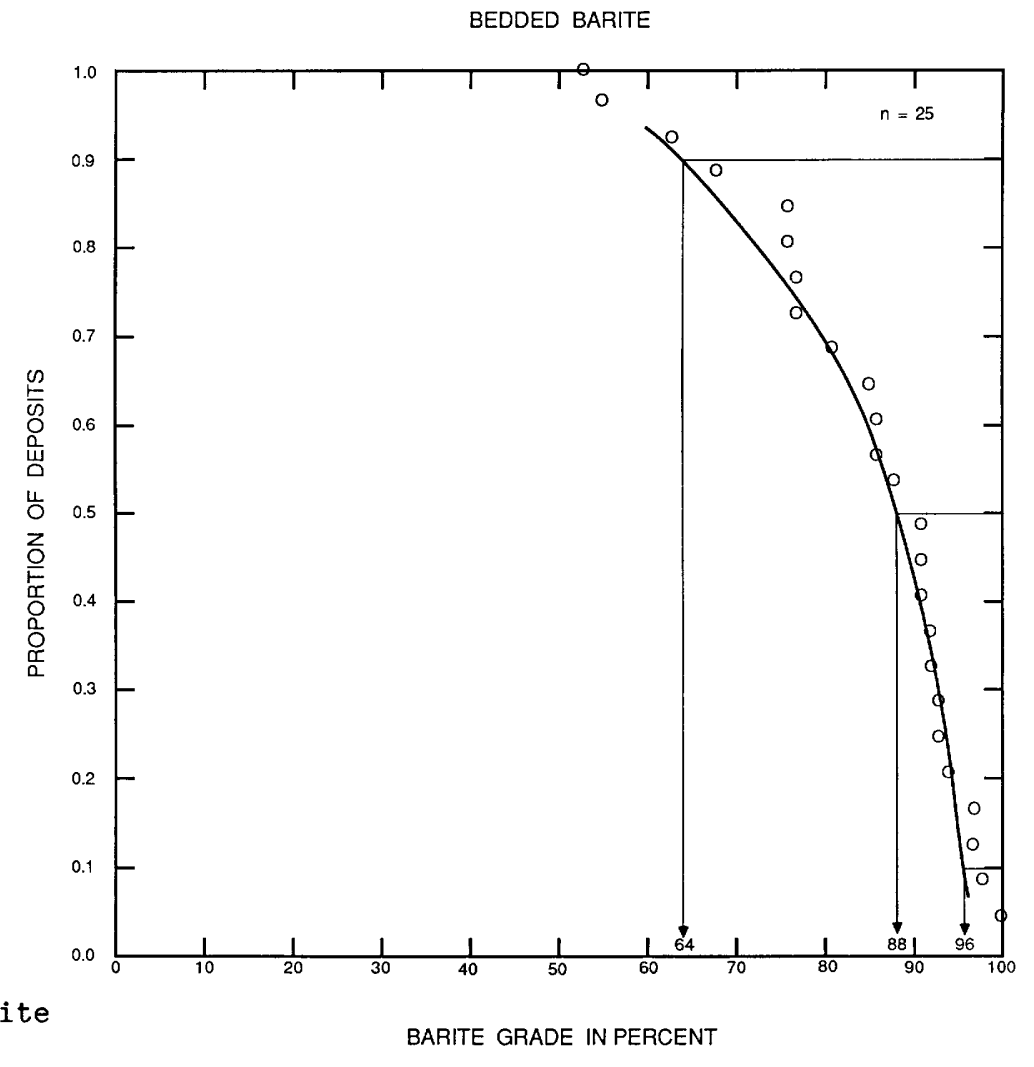

Figure 165. Barite grades of bedded barite deposits. 


\title{
DESCRIPTIVE MODEL OF EMERALD VEINS
}

\author{
By Dennis P. Cox
}

DESCRIPTION Emerald in plagioclase-dolomite veins in black shale.

GENERAL REFERENCES Sinkankas (1981), p. 338-358, 407-435.

\section{GEOLOGICAL ENVIRONMENT}

Rock Types Black shale, claystone, siltstone, locally calcareous. Minor sandstone, limestone, conglomerate, and evaporites. Locally coarse dolomite breccia filled by carbonates and oligoclase.

Textures Diabasic dikes present but not prominent.

Age Range Cretaceous and Tertiary.

Depositional Environment Thick epicontinental anoxic marine shale. Evaporites may have provided saline solutions.

Tectonic Setting(s) Major faults. Minor intrusions may have provided heat sources for fluid circulation.

Associated Deposit Types May be associated with $\mathrm{Pb}-\mathrm{Zn}$ deposits on a regional scale.

DEPOSIT DESCRIPTION

dineralogy Emerald + greenish beryl + oligoclase + dolomite + calcite + pyrite + fluorite + rutile + quartz. Apatite, parisite, and REE dolomite reported from Muzo.

Texture/Structure Crustified banding, vuggy, coarsely crystalline.

Alteration Shale altered to black hornfels, fossils replaced by oligoclase. Dolomitization.

Ore Controls Major fault at intersections of minor cross faults, sharp-walled veins, and tabular breccia bodies. Veins locally confined to sedimentary strata that overlie or underlie ferruginous beds.

Weathering Plagioclase weathers to pockets of kaolinite.

Geochemical Signature In veins: high $\mathrm{Be}, \mathrm{Na}, \mathrm{Mg}$; low $\mathrm{Li}, \mathrm{Ba}, \mathrm{K}$, Mo, $\mathrm{Pb}$ relative to shale outside of mineralized areas. At Muzo, REE in veins, $\mathrm{Cu}$ in underlying beds.

\section{EXAMPLES}

Gachala district, CLBA (Escovar, 1979)

Muzo district, CLBA (Sinkankas, 1981) 


\title{
DESCRIPTIVE MODEL OF SOUTHEAST MISSOURI Pb-Zn
}

\author{
By Joseph A. Briskey
}

SYNONYMS Carbonate-hosted $\mathrm{Pb}-\mathrm{Zn}$; Mississippi Valley type.

DESCRIPTION Stratabound, carbonate-hosted deposits of galena, sphalerite, and chalcopyrite in rocks having primary and secondary porosity, commonly related to reefs on paleotopographic highs (see fig. 166). (For grade-tonnage model see Appalachian Zn deposit model.)

GENERAL REFERENCES Snyder and Gerdemann (1968), Thacker and Anderson (1977).

\section{GEOLOGICAL ENVIRONMENT}

Rock Types Dolomite; locally ore bodies also occur in sandstone, conglomerate, and calcareous shales.

Textures Calcarenites are most common lithology. Tidalites, stromatolite finger reefs, reef breccias, slump breccias; oolites, crossbedding, micrites.

Age Range Known deposits are in Cambrian to Lower Ordovician strata.

Depositional Environment Host rocks are shallow-water marine carbonates, with prominent facies control by reefs growing on flanks of paleotopographic basement highs. Deposits commonly occur at margins of clastic basins.

Tectonic Setting(s) Stable cratonic platform.

Associated Deposit Types Precambrian volcanic-hosted magnetite; $\mathrm{Ba}-\mathrm{Pb}$ deposits occur higher in the Cambrian section.

\section{DEPOSIT DESCRIPTION}

Mineralogy Galena, sphalerite, chalcopyrite, pyrite, marcasite. Minor siegenite, bornite, tennantite, barite, bravoite, digenite, covellite, arsenopyrite, fletcherite, adularia, pyrrhotite, magnetite, millerite, polydymite, vaesite, djurleite, chalcocite, anilite, and enargite in order of abundance. Dolomite and minor quartz.

Texture/Structure Early fine-grained replacement; main stage coarse-grained replacement and vuggy or colloform open space filling. Hypogene leaching of galena is common.

Alteration Regional dolomitization; latter brown, ferroan, and bitumen-rich dolomite; extensive carbonate dissolution and development of residual shale; mixed-layer illite-chlorite altered to $2 \mathrm{M}$ muscovite; dickite and kaolinite in vugs; very minor adularia.

Ore Controls Open-space filling and replacement, most commonly at the interface between gray and tan dolomite, but also in traps at any interface between permeable and impermeable units. Any porous units may host ore: sandstone pinchouts; dissolution collapse breccias; faults; permeable reefs; slump, reef, and fault breccias; coarsely crystalline dolostone.

Geochemical Signature Regional anomalous amounts of $\mathrm{Pb}, \mathrm{Zn}, \mathrm{Cu}, \mathrm{Mo}, \mathrm{Ag}$, Co, and $\mathrm{Ni}$ in insoluble residues. Zoning is roughly $\mathrm{Cu}( \pm \mathrm{Ni} \pm \mathrm{CO})-\mathrm{Pb}-\mathrm{Zn}$-iron sulfide going up section; ores contain about $30 \mathrm{ppm} \mathrm{Ag}$; inconsistent lateral separation of metal zones. Background for carbonates: $\mathrm{Pb}=9 \mathrm{ppm}$; $\mathrm{Zn}=20 ; \mathrm{Cu}=4$.

\section{EXAMPLES}

Viburnum subdistrict, USMO (Economic Geology 1977; Heyl, 1982) 


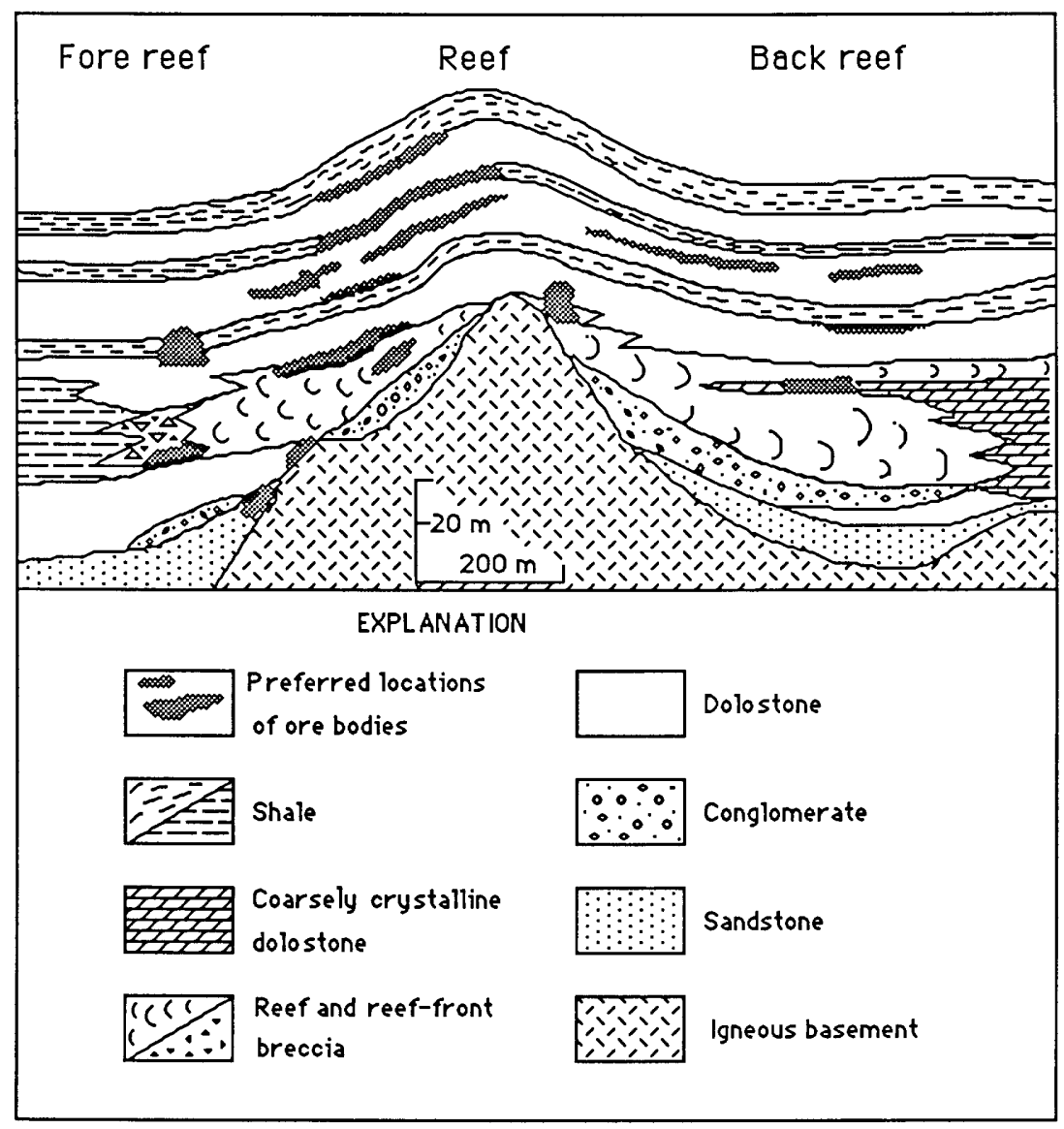

Figure 166. Cartoon cross section of a southeast Missouri $\mathrm{Pb}-\mathrm{Zn}$ deposit (modified from Evans, 1977). 


\section{DESCRIPTIVE MODEL OF APPALACHIAN Zn}

By Joseph A. Briskey

SYNONYMS Carbonate-hosted Zn; Mississippi Valley type.

DESCRIPTION Stratabound deposits of sphalerite and minor galena in primary and secondary voids in favorable beds or horizons in thick platform dolostone and limestone (see fig. 167).

GENERAL REFERENCE Hoagland (1976).

GEOLOGICAL ENVIRONMENT

Rock Types Dolostone and limestone.

Textures Subtidal, intratidal, and supratidal textures with high porosity are common, especially in the dolostones; limestones are commonly micritic, some with birdseye textures.

Age Range Appalachian deposits occur in rocks of Cambrian to Middle Ordovician age. Other deposits are in rocks as old as Proterozoic and as young as Triassic.

Depositional Environment Shallow-water, tidal and subtidal marine environments.

Tectonic Setting(s) Stable continental shelf.

Associated Deposit Types Stratabound carbonate-hosted deposits of barite-fluorite-sphalerite. DEPOSIT DESCRIPTION

Mineralogy Sphalerite, with variable but subordinate pyrite and minor marcasite, and with minor barite, fluorite, gypsum, and anhydrite. Galena is usually absent or rare, but may be abundant locally.

Texture/Structure Mainly open space filling of coarse to medium crystalline sphalerite and pinkish dolomite. Sphalerite commonly displays banding. Locally, fine sphalerite in finely varved dolomite composes the breccia matrix.

Alteration Extensive finely crystalline dolostone occurs regionally and coarse crystalline dolomite is more common nearer to ore bodies. Silicification is typically closely associated with ore bodies. Extensive limestone dissolution and development of residual shale.

Ore Controls Ore occurs within dissolution collapse breccias that occur (1) throughout readily soluble limestone beds, or (2) in paleo-aquifer solution channels controlled by fractures or folds in limestone. Breccias commonly have domal cross sections above limestone aquifers that have been thinned by solution.

Weathering Zinc silicate and carbonate ores form in the zone of weathering and oxidation.

Geochemical Signature Readily detectable zinc anomalies in residual soils and in stream sediments. Primary zine haloes in carbonate rocks near ore are not large enough to assist in exploration. Background in carbonate rocks: $\mathrm{Zn}=20 \mathrm{ppm} ; \mathrm{Pb}=9 \mathrm{ppm}$.

EXAMPLES

Mascot-Jefferson City district, USTN (Crawford and Hoagland, 1968; McCormick and others, 1971; Fulweiler and McDougal, 1971)

Copper Ridge district, USTN (Hill and others, 1971) 
Model 32b--Con.

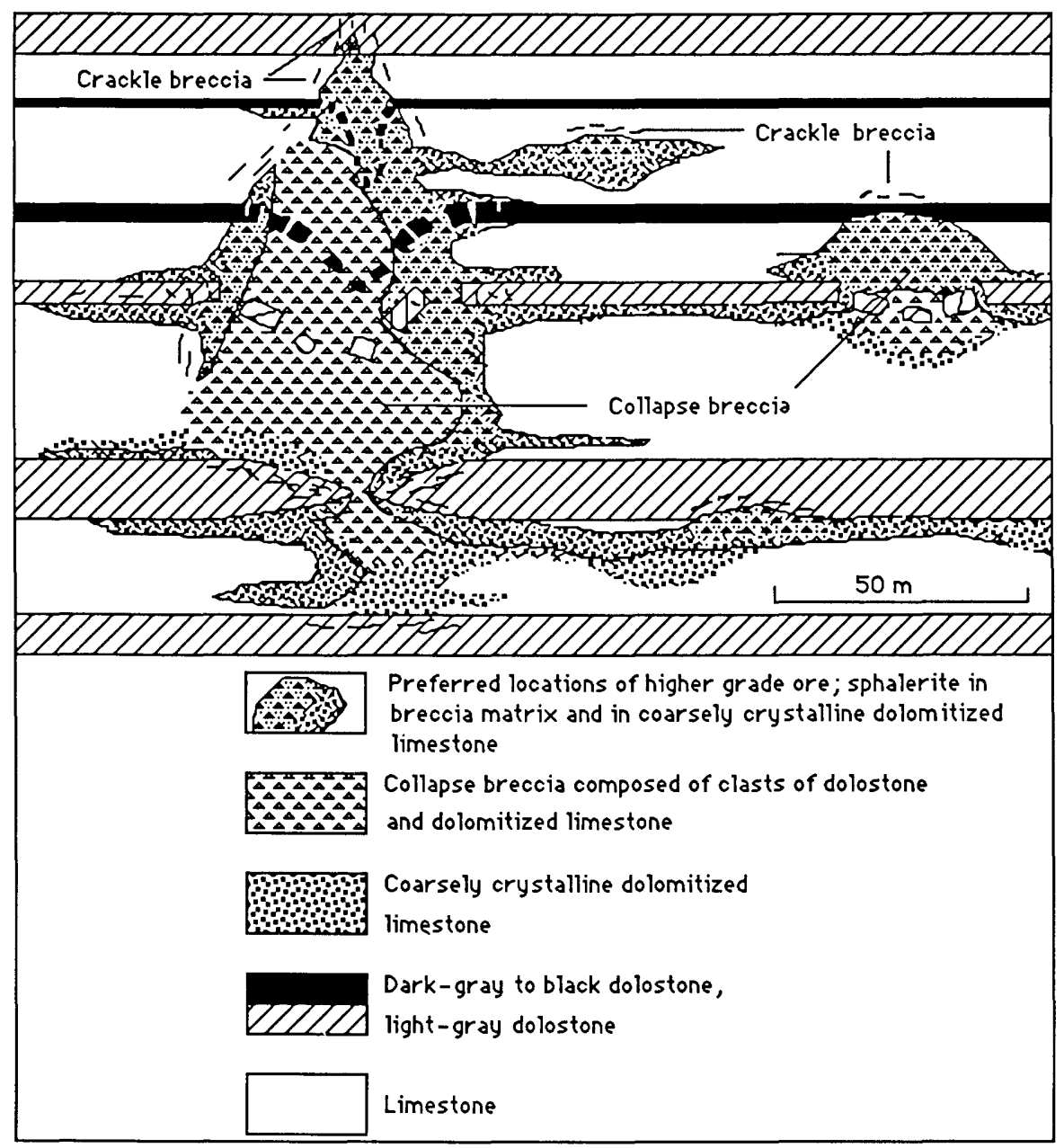

Figure 167. Cartoon cross section showing relationship of zinc ore to collapse breccia and dolomitized limestone in the Mascott-J efferson City district, Tennessee. Modified from Armstrong and Lawrence (1983). 


\section{GRADE AND TONNAGE MODEL OF SOUTHEAST MISSOURI Pb-Zn AND APPALACHIAN Zn DEPOSITS}

By Dan L. Mosier and Joseph A. Briskey

COMMENTS The models for stratabound carbonate-hosted $\mathrm{Pb}-\mathrm{Zn}$ deposits, and for stratabound carbonate-hosted $\mathrm{Zn}$ deposits, are treated as end members that, in a general way, define a larger class of geologically complex stratabound carbonate-hosted deposits containing variable proportions of $\mathrm{Pb}$ or $\mathrm{Zn}$. Grade-tonnage estimates were made for districts only, because of difficulties in defining the limits of an individual deposit within these typically large regionally mineralized systems. Numerous small districts containing less than about a million tonnes of ore are not included in this compilation, mainly because of the paucity of reliable data about reserves and past production, but also because they are outside the scope of this investigation. Lead grade is correlated with silver grade $(r=0.87, n=10)$. See figs. 168-171.

\section{DEPOSITS}

Name

$\begin{array}{ll}\text { Alpine-Lafatsch } & \text { ASTR-ITLY-YUGO } \\ \text { Austinville } & \text { USVA } \\ \text { Central Missouri } & \text { USMO } \\ \text { Central Tennessee } & \text { USTN } \\ \text { East Tennessee } & \text { USTN } \\ \text { Friedensville } & \text { USPA } \\ \text { Gayna R.-Godlin L. } & \text { CNNT } \\ \text { Kentucky-Illinois } & \text { USKN } \\ \text { Metalline } & \text { USWA } \\ \text { Monarch-Kicking Horse } & \text { CNBC }\end{array}$

$\underline{\text { Name }}$

Nanisivik

Newfoundland Zinc

North Arkansas-Ozark

Pine Point

Polaris-Eclipse

Robb Lake

Southeast Missouri

Tri State

Upper Mississippi Valley

Upper Silesia
Country

CNNT

CNNF

USAR

CNNT

CNNT

CNBC

USMO

USMO-USOK

USWI

PLND 
SOUTHEAST MISSOURI LEAD--ZINC AND APPALACHIAN ZINC

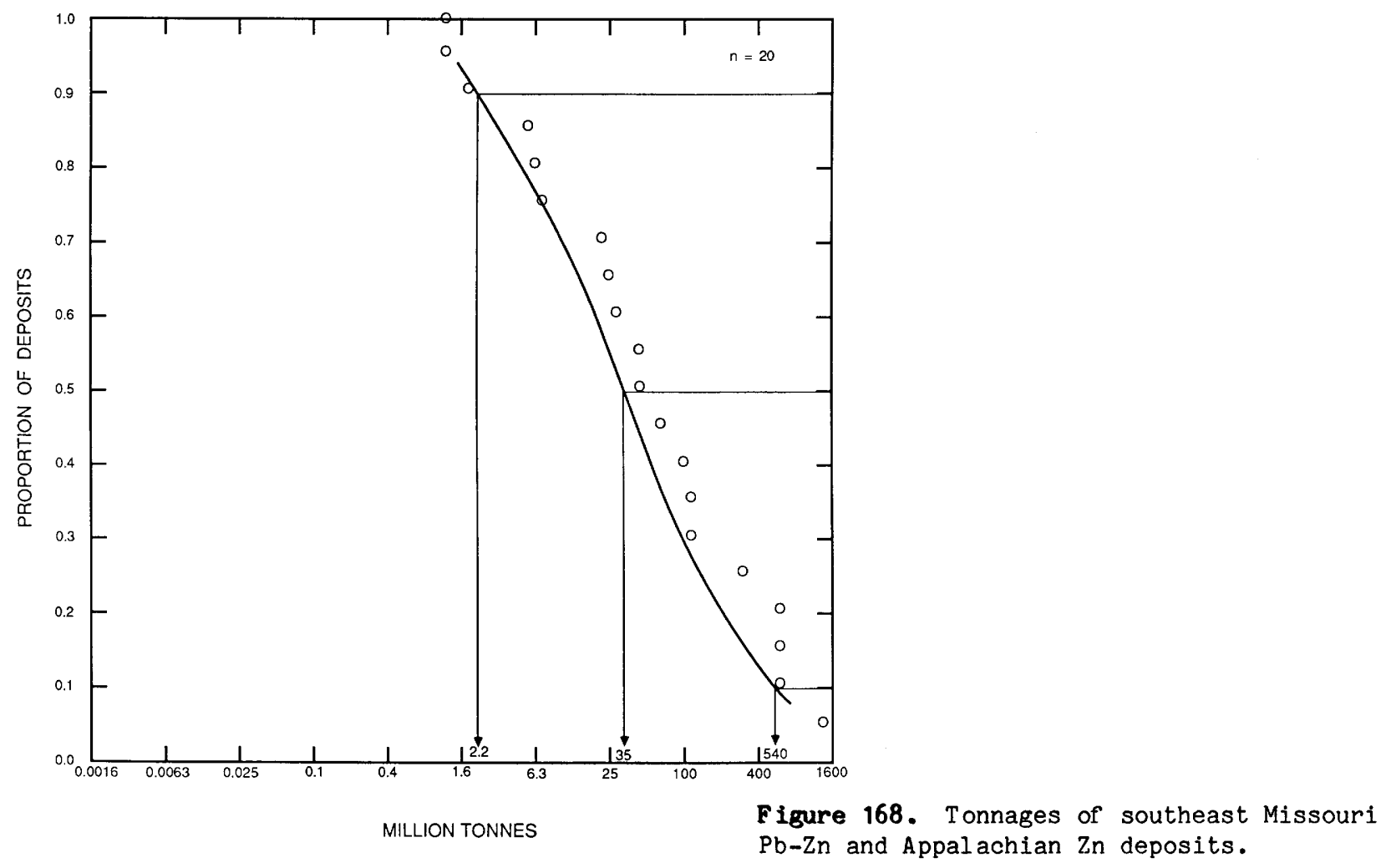

SOUTHEAST MISSOURI LEAD--ZINC AND APPALACHIAN ZINC

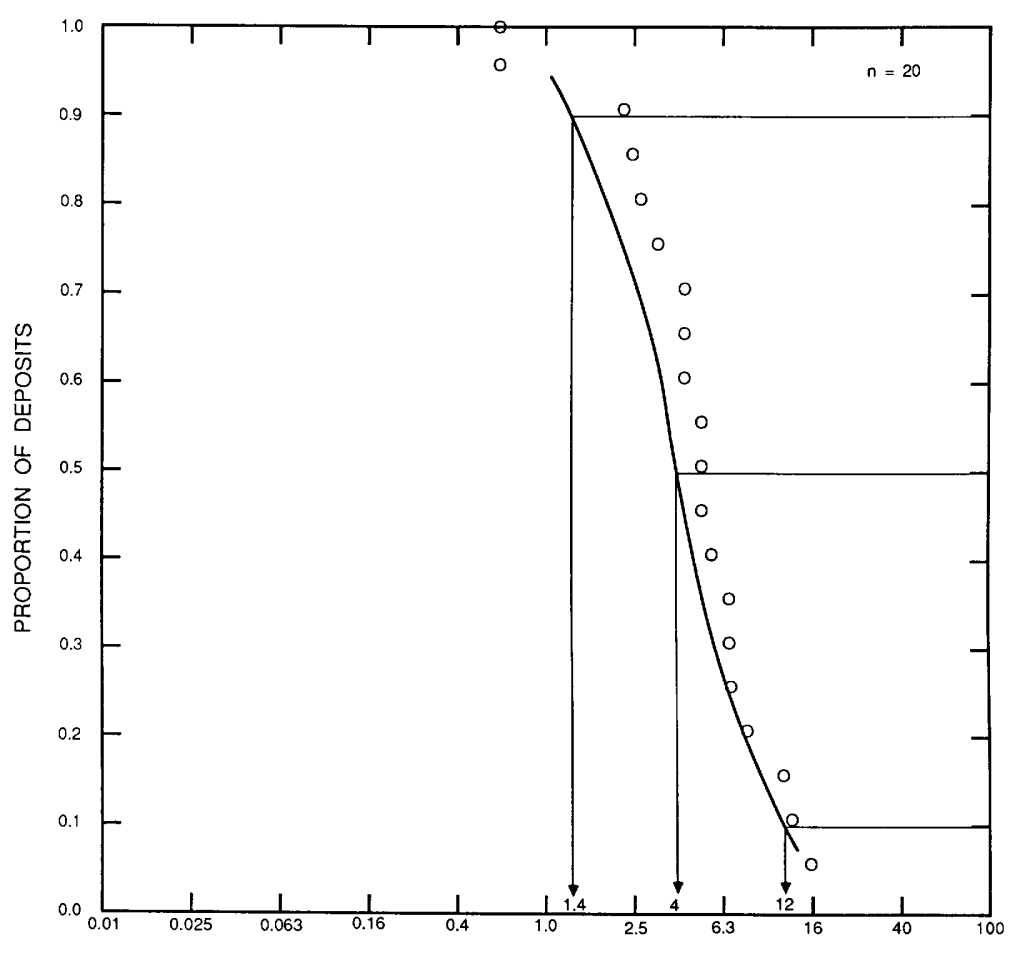

ZINC GRADE IN PERCENT

Figure 169. Zinc grades of southeast

Missouri $\mathrm{Pb}-\mathrm{Zn}$ and Appalachian $\mathrm{Zn}$ deposits. 
Models $32 \mathrm{a}$ and $32 \mathrm{~b}--$ Con.

SOUTHEAST MISSOURI LEAD--ZINC AND APPALACHIAN ZINC

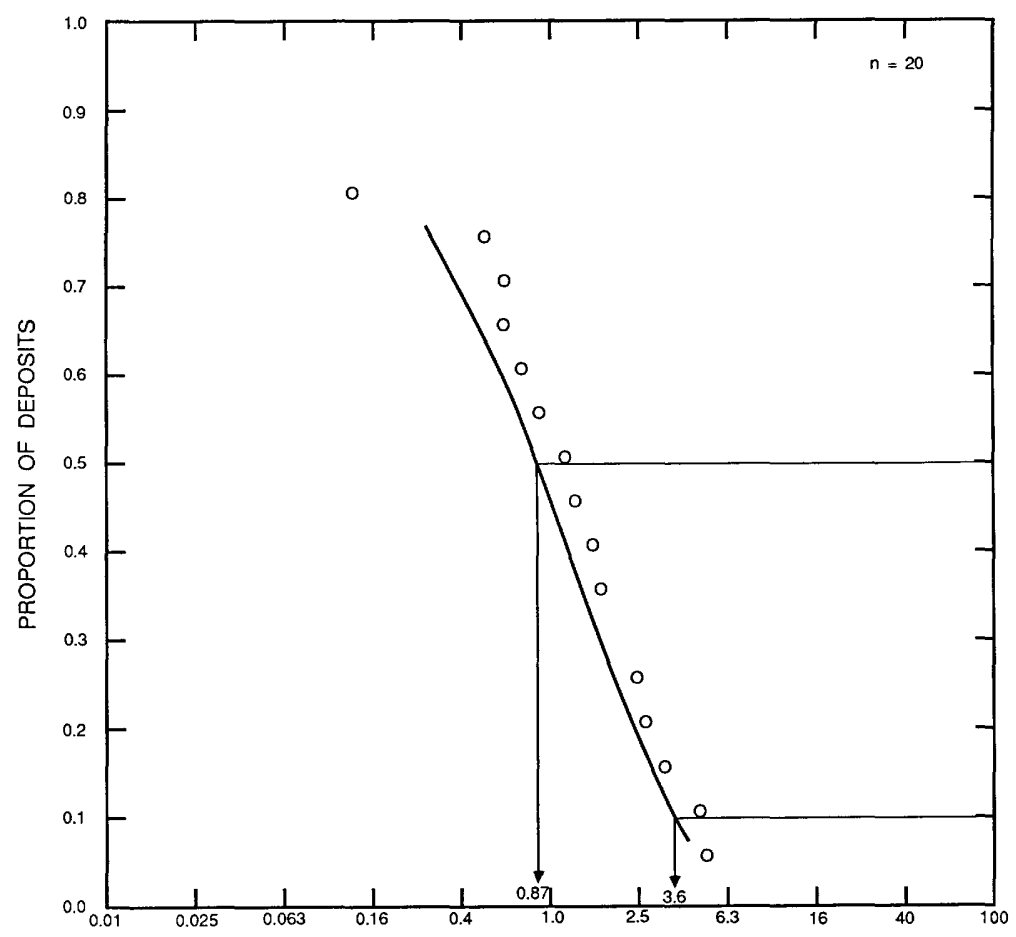

Figure 170. Lead grades of southeast Missouri $\mathrm{Pb}-\mathrm{Zn}$ and Appalachian $\mathrm{Zn}$ deposits.

LEAD GRADE IN PERCENT

SOUTHEAST MISSOURI LEAD--ZINC AND APPALACHIAN ZINC

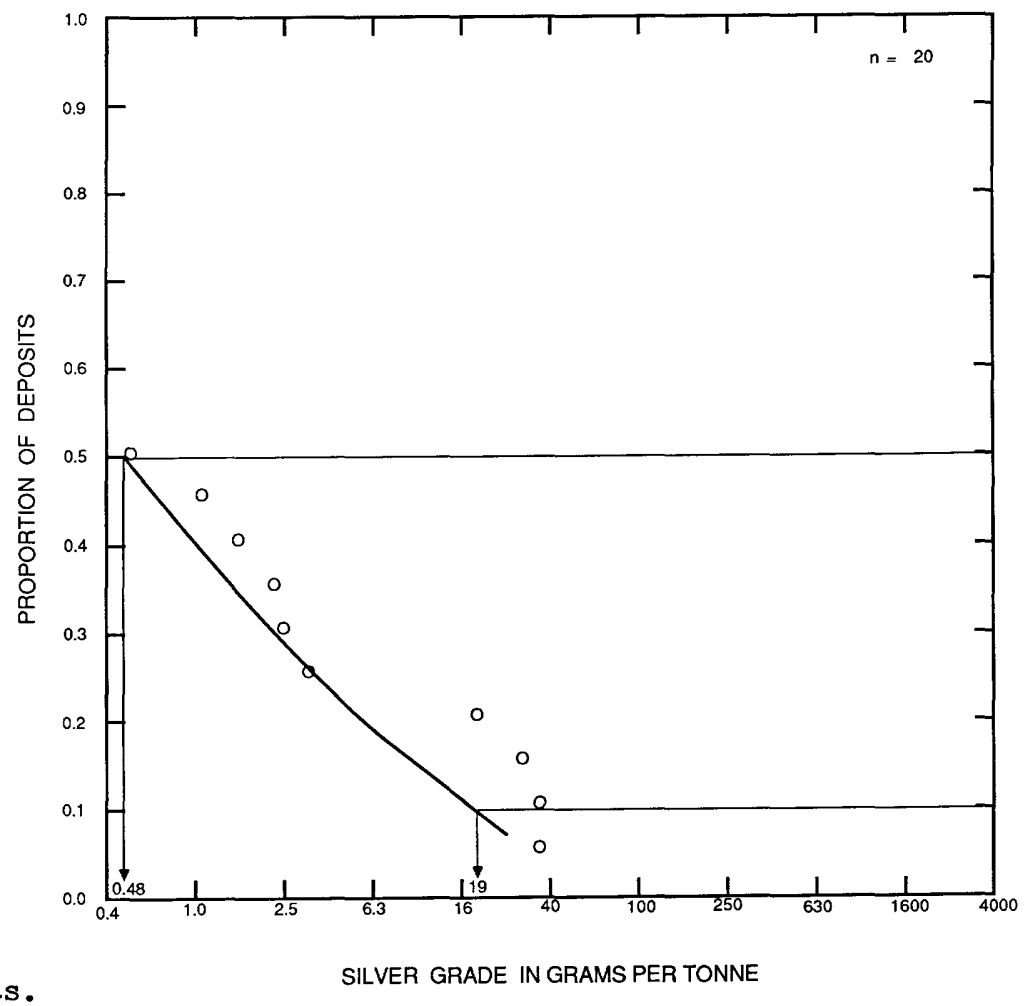

Figure 171. Silver grades of southeast Missouri $\mathrm{Pb}-\mathrm{Zn}$ and Appalachian $\mathrm{Zn}$ deposits. 


\title{
DESCRIPTIVE MODEL OF KIPUSHI $\mathrm{Cu}-\mathrm{Pb}-\mathrm{Zn}$
}

\author{
By Dennis P. Cox and Lawrence R. Bernstein
}

DESCRIPTION Massive base-metal sulfides and As-sulfosalts in dolomite breccias characterized by minor Co, Ge, Ga, U, and $\mathrm{V}$.

\section{GEOLOGICAL ENVIRONMENT}

Rock Types Dolomite, shale. No rocks of unequivocal igneous origin are related to ore formation. [The pseudoaplite at Tsumeb is herein assumed to be a metasedimentary rock following H. D. LeRoex (1955, unpublished report).]

Textures Fine-grained massive and carbonaceous, laminated, stromatolitic dolomites.

Age Range Unknown; host rocks are Proterozoic in Africa, Devonian in Alaska, Pennsylvanian in Utah.

Depositional Environment High fluid flow along tabular or pipe-like fault-or karst (?)-breccia zones.

Tectonic Setting(s) Continental platform or shelf terrane with continental or passive margin rifting. Ore formation at Tsumeb and Ruby Creek predates folding.

Associated Deposit Types Sedimentary copper, U-veins, barite veins. Sedimentary exhalative Pb-Zn may be a lateral facies.

\section{DEPOSIT DESCRIPTION}

Mineralogy Ruby Creek: pyrite, bornite, chalcocite, chalcopyrite, carrollite, sphalerite, tennantite. Tsumeb: galena, sphalerite, bornite, tennantite, enargite. Kipushi: sphalerite, bornite, chalcopyrite, carrollite, chalcocite, tennantite, pyrite. Less abundant minerals in these deposits are linnaeite, Co-pyrite, germanite, renierite, gallite, tungstenite, molybdenite, and native Bi. Bituminuous matter in vugs. At Apex mine, marcasite.

Texture/Structure Massive replacement, breccia filling, or stockwork. Replacement textures of pyrite after marcasite at Ruby Creek and Apex.

Alteration Dolomitization, sideritization, and silicification may be related to mineralization. Early pyrite or arsenopyrite as breccia filling or dissemination.

Ore Controls Abundant diagenetic pyrite or other source of $S$ acts as precipitant of base metals in zones of high porosity and fluid flow. Bitumens indicate reducing environment at site of ore deposition.

Weathering Malachite-azurite, black Co-oxide, or pink Co-arsenate. Oxidation at Tsumeb has produced large crystals of many rare minerals. Oxidized Ge-Ga ore at Apex consists of iron oxides and jarosite; Ge and Ga minerals are not observed.

Geochemical and Geophysical Signature $\mathrm{Cu}, \mathrm{Zn}, \mathrm{Pb}, \mathrm{As}, \mathrm{Co}, \mathrm{Ag}, \mathrm{Ge}, \mathrm{Ga}, \mathrm{Mo}, \mathrm{W}, \mathrm{Sn}, \mathrm{Bi}, \mathrm{U}$ and $\mathrm{V}$. Metal ratios: high $\mathrm{Cu} / \mathrm{Fe}$ and locally high $\mathrm{Cu} / \mathrm{S}$ in interior zones; high $\mathrm{Co} / \mathrm{Ni}, \mathrm{As} / \mathrm{Sb}$ and $\mathrm{Ag} / \mathrm{Au}$. May be weakly radioactive.

\section{EXAMPLES}

Ruby Creek, ASAK

Tsumeb, NAMB

Kipushi, ZIRE

Apex Mine, USUT
(Runnels, 1969)

(Sohnge, 1961); Wilson (1977)

(Intiomale and Dosterbosch, 1974)

(Bernstein, 1986) 
Model $34 a$

\section{DESCRIPTIVE MODEL OF SUPERIOR Fe}

By William F. Cannon

DESCRIPTION Banded iron-rich sedimentary rock, generally of great lateral extent, typically layered on centimeter scale with siliceous (chert) beds interlayered with iron-rich beds.

GENERAL REFERENCE James (1954).

GEOLOGICAL ENVIRONMENT

Rock Types Commonly interlayered with quartzite, shale, dolomite.

Textures Iron-formations and host rocks commonly contain sedimentary textures typical of shallowwater deposition in tectonically stable regions.

Age Range Mostly Early Proterozoic (2.0 0.2 b.y.). Less commonly Middle and Late Proterozoic.

Depositional Environment Stable, shallow-water marine environment, commonly on stable continental shelf or intracratonic basin.

Tectonic Setting(s) Now commonly preserved in forelands of Proterozoic orogenic belts.

Associated Deposit Types Sedimentary manganese deposits may occur stratigraphically near or be interbedded with iron-formations.

\section{DEPOSIT DESCRIPTION}

Mineralogy Hematite, magnetite, siderite, fine-grained quartz.

Texture/Structure Nearly always banded at centimeter scale; very fine grained where not metamorphosed.

Alteration None related to ore deposition. Commonly metamorphosed to varying degrees or weathered and enriched by supergene processes.

Ore Controls No primary controls of local importance. Supergene ores may be localized by irregularities in present or paleo erosion surface.

Weathering Alteration of original iron mineral to Fe-hydroxides and hematite. Silica partly to totally leached. End product of weathering is high-grade supergene ore.

Geophysical Signature Magnetic anomalies.

\section{EXAMPLES}

Mesabi Range, USMN (James, 1983)

\section{GRADE AND TONNAGE MODEL OF SUPERIOR Fe AND ALGOMA Fe DEPOSITS}

By Dan L. Mosier and Donald A. Singer

COMMENTS Archean and Proterozoic deposits (Algoma and Superior types) are both included because they are not significantly different in tonnage or grades. See figs. 172-174

DEPOSITS

Name

Altamira-Frontera

Amapa

An-shan

Bahia

Bailadila
Country

VNZL

BRZL

CINA

BRZL

INDA
Name

Bellary

Bicholim

Burnt Hill-Knob Lake

Cerro Bolivar

Chityal and others
Country

INDA

INDA

CNQU

VNZL

INDA 
Model 34a--Con.

$\begin{array}{ll}\text { Cuyuna } & \text { USMN } \\ \text { Dhalli-Rajhara } & \text { INDA } \\ \text { El Pao } & \text { VNZL } \\ \text { Fiskefjord } & \text { NRWY } \\ \text { Fort Apache } & \text { USAZ } \\ \text { Fort Gourand } & \text { MAUR } \\ \text { Gogebic } & \text { USMN } \\ \text { Gorumahisani and others } & \text { INDA } \\ \text { Goulais } & \text { CNON } \\ \text { Guntur } & \text { INDA } \\ \text { Isua } & \text { GRLD } \\ \text { Iron Monarch-Iron Knob } & \text { AUSA } \\ \text { Jussaari } & \text { FNLD } \\ \text { Kanjamalai and others } & \text { INDA } \\ \text { Kemmangundi and others } & \text { INDA } \\ \text { Koolyanobbing } & \text { AUWA } \\ \text { Krivoi-Rog } & \text { URRS } \\ \text { Kudremukh and others } & \text { INDA } \\ \text { Kung-changling } & \text { CINA } \\ \text { Kusalpur } & \text { INDA } \\ \text { Labrador Quebec } & \text { CNQU } \\ \text { Lohara and others } & \text { INDA } \\ \text { Los Castillos } & \text { VNZL } \\ \text { Maria Luisa } & \text { VNZL } \\ \text { Marquette } & \text { USMN } \\ \text { Mato Grosso } & \text { BRZL } \\ \text { Menominee } & \text { USMN } \\ \text { Mesabi } & \text { USMN } \\ \text { Minas Gerais } & \text { BRZL }\end{array}$

$\begin{array}{ll}\text { Moose Mountain } & \text { CNON } \\ \text { Mount Gibson } & \text { AUWA } \\ \text { Mount Gould } & \text { AUWA } \\ \text { Mount Hale } & \text { AUWA } \\ \text { Mount Philip } & \text { AUQL } \\ \text { Musan } & \text { NKOR } \\ \text { Mutum } & \text { BLVA } \\ \text { Noamundi-Joda-Gua etc. } & \text { INDA } \\ \text { Norberg } & \text { SWDN } \\ \text { Pa-pan-ling } & \text { CINA } \\ \text { Pen-chi-hu } & \text { CINA } \\ \text { Piacoa } & \text { VNZL } \\ \text { Porkonen } & \text { FNLD } \\ \text { Rowghat } & \text { INDA } \\ \text { Sangalwara } & \text { INDA } \\ \text { Santa Barbara } & \text { VNZL } \\ \text { Serria do Carajas } & \text { BRZL } \\ \text { Sirigao } & \text { INDA } \\ \text { Ssu-chia-ying } & \text { CINA } \\ \text { Stripa-Striberg } & \text { SWDN } \\ \text { Sydvananger } & \text { NRWY } \\ \text { Tallering Peak } & \text { AUWA } \\ \text { Thabazimbi } & \text { SAFR } \\ \text { Tonkolili } & \text { SRLN } \\ \text { Vermilion } & \text { USMN } \\ \text { Vestpolltind } & \text { NRWY } \\ \text { Weld Range-Wilgie Mia } & \text { AUWA }\end{array}$

Minas Gerais BRZL

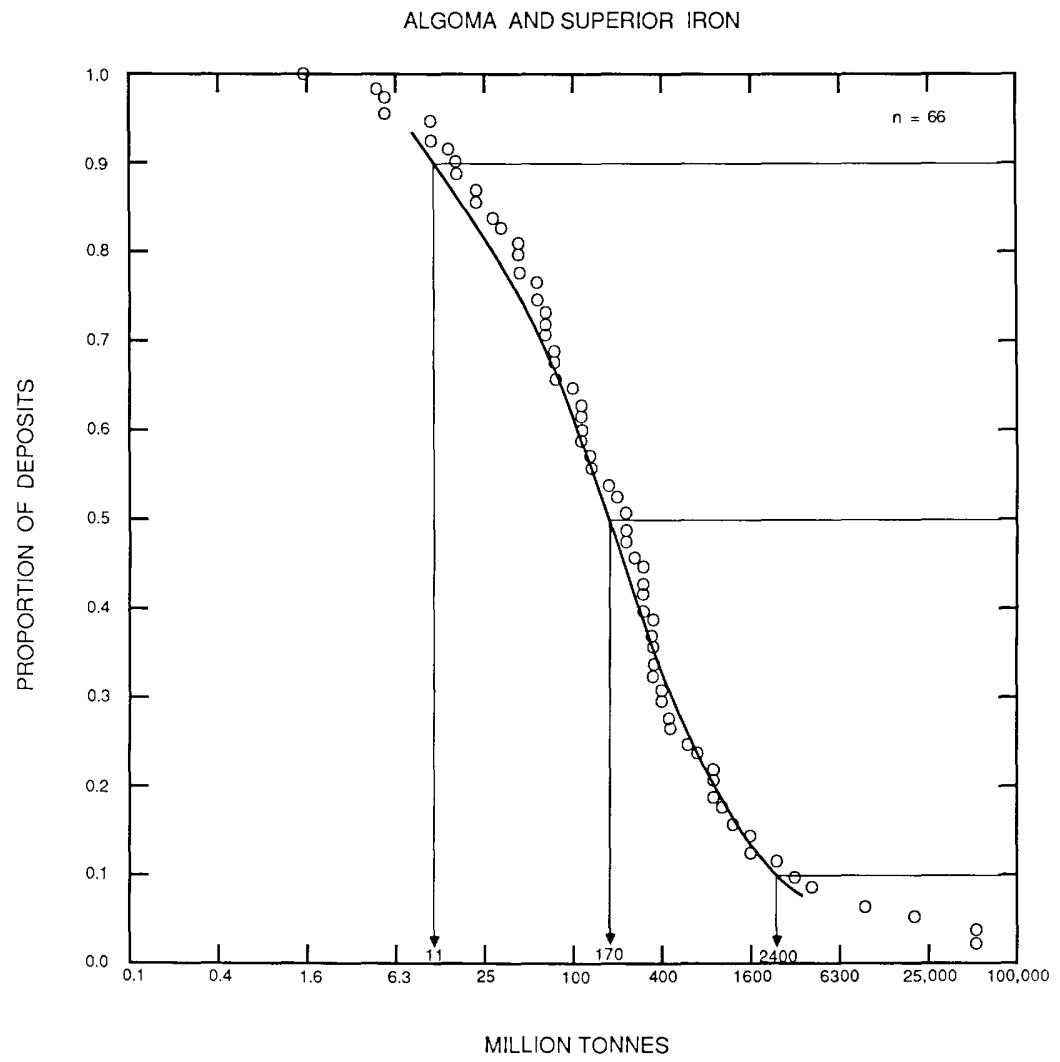

Figure 172. Tonnages of Algoma $\mathrm{Fe}$ and Superior $\mathrm{Fe}$ deposits. 
Model 34a--Con.

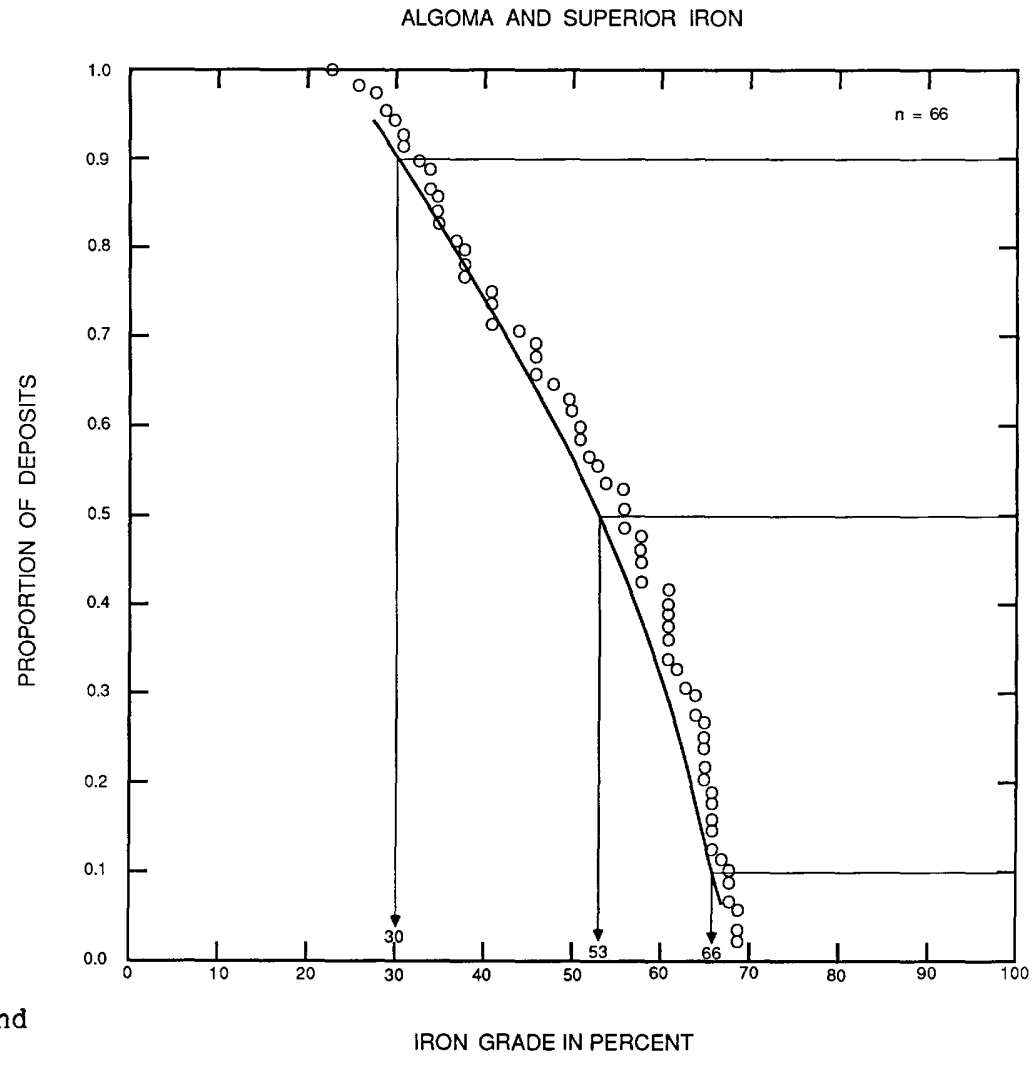

Figure 173. Iron grades of $\mathrm{Algoma} \mathrm{Fe}$ and Superior Fe deposits.

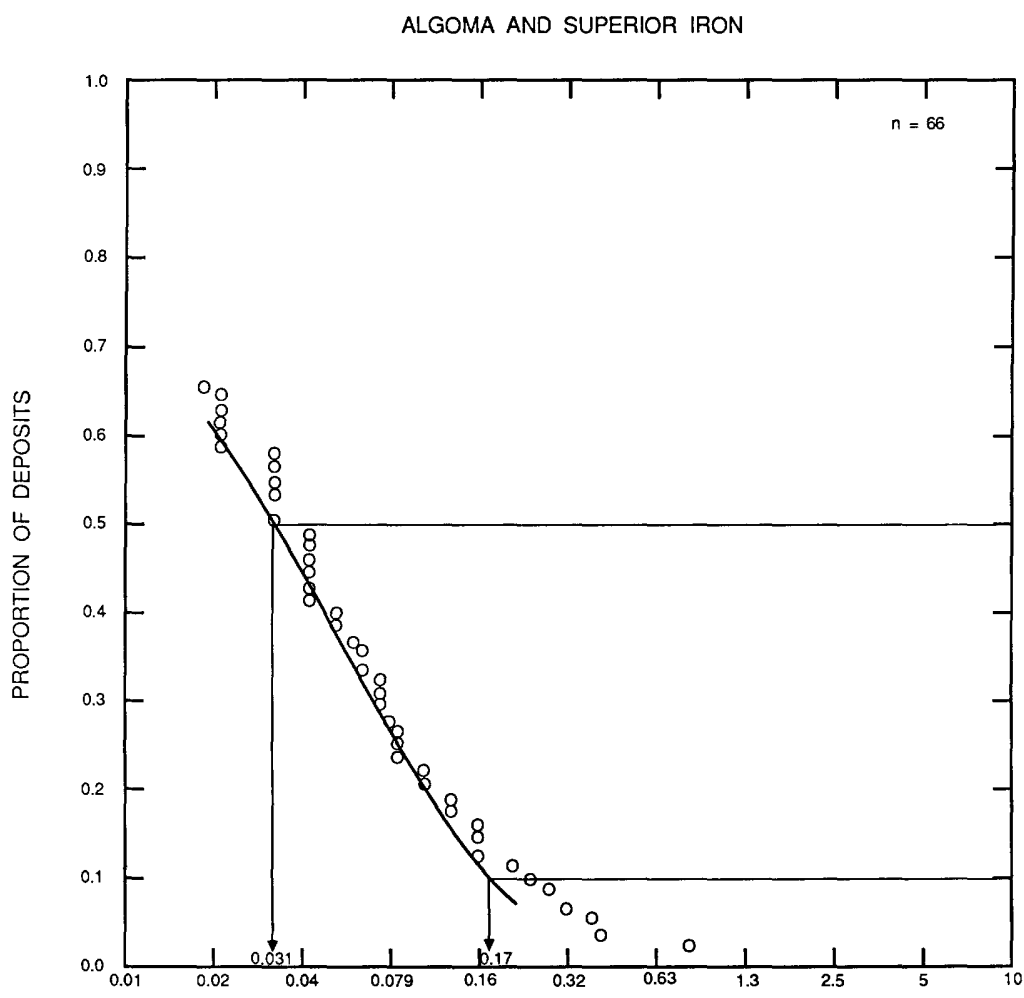

Figure 174. Phosphorus grades of Algoma $\mathrm{Fe}$ and Superior $\mathrm{Fe}$ deposits. 


\section{DESCRIPTIVE MODEL OF SEDIMENTARY Mn}

By William F. Cannon and Eric R. Force

APPROXIMATE SYNONYM Bathtub-ring Mn.

DESCRIPTION Shallow marine (non-volcanogenic) sedimentary Mn deposits formed around rims of anoxic basins during transgression (see fig. 175).

GENERAL REFERENCE Cannon and Force (1983).

GEOLOGICAL ENVIRONMENT

Rock Types Shallow marine sediments, most commonly carbonates, clay, and glauconitic sand, commonly with shellbeds, in transgressive sequences associated with anoxic basins.

Age Range Mostly in "anoxic events," narrow time periods within the early Paleozoic, Jurassic, and mid-Cretaceous, but may be in rocks of any age associated with anoxic basins.

Depositional Environment Shallow (50-300 m) marine, commonly in sheltered sites around paleoislands. Most deposits overlie oxidized substrates, but basinward, carbonate deposits may be in chemically reduced settings.

Tectonic Setting(s) Stable cratonic interior basin or margin.

Associated Deposit Types Locally, sedimentary phosporites, sediment-hosted Cu.

DEPOSIT DESCRIPTION

Mineralogy A variety of Mn carbonates (mostly basinward) and oxides (mostly landward).

Texture/Structure Commonly as oolites, pisolites, laminae, and shell replacements.

Alteration Supergene alteration to high-grade ore is common.

Ore Controls Oxidation-reduction interface (involves age, paleobasin reconstruction, paleodepth of site) and lack of clastic dilution.

Weathering Mn carbonates may weather to brown, nondescript rock. Black secondary oxides are common.

Geochemical Signature None known.

\section{EXAMPLES}

Molango (Jurassic), MXCO

$\begin{array}{ll}\text { Nikopol (Oligocene), USSR } & \text { (Sapozhnikov, 1970) } \\ \text { Groote Eyland (Cretaceous), AUTN } & \text { (Frakes and Bolton, 1984) }\end{array}$

(Tavera and Alexandri, 1972)

\section{GRADE AND TONNAGE MODEL OF SEDIMENTARY Mn}

By Dan L. Mosier

DATA REFERENCES Most data from DeYoung and others (1984).

COMMENTS Because available grade and tonnage estimates represent mines from, in some cases, very extensive deposits and because the numbers are calculated at differing cutoff grades, the endowment of these deposits is undoubtedly much larger than indicated in these figures. See figs. 176-177. 
Model 34b--Con.

\section{DEPOSITS}

Name

\section{Akviran}

Andhra Pradesh

Ansongo

Azul-Carajas

Bolske-Tokmak

Chiatura

Chiwefwe

Groote Eylandt

Gujarat

Horseshoe

Hsiangtan

Imini

Istranca

Kalahari

Kamenskoe

Kaochiao

Madhya Pradesh

Manuel Killigrews

$\begin{array}{lll}\text { Country } & & \text { Name } \\ \text { TRKY } & & \text { Matese-Ciociaria } \\ \text { INDA } & & \text { Molango } \\ \text { MALI } & & \text { Morro da Mina } \\ \text { BRZL } & & \text { Naniango } \\ \text { URRS } & & \text { Nikolaevskoe } \\ \text { URRS } & & \text { Nikopol } \\ \text { ZIMB } & & \text { Nizne-Udinskaja } \\ \text { AUNT } & & \text { Otjosondu } \\ \text { INDA } & & \text { Ravensthorpe } \\ \text { AUWA } & & \text { Seiba } \\ \text { CINA } & & \text { Shimoga (Karnatoka) } \\ \text { MRCO } & \text { Timna } \\ \text { TRKY } & \text { Uracum } \\ \text { SAFR } & \text { Urkut } \\ \text { URRS } & \text { Usinsk } \\ \text { CINA } & \text { Varna } \\ \text { INDA } & \text { Wafangtzu } \\ \text { CNNF } & & \end{array}$

Country

ITLY

MXCO

BRZL

UVOL

URRS

URRS

URRS

SAFR

AUWA

URRS

INDA

ISRL

BRZL

HUNG

URRS

BULG

CINA

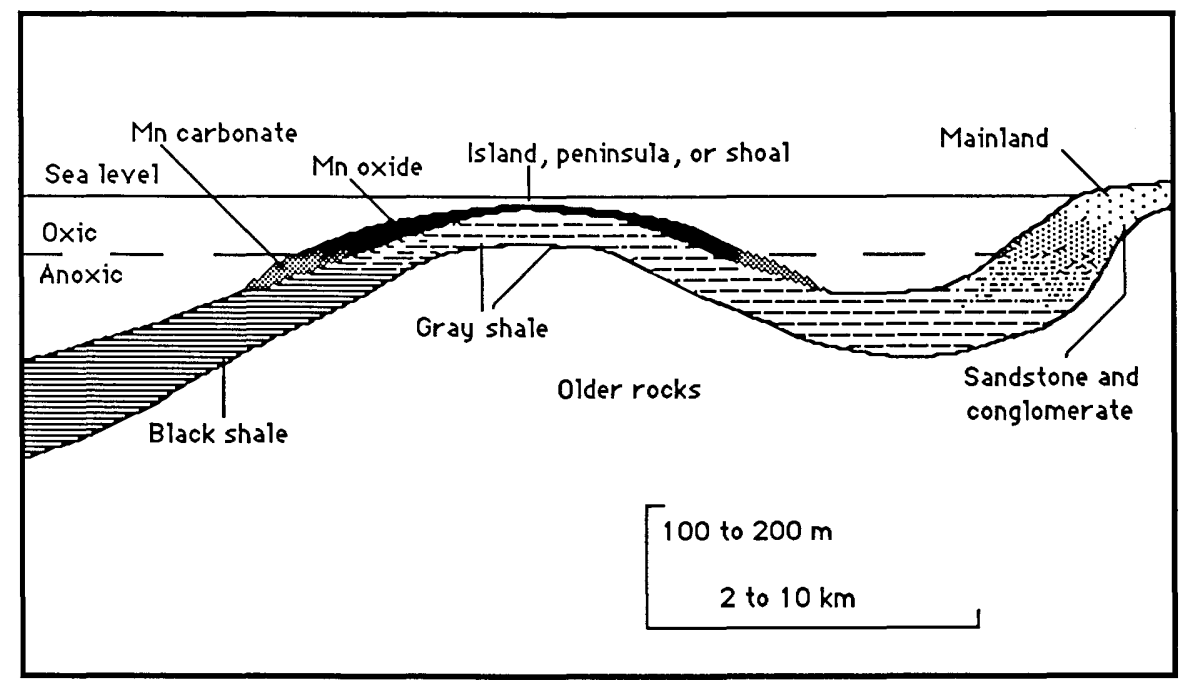

Figure 175. Cartoon cross section showing relation of sedimentary facies to sedimentary Mn deposits. 


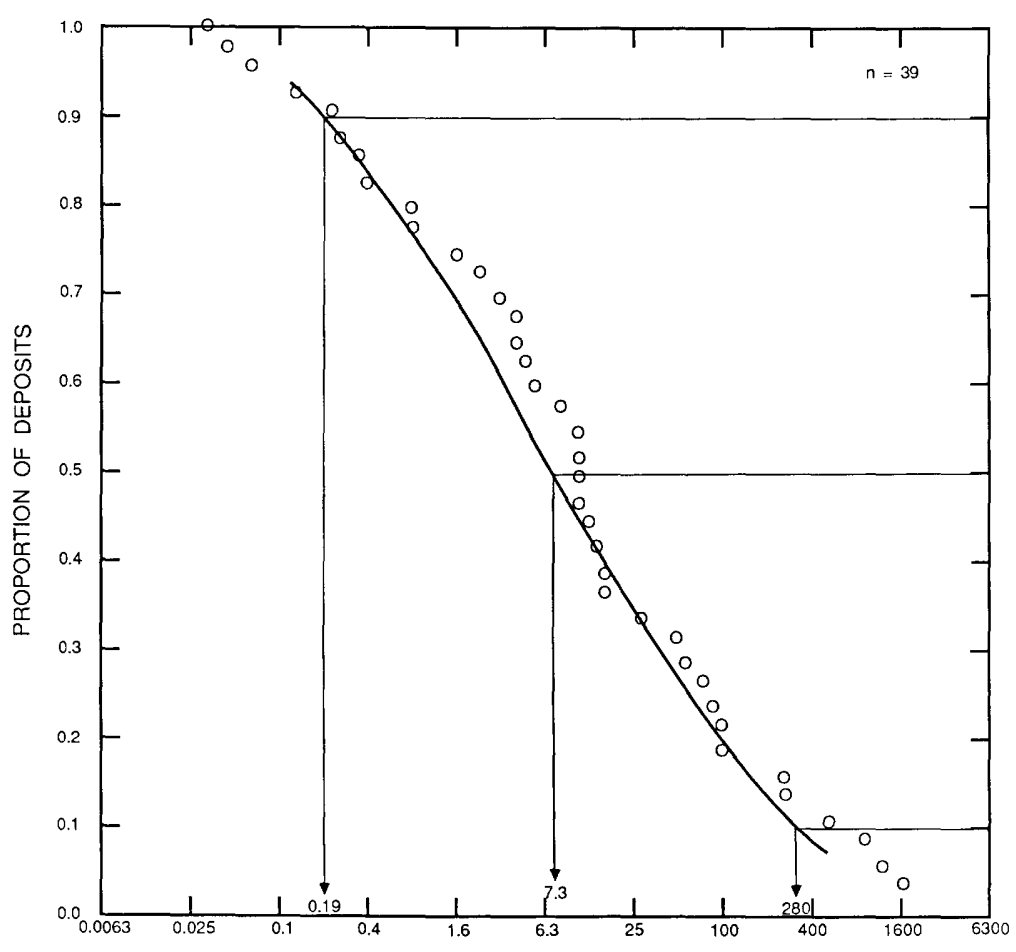

Model 34b--Con.

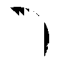

MILLION TONNES

Figure 176. Tonnages of sedimentary Mn SEDIMENTARY MANGANESE
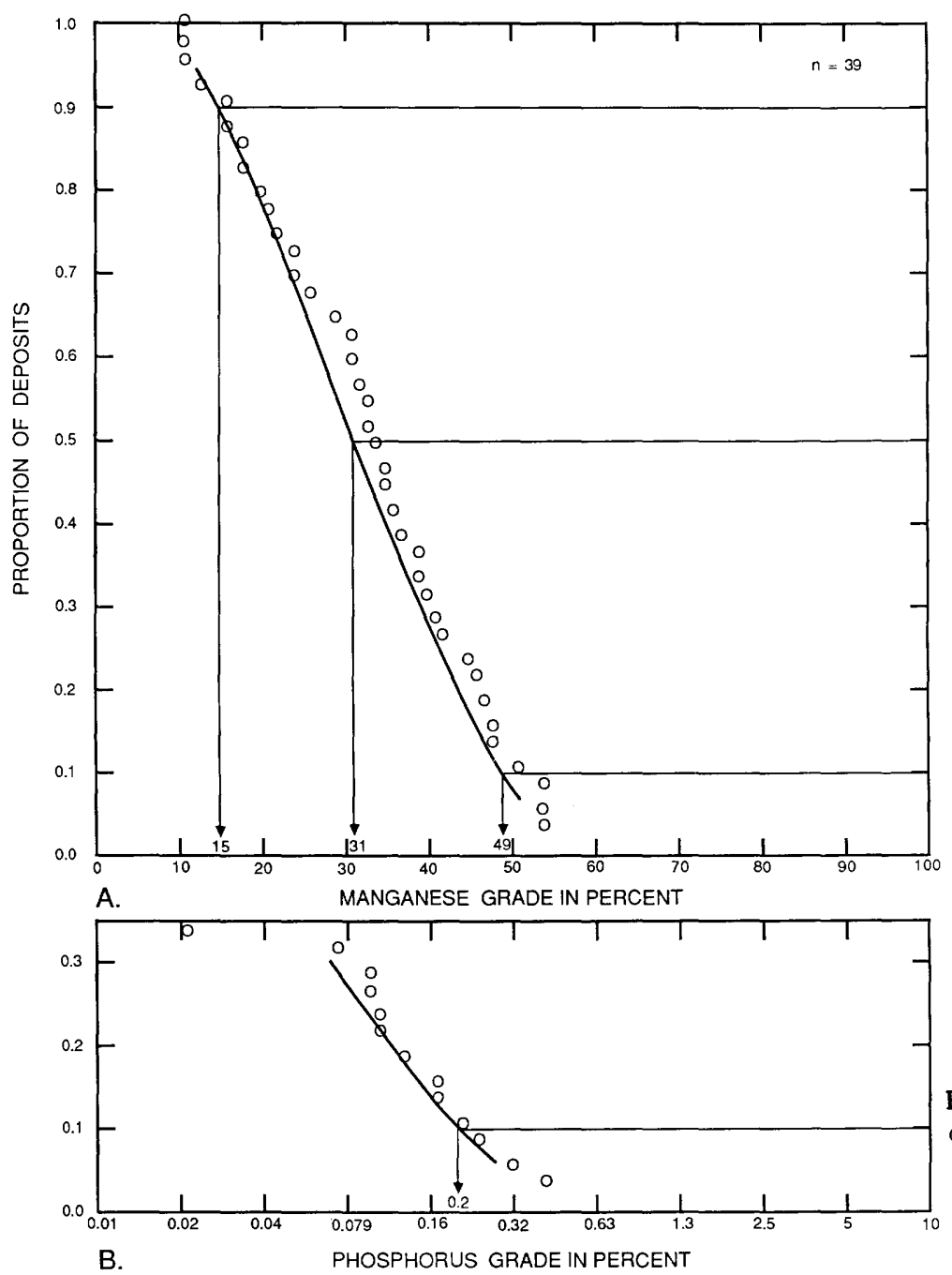

Figure 177. Metal grades of sedimentary Mn deposits. A, Manganese. B, Phosphorus. 
Model $34 \mathrm{c}$

\section{DESCRIPTIVE MODEL OF UPWELLING TYPE PHOSPHATE DEPOSITS}

By Dan L. Mosier

DESCRIPTION Phosphorite sediments form a major stratigraphic unit within a sequence of marine sediments in upwelling areas in basins with good connection to the open sea.

GENERAL REFERENCES Slansky (1980), Sheldon (1964).

\section{GEOLOGICAL ENVIRONMENT}

Rock Types Phosphorite, marl, shale, chert, limestone, dolomite, and volcanic materials.

Age Range Precambrian through Miocene.

Depositional Environment Marine sedimentary basins with good connection to the open sea and upwelling, areas highly productive of plankton. Deposition occurs mostly in warm latitudes, mostly between the 40th parallels.

Tectonic Setting(s) Intra-plate shelf, platform, miogeosynclines, and eugeosynclines.

Associated Deposit Types Sedimentary manganese.

DEPOSIT DESCRIPTION

Mineralogy Apatite + fluorapatite + dolomite + calcite + quartz + clays (montmorillonite or illite) \pm halite \pm gypsum \pm iron oxides \pm siderite \pm pyrite \pm carnotite.

Texture/Structure Pellets, nodules, phosphatized shell and bone material.

Alteration None related to ore.

Ore Controls Basins, or parts of basins, favorable for the accumulation of organic rich sediments and for their evolution into phosphorites. Individual beds may be a meter thick or more and may extend over hundreds of square kilometers.

Weathering Limonite and goethite.

Geochemical Signature P, N, F, C, and U. Anomalously radioactive.

EXAMPLES

Southeast, USID (Gulbrandsen and Krier, 1980)

Meskala, MRCO (British Sulphur Corp. Ltd., 1980)

Stra Quertane, TUNS (British Sulphur Corp. Ltd., 1980)

GRADE AND TONNAGE MODEL OF UPWELLING TYPE PHOSPHATE DEPOSITS

By Dan L. Mosier

COMMENTS See figs. 178-179.

DATA REFERENCE Krauss and others (1984). 
Name

Abu Tartur

Akashat

Aktyubinsk

Al-Hasa/Oatrana

Arad

Beersheva

$\mathrm{Bu}$ Craa

Brooks Range

Chilisai

Djebel Onk

D-Tree

Duchess

Eastern A\&B

El Hamrawe in

Ganntour

Hahotoe

Haikou

Hubsugul

Id fu-Qena

Kalaa Khasba

Kara Tau

Khneifiss

Kondonakasi

Kun Ming

Lady Annie

Lee Creek

Le Kouif

Lily Creek

Makhtesh

Mazidagi.

\begin{tabular}{|c|c|}
\hline Country & $\underline{\text { Name }}$ \\
\hline EGPT & Mdilla \\
\hline IRAQ & Meskala \\
\hline URRS & Metalaoui \\
\hline JRDN & Montana \\
\hline ISRL & Moulares \\
\hline ISRL & Mrata \\
\hline MRCO & Mzaita \\
\hline USAK & Nahal-Zin \\
\hline URRS & New Cuyama \\
\hline ALGR & Oronta \\
\hline AUQL & Oulad-Abdoun \\
\hline AUQL & Patos de Minas \\
\hline SYRA & Qusseir \\
\hline EGPT & Redeyef \\
\hline MRCO & Ruseifa \\
\hline TOGO & Safagar \\
\hline CINA & San Juan de la Costa \\
\hline MNGL & Sechura \\
\hline EGPT & Sehib \\
\hline TUNS & S.E. Idaho \\
\hline URRS & Shediyah \\
\hline SYRA & Sherrin Creek \\
\hline ANGL & Stra Quertane \\
\hline CINA & Taiba \\
\hline AUQL & Thamar-Kotra \\
\hline USNC & Thies \\
\hline ALGR & Uinta Mtns \\
\hline AUQL & Vernal \\
\hline USRL & Warm Springs \\
\hline TRKY & Wyoming \\
\hline
\end{tabular}

Country

TUNS

MRCO

TUNS

USMT

TUNS

TUNS

ALGR

ISRL

USCA

ISRL

MRCO

BRZL

EGPT

TUNS

JRDN

EGPT

MXCO

PERU

TUNS

USID

JRDN

AUQL

TUNS

SNGL

INDA

SNGL

USUT

USUT

USMT

USWY 
Model 34c--Con.

PHOSPHATE, UPWELLING TYPE

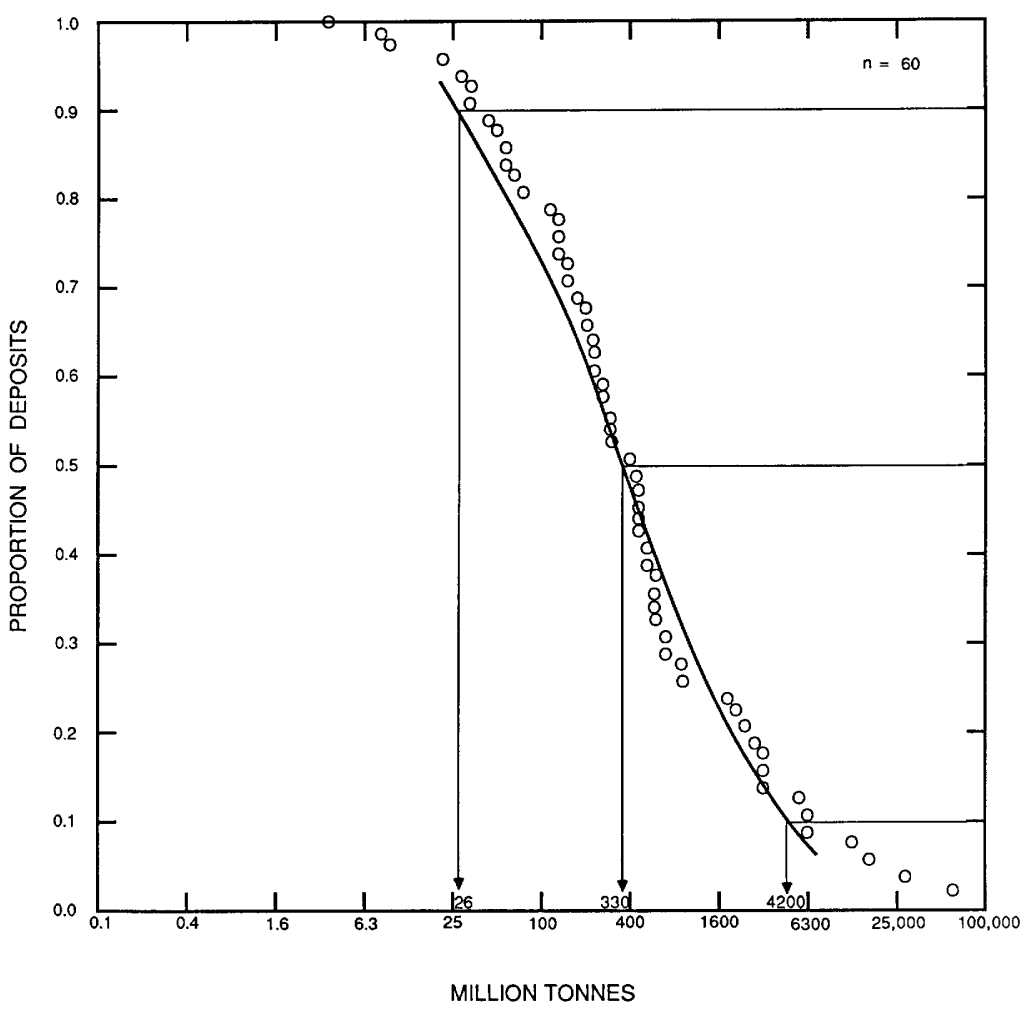

F igure 178. Tonnages of upwelling-type phosphate deposits.

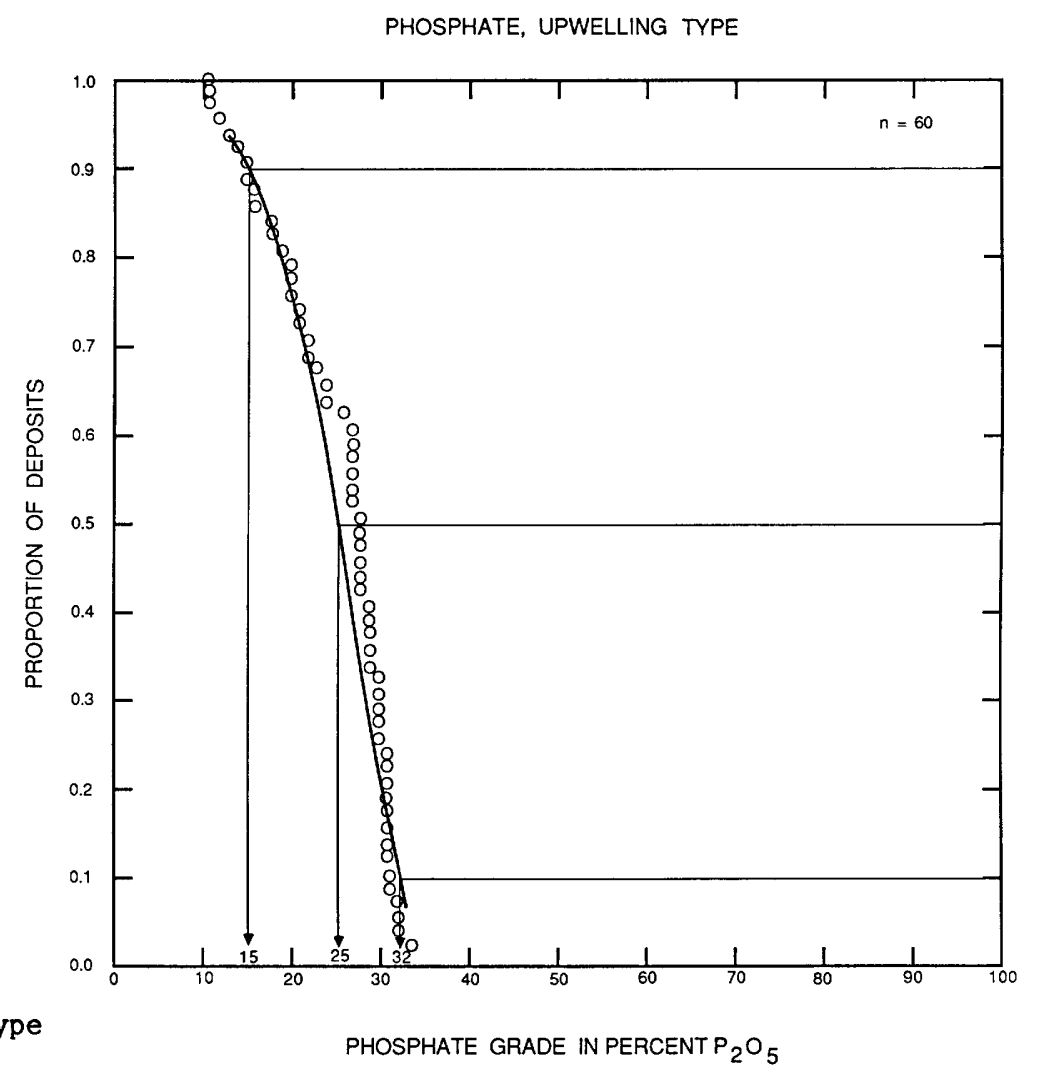

Figure 179. $\mathrm{P}_{2} \mathrm{O}_{5}$ grades of upwelling-type phosphate deposits. 


\title{
DESCRIPTIVE MODEL OF WARM-CURRENT TYPE PHOSPHATE DEPOSITS
}

\author{
By Dan L. Mosier
}

DESCRIPTION Phosphorites formed in warm currents along the eastern coasts of continents; consist of phosphatic limestone or sandstone.

GENERAL REFERENCES Cathcart and Gulbrandsen (1973), Sheldon (1964).

\section{GEOLOGICAL ENVIRONMENT}

Rock Types Phosphatic limestone and sandstone; chert and diatomaceous material may be present.

Age Range Early Cretaceous through Pliocene.

Depositional Environment Basins of structural lows on the flanks of rising domes, at the mouths of rivers and estuaries. Deposition occurs in warm latitudes, mostly between the 40 th parallels. Deposits are formed by dynamic upwelling or by the cool countercurrent associated with warm density current.

Tectonic Setting(s) Continental shelf; may be associated with eugeosynclinal rocks.

\section{DEPOSIT DESCRIPTION}

Mineralogy Fluorapatite + quartz + dolomite + montmorillonite + kaolinite + calcite \pm wavellite \pm crandallite \pm illite \pm clinoptilolite \pm palygorskite \pm smectite \pm collophane.

Texture/Structure Phosphatic pellets and fossil fragments with a carbonate matrix.

Ore Controls Stratigraphic phosphatic horizons within embayments and estuarine environments in proximity to the open sea. Basins on flanks of structural highs (domes, arches, anticlines) are important controls for phosphate deposition.

Weathering Goethite.

Geochemical Signature P, C, U, N, F. Anomalously radioactive.

EXAMPLES

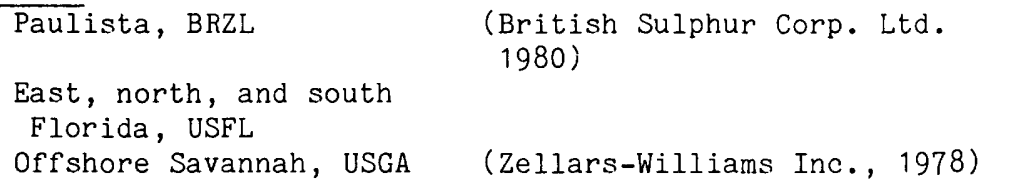

\section{GRADE AND TONNAGE MODEL OF HARM-CURRENT TYPE PHOSPHATE DEPOSITS}

By Dan L. Mosier

DATA REFERENCE Krauss and others, (1984).

COMMENTS About half of the deposits are actually districts. Grades have been adjusted to reflect in-place grades rather than commonly reported concentrate grades. See figs. 180-181.

DEPOSITS

Name

Big Four Bonny Lake Clear Springs

East Florida

Fort Green

Hard Rock

Country
USFL
USFL
USFL
USFL
USFL
USFL

$\underline{\text { Name }}$

Haynsworth

Kingsford

Lonesome

Noralyn-Phosphoria

North Florida

North Carolina
Country

USFL

USFL

USFL

USFL

USFL

USNC 
Model 34d--Con.

Northeast Florida

offshore Savannah

Paulista
USFL

USGA

BRZL
Rockland

Savannah River

South Florida
USFL

USGA

USFL

PHOSPHATE, WARM--CURRENT TYPE

Figure 180. Tonnages of warm-current type phosphate deposits.

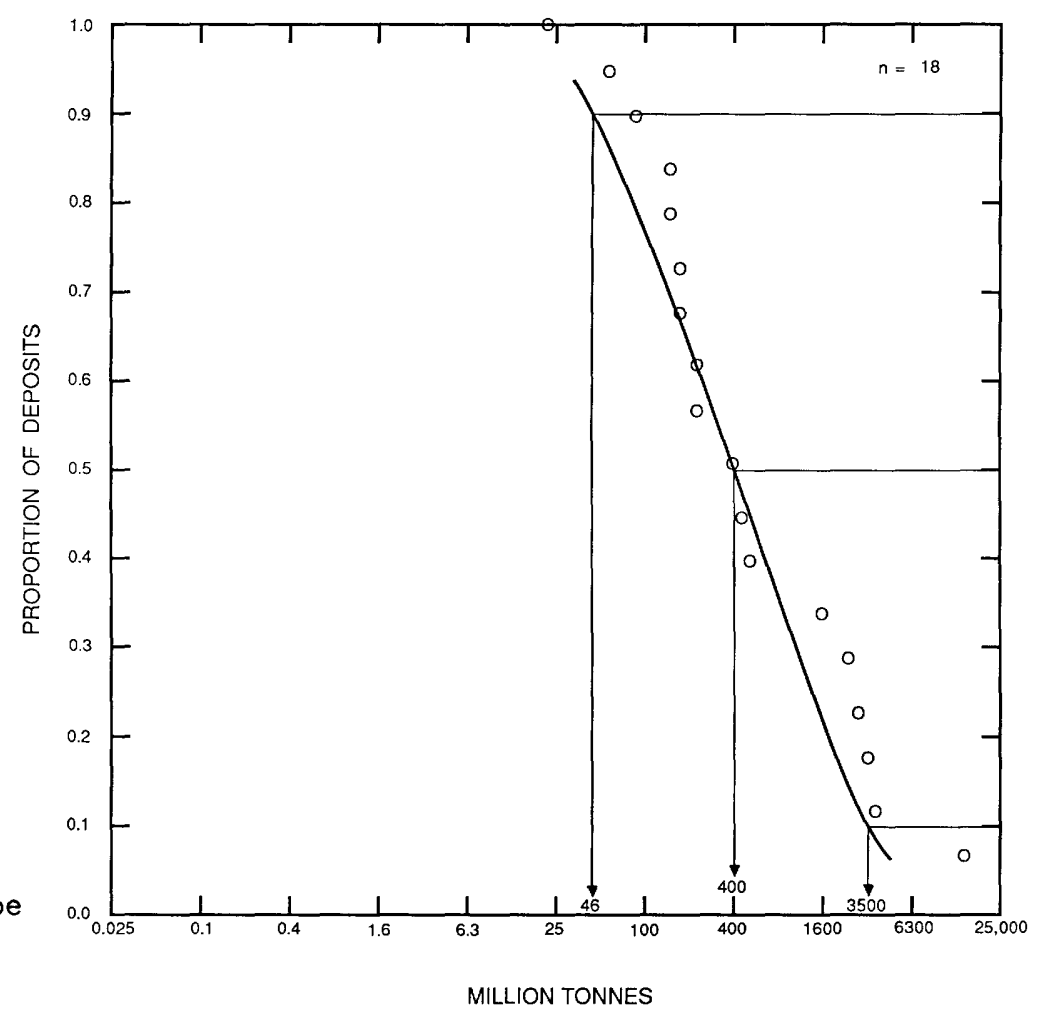

PHOSPHATE, WARM--CURRENT TYPE

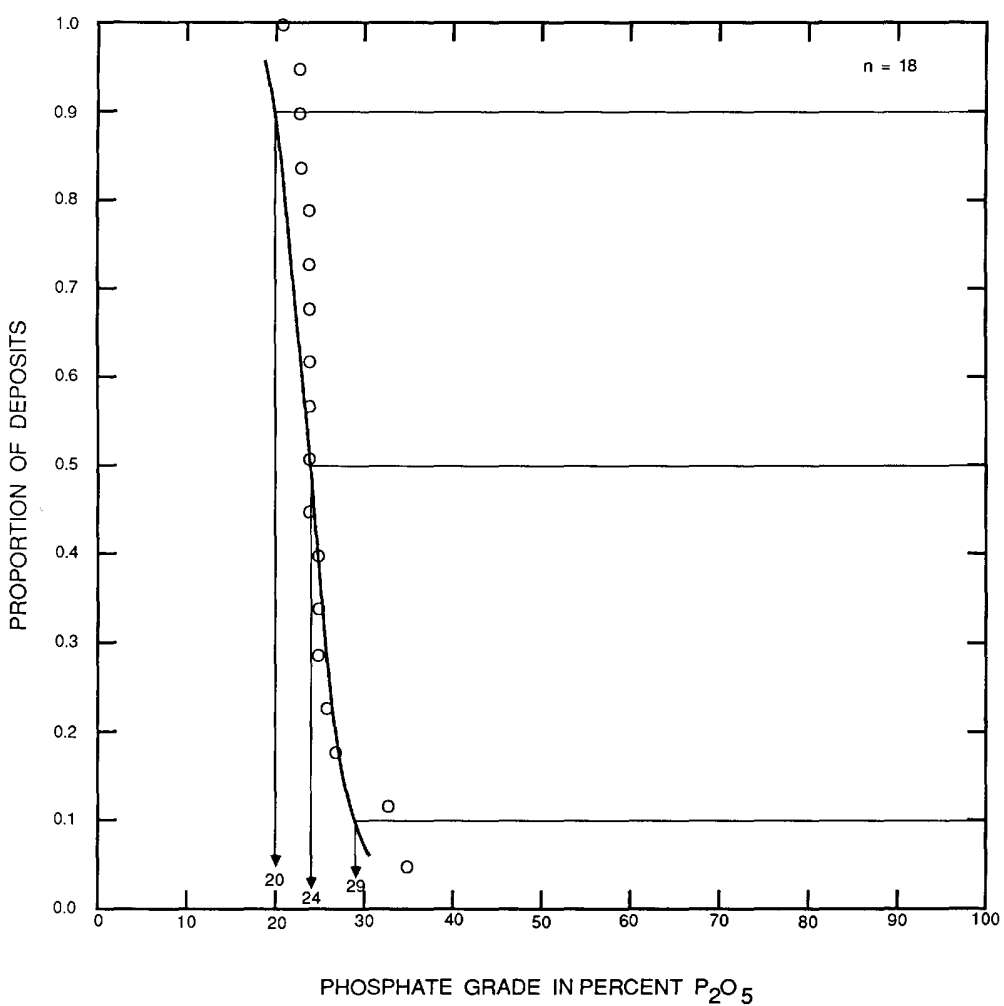

Figure 181. $\mathrm{P}_{2} \mathrm{O}_{5}$ grades of warm-current type phosphate deposits. 


\title{
DESCRIPTIVE MODEL OF LOW-SULFIDE AU-QUARTZ VEINS
}

\author{
$\begin{aligned} & \text { By Byron R. Berger } \\ & \text { APPROXIMATE SYNONYMS Mesothermal quartz veins, Mother Lode veins. }\end{aligned}$
}

DESCRIPTION Gold in massive persistent quartz veins mainly in regionally metamorphosed volcanic rocks and volcanic sediments.

GEOLOGICAL ENVIRONMENT

Rock Types Greenstone belts; oceanic metasediments: regionally metamorphosed volcanic rocks, graywacke, chert, shale, and quartzite. Alpine gabbro and serpentine. Late granitic batholiths.

Age Range Precambrian to Tertiary.

Depositional Environment Continental margin mobile belts, accreted margins. Veins are generally post-metamorphic and locally cut granitic rocks.

Tectonic Setting(s) Fault and joint systems produced by regional compression.

Associated Deposit Types Placer Au-PGE, kuroko massive sulfide, Homestake gold.

DEPOSIT DESCRIPTION

Mineralogy Quartz + native gold + pyrite + galena + sphalerite + chalcopyrite + arsenopyrite \pm pyrrhotite. Locally tellurides \pm scheelite \pm bismuth \pm tetrahedrite \pm stibnite \pm molybdenite \pm fluorite. Productive quartz is grayish or bluish in many instances because of fine-grained sulfides. Carbonates of $\mathrm{Ca}, \mathrm{Mg}$, and $\mathrm{Fe}$ abundant.

Texture/Structure Saddle reefs, ribbon quartz, open-space filling textures commonly destroyed by vein deformation.

Alteration Quartz + siderite and (or) ankerite + albite in veins with halo of carbonate alteration. Chromian mica + dolomite and talc + siderite in areas of ultramafic rocks. Sericite and disseminated arsenopyrite + rutile in granitic rocks.

Ore Controls Veins are persistent along regional high-angle faults, joint sets. Best deposits overall in areas with greenstone. High-grade ore shoots locally at metasediment-serpentine contacts. Disseminated ore bodies where veins cut granitic rocks.

Weathering Abundant quartz chips in soil. Gold may be recovered from soil by panning.

Geochemical Signature Arsenic best pathfinder in general; $\mathrm{Ag}, \mathrm{Pb}, \mathrm{Zn}, \mathrm{Cu}$.

EXAMPLES

$\begin{array}{ll}\text { Grass Valley, USCA } & \text { (Lindgren, 1896) } \\ \text { Mother Lode, USCA } & \text { (Knopf, 1929) } \\ \text { Ballarat Goldfield, } & \\ \text { Victoria, AUVT } & \text { (Baragwanath, 1953) } \\ \text { Goldfields of Nova Scotia, CNNS } & \text { (Malcolm, 1929) }\end{array}$

GRADE AND TONNAGE MODEL OF LOW-SULFIDE AU-QUARTZ VEINS

By James D. BIiss

COMMENTS All mines within $1.6 \mathrm{~km}$ were combined and only deposits containing more than 99 tonnes are included. Gold grade is correlated with tonnage $(r=-0.30)$ and with silver grade ( $r=0.45$, $n$ =39). See figs. 182-183. 
Model 36a--Con.

\section{DEPOSITS}

\begin{tabular}{|c|c|c|c|}
\hline Name & Country & Name & Country \\
\hline Al & AUVT & Colfax & USCA \\
\hline Achilles & NZLD & Colombo & USCA \\
\hline Alabama Shoot & AUVT & Comet & USAK \\
\hline Alex Hill-Mad Kiss & GUYN & Confidence & USCA \\
\hline Alice & USCA & Coulterville & USCA \\
\hline Alleghany East & USCA & Coulterville South & USCA \\
\hline Alleghany West & USCA & Country Harbour & CNNS \\
\hline Alto & USCA & Cove District & USCA \\
\hline Amador City & USCA & Cow Bay & CNNS \\
\hline American Bar & USCA & Cox, Bolyan \& Loberg & USAK \\
\hline Ample & CNBC & Cranberry Hill & CNNS \\
\hline Angels-Carson & USCA & Dalesford & AUVT \\
\hline Argo & USCA & Damascus & USCA \\
\hline Argus Hill & AUVT & Defender & USCA \\
\hline Ashland & USOR & Delta & USCA \\
\hline Atlas & USCA & Demarest & USCA \\
\hline Bagby & USCA & Dinero & USCA \\
\hline Bagby Valley & USCA & Dominion Consolidated & NZLD \\
\hline Ballarat & AUVT & Dorothea & USOR \\
\hline Barrandum & USCA & Eagle Bluff-River Bend & USCA \\
\hline Bear Valley & USCA & Eagle Shawmut & USCA \\
\hline Bear Valley South & USCA & Early-Sweetwater & USCA \\
\hline Beaver Dam & CNNS & East Rawdon & CNNS \\
\hline Belden & USCA & Eclipse No. 1 & USCA \\
\hline Bendigo & AUVT & Ecum Secum & CNNS \\
\hline Bendigo & NZLD & El Dorado & USCA \\
\hline Berry Creek & USCA & El Portal & USCA \\
\hline Bethanga & AUVT & Eliza-Schroeder & USCA \\
\hline Big Oak Flat & USCA & Empire-Lone Star & USCA \\
\hline Birthday-William Fancy & AUVT & Enterprise & USCA \\
\hline Black Bear & USCA & Esmeralda & USCA \\
\hline Black Boy & USCA & Ester Dome SE & USAK \\
\hline Blackstone & USCA & Experimental & USCA \\
\hline Blockhouse & CNNS & Felicianna & USCA \\
\hline Blue Lead & USAK & Fifteen-mile Brook & CNNS \\
\hline Blue Mountain & USCA & Fifteen-mile Stream & CNNS \\
\hline Bonanza & NZLD & Fifty-five & USCA \\
\hline Bondurant & USCA & Fine Gold & USCA \\
\hline Braden & USOR & Finney & USCA \\
\hline Bralorne-Pioneer & CNBC & Five Pines & USCA \\
\hline Broken Hills & USCA & Forbestown & USCA \\
\hline Brookfield & CNNS & Ford & USCA \\
\hline Buller-Mokihinui & NZLD & Forest Hill & CNNS \\
\hline Caledonia & AUVT & Four Hells Mine & USCA \\
\hline Canyon Creek-East Fork & USCA & Fourth Crossing & USCA \\
\hline Caribou & CNNS & Francis Ormand & AUVT \\
\hline Caribou-Aurum & CNBC & Franklin & USCA \\
\hline Carleton & CNNS & French & USCA \\
\hline Carolin & $\mathrm{CNBC}$ & French Gulch & USCA \\
\hline Cassilis & AUVT & Fryer's Creek & AUVT \\
\hline Central & USCA & Gabriels Gully & NZLD \\
\hline Central Rawdon & CNNS & Galice North & USOR \\
\hline Chewton & AUVT & Gabretta & USCA \\
\hline Chichagof & USAK & Gabrinus & USCA \\
\hline Cleary $\mathrm{Hill}$ & USAK & Gem & USCA \\
\hline Clunes Goldfield & AUVT & Gem Olive & USCA \\
\hline Coarsegold & USCA & German Bar & USCA \\
\hline Cobol & USAK & Giant King & USCA \\
\hline Cochrane Hill & CNNS & Gibralter & USCA \\
\hline
\end{tabular}


Model 36a--Con.

\begin{tabular}{|c|c|c|c|}
\hline Gladstone & USCA & Lone Mary & USCA \\
\hline Glencoe-Woodhouse & USCA & Long Tunnel & AUVT \\
\hline Globe-Ralston & USCA & Lord Nelson & AUVT \\
\hline Gold Bug & USCA & Lucky Bart & USOR \\
\hline Gold Point & USCA & Lucky Shot-War Baby & USAK \\
\hline Gold Reef & USCA & Lyell Goldfield & NZLD \\
\hline Gold River & USCA & Mabel & USAK \\
\hline Gold Chariot & USCA & Malden North & AUVT \\
\hline Golden Eagle & USCA & Mammoth & USCA \\
\hline Golden Jubilee & USCA & Mariners & AUVT \\
\hline Golden-El Dorado & USCA & Mariposa & USCA \\
\hline Goldenville & CNNS & Maude \& Yellow Girl & AUVT \\
\hline Grand Victory & USCA & Midas & USCA \\
\hline Granite Hill & USOR & Mikado & USAK \\
\hline Granite King & USCA & Miller Lake & CNNS \\
\hline Grant & USAK & Minto & CNBC \\
\hline Grass Valley & USCA & Mizpah & USAK \\
\hline Green Excelsior & USCA & Mohawk-Dome View & USAK \\
\hline Greenback & USOR & Mokelumne & USCA \\
\hline Gwynne & USCA & Molega & CNNS \\
\hline Hall Creek & $\mathrm{CNBC}$ & Montaque & CNNS \\
\hline Ham \& Birney & USCA & Moore's Flat & USCA \\
\hline Harriet & $\mathrm{CNBC}$ & Moose River & CNNS \\
\hline Harrigan Cove & CNNS & Moosehead & CNNS \\
\hline Hathaway & USCA & Mooseland & CNNS \\
\hline Hazel & USCA & Mormon Bar & USCA \\
\hline Hedley Camp & CNBC & Morning Star & AUVT \\
\hline Henry Ford & USAK & Morris Ravine & USCA \\
\hline Herman & USCA & Mount Bullion & USCA \\
\hline $\mathrm{Hi}-\mathrm{Yu}$ & USAK & Mount Gaines & USCA \\
\hline Hillgrove & AUNS & Mount Pleasant & USCA \\
\hline Hirst-Chichagof & USAK & Mount Shasta & USCA \\
\hline Homestake-McCarty & USAK & Mount Uniacke & CNNS \\
\hline Hornitos & USCA & Mount Vernon & USCA \\
\hline Horseshoe I & USCA & Mountain King & USCA \\
\hline Hunter Valley & USCA & Nalden South & AUVT \\
\hline Iconoclast & USCA & Nashville & USCA \\
\hline Indian Path Mine & CNNS & National & USCA \\
\hline Invincible Lode & NZLD & new Bendigo & AUVT \\
\hline Isaac's Harbour & CNNS & New Era-Rowe & AUVT \\
\hline Jabal Guyan & SAAR & Nimrod & AUVT \\
\hline Jamestown & USCA & North Murphy & USCA \\
\hline Joe Walker & USCA & North Star & USAK \\
\hline Jubilee & NZLD & Nuggetty & AUVT \\
\hline Jubilee-New Jubilee & AUVT & O'Connors & AUVT \\
\hline Julian-Banner & USCA & Old Diggings & USCA \\
\hline $\mathrm{K} \cdot \mathrm{C} \cdot$ & USCA & Oldham & CNNS \\
\hline Kelsey & USCA & Ophir & USCA \\
\hline Kelsey North & USCA & Oregon Bell & USOR \\
\hline Kemptville & CNNS & Oriential & AUVT \\
\hline Killag & CNNS & Oro Grande-Buena Vista & USC \\
\hline Kinsley & USCA & Oturehua Field & NZLD \\
\hline Kinsley North & USCA & Ovens & CNNS \\
\hline Kotchkar Mines & USSR & Oya & JAPN \\
\hline Lake Catcha & CNNS & Paloma-Gwin & USCA \\
\hline Lamphear & USCA & Paparoa Range & NZLD \\
\hline Lawrencetown & CNNS & Patrick & USCA \\
\hline Leipsigate & CNNS & Penryn & USCA \\
\hline Leviathan & AUVT & Phoenix & USCA \\
\hline Liberty & USCA & Pipestem & $\mathrm{CNBC}$ \\
\hline Little Squaw & USAK & Placerville & USCA \\
\hline Locarno & USCA & Pleasant River & CNNS \\
\hline Loch Fyne & AUVT & Porto Rico & CNBC \\
\hline
\end{tabular}


Model 36a--Con.

\begin{tabular}{|c|c|}
\hline Pyramid & USCA \\
\hline R.R. Flat South & USCA \\
\hline Rainbow & USOR \\
\hline Rainbow & USCA \\
\hline Ranch & USCA \\
\hline Ravenswood & NZLD \\
\hline Reefton Goldfield & NZLD \\
\hline Reicher Trost & PLND \\
\hline Renfrew & CNNS \\
\hline Rich & USCA \\
\hline Rich Gulch & USCA \\
\hline Rich Gulch (Virgilia) & USCA \\
\hline Rindge No. 1 & USCA \\
\hline Robert $\mathrm{E}$ & USOR \\
\hline Robertson & USOR \\
\hline Rose of Denmark & AUVT \\
\hline Rosethistle \& Shamrock & AUVT \\
\hline Royal Mountain King & USCA \\
\hline Ryan & USCA \\
\hline Ryan Group & USAK \\
\hline S. Branch Stweiacke & CNNS \\
\hline Sailor's Gully & AUVT \\
\hline Salmon River & CNNS \\
\hline Salsigne & F RNC \\
\hline Sambas & AUVT \\
\hline Sand ford & USAK \\
\hline Scott Bar & USCA \\
\hline Seal Harbour & CNNS \\
\hline Second Relief & CNBC \\
\hline Sesson Mine & USCA \\
\hline Sheep Ranch & USCA \\
\hline Shenandoah Mine & USCA \\
\hline Sliger & USCA \\
\hline Soo & USAK \\
\hline
\end{tabular}

Soulsbyville USCA

South Uniacke CNNS

Spring Gully AUVT

Stonewall USCA

Sultan AUVT

Surf Inlet CNBC

Sutter Creek USCA

Sylvanite USOR

Tangier CNNS

Taylor USCA

Tipperary Mine NZLD

Toombou AUVT

Treadwell Mines USAK

Truscott USCA

Uncle Sam USCA

Upper Seal Harbour CNNS

Valley View USCA

Vogler's Cove CNNS

Ward CNBC

Warrington USCA

Washington USCA

Wattle Gully AUVT

Waverley CNNS

Wayside CNBC

West Gore CNNS

West Jacksonville USCA

Westland NZLD

Whiteburn CNNS

Whitlock East USCA

Whitlock West USCA

Wilshire-Bishop USCA

Wine Harbour CNNS

Yankee Hill USCA

Zeila USCA

LOW--SULFIDE GOLD--QUARTZ VEIN

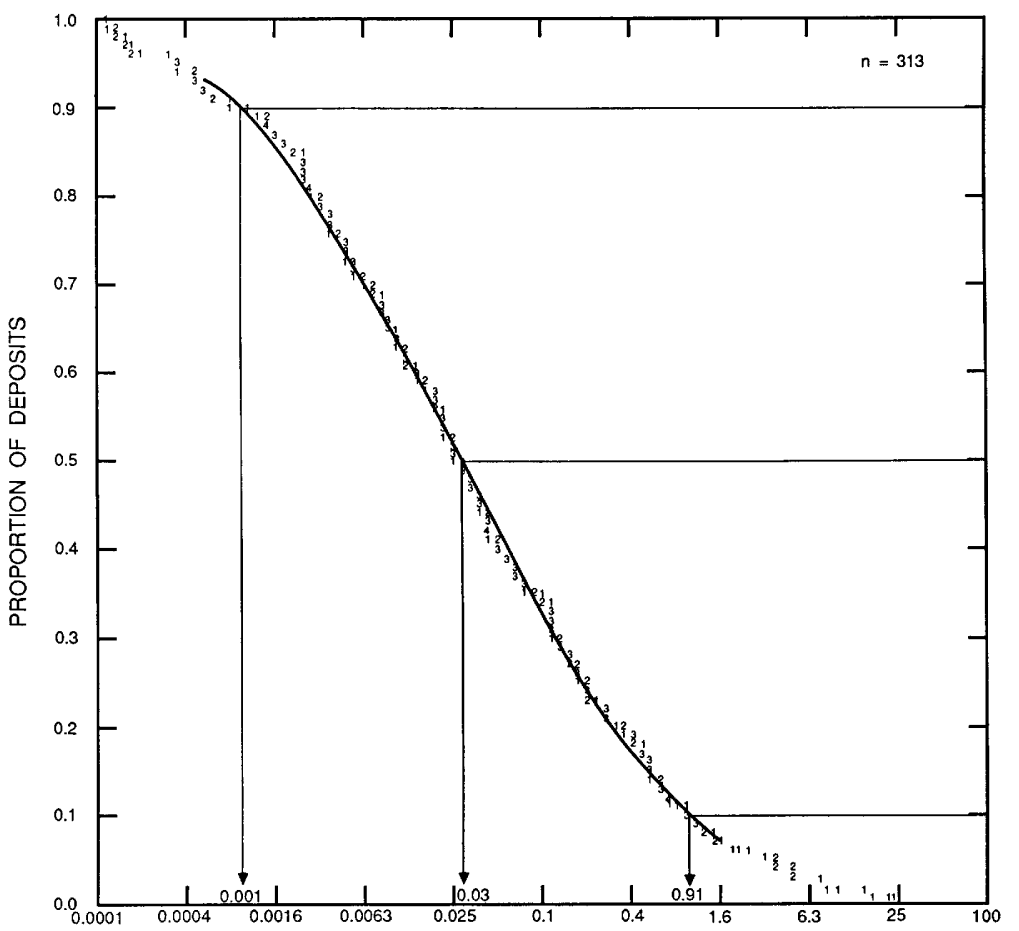

MILLION TONNES
Figure 182. Tonnages of low-sulfide Auquartz vein deposits. 
Model 36a--Con.

LOW--SULFIDE GOLD--QUARTZ VEIN
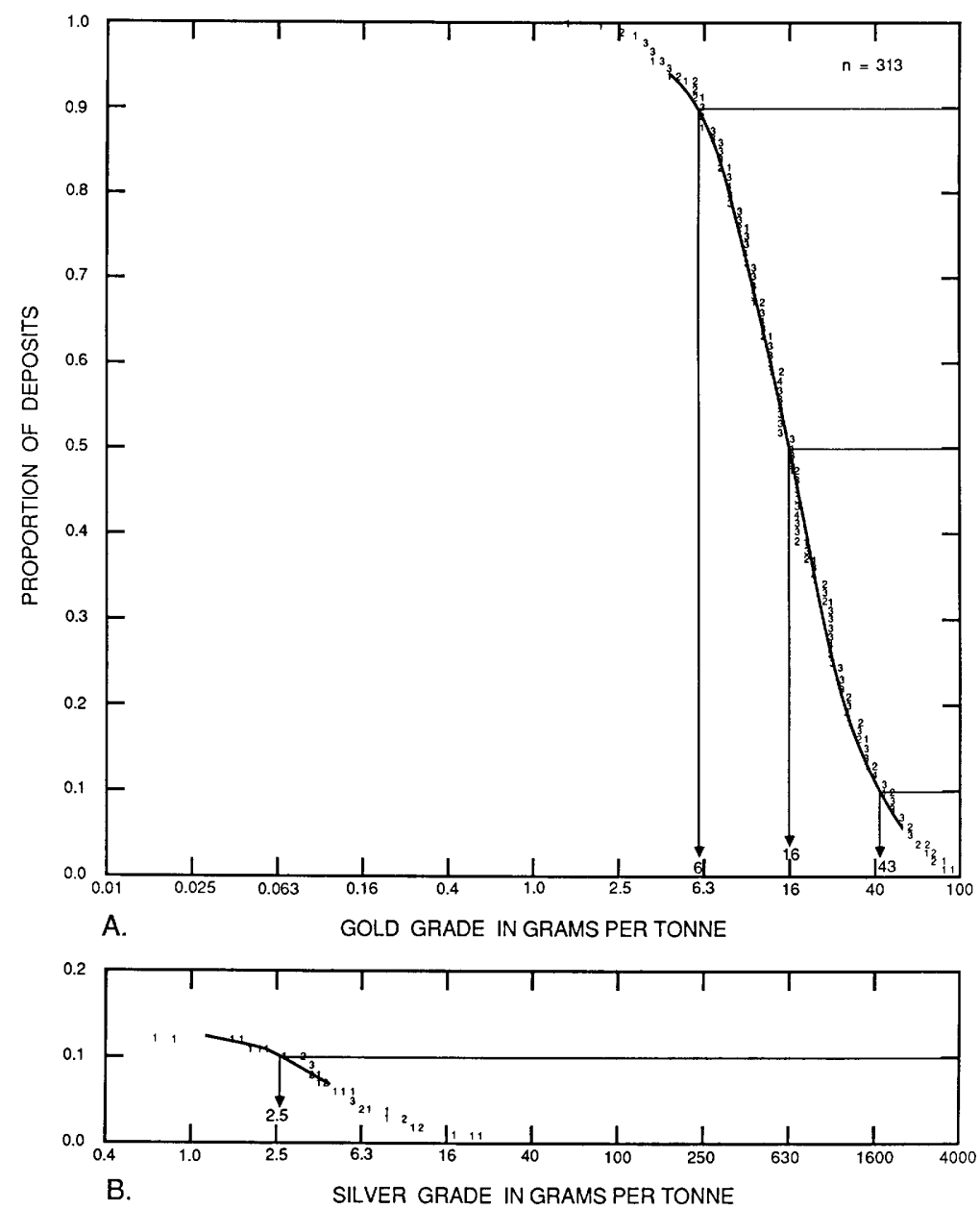

Figure 183. Precious-metal grades of low-sulfide Au-quartz vein deposits. A, Gold. B, Silver. 


\title{
DESCRIPTIVE MODEL OF HOMESTAKE Au
}

\author{
By Byron R. Berger
}

APPROXIMATE SYNONYMS Volcanogenic gold, iron-formation-hosted Au, Archean lode gold.

DESCRIPTION Stratabound to stratiform gold deposits in iron-rich chemical sediments in Archean metavolcanic terrane.

GENERAL REFERENCES Ridler (1970), Hutchinson (1976), Philips and others (1984), Fripp (1976), Colvine and others (1984).

GEOLOGICAL ENVIRONMENT

Rock Types Regionally metamorphosed mafic and felsic metavolcanic rocks, komatiites, and volcaniclastic sediments interlayered with banded iron-formation. Intruded by felsic plutonic rocks and locally by quartz porphyry, and syenite porphyry.

Age Range Mainly Archean.

Depositional Environment Controversial: submarine hot-spring activity related to volcanism, or later hydrothermal activity related to intrusive rocks.

Tectonic Setting(s) Archean greenstone belts. Commonly near regional division or "break" between predominantly metavolcanic and predominantly metasedimentary rocks. Greenschist-facies metamorphism.

Associated Deposit Types Kuroko massive sulfide deposits, Algoma Fe, low-sulfide gold-quartz veins.

\section{DEPOSIT DESCRIPTION}

Mineralogy Native gold + pyrite + pyrrhotite \pm arsenopyrite \pm magnetite \pm sphalerite \pm chalcopyrite. May contain minor tetrahedrite + scheelite + wolframite + molybdenite \pm fluorite \pm stibnite. Realgar at Hemlo deposit. Some deposits show zoning from proximal pyrrhotite \pm magnetite to distal arsenopyrite.

Texture/Structure Narrow thinly laminated beds, veins, or lenses, overlying stringers (stockworks).

Alteration Host rocks contain quartz + siderite and (or) ankerite + tourmaline + chlorite + magnetite in mafic volcanic terranes. Chromian mica and chlorite particularly around veins and stockworks. Banded oxide-facies iron-formation replaced by pyrite or pyrrhotite.

Ore Controls Bedded ores in Fe-rich siliceous or carbonate-rich chemical sediments with vein and stockworks in feeder zones to these sediments, often interlayered with flow rocks. Beds may be cut by condordant or sharply discordant quartz-carbonate veins with gold.

Weathering Gossans from oxide and carbonate iron-formation.

Geochemical Signature $\mathrm{Au}+\mathrm{Fe}+\mathrm{As}+\mathrm{B}+\mathrm{Sb}$ (+ platinum-group metals in mafic volcanic terranes). $\mathrm{Bi}, \mathrm{Hg}$, and minor $\mathrm{Cu}-\mathrm{Pb}-\mathrm{Zn}-\mathrm{Ag}-\mathrm{Mo}$.

\section{EXAMPLES}

Homestake, USSD

Passagem, BRZL

Dome Mine, CNON

Agnico Eagle, CNQB

Vubachikwe, ZIMB
(Rye and Rye, 1974)

(Fleisher and Routhier, 1973)

(Fryer and others, 1979)

(Barnett and others, 1982)

(Fripp, 1976) 
Model 36b--Con.

\section{GRADE AND TONNAGE MODEL OF HOMESTAKE Au}

By Dan L. Mosier

COMMENTS Deposits were combined when they occur within $1.6 \mathrm{~km}$ of

each other. Grades and tonnages were not found to be significantly different for deposits associated with different host rocks. See figs. 184-186

\section{DEPOSITS}

$\underline{\text { Name }}$

Agassiz

Albino

Ankerite-Aunor-Delnite

Arrowhead

Ashley

Bankfield-Tombill

Barbara-Surprise

Barber-Larder

Barberton

Barry Hollinger

Bellevue

Bidgood-Moffatt-Hall

Big Bell

Black Range-Oroya

Bob

Bonnievale

Bouscadillac and others

Broulan and others

Buffalo Red Lake

Burbanks

Calder-Bousquet

Campbell Red Lake-Dickenson

Carshaw-Tommy Burns

Cathroy Larder

Central Manitoba

Central Patricia

Cheminis-Fernland-Omega CNON

Chesterville

Connemara

Coolgardie

Copperhead

Cosmopolitan

Cullaton Lake

Davidson

Day Dawn-Main Line AUWA

De Santis CNON

Dome-Paymaster-Preston CNON

Edna May AUWA

Emu-Great Eastern AUWA

Fraser's AUWA

Fuller-Tisdale CNON

Geita TNZN

Gimlet-Slippery AUWA

Gladstome-Sand Queen AUWA

God's Lake CNMN

Gold Eagle-McKenzie CNON

Gold Hawk CNON

Gold Hill CNON

Golden Ridge AUWA

Gongo Socco country

CNON

NON

CNON

NON

UNON

AFR

AUWA

NON

AUWA

IMB

NON

NON

AWA

NQU

NON

NON

NMN

TON

NON

AUWA

UWA

UWA

CNNT

CNON

A

N

A

WA

ON

ZN

WA

N

ON

BRZL

\begin{tabular}{|c|c|}
\hline Name & Country \\
\hline Gurney & CNMN \\
\hline Hard Rock-McLeod-Cockshutt & CNON \\
\hline Hasaga-Howey & CNON \\
\hline Hollinger and others & CNON \\
\hline Homestake & USSD \\
\hline Hutti & INDA \\
\hline Ida $\mathrm{H}$ & AUWA \\
\hline Island Lake & CNMN \\
\hline Jason & CNON \\
\hline Jerome & CNON \\
\hline Kerr Addison & CNON \\
\hline Kiabakari & TNZN \\
\hline Kilo-Moto & CNGO \\
\hline Kolar & INDA \\
\hline Laguerre & CNON \\
\hline Lancefield & AUWA \\
\hline Lapa Cadillac & CNQU \\
\hline Leitch-Sand River & CNON \\
\hline Lingman & CNON \\
\hline Little Long Lac & CNON \\
\hline Madsen & CNON \\
\hline Magnet Cons. & CNON \\
\hline Marble Bar & AUWA \\
\hline Martin-Bird & CNON \\
\hline Matachewan Cons. \& others & CNON \\
\hline Matona-Stairs & CNON \\
\hline McFinley & CNON \\
\hline McMarmac & CNON \\
\hline McWatters & CNQU \\
\hline Menzies & AUWA \\
\hline Minto-Tyranite & CNON \\
\hline Morris-Kirkland & CNON \\
\hline Morro Velho & BRZL \\
\hline Mt. Magnet & AUWA \\
\hline Mt. Morgans & AUWA \\
\hline Naybob & CNON \\
\hline Nobles Nob & AUWA \\
\hline Norseman-Dundas & AUWA \\
\hline Orpit & CNON \\
\hline Paddy's Flat & AUWA \\
\hline Palmer's Find & AUWA \\
\hline Passagem & BRZL \\
\hline Pickle Crow & CNON \\
\hline Queenston & CNON \\
\hline Raposos & BRZL \\
\hline Red Crest & CNON \\
\hline Red Lake Gold Shore & CNON \\
\hline Ross & CNON \\
\hline Rouyn Merger & CNQU \\
\hline Sanshaw & CNON \\
\hline
\end{tabular}


Model 36b--Con.

Shamva-Cymric Gp.

Son of Gwalia

Stadacona

Starratt-0lsen

Talmora Longlac

Thompson Bousquet

Timoni

Triton
ZIMB

AUWA

CNQU

CNON

CNON

CNQU

AUWA

AUWA
Uchi

Upper Beaver

Upper Canada

Wasa Lake

White Feather

Wilmar and others

Wiluna-Moonlight

Youanmi
CNON

CNON

CNON

CNQU

AUWA

CNON

AUWA

AUWA

HOMESTAKE GOLD

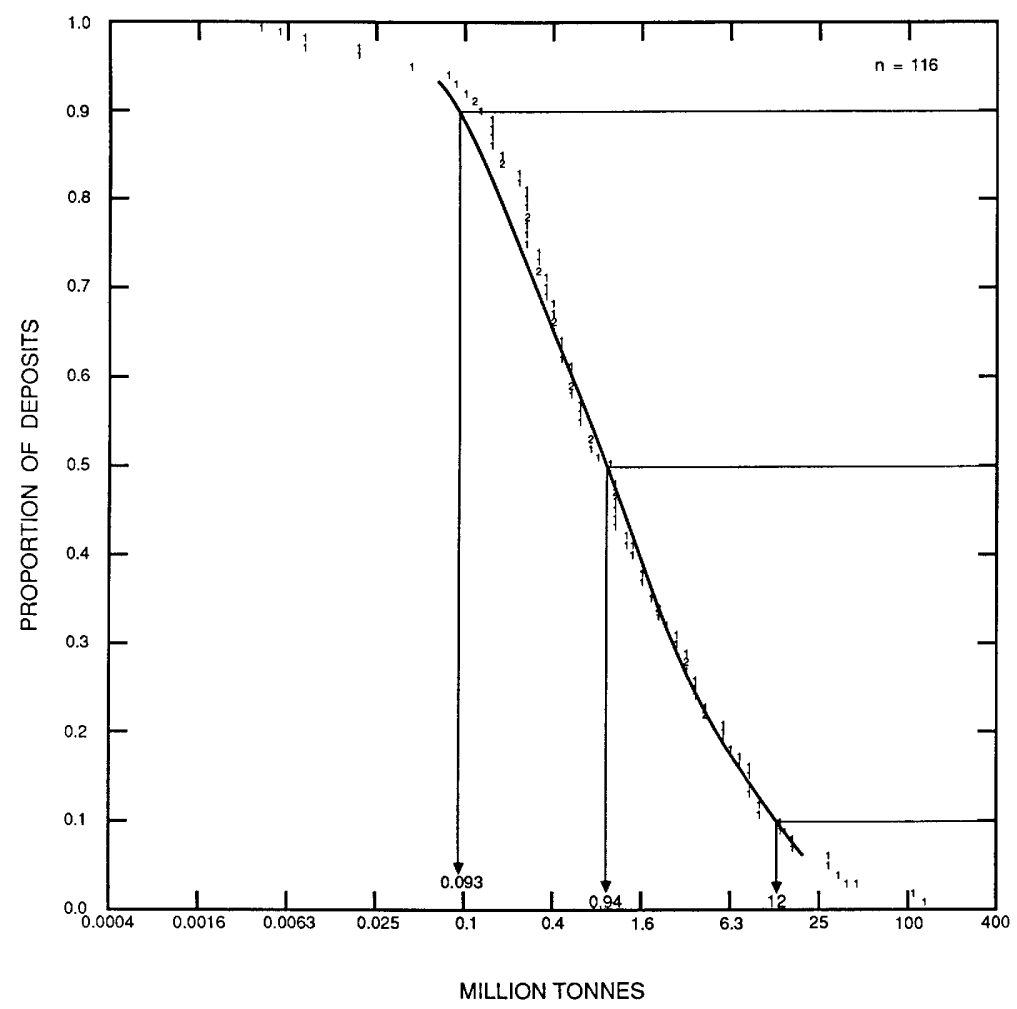

Figure 184. Tonnages of Homestake Au deposits. 
Model 36b--Con.

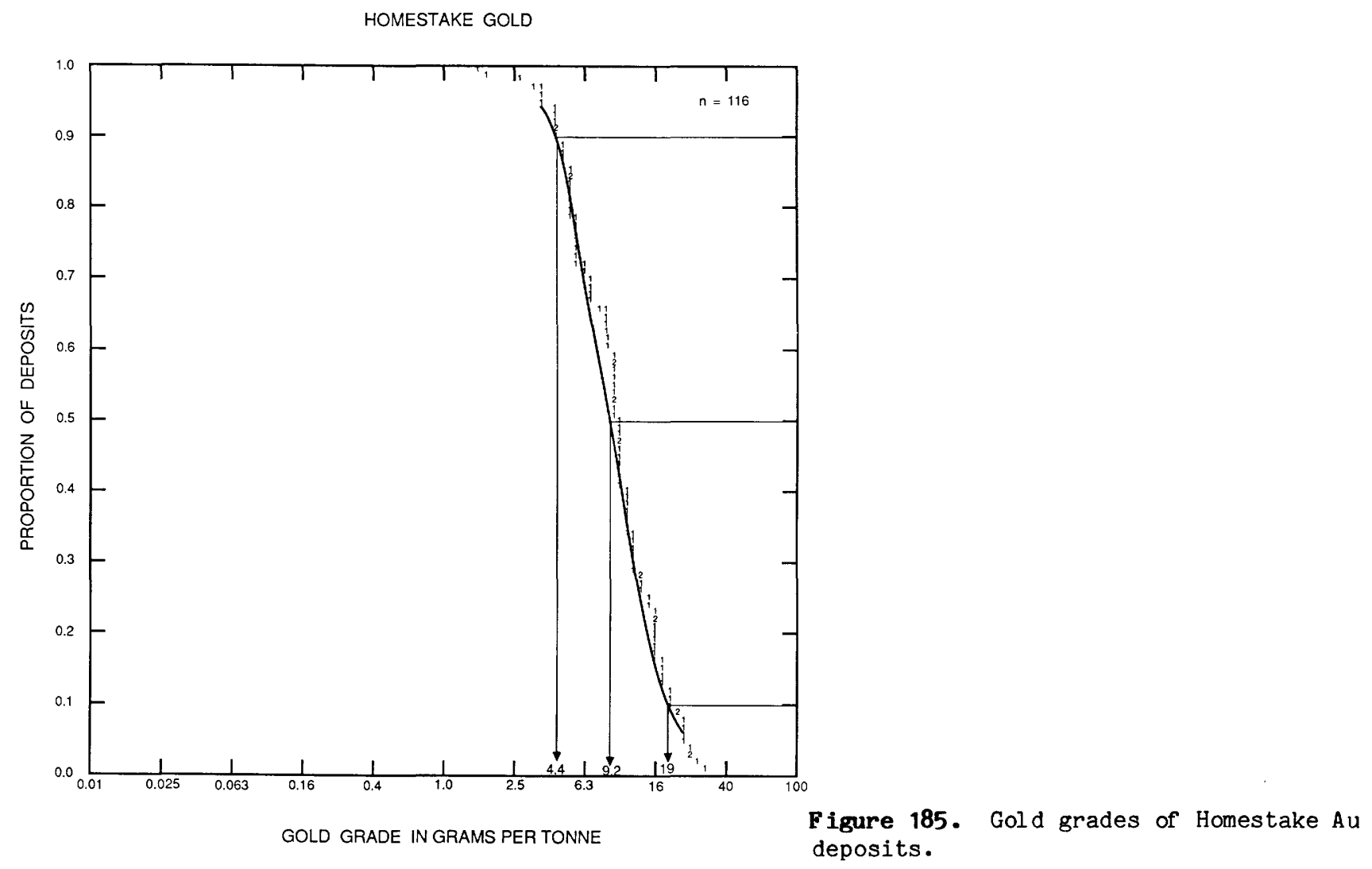

HOMESTAKE GOLD

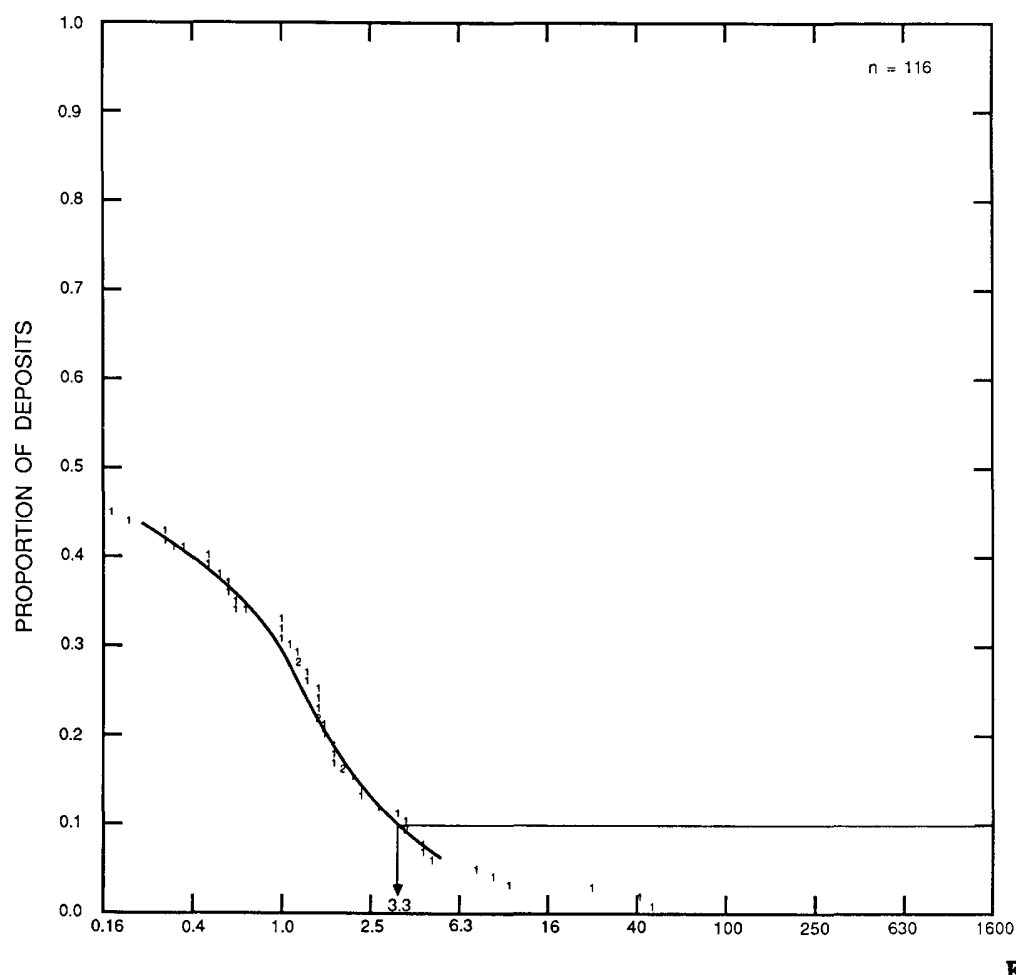

Figure 186. Silver grades of Homestake Au deposits. 
Model 37 a

\section{DESCRIPTIVE MODEL OF UNCONFORMITY U-Au}

By Richard I. Grauch and Dan L. Mosier

APPROXIMATE SYNONYM Veinlike type U (Dahlkamp and Adams, 1981).

DESCRIPTION Uranium mineralization occurs as fracture- and breccia-filling in metapelites, metapsammites and quartz arenites located below, above, or across an unconformity separating Early and Middle Proterozoic rocks.

GENERAL REFERENCE Nash and others (1981).

GEOLOGICAL ENVIRONMENT

Rock Types Regionally metamorphosed carbonaceous pelites, psammites, carbonate rocks. Younger unmetamorphosed quartz arenites.

Textures Metamorphic foliation and later brecciation.

Age Range In rocks of Early and Middle Proterozoic age (1,800-1,200 m.y.), affected by Proterozoic regional metamorphism.

Depositional Environment Host rocks are sedimentary shelf deposits and overlying continental sandstone. Deposits result from complex processes including regional metamorphism, weathering and supergene enrichment related to Proterozoic unconformity, and later remobilization and enrichment beneath cover of younger strata.

Tectonic Setting(s) Intracratonic sedimentary basins on the flanks of Archean domes. Tectonically stable since Middle Proterozoic.

Associated Deposit Types Gold-and nickel-rich uranium deposits may occur but are poorly understood and no models are available.

\section{DEPOSIT DESCRIPTION}

Mineralogy Pitchblende + uraninite \pm coffinite \pm pyrite \pm chalcopyrite \pm galena \pm sphalerite \pm arsenopyrite \pm niccolite. Chlorite + quartz + calcite + dolomite + hematite + siderite + sericite. Locally late quartz-chlorite veins contain native gold or silver, uraninite, galena, and tellurides of $\mathrm{Bi}, \mathrm{Ni}, \mathrm{Pb}$ and $\mathrm{Pd}$. Latest quartz-calcite veins contain pyrite, chalcopyrite, and bituminous matter.

Texture/Structure Breccia filling, veins, and disseminations. Coarse euhedral uraninite and fine colloform pitchblende. Latest quartz-calcite veins show open-space fillings, colloform texture.

Alteration Multistage chloritization is dominant. Local sericitization, dolomitization, hematitization, kaolinitization. Incipient and vuggy vein-type silicification occur throughout the alteration envelope. Alteration envelope is variably enriched in $\mathrm{Mg}, \mathrm{P}$, REE, and a variety of metals. Alkali elements are depleted.

Ore Controls Fracture porosity controlled ore distribution in the metamorphites and to a limited extent in the overlying quartz arenite. The unconformity acted as a major disruption in the flow of ore-forming fluids but did not necessarily act as a locus of ore formation.

Weathering Secondary U minerals uranyl-phosphate, metatorbernite, autunite, uranophane, gummite, sklodowskite.

Geochemical and Geophysical Signature Increase in U, Mg, $\mathrm{P}$ and locally in $\mathrm{Ni}, \mathrm{Cu}, \mathrm{Pb}, \mathrm{Zn}, \mathrm{Co}, \mathrm{As}$; decrease in $\mathrm{SiO}_{2}$. Locally Au, associated with $\mathrm{Ag}, \mathrm{Te}, \mathrm{Ni}, \mathrm{Pd}, \mathrm{Re}, \mathrm{Mo}, \mathrm{Hg}, \mathrm{REE}, \mathrm{Y}$ and $\mathrm{Rb}$. Anomalous radioactivity. Graphitic schists in some deposits are strong electromagnetic conductors.

EXAMPLES

Rabbit Lake, CNSK

CIuff Lake, CNSK

(Hoeve and Sibbald, 1978)

(Laine, 1985) 
Key Lake, CNSK
Jabiluka, AUNT
Ranger, AUNT
(Dahlkamp, 1978)

(Binns and others, 1980, Grauch, 1984)

(Eupene, 1979)

GRADE AND TONNAGE MODEL OF UNCONFORMITY U-Au

By Dan L. Mosier

COMMENTS Deposits are defined by a separation of $100 \mathrm{~m}$ stratigraphically and along strike. Sufficient number of Au grades were not available to construct a plot. See figs. 187, 188.

\section{DEPOSITS}

Name

Cluff Lake-Claude

Cluff Lake D

Cluff Lake $\mathrm{N}$

Cluff Lake OP

Cluff Lake $R$

Cluff Bay A

Cluff Bay B

Dawn Lake

Dyson's (Rum Jungle)

El Sherana

El Sherana West

Fond-du-Lac

Jabiluka I

Jabiluka II

Key Lake (Deilmann)

Key Lake (Gaertner)

Koolpin Creek

Koongarra

\section{Country}

CNSK

CNSK

CNSK

CNSK

CNSK

CNSK

CNSK

CNSK

AUNT

AUNT

AUNT

CNON

AUNT

AUNT

CNSK

CNSK

AUNT

AUNT
Name

McClean Lake

Maurice Bay

Midwest Lake

Mount Burton (Rum Jungle)

Mount Finch (Rum Jungle) AUNT

Nabarlek

Palette

Rabbit Lake

Ranger No. 1

Ranger No. 3

Rockhole-Teages

Scinto 5

Skull

Sleisbeck

Stewart Island

West Bear

White's (Rum Jungle)
Country

CNSK

CNSK

CNSK

AUNT

AUNT

CNSK

AUNT

AUNT

AUNT

AUNT

AUNT

AUNT

AUNT

CNSK

CNSK

AUNT 
Model 37a--Con.

UNCONFORMITY URANIUM--GOLD

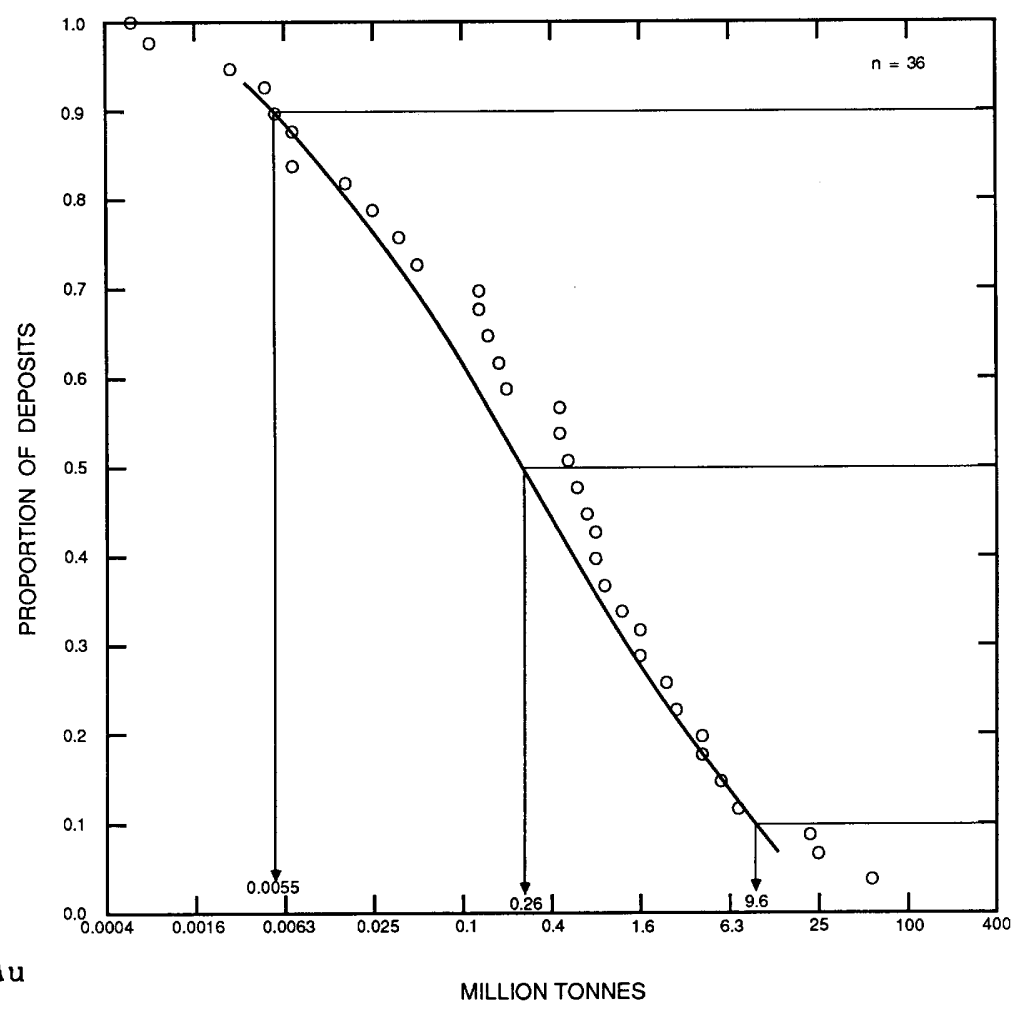

Ponnages of unconformity 187 . Tou deposits.

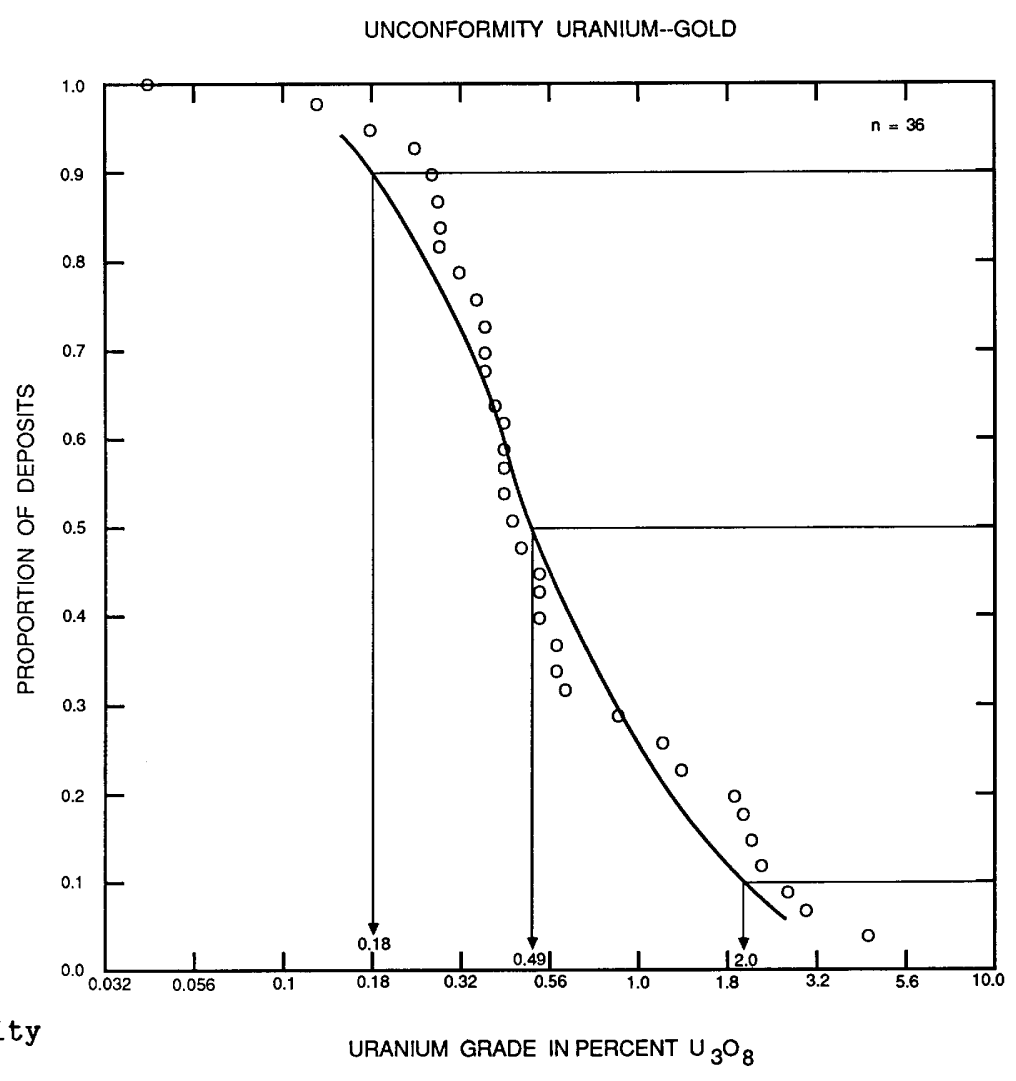

Figure 188. Uranium grades of unconformity U-Au deposits. 


\section{DESCRIPTIVE MODEL OF GOLD ON FLAT FAULTS}

By Bruce A. Bouley*

DESCRIPTION Disseminated gold in breccia along low-angle faults

GENERAL REFERENCE Wilkins (1984).

GEOLOGICAL ENVIRONMENT

Rock Types Breccia derived from granitic rocks, gneiss, schist, mylonite and unmetamorphosed sedimentary and volcanic rocks. Rhyolitic dikes and plugs.

Textures Chaotic jumble of rock and vein material.

Age Range Unknown. Examples in southern California and southwestern Arizona are mainly Mesozoic and Tertiary.

Depositional Environment Permeable zones: source of heat and fluids unknown.

Tectonic Setting(s) Low-angle faults in crystalline and volcanic terrane. Including detachment faults related to some metamorphic core complexes and thrust faults related to earlier compressives regimes.

Associated Deposit Types Epithermal quartz adularia veins in hanging-wall rocks of some districts. DEPOSIT DESCRIPTION

Mineralogy Gold, hematite, chalcopyrite, minor bornite, barite, and fluorite.

Texture/Structure Micrometer-size gold and specular hematite in stockwork veining and brecciated rock.

Alteration Hematite, quartz, and chlorite. Silicification. Carbonate minerals.

Ore Controls Intensely brecciated zones along low-angle faults. Steep normal faults in hanging wall. Sheeted veins.

Weathering Most ore is in oxidized zone because of lower cost of recovery. Mn oxides.

Geochemical Signature $\mathrm{Au}, \mathrm{Cu}, \mathrm{Fe}, \mathrm{F}, \mathrm{Ba}$. Very low level anomalies in $\mathrm{Ag}, \mathrm{As}$, $\mathrm{Hg}$, and $\mathrm{W}$.

EXAMPLES :

Picacho, USCA

Copper Penny and Swansea, USAZ

(Van Nort and Harris, 1984)

(Wilkins and Heidrick, 1982)

* Present address: Callahan Mining Corp., 6245 North 24 th Street, Phoenix, AZ 85016. 
Model $38 \mathrm{a}$

\title{
DESCRIPTIVE MODEL OF LATERITIC Ni
}

\author{
By Donald A. Singer
}

DESCRIPTION Nickel-rich, in situ lateritic weathering products developed from dunites and peridotites. Ni-rich iron oxides are most common. Some deposits are predominantly Ni silicates.

GENERAL REFERENCE Evans and others (1979).

GEOLOGICAL ENVIRONMENT

Rock Types Ultramafic rocks, particularily peridotite, dunite, and serpentinized peridotite.

Age Range Precambrian to Tertiary source rocks, typically Cenozoic weathering.

Depositional Environment Relatively high rates of chemical weathering (warm-humid climates) and relatively low rates of physical erosion.

Tectonic Setting(s) Convergent margins where ophiolites have been emplaced. Uplift is required to expose ultramafics to weathering.

Associated Deposit Types Podiform chromite, PGE placers, serpentine-hosted asbestos.

DEPOSIT DESCRIPTION

Mineralogy Garnierite, poorly defined hydrous silicates, quartz, and goethite. Goethite commonly contains much $\mathrm{Ni}$.

Texture/Structure Red-brown pisolitic soils, silica-rich boxworks.

Alteration Zoned--from top: (1) Red, yellow, and brown limonitic soils; (2) saprolites-continuous transition from soft saprolite below limonite zone, hard saprolite and saprolitized peridotite, to fresh peridotite. Boxwork of chalcedony and garnierite occurs near bedrockweathered rock.

Ore Controls Upper limonite zone containing 0.5-2 percent $\mathrm{Ni}$ in iron-oxides; lower saprolite and boxwork zone typically contains 2-4 percent $\mathrm{Ni}$ in hydrous silicates. The oxide and silicate ores are end members and most mineralization contains some of both.

Weathering The profile from red-brown pisolitic soil down to saprolite represents the products of chemically weathered ultramafic rocks.

Geochemical Signature Enriched in $\mathrm{Ni}$, Co, $\mathrm{Cr}$; depleted in $\mathrm{MgO}$ relative to fresh peridotite (less than 40 percent $\mathrm{MgO})$.

\section{EXAMPLES}

Poro, NCAL

(Troly and others, 1979)

Cerro Matoso, CLBA

(Gomez and others, 1979)

Nickel Mountain, USOR

(Chace and others, 1969)

Greenvale, AUQL

(Burger, 1979)

\section{GRADE AND TONNAGE MODEL OF LATERITIC Ni}

By Donald A. Singer

COMMENTS Higher grades are typically associated with the silicate type. Numerous low-grade (less than 1 percent $\mathrm{Ni}$ ) and low-tonnage deposits are not included. Nickel grade is correlated with tonnage $(r=-0.31)$. See figs. 189,190 . 
DEPOSITS

Name

Ambatory
Analumay
Barro Alto
Berong
Bhimatangar
Blue Ridge
Br. Solomon Is.
Buka
Cabo Rojo
Cerro Matoso
Claude Hills
Cyclops
Dinagat Is.
Euboea
Exmibal
Falconbridge
Gag Is.
Golesh Mt.
Golos
Goro
Greenvale
Hagios Ioannis
Halmahera
Ipaneme
Jacupuenga
Kaliapani
Kansa
Kauadarci
Laguney
Lake Joanina
Leviso R.
Loma de Hierro
Long Point
Marlborough
Masinloc
Mayari

Country
MDGS
MDGS
BRZL
PLPN
INDA
PLPN
SLMN
PLPN
PTRC
CLBA
AUSA
INDS
PLPN
GREC
GUAT
DMRP
INDS
YUGO
YUGO
NCAL
AUQL
GREC
INDS
BRZL
BRZL
JNDA
INDA
YUGO
PLPN
GREC
CUBA
VNZL
PLPN
AUQL
PLPN
CUBA

Name

Moa Bay

Moorsom

Moramanga

Morro de Engenho

Mwaytung

Nepoui

New Frontier

Niquelandia

Nonoc

Obi.

Ora Banda

Orsk

Pujada Pen.

Pomalea

Poro

Poum

Pratapolis

Prony

Ramona-Loma

Riddle

Rio Tuba

Sablayon

Sao Joaodo Piaui.

Santa Cruz

Saruabi

S.E. Kalimantan

Sidamo

Simlipal

Soroako

Sukinda

Suriagao

Taco Bay

Thio

Tiebaghi

Wingelinna-Daj.sy
Country

CUBA

PLPN

MDGS

BRZL

BRMA

NCAL

PLPN

BRZL

PLPN

INDS

AUWA

URRS

PLPN

INDS

NCAL

NCAL

BRZL

NCAL

CUBA

USOR

PLPN

PLPN

BRZL

PLPN

INDA

INDS

ETHP

INDA

INDS

INDA

PLPN

CUBA

NCAL

NCAL

AUWA 
LATERITIC NICKEL

Model 38a--Con.

Figure 189. Tonnages of lateritic $\mathrm{Ni}$ deposits.

Figure 190. Metal grades of lateritic $\mathrm{Ni}$ deposits. A, Nickel. $\underline{B}$, Cobalt.
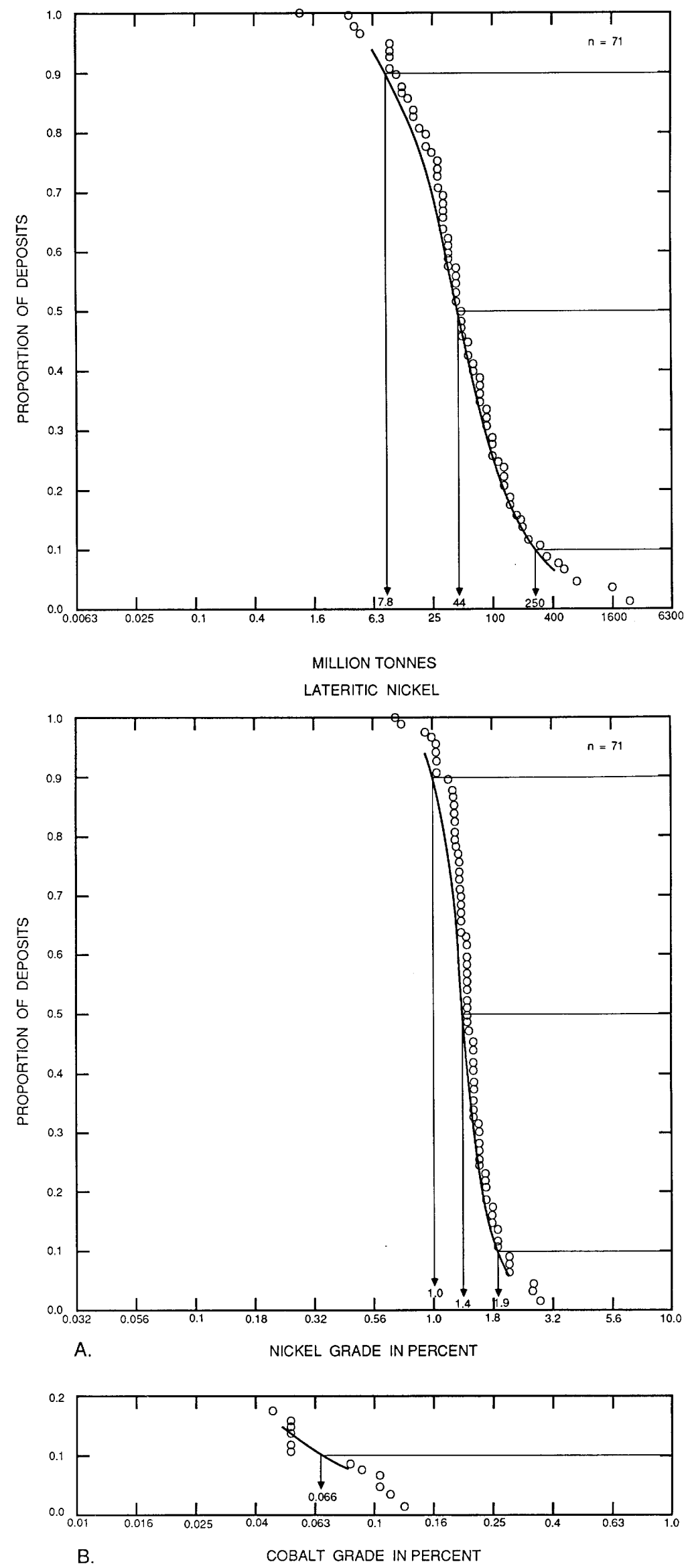


\section{DESCRIPTIVE MODEL OF LATERITE TYPE BAUXITE DEPOSITS}

By Sam H. Patterson

APPROXIMATE SYNONYM Aluminum ore (Patterson, 1967).

DESCRIPTION Weathered residual material in subsoil formed on any rock containing aluminum.

GENERAL REFERENCE Patterson (1984).

GEOLOGICAL ENVIRONMENT

Rock Types Weathered rock formed on aluminous silicate rocks.

Textures Pisolitic, massive, nodular, earthy.

Age Range Mainly Cenozoic, one Cretaceous deposit known.

Depositional Environment Surficial weathering on well-drained plateaus in region with warm to hot and wet climates. Locally deposits in poorly drained areas low in $\mathrm{Fe}$ due to its removal by organic complexing.

Tectonic Setting(s) Typically occurs on plateaus in tectonically stable areas.

Associated Deposit Types Overlain by thin "A" horizon soil, underlain by saprolite (parent rock in intermediate stages of weathering).

DEPOSIT DESCRIPTION

Mineralogy Mainly gibbsite and mixture of gibbsite and boehmite; gangue minerals hematite, goethite, anatase, locally quartz.

Texture/Structure Pisolitic, massive, earthy, nodular.

Alteration Aluminous rocks are altered by weathering to bauxite.

Ore Controls Thoroughly weathered rock, commonly erosional boundaries of old plateau remnants.

Weathering Intensive weathering required to form bauxite. Bauxite continues to form in present weathering environment in most deposits.

Geochemical Signature: Al, Ga.

EXAMPLES

Australia, Brazil, Guinea

examples are reviewed in

Patterson (1967)

GRADE AND TONNAGE MODEL OF LATERITE TYPE BAUXITE DEPOSITS

By Dan L. Mosier

REFERENCES Patterson (1967) and numerous other papers.

COMMENTS A district has been defined as a deposit or a group of deposits in which each deposit is not separated by more than $20 \mathrm{~km}$ from an adjacent deposit. Using this rule, most district names in the published literature have been retained; however, some previously regarded districts have been divided into two or more districts, which therefore are named after the largest deposit in that district or a local place name. See figs. 191, 192. 
Model 38b--Con.

\section{DEPOSITS}

Name

Affoh

Almeirim

Alumen

Analavory

Anantagiri

Asafo

Aurukum

Awaso

Ayekoye

Bihar

Bakhuis Mountains

Balea-Sitaouma

Bamboutos

Bangam

Barao de Cocais-Caete

Barra do Piraj.

Bhavnagar

Bilaspur

Bintan Island

Blue MountainsOko Mountains

Boe

Bom Repouso-Cambuj.

Boolarra

Caldas

Cape Bougainville

Caroline Islands

Cataguases

Champagne (Oakwood)

Chintapalli-Gurtedu

Chittering

Croker Island

D'Ana lamaitso

D'Ankazobe

Dabola

Debele (Kindia)

Del Park-Huntly

Descoberto

Divinolandia de Minas

East Maui

Emmaville

Fenoarivo

Fongo Tongo

Fria-Kimbo

Gambe

Gove

Hampton

Iles de Los

Intendencia de Arauca

Irituia

Itanhandu-Resende

Jamirapat-Khuria

Jamnagar (Saurashtra)

Jarrahdale

Kalahandi-Koraput

Kauaj.

Kaw Mountains

Kerikeri

Kheda (Kaira)
Country

GHNA

BRZL

MZMB

MDGS

INDA

GHNA

AUQL

GHNA

GNEA

INDA

SRNM

MALI

CMRN

CMRN

BRZL

BRZL

INDA

INDA

INDS

GUYN

GNBS

BRZL

AUVT

BRZL

AUWA

CARL

BRZL

AUNS

INDA

AUWA

AUNT

MDGS

MDGS

GNEA

GNEA

AUWA

BRZL

BRZL

USHI

AUNS

MDGS

CMRN

GNEA

BRZL

AUNT

AUQL

GNEA

CLBA

BRZL

BRZL

INDA

INDA

AUWA

INDA

USHI

FRGN

NZLD

INDA
Name

Khushab (Sargohda) PKTN

Kibi GHNA

Kolaba-Ratnagiri. INDA

Kolhapur INDA

Koro Plateau CHAD

Kutch INDA

Los Pijiguaos VNZL

Maikala Range INDA

Majnpat INDA

Manantenina MDGS

Manus Island PPNG

Marangaka MDGS

Marchinbar Island AUNT

Mariana BRZL

Mazagao BRZL

Mimoso do Sul BRZL

Minim-Martap CMRN

Mitchell Plateau AUWA

Mlanje Mountain MLWI

Moengo SRNM

Mogi das Cruzes BRZL

Mokanji Hills SRLN

Monghyr INDA

Moss Vale AUNS

Mount Ejuanema-Nsisreso AUNS

Mount Saddleback AUWA

Myalla AUNT

Nassau Mountains SRNM

Nhamunda BRZL

Nilgiri Hills INDA

North Weipa AUQL

Northern Ireland IRLD

Nuria VNZL

NW Group GUYN

Nyinahin GHNA

Ourem BRZL

Ouse AUTS

Palni. Hills INDA

Paragominas BRZL

Paranam SRNM

Parish AUNS

Pocos de Caldas-Aguas BRZL

Ramunia-Telok Ramunia MLYS

Ranchi-Palamau INDA

St. Leonards AUTS

Salem Hills USOR

Saline-Pulaski USAR

Sambalpur INDA

Sangaredi GNEA

Santa Barbara BRZL

Sao Domingos do Capim BRZL

Sao Paulo BRZL

Shevaroy Hills INDA

South Weipa AUQL

Tamboriné Mountajn AUQL

Tougue GNEA

Trombetas BRZL

Turtle Head AUQL 
Model 38b--Con.

$\begin{array}{llll}\text { Upata } & \text { VNZL } & \text { Wenlock River } & \text { AUQL } \\ \text { Valle del General } & \text { CORI } & \text { West Maui } & \text { USHI } \\ \text { Weipa-Andoom-Pera Head } & \text { AUQL } & \text { Weza } & \text { SAFR }\end{array}$

BAUXITE, LATERITE TYPE

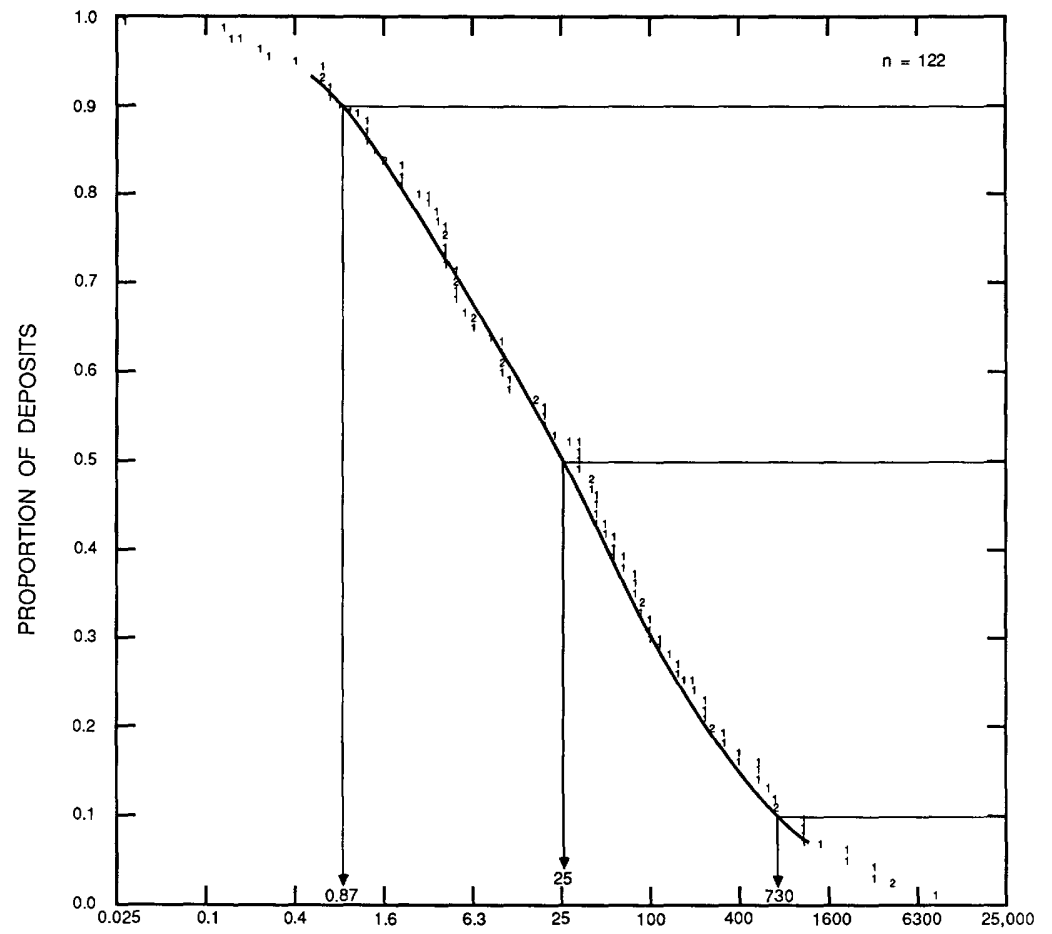

Figure 191. Tonnages of laterite-type bauxite deposits. Individual digits represent number of deposits.

MILLION TONNES

BAUXITE, LATERITE TYPE

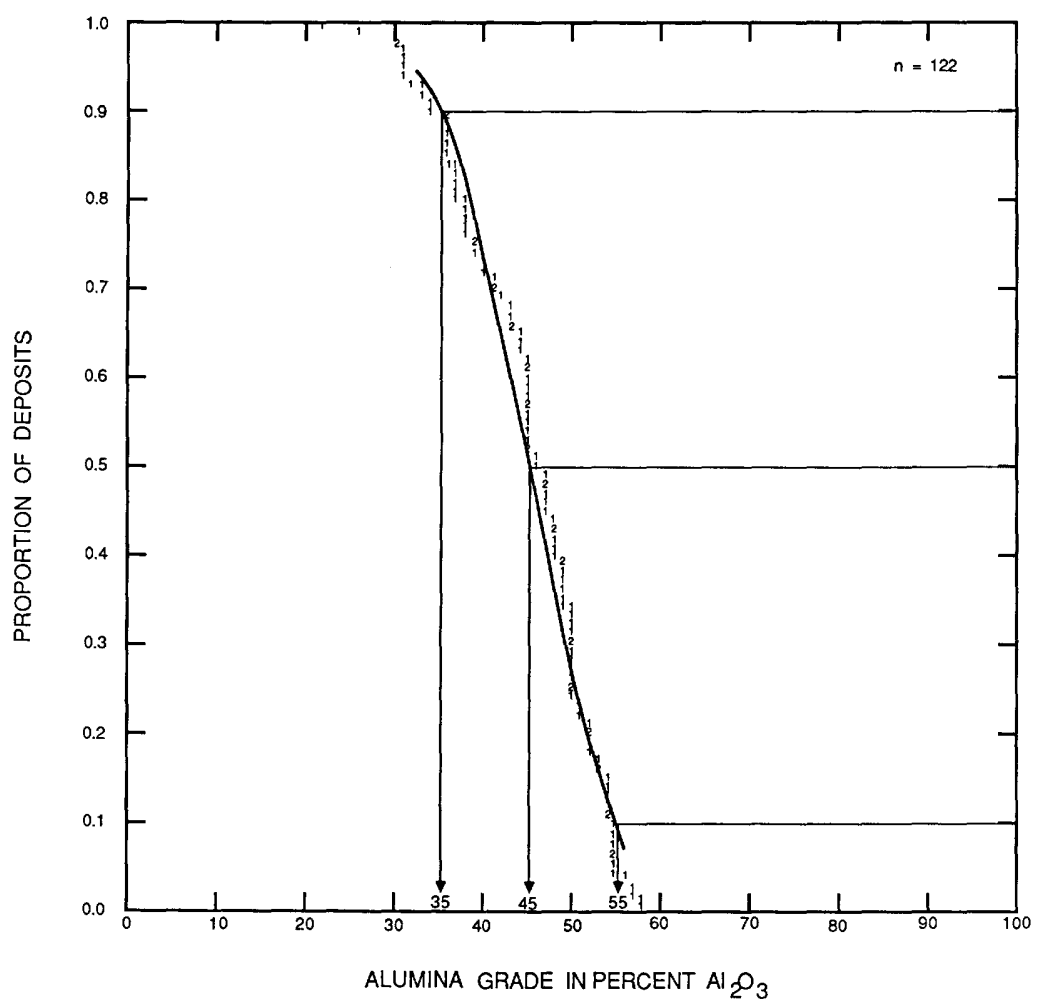

Figure 192. Alumina grades of lateritetype bauxite deposits. Individual digits represent number of deposits. 
Model $38 \mathrm{c}$

\title{
DESCRIPTIVE MODEL OF KARST TYPE BAUXITE DEPOSITS
}

\author{
By Sam H. Patterson
}

APPROXIMATE SYNONYM Aluminum ore (Bardossy, 1982).

DESCRIPTION Weathered residual and transported materials.

GENERAL REFERENCE Bardossy (1982).

GEOLOGICAL ENVIRONMENT

Rock Types Residual and transported material on carbonate rocks. Transported material may be felsic volcanic ash from a distant source or any aluminous sediments washed into the basin of deposition.

Textures Pisolitic, nodular, massive, earthy.

Age Range Paleozoic to Cenozoic.

Depositional Environment Surficial weathering mainly in wet tropical area.

Tectonic Setting(s) Stable land areas allowing time for weathering and protected from erosion.

Associated Deposit Types Limestone, dolomite, and shale; some are associated with minor coal and are low in $\mathrm{Fe}$ due to organic complexing and removal of Fe during formation.

DEPOSIT DESCRIPTION

Mineralogy Mainly gibbsite in Quaternary deposits in tropical areas. Gibbsite and boehmite mixed in older Cenozoic deposits, boehmite in Mesozoic deposits and in Paleozoic deposits; gangue

minerals hematite, goethite, anatase, kaolin minerals, minor quartz.

Texture/Structure Pisolitic, massive, nodular.

Alteration Formation of bauxite is itself a form of alteration of aluminous sediments.

Ore Controls Deposits tend to be concentrated in depressions on karst surfaces.

Weathering Intense weathering required to form bauxite. Bauxite continues to form in the present weathering environment in most deposits.

Geochemical Signature Al, Ga.

EXAMPLE European and Jamaican examples are reviewed in Bardossy (1982).

\section{GRADE AND TONNAGE MODEL OF KARST TYPE BAUXITE DEPOSITS}

By Dan L. Mosier

COMMENTS See figs. 193, 194.

DEPOSITS

$\underline{\text { Name }}$

Abruzzi

Aceitillar

Adana-Saimbey $1 i$

Akeski

Beceite-

Fuendesplada SPAN

Bulbula
Country

ITLY

DMRP

TRKY

TRKY

IRAN
Name

Camarasa-0liana

Campania

Clarendon Plateau

Drnis-Obrovac

Fenyoto

Gant

Halimba
Country

SPAN

ITLY

JMCA

YUGO

HUNG

HUNG

HUNG 
Model 38c---Con.

$\begin{array}{ll}\text { Imotski-Mostar } & \text { YUGO } \\ \text { Islahiye } & \text { TRKY } \\ \text { Iszkaszentgyorgy } & \text { HUNG } \\ \text { Jajce } & \text { YUGO } \\ \text { LangSen } & \text { VTNM } \\ \text { Maggotty } & \text { JMCA } \\ \text { Manchester Plat. } & \text { JMCA } \\ \text { Megara-Eleusis } & \text { GREC } \\ \text { Muzaffarabad } & \text { PKTN } \\ \text { Nagyegyhaza } & \text { HUNG } \\ \text { N.C. Puerto Rico } & \text { PTRC } \\ \text { N.E. Alabama } & \text { USAL } \\ \text { Niksicka Zupa } & \text { YUGO } \\ \text { N.W. Georgia } & \text { USGA } \\ \text { Nyirad } & \text { HUNG }\end{array}$

Padurea Craiului RMNA

Parnassus-Helikon GREC

Payas TRKY

Punch INDA

Rochelois Plat. HATI

San Giovanni

Rotondo ITLY

Seydisehr TRKY

Sohodol-Cimpeni RMNA

Spinazzola ITLY

St. Ann Plateau JMCA

Unterlaussa ASTR

Vlasenica YUGO

Zonguldak TRKY 
Model 38c--Con.

BAUXITE, KARST TYPE

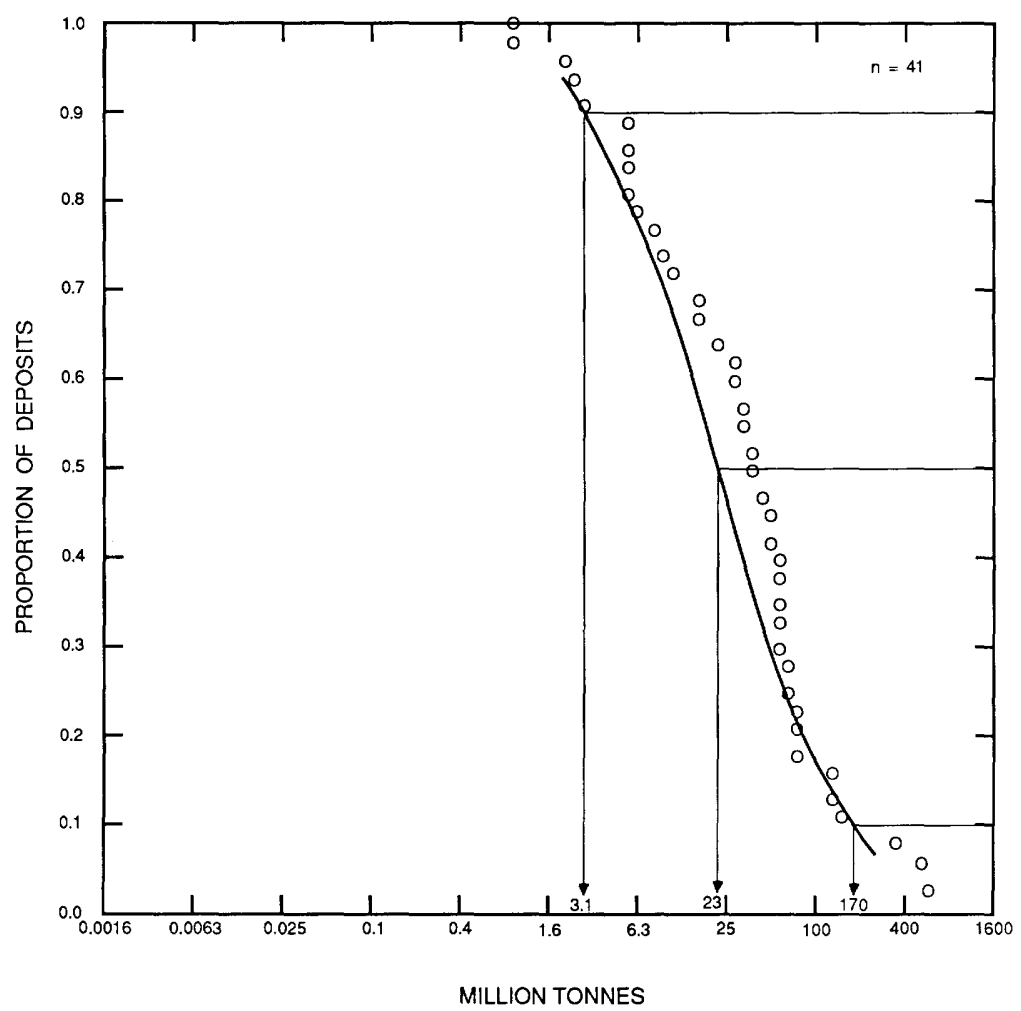

Figure 193. Tonnages of karst-type bauxite deposits.

BAUXITE, KARST TYPE

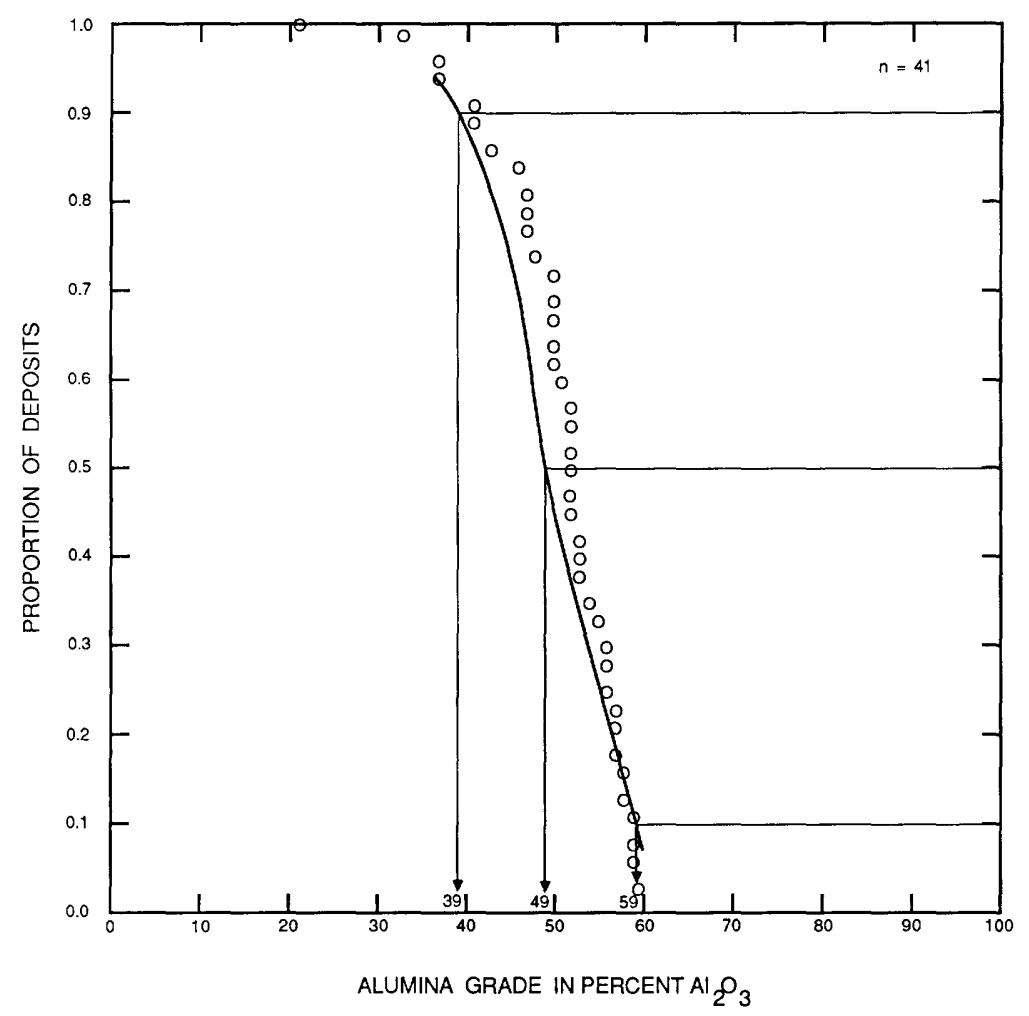

Figure 194. Alumina grades of karst-type bauxite deposits. 


\title{
DESCRIPTIVE MODEL OF PLACER AU-PGE
}

\author{
By Warren E. Yeend
}

DESCRIPTION Elemental gold and platinum-group alloys in grains and (rarely) nuggets in gravel, sand, silt, and clay, and their consolidated equivalents, in alluvial, beach, eolian, and (rarely) glacial deposits (see fig. 195).

GENERAL REFERENCES Boyle (1979), Wells (1973), Lindgren (1911).

GEOLOGICAL ENVIRONMENT

Rock Types Alluvial gravel and conglomerate with white quartz clasts. Sand and sandstone of secondary importance.

Textures Coarse clastic.

Age Range Cenozoic. Older deposits may have been formed but their preservation is unlikely.

Depositional Environment High-energy alluvial where gradients flatten and river velocities lessen, as at the inside of meanders, below rapids and falls, beneath boulders, and in vegetation mats. Winnowing action of surf caused Au concentrations in raised, present, and submerged beaches.

Tectonic Setting(s) Tertiary conglomerates along major fault zones, shield areas where erosion has proceeded for a long time producing multicycle sediments; high-level terrace gravels.

Associated Deposit Types Black sands (magnetite, ilmenite, chromite); yellow sands (zircon, monazite). Au placers commonly derive from various Au vein-type deposits as well as porphyry copper, Cu skarn, and polymetallic replacement deposits.

\section{DEPOSIT DESCRIPTION}

Mineralogy Au, platinum-iron alloys, osmium-iridium alloys; gold commonly with attached quartz, magnetite, or ilmenite.

Texture/Structure Flattened, rounded edges, flaky, flour gold extremely fine grained flakes; very rarely equidimensional nuggets.

Ore Controls Highest Au values at base of gravel deposits in various gold "traps" such as natural riffles in floor of river or stream, fractured bedrock, slate, schist, phyllite, dikes, bedding planes, all structures trending transverse to direction of water flow. Au concentrations also occur within gravel deposits above clay layers that constrain the downward migration of Au particles.

Geochemical Signature Anomalous high amounts of $\mathrm{Ag}, \mathrm{As}, \mathrm{Hg}, \mathrm{Sb}, \mathrm{Cu}, \mathrm{Fe}, \mathrm{S}$, and heavy minerals magnetite, chromite, ilmenite, hematite, pyrite, zircon, garnet, rutile. Au nuggets have decreasing $\mathrm{Ag}$ content with distance from source.

EXAMPLES

Sierra Nevada, USCA (Lindgren, 1911; Yeend, 1974)

Victoria, AUVT

(Knight, 1975)

GRADE AND TONNAGE MODEL OF PLACER Au-PGE

By Greta J. Orris and James D. Bliss

REFERENCE Orris and Bliss (1985).

COMMENTS Placers used for this model are predominantly Quaternary in age and alluvial in nature. Many of the placer deposits contain a mix of depositional environments and energy level--deposits along minor tributaries have been worked with deposits downstream on a higher order stream, bench (or terrace) gravels have been mined with more recent deposits on valley floor. Some of the placers included in this model were formed by complex glacial-fluvial processes. Deposits not 
Model 39a--Con.

included in this model are those primarily cataloged as desert placers, pre-Tertiary or Tertiary age placers, beach placers, eolian placers, residual placers, eluvial placers, and gravel-plain deposits. These types, however, may be minor components of those deposits selected to be included. In most cases, the grade and tonnage figures are for districts or for placer operations within one mile $(1.6 \mathrm{~km})$ of one another. For some placers, early production figures were missing due to poor records of early gold rush work. In most cases, reserve figures (if a reserve is known) are not available. Some tonnage figures were estimated from approximate size of workings. Some grades were based on very limited information and in some cases extrapolated from information on manpower figures, type of equipment used, and estimates of the total contained gold produced.

Cutoff grades are dependent on the mining methods used to exploit placers. Methods of placer mining included in this model are as diverse as the depositional environment. These methods include panning, sluicing, hydraulic mining, and dredging. Draglines were used to mine some placers. Cut-off grades are also dependent on the value of gold during the period, or periods, of operation.

Some placer deposits were excluded due to grade or tonnage figures not compatible with the majority of placers found in the model. Placers exploited through drift mining exhibit grades that are too large and tonnages that are too small to be included in this model. Similarly, the large regional placers formed at the junction of mountainous areas and an adjacent plain or valley were excluded because they can be mined with large-volume dredges which are economic at grades not viable under other conditions. Both grades and tonnages of these placers are incompatible with this model.

Placer sizes were initially recorded in terms of cubic meters and the grades recorded as grams per cubic meter. In order to conform to other deposit models herein, deposit volume and grades have been converted to metric tons and grams per metric ton using 2.0 metric tons per cubic meter-the average density of wet sand and gravel. Gold grade is correlated with tonnage ( $r=-0.35$ ) and with silver grade $(r=0.66, n=16)$. See figs. $196,197$.

\section{DEPOSITS}

$\underline{\text { Name }}$

Adelong Creek

Alma (Mills) Placer USCO

Araluen Valley AUNS

Bannack USMT

Big Badja River AUNS

Blue River USCO

Boulder River USMT

Bullrun Placer USOR

Buxton Creek CNBC

Camanche USCA

Cobweb Diggings AUNS

Copper Basin USAZ

Corduroy Creek USID

Crooked Creek USID

Cullengoral AUNS

Deep Gravel USOR

Dixie Placer USOR

E1 Dorado USMT

Elkhorn Creek USMT

Elliston USMT

Fall Creek USID

Foots Creek USOR

Forest Creek USOR

French Gulch USCO

George Prezel USID

Georgia Gulch USCO

Gold Run (Summit Co.) USCO

Gold Run (Boulder Co.) USCO

Golden Rule USID

Green River USUT

Horse Praire USMT
Name

Humbug Creek

Hundred Dollar Gulch USID

Iowa Gulch

Jembaicumbene Creek AUNS

Jordan Creek USID

Lamb Creek USID

Llano de Oro USOR

Lowe Placer USCO

Lower Beaver Creek USCO

Lowland Creek USMT

Lynx Creek USAZ

Missouri Creek USCO

Mitchell Creek USMT

Nugget Creek (South Fork) USID

Ophir USMT

Pactolus USCO

Picuris USNM

Pioneer USMT

Prickly Pear Creek USMT

Rio Challana BLVA

Rio Chimate BLVA

Rio Tuichi (upper reach) BLVA

Rio Yolosano BLVA

Rio Yuyo BLVA

Sand Creek USID

Schissler Creek USID

Snowstorm area USCO

Sterling Creek USOR

Sumpter Bar USOR

Swan River USCO

T93-R77W Placer USCO 


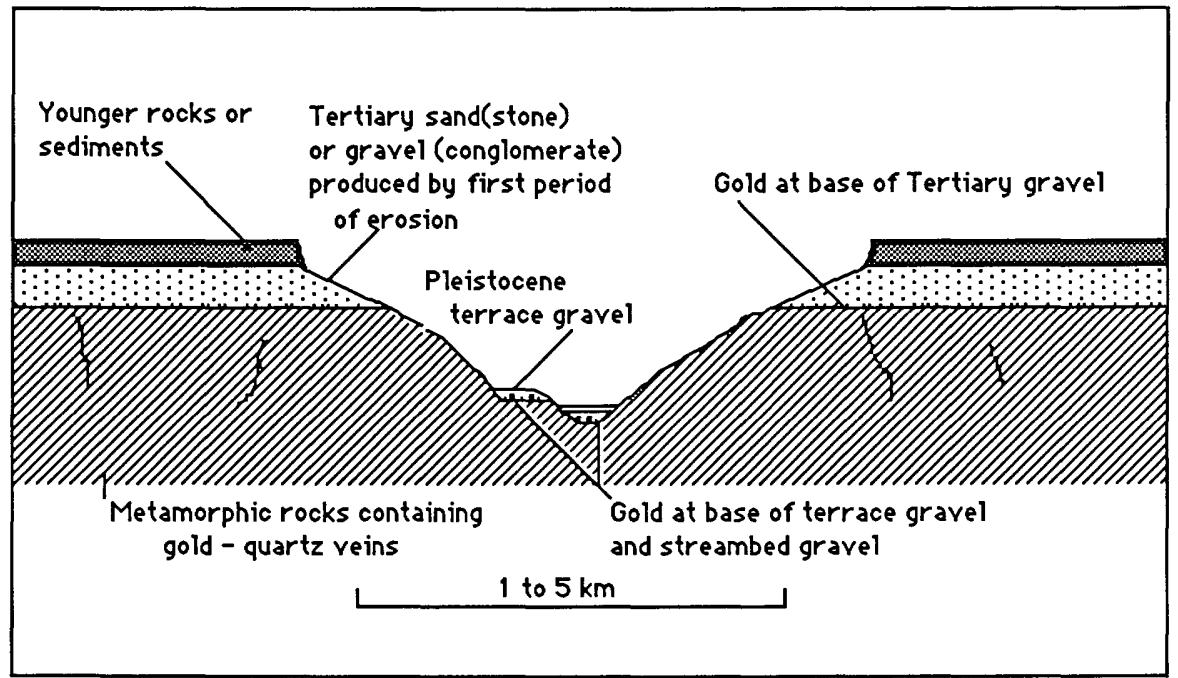

Figure 195. Cartoon cross section showing three stages of heavy mineral concentrations typical of $\mathrm{placer}$ Au-PGE deposits.

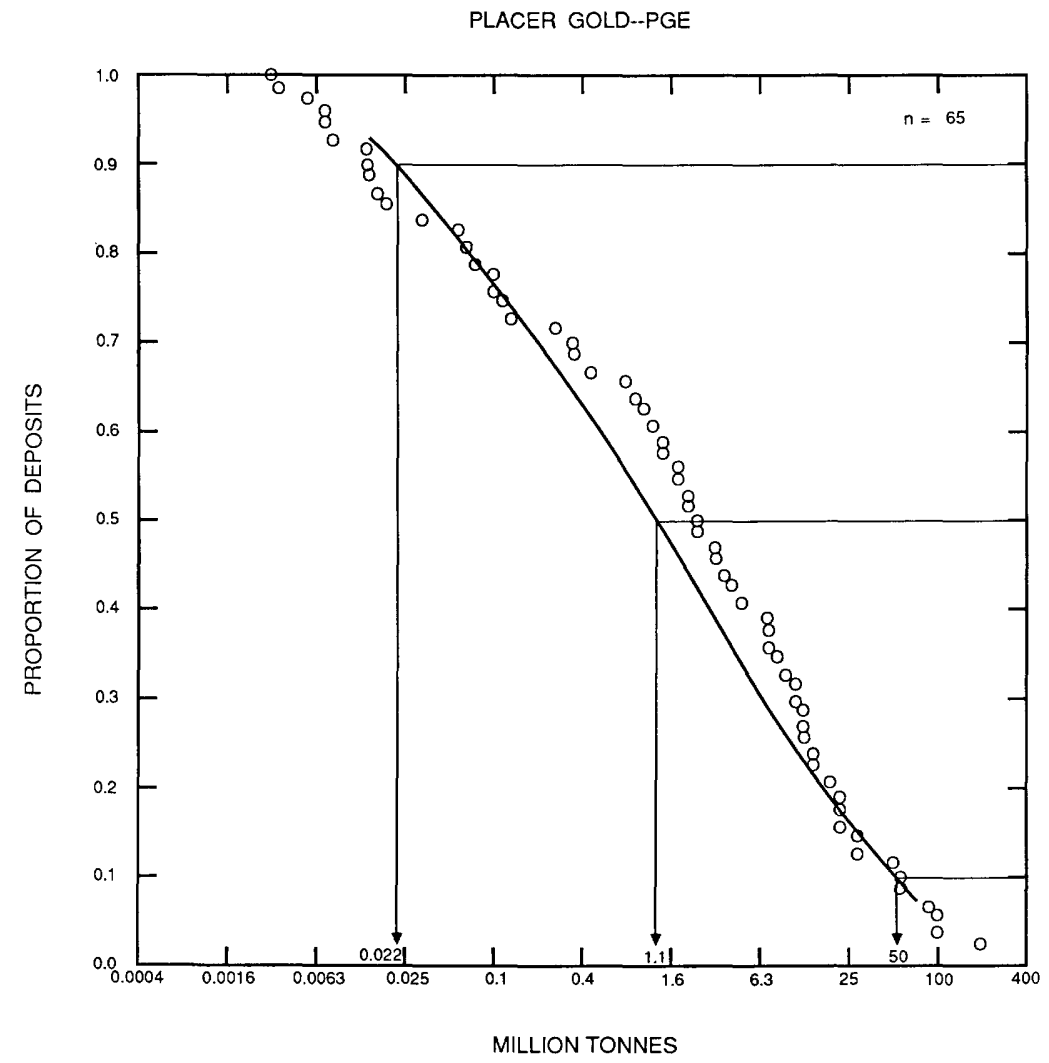

Figure 196. Tonnages of placer Au-PGE deposits. Individual digits represent number of deposits. 
Model 39a--Con.
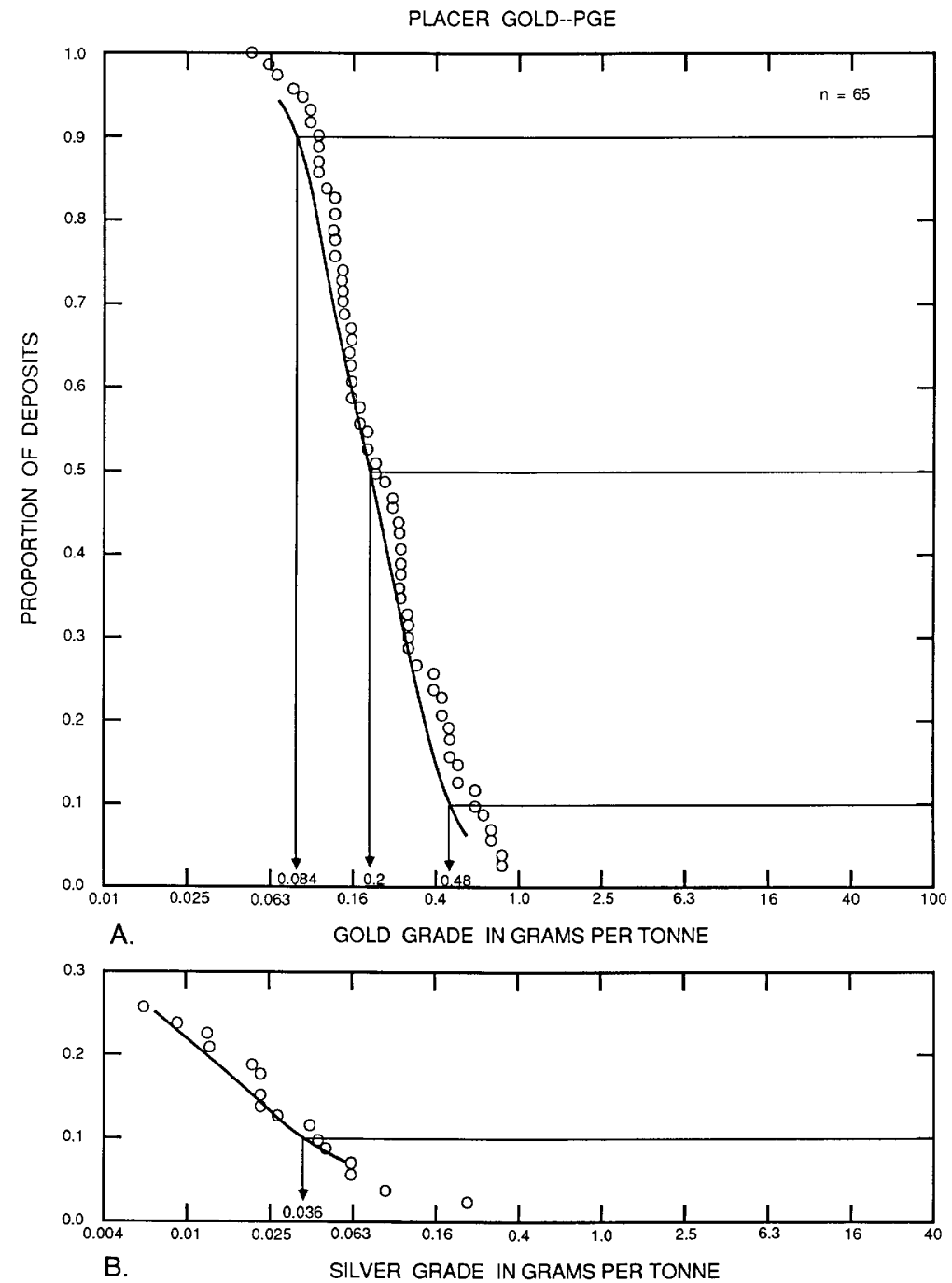

Figure 197. Precious-metal grades of placer Au-PGE deposits. $\underline{A}$, Gold. $\underline{B}$, Silver. 


\section{DESCRIPTIVE MODEL OF PLACER PGE-Au}

By Warren E. Yeend and Norman J Page

DESCRIPTION Platinum-group alloys and elemental gold in grains and (rarely) nuggets in gravel, sand, silt, and clay, and their consolidated equivalents, in alluvial, beach, eolian, and (rarely) glacial deposits derived from ultramafic sources.

GENERAL REFERENCES Boyle (1979), Wells (1973), Lindgren (1911), Mertie (1969).

GEOLOGICAL ENVIRONMENT

Rock Types Alluvial gravel and conglomerate and heavy minerals indicative of ultramafic sources and low-grade metamorphic terrane. Sand and sandstone of secondary importance.

Textures Coarse to fine clastic.

Age Range Tertiary to Holocene. Older deposits may have been formed but their preservation is unlikely.

Depositional Environment Marine (near shore), rivers and streams (medium to low gradient), desert (eolian) sand dunes, in-situ weathering.

Tectonic Setting(s) Paleozoic to Mesozoic accreted terranes, Tertiary conglomerates along major fault zones; low terrace deposits; high-level terrace gravels.

Associated Deposit Types Alaskan PGE deposits.

DEPOSIT DESCRIPTION

Mineralogy Platinum-iron alloys (isoferroplatinum with rarer ferroanplatinum, tetraferroplatinum, and tulameenite), platinum-iridium, gold, osmium-iridium alloys; magnetite, chromite, or ilmenite.

Texture/Structure Flattened, rounded edges, flaky, flour-sized alloys and gold; very rarely equidimensional nuggets.

Ore Controls Highest Au values at base of gravel deposits or on argillaceous to clayey beds within gravel sequence; metal alloys concentrated in "traps" such as natural riffles in floor of river or stream, fractured bedrock, slate, schist, phyllite, dikes, bedding planes, and in structures trending transverse to direction of water flow. For PGE, predominantly zoned "Alaskan" type ultramafic complexes and minor ophiolites as source rocks; streams or rivers usually head in regions of ultramafic rocks.

Geochemical Signature Anomalously high amounts of $\mathrm{Ag}, \mathrm{As}, \mathrm{Hg}, \mathrm{Sb}, \mathrm{Cu}, \mathrm{Fe}, \mathrm{S}, \mathrm{Cr}$.

\section{EXAMPLES}

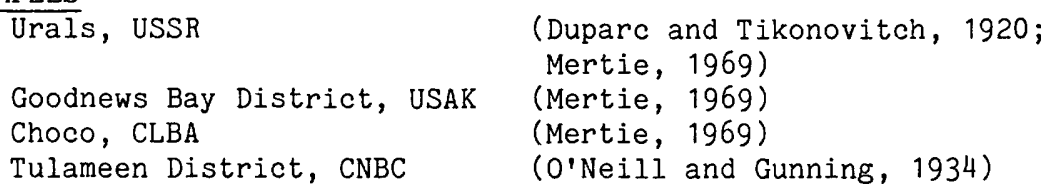

\section{GRADE AND TONNAGE MODEL OF PLACER PGE-Au}

By Donald A. Singer and Norman J Page

DATA REFERENCE Calkins and others, 1978.

COMMENTS All deposits used for the model are from the Urals of USSR. The platinum grade plot suggests three populations. Many of the deposits with grades less then 1,000 ppb Pt were probably mined by dredges, whereas the majority of deposits were mined by conventional placering methods. Some of the very high grades may represent reporting errors such as grades for a high-grade portion of a deposit being reported as representative of the total deposit. Probably because of the 
effects of combining deposits mined by two technologies, tonnage is correlated with platinum grade $(r=-0.42)$ and with gold grade $(r=-0.54, n=23)$. Platinum grade is correlated with gold grade $(r=0.58, n=23)$, with osmium grade $(r=0.89, n=21)$, with iridium grade $(r=0.98, n=10)$, and with palladium grade $(r=0.99, n=13)$. Osmium grade is correlated with iridium grade $(r=0.97, n=9)$ and with palladium grade $(r=0.89, n=12)$. Iridium grade is correlated with palladium grade $(r=0.97, n=9)$. Other correlations were not significant with the available number of samples. See figs. 198-200.

\section{DEPOSITS}

$\underline{\text { Name }}$

Aleksandrovskii Log

Alexii-0lginsky Log

Anianowsky Lojok

Arkhangelskii Log

Besimianni Log

Bielgorsky Log

Bobrowka River

Bolshaya Choumika R.

Bolshaya Kamenouchka

Bolshaya Ossokina R.

Bolshaya Prostokischenka

Bolshaya Sosnovka

Bolshoi Pokap R.

Bolshoi Sakciam

Boyandinskaia

Ejowka

Gloubokia 1

Gloubokia 2

Illinsky Log

Ivov $R$.

Jerusalimsky-Priisk

Jourawlik R.

Judinsky-Lojok

Kamenka

Kamenka R.

Kisslaia-Peruonatchainik URRS

Kitlim, Severniy R. URRS

Korobowsky Lojok URRS

Kossia R. URRS

Kossoi-Log URRS

Kossorgskii Log URRS

Krutoi Log URRS

Lobwa R. URRS

Log No. 1-Propretschnoi URRS

Log No. 2-Suftlii Bor URRS

Log No. 3-Suftlii Bor URRS

Log No. 6-Suftlii Bor URRS

Log No. 7-Suftlii Bor URRS

Logwinska URRS

Lojok at Bisserskaya URRS

Lojok No. I\&2 Omoutnaia URRS

Main Valley of Kisslaia URRS

Malaia Koswa R.

URRS

\begin{tabular}{|c|c|}
\hline Name & Country \\
\hline Malaia Prostokischenka & URRS \\
\hline Malaia Sosnowka & URRS \\
\hline Malomalsky-Priisk & URRS \\
\hline Malot Pokap & URRS \\
\hline Martian R. & URRS \\
\hline Melnitschnaia & URRS \\
\hline Molitchowka & URRS \\
\hline Morphine-Log & URRS \\
\hline Niasman $R$ & URRS \\
\hline Nikolai-Tschoudotworsky & URRS \\
\hline Novoi-Log & URRS \\
\hline Obodranny-Lojok & USSR \\
\hline Panowka & URRS \\
\hline Patchek & URRS \\
\hline Pestchanka R. & URRS \\
\hline Phedinan R.-Triok & URRS \\
\hline Podbornaia & URRS \\
\hline Podmoskowoi-Log & URRS \\
\hline Popowsky -Lojok & URRS \\
\hline Popretschne-Log & URRS \\
\hline Roublewik R. & URRS \\
\hline Sirkov Log & URRS \\
\hline Small unnamed-Weressowy & URRS \\
\hline Solovyevskii Log & URRS \\
\hline Soukhoi Log & URRS \\
\hline Srednia-Prostokischenka & URRS \\
\hline Stepanoff-Log & URRS \\
\hline Syssim R. & URRS \\
\hline Tilai R. & URRS \\
\hline Toura R. & URRS \\
\hline Trudny-Log & URRS \\
\hline Tsauch R. & URRS \\
\hline Tschachewitaia & URRS \\
\hline Tscheh R. & URRS \\
\hline Unnamed creek-B. Sosnowka & URRS \\
\hline Verkho-Tourie & URRS \\
\hline Wyssim R. & URRS \\
\hline Yermakof-Log & URRS \\
\hline Zaetzeff, R. & URRS \\
\hline Zemlianoi-Mostik Log & URRS \\
\hline
\end{tabular}


Model 39b--Con.

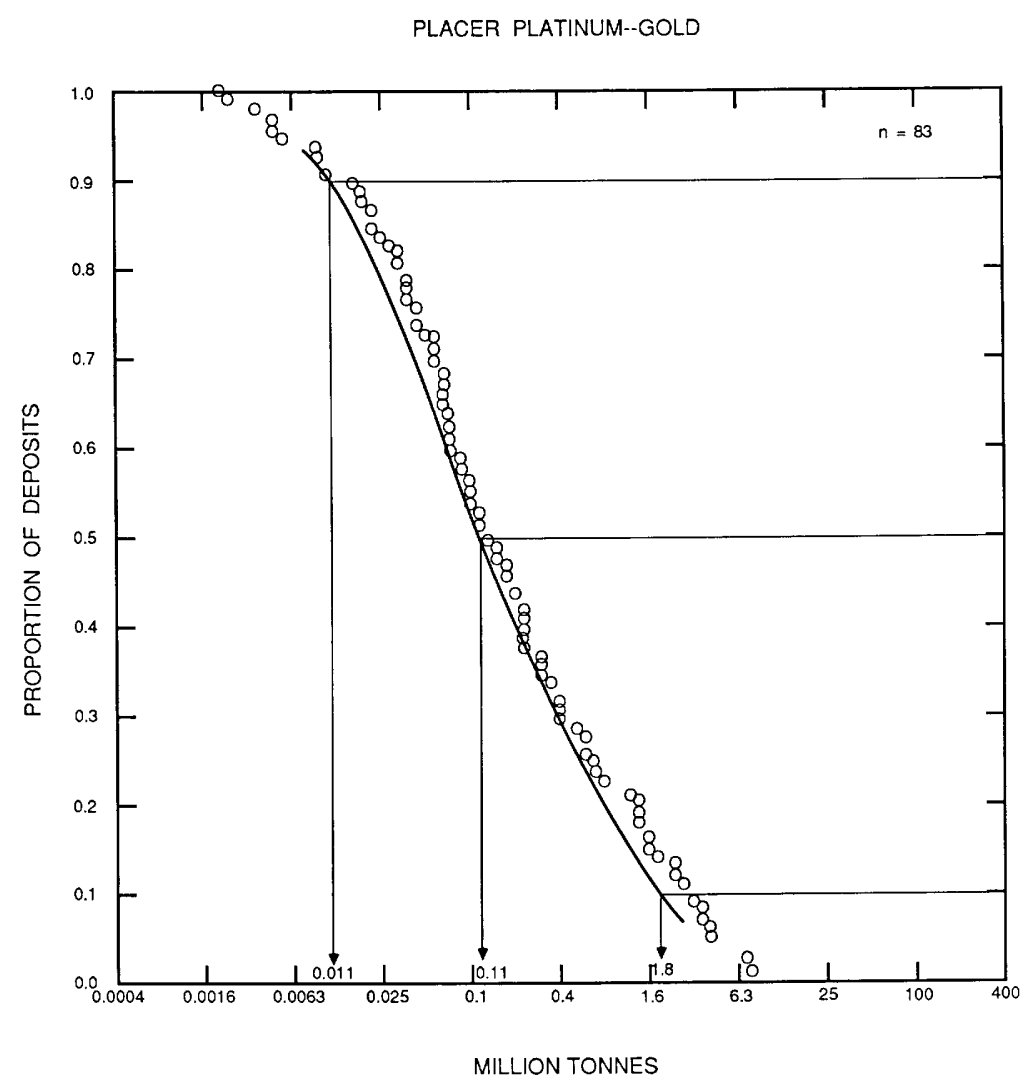

Figure 198. Tonnages of $\mathrm{placer} P \mathrm{PGE}-\mathrm{Au}$ deposits. 

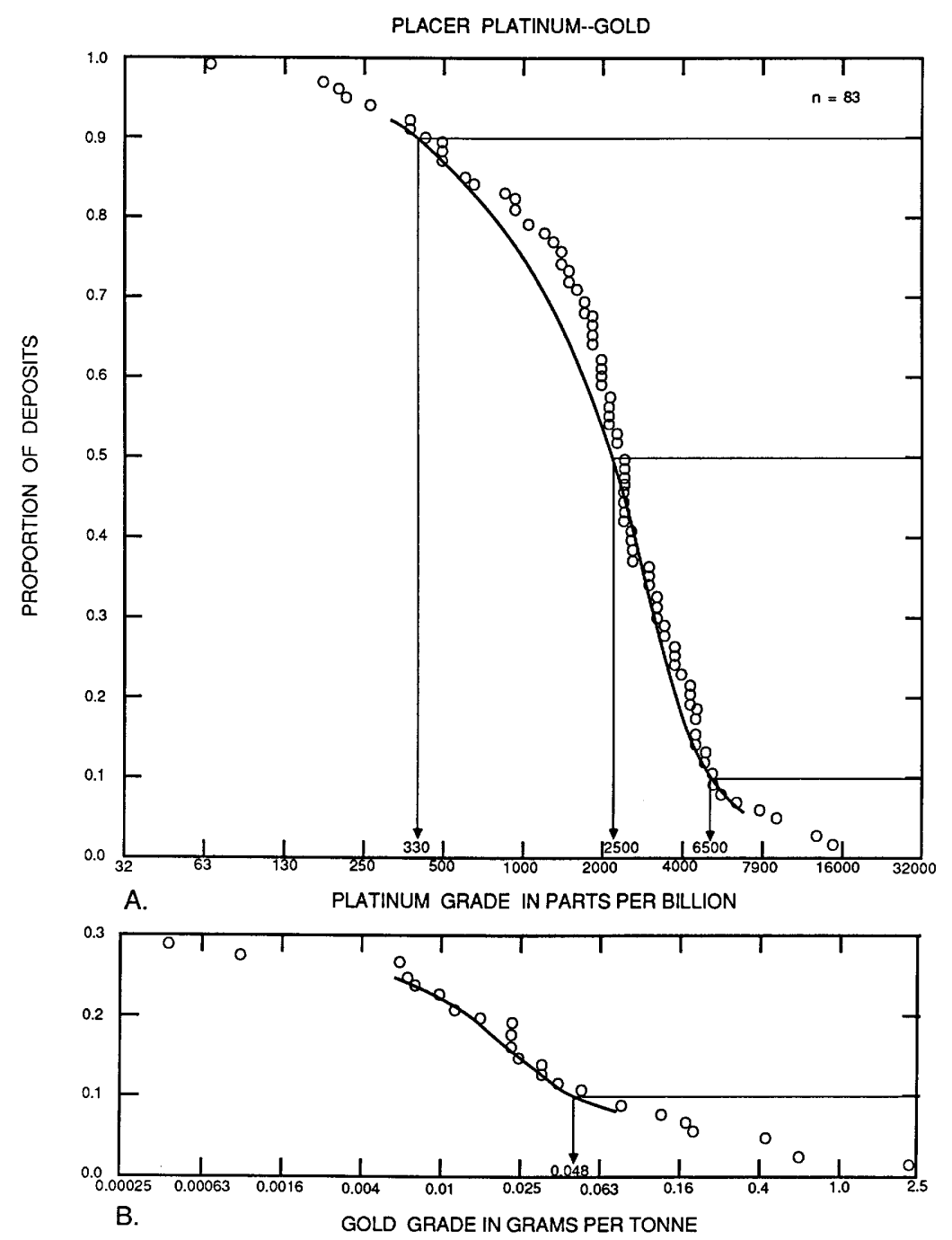

Figure 199. Precious-metal grades of placer PGE-Au deposits. A, Platinum. $\underline{B}$, Gold. 
Model 39b--Con.

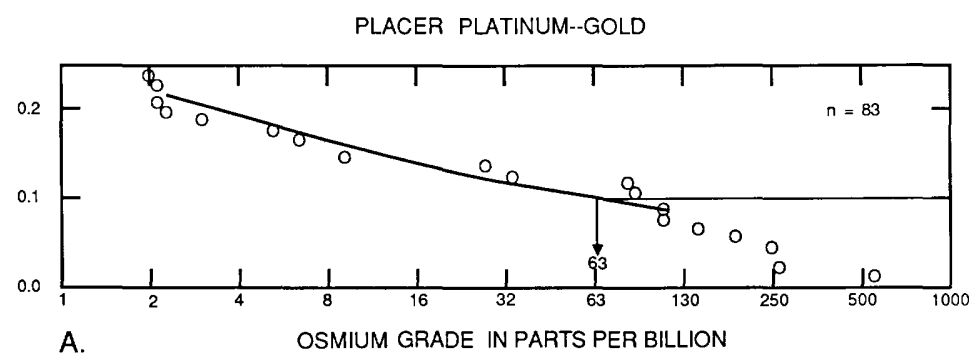

A.

OSMIUM GRADE IN PARTS PER BILLION
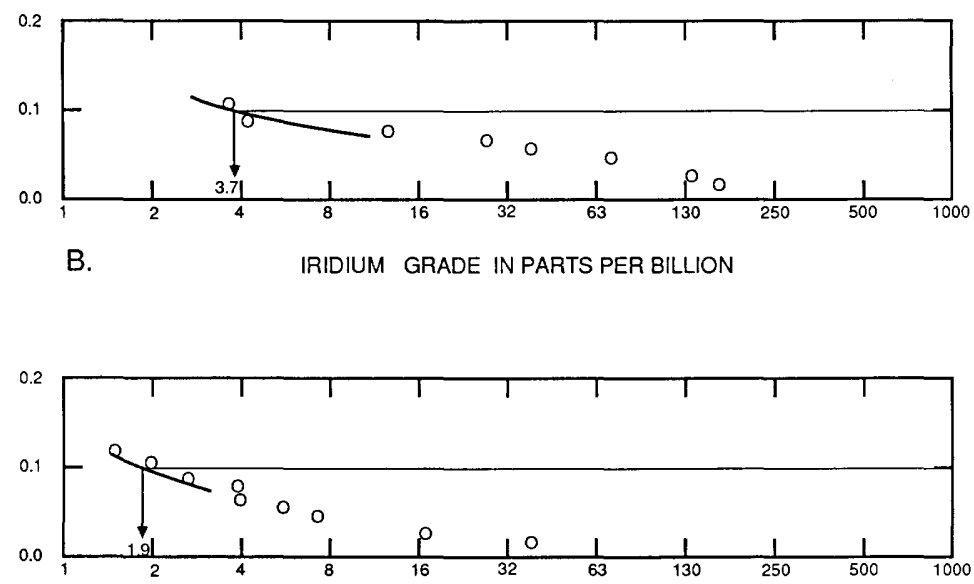

C.

PALLADIUM GRADE IN PARTS PER BILLION

Figure 200. Other PGE grades of placer PGE-Au deposits. A, Osmium. B, Iridium. $\underline{\mathrm{C}}$, Palladium. 
Model 39c

\section{DESCRIPTIVE MODEL OF SHORELINE PLACER Ti}

By Eric R. Force

DESCRIPTION IImenite and other heavy minerals concentrated by beach processes and enriched by weathering.

GENERAL REFERENCE Force (1976).

GEOLOGICAL ENVIRONMENT

Rock Types Well-sorted medium- to fine-grained sand in dune, beach, and inlet deposits commonly overlying shallow marine deposits.

Age Range Commonly Miocene to Holocene, but may be any age.

Depositional Environment Stable coastal region receiving sediment from deeply weathered metamorphic terranes of sillimanite or higher grade.

Tectonic Setting(s) Margin of craton. Crustal stablity during deposition and preservation of deposits.

DEPOSIT DESCRIPTION

Mineralogy Altered (low Fe) ilmenite \pm rutile \pm zircon. Trace of monazite, magnetite, and pyroxene; amphibole rare or absent. Quartz greatly exceeds feldspar.

Texture/Structure Elongate "shoestring" ore bodies parallel to coastal dunes and beaches.

Ore Controls High-grade metamorphic source; stable coastline with efficient sorting and winnowing; weathering of beach deposits.

Weathering Leaching of $\mathrm{Fe}$ from ilmenite and destruction of labile heavy minerals results in residual enrichment of deposits.

Geochemical and Geophysical Signature High Ti, $\mathrm{Zr}$, REE, Th and U. Gamma radiometric anomalies resulting from monazite content. Induced-polarization anomalies from ilmenite.

\section{EXAMPLES}

Green Cove Springs, USFL (Pirkle and others, 1974)

Trail Ridge, USFL

Lakehurst, USNJ

Eneabba, AUWA

(Pirkle and Yoho, 1970)

(Markiewicz, 1969)

(Lissiman and Oxenford, 1973)

GRADE AND TONNAGE MODEL OF SHORELINE PLACER Ti

By Emil D. Attanasi and John H. DeYoung, Jr.

COMMENTS Grade and tonnage estimates represent mining units rather than individual lenses. Grades are represented as percent $\mathrm{TiO}_{2}$ from rutile, ilmenite, leucoxene, percent $\mathrm{ZrO}_{2} \mathrm{from}_{\mathrm{z} i r c o n}$, and percent rare-earth oxides from monazite. Zircon is correlated with rutile $(r=0.49, n=50)$, ilmenite $(r=0.58, n=52)$, leucoxene $(r=0.55, n=24)$, and monazite $(r=0.55, n=29)$. Ilmenite is correlated with leucoxene $(r=0.66, n=24)$ and with monazite $(r=0.66, n=29)$. See figs. 201-205.

\section{DEPOSITS}

$\underline{\text { Name }}$

Agnes Waters

Barrytown

Birchfield

Bothaville-

Wolmaransstad

270

Country
AUQL
NZLD
NZLD
SAFR

SAFR
Name

Boulougne-Folkston Bridge Hill Ridge

Brunswick-Altamaha Camaratuba Capel Shoreline
Country

USFL

AUNS

USGA

BRZL

AUWA 


$\begin{array}{llll}\text { Carolina } & \text { SAFR } & \text { Munbinea Shoreland } & \text { AUWA } \\ \text { Charleston-B } & \text { USSC } & \text { Munmorah } & \text { AUNS } \\ \text { Charleston-C } & \text { USSC } & \text { Muriwai } & \text { NZLD } \\ \text { Charleston-I } & \text { USSC } & \text { N.L. Industries } & \\ \text { Charleston-K } & \text { USSC } & \text { (Aurora) } & \text { USNC } \\ \text { Charleston-L } & \text { USSC } & \text { Natchez Trace State } & \text { AUQL } \\ \text { Charleston-N } & \text { USSC } & \text { Park } & \text { USTN } \\ \text { Cumberland Island } & \text { USGA } & \text { North Camden (Keer- } & \\ \text { Curtis Island } & \text { AUQL } & \text { McGee) } & \text { USTN } \\ \text { East Rosetta } & \text { EGPT } & \text { Oak Grove (Ethy) } & \text { USTN } \\ \text { Eneabba Shoreline } & \text { AUWA } & \text { Orissa (Chatrapur) } & \text { INDA } \\ \text { Evans Head-Wooli area } & \text { AUNS } & \text { Poerua River } & \text { NZLD } \\ \text { Fraser Island } & \text { AUQL } & \text { Pulmoddai } & \text { SRIL } \\ \text { Gingin Shoreline } & \text { AUWA } & \text { Quilon (Chavara) } & \text { INDA } \\ \text { Gladstone Mainland } & \text { AUQL } & \text { Richards Bay } & \text { SAFR } \\ \text { Green Cove Springs } & \text { USFL } & \text { Ross } & \text { NZLD } \\ \text { Highland-Trail Ridge } & \text { USFL } & \text { Scott River } & \text { AUWA } \\ \text { Hilton Head Island } & \text { USSC } & \text { Ship Island } & \text { USMS } \\ \text { Hokitika North } & \text { NZLD } & \text { Silica Mine } & \text { USTN } \\ \text { Hokitika South } & \text { NZLD } & \text { Stockton Bight } & \text { AUNS } \\ \text { Inskip Point (Cooloola } & & \text { Tuncurry-Tomago area } & \text { AUNS } \\ \text { area) } & \text { AUQL } & \text { Waiho River } & \text { NZLD } \\ \text { Jacksonville Area } & \text { USFL } & \text { Waroona Shoreline } & \text { AUWA } \\ \text { Karamea } & \text { NZLD } & \text { Westport } & \text { NZLD } \\ \text { Lakehurst (Glidden) } & \text { USNJ } & \text { Yoganup Shoreline } & \text { AUWA } \\ \text { Manavalakurichi } & \text { INDA } & \text { Yulee } & \text { USFL } \\ \text { Manchester (Asarco) } & \text { USNJ } & & \\ \text { Moreton Island } & \text { AUQL } & \end{array}$

SHORELINE PLACER TITANIUM

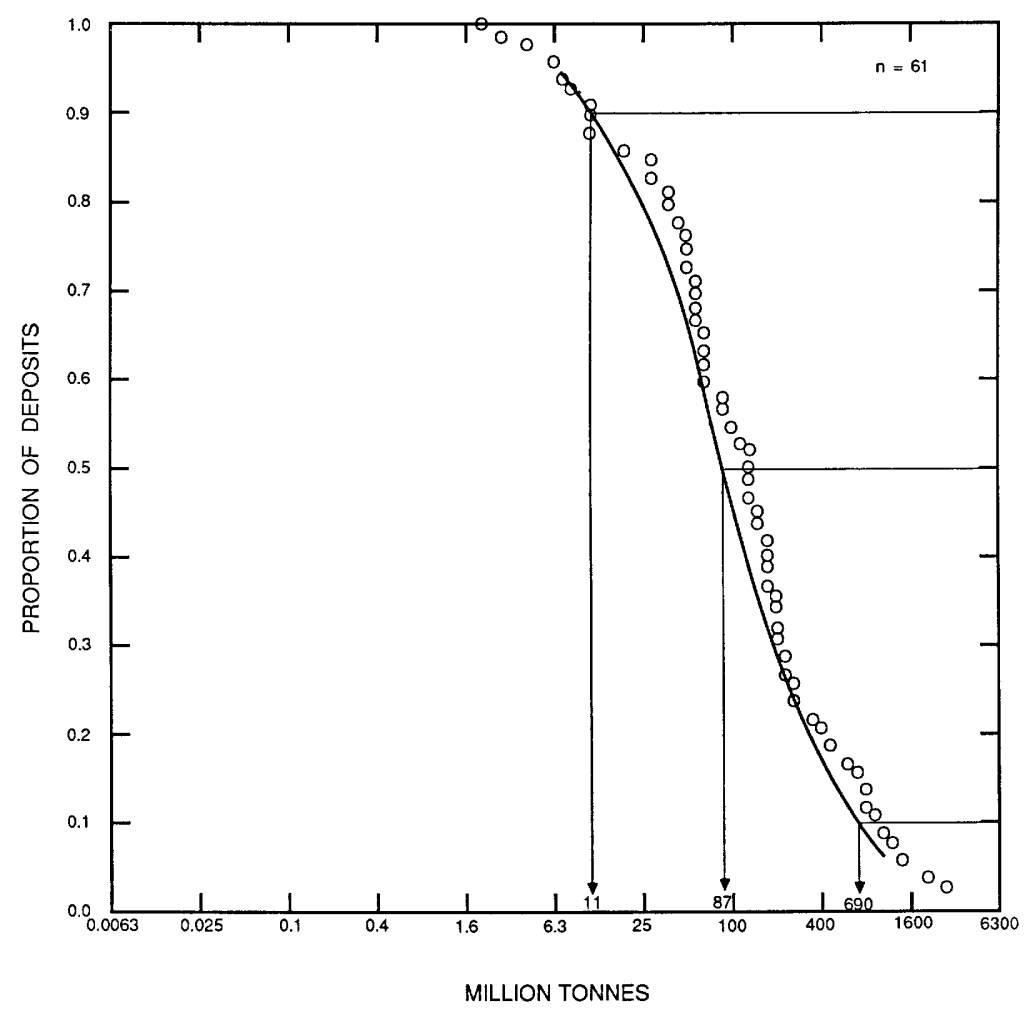

Figure 201. Tonnages of shoreline placer Ti deposits. 
Model 39c--Con.

Figure 202. $\mathrm{ZrO}_{2}$ grades from zircon in shoreline placer $\mathrm{Ti}$ deposits.
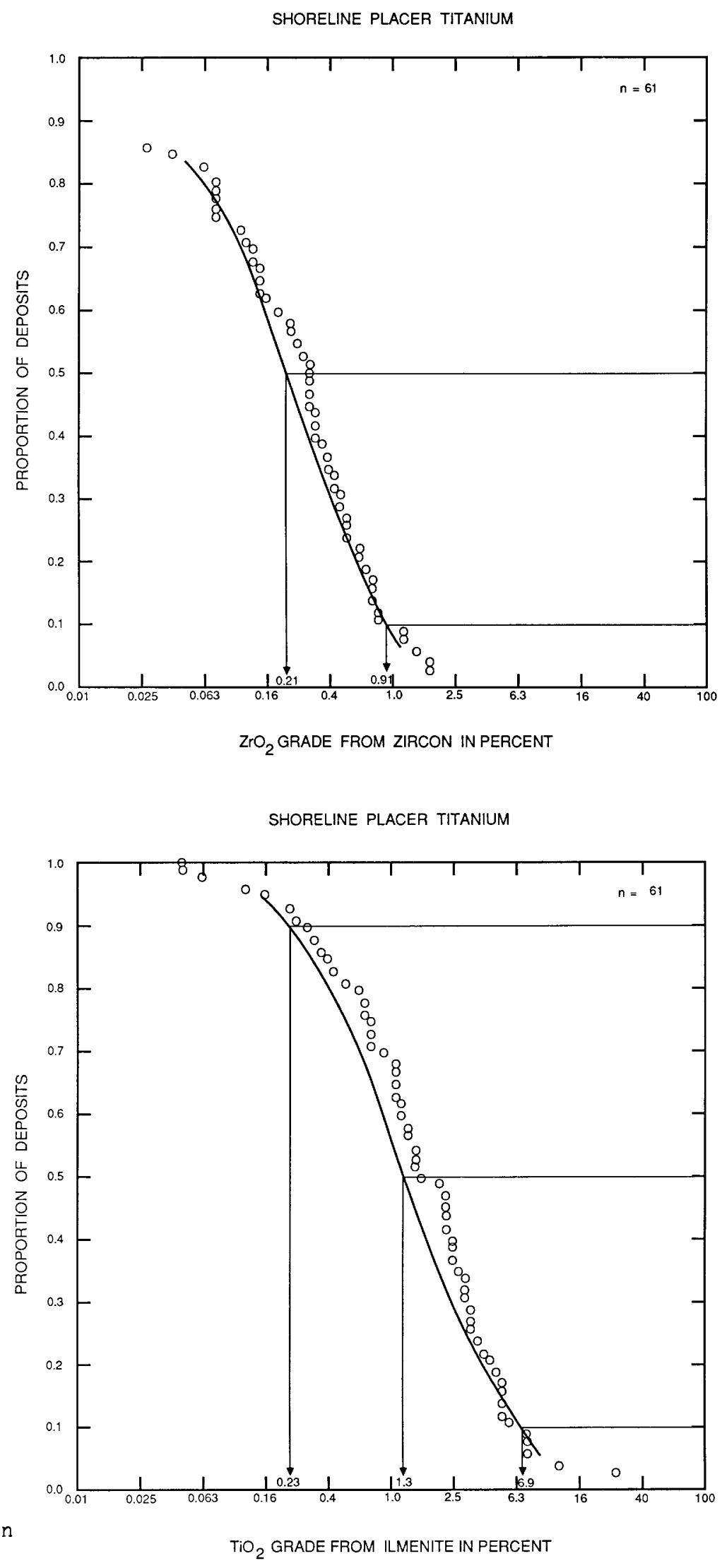

Figure 203. $\mathrm{TiO}_{2}$ grades from ilmenite in shoreline placer $\mathrm{Ti}$ deposits.
$\mathrm{TiO}_{2}$ GRADE FROM ILMENITE IN PERCENT 
SHORELINE PLACER TITANIUM

Model 39c--Con.

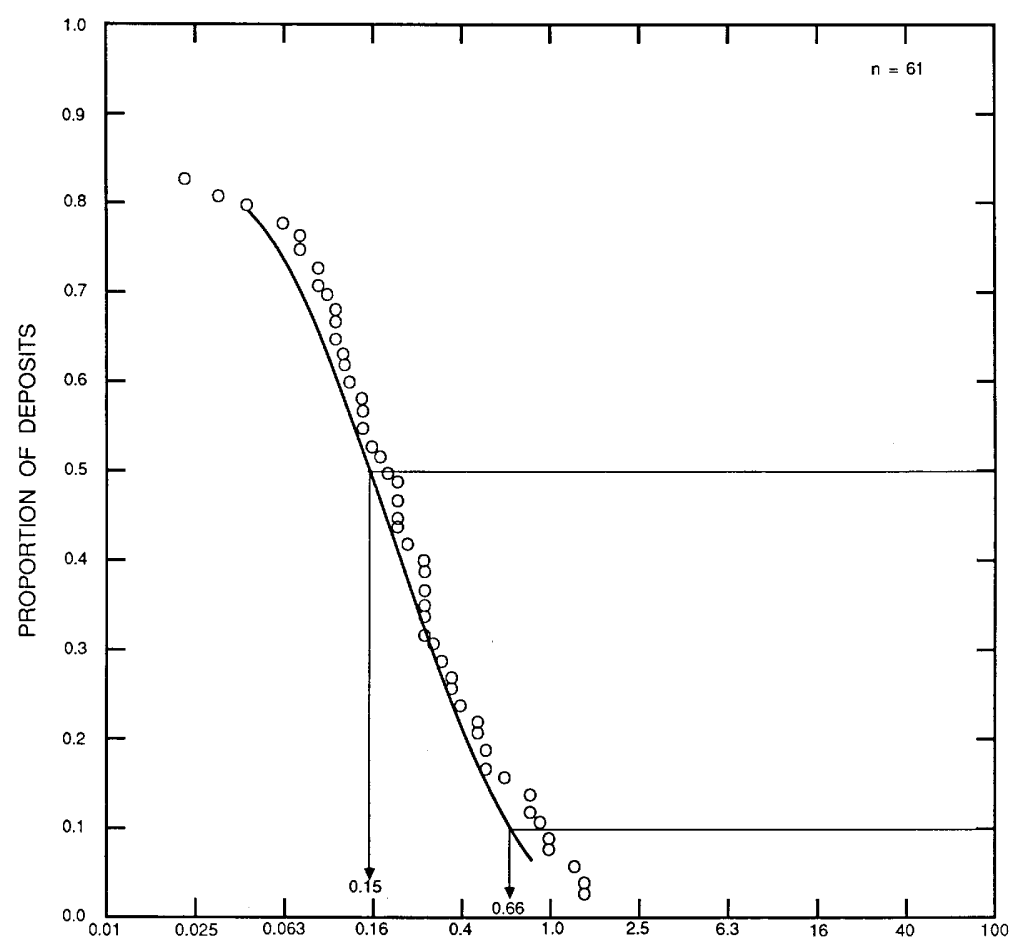

$\mathrm{TIO}_{2}$ GRADE FROM RUTILE IN PERCENT

Figure 204. $\mathrm{TiO}_{2}$ grades from rutile in shoreline placer $\mathrm{T} i$ deposits.

SHORELINE PLACER TITANIUM

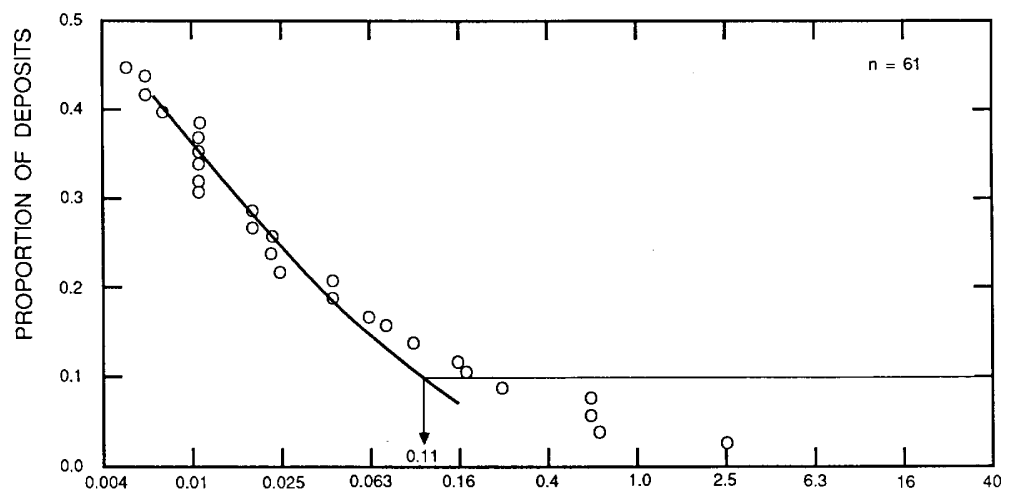

A. RARE--EARTH-OXIDE GRADE FROM MONAZITE IN PERCENT

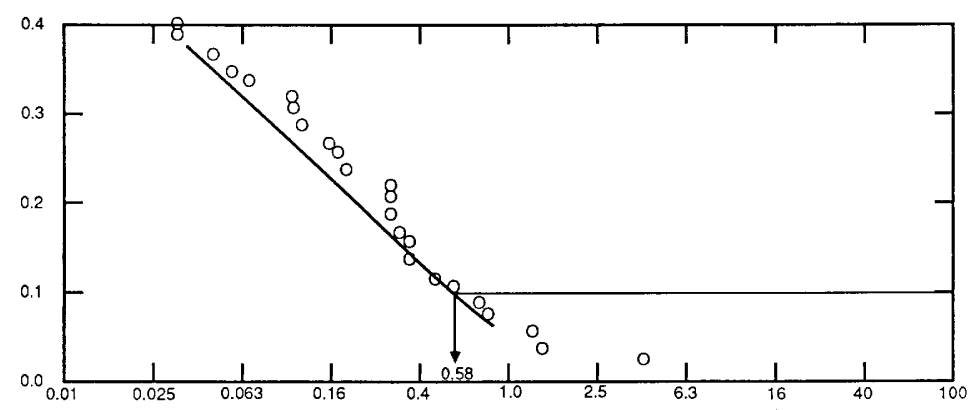

B. $\mathrm{TIO}_{2}$ GRADE FROM LEUCOXENE IN PERCENT

Figure 205. Other metal grades of shoreline placer $\mathrm{T} i$ deposits. A, REE oxide from monazite. $\underline{B}, \mathrm{TiO}_{2}$ from leucoxene. 


\section{DESCRIPTIVE MODEL OF DIAMOND PLACERS}

\section{By Dennis P. Cox}

DESCRIPTION Diamonds in alluvial and beach sediments and in sandstone and conglomerate. GENERAL REFERENCES Orlov (1973), Lampietti and Sutherland (1978).

GEOLOGICAL ENVIRONMENT

Rock Types Sand and gravel alluvial and beach deposits. Conglomerate beds may contain paleoplacers.

Textures Coarse clastic.

Age Range Tertiary and Quaternary.

Depositional Environment Streams draining areas of kimberlite pipes or diamond concentrations in sedimentary or metamorphic rocks. Alluvial diamond deposits may be $1,000 \mathrm{~km}$ from source. It is possible that some diamonds may have been derived from Archean greenstone belts.

Tectonic Setting(s) Stable craton.

Associated Deposit Types Diamond pipes.

\section{DEPOSIT DESCRIPTION}

Mineralogy Diamond, bort or carbonado (polycrystalline, generally dark colored), ballas (spherulitic, polycrystalline and amorphous carbonado).

Texture/Structure Diamonds derived from ancient placers in sedimentary rock commonly retain sand grains cemented to grooves or indentations in the crystal.

Ore Controls Diamonds are concentrated in low-energy parts of stream systems with other heavy minerals. Diamonds decrease in size and increase in quality (fewer polycrystalline types) with distance from their source.

Geochemical Signature $\mathrm{Cr}$, Ti, Mn, Ni, Co, PGE, Ba. Anomalous Ni and Nb together with the heavy minerals pyrope, $\mathrm{Mg}$-ilmenite, and phlogopite indicate nearby kimberlite pipes.

EXAMPLES

African deposits

Venezuelan deposits
(Sutherland, 1982)

(Fairbairn, 1971; Reid and

Bisque, 1975) 


\title{
DESCRIPTIVE MODEL OF ALLUVIAL PLACER Sn
}

\author{
By Bruce L. Reed
}

DESCRIPTION Cassiterite and associated heavy minerals in silt- to cobble-size nuggets concentrated by the hydraulics of running water in modern and fossil streambeds.

GENERAL REFERENCES Hosking (1974), Taylor (1979), Sainsbury and Reed (1973).

GEOLOGICAL ENVIRONMENT

Rock Types Alluvial sand, gravel, and conglomerate indicative of rock types that host lode tin deposits.

Textures Fine to very coarse clastic.

Age Range Commonly late Tertiary to Holocene, but may be any age.

Depositional Environment Generally moderate to high-level alluvial, where stream gradients lie within the critical range for deposition of cassiterite (for instance, where stream velocity is sufficient to result in good gravity separation but not enough so the channel is swept clean). Stream placers may occur as offshore placers where they occupy submerged valleys or strandines.

Tectonic Setting(s) Alluvial deposits derived from Paleozoic to Cenozoic accreted terranes or stable cratonic foldbelts that contain highly evolved granitoid plutons or their extrusive equivalents (see Model 14b, geochemical signature). Tectonic stability during deposition and preservation of alluvial deposits.

Associated Deposit Types Alluvial gravels may contain by-product ilmenite, zircon, monazite, and, where derived from cassiterite-bearing pegmatites, columbite-tantalite. Economic placers are generally within a few $(<8)$ kilometers of the primary sources. Any type of cassiterite-bearing tin deposit may be a source. The size and grade of the exposed source frequently has little relation to that of the adjacent alluvial deposit.

\section{DEPOSIT DESCRIPTION}

Mineralogy Cassiterite; varying amounts of magnetite, ilmenite, zircon, monazite, allanite, xenotime, tourmaline, columbite, garnet, rutile, and topaz may be common heavy resistates.

Texture/Structure Cassiterite becomes progressively coarser as the source is approached; euhedral crystals indicate close proximity to primary source. Where a marine shoreline intersects or transgresses a stream valley containing alluvial cassiterite the shoreline placers normally have a large length-to-width ratio.

Ore Controls Cassiterite tends to concentrate at the base of stream gravels and in traps such as natural riffles, potholes, and bedrock structures transverse to the direction of water flow. The richest placers lie virtually over the primary source. Streams that flow parallel to the margin of a tin-bearing granite are particularly favorable for placer tin accumulation.

Geochemical Signature Anomalously high amounts of Sn, As, B, F, W, Be, W, Cu, Pb, Zn. Panned concentrate samples are the most reliable method for detection of alluvial cassiterite.

EXAMPLES

Southeast Asian tin fields (Hosking, 1974)

(Newell, 1971)

(Simatupang and others, 1974)

(Westerveld, 1937 


\section{REFERENCES}

Abbott, J. T., and Williams, S. A., 1981, The Pine Grove molybdenum system, southern Wah Wah Mountains, Beaver County, Utah [abs.] : American Institute of Mining, Metallurgical and Petroleum Engineers, 101st Meeting, February 22-26, 1981 Program, p. 21.

Adamides, N. G., 1980, The form and environment of formation of the Kalavos ore deposits, Cyprus, in Panayiotou, A., ed., Ophiolites, Proceedings International Ophiolite Symposium, Nicosia, Cyprus, 1979: Cyprus Geological Survey Department, p. 117-128.

Allcock, J. B., 1982, Skarn and porphyry mineralization at Mines Gaspe, Murdochville, Quebec: Economic Geology, v. 77, p. 971-999.

Armstrong, C. H., and Lawrence, W. F., 1983, Geology of U.S. Steel zinc mine, in Tennessee zinc deposits fieldtrip guidebook: Virginia Technical Institute, Department of Geological Sciences Guidebook, no. 9, p. 63-72.

Arndt, N. T., and Nisbet, E. G., 1982, Komatiites: London, George Allen and Unwin, $526 \mathrm{p}$.

Ashley, P. M., 1980, Geology of the Ban Ban Zinc deposit, a sulfide bearing skarn deposit, southeast Queensland, Australia: Economic Geology, v. 75, p. 15-29.

Ashley, R. P. 1982, Occurrence model for enargitegold deposits, in Erickson, R. L., ed., Characteristics of mineral deposit occurrences: U.S. Geological Survey Open-File Report 82-795, p. 126-129.

Atkinson, W. J., Hughes, F. B., and Smith, C. B., 1984, A review of kimberlitic rocks of Western Australia, in Kornprobst, J., ed., Kimberlites and related rocks (Developments in Petrology Vol. 11A): Amsterdam, Elsevier, p. 195-224.

Atkinson, W. W., Jr., and Einaudi, M. T., 1978, Skarn formation and mineralization in the contact aureole at Carr Fork, Bingham, Utah: Economic Geology, v. 73, p. 1326-1365.

Atkinson, W. W., Jr., Kaczmarowski, J. H. and Erickson, A. J., Jr., 1982, Geology of the skarn breccia orebody Victoria Mine, Elko County Nevada: Economic Geology, v. 77, p. 899-918.

Averitt, P., 1945, Quicksilver deposits of the Knoxville district, Napa, Yolo, and Lake Counties, California: California Journal of Mines and Geology, v. 41, no. 2, p. 65-89.

Bailey, E. H., and Phoenix, D. A., 1944, Quicksilver deposits of Nevada: University of Nevada Bulletin, v. 38, no. 5, 206 p.

Bailey, Edgar, 1964, Geology and quicksilver deposits of the New Almaden district, California: U.S. Geological Survey Professional Paper 360, 206 p.

Baragwanath, W., 1953, Ballarat Goldfield, in Edwards, A. B., ed., Geology of Australian ore deposits: Empire Mining and Metallurgical Congress, 5th, Melbourne, Australia, Australasian Institute of Mining and Metallurgy, v. 1, p. 986-1002.

Bardossy, Gyorgy, 1982, Karst bauxites, bauxite deposits on carbonate rocks, in Developments in economic geology 14: Amsterdam, Elsevier, 441 p.
Barnett, E. S. Hutchinson, R. W., Adamcik, Anton, and Barnett, R., 1982, Geology of the Agnico-Eagle gold deposit, Quebec, in Hutchinson, R. W., Spence, C. D., and Franklin, J. M., eds., Precambrian sulfide deposits, H.S. Robinson memorial volume: Geological Association of Canada Special Paper 25, p. 403-426.

Bartholome, P., Evrard, P., Katekesha, F., Lopez-Ruiz, J. and Ngongo, M. 1976, Diagenetic ore-forming processes at Kamoto, Katanga, Republic of Congo, in Amstutz G. C., and Bernard, A. J., eds., Ores in sediments: New York, SpringerVerlag, p. $21-42$.

Barton, P. B., Jr., Bethke, P. M., and Roedder, E., 1977, Environment of ore deposition in the Creede mining district, San Juan Mountains, Colorado, Part III. Progress toward the interpretation of the chemistry of the oreforming fluid for the $\mathrm{OH}$ vein: Economic Geology, v. 71, p. 1-24.

Bateman A. M., and McLaughlin D. H., 1920, Geology and ore deposits of Kennecott, Alaska: Economic Geology, v. 15, p. 1-80.

Becker, G., 1888, Quicksilver deposits of the Pacific slope: U.S. Geological Survey Monograph 13.

----1882, Geology of the Comstock Lode and the Washoe District: U.S. Geological Survey Monograph 3, $422 \mathrm{p}$.

Bennett, E. H., 1977, Reconnaissance geology and geochemistry of the Blackbird Mountain-Panther Creek region, Lemhi County, Idaho: Idaho Bureau of Mines and Geology Pamphlet 167, 108 p.

Berger, B. R., 1985, Geologic-geochemical features of hot-spring precious metal deposits, in Tooker, $\mathrm{E}$. W. ed., Geologic characteristics of sediment- and volcanic-hosted disseminated gold deposits-Search for an occurrence model: U.S. Geological Survey Bulletin 1646, p. 47-54.

Bernstein, Lawrence R., 1986, Geology and mineralogy of the Apex germanium-gallium mine, Washington County, Utah: U.S. Geological Survey Bulletin 1577, 9 p.

Berry, E. W., and Singewald, J. T., 1922, The geology and paleontology of the Huancavelica mercury district: Baltimore, Johns Hopkins University Studies in Geology, no. 2, 101 p.

Bichan, R., 1969, Chromite seams in the Hantley Complex of the Great Dike of Rhodesia, in Wilson, H. D. B., Magmatic ore deposits: Economic Geology Monograph 4, p. 95-113.

Binns, R. A., Ayers, D. E., Wilmshurst, J. R., and Ramsden, A. R., 1980, Petrology and geochemistry of alteration associated with uranium mineralization at Jabiluka, Northern Territory, Australia, in Ferguson, John, and Goleby, A. B., eds., Uranium in the Pine Creek geosyncline: Vienna, International Atomic Energy Agency, p. 417-438.

Bjorlykke, A., and Sangster, D. F., 1981, An overview of sandstone lead deposits and their relationship to red-bed copper and carbonate-hosted leadzinc deposits, in Skinner, B. J., ed., Economic Geology Seventy-fifth Anniversary Volume: Economic Geology Publishing Company, p. 179213. 
Blake, D. H., 1972, Regional and economic geology of the Herberton-Mount Garnet area, Herberton Tinfield, North Queensland: Australia Bureau of Mineral Resources Bulletin 124, 265 p.

Blake, D. W., Theodore, T. G., Batchelder, J. N., and Kretschmer, E. L., 1979, Structural relations of igneous rocks and mineralization in the Battle Mountain mining district, Lander County, Nevada, in Ridge, J. D., ed., Papers on mineral deposits of western North America: Nevada Bureau of Mines Geological Report 33, p 87-99.

Blixt, J. E., 1933, Geology and gold deposits of the North Moccasin Mountains, Fergus County, Montana: Montana Bureau of Mines and Geology Memoir 8, $25 \mathrm{p}$.

Bonnichsen, B., 1972, Sulfide minerals in the Duluth Complex, in Sims, P. K., and Morey, G. B., eds., Geology of Minnesota: A centennial volume: St. Paul, Minn., Minnesota Geological Survey, p. 388-393.

Bookstrom, A. A., 1977, The magnetite deposits of El Romeral, Chile: Economic Geology, v. 72, p. $1101-1130$.

Boyce, A. J., Anderson, R., and Russell, M. J., 1983, Rapid subsidence and early Carboniferous basemetal mineralization in Ireland: Institution of Mining and Metallurgy Transactions, Section B, v. 92, p. B55-B66.

Boyd, R., and Mathiesen, C. O., 1979, The nickel mineralization of the Rana Mafic Intrusion, Nordland, Norway: The Canadian Mineralogist, v. 17, p. 287-298.

Boyle, R. W., 1979, The geochemistry of gold and its deposits: Geological Survey Canada Bulletin 280, $584 \mathrm{p}$.

Bracho, F. V., 1960, Yacimientos de estano en la Sierra de Chapultepec, Zac., la Ochoa, Dgo. y Cosio, Ags.: Mexico Consejo de Recursos Naturales no Renovables, Bull. 48, 116 p.

----1961, Yacimientos de estano en la Ochoa, Dgo. y Juan Aldama, Zac.: Mexico Consejo de Recursos Naturales no Renovables, Bull. 60, 87 p.

Briskey, J. A., 1982, Summary of the general geologic characteristics of sandstone-hosted lead-zinc deposits, in Erickson, R. L., ed., Characteristics of mineral deposit occurrences: U.S. Geological Survey Open-File Report 82-795, p. 183-185.

British Sulphur Corporation Ltd., 1980, World survey of phosphate deposits: London, 4th edition, 1980, $238 \mathrm{p}$.

Brown, A. C., 1971, Zoning in the White Pine copper deposit, Ontonagan County, Michigan: Economic Geology, v. 66, p. 543-573.

Buchanan, L. J., 1980, Ore controls of vertically stacked deposits, Guanajuato, Mexico: American Institute of Mining Engineers, Preprint 80-82, 26 p.

Burckhardt, C. E., and Falini, Filippo, 1956, Memoria suigiacimenti Italiani di Manganese, in Reyna, J. G., ed., Symposium sobre yacimientos de Manganese: International Geology Congress 20th, v. 5, p. 221-272.

Burger, P. A., 1979, The Greenvale nickel laterite orebody, in Evans and others, eds., International Laterites Symposium, New Orleans, 1979: Society of Mining Engineers, AIME, p. 24-37.
Burt, D. R. L., and Sheppy, N. R., 1975, Mount Keith nickel sulfide deposit, in Knight, C. L., ed., Economic geology of Australia and Papua New Guinea, I. Metals: Melbourne, Australasian Institute of Mining Metallurgy Monograph 5, p. 159-168.

Cabri, L. J., and Naldrett, A. J., 1984, The nature and distribution and concentration of platinum-group elements in various geological environments: Proceedings of the $27 \mathrm{th}$ International Geological Congress, v. 10, p. 17-46.

Caia, J., 1976, Paleogeographical and sedimentological controls of copper lead and zinc mineralizations in the Lower Cretaceous sandstones of Africa: Economic Geology, v. 71, p. 409-422.

Cairnes, C. E., 1934, Slocan Mining Camp, British Columbia: Geological Survey of Canada Memoir 173, $137 \mathrm{p}$.

Calkins, J. L., Keefer, E. K., Ofsharick, R. A., Mason, G. T., Tracy, Patricia, and Alkins, Mary, 1978, Description of CRIB, the GIPSY retrieval mechanism and the interface to the General Electric Mark III Service: U.S. Geological Survey Circular 755-AK, 49 p.

Cameron, E. N., and Desborough, G. A., 1969, Occurrence and characteristics of chromite deposits--Eastern Bushveld Complex, in Wilson, H. D. B., ed., Magmatic ore deposits: Economic Geology Monograph 4, p. 95-113.

Canada Department of Energy, Mines and Resources, 1980, Canadian mineral deposits not being mined in 1980: Mineral Policy Sector Internal Report MRI 80/7, 294 p.

Cannon, W. F., and Force, E. R., 1983, Potential for high-grade shallow-marine manganese deposits in North America: New York, American Institute of Mining Engineers, Cameron Volume on Unconventional Mineral Deposits, p. 175-190.

Carlson, C. A., Wilson, S. A., Carlson, R. R., Bradley, L., Cornell, J., Gent, C., Gass, W., Groeneboer, H., Haffty, J., Haubert, A., Love, A., McDade, J. M., Moore, R., Riley, L., Moring, B. C., Singer, D. A., and Page, N. J, 1985, Analyses for platinum-group elements in samples from podiform chromite deposits, California and Oregon: U.S. Geological Survey Open-File Report 85-442, 15 p.

Cathcart, J. B., and Gulbrandsen, R. A., 1973, Phosphate deposits, in Brobst, D. A., and Pratt, W. P., eds., United States mineral resources: U.S. Geological Survey Professional Paper 820, p. 515-525.

Chace, F. M., Cumberlidge, J. T., Cameron, W. L., and Von Nort, S. D., 1969, Applied geology at the Nickel Mountain mine, Riddle Canyon: Economic Geology, v. 64, no. 1, p. 1-16.

Chrisofferson, H. C., Wallin, B., Selkman, S., and Richard, D. T., 1979, Mineralization controls in the sandstone lead-zinc deposits of Vassbo, Sweden: Economic Geology, v. 74, p 1239-1249.

Colley, Howard, 1976, Mineral deposits of Fiji (metallic deposits): Fiji Mineral Resources Division Memoir 1, 123 p.

Collins, P. L. F., 1981, The geology and genesis of the Cleveland tin deposit, western Tasmania: Economic Geology, v. 72, no. 2, p. 365-392. 
Colvine, A. C., Andres, A. J., Cherry, M. E., Durocher, M. E., Fyon, A. J., Lavigue, M. J., Jr., MacDonald, A. J., Soussan, Marmont, Poulsen, K. H., and Troup, D. G., 1984, An integrated model for the origin of Archean lode gold deposits: Ontario Geological Survey Open File Report $5524,85 \mathrm{p}$.

Constantinou,G., 1980, Metallogenesis associated with Troodos ophiolite, in Panayiotou, A., ed., Ophiolites, Proceedings International Ophiolite Symposium, Nicosia, Cyprus, 1979: Cyprus Geological Survey Department, p. 663-674.

Constantinou, George, and Govett, G. J. S., 1973, Geology, geochemistry, and genesis of Cyprus sulfide deposits: Economic Geology, v. 68, no. 6, p. 843-858.

Corbett, K. D., 1981, Stratigraphy and mineralization in the Mt. Read volcanics, Western Tasmania: Economic Geology, v. 76, p. 209-230.

Corry, A. V., 1933, Some gold deposits of Broadwater, Beaverhead, Phillips and Fergus Counties, Montana: Montana Bureau of Mines and Geology Memoir 10, $45 \mathrm{p}$.

Cox, D. P., 1967, Regional environment of the Jacobina auriferous conglomerate, Brazil: Economic Geology, v. 62, p. 773-780.

----1985, Geology of the Tanama and Helecho porphyry copper deposits and their vicinity, Puerto Rico: U.S. Geological Survey Professional Paper 1327, 59 p.

Cox, D. P., ed., 1983a, U.S. Geological SurveyINGEOMINAS mineral resource assessment of Colombia; Ore deposit models: U.S. Geological Survey Open-File Report 83-423, 64 p.

-.--1983b, U.S. Geological Survey-INGEOMINAS mineral resource assessment of Colombia; Additional ore deposit models: U.S. Geological Survey Open-file Report 83-901, 37 p.

Cox, D. P., and Singer, D. A., in press, Distribution of gold in porphyry copper deposits, in Shawe, D. R., ed., Gold in the United States: U.S. Geological Survey Professional Paper.

Crawford, Johnson, and Hoagland, A. D., 1968, The Mascott-Jefferson City zinc district, Tennessee, in Ridge, J. D., ed., Ore deposits of the United States 1933-1967: New York, American Institute of Mining Engineers, p. 242-256.

Creasey, S. C., 1950, Geology of the St. Anthony (Mammoth) area, Pinal County, Arizona, Chapter VI in Arizona zinc and lead deposits: Arizona Bureau of Mines Bulletin 156, p. 63-84.

Crerar, D. A., Namson, Jay, Chyi, M. S., Williams, Loretta, and Feigenson, M. D., 1982, Manganiferous cherts of the Franciscan Assemblage: 1. General Geology, ancient and modern analogues, and implications for hydrothermal convection at oceanic spreading centers: Economic Geology, v. 77, p. 519-540.

Cyr, J. B., Pease, R. P., and Schroeter, T. G., 1984, Geology and mineralization at Equity Silver mine: Economic Geology, v. 79, p. 947-968.

Dahlkamp, Franz J., 1978, Geologic appraisal of the Key Lake U-Ni deposits, northern Saskatchewan: Economic Geology, v. 73, p. 1430-1449.
Dahlkamp, F. J., and Adams, S. S., 1981, Geology and recognition criteria for veinlike uranium deposits of the Lower to Middle Proterozoic unconformity and strata-related types: U.S. Department of Energy, National Resource Evaluation GJBX$5(81), 253 \mathrm{p}$.

Dawson, J. B., 1980, Kimberlites and their xenoliths: New York, Springer-Verlag, 252 p.

Dawson, K. R., 1974, Niobium (Columbium) and Tantalium in Canada: Geological Survey of Canada, Economic Geology Report No. 29, 157 p.

Derkman, K., and Klemm, D. D., 1977, Strata-bound kies-ore deposits in ophiolitic rocks of the "Tauernfenster" (eastern Alps, Austria/Italy), in Klemm, D. D., and Schneider, H. J., eds., Time and stratabound ore deposits: New York, Springer-Verlag, p. 305-313.

DeYoung, J. H., Jr., Sutphin, D. W., and Cannon, W. F., 1984, International strategic minerals inventory; Summary report--Manganese: U.S. Geological Survey Circular 930-A, 22 p.

Dick, L. A., and Hodgson, C. T., 1982, The MacTung $\mathrm{W}-\mathrm{Cu}(\mathrm{Zn})$ contact metasomatic and related deposits of the northeastern Canadian Cordillera: Economic Geology, v. 77, p. 845-867.

Dickey, J. S., Jr., 1975, A hypothesis of origin for podiform chromite deposits: Geochimica et Cosmochimica Acta, v. 39, p. 1061-1074.

Dobson, D. C., 1982, Geology and alteration of the Lost River tin-tungsten-fluorine deposit, Alaska: Economic Geology, v. 77, p. 1033-1052.

Duke, M. A., and Hutchinson, R. W., 1974, Geological relationships between massive sulfide bodies and ophiolitic volcanic rocks near York Harbour, Newfoundland: Canadian Journal of Earth Science, v. 11, p. 53-69.

Duparc, L., and Tikonovitch, M., 1920, Le platine et les gites platiniferes de l'Oural et du monde: Geneva, Sonor, 542 p.

Eargle, D. H., Dickinson, K. A., and Davis, B. O., 1975, South Texas uranium deposits: Bulletin of the American Association of Petroleum Geologists, v. 59, p. 766-779.

Eberle, M. C., and Atkinson, W. W., 1983, Results of mapping at Iron Mountain, Laramie anorthosite complex, Wyoming: Geological Society of America Abstract with Program, v. 15, no. 6, p. 565.

Eckel, E. B., 1949, Geology and ore deposits of the La Plata district, Colorado: U.S. Geological Survey Professional Paper 219, 179 p.

Eckstrand, O. R., ed., 1984, Canadian mineral deposit types, a geological synopsis: Geological Survey of Canada, Economic Geology Report 36, 86 p.

Economic Geology, 1977, An issue devoted to the Viburnum trend, southeast Missouri: Economic Geology, v. 72, p. 337-490.

Einaudi, M. T., 1981, Skarns associated with porphyry plutons. I. Description of deposits, southwestern North America, II. General features and origin, in Titley, S. R., ed., Advances in geology of the porphyry copper deposits of southwestern North America: Tucson, University of Arizona Press, p. 139-183.

Einaudi, M. T., and Burt, D. M., 1982, Introduction-terminology, classification, and composition of 
skarn deposits: Economic Geology, v. 77, p. 745754.

Einaudi, M. T., Meinert, L. D., and Newberry, R. S., 1981, Skarn deposits: in Skinner, B. J., ed., Economic Geology, Seventy-fifth Anniversary Volume: Economic Geology Publishing Company, p. 317-391.

Ensign, C. O., Jr., White, W. S., Wright, J. C., Patrick, J. L., Leone, J. L., Hathaway D. J., Trammell, J. W., Fritts, J. J., and Wright, T. L., 1968, Ccpper deposits in the Nonesuch Shale, White Pine, Michigan, in Ore deposits of the United States (Graton Sales Volume), v. 1: American Institute of Mining, Metallurgical and Petroleum Engineers, p. 460-488.

Erickson, R. L., compiler, 1982, Characteristics of mineral deposit occurrences: U.S. Geological Survey Open-File Report 82-795, 248 p.

Escovar, Ricardo, 1979, Geologia y geoquimica de las minas de esmeraldas de Gachala, Cundimarca: Ingeominas, Boletin Geologia, v. 22, p. 119-153.

Eupene, G. S., 1980, Stratigraphic, structural and temporal control of mineralization in the Alligator Rivers uranium province, Northern Territory, in Ridge, J. D., ed., Proceedings of the Fif th Quadrennial IAGOD Symposium: Stuttgart, E. Schweizerbartsche Verlagsbuchhandlung, p. 348-376.

Evans, D. J. I., Shoemaker, R. S., and Veltman, H., eds., 1979, International Laterite Symposium, New Orleans, 1979: Society of Mining Engineers, AIME, $688 \mathrm{p}$.

Evans, L. L., 1977, Geology of the Brushy Creek mine, Viburnum trend, southeast Missouri: Economic Geology, v. 77, p. 381-390.

Fahrni, K. C., McCauley, T. N., and Preto, V. A., 1976, Copper Mountain and Ingerbelle, in Sutherland Brown, A., ed., Porphyry deposits of the Canadian Cordillera: Canadian Institute Mining and Metallurgy Special Paper 15, p. 368-375.

Fairbairn, W. C., 1971, Diamonds in Venezuela: Mining Magazine, v. 125, p. 349-353.

Farnham, L. L., 1961, Manganese deposits of New Mexico: U.S. Bureau of Mines Information Circular 8030,176 p.

Feather, C. E., 1976, Mineralogy of platinum-group minerals in the Witwatersrand, South Africa: Economic Geology, v. 71, p. 1399-1428.

Ferguson, H. G., 1921, The Round Mountain district, Nevada: U.S. Geological Survey Bulletin 725, p. 383-406.

Fischer, R. P., 1974, Exploration guides to new uranium districts and belts: Economic Geology, v. 69, p. 362-376.

Fisher, N. H., 1952, The Coimadai antimony mine, in Edwards, A. B., ed., Geology of Autralian ore deposits: Melbourne, Australian Institute of Mining and Metallurgy, p. 1101-1103.

Fleischer, Ronald, and Routhier, Pierre, 1973, The "consanguineous" origin of a tourmaline-bearing gold deposit: Passagem de Mariana (Brazil): Economic Geology, v. 68, p. 11-22.

Foose, M. P., Slack, J. F., and Casadevall, Tom, 1980, Textural and structural evidence for a predeformation hydrothermal origin of the Tungsten Queen deposit, Hamme district, North
Carolina: Economic Geology, v. 75, p. 515-522.

Force, E. R., 1976, Metamorphic source rocks of titanium placer deposits--A geochemical cycle: U.S. Geological Survey Professional Paper 959B, $16 \mathrm{p}$.

Foshag, W., and Fries, C., 1942, Tin deposits of the Republic of Mexico: U.S. Geological Survey Bulletin 935-C, p. 99-176.

Fox, J. S., 1984, Besshi-type volcanogenic sulfide deposits--A review: Canadian Institute Mining and Metallurgy Bulletin, v. 77, no. 864, p. 57-68.

Frakes, L. A., and Bolton, B. R., 1984, Origin of manganese giants: Sea level change and anoxicoxic history: Geology, v. 12, p. 83-86.

Franklin, J. M., Sangster, D. M., and Lydon, J. W., 1981, Volcanic-associated massive sulfide deposits, in Skinner, B. J., ed., Economic Geology Seventy-fifth Anniversary Volume: Economic Geology Publishing Company, p. 485-627.

Fries, C., 1940, Tin deposits of the Black Range, Catron and Sierra Counties, New Mexico--A preliminary report: U.S. Geological Survey Bulletin 931-L, p. 279-294.

Frietsch, Rudyard, 1978, On the magmatic origin of iron ores of the Kiruna type: Economic Geology, v. 73, p. 478-485.

----1982, On the chemical composition of the ore breccia at Luossavaara, Northern Sweden: Mineralium Deposita, v. 17, p. 239-243.

Fripp, R. E. P., 1976, Stratabound gold deposits in Archean banded iron-formation, Rhodesia: Economic Geology, v. 71, p. 58-75.

Fryer, B. J., Kerrich, R., Hutchinson, R. W., Pierce, M. G., and Rogers, D. S., 1979: Archean preciousmetal hydrothermal systems, Dome Mine, Abitibi greenstone belt. I. Patterns of alteration and metal distribution: Canadian Journal of Earth Science, v. 16, p. 421-439.

Fulweiler, R. E., and McDougal, S. E., 1971, Beddedore structures, Jefferson City mine, Jefferson City, Tennessee: Economic Geology, v. 66, p. 763-769.

Gardner, L. S., 1967, Antimony deposits of Thailand: Thailand Department of Mineral Resources Report of Investigation No. 14, 46 p.

Geyne, A. R., Fries, C., Jr., Segerstrom, K., Black, R. F., and Wilson, I. F., 1963, Geology and mineral deposits of the Pachuca-Real del Monte district, state of Hidalgo, Mexico: Consejo de Recursos Naturales No Renovables Pubicacion 5E, 203 p.

Gilluly, J., 1932, Geology and ore deposits of the Stockton and Fairfield quadrangles, Utah: U.S. Geological Survey Professional Paper 173, 171 p.

Gold, D. P., 1984, A diamond exploration philosophy for the 1980's: Earth and Mineral Science, v. 53, p. 37-42.

Gold, D. P., Valee, M., and Charetti, J. P., 1966, Economic geology and geophysics of the Oka alkaline complex, Quebec: Canadian Institute Mining and Metallurgy Transactions, v. 70, p. 245-258.

Gomez, R., Ogryzlo, C. T., and Dor, A. A., 1979, The Cerro Matosa Nickel Project, in Evans and others, eds., International Laterite Symposium: New Orleans, 1979: Society of Mining Engineers, AIME, p. 412-458. 
Gonzales, A., 1956, Geology of the Lepanto Copper mine, Mankayan, Mountain Province, in Kinkel, A. R., Jr., and others, eds., Copper deposits of the Philippines: Philippines Bureau of Mines Special Projects Series, Publication 16, p. 17-50.

Goodwin, A. M., 1973, Archean iron-formations and tectonic basins in the Canadian Shield: Economic Geology, v. 68, p. 915-933.

Granger, H. C., and Warren, C. G., 1969, Unstable sulfur compounds and the origin of roll-type uranium deposits: Economic Geology, v. 64, p. 160-171.

Grant, J. N., Halls, C., Avila, W., and Avila, G., 1977, Igneous systems and the evolution of hydrothermal systems in some sub-volcanic tin deposits of Bolivia, in Volcanic process in orogenesis: Geological Society of London, Special Paper Publication 7, p. 117-126.

Grant, J. N., Halls, C., Sheppard, F. M. S., and Avila, W., 1980, Evaluation of the porphyry tin deposits of Bolivia, in Ishihara, S., and Takenouchi, S., eds., Granitic magmatism and related mineralization: Mining Geology Special Issue, no. 8, The Society of Mining Geologists of Japan, 247 p.

Grauch, R. I., 1984, Mineralogy and petrology of gold occurrences within the Jabiluka deposit, Northern Territory, Australia: 27th International Geological Congress, Abstracts v. 9, pt. 1, p. 2728.

Gray, F., and Page, N. J, 1985, Geologic map of the Lower Coon Mountain Pluton, Del Norte County, California: U.S. Geological Survey Open-File Report 83-148.

Graybeal, F. T., 1982, Geology of the El Tiro area, Silver Bell mining district, Pima County, Arizona, in Titley, S. R., ed., Advances in geology of the porphyry copper deposits, southwestern North America: Tucson, University of Arizona Press, p. 487-506.

Green, A. H., and Naldrett, A. J., 1981, The Langmuir volcanic peridotite-associated nickel deposits: Canadian equivalents of the western Australia occurrences: Economic Geology, v. 76, p. 15031523.

Gresham, J. J., and Loftus-Hills, G. D., 1981, The Geology of the Rambalda Nickel Field, Western Australia: Economic Geology, v. 76, p. 13731417.

Gross, S. O., 1968, Titaniferous ores of the Sanford Lake district, New York, in Ore deposits of the United States v. 1: $\overrightarrow{\mathrm{New}}$ York, American Institute of Mining Engineers, p. 140-153.

Gross, W., 1968, Evidence for a modified placer origin for auriferous conglomerate, Canavieras mine, Jacobina, Brazil: Economic Geology, v. 63, p. 271-276.

Groves, D. I., Martin, E. L., Murchie, H., and Wellington, H. K., 1972, A century of tin mining at Mount Bischoff, 1871-1971: Tasmania Geological Survey Bulletin 54, $310 \mathrm{p}$.

Groves, D. I., and Taylor, R. G., 1973, Greisenization and mineralization at Anchor tin mine, northeast Tasmania: Institute of Mining and Metallurgy Transactions, v. 82, sec. B, P. B135-146.
Giuliani, G., 1985, Le gisement de tungstene de Xihuashan (Sud Jiangxi, Chine): Relations granites, alterations deuteriques-hydrothermales, mineralisations: Mineralium Deposita, v. 20, p. 107-115.

Gulbrandsen, R. A., and Krier, D. J., 1980, Large and rich phosphorus resources in the Phosphoria Formation in the Soda Springs area, southeastern Idaho: U.S. Geological Survey Bulletin 1496, 25 p.

Gustafson, L. B., and Hunt, J. P., 1975, The porphyry copper deposit at El Salvador, Chile: Economic Geology, v. 70, p. 857-912.

Gustafson, L. B., and Williams, Neil, 1981, Sedimenthosted stratiform deposits of copper, lead and zinc, in Skinner, B. J., ed., Economic Geology Seventy-fifth Anniversary Volume: Economic Geology Publishing Company, p. 139-178.

Hamilton, J. M., Bishop, D. T., Morris, H. C., and Owens, O. E., 1982, Geology of the Sullivan orebody, Kimberly, B. C., Canada, in Hutchinson, R. W., Spence, C. D., and Franklin, J. M., eds., Precambrian sulfide deposits, H. S. Robinson Memorial Volume: Geological Association of Canada Special Paper 25, p. 597-666.

Harper, G., 1977, Geology of the Sustut copper deposit in B. C.: Canadian Institute of Mining and Metallurgy Bulletin, v. 97, no. 777, p. 97-104.

Harris, N. B., and Einaudi, M. T., 1982, Skarn deposits in the Yerington district, Nevada: Metasomatic skarn evolution near Ludwig: Economic Geology, v. 77, p. 877-898.

Harrison, J. E., 1972, Precambrian Belt basin of northwestern United States: Its geometry, sedimentation, and copper occurrences: Geological Society of America Bulletin, v. 83, p. 1215-1240.

----1982, Belt stratabound copper, in Erickson, R. L., ed. Characteristics of mineral deposit occurrences: U.S.-Geological Survey Open-File Report 82-795, p. 102-103.

Hernon, R. M., and Jones, W. R., 1968, Ore deposits of the central mining district, New Mexico, in Ridge, J. D., ed., Ore deposits of the United States, 1933-1967 (Graton-Sales volume): New York, American Institute of Mining, Metallurgy and Petroleum Engineering, p. 1212-1237.

Herz, N., and Force, E. R., 1984, Rock suites in Grenvillian terrane of the Roseland district, Virginia: Geological Society of America Special Paper 194, p. 187-214.

Heyl, A. V., 1982, Mineral deposit occurrence model for the Viburnum trend subregion of the southeast Missouri base metal and barite district, in Erickson, R. L., ed., Characteristics of mineral deposit occurrences: U.S. Geological Survey Open-File Report 82-795, p. 158-171.

Hill, W. T., Morris, R. G., and Hagegeorge, C. G., 1971, Ore controls and related sedimentary features at the Flat Gap mine, Treadway, Tennessee: Economic Geology, v. 66, p. 748-757.

Hilpert, L. S., 1969, Uranium resources of northwestern New Mexico: U.S. Geological Survey Professional Paper 603, 166 p.

Hoagland, A. D., 1976, Appalachian zinc-lead deposits, in Wolf, K. H., ed., Handbook of stratabound and 
stratiform ore deposits, vol. 6: Amsterdam, Elsevier, p. 495-534.

Hodges, C. A., Cox, D. P., Singer, D. A., Case, J. E., Berger, B. R., and Albers, J. P., 1984, U.S. Geological Survey-Ingeominas mineral resource assessment of Colombia: U.S. Geological Survey Open-File Report 84-345, 193 p.

Hoeve, Jan, and Sibbald, Thomas I. I., 1978, On the genesis of the Rabbit Lake and other unconformity-type uranium deposits in northern Saskatchewan, Canada: Economic Geology, v. 73, p. 1450-1473.

Hornbrook, E. H. W., 1967, A pilot project at the Silvermine lead deposit, Cape Breton Island, Nova Scotia, in Progress report on biogeochemical research at the Geological Survey of Canada, 1963-1966: Geological Survey of Canada Paper 67-73, pt. 1, p. 65-94.

Hosking, K. F. G., 1969, The nature of primary tin ores of the south-west of England, in A Second Technical Conference on Tin: Bangkok, International Tin Council, v. 3, p. 1157-1243.

---1974, The search for deposits from which tin can be profitably recovered now and in the foreseeable future: Fourth World Tin Conference, Kuala Lumpur; London, International Tin Council, v. 1, p. 21-83.

Hughes, G. J., Jr., 1983, Basinal setting of the Blackbird district cobalt deposits, Lemhi County, Idaho, in The genesis of Rocky Mountain ore deposits: Changes with time and tectonics: Denver Region Exploration Geologists Society Proceedings, p. 21-28.

Huspeni, J. R., Kesler, S. E., Ruiz, Joaquin, Zane, Tuta, Sutter, J. F., and Jones, L. M., 1984, Petrology and geochemistry of rhyolites associated with tin mineralization in northern Mexico: Economic Geology, v. 79, p. 87-105.

Hutchinson, R. W., 1976, Lode gold deposits: The case for volcanogenic derivation, in Pacific Northwest Minerals and Metals Conference, Portland, Oregon, 1975, Proceedings: Salem, Oregon Department of Geology and Mineral Industries, p. 64-105.

-.-1979, Evidence of exhalative origin for Tasmanian tin deposits: Canadian Institute of Mining Metallurgy Bulletin, v. 72, no. 808, p. 90-104.

1982 , Geologic setting and genesis of cassiteritesulphide mineralization at Renison Bell, western Tasmania--A discussion: Economic Geology, v. 77, p. 199-206.

Hutchinson, R. W., Spence, C. D., and Franklin, J. M., eds., 1982, Precambrian sulfide deposits, H.S. Robinson Memorial Volume: Geological Association of Canada Special Paper 25, 791 p.

Hsu, K. C., 1943, Tungsten deposits of southern Kiangsi, China: Economic Geology, v. 38, p. 431474.

Imai, Hideki, Lee, M. S., Takenouchi, S., Fujiki, Y., Iida, K., Sakimoto, T., and Tsukagoshi, S., 1978, Geologic structure and mineralization of polymetallic xenothermal vein-type deposits in Japan, in Imai, Hideki, ed., Geological studies of mineral deposits in Japan and East Asia: Tokyo University Press, p. 86-122.
Intiomale, M. M., and Oosterbosch, R., 1974, Geologie et geochimie du gisement de Kipushi, Zaire, in Bartholome, Paul, ed., Gisements stratiformes et provinces cupriferes: Liege, Societe Geologique de Belgique, p. 123-164.

Isachsen, Y. W., and Evensen, C. G., 1956, Geology of uranium deposits of the Shinarump and Chinle Formations on the Colorado Plateau: U.S. Geological Survey Professional Paper 300, p. 263-280.

Ishihara, S., ed., 1974, Geology of the kuroko deposits: Society of Mining Geologists of Japan, Special Issue 6, $473 \mathrm{p}$.

Irvine, T. N., 1974, Petrology of the Duke Island ultramafic complex, southeastern Alaska: Geological Society of America Memoir 138, 240 p.

Jackson, E. D., 1969, Chemical variation in coexisting chromite and olivine in chromite zones of the Stillwater Complex, in Wilson, H. D. B., ed., Magmatic ore deposits: Economic Geology Monograph 4, p. 41-71.

James, H. L., 1954, Sedimentary facies of iron formation: Economic Geology, v. 49, p. 235-293.

1983, Distribution of banded iron-formation in space and time, in Trendall, A. F., and Morris, R. C., eds., Iron formation; Facts and problems: Amsterdam, Elsevier, p. 471-490.

Janecka, J., and Stemprok, M., 1967, Endogenous tin mineralization in the Bohemian massif, in $A$ technical conference on tin: London, International Tin Council, v. 1, p. 245-266.

Jensen, M. L., and Bateman, A. M., 1981, Economic mineral deposits, 3rd ed.: New York, John Wiley \& Sons, 593 p.

Joralemon, P., 1951, The occurrence of gold at the Getchell mine, Nevada: Economic Geology, v. 46, p. 267-310.

Joubin, F., and James, D. G., 1956, Rexspar uranium deposits: Canadian Mining Journal, v. 77, p. 5060.

Kanehira, K., and Tatsumi, T., 1970, Bedded cupriferous iron sulfide deposits in Japan, A review, in Tatsumi T., ed., Volcanism and ore genesis: Tokyo, University of Tokyo Press, p. 51 76.

Karup-Moller, S., and Brummer, J. J., 1970, The George Lake zinc deposits, Wollaston Lake area, northeastern Saskatchewan: Economic Geology, v. 65 , p. 862-874.

Kelly, W. C., and Goddard, E. N., 1969, Telluride ores of Boulder County, Colorado: Geological Society of America Memoir 109, 237 p.

Kelly, W. C., and Rye, R. O., 1979, Geologic, fluid inclusion and stable isotope studies of the tintungsten deposits of Panasqueira, Portugal: Economic Geology, v. 74, p. 1721-1822.

Kerr, P. F., Brophy, G. P., Dahl, H. M., Green, J., and Woolard, L. E., 1957, Marysvale, Utah, uranium area; geology, volcanic relations, and hydrothermal alteration: Geological Society of America Special Paper 64, 212 p.

Kirkham, R. V., 1984, Volcanic redbed copper, in Eckstrand, O. R., ed., Canadian mineral deposit types: A geological synopsis: Geological Survey of Canada Report 36, p. 37. 
Klau, W., and Large, D. E., 1980, Submarine exhalative $\mathrm{Cu}-\mathrm{Pb}-\mathrm{Zn}$ deposits: A discussion of their classification and metallogenesis: Geologisches Jahrbuch, sec. D, no. 40, p. 13-58.

Knight, C. L., ed., 1975, Economic geology of Australia and Papua New Guinea: The Australasian Institute of Mining and Metallurgy, $1126 \mathrm{p}$.

Knopf, Adolf, 1913, Ore deposits of the Helena mining region, Montana, U.S. Geological Survey Bulletin $527,143 \mathrm{p}$.

---1929, The Mother Lode system of California: U.S. Geological Survey Professional Paper 73, 226 p.

Koski, R. A., and Cook, D. S., 1982, Geology of the Christmas porphyry copper deposit, in Titley, $\mathrm{S}$. R., ed. Advances in geology of the porphyry copper deposits, southwestern North America: Tucson, University of Arizona Press, p. 353-374.

Koski, R. A., and Derkey, R. E., 1981, Massive sulfide deposits in ocean-crust and island-arc terranes in southwestern Oregon: Oregon Geology, v. 43, no. 9 , p. 119-125.

Krauss, V., and Schmidt, H., 1979, Rohstoffwirtshaftliche Landerberichte XXII. UdSSR. Nickel Kobalt Platin Metalle: Hannover, Bundesanstalt fur Geowissenschaften und Rohstoff, 184 p.

Krauss, U. H., Saam, H. G., and Schmidt, H. W., 1984 , International strategic minerals inventory: Summary report--Phosphate: U.S. Geological Survey Circular 930-C, 41 p.

Krebs, Wolfgang, 1981, The geology of the Meggen ore deposit, in Wolf, K. H., ed., Handbook of stratabound and stratiform ore deposits, Part III: Amsterdam , Elsevier, 509-549.

Kwak, T. A. P., and Askins, P. W., 1981, Geology and genesis of the $\mathrm{F}-\mathrm{Sn}-\mathrm{W}-(\mathrm{Be}-\mathrm{Zn})$ skarn (wrigglite) at Moina, Tasmania: Economic Geology, v. 76, p. 439-467.

Kuypers, E. P., and Denyer, P., 1979, Volcanic exhalative manganese deposits of the Nicoya ophiolite complex, Costa Rica: Economic Geology, v. 74, p. 672-678.

Laine, R., ed., 1985, Carswell structure uranium deposits: Geologic Society of Canada Special Paper 29.

Lampietti, F. M. J., and Sutherland, D. G., 1978, Prospecting for diamonds, some current aspects: Mining Magazine, v. 132, p. 117-123.

Landis, Gary P., and Rye, R. O., 1974, Geologic fluid inclusion and stable isotope studies of the Pasto Bueno tungsten-base metal ore deposit, northern Peru: Economic Geology, v. 69, p. 1025-1059.

Langton, J. M., and Williams, S. A., 1982, Structural, petrological, and mineralogical controls for the Dos Pobres ore body, in Titley, S. R., ed., Advances in geology of the porphyry copper deposits, southwestern North America: Tucson, University of Arizona Press, p. 335-352.

Lanier, George, John, E. C., Swensen, A. J., Reid, Julia, Bard, C. E., Caddy, S. W., and Wilson J. C., 1978, General geology of the Bingham mine, Bingham Canyon, Utah: Economic Geology, v. 73, p. $1228-1241$.

Lapham, D. M., 1968, Triassic magnetite and diabase of Cornwall, Pennsylvania, in Ridge, J. D., ed.,
Ore deposits of the United States, 1933-1967 (Graton-Sales volume): New York, American Institute of Mining, Metallurgical and Petroleum Engineers, p. 1212-1237.

Large, D. E., 1980, Geologic parameters associated with sediment-hosted, submarine exhalative $\mathrm{Pb}$ $\mathrm{Zn}$ deposits: An empirical model for mineral exploration, in Stratiform $\mathrm{Cu}-\mathrm{Pb}-\mathrm{Zn}$ deposits: Geologisches Jahrbuch, series D, vol. 40, p. 59129.

1981, Sediment-hosted submarine exhalative lead-zinc deposits--A review of their geological characteristics and genesis, in Wolf, K. H., ed., Handbook of strata-bound and stratiform ore deposits: Amsterdam, Elsevier, v. 9, p. 469-508.

1983, Sediment-hosted massive sulfide lead-zinc deposits: An empirical model, in Sangster, D. F., ed., Sediment-hosted stratiform lead-zinc deposits: Mineralogical Association of Canada Short Course Handbook, v. 8, p. 1-30.

Laughlin, W. H., 1984, Canadian reserves as of January 1, 1983: Gold, silver, lead, zinc, copper, nickel, molybdenum: Energy, Mines and Resources Canada, Mineral Bulletin MR201, 33 p.

Lawrence, E. F., 1963, Antimony deposits of Nevada: Nevada Bureau of Mines and Geology Bulletin 61, $248 \mathrm{p}$.

Leblanc, M., 1981, Ophiolites Precambriennes et gites arsenides de cobalt (Bou Azzer, Maroc): Notes et Memoires, v. 280, 306 pp.

Leblanc, M., and Bilaud, P., 1982, Cobalt arsenide ore bodies related to an Upper Proterozoic ophiolite: Bou Azzer (Morocco): Economic Geology, v. 77, p 162-175.

Leblanc, Marc, and Violette, J. F., 1983, Distribution of aluminum-rich chromite pods in ophiolite peridotites: Economic Geology, v. 78, p. 293301.

Lechner, K., and Plochinger, B., 1956, Die manganerzlagerstatten Osterreichs, in Reyna, J. G., ed., Symposium sobre yacimiento de manganeso: International Geological Congress, 20th, Mexico, v. 5, p. 299-313.

Lee-Moreno, J. L., 1980, The metallogenic tin province in Mexico, in Metallogenesis in Latin America: International Union of Geological Sciences Publication No. 5, p. 37-54.

Liang Zhenting, Chen Shanyou, and Liu Youxi, eds., 1984, Excursion guide: Geology of the Dachang tin field: Nanning, China, Organizing Committee of the International Symposium on Geology of Tin Deposits, $26 \mathrm{p}$.

Lincoln, J. B., 1983, Schaffer-Aultman kimberlite complexes, Albany County, Wyoming, in Genesis of Rocky Mountain ore deposits: Changes with time and tectonics: Denver Region Exploration Geologists Society Proceedings p. 71-78.

Lindgren, W., 1896, The gold-quartz veins of Nevada City and Grass Valley districts, California: U.S. Geological Survey 17th Annual Report, pt. 2, p. 1-262.

---1900, The gold and silver veins of Silver City, DeLamar and other mining districts in Idaho: U.S. Geological Survey 20th Annual Report, pt. 3, p. 67-255. 
----1911, The Tertiary gravels of the Sierra Nevada of California: U.S. Geological Survey Professional Paper 73, $226 \mathrm{p}$.

Lindgren, W., and Ransome, F. L., 1906, Geology and gold deposits of the Cripple Creek district, Colorado, U.S. Geological Survey Professional Paper 54, $516 \mathrm{p}$.

Lindgren, W., and Ross, C. P., 1916, The iron deposits of Daiquiri Cuba: American Institute of Mining Engineers Transactions, v. 53, p. 40-46.

Lindsey, D. A., 1982, Copper shales, in Erickson, R. L., ed., Characteristics of mineral deposit occurrences: U.S. Geological Survey Open File Report 82-795, p. 196-199.

Lissiman, J. C., and Oxenford, R. J., 1973, The Allied Minerals, N. L., heavy mineral sand deposit at Eneabba, Western Australia: Australasian Inst. Mining and Metallurgy Conference Proceedings, p. 153-161.

Loughlin, G. F., and Koschman, A. H., 1935, Geology and ore deposits of the Cripple Creek district, Colorado: Colorado Scientific Society Proceedings, v. 13 , no. 6,435 p.

Lowell, J. D., and Guilbert, J. M., 1970, Lateral and vertical alteration-mineralization zoning in porphyry copper deposits: Economic Geology, v. 65, p. 373-408.

Lozano, H., Perez, H., and Vesga, C. J., 1977, Prospeccion geoquimica y genesis del mercurio en el flanco occidental de la Cordillera Central Municipios de Aranzazu, Salamina y Pacora Departamento de Caldas (Colombia): INGEOMINAS unpublished report.

Lufkin, J. L., 1972, Tin mineralization within rhyolite flow-domes, Black Range, New Mexico: Stanford, Calif., Stanford University, Ph.D. thesis, $148 \mathrm{p}$.

McCormick, J. E., Evans, L. L., Palmer, R. A., and Rasnick, F. D., 1971, Environment of the zinc deposits of the Mascot-Jefferson City district, Tennessee: Economic Geology, v. 66, p. 757-762.

Mackin, J. H., 1968, Iron ore deposits of the Iron Springs deposit, southwestern Utah, in Ridge, J. D., ed., Ore deposits of the United States 19331967 (Graton-Sales volume), New York, American Institute of Mining, Metallurgical and Petroleum Engineers, v. 2, p. 992-1019.

Malcolm, W., 1929, Goldfields of Nova Scotia: Canadian Geological Survey Memoir 156, 253 p.

Markiewicz, F. E., 1969, Ilmenite deposits of the New Jersey coastal plain, in Geology of selected areas in New Jersey and eastern Pennsylvania: New Brunswick, N.J., Rutgers University Press, p. 363-382.

Marston, R. J., Groves, D. I., Hudson, D. R., and Ross, J. R., 1981, Nickel sulfide deposits in western Australia: A review: Economic Geology, v. 76, p. $1330-1336$.

Martin, J. E., and Allchurch, P. D., 1975, Perseverance nickel deposit, Agnew, in Knights, C. L., ed., Economic geology of Australia and Papua New Guinea, I. Metals: Melbourne, The Australasian Institute of Mining and Metallurgy Proceedings Monograph 5, p. 149-155.

Menzie, W. D., and Mosier, D. L., 1985, Grade, tonnage and lithologic data for sediment-hosted submarine exhalative $\mathrm{Zn}-\mathrm{Pb}$ and sandstonehosted $\mathrm{Pb}-\mathrm{Zn}$ deposits; U.S. Geological Survey Open-File Report 85-206, 17 p.

Mertie, J. B., Jr., 1969, Economic geology of the platinum metals: U.S. Geological Survey Professional Paper 630, 120 p.

Meyer, A., 1941, In the Choco Colombia: Engineering and Mining Journal, v. 142, p. 35-39.

Michaud, J. G., 1980, Les Malines and Largentiere lead-zinc deposits in the Mesozoic carbonate and detrital formations on the southern edge of the French Central Massif: Chronique de la Recherche Miniere 454, p. 36-64 (in French).

Miller, M. H., 1973, Antimony, in Brobst, D. A., and Pratt, W. P., eds., United States mineral resources: U.S. Geological Survey Professional Paper 820, p. 45-50.

Minter, W. E. L., 1982, The golden Proterozoic, in Tankard and others, eds., Crustal evolution of southern Africa: New York, Springer-Verlag, p. 801-829.

Molyneux, T. G., 1969, The geology of the area in the vicinity of Magnet Heights, Eastern Transvaal, with special reference to magnetic iron ore, Symposium ore, Bushveld igneous complex and other intrusions: Geological Society of South Africa Special Publication no. 1, p. 228-241.

Morris, H. T., 1968, The main Tintic mining district, Utah, in Ridge, J. D., Ore deposits of the United States, 1933-1967 (Graton-Sales Volume): New York, American Institute of Mining and Metallurgical Engineers, p. 1043-1073.

Morris, H. T., and Lovering, T. S., 1979, General geology and mines of the East Tintic mining district, Utah and Juab Counties, Utah: U.S. Geological Survey Professional Paper 1024, 203 p.

Mosier, D. L., Menzie, W. D., and Kleinhampl, F. J., 1986, Geologic and grade-tonnage information on Tertiary epithermal precious- and base-metal vein districts associated with volcanic rocks: U.S. Geological Survey Bulletin 1666, 39 p.

Mosier, D. L., Singer, D. A., and Salem, B. B., 1983, Geologic and grade-tonnage information on volcanic-hosted copper-zinc-lead massive sulfide deposits: U.S. Geological Survey Open-File Report 83-89, 78 p.

Mutschler, F. E., Wright, E. G., Ludington, Steve, and Abbott, J. T., 1981, Granitic molybdenite systems: Economic Geology, v. 76, p. 874-897.

Nakamura, T., 1970, Mineral zoning and characteristic minerals in the polymetallic veins of the Ashio copper mine, in Tatsumi, T., ed., Volcanism and ore genesis: Tokyo, University of Tokyo Press, p. 231-246.

Nakamura, T., and Hunahashi, M., 1970, Ore veins of Neogene volcanic affinity in Japan, in Tatsumi, T. ed., Volcanism and ore genesis: Tokyo, University of Tokyo Press, p. 215-230.

Nash, J. T., 1981, Geology and genesis of major world hardrock uranium deposits--An overview: U.S. Geological Survey Open-File Report 81-166, 123 P.

Nash, J. T., Granger, H. C., and Adams, S. S., 1981, Geology and concepts of genesis of important types of uranium deposits, in Skinner, B. J., ed., 
Economic Geology, Seventy-fifth Anniversary Volume: Economic Geology Publishing Company, p. 63-116.

Newberry, R. J., 1982, Tungsten-bearing skarns in the Sierra Nevada. I. The Pine Creek mine, California: Economic Geology, v. 77, p. 823-844.

Newell, R. A., 1971, Characteristics of the stanniferous alluvium in the Southern Kinta Valley, West Malaysia: Geological Society of Malaysia Bulletin 4, p. 15-37.

Nokleberg, W. J., 1981, Geologic setting, petrology, and geochemistry of zoned tungsten-bearing skarns at the Strawberry mine, central Sierra Nevada, California: Economic Geology, v. 26, p. 111-133.

Nolan, T. B., 1962, The Eureka mining district Nevada: U.S. Geological Survey Professional Paper 406, 78 p.

Ohmoto, H., and Skinner, B. J., eds., 1983, The Kuroko and related volcanogenic massive sulfide deposits: Economic Geology, Monograph 5, 604 p.

Olsen, J. C., Shawe, D. R., Prey, L. C., Sharp, W. N., and Hewlett, D. F., 1954, Rare earth mineral deposits of the Mountain Pass district, San Bernardino County, California: U.S. Geological Survey Professional Paper 261.

O'Neill, J. J., and Gunning, H. C., 1934, Platinum and allied metal deposits of Canada: Canada Geological Survey, Economic Geology Series no. $13,165 \mathrm{p}$.

Orlov, Y. L., 1973, The mineralogy of the diamond: New York, John Wiley \& Sons, [translation from Izdatel'stva Nauka], $235 \mathrm{p}$.

Orris, G. J., and Bliss, J. D., 1985, Geologic and gradevolume data on 330 gold placer deposits: U.S. Geological Survey Open-File Report 85-213, 172 P.

Page, L. R., and McAllister, J. F., 1944, Tungsten deposits, Isla de Pinos, Cuba: U.S. Geological Survey Bulletin 935-D, 246 p.

Page, N. J, 1977, Stillwater complex, Montana: Rock succession, metamorphism and structure of the complex and adjacent rocks: U.S. Geological Survey Professional Paper 999, 79 p.

Page, N. J, Carlson, R. R., Miller, Michael, Carlson, C. A., and Gray, Floyd, 1982a, Map showing geochemical characteristics of platinum-group elements and gold in rock samples from the Kalmiopsis Wilderness, southwestern Oregon: U.S. Geological Survey Miscellaneous Field Studies Map MF-1240-F, scale 1:62,500.

Page, N. J, Cassard, Daniel, and Haffty, Joseph, 1982b, Palladium, platinum, rhodium, ruthenium, and iridium in chromitites from the Massif du Sud and Tiebaghi Massif, New Caledonia, Economic Geology, v. 77, p. 1571-1577.

Page, N. J, Engin, Tandogan, and Haffty, Joseph, 1979, Palladium, platinum, and rhodium concentrations in mafic and ultramafic rocks from the Kizildag and Guleman areas, Turkey, and the Faryab and Esfandagheh-Abdasht areas, Iran: U.S. Geological Survey Open-File Report 79-340, 15 p.

Page, N. J, Engin, Tandogan, and Singer, D. A., and Haffty, Joseph, 1984, Distribution of platinum- group elements in the Bati Kef chromite deposit, Guleman-Elagig area, eastern Turkey: Economic Geology, v. 79, p. 177-184.

Page, N. J, Foose, M. P., and Lipin, B. R., 1982C, Characteristics of metallic deposits associated with ultramafic and mafic rocks, in Erickson, $\mathrm{R}$. L., ed., Characterists of mineral deposit occurrences: U.S. Geological Survey Open-File Report 82-795, p. 1-12.

Pan, Yuh-Shyi, 1974, The genesis of the Mexican type tin deposits in acid volcanics: New York, Columbia University, Ph.D. thesis, 286 p.

Panayiotou, A., 1980, Cu-Ni-Co-Fe sulfide mineralization, Limmasol Forest, Cyprus, in Panayiotou, A., ed., Ophiolites, Proceedings International Ophiolite Symposium, Nicosia, Cyprus 1979: Cyprus Geological Survey Department, p. 102-116.

Park, C. F., 1942, Manganese resources of the Olympic Peninsula, Washington: U.S. Geological Survey Bulletin 931-R, p. 435-457.

---1946, The spilite and manganese problems of the Olympic Peninsula, Washington: American Journal of Science, v. 244, no. 5, p. 305-323.

Parker, R. L., and Sharp, W. N., 1970, Maficultramafic igneous rocks and associated carbonatites of the Gem Park complex, Custer and Fremont Counties, Colorado: U.S. Geological Survey Professional Paper 649, 24 p.

Patterson, D. J., Ohmoato, H., and Solomon, M., 1981, Geologic setting and genesis of cassiteritesulfide mineralization at Renison Bell, western Tasmania: Economic Geology, v. 76, p. 393-438.

Patterson, S. H., 1967, Bauxite reserves and potential aluminum resources of the world: U.S. Geological Survey Bulletin 1228, 176 p.

----1984, Bauxite and nonbauxite aluminum resources and production--An update, in Jacob, Leonard, Jr., ed., Bauxite--Proceedings of the 1984 Bauxite Symposium, Los Angeles, California: New York, American Institute of Mining, Metallurgical, and Petroleum Engineers, p. 3-30.

Paulson, E. G., 1964, Mineralogy and origin of the titaniferous deposit at Pluma Hidalgo, Oaxaca, Mexico: Economic Geology, v. 59, p. 753-767.

Pavlova, I. G., and Rundquist, D. V., 1980, Zoning of ores and hydrothermal rocks of molybdenumcopper-porphyry deposits under different conditions of formation, in Ridge, J. D., ed., Proceedings of the Fifth Quadrennial IAGOD Symposium, Stuttgart, E. Schweizer bart'sche, p. 113-124.

Payne, J. G., Bratt, J. A., and Stone, B. G., 1980, Deformed Mesozoic $\mathrm{Cu}-\mathrm{Zn}$ sulfide deposits in the Britannia district, British Columbia: Economic Geology, v. 75, p. 700-721.

Peredery, W. V., 1979, Relationship of ultramafic amphibolites to metavolcanic rocks and serpentinites in the Thompson belt, Manitoba: Canadian Mineralogist, v. 17, p. 187-200.

Perkins, Mike, and Nieman, Bill, 1983, Epithermal gold mineralization in the South Mountain volcanic dome, Summitville, Colorado, in Genesis of Rocky Mountain ore deposits: Changes with time and tectonics: Denver Region Exploration Geologists Society Proceedings, p. 71-78. 
Perkle, E. C., Perkle, W. A., and Yoho, W. H., 1974, The Green Cove Springs and Boulougne heavymineral sand deposits of Florida: Economic Geology, v. 69, p. 1129-1137.

Perkle, E. C., and Yoho, W. H., 1970, The heavy mineral body of Trail Ridge, Florida: Economic Geology, v. 65, p. 17-30.

Peterson, E. U., and Zantop, Half, 1980, The Oxec deposit, Guatemala: An ophiolite copper occurrence: Economic Geology, v. 75, p. 10531065.

Philips, G. N., Groves, D. I., and Martyn, J. E., 1984, An epigenetic origin for Archean banded ironformation-hosted gold deposits: Economic Geology, v. 79, p. 162-171.

Plimer, I. R., 1980, Exhalative $S n$ and $W$ deposits associated with mafic volcanism as precursors to $\mathrm{Sn}$ and $\mathrm{W}$ deposits associated with granites: Mineralium Deposita, v. 15, p. 275-289.

Prescott, Basil, 1926, The underlying principles of the limestone replacement deposits of the Mexican province: Engineering and Mining Journal, v. 122, p. 246-253, 289-296.

Pretorius, D. A., 1981, Gold and uranium in quartzpebble conglomerate: in Skinner, B. J., ed., Economic Geology Seventy-fifth Anniversary Volume: Economic Geology Publishing Company, p. 117-138.

Prinz, W. C., 1963, Manganese, in Mineral and water resources of Montana: - Washington, U.S. Government Printing Office, p. 83-86.

Radtke, A. S., Rye, R. O., and Dickson, F. W., 1980, Geology and stable isotope studies of the Carlin gold deposit, Nevada: Economic Geology, v. 75, p. 641-672.

Ransome, F. L., 1909, Geology and ore deposits of Goldfield, Nevada: U.S. Geological Survey Professional Paper 66, 258 p.

Razin, L. V., 1976, Geologic and genetic features of forsterite dunites and their platinum-group mineralization: Economic Geology, v. 71, p. 1371-1376.

Reed, B. L., 1982, Tin greisen model, in Erickson, R. L., ed., Characteristics of mineral deposit occurrences: U.S. Geological Survey Open-File Report 82-795, p. 55-61.

Reid, A. R., and Bisque, R. E., 1975, Stratigraphy of the diamond-bearing Roraima Group, Estado Bolivar, Venezuela: Quarterly of the Colorado School of Mines, v. 70, no. 1, p. 61-82.

Research Group of Porphyrite Iron Ore of the MiddleLower Yangtze Valley, 1977, Porphyrite iron ore-A genetic model of a group of iron ore deposits in andesitic volcanic area: Acta Geologica Sinica, v. 51, no. 1, p. 1-18.

Reynolds, R. L., and Goldhaber, M. B., 1983, Iron disulfide minerals and the genesis of roll-type uranium deposits: Economic Geology, v. 78, p. 105-120.

Rickard, D. T., Willden, M. Y., Marinder, N. E., and Donnelly, T. H., 1979, Studies on the genesis of the Laisvall sandstone lead-zinc deposits, Sweden: Economic Geology, v. 74, p. 1255-1285.

Ridler, R. H., 1970, Relationship of mineralization to volcanic stratigraphy in the Kirkland-Larder Lakes Area, Ontario: Geological Association of
Canada Proceedings, v. 21, p. 33-42.

Riordan, P. H., 1957, The structural environment of the Thetford-Black Lake asbestos deposit: Geological Association of Canada Proceedings, v. 9, p. 83-93.

Ripley, E. M., 1981, Sulfur isotopic studies of Dunka Road $\mathrm{Cu}-\mathrm{Ni}$ deposit, Duluth Complex, Minnesota: Economic Geology, v. 76, p. 610-620.

Ripley, E. M., and Ohmoto, Hiroshi, 1977, Mineralogic, sulfuric isotope and fluid inclusion studies of the stratabound copper deposits at the Raul mine, Peru: Economic Geology, v. 72, p. 1017-1041.

Roberts, D. E., and Hudson, G. R. T., 1983, The Olympic Dam copper-uranium-gold deposit, Roxby Downs, South Australia: Economic Geology, v. 78, p. 799-822.

Rocha, V. S., and Wilson, I. F., 1948, Los yacimientos de manganeso de Talamantes, Municipio de Allende, estado de Chihuahua: Mexico Comite Directivo Para la Investigacion de Los Recursos Minerales de Mexico, Bulletin 18, 39 p.

Roper, M. W., and Wallace, A. B., 1981, Geology of the Aurora uranium prospect, Malheur County, Oregon, in Goodell, P. C., and Waters, A. C., eds., Uranium in volcanic and volcaniclastic rocks: American Association of Petroleum Geologists Studies in Geology no. 13, p. 81-88.

Roscoe, S. M., 1969, Huronian rocks and uraniferous conglomerates in the Canadian Shield: Geological Survey of Canada Paper 68-90, 205 p.

Ross, J. R., and Travis, G. L., 1981, The nickel sulfide deposits of Western Australia in global perspective: Economic Geology, v. 76, p. 12911329.

Roy, Supriya, 1981, Manganese deposits: New York, Academic Press, 458 p.

Ruelle, J. C. L., 1982, Depositional environments and genesis of stratiform copper deposits of the Redstone copper belt, MacKenzie Mountains, N. W. T., in Hutchinson, R. W., Spence, C. D., and Franklin J. M., eds. Precambrian sulfide deposits, H. S. Robinson Memorial Volume: Geological Association of Canada Special Paper 25, p. 701 738.

Ruiz F., Carlos, 1965, Geologia y yacimientos metaliferos de Chile: Santiago, Chile, Instituto de Investigaciones Geologicas, 305 p.

Runnels, D. D., 1969, The mineralogy and sulfur isotopes of the Ruby Creek copper prospect, Bornite, Alaska: Economic Geology v. 64, p. 7590.

Rye, D. M., and Rye, R. O., 1974, Homestake gold mine, South Dakota: I. Stable isotope studies: Economic Geology, v. 69, p. 293-317.

Sainsbury, C. L., 1964, Geology of the Lost River Mine area, Alaska: U.S. Geological Survey Bulletin $1287,101 \mathrm{p}$.

Sainsbury, C. L., and Reed, B. L., 1973, Tin, in Brobst, D. B., and Pratt, W. P., eds., United States mineral resources: U.S. Geological Survey Professional Paper 820, p. 637-651.

Saito, Massao, and Sato, Eitaro, 1978, On the recent exploration at the Iwato gold mine: Mining Geology, v. 28, p. 191-202.

Samama, J. C., 1976, Comparative review of the genesis of the copper-lead sandstone-type 
deposits, in Wolf, H. K., ed., Handbook of stratabound and stratiform ore deposits: Amsterdam, Elsevier, v. 6, p. 1-20.

Sangster, D. F., 1984, Felsic intrusion-associated silver-lead-zinc veins, in Eckstrand, R. O., ed., Canadian mineral deposit types, a geological synopsis: Geological Survey of Canada Report no. 36, p. 66 .

Sangster, D. F., and Kirkham, R. V., 1974, Disseminated base metal mineralization along the Wollaston Lake fold belt, Saskatchewan: Geological Survey of Canada Paper 74-I, pt. A, p. 143-144.

Sapozhnikov, P. G., 1970, Manganese deposits of the Soviet Union: Jerusalem, Israel Program for Scientific Translations, 522 p.

Saupe, Francis, 1973, La Geologie du gisements de mercure d'Almaden: Science de la Terre, Memoir 29, p. 7-341.

Scherba, G. N., 1970, Greisens: International Geology Review, v. 12, p. 114-150, 230-255.

Schmitt, J. M., and Thiry, M., 1977, Mineralisation en plomb par evolution pedogenetiques d'une serie arkosique des trais (Zeida, Haute Moulouya, Maroc): Bureau Recherches Geologie et Minieres Bulletin, 2nd ser., sec. 2, no. 2, p. 113-133.

Scott, Philip, 1980a, Salmon River lead deposit, in McMillian, K. A., ed., Mineral Resources Division report of activities 1979: Nova Scotia Department of Mines and Energy Report 80-1, p. 91-94.

--1980b, Geochemistry and petrography of the Salmon River lead deposit, Cape Breton Island, Nova Scotia: Wolfville, Nova Scotia, Acadia University M.S. thesis, 111 p.

Scratch, R. B., Watson, G. P., Kerrich, R., and Hutchinson, R. W., 1984, Fracture-controlled antimony-quartz mineralization, Lake George deposit, New Brunswick: Mineralogy, geochemistry, alteration, and hydrothermal regimes: Economic Geology, v. 79, no. 5, p. $1159-1186$.

Scull, B. J., 1958, Origin and occurrence of barite in Arkansas: Arkansas Geological and Conservation Commission Information Circular 18, $101 \mathrm{p}$.

Seraphim, R. H., 1975, Denali--A nonmetamorphosed stratiform sulfide deposit: Economic Geology, v. 70, p. 949-959.

Sestini, G., 1973, Sedimentology of a paleoplacer: The gold-bearing Tarkwaian of Ghana, in Amstutz, G. C., and Bernard, A. J., eds., Ores in sediments: Heidelberg, Springer-Verlag, p. 275-305.

Shawe, D. R., Foord, E. E., and Conklin, N. M., 1984 , Huebnerite veins near Round Mountain, Nye County, Nevada: U.S. Geological Survey Professional Paper 1287, 42 p.

Shawe, D. R., Poole, F. G., and Brobst, D. A., 1969, Newly discovered bedded barite deposits in East Northumberland Canyon, Nye County, Nevada: Economic Geology, v. 64, p. 245-254.

Sheldon, R. P., 1964, Paleolatitudinal and paleogeographic distribution of phosphorite: U.S. Geological Survey Professional Paper 501-C, p. C106-C113.

Shride, A. F., 1969, Asbestos, in Mineral and water resources of Arizona: Arizona Bureau of Mines
Bulletin 180, p. 303-311.

-1973, Asbestos, in Brobst, D. A., and Pratt, W. P., eds., United States mineral resources: U.S. Geological Survey Professional Paper 820, p. 6373.

Sillitoe, R. H., 1979, Some thoughts on gold-rich porphyry copper deposits: Mineralium Deposita, v. 14, p. 161-174.

1983, Enargite-bearing massive sulfide deposits, high in porphyry copper systems: Economic Geology, v. 78, p. 348-352.

Sillitoe, R. H., Halls, C., and Grant, J. N., 1975, Porphyry tin deposits in Bolivia: Economic Geology, v. 70, p. 913-927.

Simatupang, M., Rubini, S., Sutedjo, M., and Noerdin, A., 1974, Indonesian tin resources and potential: Fourth World Tin Conference, Kuala Lumpur; London, International Tin Council, v. 1, p. 101120.

Sinclair, W. E., 1955, Asbestos, its origin, production, and utilization: London, Mining Publications, 365 P.

Singer, D. A., Menzie, W. D., DeYoung, J. H., Jr., Sander, M., and Lott, A., 1980, Grade and tonnage data used to construct models for the regional Alaskan Mineral Resource Assessment Program: U.S. Geological Survey Open-File Report 80-799, 58 p.

Singer, D. A., and DeYoung, J. H., Jr., 1980, What can grade-tonnage relations really tell us?: International Geological Congress, 26th, Colloquia C1, Mineral Resources, Paris, France, p. 91-101.

Singer, D. A., and Mosier, D. L., eds., 1983a, Mineral deposit grade-tonnage models: U.S. Geological Survey Open-File Report 83-623, 100 p.

----1983b, Mineral deposit grade-tonnage models II: U.S. Geological Survey Open-File Report 83-902, $101 \mathrm{p}$.

Sinkankas, John, 1981, Emeralds and other beryls: Radnor, Penn., Nelson, 665 p.

Slansky, Maurice, 1980, Ancient upwelling models-Upper Cretaceous and Eocene phosphorite deposits around west Africa, in Sheldon, R. P., and Burnett, W. C., eds., Fertilizer mineral potential in Asia and the Pacific: Honolulu, East-West Resource Systems Institute, Proceedings of the Fertilizer Raw Materials Resources Workshop, August 20-24, 1979, p. 145158.

Smirnov, V. I., Ginzburg, A. I., Grigoriev, V. M., and Yakovlev, G. F., 1983, Studies of mineral deposits: Moscow, Miv, 288 p.

Smith, W. C., Segerstrom, K., and Guiza, R., 1950, Tin deposits of Durango, Mexico: U.S. Geological Survey Bulletin 962-D, p. 155-203.

Snyder, F. G., and Gerdemann, P. E., 1968, Geology of the southeast Missouri lead district, in Ridge, $J$. D., ed., Ore deposits of the United States, 19331967: New York, American Institute of Mining Engineers, p. 326-358.

Snyder, W. S., 1978, Manganese deposited by submarine hot springs in chert-greenstone complexes, western United States: Geology, v. 6, p. 741744. 
Soeda, Akira, and Watanabe, Makoto, 1981, Electrumsilver telluride ores of the Takeno mine, Hyogo Prefecture, SW Japan, and their genetic significance: Mining Geology Special Issue 10, p. 43-52.

Sohnge, P. G., 1964, The geology of the Tsumeb Mine: Proceedings of the Geological Society of South Africa, v. 65, no. 2, p. 367-382.

Soregaroli, A. E., and Whitford, D. F., 1976, Brenda, in Sutherland Brown, A., ed., Porphyry deposits of the Canadian Cordillera: Canadian Institute of Mining and Metallurgy Special volume 15, p. 186194.

Sorem, R. K., and Gunn, D. W., 1967, Mineralogy of manganese deposits, Olympic Peninsula, Washington: Economic Geology, v. 62, p. 22-56.

Steven, T. A., and Eaton, G. P., 1975, Environment of ore deposition in the Creede Mining District, San Juan Mountains, Colorado: Part I. Geologic hydrologic, and geophysical setting: Economic Geology, v. 70, p. 1023-1037.

Sutherland, D. G., 1982, The transport and sorting of diamonds by fluvial and marine processes: Economic Geology, v. 77, p. 1613-1620.

Swanson, S. A., Strong, D. F., and Thurlow, J. G., eds., 1981, The Buchans orebodies: Fifty years of geology and mining: Geological Association of Canada Special Paper no. 22, 350 p.

Taliaferro, N. L., and Hudson, F. S., 1943, Genesis of the manganese deposits of the Coast Ranges of California, in Manganese in California: California Division of Mines Bulletin 125, p. 217275.

Taneda, S., and Mukaiyama, H., 1970, Gold deposits and Quaternary volcanoes in the southern Kyushu: Guidebook II, Excursion B8, International Association on the Genesis of Ore Deposits, Tokyo-Kyoto Meeting, 1970.

Tavera, I. E., and Alexandri, Rafael, 1972, Molango manganese deposits, Hidalgo, Mexico [abs.]: Acta Mineralogica Petrographica, v. 20, p. 387388.

Taylor, H. P., Jr., 1967, The zoned ultramafic complexes of southeastern Alaska, in Wyllie, P. J., ed., Ultramafic and related rocks: New York, John Wiley \& Sons, p. 96-118.

Taylor, R. G., 1979, Geology of tin deposits: Amsterdam, Elsevier, 543 p.

Taylor, Stewart, 1984, Structural and paleotopographic controls of lead-zinc mineralization in the Silvermines orebodies, Republic of Ireland: Economic Geology, v. 79, 529-548.

Temple, A. K., and Grogan, R. M., 1965, Carbonatite and related alkalic rocks at Powderhorn, Colorado: Economic Geology, v. 60, p. 672-692.

Thacker, J. L., and Anderson, K. H., 1977, The geologic setting of the Southeast Missouri lead district--Regional geologic history, structure, and stratigraphy: Economic Geology, v. 72, p. 339-348.

Thayer, T. P., 1964, Principal features and origin of podiform chromite deposits and some observations on the Guliman-Soridag district, Turkey: Economic Geology, v. 59, p. 1497-1524.

Theodore, T. G., and Menzie, W. D., 1983, Fluorinedeficient porphyry molybdenum deposits in the western North American Cordillera: Proceedings of IAGOD Symposium, Tbikis, USSR, September 1982.

Thomas, B. E., 1949, Ore deposits of the Wallapai District, Arizona: Economic Geology, v. 44, p. 663-705.

Thompson, J. F. H., and Naldrett, A. J., 1984, Sulfidesilicate reactions as a guide to $\mathrm{Ni}-\mathrm{Cu}-\mathrm{Co}$ mineralization in central Maine, USA, in Buchanon, D. L., and Jones, M. J., eds., Sulfide deposits in mafic and ultramafic rocks: London, Institution of Mining and Metallurgy, p. 103-113.

Thornett, J. R., 1981, The Sally Malay deposit: Gabbroid associated nickel copper sulfide mineralization in the Halls Creek mobile zone, Western Australia: Economic Geology, v. 76, p. $1565-1580$.

Tingley, J. V., and Berger, B. R., 1985, Lode gold deposits of Round Mountain, Nevada: Nevada Bureau of Mines and Geology, Bulletin 100, 62 p.

Tischendorf, G., 1977, Geochemical and petrographic characteristics of silicic magmatic rocks associated with rare element mineralization, in Stemprok, M., Burnol, L., and Tischendorf, G., eds., Symposium, Metallization Associated with Acid Magmatism (MAWAM): Prague Geological Survey, v. 2, p. 41-96.

Titley, S. R., 1982, The style and progress of mineralization and alteration in porphyry copper systems, in Titley, S. R., ed., Advances in geology of the porphyry copper deposits: Tucson, University of Arizona Press, p. 93-116.

Todd, S. G., Keith, D. W., Lekoy, L. W., Schissel, D. J., Maun, E. L., and Irvine, T. N., 1982, The JM platinum-palladium reef of the Stillwater Complex, Montana: Stratigraphy and petrology: Economic Geology, v. 77, p. 1454-1480.

Tooker, E. W., 1985, Discussion of the disseminatedgold-ore occurrence model, in Tooker, E. W., ed., Geologic characteristics of sediment-and volcanic-hosted disseminated gold deposits-Search for an occurrence model: U.S. Geological Survey Bulletin 1646, p. 107-150.

Tourtelot, E. B., and Vine, J. D., 1976, Copper deposits in sedimentary and volcanogenic rocks: U.S. Geological Survey Professional Paper 907-C, $34 \mathrm{p}$.

Troly, G., Esterle, M., Pelletier, B. G., and Reibell, W., 1979, Nickel deposits in New Caledonia--Some factors influencing their formation, in Evans, D. J., Shoemaker, R. J., and Veltman, H., eds., International Laterite Symposium, New Orleans, 1979: New York, Society of Mining Engineers, AIME, p. 85-120.

Turneaure, F. S., 1971, The Bolivian tin-silver province: Economic Geology, v. 66, p. 215-225.

Turner-Peterson, C. E., and Fishman, N. S., 1986, Geologic synthesis and genetic models for uranium mineralization, Grants uranium region, New Mexico, in Turner-Peterson, C. E., and Santos, E. S., eds., A basin analysis case study-The Morrison Formation, Grants uranium region, New Mexico: American Association of Petroleum Geologists Studies in Geology no. 22.

Tuttle, O. F., and Gittins, J., eds., 1966, Carbonatites: New York, John Wiley \& Sons, 591 p. 
Uchida, Etsuo, and Iiyana, J. T., 1982, Physicochemical study of skarn formation at the Shinyama ironcopper ore deposits of the Kamaishi mine, northeastern Japan: Economic Geology, v. 77, p. 809-822.

Van Nort, S. D., and Harris, Michael, 1984, Geology and mineralization of the Picacho gold prospect, Imperial County, California, in Wilkins, Joe, Jr., ed., Gold and silver deposits of the Basin and Range Province, Western U.S.A.: Arizona Geological Society Digest, v. 15, p. 1-27.

Vermaak, C. F., and Hendriks, L. P., 1976, A review of the mineralogy of the Merensky Reef, with specific reference to new data on the precious metal mineralogy: Economic Geology, v. 71, p. 1244-1269.

Walker, R. R., Matulich, A., Amos, A. C., Watkins, J. J., and Mannard, G. W., 1975, The geology of the Kidd Creek mine: Economic Geology, v. 70, p. 80-89.

Walthier, T. N., Araneda G., Ramon, and Crawford, J. W., 1982, The El Indio gold, silver, and copper deposit region of Coquimbo, Chile, in Watson, $\mathrm{S}$. T., ed., Transactions of the Third Circum-Pacific Energy and Mineral Resources Conference: Honolulu, The Circum-Pacific Council for Energy and Mineral Resources, p. 349-355.

Wandke, A., and Martinez, J., 1928, The Guanajuato mining district, Guanajuato, Mexico: Economic Geology, v. 23, p. 1-44.

Wedepohl, K. H., 1971, "Kupferschiefer" as a prototype of syngenetic sedimentary ore deposits: International Association on Genesis of Ore Deposits, Tokyo-Kyoto, 1970, Proceedings, Special Issue 3, p. 268-273.

Weiblen, P. W., and Morey, G. B., 1980, A summary of the stratigraphy, petrology and structure of the Duluth Complex: American Journal of Science, v. 280-A, p. 88-133.

Wells, F. G., Cater, F. W., Jr., and Rynearson, G. A., 1946, Chromite deposits of Del Norte County, California: California Division of Mines and Geology Bulletin 134, p. 1-76.

Wells, J. H., 1973, Placer examination--Principles and practice: U.S. Department of Interior, Bureau of Land Management Bulletin 4, 204 p.

West, R. J., and Aiken, D. M., 1982, Geology of the Sierrita-Esperanza deposit, in Titley, S. R., ed., Advances in the geology of the porphyry copper deposits, southwestern North America: Tucson, University of Arizona Press, p. 433-466.

Westerveld, J., 1937, The tin ores of Banca, Billeton, and Singkep, Malay Archipelago--A discussion: Economic Geology, v. 32, p. 1019-1041.

Westra, Gerhard, 1982a, Alteration and mineralization in the Ruth porphyry copper deposit near Ely, Nevada: Economic Geology, v. 77, p. 950-970.

----1982b, The Mount Hope stockwork molydenum deposit: Geological Society of America Abstracts with Programs, v. 14, p. 646.

Westra, Gerhard, and Keith, S. B., 1981, Classification and genesis of stockwork molybdenum deposits: Economic Geology, v. 76, p. 844-873.

White, D. E., 1962, Antimony in the United States: U.S. Geological Survey Mineral Investigation Resource Map MR-20, scale 1:3,168,000.
---1981, Active geothermal systems and hydrothermal ore deposits, in Skinner, B. J., ed., Economic Geology, Seventy-fifth Anniversary Volume: Economic Geology Publishing Company, p. 392-423.

White, D. E., and Roberson, C. E., 1962, Sulfur Bank, California, a major hot spring quicksilver deposit: Geological Society of America, Buddington volume, p. 397-428.

White, W. H., Bookstrom, A. A., Kamilli, R. J., Ganster, M. W., Smith, R. P., Ranta, D. E., and Steininger, R. C., 1981, Character and origin of Climax type molybdenum deposits, in Skinner, B. J., ed., Economic Geology, 75th Anniversary Volume: Economic Geology Publishing Company, p. 270-316.

White, W. S., 1968, The native copper deposits of northern Michigan, in Ridge, J., ed., Ore deposits of the United States (Graton-Sales Volume), v. 1: New York, American Institute of Mining, Metallurgical and Petroleum Engineers, p. 303325.

Wilkins, Joe, Jr., 1984, The distribution of gold- and silver-bearing deposits in the Basin and Range province, Western United States, in Wilkins, Joe, Jr., ed., Gold and silver deposits of the Basin and Range Province, Western U.S.A.: Arizona Geological Society Digest, v. 15, p. 1-27.

Wilkins, Joe, Jr., and Heidrick, T. L., 1982; Base and precious metal mineralization related to lowangle tectonic features in the Whipple Mountains, California, and Buckskin Mountains, Arizona, in Mesozoic-Cenozoic tectonic evolution of the Colorado River region, California, Arizona and Nevada, AndersonHamilton Volume: San Diego State University, p. 182-204.

Williams, D. A. C., 1979, The association of some nickel sulfide deposits with komatiitic volcanism in Rhodesia: Canadian Mineralogist, v. 17, p. 337-349.

Williams, J., 1969, The vanadiferous magnetic iron ore of the Bushveld igneous complex, in Wilson, H. D. B., ed., Magmatic ore deposits: Economic Geology Monograph 4, p. 187-208.

Williamson, Anthony, and Rogerson, R. J., 1983, Geology and mineralization of Misima Island: Geological Survey of Papua New Guinea Report $83 / 12,137$ p.

Wilson, I. F., 1955, Geology and mineral deposits of the Boleo copper district, Baja California, Mexico: U.S. Geological Survey Professional Paper 273, $134 \mathrm{p}$.

Wilson, W. E., ed., 1977, Tsumeb! The world's greatest mineral locality: The Mineralogical Record, v. 8 , no. 3, $111 \mathrm{p}$.

Witkind, I. J., 1973, Igneous rocks and related mineral deposits of the Barker quadrangle, Little Belt Mountains, Montana: U.S. Geological Survey Professional Paper 752, 58 p.

Yajima, Junkichi, and Ohta, E., 1979, Two-stage mineralization and formation process of the Toyoha deposits, Hokkaido, Japan: Mining Geology, v. 29, p 291-306.

Yamada, K., Sudo, S., Sato, T., Fujii, N., Sawa, T., Hatori, H., Satoh, H., and Aikawa, T., 1980, 
Mineral resources inventory and evaluation system (MINES): Geological Survey of Japan Report no. 260, 35 p. and two appendixes.

Yeend, W. E., 1974, Gold-bearing gravels of the ancestral Yuba River, Sierra Nevada, California: U.S. Geological Survey Professional Paper 772, 44 p.

Ypma, P. J. M., and Simons, J. H., 1969, Genetic aspects of tin mineralization in Durango, Mexico: Proceedings of the Second Technical Conference on Tin, Bangkok; London, International Tin Council, v. 1, p. 177-192.
Yui, Shunzo, 1983, Textures of some Japanese Besshitype ores and their implications for kuroko genesis, in Ohmoto, Hiroshi, and Skinner, B. J, eds., The kuroko and related volcanogenic massive sulfide deposits: Economic Geology Monograph 5, p. 231-240.

Zellars-Williams, Inc., 1978, Evaluation of the phosphate deposits of Florida using the minerals availability system--Final report: Prepared for the Department of the Interior, Bureau of Mines Contract No. J0377000, 196 p. 
Appendix A. Locality Abbreviations

\begin{tabular}{|c|c|c|c|}
\hline AGTN & Argentina & IRLD & Ireland \\
\hline ALGR & Algeria & ISRL & Israel \\
\hline ANGL & Angola & ITLY & Italy \\
\hline ASTR & Austria & IVCO & Ivory Coast \\
\hline AUNS & Australia, New South Wales & JAPN & Japan \\
\hline AUNT & Australia, N. Territory & JMCA & Jamaica \\
\hline AUQL & Australia, Queensland & JRDN & Jordan \\
\hline AUSA & Australia, South Australia & KNYA & Kenya \\
\hline AUTS & Australia, Tasmania & MALI & Mali \\
\hline AUVT & Australia, Victoria & MAUR & Mauritania \\
\hline AUWA & Australia, Western Australia & MDGS & Madagascar (Malagasy Rep.) \\
\hline BLVA & Bolivia & MLWI & Malawi \\
\hline BOTS & Botswana & MLYS & Malaysia \\
\hline BRMA & Burma & MNGL & Mongolia \\
\hline BRZL & Brazil & MRCO & Morocco \\
\hline BULG & Bulgaria & $\mathrm{MXCO}$ & Mexico \\
\hline CARL & Caroline Islands & MZMB & Mozambique \\
\hline CHAD & Chad & NAMB & Namibia \\
\hline CILE & Chile & NCAL & New Caledonia \\
\hline CINA & China & NCRG & Nicaragua \\
\hline CLBA & Colombia & NKOR & North Korea \\
\hline CMRN & Cameroon & NRWY & Norway \\
\hline CNAL & Canada, Alberta & NZLD & New Zealand \\
\hline CNBC & Canada, British Columbia & OMAN & Oman \\
\hline CNGO & Congo & PANA & Panama \\
\hline CNMN & Canada, Manitoba & PERU & Peru \\
\hline CNNB & Canada, New Brunswick & PKTN & Pakistan \\
\hline CNNF & Canada, Newfoundland & PLND & Poland \\
\hline CNNS & Canada, Nova Scotia & PLPN & Philippines \\
\hline CNNT & Canada, Northwest Territories & PORT & Portugal \\
\hline CNON & Canada, Ontario & PPNG & Papua New Guinea \\
\hline CNQU & Canada, Quebec & PTRC & Puerto Rico \\
\hline CNSK & Canada, Saskatchewan & RMNA & Romania \\
\hline $\mathrm{CNYT}$ & Canada, Yukon Territory & SAAR & Saudi Arabia \\
\hline CORI & Costa Rica & SAFR & South Africa \\
\hline CUBA & Cuba & SKOR & South Korea \\
\hline CYPS & Cyprus & SLMN & Solomon Islands \\
\hline CZCL & Czechoslovakia & SNGL & Senegal \\
\hline DMRP & Dominican Republic & SPAN & Spain \\
\hline ECDR & Ecuador & SRIL & Sri Lanka \\
\hline EGPT & Egypt & SRLN & Sierra Leon \\
\hline ELSA & El Salvador & SRNM & Surinam \\
\hline ETHP & Ethiopia & SUDN & Sudan \\
\hline FIJI & Fiji & SWAF & SW Africa \\
\hline FNLD & Finland & SWAZ & Swaziland \\
\hline FRNC & France & SWDN & Sweden \\
\hline GHNA & Ghana & SYRA & Syria \\
\hline GNBS & Guinea-Bissau & THLD & Thailand \\
\hline GNEA & Guinea & TIWN & Taiwan \\
\hline GRBR & Great Britain & TNZN & Tanzania \\
\hline GREC & Greece & TOGO & Togo \\
\hline GRLD & Greenland & TRKY & Turkey \\
\hline GRME & East Germany & TUNS & Tunisia \\
\hline GRMY & West Germany & UGND & Uganda \\
\hline GUAT & Guatemala & UVOL & Upper Volta (Burkina Fasso) \\
\hline GUYN & Guyana & URAM & USSR, Armenia \\
\hline HAT I & Haiti & URKZ & USSR, Kazakhstan \\
\hline HNDR & Honduras & URRS & USSR, Russian Rep. \\
\hline HONG & Hong Kong & URTD & USSR, Tadzhikistan \\
\hline HUNG & Hungary & URUZ & USSR, Uzbekistan \\
\hline INDA & India & USAK & US, Alaska \\
\hline INDS & Indonesia & USAR & US, Arkansas \\
\hline IRAN & Iran & USAZ & US, Arizona \\
\hline IRAQ & Iraq & USCA & US, California \\
\hline
\end{tabular}


Appendix A. Locality Abbreviations--Continued

$\begin{array}{llll}\text { USCO } & \text { US, Colorado } & \text { USOK } & \text { US, Oklahoma } \\ \text { USFL } & \text { US, Florida } & \text { USOR } & \text { US, Oregon } \\ \text { USGA } & \text { US, Georgia } & \text { USPA } & \text { US, Pennsylvania } \\ \text { USHI } & \text { US, Hawaii } & \text { USTN } & \text { US, Tennessee } \\ \text { USID } & \text { US, Idaho } & \text { USTX } & \text { US, Texas } \\ \text { USKY } & \text { US, Kentucky } & \text { USUT } & \text { US, Utah } \\ \text { USMA } & \text { US, Massachusetts } & \text { USVA } & \text { US, Virginia } \\ \text { USME } & \text { US, Maine } & \text { USVT } & \text { US, Vermont } \\ \text { USMI } & \text { US, Michigan } & \text { USWA } & \text { US, Washington } \\ \text { USMN } & \text { US, Minnesota } & \text { USWI } & \text { US, Wisconsin } \\ \text { USMO } & \text { US, Missouri } & \text { USWY } & \text { US, Wyoming } \\ \text { USMT } & \text { US, Montana } & \text { VNZL } & \text { Venezuela } \\ \text { USNC } & \text { US, North Carolina } & \text { VTNM } & \text { Vietnam } \\ \text { USND } & \text { US, North Dakota } & \text { YUGO } & \text { Yugoslavia } \\ \text { USNJ } & \text { US, New Jersey } & \text { ZIMB } & \text { Zimbabwe } \\ \text { USNM } & \text { US, New Mexico } & \text { ZIRE } & \text { Zaire } \\ \text { USNV } & \text { US, Nevada } & \text { ZMBA } & \text { Zambia } \\ \text { USNY } & \text { US, New York } & & \end{array}$


Appendix B. Summary statistics of grade-tonnage models by Donald A. Singer

[Logarithms (base 10) except $\mathrm{Al}_{2} \mathrm{O}_{3}, \mathrm{Fe}, \mathrm{Cr}_{2} \mathrm{O}_{3}$, fiber, $\mathrm{M}$, and $\mathrm{P}_{2} \mathrm{O}_{5}$, which are percent. S. D., standard deviation]

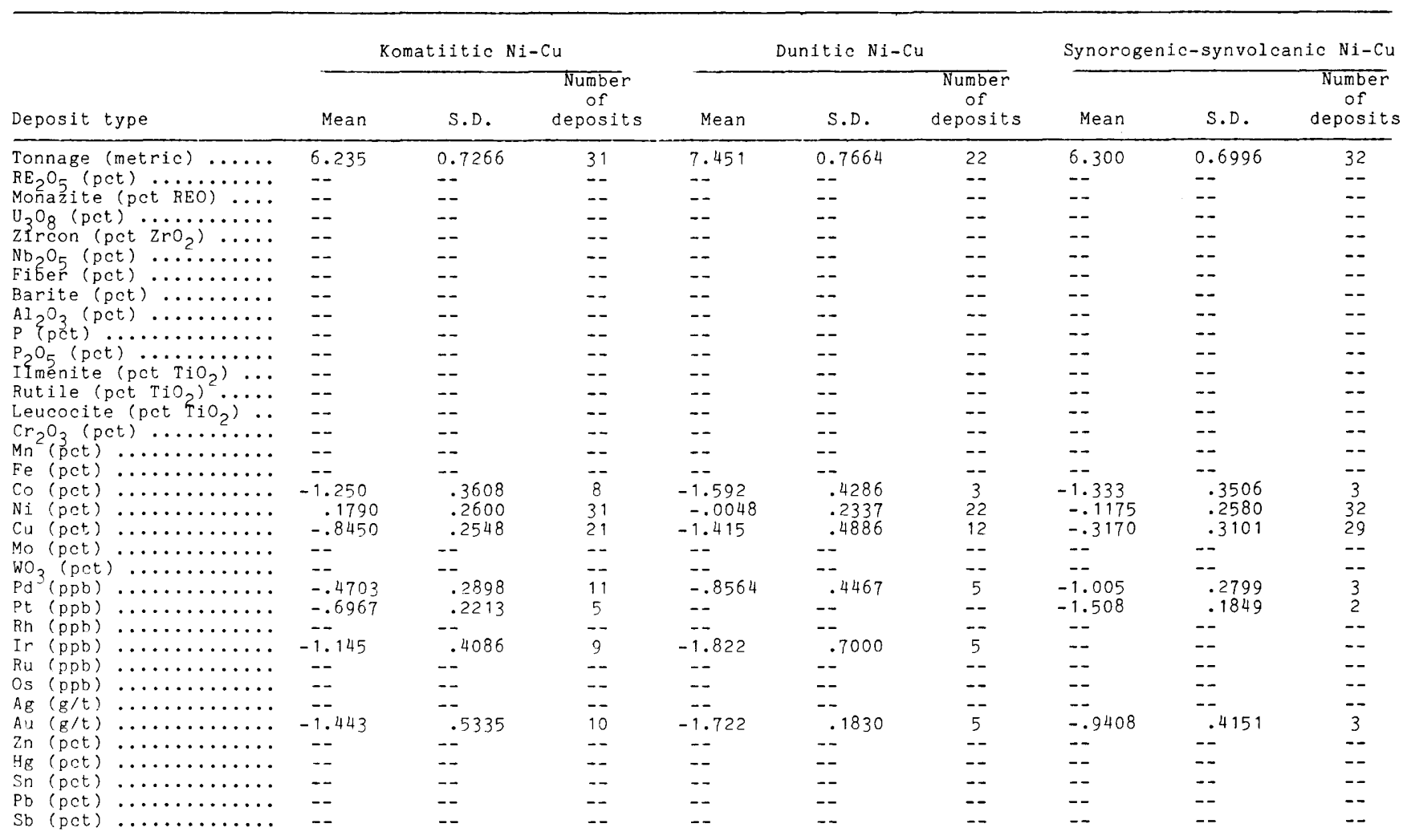

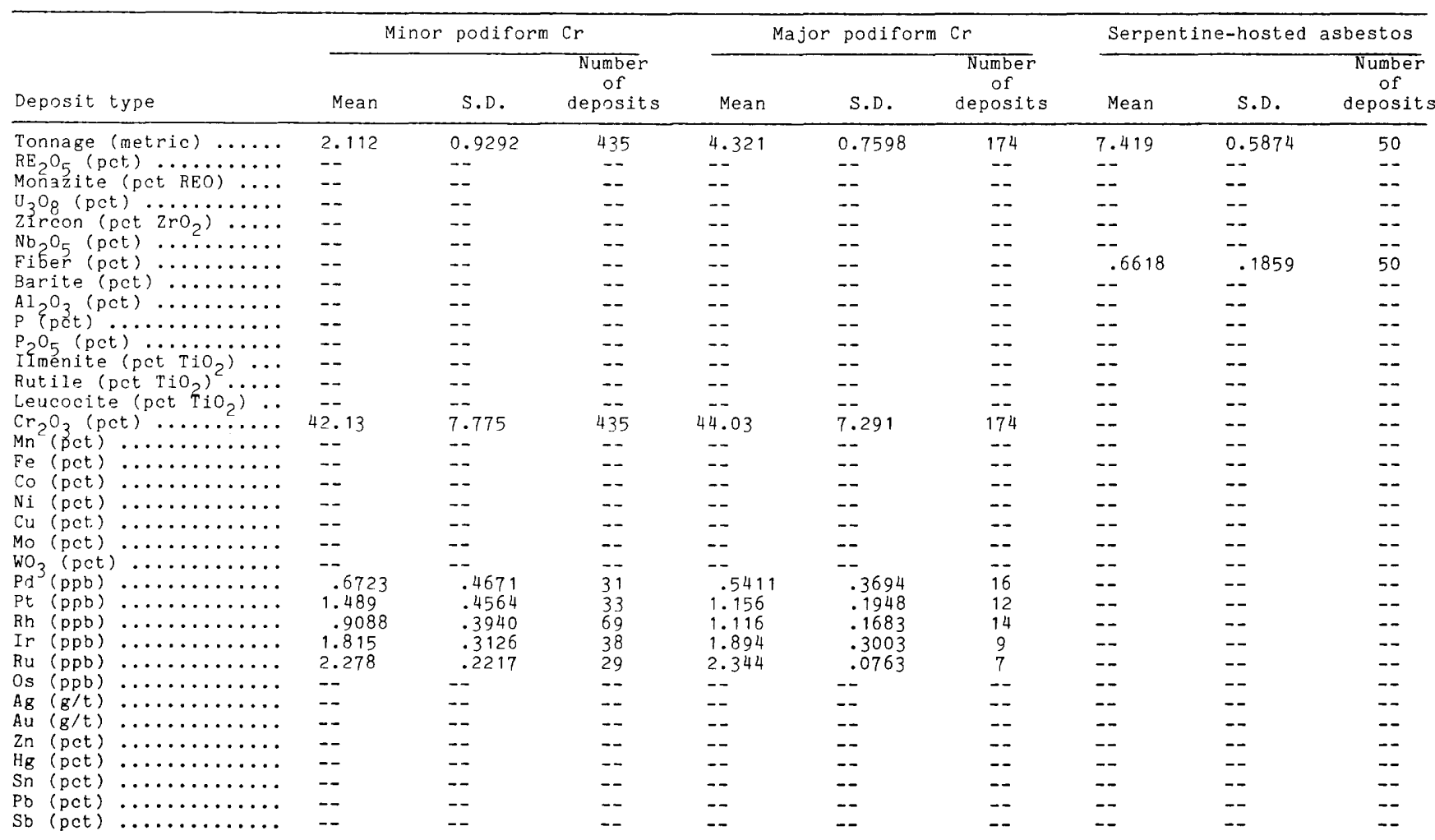


Appendix B. Summary statistics of grade-tonnage models--Continued

\begin{tabular}{|c|c|c|c|c|c|c|c|c|c|}
\hline \multirow[b]{2}{*}{ Deposit type } & \multicolumn{3}{|c|}{ Carbonatite } & \multicolumn{3}{|c|}{ W skarn } & \multicolumn{3}{|c|}{ Sn skarn } \\
\hline & Mean & S.D. & $\begin{array}{c}\text { Number } \\
\text { of } \\
\text { deposits }\end{array}$ & Mean & S.D. & $\begin{array}{c}\text { Number } \\
\text { of } \\
\text { deposits }\end{array}$ & Mean & S.D. & $\begin{array}{l}\text { Number } \\
\text { of } \\
\text { deposits }\end{array}$ \\
\hline $\begin{array}{l}\text { Tonnage (metric) } \ldots \ldots \\
\mathrm{RE}_{2} \mathrm{O}_{5}(\mathrm{pct})\end{array}$ & $\begin{array}{r}7.777 \\
-10013\end{array}$ & 0.4414 & 20 & 6.016 & 1.025 & 28 & 6.774 & 0.6178 & 4 \\
\hline 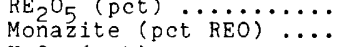 & $\begin{array}{l}-1.013 \\
--\end{array}$ & 1.207 & $\begin{array}{c}5 \\
--\end{array}$ & $\overline{-}$ & $\begin{array}{l}-- \\
--\end{array}$ & $=$ & -- & $\begin{array}{l}-- \\
--\end{array}$ & $\begin{array}{l}-- \\
--\end{array}$ \\
\hline $\mathrm{U}_{3} \mathrm{O}_{8}$ (pet) $\ldots \ldots \ldots \ldots$ & -- & -- & -- & -- & -- & -- & -- & -- & -- \\
\hline $\begin{array}{l}\left.\operatorname{Zircon}(p c t) \mathrm{ZrO}_{2}\right) \ldots \ldots \\
\mathrm{Nb}_{2} \mathrm{O}_{5}(\mathrm{pct})\end{array}$ & $\begin{array}{l}-- \\
-.1951\end{array}$ & .3562 & $\overline{20}$ & -- & $=-$ & $=$ & $=$ & $=-$ & -- \\
\hline Eiber (pct) $\ldots \ldots \ldots \ldots$ & --1951 & $\therefore-3502$ & -- & $\begin{array}{l}-- \\
-\end{array}$ & -- & $=$ & & & -- \\
\hline Barite (pct) $\ldots \ldots \ldots \ldots$ & -- & -- & -- & -- & - & -- & -- & -- & -- \\
\hline 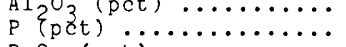 & $\begin{array}{l}-- \\
--\end{array}$ & -- & $\begin{array}{l}-- \\
--\end{array}$ & $\begin{array}{l}-- \\
--\end{array}$ & $\begin{array}{l}-- \\
--\end{array}$ & -- & -- & $\begin{array}{l}-- \\
--\end{array}$ & -- \\
\hline $\begin{array}{l}\mathrm{P}_{2} \mathrm{O}_{5} \text { (pct) } \\
\text { ITmenite (pct Tio, }\end{array}$ & $=-$ & -- & -- & $\begin{array}{l}-- \\
--\end{array}$ & $\begin{array}{l}-- \\
--\end{array}$ & -- & -- & -- & $\because$ \\
\hline Rutile $\left(\mathrm{pct} \mathrm{TiO}_{2}\right) \ldots .$. & -- & -- & -- & -- & -- & -- & -- & -- & $\cdots$ \\
\hline $\begin{array}{l}\text { Leucocite } \\
\left.\mathrm{Cr}_{2} \mathrm{O}_{2} \text { (pet } \text { (pct } \mathrm{TiO}_{2}\right) \ldots\end{array}$ & -- & -- & -- & -- & -- & -- & $=-$ & -- & $=$ \\
\hline $\mathrm{Mn}^{2}(p<t) \cdots \cdots \cdots \cdots \cdots \cdots$ & -- & -- & -- & -- & -- & -- & -- & -- & -- \\
\hline $\mathrm{Fe}$ (pct) $\ldots \ldots \ldots \ldots \ldots$ & -- & -- & -- & -- & -- & -- & -- & -- & -- \\
\hline$N i($ pet $), \ldots \ldots \ldots \ldots \ldots$ & -- & -- & -- & -- & $\overline{--}-$ & -- & -- & -- & $\ldots$ \\
\hline $\mathrm{Cu}$ (pct) $\ldots \ldots \ldots \ldots \ldots$ & & -- & -- & -- & -- & -- & -- & -- & -- \\
\hline Mo (pct),$\cdots \cdots \cdots \cdots \cdots \cdots$ & -- & -- & -- & -- & -- & $\overline{-}$ & -- & -- & -- \\
\hline 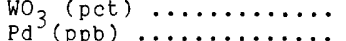 & $\because-$ & -- & $=$ & -.1820 & $\therefore 2430$ & 28 & $=-$ & -- & -- \\
\hline Pt $(p p b) \quad \ldots \ldots \ldots \ldots \ldots \ldots$ & -- & -- & -- & 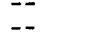 & $\overline{--}$ & $=$ & -- & $\because$ & $=$ \\
\hline $\begin{array}{l}\text { Rh }(p p b) \\
\text { Ir }(p p b)\end{array}$ & -- & -- & -- & -- & -- & -- & -- & -- & -- \\
\hline $\mathrm{Ru}(\mathrm{ppb}) \quad \ldots \ldots \ldots \ldots \ldots \ldots$ & -- & -- & -- & -- & 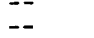 & -- & -- & -- & -- \\
\hline os (ppb) $\quad \cdots \cdots \cdots \cdots \cdots$ & -- & -- & -- & $\ldots$ & -- & -- & -- & -- & -- \\
\hline$A g(g / t)$. & -- & -- & -- & -- & -- & -- & -- & -- & -- \\
\hline $\mathrm{zn}$ (oct) & -- & -- & -- & -- & $\cdots$ & $\cdots$ & -- & & - \\
\hline $\mathrm{Hg}($ pct $), \ldots \ldots \ldots \ldots \ldots$ & -- & -- & -- & -- & -- & - & - & -- & -- \\
\hline$S_{n}$ (pct) $\ldots \ldots \ldots \ldots \cdots \cdots$ & -- & -- & -- & -- & -- & -- & -.5031 & .3014 & 4 \\
\hline $\begin{array}{ll}P b & (p c t) \cdot \cdot\end{array}$ & -- & -- & -- & -- & -- & - & -- & $\cdots$ & -- \\
\hline$s b(p c t) \ldots \ldots$ & -- & -- & -- & -- & -- & -- & -- & -- & $\cdots$ \\
\hline
\end{tabular}

\begin{tabular}{|c|c|c|c|c|c|c|c|c|c|}
\hline \multirow[b]{2}{*}{ Deposit type } & \multicolumn{3}{|c|}{ Replacement Sn } & \multicolumn{3}{|c|}{ W vein } & \multicolumn{3}{|c|}{ Sn vein } \\
\hline & Mean & S.D. & $\begin{array}{l}\text { Number } \\
\text { of } \\
\text { deposits }\end{array}$ & Mean & S.D. & $\begin{array}{c}\text { Number } \\
\text { of } \\
\text { deposits }\end{array}$ & Mean & S.D. & $\begin{array}{l}\text { Number } \\
\text { of } \\
\text { deposits }\end{array}$ \\
\hline $\begin{array}{l}\text { Tonnage (metric) } \ldots \ldots \\
R_{0} O_{5}(p c t)\end{array}$ & 6.720 & 0.5493 & 6 & 5.748 & 0.8574 & 16 & 5.374 & 1.000 & 43 \\
\hline $\begin{array}{l}\mathrm{RE}_{2} \mathrm{O}_{5} \text { (pct) } \\
\text { Monazite (pct } \mathrm{REO}\end{array}$ & $=$ & $\begin{array}{l}-- \\
--\end{array}$ & $\begin{array}{ll}-- \\
--\end{array}$ & $\begin{array}{l}-- \\
--\end{array}$ & $\therefore$ & $\begin{array}{l}-- \\
--\end{array}$ & $=$ & $\because-$ & $=-$ \\
\hline 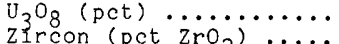 & -- & -- & -- & -- & - & - & - & & -- \\
\hline $\begin{array}{l}\mathrm{Zrcon}(\text { pet } \\
\left.\mathrm{Nb}_{2} \mathrm{rrO}_{2}\right)\end{array}$ & -- & $\begin{array}{ll}-- \\
--\end{array}$ & -- & $=-$ & -- & -- & -- & $=-$ & -- \\
\hline $\begin{array}{l}\text { Fiber (pct) } \\
\text { Barite }(p c t) \\
\ldots\end{array}$ & -- & -- & -- & -- & -- & - & -- & - & -- \\
\hline 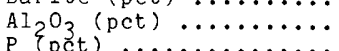 & -- & - & $\overline{-}$ & $=-$ & $=$ & $=-$ & -- & -- & $\begin{array}{l}-- \\
--\end{array}$ \\
\hline${ }_{P_{2} O_{5}(p c t)}^{(p c t)} \cdots \cdots \cdots \cdots \cdots$ & -- & -- & 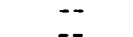 & -- & -- & -- & -- & -- & -- \\
\hline IImenite (pct $\left.\mathrm{TiO}_{2}\right) \ldots$ & -- & -- & - & $\because-$ & -- & -- & -- & -- & -- \\
\hline $\begin{array}{l}\left.\text { Rutile (pct } \mathrm{TiO}_{2}\right) \\
\text { Leucocite } \\
\text { (pct }\end{array}$ & -- & -- & -- & -- & -- & -- & - & - & $=$ \\
\hline $\mathrm{Cr}_{2} \mathrm{O}_{3}$ (pct) $\ldots . \cdots \cdots$ & -- & $\overline{--}$ & -- & 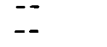 & -- & $\begin{array}{l}-- \\
--\end{array}$ & -- & -- & $\begin{array}{l}-- \\
-\end{array}$ \\
\hline $\begin{array}{l}M n(p c t) \\
\mathrm{Fe}(p c t)\end{array}$ & $=$ & -- & -- & -- & -- & -- & & -- & -- \\
\hline Co (pct) $\ldots \ldots \ldots \ldots$.......... & -- & -- & -- & - & -- & -- & & $\ldots$ & -- \\
\hline$N i$ (pct) $\quad \cdots \cdots \cdots \cdots \cdots$ & -- & -- & -- & -- & -- & -- & -- & -- & $\ldots$ \\
\hline $\begin{array}{l}C_{\text {Cu }}^{\text {Mo }}(p c t) \\
\text { Mo }\end{array}$ & - & $\because$ & $=-$ & $=$ & -- & 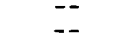 & -- & -- & -- \\
\hline Wo $_{3}$ (pct) $\ldots \ldots \ldots \ldots \ldots \ldots$ & -- & -- & -- & -.0400 & .1408 & $\overline{16}$ & - & $=$ & $=$ \\
\hline 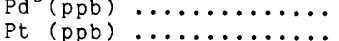 & -- & -- & 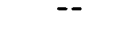 & -- & -- & -- & -- & -- & -- \\
\hline $\mathrm{Rh}(\mathrm{ppb}) \quad \ldots \ldots \ldots \cdots \cdots \cdots$ & -- & -- & -- & -- & -- & 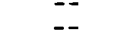 & $=$ & -- & -- \\
\hline $\operatorname{Ir}(p p b) \quad \ldots \ldots \ldots \ldots \ldots$ & -- & -- & -- & -- & -- & -- & -- & -- & -- \\
\hline $\begin{array}{l}R u(p p b) \\
O s\end{array}(p p b) \cdots \cdots \cdots \cdots \cdots \cdots \cdots$ & -- & -- & -- & -- & -- & -- & -- & -- & -- \\
\hline$A g(g / t) \ldots \ldots \ldots \ldots \ldots$ & -- & -- & -- & -- & -- & -- & - & - & $=-$ \\
\hline$z_{n}($ pct $) \quad \ldots \ldots \cdots \cdots \cdots \cdots$ & -- & -- & -- & -- & -- & -- & -- & -- & -- \\
\hline $\mathrm{Hg}(\mathrm{pct}) \ldots \ldots \ldots \ldots$ & -- & -- & -- & -- & -- & -- & -- & - & $=$ \\
\hline $\begin{array}{l}\text { Sn } \\
\text { ph }\end{array}$ & -.0965 & .1265 & 6 & -- & -- & $-\cdot$ & .1038 & .202 & 43 \\
\hline 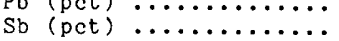 & $=-$ & $=$ & -- & -- & -- & -- & $=-$ & $=-$ & -- \\
\hline
\end{tabular}


Appendix B. Summary statistics of grade-tonnage models--Continued

\begin{tabular}{|c|c|c|c|c|c|c|c|c|c|}
\hline \multirow[b]{2}{*}{ Deposit type } & \multicolumn{3}{|c|}{ Sn greisen } & \multicolumn{3}{|c|}{ Climax Mo } & \multicolumn{3}{|c|}{ Porphyry copper } \\
\hline & Mean & S.D. & $\begin{array}{c}\text { Number } \\
\text { of } \\
\text { deposits }\end{array}$ & Mean & S.D. & $\begin{array}{c}\text { Number } \\
\text { of } \\
\text { deposits }\end{array}$ & Mean & S.D. & $\begin{array}{l}\text { Number } \\
\text { of } \\
\text { deposits }\end{array}$ \\
\hline $\mathrm{RE}_{2} \mathrm{O}_{5}(p c t) \ldots \ldots \cdots \cdots$ & -- & -- & -- & -- & -- & -- & -- & -- & -- \\
\hline Monazite (pet REO) .... & -- & -- & -- & -- & -- & -- & -- & -- & -- \\
\hline $\mathrm{U}_{3} \mathrm{O}_{8}$ (pct) $\ldots \ldots \ldots \ldots$ & -- & -- & -- & -- & -- & -- & -- & -- & -- \\
\hline Z1rcon (pet $\left.\mathrm{ZrO}_{2}\right) \ldots$. & -- & -- & -- & -- & -- & -- & -- & -- & -- \\
\hline $\mathrm{Al}_{2} \mathrm{O}_{3}$ (pct) $\ldots \ldots \cdots \cdots$ & -- & -- & -- & -- & -- & -- & -- & -- & -- \\
\hline$p\{p c t) \ldots \ldots \ldots \ldots \ldots$ & -- & -- & -- & -- & -- & -- & -- & -- & -- \\
\hline $\mathrm{P}_{2} \mathrm{O}_{5}$ (pct) $\ldots \ldots \cdots \cdots$ & -- & -- & -- & -- & -- & -- & -- & -- & -- \\
\hline Imenite $\left(\right.$ pct $\left.\mathrm{TiO}_{2}\right) \ldots$ & -- & -- & -- & -- & -- & -- & -- & -- & -- \\
\hline $\begin{array}{l}\left.\text { Rutile (pct } \mathrm{TiO}_{2}\right) \ldots \ldots \\
\text { Leucocite (pct }{ }_{\mathrm{TiO}}, \ldots\end{array}$ & -- & -- & -- & -- & -- & -- & -- & -- & -- \\
\hline $\begin{array}{l}\left.\text { Leucocite (pct } \mathrm{TiO}_{2}\right) \ldots \\
\mathrm{Cr}, \mathrm{O}_{2} \text { (pct) } \ldots \ldots \ldots \ldots \ldots\end{array}$ & $=$ & -- & -- & $\begin{array}{l}-- \\
-\end{array}$ & -- & -- & $\overline{--}$ & -- & -- \\
\hline 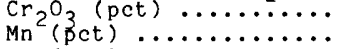 & -- & -- & $\overline{--}$ & -- & $\overline{--}$ & $\begin{array}{ll}-- \\
--\end{array}$ & $\begin{array}{l}-- \\
--\end{array}$ & $\overline{--}$ & $\begin{array}{ll}-- \\
--\end{array}$ \\
\hline $\mathrm{Fe}$ (pct) $\ldots \ldots \ldots \ldots$ & -- & -- & -- & -- & -- & -- & -- & -- & -- \\
\hline $\mathrm{Pd}^{3}(\mathrm{ppb}) \quad \ldots \ldots \ldots \ldots \ldots$ & -- & -- & $-\overline{0}$ & -- & -- & -- & -- & 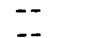 & -- \\
\hline $\begin{array}{l}\text { Pt }(p p b) \\
R h(p p b) \\
R h \ldots \cdots \cdots \cdots \cdots\end{array}$ & -- & $=$ & - & -- & -- & -- & $\ldots$ & -- & -- \\
\hline Ir $(\mathrm{ppb}) \ldots \ldots \ldots \ldots$ & -- & -- & -- & -- & -- & -- & -- & -- & -- \\
\hline$R u(p p b) \quad \ldots \ldots \ldots \ldots \ldots$ & -- & -- & -- & -- & -- & -- & -- & -- & -- \\
\hline os $(p p b) \quad \ldots \ldots \ldots \ldots \ldots$ & -- & -- & -- & -- & -- & -- & -- & -- & $=$ \\
\hline $\mathrm{Ag}(\mathrm{g} / \mathrm{t}) \ldots \ldots \ldots \ldots \ldots$ & -- & -- & -- & -. & -- & -- & .2180 & .3646 & 76 \\
\hline $\mathrm{Au}(\mathrm{g} / \mathrm{t}) \ldots \ldots \ldots \ldots \ldots$ & -- & -- & -- & -- & -- & -- & -.9077 & .7012 & 81 \\
\hline$Z n$ (pct) $\ldots \ldots \cdots \cdots \cdots$ & -- & -- & -- & -- & -- & -- & -- & -- & -- \\
\hline $\mathrm{Hg}$ (pct) $\ldots \ldots \ldots \ldots \ldots$ & -- & -- & -- & -- & -- & -- & -- & -- & -- \\
\hline$s_{n}(p c t) \quad \ldots \ldots \ldots \ldots$ & -.5491 & .1707 & 10 & -- & -- & -- & -- & -- & -- \\
\hline$P b$ (pct) $\ldots \ldots \ldots \ldots \cdots$ & -- & -- & -- & -- & -- & -- & -- & -- & -- \\
\hline$S b$ (pct) $\ldots \ldots \ldots \ldots \ldots$ & -- & -- & -- & -- & -- & -- & -- & -- & -- \\
\hline
\end{tabular}

\begin{tabular}{|c|c|c|c|c|c|c|c|c|c|}
\hline \multirow[b]{2}{*}{ Deposit type } & \multicolumn{3}{|c|}{ Porphyry $\mathrm{Cu}$, skarn-related } & \multicolumn{3}{|c|}{ Cu skarn } & \multicolumn{3}{|c|}{$\mathrm{Zn}-\mathrm{Pb}$ skarn } \\
\hline & Mean & S.D. & $\begin{array}{c}\text { Number } \\
\text { of } \\
\text { deposits }\end{array}$ & Mean & S.D. & $\begin{array}{l}\text { Number } \\
\text { of } \\
\text { deposits }\end{array}$ & Mean & S.D. & $\begin{array}{c}\text { Number } \\
\text { of } \\
\text { deposits }\end{array}$ \\
\hline Tonnage (metric) $\ldots .$. & 7.901 & 0.4726 & 18 & 5.747 & 0.9505 & 64 & 6.151 & 0.7302 & 34 \\
\hline $\mathrm{RE}_{2} \mathrm{O}_{5}$ (pct) $\ldots \ldots \ldots$ & -- & -- & -- & -- & -- & -- & -- & -- & -- \\
\hline & -- & $\begin{array}{l}-- \\
--\end{array}$ & -- & -- & -- & -- & -- & -- & -- \\
\hline 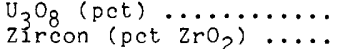 & -- & -- & -- & -- & -- & $\begin{array}{ll}-- \\
--\end{array}$ & -- & -- & -- \\
\hline $\mathrm{Nb}_{2} \mathrm{O}_{5}$ (pct) $\quad \ldots \ldots \ldots \ldots$ & -- & -- & -- & -- & -- & $\begin{array}{ll}-- \\
--\end{array}$ & -- & -- & $\begin{array}{ll}-- \\
--\end{array}$ \\
\hline Fiber (pct) $\ldots \ldots \cdots \cdots$ & -- & -- & - & -- & -- & -- & -- & -- & -- \\
\hline Barite (pct) $\ldots \ldots \cdots$ & -- & -- & -- & - & -- & -- & -- & -- & -- \\
\hline $\mathrm{Al}_{2} \mathrm{O}_{3}$ (pct) $\ldots \ldots \cdots \cdots \cdot$ & -- & -- & -- & -- & -- & -- & -- & -- & -- \\
\hline 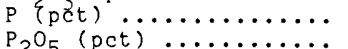 & $\begin{array}{l}-- \\
--\end{array}$ & $\begin{array}{ll}-- \\
--\end{array}$ & -- & $\begin{array}{l}-- \\
--\end{array}$ & -- & -- & -- & -- & -- \\
\hline $\begin{array}{l}\mathrm{P}_{2} \mathrm{O}_{5} \text { (pct) } \\
\left.\text { IImenite } \mathrm{Bu}_{\mathrm{Ti}} \mathrm{O}_{2}\right) \cdots \cdots\end{array} \cdots$ & -- & - & -- & -- & -- & -- & $\overline{--}$ & -- & $\overline{--}$ \\
\hline Rutile $\left(\right.$ pct $\left.\mathrm{TiO}_{2}\right) \ldots \ldots$ & -- & -- & -- & -- & -- & -- & -- & -- & -- \\
\hline Leucocite $\left(\right.$ pct $\left.\mathrm{TiO}_{2}\right) \ldots$ & -- & -- & -- & -- & -- & -- & -- & -- & -- \\
\hline 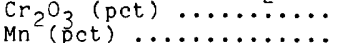 & $\begin{array}{l}-- \\
--\end{array}$ & -- & -- & -- & $\overline{--}$ & -- & -- & -- & $\overline{--}$ \\
\hline $\mathrm{Fe}($ pct $) \ldots \ldots \ldots \ldots \cdots$ & -- & -- & - & -- & -- & -- & -- & -- & $\overline{--}$ \\
\hline Co (pct) $\ldots \ldots \ldots \ldots \ldots$ & -- & -- & -- & -- & -- & -- & -- & -- & -- \\
\hline$N i$ (pct) $\ldots \ldots \ldots \ldots \ldots$ & -- & -- & -- & -- & -- & -- & -- & -- & -- \\
\hline $\mathrm{Cu}$ (pct) $\ldots \ldots \ldots \ldots \ldots$ & -.0081 & .2211 & 18 & .2266 & .2880 & 64 & -.3377 & .4585 & 17 \\
\hline Mo (pct) $\ldots \ldots \ldots \ldots \ldots$ & -1.657 & .2591 & 4 & -- & -- & -- & -- & -- & -- \\
\hline $\mathrm{WO}_{3}(\mathrm{pct}) \quad \ldots \ldots \ldots \ldots \ldots$ & -- & -- & -- & -- & -- & -- & -- & -- & -- \\
\hline $\begin{array}{l}\mathrm{Pd}^{3}(\mathrm{ppb}) \\
\mathrm{Pt}(\mathrm{ppb})\end{array}$ & -- & $=$ & -- & -- & -- & -- & -- & -- & -- \\
\hline $\begin{array}{l}\mathrm{Pt} \\
\mathrm{Rh}(\mathrm{ppb})\end{array}$ & -- & $\overline{--}$ & -- & $\overline{--}$ & $\overline{--}$ & $\overline{--}$ & -- & -- & $\begin{array}{l}-- \\
--\end{array}$ \\
\hline Ir $(\mathrm{ppb}) \ldots \ldots \ldots \cdots \cdots$ & -- & -- & -- & -- & -- & -- & -- & -- & -- \\
\hline$R u(p p b) \quad \ldots \ldots \ldots \ldots \ldots$ & -- & -- & -- & -- & -- & -- & -- & -- & -- \\
\hline Os $(p p b) \quad \cdots \cdots \cdots \cdots \cdots \cdot$ & -.6798 & --4185 & $\overline{0}$ & -- & --6055 & $\bar{z}-$ & -- & -- & $\overline{-}$ \\
\hline $\begin{array}{ll}A g & (g / t) \\
A u & (g / t)\end{array}$ & $\begin{array}{r}.0798 \\
-.4829\end{array}$ & $\begin{array}{l}.4185 \\
.5020\end{array}$ & $\begin{array}{l}9 \\
6\end{array}$ & $\begin{array}{l}1.331 \\
.2496\end{array}$ & $\begin{array}{l}.6955 \\
.6107\end{array}$ & $\begin{array}{l}15 \\
16\end{array}$ & $\begin{array}{l}2.059 \\
-.3489\end{array}$ & $\begin{array}{l}.3908 \\
.5134\end{array}$ & $\begin{array}{c}22 \\
7\end{array}$ \\
\hline $\mathrm{Zn}$ (pct) $\ldots \ldots \ldots \ldots \ldots$ & -- & -- & -- & -- & -- & -- & .7719 & .2709 & 34 \\
\hline $\mathrm{Hg}(p c t) \ldots \ldots \ldots \ldots \ldots$ & -- & -- & -- & -- & -- & -- & -- & -- & -- \\
\hline $\operatorname{sn}(p c t) \ldots \ldots \ldots \ldots \ldots$ & -- & -- & -- & -- & -- & -- & -- & -- & -- \\
\hline $\mathrm{Pb}($ pct) $\cdots \cdots \cdots \cdots \cdots \cdot$ & -- & -- & -- & -- & -- & -- & .5076 & .3053 & 30 \\
\hline$S b(p c t) \quad \ldots \ldots \cdots \cdots \cdots$ & -- & -- & -- & -- & -- & -- & -- & & -- \\
\hline
\end{tabular}


Appendix B. Summary statistics of grade-tonnage models--Continued

\begin{tabular}{|c|c|c|c|c|c|c|c|c|c|}
\hline \multirow[b]{2}{*}{ Deposit type } & \multicolumn{3}{|c|}{ Fe skarn } & \multicolumn{3}{|c|}{ Polymetallic replacement } & \multicolumn{3}{|c|}{ Replacement $\mathrm{Mn}$} \\
\hline & Mean & S.D. & $\begin{array}{c}\text { Number } \\
\text { of } \\
\text { deposits }\end{array}$ & Mean & S.D. & $\begin{array}{c}\text { Number } \\
\text { of } \\
\text { deposits }\end{array}$ & Mean & S.D. & $\begin{array}{l}\text { Number } \\
\text { of } \\
\text { deposits }\end{array}$ \\
\hline Tonnage (metric) $\ldots . .$. & 6.858 & 1.041 & 168 & 6.261 & 0.6884 & 52 & 4.348 & 1.073 & 37 \\
\hline $\mathrm{RE}_{2} \mathrm{O}_{5}$ (pct) $\ldots \ldots \ldots \cdots$ & -- & - & -- & -- & -- & -- & -- & -- & -- \\
\hline Monazite (pet REO) .... & -- & -- & -- & -- & -- & -- & -- & -- & -- \\
\hline $\begin{array}{l}\mathrm{U}_{3} \mathrm{O}_{8} \text { (pct) } \\
\mathrm{Z}_{\mathrm{r} \text { ron }}(\mathrm{pct} \\
\mathrm{ZrO}\end{array} ; \cdots \cdots \cdots$ & -- & $\begin{array}{l}-- \\
--\end{array}$ & -- & $\begin{array}{l}-- \\
--\end{array}$ & -- & -- & $\overline{--}$ & $\ddot{--}$ & -- \\
\hline 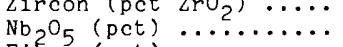 & - & -- & - & -- & $\cdots$ & - & -- & - & -- \\
\hline Fiber (pct) $\cdots \cdots \cdots \cdots$ & -- & -- & -- & -- & -- & -- & - & -- & -- \\
\hline $\begin{array}{l}\text { Barite (pct) } \ldots \cdots \cdots \cdots \\
\mathrm{Al}^{2} \mathrm{O}_{2} \text { (pct) } \ldots \ldots \cdots \cdots\end{array}$ & -- & -- & 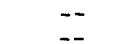 & -- & $\overline{-}$ & -- & -- & 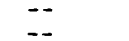 & -- \\
\hline 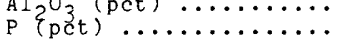 & -- & -- & -- & -- & $\overline{--}$ & -- & -1.481 & .4493 & 3 \\
\hline $\mathrm{P}_{2} \mathrm{O}_{5}$ (pet) $\ldots \ldots \cdots \cdots \cdots$ & -- & -- & -- & -- & -- & -- & -- & -- & -- \\
\hline Imenite $\left(\right.$ pct $\left.\mathrm{TiO}_{2}\right) \ldots$ & -- & $\cdots$ & -- & - & -- & -- & -- & -- & -- \\
\hline Rutile (pct $\left.\mathrm{TiO}_{2}\right)^{2} \ldots \ldots$ & -- & -- & -- & -- & -- & -- & -- & -- & -- \\
\hline $\begin{array}{l}\left.\text { Leucocite } \text { (pct } \mathrm{TiO}_{2}\right) \\
\mathrm{Cr}_{2} \mathrm{O}_{2} \text { (pet) } \ldots \mathrm{C}_{2} \ldots \ldots\end{array}$ & -- & $\begin{array}{l}-- \\
--\end{array}$ & -- & -- & -- & $\begin{array}{l}-- \\
--\end{array}$ & -- & -- & -- \\
\hline$M n^{2}(p c t) \quad \ldots \ldots \cdots \cdots \cdots \cdots$ & -- & -- & -- & -- & -- & -- & 32.54 & 11.28 & $\overrightarrow{37}$ \\
\hline $\mathrm{Fe}(p c t) \ldots \ldots \ldots \ldots$ & 49.61 & 10.28 & 168 & -- & -- & -- & -- & -- & -- \\
\hline Co (pct) $\ldots \ldots \ldots \ldots \cdots$ & -- & -- & -- & -- & -- & -- & -- & -- & -- \\
\hline $\mathrm{Ni}$ (pct),$\cdots \cdots \cdots \cdots \cdots \cdot$ & -- & -- & -- & -- & -- & $\overline{35}$ & $\begin{array}{l}-- \\
-.0546\end{array}$ & .2839 & $\overline{4}$ \\
\hline 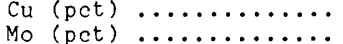 & -- & $\begin{array}{ll}-- \\
--\end{array}$ & -- & $\begin{array}{l}-.6327 \\
--\end{array}$ & $\therefore 5121$ & $\begin{array}{l}3 b \\
--\end{array}$ & $\because .0540$ & $-0<39$ & -- \\
\hline $\mathrm{WO}_{3}(\mathrm{pct}) \ldots \ldots \ldots \ldots$ & -- & -- & -- & -- & -- & - & -- & -- & -- \\
\hline $\mathrm{Pd}^{3}(\mathrm{ppb}) \quad \ldots \ldots \ldots \ldots \ldots$ & -- & -- & -- & -- & -- & -- & -- & -- & -- \\
\hline Pt $(p p b) \quad \ldots \ldots \ldots \ldots \ldots$ & -- & -- & -- & -- & -- & -- & -- & -- & -- \\
\hline $\mathrm{Rh}(\mathrm{ppb}) \quad \ldots \ldots \ldots \ldots \ldots$ & -- & -- & -- & -- & -- & -- & -- & -- & -- \\
\hline $\begin{array}{l}\text { Ir }(p p b) \\
\text { Ru }(p p b)\end{array}$ & -- & -- & -- & -- & -- & -- & -- & $\ldots$ & -- \\
\hline $\begin{array}{l}\mathrm{Ru}(\mathrm{ppb}) \\
\mathrm{Os}(\mathrm{ppb})\end{array}$ & $=$ & $=$ & $=-$ & $\overline{--}$ & -- & -- & $\cdots$ & -- & -- \\
\hline $\mathrm{Ag}(\mathrm{g} / \mathrm{t}) \ldots \ldots \cdots \cdots \cdots$ & -- & -- & -- & 2.286 & .4599 & 45 & -- & -- & -- \\
\hline Au $(g / t) \quad \ldots \ldots \ldots \ldots \cdots$ & -- & - & $=-$ & -.1462 & .7319 & 35 & -- & -- & - \\
\hline$z n$ (pct) $\ldots \ldots \ldots \ldots \ldots$ & -- & -- & -- & .5937 & .5361 & 51 & -- & -- & -- \\
\hline $\mathrm{Hg}$ (pct) $\ldots \ldots \ldots \ldots \ldots$ & -- & -- & -- & -- & -- & -- & -- & -- & -- \\
\hline 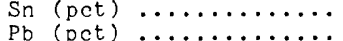 & $\overline{--}$ & $\begin{array}{ll}-- \\
--\end{array}$ & $=$ & -7041 & -4749 & $\overline{52}$ & -- & -- & -- \\
\hline sb (pct) $\ldots \ldots \ldots \ldots \ldots \ldots$ & -- & -- & -- & $\therefore 104$ & -8 & - & -- & -- & -- \\
\hline
\end{tabular}

\begin{tabular}{|c|c|c|c|c|c|c|c|c|c|}
\hline \multirow[b]{2}{*}{ Deposit type } & \multicolumn{3}{|c|}{ Porphyry $\mathrm{Cu}-\mathrm{Au}$} & \multicolumn{3}{|c|}{ Porphyry Cu-Mo } & \multicolumn{3}{|c|}{ Porphyry Mo, low-F } \\
\hline & Mean & S.D. & $\begin{array}{c}\text { Number } \\
\text { of } \\
\text { deposits }\end{array}$ & Mean & S.D. & $\begin{array}{c}\text { Number } \\
\text { of } \\
\text { deposits }\end{array}$ & Mean & S.D. & $\begin{array}{c}\text { Number } \\
\text { of } \\
\text { deposit }\end{array}$ \\
\hline Tonnage (metric) $\ldots \ldots$ & 8.005 & 0.4746 & 40 & 8.706 & 0.4831 & 16 & 7.974 & 0.6053 & 33 \\
\hline $\mathrm{RE}_{2} \mathrm{O}_{5}$ (pct) $\ldots \ldots \cdots \cdots$ & $-\cdots$ & $\therefore$ & -- & $-\ldots$ & -- & $\ldots$ & -- & & $\ldots$ \\
\hline Monazite (pet REO) .... & -- & -- & -- & -- & -- & -- & -- & -- & -- \\
\hline $\mathrm{U}_{3} \mathrm{O}_{8}(p c t) \quad \ldots \ldots \cdots \cdots$ & -- & -- & -- & -- & -- & -- & -- & -- & $\cdots$ \\
\hline Zircon (pet $\left.\mathrm{ZrO}_{2}\right) \ldots \ldots$ & -- & -- & -- & -- & $\cdots$ & -- & -- & -- & -- \\
\hline 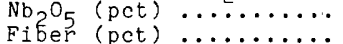 & $\begin{array}{l}-- \\
--\end{array}$ & $\begin{array}{l}-- \\
--\end{array}$ & $\begin{array}{l}-- \\
--\end{array}$ & $\begin{array}{l}-- \\
--\end{array}$ & -- & $\begin{array}{l}-- \\
--\end{array}$ & 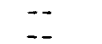 & -- & -- \\
\hline Barite (pct) $\ldots \ldots \ldots \ldots$ & -- & -- & -- & $\overline{--}$ & -- & -- & $\because$ & -- & -- \\
\hline $\mathrm{Al}_{2} \mathrm{O}_{3}$ (pct) $\ldots \ldots \ldots \ldots$ & -- & -- & -- & -- & -- & -- & -- & -- & -- \\
\hline$p\{p c t) \quad \ldots \cdots \cdots \cdots \cdots$ & -- & -- & -- & -- & -- & -- & -- & -- & -- \\
\hline $\mathrm{P}_{2} \mathrm{O}_{5}$ (pct) $\cdots \cdots \cdots \cdots \cdot$ & -- & -- & -- & -- & -- & -- & -- & -- & -- \\
\hline IImenite $\left(\right.$ pct $\left.\mathrm{TiO}_{2}\right) \ldots$ & -- & - & -- & -- & -- & -- & -- & -- & -- \\
\hline Rutile $\left(\right.$ pct $\left.\mathrm{TiO}_{2}\right) \ldots$ & -- & -- & -- & -- & -- & -- & -- & -- & -- \\
\hline Leucocite $\left(\right.$ pct $\left.\mathrm{TiO}_{2}\right) \ldots$ & -- & -- & - & -- & -- & - & -- & -- & -- \\
\hline $\mathrm{Cr}_{2} \mathrm{O}_{3}$ (pet) $\ldots \ldots \ldots \ldots$ & -- & -- & -- & -- & -- & -- & -- & - & -- \\
\hline$M^{2}{ }^{2}(p c t) \quad \cdots \cdots \cdots \cdots \cdots$ & -- & -- & -- & $\cdots$ & -- & -- & -- & -- & -- \\
\hline Fe (pct) $\ldots \ldots \ldots \ldots \cdots$ & -- & -- & -- & -- & -- & -- & -- & -- & -- \\
\hline Co (pct) $\cdots \cdots \cdots \cdots \cdots$ & -- & - & -- & -- & -- & -- & -- & -- & -- \\
\hline Ni (pct) $\ldots \cdots \cdots \cdots \cdots$ & -- & -- & -- & -- & -- & $=-$ & -- & -- & -- \\
\hline $\mathrm{Cu}$ (pct) $\ldots \ldots \ldots \ldots \ldots$ & -.2968 & .1205 & 40 & -.3777 & .1679 & 16 & -- & -- & -- \\
\hline Mo (pct) $\ldots \ldots \ldots \ldots \ldots$ & -2.516 & .3681 & 20 & -1.802 & .2683 & 16 & -1.070 & .1459 & 33 \\
\hline $\mathrm{WO}_{3}$ (pct) $\ldots \ldots \ldots \ldots \cdots$ & -- & -- & -- & -- & -- & -- & -- & -- & -- \\
\hline $\begin{array}{l}P d^{2}(p p b){ }^{(p p b)} \\
P t\end{array}$ & -- & $\overline{--}$ & -- & $\begin{array}{l}-- \\
--\end{array}$ & -- & $\begin{array}{ll}-- \\
--\end{array}$ & -- & $\overline{--}$ & $\overline{--}$ \\
\hline$R h(p p b) \quad \ldots \ldots \ldots \ldots \ldots$ & -- & -- & -- & -- & -- & -- & -- & -- & -- \\
\hline Ir $(p p b) \quad \ldots \ldots \ldots \ldots$ & -- & -- & -- & -- & -- & -- & -- & -- & -- \\
\hline$R u(p p b), \ldots \ldots \ldots \ldots$ & -- & -- & -- & -- & -- & -- & -- & -- & -- \\
\hline os $(p p b) \quad \ldots \ldots \ldots \ldots \ldots$ & -- & -- & -- & -- & -- & -- & -- & -- & - \\
\hline$A g(g / t) \quad \ldots \ldots \ldots \ldots \ldots$ & .2012 & .3720 & 27 & .0852 & .4162 & 16 & -- & -- & -- \\
\hline$A u(g / t) \ldots \ldots \ldots \ldots \cdots$ & -.4178 & .2138 & 40 & -1.908 & .4189 & 10 & -- & -- & -- \\
\hline $\mathrm{Zn}$ (pct) $\ldots \ldots \ldots \ldots \ldots$ & -- & -- & -- & -- & -- & -- & - & -- & -- \\
\hline$H g(p c t) \quad \ldots \ldots \ldots \ldots \ldots$ & -- & -- & -- & -- & -- & -- & -- & -- & -- \\
\hline Sn (pct) $\cdots \cdots \cdots \cdots \cdots$ & -- & - & -- & -- & -- & -- & -- & -- & -- \\
\hline $\mathrm{Pb}$ (pct) $\ldots \ldots \ldots \ldots \ldots$ & -- & -- & -- & -- & -- & -- & -- & -- & -- \\
\hline$s b(p c t) \ldots \ldots \ldots \ldots \ldots$ & -- & -- & -- & -- & -- & -- & -- & -- & -- \\
\hline
\end{tabular}


Appendix B. Summary statistics of grade-tonnage models--Continued

\begin{tabular}{|c|c|c|c|c|c|c|c|c|c|}
\hline \multirow[b]{2}{*}{ Deposit type } & \multicolumn{3}{|c|}{ Polymetallic vein } & \multicolumn{3}{|c|}{ Cyprus massive sulfide } & \multicolumn{3}{|c|}{ Besshi massive sulfide } \\
\hline & Mean & S.D. & $\begin{array}{c}\text { Number } \\
\text { of } \\
\text { deposits }\end{array}$ & Mean & S.D. & $\begin{array}{c}\text { Number } \\
\text { of } \\
\text { deposits }\end{array}$ & Mean & S.D. & $\begin{array}{c}\text { Number } \\
\text { of } \\
\text { deposits }\end{array}$ \\
\hline Tonnage (metric) $\ldots \ldots$ & 3.880 & 1.109 & 75 & 6.105 & 0.8765 & 49 & 5.339 & 0.9701 & 44 \\
\hline $\mathrm{RE}_{2} \mathrm{O}_{5}$ (pct) $\ldots \ldots \cdots \cdots$ & -- & -- & $\cdots$ & -- & -- & -- & -- & -- & -- \\
\hline Monazite (pet REO) $\ldots$ & -- & -- & -- & -- & -- & -- & -- & -- & -- \\
\hline 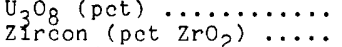 & -- & -- & $\overline{--}$ & -- & $\overline{--}$ & $\overline{--}$ & -- & $\overline{--}$ & -- \\
\hline $\mathrm{Nb}_{2} \mathrm{O}_{5}$ (pct) $\ldots . . . \cdots \cdots$ & -- & -- & $\overline{-}$ & $\overline{--}$ & $\overline{--}$ & -- & -- & -- & $\ddot{--}$ \\
\hline Fiber (pct) $\ldots \ldots \ldots \ldots$ & -- & -- & -- & -- & -- & -- & -. & -- & -. \\
\hline Barite (pct) $\ldots \ldots \ldots \ldots$ & -- & -- & -- & -- & -- & -- & -- & -- & -- \\
\hline $\mathrm{Al}_{2} \mathrm{O}_{3}$ (pct) $\ldots \cdots \cdots \cdots \cdot$ & -- & -- & -- & -- & -- & -- & -- & -- & -- \\
\hline$p\{p e t\} \quad \ldots \ldots \ldots \ldots \ldots$ & -- & -- & -- & -- & -- & -- & -- & -- & -- \\
\hline $\mathrm{P}_{2} \mathrm{O}_{5}$ (pct) $\ldots \ldots \ldots \ldots \cdots$ & -- & -- & -- & -- & -- & -- & -- & -- & -- \\
\hline Imenite $\left(\right.$ pct $\left.\mathrm{TiO}_{2}\right) \ldots$ & -- & -- & -- & -- & -- & -- & -- & -- & -- \\
\hline $\begin{array}{l}\left.\text { Rutile (pet } \mathrm{TiO}_{2}\right)^{2} \cdots \\
\text { Leucocite (pet Tio }\end{array}$ & -- & -- & -- & $\begin{array}{l}-- \\
--\end{array}$ & $\begin{array}{ll}-- \\
--\end{array}$ & $\overline{--}$ & -- & $\begin{array}{l}-- \\
--\end{array}$ & -- \\
\hline 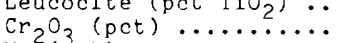 & -- & -- & -- & -- & $\ldots$ & $\ldots$ & -- & -- & $\begin{array}{l}-- \\
--\end{array}$ \\
\hline$M n^{2}(p c t) \ldots \ldots \ldots \ldots$ & -- & -- & -- & -- & -- & -- & -- & -- & -- \\
\hline Fe $(p c t), \ldots \ldots \ldots \ldots \ldots$ & -- & -- & -- & -- & -- & -- & -- & -- & -- \\
\hline Co (pct) $\ldots \ldots \cdots \cdots \cdots$ & -- & -- & -- & -- & $\cdots$ & -- & -- & -- & -- \\
\hline $\mathrm{Ni}(p c t) \ldots \ldots \ldots \ldots \ldots$ & -- & -- & -- & -- & -- & -- & -- & -- & -- \\
\hline $\mathrm{Cu}(\mathrm{pct}), \ldots \ldots \ldots \ldots \ldots$ & -.7169 & .8378 & 33 & .2040 & .3068 & 49 & .1633 & .2798 & 44 \\
\hline Mo (pct) $\ldots \ldots \ldots \ldots \ldots$ & -- & -- & -- & -- & -- & -- & -- & -- & -- \\
\hline $\mathrm{wO}_{3}$ (pct) $\ldots \ldots \ldots \ldots \ldots$ & -- & -- & -- & -- & -- & -- & -- & -- & -- \\
\hline$P d^{3}(p p b) \quad \ldots \ldots \ldots \ldots \cdots$ & -- & -- & -- & -- & -- & -- & -- & - & -- \\
\hline Pt $(p p b) \quad \ldots \ldots \ldots \cdots \cdots$ & -- & -- & -- & -- & -- & -- & -- & -- & -- \\
\hline$R h(p p b) \quad \ldots \ldots \ldots \ldots \ldots$ & -- & -- & -- & -- & -- & -- & -- & -- & -- \\
\hline $\operatorname{Ir}(p p b) \quad \ldots \ldots \ldots \cdots \cdots$ & -- & -- & -- & -- & -- & -- & -- & -- & -- \\
\hline$R u(p p b) \quad \ldots \ldots \cdots \cdots \cdots$ & -- & -- & -- & -- & -- & -- & -- & -- & -- \\
\hline Os $(p p b) \quad \ldots \ldots \ldots \cdots$ & -- & -- & -- & -- & -- & -- & -- & -- & -- \\
\hline$A g(g / t) \quad \ldots \ldots \ldots \ldots \ldots$ & 2.938 & .5935 & 74 & 1.109 & .6457 & 15 & .8956 & .3838 & 14 \\
\hline $\mathrm{Au}(g / t) \quad \ldots \ldots \ldots \ldots \ldots$ & -.2088 & 1.166 & 54 & -.0417 & .6893 & 15 & -.4650 & .4697 & 14 \\
\hline$Z n(p c t) \ldots \ldots \ldots \ldots$ & .4439 & .3718 & 60 & -.1021 & .7085 & 16 & -.2506 & .2755 & 6 \\
\hline $\mathrm{Hg}$ (pct) $\ldots \ldots \ldots \ldots \ldots$ & -- & -- & -- & -- & -- & -- & -- & -- & -- \\
\hline$S_{n}(p c t) \quad \ldots \ldots \cdots \cdots \cdots$ & $-\infty$ & -- & -- & -- & -- & -- & -- & -- & -- \\
\hline $\mathrm{Pb}$ (pct) $\ldots \ldots \ldots \ldots \cdots \cdot$ & .9529 & .4426 & 75 & -1.333 & .5774 & 3 & -- & -- & -- \\
\hline$S b(p c t) \quad \ldots \ldots \ldots \cdots \cdots$ & -- & -- & -- & -- & -- & -- & -- & -- & -- \\
\hline
\end{tabular}

\begin{tabular}{|c|c|c|c|c|c|c|c|c|c|}
\hline \multirow[b]{2}{*}{ Deposit type } & \multicolumn{3}{|c|}{ Volcanogenic Mn } & \multicolumn{3}{|c|}{ Creede epithermal vein } & \multicolumn{3}{|c|}{ Comstock epithermal vein } \\
\hline & Mean & S.D. & $\begin{array}{c}\text { Number } \\
\text { of } \\
\text { deposits }\end{array}$ & Mean & S.D. & $\begin{array}{c}\text { Number } \\
\text { of } \\
\text { deposits }\end{array}$ & Mean & S.D. & $\begin{array}{c}\text { Number } \\
\text { of } \\
\text { deposits }\end{array}$ \\
\hline Tonnage (metric) ...... & 4.674 & 0.9607 & 93 & 6.151 & 0.9382 & 27 & 5.884 & 0.8379 & 41 \\
\hline $\mathrm{RE}_{2} \mathrm{O}_{5}$ (pct) $\cdots \cdots \cdots \cdots$ & -- & -- & -- & -- & -- & -- & -- & & -- \\
\hline $\begin{array}{l}\text { Monazite (pct REO) } \ldots \ldots \\
\mathrm{U}_{3} \mathrm{O}_{8} \text { (pct) } \ldots \ldots \ldots \ldots \ldots\end{array}$ & -- & -- & $\begin{array}{l}-- \\
--\end{array}$ & $=$ & $\begin{array}{ll}-- \\
--\end{array}$ & & & -- & -- \\
\hline 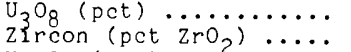 & $\overline{--}$ & $\because$ & - & - & -- & $=$ & $\overline{--}$ & -- & -- \\
\hline $\mathrm{Nb}_{2} \mathrm{O}_{5}$ (pct) $\ldots \ldots \ldots$ & -- & -- & - & -- & - & - & -- & - & -- \\
\hline Fiber (pct) $\ldots \ldots \ldots \ldots$ & -- & -- & -- & -- & -- & -- & -- & -- & -- \\
\hline Barite (pct) $\ldots \ldots \ldots$ & -- & -- & -- & -- & -- & -- & -- & -- & -- \\
\hline 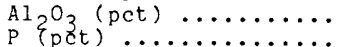 & $-\overline{-1} 055$ & $-\overline{.5115}$ & -- & -- & $\cdots$ & -- & -- & -- & -- \\
\hline 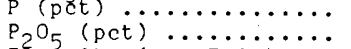 & $\begin{array}{l}-1.055 \\
--\end{array}$ & $\begin{array}{l}.5115 \\
--\end{array}$ & $\begin{array}{c}8 \\
--\end{array}$ & $\overline{--}$ & -- & -- & $\overline{--}$ & -- & - \\
\hline Ilmenite (pct $\mathrm{TiO}_{2}$ ) ... & -- & -- & -- & - & -- & -- & -- & $\overline{--}$ & $\begin{array}{l}-- \\
--\end{array}$ \\
\hline $\begin{array}{l}\left.\text { Rutile (pct } \mathrm{TiO}_{2}\right) \\
\text { Leucocite (pct } \mathrm{T} \text {. }\end{array}$ & - & -- & -- & -- & -- & - & -- & -- & -- \\
\hline $\begin{array}{l}\text { Leucocite }\left(\text { pet } \mathrm{TiO}_{2}\right) \ldots \\
\mathrm{Cr}_{2} \mathrm{O}_{3} \text { (pct) } \ldots \ldots \ldots \ldots \ldots\end{array}$ & -- & -- & $=-$ & -- & -- & -- & -- & -- & -- \\
\hline 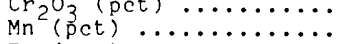 & $3 \overline{8.80}$ & $\overline{9} .723$ & $\overline{93}$ & -- & -- & -- & -- & $\overline{--}$ & -- \\
\hline $\mathrm{Fe}$ (pct) $\ldots \ldots \cdots \cdots \cdots$ & -- & -- & -- & -- & -- & -- & -- & -- & -- \\
\hline Co (pct) $\quad \ldots \cdots \cdots \cdots \cdots$ & -- & -- & -- & -- & -- & -- & -- & -- & -- \\
\hline$N i \quad(p c t) \quad \ldots \cdots \cdots \cdots \cdots$ & -- & -- & -- & -- & -- & -- & -- & -- & -- \\
\hline $\begin{array}{c}C_{M}^{C u}(p c t) \\
M o\end{array}$ & -- & -- & -- & .5254 & .4843 & 19 & -1.816 & .7955 & 18 \\
\hline 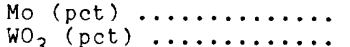 & -- & -- & -- & -- & -- & -- & -- & -- & -- \\
\hline 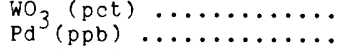 & $\begin{array}{l}-- \\
--\end{array}$ & -- & $\begin{array}{ll}-- \\
--\end{array}$ & $\overline{--}$ & $\overline{--}$ & $\begin{array}{ll}-- \\
--\end{array}$ & $\begin{array}{ll}-- \\
--\end{array}$ & $\begin{array}{ll}-- \\
--\end{array}$ & $\begin{array}{l}-- \\
--\end{array}$ \\
\hline Pt (ppb) $\ldots \ldots \ldots \ldots \ldots$ & -- & -- & -- & -- & -- & -- & -- & -- & -- \\
\hline $\mathrm{Rh}(\mathrm{ppb}) \quad \ldots \ldots \ldots \ldots \ldots$ & -- & -- & -- & -- & -- & -- & -- & -- & -- \\
\hline Ir (ppb) $\quad \cdots \cdots \cdots \cdots \cdots$ & -- & -- & -- & -- & -- & -- & -- & -- & -- \\
\hline $\begin{array}{l}R u(p p b) \\
O s(p p b)\end{array} \cdots \cdots \cdots \cdots \cdot \cdots \cdot$ & -- & -- & $=-$ & -- & -- & -- & -- & -- & -- \\
\hline 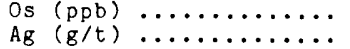 & -- & -- & - & 2.099 & .4766 & 27 & 2.060 & .8156 & $\overline{41}$ \\
\hline 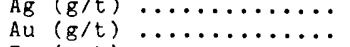 & -- & -- & -- & .3265 & .5874 & 23 & .8726 & $\begin{array}{l}.8150 \\
.4410\end{array}$ & $\begin{array}{l}41 \\
41\end{array}$ \\
\hline$Z_{n}(p c t) \quad \ldots \ldots \ldots \ldots \ldots$ & -- & -- & -- & .2744 & .5545 & 26 & -1.594 & 1.702 & 3 \\
\hline $\mathrm{Hg}(p c t) \quad \cdots \cdots \cdots \cdots \cdots$ & -- & -- & -- & -- & -- & -- & -- & -- & -- \\
\hline$S^{S n}$ (pct) $\quad \cdots \cdots \cdots \cdots \cdots \cdots$ & -- & -- & -- & -- & -- & -- & -- & -- & -- \\
\hline $\mathrm{Pb}$ (pct) $\quad \cdots \cdots \cdots \cdots \cdots$ & -- & -- & -- & .4057 & .2740 & 24 & -1.870 & .9817 & 19 \\
\hline$S b(p c t) \ldots \ldots \ldots \ldots \ldots$ & -- & -- & -- & -- & -- & -- & -- & -- & -- \\
\hline
\end{tabular}




\begin{tabular}{|c|c|c|c|c|c|c|c|c|c|}
\hline \multirow[b]{2}{*}{ Deposit type } & \multicolumn{3}{|c|}{ Sado epithermal vein } & \multicolumn{3}{|c|}{ Epithermal quartz-alunite $\mathrm{Au}$} & \multicolumn{3}{|c|}{ Volcanogenic U } \\
\hline & Mean & S.D. & $\begin{array}{c}\text { Number } \\
\text { of } \\
\text { deposits }\end{array}$ & Mean & S.D. & $\begin{array}{c}\text { Number } \\
\text { of } \\
\text { deposits }\end{array}$ & Mean & S.D. & $\begin{array}{c}\text { Number } \\
\text { of } \\
\text { deposits }\end{array}$ \\
\hline Tonnage (metric) $\ldots \ldots$ & 5.472 & 0.7876 & 20 & 6.199 & 0.6663 & 8 & 5.535 & 0.9451 & 21 \\
\hline $\mathrm{RE}_{2} \mathrm{O}_{5}$ (pct) $\ldots \ldots \ldots \cdots$ & -- & -- & -- & -- & -- & -- & -- & -- & -- \\
\hline Monazite (pet REO) .... & -- & -- & -- & -- & -- & -- & -- & -- & -- \\
\hline 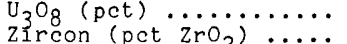 & -- & -- & -- & -- & -- & -- & -.9353 & .2656 & 21 \\
\hline $\begin{array}{l}\mathrm{Zircon}(\text { pet } \\
\left.\mathrm{ZrO}_{2}\right)\end{array}$ & -- & -- & -- & $\overline{--}$ & -- & $\overline{--}$ & -- & -- & $\begin{array}{ll}-- \\
--\end{array}$ \\
\hline Fiber (pct) $\ldots \ldots \ldots \ldots$ & -- & -- & -- & -- & -- & -- & -- & -- & -- \\
\hline Barite (pct) $\ldots \ldots \ldots$ & -- & -- & -- & -- & -- & - & -- & -- & -- \\
\hline $\mathrm{Al}_{2} \mathrm{O}_{3}$ (pct) $\ldots \ldots \ldots \ldots$ & -- & -- & -- & -- & -- & -- & -- & -- & -- \\
\hline$p$ (pet) $\ldots \ldots \ldots \ldots \ldots \cdots$ & -- & -- & -- & $\because-$ & -- & -- & -- & -- & -- \\
\hline $\mathrm{P}_{2} \mathrm{O}_{5}$ (pct) $\ldots \ldots \ldots \cdots$ & -- & -- & -- & -- & -- & -- & -- & -- & -- \\
\hline IImenite $\left(\right.$ pct $\left.\mathrm{TiO}_{2}\right) \ldots$ & -- & -- & -- & -- & -- & - & - & -- & -- \\
\hline $\begin{array}{l}\left.\text { Rutile (pct } \mathrm{TiO}_{2}\right)^{2}, \cdots \\
\left.\text { Leucocite (pct } \mathrm{TiO}_{3}\right) \cdot\end{array}$ & $\overline{--}$ & -- & -- & $\because$ & -- & -- & 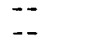 & $\overline{--}$ & -- \\
\hline $\begin{array}{l}\left.\text { Leucocite (pct } \mathrm{TiO}_{2}\right) \ldots \\
\mathrm{Cr}_{2} \mathrm{O}_{3} \text { (pct) } \ldots . . . \cdots\end{array}$ & - & -- & -- & - & -- & -- & -- & -- & -- \\
\hline$M n^{2}(p c t) \quad \ldots \ldots \cdots \cdots \cdots \cdots$ & -- & -- & -- & - & -- & -- & -- & -- & -- \\
\hline $\mathrm{Fe}$ (pct) $\ldots \ldots \ldots \ldots \cdots$ & -- & -- & -- & -- & -- & -- & -- & -- & -- \\
\hline Co (pct) $\quad \cdots \cdots \cdots \cdots \cdots$ & -- & -- & -- & -- & -- & -- & -- & -- & -- \\
\hline$N i$ (pct) $\quad \cdots \cdots \cdots \cdots \cdots$ & --7300 & --150 & -- & -- & -- & -- & -- & -- & -- \\
\hline 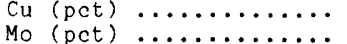 & $\begin{array}{l}-.7200 \\
-.\end{array}$ & $\begin{array}{l}1.153 \\
--\end{array}$ & 9 & -.6255 & 1.045 & 5 & -- & -- & -- \\
\hline 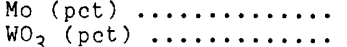 & -- & $\overline{--}$ & -- & -- & -- & -- & -- & $\overline{--}$ & -- \\
\hline 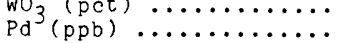 & -- & - & -- & -- & -- & -- & -- & -- & $\begin{array}{ll}-- \\
--\end{array}$ \\
\hline Pt $(p p b) \quad \ldots \ldots \ldots \ldots \ldots$ & -- & -- & -- & -- & -- & -- & -- & -- & - \\
\hline$R h(p p b) \quad \ldots \ldots \ldots \ldots \ldots$ & -- & -- & -- & -- & -- & -- & -- & -- & -- \\
\hline Ir $(p p b) \quad \ldots \ldots \ldots \ldots \ldots$ & -- & -- & -- & -- & -- & -- & -- & -- & -- \\
\hline$R u(p p b) \quad \cdots \cdots \cdots \cdots \cdots$ & -- & -- & -- & -- & -- & -- & -- & -- & -- \\
\hline os $(p p b) \quad \ldots \ldots \ldots \ldots \ldots$ & -- & -- & -- & -- & -- & -- & -- & -- & -- \\
\hline $\mathrm{Ag}(g / t) \quad \ldots \ldots \ldots \ldots \cdots$ & 1.579 & .6647 & 20 & 1.251 & .6788 & 8 & -- & -- & -- \\
\hline $\mathrm{Au}(\mathrm{g} / \mathrm{t}) \quad \ldots \cdots \cdots \cdots \cdots$ & .8363 & .4007 & 18 & .8927 & .2341 & 8 & -- & -- & -- \\
\hline$Z n(p c t) \quad \cdots \cdots \cdots \cdots \cdots$ & -.602 & -- & 1 & -- & -- & -- & -- & -- & -- \\
\hline $\mathrm{Hg}(p c t) \quad \cdots \cdots \cdots \cdots \cdots$ & -- & -- & -- & -- & -- & -- & -- & -- & -- \\
\hline$s n$ (pct) $\cdots \cdots \cdots \cdots \cdots \cdot$ & $=-872$ & --2120 & -- & -- & -- & -- & -- & -- & - \\
\hline 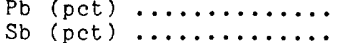 & $-2 \cdot 372$ & .2129 & 2 & $\because-$ & $-\infty$ & $\overline{--}$ & -- & $=-$ & $\overline{--}$ \\
\hline & & & 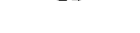 & & & & & & \\
\hline
\end{tabular}

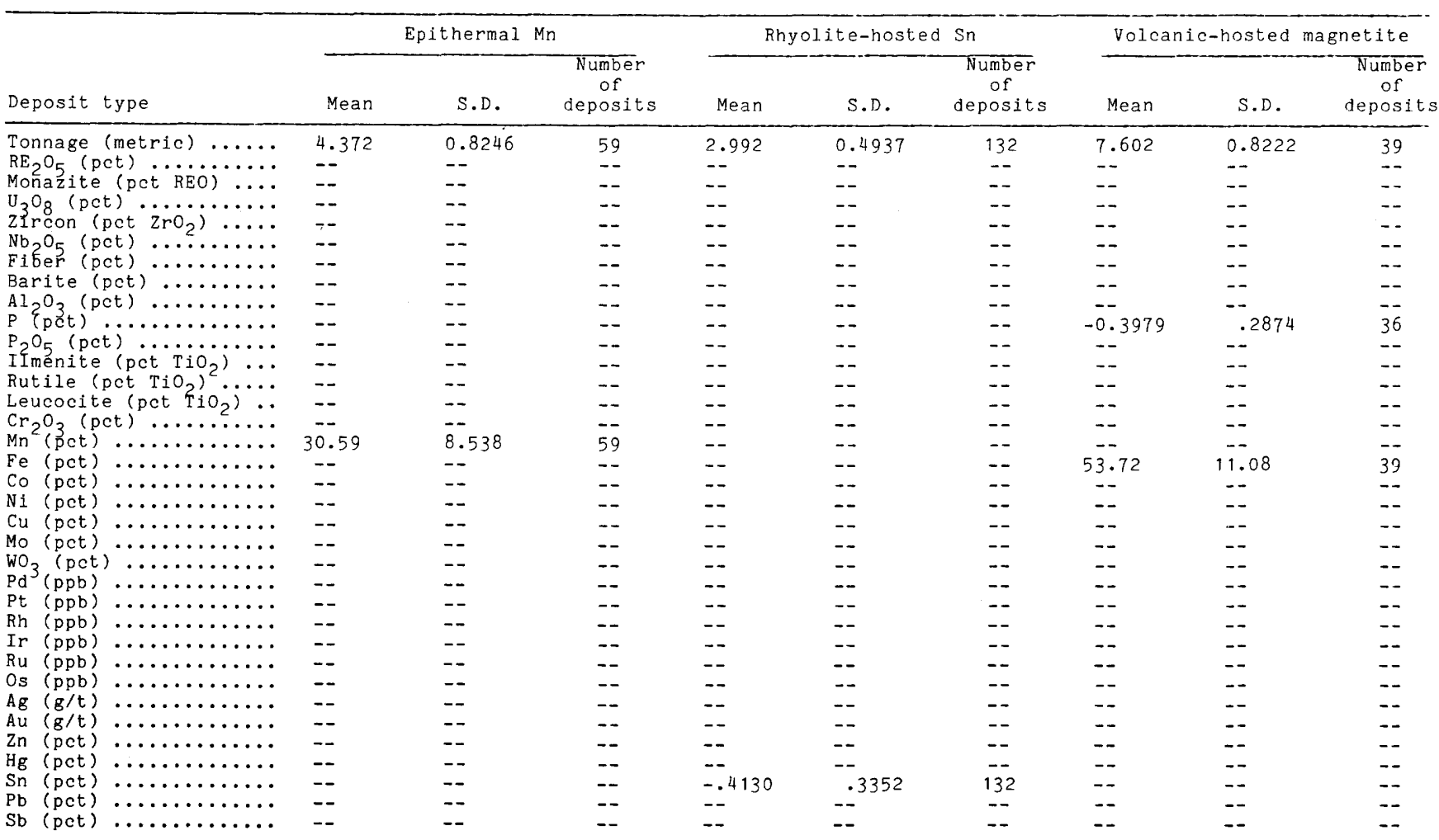


Appendix B. Summary statistics of grade-tonnage models--Continued

\begin{tabular}{|c|c|c|c|c|c|c|c|c|c|}
\hline \multirow[b]{2}{*}{ Deposit type } & \multicolumn{3}{|c|}{ Carbonate-hosted $\mathrm{Au}-\mathrm{Ag}$} & \multicolumn{3}{|c|}{ Hot-spring $\mathrm{Hg}$} & \multicolumn{3}{|c|}{ Silica-carbonate $\mathrm{Hg}$} \\
\hline & Mean & S.D. & $\begin{array}{c}\text { Number } \\
\text { of } \\
\text { deposits }\end{array}$ & Mean & S.D. & $\begin{array}{l}\text { Number } \\
\text { of } \\
\text { deposits }\end{array}$ & Mean & S.D. & $\begin{array}{l}\text { Number } \\
\text { of } \\
\text { deposit }\end{array}$ \\
\hline Tonnage (metric) ...... & 6.706 & 0.5202 & 35 & 3.978 & 1.312 & 20 & 4.448 & 1.038 & 28 \\
\hline $\begin{array}{l}\mathrm{RE}_{2} \mathrm{O}_{5} \text { (pct) } \\
\text { Monazite (pct }\end{array}$ & $=$ & -- & -- & -- & -- & -- & -- & -- & -- \\
\hline $\begin{array}{l}\text { Monazite } \\
U_{3} O_{8} \text { (pet) }\end{array}$ & -- & -- & -- & -- & $=$ & $=$ & $=$ & $=$ & $\overline{--}$ \\
\hline Zlrcon (pct $\mathrm{ZrO}_{2}$ ) $\ldots$... & -- & -- & -- & -- & $=$ & - & - & - & - \\
\hline $\begin{array}{l}\mathrm{Nb}_{2} \mathrm{O}_{5} \\
\text { Fiber (pct) } \\
\text { (pt) }\end{array} \ldots \ldots \ldots \ldots \ldots$ & -- & -- & $=-$ & -- & -- & -- & $=$ & -- & -- \\
\hline Barite (pct) $\ldots \ldots \ldots \ldots$ & - & $=$ & -- & $\overline{-}$ & $=$ & $\because$ & $=$ & $\overline{--}$ & $=$ \\
\hline 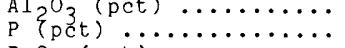 & $\begin{array}{l}-- \\
--\end{array}$ & $\begin{array}{l}-- \\
--\end{array}$ & $\begin{array}{ll}-- \\
--\end{array}$ & $\begin{array}{l}-- \\
--\end{array}$ & -- & $\begin{array}{ll}-- \\
--\end{array}$ & -- & & $\begin{array}{l}-- \\
--\end{array}$ \\
\hline$P_{2} O_{5} \quad(p c t) \ldots \ldots \ldots \cdots \cdots$ & -- & -- & -- & -- & -- & -- & -- & -- & -- \\
\hline Rutile (pct $\left.\mathrm{TiO}_{2}\right)^{2} \ldots \ldots$ & -- & $=$ & $\overline{--}$ & $=$ & -- & $=$ & -- & - & - \\
\hline Leucocite (pct $\left.\mathrm{TiO}_{2}\right) \ldots$ & -- & -- & -- & -- & -- & -- & -- & - & -- \\
\hline 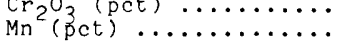 & -- & -- & -- & -- & -- & -- & -- & -- & $\because$ \\
\hline $\mathrm{Fe}$ (pet) $\ldots \ldots \ldots \ldots \ldots$ & -- & -- & -- & -- & -- & -- & -- & -- & -- \\
\hline $\begin{array}{cl}C o & \text { (pct) }\end{array} \cdots \cdots \cdots \cdots \cdots \cdots$ & -- & -- & -- & -- & -- & $=$ & -- & -- & -- \\
\hline $\mathrm{cu}$ (pet),$\ldots \ldots \cdots \cdots \cdots \cdots$ & - & -- & -- & - & -- & -- & -- & -- & -- \\
\hline Mo (pot) $\ldots \ldots \ldots \ldots \ldots$ & -- & -- & -- & -- & -- & -- & -- & -- & -- \\
\hline WO $_{3}$ (pct) $\cdots \cdots \cdots \cdots \cdots$ & -- & -- & -- & -- & -- & -- & -- & -- & -- \\
\hline $\begin{array}{l}P^{P d}(p p b) \\
P t(p p b)\end{array}$ & -- & -- & -- & -- & -- & $=$ & -- & $=$ & $=$ \\
\hline $\operatorname{Rh}(p p b) \quad \ldots \ldots \ldots \ldots \ldots$ & -- & - & -- & $=$ & - & $=$ & - & -- & $=$ \\
\hline Ir (ppb) $\cdots \cdots \cdots \cdots \cdots \cdots$ & -- & -- & -- & -- & -- & -- & -- & -- & -- \\
\hline os $(p p b) \quad \ldots \cdots \cdots \cdots \cdots \cdots \cdots$ & $\overline{--}$ & -- & 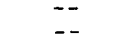 & -- & -- & -- & $=-$ & -- & $=$ \\
\hline$A_{g}(g / t) \ldots \ldots \cdots \cdots \cdots$ & 1.340 & .7148 & 5 & -- & -- & -- & -- & -- & -- \\
\hline Au $(g / t) \quad \cdots \cdots \cdots \cdots \cdots$ & .4106 & 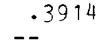 & 34 & -- & $=$ & -- & -- & -- & -- \\
\hline $\begin{array}{l}\mathrm{Zn} \text { (pct) } \\
\mathrm{Hg} \text { (pet) } \ldots \ldots \cdots \cdots \cdots\end{array}$ & -- & -- & -- & $-\quad 4622$ & .2002 & 20 & -.4070 & -1738 & $\overline{28}$ \\
\hline sn (pet) $\ldots \ldots \ldots \ldots \ldots$ & -- & -- & -- & -- & -- & - & -- & -- & -- \\
\hline $\begin{array}{ll}P b & \text { (pct) }\end{array}$ & -- & $=-$ & $=$ & $=$ & $=-$ & -- & -- & -- & -- \\
\hline so $(p e r) \quad \cdots \cdots \cdots$ & & & & & & & & & \\
\hline
\end{tabular}

\begin{tabular}{|c|c|c|c|c|c|c|c|c|c|}
\hline \multirow[b]{2}{*}{ Deposit type } & \multicolumn{3}{|c|}{ Sb veins } & \multicolumn{3}{|c|}{ Disseminated $\mathrm{Sb}$} & \multicolumn{3}{|c|}{ Kuroko massive sulfide } \\
\hline & Mean & S.D. & $\begin{array}{l}\text { Number } \\
\text { of } \\
\text { deposits }\end{array}$ & Mean & S.D. & $\begin{array}{c}\begin{array}{c}\text { Number } \\
\text { of } \\
\text { deposits }\end{array}\end{array}$ & Mean & S.D. & $\begin{array}{l}\text { Number } \\
\text { of } \\
\text { deposits }\end{array}$ \\
\hline Tonnage (metric) $\ldots . .$. & 2.256 & 1.117 & 31 & 4.943 & 0.8211 & 23 & 6.175 & 0.8495 & 432 \\
\hline $\begin{array}{l}\mathrm{RE}_{2} \mathrm{O}_{5} \text { (pct) } \\
\text { Monazite (pct }\end{array}$ & $\begin{array}{l}-- \\
--\end{array}$ & 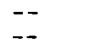 & -- & $\begin{array}{l}-- \\
--\end{array}$ & $\begin{array}{l}-- \\
--\end{array}$ & $\begin{array}{l}-- \\
--\end{array}$ & -- & $\begin{array}{l}-- \\
--\end{array}$ & $=$ \\
\hline $\mathrm{U}_{3} \mathrm{O}_{8}$ (pct) $\ldots \ldots \ldots$ & - & - & $\because$ & -- & -- & - & -- & -- & $=-$ \\
\hline $\begin{array}{l}\left.\mathrm{Zircon}_{\text {(pet }} \mathrm{ZrO}_{2}\right) \\
\mathrm{Zrb}_{2} \mathrm{O}_{5} \text { (pet) }\end{array} \ldots \ldots$ & -- & $\begin{array}{l}-- \\
--\end{array}$ & $\begin{array}{ll}-- \\
--\end{array}$ & -- & $\begin{array}{l}-- \\
--\end{array}$ & -- & -- & $=$ & \\
\hline Fiber (pot) $\cdots \cdots \cdots \cdots \cdots$ & -- & -- & -- & -- & -- & -- & -- & -- & -- \\
\hline $\begin{array}{l}\text { Barite }(p c t) \\
\text { Al }\end{array}$ & $=$ & $=$ & -- & $=$ & -- & -- & -- & -- & -- \\
\hline 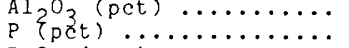 & $\overline{--}$ & $\begin{array}{l}-- \\
--\end{array}$ & -- & 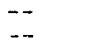 & -- & -- & -- & $=$ & -- \\
\hline 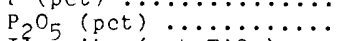 & -- & $\overline{-}$ & -- & -- & -- & -- & -- & -- & -- \\
\hline $\begin{array}{l}\text { Ifmenite }\left(p c t \mathrm{TiO}_{2}\right) \\
\text { Rutile }\end{array}$ & -- & -- & -- & -- & -- & -- & -- & -- & - \\
\hline 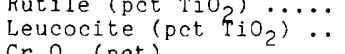 & $\because$ & $\begin{array}{l}-- \\
--\end{array}$ & $\because-$ & $\begin{array}{l}-- \\
--\end{array}$ & $\begin{array}{l}-- \\
--\end{array}$ & -- & $\begin{array}{l}-- \\
--\end{array}$ & $\begin{array}{l}-- \\
--\end{array}$ & $\begin{array}{l}-- \\
--\end{array}$ \\
\hline 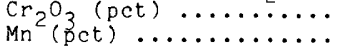 & $\begin{array}{l}-- \\
--\end{array}$ & $\begin{array}{l}-- \\
--\end{array}$ & -- & $=$ & $=$ & -- & -- & -- & -- \\
\hline $\mathrm{Fe}(\mathrm{pct}) \quad \ldots \ldots \ldots \ldots \ldots \ldots$ & - & -- & -- & -- & -- & $\overline{--}$ & $\overline{--}$ & -- & $\overline{--}$ \\
\hline co (pct) $\ldots \ldots \ldots \ldots \ldots$ & -- & -- & -- & -- & -- & -- & -- & -- & -- \\
\hline $\begin{array}{l}\mathrm{Ni} \text { (pct) } \\
\mathrm{Cu}\end{array}$ & -- & -- & -- & -- & -- & -- & .0999 & .3493 & 432 \\
\hline Mo (pct) $\quad \ldots \ldots \ldots \ldots \ldots \ldots$ & -- & -- & -- & -- & -- & -- & -- & -- & --- \\
\hline 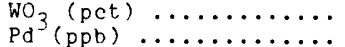 & $\begin{array}{l}-- \\
--\end{array}$ & -- & $=-$ & $\overline{--}$ & $\begin{array}{l}-- \\
--\end{array}$ & $\begin{array}{l}-- \\
--\end{array}$ & $\begin{array}{l}-- \\
--\end{array}$ & -- & -- \\
\hline pt (ppb) $\ldots \ldots \ldots \ldots \ldots$ & -- & -- & -- & -- & -- & $=-$ & $\overline{--}$ & $\because-$ & $=$ \\
\hline$R_{R}^{R h}(p p b) \quad \cdots \cdots \cdots \cdots \cdots$ & -- & -- & -- & -- & -- & -- & -- & -- & -- \\
\hline 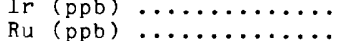 & -- & -- & -- & -- & $=$ & $=-$ & -- & $=$ & -- \\
\hline $0_{s}(p p b) \quad \ldots \ldots \ldots \cdots \cdots \cdots \cdots$ & -- & -- & -- & -- & -- & -- & -- & -- & $=$ \\
\hline$A g(g / t) \quad \ldots \ldots \ldots \ldots \ldots$ & 1.561 & .2851 & 8 & .0792 & -- & 1 & 1.459 & .51 & 284 \\
\hline $\mathrm{Au}(g / t) \quad \ldots \ldots \ldots \ldots \ldots$ & .7111 & .6872 & 9 & -.5278 & 1.172 & 2 & -.1080 & .52 & 238 \\
\hline $\mathrm{Zn}$ (pct) $\quad \cdots \cdots \cdots \cdots \cdots \cdots$ & -- & -- & -- & -- & -- & -- & .4482 & .4626 & 330 \\
\hline $\begin{array}{l}H^{H} \\
S n(p c t)\end{array}$ & $=$ & -- & $=$ & -- & $=$ & $=$ & & & -- \\
\hline${ }_{\mathrm{Pb}}(\mathrm{pct}), \ldots \ldots \ldots \ldots \ldots \ldots \ldots$ & -- & -- & -- & -- & -- & -- & -.1269 & .5506 & 184 \\
\hline $\mathrm{Sb}$ (pct) $\ldots \ldots \ldots \ldots$ & 1.540 & .2200 & 81 & .5505 & .2308 & 23 & & -- & -- \\
\hline
\end{tabular}


Appendix B. Summary statistics of grade-tonnage models--Continued

\begin{tabular}{|c|c|c|c|c|c|c|c|c|c|}
\hline \multirow[b]{2}{*}{ Deposit type } & \multicolumn{3}{|c|}{ Algoma $\mathrm{Fe}$ and Superior $\mathrm{Fe}$} & \multicolumn{3}{|c|}{ Sandstone-hosted $\mathrm{Pb}-\mathrm{Zn}$} & \multicolumn{3}{|c|}{ Sediment-hosted $\mathrm{Cu}$} \\
\hline & Mean & S.D. & $\begin{array}{c}\text { Number } \\
\text { of } \\
\text { deposits }\end{array}$ & Mean & S.D. & $\begin{array}{c}\text { Number } \\
\text { of } \\
\text { deposits }\end{array}$ & Mean & S.D. & $\begin{array}{c}\text { Number } \\
\text { of } \\
\text { deposits }\end{array}$ \\
\hline Tonnage (metric) ...... & 8.218 & 0.9105 & 66 & 6.729 & 0.8268 & 20 & 7.341 & 0.9186 & 57 \\
\hline $\mathrm{RE}_{2} \mathrm{O}_{5}$ (pct) $\ldots \ldots \ldots \cdots$ & -- & -- & -- & -- & -- & -- & -- & -- & -- \\
\hline Monazite (pet REO) $\ldots$. & -- & -- & -- & -- & -- & -- & -- & -- & -- \\
\hline 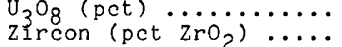 & $\overline{--}$ & $\overline{--}$ & $\overline{-}$ & -- & $\begin{array}{l}-- \\
--\end{array}$ & -- & -- & $\overline{--}$ & $\cdots$ \\
\hline $\mathrm{Nb}_{2} \mathrm{O}_{5}$ (pct) $\quad \ldots . . . . . .$. & -- & -- & -- & $\because$ & -- & $\because$ & -- & -- & -- \\
\hline Fiber (pct) $\ldots \ldots \ldots \ldots$ & -- & -- & -- & -- & -- & -- & -- & -- & -- \\
\hline Barite (pct) $\ldots \cdots \cdots \cdot$ & -- & -- & -- & -- & -- & -- & -- & -- & -- \\
\hline $\mathrm{AI}_{2} \mathrm{O}_{3}$ (pct) $\ldots \cdots \cdots \cdot \cdot$ & -- & -- & -- & -- & -- & -- & -- & -- & -- \\
\hline$p\{p(t) \quad \ldots \cdots \cdots \cdots \cdots \cdots$ & -1.256 & .4853 & 47 & -- & -- & -- & -- & -- & -- \\
\hline $\mathrm{P}_{2} \mathrm{O}_{5}$ (pct) $\ldots \ldots \ldots \ldots$ & -- & -- & -- & -- & -- & -- & -- & -- & -- \\
\hline IImenite $\left(\right.$ pct $\left.\mathrm{TiO}_{2}\right) \ldots$ & -- & -- & -- & -- & -- & -- & -- & -- & -- \\
\hline Rutile $\left(\text { pct } \mathrm{TiO}_{2}\right)^{2} \ldots$. & -- & -- & -- & -- & -- & -- & -- & -- & -- \\
\hline Leucocite $\left(\right.$ pct $\left.\mathrm{TiO}_{2}\right) \ldots$ & -- & -- & -- & - & -- & -- & -- & - & - \\
\hline 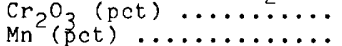 & $\ddot{--}$ & -- & -- & -- & -- & -- & -- & -- & -- \\
\hline $\mathrm{Fe}$ (pct) $\quad \ldots \ldots \ldots \ldots \ldots$ & 50.83 & $1 \overline{3.65}$ & $6 \overline{6}$ & -- & -- & - & -- & -- & - \\
\hline Co (pct) $\ldots \ldots \ldots \ldots \ldots$ & -- & -- & -- & -- & -- & -- & -.6226 & .1919 & 10 \\
\hline Ni (pct) $\ldots \ldots \ldots \cdots \cdots$ & -- & -- & -- & -- & -- & -- & -- & -- & $-\overline{-}$ \\
\hline $\mathrm{Cu}$ (pct) $\ldots \ldots \ldots \ldots \cdots$ & -- & -- & -- & -- & -- & -- & .3317 & .2540 & 57 \\
\hline Mo (pct) $\ldots \ldots \ldots \cdots \cdots$ & -- & -- & -- & -- & -- & -- & -- & -- & -- \\
\hline wO $_{3}$ (pct) $\ldots \ldots \cdots \cdots \cdots$ & -- & -- & $\cdots$ & - & -- & -- & -- & -- & -- \\
\hline $\mathrm{Pd}^{\prime}(\mathrm{ppb}) \quad \ldots \ldots \ldots \ldots \ldots$ & -- & -- & -- & -- & -- & -- & $-\rightarrow$ & -- & -- \\
\hline Pt $(p p b) \quad \ldots \ldots \cdots \cdots \cdots$ & -- & -- & -- & -- & - & -- & -- & -- & -- \\
\hline$R h(p p b) \quad \ldots \ldots \ldots \ldots \ldots$ & -- & -- & -- & -- & -- & -- & -- & -- & -- \\
\hline Ir $(p p b) \quad \ldots \ldots \cdots \cdots \cdots$ & -- & -- & -- & -- & -- & -- & -- & -- & -- \\
\hline Ru (ppb) $\ldots \ldots \ldots \ldots \ldots$ & -- & -- & -- & -- & -- & -- & -- & -- & -- \\
\hline os $(p p b) \quad \ldots \ldots \ldots \ldots \ldots$ & -- & -- & -- & -- & -- & -- & -- & -- & $-\overline{-}$ \\
\hline $\operatorname{Ag}(g / t) \quad \ldots \ldots \ldots \ldots \ldots$ & -- & -- & -- & 1.050 & .5824 & 9 & 1.208 & .7646 & 12 \\
\hline Au $(g / t) \quad \cdots \cdots \cdots \cdots \cdots$ & -- & -- & -- & -- & -- & $-\overline{-}$ & -- & -- & -- \\
\hline$z n$ (pct) $\ldots \ldots \ldots \ldots \cdots$ & -- & -- & -- & -.2320 & .6769 & 14 & $\cdots$ & -- & -- \\
\hline $\mathrm{Hg}(p c t) \ldots \ldots \ldots \ldots \ldots$ & -- & -- & -- & -- & -- & -- & -- & -- & -- \\
\hline $\operatorname{Sn}$ (pct) $\ldots \ldots \ldots \ldots \ldots$ & -- & -- & -- & -- & -- & -- & -- & -- & $\cdots$ \\
\hline $\mathrm{Pb}$ (pct) $\ldots \ldots \cdots \cdots \cdots$ & -- & -- & -- & .3332 & .3011 & 20 & -- & -- & -- \\
\hline$S b(p c t) \quad \ldots \ldots \ldots \cdots \cdots$ & -- & -- & -- & -- & -- & -- & -- & -- & -- \\
\hline
\end{tabular}

\begin{tabular}{|c|c|c|c|c|c|c|c|c|c|}
\hline \multirow[b]{2}{*}{ Deposit type } & \multicolumn{3}{|c|}{ Sedimentary exhalative $\mathrm{Zn}-\mathrm{Pb}$} & \multicolumn{3}{|c|}{ Bedded barite } & \multicolumn{3}{|c|}{$\begin{array}{c}\text { Southeast Missouri } \mathrm{Pb}-\mathrm{Zn} \\
\text { and Appalachian } \mathrm{Zn}\end{array}$} \\
\hline & Mean & S.D. & $\begin{array}{l}\text { Number } \\
\text { of } \\
\text { deposits }\end{array}$ & Mean & S.D. & $\begin{array}{c}\text { Number } \\
\text { of } \\
\text { deposits }\end{array}$ & Mean & S.D. & $\begin{array}{c}\text { Number } \\
\text { of } \\
\text { deposits }\end{array}$ \\
\hline Tonnage (metric) $\ldots . .$. & 7.167 & 0.7315 & 45 & 6.259 & 0.9271 & 25 & 7.542 & 0.9299 & 20 \\
\hline $\begin{array}{l}\mathrm{RE}_{2} \mathrm{O}_{5} \text { (pct) } \\
\text { Monnazite (pct } \mathrm{REO}_{3} \cdots \cdots\end{array}$ & -- & -- & -- & -- & -- & -- & -- & -- & - \\
\hline $\begin{array}{l}\text { Monazazite (pct REO) } \cdots \cdots \\
\mathrm{U}_{3} \mathrm{O}_{8} \text { (pct) } \ldots \ldots \ldots \cdots\end{array}$ & $\begin{array}{ll}-- \\
--\end{array}$ & $\begin{array}{ll}-- \\
--\end{array}$ & $\begin{array}{l}-- \\
--\end{array}$ & -- & -- & -- & -- & -- & -- \\
\hline zircon (pct $\left.\mathrm{ZrO}_{2}\right) \cdots \cdots$ & $\therefore$ & - & -- & -- & -- & -- & -- & -- & -- \\
\hline $\begin{array}{l}\mathrm{Nb}_{2} \mathrm{O}_{5} \text { (pct) } \\
\mathrm{Fiber} \text { (pct) }\end{array}$ & -- & -- & -- & -- & -- & -- & -- & -- & - \\
\hline $\begin{array}{l}\text { Fiber (pct) } \cdots \cdots \cdots \cdots \\
\text { Barite (pct) } \ldots \ldots \cdots\end{array}$ & -- & -- & -- & $8 \overline{3.02}$ & $\overline{13.00}$ & $-\overline{-}$ & -- & -- & -- \\
\hline $\mathrm{Al}_{2} \mathrm{O}_{3}$ (pct) $\ldots \ldots \cdots \cdots \cdots$ & $\overline{--}$ & -- & $\overline{--}$ & & & 25 & -- & -- & -- \\
\hline$p\{p c t) \ldots \ldots \ldots \ldots \ldots$ & -- & -- & -- & -- & -- & - & -- & -- & $\begin{array}{ll}-- \\
--\end{array}$ \\
\hline $\mathrm{P}_{2} \mathrm{O}_{5}$ (pct) $\ldots \ldots \ldots \cdots \cdots$ & -- & -- & -- & -- & -- & -- & -- & - & -- \\
\hline $\begin{array}{l}\text { Iménite }\left(\text { pct } \mathrm{TiO}_{2}\right) \ldots \\
\text { Rutile }\left(\text { pct } \mathrm{TiO}_{2}\right)^{2} \ldots \ldots\end{array}$ & -- & - & -- & -- & -- & -- & -- & -- & -- \\
\hline Leucocite (pct $\left.\mathrm{TiO}_{2}\right) \ldots$ & $\overline{--}$ & -- & -- & $\begin{array}{l}-- \\
--\end{array}$ & -- & -- & -- & -- & -- \\
\hline $\mathrm{Cr}_{2} \mathrm{O}_{3}$ (pct) $\ldots \ldots \ldots$ & -- & -- & -- & -- & -- & -- & - & - & - \\
\hline 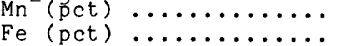 & -- & -- & -- & -- & -- & -- & -- & -- & -- \\
\hline 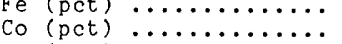 & -- & -- & $\overline{--}$ & $\begin{array}{ll}-- \\
--\end{array}$ & $\begin{array}{ll}-- \\
--\end{array}$ & -- & $\begin{array}{ll}-- \\
--\end{array}$ & $\begin{array}{ll}-- \\
--\end{array}$ & -- \\
\hline $\mathrm{Ni}$ (pct) $\ldots \ldots \ldots \ldots \ldots$ & -- & -- & -- & -- & -- & -- & -- & -- & -- \\
\hline $\mathrm{Cu}(p c t), \ldots \ldots \ldots \ldots \ldots$ & -.7273 & .4797 & 11 & -- & -- & -- & -- & -- & -- \\
\hline Mo (pct) $\cdots \cdots \cdots \cdots \cdots$ & -- & -- & -- & -- & -- & -- & -- & -- & -- \\
\hline $\mathrm{WO}_{3}$ (pct) $\ldots \ldots \cdots \cdots \cdots \cdot$ & -- & -- & -- & -- & -- & -- & -- & -- & -- \\
\hline 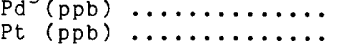 & $=-$ & -- & $\begin{array}{l}-- \\
--\end{array}$ & $\begin{array}{l}-- \\
--\end{array}$ & -- & -- & $\begin{array}{ll}-- \\
--\end{array}$ & $\begin{array}{ll}-- \\
--\end{array}$ & -- \\
\hline $\mathrm{Rh}(\mathrm{ppb}) \ldots \ldots \ldots \ldots \ldots$ & -- & -- & -- & -- & -- & -- & -- & -- & $-\overline{-}$ \\
\hline $\operatorname{Ir}(p p b) \ldots \ldots \ldots \ldots \ldots$ & -- & -- & -- & -- & -- & -- & - & -- & -- \\
\hline$R u(p p b) \quad \cdots \cdots \cdots \cdots \cdots$ & -- & -- & -- & -- & -- & -- & -- & -- & -- \\
\hline Os $(p p b) \quad \cdots \cdots \cdots \cdots \cdots$ & -- & -- & -- & -- & -- & -- & -- & -- & -- \\
\hline$A g(g / t) \ldots \ldots \cdots \cdots \cdots$ & 1.6367 & .4705 & 37 & -- & -- & -- & .6693 & .6917 & 10 \\
\hline 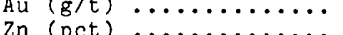 & --7510 & --2008 & in & -- & -- & -- & --6070 & -- & $-\overline{-}$ \\
\hline 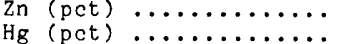 &. .7519 &. .2908 & $\begin{array}{l}45 \\
--\end{array}$ & $\begin{array}{ll}-- \\
--\end{array}$ & $-\overline{-}$ & $\begin{array}{l}-- \\
--\end{array}$ & .6079 & .3623 & 20 \\
\hline 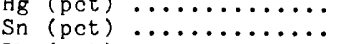 & -- & -- & -- & -- & -- & -- & -- & $\overline{--}$ & -- \\
\hline $\mathrm{Pb}(p c t) \ldots \ldots \ldots \ldots$ & .4443 & .3443 & 45 & -- & -- & -- & .0893 & .4068 & 16 \\
\hline$S b(p c t) \quad \ldots \ldots \cdots \cdots$ & -- & -- & -- & -- & -- & -- & 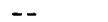 & -- & -- \\
\hline
\end{tabular}


Appendix B. Summary statistics of grade-tonnage models--Continued

\begin{tabular}{|c|c|c|c|c|c|c|c|c|c|}
\hline \multirow[b]{2}{*}{ Deposit type } & \multicolumn{3}{|c|}{ Sedimentary Mn } & \multicolumn{3}{|c|}{ Phosphate, upwelling } & \multicolumn{3}{|c|}{ Phosphate, warm current } \\
\hline & Mean & S.D. & $\begin{array}{c}\text { Number } \\
\text { of } \\
\text { deposits }\end{array}$ & Mean & S.D. & $\begin{array}{c}\text { Number } \\
\text { of } \\
\text { deposits }\end{array}$ & Mean & S.D. & $\begin{array}{c}\text { Number } \\
\text { of } \\
\text { deposits }\end{array}$ \\
\hline Tonnage (metric) ...... & 6.862 & 1.240 & 39 & 8.520 & 0.8611 & 60 & 8.603 & 0.7360 & 18 \\
\hline $\mathrm{RE}_{2} \mathrm{O}_{5}$ (pct) $\ldots \ldots \ldots \cdots$ & -- & -- & -- & -- & -- & -- & -- & -- & -- \\
\hline Monazite (pet REO) $\ldots$. & -- & -- & -- & -- & -- & -- & -- & -- & -- \\
\hline $\begin{array}{l}\mathrm{U}_{3}^{\mathrm{O}} \text { (pct) } \\
z^{1} \text { rcon }\left(p c t \quad \mathrm{ZrO}_{2}\right) \\
\cdots\end{array}$ & -- & $=-$ & -- & -- & $\overline{--}$ & $\overline{--}$ & -- & -- & -- \\
\hline 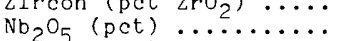 & -- & -- & -- & -- & $\begin{array}{ll}-- \\
--\end{array}$ & $\begin{array}{l}-- \\
--\end{array}$ & $=-$ & -- & -- \\
\hline Fiber (pet) $\ldots \ldots \ldots \ldots$ & -- & -- & -- & -- & -- & -- & -- & -- & -- \\
\hline Barite (pet) $\ldots \ldots \ldots$ & -- & -- & -- & -- & -- & -- & -- & -- & -- \\
\hline $\mathrm{Al}_{2} \mathrm{O}_{3}$ (pct) $\ldots \ldots \ldots \ldots$ & -- & -- & -- & -- & -- & -- & -- & -- & -- \\
\hline$P$ \{pct) $\quad \cdots \cdots \cdots \cdots \cdots \cdot$ & -.9034 & .3273 & 13 & $23^{--06}$ & -5604 & $\overrightarrow{60}$ & $24^{--} 16$ & --402 & $-\overline{-}$ \\
\hline${ }^{\mathrm{P}_{2} \mathrm{O}_{5} \text { (pet) }}$ (pcot $\left.\mathrm{TiO}_{2}\right) \cdots$ & $\overline{-}$ & $\begin{array}{l}-- \\
--\end{array}$ & $\begin{array}{l}-- \\
--\end{array}$ & $\begin{array}{c}23.96 \\
--\end{array}$ & $\begin{array}{l}6.604 \\
--\end{array}$ & $\begin{array}{ll}60 \\
--\end{array}$ & 24.10 & $\begin{array}{l}3.402 \\
--\end{array}$ & 18 \\
\hline Rutile (pet $\left.\mathrm{TiO}_{2}\right)^{2} \ldots$. & -- & -- & - & -- & -- & - & -- & -- & -- \\
\hline Leucocite (pct $\left.\mathrm{TiO}_{2}\right) \ldots$ & -- & -- & -- & -- & -- & -- & -- & -- & -- \\
\hline $\mathrm{Cr}_{2} \mathrm{O}_{3}$ (pct) $\ldots \ldots \ldots \ldots$ & -- & $\overline{-1}-$ & -- & -- & -- & -- & -- & -- & -- \\
\hline $\begin{array}{l}M^{2}(p c t) \\
F e\end{array}$ & $\begin{array}{l}31.38 \\
-.\end{array}$ & $\begin{array}{l}13.05 \\
--\end{array}$ & 39 & $\begin{array}{ll}-- \\
--\end{array}$ & -- & $\begin{array}{ll}-- \\
--\end{array}$ & $=-$ & -- & -- \\
\hline Co $(p c t) \quad \ldots \ldots \ldots \ldots \ldots$ & -- & -- & -- & -- & -- & -- & -- & -- & - \\
\hline $\mathrm{Ni}$ (pct) $\ldots \ldots \ldots \ldots \ldots$ & -- & -- & -- & -- & -- & -- & -- & -- & -- \\
\hline $\mathrm{Cu}(p c t) \ldots \ldots \ldots \ldots \ldots$ & -- & -- & -- & -- & -- & -- & -- & -- & -- \\
\hline Mo $(p c t), \ldots \ldots \ldots \ldots \ldots$ & -- & -- & -- & -- & - & -- & -- & -- & -- \\
\hline $\mathrm{WO}_{3}(p c t) \quad \ldots \ldots \ldots \ldots$ & -- & -- & -- & -- & -- & -- & -- & -- & -- \\
\hline$P d^{3}(p p b) \quad \ldots \ldots \ldots \ldots \ldots$ & -- & -- & -- & -- & -- & -- & -- & -- & -- \\
\hline Pt $(p p b), \ldots \ldots \ldots \ldots$ & -- & -- & -- & -- & -- & -- & -- & -- & -- \\
\hline Rh $(p p b) \quad \ldots \ldots \cdots \cdots$ & -- & -- & -- & -- & -- & -- & -- & -- & - \\
\hline Ir $(p p o), \ldots \ldots \cdots \cdots \cdots$ & -- & -- & -- & -- & -- & $\overline{--}$ & -- & -- & -- \\
\hline 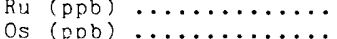 & - & - & -- & - & -- & -- & -- & -- & $\begin{array}{ll}-- \\
--\end{array}$ \\
\hline Ag $(g / t) \quad \ldots \ldots \cdots \cdots \cdots \cdots$ & -- & -- & -- & -- & -- & -- & -- & -- & $-\overline{-}$ \\
\hline Au $(g / t) \ldots \ldots \ldots \ldots \ldots$ & -- & -- & -- & -- & -- & -- & -- & -- & -. \\
\hline$Z n(p c t) \ldots \ldots \ldots \ldots$ & -- & -- & -- & -- & -- & -- & -- & -- & -- \\
\hline $\mathrm{Hg}(p c t) \ldots \ldots \ldots \ldots \ldots$ & -- & -- & -- & -- & -- & -- & -- & -- & -- \\
\hline$S n(p c t) \quad \ldots \ldots \ldots \ldots \ldots$ & - & -- & -- & -- & -- & -- & -- & -- & -- \\
\hline$P b$ (pct) $\cdots \cdots \cdots \cdots \cdots$ & -- & -- & -- & -- & -- & -- & -- & -- & -- \\
\hline$S b$ (pct) $\ldots . .$. & -- & -- & -- & -- & -- & -- & -- & -- & -- \\
\hline
\end{tabular}

\begin{tabular}{|c|c|c|c|c|c|c|c|c|c|}
\hline \multirow[b]{2}{*}{ Deposit type } & \multicolumn{3}{|c|}{ Low-sulfide Au-quartz veins } & \multicolumn{3}{|c|}{ Homestake Au } & \multicolumn{3}{|c|}{ Unconformity U-Au } \\
\hline & Mean & S.D. & $\begin{array}{c}\text { Number } \\
\text { of } \\
\text { deposits }\end{array}$ & Mean & S.D. & $\begin{array}{c}\text { Number } \\
\text { of } \\
\text { deposits }\end{array}$ & Mean & S.D. & $\begin{array}{c}\text { Number } \\
\text { of } \\
\text { deposits }\end{array}$ \\
\hline Tonnage (metric) $\ldots . .$. & 4.470 & 1.163 & 313 & 5.974 & 0.8592 & 116 & 5.356 & 1.274 & 36 \\
\hline $\mathrm{RE}_{2} \mathrm{O}_{5}$ (pct) $\ldots \ldots \ldots \ldots$ & -- & -- & -- & -- & -- & -- & -- & -- & - \\
\hline Monazite (pet REO) .... & - & -- & -- & -- & -- & -- & -- & -- & -- \\
\hline 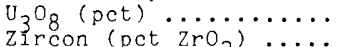 & -- & -- & -- & -- & -- & -- & -.2816 & .4167 & 36 \\
\hline 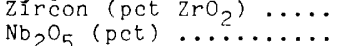 & $\begin{array}{ll}-- \\
--\end{array}$ & $\begin{array}{ll}-- \\
--\end{array}$ & $\begin{array}{l}-- \\
--\end{array}$ & $\begin{array}{l}-- \\
--\end{array}$ & -- & $\begin{array}{l}-- \\
--\end{array}$ & -- & -- & $\begin{array}{l}-- \\
--\end{array}$ \\
\hline Fiber (pct) $\ldots \cdots \cdots \cdots$ & - & - & -- & - & -- & -- & -- & -- & -- \\
\hline Barite (pct) $\ldots \ldots \ldots$. & -- & -- & -- & -- & -- & -- & -- & -- & -- \\
\hline $\mathrm{Al}_{2} \mathrm{O}_{3}(p c t) \quad \cdots \cdots \cdot \cdot \cdot \cdot \cdot$ & -- & -- & -- & -- & -- & -- & -- & -- & -- \\
\hline & -- & -- & -- & $\begin{array}{l}-- \\
--\end{array}$ & $\because-$ & -- & $\begin{array}{ll}-- \\
--\end{array}$ & -- & -- \\
\hline IImenite (pct $\left.\mathrm{TiO}_{2}\right) \cdots$ & -- & -- & -- & -- & - & -- & 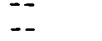 & $\begin{array}{l}-- \\
--\end{array}$ & $\begin{array}{ll}-- \\
--\end{array}$ \\
\hline Rutile (pct $\mathrm{TiO}_{2}$ ) ..... & -- & -- & -- & -- & -- & -- & -- & -- & -- \\
\hline Leucocite (pet $\left.\mathrm{TiO}_{2}\right) \ldots$ & -- & -- & -- & -- & -- & -- & -- & -- & -- \\
\hline $\begin{array}{l}\mathrm{Cr}_{2} \mathrm{O}_{3} \text { (pet) } \ldots \ldots \cdots \cdots \\
\mathrm{Mn}{ }^{\text {(pct }} \quad \ldots \ldots \\
\ldots\end{array}$ & -- & -- & $=$ & -- & -- & $\begin{array}{ll}-- \\
--\end{array}$ & $\ddot{--}$ & $\begin{array}{l}-- \\
--\end{array}$ & -- \\
\hline $\mathrm{Fe}(\mathrm{pct}) \ldots \ldots \ldots \ldots$ & -- & -- & -- & -- & -- & -- & -- & -- & -- \\
\hline Co (pct) $\ldots \ldots \ldots \ldots \ldots$ & -- & -- & -- & -- & -- & -- & -- & -- & -- \\
\hline $\mathrm{Ni}(p c t), \ldots \ldots \ldots \ldots \ldots$ & -- & -- & -- & -- & -- & -- & -- & -- & -- \\
\hline $\mathrm{Cu}(p c t), \ldots \ldots \ldots \ldots$ & -- & -- & -- & -- & -- & -- & -- & -- & -- \\
\hline Mo (pct),$\cdots \cdots \cdots \cdots \cdots$ & -- & -- & -- & -- & -- & -- & -- & -- & -- \\
\hline $\mathrm{WO}_{3}$ (pct) $\cdots \cdots \cdots \cdots \cdots \cdot$ & -- & -- & -- & -- & -- & -- & -- & -- & -- \\
\hline $\begin{array}{l}P d^{2}(p p b) \\
P t\end{array}$ & -- & -- & -- & -- & -- & -- & -- & -- & -- \\
\hline $\begin{array}{l} \\
R h\end{array}$ & -- & -- & -- & -- & - & -- & -- & -- & 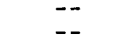 \\
\hline Ir $(p p b) \quad \ldots \ldots \cdots \cdots \cdots$ & -- & -- & -- & -- & -- & -- & -- & -- & -- \\
\hline$R u(p p b) \quad \ldots \ldots \ldots \ldots \ldots$ & -- & -- & -- & -- & -- & -- & -- & -- & -- \\
\hline os (ppb) $\cdots \cdots \cdots \cdots \cdots$ & --800 & -- & -- & -- & -- & -- & -- & -- & -- \\
\hline$A g(g / t) \quad \cdots \cdots \cdots \cdots \cdots$ & .6961 & .3563 & 39 & .2093 & .5234 & 52 & -- & -- & -- \\
\hline $\mathrm{Au}(\mathrm{g} / \mathrm{t}) \quad \ldots \ldots \ldots \ldots \cdots$ & 1.203 & .3327 & 313 & .9647 & .2518 & 116 & -- & -- & -- \\
\hline$z n$ (pct) $\ldots \ldots \ldots \ldots \cdots$ & -- & -- & -- & -- & -- & -- & -- & -- & -- \\
\hline $\mathrm{Hg}$ (pct) $\quad \cdots \cdots \cdots \cdots \cdots$ & -- & -- & -- & -- & -- & -- & -- & - & -- \\
\hline $\begin{array}{l}S n \text { (pct) } \\
p b\end{array}$ & -- & -- & -- & -- & -- & -- & -- & -- & -- \\
\hline 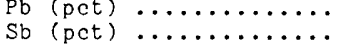 & -- & -- & $\begin{array}{ll}-- \\
--\end{array}$ & $\begin{array}{ll}-- \\
--\end{array}$ & $=$ & $=$ & $=$ & -- & -- \\
\hline So (pct) $\cdots \cdots \cdots \cdots \cdots$ & & & -- & -- & & - & - & - & -- \\
\hline
\end{tabular}


Appendix B. Summary statistics of grade-tonnage models--Continued

\begin{tabular}{|c|c|c|c|c|c|c|c|c|c|}
\hline \multirow[b]{2}{*}{ Deposit type } & \multicolumn{3}{|c|}{ Lateritic $\mathrm{Ni}$} & \multicolumn{3}{|c|}{ Laterite bauxite } & \multicolumn{3}{|c|}{ Karst bauxite } \\
\hline & Mean & S.D. & $\begin{array}{c}\text { Number } \\
\text { of } \\
\text { deposits }\end{array}$ & Mean & S.D. & $\begin{array}{c}\text { Number } \\
\text { of } \\
\text { deposits }\end{array}$ & Mean & S.D. & $\begin{array}{c}\text { Number } \\
\text { of } \\
\text { deposits }\end{array}$ \\
\hline Tonnage (metric) ...... & 7.645 & 0.5864 & 71 & 7.401 & 1.142 & 122 & 7.366 & 0.6811 & 41 \\
\hline $\mathrm{RE}_{2} \mathrm{O}_{5}$ (pct) $\quad \ldots \ldots \cdots \cdots$ & -- & -- & -- & -- & - & -- & -- & -- & -- \\
\hline Monazite (pct REO) $\cdots$ & -- & -- & -- & -- & -- & -- & -- & -- & $\cdots$ \\
\hline 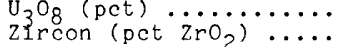 & $\begin{array}{l}-- \\
--\end{array}$ & -- & -- & $\overline{--}$ & -- & -- & -- & $\because-$ & -- \\
\hline $\mathrm{Nb}_{2} \mathrm{O}_{5}$ (pct) $\ldots \ldots \ldots$ & -- & - & -- & -- & - & - & -- & -- & -- \\
\hline Fiber (pct),$\ldots \ldots \ldots \ldots$ & -- & -- & -- & -. & -- & -- & -- & - & -- \\
\hline Barite (pct) $\ldots \ldots \ldots$ & -- & -- & -- & -- & -- & -- & -- & & $-\overline{9}$ \\
\hline $\mathrm{Al}_{2} \mathrm{O}_{3}$ (pct) $\ldots \ldots \ldots \ldots$ & -- & -- & -- & 44.97 & 7.747 & 122 & 49.18 & 7.930 & 41 \\
\hline$p\{$ \{ct $) \ldots \ldots \ldots \ldots \ldots$ & -- & -- & -- & -- & -- & -- & -- & -- & -- \\
\hline $\mathrm{P}_{2} \mathrm{O}_{5}$ (pct) $\ldots \ldots \cdots \cdots$ & -- & -- & -- & -- & -- & -- & -- & -- & -- \\
\hline IImenite $\left(\right.$ pet $\left.\mathrm{TiO}_{2}\right) \ldots$ & -- & - & -- & -- & -- & -- & -- & -- & -- \\
\hline Rutile $\left(\text { pct } \mathrm{TiO}_{2}\right)^{2} \ldots$. & -- & -- & -- & -. & -- & -- & -- & -- & -- \\
\hline Leucocite $\left(\right.$ pct $\left.\mathrm{TiO}_{2}\right) \ldots$ & -- & -- & -- & -- & -- & -- & -- & -- & $\cdots$ \\
\hline $\mathrm{Cr}_{2} \mathrm{O}_{3}$ (pet) $\ldots \ldots \ldots \ldots$ & -- & -- & -- & -- & -- & -- & -- & -- & -- \\
\hline $\begin{array}{l}\mathrm{Mn}^{2}(\mathrm{pct}) \\
\mathrm{Fe}{ }^{(p c t)}{ }^{\prime}\end{array}$ & -- & -- & -- & -- & -- & -- & -- & -- & -- \\
\hline 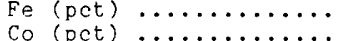 & $-\overline{-1} 150$ & --.1665 & $-\overline{-}$ & -- & -- & -- & -- & -- & -- \\
\hline $\begin{array}{l}\text { Co (pct) } \quad \cdots \cdots \cdots \cdots \cdots \cdots \\
N i \text { (pct) }\end{array}$ & -1.159 & $\begin{array}{l}.1005 \\
.1043\end{array}$ & 12 & -- & -- & -- & -- & -- & -- \\
\hline 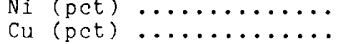 & $\therefore-1340$ & $\therefore 1043$ & $\begin{array}{l}71 \\
--\end{array}$ & -- & -- & -- & -- & -- & -- \\
\hline Mo (pet) $\ldots \ldots \cdots \cdots \cdots \cdots$ & -- & -- & -. & $\ldots$ & -- & -- & -- & -- & $\begin{array}{l}-- \\
--\end{array}$ \\
\hline $\mathrm{WO}_{3}(\mathrm{pct}) \ldots \ldots \ldots \ldots \ldots$ & -- & -- & -- & -- & -- & - & -- & -- & -- \\
\hline $\mathrm{Pd}^{3}(\mathrm{ppb}) \ldots \ldots \ldots \ldots \ldots$ & -- & -- & -- & -- & -- & -- & -- & -- & -- \\
\hline Pt $(p p b) \quad \ldots \ldots \ldots \ldots \ldots$ & -- & -- & -- & -- & -- & -- & -- & -- & -- \\
\hline$R h(p p b) \quad \ldots \ldots \ldots \ldots \ldots$ & -- & -- & -- & -- & -- & -- & -- & -- & -- \\
\hline Ir $(p p b) \quad \ldots \ldots \ldots \ldots \ldots$ & -- & -- & -- & -- & -- & -- & -- & -- & $-\infty$ \\
\hline$R u(p p b) \quad \ldots \ldots \ldots \ldots \ldots$ & -- & -- & -- & -- & -- & -- & -- & -- & -- \\
\hline Os $(p p b) \quad \ldots \ldots \ldots \ldots \ldots$ & -- & -- & -- & -- & -- & -- & -- & -- & -- \\
\hline $\operatorname{Ag}(g / t) \quad \ldots \ldots \ldots \ldots \ldots$ & -- & -- & -- & -- & -- & -- & -- & -- & -- \\
\hline $\operatorname{Au}(g / t) \quad \ldots \ldots \cdots \cdots \cdots$ & -- & -- & -- & -- & -- & -- & -- & -- & -- \\
\hline $\operatorname{Zn}(p c t) \quad \ldots \ldots \ldots \cdots \cdots$ & -- & -- & -- & -- & -- & -- & -- & -- & - \\
\hline $\mathrm{Hg}(p c t) \quad \ldots \ldots \ldots \ldots \ldots$ & -- & -- & -- & -- & -- & -- & -- & -- & -- \\
\hline$S n(p c t) \quad \ldots \ldots \ldots \cdots \cdots$ & -- & -- & -- & -- & -- & -- & -- & -- & -- \\
\hline $\mathrm{Pb}(p c t) \quad \ldots \ldots \ldots \ldots \cdots$ & -- & -- & -- & -- & -- & -- & -- & -- & -- \\
\hline$S b(p c t) \ldots \ldots \ldots \ldots \ldots$ & -- & -- & -- & -- & -- & -- & -- & -- & -- \\
\hline
\end{tabular}

\begin{tabular}{|c|c|c|c|c|c|c|c|c|c|}
\hline \multirow[b]{2}{*}{ Deposit type } & \multicolumn{3}{|c|}{ Placer Au-PGE } & \multicolumn{3}{|c|}{ Placer PGE-Au } & \multicolumn{3}{|c|}{ Shoreline placer Ti } \\
\hline & Mean & S.D. & $\begin{array}{c}\text { Number } \\
\text { of } \\
\text { deposits }\end{array}$ & Mean & S.D. & $\begin{array}{c}\text { Number } \\
\text { of } \\
\text { deposits }\end{array}$ & Mean & S.D. & $\begin{array}{c}\text { Number } \\
\text { of } \\
\text { deposits }\end{array}$ \\
\hline Tonnage (metric) $\ldots \ldots$ & 6.030 & 1.312 & 65 & 5.112 & 0.8548 & 83 & 7.942 & 0.7014 & 61 \\
\hline $\mathrm{RE}_{2} \mathrm{O}_{5}$ (pct) $\ldots \ldots \ldots \cdots$ & -- & -- & -- & -- & -- & -- & -- & -- & -- \\
\hline $\begin{array}{l}\text { Monazite (pct REO) } \ldots \ldots \\
\mathrm{U}_{2} \mathrm{O}_{8} \text { (pct) } \ldots \ldots\end{array}$ & $\begin{array}{l}-- \\
--\end{array}$ & $\begin{array}{l}-- \\
-\end{array}$ & -- & -- & -- & $\begin{array}{l}-- \\
--\end{array}$ & -1.5262 & $\therefore .8190$ & 23 \\
\hline $\mathrm{Z}_{1}^{3}$ con $\left(\right.$ pet $\left.\mathrm{ZrO}_{2}\right) \ldots$ & -- & -- & - & - & - & - & -.5703 & .4221 & 52 \\
\hline $\mathrm{Nb}_{2} \mathrm{O}_{5}$ (pct) $\ldots \ldots \cdots \cdots \cdot$ & -- & -- & -- & -- & -- & -- & -- & -- & -- \\
\hline $\begin{array}{l}\text { FiБer (pct) } \cdots \cdots \\
\text { Barite (pct) } \ldots \ldots \cdots\end{array}$ & $\begin{array}{l}-- \\
--\end{array}$ & $\begin{array}{l}-- \\
--\end{array}$ & $\begin{array}{ll}-- \\
--\end{array}$ & $\begin{array}{l}-- \\
--\end{array}$ & $\begin{array}{l}-- \\
--\end{array}$ & $\begin{array}{ll}-- \\
--\end{array}$ & $\begin{array}{l}-- \\
--\end{array}$ & $\begin{array}{l}-- \\
--\end{array}$ & $\begin{array}{l}-- \\
--\end{array}$ \\
\hline $\mathrm{Al}_{2} \mathrm{O}_{3}$ (pct) $\ldots \cdots \cdots \cdots$ & - & -- & - & - & - & -- & -- & -- & -- \\
\hline$P\{p c t) \quad \ldots \ldots \ldots \ldots \cdots \cdots$ & -- & -- & -- & -- & -- & -- & -- & -- & -- \\
\hline $\mathrm{P}_{2} \mathrm{O}_{5}$ (pct) $\ldots \ldots \ldots \ldots$ & -- & -- & -- & -- & -- & -- & -- & -- & -- \\
\hline IImenite $\left(\right.$ pct $\left.\mathrm{TiO}_{2}\right) \ldots$ & -- & -- & -- & -- & -- & -- & .1026 & .5755 & 61 \\
\hline Rutile $\left(\right.$ pot $\left.\mathrm{TiO}_{2}\right) \ldots$. & -- & -- & -- & -- & -- & -- & -.6723 & .4220 & 50 \\
\hline Leucocite $\left(\right.$ pct $\left.\mathrm{TiO}_{2}\right) \ldots$ & -- & -- & -- & -- & -- & -- & -.5469 & .5439 & 24 \\
\hline $\mathrm{Cr}_{2} \mathrm{O}_{3}$ (pct) $\ldots \ldots \ldots \ldots$ & -- & -- & -- & -- & -- & -- & -- & -- & -- \\
\hline 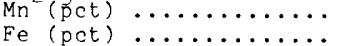 & $\begin{array}{ll}-- \\
--\end{array}$ & $\begin{array}{ll}-- \\
--\end{array}$ & -- & -- & -- & -- & -- & -- & -- \\
\hline Co (pct) $\quad \ldots \ldots \ldots \ldots \cdots \cdots$ & -- & -- & -- & -- & $=-$ & -- & $=-$ & -- & -- \\
\hline $\mathrm{Ni}$ (pct) $\ldots \ldots \ldots \cdots$ & -- & -- & -- & -- & -- & -- & -- & -- & -- \\
\hline $\mathrm{Cu}(p c t) \quad \ldots \ldots \cdots \cdots$ & -- & -- & -- & -- & -- & -- & -- & -- & -- \\
\hline Mo (pct) $\ldots \ldots \ldots \ldots \ldots$ & -- & -- & $=$ & -- & -- & -- & -- & -- & -- \\
\hline $\mathrm{wO}_{3}$ (pct) $\ldots \ldots \ldots \ldots \ldots$ & -- & -- & -- & -- & -- & -- & -- & -- & -- \\
\hline$P d^{3}(p p b) \ldots \ldots \ldots \ldots$ & -- & -- & -- & -2.825 & .9818 & 13 & -- & -- & -- \\
\hline Pt $(p p b) \quad \ldots \ldots \ldots \ldots \cdots$ & -- & -- & -- & .2010 & .5701 & 83 & -- & -- & -- \\
\hline$R h(p p b) \quad \ldots \cdots \cdots \cdots \cdots$ & -- & -- & -- & -- & -- & -- & -- & -. & -- \\
\hline Ir $(\mathrm{ppb}) \ldots \ldots \cdots \cdots \cdots$ & -- & -- & -- & -2.077 & 1.193 & 10 & -. & -- & -- \\
\hline$R u(p p b) \quad \ldots \ldots \ldots \cdots \cdots$ & -- & -- & -- & -- & -- & -- & -- & -- & -- \\
\hline Os $(p p b) \quad \ldots \ldots \ldots \ldots \ldots$ & -- & -- & 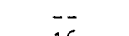 & -1.805 & 1.068 & 21 & -- & -- & -- \\
\hline $\mathrm{Ag}(\mathrm{g} / \mathrm{t}) \quad \ldots \cdots \cdots \cdots \cdots$ & -1.571 & .3954 & 15 & - & -- & -- & -- & -- & -- \\
\hline $\mathrm{Au}(g / t) \quad \ldots \ldots \ldots \cdots \cdots$ & -.6983 & .2928 & 65 & -1.531 & .8495 & 23 & -- & -- & -- \\
\hline$z n(p c t) \quad \ldots \ldots \ldots \ldots \ldots$ & -- & -- & -- & -- & -- & -- & -- & -- & -- \\
\hline $\mathrm{Hg}(p c t) \quad \ldots \ldots \ldots \ldots \ldots$ & -- & -- & -- & -- & -- & -- & -- & -- & -- \\
\hline$s_{n}(p c t), \ldots \ldots \cdots \cdots$ & -- & -- & -- & -- & -- & -- & -- & -- & -- \\
\hline $\mathrm{Pb}$ (pct) $\ldots \ldots \cdots \cdots \cdots$ & -- & - & -- & -- & -- & -- & -- & -- & -- \\
\hline Sb (pct) $\ldots \ldots \ldots \cdots \cdots$ & -- & -- & -- & -- & -- & -- & -- & -- & -- \\
\hline
\end{tabular}


Appendix C. Commodity/Geochemical Index by Paul B. Barton

This file shows economic (or potentially economic) commodities as primary products or by-products; it also indicates geochemical anomalies. These represent the elements present anywhere in the deposit, not solely in haloes distinct from ore. The listing covers only those deposits for which models are present elsewhere in this compilation. Figure 206 is a graphical presentation of some of the information in the following table. It provides an overview of the distribution of the elements among deposit types.

In an effort to represent the commonness or rarity of features, numbers are assigned. Universally present products/anomalies rate a +5 (shown simply as "5") grading down through 0 to -5 (shown as "(-5)") in a system similar to PROSPECTOR. The "O" value will seldom, if ever, be shown as it is the "don't know" (or "don't care") default. Note that negative numbers for "Primary" or "By-product" are not used, although they might be applied to indicate serious deleterious elements, such as phosphorus in iron ores. In almost all instances at present, these values will be guesses based on experience, not hard data; however, we do urge the compilation of data to make such assignments possible eventually. It is our intent to have the "1", "2", "3", "4", and "5" scores correspond respectively to the $0-10,10-30,30-70,70-90$, and 90-100 percent frequency relationship between the element and the deposit type. Obviously such statistical approaches are meaningless for deposit types having few representatives, such as emerald veins (31c), but the value can still be useful as an estimate of the compiler's opinion regarding the probable generality of the observation. The abbreviated suffixes "(prox.)" and "(dist.)" indicate respectively proximal (or nearer source) and distal (or farther from the source). For more complex relations please refer back to the models.

Figure 206 shows only the presence of an element at some unspecified anomalous level, either proximally or distally with respect to the deposit. The elements are grouped in such a way that the distinction between those of granitic and mafic associations can be easily made. The elements of high mobility in hydrothermal environments form a distinct grouping on the right side of the matrix.

It should be obvious from examination of the table and figure below that the presence of a given element seldom, if ever, "proves" the existence of an ore deposit. Anomalous amounts of some elements such as copper, gold, iron, and zinc are so common in so many settings that their presence tells very little about the possible character of the host deposit. Their presence is encouraging, however, and indicates that additional studies may be warranted.

\begin{tabular}{|c|c|c|c|c|}
\hline Element & Primary & By-product & $\begin{array}{l}\text { Geochemical } \\
\text { anomaly }\end{array}$ & Deposit type and model number \\
\hline $\mathrm{Ag}$ & $\begin{array}{l}3 \\
2 \\
4\end{array}$ & $\begin{array}{l}3 \\
3 \\
4 \\
4 \\
5 \text { (dist.) }\end{array}$ & $\begin{array}{l}3 \\
4 \text { (dist.) } \\
5 \\
5 \\
5 \\
4 \\
4 \\
4 \text { (dist.) } \\
5 \\
5 \text { (prox.) } \\
5 \text { (dist.) } \\
5 \text { (dist.) } \\
5 \\
5 \\
5 \\
4 \\
4 \\
5 \\
3 \\
5 \text { (prox.) }\end{array}$ & $\begin{array}{l}\text { Sn skarn (14b) } \\
\text { porphyry Cu (17) } \\
\text { porphyry Cu, skarn-related (18a) } \\
\text { Cu skarn (18b) } \\
\text { Zn-Pb skarn (18c) } \\
\text { polymetallic replacement (19a) } \\
\text { replacement Mn (19b) } \\
\text { porphyry Sn (20a) } \\
\text { Sn-polymetallic veins (20b) } \\
\text { porphyry Cu-Au (20c) } \\
\text { porphyry Cu-Mo (21a) } \\
\text { porphyry Mo, low-F (21b) } \\
\text { volcanic-hosted Cu-As-Sb (22a) } \\
\text { Au-Ag-Te veins (22b) } \\
\text { polymetallic veins (22c) } \\
\text { basaltic Cu (23) } \\
\text { Cyprus nassive sulfide (24a) } \\
\text { Besshi massive sulfide (24b) } \\
\text { Blackbird Co-Cu (24d) } \\
\text { hot-spring Au-Ag (25a) }\end{array}$ \\
\hline
\end{tabular}




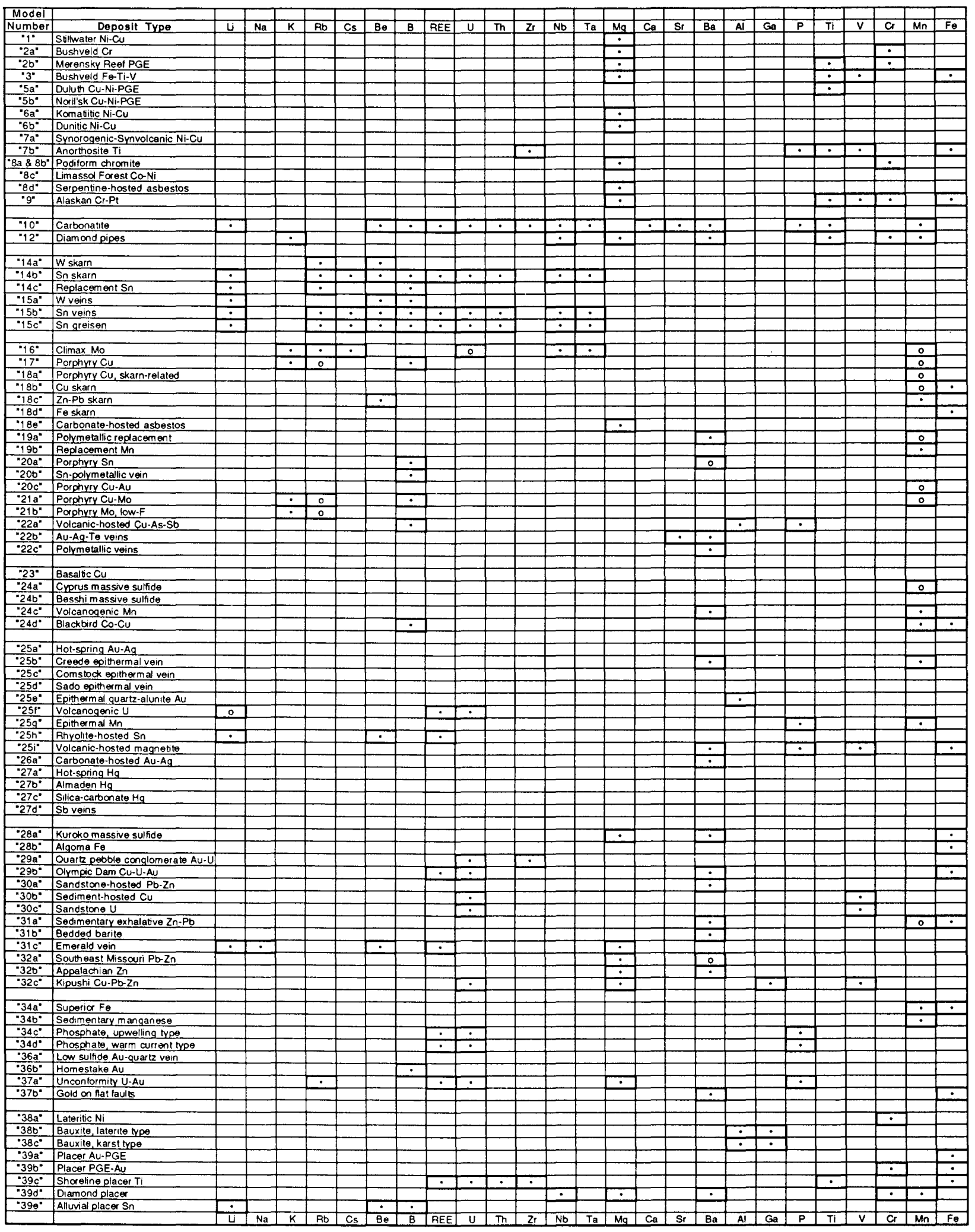

Figure 206. Matrix diagram showing deposit models and their geochemical signature. Closed and open circles indicate that the element is anomalous proximally or distally to the deposit respectively. 


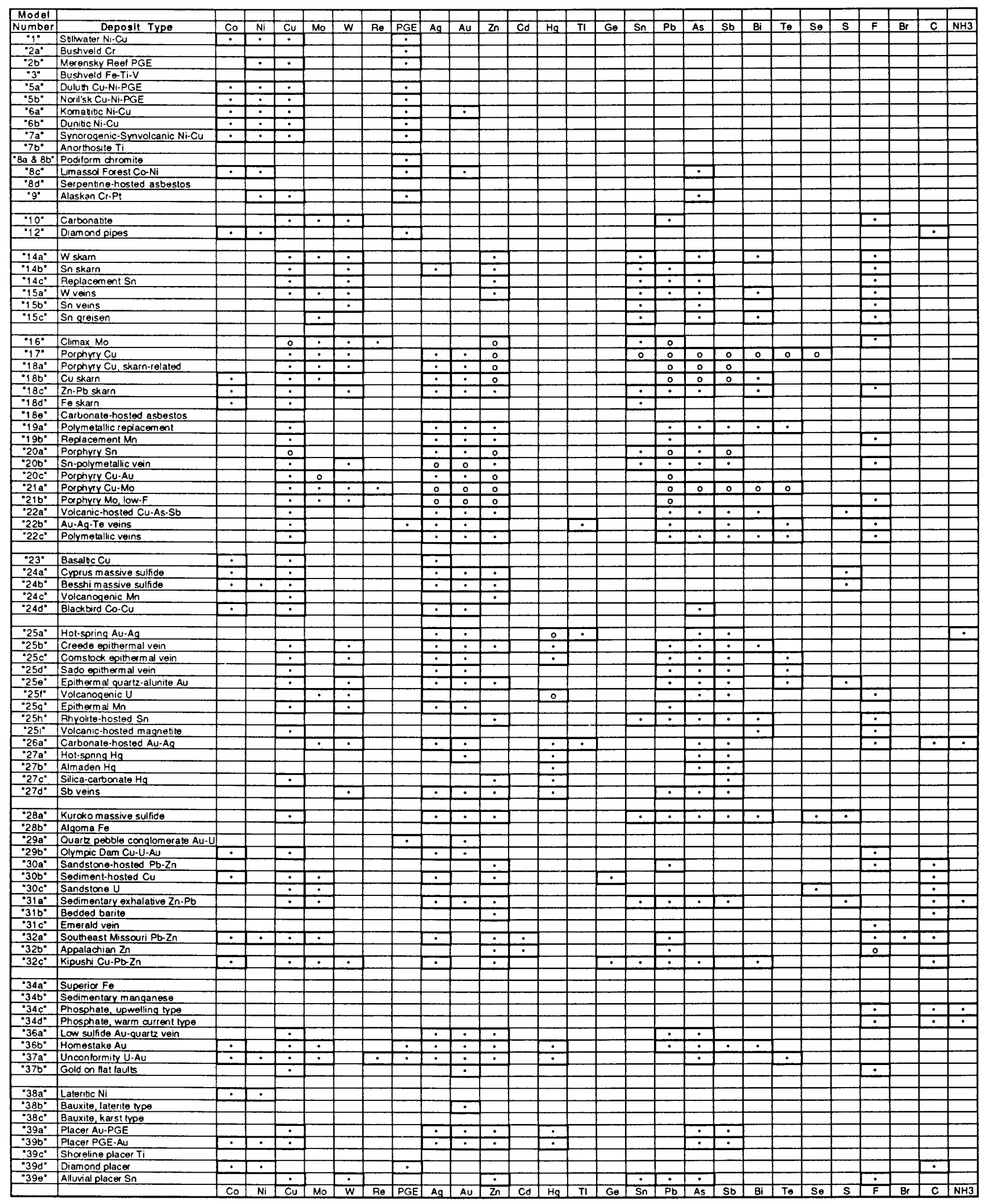

Figure 206. Continued. 
Appendix C. Commodity/Geochemical Index--Continued

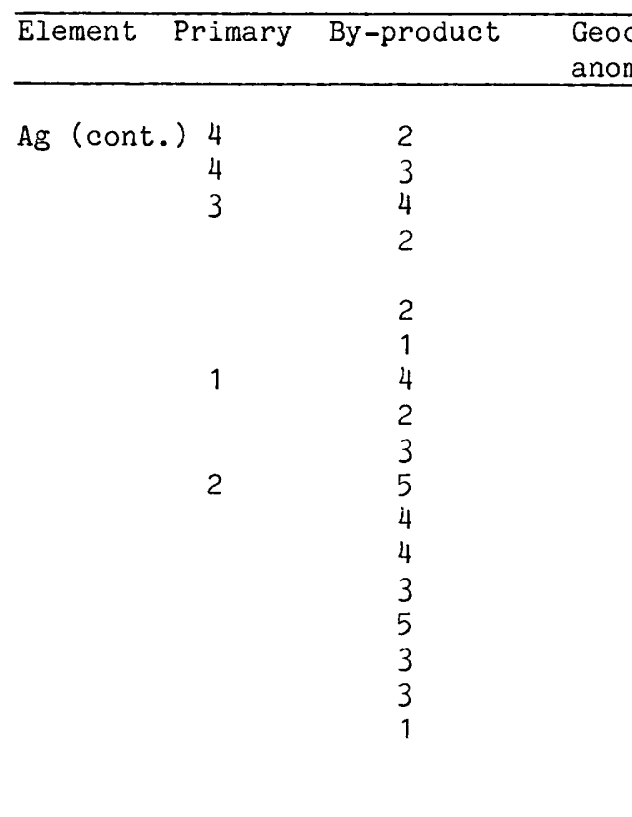

Al

5

5

As

5

5

3

3

3

5

4

5

5

5
5
5
5
5
5
4

Deposit type and model number

Creede epithermal vein (25b)

Comstock epithermal vein (25c)

Sado epithermal vein (25d)

epithermal quartz-alunite $\mathrm{Au}$ (25e)

epithermal Mn (25g)

carbonate-hosted Au-Ag (26a)

simple Sb (27d)

kuroko massive sulfide (28a)

Olympic Dam Cu-U-Au (29b)

sandstone-hosted $\mathrm{Pb}-\mathrm{Zn}$ (30a)

sediment-hosted $\mathrm{Cu}$ (30b)

sedimentary exhalative $\mathrm{Zn}-\mathrm{Pb}$ (31a)

southeast Missouri $\mathrm{Pb}-\mathrm{Zn}$ (32a)

Kipushi $\mathrm{Cu}-\mathrm{Pb}-\mathrm{Zn}$ (32c)

low-sulfide Au-quartz veins (36a)

Homestake Au (36b)

placer Au-PGE (39a)

placer PGE-Au (39b)

unconformity U-Au (37a)

gold on flat faulis (37b)

volcanic-hosted $\mathrm{Cu}-\mathrm{As}-\mathrm{Sb}$ (22a)

epithermal quartz-alunite $\mathrm{Au}$ (25e)

bauxite, laterite type (38b)

bauxite, karst type (38c)

unconformity U-Au (37a)

Limassol Forest Co-Ni (8c)

Alaskan PGE (9)

$W$ skarn (14a)

replacement $\mathrm{Sn}(14 \mathrm{c})$

$W$ veins (15a)

$S n$ veins $(15 b)$

Sn greisen (15c)

porphyry $\mathrm{Cu}(17)$

Cu skarn (18b)

$\mathrm{Zn}-\mathrm{Pb}$ skarn (18c)

polymetallic replacement (19a)

porphyry $\mathrm{Sn}$ (20a)

Sn-polymetallic veins (20b)

porphyry Cu-Mo (21a)

volcanic-hosted Cu-As-Sb (22a)

polymetallic veins (22c)

Blackbird Co-Cu (24d)

hot-spring $\mathrm{Au}-\mathrm{Ag}$ (25a)

Creede epithermal vein (25b)

Comstock epithermal vein (25c)

epithermal quartz-alunite $\mathrm{Au}$ (25e)

Sado epithermal vein (25d)

volcanogenic U (25f)

rhyolite-hosted $\mathrm{Sn}(25 \mathrm{~h})$

carbonate-hosted Au (26a)

hot-spring $\mathrm{Hg}$ (27a)

Almaden $\mathrm{Hg}$ ( $27 \mathrm{~b}$ )

simple $\mathrm{Sb}$ (27d)

kuroko massive sulfide (28a)

Homestake Au (28c)

sedimentary exhalative $\mathrm{Zn}-\mathrm{Pb}$ (31a)

Kipushi Cu-Pb-Zn (32c)

low-sulfide Au-quartz veins (36a)

Homestake Au (36b) 
Appendix C. Commodity/Geochemical Index--Continued

\begin{tabular}{|c|c|c|c|c|}
\hline Element & Primary & By-product & $\begin{array}{l}\text { Geochemical } \\
\text { anomaly }\end{array}$ & Deposit type and model number \\
\hline \multirow[t]{4}{*}{ As (cont } & & & 4 & unconformity U-Au (37a) \\
\hline & & & 1 & gold on flat faults (37b) \\
\hline & & & 4 & placer Au-PGE (39a) \\
\hline & & & 4 & placer PGE-Au (39b) \\
\hline \multirow[t]{37}{*}{$\mathrm{Au}$} & & 2 & 3 & komatiitic $\mathrm{Ni}-\mathrm{Cu}(6 \mathrm{a})$ \\
\hline & & 4 & 5 & porphyry $\mathrm{Cu}(17)$ \\
\hline & & 3 & 4 & porphyry $\mathrm{Cu}$, skarn-related (18a) \\
\hline & & 4 & 4 & Cu skarn $(18 b)$ \\
\hline & & 4 & 4 & $\mathrm{Zn}-\mathrm{Pb}$ skarn $(18 \mathrm{c})$ \\
\hline & 1 & 5 & 5 (prox.) & porphyry $\mathrm{Cu}-\mathrm{Au}(20 \mathrm{c})$ \\
\hline & & 3 & 5 (dist.) & porphyry $\mathrm{Cu}-\mathrm{Mo}(21 \mathrm{a})$ \\
\hline & & 3 & 4 & Fe skarn $(18 d)$ \\
\hline & 1 & 3 & 4 & polymetallic replacement (19a) \\
\hline & & & 4 & replacement Mn (19b) \\
\hline & & 3 & 4 & Sn-polymetallic veins $(20 b)$ \\
\hline & & & 4 (dist.) & porphyry Mo, low-F (21b) \\
\hline & & 4 & 4 & volcanic-hosted $\mathrm{Cu}-\mathrm{As}-\mathrm{Sb}$ (22a) \\
\hline & 5 & & 5 & $A u-A g-T e$ veins $(22 b)$ \\
\hline & 2 & 4 & $\begin{array}{l}5(\text { prox }) \\
(-3)\end{array}$ & $\begin{array}{l}\text { polymetallic veins }(22 \mathrm{c}) \\
\text { basaltic } \mathrm{Cu}(23)\end{array}$ \\
\hline & 2 & 4 & 5 & Cyprus massive sulfide (24a) \\
\hline & 1 & 3 & 4 & Besshi massive sulfide (24b) \\
\hline & & 2 & 3 & Blackbird $\mathrm{Co}-\mathrm{Cu}(24 \mathrm{~d})$ \\
\hline & 4 & 2 & 5 & hot-spring $\mathrm{Au}-\mathrm{Ag}$ (25a) \\
\hline & 2 & 4 & 4 & Creede epithermal vein (25b) \\
\hline & 4 & 3 & 5 & Comstock epithermal vein (25c) \\
\hline & 4 & 3 & 5 & Sado epithermal vein (25d) \\
\hline & 5 & & 5 & epithermal quartz-alunite $\mathrm{Au}(25 \mathrm{e})$ \\
\hline & & & 3 & epithermal Mn (25g) \\
\hline & 5 & & 5 & carbonate-hosted Au (26a) \\
\hline & & 1 & 3 & hot-spring $\mathrm{Hg}(27 \mathrm{a})$ \\
\hline & & 1 & 3 & simple $\mathrm{Sb}(27 \mathrm{~d})$ \\
\hline & & 3 & 5 & kuroko massive sulfide (28a) \\
\hline & 5 & & 5 & Homestake Au (28c) \\
\hline & 4 & 2 & 5 & quartz pebble conglomerate Au-U (29a) \\
\hline & & 3 & 5 & Olympic Dam Cu-U-Au (29b) \\
\hline & 5 & & 5 & low-sulfide Au-quartz veins (36a) \\
\hline & 5 & & 5 & Homestake Au (36b) \\
\hline & & 3 & 5 & unconformity U-Au (37a) \\
\hline & & & 5 & gold on flat faults (37b) \\
\hline & 5 & 1 & 5 & placer Au-PGE (39a) \\
\hline & & 1 & 4 & placer PGE-Au (39b) \\
\hline \multirow[t]{12}{*}{$\mathrm{B}$} & & & 1 & carbonatite $(10)$ \\
\hline & & & 5 & Sn skarn $(14 b)$ \\
\hline & & & 4 & replacement $\mathrm{Sn}(14 \mathrm{c})$ \\
\hline & & & 2 & $W$ veins $(15 a)$ \\
\hline & & & 4 & Sn veins $(15 b)$ \\
\hline & & & 4 & Sn greisen $(15 c)$ \\
\hline & & & 3 & porphyry copper (17) \\
\hline & & & 4 (prox.) & porphyry $\mathrm{Sn}(20 \mathrm{a})$ \\
\hline & & & 3 & Blackbird $\mathrm{Co}-\mathrm{Cu}(24 \mathrm{~d})$ \\
\hline & & & 3 & kuroko massive sulfide (28a) \\
\hline & & & 3 & sedimentary exhalative $\mathrm{Zn}-\mathrm{Pb}$ (31a) \\
\hline & & & 4 & Homestake $\mathrm{Au}(36 \mathrm{~b})$ \\
\hline \multirow[t]{3}{*}{$\mathrm{Ba}$} & 1 & & 4 & carbonatite $(10)$ \\
\hline & & & 3 & diamond pipes (12) \\
\hline & & & $\begin{array}{l}3 \\
4 \text { (dist.) }\end{array}$ & $\begin{array}{l}\text { polymetallic replacement (19a) } \\
\text { porphyry } \mathrm{Sn}(20 \mathrm{a})\end{array}$ \\
\hline
\end{tabular}


Appendix C. Commodity/Geochemical Index--Continued

\begin{tabular}{|c|c|c|c|c|}
\hline Element & Primary & By-product & $\begin{array}{l}\text { Geochemical } \\
\text { anomaly }\end{array}$ & Deposit type and model number \\
\hline Ba (cont & 5 & 1 & $\begin{array}{l}3 \\
4 \text { (dist.) } \\
3 \\
4 \\
3 \\
3 \\
3 \\
3 \\
3 \\
4 \text { (dist.) } \\
5 \\
3 \text { (dist.) } \\
3 \\
3 \\
3\end{array}$ & $\begin{array}{l}\text { Au-Ag-Te veins (22b) } \\
\text { polymetallic veins (22c) } \\
\text { volcanogenic Mn (24c) } \\
\text { Creede epithermal vein (25b) } \\
\text { volcanic-hosted magnetite (25i) } \\
\text { carbonate-hosted Au (26a)-Ag } \\
\text { kuroko massive sulfide (28a) } \\
\text { Olympic Dam Cu-U-Au (29b) } \\
\text { sandstone-hosted Pb-Zn (30a) } \\
\text { sedimentary exhalative } \mathrm{Zn-Pb} \mathrm{(31a)} \\
\text { bedded barite ( } 31 \mathrm{~b}) \\
\text { southeast Missouri Pb-Zn (32a) } \\
\text { Appalachian Zn (32b) } \\
\text { gold on flat faults (37b) } \\
\text { diamond placers (39d) }\end{array}$ \\
\hline $\mathrm{Be}$ & 5 & 1 & $\begin{array}{l}1 \\
5 \\
4 \\
3 \\
3 \\
2 \\
4 \\
5\end{array}$ & $\begin{array}{l}\text { carbonatite }(10) \\
\text { W skarn }(14 a) \\
\text { Sn skarn }(14 b) \\
W \text { veins }(15 a) \\
\text { Sn greisen }(15 c) \\
\text { Zn-Pb skarn }(18 c) \\
\text { rhyolite-hosted Sn (25h) } \\
\text { emerald veins (31c) }\end{array}$ \\
\hline $\mathrm{Bi}$ & & 2 & $\begin{array}{l}4 \\
5 \\
3 \\
2 \\
2 \\
3 \\
3 \\
4 \\
2 \\
3 \\
3 \\
2 \\
3 \\
3 \\
3\end{array}$ & $\begin{array}{l}\text { W skarn (14a) } \\
\text { W veins (15a) } \\
\text { Sn greisen (15c) } \\
\text { porphyry Cu (17) } \\
\text { Cu skarn (18b) } \\
\text { Zn-Pb skarn (18c) } \\
\text { polymetallic replacement (19a) } \\
\text { Sn-polymetallic veins (20b) } \\
\text { Creede epithermal vein (25b) } \\
\text { rhyolite-hosted Sn (25h) } \\
\text { volcanic-hosted magnetite (25i) } \\
\text { kuroko massive sulfide (28a) } \\
\text { Kipushi Cu-Pb-Zn (32c) } \\
\text { Homestake Au (36b) } \\
\text { unconformity } \mathrm{U}-\mathrm{Au} \mathrm{(37a)}\end{array}$ \\
\hline $\mathrm{Br}$ & & 2 & $\begin{array}{l}5 \\
3\end{array}$ & $\begin{array}{l}\text { marine potash } \\
\text { southeast Missouri } \mathrm{Pb}-\mathrm{Zn}(32 \mathrm{a})\end{array}$ \\
\hline C (diam & $\begin{array}{l}5 \\
5\end{array}$ & & & $\begin{array}{l}\text { diamond pipes (12) } \\
\text { diamond placers (39d) }\end{array}$ \\
\hline C (orgar & c) & & $\begin{array}{l}5 \\
5 \\
4 \\
4 \\
3 \\
4 \\
3 \\
3\end{array}$ & $\begin{array}{l}\text { carbonate-hosted } \mathrm{Au} \text { (26a) } \\
\text { sandstone } \mathrm{U}(30 \mathrm{C}) \\
\text { sedimentary exhalative } \mathrm{Zn-Pb}(31 \mathrm{a}) \\
\text { quartz pebble conglomerate } \mathrm{Au}-\mathrm{U} \text { (29a) } \\
\text { southeast Missouri } \mathrm{Pb}-\mathrm{Zn} \mathrm{(32a)} \\
\text { phosphate, upwelling type (34c) } \\
\text { phosphate, warm-current type (34d) } \\
\text { unconformity U-Au (37a) }\end{array}$ \\
\hline $\mathrm{C}$ a & & & $\begin{array}{l}(-4) \\
(-4) \\
(-5)\end{array}$ & $\begin{array}{l}\text { kuroko massive sulfide (28a) } \\
\text { Cyprus massive sulfide }(24 a) \\
\text { southeast Missouri } \mathrm{Pb}-\mathrm{Zn}(32 \mathrm{a})\end{array}$ \\
\hline
\end{tabular}


Appendix C. Commodity/Geochemical Index--Continued

\begin{tabular}{|c|c|c|c|c|}
\hline Element & Primary & By-product & $\begin{array}{l}\text { Geochemical } \\
\text { anomaly }\end{array}$ & Deposit type and model number \\
\hline $\mathrm{Ca}$ (cont & & & $\begin{array}{l}(-5) \\
(-3) \\
3\end{array}$ & $\begin{array}{l}\text { Appalachian } \mathrm{Zn}(32 \mathrm{~b}) \\
\text { Blackbird Co-Cu ( } 24 \mathrm{~d}) \\
\text { unconformity U (37a) }\end{array}$ \\
\hline $\mathrm{Cd}$ & & $\begin{array}{l}4 \\
4\end{array}$ & & $\begin{array}{l}\text { southeast Missouri } \mathrm{Pb}-\mathrm{Zn} \text { (32a) } \\
\text { Appalachian } \mathrm{Zn}(32 \mathrm{~b})\end{array}$ \\
\hline Co & 5 & $\begin{array}{l}1 \\
2 \\
4 \\
3\end{array}$ & $\begin{array}{l}5 \\
4 \\
5 \\
3 \\
5 \\
5 \\
5 \\
4 \\
2 \\
3 \\
2 \\
1 \\
3 \\
4 \\
5 \\
3 \\
2 \\
2 \\
4 \\
3 \\
5 \\
3 \\
4 \\
3\end{array}$ & $\begin{array}{l}\text { Stillwater Ni-Cu (1) } \\
\text { Duluth Cu-Ni-PGE (5a) } \\
\text { Noril'sk Cu-Ni-PGE (5b) } \\
\text { komatiitic Ni-Cu (6a) } \\
\text { dunitic Ni (6b) } \\
\text { synorogenic-synvolcanic Ni-Cu (7a) } \\
\text { Limassol Forest Co-Ni (8c) } \\
\text { diamond pipes (12) } \\
\text { Cu skarn (18b) } \\
\text { Zn-Pb skarn (18c) } \\
\text { Fe skarn (18d) } \\
\text { basaltic Cu (23) } \\
\text { Cyprus massive sulfide (24a) } \\
\text { Besshi massive sulfide (24b) } \\
\text { Blackbird Co-Cu (24d) } \\
\text { Olympic Dam Cu-U-Au (29b) } \\
\text { sediment-hosted Cu (30b) } \\
\text { sedimentary exhalative } \mathrm{Zn-Pb} \mathrm{(31a)} \\
\text { southeast Missouri Pb-Zn (32a) } \\
\text { Kipushi Cu-Pb-Zn (32c) } \\
\text { lateritic Ni (38a) } \\
\text { Homestake Au (36b) } \\
\text { unconformity U (37a) } \\
\text { diamond placers (39d) }\end{array}$ \\
\hline $\mathrm{Cr}$ & $\begin{array}{l}5 \\
2\end{array}$ & 1 & $\begin{array}{l}5 \\
5 \\
5 \\
5 \\
5 \\
5 \\
3 \\
5 \\
5 \\
3\end{array}$ & $\begin{array}{l}\text { Bushveld } \mathrm{Cr}(2 \mathrm{a}) \\
\text { Merensky Reef PGE (2b) } \\
\text { dunitic Ni (6b) } \\
\text { podiform } \mathrm{Cr}(8 \mathrm{a}) \\
\text { Alaskan PGE (9) } \\
\text { diamond pipes (12) } \\
\text { Besshi massive sulfide (24b) } \\
\text { lateritic Ni (38a) } \\
\text { placer PGE-Au (39b) } \\
\text { diamond placers (39d) }\end{array}$ \\
\hline Cs & & & $\begin{array}{l}4 \\
4\end{array}$ & $\begin{array}{l}\text { Sn skarn }(14 b) \\
\text { Climax Mo }(16)\end{array}$ \\
\hline $\mathrm{Cu}$ & 1 & $\begin{array}{l}4 \\
1 \\
3 \\
4 \\
3 \\
3 \\
1 \\
1 \\
1 \\
2\end{array}$ & $\begin{array}{l}5 \\
5 \\
5 \\
5 \\
5 \\
4 \\
5 \\
5 \\
3 \\
4 \\
4 \\
5 \\
3 \\
4(\text { prox.) } \\
5 \text { (prox.) }\end{array}$ & $\begin{array}{l}\text { Stillwater Ni-Cu (1) } \\
\text { Merensky Reef PGE (2b) } \\
\text { Duluth Cu-Ni-PGE (5a) } \\
\text { Noril'sk Cu-Ni-PGE (5b) } \\
\text { komatiitic Ni-Cu (6a) } \\
\text { dunitic Ni (6b) } \\
\text { synorogenic-synvolcanic Ni-Cu (7a) } \\
\text { Alaskan PGE (9) } \\
\text { carbonatite (10) } \\
\text { W skarn (14a) } \\
\text { Sn skarn (14b) } \\
\text { replacement Sn (14c) } \\
\text { W veins (15a) } \\
\text { Climax Mo (16) } \\
\text { porphyry Cu (17) }\end{array}$ \\
\hline
\end{tabular}


Appendix C. Commodity/Geochemical Index--Continued

\begin{tabular}{|c|c|c|c|c|}
\hline Element & Primary & By-product & $\begin{array}{l}\text { Geochemical } \\
\text { anomaly }\end{array}$ & Deposit type and model number \\
\hline $\mathrm{Cu}$ (cont & $\begin{array}{l}3 \\
5 \\
5 \\
5 \\
\\
2 \\
5 \\
5 \\
5\end{array}$ & $\begin{array}{l}3 \\
3 \\
3 \\
3 \\
3\end{array}$ & $\begin{array}{l}5 \\
5 \text { (prox.) } \\
5 \\
4 \\
5 \text { (prox.) } \\
4 \\
4 \text { (dist.) } \\
5 \\
5 \text { (prox.) } \\
5 \text { (prox.) } \\
5 \text { (prox.) } \\
5 \\
4 \\
5 \text { (prox.) } \\
5 \\
5 \\
5 \\
3 \\
5 \\
5 \\
5 \\
5 \\
5 \\
3 \\
3 \\
3 \\
5 \\
5 \\
5 \\
4 \\
5 \text { (prox.) } \\
5 \\
5 \\
4 \\
4 \\
4 \\
5 \\
3 \\
3 \\
\\
\\
\\
\end{array}$ & $\begin{array}{l}\text { porphyry Cu, skarn-related (18a) } \\
\text { Cu skarn (18b) } \\
\text { Zn-Pb skarn (18c) } \\
\text { Fe skarn (18d) } \\
\text { polymetallic replacement (19a) } \\
\text { replacement Mn (19b) } \\
\text { porphyry Sn (20a) } \\
\text { Sn-polymetallic veins (20b) } \\
\text { porphyry Cu-Au (20c) } \\
\text { porphyry Cu-Mo (21a) } \\
\text { porphyry Mo, low-F (21b) } \\
\text { volcanic-hosted Cu-As-Sb (22a) } \\
\text { Au-Ag-Te veins (22b) } \\
\text { polymetallic veins (22c) } \\
\text { basaltic Cu (23) } \\
\text { Cyprus massive sulfide (24a) } \\
\text { Besshi massive sulfide (24b) } \\
\text { volcanogenic Mn (24c) } \\
\text { Blackbird Co-Cu (24d) } \\
\text { Creede epithermal vein (25b) } \\
\text { Comstock epithermal vein (25c) } \\
\text { Sado epithermal vein (25d) } \\
\text { epithermal quartz-alunite Au (25e) } \\
\text { epithermal Mn ( } 25 g) \\
\text { volcanic-hosted magnetite (25i) } \\
\text { silica-carbonate Hg (27c) } \\
\text { kuroko massive sulfide (28a) } \\
\text { Olympic Dam Cu-U-Au (29b) } \\
\text { sediment-hosted Cu (30b) } \\
\text { sandstone U ( } 30 c) \\
\text { sedimentary exhalative Zn-Pb (31a) } \\
\text { southeast Missouri Pb-Zn (32a) } \\
\text { Kipushi Cu-Pb-Zn (32c) } \\
\text { low-sulfide Au-quartz veins (36a) } \\
\text { Homestake Au (36b) } \\
\text { unconformity U ( } 37 a) \\
\text { gold on flat faults (37b) } \\
\text { placer Au-PGE (39a) } \\
\text { placer PGE-Au ( } 39 b)\end{array}$ \\
\hline$F$ & & $\begin{array}{l}3 \\
3\end{array}$ & $\begin{array}{l}2 \\
2 \\
4 \\
5 \\
4 \\
5 \\
5 \\
3 \\
3 \\
5 \\
5 \text { (prox.) } \\
4 \\
3 \\
2 \\
3 \\
3 \\
2 \\
3 \text { (dist.) } \\
5 \\
5 \\
4\end{array}$ & $\begin{array}{l}\text { carbonatite }(10) \\
\text { W skarn (14a) } \\
\text { Sn skarn (14b) } \\
\text { replacement Sn (14c) } \\
\text { W veins (15a) } \\
\text { Sn greisen (15c) } \\
\text { Climax Mo (16) } \\
\text { Zn-Pb skarn (18c) } \\
\text { porphyry Mo, low-F (21b) } \\
\text { Au-Ag-Te veins (22b) } \\
\text { volcanogenic U ( } 25 \mathrm{f}) \\
\text { rhyolite-hosted Sn (25h) } \\
\text { volcanic-hosted magnetite (25i) } \\
\text { carbonate-hosted Au (26a) } \\
\text { Olympic Dam Cu-U-Au (29b) } \\
\text { sandstone-hosted Pb-Zn (30a) } \\
\text { southeast Missouri Pb-Zn (32a) } \\
\text { Appalachian Zn (32b) } \\
\text { phosphate, upwelling type (34c) } \\
\text { phosphate, warm current type (34d) } \\
\text { gold on flat faults } 37 b\end{array}$ \\
\hline
\end{tabular}


Appendix C. Commodity/Geochemical Index--Continued

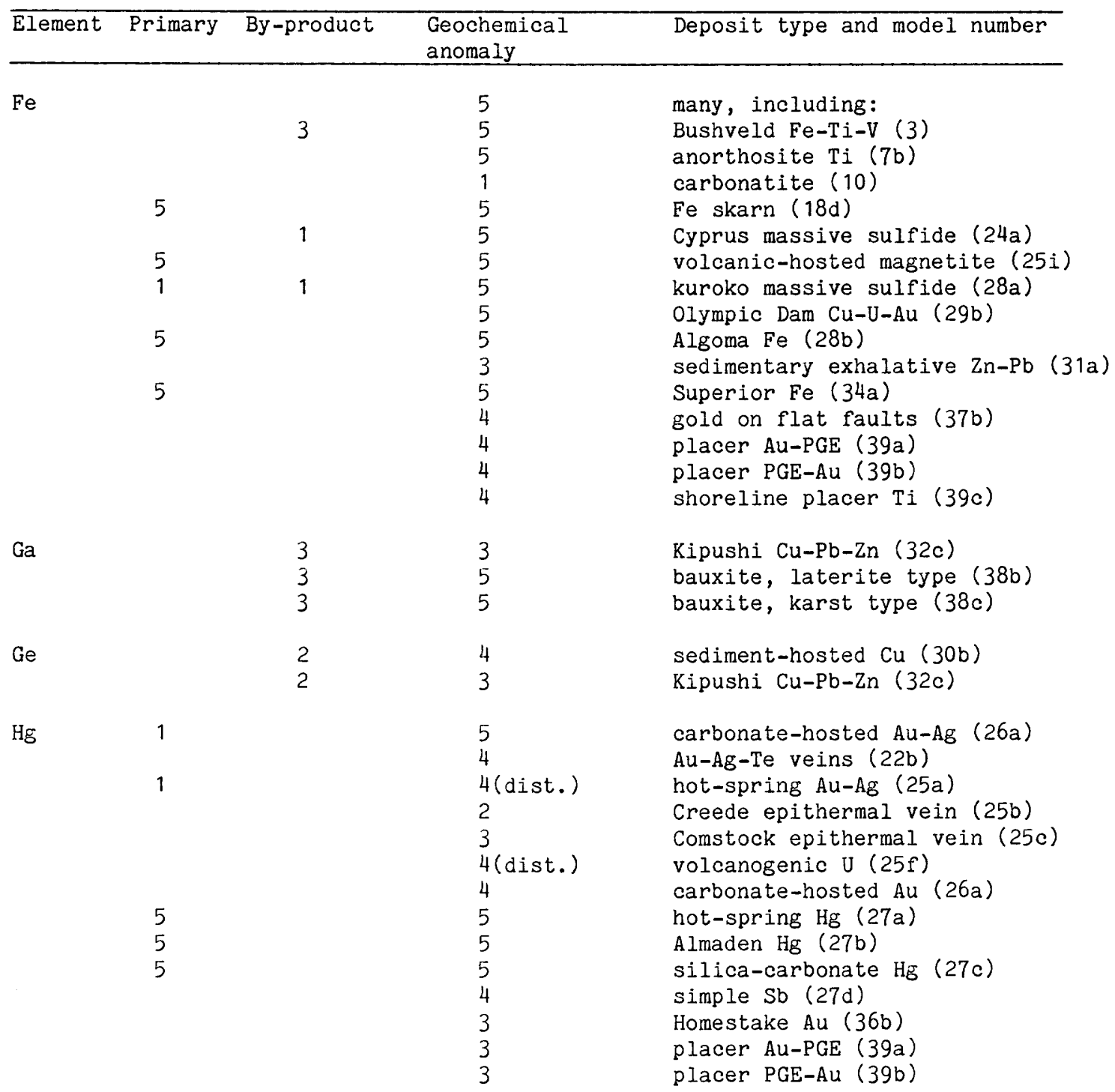

Ir (see PGE)

K

$$
\begin{aligned}
& (-4) \\
& (-5) \\
& (-5) \\
& 4 \\
& (-3) \\
& 4
\end{aligned}
$$

Li

$\mathrm{Mg}$

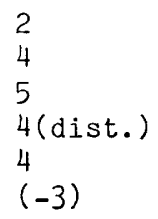

5

5

5

5

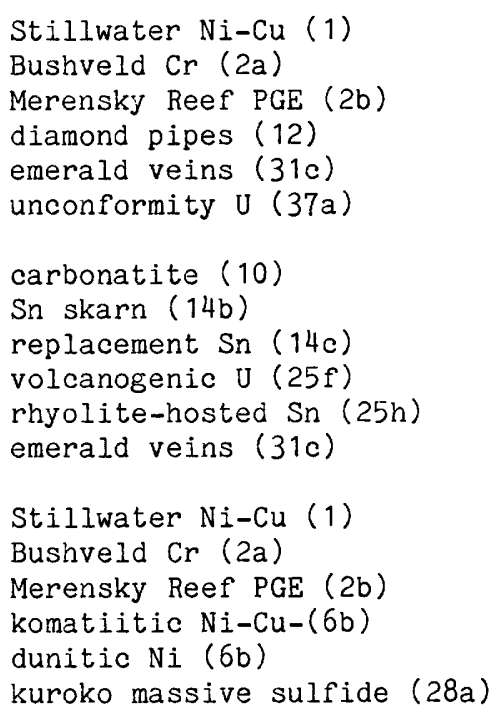


Appendix C. Commodity/Geochemical Index--Continued

\begin{tabular}{|c|c|c|c|c|}
\hline Element & Primary & By-product & $\begin{array}{l}\text { Geochemical } \\
\text { anomaly }\end{array}$ & Deposit type and model number \\
\hline \multicolumn{3}{|c|}{$\mathrm{Mg}$ (cont.) } & $\begin{array}{l}3 \\
5 \\
5 \\
4\end{array}$ & $\begin{array}{l}\text { dolomitic Cu-Co } \\
\text { southeast Missouri } \mathrm{Pb}-\mathrm{Zn} \text { (32a) } \\
\text { Appalachian } \mathrm{Zn} \mathrm{(32b)} \\
\text { emerald veins (31c) }\end{array}$ \\
\hline \multirow[t]{5}{*}{ Mn } & & & $\begin{array}{l}3 \\
4 \\
4 \text { (dist.) } \\
5 \\
4 \text { (dist.) }\end{array}$ & $\begin{array}{l}\text { carbonatite }(10) \\
\text { diamond pipes }(12) \\
\text { porphyry Cu }(17) \\
\text { Zn-Pb skarn }(18 c) \\
\text { polymetallic replacement (19a) }\end{array}$ \\
\hline & 5 & & $\begin{array}{l}5 \\
4 \text { (dist.) } \\
4 \text { (dist.) } \\
5 \text { (dist.) } \\
4 \text { (dist.) }\end{array}$ & $\begin{array}{l}\text { replacement } \mathrm{Mn}(19 \mathrm{~b}) \\
\text { porphyry } \mathrm{Cu}-\mathrm{Au}(20 \mathrm{c}) \\
\text { porphyry Cu-Mo }(21 \mathrm{a}) \\
\text { polymetallic veins (22c) } \\
\text { Cyprus massive sulfide (24a) }\end{array}$ \\
\hline & 5 & & $\begin{array}{l}5 \\
4\end{array}$ & $\begin{array}{l}\text { volcanogenic } \mathrm{Mn}(24 \mathrm{c}) \\
\text { Blackbird } \mathrm{Co}-\mathrm{Cu}(24 \mathrm{~d})\end{array}$ \\
\hline & 5 & & $\begin{array}{l}3 \\
5 \\
4 \text { (dist.) }\end{array}$ & $\begin{array}{l}\text { Creede epithermal vein }(25 \mathrm{~b}) \\
\text { epithermal } \mathrm{Mn}(25 \mathrm{~g}) \\
\text { sedimentary exhalative } \mathrm{Zn}-\mathrm{Pb} \text { ( } 31 \mathrm{a})\end{array}$ \\
\hline & 5 & & $\begin{array}{l}5 \\
4 \\
4\end{array}$ & $\begin{array}{l}\text { sedimentary Mn }(34 b) \\
\text { unconformity } \mathrm{U}(37 \mathrm{a}) \\
\text { diamond placers }(39 \mathrm{~d})\end{array}$ \\
\hline \multirow[t]{16}{*}{ Mo } & & & 4 & carbonatite $(10)$ \\
\hline & & 2 & 5 & W skarn $(14 a)$ \\
\hline & & 2 & 5 & W veins $(15 a)$ \\
\hline & & 1 & 5 & Sn greisen (15c) \\
\hline & & 5 & 5 (prox.) & Climax Mo (16) \\
\hline & & 3 & 5 (prox.) & porphyry $\mathrm{Cu}(17)$ \\
\hline & & 2 & 5 & porphyry $\mathrm{Cu}$, skarn-related (18a) \\
\hline & & 1 & 4 & Cu skarn $(18 b)$ \\
\hline & & 1 & 5 (dist.) & porphyry $\mathrm{Cu}-\mathrm{Au}(20 \mathrm{c})$ \\
\hline & & 4 & 5 (prox.) & porphyry $\mathrm{Cu}-\mathrm{Mo}$ (21a) \\
\hline & 5 & & $\begin{array}{l}5 \text { (prox.) } \\
5 \text { (prox.) } \\
2 \\
3 \\
4\end{array}$ & $\begin{array}{l}\text { porphyry Mo, low-F (21b) } \\
\text { volcanogenic U ( } 25 \mathrm{f}) \\
\text { carbonate-hosted } \mathrm{Au}(26 \mathrm{a}) \\
\text { sediment-hosted } \mathrm{Cu}(30 \mathrm{~b}) \\
\text { sandstone } \mathrm{U}(30 \mathrm{c})\end{array}$ \\
\hline & & & $\begin{array}{l}2 \\
(-3)\end{array}$ & $\begin{array}{l}\text { sedimentary exhalative } \mathrm{Zn}-\mathrm{Pb} \text { (31a) } \\
\text { emerald veins ( } 31 \mathrm{c})\end{array}$ \\
\hline & & & 4 & southeast Missouri $\mathrm{Pb}-\mathrm{Zn}$ (32a) \\
\hline & & & 3 & Kipushi $\mathrm{Cu}-\mathrm{Pb}-\mathrm{Zn}(32 \mathrm{c})$ \\
\hline & & & 2 & Homestake $\mathrm{Au}(36 \mathrm{~b})$ \\
\hline & & & 2 & unconformity U-Au (37a) \\
\hline \multicolumn{2}{|c|}{$\mathrm{N}\left(\right.$ as $\left.\mathrm{NH}_{4}^{+}\right)$} & & $\begin{array}{l}3 \\
3 \\
3 \\
3\end{array}$ & $\begin{array}{l}\text { carbonate-hosted } \mathrm{Au} \text { ( } 26 \mathrm{a}) \\
\text { sedimentary exhalative } \mathrm{Zn}-\mathrm{Pb}(31 \mathrm{a}) \\
\text { phosphate, upwelling type (34c) } \\
\text { phosphate, warm-current type (34d) }\end{array}$ \\
\hline $\mathrm{Na}$ & & & $\begin{array}{l}(-4) \\
(-5) \\
(-5) \\
(-3)\end{array}$ & $\begin{array}{l}\text { Stillwater Ni-Cu (1) } \\
\text { Bushveld Cr (2a) } \\
\text { Merensky Reef PGE (2b) } \\
\text { Blackbird Co-Cu (24d) }\end{array}$ \\
\hline \multirow[t]{2}{*}{$\mathrm{Nb}$} & & & $\begin{array}{l}(-4) \\
(-5) \\
5\end{array}$ & $\begin{array}{l}\text { kuroko massive sulfide (28a) } \\
\text { Cyprus massive sulfide }(24 a) \\
\text { emerald veins ( } 31 c)\end{array}$ \\
\hline & 4 & 1 & $\begin{array}{l}4 \\
4\end{array}$ & $\begin{array}{l}\text { carbonatite }(10) \\
\text { diamond pipes }(12)\end{array}$ \\
\hline
\end{tabular}


Appendix C. Commodity/Geochemical Index--Continued

\begin{tabular}{|c|c|c|c|c|}
\hline Element & Primary & By-product & $\begin{array}{l}\text { Geochemical } \\
\text { anomaly }\end{array}$ & Deposit type and model number \\
\hline $\mathrm{Nb}$ (cont & & & $\begin{array}{l}3 \\
4\end{array}$ & $\begin{array}{l}\text { Climax Mo ( } 16) \\
\text { diamond placers (39d) }\end{array}$ \\
\hline $\mathrm{Ni}$ & $\begin{array}{l}4 \\
4 \\
5 \\
5 \\
5 \\
1 \\
1\end{array}$ & $\begin{array}{l}1 \\
2 \\
1 \\
1\end{array}$ & $\begin{array}{l}5 \\
5 \\
5 \\
5 \\
5 \\
5 \\
5 \\
5 \\
5 \\
5 \\
3 \\
4 \\
5 \\
5 \\
4\end{array}$ & $\begin{array}{l}\text { Stillwater Ni-Cu (1) } \\
\text { Merensky Reef PGE (2b) } \\
\text { Duluth Cu-Ni-PGE (5a) } \\
\text { Noril'sk Cu-Ni-PGE (5b) } \\
\text { komatiitic Ni-Cu-(6a) } \\
\text { dunitic Ni (6b) } \\
\text { synorogenic-synvolcanic Ni-Cu (7a) } \\
\text { Limassol Forest Co-Ni (8c) } \\
\text { Alaskan PGE (9) } \\
\text { diamond pipes (12) } \\
\text { Besshi massive sulfide (24b) } \\
\text { southeast Missouri Pb-Zn (32a) } \\
\text { unconformity U (37a) } \\
\text { lateritic Ni (38a) } \\
\text { diamond placers (39d) }\end{array}$ \\
\hline
\end{tabular}

Os (see PGE)

P

1

5

2

5

$\mathrm{Pb}$

$\begin{array}{lll}1 & 1 & 5 \\ & & (-4) \\ & (-5) \\ & (-5) \\ & 5 \\ & & 4 \\ & & 4 \\ & 2 & 5 \\ 5 & & 5 \\ 5 & & 5\end{array}$

\begin{tabular}{|c|c|c|}
\hline & & $\begin{array}{l}3 \\
3 \\
4\end{array}$ \\
\hline & 1 & $\begin{array}{l}3 \\
4 \text { (dist.) } \\
4 \text { (dist.) } \\
3 \\
4 \text { (dist.) }\end{array}$ \\
\hline 2 & 4 & 5 \\
\hline 4 & 2 & $\begin{array}{l}5 \text { (dist.) } \\
4 \\
4 \text { (dist.) }\end{array}$ \\
\hline & 2 & $\begin{array}{l}4 \\
4 \text { (dist.) } \\
4 \text { (dist.) } \\
4 \text { (dist.) } \\
4\end{array}$ \\
\hline 3 & 2 & 5 \\
\hline & 4 & 5 \\
\hline & 4 & 5 \\
\hline & 3 & $\frac{3}{4}$ (prox.) \\
\hline & & $\begin{array}{l}3 \\
3\end{array}$ \\
\hline 1 & 3 & 5 \\
\hline 5 & & 5 \\
\hline 4 & & $\begin{array}{l}3 \\
5\end{array}$ \\
\hline
\end{tabular}

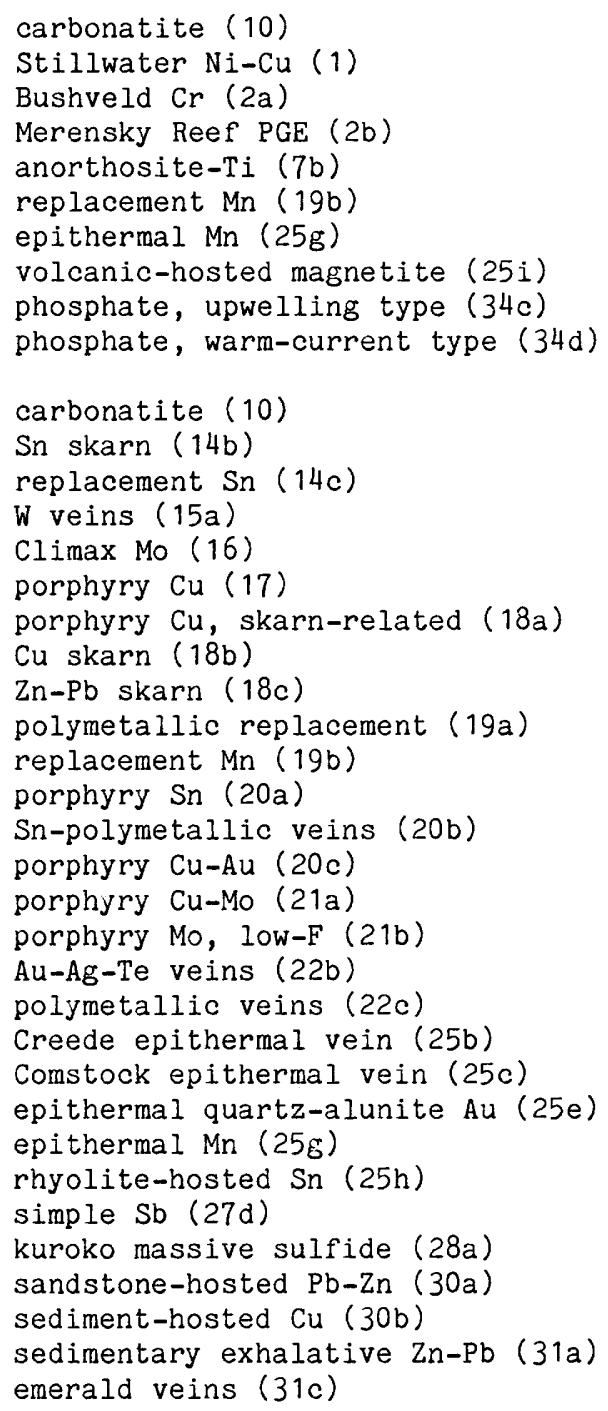


Appendix C. Commodity/Geochemical Index--Continued

\begin{tabular}{lccl}
\hline Element Primary & By-product & $\begin{array}{l}\text { Geochemical } \\
\text { anomaly }\end{array}$ & Deposit type and model number \\
\hline $\mathrm{Pb}$ (cont.) 5 & 2 & 5 & $\begin{array}{l}\text { southeast Missouri Pb-Zn (32a) } \\
\text { Appalachian } \mathrm{Zn} \mathrm{(32b)}\end{array}$ \\
& 3 & 3 & Kipushi Cu-Pb-Zn (32c) \\
& 3 & 5 & low-sulfide Au-quartz veins (36a) \\
& 4 & 4 & Homestake Au (36b) \\
& & 4 & unconformity U-Au (37a)
\end{tabular}

Pd (see PGE)

Pt (incl. all PGE)

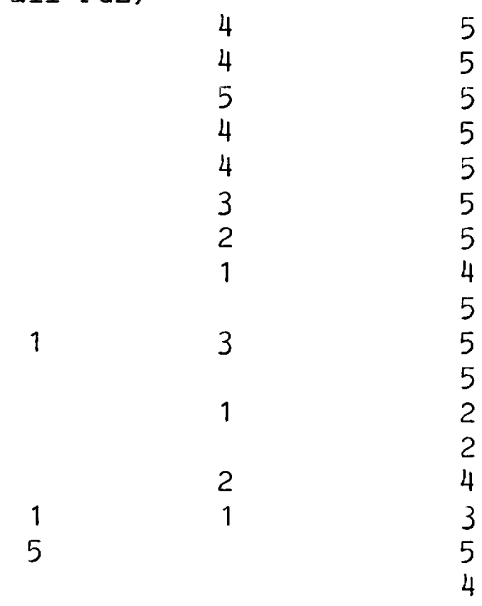

Stillwater $\mathrm{Ni}-\mathrm{Cu}(1)$

Bushveld $\mathrm{Cr}$ (2a)

Merensky Reef PGE (2b)

Duluth $\mathrm{Cu}-\mathrm{Ni}-\mathrm{PGE}$ (5a)

Noril'sk Cu-Ni-PGE (5b)

komatiitic $\mathrm{Ni}-\mathrm{Cu}(6 \mathrm{a})$

dunitic $\mathrm{Ni}(6 \mathrm{~b})$

synorogenic-synvolcanic $\mathrm{Ni}-\mathrm{Cu}$ (7a)

podiform $\mathrm{Cr}(8 \mathrm{a})$

Alaskan PGE (9)

diamond pipes (12)

$\mathrm{Au}-\mathrm{Ag}-\mathrm{Te}$ veins (22b)

Homestake Au (28c)

quartz pebble conglomerate Au-U (29a)

placer Au-PGE (39a)

placer PGE-Au (39b)

diamond placers (39d)

Rare Earths

2

$\begin{array}{ll}2 & 5 \\ 1 & 3 \\ & 3 \\ & 2 \\ & 3 \\ 1 & 5 \\ 1 & 4 \\ 1 & 4 \\ 2 & 3 \\ 2 & 5\end{array}$

carbonatite (10)

$W$ veins (15a)

volcanogenic U (25f)

rhyolite-hosted $\mathrm{Sn}(25 \mathrm{~h})$

Olympic Dam Cu-U-Au (29b)

emerald veins (31c)

phosphate, upwelling type (34c)

phosphate, warm-current type (34d)

unconformity U-Au (37a)

shoreline placer $\mathrm{Ti}$ (39c)

$\mathrm{Rb}$

$\begin{array}{ll}5 & \text { Sn skarn (14b) } \\ 5 & \text { replacement Sn (14c) } \\ 4 & \text { Climax Mo (16) } \\ 3 \text { (dist.) } & \text { porphyry Cu (17) } \\ 4 \text { (dist.) } & \text { porphyry Cu-Mo (21a) } \\ 3 & \text { unconformity U-Au (37a) } \\ 4 & \text { Sn skarn (14b) } \\ 5 & \text { Climax Mo (16) } \\ 5 & \text { Porphyry Mo, LW-F (21b) } \\ 3 & \text { Unconformity U-Au (37a) }\end{array}$

Rh (see PGE)

Ru (see PGE)

S

1

2
2

5

kuroko massive sulfide (28a)

Cyprus massive sulfide (24a)

$\mathrm{Sb}$ 
Appendix C. Commodity/Geochemical Index--Continued

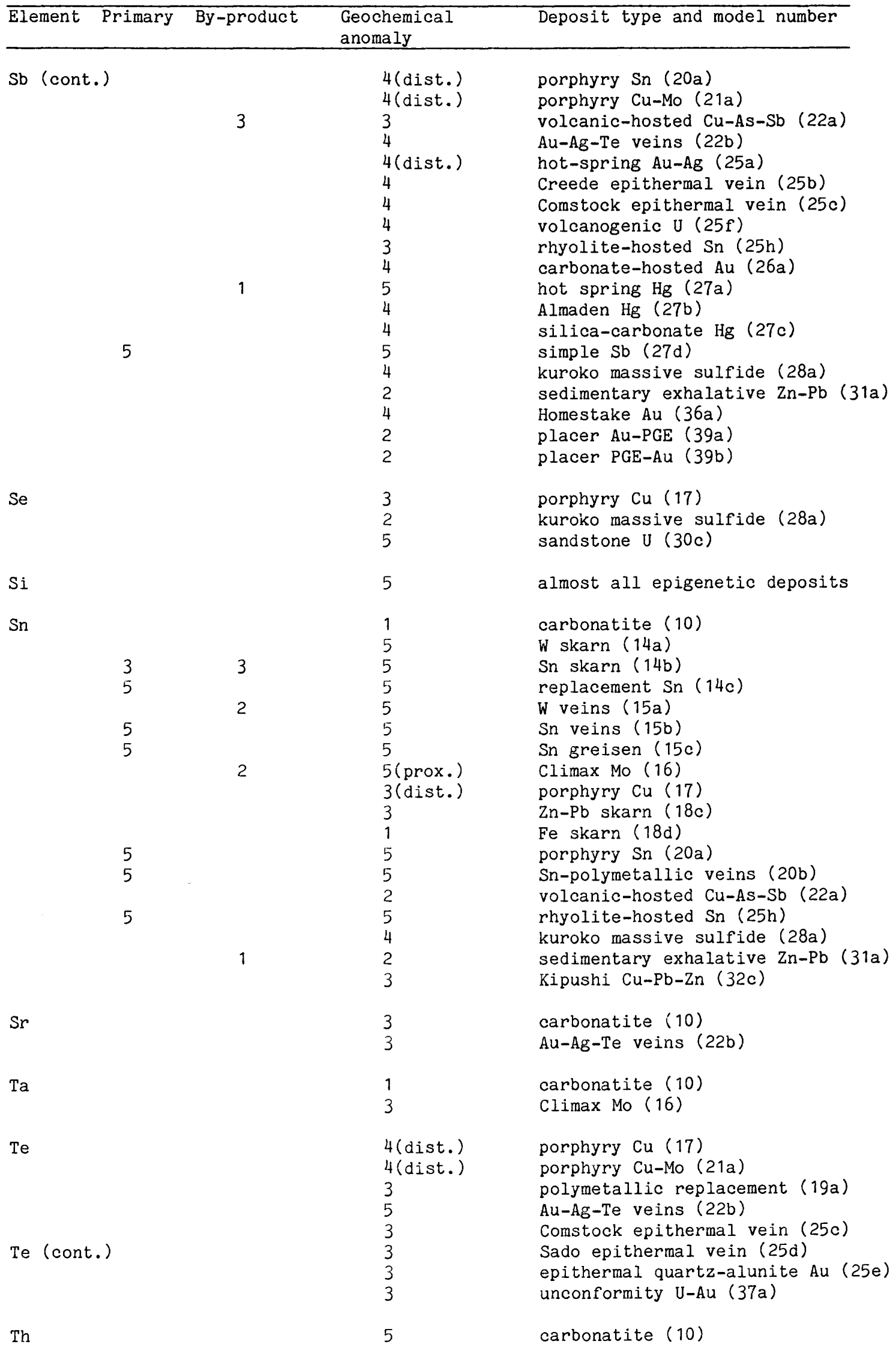


Appendix C. Commodity/Geochemical Index--Continued

\begin{tabular}{|c|c|c|c|c|}
\hline Element & Primary & By-product & $\begin{array}{l}\text { Geochemical } \\
\text { anomaly }\end{array}$ & Deposit type and model number \\
\hline \multicolumn{2}{|c|}{ Th (cont.) } & 2 & 5 & shoreline placer $\mathrm{Ti}(39 \mathrm{c})$ \\
\hline \multirow[t]{9}{*}{$\mathrm{Ti}$} & & & 4 & Merensky Reef PGE (2b) \\
\hline & & & 5 & Bushveld Fe-Ti-V (3) \\
\hline & & & 4 & Duluth $\mathrm{Cu}-\mathrm{Ni}-\mathrm{PGE}$ (5a) \\
\hline & 5 & & 5 & anorthosite-Ti (7b) \\
\hline & & & 4 & Alaskan PGE (9) \\
\hline & & & 4 & carbonatite $(10)$ \\
\hline & & & 5 & diamond pipes (12) \\
\hline & 5 & & 5 & shoreline placer $\mathrm{Ti}(39 \mathrm{c})$ \\
\hline & & & 5 & diamond placers (39d) \\
\hline \multicolumn{2}{|l|}{$\mathrm{T} 1$} & & $\begin{array}{l}4 \text { (dist.) } \\
4\end{array}$ & $\begin{array}{l}\text { hot-spring } \mathrm{Au}-\mathrm{Ag}(25 \mathrm{a}) \\
\text { carbonate-hosted } \mathrm{Au}(26 \mathrm{a})\end{array}$ \\
\hline \multirow[t]{11}{*}{$\mathrm{U}$} & & 1 & 5 & carbonatite (10) \\
\hline & & & 3 (dist.) & Climax Mo $(16)$ \\
\hline & 1 & 4 & 4 & quartz pebble conglomerate $\mathrm{Au}-\mathrm{U}$ (29a) \\
\hline & & 3 & 4 & Olympic Dam Cu-U-Au (29b) \\
\hline & & & 2 & sediment-hosted $\mathrm{Cu}(30 \mathrm{~b})$ \\
\hline & 5 & & 5 & sandstone $\mathrm{U}(30 \mathrm{c})$ \\
\hline & & & 2 & Kipushi $\mathrm{Cu}-\mathrm{Pb}-\mathrm{Zn}(32 \mathrm{c})$ \\
\hline & & 2 & 5 & phosphate, upwelling type (34c) \\
\hline & & 2 & 5 & phosphate, warm-current type (34d) \\
\hline & 5 & & 5 & unconformity $\mathrm{U}(37 \mathrm{a})$ \\
\hline & & 1 & 5 & shoreline placer $\mathrm{Ti}(39 \mathrm{c})$ \\
\hline \multirow[t]{7}{*}{$\mathrm{V}$} & 3 & & 5 & Bushveld Fe-Ti-V (3) \\
\hline & & 1 & 5 & anorthosite-Ti (7b) \\
\hline & & & 4 & Alaskan PGE (9) \\
\hline & & 1 & 4 & volcanic-hosted magnetite (25i) \\
\hline & & & 2 & sediment-hosted $\mathrm{Cu}(30 \mathrm{~b})$ \\
\hline & 1 & 4 & 5 & sandstone $U(30 \mathrm{c})$ \\
\hline & & & 3 & Kipushi $\mathrm{Cu}-\mathrm{Pb}-\mathrm{Zn}(32 \mathrm{c})$ \\
\hline \multirow[t]{21}{*}{ W } & & & 1 & carbonatite (10) \\
\hline & 5 & & 5 & W skarn (14a) \\
\hline & 5 & & 5 & Sn skarn $(14 b)$ \\
\hline & & 1 & 4 & replacement $\mathrm{Sn}(14 \mathrm{c})$ \\
\hline & 5 & & 5 & $W$ veins $(15 a)$ \\
\hline & & 2 & 5 & Sn veins $(15 b)$ \\
\hline & & 1 & 5 (prox.) & Climax Mo $(16)$ \\
\hline & & & $3($ prox.) & porphyry $\mathrm{Cu}(17)$ \\
\hline & & & 2 & porphyry $\mathrm{Cu}$, skarn-related (18a) \\
\hline & & 1 & 3 & $\mathrm{Zn}-\mathrm{Pb}$ skarn $(18 \mathrm{c})$ \\
\hline & & 2 & 4 & Sn-polymetallic veins $(20 \mathrm{~b})$ \\
\hline & & & 4 (prox.) & porphyry Cu-Mo (21a) \\
\hline & & 1 & 5 (prox.) & porphyry Mo, low-F (21b) \\
\hline & & & 2 & Creede epithermal vein (25b) \\
\hline & & & 2 & Comstock epithermal vein $(25 c)$ \\
\hline & & & 1 & epithermal quartz-alunite $\mathrm{Au}$ (25e) \\
\hline & & & 2 & volcanogenic U (25f) \\
\hline & & 1 & 3 & epithermal $\mathrm{Mn}(25 \mathrm{~g})$ \\
\hline & & & 4 & carbonate-hosted Au ( $26 a)$ \\
\hline & & & 4 & simple $\mathrm{Sb}(27 \mathrm{~d})$ \\
\hline & & & 3 & Kipushi $\mathrm{Cu}-\mathrm{Pb}-\mathrm{Zn}(32 \mathrm{c})$ \\
\hline \multirow[t]{4}{*}{$\mathrm{Zn}$} & & 1 & 4 & $W$ skarn $(14 a)$ \\
\hline & & 1 & 4 & Sn skarn $(14 b)$ \\
\hline & & & 4 & replacement $\mathrm{Sn}(14 \mathrm{c})$ \\
\hline & & 1 & 3 & $W$ veins $(15 a)$ \\
\hline
\end{tabular}


Appendix C. Commodity/Geochemical Index--Continued

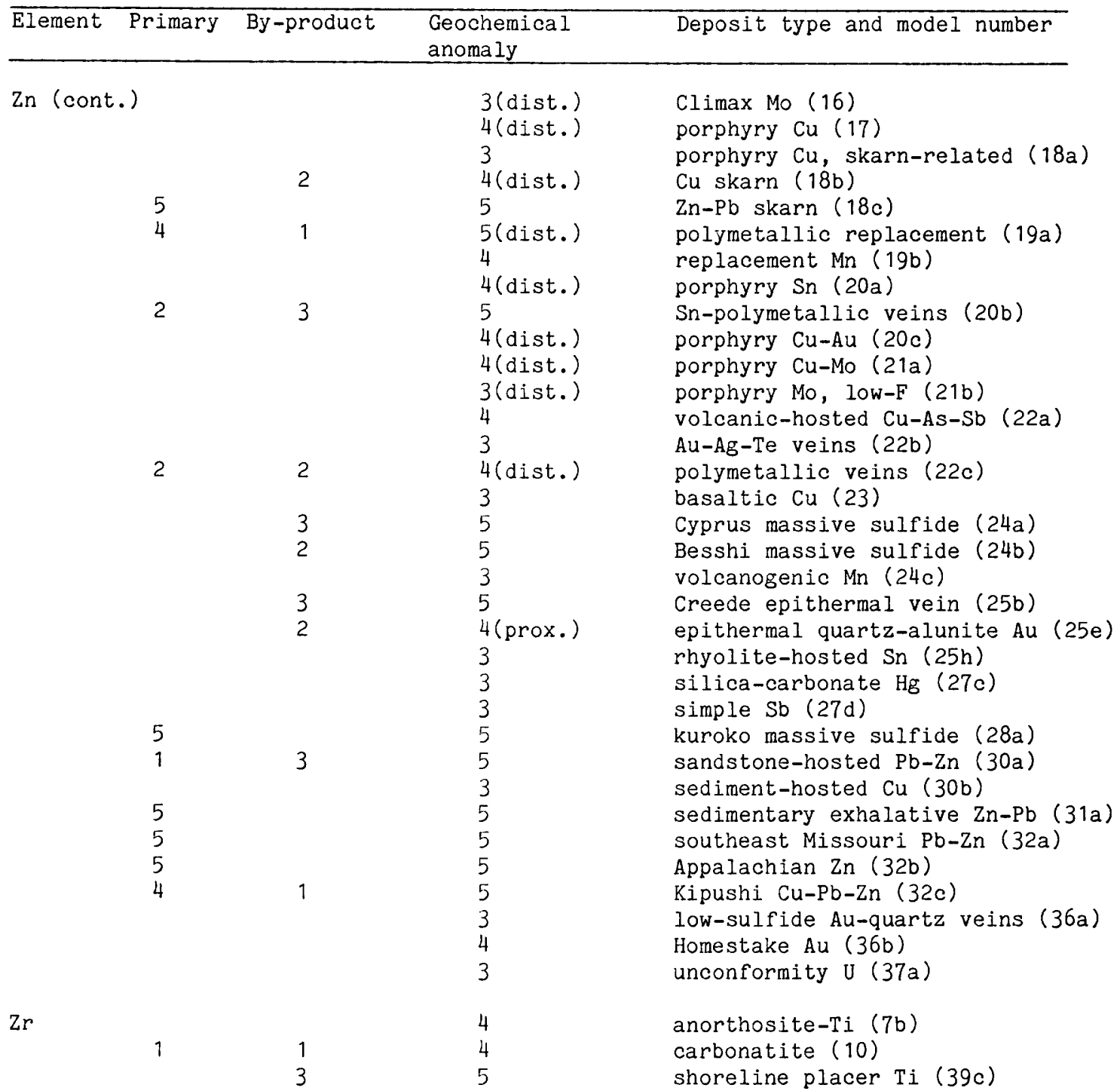


Appendix D. Mineralogical Index by Paul B. Barton

The mineralogy of the deposits is indicated in six categories describing the mode of occurrence of the mineral. Each category, which constitutes a column, is labeled as follows: "Ore mineral" (the mineral is commonly the source of the metal or other valuable product of the deposit), "Gangue mineral" (the mineral has no value but is closely associated in time and space with the ore minerals), "Host rock mineral" and "Associated rock mineral" (the mineral is characteristic of the rocks in which the deposit is found or with which it is genetically associated), "Alteration mineral" (the mineral is produced in rocks near the deposit by hydrothermal processes related to ore deposition or transport), and "Weathering mineral" (the mineral is produced by weathering or supergene enrichment).

An "ore" mineral is so designated if it is a mineral which under reasonable circumstances might be used to provide a concentrate of a valuable substance. Thus traces of bismuthinite are "ores", as are pyrite or arsenopyrite crystals that carry gold, and so is pyrite in sufficient abundance that it might be used as a source of sulfur. But accessory pyrite without economic values is "gangue" because neither iron nor sulfur would normally be produced from it; multiple entries for some minerals are expected. The "host" category is necessarily incomplete inasmuch as variations in host lithology are not necessarily critical parts of the model; for example a vein could cut a pegmatite containing minerals such as beryl or spodumene, neither of which would be very informative if added to the "host" minerals list.

Numerical values are given as a measure of the degree to which a mineral is present in the deposit of the type considered; the numbers are NOT the amount of mineral, but its universality anywhere in the deposit among all deposits of that class. The values "1", "2", "3", "4", and "5" correspond respectively to $0-10,10-30,30-70,70-90$, and $90-100$ percent and, until definitive documentation for a given model type is available, will usually be no better than guesses based on experience. The numbers are modified by a letter suffix to give a qualitative estimate of the abundance of the mineral: " $\mathrm{m}$ " indicates a major component, which we define as 10 volume percent; " $t$ " indicates traces, which we define as 1 volume percent; intermediate values are given no designation. Detail on the spatial distribution of minerals resides in the models themselves.

\begin{tabular}{lllllll}
\hline Mineral & Ore & Gangue & Host & Assoc- Alter- Weath- Deposit type and model number \\
min- & min- & rock iated ation ering & \\
& eral & eral & min- rock min- min- & min- eral eral \\
& & & eral min- & eral \\
\hline
\end{tabular}

$\begin{array}{lll}\text { Adularia } & 4 & \\ \text { (also see } & 3 & \\ \text { feldspar) } & 4 & 3 \\ & 3 & 3 \\ & 3 & \\ & 3 & 4 \\ & 4 & 4 \\ \text { Albite } & 2 t & \\ \text { (also see } & & 4 \mathrm{~m} \\ \text { feldspar) } & & 3 \\ & & 4 \\ & & 3\end{array}$

$\mathrm{Au}-\mathrm{Ag}-\mathrm{Te}$ veins (22b)

polymetallic veins (22c)

hot-spring $\mathrm{Au}-\mathrm{Ag}$ (25a)

Creede epithermal vein (25b)

Comstock epithermal vein (25c)

Sado epithermal vein (25d)

volcanogenic $U$ (25f)

rhyolite-hosted $\mathrm{Sn}(25 \mathrm{~h})$

hot-spring $\mathrm{Hg}$ (27a)

southeast Missouri $\mathrm{Pb}-\mathrm{Zn}$ (32a)

$W$ veins (15a)

porphyry $\mathrm{Cu}$ (17)

Besshi massive sulfide (24b)

volcanic-hosted magnetite (25i)

kuroko massive sulfide (28a)

sedimentary exhalative $\mathrm{Zn}-\mathrm{Pb}$ (31a)

emerald veins (31c)

low-sulfide Au-quartz veins (36a) 
Appendix D. Mineralogical Index--Continued

\begin{tabular}{lllllll}
\hline Mineral & Ore & Gangue & Host & Assoc- Alter- Weath- Deposit type and model number \\
min- & min- & rock & iated ation ering \\
eral & eral & min- rock min- min- \\
& & & eral min- eral eral & eral \\
& & & &
\end{tabular}

Alleghenyite

Al oxides and hydroxides $5 \mathrm{~m}$ $5 \mathrm{~m}$

Alunite

3

Amphibole

$\begin{array}{ll}\text { Mn-rich } & 4 \\ \text { actinolite } & 3 \\ \text { (includes } & 3 \\ \text { tremolite) } & 3 \\ & 4\end{array}$

anthophylite

cummingtonite

Anatase

Andalusite

Anhydrite
4
3
3
3
4

3

3

4

4

4

3

4

\section{3}

$\begin{array}{ll}3 m & 3 m \\ 4 & \end{array}$

3

3

3

2

$2 \mathrm{~m}$

2 volcanogenic $\mathrm{Mn}$ (24c)

$5 \mathrm{~m}$ bauxite, laterite type (38b)

$5 \mathrm{~m}$ bauxite, karst type (38c)

Alunite is a common result of the oxidation of sulfides in Al-bearing carbonate-poor rocks. porphyry $\mathrm{Cu}$ (17)

volcanic-hosted $\mathrm{Cu}-\mathrm{As}-\mathrm{Sb}$ (22a)

hot-spring $\mathrm{Au}-\mathrm{Ag}$ (25a)

Creede epithermal vein (25b)

Sado epithermal vein (25d)

epithermal quartz-alunite $\mathrm{Au}$ (25e)

volcanogenic $U(25 f)$

hot-spring $\mathrm{Hg}(27 \mathrm{a})$

Amphibole is a common late-stage alteration in skarns of all types.

$\mathrm{Zn}-\mathrm{Pb}$ skarn $(18 \mathrm{c})$

porphyry $\mathrm{Cu}$ (17)

porphyry $\mathrm{Cu}$, skarn-related (18a)

Cu skarn (18b)

$\mathrm{Zn}-\mathrm{Pb}$ skarn (18c)

porphyry $\mathrm{Cu}-\mathrm{Au}$ (20c)

Besshi massive sulfide (24b)

volcanic-hosted magnetite (25i)

serpentine-hosted asbestos (8d)

kuroko massive sulfide (28a)

Homestake $\mathrm{Au}(28 \mathrm{c})$

bauxite, laterite type (38b)

bauxite, karst type (38c)

porphyry $\mathrm{Cu}$ (17)

porphyry $\mathrm{Cu}-\mathrm{Mo}$ (21a)

volcanic-hosted Cu-As-Sb (22a)

epithermal quartz-alunite $\mathrm{Au}$ (25e)

Duluth Cu-Ni-PGE (5a)

Noril'sk Cu-Ni-PGE (5b)

porphyry $\mathrm{Cu}$ (17)

porphyry $\mathrm{Cu}-\mathrm{Au}$ (20c)

porphyry Cu-Mo (21a)

Cyprus massive sulfide (24a)

kuroko massive sulfide (28a)

Olympic Dam Cu-U-Au (29b)

Appalachian Zn (32b) 
Appendix D. Mineralogical Index--Continued

\begin{tabular}{lllllll}
\hline Mineral & Ore & Gangue & Host & Assoc- Alter- Weath- Deposit type and model number \\
min- & min- & rock iated ation ering & \\
eral & eral & min- rock min- min- & eral min- eral eral \\
& & & eral & & \\
\hline
\end{tabular}

Apatite

apatite,

(includes fluor-

francolite,

collophane)

Antimony $2 t$

(native)

3
$1 \mathrm{~m} \quad 4$
5

$5 m$

$5 \mathrm{~m}$

Argentite

5 Argentite is a common product of the supergene enrichment of silver ores.

$3 t$

$3 t$

$3 t$

$3 t$

$5 t$

$4 t$

$2 t$

anorthosite-Ti (7b)

carbonatite (10)

volcanic-hosted magnetite (25i)

phosphate, upwelling type (34c)

phosphate, warm-current type (34d)

simple Sb (27d)

Arsenates

rhyolite-hosted Sn (25h)

Arsenides

$\begin{array}{ll}4 t & 2 \\ 3 & 3 \\ 1 t & 3 t \\ 4 & 4 \\ 3 t & 2\end{array}$

Merensky Reef PGE (2b)

Noril'sk Cu-Ni-PGE (5b)

dunitic $\mathrm{Ni}$ ( $6 \mathrm{~b}$ )

Limassol Forest Co-Ni (8c)

Alaskan PGE (9)

Cu skarn (18b)

Arsenopyrite

W skarn (14a)

Sn skarn (14b)

replacement $\mathrm{Sn}(14 \mathrm{c})$

$W$ veins (15a)

$\mathrm{Sn}$ veins (15b)

Sn greisen (15c)

Cu skarn (18b)

$\mathrm{Zn}-\mathrm{Pb}$ skarn (18c)

porphyry $\mathrm{Sn}$ (20a)

Sn-polymetallic veins (20b)

volcanic-hosted $\mathrm{Cu}-\mathrm{As}-\mathrm{Sb}$ (22a)

polymetallic veins (22c)

Blackbird $\mathrm{Co}-\mathrm{Cu}$ (24d)

hot-spring $\mathrm{Au}-\mathrm{Ag}$ (25a)

Creede epithermal vein (25b)

Comstock epithermal vein (25c)

carbonate-hosted $\mathrm{Au}$ (26a)

simple Sb (27d)

sedimentary exhalative $\mathrm{Zn}-\mathrm{Pb}$ (31a)

southeast Missouri $\mathrm{Pb}-\mathrm{Zn}$ (32a) 
Appendix D. Mineralogical Index--Continued

\begin{tabular}{lllllll}
\hline Mineral & Ore & Gangue & Host Assoc- Alter- Weath- Deposit type and model number \\
& min- & min- & rock iated ation ering & \\
& eral & eral & min- rock min- min- \\
eral min- eral eral & eral \\
& & & & & \\
\hline
\end{tabular}

Arsenopyrite

(cont.)

2
4
4
3

Asbestos

(see chrysotile)

Ba-silicates $\quad 4$

Barite 4

4

3

3

3

3

$4 \mathrm{~m}$

$1 \mathrm{~m}$

2

$1 \mathrm{~m}$

3$$
\begin{aligned}
& 3 \\
& 2
\end{aligned}
$$

Berthierite

$$
2 t
$$

Beryl

3

$3 t$

$5 t$

Biotite

\author{
Kipushi Cu-Pb-Zn (32c) \\ low-sulfide Au-quartz veins (36a) \\ Homestake Au (36b) \\ unconformity $U(37 a)$
}

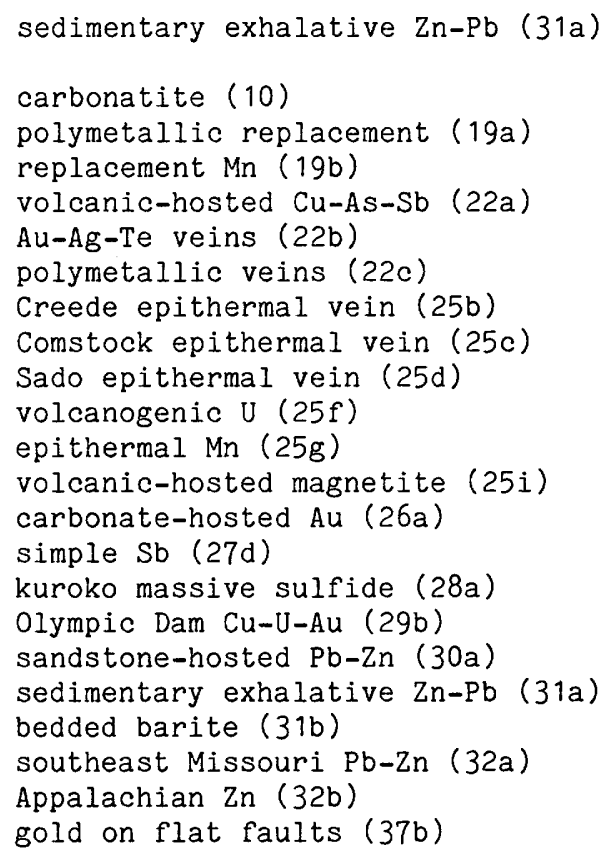

Biotite is a common mineral in igneous and metamorphic rocks. carbonatite (10)

low-sulfide Au-quartz veins (15d) porphyry $\mathrm{Cu}$ (17) porphyry $\mathrm{Cu}$, skarn-related (18a) porphyry $\mathrm{Cu}-\mathrm{Au}$ (20c) porphyry Cu-Mo (21a) porphyry Mo, low-F (21b) volcanic-hosted magnetite (25i) 
Appendix D. Mineralogical Index--Continued

\begin{tabular}{lllllll}
\hline Mineral & Ore & Gangue & Host & Assoc- Alter- \\
min- & min- & rock iated & ation \\
eral & eral & min- rock & min- & min- \\
eral min- & eral & eral \\
& & & & eral & & \\
\hline
\end{tabular}

Bismuth

$3 t$

$4 t$

$2 t$

$3 t$

Bismuthinite

$4 t$

$3 t$

$4 t$

$3 t$

$3 t$

$2 t$

$4 t$

$2 t$

Boehmite

$4 m$

\section{Bornite}

3

$3 t$

$3 t$

$3 t$

2

3

3

3

4

3

3

2

2

3

$3 t$

3

5

$3 t$

4

$2 t$

2

5

$2 t$

Brannerite

$4 t$

$4 t$

$4 t$

Bravoite

$2 t$

$2 t$

Brucite
W skarn (14a)

Sn-polymetallic veins (20b)

Kipushi $\mathrm{Cu}-\mathrm{Pb}-\mathrm{Zn}$ (32c)

low-sulfide Au-quartz veins (36a)

W veins (15a)

Sn veins (15b)

Sn greisen (15c)

$\mathrm{Cu}$ skarn (18b)

$\mathrm{Zn}-\mathrm{Pb}$ skarn $(18 \mathrm{c})$

polymetallic replacement (19a)

Sn-polymetallic veins (20b)

sedimentary exhalative $\mathrm{Zn}-\mathrm{Pb}$ (31a)

bauxite, karst type (38c)

Bornite may be a supergene, as well as hypogene, copper mineral.

Noril'sk Cu-Ni-PGE (5b)

Alaskan PGE (9)

W skarn (14a)

$W$ veins (15a)

porphyry $\mathrm{Cu}$ (17)

porphyry $\mathrm{Cu}$, skarn-related (18a)

Cu skarn (18b)

$\mathrm{Zn}-\mathrm{Pb}$ skarn (18c)

porphyry $\mathrm{Cu}-\mathrm{Au}(20 \mathrm{c})$

volcanic-hosted $\mathrm{Cu}-\mathrm{As}-\mathrm{Sb}$ (22a)

basaltic $\mathrm{Cu}$ (23)

Besshi massive sulfide (24b)

Creede epithermal vein (25b)

epithermal quartz-alunite $\mathrm{Au}$ (25e)

silica-carbonate $\mathrm{Hg}$ (27c)

kuroko massive sulfide (28a)

Olympic Dam Cu-U-Au (29b)

sandstone-hosted $\mathrm{Pb}-\mathrm{Zn}$ (30a)

sediment-hosted $\mathrm{Cu}(30 \mathrm{~b})$

sandstone $U(30 \mathrm{c})$

southeast Missouri $\mathrm{Pb}-\mathrm{Zn}$ (32a)

Kipushi $\mathrm{Cu}-\mathrm{Pb}-\mathrm{Zn}$ (32c)

gold on flat faults (37b)

volcanogenic U (25f)

quartz pebble conglomerate $\mathrm{Au}-\mathrm{U}$ (29a)

Olympic Dam Cu-U-Au (29b)

sandstone-hosted $\mathrm{Pb}-\mathrm{Zn}$ (30a)

southeast Missouri Pb-Zn (32a)

serpentine-hosted asbestos (8d) 
Appendix D. Mineralogical Index--Continued

\begin{tabular}{lllllll}
\hline Mineral & Ore & Gangue & Host & Assoc- Alter- Weath- Deposit type and model number \\
min- & min- & rock iated ation ering \\
eral & eral & min- rock min- min- \\
eral min- eral eral & eral
\end{tabular}

Buddingtonite

$$
3
$$

hot-spring Au-Ag (25a)

Calaverite

(see tellurides)

Carbonates

(see specific carbonates

below)

$\begin{array}{llll} & & & 5 m \\ & & & 5 m \\ 5 m & & 5 m & \\ & 5 m & & \\ & 5 m & & \\ & 5 m & & \\ & 5 m & & \\ & 5 m & & \\ & 5 m & & \\ 5 m & 5 m & & 5 \\ 4 & & & 3 \\ 4 & & & 3\end{array}$

4

5

$\begin{array}{lll}3 m & 3 m & 3 \\ 5 m & & 4\end{array}$

ankerite

3

$3 m \quad 3 m$

calcite
Carbonates are very common gangue and host-rock minerals in a wide variety of ores.

Limassol Forest Co-Ni (8c)

carbonatite (10)

W skarn (14a)

Sn Skarn (14b)

replacement Sn (14c)

porphyry $\mathrm{Cu}$, skarn-related (18a)

Cu skarn (18b)

$\mathrm{Zn}-\mathrm{Pb}$ skarn $(18 \mathrm{c})$

Fe skarn (18d)

polymetallic replacement (19a)

replacement Mn (19b)

$\mathrm{Au}-\mathrm{Ag}-\mathrm{Te}$ veins (22b)

polymetallic veins $(22 \mathrm{c})$

basaltic $\mathrm{Cu}$ (23)

Besshi massive sulfide (24b)

volcanogenic Mn (24c)

Creede epithermal vein (25b)

Comstock epithermal vein (25c)

Sado epithermal vein (25d)

epithermal Mn (25g)

carbonate-hosted Au (26a)

volcanic-hosted magnetite (25i)

silica-carbonate $\mathrm{Hg}$ (27c)

Olympic Dam Cu-U-Au (29b)

Kipushi $\mathrm{Cu}-\mathrm{Pb}-\mathrm{Zn}$ (32c)

carbonatite (10)

polymetallic veins (22c)

low-sulfide Au-quartz veins (36a)

Homestake Au (36b)

carbonatite (10)

Sn greisen (15c)

porphyry $\mathrm{Cu}$ (17)

replacement Mn (19b)

$\mathrm{Au}-\mathrm{Ag}-\mathrm{Te}$ veins (22b)

polymetallic veins (22c)

basaltic $\mathrm{Cu}$ (23)

Cyprus massive sulfide (24a)

Creede epithermal vein (25b)

Comstock epithermal vein (25c)

Sado epithermal vein (25d)

epithermal quartz-alunite $\mathrm{Au}$ (25e)

epithermal Mn (25g)

Almaden $\mathrm{Hg}(27 \mathrm{~b})$

simple Sb (27d) 
Appendix D. Mineralogical Index--Continued

\begin{tabular}{|c|c|c|c|c|c|c|c|}
\hline Mineral & $\begin{array}{l}\text { Ore } \\
\text { min- } \\
\text { eral }\end{array}$ & $\begin{array}{l}\text { Gangue } \\
\text { min- } \\
\text { eral }\end{array}$ & $\begin{array}{l}\text { Host } \\
\text { rock } \\
\text { min- } \\
\text { eral }\end{array}$ & $\begin{array}{l}\text { Assoc- } \\
\text { iated } \\
\text { rock } \\
\text { min- } \\
\text { eral }\end{array}$ & $\begin{array}{l}\text { Alter- } \\
\text { ation } \\
\text { min- } \\
\text { eral }\end{array}$ & $\begin{array}{l}\text { Weath- } \\
\text { ering } \\
\text { min- } \\
\text { eral }\end{array}$ & Deposit type and model number \\
\hline $\begin{array}{l}\text { calcite } \\
\text { (cont.) }\end{array}$ & & $\begin{array}{l}3 \\
4 \\
4 m \\
4 \\
4\end{array}$ & & & & & $\begin{array}{l}\text { emerald veins (31c) } \\
\text { sandstone-hosted } \mathrm{Pb}-\mathrm{Zn}(30 \mathrm{a}) \\
\text { phosphate, upwelling type (34c) } \\
\text { phosphate, warm-current type (34d) } \\
\text { unconformity U (38d) }\end{array}$ \\
\hline dolomite & & $\begin{array}{l}4 \mathrm{~m} \\
4 \\
4 \\
2 \\
\\
5 \\
5 \\
5 \mathrm{~m} \\
4 \\
4 \mathrm{~m} \\
4 \mathrm{~m} \\
4\end{array}$ & $\begin{array}{l}3 \\
3 m\end{array}$ & 5 & $\begin{array}{l}4 \mathrm{~m} \\
4 \\
5 \\
3 \\
5 \\
5 \mathrm{~m} \\
5 \mathrm{~m} \\
4 \mathrm{~m}\end{array}$ & & $\begin{array}{l}\text { carbonatite (10) } \\
\text { polymetallic replacement (19a) } \\
\text { replacement Mn (19b) } \\
\text { Au-Ag-Te veins (22b) } \\
\text { polymetallic veins (22c) } \\
\text { silica-carbonate Hg (27c) } \\
\text { sedimentary exhalative } \mathrm{Zn-Pb} \mathrm{(31a)} \\
\text { emerald veins (31c) } \\
\text { southeast Missouri Pb-Zn (32a) } \\
\text { Appalachian Zn (32b) } \\
\text { Kipushi Cu-Pb-Zn (32c) } \\
\text { Superior Fe ( } 34 \mathrm{a}) \\
\text { phosphate, upwelling type (34c) } \\
\text { phosphate, warm-current type (34d) } \\
\text { unconformity U (37b) }\end{array}$ \\
\hline rhodochr & $\begin{array}{l}5 m \\
4 m \\
5 m \\
3 m\end{array}$ & $\begin{array}{l}2 \\
3 \\
3 \\
3 \\
3 \\
\\
4 \\
3 \\
3\end{array}$ & & & 3 & & $\begin{array}{l}\text { carbonatite (10) } \\
\text { Climax Mo (16) } \\
\text { Zn-Pb skarn (18c) } \\
\text { polymetallic replacement (19a) } \\
\text { replacement Mn (19b) } \\
\text { polymetallic veins (22c) } \\
\text { volcanogenic Mn (24c) } \\
\text { Creede epithermal vein (25b) } \\
\text { Comstock epithermal vein (25c) } \\
\text { Sado epithermal vein (25d) } \\
\text { epithermal Mn (25g) } \\
\text { sedimentary Mn (34b) }\end{array}$ \\
\hline siderite & $3 m$ & $\begin{array}{l}3 \\
3 \\
3 \\
2 t \\
3 \\
3 \\
3 \\
3\end{array}$ & $3 m$ & $3 m$ & $\begin{array}{l}4 m \\
3\end{array}$ & & $\begin{array}{l}\text { replacement Sn (14c) } \\
\text { Sn-polymetallic veins (20b) } \\
\text { carbonatite (10) } \\
\text { polymetallic veins (22c) } \\
\text { Creede epithermal vein (25b) } \\
\text { simple Sb (27d) } \\
\text { Algoma Fe (28b) } \\
\text { Kipushi Cu-Pb-Zn (32c) } \\
\text { Superior Fe ( } 34 a) \\
\text { phosphate, upwelling type (34c) } \\
\text { low-sulfide Au-quartz veins (36a) } \\
\text { Homestake Au (36b) } \\
\text { unconformity U (37a) }\end{array}$ \\
\hline Carnotit & & & & & & $\begin{array}{l}5 \\
3 t\end{array}$ & $\begin{array}{l}\text { sandstone } \mathrm{U}(30 \mathrm{c}) \\
\text { phosphate, upwelling type }(34 \mathrm{c})\end{array}$ \\
\hline
\end{tabular}


Appendix D. Mineralogical Index--Continued

\begin{tabular}{lllllll}
\hline Mineral & Ore & Gangue & Host & Assoc- Alter- & Weath- Deposit type and model number \\
& min- & min- & rock iated ation ering & \\
& eral & eral & min- rock min- min- \\
& & & eral min- eral eral & eral \\
\end{tabular}

Carrollite $3 t$ $3 t$

$3 t$

$4 t$

Cassiterite

$3 t$
5
5
$4 t$
5
5
$3 t$
$1 t$
5
5
5
$1 t$

\section{Celestite}

Chalcedony

(includes opal)

$$
\begin{aligned}
& 4 \\
& 5 \\
& 3 \\
& 5 \\
& 5 m \\
& 5 m \\
& 4 m \\
& 4 m \\
& 3 \\
& 4 m \\
& 5 \\
& 5 \\
& 5
\end{aligned}
$$

Limassol Forest $\mathrm{Co}-\mathrm{Ni}(8 \mathrm{c})$

Olympic Dam Cu-U-Au (29b)

sediment-hosted $\mathrm{Cu}(30 \mathrm{~b})$

Kipushi $\mathrm{Cu}-\mathrm{Pb}-\mathrm{Zn}$ (32c)

W skarn (14a)

Sn skarn (14b)

replacement Sn (14c)

$W$ veins (15a)

$\mathrm{Sn}$ veins $(15 b)$

Sn greisen (15c)

Climax Mo (16)

Fe skarn (18d)

porphyry $\mathrm{Sn}$ (20a)

Sn-polymetallic veins (20b)

rhyolite-hosted Sn (25h)

sedimentary exhalative $\mathrm{Zn}-\mathrm{Pb}$ (31a)

$\mathrm{Au}-\mathrm{Ag}-\mathrm{Te}$ veins (22b)

replacement $M n$ (19b)

volcanic-hosted $\mathrm{Cu}-\mathrm{As}-\mathrm{Sb}$ (22a)

polymetallic veins (22c)

Cyprus massive sulfide (24a)

hot-spring $\mathrm{Au}-\mathrm{Ag}$ (25a)

Creede epithermal vein (25b)

Comstock epithermal vein (25c)

Sado epithermal vein (25d)

epithermal quartz-alunite $\mathrm{Au}$ (25e)

volcanogenic U (25f)

epithermal Mn (25g)

rhyolite-hosted $\mathrm{Sn}$ (25h)

hot-spring $\mathrm{Hg}$ (27a)

4

silica-carbonate $\mathrm{Hg}$ (27c)

simple Sb (27d)

Chalcocite

and related

$\mathrm{Cu}_{\mathrm{x}} \mathrm{s}$

phases

5 Chalcocite and related $\mathrm{Cu}_{\mathrm{x}} \mathrm{S}$ minerals are extremely common as supergene alterations of copper-bearing sulfides and as supergene replacements of chalcopyrite and, to a lesser extent, other primary sulfides. volcanic-hosted $\mathrm{Cu}-\mathrm{As}-\mathrm{Sb}(22 \mathrm{a})$ basaltic $\mathrm{Cu}$ (23) volcanic-hosted magnetite (25i) simple $\mathrm{Sb}$ (27d)

Olympic Dam Cu-U-Au (29b) 
Appendix D. Mineralogical Index--Continued

\begin{tabular}{lllllll}
\hline Mineral & Ore & Gangue & Host & Assoc- Alter- Weath- Deposit type and model number \\
min- & min- & rock iated ation ering \\
eral & eral & min- rock min- min- & eral min- eral eral \\
& & & eral & & &
\end{tabular}
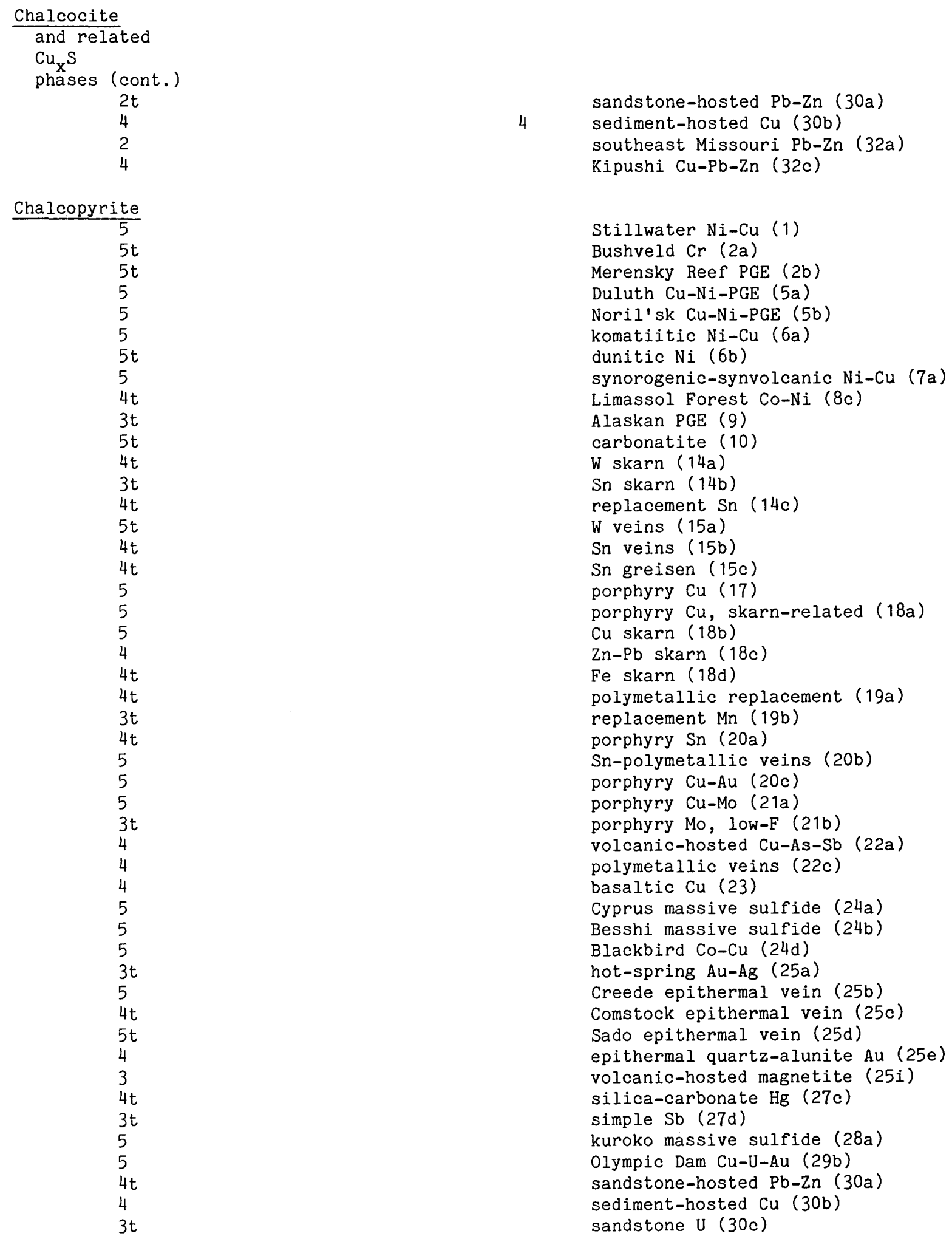
Appendix D. Mineralogical Index--Continued

\begin{tabular}{lllllll}
\hline Mineral & Ore & Gangue & Host Assoc- Alter- Weath- Deposit type and model number \\
& min- & min- & rock iated ation ering & \\
& eral & eral & min- rock min- min- & \\
& & & eral min- eral eral & \\
& & & eral
\end{tabular}

Chalcopyrite (cont.)

$4 t$

$4 t$

4

$4 t$

$3 t$

$4 t$

$4 t$ sedimentary exhalative $\mathrm{Zn}-\mathrm{Pb}$ (31a)

southeast Missouri $\mathrm{Pb}-\mathrm{Zn}$ (32a)

Kipushi $\mathrm{Cu}-\mathrm{Pb}-\mathrm{Zn}$ (32c)

low-sulfide Au-quartz veins (36a)

Homestake Au (36b)

unconformity $U$ (37a)

gold on flat faults (37b)

Chert

$\begin{array}{lll} & & 4 m \\ & & 4 m \\ & 4 m & 1 m \\ 4 m & 5 m & 5 m \\ 5 m & 4 m & 4 m \\ & 5 m & \\ & 5 m & 5 m\end{array}$

Cyprus massive sulfide (24a)

volcanogenic $\mathrm{Mn}$ (24c)

kuroko massive sulfide (28a)

Algoma $\mathrm{Fe}$ (28b)

sedimentary exhalative $\mathrm{Zn}-\mathrm{Pb}$ (31a)

Superior $\mathrm{Fe}$ (34a)

Homestake Au (36b)

Chlorite

3

2

3

$4 \mathrm{~m}$

$4 \mathrm{~m}$

$3 m$

4

3

4

4

3

4

3

5

4

3

3

3

3

3
4
5

4

4

3

$5 \mathrm{~m}$

$5 \mathrm{~m}$

Chromite

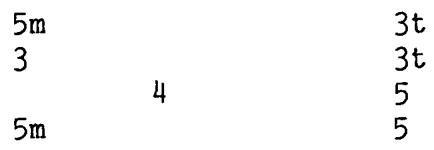

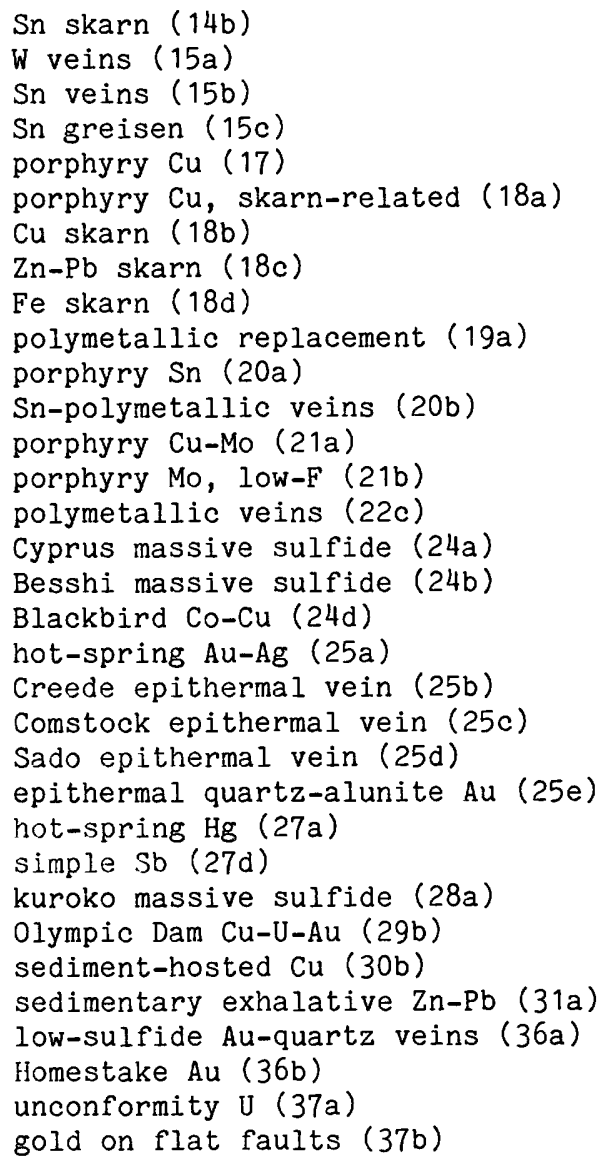


Appendix D. Mineralogical Index--Continued

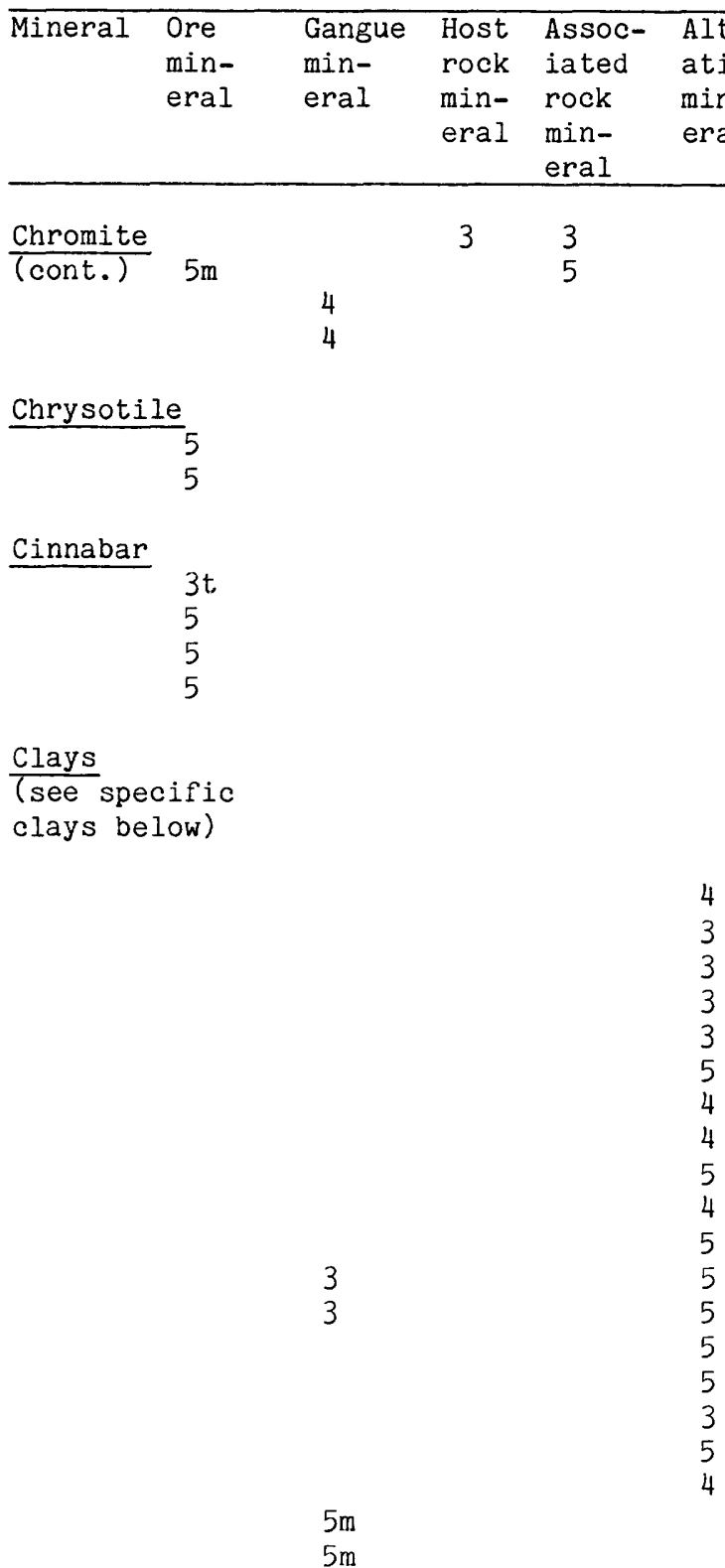

ammonium-

bearing

epithermal quartz-alunite $\mathrm{Au}(25 \mathrm{e})$ carbonate-hosted Au (26a) sedimentary exhalative $\mathrm{Zn}-\mathrm{Pb}$ (31a)

illite

Cyprus massive sulfide (24a) Creede epithermal vein (25b) Comstock epithermal vein (25c) carbonate-hosted Au (26a)

kaolinite and dickite

$5 \mathrm{~m} \quad$ Kaolinite is commonly formed through the reaction of sulfuric acid derived from oxidizing sulfides with felsic rocks. 
Appendix D. Mineralogical Index--Continued

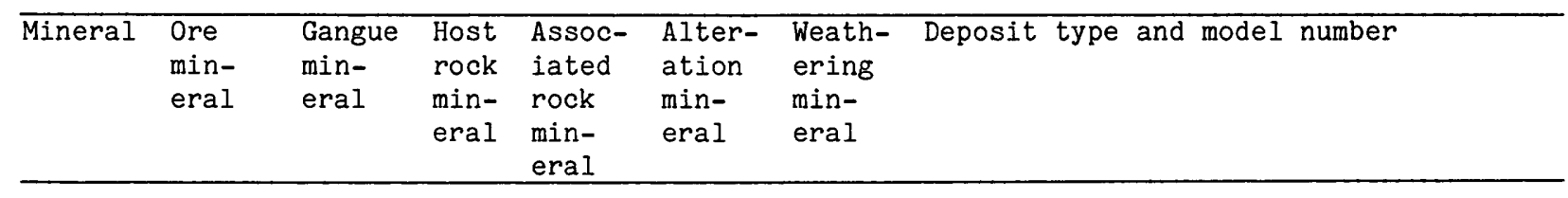

kaolinite and dickite (cont.)

ontmorillonite

(smectite)

sericite
4 porphyry $\mathrm{Cu}(17)$

porphyry $\mathrm{Cu}-\mathrm{Au}(20 \mathrm{c})$

porphyry Cu-Mo (21a)

volcanic-hosted $\mathrm{Cu}-\mathrm{As}-\mathrm{Sb}(22 \mathrm{a})$

Comstock epithermal vein (25c)

Sado epithermal vein (25d)

epithermal quartz-alunite $\mathrm{Au}$ (25e)

volcanogenic $U(25 f)$

epithermal Mn (25g)

rhyolite-hosted $\mathrm{Sn}$ (25h)

volcanic-hosted magnetite (25i)

carbonate-hosted $\mathrm{Au}$ (32a)

hot-spring $\mathrm{Hg}$ (27a)

southeast Missouri Pb-Zn (32a)

unconformity $U$ (37a)

Creede epithermal vein (25b)

Comstock epithermal vein (25c)

Sado epithermal vein (25d)

epithermal quartz-alunite $\mathrm{Au}$ (25e)

volcanogenic $U$ (25f)

rhyolite-hosted $\mathrm{Sn}(25 \mathrm{~h})$

carbonate-hosted $\mathrm{Au}$ (26a)

kuroko massive sulfide (28a)

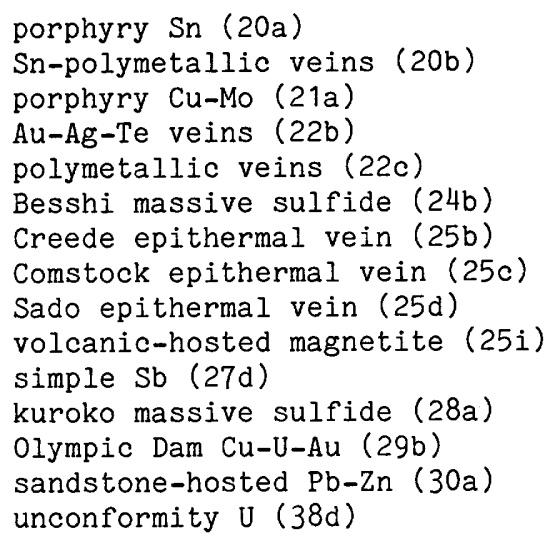

Stillwater $\mathrm{Ni}-\mathrm{Cu}$ (1)

dunitic $\mathrm{Ni}$ (6b)

Limassol Forest Co-Ni (8c)

Cu skarn (18b)

Fe skarn (18d)

Besshi massive sulfide (24b) 
Appendix D. Mineralogical Index--Continued

\begin{tabular}{lllllll}
\hline Mineral & Ore & Gangue & Host Assoc- Alter- Weath- Deposit type and model number \\
& min- & min- & rock iated ation ering & \\
& eral & eral & min- rock min- min- & min \\
& & & eral min- eral eral & eral \\
\hline
\end{tabular}

$\frac{\text { Co-bearing }}{\frac{\text { arsenides }}{\text { sulfides }}}$,
$\frac{\text { and sulf }}{\text { arsenides }}$
5
$4 t$
3
$2 t$
$2 t$
$4 t$

\section{Coffinite}

$5 t$

$4 t$

$5 t$

$4 t$

Copper (native)

4

$3 t$

Cordierite

Covellite

Cubanite

4
4
2
$3 t$
$3 t$

Diamond

$5 t t$

5 tt

Diaspore

2

2
Blackbird Co-Cu (24d)

Olympic Dam Cu-U-Au (29b)

sediment-hosted $\mathrm{Cu}$ (30b)

sedimentary exhalative $\mathrm{Zn}-\mathrm{Pb}$ (31a)

southeast Missouri $\mathrm{Pb}-\mathrm{Zn}$ (32a)

Kipushi $\mathrm{Cu}-\mathrm{Pb}-\mathrm{Zn}$ (32c)

volcanogenic U (25f)

Olympic Dam Cu-U-Au (29b)

sandstone $U$ (30c)

unconformity $U$ (38d)

Native copper is a common mineral in oxidized copper ores; it also occurs as a trace deuteric mineral in some mafic rocks.

basaltic $\mathrm{Cu}$ (23)

sediment-hosted $\mathrm{Cu}(30 \mathrm{~b})$

kuroko massive sulfide (28a)

porphyry $\mathrm{Cu}$ (17)

epithermal quartz-alunite Au (25e)

Covellite is a very common supergene mineral in oxidized copper ores. volcanic-hosted $\mathrm{Cu}-\mathrm{As}-\mathrm{Sb}$ (22a) epithermal quartz-alunite $\mathrm{Au}$ (25e) volcanic-hosted magnetite (25i) southeast Missouri $\mathrm{Pb}-\mathrm{Zn}$ (32a)

Duluth Cu-Ni-PGE (5a)

Noril'sk Cu-Ni-PGE (5b)

dunitic $\mathrm{Ni}$ (6b)

Cyprus massive sulfide (24a)

Besshi massive sulfide (24b)

diamond pipes (12)

diamond placers (39d)

porphyry $\mathrm{Cu}$ (17)

volcanic-hosted Cu-As-Sb (22a)

epithermal quartz-alunite $\mathrm{Au}$ (25e)

Diopside (see pyroxenes) 
Appendix D. Mineralogical Index--Continued

\begin{tabular}{lllllll}
\hline Mineral & Ore & Gangue & Host & Assoc- Alter- Weath- Deposit type and model number \\
& min- & min- & rock iated ation ering & \\
& eral & eral & min- rock min- min- & eral min- eral eral \\
& & & eral & & \\
& & & & &
\end{tabular}

\section{Dumortierite}

volcanic-hosted $\mathrm{Cu}-\mathrm{As}-\mathrm{Sb}(22 \mathrm{a})$

\section{Enargite-}

luzonite

$$
\begin{aligned}
& 2 t \\
& 2 t \\
& 3 \\
& 5 \\
& 5 \\
& 1 t \\
& 1 t \\
& 2
\end{aligned}
$$

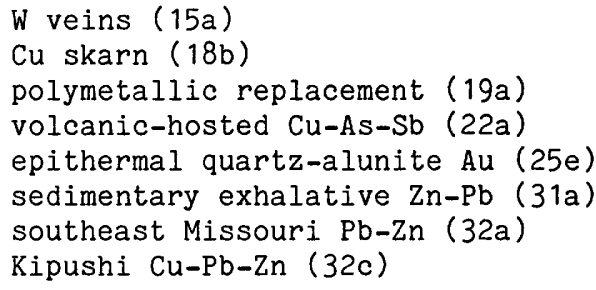

Epidote

$\begin{array}{ll}3 t & 3 \\ 4 & 3 \\ 4 & 4 \\ 4 & 4\end{array}$

porphyry $\mathrm{Cu}(17)$

Cu skarn (18b)

Fe skarn (18d)

basaltic $\mathrm{Cu}$ (23)

volcanic-hosted magnetite (25i)

Ferrimolybdite

4t Ferrimolybdite is a common oxidation product in Mo-bearing ores.

Fletcherite (see sulfospinels)

Fluorite

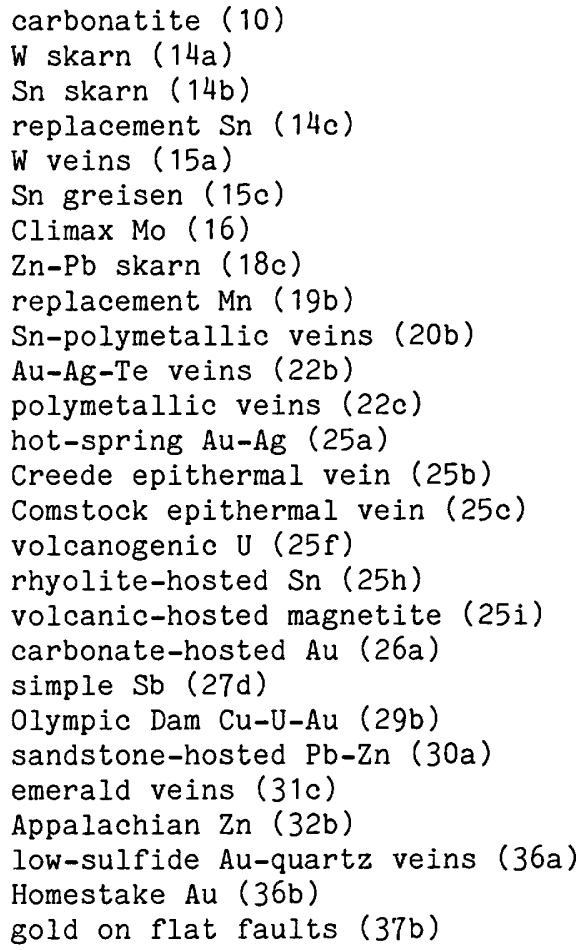


Appendix D. Mineralogical Index--Continued

\begin{tabular}{lllllll}
\hline Mineral & Ore & Gangue & Host & Assoc- Alter- Weath- Deposit type and model number \\
min- & min- & rock iated ation ering & \\
& eral & eral & min- rock min- min- \\
& & & eral min- eral eral \\
& & & eral
\end{tabular}

Ga minerals

$2 t$

Kipushi $\mathrm{Cu}-\mathrm{Pb}-\mathrm{Zn}(32 \mathrm{c})$

Gahnite

kuroko massive sulfide (28a)

Galena

$3 t$
2
$2 t$
$3 t$
$3 t$
$2 t$
$3 t$
5
4
$2 t$
$4 t$
2
4
4
$3 t$
5
4
$4 t$
$4 t$
$4 t$
$2 t$
4
5
$2 t$
$2 t$
5
$3 t$
5
$2 t$
3
$4 t$
$4 t$

$4 t$

Garnet

almandine

carbonatite (10)

replacement $\mathrm{Sn}$ (14c)

$W$ veins (15a)

Sn veins (15b)

Sn greisen (15c)

porphyry $\mathrm{Cu}$, skarn-related (18a)

Cu skarn (18b)

$\mathrm{Zn}-\mathrm{Pb}$ skarn (18c)

polymetallic replacement (19a)

replacement Mn (19b)

Sn-polymetallic veins (20b)

porphyry Cu-Mo (21a)

$\mathrm{Au}-\mathrm{Ag}-\mathrm{Te}$ veins (22b)

polymetallic veins (22c)

Besshi massive sulfide (24b)

Creede epithermal vein (25b)

Comstock epithermal vein (25c)

Sado epithermal vein (25d)

epithermal quartz-alunite $\mathrm{Au}$ (25e)

silica-carbonate $\mathrm{Hg}$ (27c)

simple Sb (27d)

kuroko massive sulfide (28a)

sandstone-hosted $\mathrm{Pb}-\mathrm{Zn}$ (30a)

sediment-hosted $\mathrm{Cu}(30 \mathrm{~b})$

sandstone $U(30 c)$

sedimentary exhalative $\mathrm{Zn}-\mathrm{Pb}$ (31a)

bedded barite (31b)

southeast Missouri $\mathrm{Pb}-\mathrm{Zn}$ (32a)

Appalachian $\mathrm{Zn} \mathrm{(32b)}$

Kipushi $\mathrm{Cu}-\mathrm{Pb}-\mathrm{Zn}$ (32c)

low-sulfide Au-quartz veins (36a)

unconformity U-Au (37a)

Garnet is a common mineral in most skarns, in some regionally metamorphosed rocks, and in some igneous rocks.

andradite

$4 m$
$4 m$

4

(Sn-bearing)

and.-gros.-spess.
W skarn (14a)

W skarn (14a)

Cu skarn (18b)

volcanic-hosted magnetite (25i)

Sn skarn (14b)

$\mathrm{Zn}-\mathrm{Pb}$ skarn $(18 \mathrm{c})$ 
Appendix D. Mineralogical Index--Continued

\begin{tabular}{lllllll}
\hline Mineral & Ore & Gangue & Host & Assoc- Alter- Weath- Deposit type and model number \\
min- & min- & rock iated ation ering & \\
& eral & eral & min- rock min- min- \\
& & & eral min- eral eral & \\
& & & eral
\end{tabular}

Garnet (cont.) grossularandradite $3 m$

$5 m$
3
4
5

pyrope

spessartine

\section{3}

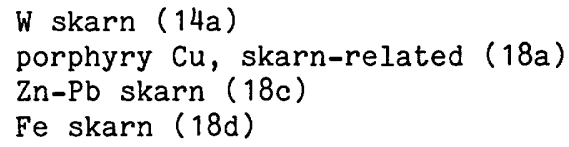

Climax Mo $(16)$

$\mathrm{Zn}-\mathrm{Pb}$ skarn (18c)

W skarn (14a)

volcanogenic Mn (24c)

podiform $\mathrm{Cr}(8 \mathrm{a})$

5 lateritic $\mathrm{Ni}$ (38a)

Ge minerals

$\underline{\text { Gold }}$

$3 t$
$4 t$
$2 t$
$4 t$
$5 t$
$4 t$
$4 t$
$5 t$
$4 t$
$5 t$
$4 t$
$5 t$
$5 t$
$5 t$
$3 t$
$5 t$
$3 t$
$4 t$
$5 t$
$4 t$
$5 t$
$5 t$

sediment-hosted $\mathrm{Cu}(30 \mathrm{~b})$

Kipushi $\mathrm{Cu}-\mathrm{Pb}-\mathrm{Zn}$ (32c)

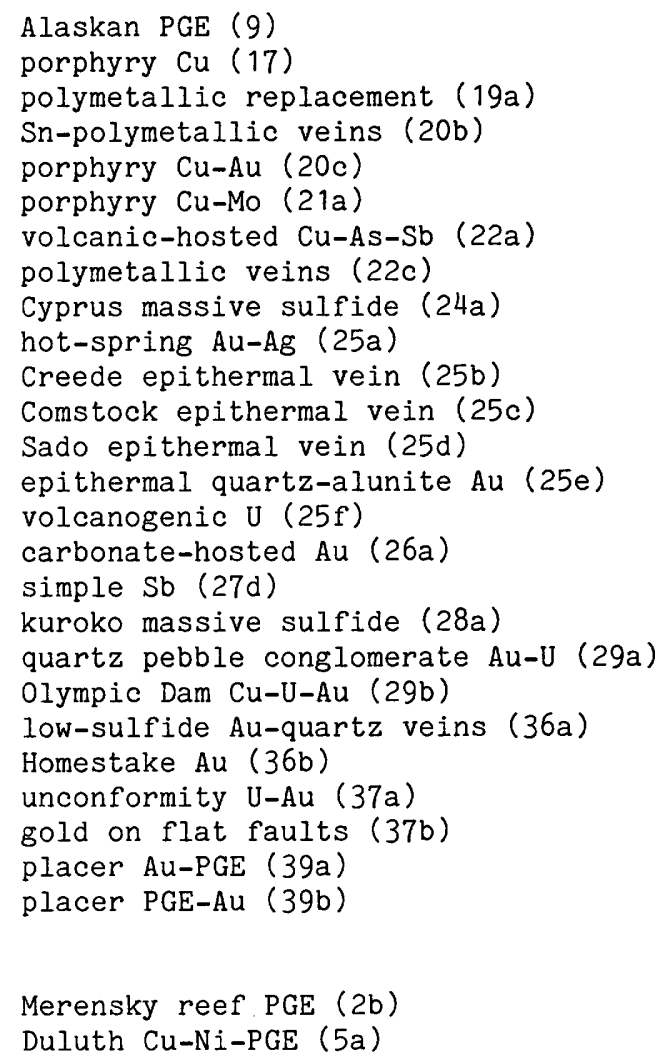


Appendix D. Mineralogical Index--Continued

\begin{tabular}{lllllll}
\hline Mineral & Ore & Gangue & Host & Assoc- Alter- Weath- Deposit type and model number \\
min- & min- & rock iated ation ering & \\
& eral & eral & min- rock min- min- \\
eral min- eral eral & eral
\end{tabular}

Graphite (cont.)

3

2

Greenockite

$2 t$

\section{Gypsum}

$2 t$

3

22

Halite

Hematite

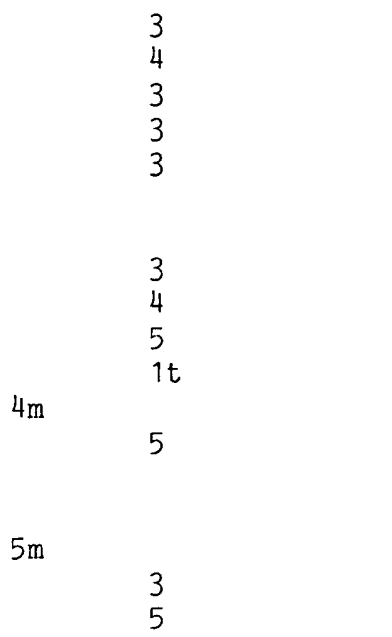

3

3

3

2

3

4

5

3

Hematite/Goethite synorogenic-synvolcanic $\mathrm{Ni}-\mathrm{Cu}$ (7a)

simple Sb (27d)

kuroko massive sulfide (28a)

4t Greenockite is a common trace mineral developed in the early stages of oxidation of cadmium-bearing sphalerite. Greenockite is rare as a primary mineral. sediment-hosted $\mathrm{Cu}(30 \mathrm{~b})$

Appalachian $\mathrm{Zn}$ (32b) phosphate, upwelling type (34c) kuroko massive sulfide (28a)

Halite occurs as a daughter mineral in fluid inclusions from many porphyry copper and molybdenum deposits and from a few other deposits.

5 Hematite is a common weathering product of iron minerals.

Carbonatite (10)

Sn veins (15b)

porphyry $\mathrm{Cu}$, skarn-related (18a)

Cu skarn (18b)

polymetallic veins (22c)

basaltic $\mathrm{Cu}$ (23)

volcanogenic $\mathrm{Mn}$ (24c)

Creede epithermal vein (25b)

Comstock epithermal vein (25c)

rhyolite-hosted Sn (25h)

kuroko massive sulfide (28a)

$5 \mathrm{~m} \quad$ Algoma $\mathrm{Fe} \mathrm{(28b)}$

Olympic Dam Cu-U-Au (29b)

sediment-hosted $\mathrm{Cu}(30 \mathrm{~b})$

sandstone U (30c)

$5 \mathrm{~m}$ Superior $\mathrm{Fe}$ (34a)

unconformity U (37a)

gold on flat faults (37b)

4 Hematite and goethite are common weathering products of iron-bearing sulfides. They are often grouped under the blanket term "limonite." carbonate-hosted $\mathrm{Au}$ (26a)

hot-spring $\mathrm{Hg}$ (27a)

phosphate, upwelling type (34c)

Cyprus massive sulfide (24a) 
Appendix D. Mineralogical Index--Continued

\begin{tabular}{lllllll}
\hline Mineral & Ore & Gangue & Host & Assoc- Alter- Weath- Deposit type and model number \\
& min- & min- & rock iated ation ering & \\
& eral & eral & min- rock min- min- & \\
& & & eral min- eral eral & \\
& & & & eral
\end{tabular}

Idocrase

Illite (see clays)

Ilmenite

$\begin{array}{llll} & 3 & & 4 \\ 5 m & 4 & & 5 \\ & & & \\ & 3 & 5 & \\ & 4 & & \\ & 4 & & \\ & 4 & & \end{array}$

Ilvaite

3

Jarosite

Jasperoid

(includes

silicification in

carbonate rocks)
Sn skarn (14b)

porphyry $\mathrm{Cu}$, skarn-related (18a)
Ilmenite is a common accessory mineral in igneous and metamorphic rocks. Bushveld $\mathrm{Cr}$ (2a)

Bushveld Fe-Ti-V (3)

anorthosite-Ti (7b)

diamond pipes (12)

replacement $\mathrm{Sn}(14 \mathrm{c})$

placer Au-PGE (39a)

placer PGE-Au (39b)

shoreline placer $\mathrm{Ti}$ (39c)

diamond placers (39d)

$\mathrm{Zn}-\mathrm{Pb}$ skarn $(18 \mathrm{c})$

Fe skarn (18d)

Jarosite is a common product of the supergene oxidation of iron sulfides. carbonate-hosted $\mathrm{Au}$ ( $26 \mathrm{a})$

Jasperoid here refers to massive silica replacement of pre-existing (usually carbonate) rock. polymetallic replacement (19a) polymetallic veins (22c) hot-spring $\mathrm{Au}-\mathrm{Ag}$ (25a) silica-carbonate $\mathrm{Hg}$ (27c) carbonate-hosted Au (26a) sedimentary exhalative $\mathrm{Zn}-\mathrm{Pb}$ (31a) southeast Missouri $\mathrm{Pb}-\mathrm{Zn}$ (32a) Appalachian $\mathrm{Zn}$ (32b) Kipushi $\mathrm{Cu}-\mathrm{Pb}-\mathrm{Zn}$ (32c)

Kaolinite (see clays)

$\underline{\mathrm{K}-\mathrm{feldspar}}$

(also see

adularia)

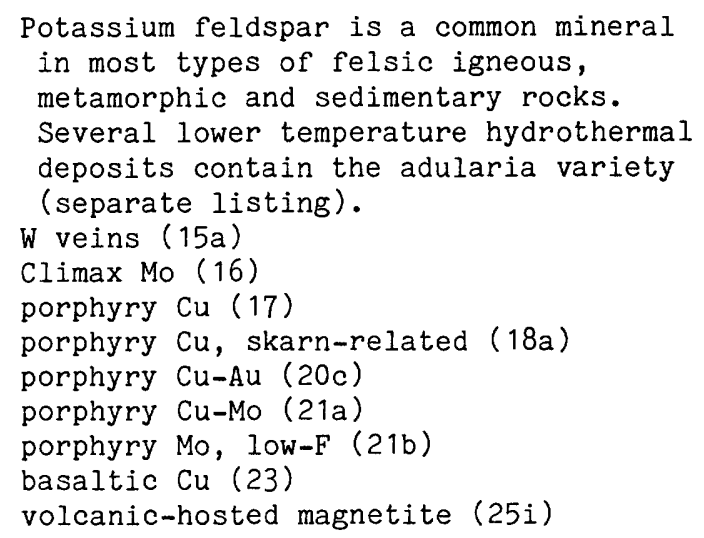


Appendix D. Mineralogical Index--Continued

\begin{tabular}{llllllll}
\hline Mineral & Ore & Gangue & Host & Assoc- Alter- Weath- Deposit type and model number \\
& min- & min- & rock iated ation ering & \\
& eral & eral & min- rock min- min- & \\
& & & eral min- eral eral & eral
\end{tabular}

Leucoxene

3

Linneaite

(also see sulfospinels)

$$
\begin{aligned}
& 2 t \\
& 3 t \\
& 3 t
\end{aligned}
$$

Luzonite (see enargite-luzonite)

\section{Magnetite}

2

3

4

2

$5 m \quad \begin{array}{lll}2 t \\ 4\end{array} \quad 4 \quad 4$

Ti-rich

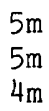

V-rich

$5 m$
$4 m$

Malayaite volcanogenic U (25f)

dunitic $\mathrm{Ni}(6 \mathrm{~b})$

sandstone-hosted $\mathrm{Pb}-\mathrm{Zn}$ (30a)

Kipushi $\mathrm{Cu}-\mathrm{Pb}-\mathrm{Zn}$ (32c)

Magnetite is a common accessory mineral in many types of rocks.

Bushveld $\mathrm{Cr}(2 \mathrm{a})$

Bushveld $\mathrm{Fe}-\mathrm{Ti}-\mathrm{V}$ (3)

dunitic $\mathrm{Ni}(6 \mathrm{~b})$

synorogenic-synvolcanic $\mathrm{Ni}-\mathrm{Cu}$ (7a)

anorthosite-Ti (7b)

podiform $\mathrm{Cr}$ (8a)

Limassol Forest Co-Ni (8c)

serpentine-hosted asbestos (8d)

Alaskan PGE (9)

carbonatite (10)

w skarn (14a)

Sn skarn (14b)

replacement Sn (14c)

porphyry $\mathrm{Cu}$ (17)

porphyry $\mathrm{Cu}$, skarn-related (18a)

Cu skarn (18b)

$\mathrm{Zn}-\mathrm{Pb}$ skarn $(18 \mathrm{c})$

Fe skarn (18d)

Sn-polymetallic veins (20b)

porphyry Cu-Au (20c)

Besshi massive sulfide (24b)

Blackbird Co-Cu (24d)

volcanic-hosted magnetite (25i)

kuroko massive sulfide (28a)

Algoma $\mathrm{Fe}$ (28b)

Olympic Dam Cu-U-Au (29b)

southeast Missouri $\mathrm{Pb}-\mathrm{Zn}$ (32a)

Superior $\mathrm{Fe}$ (34a)

Homestake Au (36b)

placer Au-PGE (39a)

placer PGE-Au (39b)

Bushveld Fe-Ti-V (3)

anorthosite $\mathrm{Ti}$ (7b)

Alaskan PGE (9)

Bushveld Fe-Ti-V (3)

Alaskan PGE (9)

2

Sn skarn (14b) 
Appendix D. Mineralogical Index--Continued

\begin{tabular}{llllllll}
\hline Mineral & Ore & Gangue & Host & Assoc- Alter- Weath- Deposit type and model number \\
& min- & min- & rock iated ation ering & \\
& eral & eral & min- rock min- min- & \\
& & & eral min- eral eral & eral \\
\hline
\end{tabular}

Marcasite

4 Marcasite is common as an incipient

stage in the oxidation of pyrrhotite. polymetallic replacement (19a)

Cyprus massive sulfide (24a)

hot-spring $\mathrm{Hg}(27 \mathrm{a})$

simple $\mathrm{Sb}$ (27d)

sandstone-hosted $\mathrm{Pb}-\mathrm{Zn}$ (30a)

sandstone $U(30 \mathrm{c})$

sedimentary exhalative $\mathrm{Zn}-\mathrm{Pb}$ (31a)

southeast Missouri $\mathrm{Pb}-\mathrm{Zn}$ (32a)

Appalachian $\mathrm{Zn} \mathrm{(32b)}$

Kipushi $\mathrm{Cu}-\mathrm{Pb}-\mathrm{Zn}(32 \mathrm{c})$

Melnikovite

sedimentary exhalative $\mathrm{Zn}-\mathrm{Pb}$ (31a)

Mercury

(native)

hot-spring $\mathrm{Hg}$ (27a)

Almaden $\mathrm{Hg}$ (27b)

silica-carbonate $\mathrm{Hg}$ (27c)

Millerite

Noril'sk Cu-Ni-PGE (5b)

sandstone-hosted $\mathrm{Pb}-\mathrm{Zn}$ (30a)

sedimentary exhalative $\mathrm{Zn}-\mathrm{Pb}$ (31a)

southeast Missouri $\mathrm{Pb}-\mathrm{Zn}$ (32a)

Mn oxides

and silicates

$5 m$

$5 m$

$4 \mathrm{~m}$

Molybdenite $5 m$
These are common oxidation products of manganese-bearing ores. replacement Mn (19b) Cyprus massive sulfide (24a) volcanogenic $\mathrm{Mn}$ (24c) sedimentary Mn (34b)

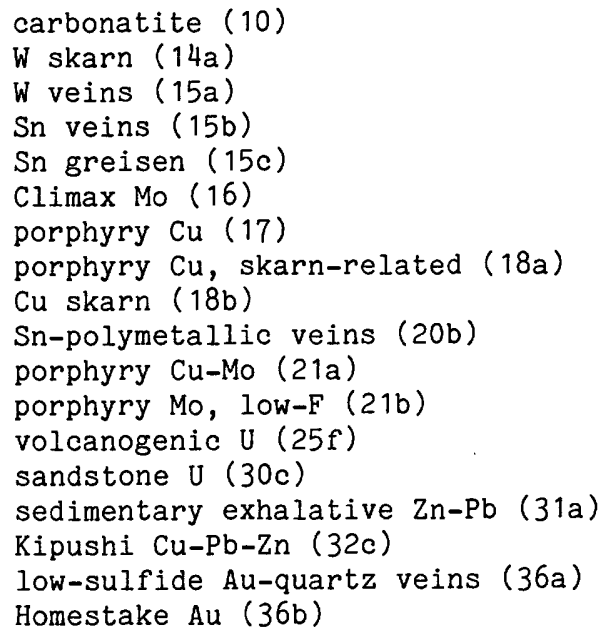


Appendix D. Mineralogical Index--Continued

\begin{tabular}{lllllll}
\hline Mineral & Ore & Gangue & Host & Assoc- Alter- Weath- Deposit type and model number \\
min- & min- & rock iated ation ering & \\
eral & eral & min- rock min- min- \\
eral min- eral eral & eral \\
& & & & & \\
\hline
\end{tabular}

\section{Muscovite}

$\begin{array}{lll}4 m & 5 & 5 m \\ 4 & 4 & 4 \\ 3 & & 5 m \\ 4 m & & 5 m \\ 2 & & 5 m \\ & & 4 m \\ 2 m & & 3 m \\ & & 4 \\ & & 3\end{array}$

Cr-rich

V-rich

$\underline{\mathrm{Ni} \text { silicates }}$

$\mathrm{Ni}$ sulfides, arsenides, and sulfarsenides

(see also

pentlandite)

5
5
$3 t$
$4 t$
$3 t$

Niobium $\frac{\text { minerals }}{4}$

Olivine

Organic matter
Muscovite is a common mineral in igneous and metamorphic rocks. It also occurs as in some felsic skarns, in veins, and as the fine-grained, wallrock alteration known as sericite (see clays). Sn skarn (14b) replacement $\mathrm{Sn}(14 \mathrm{c})$

$W$ veins (15a)

Sn veins (15b)

Sn greisen (15c)

Climax Mo (16) porphyry $\mathrm{Cu}$ (17) porphyry $\mathrm{Cu}$, skarn-related (18a) southeast Missouri $\mathrm{Pb}-\mathrm{Zn}$ (32a)

low-sulfide Au-quartz veins (36a) Homestake Au (36b)

$\mathrm{Au}-\mathrm{Ag}-\mathrm{Te}$ veins (22b)

sandstone $U$ (30c)

5

lateritic Ni (38a)

dunitic $\mathrm{Ni}(6 \mathrm{~b})$

Limassol Forest $\mathrm{Co}-\mathrm{Ni}$ (8c)

sandstone-hosted $\mathrm{Pb}-\mathrm{Zn}(30 \mathrm{a})$

southeast Missouri $\mathrm{Pb}-\mathrm{Zn}$ (32a)

unconformity $U$ ( $37 \mathrm{a})$

carbonatite (10)

Olivine is a common mineral in mafic igneous rocks (including those associated with models 1 through 12).

Organic matter is found in many sedimentary and a few metamorphic rocks. The ore types noted here are those for which some relationship is probable.

carbonate-hosted Au (26a)

silica-carbonate $\mathrm{Hg}$ (27c)

kuroko massive sulfide (28a)

quartz pebble conglomerate Au-U (29a) 
Appendix D. Mineralogical Index--Continued

\begin{tabular}{llllllll}
\hline Mineral & Ore & Gangue & Host & Assoc- Alter- Weath- Deposit type and model number \\
min- & min- & rock iated ation ering & \\
eral & eral & min- rock min- min- & mal min- eral eral \\
& & & eral & eral
\end{tabular}

Organic matter

$\begin{array}{lll}4 t & 4 t & \\ & 4 & \\ & 5 & \\ & 4 & 4 \\ 3 & 2 & \\ 4 t & 4 & \\ 2 t & & \end{array}$

sandstone-hosted $\mathrm{Pb}-\mathrm{Zn}$ (30a)

sediment-hosted $\mathrm{Cu}(30 \mathrm{~b})$

sandstone $U(30 c)$

sedimentary exhalative $\mathrm{Zn}-\mathrm{Pb}$ (31a)

southeast Missouri $\mathrm{Pb}-\mathrm{Zn}$ (32a)

Kipushi $\mathrm{Cu}-\mathrm{Pb}-\mathrm{Zn}$ (32c)

unconformity U-Au (37a)

Orpiment

3

volcanogenic U (25f)

carbonate-hosted $\mathrm{Au}$ (26a)

\begin{tabular}{r} 
Pentlandite \\
\hline 5 \\
$4 t$ \\
$5 t$ \\
5 \\
5 \\
5 \\
5 \\
5 \\
3 \\
$2 t$
\end{tabular}

Stillwater $\mathrm{Ni}-\mathrm{Cu}$ (1)

Bushveld $\mathrm{Cr}$ (2a)

Merensky Reef PGE (2b)

Duluth Cu-Ni-PGE (5a)

Noril'sk Cu-Ni-PGE (5b)

komatiitic $\mathrm{Ni}-\mathrm{Cu}$ (6a)

dunitic $\mathrm{Ni}$ (6b)

synorogenic-synvolcanic $\mathrm{Ni}-\mathrm{Cu}$ (7a)

Limassol Forest $\mathrm{Co}-\mathrm{Ni}$ ( $8 \mathrm{c}$ )

Alaskan PGE (9)

PGE minerals

$5 t$

Stillwater $\mathrm{Ni}-\mathrm{Cu}$ (1)

Bushveld $\mathrm{Cr}$ (2a)

Merensky Reef PGE (2b)

Duluth Cu-Ni-PGE (5a)

Noril'sk Cu-Ni-PGE (5b)

komatiitic $\mathrm{Ni}-\mathrm{Cu}$ (6a)

podiform $\mathrm{Cr}$ (8a)

Alaskan PGE (9)

quartz pebble conglomerate Au-U (29a)

placer Au-PGE (39a)

placer PGE-Au (39b)

Phlogopite

\section{5}

4

Phosphates

$1 \mathrm{~m}$
$5 \mathrm{~m}$
$5 \mathrm{~m}$

5

$4 m$

1

5

Plagioclase

(also see

albite) carbonatite (10)

diamond pipes (12)

diamond placers (39d)

carbonatite (10)

$5 \mathrm{~m}$ phosphate, upwelling type (34c)

$5 \mathrm{~m}$ phosphate, warm-current type (34d) 
Appendix D. Mineralogical Index--Continued

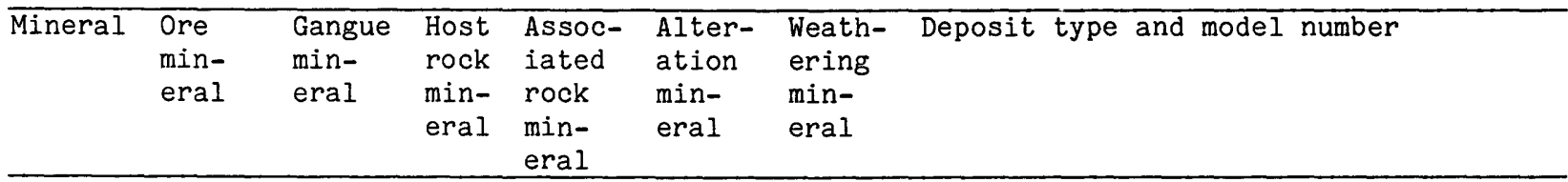

\section{Pyrite}

Pyrite is a very common and abundant mineral in many ore deposits and as the product of sulfidic alteration of Fe-bearing wallrocks. Duluth Cu-Ni-PGE (5a)

Noril'sk Cu-Ni-PGE (5b)

komatiitic $\mathrm{Ni}-\mathrm{Cu}$ ( $6 \mathrm{a})$

dunitic $\mathrm{Ni}$ (6b)

synorogenic-synvolcanic $\mathrm{Ni}-\mathrm{Cu}$ (7a)

Limassol Forest $\mathrm{CO}-\mathrm{Ni}$ (8c)

4 carbonatite (10)

W skarn (14a)

Sn skarn (14b)

replacement Sn (14c)

$W$ veins (15a)

Sn veins (15b)

Sn greisen (15c)

Climax Mo (16)

porphyry $\mathrm{Cu}(17)$

porphyry $\mathrm{Cu}$, skarn-related (18a)

Cu skarn (18b)

$\mathrm{Zn}-\mathrm{Pb}$ skarn (18c)

Fe skarn (18d)

polymetallic replacement (19a)

replacement $\mathrm{Mn}$ (19b)

porphyry $\mathrm{Sn}(20 \mathrm{a})$

Sn-polymetallic veins (20b)

porphyry $\mathrm{Cu}-\mathrm{Au}$ (20c)

porphyry Cu-Mo (21a)

porphyry Mo, low $-\mathrm{F}$ (21b)

volcanic-hosted $\mathrm{Cu}-\mathrm{As}-\mathrm{Sb}$ (22a)

$\mathrm{Au}-\mathrm{Ag}-\mathrm{Te}$ veins (22b)

polymetallic veins (22c)

basaltic $\mathrm{Cu}$ (23)

Cyprus massive sulfide (24a)

Besshi massive sulfide (24b)

Blackbird Co-Cu (24d)

hot-spring Au-Ag (25a)

Creede epithermal vein (25b)

Comstock epithermal vein (25c)

Sado epithermal vein (25d)

epithermal quartz-alunite $\mathrm{Au}$ (25e)

volcanogenic $U(25 f)$

volcanic-hosted magnetite (25i)

carbonate-hosted $\mathrm{Au}$ (26a)

hot-spring $\mathrm{Hg}$ (27a)

silica-carbonate $\mathrm{Hg}$ (27c)

simple Sb (27d)

kuroko massive sulfide (28a)

quartz pebble conglomerate Au-U (29a)

sandstone-hosted $\mathrm{Pb}-\mathrm{Zn}$ (30a)

sediment-hosted $\mathrm{Cu}(30 \mathrm{~b})$

sandstone $U(30 \mathrm{c})$

sedimentary exhalative $\mathrm{Zn}-\mathrm{Pb}$ (31a)

bedded barite (31b)

emerald veins (31c)

southeast Missouri $\mathrm{Pb}-\mathrm{Zn}$ (32a) 
Appendix D. Mineralogical Index--Continued

\begin{tabular}{lllllll}
\hline Mineral & Ore & Gangue & Host & Assoc- Alter- Weath- Deposit type and model number \\
& min- & min- & rock iated ation ering & \\
& eral & eral & min- rock min- min- & \\
& & & eral min- eral eral & \\
& & & eral
\end{tabular}

Pyrite (cont.)

4
5
$4 t$
5
5
3

Pyrophylite

Pyroxene

4

2

$$
\begin{aligned}
& 5 \\
& 5 \\
& 5 m
\end{aligned}
$$

diopside

$4 m$

$$
\begin{aligned}
& 5 m \\
& 3 \\
& 4 m \\
& 5 m \\
& 4
\end{aligned}
$$

hedenbergite

$$
4 m
$$

Mn-rich

Pyrrhotite

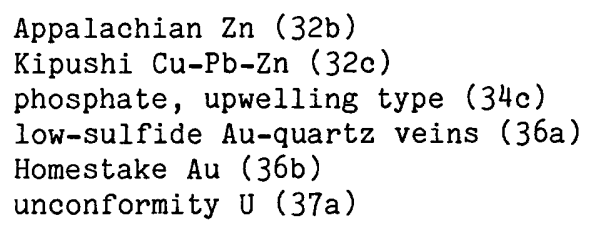

Pyroxene is a common rock-forming mineral in mafic igneous rocks and in metamorphic rocks associated with some deposit types 1 through 10. carbonatite (10)

Cu skarn (18b)

$\mathrm{Zn}-\mathrm{Pb}$ skarn (18c)

Fe skarn (18d)

shoreline placer $\mathrm{Ti}$ (39c)

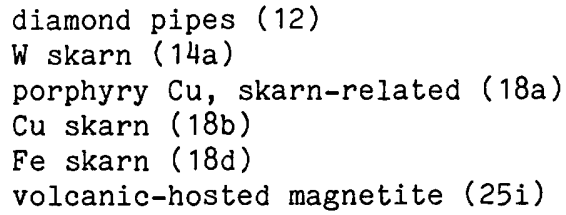

W skarn $(14 a)$

Fe skarn (18d)

$\mathrm{Zn}-\mathrm{Pb}$ skarn $(18 \mathrm{c})$

$\mathrm{Zn}-\mathrm{Pb}$ skarn $(18 \mathrm{c})$

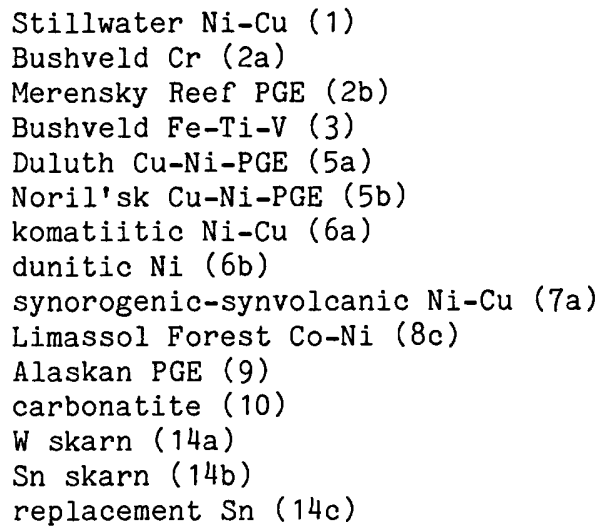


Appendix D. Mineralogical Index--Continued

\begin{tabular}{lllllll}
\hline Mineral & Ore & Gangue & Host & Assoc- Alter- & Weath- Deposit type and model number \\
& min- & min- & rock iated ation ering & \\
& eral & eral & min- rock min- min- & eral min- eral eral \\
& & & eral & & \\
\hline
\end{tabular}

Pyrrhotite (cont.)

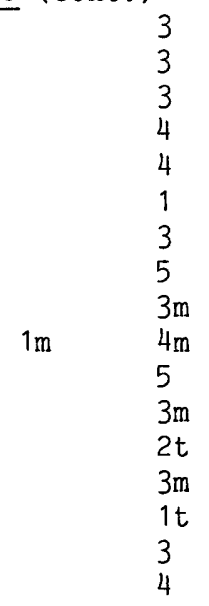

Quartz

Rare earth-

bearing

minerals

$\begin{array}{lll}4 & & 3 t \\ 5 t & 2 t & \\ 3 & 5 t & \end{array}$

$\underline{\text { Realgar }}$

4
$3 t$
5
$1 t$

Rhodonite

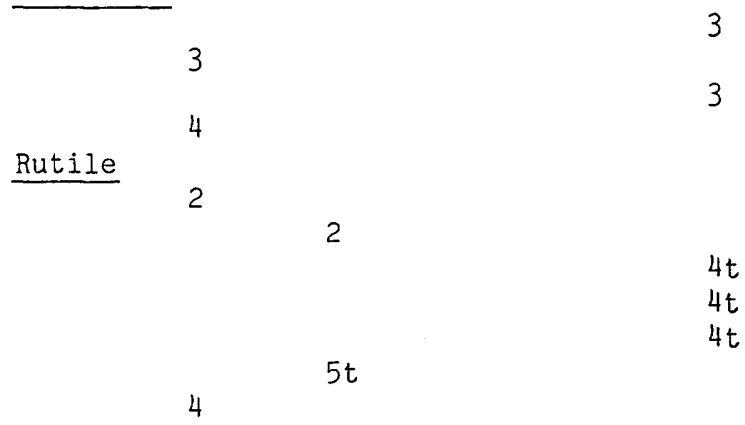

Scapolite

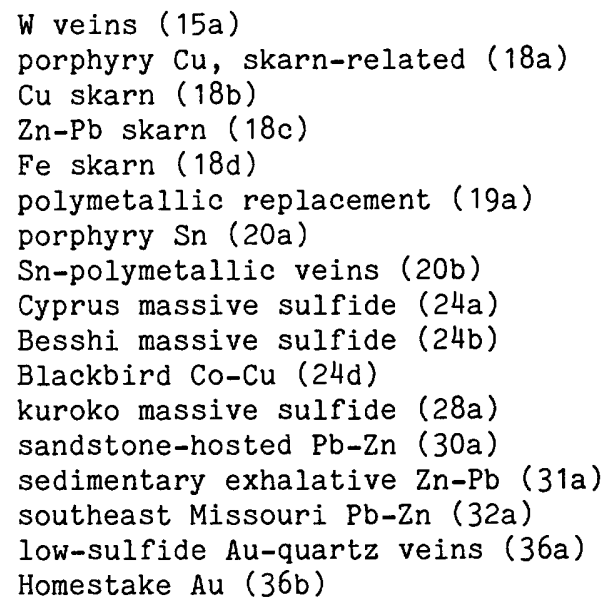

Quartz is almost universal in hydrothermal ores and a common and abundant constituent of most rocks.

carbonatite (10)

$W$ veins (15a)

volcanogenic $U(25 f)$

Olympic Dam Cu-U-Au (29b)

emerald veins (31c)

shoreline placer $\mathrm{Ti}$ (39c)

hot-spring Au-Ag (25a)

volcanogenic $U$ (25f)

carbonate-hosted $\mathrm{Au}(26 \mathrm{a})$

Homestake Au (36b)

Climax Mo (16)

replacement Mn (19b)

$\mathrm{Zn}-\mathrm{Pb}$ skarn $(18 \mathrm{c})$

volcanogenic Mn (24c)

anorthosite $\mathrm{Ti}(7 \mathrm{~b})$

carbonatite (10)

porphyry $\mathrm{Cu}$ (17)

porphyry Cu-Mo (21a)

Olympic Dam Cu-U-Au (29b)

emerald veins (31c)

shoreline placer Ti (39c) 
Appendix D. Mineralogical Index--Continued

\begin{tabular}{lllllll}
\hline Mineral & Ore & Gangue & Host & Assoc- Alter- Weath- Deposit type and model number \\
min- & min- & rock iated ation ering & \\
eral & eral & min- rock min- min- \\
eral min- eral eral & eral
\end{tabular}

Scheelite

$$
\begin{aligned}
& 5 \\
& 4 t \\
& 4 t \\
& 3 t \\
& 2 t \\
& 2 t \\
& 3 t \\
& 4 t \\
& 3 t \\
& 3 t \\
& 3 t
\end{aligned}
$$

Selenides

$$
\begin{aligned}
& 2 t \\
& 3 t \\
& 2 t
\end{aligned}
$$

\section{Serpentine}

$4 m \quad 4 m$

Silver (native)

$$
\begin{aligned}
& 4 t \\
& 2 t \\
& 4 t \\
& 4 t
\end{aligned}
$$

\section{3}

$5 m$

$\begin{array}{ll}5 \mathrm{~m} & 5 \mathrm{~m} \\ 5 \mathrm{~m} & 2\end{array}$

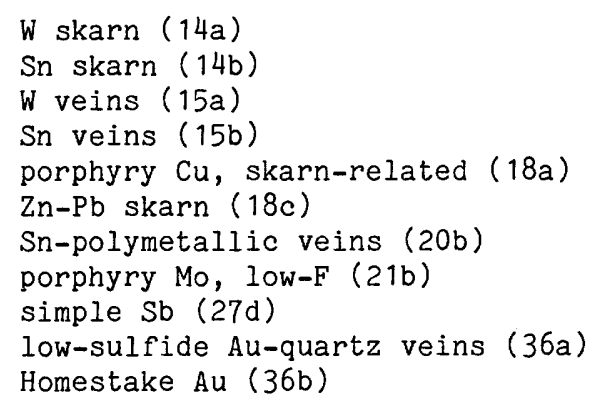

Serpentine minerals are the common products of the low-temperature metamorphism of ultramafic and mafic rocks.

serpentine-hosted asbestos (8d) carbonatite (10)

diamond pipes (12)

carbonate-hosted asbestos (18e)

silica-carbonate $\mathrm{Hg}$ (27c)

simple Sb (27d)

Native silver is a common weathering product of silver-bearing sulfide ores.

basaltic $\mathrm{Cu}$ (23)

3t Creede epithermal vein (25b)

Olympic Dam Cu-U-Au (29b)

sediment-hosted $\mathrm{Cu}(30 \mathrm{~b})$

4t Argentite and a wide variety of silver sulfosalts are common products of the oxidation and supergene enrichment of silver-bearing sulfide ores.

porphyry Cu-Mo (21a)

porphyry Mo, low-F (21b)

polymetallic veins (22c)

Creede epithermal vein (25b)

Comstock epithermal vein (25c)

Sado epithermal vein (25d)

epithermal quartz-alunite $\mathrm{Au}$ (25e)

simple $\mathrm{Sb}$ (27d)

kuroko massive sulfide (28a)

sandstone-hosted $\mathrm{Pb}-\mathrm{Zn}$ (30a)

sedimentary exhalative $\mathrm{Zn}-\mathrm{Pb}$ (31a) 
Appendix D. Mineralogical Index--Continued

\begin{tabular}{lllllll}
\hline Mineral & Ore & Gangue & Host & Assoc- Alter- Weath- Deposit type and model number \\
min- & min- & rock iated ation ering & \\
eral & eral & min- rock min- min- & mal min- eral eral \\
& & & eral & & \\
\hline
\end{tabular}

Spessartite see Garnet

Sphalerite $4 t$ carbonatite (10)

W skarn (14a)

Sn skarn (14b)

replacement $\mathrm{Sn}(14 \mathrm{c})$

$W$ veins (15a)

Sn veins (15b)

$\mathrm{Sn}$ greisen (15c)

porphyry Cu, skarn-related (18a)

Cu skarn (18b)

$\mathrm{Zn}-\mathrm{Pb}$ skarn (18c)

polymetallic replacement (19a)

replacement $\mathrm{Mn}$ (19b)

porphyry $\mathrm{Sn}$ (20a)

Sn-polymetallic veins (20b)

porphyry Cu-Mo (21a)

volcanic-hosted Cu-As-Sb (22a)

$\mathrm{Au}-\mathrm{Ag}-\mathrm{Te}$ veins (22b)

polymetallic veins (22c)

basaltic $\mathrm{Cu}$ (23)

Cyprus massive sulfide (24a)

Besshi massive sulfide (24b)

hot-spring Au-Ag (25a)

Creede epithermal vein (25b)

Comstock epithermal vein (25c)

Sado epithermal vein (25d)

epithermal quartz-alunite $\mathrm{Au}$ (25e)

silica-carbonate $\mathrm{Hg}$ (27c)

simple $\mathrm{Sb}$ (27d)

kuroko massive sulfide (28a)

sandstone-hosted $\mathrm{Pb}-\mathrm{Zn}(30 \mathrm{a})$

sediment-hosted $\mathrm{Cu}$ (30b)

sandstone $U$ (30c)

sedimentary exhalative $\mathrm{Zn}-\mathrm{Pb}$ (31a)

bedded barite (31b)

southeast Missouri Pb-Zn (32a)

Appalachian $\mathrm{Zn}$ (32b)

Kipushi $\mathrm{Cu}-\mathrm{Pb}-\mathrm{Zn}$ (32c)

Homestake $\mathrm{Au}$ (36b)

unconformity U-Au (37a)

Sphene

3

$5 t$

$2 t$

$\underline{\text { Spinel }}$

4

Stannite

$3 t$

$4 t$

$2 t$

$4 t$

$4 t$ carbonatite $(10)$

porphyry $\mathrm{Cu}(17)$

volcanic-hosted magnetite (25i)

carbonatite (10)

replacement $\mathrm{Sn}(14 \mathrm{c})$

Sn veins (15b)

$\mathrm{Zn}-\mathrm{Pb}$ skarn (18c)

porphyry $\mathrm{Sn}(20 \mathrm{a})$

Sn polymetallic veins (20b) 
Appendix D. Mineralogical Index--Continued

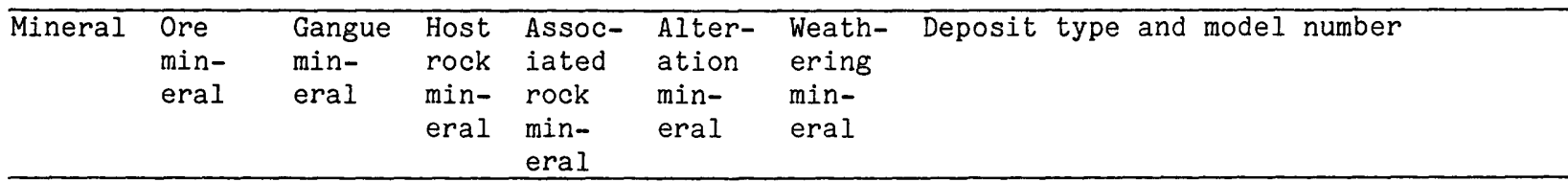

Stibnite 3

$3 t$

$2 t$

$3 t$

$4 t$

5

$2 t$

Strontianite

3

Sulfosalts
$\mathrm{Au}-\mathrm{Ag}-\mathrm{Te}$ veins (22b)

hot-spring Au-Ag (25a)

Creede epithermal vein (25b)

carbonate-hosted Au (26a)

silica-carbonate $\mathrm{Hg}$ (27c)

simple Sb (27d)

Homestake Au (36b)

carbonatite (10)

The term "sulfosalts" is here used to represent all of the minerals that combine silver or base metal sulfides with As- Sb- or Bi-sulfides; enargite-luzonite and tetrahedritetennantite fall within this broad usage, but the $\mathrm{Fe}$, $\mathrm{Co}$ and $\mathrm{Ni}$ sulfarsenides and sulfantimonides do not.

replacement $\mathrm{Sn}(14 \mathrm{c})$

$W$ veins (15a)

Sn greisen (15c)

porphyry $\mathrm{Cu}$, skarn-related (18a)

Cu skarn (18b)

polymetallic replacement (19a)

Sn-polymetallic veins (20b)

porphyry Cu-Mo (21a)

porphyry Mo, low-F (21b)

volcanic-hosted $\mathrm{Cu}-\mathrm{As}-\mathrm{Sb}$ (22a)

$\mathrm{Au}-\mathrm{Ag}-\mathrm{Te}$ veins (22b)

polymetallic veins (22c)

Besshi massive sulfide (24b)

Creede epithermal vein (25b)

Comstock epithermal vein (25c)

Sado epithermal vein (25d)

epithermal quartz-alunite $\mathrm{Au}$ (25e)

simple $\mathrm{Sb}$ (27d)

kuroko massive sulfide (28a)

sandstone-hosted $\mathrm{Pb}-\mathrm{Zn}$ (30a)

sedimentary exhalative $\mathrm{Zn}-\mathrm{Pb}$ (31a)

southeast Missouri $\mathrm{Pb}-\mathrm{Zn}$ (32a)

Kipushi $\mathrm{Cu}-\mathrm{Pb}-\mathrm{Zn}$ (32c)

Homestake $\mathrm{Au}$ (36b)

unconformity $\mathrm{U}$ (37a)

dunitic $\mathrm{Ni}(6 \mathrm{~b})$

Olympic Dam Cu-U-Au (29b)

sandstone-hosted $\mathrm{Pb}-\mathrm{Zn}$ (30a)

sediment-hosted $\mathrm{Cu}$ (30b)

southeast Missouri $\mathrm{Pb}-\mathrm{Zn}$ (32a)

Kipushi $\mathrm{Cu}-\mathrm{Pb}-\mathrm{Zn}$ (32c) 
Appendix D. Mineralogical Index--Continued

\begin{tabular}{lllllll}
\hline Mineral & Ore & Gangue & Host & Assoc- Alter- Weath- Deposit type and model number \\
min- & min- & rock iated ation ering \\
eral & eral & min- rock min- min- \\
eral min- eral eral & eral
\end{tabular}

Sulfur (native)

$\begin{array}{llll} & 2 t & \begin{array}{l}\text { Native sulfur is sometimes found as } \\ \text { an intermediate stage in the oxida- } \\ \text { tion of sulfide ores. } \\ \text { epithermal quartz-alunite Au (25e) } \\ \text { hot-spring Hg (27a) }\end{array}\end{array}$

Sylvanite (see tellurides)

Talc

serpentine-hosted asbestos (8d)

$\frac{\text { Tantalum }}{\text { minerals }}$
$3 t$
$5 t$
$3 t$
$3 t$
$3 t$
$4 t$
$2 t$
$3 t$
$2 t$
$2 t$
$2 t$
$5 t$
$4 t$
$3 t$
$4 t$
$3 t$
$2 t$

Tennantitetetrahedrite

$3 t$
$3 t$
$3 t$
$4 t$
4
$3 t$
$4 t$
4
4
4
$3 t$
$5 t$
$4 t$
$3 t$
$4 t$
$3 t$
$3 t$
$2 t$
5
$3 t$

replacement $\mathrm{Sn}(14 \mathrm{c})$

$W$ veins (15a)

porphyry $\mathrm{Cu}$, skarn-related (18a)

Cu skarn (18b)

polymetallic replacement (19a)

porphyry Cu-Mo (21a)

porphyry Mo, low $-F$ (21b)

volcanic-hosted $\mathrm{Cu}-\mathrm{As}-\mathrm{Sb}$ (22a)

$\mathrm{Au}-\mathrm{Ag}-\mathrm{Te}$ veins (22b)

polymetallic veins (22c)

Besshi massive sulfide (24b)

Creede epithermal vein (25b)

Sado epithermal vein (25d)

simple $\mathrm{Sb}$ (27d)

kuroko massive sulfide (28a)

sandstone-hosted $\mathrm{Pb}-\mathrm{Zn}$ (30a)

sedimentary exhalative $\mathrm{Zn}-\mathrm{Pb}$ (31a)

southeast Missouri $\mathrm{Pb}-\mathrm{Zn}$ (32a)

Kipushi $\mathrm{Cu}-\mathrm{Pb}-\mathrm{Zn}(32 \mathrm{c})$

Homestake $\mathrm{Au}$ (36b) 
Appendix D. Mineralogical Index--Continued

\begin{tabular}{lllllll}
\hline Mineral & Ore & Gangue & Host & Assoc- Alter- & Weath- Deposit type and model number \\
& min- & min- & rock iated ation ering & in \\
eral & eral & min- rock & min- min- \\
& & & eral min- eral eral & eral \\
\hline
\end{tabular}

Topaz

4
3
2
3

\section{Tourmaline}

3

$$
3
$$

3
4
$4 \mathrm{~m}$
2
3
3
3
2

$\frac{\text { Tungstenite }}{2}$

Ulvospinel 3

Uraninite crystaline $4 t$ $5 t$

pitchblende $5 t$ $5 t$ $5 t$

V-oxides $4 t$

Valleriite $3 t$ $2 t$ $2 t$

Vanadates

Witherite

$$
\begin{aligned}
& 4 \\
& 3 \\
& 3 \\
& 4 \\
& 4 m \\
& 2 \\
& 4 \\
& 4 \\
& 3 \\
& 5
\end{aligned}
$$$$
4 \mathrm{~m}
$$$$
2
$$$$
4
$$$$
3
$$

$\begin{array}{ll} & 3 \\ 3 & 3\end{array}$

$$
3
$$$$
4 \mathrm{~m}
$$$$
2
$$$$
3
$$$$
3
$$$$
3
$$

3

\author{
Sn skarn (14b) \\ replacement Sn (14c) \\ Sn veins (15b) \\ Sn greisen (15c) \\ Climax Mo (16)
}

Sn skarn (14b)

replacement $\mathrm{Sn}$ (14c)

$W$ veins (15a)

Sn veins (15b)

Sn greisen (15c)

porphyry $\mathrm{Cu}$ (17)

porphyry $\mathrm{Sn}$ (20a)

Sn-polymetallic veins (20b)

volcanic-hosted $\mathrm{Cu}-\mathrm{As}-\mathrm{Sb}$ (22a)

Besshi massive sulfide (24b)

Blackbird Co-Cu (24d)

volcanic-hosted magnetite (25i)

kuroko massive sulfide (28a)

Olympic Dam Cu-U-Au (29b)

sedimentary exhalative $\mathrm{Zn}-\mathrm{Pb}$ (31a)

Homestake Au (36b)

Kipushi $\mathrm{Cu}-\mathrm{Pb}-\mathrm{Zn}(32 \mathrm{c})$

anorthosite-Ti (7b)

quartz pebble conglomerate Au-U (29a) unconformity $U$ (37a)

volcanogenic U $(25 f)$

sandstone $U(30 c)$

unconformity $\mathrm{U}$ (37a)

$4 t$ sandstone $U(30 c)$

Noril'sk Cu-Ni-PGE (5b)

Besshi massive sulfide (24b)

sedimentary exhalative $\mathrm{Zn}-\mathrm{Pb}$ (31a)

4 sandstone U (30c)

bedded barite (31b) 
Appendix D. Mineralogical Index--Continued

\begin{tabular}{lllllll}
\hline Mineral & Ore & Gangue & Host & Assoc- Alter- Weath- Deposit type and model number \\
min- & min- & rock iated ation ering \\
eral & eral & min- rock min- min- \\
eral min- eral eral & eral
\end{tabular}

Wolframite $3 t$ 5 4 3 $3 t$ 4 $3 t$

Wollastonite

Zeolites

$$
\begin{aligned}
& 4 \\
& 5 \\
& 4
\end{aligned}
$$$$
3
$$$$
2
$$

$4 \mathrm{~m}$

4

4

4

4

Zinnwaldite

$$
2 t
$$

2

Zircon

$3 t$
$4 t \quad 3 t$

Zunyite

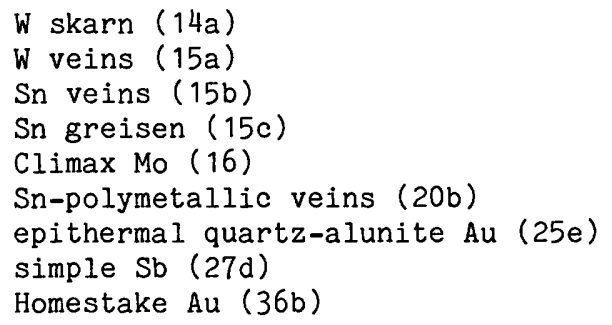

$W$ veins (15a)

anorthosite $\mathrm{Ti}$ (7b)

carbonatite (10)

shoreline placer $\mathrm{Ti}$ (39c) 
Appendix E. Index of Deposits

\begin{tabular}{|c|c|c|c|c|c|}
\hline Name & Country & Model No & Name & Country & Model No \\
\hline Aarja & OMAN & $24 a$ & Alaska & ZIMB & $30 b$ \\
\hline Abbott & USCA & $27 \mathrm{c}$ & Albert & CNQU & $28 a$ \\
\hline Abdasht & IRAN & $8 a$ & Albert Lea Group & USAZ & $22 c$ \\
\hline Aberfoyle & AUTS & $15 b$ & Albino & CNON & $36 \mathrm{~b}$ \\
\hline Abeshiro (Sakura) & JAPN & $28 a$ & Aldermac & CNQU & $28 a$ \\
\hline Abitibi & CNQU & $8 d$ & Aleksandrovskii Log & URRS & $39 b$ \\
\hline Abra Negra & MXCO & $25 g$ & Aleshinka & URRS & $18 \mathrm{~d}$ \\
\hline Abruzzi & ITLY & $38 c$ & Alex Hill-Mad Kiss & GUYN & $36 a$ \\
\hline Abu Tartur & EGPT & $34 c$ & Alexii-Olginsky Log & URRS & $39 b$ \\
\hline Abuhemsin (Abiulya) & TRKY & $24 c$ & Alice & USCA & $36 a$ \\
\hline Abundancia & TRKY & $24 c$ & Alice Louise & NCAL & $8 a$ \\
\hline Ace of Spades & USCA & $8 a$ & Alice Mine & USCA & $8 a$ \\
\hline Aceitillar & DMRP & $38 c$ & Allan (Johnson) & USCA & $8 a$ \\
\hline Achilles & NZLD & $36 a$ & Allard River & CNQU & $28 a$ \\
\hline Adaevka & URRS & $18 d$ & AIleghany & USCA & $36 a$ \\
\hline Adak-Lindskold & SWDN & $28 a$ & Alligator Ridge & USNV & $26 a$ \\
\hline Adana-Saimbeyli & TRKY & $38 c$ & Alma (Mills) Placer & USCO & $39 a$ \\
\hline Adanac (Ruby Creek) & CNBC & $21 b$ & Almaden & SPAN & $27 b$ \\
\hline Adelong Creek & AUNS & $39 a$ & Almagrera-Lapilla & SPAN & $28 a$ \\
\hline Adobe Canyon & USCA & $8 a$ & Almeirim & BRZL & $38 b$ \\
\hline Adventure Creek & AUQL & $15 \mathrm{~b}$ & Alpha & NCAL & $8 a$ \\
\hline Advocate & CNNF & $8 d$ & Alpine-Lafatsch & ASTR-I & \\
\hline Aetna & USCA & $27 c$ & & YUGO & $32 a, 32 b$ \\
\hline Affoh & GHNA & $38 \mathrm{~b}$ & Alta Hill & USCA & $8 a$ \\
\hline Afterthought & USCA & $28 a$ & Altamira-Frontera & VNZL & $34 a, 28 b$ \\
\hline Afton & $\mathrm{CNBC}$ & $20 c$ & Altenberg & GRME & $15 c$ \\
\hline Agalteca & HNDR & $18 d$ & Althouse & USOR & $8 a$ \\
\hline Agassiz & CNMN & $36 \mathrm{~b}$ & Altindag & TRKY & $8 a$ \\
\hline Agnes Waters & AUQL & $39 c$ & Alto & USCA & $36 a$ \\
\hline Agnew (Perseverance) & AUWA & $6 b$ & Altoona-Elkhor-Mercury & CNBC & $22 c$ \\
\hline Agnico Eagle & CNQU & $36 b$ & Alumen & MZMB & $38 \mathrm{~b}$ \\
\hline Agordo-Brosso & ITLY & $18 \mathrm{~b}$ & Alyce and Blue Jay & USCA & $8 a$ \\
\hline Agrokipia & CYPS & $24 a$ & $\mathrm{Am}$ & CNBC & 17 \\
\hline Aguilar & AGTN & $18 c$ & Amacan & PLPN & 17 \\
\hline Aijala & FNLD & $28 a$ & Amador City & USCA & $36 a$ \\
\hline Ain Mokra & ALGR & $18 d$ & Amapa & BRZL & $34 a, 28 b$ \\
\hline Ain Oudrer & ALGR & $18 \mathrm{~d}$ & Amax & CNMN & $6 \mathrm{~b}$ \\
\hline Ajax (Monte Carlo) & CNBC & 17 & Amazon & USMT & $22 c$ \\
\hline A jax & USOR & $8 a$ & Ambatory & MDGS & $38 a$ \\
\hline Ajax (Dak River) & CNBC & $21 b$ & Ambelikou & CYPS & $24 a$ \\
\hline A jo & USAZ & 17 & American Asbestos & USCA & $8 a$ \\
\hline Akarca & TRKY & $8 a$ & American Bar & USCA & $36 a$ \\
\hline Akarsen & TRKY & $28 a$ & American Fork & USUT & $19 a$ \\
\hline Akashat & IRAQ & $34 c$ & Amigos & MXCO & $25 h$ \\
\hline Akatani & JAPN & $18 d$ & Ammeberg & SWDN & $18 c$ \\
\hline Akcabuk & TRKY & $8 a$ & Amores & CUBA & $8 a$ \\
\hline Akcakilise Topkirazlar & TRKY & $24 c$ & Amphoe Phra Saeong & THLD & $27 d$ \\
\hline Akenobe & JAPN & $20 \mathrm{~b}$ & Ample & $\mathrm{CNBC}$ & $36 a$ \\
\hline Akeski & TRKY & $38 c$ & Amulet & CNQU & $28 a$ \\
\hline Akinokawa (Onishi) & JAPN & $24 b$ & An-shan & CINA & $34 a, 28 b$ \\
\hline Akkoy & TRKY & $28 a$ & Ana Yatak-Ergani & TRKY & $24 a$ \\
\hline Akkoya & TRKY & $8 a$ & Analavory & MDGS & $38 b$ \\
\hline Akoluuk & TRKY & $24 c$ & Ana lumay & MDGS & $38 a$ \\
\hline Akseki Gokceovacik & TRKY & $24 c$ & Anantagiri & INDA & $38 b$ \\
\hline Aktyubinsk & URRS & $34 c$ & Anayatak-Cakmakkaya & TRKY & $28 a$ \\
\hline Akulla Vastra & SWDN & $28 a$ & Anchor & AUTS & $15 c$ \\
\hline Akviran & TRKY & $34 b$ & Andacolla & CILE & 17 \\
\hline Al & AUVT & $36 a$ & Anderson Lake & CNMN & $28 a$ \\
\hline Al-Hasa/Oatrana & JRDN & $34 c$ & Andhra Pradesh & INDA & $34 \mathrm{~b}$ \\
\hline Alabama bauxite & USAL & $38 c$ & Andizlik & TRKY & $8 a$ \\
\hline Alabama Shoot & AUVT & $36 a$ & Anduramba & AUQL & $21 b$ \\
\hline A lagada & PORT & $18 d$ & Angelo & AUWA & $28 a$ \\
\hline
\end{tabular}




\begin{tabular}{|c|c|c|}
\hline Country & Model No & Name \\
\hline USCA & $36 a$ & Atlas \\
\hline URRS & $39 b$ & Auerbach \\
\hline USCO & $25 b$ & Augusto Luis \& others \\
\hline CNON & $36 b$ & Aurora \\
\hline $\mathrm{CNBC}$ & 17 & Aurora \\
\hline USNV & 17 & Aurukum \\
\hline NCAL & $8 a$ & Austin Brook \\
\hline NRWY & $28 a$ & Austinville \\
\hline MALI & $34 \mathrm{~b}$ & Aventura \\
\hline USCA & $8 a$ & Avispa \\
\hline USNV & $27 d$ & Avoca \\
\hline USUT & $27 d$ & Avsar \\
\hline USNV & $27 d$ & Awaso \\
\hline USNV & $27 d$ & Axe \\
\hline USMT & $27 d$ & Aya Aya \\
\hline USID & $27 d$ & Ayazmant \\
\hline
\end{tabular}

Angels-Carson

Anianowsky Lojok

Animas

Ankerite-Aunor-Delnite

Ann

Ann Mason

Anna Madeleine

Anne

Ansongo

Anti Axis

Antimonial

Antimony Canyon

Antimony King

Antimony Lode

Antimony Mines

Antimony Ridge

Antler

Antoine

Antonio

Apex (Del Norte Co.)

Apex (El Dorado Co.)

Apex Antimony

Apex Mines

Apliki

Applegate

Arad

Araluen Valley

Aravaipa

Araxa

Archer

Arctic

Arctic Chief

Argo

Argonaut

Arguilillas

Argus Hill

Arie

Arinteiro

Arkhangelskii Log

Arlington

Armour Group

Armstrong (A)

Arnold Hill

Arrieros

Arrowhead

Arroyo Durango

As Safra

Asafo

Asagi Zorkum

Asakawa

Asbestos $\mathrm{Hill}$

Asbestos Island

Asen

Ash Shizm

Ashio

Ashland

Ashley

Associated Chromite

Asvan

Atacocha

Atenguillo

Atlanta

Atlas

Atlas
USAZ

CNBC

CUBA

USCA

USCA

USNV

USUT

CYPS

USOR

ISRL

AUNS

USAZ

BRZL

AUTS

USAK

CNYT

USCA

CNBC

MXCO

AUVT

PPNG

SPAN

URRS

CNBC

USAZ

CNNB

USNY

MXCO

CNQU

MXCO

SAAR

GHNA

TRKY

JAPN

CNQU

CNQU

SWDN

SAAR

JAPN

USOR

CNON

USOR

TRKY

PERU

MXCO

USNV

PLPN

USAZ
$28 \mathrm{a}$

$22 \mathrm{c}$

$24 \mathrm{c}$

$8 \mathrm{a}$

$8 \mathrm{a}$

$27 d$

$32 \mathrm{c}$

$24 a$

$8 \mathrm{a}$

$34 \mathrm{c}$

$39 a$

$18 \mathrm{c}$

10

$15 \mathrm{c}$

$28 \mathrm{a}$

$18 \mathrm{~b}$

$36 a$

$18 \mathrm{~d}$

$25 \mathrm{~h}$

$36 \mathrm{a}$

17

$24 \mathrm{a}$

$39 \mathrm{~b}$

$22 \mathrm{c}$

$25 \mathrm{~g}$

$28 \mathrm{a}$

$25 i$

$25 \mathrm{~h}$

$36 \mathrm{~b}$

$25 \mathrm{~h}$

$28 \mathrm{a}$

$38 \mathrm{~b}$

$8 \mathrm{a}$

$24 b$

$8 d$

$8 d$

$28 \mathrm{a}$

$28 \mathrm{a}$

$20 \mathrm{~b}$

$36 a$

$36 \mathrm{~b}$

$8 \mathrm{a}$

$18 d$

$19 a$

$25 \mathrm{~g}$

$26 a$

$20 \mathrm{c}$

$19 \mathrm{~b}$
Ayekoye

Aznacollar

Azul-Carajas

$B$ and $B$

B. C.

B. C. Moly

Babcock

Baby foot

Badger

Bagacay

Bagby

Bagby Valley

Bagdad

Baghain

Bagin

Bagirsakdire

Bailadila

Bailadores

Bailey

Baisoara

Bajo

Bakerville

Bakhuis Mountains

Balaklala

Balcicakiri

Bald Mountain

Baldwin

Balea-Sitaouma

Ballarat

Ballynoe

Balmat

Baltic and Revenue

Baltimore

Baluba

Bama

Bamble

Bamboutos

Ban Ban

Bandgan

Bangam

Bankfield-Tombill

Bannack

Barao de Cocais-Caete

Barbara-Surprise

Barber-Larder

Barberton

Barite (Mouse)

Barite Mtn.
USCA

URUR

CUBA

USNV

USOR

AUQL

CNNB

USVA

CUBA

CUBA

IRLD

TRKY

GHNA

CNBC

PLPN

TRKY

GNEA

SPAN

BRZL

USNV

CNBC

CNBC

USOR

USOR

USAZ

PLPN

USCA

USCA

USAZ

IRAN

TRKY

TRKY

INDA

VNZL

CNYT

RMNA

JAPN

AUQL

SRNM

USCA

TRKY

USME

USNV

MALI

AUVT

IRLD

USNY

USCO

USMT

ZMBA

SPAN

NRWY

CMRN

AUQU

PKTN

CMRN

CNON

USMT

BRZL

AUWA

CNON

SAFR

CNYT

CNYT

$36 a$

$18 \mathrm{~d}$

$24 \mathrm{c}$

$25 \mathrm{c}$

$25 \mathrm{f}$

$38 \mathrm{~b}$

$28 \mathrm{a}$

$32 a, 32 b$

$8 \mathrm{a}$

$24 \mathrm{c}$

$28 \mathrm{a}$

$8 a$ 


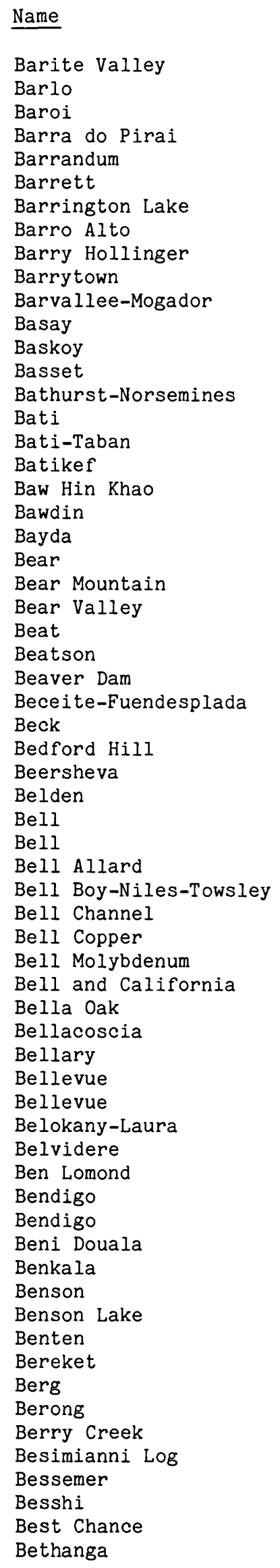

\begin{tabular}{|c|c|}
\hline Country & Mode 1 No \\
\hline SAFR & $31 b$ \\
\hline PLPN & $24 a$ \\
\hline INDA & $31 a$ \\
\hline BRZL & $38 b$ \\
\hline USCA & $36 a$ \\
\hline USME & $28 \mathrm{a}$ \\
\hline $\mathrm{CNMN}$ & $28 a$ \\
\hline BRZL & $38 a$ \\
\hline CNON & $36 b$ \\
\hline NZLD & $39 c$ \\
\hline $\mathrm{CNQU}$ & $28 a$ \\
\hline PLPN & 17 \\
\hline TRKY & $28 a$ \\
\hline GRBR & $15 b$ \\
\hline CNNT & $28 a$ \\
\hline TRKY & $8 a$ \\
\hline TRKY & $8 a$ \\
\hline TRKY & $8 a$ \\
\hline THLD & $31 b$ \\
\hline BRMA & $28 a$ \\
\hline OMAN & $24 a$ \\
\hline USNV & 17 \\
\hline USNM & $19 b$ \\
\hline USCA & $36 a$ \\
\hline USCA & $8 a$ \\
\hline USAK & $28 a$ \\
\hline CNNS & $36 a$ \\
\hline SPAN & $38 c$ \\
\hline USCA & $18 d$ \\
\hline CNQU & $28 a$ \\
\hline ISRL & $34 c$ \\
\hline USCA & $36 a$ \\
\hline $\mathrm{CNBC}$ & $22 c$ \\
\hline USNV & $19 a$ \\
\hline $\mathrm{CNQU}$ & $28 a$ \\
\hline USMT & $22 c$ \\
\hline CNQU & $28 a$ \\
\hline $\mathrm{CNBC}$ & $20 c$ \\
\hline $\mathrm{CNBC}$ & $21 b$ \\
\hline USCO & $22 c$ \\
\hline USCA & $27 c$ \\
\hline NCAL & $8 a$ \\
\hline INDA & $34 a, 28 b$ \\
\hline AUWA & $36 \mathrm{~b}$ \\
\hline NCAL & $8 a$ \\
\hline URRS & $30 a$ \\
\hline USVT & $8 d$ \\
\hline AUQL & $25 f$ \\
\hline AUVT & $36 a$ \\
\hline NZLD & $36 a$ \\
\hline ALGR & $18 d$ \\
\hline URRS & $18 d$ \\
\hline USNY & $25 i$ \\
\hline $\mathrm{CNBC}$ & $18 b$ \\
\hline JAPN & $25 d$ \\
\hline TRKY & $8 a$ \\
\hline $\mathrm{CNBC}$ & $21 a$ \\
\hline PLPN & $38 a$ \\
\hline USCA & $36 a$ \\
\hline URRS & $39 b$ \\
\hline CNON & $18 d$ \\
\hline JAPN & $24 b$ \\
\hline CNYT & $18 b$ \\
\hline AUVT & $36 a$ \\
\hline
\end{tabular}

Name

Bethlehem

Betts Cove

Bezkere-Bulurlii

Bhavnagar

Bhimatangar

Bicholim

Bicir-Cakir

Bicir-Gul

Bidgood-Modfatt-Hall

Bidjovagge

Bielgorsky Log

Big Badja River

Big Bear

Big Bell

Big Ben

Big Bend

Big Bend

Big Chief

Big Cottonwood

Big Dipper

Big Four

Big Four

Big Four

Big Hill

Big Horn (Yarrow Ck)

Big Mike

Big Oak Flat

Big Onion

Big Pine Claim

Big Syncline

Big Yank No. 1

Bihar

Bilaspur

Binder No. 1

Bingham

Binghampton

Bingo

Bintan Island

Birch Lake

Birch Tree

Birchfield

Birchfield

Birthday-William Fancy

Bisbee

Bizmisen-Akusagi

Bjorkasen

Bjurfors

Bjurliden

Bjurtrask

Black Bart (Great Western)

Black Bart Claim (Avery)

Black Bart Group

Black Bear

Black Bear

Black Beauty

Black Boy

Black Boy

Black Chrome

Black Crow-San Juan

Black Cub

Black Diablo

Black Diamond

Black Diamond (Grey Eagle Gp.) USCA

Black Hawk
Country Model No

CNBC 21a

CNNF 24a

TRKY $8 \mathrm{a}$

INDA $\quad 38 \mathrm{~b}$

INDA $38 \mathrm{a}$

INDA $34 \mathrm{a}, 28 \mathrm{~b}$

TRKY 8a

TRKY 8a

CNON 36b

NRWY 28a

URRS $\quad 39 b$

AUNS $\quad 39 a$

USOR $8 \mathrm{a}$

AUWA $\quad 36 \mathrm{~b}$

USMT 16

USCA $28 a$

USCA $\quad 8 a$

USOR $8 \mathrm{a}$

USUT $\quad 19 a$

USCA $8 \mathrm{a}$

USFL . $\quad 34 \mathrm{~d}$

USMT 220

USOR $8 \mathrm{a}$

USME $28 \mathrm{a}$

CNAL $\quad 30 \mathrm{~b}$

USNV $24 a$

USCA $36 a$

CNBC 17

USCA 8a

SAFR $31 \mathrm{a}$

USOR $8 \mathrm{a}$

INDA $\quad 38 \mathrm{~b}$

INDA $38 \mathrm{~b}$

USCA $8 \mathrm{a}$

USUT 17

USAZ 28a

ZIRE 10

INDS $38 \mathrm{~b}$

CNSK $28 \mathrm{a}$

CNMN $6 \mathrm{~b}$

NZLD $39 c$

USNM 19b

AUVT $36 \mathrm{a}$

USAZ 17

TRKY 18d

NRWY 28a

SWDN $\quad 28 \mathrm{a}$

SWDN $\quad 28 a$

SWDN 28a

USCA $8 \mathrm{a}$

USCA $8 a$

USCA $8 \mathrm{a}$

USCA $36 a$

USCA $8 \mathrm{a}$

USOR $8 \mathrm{a}$

USCA $36 a$

USOR $8 \mathrm{a}$

USCA $8 a$

USNM $\quad 25 \mathrm{~g}$

CNYT $18 \mathrm{~b}$

USNV $24 c$

USOR $8 \mathrm{a}$

$8 \mathrm{a}$
$8 \mathrm{a}$

$18 \mathrm{c}$ 


\begin{tabular}{|c|c|c|c|c|c|}
\hline Name & Country & Model No & Name & Country & Model \\
\hline Black Hawk & USOR & $8 a$ & Boneng Lobo & PLPN & $20 c$ \\
\hline Black Lake & CNQU & $8 d$ & Bongbongan & PLPN & $24 a$ \\
\hline Black Mtn. & SAFR & $31 \mathrm{a}$ & Bonnievale & AUWA & $36 \mathrm{~b}$ \\
\hline Black Otter & USOR & $8 a$ & Bonny Lake & USFL & $34 d$ \\
\hline Black Range & USNM & $25 h$ & Bonsecours & NCAL & $8 a$ \\
\hline Black Range-Oroya & AUWA & $36 b$ & Booker Lease & USCA & $8 a$ \\
\hline Black Rock Chrome & USCA & $8 a$ & Boolarra & AUVT & $38 b$ \\
\hline Black Streak & USOR & $8 a$ & Bor & YUGO & $22 a$ \\
\hline Black Swan & AUWA & $6 b$ & Boss Mountain & CNBC & $21 b$ \\
\hline Black Warrior & USNV & $27 d$ & Bossmo & NRWY & $28 a$ \\
\hline Black Warrior & USOR & $8 a$ & Boston Group & CUBA & $24 c$ \\
\hline Blackbird & USID & $24 d$ & Bosum & $\mathrm{CNBC}$ & $22 c$ \\
\hline Blackstone & USCA & $36 a$ & Boswell River & CNYT & $21 b$ \\
\hline Blairton & CNON & $18 d$ & Bothaville-Wolmaransstad & SAFR & $39 c$ \\
\hline Blind River & CNON & $29 a$ & Bou Azzer & MRCO & $8 c$ \\
\hline Blinman & AUSA & $19 \mathrm{~b}$ & Bou Mia & MRCO & $30 a$ \\
\hline Blockhouse & CNNS & $36 a$ & Bou Sellam & MRCO & $30 a$ \\
\hline Bloodwood Creek & AUQL & $15 b$ & Boulder River & USMT & $39 a$ \\
\hline Bloody Canyon & USNV & $27 d$ & Boulougne-Folkston & USFL & $39 c$ \\
\hline Blue Bell & $\mathrm{CNBC}$ & $19 a$ & Bouscadillac and others & CNON & $36 \mathrm{~b}$ \\
\hline Blue Brush & USCA & $8 a$ & Bovard & USNV & $25 c$ \\
\hline Blue Creek Tunnel & USCA & $8 a$ & Bowden Lake & CNMN & $6 \mathrm{~b}$ \\
\hline Blue Dick & USNV & $27 d$ & Bowden Prospect & USCA & $8 a$ \\
\hline Blue Grouse & CNBC & $18 \mathrm{~b}$ & Bowie Estate & USCA & $8 a$ \\
\hline Blue Jay & USCA & $24 c$ & Bowser & USOR & $8 a$ \\
\hline Blue Jay & USOR & $27 d$ & Boyandinskaia & URRS & $39 b$ \\
\hline Blue Lead & USAK & $36 a$ & Boylen & CNQU & $30 a$ \\
\hline Blue Ledge & USCA & $28 a$ & Bozkonus & TRKY & $8 a$ \\
\hline Blue Moon & USCA & $28 a$ & Bozotluk-No. 551 & TRKY & $8 a$ \\
\hline Blue Mountain & USCA & $36 a$ & Bozshchaku & URRS & 17 \\
\hline Blue Mountains-oko Mountains & GUYN & $38 b$ & Br. Solomon Is. & SLMN & $38 a$ \\
\hline Blue Nose & USNV & $27 d$ & Brachy & FRNC & $19 b$ \\
\hline Blue Ribbon & USNV & $27 \mathrm{~d}$ & Braden & USOR & $36 a$ \\
\hline Blue Ridge & PLPN & $38 a$ & Bradley & USNV & $27 d$ \\
\hline Blue River & USCO & $39 a$ & Bragdor & USCA & $8 a$ \\
\hline Blue Sky (Lucky Strike) & USCA & $8 a$ & Bralorne-Pioneer & CNBC & $36 a$ \\
\hline Blue Star & USNV & $26 a$ & Bray-Beulah & USNV & $27 d$ \\
\hline Bluebird & USAZ & 17 & Brejui & BRZL & $14 a$ \\
\hline Bluestone & USNV & $18 \mathrm{~b}$ & Brenda & CNBC & $21 \mathrm{a}$ \\
\hline Bob & ZIMB & $36 b$ & Brenmac & USWA & 17 \\
\hline Bobrowka River & URRS & $39 b$ & Bretz & USOR & $25 \mathrm{f}$ \\
\hline Bodennec & FRNC & $28 a$ & Bretz & USOR & $27 a$ \\
\hline Bodie & USCA & $25 c$ & Bridge Hill Ridge & AUNS & $39 c$ \\
\hline Boe & GNBS & $38 \mathrm{~b}$ & Briggs Creek & USOR & $8 a$ \\
\hline Boiler Pit & USCA & $8 a$ & Briseida Group \& others & CUBA & $24 c$ \\
\hline Boleo & $\mathrm{MXCO}$ & 23 & Bristol (Jack Rabbit) & USNV & $19 a$ \\
\hline Boliden & SWDN & $28 \mathrm{a}$ & Britannia & CNBC & $28 a$ \\
\hline Bolkardag & TRKY & $19 a$ & British Canadian & CNQU & $8 d$ \\
\hline Bolshaya Choumika R. & URRS & $39 b$ & Broken Hill & AUNT & $31 \mathrm{a}$ \\
\hline Bolshaya Kamenouchka & URRS & $39 b$ & Broken Hill & SAFR & $31 \mathrm{a}$ \\
\hline Bolshaya Ossokina R. & URRS & $39 b$ & Broken Hills & USCA & $36 a$ \\
\hline Bolshaya Prostokischenka & URRS & $39 b$ & Brookfield & CNNS & $31 b$ \\
\hline Bolshaya Sosnovka & URRS & $39 b$ & Brookfield & CNNS & $36 a$ \\
\hline Bolsherechensk & URRS & $18 d$ & Broulan and others & CNON & $36 b$ \\
\hline Bolshoi Pokap R. & URRS & $39 b$ & Brown Scratch & USOR & $8 a$ \\
\hline Bolshoi Sakciam & URRS & $39 b$ & Brownsville & AUQL & $15 b$ \\
\hline Bolske-Tokmak & URRS & $34 b$ & Bruce & USAZ & $28 a$ \\
\hline Bom Repouso-Cambui & BRZL & $38 b$ & Bruner & USNV & $25 d$ \\
\hline Bonanza & NZLD & $36 a$ & Brunswich & CNNB & $28 a$ \\
\hline Bonanza & USCA & $8 a$ & Brunswick-Altamaha & USGA & $39 c$ \\
\hline Bonanza & USCO & $25 b$ & Brynor & CNBC & $18 d$ \\
\hline Bonanza & $\mathrm{CNBC}$ & $24 a$ & Bu Craa & MRCO & $34 c$ \\
\hline Bond Creek & USAK & 17 & Buchans & CNNF & $28 a$ \\
\hline Bondurant & USCA & $36 a$ & Buckeye & USCA & $24 c$ \\
\hline
\end{tabular}




\begin{tabular}{|c|c|c|c|c|c|}
\hline Name & Country & Model No & Name & Country & Model No \\
\hline Buckhorn & USNV & $25 f$ & Camptonville area & USCA & $8 a$ \\
\hline Buckingham & USNV & $21 b$ & Cana Brava & BRZL & $8 d$ \\
\hline Bucko & CNMN & $6 b$ & Canadian Jamieson & CNON & $28 a$ \\
\hline Buena Esperanza & CILE & 23 & Cananea & $\mathrm{MXCO}$ & 17 \\
\hline Bueycito & CUBA & $24 c$ & Cananea (Capote) & MXCO & $18 a$ \\
\hline Buffalo Red Lake & CNON & $36 b$ & Canariaco & PERU & 17 \\
\hline Bugugan & TRKY & $8 a$ & Cannivan Gulch & USMT & $21 b$ \\
\hline Buka & PLPN & $38 a$ & Canoe Landing & CNNB & $28 a$ \\
\hline Bulacan & PLPN & $18 d$ & Cantung & CNNT & $14 a$ \\
\hline Bulbula & IRAN & $38 c$ & Canyon Creek-East Fork & USCA & $36 a$ \\
\hline Buller-Mokihinui & NZLD & $36 a$ & Capacmarca & PERU & $18 d$ \\
\hline Bullion & USCO & $22 c$ & Cape Bougainville & AUWA & $38 b$ \\
\hline Bullrun Placer & USOR & $39 a$ & Capel Shoreline & AUWA & $39 c$ \\
\hline Bully Hill & USCA & $28 \mathrm{a}$ & Capitan & USNM & $18 \mathrm{~d}$ \\
\hline Bunker & USCA & $8 a$ & Captain & CNNB & $28 \mathrm{a}$ \\
\hline Burbanks & AUWA & $36 b$ & Captains Flat & AUNS & $28 a$ \\
\hline Buritirama & BRZL & $24 c$ & Caracota & BLVA & $27 d$ \\
\hline Burned Cabin & USOR & $8 a$ & Carawison & PLPN & $24 a$ \\
\hline Burns Basin & USNV & $27 d$ & Carey/East Broughton & CNQU & $8 d$ \\
\hline Burnt Hill-Knob Lake & CNQU & $34 a, 28 b$ & Cariboo Bell & CNBC & $20 c$ \\
\hline Burra & AUSA & $30 \mathrm{~b}$ & Caribou & CNNB & $28 \mathrm{a}$ \\
\hline Bursi & NRWY & $28 a$ & Caribou & CNNS & $36 a$ \\
\hline Bushveld & SAFR & $2 a, 2 b, 3$ & Caribou-Aurum & CNBC & $36 a$ \\
\hline Butilad & PLPN & 17 & Carleton & CNNS & $36 a$ \\
\hline Butler Claims & USCA & $8 a$ & Carlin & USNV & $26 a$ \\
\hline Butler, Estate Chrome & USCA & $8 a$ & Carmel & PLPN & $24 a$ \\
\hline Butte & USMT & 17 & Carmen & CILE & $18 d$ \\
\hline Butte & USNV & $27 a$ & Carmi & $\mathrm{CNBC}$ & $21 b$ \\
\hline Buttercup Chrome & USCA & $8 a$ & Carn Brea-Tincroft & GRBR & $15 b$ \\
\hline Buxton Creek & $\mathrm{CNBC}$ & $39 a$ & Carnation-Jennie Lind & CNBC & $22 c$ \\
\hline Buyiik Gurleyen & TRKY & $8 a$ & Carnilya E. & AUWA & $6 a$ \\
\hline Buyiik Karamanli & TRKY & $8 a$ & Carnilya Hill & AUWA & $6 a$ \\
\hline Buyuk Yenice & TRKY & $27 d$ & Carocoles & BLVA & $15 b$ \\
\hline Bwana Mkubwa & ZMBA & $30 \mathrm{~b}$ & Carolin & $\mathrm{CNBC}$ & $36 a$ \\
\hline C.O.D. & USAZ & $22 c$ & Carolina & SAFR & $39 c$ \\
\hline $\mathrm{CC}$ & $\mathrm{CNBC}$ & $28 a$ & Caroline Islands & CARL & $38 b$ \\
\hline $\mathrm{Cab}$ & CNYT & $14 a$ & Carpenter & USAZ & 17 \\
\hline Cabo Rojo & PTRC & $38 a$ & Carpio & SPAN & $28 a$ \\
\hline Cadiz & CUBA & $24 c$ & Carr Boyd & AUWA & $7 a$ \\
\hline Calabogie & CNON & $18 d$ & Carr Fork & USUT & $18 b$ \\
\hline Caldas & BRZL & $38 b$ & Carrock Fell & GRBR & $15 a$ \\
\hline Calder-Bousquet & CNQU & $36 b$ & Carshaw-Tommy Burns & CNON & $36 \mathrm{~b}$ \\
\hline Caledonia & AUVT & $36 a$ & Casa de Janos & $\mathrm{MXCO}$ & $25 \mathrm{~g}$ \\
\hline Caledonia & $\mathrm{CNBC}$ & $18 \mathrm{~b}$ & Casapalca & PERU & $25 b$ \\
\hline Caledonia & CUBA & $8 a$ & Casas Grandes & $\mathrm{MXCO}$ & $25 g$ \\
\hline Caley & CNYT & $8 d$ & Cash & CNYT & 17 \\
\hline Calico & USCA & $25 c$ & Casino & CNYT & 17 \\
\hline California Group & USAZ & $25 \mathrm{~g}$ & Cassiar Mine & $\mathrm{CNBC}$ & $8 d$ \\
\hline California-Hartney-Marion & $\mathrm{CNBC}$ & $22 c$ & Cassilis & AUVT & $36 a$ \\
\hline Calistoga & USCA & $25 c$ & Cassius & HATI & $18 b$ \\
\hline Calumet & USMI & 23 & Castillo Buitron & SPAN & $28 a$ \\
\hline Calvert (Red Button) & USMT & $14 a$ & Castillode Palanco & SPAN & $24 c$ \\
\hline Camaguey & CUBA & $8 a$ & Casting & USNV & $18 \mathrm{~b}$ \\
\hline Camanche & USCA & $39 a$ & Castle Dome & USAZ & 17 \\
\hline Camarasa-0liana & SPAN & $38 c$ & Castle Island & USAK & $31 b$ \\
\hline Camaratuba & BRZL & $39 c$ & Castrita & $\mathrm{MXCO}$ & $25 \mathrm{~h}$ \\
\hline Camden Mine & USCA & $8 a$ & Castro Mine & USCA & $8 a$ \\
\hline Camiglia & ITLY & $18 d$ & Castro Verde & PORT & $28 a$ \\
\hline Camlica Koyee & TRKY & $27 d$ & Cataguases & BRZL & $38 b$ \\
\hline Campanamah & AGTN & 17 & Catak & TRKY & $8 a$ \\
\hline Campanario & SPAN & $28 a$ & Catak-Koraalan & TRKY & $8 a$ \\
\hline Campania & ITLY & $38 c$ & Catalao & BRZL & 10 \\
\hline Campbell & USOR & $8 a$ & Catas de las Vacas & $\mathrm{MXCO}$ & $25 h$ \\
\hline Campbell Red Lake-Dickenson & CNON & $36 b$ & Catas el Durango & $\mathrm{MXCO}$ & $25 \mathrm{~h}$ \\
\hline
\end{tabular}


Catavi

Catface

Catheart

Cathroy Larder

Cathy (Walt)

Catolsinir

Cattle Grid

Cattle Springs

Cavdarli-Komurluk

Cave Canyon

Cavyell Horse Mountain

Cayirli Koy

Cedar Creek

Cehegin

Celebration

Cenger

Cenger-Adatepe

Cenger-Demirk

Cenger-Domuza

Centennial

Central

Central Cerbat District

Central Manitoba

Central Patricia

Central Rawdon

Central Tennessee

Cerro Blanco

Cerro Bolivar

Cerro Colorado

Cerro Colorado

Cerro Gordo

Cerro Grande

Cerro Matoso

Cerro Prieto

Cerro Verde

Cerro de Cobre

Cerro de Mercado

Cervantite

Cezni

Chacarilla

Chador-Malu

Chagrin

Chahehgaz

Chalchihuites

Chal cobamba

Challange area

Chambers

Chambiashi

Champagne (Oakwood)

Champion-New London

Chang Po-Tongkeng

Charcas

Charco Redondo-Casualidad

Charleston placers

Chaucha

Chavarria

Chavin

Cheminis-Fernland-Omega

Chestatee

Chester

Chesterville

Chewton

Chiatura

Chibuluma
BLVA

USMN

CNON

CNYT

TRKY

AUSA

USCA

TRKY

USCA

USOR

TRKY

USOR

SPAN

USOR

TRKY

TRKY

TRKY

TRKY

CNMN

USCA

USAZ

CNMN

CNON

CNNS

USTN

MXCO

VNZL

CILE

PANA

USCA

MXCO

CLBA

MXCO

PERU

CLBA

MXCO

USNV

TRKY

BLVA

IRAN

NCAL

IRAN

MXCO

PERU

USCA

USOR

ZMBA

UNS

USAZ

CINA

MXCO

CUBA

USSC

ECDR

MXCO

PERU

CNON

USGA

CNNB

CNON

AUVT

URRS

ZMBA

$\begin{array}{ll}20 \mathrm{a} & \text { Chibuluma West } \\ 17 & \text { Chicago } \\ 17 & \text { Chicago } \\ 36 \mathrm{~b} & \text { Chichagof } \\ 31 \mathrm{~b} & \text { Chichibu } \\ 8 \mathrm{a} & \text { Chicote Grande } \\ 30 \mathrm{~b} & \text { Child Harold } \\ 8 \mathrm{a} & \text { Childs Mine }\end{array}$

Chilisai

Chingola-Nchanga

Chinkuashih

Chintapalli-Gurtedu

Chisel Lake

Chitose

Chittering

Chityal and others

Chiwefwe

Chloride Flat

Chloride District

Choates

Choghart

Choja

Chongwe

Chorolque

Christain Place

Christmas

Chrome Camp

Chrome Gulch

Chrome Hill

Chrome King (Josephine Co.)

Chrome King (Jackson Co.)

Chrome No. 3

Chrome Ridge

Chuquicamata

Chushiro

Cia Minera Norcro

Cinovec

Cirque

Cirque Barite

Cista

Ciudad Obregon

Clara $\mathrm{H}$

Clarendon Plateau

Clary and Langford

Claude Hills

Clear Springs

Cleary Hill

Cleopatra

Cleveland

Cliff Roy

Climax

Clinton

Clinton Creek

Clover Leaf

Cluff Lake

Clunes Goldfield

Coal Creek

Coalstoun

Coarsegold

Coasano

Coast Copper

Cobol

Cobriza

Cobweb Diggings
ZMBA

USCA

USCA

USAK

JAPN

BLVA

NCAL

CNON

URRS

ZMBA

TIWN

INDA

CNMN

JAPN

AUWA

INDA

ZIMB

USNM

USAZ

USNV

IRAN

JAPN

ZMBA

BLVA

USCA

USAZ

USCA

USCA

USCA

USOR

USOR

USOR

USOR

CILE

JAPN

HNDR

CZCL

CNBC

CNBC

CZCL

MXCO

USCA

JMCA

USCA

AUSA

USFL

USAK

USOR

AUTS

USNM

USCO

CNQU

CNYT

USCA

CNSK

AUVT

USAK

AUQL

USCA

USAK

CNBC

USAK

PERU

AUNS

$30 \mathrm{~b}$

$27 \mathrm{c}$

$8 \mathrm{a}$

$36 a$

$18 d$

$15 \mathrm{a}$

$8 \mathrm{a}$

$18 d$

$34 \mathrm{c}$

$30 \mathrm{~b}$

$25 \mathrm{e}$

$38 \mathrm{~b}$

$28 a$

$25 d$

$38 \mathrm{~b}$

$34 \mathrm{a}, 28 \mathrm{~b}$

$34 \mathrm{~b}$

$19 \mathrm{~b}$

$22 c$

27d

$25 i$

$24 \mathrm{~b}$

$30 \mathrm{~b}$

$20 \mathrm{a}$

$8 a$

$18 a$

$8 a$

$8 a$

$8 a$

$8 a$

$8 a$

$8 a$

$8 a$

17

$24 \mathrm{~b}$

$27 d$

$15 \mathrm{c}$

$31 a$ 


\begin{tabular}{|c|c|c|c|c|c|}
\hline Name & Country & Model No & Name & Country & Model No \\
\hline Cochrane Hill & CNNS & $36 a$ & Coteje & BLVA & $25 f$ \\
\hline Coco Mina & NCGA & $25 b$ & Coto & PLPN & $8 a$ \\
\hline Codd Prospect & USCA & $8 a$ & Cottonwood & USNV & $27 d$ \\
\hline Coeur d'Alene & USID & $27 d$ & Coulterville & USCA & $36 a$ \\
\hline Coggins & USCA & $8 a$ & Country Harbour & CNNS & $36 a$ \\
\hline Coimadai & AUVT & $27 d$ & Courtwright & USCA & $8 a$ \\
\hline Colchester & CNNF & $24 a$ & Courtwright (Daggett) & USCA & $8 a$ \\
\hline Coleman & USNV & $27 a$ & Courvan Mine & CNQU & $8 d$ \\
\hline Colfax & USCA & $36 a$ & Cove District & USCA & $36 a$ \\
\hline Collard Mine & USOR & $8 a$ & Cow Bay & CNNS & $36 a$ \\
\hline Colombo & USCA & $36 a$ & Cow Creek Gp. & USCA & $8 a$ \\
\hline Colquemarca & PERU & $18 \mathrm{~d}$ & Cowley Creek & CNYT & $18 b$ \\
\hline Colqui & PERU & $25 b$ & Cox, Bolyan \& Loberg & USAK & $36 a$ \\
\hline Comet & USAK & $36 a$ & Craigmont & $\mathrm{CNBC}$ & $18 a$ \\
\hline Commander & USCA & $8 a$ & Cranberry Hill & CNNS & $36 a$ \\
\hline Comstock & CNBC & $22 c$ & Cranbourne & CNQU & $8 d$ \\
\hline Comstock & USNV & $25 c$ & Crandon & USWI & $28 a$ \\
\hline Concepcion Del Oro & $\mathrm{MXCO}$ & $18 \mathrm{~b}$ & Creede & USCO & $25 b$ \\
\hline Conception & SPAN & $28 a$ & Crescent & USWA & $24 c$ \\
\hline Confidence & USCA & $36 a$ & Creston & $\mathrm{MXCO}$ & $21 b$ \\
\hline Conigo & CNQU & $28 a$ & Creta & USOK & $30 \mathrm{~b}$ \\
\hline Connemara & ZIMB & $36 b$ & Cripple Creek & USCO & $22 b$ \\
\hline Conrad Lodes & AUNW & $15 b$ & Croker Island & AUNT & $38 b$ \\
\hline Consolation & NCAL & $8 a$ & Cromita & CUBA & $8 a$ \\
\hline Contact & USCA & $27 c$ & Cronin & CNBC & $28 a$ \\
\hline Continental & CNQU & $8 d$ & Crooked Creek & USID & $39 a$ \\
\hline Continental & USNM & $18 a$ & Crouch & USOR & $8 a$ \\
\hline Conyarigi & TRKY & $27 d$ & Crowell Area & USTX & $30 \mathrm{~b}$ \\
\hline Coolgardie & AUWA & $36 b$ & Crown & USOR & $8 a$ \\
\hline Coolgarra Dist. & AUQL & $15 b$ & Crown King & USAZ & $19 b$ \\
\hline Coon Mt. Nos. $1-3$ & USCA & $8 a$ & Cuajone & PERU & 17 \\
\hline Copper Basin & USAZ & 17 & Cubenas & CUBA & $24 c$ \\
\hline Copper Basin & USNV & $18 a$ & Cubuagan & PLPN & 17 \\
\hline Copper Canyon & USNV & $18 b$ & Cubuagan & PLPN & $20 c$ \\
\hline Copper Cities & USAZ & 17 & Cubuklu Koyu & TRKY & $24 c$ \\
\hline Copper Creek & USAZ & 17 & Cuchillo-Negro & USNM & $18 d$ \\
\hline Copper Creek (Low Divide) & USCA & $8 a$ & Cueva de la Mora & SPAN & $28 a$ \\
\hline Copper Crown & CNBC & $28 \mathrm{a}$ & Cullaton Lake & CNNT & $36 \mathrm{~b}$ \\
\hline Copper Flat & USNM & $18 d$ & Cullengoral & AUNS & $39 a$ \\
\hline Copper George & AUWA & $28 a$ & Culver Bear & USCA & $27 c$ \\
\hline Copper Hill & USCA & $28 a$ & Cumberland Island & USGA & $39 c$ \\
\hline Copper Mountain & $\mathrm{CNBC}$ & 17 & Cummings & USCA & $24 c$ \\
\hline Copper Mountain & $\mathrm{CNBC}$ & $20 c$ & Cupra D'Estrie & CNQU & $28 a$ \\
\hline Copper Penny & USAZ & $37 \mathrm{~b}$ & Cuprus & CNMN & $28 a$ \\
\hline Copper Queen & CNBC & $18 b$ & Curiol-Playa Real-Pavones & CORI & $24 c$ \\
\hline Copper Ridge & USTN & $32 b$ & Curtis Island & AUQL & $39 c$ \\
\hline Copperhead & AUWA & $36 b$ & Cuyuna & USMN & $34 a, 28 b$ \\
\hline Corbet & CNQU & $28 a$ & Cyclone Gap & USCA & $8 a$ \\
\hline Cordero & USNV & $27 a$ & Cyclops & INDS & $38 a$ \\
\hline Cordon & PLPN & 17 & Cynthia & GREC & $19 \mathrm{~b}$ \\
\hline Cordon Estaneros & $\mathrm{MXCO}$ & $25 \mathrm{~h}$ & Cynthia & USOR & $8 a$ \\
\hline Corduroy Creek & USID & $39 a$ & D'Analamaitso & MDGS & $38 b$ \\
\hline Cork-Province & CNBC & $22 c$ & D'Ankazobe & MDGS & $38 b$ \\
\hline Cornell & $\mathrm{CNBC}$ & $18 b$ & D-Tree & AUQL & $34 c$ \\
\hline Cornwall & USPA & $18 d$ & Dabola & GNEA & $38 b$ \\
\hline Cornwall Sn & GRBR & $15 b$ & Daffodil & CNON & $8 d$ \\
\hline Corocoro & BLVA & $30 \mathrm{~b}$ & Dagardi & TRKY & $27 d$ \\
\hline Corona & USCA & $27 c$ & Dagardi & TRKY & $8 a$ \\
\hline Coronation & CNSK & $28 \mathrm{a}$ & Dagkuplu & TRKY & $8 a$ \\
\hline Cortez & USNV & $19 a$ & Daiquiri & CUBA & $18 \mathrm{~d}$ \\
\hline Cortez & USNV & $26 a$ & Daisy (Aldelabron) & USCA & $8 a$ \\
\hline Cosan & TRKY & $8 a$ & Dalesford & AUVT & $36 a$ \\
\hline Cosmopolitan & AUWA & $36 \mathrm{~b}$ & Damascus & USCA & $36 a$ \\
\hline Costerfield & AUVT & $27 d$ & Damba & ZIMB & $6 a$ \\
\hline
\end{tabular}


Name

Dammer Nissar

Danacik

Danisment

Dannemora

Danville-Hanchette

Dardanelles

Dargo Range Dist.

Dark Star

Darrington

Darwin

Darwin

Dassoumble

Davidson

Davis

Dawn Lake

Day Dawn-Main Line

Dayton

Dcev 7

De Santis

Debele (Kindia)

Dee

Deep Gorge Chrome

Deep Gravel

Deer Isle

Defender

Defiance

Del Park-Huntly

Delamar

Delare Prospect

Delbridge

Delta

Delta

Demarest

Demirkapi

Demirli

Denali Copper

Derekoy

Descoberto

Desert

Despina

Detert

Detour

Detroit

Devils Elbow

Dewey's

Dexing

Dhalli-Rajhara

Diamond

Dickerson

Dickey and Drisbach

Dickstone

Dikulume-Mashamba

Dinagat

Dinagat Is.

Dinamita

Dinero

Dirty Face

Discovery

Divide

Divinolandia de Minas

Divrigi

Dixie Placer

Dizon

Djebel El Aziza

\section{Coun}

PKTN

TRKY

TRKY

SWDN

USAZ

CNBC

AUQL

USOR

USCA

USCA

USNV

IVCO

CNON

USMA

CNSK

AUWA

USNV

NCAL

CNON

GNEA

USNV

USOR

USOR

USME

USCA

USAZ

AUWA

USID

USOR

CNQU

CUBA

USCA

USCA

USNV

TRKY

USAK

TRKY

BRZL

USCA

CNQU

USCA

CNQU

USUT

CNNB

USCA

CINA

INDA

USCA

USCA

USCA

CNMN

ZIRE

PLPN

PLPN

MXCO

USCA

USOR

CNMN

USNV

BRZL

T RKY

USOR

PLPN

TUNS
Model No Name

Djebel Guettara

Djebel Onk

Doe Flat

Dogu Ezan

Dogu Kef

Doi Pha Khan

Dolores

Dolores

Dome-Paymaster-Preston

Dominion Consolidated

Dominion Gulf

Domuzburnu II

Don Jon

Don Pedro

Don Teodoro

Donatelli

Dorothea

Dorothy

Dorriss

Dos Pobres

Double Ed

Douglas $\mathrm{Hill}$

Dovis

Dozier

Drina

Drnis-Obrovac

Drumm

Dry Canyon

Dry Creek

Dublin Gulch (GSZ)

Duchess

Dudas

Dugald River

Duke Island

Dulcoath

Duluth Complex

Dumagami

Dumont

Dumont Bourlamque

Duncan Lake

Dungun

Dunraine

Durnovskoe

Duthie

Dy

Dyce Siding

Dyson's (Rum Jungle)

Dzama

Dzhezhkazgan (Magakyan)

E. Kempville

E. Scotia

Eagle

Eagle

Eagle Bluff-River Bend

Eagle Mountain

Eagle Shawmut

Earl Smith

Early Bird

Early Sunrise

Early-Sweetwater

East Florida (Deseret Ranch)

East Maui

East Ore Body

East Rawdon
Model No

ALGR $24 c$

ALGR $34 \mathrm{c}$

USCA $8 a$

TRKY $8 \mathrm{a}$

TRKY 8a

THLD 27d

MXCO 18c

MXCO 25c

CNON 36b

NZLD $\quad 36 a$

CNON $\quad 10$

TRKY 8a

CNMN 28a

USCA $8 \mathrm{a}$

MXCO 25h

USNV 27d

USOR $\quad 36 \mathrm{a}$

CNBC $\quad 17$

USCA $8 \mathrm{a}$

USAZ 20c

CNBC $28 \mathrm{a}$

USNV $18 \mathrm{~b}$

IRAN $8 \mathrm{a}$

USCA $8 \mathrm{a}$

YUGO 19a

YUGO $38 \mathrm{c}$

USNV 27d

USNV 27d

USOR $8 \mathrm{a}$

CNYT $14 \mathrm{a}$

AUQL $34 \mathrm{c}$

USNV 27d

AUQL

USAK

GRBR

USMN

CNQU

CNQU

CNQU

CNBC

MDGS

CNQU

URRS

CNBC

CNYT

CNMN

AUNT

URRS

URRS

CNNS

AUWA

CNBC

USAK

USCA

USCA

USCA

USCA

USCA

USOR

USCA

USFL

USHI

PLPN

CNNS 
East Rosetta

East Sullivan

East Tennessee

East Tintic

Eastern A\&B

Eaton

Eclipse No. 1

Ecum Secum

Edeline

Eden

Edna May

Eggling and Williams

Ego

Ehime

Ejowka

Ekstromberg

El Abra

El Abra

El Algarrobo

El Arco

El Atascadero

El Baluarte

El Barroso

E1 Borrego 非 1

E1 Borrego \#2

El Calabrote

El Capulin

El Cid

El Coloradillo

El Corral

El Cristal

El Cuervo

El Dorado

El Dorado

El Dorado

El Dorado

El Duraznillo

El Durazno

El Encino (La Ochoa)

El Encino (Jalisco)

El Gotera

El Hamrawein

El Huacal

E1 Indio

El Indio, Tadeo, San Antonio

El Ladrillo

El Mamey

El Mezquite

El Mochito

El Naranjo, Buena Suerte

El Noladero

El Nopal (Juan Aldama)

E1 Nopal (La Ochoa)

El Nopal (Nopal I and III)

El Pachon

El Pao

El Pedroso

El Penasco

El Perdido

El Picacho

El Pleito

El Polvillo

El Portal
EGPT

CNQU

USTN

USUT

SYRA

USNV

USCA

CNNS

USCA

USCA

AUWA

USCA

CNON

JAPN

URRS

SWDN

CILE

MXCO

CILE

MXCO

MXCO

MXCO

MXCO

MXCO

MXCO

MXCO

$\mathrm{MXCO}$

CUBA

MXCO

$\mathrm{MXCO}$

MXCO

SPAN

CILE

MXCO

USCA

USMT

MXCO

MXCO

MXCO

$\mathrm{MXCO}$

MXCO

EGPT

MXCO

CILE

MXCO

MXCO

MXCO

$\mathrm{MXCO}$

HNDR

MXCO

MXCO

MXCO

MXCO

MXCO

AGTN

VNZL

SPAN

MXCO

$\mathrm{MXCO}$

MXCO

MXCO

MXCO

USCA

$\begin{array}{ll}39 \mathrm{c} & \text { El Porvenir (Milpo) } \\ 28 \mathrm{a} & \text { El Primero } \\ 32 \mathrm{a}, 32 \mathrm{~b} & \text { El Profesor } \\ 19 \mathrm{a} & \text { El Rincon } \\ 34 \mathrm{a} & \text { El Romadizo }\end{array}$

34c El Romadizo

27d El Romeral

36a El Salvador

36a El Santo Nino

8a El Sherana

$8 a$

$36 \mathrm{~b}$

$8 a$

$28 \mathrm{a}$

$24 \mathrm{~b}$

$39 b$

$25 i$

17

$25 \mathrm{~h}$

$25 i$

17

$25 \mathrm{~h}$

$25 \mathrm{~h}$

$25 \mathrm{~h}$

$25 \mathrm{~h}$

$25 \mathrm{~h}$

$25 \mathrm{~h}$

$25 \mathrm{~h}$

$8 \mathrm{a}$

$25 \mathrm{~h}$

$25 \mathrm{~h}$

$25 \mathrm{~h}$

$24 \mathrm{c}$

$25 i$

$25 \mathrm{~h}$

$36 \mathrm{a}$

$39 a$

$25 \mathrm{~h}$

$25 \mathrm{~h}$

$25 \mathrm{~h}$

$25 i$

$25 \mathrm{~h}$

$34 \mathrm{c}$

$25 \mathrm{~h}$

$25 \mathrm{e}$

$25 \mathrm{~h}$

$25 \mathrm{~h}$

$25 \mathrm{~h}$

$25 \mathrm{f}$

$18 \mathrm{c}$

$25 \mathrm{~h}$

$25 \mathrm{~h}$

$25 \mathrm{~h}$

$25 \mathrm{~h}$

$25 \mathrm{f}$

17

$34 \mathrm{a}, 28 \mathrm{~b}$

$18 d$

$25 \mathrm{~h}$

$25 \mathrm{~h}$

$25 \mathrm{~h}$

$25 \mathrm{~h}$

$25 \mathrm{~h}$

$36 a$
El Sherana West

El Socavon

El Sol y La Luna

El Soldado

El Tarango

El Teniente

El Tigre

El Venado

El Volcan-Piedra Iman

El Zanzon

Elalmis

Elatsite

Elder Claim

Elder Creek

Eldirek

Electric

Eliza-Schroeder

Elk Creek Claim

Elkhorn Chromite

Elkhorn Creek

Ellingwood

Elliot Lake

Ellis

Elliston

Eltay

Ely

Embury Lake

Emerald-Dodger

Emerson

Emigrant Springs

Emirli

Emmaville

Empire Le Tac

Empire-Lone Star

Emporer Mine

Empress

Emu Creek

Emu Dist.

Emu-Great Eastern

Endako

Eneabba Shoreline

Enterprise

Enterprise

Epoch

Equity Silver

Ermenis

Errington

Erzegebirge

Escondida

Eskdale

Esmeralda

Esperancita

Esperanza

Esperanza

Espiritu Santo

PERU

USCA

MXCO

$\mathrm{MXCO}$

MXCO

CILE

CILE

MXCO

AUNT

AUNT

MXCO

MXCO

CILE

$\mathrm{MXCO}$

CILE

MXCO

MXCO

$\mathrm{MXCO}$

MXCO

TRKY

BULG

USCA

USCA

TRKY

USNV

USCA

USCA

USOR

USMT

USCA

CNON

USCA

USMT

URRS

USNV

CNMN

CNBC

USME

USNV

TRKY

AUNS

CNQU

USCA

FIJI 


\begin{tabular}{|c|c|c|c|c|c|}
\hline Name & Country & Model No & Name & Country & Model No \\
\hline Essex and Steptoe & USNV & $19 b$ & Forest Creek & USOR & $39 a$ \\
\hline Estacao & CNON & $28 a$ & Forest Hill & CNNS & $36 a$ \\
\hline Estacion Llanos & $\mathrm{MXCO}$ & $25 g$ & Forest Queen & USCA & $8 a$ \\
\hline Ester Dome SE & USAK & $36 a$ & Fornas & SPAN & $24 a$ \\
\hline Esterly Chrome & USOR & $8 a$ & Forrestania Group & AUWA & $6 \mathrm{~b}$ \\
\hline Esther and Phyllis & USCA & $8 a$ & Fort Apache & USAZ & $34 a, 28 b$ \\
\hline Estrella-Sopresa & CUBA & $24 c$ & Fort Gourand & MAUR & $34 a, 28 b$ \\
\hline Estyunin & URRS & $18 \mathrm{~d}$ & Fort Green & USFL & $34 d$ \\
\hline Euboea & GREC & $38 a$ & Foster & USOR & $8 a$ \\
\hline Eulaminna & AUWA & $28 a$ & Foster Mountain & USCA & $24 c$ \\
\hline Eureka & USCO & $25 b$ & Four Hells Mine & USCA & $36 a$ \\
\hline Eureka & USNV & $19 a$ & Four Point & USOR & $8 a$ \\
\hline Eustis & CNQU & $28 a$ & Four-of-July & USID & $27 d$ \\
\hline Eva May & USMT & $22 c$ & Fourth Crossing & USCA & $36 a$ \\
\hline Evans Head-Wooli area & AUNS & $39 c$ & Fourth of July & USCA & $8 a$ \\
\hline Exmibal & GUAT & $38 a$ & Fox & CNMN & $28 a$ \\
\hline Exotica & CILE & 17 & Francis Ormand & AUVT & $36 a$ \\
\hline Experimental & USCA & $36 a$ & Franklin & USCA & $36 a$ \\
\hline F Group & CNON & $28 a$ & Fraser Island & AUQL & $39 c$ \\
\hline$F$ and $L$ Mine & USNV & $27 a$ & Fraser's & AUWA & $36 b$ \\
\hline $\mathrm{FL} \& \mathrm{DH}$ & $\mathrm{CNMN}$ & $28 a$ & Freddie Wells & AUNS & $28 a$ \\
\hline Fabian & USCA & $24 c$ & French & USCA & $36 a$ \\
\hline Fairview & USCA & $8 a$ & French Gulch & USCA & $36 a$ \\
\hline Fairview & USNV & $25 c$ & French Gulch & USCO & $39 a$ \\
\hline Falconbridge & DMRP & $38 a$ & French Hill & USCA & $8 a$ \\
\hline Fall Creek & USID & $39 a$ & Fretais & PORT & $28 a$ \\
\hline Falun & SWDN & $18 \mathrm{c}$ & Fria-Kimbo & GNEA & $38 b$ \\
\hline Fanrouche & NCAL & $8 a$ & Friday & USOR & $8 a$ \\
\hline Farewell Lake & CNMN & $28 a$ & Frieda River & PPNG & $20 c$ \\
\hline Faro & CNYT & $31 a$ & Friedensville & USPA & $32 a, 32 b$ \\
\hline Faucogney & FRNC & $24 c$ & Frotet Lake & $\mathrm{CNQU}$ & $28 a$ \\
\hline Felicianna & USCA & $36 a$ & Fryer's Creek & AUVT & $36 a$ \\
\hline Fenoarivo & MDGS & $38 b$ & Fujinokawa & JAPN & $27 d$ \\
\hline Fenyoto & HUNG & $38 c$ & Fukazawa & JAPN & $28 a$ \\
\hline Fiddler's Green & USCA & $8 a$ & Fuke & JAPN & $25 c$ \\
\hline Fields and Stoker & USCA & $8 a$ & Fuller-Tisdale & CNON & $36 b$ \\
\hline Fierro & USNM & $18 \mathrm{c}$ & Funter Bay & USAK & $7 a$ \\
\hline Fierro-Hannover & USNM & $18 d$ & Furuhaugen & NRWY & $28 a$ \\
\hline Fifteen-mile Brook & CNNS & $36 a$ & Furutobe-Ainai & JAPN & $28 a$ \\
\hline Fifteen-mile Stream & CNNS & $36 a$ & $\mathrm{Fx}$ & CNBC & $31 a$ \\
\hline Fifty-five & USCA & $36 a$ & Gabretta & USCA & $36 a$ \\
\hline Filon Sur-Esperanza & SPAN & $28 a$ & Gabriels Gully & NZLD & $36 a$ \\
\hline Finan & USCA & $8 a$ & Gabrinus & USCA & $36 a$ \\
\hline Findikli & TRKY & $8 a$ & Gachala & CLBA & $31 c$ \\
\hline Fine Gold & USCA & $36 a$ & Gag Is. & INDS & $38 a$ \\
\hline Finney & USCA & $36 a$ & Ga laxy & $\mathrm{CNBC}$ & 17 \\
\hline Fish Lake & CNBC & $20 c$ & Galena Farm and vicinity & CNBC & $22 c$ \\
\hline Fisher Maiden Group & CNBC & $22 c$ & Galice North & USOR & $36 a$ \\
\hline Fiskefjord & NRWY & $34 a, 28 b$ & Gallagher & USOR & $8 a$ \\
\hline Five Pines & USCA & $36 a$ & Gallinas & USNM & $18 d$ \\
\hline F jeldgruve & NRWY & $28 a$ & Galore Creek & CNBC & $20 c$ \\
\hline Flaat & NRWY & $7 a$ & Galvan & $\mathrm{MXCO}$ & $25 h$ \\
\hline Flambeau & USWI & $28 a$ & Gambe & BRZL & $38 b$ \\
\hline Flexar & CNSK & $28 \mathrm{a}$ & Gambier Island & $\mathrm{CNBC}$ & $21 a$ \\
\hline Flin Flon & CNMN & $28 a$ & Gamle Folldal & NRWY & $28 a$ \\
\hline Flint-Martin & CNBC & $22 c$ & Ganntour & MRCO & $34 c$ \\
\hline Florence & USAZ & 17 & Gant & HUNG & $38 c$ \\
\hline Florida Canyon & USNV & $26 a$ & Gap & USPA & $7 \mathrm{a}$ \\
\hline Fond-du-Lac & CNON & $38 d$ & Gardner Mine & USOR & $8 a$ \\
\hline Fongo Tongo & CMRN & $38 b$ & Garon Lake & CNQU & $28 a$ \\
\hline Fonnfjell & NRWY & $28 a$ & Garpenberg Norra & SWDN & $18 c$ \\
\hline Foots Creek & USOR & $39 a$ & Garpenberg Odal & SWDN & $18 c$ \\
\hline Forbestown & USCA & $36 a$ & Gas Canyon & USCA & $8 a$ \\
\hline Ford & USCA & $36 a$ & Gaspe & CNQU & $21 a$ \\
\hline
\end{tabular}


Gaspe (Needle Mountain)

\section{Gaviao}

Gavilancillos

Gayna R.-Godlin L.

Geach

Geevor

Geita

Gelvenakko

Gem

Gem

Gem

Gem Olive

Gem Park

General Gallieni

Geol. Reser. No. 34

George Copper

George Lake

George Prezel

Georgia bauxite

Gerdag

German Bar

Getchell

Ghost Lake

Giant King

Giant Mascot

Gibraltar

Gibralter

Gibsonville

Giken-Charlotta

Gill (Gill Ranch)

Gillan

Gilliam

Gillis Prospect

Gilmont

Giltedge

Gimlet-Slippery

Gingin Shoreline

Giresun

Girilambone

Gjersvik

Glacier Gulch

Glacier Peak

Gladstome-Sand Queen

Gladstone

Gladstone Mainland

Glass Butte

Glencoe-Woodhouse

Gleneindale Dist.

Glib en Nam

Globe-Ralston

Gloria-Elvira-Polaris

Glory Ho

Gloryana

Gloubokia

Gocek Koyu

God's Lake

Gogebic

Golalan

Golconda Fraction

Gold Acres

Gold Bar

Gold Bug

Gold Bug Claim

Gold Chariot

\section{CNQU}

PORT

MXCO

CNNT

USCA

GRBR

TNZN

SWDN

CNYT

USCA

CNBC

USCA

USCO

NCAL

CNMN

CNBC

CNSK

USID

USCO

TRKY

USCA

USNV

CNMN

USCA

CNBC

CNBC

USCA

USCA

NRWY

USCA

USCA

AUQL

USCA

CNQU

USMT

AUWA

AUWA

TRKY

AUNS

NRWY

CNBC

USWA

AUWA

USCA

AUQL

USOR

USCA

AUQL

MRCO

USCA

CUBA

USOR

USNM

URRS

TRKY

CNMN

USMN

TRKY

USCA

USNV

USNV

USCA

USCA

USCA
$18 \mathrm{a}$

$28 \mathrm{a}$

$25 \mathrm{~h}$

$32 \mathrm{a}, 32 \mathrm{~b}$

$8 \mathrm{a}$

$15 b$

$36 \mathrm{~b}$

$28 \mathrm{a}$

$18 \mathrm{~b}$

$36 a$

$21 b$

$36 a$

10

$8 a$

$6 \mathrm{~b}$

$28 \mathrm{a}$

$30 \mathrm{a}$

$39 a$

$8 \mathrm{c}$

$8 a$

$36 a$

$26 a$

$28 a$

$36 a$

$7 \mathrm{a}$

$21 \mathrm{a}$

$36 a$

$8 \mathrm{a}$

$28 a$

$8 a$

$8 a$

$14 b$

$8 a$

$8 d$

$26 a$

$36 b$

$39 c$

$18 d$

$28 \mathrm{a}$

$28 \mathrm{a}$

$21 \mathrm{~b}$

17

$36 \mathrm{~b}$

$36 a$

$39 c$

$27 \mathrm{a}$

$36 a$

$15 \mathrm{~b}$

$24 \mathrm{c}$

$36 \mathrm{a}$

$24 \mathrm{c}$

$8 \mathrm{a}$

$25 \mathrm{~g}$

$39 \mathrm{~b}$

$24 \mathrm{c}$

$36 \mathrm{~b}$

$34 a, 28 b$

$8 a$

$8 a$

$26 a$

$26 a$

$36 a$

$8 \mathrm{a}$

$36 a$
Gold Coast

Gold Eagle-McKenzie

Gold Hawk

Gold Hill

Gold Hill

Gold Mountain

Gold Point

Gold Quarry

Gold Reef

Gold River

Gold Run (Boulder Co.)

Gold Run (Summit Co.)

Goldbanks

Golden Age

Golden Eagle

Golden Gate

Golden Grove

Golden Jubilee

Golden Ridge

Golden Rule

Golden-El Dorado

Goldenville

Goldfield

Golesh Mt.

Golos

Goncolda

Gongo Socco

Goodenough

Goodnews Bay

Gora Magnitnaya

Gora Vysokaya

Goro

Gorumahisani and others

Gorunur

Goulais

Gove

Governor

Govniikbelen

Goynuk

Gr2h

Gran Piedra

Grand Victory

Grangesberg

Granisle

Granite $\mathrm{Hill}$

Granite King

Grant

Grants

Grass Valley

Gray Boy

Gray Buck Gp.

Gray Eagle

Gray Eagle

Great Dyke

Great Eastern-Mt. Jackson

Green (Americus)

Green Antimony

Green Coast

Green Cove Springs

Green Excelsior

Green Mine

Green Ridge

Green River

Green's Capco Leases

PPNG

CNON

CNON

CNON

USCO

USUT

USCA

USNV

USCA

USCA

USCO

USCO

USNV

CNQU

USCA

USAZ

AUWA

USCA

AUWA

USID

USCA

CNNS

USNV

YUGO

YUGO

USOR

BRZL

CNMN 
Greenback

Greens Creek

Greenvale

Grenville

Grey Eagle

Grey River

Greystone

Gribble

Griffin Chromite

Griffith

Groote Eylandt

Groundhog

Grum

Gruvberget

Guadalupe

Guadalupe \& Calvo

Guadalupe \& Solis

Guanaba Group

Guanacevi

Guana juato

Guillermina

Gujarat

Gullbridge

Gunbasi (Akcakese)

Gundie

Gunlet-Uckopur

Gunliik Basi

Gunn Claims

Guntur

Gurney

Gurranda

Gurrumba Dist.

Guseva Gora

Guttusjon

Gwai River

Gwynne

$\mathrm{HB}$

HW

Hacan

Hagios Ioannis

Hahotoe

Haikou

Hale-Mayabo

Hales Siding

Half Chrome

Half Mile Lake (SG)

Halimba

$\mathrm{HaII}$

Hall Creek

Halliwell

Halmahera

Ham \& Birney

Hambone

Hamme District

Hampton

Hanaoka (Doy.-Tsut.)

Hanaoka (Mats.-Sha.)

Hanawa (Aket.-Osak.)

Hand Camp

Hanover

Hanscum

Hanson Lake

Happy Go Lucky

Happy Return

\begin{tabular}{|c|c|}
\hline suntry & Model No \\
\hline USOR & $36 a$ \\
\hline USAK & $28 \mathrm{a}$ \\
\hline AUQL & $38 a$ \\
\hline GRBR & $15 \mathrm{~b}$ \\
\hline USOR & $27 d$ \\
\hline CNNF & $15 a$ \\
\hline USNV & $31 \mathrm{~b}$ \\
\hline USNV & $27 d$ \\
\hline USOR & $8 a$ \\
\hline USNM & $25 g$ \\
\hline AUNT & $34 b$ \\
\hline USNM & $18 c$ \\
\hline CNYT & $31 \mathrm{a}$ \\
\hline SWDN & $25 i$ \\
\hline $\mathrm{MXCO}$ & $25 \mathrm{~h}$ \\
\hline MXCO & $25 d$ \\
\hline MXCO & $25 i$ \\
\hline CUBA & $24 c$ \\
\hline MXCO & $25 c$ \\
\hline MXCO & $25 c$ \\
\hline CUBA & $8 a$ \\
\hline INDA & $34 b$ \\
\hline CNNF & $28 a$ \\
\hline TRKY & $24 c$ \\
\hline AUNW & $15 b$ \\
\hline TRKY & $8 a$ \\
\hline TRKY & $8 a$ \\
\hline USCA & $8 a$ \\
\hline INDA & $34 a, 28 b$ \\
\hline CNMN & $36 b$ \\
\hline AUNS & $31 b$ \\
\hline AUQL & $15 b$ \\
\hline USSR & 9 \\
\hline SWDN & $30 a$ \\
\hline ZIMB & $30 \mathrm{~b}$ \\
\hline USCA & $36 a$ \\
\hline $\mathrm{CNBC}$ & $31 a$ \\
\hline $\mathrm{CNBC}$ & $28 a$ \\
\hline TRKY & $28 a$ \\
\hline GREC & $38 a$ \\
\hline TOGO & $34 c$ \\
\hline CINA & $34 c$ \\
\hline PLPN & 17 \\
\hline AUQL & $15 b$ \\
\hline USCA & $8 a$ \\
\hline CNMN & $28 a$ \\
\hline HUNG & $38 c$ \\
\hline USNV & $21 b$ \\
\hline $\mathrm{CNBC}$ & $36 a$ \\
\hline CNQU & $28 a$ \\
\hline INDS & $38 a$ \\
\hline USCA & $36 a$ \\
\hline CNMN & $6 b$ \\
\hline USNC & $15 a$ \\
\hline AUQL & $38 b$ \\
\hline JAPN & $28 a$ \\
\hline JAPN & $28 a$ \\
\hline JAPN & $28 a$ \\
\hline CNNF & $24 a$ \\
\hline USNM & $18 c$ \\
\hline USOR & $8 a$ \\
\hline CNSK & $28 a$ \\
\hline USCA & $8 a$ \\
\hline USNV & $27 d$ \\
\hline
\end{tabular}

Name

Country

Model No

Hard Luck

Hard Rock

Hard Rock-McLeod-Cockshutt

Harkoy

Harp and Sons Ranch

Harriet

Harrigan Cove

Harrison

Hasaga-Howey

Haskin Mountain

Hathaway

Hatillo

Hatton

Havelock Mine

Hawks Rest View

Hayden Hill

Hayden and Hilt

Haynsworth

Hazel

Heath Steele

Heddleston

Hedley Camp

Helemar

Helen

Helvetia

Henderson

Hendricks No. 2

Hendricks-Twilight

Henry Ford

Henry district

Herberton

Hercules

Hercules

Hermada

Herman

Herpit Yayla

Herrerias

Hersjo

$\mathrm{Hi}-\mathrm{Yu}$

Hierbaniz

Hierro Indio

Higashiyame

High Dome

High Grade

High Lake

High Plateau

Highland-Trail Ridge

Highmont

Hill-Top Chrome

Hillgrove

Hilton

Hilton Head Island

Hinobaan

Hirabaya

Hiragane

Hirota

Hirst-Chichagof

Hitachi

Hitura

Hixbar

Hodge Ranch

Hoff

Hoidal

Hokitika North
USNV

USFL

CNON

TRKY

USCA

CNBC

CNNS

USCA

CNON

$\mathrm{CNBC}$

USCA

DMRP

USAZ

SWAZ

USOR

USCA

USCA

USFL

USCA

CNNB

USMT

CNBC

USCA

USCA

USAZ

USCO

USCA

USAZ

USAK

USUT

AUQL

AUTN

MXCO

USID

USCA

TRKY

SPAN

NRWY

USAK

MXCO

AGTN

JAPN

USCA

USCA

CNNT

USCA

USFL

CNBC

USCA

AUNS

AUQL

USSC

PLPN

JAPN

JAPN

JAPN

USAK

JAPN

FNLD

PLPN

USCA

USCA

NRWY

NZLD
$27 d$

$34 d$

$36 \mathrm{~b}$

$28 \mathrm{a}$

$8 \mathrm{a}$

$36 a$

$36 a$

$27 \mathrm{c}$

$36 \mathrm{~b}$

$21 \mathrm{~b}$

$36 a$

$18 \mathrm{~d}$

$25 \mathrm{~g}$

$8 d$

$8 a$

$25 d$

$8 \mathrm{a}$

$34 d$

$36 a$

$28 \mathrm{a}$

17

$36 a$

$8 \mathrm{a}$

$27 \mathrm{c}$

17

16

$8 a$

$19 \mathrm{~b}$

$36 a$

$25 \mathrm{f}$

$15 \mathrm{~b}$

$28 \mathrm{a}$

$25 i$

$27 d$

$36 a$

$8 \mathrm{a}$

$28 \mathrm{a}$

$28 \mathrm{a}$

$36 a$

$25 \mathrm{~h}$

$18 d$

$24 \mathrm{~b}$

$8 \mathrm{a}$

$25 d$

$28 \mathrm{a}$

$8 \mathrm{a}$

$39 c$

$21 a$

$8 \mathrm{a}$

$36 \mathrm{a}$

$31 \mathrm{a}$

$39 c$

$20 \mathrm{c}$

$24 b$

$18 \mathrm{~b}$

$24 \mathrm{~b}$

$36 a$

$24 \mathrm{~b}$

$6 \mathrm{a}$

$28 a$

$8 a$

$8 \mathrm{a}$

$28 \mathrm{a}$

$39 \mathrm{c}$ 


\begin{tabular}{|c|c|c|}
\hline Country & Mode1 No & Name \\
\hline NZLD & $39 c$ & Illinsky Log \\
\hline USCA & $8 a$ & Imade \& Ouchi \\
\hline CNON & $36 b$ & Imanccasa \\
\hline USNV & $27 d$ & Imini \\
\hline USCA & $8 a$ & Imori \\
\hline USCA & $8 a$ & Imotski-Mostar \\
\hline CNBC & $31 a$ & Independence \\
\hline USSD & $36 b$ & Indian Chief \\
\hline USAK & $36 a$ & Indian Path Mine \\
\hline AUWA & $6 b$ & Infiernillo \\
\hline CNNT & $28 a$ & Ingerbelle \\
\hline CNBC & $18 \mathrm{~b}$ & Inguaran \\
\hline CNQU & $28 a$ & Innai \\
\hline
\end{tabular}

Hokitika South

Holbrook and McGuire

Hollinger and others

Hollywood

Holseman (and others)

Holston (Vaughn)

Homestake

Homes take

Homestake-McCarty

Honeymoon Well

Hood River

Hope

Horne-Quemont

Hornitos

Horse Canyon

Horse Praire

Horseshoe

Horseshoe

Horseshoe Chrome

Horseshoe I

Hosanger

Hosokura

Hostotipaquilla

Houser \& Burges

Howards Pass

Hoyt

Hsiangtan

Huacravilca

Huai Nai Khao

Hualpai

Huancabamba

Hub

Hubsugul

Huckleberry

Hudson (Fuller Claims)

Hull

Humbug Creek

Hundred Dollar Gulch

Hunnan

Hunter

Hunter Valley

Hunters Road

Huntingdon

Hutt $i$

Hyatt No. 1

Hyers Island

I-Wonder

I.H.X.

Ichinokawa

Iconoclast

Ida $\mathrm{H}$.

Idaho

Idaho Almaden

Idaho-Alamo Group

Idaho-Alamo-Silver Bell

Idaho phosphate

Idfu-Qena

IdikeI

Idkerberget

Iide

Ikisulu-Gercek

Ilave

Iles de Los

Illinois River
USCA $\quad 36 a$

USNV $26 a$

USMT $\quad 39 a$

AUWA 34b

USCA $8 \mathrm{a}$

USOR $8 \mathrm{a}$

USCA $36 a$

NRWY $7 \mathrm{a}$

JAPN $25 b$

MXCO 25c

USOR 8a

CNYT $31 \mathrm{a}$

USNV 27d

CINA $34 b$

PERU 18d

THLD 27d

CNBC 18d

PERU 18d

CZCL 15c

MNGL $34 \mathrm{c}$

CNBC 21a

USCA $8 \mathrm{a}$

CNQU 18d

USOR 39a

USID 39a

CINA 19a

CNQU 28a

USCA

ZIMB

CNQU

INDA

PANA

CNMN

USCA

USNV

JAPN

USCA

AUWA

USID

USID

CNBC

CNBC

USID

EGPT

MRCO

SWDN

JAPN

TRKY

CUBA

GNEA

USOR
Ino

Ino-Capaya

Inskip Point

Inspiration

Intendencia de Arauca

Invincible Lode

Iowa Gulch

Ipaneme

Irene Chromite

Irituia

Iron Duke

Iron Dyke

Iron Hat

Iron Hill

Iron King

Iron King

Iron Mask

Iron Mike

Iron Monarch-Iron Knob

Iron Mountain

Iron Mountain

Iron Mountain

Iron Mountain

Iron Springs

Irsahan

Irvine Bank

Isaac's Harbour

Isla de Pinos

Islahiye

Island Copper

Island Lake

Iso-Magusi-New Insco

Israil

Istranca

Isua

Iszkaszentgyorgy

Itanhandu-Resende

Ithaca Peak

Ivanhoe-Canadian

Ivov $\mathrm{R}$.

Iwami

Iwato

Iyo

Izok Lake

Izushi

J.M. Meadows Group

JVB Claim

Jabal Guyan

Jabal Sayid

Jabiluka

Jack Forth
URRS 39b

JAPN 24b

PERU 18d

MRCO 34b

JAPN 24b

YUGO $38 \mathrm{c}$

USOR $8 \mathrm{a}$

CNBC $\quad 18 b$

CNNS 36a

CILE 25i

CNBC 20C

MXCO 17

JAPN 25d

JAPN 18d

PLPN 17

AUQL $39 c$

USAZ 21a

CLBA $38 \mathrm{~b}$

NZLD $\quad 36 a$

USCO 39a

BRZL $\quad 38 a$

USOR $8 \mathrm{a}$

BRZL $\quad 38 b$

CNBC 18d

USOR $28 \mathrm{a}$

USCA 18d

USCO 10

USAZ $28 \mathrm{a}$

USOR $8 \mathrm{a}$

CNBC 17

CNBC 18d

AUSA

USCA

USNM

USOR

USNM

USUT

TRKY

AUQL

CNNS

CUBA

TRKY

CNBC

CNMN

CNQU

TRKY

TRKY

GRLD

HUNG

BRZL

USAZ

CNBC

URRS

JAPN

JAPN

JAPN

CNNT

JAPN

USAZ

USNM

SAAR

SAAR

AUNT

USCA
$34 a, 28 b$

$28 \mathrm{a}$

$14 a$

$8 \mathrm{a}$

$18 d$

$18 d$

$28 \mathrm{a}$

$15 \mathrm{~b}$

$36 a$

$15 \mathrm{a}$

$38 \mathrm{c}$

17

$36 \mathrm{~b}$

$28 \mathrm{a}$

$28 \mathrm{a}$

$34 \mathrm{~b}$

$34 a, 28 b$

$38 \mathrm{c}$

$38 \mathrm{~b}$

17

$22 \mathrm{c}$

$39 \mathrm{~b}$

$28 \mathrm{a}$

$25 \mathrm{e}$

$24 \mathrm{~b}$

$28 \mathrm{a}$

$24 b$

$25 \mathrm{~g}$

$25 \mathrm{~g}$

$36 a$

$28 \mathrm{a}$

$38 d$

$8 \mathrm{a}$ 
Jack Sprat Gp.

Kalamazoo-San Manuel

Jackson

Jacksonville Area

Jacobina

Jacupuenga

Jajce

Jakobsbakken

Jameland

James Bay

Jamestown

Jamirapat-Khuria

Jamnagar (Saurashtra)

Jarrahdale

Jason

Jay Bird

Jedway

Jefferson City

Jefferson Lake

Jeffrey Lake

Jembaicumbene Creek

Jerez de los Caballeros

Jerome

Jerome

Jerritt Canyon

Jersey Emerald

Jerusalimsky-Priisk

$\mathrm{Jib}$

Jicarilla

Jim Bus

Jo7

Joanne

Joe Walker

Johns

Johnson-Heizer

Joinville

Joliet

Jones Camp

Jordan Creek

Jose

Josefina

Josephine

Josephine No. 4

Josselin

Jourawlik R.

Joutel

Jubilee

Jubilee-New Jubilee

Jud insky-Lojok

Judy (Hicks)

Julian

Julian-Banner

Juncos

June

Jussaari

Jutinicu

K.C.

Kachar

Kadzharan

Kagit Octu

Kahal de Brezina

Kalaa Khasba

Kalahandi-Koraput

Kalahari

Kalamaton

$\begin{array}{lll}\text { USOR } & 8 \mathrm{a} & \text { Kalengwa } \\ \text { USFL } & 39 \mathrm{c} & \text { Kaliapani } \\ \text { BRZL } & 29 \mathrm{a} & \text { Kalimantan Ni } \\ \text { BRZL } & 38 \mathrm{a} & \text { Kalkan } \\ \text { YUGO } & 38 \mathrm{c} & \text { Kalkanli } \\ \text { NRWY } & 28 \mathrm{a} & \text { Kalmakyr } \\ \text { CNON } & 28 \mathrm{a} & \text { Kalushi (Kalulushi) } \\ \text { CNON } & 10 & \text { Kalvbacken } \\ \text { USCA } & 36 \mathrm{a} & \text { Kam Kotia } \\ \text { INDA } & 38 \mathrm{~b} & \text { Kamaishi } \\ \text { INDA } & 38 \mathrm{~b} & \text { Kambaikhin central } \\ \text { AUWA } & 38 \mathrm{~b} & \text { Kambaikhin east } \\ \text { CNON } & 36 \mathrm{~b} & \text { Kambaikhin north } \\ \text { USOR } & 27 \mathrm{~d} & \text { Kambalda } \\ \text { CNBC } & 18 \mathrm{~d} & \text { Kamegamori } \\ \text { USTN } & 32 \mathrm{~b} & \text { Kamenka } \\ \text { USCA } & 8 \mathrm{~d} & \text { Kamenka R. } \\ \text { CNQU } & 8 \mathrm{~d} & \text { Kamenskoe } \\ \text { AUNS } & 39 \mathrm{a} & \text { Kami } \\ \text { SPAN } & 18 \mathrm{~d} & \text { Kamitkita (Kominosawa) } \\ \text { CNON } & 36 \mathrm{~b} & \text { Kamoto } \\ \text { USAZ } & 28 \mathrm{a} & \text { Kansanshi } \\ \text { USNV } & 26 \mathrm{a}, 27 \mathrm{~d} & \text { Kanayama } \\ \text { CNBC } & 31 \mathrm{a} & \text { Kandira } \\ \text { URRS } & 39 \mathrm{~b} & \text { Kangaroo Court Mine }\end{array}$

URRS $\quad 39 b \quad$ Kangaroo Court Mine

CNBC $\quad 18 \mathrm{~d}$

USNM 18d

USOR

NCAL

CNMN

USCA

USOR

USNV

BRZL

CNQU

USNM

USID

CUBA

AGTN

USCA

USOR

CNQU

URRS

CNQU

NZLD

AUVT

URRS

USCA

USCA

USCA

CNBC

CNBC

FNLD

CUBA

USCA

URRS

URAM

TRKY

ALGR

TUNS

INDA

SAFR

PLPN
Kanjamalai

Kankberg

Kanmantoo

Kansa

Kanye

Kaochiao

Kapedhes

Kapin

Kapunda

Kara Tau

Karaculha

Karageban

Karamadazi

Karamea

Karangnunggal

Karani

Karaninar

Karasivri

Karatas

Karatas-Kumocak

Karen

Kartalkoyu

Kasuga

Kata

Katherine

Kauai

Kaunisvaara-Masugnsbyn

Kavadarci.

Kavakcali

Kavakdere

Kawasaki

Kazadere-Kandil

Kedbeg Copper

Kedtrask

Keewenaw

Kefdag-East

Kelapa Kampit
Kaw Mountains
USAZ $\quad 17$

ZMBA $30 \mathrm{~b}$

INDA $\quad 38 a$

INDS $\quad 38 a$

TRKY 18d

TRKY 28a

URUZ 17

ZMBA $\quad 30 \mathrm{~b}$

SWDN $18 c$

CNON $28 \mathrm{a}$

JAPN $18 b$

URRS $18 d$

URRS $18 d$

URRS 18d

AUWA $6 a$

JAPN 24b

URRS $39 b$

URRS $39 \mathrm{~b}$

URRS 34b

BLVA $15 a$

JAPN $28 a$

ZIRE $\quad 30 \mathrm{~b}$

ZMBA 30b

JAPN 24b

TRKY $8 a$

USCA 8a

INDA $34 a, 28 b$

SWDN 28a

AUSA $\quad 30 \mathrm{~b}$

INDA $38 \mathrm{a}$

BOTS $18 \mathrm{e}$

CINA 34b

CYPS $24 a$

TRKY $8 \mathrm{a}$

AUSA $30 \mathrm{~b}$

URRS 340

TRKY 8a

TRKY 8a

TRKY 18d

NZLD $39 \mathrm{c}$

INDS $\quad 25 \mathrm{~g}$

TRKY 8a

TRKY 8a

TRKY 8a

TRKY 25g

TRKY 8a

CNBC 21b

TRKY 8a

JAPN $25 \mathrm{e}$

PERU 25b

USAZ 25c

USHI $38 \mathrm{~b}$

SWDN 18d

YUGO 38a

TRKY $8 \mathrm{a}$

TRKY 8a

FRGN $38 \mathrm{~b}$

JAPN 25d

TRKY 8a

URRS 18b

SWDN 28a

CNYT $\quad 18 b$

TRKY 8a

INDO 15b 
Kelly-Desmond

Kelsey

Kelsey North

Kemikli Inbasi

Kemmangundi and others

Kempfield

Kemptville

Kenbridge

Kennecott

Kennon

Keno Hill-Galena Hill

Kentucky-Illinois

Kerikeri

Kerr Addison

Kesikkopru

Ketstone-Union

Keweenaw

Key Anacon

Key Lake (Deilmann, Gaertner)

Keystone

Keystone

Khans Creek

Kheda (Kaira)

Khnaiguiyah

Khneifiss

Khushab (Sargohda)

Khuzdar

Kiabakari

Kibi

Kidd Creek

Kieslager

Kiirunavaara

Kilembe

Kilic-Kafasi 1

Kilic-Kafasi 2

Killag

Killifreth

Killingdal

Kilo-Moto

Kimheden

King Fissure

King Island

King Solomon

King-King

Kingsford

Kingsley

Kingston

Kinlock

Kinsley

Kinsley North

Kipushi

Kiranocak

Kirwin

Kishu

Kisslaia-Peruonatchainik

Kitlim, Severniy R.

Kittelgruvan

Kizilkaya

Kleinsorge Gp.

Kliripan

Knoxville

Koca

Kodiak Cub

Koff Zone
CNQ

USCA

USCA

TRKY

INDA

AUNS

CNNS

CNON

USNM

PLPN

CNYT

USKN

NZLD

CNON

TRKY

USCA

USMI

CNNB

CNSK

USCA

USCA

AUNS

INDA

SAAR

SYRA

PKTN

PKTN

TNZN

GHNA

CNON

ASTR

SWDN

UGND

TRKY

TRKY

CNNS

GRBR

NRWY

CNGO

SWDN

CNBC

AUTS

USMT

PLPN

USFL

USOR

USNM

SAFR

USCA

USCA

ZIRE

TRKY

USWY

JAPN

URRS

URRS

SWDN

TRKY

USCA

INDS

USCA

TRKY

CNYT

CNMN

\section{$28 a$}

$36 a$

$36 a$

$8 \mathrm{a}$

$34 a, 28 b$

$31 \mathrm{~b}$

$36 a$

$7 \mathrm{a}$

$18 \mathrm{c}$

$20 \mathrm{c}$

$22 \mathrm{c}$

$32 \mathrm{a}, 32 \mathrm{~b}$

$38 \mathrm{~b}$

$36 \mathrm{~b}$

$18 \mathrm{~d}$

$28 \mathrm{a}$

23

$28 \mathrm{a}$

$38 d$

$27 \mathrm{c}$

$28 a$

$28 \mathrm{a}$

$38 \mathrm{~b}$

$28 \mathrm{a}$

$34 \mathrm{c}$

$38 \mathrm{~b}$

$31 \mathrm{~b}$

$36 \mathrm{~b}$

$38 \mathrm{~b}$

$28 \mathrm{a}$

$24 \mathrm{~b}$

$25 i$

$30 b$

$8 a$

$8 a$

$36 a$

$15 \mathrm{~b}$

$28 \mathrm{a}$

$36 \mathrm{~b}$

$28 \mathrm{a}$

$31 \mathrm{a}$

$14 a$

$22 \mathrm{c}$

17

$34 d$

$8 \mathrm{a}$

$19 \mathrm{~b}$

$8 d$

$36 a$

$36 a$

$32 \mathrm{c}$

$8 \mathrm{a}$

17

$20 \mathrm{~b}$

$39 \mathrm{~b}$

$39 \mathrm{~b}$

$28 \mathrm{a}$

$28 \mathrm{a}$

$8 \mathrm{a}$

$25 \mathrm{~g}$

$27 \mathrm{c}$

$8 \mathrm{a}$

$18 \mathrm{~b}$

$28 \mathrm{a}$
Kokkinopezoula

Kokkinoyia

Kolaba-Ratnagiri

Kolar

Kolhapur

Kolubara-Azbest

Komek

Komurluk Koyunun

Kondonakasi

Konkola (Bancroft)

Koolpin Creek

Koolyanobbing

Koongarra

Koprubasi

Koro Plateau

Korobowsky Lojok

Korucular

Kosaka (Motoyama)

Kosaka (Uch.-Uwa.)

Kossia R.

Kossoi-Log

Kossorgskii Log

Kostere

Kotalahti

Kotchkar Mines

Kotsu

Kounrad

Koyama

Koycegiz-Curukcu

Koycegiz-Kurardi

Koycegiz-Orta

Kozyrevka

Krain

Kremmel and Froelich

Kristineberg

Krivoi-Rog

Kroumovo

Kruglogorsk

Krupka

Krutoi Log

Kucuk Yenice

Kudremukh and others

Kudu Asbestos Mine

Kuldoden

Kun Ming

Kundikan-Keluskdere

Kundikan-Kelusktepe

Kune

Kung-changling

Kunitomi

Kupferschiefer

Kure (Asikoy, Bakibaba)

Kurosawa

Kurudere

KurzhunkuI

Kusalpur

Kushikino-Arakawa

Kutch

Kutcho Creek

Kutlular

Kuvarshan

Kuyuluk Isletmesi

Kuzkavak

Kwanika

CYPS $24 a$

CYPS $24 a$

INDA $38 \mathrm{~b}$

INDA $\quad 36 \mathrm{~b}$

INDA $38 \mathrm{~b}$

YUGO 8d

TRKY 8a

TRKY 24c

ANGL $34 \mathrm{c}$

ZMBA $30 \mathrm{~b}$

AUNT 38d

AUWA $34 a, 28 b$

AUNT 38d

TRKY 28a

CHAD $38 b$

URRS 39b

TRKY $24 c$

JAPN $28 \mathrm{a}$

JAPN $28 \mathrm{a}$

URRS 39b

URRS $39 \mathrm{~b}$

URRS 39b

TRKY 28a

FNLD

USSR

JAPN

URKZ

JAPN

TRKY 


\begin{tabular}{llll} 
Country & Model No & & Name \\
\cline { 3 - 4 } FNLD & $7 \mathrm{a}$ & & Laguna Colorado \\
CYPS & $24 \mathrm{a}$ & & Laguna del Cuervo \\
AGTN & $20 \mathrm{c}$ & Lagunazo \\
USNM & $25 \mathrm{f}$ & Laguney \\
SPAN & $24 \mathrm{c}$ & Lahanos \\
MXCO & 17 & Lainijaur \\
CUBA & $8 \mathrm{a}$ & Laisvall \\
MXCO & $18 \mathrm{~d}$ & Lajas \\
MXCO & $25 \mathrm{~h}$ & Lake Asbestos \\
MXCO & $25 \mathrm{~h}$ & Lake Catcha \\
MXCO & $25 \mathrm{~h}$ & Lake City \\
MXCO & $25 \mathrm{~h}$ & Lake Dufault \\
MXCO & $25 \mathrm{~h}$ & Lake George \\
MXCO & $25 \mathrm{~h}$ & Lake Joanina \\
MXCO & $25 \mathrm{~h}$ & Lake Valley \\
MXCO & $27 \mathrm{~d}$ & Lakehurst (Glidden) \\
MXCO & $25 \mathrm{~h}$ & Lakeshore \\
MXCO & $19 \mathrm{a}$ & Lamb Creek \\
MXCO & $25 \mathrm{~h}$ & Lambert \\
MXCO & $25 \mathrm{~h}$ & Lammereck \\
MXCO & $25 \mathrm{~h}$ & Lampazos \\
MXCO & 17 & Lamphear \\
MXCO & $25 \mathrm{i}$ & Lancefield \\
MXCO & $25 \mathrm{~h}$ & Lancha \\
MXCO & $25 \mathrm{~h}$ & LangSen \\
MXCO & $25 \mathrm{~h}$ & Langban \\
SPAN & $28 \mathrm{a}$ & Lanedal
\end{tabular}

Kylmakoski

Kynousa

La Alumbrera

La Bajada

La Calanesa

La Caridad

La Caridad

La Carmen

La Chapeteada

La Chililla

La Chinche

La Chorrera

La Cinta Corrida

La Cocona

La Colocion

La Cruz

La Desparramada

La Encantada

La Escondida

La Esperanza

La Estrella

La Florida

La Grulla

La Guera

La Hormiga

La Huacalona

La Joya

La Joya

La Laguna

La Leona

La Leona (Sonora)

La Libertad

La Libertad

La Liendre

La Loba

La Mula

La Noria

La Paloma

La Perla-La Negra

La Piedra Iman

La Plata District

La Polvosa

La Puntilla

La Quemada

La Reforma

La Torrera

La Triste

La Unica

La Venadita

La Verde

La Vibora

La Victoria

La Victoria

La Vieja-El Agua

La Zarza

Lacey

Lackner Lake

Ladd

Lady Annie

Lady Loretta

Lafayette

Lagnokaha

Lagonoy

Laguerre
SPAN 28a

USCA $27 \mathrm{c}$

DMRP 18d

MXCO 25h

$\mathrm{MXCO} \quad 25 \mathrm{~g}$

MXCO 25d

USCA $27 \mathrm{c}$

MXCO 25h

MXCO 25h

MXCO 25h

$\mathrm{MXCO} \quad 25 \mathrm{~g}$

MXCO 18d

$\mathrm{MXCO} \quad 25 \mathrm{i}$

$\mathrm{MXCO} \quad 18 \mathrm{~d}$

USCO 22b

MXCO 25h

MXCO 25h

MXCO 25h

MXCO 19a

SPAN 28a

MXCO 25h

CUBA $24 \mathrm{c}$

$\mathrm{MXCO} \quad 25 \mathrm{~h}$

MXCO

MXCO

CUBA

MXCO

MXCO

SPAN

USCA

CNON

USCA

AUQL

AUQL

CNQU

UVOL

PLPN

CNON
Langban

Langdal

Langley Chrome

Langmuir 2

Langmuir 1

Langsele

Lapa Cadillac

Lappuattnet

Laramie Range

Larap-Calambayungan

Largentiere

Las Aguilas

Las Amarillas

Las Ambollas

Las Animas Cerro Prieto

Las Brisas

Las Cabesses

Las Calaveras

Las Flores

Las Fundiciones

Las Marias

Las Pegazones

Las Perlitas

Las Tablas

Las Truchas

Las Varas-La Vaca

Lasail

Lasbela

Lassic Peak

Last Buck

Last Chance

Last Chance

Laton

Laukunkawges

Laurium

Lava Bed

Laverton-Mt. Lucky

Lawrencetown

Le Kouif
AGTN

MXCO

SPAN

PLPN

SPAN

SWDN

SWDN

MXCO

CNQU

CNNS

USCO

CNQU

CNNB

GREC

USNM

USNJ

USAZ

USID

USCA

ASTR

MXCO

USCA

AUWA

SPAN

VTNM

SWDN

SWDN

USOR

CNON

CNON

SWDN

CNQU

SWDN

USWY

PLPN

FRNC

$\mathrm{MXCO}$

MXCO

FRNC

MXCO

CLBA

FRNC

MXCO

$\mathrm{MXCO}$

MXCO

$\mathrm{MXCO}$

MXCO

MXCO

MXCO

MXCO

MXCO

OMAN

PKTN

USCA

USOR

USNV

USOR

USCA

FNLD

GREC

USCA

AUWA

CNNS

ALGR
$25 f$

$25 \mathrm{f}$

$28 \mathrm{a}$

$38 \mathrm{a}$

$28 a$

$7 \mathrm{a}$

$30 \mathrm{a}$

$25 \mathrm{~g}$

$8 d$

$36 a$

$25 \mathrm{~b}$

$28 \mathrm{a}$

$27 d$

$38 \mathrm{a}$

$19 \mathrm{~b}$

$39 c$

$18 \mathrm{a}$

$39 a$

$8 \mathrm{a}$

$19 b$

$19 a$

$36 a$

$36 \mathrm{~b}$

$28 \mathrm{a}$

$38 \mathrm{c}$

$18 \mathrm{c}$

$28 a$

$8 a$

$6 a$

$6 a$

$28 \mathrm{a}$

$36 \mathrm{~b}$

$7 \mathrm{a}$

$7 \mathrm{~b}$

$18 d$

$30 \mathrm{a}$

$25 \mathrm{~h}$

$25 \mathrm{~h}$

$19 \mathrm{~b}$

$18 d$

$8 d$

$19 \mathrm{~b}$

$25 \mathrm{~h}$

$25 \mathrm{~h}$

$25 \mathrm{~h}$

$25 \mathrm{~h}$

$25 \mathrm{~h}$

$25 \mathrm{~h}$

$25 \mathrm{~h}$

$18 d$

$25 \mathrm{~g}$

$24 \mathrm{a}$

$24 \mathrm{c}$

$8 a$

$8 a$

$27 d$

$8 a$

$8 a$

$7 \mathrm{a}$

$19 \mathrm{a}$

$18 d$

$24 \mathrm{c}$

$36 \mathrm{a}$

$34 \mathrm{c}$ 
Name

Leadsmith

Lebyazhka

Lee Creek

Legal Tender

Leipsigate

Leitch-Sand River

Lena

Lenora-Twin $\mathrm{J}$

Leoncitos

Lepanto

Letty

Levant

Leveaniemi

Levi

Leviathan

Leviso R.

Liaoning

Liberty (Stanislaw Co.)

Liberty (Siskyou Co.)

Liberty (Calaveras Co.)

Liberty Bond Claim

Lights Creek

Lili

Lily (Ikeno)

Lily Creek

Limasol Forest

Limni

Linda Marie

Lingman

Lingwick

Lion Den

Lithia

Little Bay

Little Boy

Little Castle Creek

Little Chief

Little Hope

Little Long Lac

Little Nell

Little Rock Mine

Little Siberia

Little Squaw

Liverpool

Livitaca-Velille

Llallagua

Llano de Oro

Lobwa $R$.

Locarno

Loch Fyne

Loei-Chiengkarn

Lof thouse

Logwinska

Lohara and others

Lojok No. 1\&2 Omoutnaia

Lojok at Bisserskaya

Lokken

Lolita

Loma de Hierro

Lomero Poyatos

Lomonosov

Lone Gravel

Lone Mary

Lone Mountain

Lone Mountain

\begin{tabular}{|c|c|c|}
\hline Country & Model No & Name \\
\hline CNBC & $22 c$ & Lonesome \\
\hline URRS & $18 \mathrm{~d}$ & Long Ledge Gp. \\
\hline USNC & $34 c$ & Long Point \\
\hline USMT & $22 c$ & Long Tunnel \\
\hline CNNS & $36 a$ & Lord Nelson \\
\hline CNON & $36 \mathrm{~b}$ & Loreto \\
\hline URRS & $30 \mathrm{~b}$ & Lornex \\
\hline CNBC & $28 a$ & Lorraine \\
\hline MXCO & $25 \mathrm{~h}$ & Lorraine \\
\hline PLPN & $22 a$ & Lorraine \\
\hline USCA & $8 a$ & Los Angeles \\
\hline GRBR & $15 \mathrm{~b}$ & Los Arrieros \\
\hline SWDN & $25 i$ & Los Borregos \\
\hline SWDN & $28 a$ & Los Bronces \\
\hline AUVT & $36 a$ & Los Caballos \\
\hline CUBA & $38 a$ & Los Campamentos \\
\hline CINA & $19 a$ & Los Castillos \\
\hline USCA & $24 c$ & Los Condores \\
\hline USCA & $36 a$ & Los Cuatillos \\
\hline USCA & $8 a$ & Los Garcia \\
\hline USCA & $8 a$ & Los Lobos \\
\hline USCA & 17 & Los Mantiales \\
\hline $\mathrm{CNQU}$ & $8 d$ & Los Pelambres \\
\hline $\mathrm{CNBC}$ & $18 \mathrm{~b}$ & Los Pijiguaos \\
\hline AUQL & $34 c$ & Los Pilares \\
\hline CYPS & $8 c$ & Los Pinacates \\
\hline CYPS & $24 a$ & Los Puertos \\
\hline USOR & $8 a$ & Los Vasitos \\
\hline CNON & $36 \mathrm{~b}$ & Los Volcanes \\
\hline $\mathrm{CNQU}$ & $28 a$ & Los Volcanes \\
\hline USCA & $27 \mathrm{c}$ & Lost Creek \\
\hline USNV & $27 d$ & Lost Lake \\
\hline CNNF & $24 a$ & Lost Lee \\
\hline USOR & $8 a$ & Lost River \\
\hline USCA & $8 a$ & Lotty \\
\hline CNYT & $18 \mathrm{~b}$ & Lousal \\
\hline USCA & $8 a$ & Louvem \\
\hline CNON & $36 \mathrm{~b}$ & Lovstrand \\
\hline USMT & $22 c$ & Lowe Placer \\
\hline USCA & $8 a$ & Lower Beaver Creek \\
\hline USOR & $8 a$ & Lowland Creek \\
\hline USAK & $36 a$ & Lowry \\
\hline USMT & $22 c$ & Lubin (Legnica-Glogow) \\
\hline PERU & $18 d$ & Lucia (Generosa) \\
\hline BLVA & $20 \mathrm{a}$ & Lucifer \\
\hline USOR & $39 a$ & Lucky Bart \\
\hline URRS & $39 b$ & Lucky Boy \\
\hline USCA & $36 a$ & Lucky Four \\
\hline AUVT & $36 a$ & Lucky Friday \\
\hline THLD & $18 b$ & Lucky Girl \\
\hline USNV & $27 d$ & Lucky Hunch \\
\hline URRS & $39 b$ & Lucky Knock \\
\hline INDA & $34 a, 28 b$ & Lucky L. \& R. \\
\hline URRS & $39 b$ & Lucky Lass \\
\hline URRS & $39 b$ & Lucky Mike \\
\hline NRWY & $24 a$ & Lucky Nine Gp. \\
\hline CUBA & $8 a$ & Lucky Ship \\
\hline VNZL & $38 a$ & Lucky Shot-War Baby \\
\hline SPAN & $28 \mathrm{a}$ & Lucky Star \\
\hline URRS & $18 \mathrm{~d}$ & Lucky Strike \\
\hline USCA & $8 a$ & Lucky Strike \\
\hline USCA & $36 a$ & Lueshe \\
\hline USNM & $19 \mathrm{~b}$ & Lumbay \\
\hline USNV & $19 a$ & Lumwana \\
\hline
\end{tabular}

USFL $\quad 34$

USCA $8 a$

PLPN $\quad 38 \mathrm{a}$

AUVT $\quad 36 a$

AUVT $36 a$

MXCO 25h

CNBC 21a

CNBC 20c

CNQU $\quad 7 a$

PLPN 24a

MXCO 25h

MXCO 25h

MXCO 25g

CILE $\quad 17$

MXCO 25h

MXCO 25h

VNZL $34 a, 28 b$

AGTN $15 \mathrm{a}$

MXCO 25h

MXCO 25h

MXCO 25h

AGTN 25b

CILE $\quad 17$

VNZL 38b

MXCO 17

MXCO 25h

MXCO $25 f$

MXCO 25i

MXCO 19b

MXCO 25g

USMT $\quad 14 a$

CNMN 28a

USOR $8 \mathrm{a}$

USAK $14 b, 15 c$

USCA $8 a$

PORT 28a

CNQU 28a

SWDN $30 a$

USCO 39a

USCO 39a

USMT $\quad 39 a$

USNV 27d

PLND 30b

CUBA 24c

MXCO $24 \mathrm{c}$

USOR $36 \mathrm{a}$

USCA $8 a$

CNBC $\quad 18 \mathrm{~b}$

USOR $\quad 8 a$

USCA $8 a$

USOR $\quad 8 a$

USWA 27d

USOR $8 \mathrm{a}$

USOR $25 \mathrm{f}$

CNBC $\quad 14 a$

USOR $\quad 8 \mathrm{a}$

CNBC 21b

USAK $36 a$

USOR $\quad 8 a$

USCA $\quad 8 a$

USOR $\quad 8 a$

ZIRE $\quad 10$

PLPN 20c

ZNBA $30 \mathrm{~b}$ 


\begin{tabular}{|c|c|c|c|c|c|}
\hline Name & Country & Model No & Name & Country & Model No \\
\hline Luna-Bash & PLPN & 17 & Manacas Group & CUBA & $24 c$ \\
\hline Luossauaara & SWDN & $25 i$ & Manantenina & MDGS & $38 b$ \\
\hline Lyell Goldfield & NZLD & $36 a$ & Manavalakurichi & INDA & $39 c$ \\
\hline Lyndhurst & CNQU & $28 a$ & Manchester & USCA & $8 a$ \\
\hline Lynn Lake & CNMN & $7 a$ & Manchester (Asarco) & USNJ & $39 c$ \\
\hline Lynx & CNQU & $28 a$ & Manchester Plat. & JMCA & $38 c$ \\
\hline Lynx Creek & USAZ & $39 a$ & Mandy & CNMN & $28 a$ \\
\hline Lyon & USNV & $18 a$ & Manga de Lopez & $\mathrm{MXCO}$ & $25 h$ \\
\hline Lyon Lake & CNON & $28 a$ & Mangampetta $\mathrm{N}$. & INDA & $31 \mathrm{~b}$ \\
\hline$M$ and $M$ Group & USNM & $25 g$ & Mangampetta $\mathrm{S}$. & INDA & $31 b$ \\
\hline Maanshan & HONG & $18 \mathrm{~d}$ & Manganese Chief & USNM & $25 g$ \\
\hline Mabel & USAK & $36 a$ & Manganese Development & USAZ & $25 g$ \\
\hline Mac & $\mathrm{CNBC}$ & $18 \mathrm{~d}$ & Mangula (Miriam) & ZIMB & $30 \mathrm{~b}$ \\
\hline MacArthur & USNV & 17 & Mangum & USOK & $30 \mathrm{~b}$ \\
\hline MacBride Lake & CNMN & $28 a$ & Manhattan & USCA & $27 a$ \\
\hline MacMillan & CNYT & $31 a$ & Manibridge & CNMN & $6 b$ \\
\hline Machimi & JAPN & $24 b$ & Manitou Island & CNON & 10 \\
\hline Machkatica & YUGO & $21 b$ & Mankayan & PLPN & $28 a$ \\
\hline Mackay & USCA & $8 a$ & Mansfeld & GRMY & $30 \mathrm{~b}$ \\
\hline Mackey & USID & $18 \mathrm{~b}$ & Mantos Blancos & CILE & 17 \\
\hline Mactung & CNNT & $14 a$ & Manuel & CUBA & $24 c$ \\
\hline Macusani & PERU & $25 f$ & Manuel Killigrews & CNNF & $34 b$ \\
\hline Madeira & USCA & $8 a$ & Manus Island & PPNG & $38 b$ \\
\hline Madeni & TRKY & $27 d$ & Manzanillas & MXCO & $25 h$ \\
\hline Madenkoy & TRKY & $28 a$ & Mapula & PLPN & $20 \mathrm{c}$ \\
\hline Madhya Pradesh & INDA & $34 b$ & Marais Kiki & NCAL & $8 a$ \\
\hline Madrid & USCA & $8 a$ & Maralls Capro Leases & USCA & $8 a$ \\
\hline Madrigal & PERU & $25 b$ & Maranboy & AUNT & $15 \mathrm{~b}$ \\
\hline Madsen & CNON & $36 b$ & Marangaka & MDGS & $38 b$ \\
\hline Madziwa & ZIMB & $7 a$ & Marbella & SPAN & $18 d$ \\
\hline Magdalena & CUBA & $24 c$ & Marble Bar & AUWA & $36 b$ \\
\hline Magda lena & USNM & $19 a$ & Marble Bay & CNBC & $18 \mathrm{~b}$ \\
\hline Maggie & $\mathrm{CNBC}$ & 17 & Marbridge & CNQU & $6 a$ \\
\hline Maggie Creek & USNV & $26 a$ & Marchinbar Island & AUNT & $38 b$ \\
\hline Maggotty & JMCA & $38 c$ & Marcopper & PLPN & $20 c$ \\
\hline Magnet Cons. & CNON & $36 b$ & Marcos & PLPN & $28 a$ \\
\hline Magnet Cove & USAR & $31 \mathrm{~b}$ & Margaret & USWA & 17 \\
\hline Maikala Range & INDA & $38 b$ & Maria Christina & CILE & $19 a$ \\
\hline Main Valley of Kisslaia & URRS & $39 b$ & Maria Luisa & VNZL & $34 a, 28 b$ \\
\hline Mainpat & INDA & $38 b$ & Marian & PLPN & $20 c$ \\
\hline Maiva & SWDN & $30 a$ & Mariana & BRZL & $38 b$ \\
\hline Majdanpek & YUGO & 17 & Marietta & USMT & $22 c$ \\
\hline Majestic-Sapphire & $\mathrm{CNBC}$ & $22 c$ & Mariners & AUVT & $36 a$ \\
\hline Makhtesh & USRL & $34 c$ & Mariposa & USCA & $36 a$ \\
\hline Makimine, Hibira & JAPN & $24 b$ & Marks \& Tompson & USOR & $8 a$ \\
\hline Makola & FNLD & $7 a$ & Marlborough & AUQL & $38 a$ \\
\hline Malaia Koswa R. & URRS & $39 b$ & Marmoraton & CNON & $18 \mathrm{~d}$ \\
\hline Malaia Prostokischenka & URRS & $39 b$ & Marquette & USMN & $34 a, 28 b$ \\
\hline Malaia Sosnowka & URRS & $39 b$ & Martian $\mathrm{R}$. & URRS & $39 b$ \\
\hline Malaiba & PLPN & $28 a$ & Martin-Bird & CNON & $36 b$ \\
\hline Malden North & AUVT & $36 a$ & Martinovo & BULG & $18 d$ \\
\hline Malko Trnova & BULG & $18 b$ & Martison Lake & CNON & 10 \\
\hline Malmberget & SWDN & $25 i$ & Mary Jane & USCA & $8 a$ \\
\hline Malmbjerg & GRLD & 16 & Mary Walker & USOR & $8 a$ \\
\hline Malomalsky-Priisk & URRS & $39 b$ & Marysvale & USUT & $25 f$ \\
\hline Malot Pokap & URRS & $39 b$ & Marysville District & USMT & $22 c$ \\
\hline Mamie & CNBC & $28 a$ & Mascot & USTN & $32 b$ \\
\hline Mammoth & USAZ & $19 \mathrm{~b}$ & Masinloc & PLPN & $38 a$ \\
\hline Mammoth (Kern Co.) & USCA & $28 a$ & Maslovo & URRS & $18 \mathrm{~d}$ \\
\hline Mammoth (Shasta Co.) & USCA & $36 a$ & Mason Valley-Malachite & USNV & $18 \mathrm{~b}$ \\
\hline Mammoth (Gunpowder) & AUQL & $30 \mathrm{~b}$ & Masonic & USCA & $25 \mathrm{e}$ \\
\hline Mammoth-St. Anthony & USAZ & $22 c$ & Matachewan Cons. \& others & CNON & $36 b$ \\
\hline Mamuro & JAPN & $25 d$ & Matamoros & MXCO & 258 \\
\hline Mamut & MDGS & $20 c$ & Matchless & NAMB & $30 \mathrm{~b}$ \\
\hline
\end{tabular}


Matchless West

Matese-Ciociaria

Mathiati North

Mati

Matona-Stairs

Matt Berry

Mattabi

Mattagami Lake

Maubach

Maude \& Yellow Girl

Maurice Bay

Mavrovouni

Mawchi

Maxwell

Mayari

Mayflower

Maykhura

Mazagao

Mazama

Mazapil

Mazidagi

Mbeya

McAdam

McArthur

McCaleb's Sourdough

McCarty

McClean Lake

McConnell

McCormick

McDame Belle

McDermitt

McFinley

McGlaughlin

McGuffy Creek Gp.

McMarmac

McMaster

McMurty

McWatters

McWatters

Mdilla

Meat Cove

Mechernich

Meeker (Sonoma Chrome)

Megara-Eleusis

Meggen

Meggen Barite

Mel Barite

Melnitschnaia

Meme

Menominee

Menzies

Mercedes

Mercur

Merrifield

Merrimac

Mesabi

Meskala

Metal Negro

Metalline

Metcalf

Metlaoui

Metsamonttu

Meululter

Mezcala

\begin{tabular}{|c|c|c|}
\hline NAMB & $30 b$ & Mic Mac \\
\hline ITLY & $34 b$ & Michiquillay \\
\hline CYPS & $24 a$ & Midas \\
\hline PLPN & $18 d$ & Middle Fork \\
\hline $\mathrm{CNON}$ & $36 b$ & Middle Ore Body \\
\hline CNYT & $31 a$ & Midlothian \\
\hline CNON & $28 a$ & Midwest Lake \\
\hline CNQU & $28 a$ & Mighty Joe \\
\hline GRMY & $30 a$ & Mikado \\
\hline AUVT & $36 a$ & Milan \\
\hline CNSK & $38 d$ & Milford area \\
\hline CYPS & $24 a$ & Millenbach \\
\hline BRMA & $15 b$ & Miller Lake \\
\hline USCA & $8 a$ & Milton \\
\hline CUBA & $38 a$ & Milton Canyon \\
\hline USCA & $8 a$ & Mimoso do Sul \\
\hline URTD & $14 a$ & Mina Dura \\
\hline BRZL & $38 b$ & Mina El Sapo \\
\hline USWA & 17 & Mina Vieja \\
\hline $\mathrm{MXCO}$ & $19 a$ & Mina del Aire \\
\hline TRKY & $34 c$ & Minarets \\
\hline TNZN & 10 & Minas Gerais \\
\hline CNQU & $8 d$ & Minawa \\
\hline AUNT & $31 a$ & Mineral Butte \\
\hline USOR & $8 a$ & Mineral King \\
\hline USCA & $8 a$ & Mineral Park \\
\hline CNSK & $38 d$ & Mineville-Port Henry \\
\hline CNBC & $18 b$ & Minim-Martap \\
\hline USCA & $8 a$ & Minniehaha \\
\hline $\mathrm{CNBC}$ & $18 c$ & Minto \\
\hline USNV & $27 \mathrm{a}$ & Minto-Tyranite \\
\hline CNON & $36 b$ & Mirabel \\
\hline USCA & $25 a$ & Mirandag Koru \\
\hline USCA & $8 a$ & Mirandag Mevki \\
\hline CNON & $36 b$ & Miriam \\
\hline CNNB & $28 a$ & Misima Island \\
\hline USCA & $8 a$ & Missouri Creek \\
\hline CNON & $6 a$ & Mistry \\
\hline CNQU & $36 b$ & Mitate \\
\hline TUNS & $34 c$ & Mitchell Creek \\
\hline CNNS & $18 c$ & Mitchell Plateau \\
\hline GRMY & $30 a$ & Mitchell River \\
\hline USCA & $8 a$ & Miyawa \\
\hline GREC & $38 c$ & Mizobe \\
\hline GRMY & $31 a$ & Mizpah \\
\hline GRMY & $31 b$ & Mizpah \\
\hline CNYT & $31 b$ & Mjodvattnet \\
\hline URRS & $39 b$ & Mlanje Mountain \\
\hline HATI & $18 b$ & Moa Bay \\
\hline USMN & $34 a, 28 b$ & Moak \\
\hline AUWA & $36 b$ & Mobrun \\
\hline CUBA & $19 b$ & Mocha \\
\hline USUT & $26 a$ & Mochikoshi \\
\hline USCA & $8 a$ & Mockingbird \\
\hline USNV & $27 d$ & Mocoa \\
\hline USMN & $34 a, 28 b$ & Modarelli. \\
\hline MRCO & $34 c$ & Moengo \\
\hline $\mathrm{MXCO}$ & $25 \mathrm{~h}$ & Moffett Creek Gp. \\
\hline USWA & $32 a, 32 b$ & Mofjell \\
\hline USAZ & 17 & Mogi das Cruzes \\
\hline TUNS & $34 c$ & Mogollon \\
\hline FNLD & $28 a$ & Mogpog \\
\hline TRKY & $8 a$ & Mohave \\
\hline $\mathrm{MXCO}$ & $25 g$ & Mohawk Claim \\
\hline
\end{tabular}

CNQU

PERU

USCA

USWA

PLPN

CNON

CNSK

USOR

USAK

USNH

USUT

CNQU

CNNS

USCA

USNV

BRZL

MXCO

CLBA

CLBA

MXCO

USCA

BRZL

JAPN

USAZ

CNBC

USAZ

USNY

CMRN

CNBC

CNBC

CNON

USCA

TRKY

TRKY

AUWA

PPNG

USCO

CNBC

JAPN

USMT

AUWA

AUQL

JAPN

JAPN

USAK

USNV

SWDN

MLWI

CUBA

CNMN

CNQU

CILE

JAPN

USOR

CLBA

USNV

SRNM

USCA

NRWY

BRZL

USNM

PLPN

USCA

USOR
$28 \mathrm{a}$

17

$36 a$

17

$8 a$

$8 d$

$38 d$

$8 \mathrm{a}$

$36 a$

$28 a$

$14 a$

$28 \mathrm{a}$

$36 a$

$8 \mathrm{a}$

$27 d$

$38 \mathrm{~b}$

$25 \mathrm{~h}$

$18 \mathrm{~b}$

$18 \mathrm{~b}$

$25 \mathrm{~h}$

$25 i$

$34 \mathrm{a}, 28 \mathrm{~b}$

$24 \mathrm{~b}$

17

$31 \mathrm{a}$

$22 \mathrm{c}$

$25 i$

$38 \mathrm{~b}$

$22 \mathrm{c}$

$36 a$

$36 \mathrm{~b}$

$27 \mathrm{c}$

$8 a$

$8 a$

$6 a$

$22 \mathrm{c}$

$39 a$

17

$19 a$

$39 a$

$38 \mathrm{~b}$

27d

$24 \mathrm{~b}$

25d

$36 \mathrm{a}$

$27 d$

$7 \mathrm{a}$

$38 \mathrm{~b}$

$38 \mathrm{a}$

$6 \mathrm{~b}$

$28 \mathrm{a}$

17

$25 c$

$8 \mathrm{a}$

17

$25 i$

$38 \mathrm{~b}$

$8 \mathrm{a}$

$28 \mathrm{a}$

$38 \mathrm{~b}$

$25 \mathrm{c}$

$18 d$

$25 \mathrm{e}$

$8 a$ 
Mohawk-Dome View

Moina

Moinho

Mokambo

Mokanji Hills

Moke lumne

Mokoman Lake

Moladezhnoye

Molango

Molega

Moleon Lake

Molitchowka

Molly Gibson

Monarch-Kicking Horse

Monghyr

Monitor

Moniwa

Monpas

Mons Cupri

Montana

Montaque

Montcalm

Monte Carmelo

Montenegro-Adriana

Montezuma

Montezuma

Montosa

Montredon

Moonlight

Moore

Moore's Flat

Moorsom

Moose Mountain

Moose River

Moosehead

Mooseland

Moramanga

Mordey

Morenci

Moreton Island

Mormon Bar

Morning Star

Morococha

Morphine-Log

Morrachini

Morris Ravine

Morris-Kirkland

Morrison

Morro Velho

Morro da Mina

Morro de Engenho

Mos

Moscatelli

Moscatelli No. 2

Moskogaissa

Moss Vale

Mother Lode

Mother Lode-Sunset

Motoyasu

Moulares

Moulton Hill

Mount Bischoff

Mount Bulga

Mount Bullion
Mount Canninda

Mount Chalmers

Mount Ejuanema-Nsisreso

Mount Emmons

Mount Finch (Rum Jungle)

Mount Gaines

Mount Gibson

Mount Gould

Mount Hale

Mount Hope

Mount Hundere

Mount Isa

Mount Lyell

Mount Morgan

Mount Mulcahy

Mount Nolan Dist.

Mount Paynter

Mount Philip

Mount Pleasant

Mount Saddleback

Mount Shasta

Mount Thomlinson

Mount Tolman

Mount Uniacke

Mount Vernon

Mount Wellington

Mountain Chief and vicinity

Mountain Con

Mountain King

Mountain Mines

Mountain Pass

Mountain Springs

Mountain View

Mountain View Gp.

Mousoulos-Kalavasos

Mowbray Creek

Moxie Pluton

Mrata

Mrima

Mrima Hill

Mt. Diablo

Mt. Edwards

Mt. Gunson

Mt. Keith

Mt. Magnet

Mt. Morgans

Mt. Oxide

Mt. Sholl

Mt. Windarra

MuNaly

Mufulira

Mugi

Mulcahy Prospect

Mule Creek

Mum and Alice June Claim

Munbinea Shoreland

Munda

Munesada

Munmorah

Munro

Murguia

Murgul

Muriwai
AUNT

AUQL

AUQL

AUNS

USCO

AUNT

USCA

AUWA

AUWA

AUWA

USNV

CNYT

AUQL

AUTS

AUQL

AUWA

AUQL

AUNS

AUQL

USCA

AUWA

USCA

CNBC

USWA

CNNS

USCA

GRBR

CNBC

CNBC

USCA

PLPN

USCA

USNV

USCA

USCA

CYPS

AUQL

USMA

TUNS

KNYA

KNYA

USCA

AUWA

AUSA

AUWA

AUWA

AUWA

AUQL

AUWA

AUWA

USCA

ZMBA

JAPN

USCA

USCA

USCA

AUWA

AUWA

JAPN

AUNS

CNON

MXCO

TRKY

NZLD
$38 \mathrm{~d}$

17

$28 \mathrm{a}$

$38 \mathrm{~b}$

16

$38 d$

$36 \mathrm{a}$

$34 a, 28 b$

$34 a, 28 b$

$34 a, 28 b$

16

$18 \mathrm{c}$

$31 \mathrm{a}$

$28 \mathrm{a}$

$28 \mathrm{a}$

$28 \mathrm{a}$

$15 \mathrm{~b}$

$15 \mathrm{~b}$

$34 a, 28 b$

$36 a$

$38 \mathrm{~b}$

$36 \mathrm{a}$

$21 \mathrm{~b}$

$21 \mathrm{~b}$

$36 \mathrm{a}$

$36 a$

$15 \mathrm{~b}$

$22 \mathrm{c}$

$22 \mathrm{c}$

$36 \mathrm{a}$

$20 \mathrm{c}$

10

$31 \mathrm{~b}$

$8 a$

$8 a$

$24 a$

$15 b$

$7 a$

$34 \mathrm{c}$

$24 \mathrm{c}$

10

$27 \mathrm{c}$

$6 a$

$30 \mathrm{~b}$

$6 \mathrm{~b}$

$36 \mathrm{~b}$

$36 \mathrm{~b}$

$30 \mathrm{~b}$

$7 a$

$6 a$

$8 a$

$30 \mathrm{~b}$

$27 \mathrm{~d}$

$8 \mathrm{a}$

$8 a$

$8 \mathrm{a}$

$39 \mathrm{c}$

$6 a$

$18 \mathrm{~d}$

$39 \mathrm{c}$

$8 d$

$25 \mathrm{~g}$

$28 \mathrm{a}$

$39 \mathrm{c}$ 


\begin{tabular}{|c|c|c|c|c|c|}
\hline Name & Country & Model No & Name & Country & Model No \\
\hline Murphy & USCA & $8 a$ & New Hosco & CNQU & $28 a$ \\
\hline Murray Brook & CNNB & $28 a$ & Newfoundland Zinc & CNNF & $32 a, 32 b$ \\
\hline Musa Danisman & TRKY & $8 a$ & Newman & USCA & $8 a$ \\
\hline Musan & NKOR & $34 a, 28 b$ & Newton & USCA & $28 a$ \\
\hline Musonoi & ZIRE & $30 \mathrm{~b}$ & Nhamunda & BRZL & $38 b$ \\
\hline Musoshi & ZIRE & $30 \mathrm{~b}$ & $\mathrm{Ni} \mathrm{Te}$ Ocutes & CUBA & $8 a$ \\
\hline Mutum & BLVA & $34 a, 28 b$ & Niasman R. & URRS & $39 b$ \\
\hline Muzaffarabad & PKTN & $38 \mathrm{c}$ & Nichelini Mine & USCA & $8 a$ \\
\hline Muzo & CLBA & $31 c$ & Nickel Mountain & USOR & $38 a$ \\
\hline Muzzleloader (Stevens No. 1) & USCA & $8 a$ & Nickel Mountain & USOR & $8 a$ \\
\hline Mwaytung & BRMA & $38 a$ & Nickel Ridge & USOR & $8 a$ \\
\hline Myalla & AUNT & $38 b$ & Nicolet Asbestos & CNQU & $8 d$ \\
\hline Myra Falls-Lynx & CNBC & $28 a$ & Nieves & $\mathrm{MXCO}$ & $27 d$ \\
\hline Mystery Lake & CNMN & $6 \mathrm{~b}$ & Niggerhead & USNM & $25 \mathrm{~g}$ \\
\hline Mzaita & ALGR & $34 c$ & $\mathrm{Nii}$ & JAPN & $24 b$ \\
\hline N. Stradbroke Island & AUQL & $39 c$ & Nikolaevskoe & URRS & $34 b$ \\
\hline N.L. Industries (Aurora) & USNC & $39 c$ & Nikolai-Tschoudotworsky & URRS & $39 b$ \\
\hline NW Group & GUYN & $38 b$ & Nikopol & URRS & $34 b$ \\
\hline Nabarlek & AUNT & $38 d$ & Niksicka Zupa & YUGO & $38 c$ \\
\hline Nacimiento & USNM & $30 \mathrm{~b}$ & Nilgiri Hills & INDA & $38 b$ \\
\hline Nacozari & $\mathrm{MXCO}$ & $25 \mathrm{~g}$ & Nimiuktuk & USAK & $31 b$ \\
\hline Nagamatsu & JAPN & $25 d$ & Nimpkish & CNBC & $18 d$ \\
\hline Nagyegyhaza & HUNG & $38 c$ & Nimrod & AUVT & $36 a$ \\
\hline Nahal-Zin & ISRL & $34 c$ & Nine Mile Brook & CNNB & $28 a$ \\
\hline Naica & MXCO & $19 a$ & Niquelandia & BRZL & $38 a$ \\
\hline Nakatatsu & JAPN & $19 a$ & Nishinokawa & JAPN & $24 b$ \\
\hline Nakayama & JAPN & $24 b$ & Nizne-Udinskaja & URRS & $34 b$ \\
\hline Nakerivaara & SWDN & $25 i$ & Noamundi-Joda-Gua etc. & INDA & $34 a, 28 b$ \\
\hline Nalden South & AUVT & $36 a$ & Noble Electric Co. & USCA & $8 a$ \\
\hline Namosi & FIJI & 17 & Nobles Nob & AUWA & $36 b$ \\
\hline Naniango & UVOL & $34 \mathrm{~b}$ & Nogal & USNM & $25 b$ \\
\hline Nanisivik & CNNT & $32 a, 32 b$ & Noji & JAPN & $24 b$ \\
\hline Nanogawa & JAPN & $24 b$ & Nonoc & PLPN & $38 a$ \\
\hline Narciso & CUBA & $8 a$ & Nonowaki & JAPN & $24 b$ \\
\hline Naruyasu & JAPN & $24 \mathrm{~b}$ & Noonday & CNBC & $22 c$ \\
\hline Nashville & USCA & $36 a$ & Norah & ZIMB & $30 b$ \\
\hline Nasliden & SWDN & $28 a$ & Noralyn-Phosphoria & USFL & $34 d$ \\
\hline Nassau Mountains & SRNM & $38 b$ & Norberg & SWDN & $34 a, 28 b$ \\
\hline Natchez Trace State & USTN & $39 c$ & Noreross & USCA & $8 a$ \\
\hline National & CNQU & $8 d$ & Nordre Gjetryggen & NRWY & $28 a$ \\
\hline National & USCA & $36 a$ & Noril'sk & USSR & $5 b$ \\
\hline Navan & IRLD & $31 a$ & Norita & CNQU & $28 a$ \\
\hline Nawa ji & JAPN & $25 c$ & Normandie/Penhale & CNQU & $8 d$ \\
\hline Naybob & $\mathrm{CNON}$ & $36 b$ & Normetal & CNQU & $28 a$ \\
\hline Neardie & AUQL & $27 d$ & Norseman-Dundas & AUWA & $36 \mathrm{~b}$ \\
\hline Needle Hill & HONG & $15 a$ & North Arkansas-Ozark & USAR & $32 a, 32 b$ \\
\hline Needle Mountain & CNCQ & $18 a$ & North Boundary & CNNB & $28 \mathrm{a}$ \\
\hline Nemogos & $\mathrm{CNON}$ & 10 & North Camden (Keer-McGee) & USTN & $39 c$ \\
\hline Nepean & AUWA & $6 a$ & North Carolina phospate & USNC & $34 d$ \\
\hline Nepisiguit & CNNB & $28 a$ & North Cerbat (Golconda) & USAZ & $22 c$ \\
\hline Nepoui & NCAL & $38 a$ & North End, West End, Spotted & Fawn & USCA8a \\
\hline Nevada King & USNV & $27 d$ & North Florida phosphate & USFL & $34 d$ \\
\hline Nevada Sulphur co. & USNV & $27 a$ & North Fork & USWA & 17 \\
\hline Nevada-Massachusetts & USNV & $14 a$ & North Fork Chrome & USCA & $8 a$ \\
\hline Nevada-Scheelite & USNV & $14 a$ & North Keystone & USCA & $28 a$ \\
\hline New Almaden & USCA & $27 c$ & North Mocassin & USMT & $22 b$ \\
\hline New Bay Pond & CNNF & $28 a$ & North Murphy & USCA & $36 a$ \\
\hline New Bendigo & AUVT & $36 a$ & North Star & CNMN & $28 \mathrm{a}$ \\
\hline New Calumet & CNQU & $19 a$ & North Star & USAK & $36 a$ \\
\hline New Cuyama & USCA & $34 c$ & North Star & USOR & $8 a$ \\
\hline New Era-Rowe & AUVT & $36 a$ & North Star (Red Mtn) & USCA & $8 a$ \\
\hline New Frontier & PLPN & $38 a$ & North Weipa & AUQL & $38 b$ \\
\hline New Hope & USCA & $8 a$ & Northair & CNBC & $28 a$ \\
\hline New Hope Claim & USOR & $8 a$ & Northeast Florida & USFL & $34 d$ \\
\hline
\end{tabular}




\begin{tabular}{|c|c|c|}
\hline Country & Model No & Name \\
\hline IRAN & $25 i$ & Oregon \\
\hline $\mathrm{CNBC}$ & $22 c$ & Oregon \\
\hline IRLD & $38 b$ & Oregon Bell \\
\hline USNV & $26 a$ & Oregon Chrome \\
\hline USNV & $31 b$ & Orendere \\
\hline USOR & $8 a$ & Orient \\
\hline AUNS & $15 b$ & Oriential \\
\hline ITLY & $25 f$ & Orijarvi \\
\hline URRS & $18 d$ & Orissa (Chatrapur) \\
\hline URRS & $18 d$ & Oro Denoro (Ema) \\
\hline URRS & $39 b$ & Oro Grande-Buena Vista \\
\hline CLBA & $27 b$ & Orogrande \\
\hline USID & $39 a$ & Oronta \\
\hline AUVT & $36 a$ & Orpit \\
\hline SAAR & $28 a$ & Orsk \\
\hline VNZL & $38 b$ & Orta Ezan \\
\hline NRWY & $24 a$ & Osamu Utsumi \\
\hline GHNA & $38 b$ & Osbourne Lake \\
\hline HUNG & $38 c$ & Osen \\
\hline AUQL & $15 b$ & Osgood Range \\
\hline NRWY & $18 c$ & Oshio \\
\hline AUVT & $36 a$ & Osokino-Aleksandrovsk \\
\hline
\end{tabular}

Northern Anomaly

Northern Bell-Jackson

Northern Ireland

Nor thumberland

Northumberland barite

Norway

Nount Wells

Novazza

Novo Maslovo

Novo Peschansk

Novoi-Log

Nueva Esperanza

Nugget Creek (South Fork)

Nuggetty

Nuqrah

Nuria

Ny Sulitjelma

Nyinahin

Nyirad

Nymbool Dist.

Nyseter

O'Connors

Oak Grove (Ethyl)

Oak Ridge

Oakleigh Creek

Oamite

Oatman

Oberpfalz

Obi

obira

Obodranny-Lojok

Ochanocagi

Ocna de Fier

$\mathrm{Oe}$

Ofelia

Offshore

Ogane

Ohguchi

Ohito

Ok

Ok Tedi

Oka

Okuki

Old Dad Mountains

old Diggings

old Waite

Oldham

Olinghouse

Olive $B$.

Olsen

Olympias Chalkidiki

Olympic Dam

Omine

Onion Springs

Opalite

Ophir

Ophir

Ophir

Ophir

Ora Banda

Orange $\mathrm{Hill}$

Orange Point

Orchan

Ore Drag
USTN

USCA

AUTS

NAMB

USAZ

GRMY

INDS

JAPN

USSR

TRKY

RMNA

JAPN

CUBA

USGA

JAPN

JAPN

JAPN

CNBC

PPNG

CNQU

JAPN

USCA

USCA

CNQU

CNNS

USNV

USOR

USCA

GREC

AUSA

JAPN

USOR

USOR

USCA

USCO

USMT

USUT

AUWA

USAK

USAK

CNQU

USNV
$39 c$

$8 a$

$15 \mathrm{a}$

$30 \mathrm{~b}$

$25 \mathrm{c}$

$30 \mathrm{a}$

$38 \mathrm{a}$

$18 \mathrm{~b}$

$39 b$

$8 \mathrm{a}$

$18 d$

$25 \mathrm{~b}$

$8 \mathrm{a}$

$34 d$

$25 \mathrm{~b}$

$25 \mathrm{c}$

$25 \mathrm{c}$

17

$20 \mathrm{c}$

10

$24 \mathrm{~b}$

$18 d$

$36 a$

$28 \mathrm{a}$

$36 a$

$25 \mathrm{c}$

$8 \mathrm{a}$

82

$19 a$

$29 b$

$24 b$

$8 \mathrm{a}$

$27 a$

$36 a$

$25 \mathrm{~b}$

$39 a$

$19 a$

$38 \mathrm{a}$

17

$28 \mathrm{a}$

$28 \mathrm{a}$

$27 d$
Ostra Hogkulla

ot josondu

Otmanlar-Harpuzlu

Otmanlar-Mesebuku

Ottery Lode

Oturehua Field

Oulad-Abdoun

Ourem

Ouse

Ovens

Oviachic $1 \& 2$

Oxec

Oxford

Oya

P. B.

P. U. P. (Zenith)

$\mathrm{Pa}-$ pan-ling

Pabineau River

Pachuca-Real del Monte

Pactolus

Paddy's Flat

Padurea Craiului

Page

Pahang

Painirova

Palette

Palmer's Find

Palni Hills

Palo Colorado

Paloma-Gwin

Pambuhan Sur

Pampa Norte

Pampachiri

Panamana-An

Panasqueria

Panchillo

Panguana

Panguna

Panowka

Panther

Paparoa Range

Paracale

\begin{tabular}{|c|c|}
\hline CNBC & $18 \mathrm{~b}$ \\
\hline USAZ & $19 b$ \\
\hline USOR & $36 a$ \\
\hline USOR & $8 a$ \\
\hline TRKY & $27 d$ \\
\hline USWA & $25 c$ \\
\hline AUVT & $36 a$ \\
\hline FNLD & $28 a$ \\
\hline INDA & $39 c$ \\
\hline CNBC & $18 \mathrm{~b}$ \\
\hline USCA & $36 a$ \\
\hline USNM & $18 d$ \\
\hline ISRL & $34 c$ \\
\hline CNON & $36 b$ \\
\hline URRS & $38 a$ \\
\hline TRKY & $8 a$ \\
\hline BRZL & $25 \mathrm{f}$ \\
\hline CNMN & $28 a$ \\
\hline NRWY & $30 a$ \\
\hline USNV & $14 a$ \\
\hline JAPN & $28 a$ \\
\hline URRS & $18 \mathrm{~d}$ \\
\hline SWDN & $28 a$ \\
\hline SAFR & $34 b$ \\
\hline TRKY & $8 a$ \\
\hline TRKY & $8 a$ \\
\hline AUNS & $15 b$ \\
\hline NZLD & $36 a$ \\
\hline MRCO & $34 c$ \\
\hline BRZL & $38 b$ \\
\hline AUTS & $38 b$ \\
\hline CNNS & $36 a$ \\
\hline MXCO & $25 g$ \\
\hline GUAT & $24 a$ \\
\hline USCA & $8 a$ \\
\hline JAPN & $36 a$ \\
\hline NCAL & $8 a$ \\
\hline USCA & $8 a$ \\
\hline CINA & $34 a, 28 b$ \\
\hline CNNB & $28 \mathrm{a}$ \\
\hline $\mathrm{MXCO}$ & $25 b$ \\
\hline USCO & $39 a$ \\
\hline AUWA & $36 b$ \\
\hline RMNA & $38 c$ \\
\hline USNV & $27 d$ \\
\hline MLYS & $15 b$ \\
\hline SWDN & $25 i$ \\
\hline AUNT & $38 d$ \\
\hline AUWA & $36 b$ \\
\hline INDA & $38 b$ \\
\hline $\mathrm{MXCO}$ & $25 \mathrm{~h}$ \\
\hline USCA & $36 a$ \\
\hline PLPN & $18 \mathrm{~d}$ \\
\hline CILE & 17 \\
\hline PERU & $18 d$ \\
\hline PLPN & $8 a$ \\
\hline PORT & $15 a$ \\
\hline MXCO & $25 \mathrm{~h}$ \\
\hline PPNG & $20 c$ \\
\hline PPNG & 17 \\
\hline URRS & $39 b$ \\
\hline USNV & $27 d$ \\
\hline NZLD & $36 a$ \\
\hline PLPN & $18 d$ \\
\hline
\end{tabular}


Name

Paradise

Paragominas

Paramillos

Paranam

Parish

Park

Park City

Park's Ranch

Parker

Parkeson

Parks

Parnassus-Helikon

Paronen

Parroquio-Magistral

Parys Mountain

Pashpap

Passagem

Pasto Bueno

Pasuquin

Patchek

Pater

Patos de Minas

Patrick

Patriquin

Patterson

Paulista

Payas

Paymogo

Payne Group

Pea Ridge

Pearsoll Peak

Pecos

Peewan

Peg Leg (Lambert)

Pelican

Pen-chi-hu

Pena Colorada

Penn

Pennington Butte

Pennsylvania

Penobscot

Penryn

Peravasa

Perconi Ranch

Perda Niedda

Pergini

Perrunal

Persberg

Perseverance

Peschansk

Pestchanka R.

Petaquilla

Petersen Mtn.

Phedinan R.-Triok

Phelps Dodge

Philipsburg

Phillips Lease

Phoenix

Phoenix

Phoenix

Piacoa

Picacho

Picila

Pickle Crow

\section{Count}

USOR

BRZL

AGTN

SRNM

AUNS

USTN

USUT

USCA

USCA

USCA

AUNS

GREC

FNLD

MXCO

GRBR

PERU

BRZL

PERU

PLPN

URRS

CNON

BRZL

USCA

USCA

USCA

BRZL

TRKY

SPAN

CNBC

USMO

USOR

USNM

USCA

USCA

USWI

CINA

MXCO

USCA

USOR

USCO

USME

USCA

CYPS

USCA

ITLY

TRKY

SPAN

SWDN

ZIMB

URRS

URRS

PANA

USCA

URRS

CNQU

USMT

USNM

BOTS

CNBC

USCA

VNZL

USCA

MXCO

CNON
Model No Name

Picuris

Piddig

Pikwe

Pilleys Island

Pillikin

Pima-Mission

Pine Bay

Pine Creek

Pine Grove

Pine Mountain Claim

Pine Nut

Pine Point

Pines

Pinnacles

Pinson

Pintada-Stauber

Pioneer

Pipe

Pipestem

Piray

Pirki

Piskala

Pitman (JB)

Pito Real

Placerville

Plagia

Plan de Tecolotes

Platies

Pleasant No. 1 \& 2

Pleasant River

Plomosas

Pluma Hidalgo

Plurhinaler

Poco Tiempo Quartz

Pocos de Caldas

Podbornaia

Podmoskowoi-Log

Poerua River

Point Leamington

Poirier

Poison Mountain

Pokrovsk

Polar Star

Polaris-Eclipse

Poludnig-Hermagor

Pomalea

Pontbriand

Ponupo

Ponupo de Manacal

Pony Shoe

Poodle Dog

Popowsky-Lojok

Popretschne-Log

Porkonen

Poro

Port Aux Moines

Porter Property

Porto Rico

Pot Lake

Potosi

Potosi

Potosi

Potrerillos

Potrero del Molino
Country

Model No

USNM

PLPN

BOTS

CNNF

USCA

USAZ

CNMN

USCA

USUT

USCA

USNV

CNNT

USOR

AUQL

USNV

USNM

USMT

CNMN

CNBC

PLPN

TRKY

TRKY

CNBC

$\mathrm{MXCO}$

USCA

GREC

MXCO

CYPS

USOR

CNNS

$\mathrm{MXCO}$

MXCO

THLD

USCA

BRZL

URRS

URRS

NZLD

CNNF

CNQU

CNBC

URRS

USCA

CNNT

AST R

INDS

CNQU

CUBA

CUBA

USCA

USCA

URRS

URRS

FNLD

NCAL

FRCN

USCA

CNBC

CNMN

BLVA

BRZL

CUBA

CILE

MXCO

$39 a$

$18 d$

$7 \mathrm{a}$

$28 \mathrm{a}$

$8 a$

$18 \mathrm{a}$

$28 \mathrm{a}$

$14 a$

16

$8 \mathrm{a}$

$21 \mathrm{~b}$

$32 a, 32 b$

$8 \mathrm{a}$

$14 \mathrm{~b}$

$26 a$

$30 \mathrm{~b}$

$39 a$

$6 \mathrm{~b}$

$36 a$

$28 \mathrm{a}$

$24 \mathrm{c}$

$24 \mathrm{c}$

$21 \mathrm{~b}$

$25 \mathrm{~g}$

$36 a$

$18 \mathrm{~d}$

$25 \mathrm{~h}$

$24 a$ 


\begin{tabular}{|c|c|c|c|c|c|}
\hline Name & Country & Model No & Name & Country & Model \\
\hline Poum & NCAL & $38 a$ & Randall & USCA & $8 a$ \\
\hline Powers & USOR & $8 a$ & Ranger & AUNT & $38 d$ \\
\hline Pozo Prieto & CUBA & $24 c$ & Rankin & CNON & $18 d$ \\
\hline Pratapolis & BRZL & $38 a$ & Rankin Inlet & CNNT & $6 a$ \\
\hline Prater & USOR & $8 a$ & Raposos & BRZL & $36 b$ \\
\hline Preble & USNV & $26 a$ & Rattlesnake Mountain & USCA & $8 a$ \\
\hline Prebuz & CZCL & $15 c$ & Raul & PERU & $24 b$ \\
\hline Presque Isle & USMI & $30 \mathrm{~b}$ & Ravensthorpe & AUWA & $34 b$ \\
\hline Price & CNBC & $28 a$ & Ravenswood & NZLD & $36 a$ \\
\hline Prickly Pear Creek & USMT & $39 a$ & Ravliden & SWDN & $28 a$ \\
\hline Primer & CNBC & 17 & Ravlidmyran & SWDN & $28 \mathrm{a}$ \\
\hline Progreso & CUBA & $24 c$ & Ray & USAZ & $21 a$ \\
\hline Prony & NCAL & $38 a$ & Ray (Tip Top) & USOR & $8 a$ \\
\hline Propretschnoi & URRS & $39 b$ & Ray Gulch & CNYT & $14 a$ \\
\hline Prunty & USNV & $27 d$ & Ray Spring & USOR & $8 a$ \\
\hline Puerto Rico bauxite & PTRC & $38 c$ & Raymond & NCAL & $24 c$ \\
\hline Pujada Pen & PLPN & $38 a$ & Razorback & AUTS & $14 c$ \\
\hline Pulmoddai & SRIL & $39 c$ & Recibimiento & $\mathrm{MXCO}$ & $18 d$ \\
\hline Punch & INDA & $38 \mathrm{c}$ & Recsk & HUNG & $18 \mathrm{a}$ \\
\hline Pyhasalmi & FNLD & $28 a$ & Red Bird & $\mathrm{CNBC}$ & $21 \mathrm{~b}$ \\
\hline Pyramid (Mariposa Co.) & USCA & $36 a$ & Red Chris & $\mathrm{CNBC}$ & $20 c$ \\
\hline Pyramid (Humboldt Co.) & USCA & $8 a$ & Red Crest & CNON & $36 b$ \\
\hline Qala-el-Nahl & SUDN & $8 d$ & Red Dog & USAK & $31 a$ \\
\hline Quartz Hill & USAK & $21 b$ & Red Elephant & USCA & $27 c$ \\
\hline Quarzazate & MRCO & $24 c$ & Red Hill-Red Hill Ext. & USNM & $25 g$ \\
\hline Que River & AUTS & $28 a$ & Red Lake Gold Shore & CNON & $36 b$ \\
\hline Quebrada Blanca & CILE & 17 & Red Ledge & USCA & $8 a$ \\
\hline Queen Bess and vicinity & CNBC & $22 c$ & Red Mountain & USAZ & 17 \\
\hline Queen Hill & AUTS & $14 c$ & Red Mountain & USCO & $25 b$ \\
\hline Queen Victoria (Swift) & CNBC & $18 \mathrm{~b}$ & Red Mountain & USOR & $8 a$ \\
\hline Queen of May & USOR & $8 a$ & Red Mountain & CNYT & $21 \mathrm{~b}$ \\
\hline Queenston & CNON & $36 b$ & Red Rick & USCA & $27 c$ \\
\hline Quelleveco & PERU & 17 & Red Slide Gp. & USCA & $8 a$ \\
\hline Questa-Goat Hill & USNM & 16 & Red Wing & CNBC & $28 a$ \\
\hline Quien-Sabe & USCA & $27 d$ & Redeyef & TUNS & $34 c$ \\
\hline Quigg & USCA & $8 a$ & Redross & AUWA & $6 a$ \\
\hline Quilon (Chavara) & INDA & $39 c$ & Redskin & USCA & $8 a$ \\
\hline Quinto & CUBA & $24 c$ & Redstone & CNNT & 23 \\
\hline Quixaba & BRZL & $14 a$ & Redwell & USCO & 16 \\
\hline Qusseir & EGPT & $34 c$ & Reed & USCA & $27 c$ \\
\hline R.R. Flat South & USCA & $36 a$ & Reed Lake & CNMN & $28 a$ \\
\hline Rabbit Lake & CNSK & $38 d$ & Reefton Goldfield & NZLD & $36 a$ \\
\hline Radiore $\mathrm{E}$ & CNQU & $28 a$ & Reeves & CNON & $8 d$ \\
\hline Rail Lake & CNMN & $28 a$ & Reeves MacDonald & CNBC & $31 \mathrm{a}$ \\
\hline Rain & USNV & $26 a$ & Reicher Trost & PLND & $36 a$ \\
\hline Rainbow & USCA & $36 a$ & Relief Canyon & USNV & $26 a$ \\
\hline Rainbow & USOR & $36 a$ & Rendall-Jackson & CNNF & $24 a$ \\
\hline Rainbow & USOR & $8 a$ & Renfrew & CNNS & $36 a$ \\
\hline Rainy Day & USOR & $8 a$ & Renison Bell & AUTS & $14 c$ \\
\hline Rajabasa & INDS & $18 c$ & Renstrom & SWDN & $28 a$ \\
\hline Rajpura-Daiba & INDA & $31 a$ & Renzy & CNQU & $7 a$ \\
\hline Rakke jaur & SWDN & $28 a$ & Republic & USWA & $25 c$ \\
\hline Rambler-Cariboo & CNBC & $22 c$ & Rex & CNYT & $8 d$ \\
\hline Rambler-Ming & CNNF & $28 a$ & Rexspar & CNBC & $25 \mathrm{f}$ \\
\hline Rammelsberg & GRMY & $31 a$ & Rhiw & GRBR & $24 c$ \\
\hline Rammelsberg Barite & GRMY & $31 b$ & Rich & USCA & $36 a$ \\
\hline Ramona-Loma & CUBA & $38 a$ & Rich Gulch & USCA & $36 a$ \\
\hline Rampura-Agucha & INDA & $31 a$ & Rich Gulch (Virgilia) & USCA & $36 a$ \\
\hline Ramsey & CNSK & $28 a$ & Richards & USCA & $8 a$ \\
\hline Ramunia-Telok Ramunia & MLYS & $38 b$ & Richards Bay & SAFR & $39 c$ \\
\hline Rana & NRWY & $7 a$ & Richey, U.S. \& S.J. & USCA & $8 a$ \\
\hline Ranch & USCA & $36 a$ & Riddle & USOR & $38 a$ \\
\hline Rancherie & USOR & $8 a$ & Rieppe & NRWY & $28 a$ \\
\hline Ranchi-Palamau & INDA & $38 b$ & Rim Rock and Homestake & USNV & $27 a$ \\
\hline
\end{tabular}


Rindge No. 1

Ringwood

Rio

Rio Blanco

Rio Challana

Rio Chimate

Rio Pallanga

Rio Tinto

Rio Tuba

Rio Tuichi (upper reach)

Rio Vivi

Rio Yolosano

Rio Yuyo

Risliden

Roan Antelope (Luanshya)

Robb Lake

Roberge Lake

Robert $\mathrm{E}$

Robert Emmet

Roberts Mtns. Dist.

Robertson

Robt. E.

Rochelois Plat.

Rock Creek

Rock Wren Mine

Rockhole-Teages

Rockland

Rocky Turn

Rod

Rodhammeren

Rodkleiv

Rokana (Nkana)

Romanera

Romerito

Rondoni

Rosario

Rose

Rose Claim

Rose of Denmark

Rosebery-Read

Roseland

Rosethistle \& Shamrock

Rosh Pinah

Rosie Claim

Rosita

Ross

Ross

Rostvangen

Roublewik R.

Round Bottom

Round Mountain $\mathrm{Au}$

Round Mountain W

Roupe

Rouyn Merger

Rowghat

Royal George

Royal Mountain King

Rua Cove

Ruby Creek

Rudna Glava

Rudtjebacken

Ruff Claim No. 32

Rum Jungle Creek South

Ruseifa

\begin{tabular}{|c|c|c|}
\hline Country & Model No & Name \\
\hline USCA & $36 a$ & Rush Valley \\
\hline USNJ & $25 i$ & Ruth \\
\hline CNBC & $22 c$ & Ruttan \\
\hline CILE & 17 & Ruwe (Mutoshi) \\
\hline BLVA & $39 a$ & Ryan \\
\hline BLVA & $39 a$ & Ryan Group \\
\hline PERU & $25 b$ & Ryllshyttan \\
\hline SPAN & $28 a$ & Ryuo \\
\hline PLPN & $38 a$ & Sabana Grande \\
\hline BLVA & $39 a$ & Sabanilla \\
\hline PTRC & $20 c$ & Sabetjok \\
\hline BLVA & $39 a$ & Sablayon \\
\hline BLVA & $39 a$ & Sacaton \\
\hline SWDN & $7 a$ & Sad Sack \\
\hline ZMBA & $30 \mathrm{~b}$ & Saddle Chrome \\
\hline $\mathrm{CNBC}$ & $32 a, 32 b$ & Sado \\
\hline CNQU & $8 d$ & Safagar \\
\hline USOR & $36 a$ & Safford (KCC) \\
\hline USMT & $22 c$ & Saghand \\
\hline USNV & $26 a$ & Sagliden \\
\hline USOR & $36 a$ & Sagmo \\
\hline USOR & $8 a$ & Sai \\
\hline HATI & $38 c$ & Sailor's Gully \\
\hline USOR & $8 a$ & Sain Bel \\
\hline USCA & $8 a$ & Saindak \\
\hline AUNT & $38 d$ & Saindak South \\
\hline USFL & $34 d$ & Saint \\
\hline CNNB & $28 a$ & Saka \\
\hline CNMN & $28 a$ & Sala \\
\hline NRWY & $28 a$ & Salem Hills \\
\hline NRWY & $28 a$ & Saligny \\
\hline ZMBA & $30 \mathrm{~b}$ & Saline-Pulaski \\
\hline SPAN & $28 a$ & Salitre \\
\hline SPAN & $28 a$ & Sally Ann \\
\hline PERU & $18 \mathrm{~d}$ & Sally Malay \\
\hline HNDR & $25 c$ & Salmon River \\
\hline CNBC & $18 d$ & Salsigne \\
\hline USCA & $8 a$ & Salt Rock \\
\hline AUVT & $36 a$ & Salur \\
\hline AUTS & $28 a$ & Sam Goosly \\
\hline USVA & $7 \mathrm{~b}$ & Samar \\
\hline AUVT & $36 a$ & Sambalpur \\
\hline NAMB & $31 a$ & Sambas \\
\hline USOR & $8 a$ & Samli \\
\hline NCRG & $18 \mathrm{~b}$ & San Antonio \\
\hline CNON & $36 b$ & San Antonio \\
\hline NZLD & $39 c$ & San Bernardo \\
\hline NRWY & $28 a$ & San Carlos \\
\hline URRS & $39 b$ & San Domingos \\
\hline USCA & $8 a$ & San Emigdio \\
\hline USNV & $25 a$ & San Fabian \\
\hline USNV & $15 a$ & San Francisco \\
\hline USCA & $8 a$ & San Erancisco \\
\hline CNQU & $36 b$ & San Giovanni Rotondo \\
\hline INDA & $34 a, 28 b$ & San Guillermo-Sierra \\
\hline AUTS & $15 b$ & San Humberto \\
\hline USCA & $36 a$ & San Juan \\
\hline USAK & $24 a$ & San Juan de Chacna \\
\hline USAK & $32 c$ & San Juan de la Costa \\
\hline YUGO & $18 d$ & San Juanera \\
\hline SWDN & $28 a$ & San Leone \\
\hline PLPN & $8 a$ & San Manuel \\
\hline AUNT & $38 d$ & San Martin \\
\hline JRDN & $34 c$ & San Mateo \\
\hline
\end{tabular}

USOR

JAPN

EGPT

USAZ

IRAN

SWDN

NRWY

JAPN

AUVT

FRNC

PKTN

PKTN

USCA

TRKY

SWDN

USOR

FRNC

USAR

BRZL

USOR

AUWA

CNNS

F RNC

USOR

TRKY

CNBC

PLPN

INDA

AUVT

TRKY

PLPN

SPAN

MXCO

MXCO

PORT

USCA

PLPN

MXCO

USUT

ITLY

SPAN

MXCO

USAZ

PERU

MXCO

MXCO

ITLY

USAZ

AGTN

PLPN

8

$8 a$

25d

$34 \mathrm{c}$

17

$25 i$

$30 \mathrm{a}$

$28 \mathrm{a}$

$25 b$

$36 a$

$28 \mathrm{a}$

17

$20 \mathrm{c}$

$8 \mathrm{a}$

$8 a$

$18 \mathrm{c}$

$38 b$

$19 b$

$38 \mathrm{~b}$

10

$8 a$

$7 a$

$36 a$

$36 a$

$8 a$

$8 \mathrm{a}$

$22 \mathrm{a}$

17

$38 \mathrm{~b}$

$36 a$

$18 \mathrm{~d}$

$20 \mathrm{c}$

$28 \mathrm{a}$

$25 \mathrm{~g}$

$18 \mathrm{~d}$

$28 \mathrm{a}$

$27 d$

$20 \mathrm{c}$

$25 \mathrm{~h}$

$19 a$

$38 \mathrm{c}$

$28 \mathrm{a}$

$25 \mathrm{~h}$

17

$18 d$

$34 \mathrm{c}$

$25 \mathrm{~h}$

$18 \mathrm{~d}$

17

$15 a$

$28 \mathrm{a}$ 
San Miguel El Alto

San Pedro

San Pedro

San Platon

San Rafael

San Ruperto

San Telmo

San Xavier

Sanchez

Sand Creek

Sand Springs

Sandford

Sanei

Sanford Lake

Sang Dong

Sanga lwara

Sangaredi

Sankyo

Sanshaw

Santa Ana

Santa Barbara

Santa Barbara

Santa Barbara

Santa Efigenia

Santa Eulalia

Santa $\mathrm{Fe}$

Santa Gertrudis

Santa Leonor

Santa Lucia

Santa Lucia

Santa Rita

Santa Rosa

Santa Rosa

Santander

Santiago Papalo

Santiago-Commonwealth-

Centennial

Santo Nino

Santo Tomas

Santo Tomas

Sao Domingos do Capim

Sao Joao do Piaui

Sao Paulo

Santa Cruz

Sapalskoe

Sar Cheshmeh

Sarbay

Sardegna

Sarialan

Sarikaya

Saruabi

Sasagatani

Sasca Montana

Satevo

Sattelberges

Saturday Anne

Saua-Toranica

Savage River

Savannah

Savannah River

Saxberget

Saysin

Sazare

Schaft Creek

\begin{tabular}{|c|c|c|}
\hline MXCO & $25 g$ & Schissler Creek \\
\hline SPAN & $28 a$ & Schist Lake \\
\hline USNM & $18 b$ & Schmid \\
\hline SPAN & $28 a$ & Scinto 5 \\
\hline $\mathrm{MXCO}$ & $25 h$ & Scotia \\
\hline $\mathrm{MXCO}$ & $25 h$ & Scott Bar \\
\hline SPAN & $28 a$ & Scott River \\
\hline USAZ & 17 & Scrafford \\
\hline USAZ & 17 & Scraton-Pontiac-Sunset \\
\hline SID & $39 a$ & Se Chakhum \\
\hline USNV & $25 c$ & Seal Harbour \\
\hline USAK & $36 a$ & Searchlight \\
\hline JAPN & $25 d$ & Sechura \\
\hline USNY & $7 \mathrm{~b}$ & Second Relief \\
\hline SKOR & $14 a$ & Sehib \\
\hline INDA & $34 a, 28 b$ & Seiad Creek (Mt. View) \\
\hline GNEA & $38 b$ & Seiba \\
\hline JAPN & $18 d$ & Seikoshi \\
\hline CNON & $36 b$ & Sekioren \\
\hline $\mathrm{MXCO}$ & $25 \mathrm{~g}$ & Selco-Scott \\
\hline BRZL & $38 \mathrm{~b}$ & Selebi \\
\hline VNZL & $34 a, 28 b$ & Selimiye \\
\hline PERU & $27 b$ & Selkirk \\
\hline $\mathrm{MXCO}$ & $25 h$ & Selukwe \\
\hline $\mathrm{MXCO}$ & $19 a$ & Senor de Huarquisa \\
\hline USNV & $26 a$ & September Morn \\
\hline $\mathrm{MXCO}$ & $25 \mathrm{~h}$ & Serb Creek \\
\hline $\mathrm{MXCO}$ & $25 h$ & Sereno \\
\hline $\mathrm{MXCO}$ & $25 h$ & Serra Negra \\
\hline PERU & $18 d$ & Serria do Carajas \\
\hline USNM & $18 \mathrm{a}$ & Sesson Mine \\
\hline CUBA & $24 c$ & Setting Net Lake \\
\hline SPAN & $28 a$ & Seven Trough \\
\hline PERU & $19 a$ & Severnoe \\
\hline $\mathrm{MXCO}$ & $8 d$ & $\begin{array}{l}\text { Sexton Mountain } \\
\text { Seydisehr }\end{array}$ \\
\hline USCO & $22 c$ & Sha \\
\hline PLPN & $20 c$ & Shackleton \\
\hline $\mathrm{MXCO}$ & 17 & Shade Chromite \\
\hline PLPN & $20 c$ & Shafer Lease \\
\hline BRZL & $38 b$ & Shag Rock \\
\hline BRZL & $38 a$ & Shagyrkul \\
\hline BRZL & $38 b$ & Shahin \\
\hline PLPN & $38 a$ & Shamrock \\
\hline URRS & $24 c$ & Shamva-Cymric Gp. \\
\hline IRAN & 17 & Shangani \\
\hline URRS & $18 d$ & Shasta King \\
\hline ITLY & $25 g$ & Shasta-California \\
\hline TRKY & $8 a$ & Shediyah \\
\hline TRKY & $8 a$ & Sheep Ranch \\
\hline INDA & $38 a$ & Sheep Tank \\
\hline JAPN & $18 \mathrm{~b}$ & Shelly \\
\hline RMNA & $18 b$ & Shenandoah Mine \\
\hline $\mathrm{MXCO}$ & $25 \mathrm{~g}$ & Sheppard Mine \\
\hline ASTR & $19 \mathrm{~b}$ & Sherrin Creek \\
\hline USOR & $8 a$ & Shertingdal \\
\hline YUGO & $19 a$ & Shevaroy Hills \\
\hline AUTS & $25 i$ & Shihmien \\
\hline USGA & $34 d$ & Shiiba, Takaragi \\
\hline USGA & $34 d$ & Shimoga (Karnatoka) \\
\hline SWDN & $18 c$ & Shimokawa \\
\hline TRKY & $8 a$ & Shimokawa (Kouchi) \\
\hline JAPN & $24 b$ & Shinga \\
\hline CNBC & 17 & Shinyama \\
\hline
\end{tabular}

\begin{tabular}{|c|c|}
\hline USID & $39 a$ \\
\hline CNMN & $28 a$ \\
\hline USOR & $8 a$ \\
\hline AUNT & $38 d$ \\
\hline AUWA & $6 a$ \\
\hline USCA & $36 a$ \\
\hline AUWA & $39 c$ \\
\hline USAK & $27 d$ \\
\hline CNBC & $22 c$ \\
\hline IRAN & $25 i$ \\
\hline CNNS & $36 a$ \\
\hline USNV & $25 c$ \\
\hline PERU & $34 c$ \\
\hline CNBC & $36 a$ \\
\hline TUNS & $34 c$ \\
\hline USCA & $8 a$ \\
\hline URRS & $34 b$ \\
\hline JAPN & $25 c$ \\
\hline TRKY & $8 a$ \\
\hline CNQU & $28 a$ \\
\hline BOTS & $7 a$ \\
\hline TRKY & $25 g$ \\
\hline BOTS & $7 a$ \\
\hline ZIMB & $6 a$ \\
\hline PERU & $18 d$ \\
\hline USCA & $8 a$ \\
\hline CNBC & $21 b$ \\
\hline BRZL & $24 c$ \\
\hline BRZL & 10 \\
\hline BRZL & $34 a, 28 b$ \\
\hline USCA & $36 a$ \\
\hline CNON & $21 \mathrm{~b}$ \\
\hline USNV & $25 c$ \\
\hline URRS & $18 d$ \\
\hline USOR & $8 a$ \\
\hline TRKY & $38 c$ \\
\hline CYPS & $24 a$ \\
\hline ZIMB & $30 \mathrm{~b}$ \\
\hline USOR & $8 a$ \\
\hline USCA & $8 a$ \\
\hline CNBC & $25 g$ \\
\hline URRS & $18 d$ \\
\hline IRAN & $8 a$ \\
\hline USCA & $8 a$ \\
\hline ZIMB & $36 b$ \\
\hline ZIMB & $6 a$ \\
\hline USCA & $28 a$ \\
\hline USCA & $18 d$ \\
\hline JRDN & $34 c$ \\
\hline USCA & $36 a$ \\
\hline USAZ & $25 c$ \\
\hline USCA & $8 a$ \\
\hline USCA & $36 a$ \\
\hline USCA & $8 a$ \\
\hline AUQL & $34 c$ \\
\hline NRWY & $30 a$ \\
\hline INDA & $38 b$ \\
\hline CINA & $8 d$ \\
\hline JAPN & $24 b$ \\
\hline INDA & $34 b$ \\
\hline JAPN & $24 b$ \\
\hline JAPN & $24 b$ \\
\hline JAPN & $24 b$ \\
\hline JAPN & $18 d$ \\
\hline
\end{tabular}


Name

Ship Island

Shirataki

Shotgun Creek

Shuikoushan

Shunsby

Sicankale

Sidamo

Sierra Gorda

Sierra Los Organos

Sierra de El Alto

Sierra de Enmedio

Sierrecilla

Sierrita-Esperanza

Sigua

Siirt Madenkoy

Silica Mine

Silva-Aysen

Silver Bell

Silver City

Silver Cloud

Silver Lakes

Silver Lease

Silver Queen

Silver Valley

Silvermines

Silverside

Silversmith-Richmond-

Ruth-Hope

Simlipal

Simmons

Simon

Sims

Sipalay

Sirac

Sirigao

Sirkov Log

Six Mile

Six-Mile

Skaide

Skorovass

Skouriotissa

Skull

Skyline Mine

Sleisbeck

Sliger

Slocan-Sovereign

Smith Geitsfield

Smithfield

Snake Mountain

Snakehead (Jumbo)

Sneffels

Snowdrift

Snowshoe

Snowstorm

Snowstorm area

Snowy Ridge

Snowy Ridge

Snyder

Søve

Soab

Socorro-Guadalupe

Socrates

Sofulu

Sogham

\begin{tabular}{|c|c|c|}
\hline Country & Model No & Name \\
\hline USMS & $39 c$ & Soho \\
\hline JAPN & $24 b$ & Sohodol-Cimpeni \\
\hline USCA & $8 a$ & Solbec \\
\hline CINA & $18 c$ & Soloviejo \\
\hline CNON & $28 a$ & Solovyevskii Log \\
\hline TRKY & $8 a$ & Sombrerete \\
\hline ETHP & $38 a$ & Sombreretillo \\
\hline CILE & 17 & Son of Gwalia \\
\hline $\mathrm{MXCO}$ & $25 \mathrm{~g}$ & Soo \\
\hline $\mathrm{MXCO}$ & $25 \mathrm{~g}$ & Soquem \\
\hline $\mathrm{MXCO}$ & $25 g$ & Sorka \\
\hline SPAN & $28 a$ & Soroako \\
\hline USAZ & $21 a$ & Sosnowka \\
\hline CUBA & $24 c$ & Sosva \\
\hline TRKY & $24 a$ & Sothman Twp. \\
\hline USTN & $39 c$ & Sotiel \\
\hline CILE & $19 a$ & Soto \\
\hline USAZ & $18 a$ & Soto (Chihuahua) \\
\hline USNV & $25 c$ & Soukhoi Log \\
\hline USNV & $27 a$ & Soulsbyville \\
\hline USCA & $18 d$ & Sour Dough \\
\hline USOR & $8 a$ & Sourdough Bay \\
\hline $\mathrm{CNBC}$ & $28 \mathrm{a}$ & Sousa Ranch \\
\hline AUQL & $15 b$ & South Crofty \\
\hline IRLD & $31 a$ & South Dufault \\
\hline ZIMB & $30 b$ & $\begin{array}{l}\text { South Florida phosphate } \\
\text { South Rusty Hill }\end{array}$ \\
\hline CNBC & $22 c$ & South Sarbay \\
\hline INDA & $38 a$ & South Thomas \\
\hline USCA & $8 a$ & South Uniacke \\
\hline USCA & $8 a$ & South Weipa \\
\hline USCA & $8 a$ & Spar Lake (Troy) \\
\hline PLPN & 17 & Spargoville \\
\hline TRKY & $8 a$ & Spenceville \\
\hline INDA & $34 a, 28 b$ & Spinazzola \\
\hline URRS & $39 b$ & Spot \\
\hline AUWA & $6 \mathrm{~b}$ & Spring Gully \\
\hline USOR & $8 a$ & Spring Hill \\
\hline NRWY & $28 a$ & Spruce Mountain \\
\hline NRWY & $24 a$ & Spruce Point \\
\hline CYPS & $24 a$ & Squirrel Hills \\
\hline AUNT & $38 d$ & Srednia-Prostokischenka \\
\hline USCA & $8 a$ & Ssu-chia-ying \\
\hline AUNT & $38 d$ & St. Adrien Mtn. \\
\hline USCA & $36 a$ & St. Ann Plat. \\
\hline $\mathrm{CNBC}$ & $22 c$ & St. Anthony \\
\hline USOR & $8 a$ & Cyr \\
\hline CNNS & $30 a$ & St. Dizier \\
\hline USNV & $31 b$ & St. George \\
\hline USCA & $8 a$ & St. Honore \\
\hline USCO & $25 b$ & St. Leonards \\
\hline USNV & $27 d$ & St. Patrick (Camp 8) \\
\hline USNM & $18 b$ & St. Pietro \\
\hline USMT & $30 b$ & Sta. Cruz \\
\hline USCO & $39 a$ & Stadacona \\
\hline USCA & $8 a$ & Stafford \\
\hline USOR & $8 a$ & Stall Lake \\
\hline USCA & $8 a$ & Standard \\
\hline NRWY & 10 & Standard and vicinity \\
\hline CNMN & $6 b$ & Stannary Hills \\
\hline MXCO & $25 \mathrm{~h}$ & Star \\
\hline USCA & $27 c$ & Star Mt.-Fubilan \\
\hline TRKY & $8 a$ & Star Mt.-Futik \\
\hline IRAN & $8 a$ & Star Mt.-Nong River \\
\hline
\end{tabular}

Country

Model No

CNBC 22c

RMNA 38c

CNQU 28a

SPAN $24 c$

URRS 39b

MXCO 19a

MXCO 25h

AUWA $\quad 36 \mathrm{~b}$

USAK $36 \mathrm{a}$

CNQU 10

URRS $\quad 18 \mathrm{~d}$

INDS $\quad 38 a$

URRS $39 b$

URRS 18d

CNON $6 \mathrm{a}$

SPAN 28a

MXCO 25h

MXCO 25g

URRS 39b

USCA $36 a$

USOR $8 \mathrm{a}$

CNMN 28a

USCA $8 a$

GRBR $\quad 15 b$

CNQU 28a

USFL 34d

CNQU 28a

URRS $18 \mathrm{~d}$

USCA $24 \mathrm{C}$

CNNS $36 a$

AUQL $\quad 38 b$

USMT $30 \mathrm{~b}$

AUWA $6 a$

USCA $28 \mathrm{a}$

ITLY $38 \mathrm{c}$

USCA $8 a$

AUVT $36 a$

USCA $8 a$

USNV $19 a$

CNMN 28a

AUQL $31 \mathrm{a}$

URRS 39b

CINA

CNQU

JMCA

USAZ

CNQU

AUTS

AUQL

CNQU

AUTS

USCA

ITLY

PLPN

CNQU

USCA

CNMN

USNV

CNBC

AUQL

USUT

PPNG

PPNG

PPNG

$34 \mathrm{a}, 28 \mathrm{~b}$

$8 d$

$38 c$

$22 \mathrm{cSt}$.

$8 d$

$14 \mathrm{c}$

$27 \mathrm{~d}$

10

$38 \mathrm{~b}$

$8 \mathrm{a}$

$25 g$

$8 \mathrm{a}$

$36 \mathrm{~b}$

$8 \mathrm{a}$

$28 a$

$26 a$

$22 \mathrm{c}$

$15 \mathrm{~b}$

$19 a$

$20 \mathrm{c}$

$20 \mathrm{c}$

17 
Name

Star Mt.-0lgal

Stark Bee

Starratt-0lsen

State School

Steamboat Springs

Stedman

Steele Brook

Stekenjokk

Stepanoff-Log

Stephane

Sterling Creek

Sterling Lake

Stevens-Miller

Stewart

Stewart Island

Stewart May

Stibnite

Stillwater

Stirling

Stockton

Stockton Bight

Stollberg

Stone \& Haskins

Stonewall

Store Gulch

Storeys Creek

Storie

Stormy Group

Stowell

Stra Quertane

Stralak

Strandzha

Stratmat

Strawberry

Stray Dog

Stripa-Striberg

Sturgeon Lake

Suffield

Suftlii Bor

Sugarloaf Hill

Sukinda

Sukulu

Sulat

Sullivan

Sullivan and Kahl

Sulphur Bank

Sultan

Sulu

Suluiyeh

Suluk

Sumadisa

Summit

Summitville

Sumpter Bar

Sun

Sunnyslope

Sunrise

Sunset

Sunshine

Sunshine

Sunshine Creek

Sunshine-Corinth

Surf Inlet

Surigao

\section{Country}

PPNG

USCA

CNON

USCA

USNV

USCA

CNQU

SWDN

URRS

NCAL

USOR

USNY

USOR

USCA

CNSK

USAR

USAK

USMT

CNNS

USAZ

AUNS

SWDN

USOR

USCA

USOR

AUTS

CNBC

CNYT

USCA

TUNS

CNON

BULG

CNNB

USCA

USOR

SWDN

CNON

CNQU

URRS

CNBC

INDA

UGND

PLPN

CNBC

USCA

USCA

AUVT

TRKY

IRAN

TRKY

YUGO

USAZ

USCO

USOR

CNMN

USCA

USCA

USCA

CNBC

USCA

CNBC

CNBC

CNBC

PLPN

\section{Model No}

17

$8 \mathrm{a}$

$36 b$

$8 \mathrm{a}$

$25 \mathrm{e}$

$8 d$

$28 \mathrm{a}$

$39 \mathrm{~b}$

$8 \mathrm{a}$

$39 a$

$25 i$

$8 \mathrm{a}$

$8 \mathrm{a}$

$38 \mathrm{~d}$

$27 \mathrm{~d}$

$27 d$

$1,2 \mathrm{a}, 2 \mathrm{~b}$

$28 \mathrm{a}$

$22 \mathrm{c}$

$39 \mathrm{c}$

$18 \mathrm{c}$

$8 \mathrm{a}$

$36 a$

$8 \mathrm{a}$

$15 a$

$21 \mathrm{~b}$

$14 a$

$28 \mathrm{a}$

$34 \mathrm{c}$

$28 \mathrm{a}$

$18 \mathrm{~b}$

$28 \mathrm{a}$

$14 a$

$8 \mathrm{a}$

$34 a, 28 b$

$28 \mathrm{a}$

$28 \mathrm{a}$

$39 \mathrm{~b}$

17

$38 \mathrm{a}$

10

$28 \mathrm{a}$

$31 a$

$8 \mathrm{a}$

$27 a$

$36 a$

$8 a$

$8 a$

$8 a$

$19 a$

$19 \mathrm{~b}$

$25 \mathrm{e}$

$39 a$

$28 a$

$8 \mathrm{a}$

$8 a$

$8 a$

$28 a$

$8 \mathrm{a}$

$21 \mathrm{~b}$

$22 \mathrm{c}$

$36 \mathrm{a}$

$38 a$
Name

Country

Model No

Surprise-Noble Five and

vicinity

Sustut

Susu Lake

Sutherland

Sutpinar

Sutro

Sutro Mine

Sutter Creek

Suzanne

Suzy Bell (Lucky Strike)

Svano

Svardsio

Swan River

Swansea

Swayne

Sweetwater

Swim Lake

Sydvananger

Sylvanite

Syssim R.

Tache Lake

Taco Bay

Tagpura

Taiba

Taio

Taisho (Nishimata)

Takahata

Takanokura

Takatama

Takaura

Takeno

Takijug Lake

Taknar

Talamantes

Tallering Peak

Talmora Longlac

Tamborine Mountain

Tanama

Tangier

Tangle Blue Divide

Tapairihua

Tapira

Tapley

Taratana

Taritipan

Tarkwa

Tasdibi

Tashiro

Taslica

Tasu-Wesfrob

Tawi-Tawi

Taylor

Tayoltita

Taysan

Tea

Teahan

Techa

Tecolote

Tecolotes

Tecopa

Tedi

Tekneli

Tekwane

\begin{tabular}{|c|c|}
\hline $\mathrm{CNBC}$ & $22 c$ \\
\hline CNBC & 23 \\
\hline CNNT & $28 a$ \\
\hline USNV & $27 d$ \\
\hline TRKY & $8 a$ \\
\hline USCA & $28 a$ \\
\hline USCA & $8 a$ \\
\hline USCA & $36 a$ \\
\hline NCAL & $8 a$ \\
\hline USCA & $8 a$ \\
\hline NRWY & $24 a$ \\
\hline SWDN & $18 c$ \\
\hline USCO & $39 a$ \\
\hline USAZ & $37 \mathrm{~b}$ \\
\hline USCA & $8 a$ \\
\hline USCA & $8 a$ \\
\hline CNYT & $31 \mathrm{a}$ \\
\hline NRWY & $34 a, 28 b$ \\
\hline USOR & $36 a$ \\
\hline URRS & $39 b$ \\
\hline CNQU & $28 a$ \\
\hline CUBA & $38 a$ \\
\hline PLPN & 17 \\
\hline SNGL & $34 c$ \\
\hline JAPN & $25 c$ \\
\hline JAPN & $28 a$ \\
\hline JAPN & $25 d$ \\
\hline JAPN & $18 d$ \\
\hline JAPN & $25 d$ \\
\hline JAPN & $24 b$ \\
\hline JAPN & $25 d$ \\
\hline CNNT & $28 a$ \\
\hline IRAN & $28 a$ \\
\hline $\mathrm{MXCO}$ & $25 g$ \\
\hline AUWA & $34 a, 28 b$ \\
\hline CNON & $36 b$ \\
\hline AUQL & $38 b$ \\
\hline PTRC & $20 c$ \\
\hline CNNS & $36 a$ \\
\hline USCA & $8 a$ \\
\hline PERU & $18 d$ \\
\hline BRZL & 10 \\
\hline USME & $28 a$ \\
\hline CUBA & $24 c$ \\
\hline INDS & $24 c$ \\
\hline GHNA & $29 a$ \\
\hline TRKY & $27 d$ \\
\hline JAPN & $28 a$ \\
\hline TRKY & $28 a$ \\
\hline CNBC & $18 b$ \\
\hline PLPN & $20 c$ \\
\hline USCA & $36 a$ \\
\hline $\mathrm{MXCO}$ & $25 c$ \\
\hline PLPN & $20 c$ \\
\hline CNYT & $31 \mathrm{~b}$ \\
\hline CNNB & $28 a$ \\
\hline URRS & $18 d$ \\
\hline USNM & $18 d$ \\
\hline $\mathrm{MXCO}$ & $25 h$ \\
\hline USCA & $19 a$ \\
\hline $\mathrm{CNBC}$ & $28 a$ \\
\hline TRKY & $8 a$ \\
\hline BOTS & $7 a$ \\
\hline
\end{tabular}




\begin{tabular}{|c|c|c|c|c|c|}
\hline Name & Country & Model No & Name & Country & Model No \\
\hline Telluride & USCO & $25 \mathrm{~b}$ & Topkirozlar & TRKY & $24 c$ \\
\hline Tem Piute district & USNV & $14 a$ & Topock & USAZ & $25 \mathrm{~g}$ \\
\hline Tenke-Fungurume & ZIRE & $30 b$ & Toquepala & PERU & 17 \\
\hline Tennessee Chrome & USOR & $8 a$ & Toscana (Cerchiara) & ITLY & $24 c$ \\
\hline Tennessee Pass & USOR & $8 a$ & Tosin & TRKY & $8 a$ \\
\hline Tepebasi & TRKY & $8 a$ & Tougue & GNEA & $38 \mathrm{~b}$ \\
\hline Tepustete & MXCO & $18 d$ & Toujours Gai & USCA & $8 a$ \\
\hline Terano & JAPN & $24 \mathrm{~b}$ & Toura R. & URRS & $39 b$ \\
\hline Terlik & TRKY & $8 a$ & Tovarnica & YUGO & $18 \mathrm{~d}$ \\
\hline Terra Nova & CNNF & $28 a$ & Toyoha & JAPN & $25 \mathrm{~b}$ \\
\hline Terrenates & $\mathrm{MXCO}$ & $25 \mathrm{~g}$ & Trail Ridge & USFL & $39 c$ \\
\hline Tetyukhe & URRS & $18 \mathrm{c}$ & Traversella & ITLY & $18 \mathrm{~b}$ \\
\hline Teutonic Bore & AUWA & $28 a$ & Treadwell Mines & USAK & $36 a$ \\
\hline Texada & CNBC & $18 d$ & Treasure Hill & USAZ & $22 c$ \\
\hline Texas & CNNB & $28 a$ & Tregioivo & ITLY & $30 a$ \\
\hline Textmont & CNON & $6 a$ & Trepca-Kopaonik & YUGO & $19 a$ \\
\hline Thabazimbi & SAFR & $34 a, 28 b$ & Tri State & USMO-USOK & $32 a, 32 b$ \\
\hline Thamar-Kotra & INDA & $34 c$ & Trinidad & USCA & $8 a$ \\
\hline Thatcher Creek & USCA & $24 c$ & Trininty & CNQU & $28 a$ \\
\hline Thetford Group & $\mathrm{CNQU}$ & $8 d$ & Triton & AUWA & $36 \mathrm{~b}$ \\
\hline Thierry & CNON & $7 a$ & Trojan & $\mathrm{CNBC}$ & 17 \\
\hline Thies & SNGL & $34 c$ & Trojan & ZIMB & $6 a$ \\
\hline Thio & NCAL & $38 a$ & Trombetas & BRZL & $38 \mathrm{~b}$ \\
\hline Third Portage & CNNB & $28 a$ & Troulli & CYPS & $24 a$ \\
\hline Thomas & USCA & $24 c$ & Trout Bay & CNON & $28 a$ \\
\hline Thompson & CNMN & $6 \mathrm{~b}$ & Trout Lake & CNBC & $21 b$ \\
\hline Thompson Bousquet & CNQU & $36 \mathrm{~b}$ & Trudny-Log & URRS & $39 b$ \\
\hline Thompson Creek & USID & $21 \mathrm{~b}$ & Truscott & USCA & $36 a$ \\
\hline Thompson Falls & USMT & $27 \mathrm{~d}$ & Tsaitsukou & CINA & $18 \mathrm{~d}$ \\
\hline Thompson Gp. & USOR & $8 a$ & Tsauch R. & URRS & $39 b$ \\
\hline Thuburnic & TUNS & $19 b$ & Tschachewitaia & URRS & $39 b$ \\
\hline Thurston \& Hardy & USAZ & $25 g$ & Tscheh R. & URRS & $39 b$ \\
\hline Tiebaghi $\mathrm{Ni}$ & NCAL & $38 a$ & Tshinsenda & ZIRE & $30 b$ \\
\hline Tiebaghi $\mathrm{Cr}$ & NCAL & $8 a$ & Tsuchihata & JAPN & $28 a$ \\
\hline Tienpaoshan & CINA & $18 \mathrm{c}$ & Tsumeb & NAMB & $32 c$ \\
\hline Tiere & UVOL & $24 c$ & Tsumo & JAPN & $18 \mathrm{~b}$ \\
\hline Tilai R. & URRS & $39 \mathrm{~b}$ & Tulameen & CNBC & $39 b$ \\
\hline Tilkim-Karanlik & TRKY & $8 a$ & Tulk's Pond & CNNF & $28 a$ \\
\hline Tilt Cove & CNNF & $24 a$ & Tulsequah & $\mathrm{CNBC}$ & $28 a$ \\
\hline Timna & ISRL & $34 \mathrm{~b}$ & Tunca & TRKY & $28 a$ \\
\hline Timoni & AUWA & $36 \mathrm{~b}$ & Tuncurry-Tomago area & AUNS & $39 c$ \\
\hline Tin Cup Peak & USOR & 10 & Turfullar & TRKY & $25 \mathrm{~g}$ \\
\hline Tintaya & PERU & $18 \mathrm{~b}$ & Turner-Albright & USOR & $24 a$ \\
\hline Tintic & USUT & $19 a$ & Turtle Head & AUQL & $38 b$ \\
\hline Tiouine & MRCO & $24 c$ & Tuscarora & USNV & $25 c$ \\
\hline Tipperary Mine & NZLD & $36 a$ & Tutunculer & TRKY & $24 \mathrm{c}$ \\
\hline T jarrojakka & SWDN & $25 i$ & Tuzlakaya & TRKY & $8 a$ \\
\hline T jokkola & SWDN & $28 a$ & Tverrfjellet & NRWY & $28 \mathrm{a}$ \\
\hline Togobomar & PLPN & $8 a$ & Twin Buttes & USAZ & $18 a, 21 a$ \\
\hline Toi & JAPN & $25 c$ & Twin Cedars & USOR & $8 a$ \\
\hline Toiyabe & USNV & $26 a$ & Twin Peaks & USCA & $27 \mathrm{c}$ \\
\hline Tokoro & JAPN & $24 \mathrm{c}$ & Twin Valley & USOR & $8 a$ \\
\hline Tolano & MXCO & $25 h$ & Tynagh & IRLD & $31 a$ \\
\hline Toledo & PLPN & $20 \mathrm{c}$ & Tybo & USNV & $22 \mathrm{c}$ \\
\hline Tolman & USID & $26 a$ & Tyrny-Auz & URRS & $14 a$ \\
\hline Tom & CNYT & $31 a$ & Tyrone & USNM & $21 a$ \\
\hline Tombstone & USAZ & $19 a$ & U.S. Group & USAZ & $25 \mathrm{~g}$ \\
\hline Tomkin & USCA & $8 a$ & UV Industries & USNV & $21 \mathrm{~b}$ \\
\hline Tomogonops & CNNB & $28 a$ & Uchi & CNON & $28 a$ \\
\hline Tonkin Springs & USNV & $26 a$ & Uchi & CNON & $36 \mathrm{~b}$ \\
\hline Tonkolili & SRLN & $34 a, 28 b$ & Uchucchacua & PERU & $18 c$ \\
\hline Tonopah & USNV & $25 c$ & Uckopru & TRKY & $8 a$ \\
\hline Toombou & AUVT & $36 a$ & Udden & SWDN & $28 a$ \\
\hline Toparlar-Alacik & TRKY & $8 a$ & Udokan & URRS & $30 \mathrm{~b}$ \\
\hline
\end{tabular}




\begin{tabular}{|c|c|c|}
\hline Country & Model No & Name \\
\hline USUT & $34 c$ & Vorderen Strubberges \\
\hline SKOR & $18 c$ & Vorontsovka \\
\hline TRKY & $14 \mathrm{a}$ & Vubachikwe \\
\hline TRKY & $19 b$ & Vulcan \\
\hline USCA & $36 a$ & Vyhne \\
\hline USOR & $8 a$ & W.P. \\
\hline FIJI & $28 \mathrm{a}$ & Waden Bay \\
\hline USNV & $22 c$ & Wafangtzu \\
\hline ASTR & $38 \mathrm{c}$ & Wagasennin \\
\hline VNZL & $38 b$ & Waiho River \\
\hline CNON & $36 b$ & Wait (Amador Co.) \\
\hline AUNS & $27 d$ & Waite (Nevada Co.) \\
\hline CNON & $36 \mathrm{~b}$ & Waite East \\
\hline USWI & $32 a, 32 b$ & Walibu \\
\hline CNNS & $36 a$ & Walker \\
\hline PLND & $32 a, 32 b$ & Wall Canyon \\
\hline BRZL & $34 b$ & Wall Street \\
\hline
\end{tabular}

Uinta Mtns.

Ulchin

Uludag

Ulukoy

Uncle Sam

Uncle Sam

Undu

Union

Unterlaussa

Upata

Upper Beaver

Upper Bellingen

Upper Canada

Upper Mississippi Valley

Upper Seal Harbour

Upper Silesia

Uracum

Uribe

Urkut

Uruachic

Usinsk

Utica

Vaddas

Vakkerlien

Val Di Peio

Valen Prospect

Valenti

Valle de Manganeso

Valle del General

Valley Copper

Valley View

Valuev

Vammala

Vamp

Vananda

Vancouver Group

Vangorda

Varna

Vassbo

Vauze

Veitsch

Vekol

Velardepa

Verkho-Tourie

Vermilion

Vermilion River

Vermillion

Vernal

Vestpolltind

Veta Blanca

Viburnum

Victoria

Victory

Victory No. 3

Vieille Montagne

Vigsnes

Violet

Viscaria

Viterbo-Roma

Vlasenica

Vogelgesang

Vogler's Cove

Volcanic Peak

Von Roi-Hewitt
USWA 31b Wallapai District

HUNG 34b

MXCO 25b

URRS 34b

CNBC 22c

NRWY

NRWY

ITLY

USOR

USCA

CUBA

CORI

CNBC

USCA

URRS

FNLD

CNMN

CNBC

$\mathrm{CNBC}$

CNYT

BULG

SWDN

CNQU

ASTR

USAZ

MXCO

URRS

USMN

USMT

CNON

USUT

NRWY

MXCO

USMO

USNV

CNBC

USCA

NCAL

NRWY

USOR

SWDN

ITLY

YUGO

USCA

CNNS

USNV

CNBC
Wallaroo

Wannaway

War Bond

War Eagle

War Eagle-Miller

Ward

Ward

Ward and Lyons

Warm Springs, North Mocassin

Warm Springs

Waroona Shoreline

Warrington

Wasa Lake

Washington

Washington

Washington Camp

Washout

Waterloo

Watsonville

Wattle Gully

Waverley

Wayside

Weaver

Wedge

Weebo Bore

Weedaroo

Weedon

Weipa-Andoom-Pera Head

Weiss

Welch

Welch Prospect

Weld Range-Wilgie Mia

Wellington

Wellington

Wenlock River

West Bear

West Chrome

West Gore

West Jacksonville

West Maui

West Niggerhead

West Ore Body

Westarm

Western Magnesite

Western Nevada

Westland
AST R

URRS

ZIMB

USCA

CZCL

USNV

CNSK

CINA

JAPN

NZLD

USCA

USCA

CNQU

USCA

USCA

USNV

USCA

USAZ

AUWA

AUWA

USCA

CNYT

USCA

CNBC

USOR

USCA

USMT

USMT

AUWA

USCA

CNQU

MXCO

USCA

USAZ

USCA

USAZ

AUQL

AUVT

CNNS

CNBC

USAZ

CNNB

AUWA

AUSA

CNQU

AUQL

TRKY

USCA

USCA

AUWA

AUNS

CNBC

AUQL

CNSK

USCA

CNNS

USCA

USHI

USNM

PLPN

CNMN

USCA

USNV

NZLD
$19 \mathrm{~b}$

$18 d$

$36 \mathrm{~b}$

$18 \mathrm{~d}$

$18 \mathrm{~d}$

$27 d$

$28 \mathrm{a}$

$34 \mathrm{~b}$

$18 d$

$39 \mathrm{c}$

$8 \mathrm{a}$

$8 a$

$28 \mathrm{a}$

$27 \mathrm{a}$

$8 \mathrm{a}$

$27 \mathrm{~d}$

$27 \mathrm{c}$

$22 \mathrm{c}$

$28 \mathrm{a}$

$6 a$

$8 \mathrm{a}$

$18 \mathrm{~b}$

$8 \mathrm{a}$

$36 a$

$8 a$

$8 a$

$22 \mathrm{~b}$

$34 \mathrm{c}$

$39 \mathrm{c}$

$36 \mathrm{a}$

$36 \mathrm{~b}$

17

$36 \mathrm{a}$

$18 \mathrm{c}$

$8 a$

$19 \mathrm{~b}$

$15 \mathrm{~b}$

$36 a$

$36 a$

$36 a$

$25 \mathrm{c}$

$28 \mathrm{a}$

$6 \mathrm{~b}$

$31 \mathrm{~b}$

$28 \mathrm{a}$

$38 \mathrm{~b}$

$28 \mathrm{a}$

$24 \mathrm{c}$

$8 \mathrm{a}$

$34 a, 28 b$

$39 a$

$22 \mathrm{c}$

$38 \mathrm{~b}$

$38 d$

$8 \mathrm{a}$

$27 d$

$36 a$

$38 \mathrm{~b}$

$25 \mathrm{~g}$

$8 \mathrm{a}$

$28 \mathrm{a}$

$8 \mathrm{a}$

$18 \mathrm{~b}$

$36 a$ 


\begin{tabular}{|c|c|c|c|c|c|}
\hline Name & Country & Mode 1 No & Name & Country & Model No \\
\hline Westport & NZLD & $39 c$ & Yava (Silvermine) & CNNS & $30 a$ \\
\hline Wexford & $\mathrm{CNBC}$ & $18 \mathrm{~b}$ & Yayca Boyna & TRKY & $8 a$ \\
\hline Weza & SAFR & $38 b$ & Yellow Jacket & USNM & $18 d$ \\
\hline Whalesback-Little Deer & CNNF & $24 a$ & Yellow Pine & USCA & $8 a$ \\
\hline Wheal Jane & GRBR & $15 b$ & Yellow Pine & USNV & $19 a$ \\
\hline Wheal Kitty-Penhalls & GRGB & $15 b$ & Yellow Pine district & USID & $14 \mathrm{a}$ \\
\hline Whim Creek & AUWA & $28 a$ & Yeonhwa & SKOR & $18 c$ \\
\hline White Bear & USCA & $8 a$ & Yeoval & AUNS & 17 \\
\hline White Cedar & USCA & $8 a$ & Yerington & USNV & 17 \\
\hline White Feather & AUWA & $36 b$ & Yermakof-Log & URRS & $39 b$ \\
\hline White Feather & USCA & $8 a$ & Yeya & CUBA & $24 c$ \\
\hline White King & USOR & $25 f$ & Yilmaz Ocagi & TRKY & $8 a$ \\
\hline White Lake & CNMN & $28 a$ & Yoganup Shoreline & AUWA & $39 c$ \\
\hline White Pine & USMI & $30 b$ & Yoichi & JAPN & $28 a$ \\
\hline White Pine & USNV & $19 a$ & Yokota (Motoyama-Hama.) & JAPN & $28 \mathrm{a}$ \\
\hline White Pine Mine & USCA & $8 a$ & York Harbour & CNNF & $24 a$ \\
\hline White's (Rum Jungle) & AUNT & $38 \mathrm{~d}$ & Yoshimoto & JAPN & $24 b$ \\
\hline Whiteburn & CNNS & $36 a$ & Yoshino (Hisaka) & JAPN & $28 \mathrm{a}$ \\
\hline Whitlock & USCA & $34 d$ & Yoshino (Main) & JAPN & $28 a$ \\
\hline Whundo & AUWA & $28 a$ & Youanmi & AUWA & $36 b$ \\
\hline Wigie 3 & AUWA & $6 a$ & Young & USOR & $8 a$ \\
\hline Wigwam & CNBC & $31 a$ & Young's Mine & USOR & $8 a$ \\
\hline Wild Cat Claim & USOR & $8 a$ & Yreka & CNBC & $18 b$ \\
\hline Wildeat & PLPN & $28 a$ & Ysxjoberg & SWDN & $14 a$ \\
\hline Wilder (Fish Creek) & USCA & $8 a$ & Yugashima & JAPN & $25 c$ \\
\hline Wildrose Canyon & USCA & $27 d$ & Yukari Zorkum & TRKY & $8 a$ \\
\hline Willecho & CNON & $28 a$ & Yulee & USFL & $39 c$ \\
\hline Wilmar and others & CNON & $36 b$ & Yunus Yayla & TRKY & $8 a$ \\
\hline Wilshire-Bishop & USCA & $36 a$ & Yurtlak & TRKY & $8 a$ \\
\hline Wiluna-Moonlight & AUWA & $36 b$ & Yuryo & JAPN & $24 b$ \\
\hline Wim & $\mathrm{CNMN}$ & $28 a$ & $\mathrm{Z}$ & CNMN & $28 \mathrm{a}$ \\
\hline Windarra & AUWA & $6 a$ & Zacate-Cerro Chino & MXCO & $25 g$ \\
\hline Windfall & USNV & $26 a$ & Zaetzeff, R. & URRS & $39 b$ \\
\hline Windsor & $\mathrm{CNQU}$ & $8 d$ & Zambales $\mathrm{Ch}$ & PLPN & $8 a$ \\
\hline Windy & $\mathrm{CNBC}$ & $28 a$ & Zanitza & $\mathrm{MXCO}$ & $18 d$ \\
\hline Windy Point & USOR & $8 a$ & Zarikan & IRAN & $18 d$ \\
\hline Wine Harbour & CNNS & $36 a$ & Zawar & INDA & $31 a$ \\
\hline Wingelinna-Daisy & AUWA & $38 a$ & Zawarmala & INDA & $31 a$ \\
\hline Winters & USCA & $25 d$ & Zeballos & $\mathrm{CNBC}$ & $18 d$ \\
\hline Wintrop & $\mathrm{CNBC}$ & $22 c$ & Zeida & $\mathrm{MRCO}$ & $30 a$ \\
\hline Witswatersrand & SAFR & $29 a$ & Zeila & USCA & $36 a$ \\
\hline Wolf Creek & USCA & $8 a$ & Zemlianoi-Mostik Log & URRS & $39 b$ \\
\hline Wolf Creek area & USCA & $8 a$ & Zerfirg Ranch & USCA & $8 a$ \\
\hline Wombat Creek & AUNS & $39 a$ & Zimapan & $\mathrm{MXCO}$ & $19 a$ \\
\hline Wonder & USOR & $8 a$ & Zimparalik & TRKY & $8 a$ \\
\hline Wonder Gp. & USOR & $8 a$ & Zindani & GREC & $8 d$ \\
\hline Wonderful-Elkhorn & CNBC & $22 c$ & Zip & $\mathrm{CNBC}$ & $18 b, 18 c$ \\
\hline Woodcutters & AUNT & $31 a$ & Zonguldak & TRKY & $38 \mathrm{c}$ \\
\hline Woodlawn & AUQL & $28 a$ & Zortman Landusky & USMT & $22 b$ \\
\hline Woodsreef Mine & AUNS & $8 d$ & & & \\
\hline Woody Woody & AUWA & $24 c$ & & & \\
\hline Wyoming & USWY & $34 c$ & & & \\
\hline Wyssim R. & URRS & $39 b$ & & & \\
\hline Xihuashan & CINA & $15 a$ & & & \\
\hline Yahualica & $\mathrm{MXCO}$ & $25 g$ & & & \\
\hline Yakobi Island & USAK & $7 a$ & & & \\
\hline Yanahara & JAPN & $24 b$ & & & \\
\hline Yanchiachangtze & CINA & $18 c$ & & & \\
\hline Yandera & PPNG & 17 & & & \\
\hline Yanikara & TRKY & $8 a$ & & & \\
\hline Yankee Hill & USCA & $36 a$ & & & \\
\hline Yaprakli & TRKY & $8 a$ & & & \\
\hline Yatani & JAPN & $25 b$ & & & \\
\hline Yava & CNNT & $28 a$ & & & \\
\hline
\end{tabular}


)

) 


\section{SELECTED SERIES OF U.S. GEOLOGICAL SURVEY PUBLICATIONS}

\section{Periodicals}

Earthquakes \& Volcanoes (issued bimonthly).

Preliminary Determination of Epicenters (issued monthly).

\section{Technical Books and Reports}

Professional Papers are mainly comprehensive scientific reports of wide and lasting interest and importance to professional scientists and engineers. Included are reports on the results of resource studies and of topographic, hydrologic, and geologic investigations. They also include collections of related papers addressing different aspects of a single scientific topic.

Bulletins contain significant data and interpretations that are of lasting scientific interest but are generally more limited in scope or geographic coverage than Professional Papers. They include the results of resource studies and of geologic and topographic investigations; as well as collections of short papers related to a specific topic.

Water-Supply Papers are comprehensive reports that present significant interpretive results of hydrologic investigations of wide interest to professional geologists, hydrologists, and engineers. The series covers investigations in all phases of hydrology, including hydrogeology, availability of water, quality of water, and use of water.

Circulars present administrative information or important scientific information of wide popular interest in a format designed for distribution at no cost to the public. Information is usually of short-term interest.

Water-Resources Investigations Reports are papers of an interpretive nature made available to the public outside the formal USGS publications series. Copies are reproduced on request unlike formal USGS publications, and they are also available for public inspection at depositories indicated in USGS catalogs.

Open-File Reports include unpublished manuscript reports, maps, and other material that are made available for public consultation at depositories. They are a nonpermanent form of publication that may be cited in other publications as sources of information.

\section{Maps}

Geologic Quadrangle Maps are multicolor geologic maps on topographic bases in 71/2- or 15-minute quadrangle formats (scales mainly $1: 24,000$ or $1: 62,500$ ) showing bedrock, surficial, or engineering geology. Maps generally include brief texts; some maps include structure and columnar sections only.

Geophysical Investigations Maps are on topographic or planimetric bases at various scales; they show results of surveys using geophysical techniques, such as gravity, magnetic, seismic, or radioactivity, which reflect subsurface structures that are of economic or geologic significance. Many maps include correlations with the geology.

Miscellaneous Investigations Series Maps are on planimetric or topographic bases of regular and irregular areas at various scales; they present a wide variety of format and subject matter. The series also includes 7 1/2-minute quadrangle photogeologic maps on planimetric bases which show geology as interpreted from aerial photographs. Series also includes maps of Mars and the Moon.
Coal Investigations Maps are geologic maps on topographic or planimetric bases at various scales showing bedrock or surficial geology, stratigraphy, and structural relations in certain coal-resource areas.

Oil and Gas Investigations Charts show stratigraphic information for certain oil and gas fields and other areas having petroleum potential.

Miscellaneous Field Studies Maps are multicolor or black-andwhite maps on topographic or planimetric bases on quadrangle or irregular areas at various scales. Pre-1971 maps show bedrock geology in relation to specific mining or mineral-deposit problems; post-1971 maps are primarily black-and-white maps on various subjects such as environmental studies or wilderness mineral investigations.

Hydrologic Investigations Atlases are multicolored or black-andwhite maps on topographic or planimetric bases presenting a wide range of geohydrologic data of both regular and irregular areas; principal scale is $1: 24,000$ and regional studies are at $1: 250,000$ scale or smaller.

\section{Catalogs}

Permanent catalogs, as well as some others, giving comprehensive listings of U.S. Geological Survey publications are available under the conditions indicated below from the U.S. Geological Survey, Books and Open-File Reports Section, Federal Center, Box 25425, Denver, CO 80225. (See latest Price and Availability List.)

"Publications of the Geological Survey, 1879-1961" may be purchased by mail and over the counter in paperback book form and as a set of microfiche.

"Publications of the Geological Survey, 1962-1970" may be purchased by mail and over the counter in paperback book form and as a set of microfiche.

"Publications of the U.S. Geological Survey, 1971-1981" may be purchased by mail and over the counter in paperback book form (two volumes, publications listing and index) and as a set of microfiche.

Supplements for $1982,1983,1984,1985,1986$, and for subsequent years since the last permanent catalog may be purchased by mail and over the counter in paperback book form.

State catalogs, "List of U.S. Geological Survey Geologic and Water-Supply Reports and Maps For (State)," may be purchased by mail and over the counter in paperback booklet form only.

"Price and Avallability List of U.S. Geological Survey Publications," issued annually, is available free of charge in paperback booklet form only.

Selected coples of a monthly catalog "New Publications of the U.S. Geological Survey" available free of charge by mail or may be obtained over the counter in paperback booklet form only. Those wishing a free subscription to the monthly catalog "New Publications of the U.S. Geological Survey" should write to the U.S. Geological Survey, 582 National Center, Reston, VA 22092.

Note.--Prices of Government publications listed in older catalogs, announcements, and publications may be incorrect. Therefore, the prices charged may differ from the prices in catalogs, announcements, and publications. 


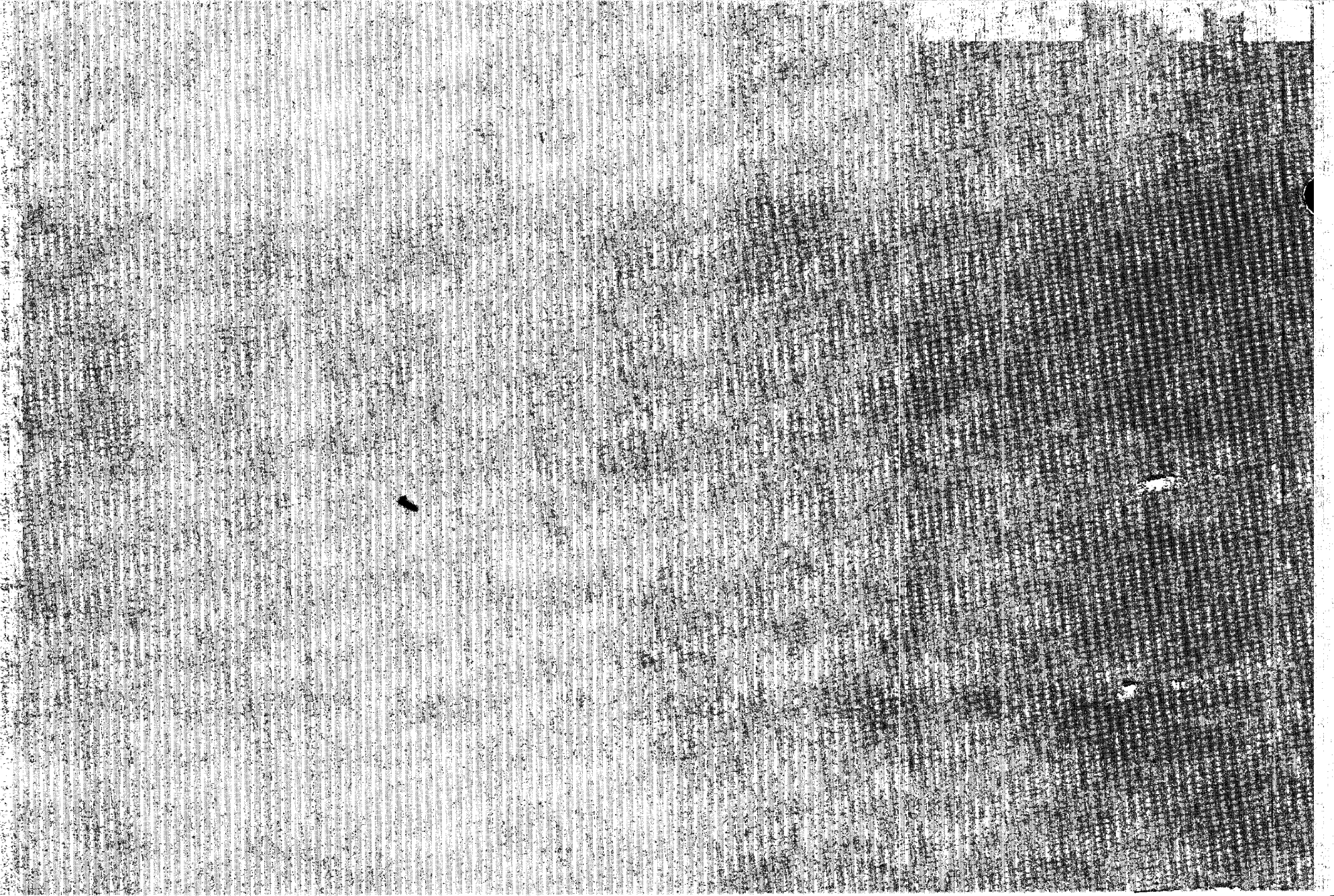

